

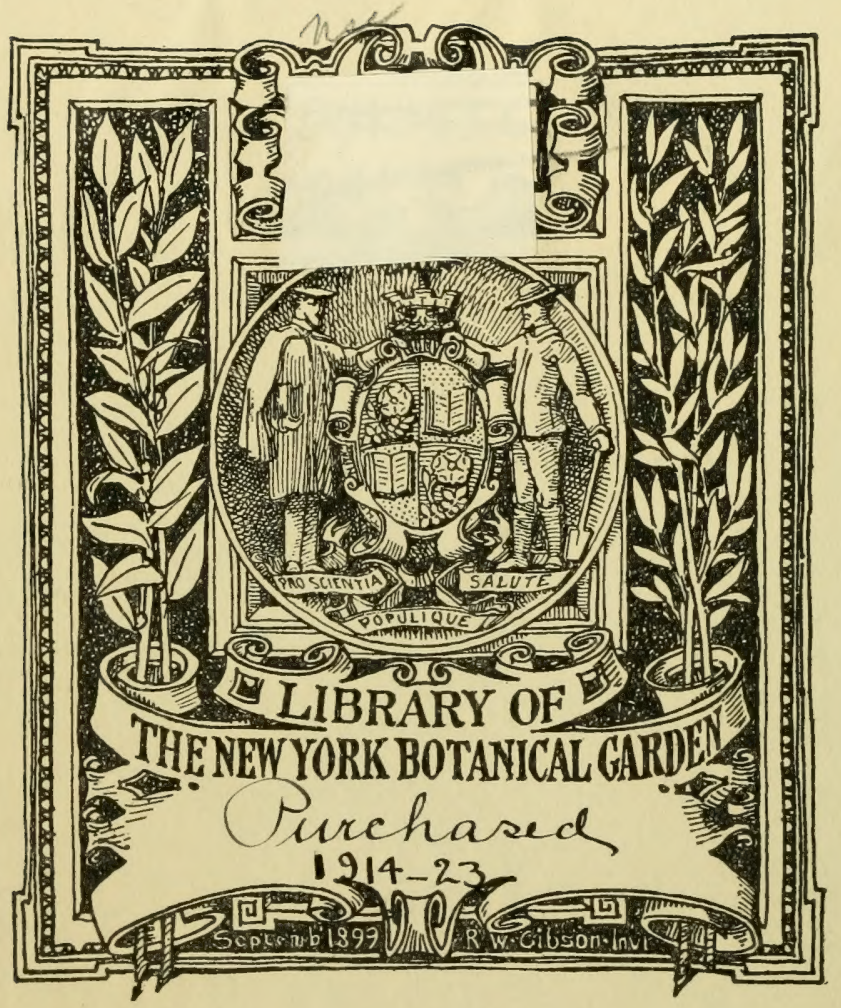






\section{DIE PFLANZENDECKE ÖSTERREICH-UNGARNS}

AUF GRUND FREMDER UND EIGENER FORSCHUNGEN GESCHILDERT

VON

Dr. AUGUST EDLER vON HAYEK, $187 / 1928$ PRIVATDOZENT FÜR SYSTEMATISCHE BOTANIK AN DER UNIVERSITÄT WIEN.

HERAUSGEGEBEN MIT EINEM DRUCKKOSTENBEITRAG DER KAISERLICHEN AKADEMIE DER WISSENSCHAFTEN IN WIEN.

\section{BAND.}

MIT 312 ABBILDUNGEN IM TEXT UND 57 TAFELN.

LEIPZIG UND WIEN.

FRANZ DEUTICKE. 1916. 
Alle Rechte vorbehalten.

Verlags-Nr. 2110. 


\section{Vorwort.}

Im Jahre 1762 , also vor mehr als 150 Jahren, sind die beiden ersten unter dem Einflusse Linnés stehenden Werke erschienen, welche die Flora einzelner Gebiete Österreich-Ungarns speziell behandeln, Jacquins ,Enumeratio stirpium plerarumque quae sponte crescunt in agro Vindobonensi" und der erste Teil von Crantz' ,Stirpes Austriacae“. Es war dies der Anfang einer intensiv einsetzenden Forschung, deren Ziel die erschöpfende Kenntnis der Pflanzenwelt unserer Heimat war, und diese Forschungsarbeit hat in den seither verstrichenen anderthalb Jahrhunderten ohne Unterbrechung mit stets sich steigernder Inund Extensität weiter gearbeitet und zu den schönsten Resultaten geführt. Viele Hunderte von größeren und kleineren Arbeiten, teils floristischen, teils pflanzengeographischen Inhaltes, zahlreiche, oft umfangreiche ältere und neuere Landesfloren, eingehende pflanzengeographische Monographien größerer Gebiete und kleinerer Gebietsteile geben Zeugnis von der diesbezüglichen Tätigkeit zahlreicher Forscher und enthalten eine reiche Fülle von außerordentlich wertvollem Beobachtungsmaterial. Aber nur ein einziges Mal, vor bereits 62 Jahren, ist durch J.K.Maly der Versuch gemacht worden, wenigstens die Ergebnisse der floristischen Forschung in Form einer Aufzählung der im Bereiche des damaligen Kaiserstaates vorkommenden Pflanzen zusammenzufassen, und erst in neuester Zeit erscheint in Ascherson und Graebners, ,Synopsis der mitteleuropäischen Flora" ein großangelegtes kritisches Florenwerk, das neben dem übrigen Mitteleuropa auch das Gesamtgebiet der österreichisch-ungarischen Monarchie in den Rahmen seiner Darstellung gezogen hat, ein Werk, dessen Vollendung jedoch leider erst in vielen Jahren zu gewärtigen ist. Eine Flora von Österreich-Ungarn aber bleibt nach wie vor ein frommer Wunsch der Botaniker.

Von vielleicht noch größerem allgemeinem Interesse als eine Flora im üblichen Sinne des Wortes mit einer Aufzählung und Beschreibung der im Gebiete vorkommenden Arten und Angabe ihrer Verbreitung scheint eine eingehende Darstellung der Vegetation in Form einer Schilderung der Pflanzengenossenschaften und -verbände und ihrer Verbreitung in ihrer Abhängigkeit von den klimatischen und Bodenverhältnissen. Eine solche Schilderung ist nicht aliein für den Botaniker und speziell den Pfianzengeographen von hoher Wichtigkeit, sondern es bieten die gewonnenen Ergebnisse einer solchen Darstellung auch den 
Schlüssel zur Lösung wichtiger florengeschichtiicher und somit auch erdgeschichtlicher Fragen. Auch in praktischer Hinsicht ist die genaue Kenntnis der Vegetationsverhältnisse eines Landes von nicht geringer Bedeutung, denn die Vegetation beeinflußt nicht nur das Landschaftsbild in hervorragendem Maße, sondern sie spiegelt auch die klimatischen Verhältnisse in getreuester Weise wieder, und es ist daher die genaue Kenntnis der natürlichen Vegetationsverhältnisse eine der wichtigsten Voraussetzungen für eine rationelle Land- und Forstwirtschaft.

Eine glänzende Darstelìung der pflanzengeographischen Verhältnisse der Monarchie aus berufenster Feder erschien zwar im Jahre 1887 im Úbersichtsbande des Werkes ,Die österreichisch-ungarische Monarchie in Wort und Bild" ; diese Darstellung beschränkt sich jedoch auf eine Schilderung der Vegetation der einzelenn Florengebiete in großen Zügen, schon mit Rücksicht auf die Raumverhältnisse allen Details ausweichend. Seither ist zwar eine Reihe ausgezeichneter umfangreicher Detailarbeiten erschienen, unter denen insbesondere die von v. Beck über das illyrische Gebiet, von Pax über die Karpathen und von Drude über den herzynischen Florenbezirk zu nennen sind, dazu eine Anzahl kleinerer Monographien; eine zusammenfassende Darstellung der Vegetationsverhältnisse von ganz Österreich-Ungarn unter Verwertung des reichen, in den verschiedensten Publikationen niedergelegten Materials ist bis jetzt nicht veröffentlicht worden.

Diese Lücke in der Literatur sucht das vorliegende Werk auszufülien. Nicht eine Flora der Monarchie mit Beschreibung der Arten und Verbreitungsangaben will es bieten, sondern eine Schilderung der Pflanzendecke in Wort und Bild, die sowohl dem Fachmann als auch dem gebildeten Laien die Vegetation Österreich-Ungarns vor Augen führen soli.

Ein kurz gehaltener allgemeiner Teil bringt einerseits das Wichtigste aus der allgemeinen Pflanzengeographie, soweit dies auf die Verhältnisse ÖsterreichUngarns Bezug hat, um auch dem Nichtfachmann das Verständnis des Buches zu erleichtern, anderseits, um Wiederholungen zu vermeiden, Bemerkungen ailgemeiner Natur über die Abhängigkeit der Pflanzengenossenschaften von K!ima und Boden und die verbreitetsten Vegetationsformationen. Der Hauptsabchnitt des Buches ist der eingehenden pflanzengeographischen Schilderung ÖsterreichUngarns gewidmet und in folgende acht Kapitel gegiiedert: 1. Die Sudetenländer. 2. Gałizien und die Bukowina mit Ausschluß der Karpathen. 3. Die Karpathen. 4. Das Ungarische Tiefland. 5. Das Westungarische Bergland. 6. Die Alpen. 7. Nordkroatien und Slawonien. 8. Die Karstiänder. Diese Gliederung wurde gewählt, um, ohne den Ergebnissen der Detaildarsteilung vorzugreifen, doch natürlich abgegrenzte und in pflanzengeographischer Beziehung halbwegs einheitliche Gebiete zur Grundiage zu wählen. Jedes dieser Kapitel, nach Erfordernis mitunter in weitere Unterabschnitte zerlegt, enthält eine Besprechung der klimatischen und Bodenverhältnisse in ihren Beziehungen zur Vegetation, an welche sich eine Schilderung der Zusammensetzung der einzelnen im Gebiete auftretenden Pflanzengenossenschaften unter steter Rücksichtnahme auf ihre Abhängigkeit von Klima und Boden anschließt. Sodann folgt eine eingehende topographische Schilderung der Vegetation, Tal für Tal, Bergkette für Bergkette, 
soweit deren Kenntnis von allgemeinerem Interesse ist, wobei sowohl dem Auftreten bestimmter Pflanzenbestände als auch den Verbreitungsgrenzen bezeichnender Arten und dem Vorkommen charakteristischer Typen entsprechende Aufmerksamkeit geschenkt wurde. Eine Vollständigkeit in den Pflanzenlisten wurde aber weder bei den einzelnen Formationen noch in der topographischen Schilderung angestrebt, sondern stets nur die bezeichnenden Arten genannt; ein Nichterwähnen einer bestimmten Art an einer bestimmten Stelle bedeutet demnach noch keineswegs, daß selbe daselbst nicht vorkommt. Von Kryptogamen wurden im allgemeinen nur Moose und Flechten und auch von diesen nur die allerwichtigsten Typen berücksichtigt. Hingegen wurde auf die reichlichste Einschaltung von Illustrationen, teils photographischer Vegetationsbilder, teils Einzeldarstellungen von wichtigen oder bezeichnenden Arten besonderes Gewicht gelegt.

Auf Grund der so auf induktivem Wege gewonnenen Resultate wird ein weiteres Kapitel unter Heranziehung paläontologischer Tatsachen die Entwicklungsgeschichte der Pflanzendecke Österreich-Ungarns seit der Tertiärzeit zum Gegenstande haben. Ein Schlußkapitel endlich wird den Versuch machen, eine Gliederung der Monarchie in einzelne pflanzengeographische Gebiete durchzuführen, deren Resultat auf einer pflanzengeographischen Karte zum Ausdruck gebracht werden soll.

Der Text des Werkes ist so gehaiten, daß er, ohne die Grenzen streng wissenschaftlicher Darstellung zu überschreiten, nach Möglichkeit auch für jeden mit der Pflanzenwelt nur halbwegs Vertrauten verständiich ist.

Eine so ins Detail gehende Darstellung der pflanzengeographischen Verhältnisse, wie sie im vorliegenden Werke zu geben versucht wird, ist kaum noch über ein Gebiet von ähnlicher räumlicher Ausdehnung veröffentlicht worden. Da aber Österreich-Ungarn vermöge seiner geographischen Lage im Zentrum Europas und seines Übergreifens auf Gebiete von ausgesprochen ost- und südeuropäischem Charakter, seines Anteiles sowohl an den höchsten Gebirgen Europas als an den großen östlichen und südlichen Ebenen und den Küsten des Mittelmeeres in pflanzengeographischer Beziehung zu den interessantesten und wichtigsten Gebieten gehört, glaubt der Verfasser, daß gerade dieses Gebiet wegen der Mannigfaitigkeit seiner FJora sich zu einem ersten Versuche in dieser Hinsicht eignet. Die detaillierte Schilderung der Vegetation der kleinsten Gebiete aber soll nicht allein auf induktivem Wege die Grundlage zu allgemeineren Ergebnissen bieten, sondern sie soll das Buch auch zu einem erwünschten Nachschlagewerk für jeden, der sich über die Flora einer bestimmten Gegend rasch orientieren will, machen. Es wird aber auch die vielfach nicht unbedeutenden Lücken zeigen in unserem Wissen und darauf hinweisen, wo die weitere Forschung anzusetzen hat, um unsere Kenntnis der Pflanzendecke Österreich-Ungarns zu vervollständigen.

Das Buch stellt jedoch keineswegs eine bloße Kompilation aus der sehr reichen, aber auch sehr zerstreuten und oft nur schwer zugảnglichen Literatur dar, denn nur der Umstand, daß Verfasser im Laufe der Jahre Gelegenheit hatte, 
große Teile des Gebietes aus eigener Anschauung kennen zu lernen, hat ihn in den Stand gesetzt, die Forschungsergebnisse so vieler zu einem einheitlichen Ganzen zu verarbeiten. Dies hat zur Folge, daß, abgesehen davon, daß sowohl die Abgrenzung der einzelnen Formationen als auch die beiden Kapitel über die Entwicklungsgeschichte der Flora und über die pflanzengeographische Gliederung des Gebietes die persönlichen Anschauungen des Verfassers wiedergeben, zahlreiche eigene Beobachtungen eingestreut sind, die als solche nicht kenntlich gemacht werden konnten. Denn die ganze Anlage des Buches, besonders die Rücksichtnahme auf eine einheitliche und dabei halbwegs lesbare Darstellung machen es unmöglich, bei jeder Formationsbenennung, jedem Pflanzenvorkommen usw. die Literaturquelle zu zitieren, der die Angabe entnommen wurde. Nur am Schlusse jedes Kapitels ist die benutzte Literatur genauestens angeführt und eine Durchsicht dieser Verzeichnisse wird zeigen, daß Verfasser bestrebt war, trotz der oft schwer zugänglichen Publikationsorte in Schulprogrammen, landund forstwirtschaftlichen Zeitschriften usw. und trotz der zahlreichen Sprachen, in denen sie erschienen sind, nach Möglichkeit keine bedeutsamere Literaturquelle außer acht zu lassen, wobei noch zu bemerken ist, daß Werke, denen tatsächlich keine Angaben entnommen worden sind, größtenteils ältere, durch neuere überholte Arbeiten, zumeist nicht zitiert worden sind. Soilte ihm doch die eine oder andere wichtigere Literaturquelle entgangen sein, bittet der Verfasser aus den oben angeführten Gründen um gütige Nachsicht.

Kurz nach dem Erscheinen der ersten Lieferung des Werkes traten unvermutet jene kriegerischen Verwicklungen ein, die selbstverständïich auch ein ruhiges wissenschaftiiches Arbeiten stark beeinträchtigen. Dank dem Entgegenkommen der Verlagshandlung sowie infolge des Umstandes, daß Manuskript und Illustrationsmaterial bereits fertig vorlagen, trat jedoch zwar eine Verlangsamung, aber keine Unterbrechung im Erscheinen des Buches ein und nach nicht viei über Jahresfrist nach Beginn des Erscheinens ist der erste Band des Werkes abgeschlossen, dem nach hoffentlich nicht allzu langer Pause der zweite folgen soll.

Indem ich aber nun diesen ersten Band der Öffentlichkeit übergebe, drängt es mich, allen jenen, die mich bei meiner Arbeit in dieser oder jener Hinsicht unterstützt haben, meinen Dank auszusprechen. In erster Linie gebührt mein Dank der hohen kaiserlichen Akademie der Wissenschaften in Wien, die durch Gewährung eines namhaften Druckkostenbeitrages die Herausgabe des Werkes in diesem Umfange und in dieser reichen illustrativen Ausstattung überhaupt erst ermöglichte. Meinen herzlichsten Dank ferner meiner wackeren Mitarbeiterin Fräulein Hedwig Ditscheiner in Wien, deren kunstfertiger Hand ich mit Ausnahme weniger, von Lektor Ad. Kasper herrührender anatomischer Detailbilder alle Originalzeichnungen von charakteristischen Pflanzenarten verdanke. Das übrige Illustrationsmaterial verdanke ich dem botan ischen und dem geographischen Institute an der Universität Wien, dem Deutschen Gebirgsverein für das Jeschken- und Isergebirge in Reichenberg, der Firma Nenke und Ostermeyer in Dresden, Frau Professor Amalie Mayer in Wien sowie den Herren Professor Hans Baer in Trient, Dr. 
Jenö v. Bernátsky in Budapest, Professor Dr. L. V. Cholnoky in Kolozsvár, Professor Dr. Karl Domin in Prag, Adjunkt Dr. August Ginzberger in Wien, Assistent Dr. Heinrich Freiherr v. Handel-Mazetti in Wien, Konstantin Freiherr von Hormuzaki in Czernowitz, Professor Dr. H. Iltis in Brünn, Fachlehrer J. Jonasch in Schatzlar, Professor Dr. Norbert Krebs in Wien, Professor Dr. K. Linsbauer in Graz, Professor Dr. L. Linsbauer in Klosterneuburg, Oberbezirksarzt Dr. J. van Linthoudt in Wien, Professor Dr. L. v. Lóczy in Budapest, Professor K. Müller in Krems, Professor Dr. F. Nabělek in Leipnik, Professor Johann Nevole in Knittelfeld, Professor E. Gyula Nyárády in Marosvasárhély, Professor Dr. Adolf Pascher in Prag, Garteninspektor J. Pauer in Olmütz, Professor G. Poschner in Bistritz, Kustosadjunjkt Dr. K. Rechinger in Wien, Professor Dr. Aladár Richter in Kolozsvár, jetzt in Pozsony, Assistent Dr. K. Rudolph in Prag, Dozent Dr. Z. v. Szabó in Budapest, Dr. J. Szafer in Lemberg, Direktor Janos Wagner in Budapest, phil. Fritz v. Wettstein in Wien und Adjunkt Dozent Dr. E. Zederbauer in Wien, die mich alie durch Zurverfügungstellung ihrer Originalphotographien zu herzlichstem Danke verpflichtet haben. Literaturbehelfe sowie wertvolle Auskünfte in sachlicher Beziehung danke ich den Herren Dr. Jenö v. Bernátsky in Budapest, Direktor Dr. Arpád v. Degen in Budapest, Professor Dr. Karl Domin in Prag, Professor Dr. H. Laus in Olmütz, Professor Dr. M. Raciborski in Krakau, Dr. J. Szafer in Lemberg, Kustos Dr. A. Zahlbruckner in Wien sowie meinem Schwager Dr. Wilhelm Schmidt, Sekretär an der Zentraìanstalt für Meteorologie und Geodynamik in Wien, der mir bei der Beschaffung der meteorologischen Literatur behilflich war, insbesondere jedoch den Herren Professor Dr. Eustach Woloszczak in Wien und Konstantin Freiherr v. Hormuzaki in Czernowitz, von denen ersterer das Kapitel über Galizien und die Bukowina einer freundlichen Durchsicht unterzog, während ohne die wertvolle Beihilfe des letzteren die Darstellung der Vegetationsverhältnisse der Bukowina äußerst İückenhaft geblieben wäre.

Trotz dieser vielfachen liebenswürdigen Unterstützung, die mir von so vielen Seiten zuteil wurde, ist doch gar manches ungeklärt geblieben; oft genug mußte ich mich auf alte schon, zweifelhafte Quellen stützen, manche Gegenden erwiesen sich als botanisch noch recht unerforscht. Im ganzen genommen aber hat es mich doch mit großer Befriedigung erfüllt, als ich bei Studium des vorhandenen Materials zur Einsicht gelangte, wieviel bereits in diesen großen und oft entlegenen Gebieten bezüglich der botanischen Erforschung geleistet worden ist, so daß ich, wenn ich auch weit entfernt davon bin, etwas nur halbwegs Erschöpfendes bieten zu wollen, doch die Überzeugung gewonnen habe, daß der Zeitpunkt nicht mehr zu früh ist, um endlich einmal eine Zusammenfassung der Forschungsresultate so Vieler zu versuchen.

Wien, im Juli 1915. 



\title{
Inhaltsübersicht des ersten Bandes.
}

\author{
Allgemeiner Teil.
}

Seite

Einleitung

Der Einfluß ron Klima und Boden auf die Verbreitung der Pflanzen . . . . . 5

I. Die Wirkung der einzelnen äußeren Faktoren auf die Pflanze . . . . . . . . 5

A. Die Wärme . . . . . . . . . . . . . . . . 5

B. Das Licht . . . . . . . . . . . . . . . . . . 7

C. Das Wasser . . . . . . . . . . . . . . . 10

1). Dic Luft . ........................... . . . 16

E. Die chemische Zusammensetzung des Bodens . . . . . . . . . . . . . 17

F. Die physikalische Beschaffen!reit des Bodens . . . . . . . . . 92

G. Die Einwirkung der Tiere und des Menschen auf die Vegetation . . . . 23

I1. Die Klimate in ihren Beziehungen zur Pflanzenwelt . . . . . . . . . . . . . 21

A. Die Wärmezonen ..................... . 24

B. Die Niederschläge und hlhre Beziehungen zur Vegetation . . . . . . . 26

C. Der Wind als klimatischer Faktor . . . . . . . . . . . . 27

D. Die Beeinflussung klimatischer Wirkungen durch edaphische Faktoren . . 2S

E. Die Klimate Österreichs-Ungarns in ihren Beziehungen zur Vegetation . 29

1. Das mediterrane Klima . . . . . . . . . . . . . . . . 29

2. Das mitteleuropäische Klima . . . . . . . . . . . . 30

3. Das Steppenklima ... . . . . . . . . . . . 33

4. Das Hochgebirgsklima .............. . . . 35

III. Die Änderungen des Klimas im Laufe der Erdgeschichte . . . . . . . . . . 39

IV Die Pflanzengenossenschaften ................... . . . 41

A. Das Zusammenleben der Pflanzen miteinander . . . . . . . . . . . . 41

B. Der Begriff der ,Pflanzenformation" . . . . . . . . . . . . . 43

C. Allgemeine Bemerkungen über die wichtigsten Formationen . . . . . . 46

1. Die Wälder . . . . . . . . . . . . . . . . 46

2. Die Grasfluren . . . . . . . . . . . . . . . . . 49

3. Die Heide . . . . . . . . . . . . . . . . . 52

4. Die Moore ....................... . . . 54

5. Die Wasser- und Uferflora ................. . 60

6. Die Flora der Felsen und des Felsschuttes . . . . . . . . . 65

7. Dic Adventivflora .. . . . . . . . . . . . . . 68

Verzeichnis der wichtigsten Literatur . . . . . . . . . . . . . 70 


\section{Spezieller Teil.}

I. Die Sudetenlånder

A. Die Vegetation der Sudetenländer in ihrer Abhängigkeit von Klima und Boden

B. Die Pflanzengenossenschaften des Gebietes . . . . . . . . . . . $\leqslant 9$

1. Die Pflanzengenossenschaften des herzynischen Berglandes . . . . 89

2. Die Pflanzengenossenschaften der Sudeten . . . . . . . . 104

3. Die Pflanzengenossenschaften Zentralböhmens . . . . . . . . . 120

4. Die Pflanzengenossenschaften von Mittel- und Südmähren und dem nordöstlichen Niederösterreich . . . . . . . . . 143

C. Spezielle pflanzengeographische Schilderung . . . . . . . . . . 163

1. Das Erzgebirge und Elstergebirge mit dem Egerland . . . . . 163

2. Der Kaiserwald und Böhmerwald mit dem oberösterreichischen Möhlviertel ................... 170

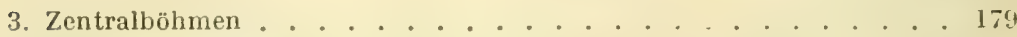

4. Das Elbesandstein- und Iausitzer-Gebirge . . . . . . . . 205

5. Die Sudeten . . . . . . . . . . . . . . . . . . . . . .

6. Das Böhmisch-mährische Gebirge mit dem niederösterreichischen

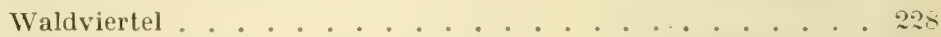

7. Mittel- und Südmähren und das nordöstliche Niederösterreich . . 236

Verzeichnis der benutzten Literatur . . . . . . . . . . . . . . 260

\section{Galizien und die Bukowina und das ostliche Schlesien mit AusschluB der} Karpathen

A. Die Vegetation in ihrer Abhängigkeit von Klima und Boden . . . . . 267

B. Die Pflanzengenossenschaften des Gebietes . . . . . . . . . . . 269

1. Die Pflanzengenossenschaften WVest- und Nordgaliziens . . . . . . 269

2. Die Pflanzengenossenschaften Ostgaliziens und der Bukowina . . . 280

3. Die Kulturgewächse Galiziens und del Bukowina . . . . . . . . 290

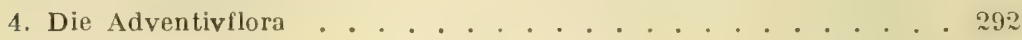

C. Pflanzengeographische Schilderung des Gebietes . . . . . . . . . . 293

Verzeichnis der benutzten Literatur . . . . . . . . . . . . . . . 311

III. Die Karpathen . . . . . . . . . . . . . . . . . . . . . 317

A. Der Einfluß der geographischen, klimatischen und Bodenverhältnisse auf die Vegetation der Karpathen .............. . . . . 317

B. Die Pflanzengenossenschaften des Gebietes . . . . . . . . . . . 328

1. Die Westkarpathen ............... . . . . . . . . . . . . . 319

2. Die Ostkarpathen ................. . . . . 349

3. Kulturpflanzen der Karpathen ............... . . . 372

4. Die Adventivflora der Karpathen . . . . . . . . . . 373

C. Spezielle pflanzengeographische Schilderung der Karpathen . . . . . . . 374

1. Die Westkarpathen ................ . . 374

a) Die KKleinen Karpathen . . . . . . . . . . . 374

b) Die Beskiden und Pieninen . . . . . . . . . . 376

c) Die Westkarpathen südöstlich der Waag . . . . . . . 381 
d) Die Zentralkarpathen nördlich der Waag . . . . . . . 389

e) Das Göllnitzer und Eperieser Gebirge . . . . . . . . 403

f) Die südlichen Vorlagen der Westkarpathen . . . . . . 407

2. Die Ostkarpathen .............. . . 410

a) Die Waldkarpathen . . . . . . . . . 410

b) Die Rodnaer und Bistritzer Alpen . . . . . . . . 413

c) Die östlichen Randgebirge Siebenbürgens . . . . . . . 424

(l) Das Burzenland . . . . . . . . . . . . 428

c) Die südlichen Randgebirge Siebenbürgens . . . . . . 437

i) Das Banater Bergland ........... . 445

g) Die westlichen Randgebirge Siebenbürgens . . . . 450

h) Das zentrale Hügelland von Siebenbürgen . . . . . 457

Verzeichnis der benutzten Literatur . . . . . . . . . . . . 46s

IV. Das ungarische Tiefland . . . . . . . . . . . . 477

A. Die klimatischen, geographischen und Bodenverhältnisse des ungarischen

Tieflandes in ihren Bezichungen zur Vegetation . . . . . . . 477

B. Die Pflanzengenossenschaften des Gebietes ... . . . . . . . 485

C. Spezielle pflanzengeographische Schilderung des Gebietes . . . . . 506

A. Die Kleine ungarische Tiefebene . . . . . . . . . 506

B. Die Große ungarische Tiefebene . . . . . . . . . 510

Verzeichnis der benutzten Literatur .............. . . 529

I. Sachregister . . . . . . . . . . . . . . 532

II. Register der Pllanzennamen . . . . . . . . . . . . . . 539

1II. Index der gengraphischen Namen . . . . . . . . . . . . 590

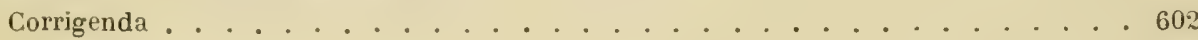




\section{DIE PFLANZENDECKE ÖSTERREICH-UNGARNS}

AUF GRUND FREMDER UND EIGENER FORSCHUNGEN GESCHILDERT

VON

Dr. AUGUST EdLER VON HAYEK, PRIVATDOZENT FÜR SYSTEMATISCHE BOTAXIK AN DER UNIVERSITÄT TVIEN.

HERAUSGEGEBEN WIT EINEM DRUCKKOSTENBEITRAG

DER KAISERIICHEN AKADEMIE DER WISSENSCHAFTEN IN WIEN.

I. BAND.

1. LIEFERUNG.

LEIPZIG UND WIEN.

FRANZ DEUTICKE.

1914.

Verlags-Nr. 2110

Vollständig in 2 Bänden ron etwa je s Lieferungen. 
Verlag von Franz Deuticke in Leipzig und Wien.

Die Erscheinung der Anisophyllie.

Eine morphologisch-physiologische Studie

von

Dr. Wilhelm Figdor,

Privatdozent für Anatomie und Physiologio der Pflanzen an der $k$. $k$. Universităt in Wien.

Mit 23 Abbildungen im Text und 7 Tafeln in Lichtdruck.

Preis M. $7 \cdot-=\mathrm{K} 8 \cdot 40$.

Landwirtschaftliche Pflanzenzüchtung und ihre Stătten in Österreich.

Dargostellt von

Prof. C. Fruhwirth,

diplomierter Landwirt, Dozent an der $\mathrm{k}$ 。 $\mathrm{k}$. Hochschule für Bodenkultur.

Preis M. $1 \cdot 80=\mathrm{K} 2 \cdot$.

Führer zu den wissenschaftlichen Exkursionen

des II. internationalen Kongresses Wien 1905.

Herausgegeben rom

Organisationskomitee des II. internationalen botanischen Kongresses unter Mitwirkung von

A. Cieslar, A. Ginzberger, H. Freih. v. Handel-Mazzetti, A. v. Hayek, K. Maly,

V. Schiffner, F. Vierhapper und E. Zederbauer.

Mit 52 Lichtdrucktafeln, 1 Titelbild und 12 Textabbildungen.

Preis in Mappe Mr. $20^{\circ}-=\mathbf{K} 20^{\circ}-$.

\section{Einführung in die Biochemie}

fur Naturhistoriker und Mediziner.

Von

Dr. Yiktor Grafe,

Privatdozent an der Wioner Universitut.

Mit 41 Abildungen im Text.

Preis M. $13^{\circ}=\mathrm{K} 15 \cdot 60$.

\section{Die Forstbetriebseinrichtung.}

Fiir Studierende und ausibende Fachminnor dargestellt von

Dr. Adolf Ritter v. Gattenberg

k. k. Hofrat und o. ̈. Professor an der k. k. Hochschule für Bodlenkultur in Wien. Zweite Auflage.

Mit 3 Tafeln in Farbendruck und 41 Figuren im 'Text.

Preis geh. II. $10^{\circ}=\mathrm{K}$ 12., geb. M. $11 \cdot 20=\mathrm{K} 13.40$.

\section{Monographie der Gattung Taraxacum.}

Von

Dr. Heinrich Freiherr v. Handel-Mazzetti,

Assistent am botanischen Institut der $k$. $k$. Oniversität in Wien.

Mit 2 Tafoln in Lichtdruck, 3 lithographischen Tafeln und 2 Karłon.

Preis M. $15^{\circ}-=$ K 18. .

\section{Flora von Brixen a. E.}

Ein mit Standorts- und Höhenangaben versehenes Verzeichnis der im weiteron Gebiete von Brixen a. E. (Siidtirol) beobachteten wildwachsenden höheren Sporen- und Samenpfanzen, der Nutzgewächse und Ziergehölze.

Vorfaist von

Dr. Anton Heimerl.

Mit einer aus dem Legate Scholz gewährten Unterstiitzung

der kaiserl. Akademie der Wissenschaften in Wien.

Preis M. $8 \cdot-=\mathrm{K} 9 \cdot 60$. 


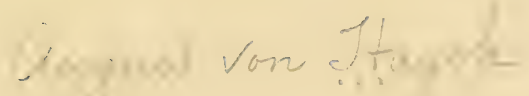

\section{Allgemeiner Teil.}





\section{Einleitung.}

Nicht allein in Europa, sondern selbst auf der ganzen Erde gibt es nur wrnige Gegenden, die in bezug auf ihre Pflanzenwelt rine solche Mannigfaltiglieit auf verhältnismäßig beschränktem Raume darbieten, wie es im Gebiete der österreichisch-ungarischen Monarchie der Fall ist. Größere Gegensätze als die im Sommer und Vinter stets grüne Vegetation an den Küsten der Adria und die Alpenflora an den Grenzen des ewigen Schnees, als die blumenreichen steppenwiesen Ostanlizims und die von dïstren IJoehwäldern umgebenen Voore der Sudeten und des Böhmerwaldes oder die sonndurchglühten Puszten Ungarns und die ernsten Buchenforste der Karpathen sind kaum denkbar und doch sind sie hier durch nur relativ kurze Entfernungen voneinander getrennt oder stoßen sogar hart aneinander.

Die Ursachen dieser Mannigfaltigkeit, in der sich uns die Pflanzendecke unserer Heimat zeigt, sind in erster Linie in der Verschiedenheit der klimatischen Verhältnisse gegeben. Fast im Zentrum Europas gelegen, erstreckt sich Österreich-Ungarn durch fast 17 Längengrade in west-östlicher f durch 9 Breitengrade in nord-südlicher Richtung über die östlichen Alpen und die Karpathen, die Tiefebenen Ungarns und Galiziens, von den Gestaden der blauen Adria über die wilden Hochgebirge Illyriens und nach Norden bis an die nebelreichen böhmischen Grenzgebirge. Und während die höchsten Gipfel der Alpen fast $4000 \mathrm{~m}$ an absoluter Höhe erreichen, sind nicht nur an den Küstengebieten der Adria, sondern auch in Ungarn viele Strecken vorhanden, die nicht einmal $100 \mathrm{~m}$ über den Meeresspiegel sich erheben. Daß derartige Differenzen in der vertikalen und horizontalen Ausdehnung eines Landes naturgemäß auch gewaltige Unterschiede im Klima der cinzelnen Gebiete mit sich bringen, ist natürlich; diese werden aber durch die Nähe des Neeres, die Gebirgsscheiden und den Anschluß an das große Landmassiv im Osten noch wesentlich verstärkt. Während die dalmatinische Insel Gurzola als durchschnittliches Temperaturmaximum 320, als Ninimum $+2^{0}$ aufweist, die Differenz zwischen der höchsten und niedersten Temperatur nur $30^{\circ}$ beträgt, weist Czernowitz in der Bukowina zwar ebenfalls $32^{0}$ als durchschnittliches Temperaturmaximum auf, aber das Ninimum beträgt rlort - $24^{0}$, die Differenz der beiden Extreme also $54^{\circ}$. Die jährliche Niederschlargmenge in den Bocche di Cattaro beträgt 456, in Alt-Aussee in den Alpen $197 \mathrm{~cm}$ im Jahre, hingegen weist Szarvas in der großen ungarischen Tiefebene nur 54 , Lobositz in Nordböhmen gar nur $44 \mathrm{~cm}$ jährlicher Niederschlagsmenge aul. 
Abgesehen von diesen Differenzen in den absoluten Zahlen machen sich auch noch bedeutende Unterschiede in der jahreszeitlichen Verteilung der Niederschläge, im jährlichen Gang der Temperatur geltend.

Daß diese großen Unterschiede im Klima nicht ohne Einfluß auf die Vegetation bleiben können, ist klar. Jedermann weiß, daß die Kokospalme im kühlen Norden nicht gedeiht, daß das Edelwei $\beta$, ins 'Tal gebracht, vergrünt, ins Kraut schießt und schlielich trotz sorgfältigster Pflege doch zugrunde geht. Und wie es bei diesen beiden Pflanzen der Fall ist, ist es auch bei allen anderen. An den Küsten der Adria mit ihren milden regenreichen Wintern, die keine Unterbrechung der Vegetationstätigkeit mit sich bringen, und den warmen trockenen Sommern finden ganz andere Pflanzen ihr Gedeihen als auf den Höhen der Alpen, die durch 9 Monate mit Schnee bedeckt sind und wo nur 3 Monate den Pflanzen zu Gebote stehen, um Blätter, Blüten und Samen entwickeln zu können, oder in den ostgalizischen Steppen, wo nach einem langen kalten Winter ein regnerischer Frühling die Flora rasch zu neuem Leben erweckt, um bald"der Sommerdürre wieder zu erliegen. Nobenidiesen klimatischen Unterschieden kommen in bezug auf rle Verteilung drr Pflanzen auch noch die lokalen Bodenverhältnisse in Betracht; ob der Standort feucht, ob trocken, ob er sonnig oder schattig, ob der Boden kalkreich oder kalkarm ist, das sind Faktoren, die in bezug auf die Verbreitung der Pflanzenarten eine ebenfalls nicht zu unterschätzende Rolle spielen.

Daß auf die Verteilung nicht nur einzelner Pflanzenarten, sondern auch ganzer Pflanzengenossenschaften die äußeren Verhältnisse von so großem Einflusse sind, hat mancherlei Ursachen. So ist die Empfindlichkeit der einzelnen Pflanzenarten gegen äußere Einflüsse eine verschiedene, und während einzelne unter den mannigfachsten Berlingungen gedeihen, sind andere in diesem Punkte sehr wählerisch. Vor allem aber sind die Pflanzen gegen schädigende äußere Einflüsse nicht wehrlos, sondern mit mancherlei Schutzmitteln gegen Trockenheit, Kälte, Lichtmangel $\mathrm{u}$. dgl. ausgestattet, die sie vielfach befähigen, auch unter recht ungünstigen äußeren Einflüssen ihr Dasein zu fristen. Endlich sind die Pflanzen bezüglich ilıres Torkommens auch auf ihresgleichen angewiesen und Arten mit gleichen Lebensbedingungen schließen sich zu Genossenschaften, zu Formationen zusammen. Und wie Pflanzen, die niedrige Temperaturen nicht vertragen, in kalten Klimaten zugrunde gehen, oder solche, die Schutzeinrichtungen gegen hochgradige Trockenheit besitzen, an feuchtem Standorte nicht gedeilıen können, sind auch Wald, Wiese, Steppe, Moor und Heide an ganz bestimmte Klimate, an ganz bestimmte Bodenverhältnisse gebunden.

Inwiefern nun die Pflanzenarten und -genossenschaften bezüglich ihrer Verbreitung von äußeren Verhältnissen beeinflußt werden, welche Schutzeinrichtungen ihnen gegen schädigende Einflüsse zu Gebote stehen und wie die einzelnen Arten sich zu Gesellschaften, zu Formationen zusammenschließen, das soll mit besonderer Berücksichtigung alles dessen, was für die Verhältnisse Österreich-Ungarns speziell in Betracht liommt, in den nachfolgenden Kiapiteln seine Darstellung finden, an die sich dann eine eingehende Schilderung der Vegetationsverhältnisse der einzelnen Ländergebiete anschließen wird. 


\section{Der Einfluli von Klima und Boden auf die Ver- breitung der Pflanzen.}

\section{Die Wirkung der einzelnen äußeren Faktoren auf die Pflanze.}

A. Die Wärme.

Daß alle Pflanzenarten ohne Unterschied zum Leben einer gewissen Menge von Wärme brauchen, ist allbekannt. Doch ist das Wärmebedürfnis bei den verschiedenen Pflanzen ein sehr verschiedenes. Während manche tropische Gewächse schon bei 'Temperaturen von einigen Graden über dem Nullpunkt „erfrieren“, können die Samen mancher Pflanzen und noch mehr die Sporen einiger niedriger Organismen recht beträchtliche Kältegrade ohne Schaden ertragen. Aber auch krautige Pflanzen kälterer Klimate überdauern oft Temperaturen unter dem Gefrierpunkte ohne Schaden. Schutzeinrichtungen, die geeignet wären, die Einwirkung niederer Temperaturen auf die Pflanze hintanzuhalten, wie sie die Tiere im Haar- beziehungsweise Federkleide besitzen, fehJen den Pflanzen, und diejenigen Eigenschaften, die man als solchen Kälteschutz zu deuten geneigt wäre, wie dicht polsterförmig rasiger Wuchs und dichte Behaarung, sind, wie festgestellt ist, nicht Inpassungs'rscheinungen gegen die Kälte, sondern gregen 'Trockenheit. Bei der geringen Eigenwärıne, die die Pflanze, zumal im Zustande der Vegetationsruhe, im Gegensatze zum Tier erzeugt, würde ein noch so dichtes Haarkleid es nicht verhindern, daß bei einer durch Monate hindurch unter dem Gefrierpunkte bleibenlen Aufentemperatur der Zellsalt der Pflanze zu Eis gefriert. Aber die Pflanzen, die in Klimaten, wo diese Möglichkeit vorhanden ist, wohnen, besitzen eben die Fähigkeit, auch solche niedrige Temperaturen ohne Schaden ertragen zu kïnnen. Jedr. Pflanzenart kann nur innerhalb bestimmter Temperaturgrenzen gerleihen, die bei ein und derselben Art ziemlich konstant sind, bei den verschiedenen Arten aber in weiten Grenzen schwanken. Speziell die untere Grenze der einer bestimmten Art zuträglichen Temperatur ist eine sehr verschiedene, und in jenen Klimaten, in denen regelnäßig im Jahre die Temperatur unter den Nullpunkt sinkt, liönen eben nur solche Arten fortkommen, die gegen Kälte nicht empfindlich sind. Freilich muß auch hier hervorgehoben werden, daß der scheinbare Tod durch Erfriren in nicht seltenen Fällen 
Kein Kailtetod, sondern ein Tod durch Austrocknen ist. Daher kommt es, daß 7. B. viele unserer Laubbäume im unbelaubten Zustande, wo ihnen die die Feuchligkeit an die Luft abgebenden Blätter mangeln, trotz des Umstandes, daß sie aus dem gefrorenen Boden nur wenig oder gar kein Wasser aufnehmen, die Winterkälte ohne Schaden überdauern, während sie, wenn nach Entfaltung des Laubes Spätfröste auftreten, ,erfrieren“, da dann die Blätter mehr Flüssigkeit an die Luft abgeben, als die Pflanze aus dem Boden aufzunehmen vermag, die Pflanzen demnach eigentlich vertrocknen.

Gerade so wie die Pflanze zum Leben einer gewissen Wärmemenge bedarf und innerhalb bestimmter Temperaturgrenzen am besten gedeiht, so sind auch die verschiedenen Lebensfunktionen der Pflanze an bestimmte 'T'emperaturen gebunden. Es gibt niedrige Temperaturen, die die Pflanze ganz gut überdauert, aber diese Temperaturen genügen nicht, um die Pflanze zum Wachsen, Entwickeln von Blättern, Blüten und Früchten zu bringen. In den Tropen wachsen die Pflanzen erstaunlich rasch, auch in unseren Breiten ist das Wachstum im Sommer ein reges, während es im Winter fast auf Null herabsinkt. Erst wenn im Frühling die Temperatur eine gewisse Höhe erreicht hat, keimen die Samen, treiben die Pflanzen Blätter und Blüten, und daß zum Ausreifen der Früchte beträchtliche Wärmemengen nötig sind, ist ja eine bekannte Erscheinung. Viele südliche Fruchtbäume, die in Nitteleuropa ganz gut gedeihen und auch den Winter im Freien, ohne Schaden zu nehmen, überlauern, reifen bei uns nie oder nur in sehr warmen Sommern ihre Früchte aus, so die Feige und in allen kühteren Gebieten Nitteleuropas auch der Weinstock, der Pfirsich usw. Zum Blühen sind im allgemeinen geringere Wärmemengen erforderlich als zum Reifen der Früchte; ja in den 'Tropen blühen sogar manche Gewächse direkt in der kühleren Jahreszeit.

Wie schon oben erwähnt, sind ausgesprochene Schutzeinrichtungen gegen die Einwirkung der Kälte bei den Pflanzen nur selten nachzuweisen, die Hauptsache ist und bleibt die Fähigkeit der betreffenden Art, niedrige Temperaturen ohne Schaden zu ertragen. Nichtsdestoweniger haben Versuche ergeben, daß manche Pflanzen bei Kultur unter niedrigen Temperaturen ihre Zweige mehr an den Boden, die Blätter beziehungsweise Nadeln mehr an den Stamm andrücken sowie daß oft in reichlicher Menge der blaue oder rote Pflanzenfarbstoff, das Anthokyan, ausgebildet wird. Das Anthokyan wirkt nicht nur als dunkle Farbe als Aufsammler der Wärmestrahlen, sondern es besitzt überhaupt die Fähigkeit, Ischt in Wä口me unzuselzen, und die häufig beobachtete Erscheinung, daß Pflanzen der Hochgebirge und des hohen Nordens nicht nur in ihren Blüten, sonderı atuch in ihren grünen Organen reirhlich Anlhokyan entwickehn, mag wohl auf diese Eigenschaft des Anthokyans zurückzuführen sein und kann somit als eine Anpassungserscheinung an das kühle Klima gedeutet werden. Auch dic dunkle Färbung der Kelche und Blütenhüllen zahlreicher alpiner Pflanzen und der Spelzen alpiner Gräser mag wohl dazu dienen, möglichst viel Wärmestrahlen zu absorbieren und so der Frucht die zur Reife nötige Wärmemenge zuzuführen. Bei Eintrilt der Winterkïlte wandeln ferner die Bäume in unseren Klimaten 
die in ihren Geweben als Reservestoffe angehäufte Stärke in löslichen Zucker um. Diese Anhäufung von Zucker scheint ebenso wie die Aufnahme größerer Mengen anorganischer Salze die Widerstandsfähigkeit der Pflanze gegen Kälte $\mathrm{zu}$ crhöhen, bewirkt aber auch eine reichere Ausbildung von Anthokyan und trägt so auch indirekt zur Erhöhung dieser Widerstandsfähigkeit bei.

Trotz dieser Einrichtungen aber kann es wohl oft vorkommen, daß bei früh eintretender Kälte alpine Gewächse ihre Früchte nicht zur Reife bringen. Da zeigt es sich nun, daß einige dieser Arten Einrichtungen aufweisen, die eine Vermehrung, freilich nicht auf geschlechtlichem Wege, auf alle Fälle sicherstellen. Sie bilden nämlich an Stelle der Blüten kleine Brutknöspchen oder Brutzwiebeln aus. Das bekannteste Beispiel dieser Art ist der ,lebendiggebärende Knöterich" oder die ,Otterwurz" (Poliggonum viviparum). Diese Art trägt gleich der verwandten Natterwurz (Polygonum Bislorla) die von kleinen Deckschüppchen gestützten Blüten in endständigen Ahren. Regelmäßig sind aber bei Polygonum viviparum in der Mhre nur die oberen Blüten entwickelt, in der Achsel der unteren Deckschüppchen des Blütenstandes stehen statt der Blüten kleine knöllchenförmiğ Knospen, rir ausfallen und zu riner selbstandigen Pflanz" weiter wachsen. Auch beim sternblütigen Steinbrech (Saxifraga stellaris) wurde wiederholt beobachtet, daß an Stelle der Blüten solche Brutknöspchen sich entwickeln (vgl. Abb. 1 auf S. 8), und ähnliches ist auch gelegentlich bei verschiedenen Gräsern, besonders häufig bei Poa alpina, aber auch bei anderen Arten von Poa und bei Festuca-Arten der Fall.

\section{B. Das Licht.}

Zwar nicht für alle Pflanzen überhaupt, aber wohl für alle grünen Pflanzen ist das Licht ein unbedingtes Lebenserfordernis. Sind doch die Pflanzen, von ganz wenigen Ausnahmsfällen abgesehen, nur bei Licht imstande, den grünen Farbstoff, das Chlorophyll auszubilden, mit Hilfe dessen sie allein in der Lage sind, ihre Nahrung aus der Luft aufzunehmen und die Kohlensảure in Nährstoffe umzusetzen, zu , assimilieren". Bekanntlich verlieren die Pflanzen, wenn sie nicht genügend Licht zur Verfügung haben, ihre grüne Farbe, sie "vergeilen". Nur ein Übermaß zu grellen Sonnenlichtes kann schädigenden Einfluß haben, indem es auf das Ghlorophyll zerstörend wirkt. Die Pflanzen zeigen daher in der Regel das Bestreben, das ihnen zu Gebote stehende Licht nach Möglichkeit auszunutzen und bei diesem Bestreben kommt der Pflanze eine andere Wirkung des Lichtes zugute, nämlich der wachstumshemmende Einflu $\beta$ desselben auf die Stengelorgane.

Im Dunkeln gehaltene Pflanzen, z. B. im Keller gehaltene Kartoffeln, treiben Sprosse, die nicht nur der grüren Färbung entbehren, sondern auch sehr rasch in die Länge wachsen und überdies nach einer eventuell vorhandenen Lichtquelle, z. B. einen Kellerfenster zustreben. Aber auch nicht im Dunkehn gehaltene Pflanzen strebrn dem Lichte zu; Zimmerpflanzen wenden sich stets gegen das Fenster. Dieses Streben nach dem Lichte, der Heliotropismus, beruht aber auf dem wachstumshemmenden Einfluß des Lichles auf den Stengel. 


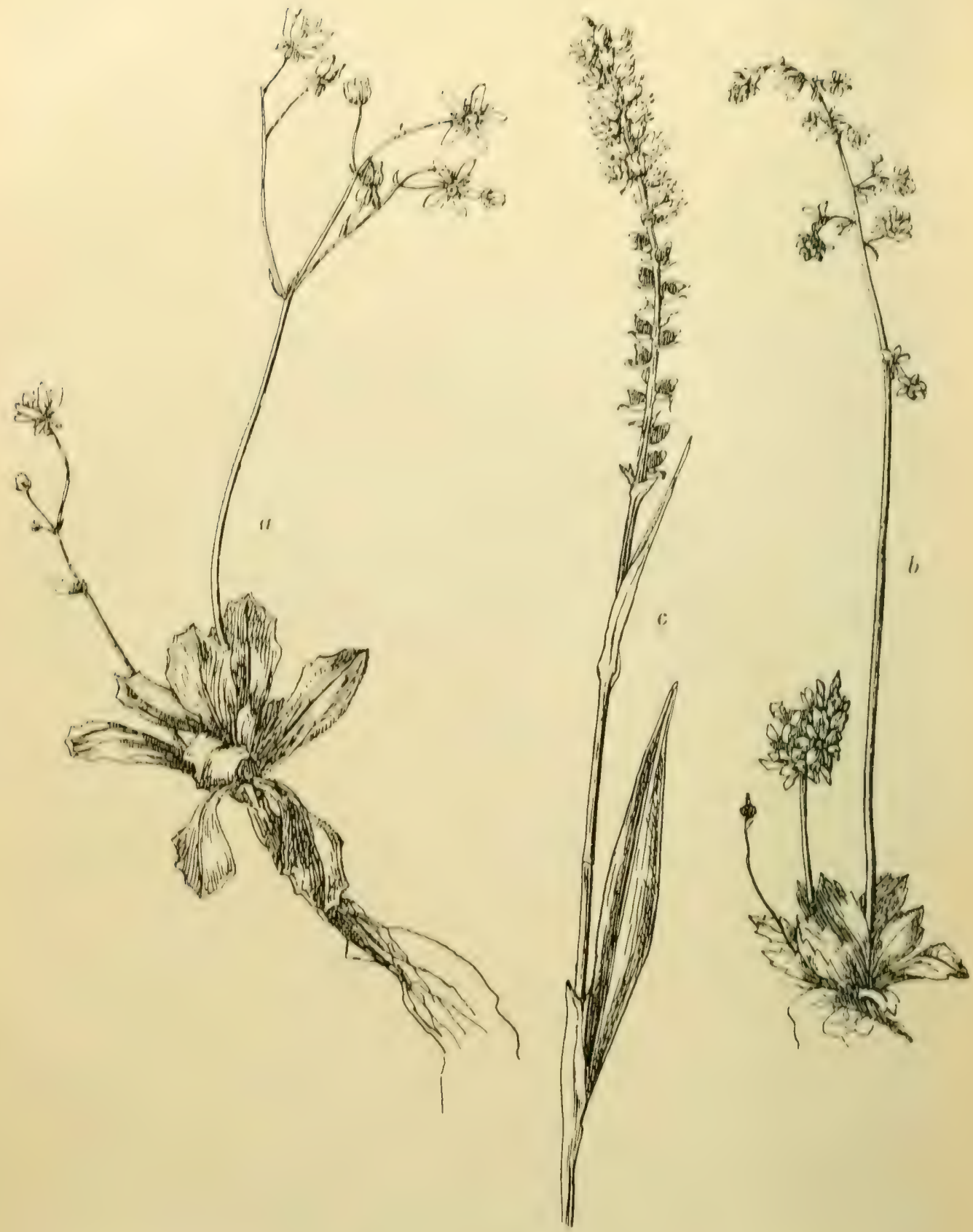

Abl, 1. " Suxifagn stellaris.

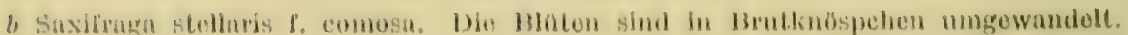

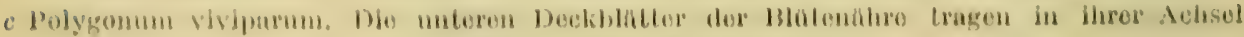

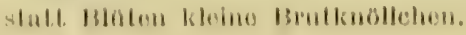




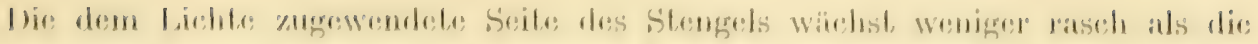

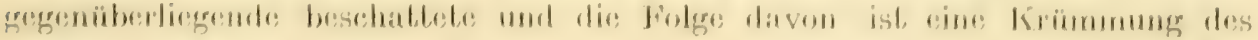
Silengels nach deer lichlscile zol.

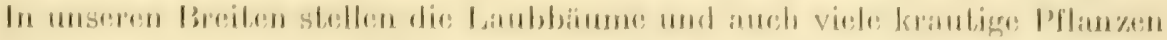

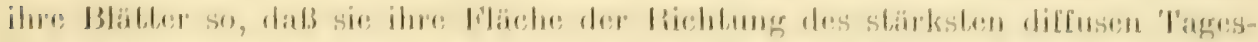

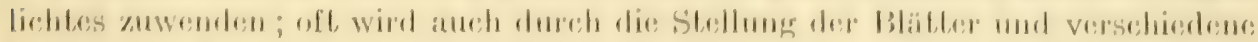

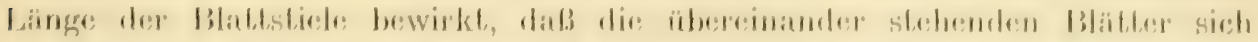

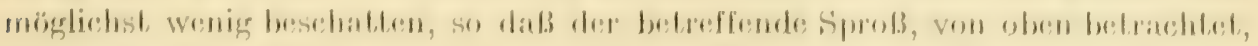

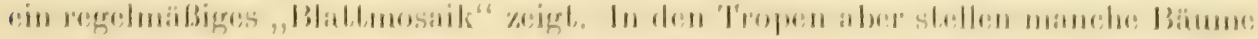

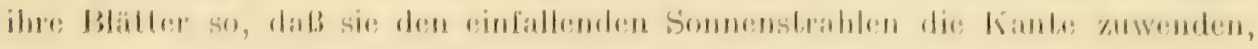

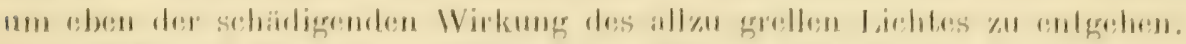

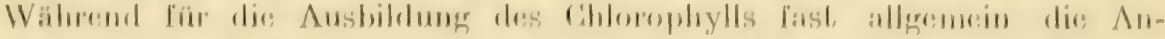

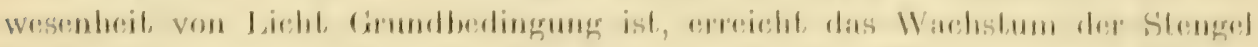

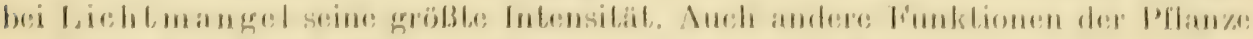

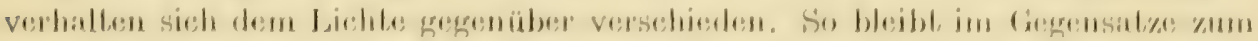

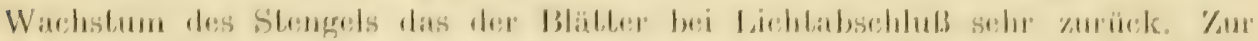

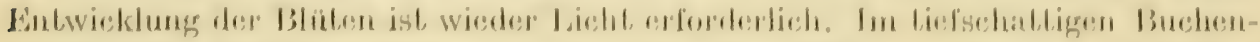

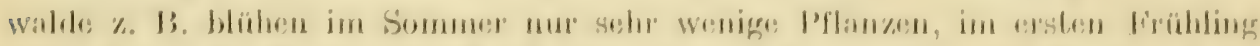

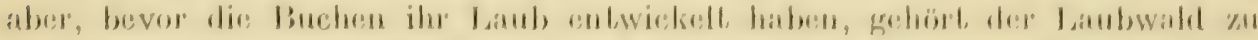

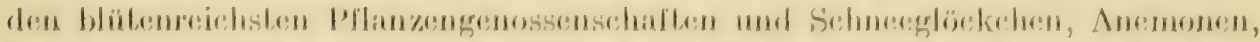

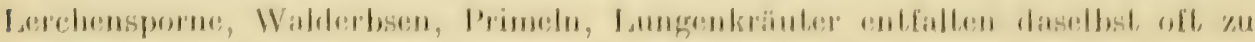

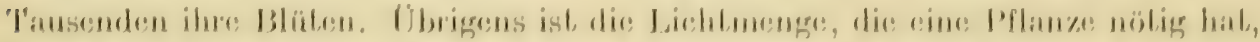

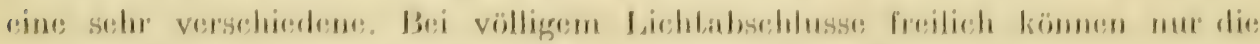

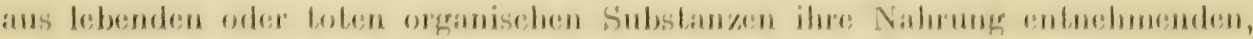

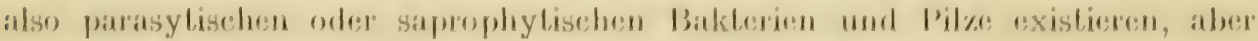

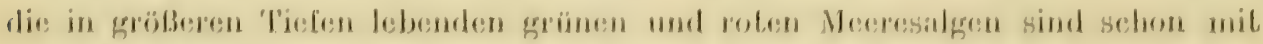

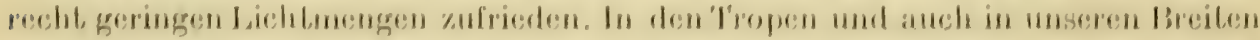

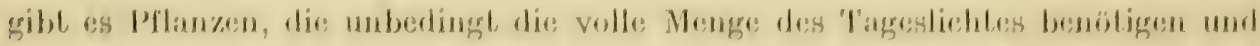

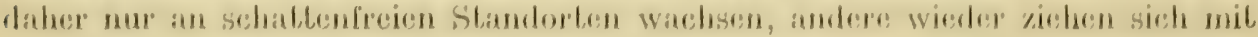

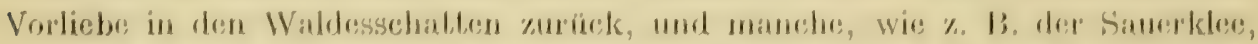

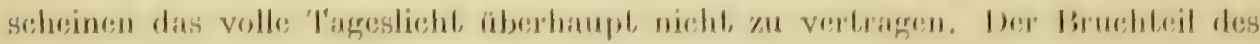

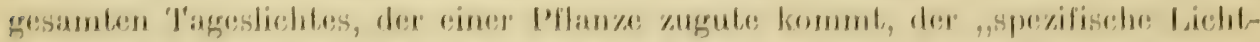

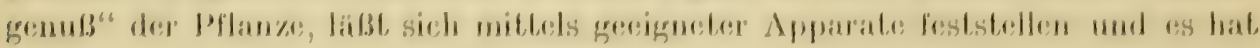

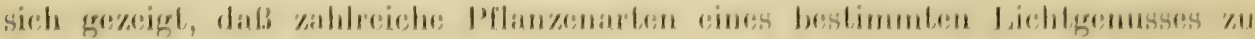
ilnesm Jientkommen bediefers.

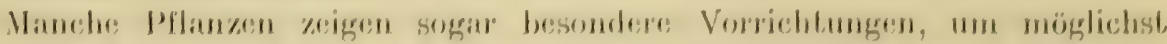

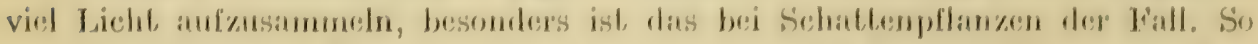

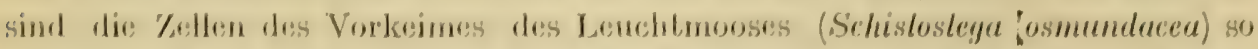

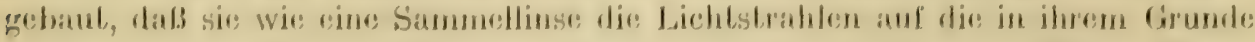

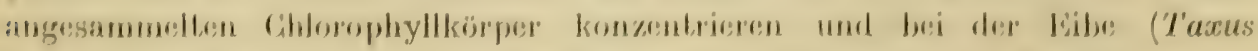

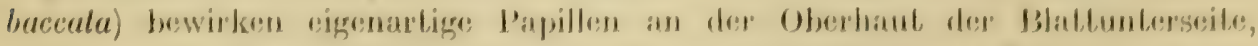

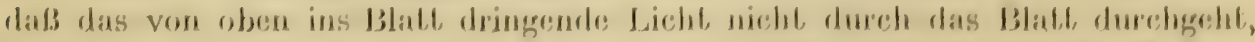

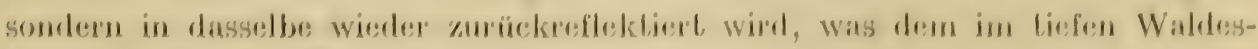

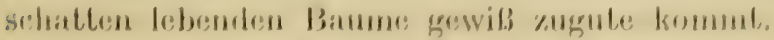


Daß der regelnäBige Wechsel von Tag und Nacht auf das Leben der Pflanze nicht ohne Einfluß ist, ist selbstverständlich. Sämtliche Lebensfunktionen der Pflanze. für die die Anwesenheit von Licht erforderlich ist, werden nur bei Tage sich vollziehen, obwohl eine gewisse Nachwirkung des Tageslichtes beziehungsweise der Finsternis nachweisbar ist; so findet z. B. das stärkste Wachstum nicht in der Nacht, sondern in den Morgenstunden statt. Auch das Schließen vieler Blüten bei Nacht, die Schlafslellung mancher Blätter sind ein Beweis dafür, daß der Wechsel zwischen Tag und Nacht auf das Leben der Pflanze nicht ohne Einfluß ist.

\section{Das Wasser.}

Jede Pflanze bedarf zum Leben einer bestimmten Menge von Wasser. Denn das Wasser ist nicht allein ein wichtiger Bestandteil des Pflanzenkörpers, sondern es dient auch als Lösungsmittel verschiedener Nährstoffe der Pflanze und vermittelt deren Wanderung und Verbreitung durch die ganze Pflanze.

Die Pflanzen nehmen das Wasser in flüssigem Zustande auf - die Farne und Blütenpflanzen hauptsächlich durch die Wurzeln, selten auch durch oberirdische Organe - und geben es dann in gasförmigem Zustande wieder an die Atmosphäre ab, sie ,transpirieren". Diese Wasserabgabe erfolgt nur zum kleineren 'Teil durch die Oberhautzellen beziehungsweise deren Außenwand hindurch - kutikulare Transpiration - hauptsächlich dienen zur Wasserabgabe kleine Öfnungen in der Oberhaut, die ,Spaltöfnungen" - „stomatäre Transpiration". Diese Spaltöffnungen sind von je einem eigenartigen Zellenpare, den ,Schließzellen", begrenzt, welche so gebaut sind, daß sie bei feuchter Luft, wenn sie prall mit Flüssigkeit gefüllt sind, also ihr Turgor steigt, auseinanderweichen und sich so die Spaltöfnung öffnet, wenn aber der Pflanze die Gefahr der Austrocknung droht und der Turgor der Schließzellen sinkit, sich ancinanderlegen und so die Spaltöffnung verschließen. Diese Einrichtung ist von hochgradiger Wichtigkeit für die Pflanze, da sie es ermöglicht, die Transpiration der Pflanze entsprechend zu regulieren.

Für ein gutes Gedeihen der Pflanze ist es unumgänglich notwendig, daß die Menge des aufgenommenen und des abgegebenen Wassers sich das Gleichgewicht halten; wenn das nicht der Fall ist und mehr Wasser abgegeben wird, als zugeführt werden kann, vertrocknet die Pflanze, im entgegengesetzten viel selteneren Falle geht sie ebenfalls, und zwar wegen ungenügender Zirkulation der Nährstoffe, zugrunde.

Ein Vertrocknen der Pflanzen kann demnach zur Ursache haben entweder zu geringe Wasserzufuhr oder zu starke Transpiration; bei reicher Wasserzufuhr und die Transpiration hemmenden äußeren Faktoren muß die Pflanze hingegen imstande sein stark zu transpirieren, um den Überschuß an Feuchtigkeit abgeben zu können.

Ungenügende Wasserzufuhr wird in erster Linie verursacht durch Trockenheit des Standortes, sei es aus klimatischen, sei es aus örtlichen 
Ursachen. In Gegenden mit lange anhaltenden Trockenperioden wird jeder Standort mit der Zeit trocken sein. In regenreicheren Klimaten sind trockene Standorte in erster Linie alle stark wasserdurchlässigen Böden, wie Kies, Sand u. dgl., bei denen das Regenwasser rasch in die Tiefe sickert. Ferner sind trockene Standorte auf der Rinde und den Ästen von Bäumen und Sträuchern, Standorte, die in unseren Klimaten zwar in der Regel nur Moose und Flechten bewohnen, auf denen aber in den 'Tropen auch zahlreiche höhere Pflanzen gedeihen.

Aber auch andere Ursachen können die Wasseraufnahme aus dem Borlen erschweren, so in erster Linie niedere Temperaturen. Wenn das Wasser im Boden sehr kalt, besonders aber natürlich, wenn es gefroren ist, ist die Aufnahme desselben durch die Pflanzen eine sehr geringe oder tatsächlich gleich Null, und daher kommt es, daß, wie oben erwähnt, viele Pflanzen bei eintretender Kälte vertrocknen und daß unsere Pflanzen im Winter Einrichtungen aufweisen, welche die Transpiration auf ein Minimum herabsetzen.

Auch eine stärkere Lösung von Salzen im Wasser erschwert dic Aufnahme desselben ungemein und das ist die Ursache, daß die Pflanzen, welche auf Salzboden und am Meeresstrande gedeihen, einen ähnlichen Bau aufweisen wie die Pflanzen trockener Standorte.

Ähnlich wie die Salze wirken auch die Humussäuren, und das erklärt uns die merkwürdige Tatsache, daß die Pflanzen der Noore, wo doch Wasser in genügender Menge zu Gebote steht, ebenfalls einen Bau aufweisen wie Trockenheit liebende Pflanzen.

Die die Transpiration fördernden äußeren Faktoren sind dieselben, die die Verdunstung überhaupt fördern, demnach also trockene Luft, höhere Temperatur, bewegte Luft, also Winde, und endlich, als auf den höheren Gebirgen ebenfalls in Betracht kommend, verdünnte Luft. Im Gegensatze hierzu wirken dunstgesättigte ruhige Luft und kühle Temperaturen hemmend auf die Transpiration.

Während der anatomische Bau der Pflanze uns nur selten eine Anpassung an bestimmte Temperaturen erkennen läßt und hicr die spezifische Konstitution des Plasmas die Hauptrolle spielt, zeigen die Pflanzen eine große Zahl von Einrichtungen, die die Wasseraufnahme und -abgabe regeln, und zwar sind dies hauptsächlich Einrichtungen, die die Transpiration entweder erleichtern orter erschweren. Doch weisen manche Pflanzen trockener Standorte auch Einrichtungern auf, die die Wasseraufnahme erleichtern. So findet man oft bei Pflanzen, die auf Sand- und Geröllboden wachsen, mächtig entwickelte sehr lange Wurzeln, welche bis in tiefere feuchtere Schichten des Bodens dringen. Auch kommt es vor, daß, was bei niederen Pflanzen, wie bei Algen, Pilzen und selbst bei Moosen, die Regel ist, Pflanzen trockener Klimate oder trockener Standorte auch durch oberirdische Organe Wasser aufnehmen, was meist durch eigens ausgebildete Drüsen oder Haare erfolgt; unter den heimischen Pflanzen ist dies z. B. für die Zistrosen (Cistus) sichergestellt worden.

Viel mannigfacher sind die Einrichtungen zur Regelung der Transpiration; unil zwar weisen speziell Pflanzen trockener Standorte stets irgend welche Ein- 
richtungen zur Einschränkung der Transpiration auf. Die Pflanzen, welche auf trockenen Standorten wachsen, werden als Xerophyten bezeichnet und der Bau derselben, welcher bezweckt, in erster Linie die Transpiration einzuschränken, wird als xerophiler Bau bezeichnet.

Eines der naheliegendsten Mittel, die Transpiration einzuschränken, ist eine entsprechende Verkleinerung der transpirierenden Oberf $\downarrow$ äche, und da die Blätter die hauptsächlich transpirierenden Organe sind, der Blätter. Tatsächlich kann man bei zahlreichen Xerophyten eine starke Verkleinerung der Blattoberfläche beobachten; als Beispiele hierfür mögen die nadelförmigen Blätter unserer Nadelhölzer, Eriken, die schmal linealen Blätter xerophiler Gräser, die walzlichen Blätter unserer Mauerpfefferarten, die schuppenförmigen Blätter des Sadebaumes (Juniperus Sabina) und der Tamarisken dienen. Bei manchen xerophilen Seseli-Arten sind die Blätter in haarfeine Zipfel gespalten und verringern so ihre Oberfläche, auch manche Kompositen, z. B. Centaurea rhenana, Crepis chondrilloides, verkleinern ihre Blattoberfläche durch weitgehende Teilung derselben. Manche Pflanzen, wie z. B. Besenginster und Pfriemen (Sarothamnus scoparius und Spartium junceum), werfen ihre wohl entwickelten Blätter mit Eintritt der heißen Jahreszeit ab. Ja die Reduktion der Blätter kann so weit gehen, daß an Stelle derselben nur kleine häutige Schüppchen vorhanden sind, wie bei den Schachtelhalmen (Equiselum) und den Meerträubelarten (Ephedra). Da aber die Blätter neben transpirierenden auch die wichtigsten assimilierenden Organe sind, in welehen das meiste Chlorophyll aufgespeichert ist, muß diese assimilatorische Tätigkeit dann auf andere Organe übergehen, und tatsächlich sehen wir nicht nur bei Equisetum- und EphedraArten, sondern auch bei Pflanzen, welche noch wohl entwickelte Blätter aufweisen, wie Spartium und Sarothamnus, daß die assimilatorische T'ätigkeit der Blätter von den Stengelorganen übernommen wird, welche, selbst wenn sie holzig sind, eine grüne, chlorophyllreiche Rinde aufweisen (sogenannte Rutensträucher).

Auf andere Eigenschaften im Baue des xerophilen Blattes, besonders die Reduktion der Interzellullarräume und somit des Durchlüftungssystems, siri hier nur kurz hingewiesen. Daß die Spaltöffnungen bei xerophil gebauten Blättern meist gering an ZahI und gewöhnlich nur an der Blattunterseite vorhanden sind, trägt gewiß ebenfalls zur Verminderung der Transpiration bei. Nicht selten kommt es auch vor, daß die Spaltöffnungen nicht direkt ins Freie münden, sondern in Gruben oder Höhlungen des Blattes; so münden sie beim Oleander (Nerium Oleander) in eigene, noch überdies von Haaren ausgekleidete Grübchen auf der Blattunterseite, bei Erica in eine die Blattunterseite der Länge nach durchziehende Rinne, bei Empelrum ist sogar das ganze Blatt nach rückwärts derart umgerollt, daß es einen dasselbe der ganzen Länge nach durchziehenden Hohlraum bildet, der nur durch einen schmalen, noch dazu mit Haaren verwebten Spalt mit der Außenwelt in Verbindung steht, und in diesen Hohlraum münden die Spaltöffnungen. Die Gruben und IJohlräume sind natürlich stets nit Wasserdampf mehr oder minder gesättigt und es wird dadurch erreicht, daß die Spalt- 


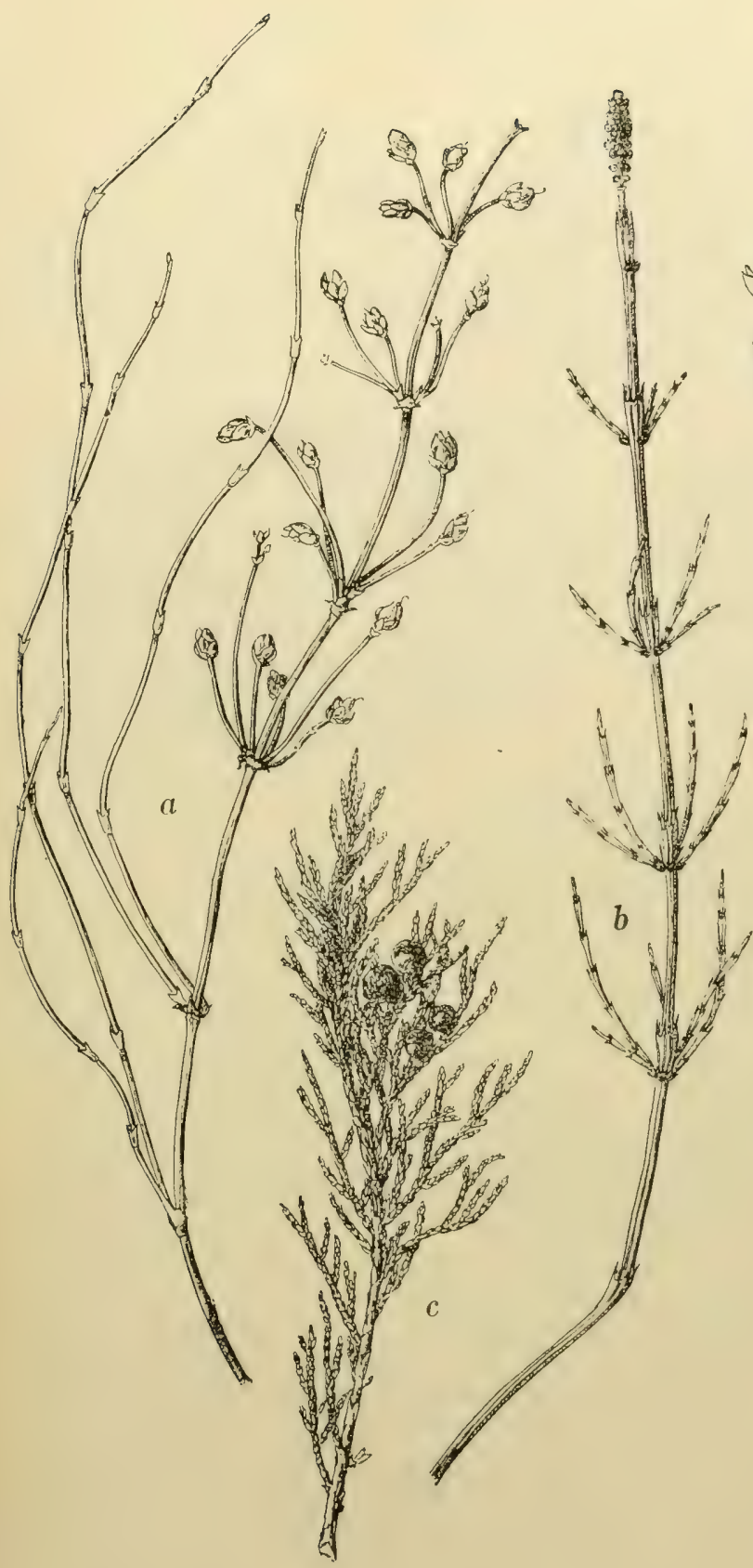

Abb. 2. Xerophil gebaute Pflanzen mit starker Reduktion der Laubblätter.

a Ephedra distachya. Die Blätter sind auf gegenständige Schüppchen an den Stengelknoten reduziert. $b$ Equisetum palustre. Den Laubblättern entsprechen die gezähnten palustre. Den Laubina „Stengelscheiden". $\begin{aligned} & c \text { Juniperus Sab } \\ & \text { schuppenförmig. }\end{aligned}$
Qundu<smiles></smiles><smiles></smiles>

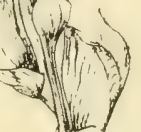

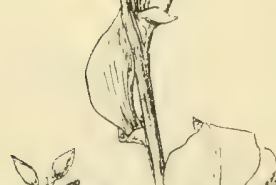
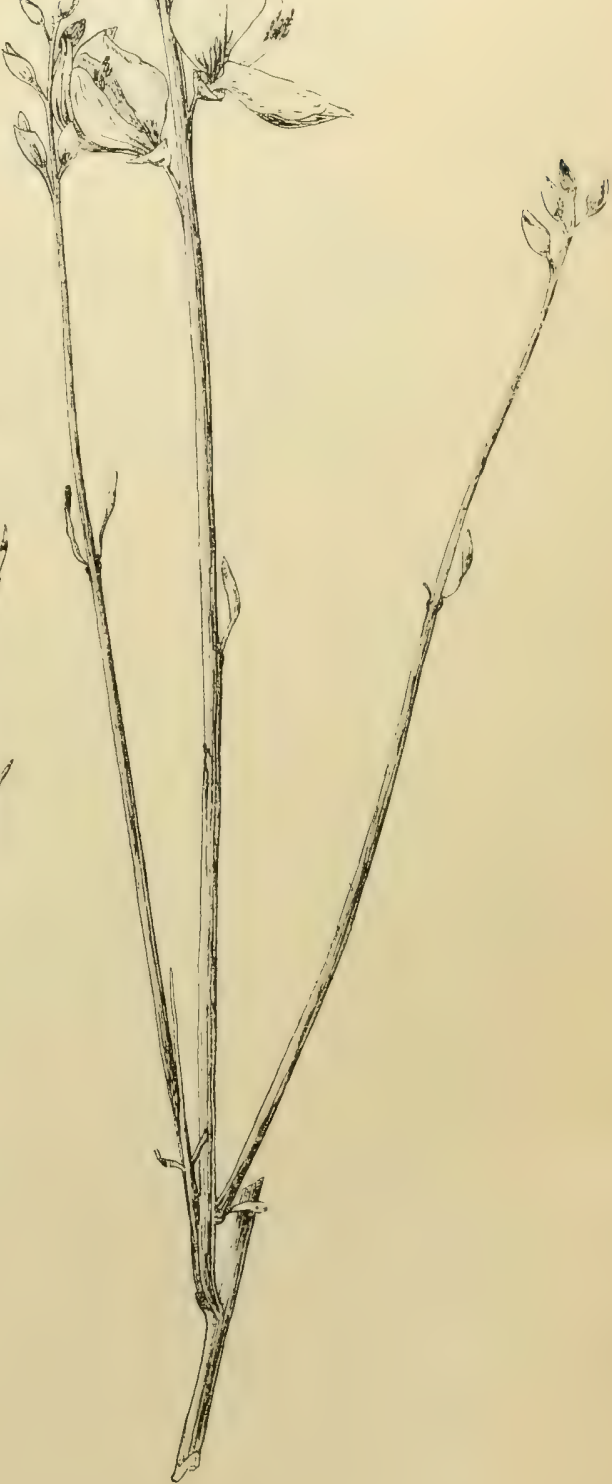

Abb. 3. Spartium junceum.

Ein typischer, ,Rutenstrauch", der" in der trockenen Jahreszeit die Laubblätter abwirft. 

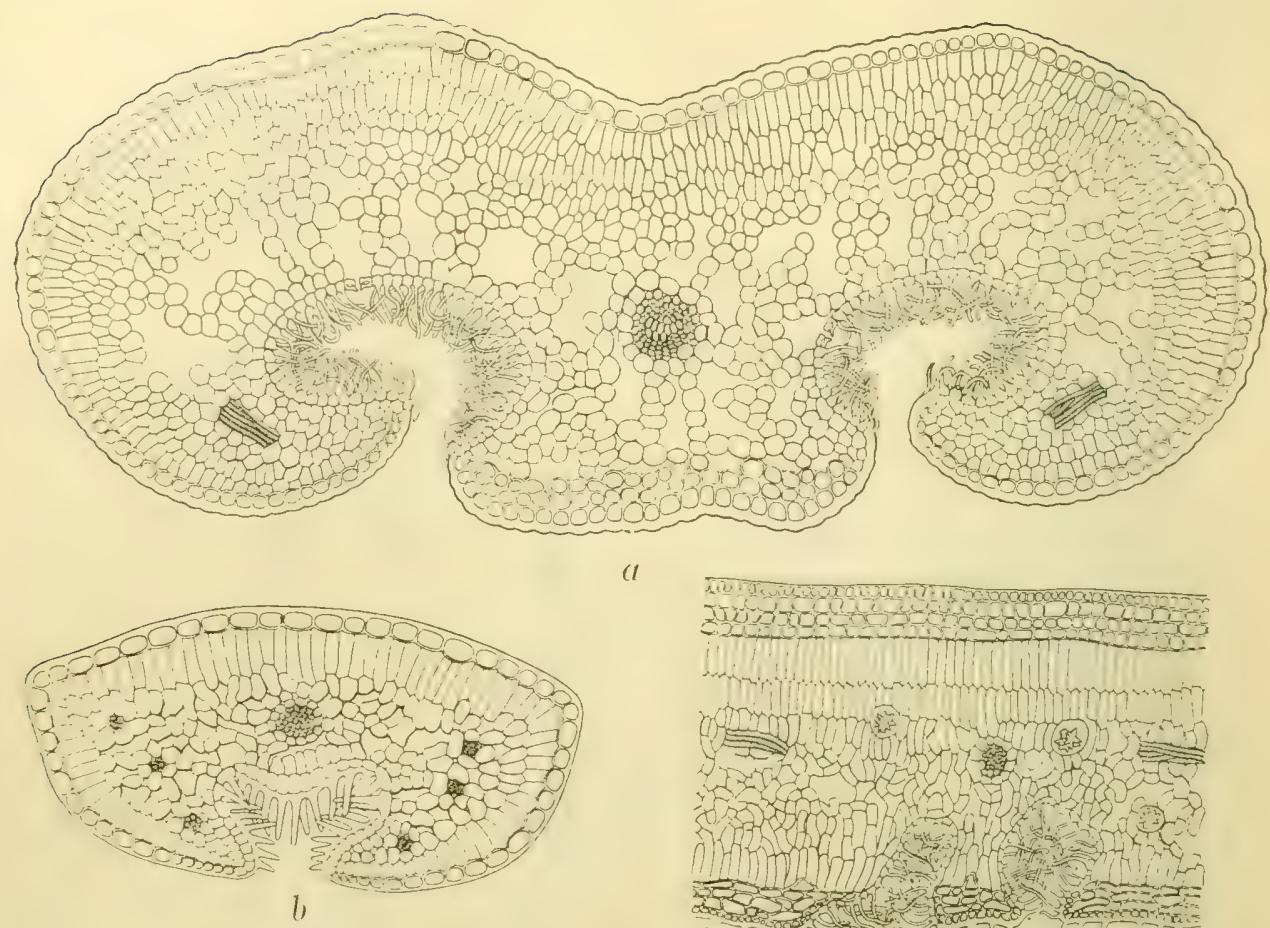

(l
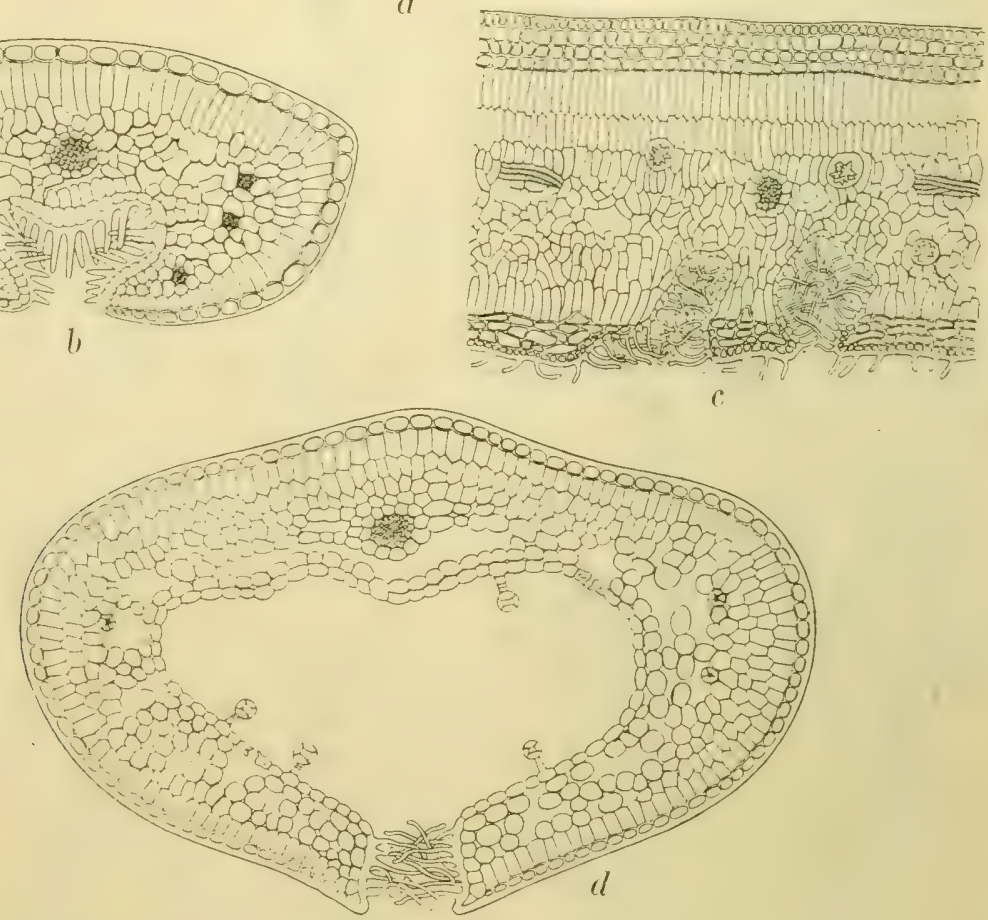

Abb. 4. Querschnitte durch xerophil gebaute Blätter.

a Loiseleuria procumbens. Die Epidermis der Oberseite mit starker Cuticula. Palissadengewebe mächtig entwickelt. Spaltöfnungen nur an der Blattunterseite in mit Haaren ausgekleideten Rinnen. b Erica carnca. Das Blatt ist unterseits von einer dicht mit Haaren ausgekleideten Rinne durchzogen, in die allein die Spaltöffnungen münden. $c$ Nerium Oleander. Unter der Epidermis eine mehrschichtige Hypodermis. Spaltöfnungen nur in dicht mit Haaren ausgekleideten Grübchen an der Blattunterseite. $d$ Enpetrum nigrum (vgl. den Text auf S. 12).

öffnungen nur in mit Wasserdampf gesättigte Räume führen und dadurch die Transpiration erschwert wird.

Andere Schutzeinrichtungen gegen zu starke Transpiration bezwecken in erster Linie die Einschränkung der zu starken Wasserabgabe durch die Zellwand 
durch, also der kutikulären T'ranspiration. Dazu gehört vor allem eine mächtige Verdickung der Kutikula, wodurch das Blatt meist eine mehr oder minder lederige Beschaffenheit erhält, wie das Blatt unserer immergrünen Nadelhölzer, des Lorbeers, der Preiselbeere usw. Auch ein dichter Úberzug mit lufthaltigen Haaren schränkt die Transpiration ganz wesentlich ein, wie dies z. B. bei den Königskerzen, Salbeiarten, BeifuBarten und zahlreichen anderen Pflanzen, vornehmlich aus den Familien der Lippenblütler und Korbblütler der Fall ist. Ein Wachsüberzug der Blätter wirkt ähnlich der verdickten Kutikula transpirationshemmend; mitunter verschließt dann auch ein Wachspfropf zeitweise die Spaltöffnungen, ähnlich wie bei den immergrünen Nadelhölzern die Spaltöffnungen mitunter durch Harz verschlossen sind. Auch die Absonderung reichlicher Mengen ätherischen Öles, wie es bei vielen xerophilen Labiaten und Kompositen der Fall ist, soll die Wasserabgabe einschränken.

Mit diesen Einrichtungen zur Herabsetzung der Transpiration geht sehr oft auch eine stärkere Ausbildung aller mechanischen Gewebe der Pflanze Hand in Hand, auch eine starke Entwicklung von Dornen ist bei vielen Xerophyten zu beobachten.

Ein anderes Mittel, die Wasseraufnahme und -abgabe im Gleichgewichte zu halten, besteht darin, daß die Pflanzen in Zeiten, wo ihnen reichliche Flüssigkeitsmengen zu Gebote stehen, möglichst viel Wasser aufnehmen und in eigenen Geweben aufspeichern. In diese Kategorie von Pflanzen gehören die Sukkulenten, die ,Fettpflanzen“. Man unterscheidet Stamm- und Blattsukkulenten; bei ersteren ist das Wasserspeichergewebe im Stengel entwickelt, während die Blätter ganz fehlen oder stark reduziert sind, bei den Blattsukkulenten hingegen ist das wasserspeichernde Gewebe in den dann meist sehr dicken und saftigen Blättern zu finden. Natürlich kommen auch Formen vor, bei denen Stamm und Blätter sukkulent gebaut sind. Stammsukkulenten sind in unseren Breiten selten, als Beispiel möge das Glasschmalz (Salicornia herbacea) dienen, hingegen sind sie in den subtropischen Wüstengebieten besonders der Gebirge reich vertreten, die Kakteen und die kaktusartigen Euphorbien sind typische Beispiele von Stammsukkulenten. Beispiele heimischer Blattsukkulenten sind die Hauswurz- und Mauerpfefferarten (Sempervivum, Sedum) sowie zahlreiche Arten der Gattung Steinbrech (Saxifraga). Doch finden sich Wasserspeichergewebe auch in Pflanzen, die äußerlich absolut nicht den Charakter von Fettpflanzen haben, so z. B. in den derb lederigen Phyllokladien des Mäusedornes (Ruscus aculeatus).

Gerade die gegenteiligen Eigenschaften wie die Xerophyten zeichnen die Bewohner feuchter Standorte, die Hygrophyten, aus. Hier fallen alle Einrichtungen weg, welche die Transpiration irgendwie behindern könnten, im Gegenteil, es bilden sich viele Eigenschaften aus, welche die Wasserabgabe befördern. Die Blätter sind gewöhnlich groß und von dünner Konsistenz, die Oberhautzellen möglichst dünnwandig, um die kutikuläre Transpiration zu fördern. Die Spaltöffnungen sind zahlreich, oft auf beiden Blattseiten vorhanden, oft treten sogar Spaltöfnungen auf, die die Fähigkit, sich zu schließen, 
völlig verloren haben und aus denen das Wasser nicht nur in gasförmiger Form, sondern auch in Tröpfchen abgeschieden wird, sogenannte Wasserspalten. Eine Behaarung fehlt meist ganz oder besteht aus wenigen oft mit Zellsaft oder Protoplasma erfüllten Haaren. Die Interzellularräume der Blätter sind groß und zahlreich, das Palissadengewebe meist minder mächtig entwickelt.

Das mitteleuropäische Klima, wo die strenge Winterkälte, wie oben erwähnt, den Pflanzen die Gefahr des Vertrocknens bringt, ist der Ausbildung von ausgesprochen hygrophilen Gewächsen nicht günstig. Solche finden sich fast nur unter den einjährigen Gewächsen, die in der feuchten Jahreszeit ihre ganze Entwicklung durchmachen, oder unter zweijährigen oder ausdauernden Pflanzen, die nur mittels niedriger Blattrosetten überwintern und die dann die dichte Schneedecke vor der Vertrocknung schützt. Die hygrophilen Holzgewächse aber sind nur in der feuchteren Jahreszeit, also im Sommer, hygrophil gebaut; im Winter werfen sie die transpirierenden Organe, die Blätter, ab, selbst die Transpirationsorgane des holzigen Stammes, die „Lentizellen", schließen sich, die Knospen sind durch undurchlässige, oft selbst harzige Knospenschuppen vor der Außenvelt geschützt und ein solcher Baum oder Strauch im blattlosen Winterstadium weist dann einen ausgesprochen xerophilen Bau auf. Diesen Wechsel zwischen hygrophilem und xerophilem Bau bieten auch zahlreiche Zwiebel- und Knollengewächse, die nur während der feuchteren Jahreszeit, meist im Frühling, ihre hygrophil gebauten Stengel und Blätter entwickeln, den Winter und oft auch den trockenen heißen Sommer nur mit ihren unterirdischen Organen überdauern. Solche Pflanzen, welche je nach der Jahreszeit xerophile oder hygrophile Anpassungserscheinungen zeigen, hat man als tropophil bezeichnet. Pflanzen, die weder ausgesprochen xerophil noch aber hygrophil gebaut sind, werden auch als mesophil bezeichnet.

Wieder einen ganz andern Bau zeigen die ganz im Wasser untergetaucht lebenden oder nur mit Schwimmblättern versehenen Wasserpflanzen. Da diese durch die ganze Oberfläche Wasser aufnehmen und abgeben, ist der Spaltöffnungsapparat stark reduziert oder fehlt ganz, nur die Schwimmblätter besitzen meist, und zwar auf ihrer Oberseite, Spaltöffnungen. Die Kutikula ist sehr dünn, die Oberhautzellen dünnwandig. Oft sind die Pflanzen zur Verhütung eines zu großen Verlustes von Nährstoffen durch Diffusion mit einer Schleimschicht bedeckt. Bei der geringen Menge des der Pflanze zur Verfügung stehenden, im Wasser gelösten Sanerstoffes ist das Durchlüftungssystem besnnders im Stengel stark ausgebildet. Das mechanische Gewebe ist bei den Bewohnern stehender Gewässer stark rüickgebildet, bei den Pflanzen rasch fließender Bäche und Flüisse hingegen gut entwickelt; letztere weisen auch oft in schmale Zipfel zerteilte Blätter auf.

\section{Die Luft.}

Die Größe des Luftdruckes ist nicht ohne Einfluß auf das Wachstum der Pflanzen. Versuche haben ergeben, daß bei starker Verringerung des Sauerstoffdruckes eine Beschleunigung des Wachstums eintritt, daß ferner eine 
Erhöhung des Luftdruckes auf 21/2 Atmosphären erst eine Verlangsamung, dann aber ebenfalls eine Beschleunigung des Wachstums mit sich bringt. Doch müssen die Änderungen im Luftrucke, die auf das Wachstum der Pflanzen einen merklichen Einfluß haben, so gewaltige sein, daß sie unter natürlichen Verhältnissen auf der Erde kaum irgendwie in Betracht kommen.

Aber in noch ganz anderer Weise äußert sich der Einfluß der Luft auf die Vegetation, nämlich in der Bewegung der Luft. Bewegte Luft, also Wind, wirkt, wie schon oben erwähnt, außerordentlich fördernd auf die Transpiration. Da aber die Schnelligkeit der Luftbewegung über dem Boden nach oben zu rasch zunimmt, sind hochwüchsige Pflanzen, insbesondere Bäume, dem Einflusse rer Winde viel mehr ausgesetzt als niedrige Pflanzen. Da überdies die Bäume infolge ihrer großen transpirierenden Oberfläche der Vertrocknung besonders stark preisgegeben sind, ist es begreiflich, daß Örtlichkeiten, die den Winden besonders stark ausgesetzt sind, wie Meeresküsten, isolierte Berggipfel usw., oft des Baumwuchses entbehren. Auch die obere Grenze eines Baumwuchses im Gebirge überhaupt ist zum großen Teil auf Rechnung der daselbst heftig wehenden Winde zu setzen. Der Wind wirkt überdies auch mechanisch auf den Baumwchs ein und nach der hauptsächlichen Windrichtung gedrehte Äste und Baumkronen sind keine seltene Erscheinung.

\section{E. Die chemische Zusammensetzung des Bodens.}

Bekanntlich entnehmen die grünen Pflanzen ihre organischen Nährstoffe der Luft, indem sie die in derselben enthaltene Kohlensäure aufnehmen und in höher zusammengesetzte organische Verbindungen überführen, sie ,,assimilieren". Der Erde aber entnehmen sie neben dem Wasser und stickstoffhaltigen Verbindungen eine Reihe von anorganischen Stoffen, und zwar sind es Kalium, Kalzium, Magnesium, Eisen, Phosphorsäure und Schwefelsäure, die die Pflanze zu ihrer Ernährung unbedingt braucht, durchwegs Stoffe, die zum mindesten in den für die Pflanze nötigen Mengen überall im Erdboden vorhanden sind. Hingegen sind Kieselerde und Tonerde beziehungsweise die Elemente Silizium und Aluminium, die in den Gesteinen der Erdoberfläche oft so reichlich enthalten sind, für die Pflanze ganz indifferent.

Wenn auch, wie gesagt, die für die Pfianzen nötigen Stoffe überall im Erdboden vorhanden sind, übt doch die chemische Zusammensetzung des Bodens einen nicht unbedeutenden Einfluß auf die Verteilung der Gewächse aus. Die wichtigste, Rolle spielt in dieser Hinsicht der Kalk. Obwohl alle Pflanzen zu ihrem Fortkommen einer geringen Menge von Kalk unbedingt bedürfen, gibt es doch eine große Menge Arten, die nur auf scheinbar kalkfreiem, d. h. nur geringe Spuren von Kalk enthaltendem Boden fortkommen, ausgesprochene Kalkbodin aber unbedingt meiden — ,kalkscheue ${ }^{6}$ Pflanzen, oder weil sie demnach mit Vorliebe auf kieselhaltigem Boden vorkommen —, ,kieselholde" Pflanzen. Andere Arten treten wieder nur auf kalkreichem Boden auf und fehlen auf Silikatgestein, kalkfreiem Sandstein usw. - kalkstete oder Kalkpflanzen.

H ayek, Die Pflanzendecke Österreich-Ungarns, I. 
Pflanzen, die Kalkboden entschieden bevorzugen, aber ab und zu auch auf kalkfreiem Boden erscheinen, werden als kalkliebend, solche, die Kieselboden bevorzugen, aber auch einen gewissen Kalkgehalt vertragen, als kieselliebend bezeichmet. Bekanntere Beispiele aus der heimischen Flora sind: für kalkscheue Pflanzen (Kieselpflanzen): Asplenium seplentrionale, Deschampsia flexuosa, Armeria elongata, Jasione montana; für kalkstete Pflanzen: Dryopteris Robertiana, Sesleria varia, Valeriana saxatilis, Amelanchier ovalis; für kalkliebende Pflanzen: Fagus silvatica, Gentiana ciliata, Scabiosa ochrolenca; für kieselliebende Pflanzen: Nardus stricta, Vaccinium Myrtillus, Calluna vulgaris. Eine große Zahl von Pflanzen ist übrigens gegenüber dem Kalkgehalte des Bodens ganz indifferent und kommt ebenso häufig auf Kalk als auf kristallinischen Schiefern oder auf Sandstein vor, z. B. Asplenium Rula muraria, Anthoxanthum odoratum, Ranunculus acer, Campanula persicifolia, Crepis biennis. Eine dicke Humusdecke vermag den Einfluß des Kalkbodens übrigens oft ganz einzudämmen und so kommt es, daß auf Humus auch kalkscheue Pflanzen auf Kalkboden vorkommen. Mehr noch als in tieferen Lagen macht sich der Einfluß des Kalkgehaltes des Bodens im Hochgebirge bemerkbar, es mag das vielleicht darauf zurückzuführen sein, daß dort die Pflanzen viel mehr mit dem anstehenden Gestein direkt in Berührung kommen. Der Einfluß der chemischen Zusammensetzung ist im Gebirge ein so großer, daß die ganze Vegetation auf Kalk und auf Urgebirge eine andere Zusammensetzung aufweist und nur wenige Arten (in den Alpen z. B. Carex sempervirens, Poa alpina, Ranunculus monlanus, Potentilla aurea, Bartschia alpina, Crepis aurea) auf Kalk und Schiefer gleich häufig sind. Viele alpine Arten haben sich in Parallelrassen gespalten, von denen die eine kalkhold oder kalkstet, die andere kalkmeidend ist; so z. B. sind Poa minor, Dianlhus alpinus, Anemone Burseriana, Gentiana Clusii, Achillea atrata Kalk-, Poa laxa, Dianthus glacialis, Anemone alba, Gentiana Kochiana, Achillea moschata Kieselpflanzen.

Zweifellos spielt jedoch nicht allein die chemische Zusammensetzung der Gesteine allein eine Rolle bei ihrem Einflusse auf die Verteilung der Gewächse. sondern auch noch ihre Wasserdurchlässigkeit und ihre größere oder geringere Fähigkeit, die Wärme zu binden. So ist es zu erklären, daß z. B. die Mannaesche (Fraxinus Ornus), die ím wärmeren Süden auf jederlei Gestein gedeiht, an der Nordgrenze ihres Verbreitungsgebietes nur auf Kalk vorkommt, daß das Federgras (Slipa pennata) in manchen Gebieten zwar die kristallinischen Schiefer und Sandsteine meidet, aber nicht nur auf Kalk, sondern auch auf kalkfreien Basalten auftritt.

Übrigens muß hervorgehoben werden, daß manche Pflanzen in verschiedenen Gebieten sich bezüglich ihres Verhaltens zur chemischen Zusammensetzung des Bodens verschieden zeigen. So kommen Sesleria disticha und Carex curvula in den Alpen nur auf kalkfreiem Boden (oder eventuell auf einer sehr dichten Humusschicht über Kalk) vor, während sie in den Karpathen auf Sandstein, Schiefer und Kalk gedeihen. Minuartia laricifolia und Saxifraga cuneifolia sind in den Westalpen ausgesprochene Kieselpflanzen, in den Ostalpen kommen 


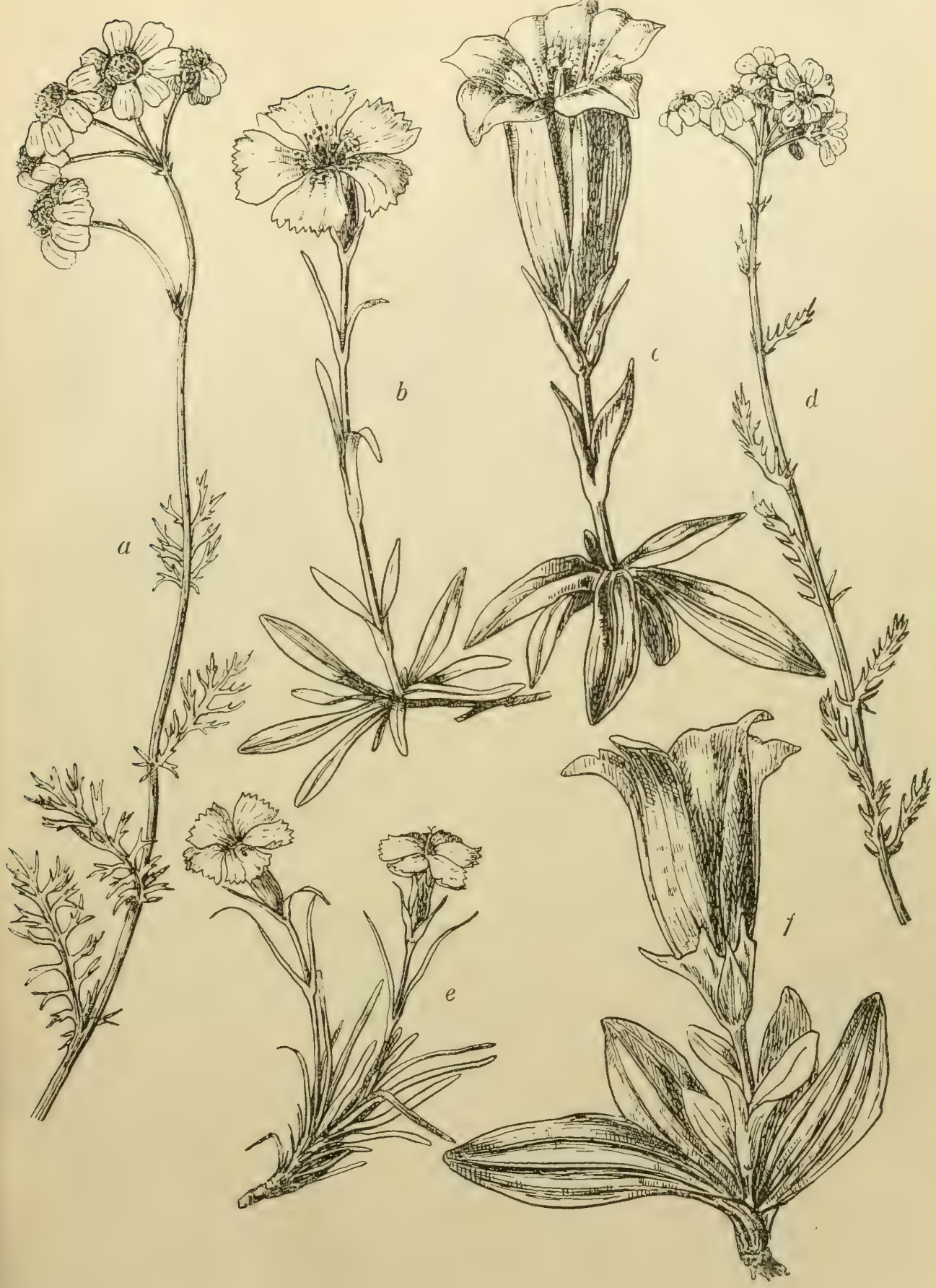

Abb. 5. Kalkstete und kalkmeidende Parallelrassen aus der Alpenflora.

$a$ Achillea atrata. $b$ Dianthus alpinus. $c$ Gentiana Clusii. $d$ Achillea moschata. $e$ Dianthus glacialis. $f$ Gentiana Kochiana. $a-c$ sind Kalk-, $d-f$ KKieselpflanzen. 
Der Einfluß von Klima und Boden.

sie ausschließlich im Kalkschutte bezichungsweise an Kalkfelsen vor; Pedicularis Oederi hingegen ist in den Westalpen Kall-, in den Ostalpen Schieferpflanze.

Von den übrigen den Boden zusammensetzenden Gesteinen üben nur wenige einen merklichen Einfluß auf die Vegetation aus. In erster Linie der Serpentin, auf dem zwei dieson eigentümlich Farne, Asplenium adulterinum und A. cuncifolium (ersterer ïbrigens anch auf Ifagnesit beobarhtret) gedeihen; anch Sempervivum Pitlonii und Polentilla Serpentini wurden bisher ausschließlich auf Serpentin beobachtet; (ndlich in unseren Brwten (nicht aber weiter südlich) auch der Farn Nolochlaena Marantae. Thlaspi alpestre, T. goesingense, Armeria elongata und (in Bosnien) Silene Armeria treten ebenfalls gern (aber nicht ausschließlich) auf Serpentin auf. Endlich wäre der zinkhaltige Boden (Galmei) zu erwähnen, dem (in Kärnten) Thlaspi cepaeaefolium eigentümlich ist.

Von besonderem Interesse ist ferner jener Boden, der eine größere Menge leicht löslicher Silz" besonders von liochsalz, kohlensaurem, salpetersaurem und schwefelsaurem Natron enthält, wie er sich einerseits in der Umgebung von Mincralquellen, anderseits aber oft in großer Menge im Tieflande findet, wozu endlich auch der Meeresstrand gehört. Dies ist die Ifeimat der eigentlichen Salzpflanzen. Es ist schon oben erwähnt worden, daß ein größerer Salzgehall des Bodens die Aufnahme von Flüssigkeit aus demselben außerordentlich erschwert und daß demnach die eigentlichen Salypflanzen alle xerophil gebaut sind. Aber auch von den xerophil gebauten Pflanzen sind nur wenige befähigt auf Silzborlon zu gedeihen; salzhallige Stellen, Mecresufer usw. wrisen allenthalben wine sehr charakteristische Florat auf. Teils sind es Pflanzen, die nur auf salzhaltigem Boden vorkommen, die ,obligaten Halophyten", fast durchwerss xerophil gebaute Arten, wie z. B. Carex hordeislichos, Aster Tripolium und die Mehrzahl der Slalice-Arten, vielfach sogar Sukkulenten, wie Salicornia herbacea, Spergularia media, Lepidium crassifolium; teils aber auch Arten, die sonst, auch auf salzfreiem Boden auftreten, die aber im Gegensatze zur Mehrzahl der anderen Gewärhse auch salzhaltigen Boden vertragen, die sogenannten fakultativen II alophyten, wie z. B. Scirpus marilimus, Schoenopleclus Tabernaemontani, Melilolus denlalus, Trifolium fragiferum, Lolus tenuis, Malricaria Chamomilla.

Endlich ist auch der Gehalt des Bodens an organischen stickstoffhaltigen Stoffen nicht ohme Einfluß auf die Vegetation. Eine große Zahl von Pflanzen ist aul cime gewisse: Mrenge dieser Stoffe angewiesen und gredeiht auf stickstoflarmen, "mageren" Böden nicht. Andere wieder nehmen mit dem magersten Sand- und (reöllbuden vorlich. Woch gibt es auch Pflanzen, denen ein Boden mit viel stickstofferehen Nährstoffen direkt verterblich wird, und gerade die Wiesenkultur mil ihrer regelmälbigen I) üngung hat goveigl, daß es cine lisihe von Pflanzenaten gribl, die bei reichlicher 1) üngung vollkommen verschwinden. J)azu gehören \%. B. von dru (irisern Bromus erectus und Molinia coerulea, ferner die „Sauergräser", d. i. die Carex-Arten des nassen Bodens. Hierher gehören ferner die Lypischen Ifeidepflanzen, wie Calluna, Corynephorus, sowie dic Mehrzahl 


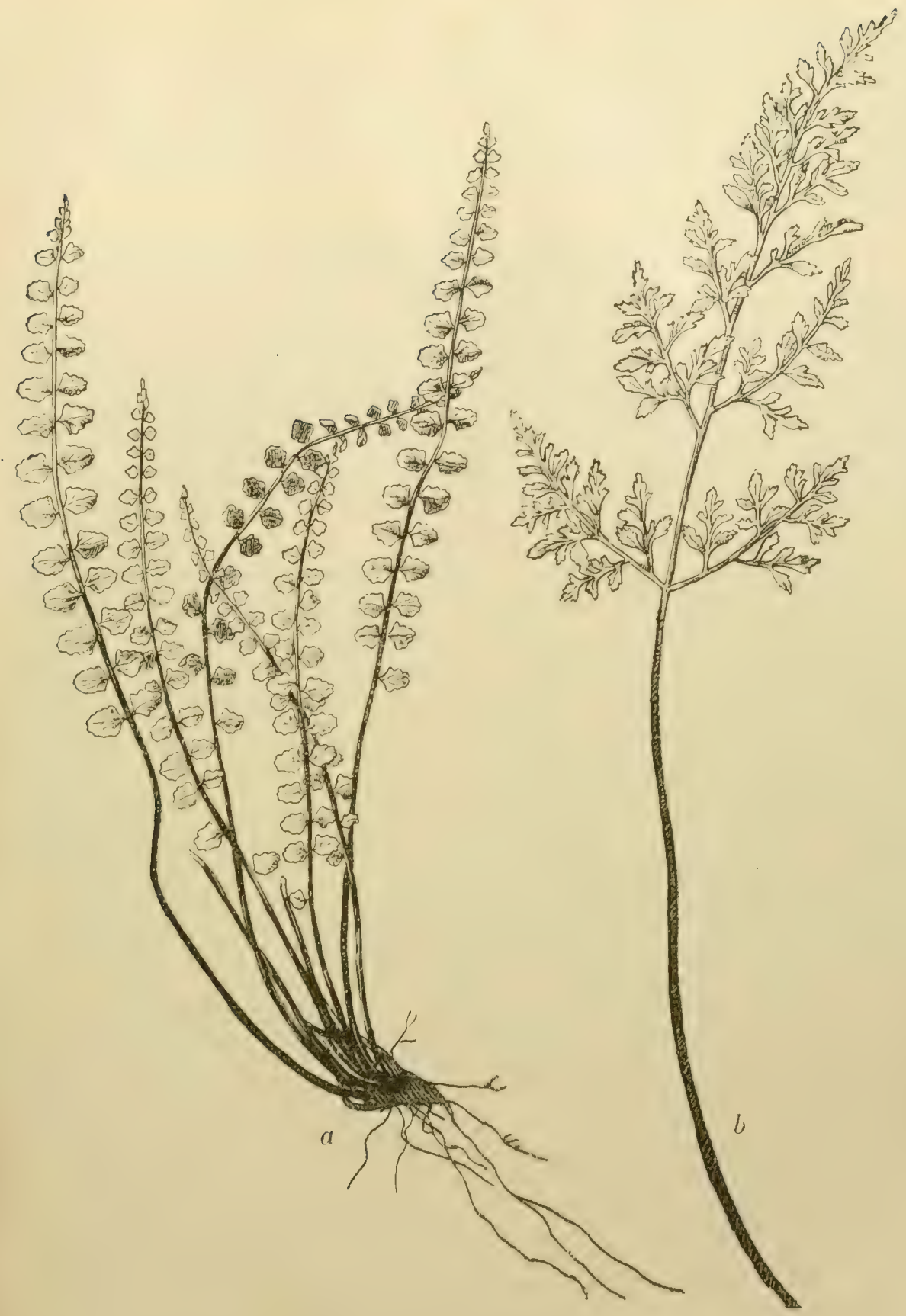

Abb. 6. Zwei Serpentinfarne.

$a$ Asplenium adulterinum. $b$ Asplenium cuncifolium.

der Orchideen, Filipendula hexapetala, Centaurea Scabiosa u. a. Auch die Mchrzahl des Leguminosen tritt gern auf nährstoffarmen, magerem Borleu auf; dies rüht daher, daß diese an ihren Wurzeln sogenannte WVurzellnöllchen 
Der Einfluß von Klima und Boden.

tragen, welche aus Bakterien zusammengesetzt sind, die imstande sind, den reinen Stickstoff der Bodenluft in Verbindungen überzuführen, die auch höhere Pflanzen ausnutzen können, welche bekanntlich nicht imstande sind, den reinen Stickstoff in Nährstoffe überzuführen. Dies ist der Grund, weshalb vielfach Leguminosen (insbesondere Lupinus-Arten) zur "Verbesserung des Bodens" kultiviert werden.

\section{F. Die physikalische Beschaffenheit des Bodens.}

Eine sehr wichtige Rolle spielt bei der Verteilung der Pflanzen auf der Erde auch die physikalische Beschaffenheit des Bodens. Nackter Felsboden ist für höhere Pflanzen unbewohnbar und nur Algen und Flechten können auf einem solchen gedeihen. Aber gerade die letzteren sind es, die die Verwitterung des Gesteins beschleunigen helfen, und auf den aus dem Verwitterungsprodukten des Steines und den abgestorbenen Flechten gebildeten Detritus können sich dann Moose ansiedeln, welche zur ersten Humusbildung führen, auf dem dann höhere Gewächse ihr Fortkommen finden.

Von großer Bedeutung ist die Wasserdurchlässigkeit des Bodens. Stark wasserdurchlässiger Boden, wie zerklüftetes Gestein und Schotter, sind stets, auch in den niederschlagsreichsten Klimaten, trockene Standorte, auf denen nur xerophile Pflanzen vorkommen. Feine Sandböden sind schon günstiger, da vermöge der Kapillarität wenigstens in einer gewissen Tiefe Feuchtigkeit zurückgehalten wird. Die günstigsten Feuchtigkeitsverhältnisse bietet der Humus auf einer wasserdurchlässigen Unterlage; der Humus hält reichlich Feuchtigkeit zurück, doch findet durch den durchlässigen Untergrund ein reger Wechsel des im Boden enthaltenen Wassers statt. Wo aber in geringer Tiefe eine wasserundurchlässige Schicht liegt, sammelt sich das Grundwasser über dieser an, und wenn der Boden nicht geneigt ist, stagniert dasselbe, und auf solchem Boden wird der Sauerstoff rasch verbraucht, es bilden sich Humussäuren und selbst Fäulnisstoffe, der Boden wird, ,sauer".

Abgesehen vom Wassergehalte, spielt aber auch die Wärme des Bodens eine Rolle. Die Wichtigkeit der Bodenwärme wurde schon oben bei der Besprechung der Wasseraufnahme aus dem Boden kurz erwähnt. Wenn auch die gestaltende Rolle der Bodenwärme noch wenig bekannt ist, so ist es doch sicher, daß viele Pflanzen eine viel stärkere Erniedrigung der Lufttemperatur als der Bodentemperatur ertragen. Die Quellen der Bodenerwärmung sind in erster Linie die Sonnenwärme, eine geringere Rolle spielen chemische Vorgänge im Boden und vielleicht auch die Eigenwärme der Erde. Die Wärmekapazität der Böden ist nach ihrer chemischen Natur verschieden, Quarzsand wird am leichstesten, Kalk und Ton weniger, Torf am schwersten erwärmt. Auch erwärmen sich dunkle Böden leichter als helle (daher die hohe Temperatur schwarzer Basaltfelsen), fester Boden rascher als poröser und stark lufthaltiger, wasserreicher schwerer als trockener, doch hält ersterer die Wärme länger fest.

Eine wichtige Rolle spielt endlich auch die Mächtigkeit des Bodens, d. h. die Decke der losen Bodenschichten über dem festen Fels und man unterscheidet 
demnach flachgründigen und tiefgründigen Boden. Auf flarhgründigem Boden können nur Pflanzen mit wenig tiefgehendem Wurzelsystem gedeihen, es fehlt demnach meist der Baumwchs, auch ist der Feuchtigkeitsgehalt des flachgründigen Bodens viel mehr von der herrschenden Witterung abhängig, er trocknet in regenarmer Zeit leicht aus und trägt demnach meist eine xerophile Vegetation.

\section{G. Die Einwirkung der Tiere und des Menschen auf die Vegetation.}

Bei den zahllosen Wechselbeziehungen zwischen Tieren und Pflanzen ist es begreiflich, daß die Tierwelt nicht ganz ohne Einfluß auf die Zusammensetzung der Pflanzendecke ist. Doch ist dieser Einfluß kein allzu großer und beschränkt sich in unseren Breiten hauptsächlich auf drei Momente: die Ausbildung von Schutzmitteh gegen Tierfraß, die Anpassung an die Vermittlung der Befruchtung durch T'iere und endlich die Verbreitung der Samen durch Tiere.

Schutzmittel gegen Tierfraß weisen gar viele Pflanzen auf. Als solche Schutzmittel können angesehen werden: Ausbildung von Dornen oder Brennhaaren (Disteln, Brennesseln), Ausbildung von Giftstoffen (Euphorbia), von bitteren oder sonst schlecht schmeckenden Stoffen oder starker Reichtum an mechanischen Geweben. Doch wirken alle diese Schutzmittel fast nur gegen Säugetiere, gegen Insektenfraß sind die Pflanzen meist wehrlos. Bemerkenswert ist, daß in trockenen Klimaten mit spärlicher Vegetation die Schutzmittel gegen Tierfraß meist weit zahlreicher sind als in feuchten Klimaten mit reichem Pflanzenwuchs; so ist dies z. B. bei uns im Bereiche des Mittelmeerklimas der Fall.

Die Befruchtung dex Pflanzen geht in zahlreichen Fällen nur durch Vermittlung der Insekten (in den Tropen auch von Vögeln) vor sich. Die zahllosen Anpassungserscheinungen in dieser Hinsicht zu schildern, ist Aufgabe der speziellen Blütenbiologie. Doch ist es begreiflich, daß Pflanzenarten, die bezüglich der Befruchtung an ganz bestimmte Insektenformen angepaßt sind, auch nur dort gedeihen beziehungsweise sich vermehren können, wo diese betreffende Insektenart vorkommt. So deckt sich z. B. das Verbreitungsareal der Gattung Aconitum mit dem der Hummeln.

Was die Verbreitung der Samen (beziehungsweise Früchte) betrifft, erfolgt selbe vielfach durch den Wind, das fließende Wasser oder durch besondere Ausstreuvorrichtungen der Früchte, in nicht wenigen Fällen aber auch durch Tiere. Dies kann dadurch geschehen, daß die Samen respektive Früchte mit Widerhaken und ähnlichen Vorrichtungen versehen sind und so am Felle oder Federkleide der Tiere hängen bleiben und durch sie verschleppt werden (Klettfrüchte). Aber auch Tiere, die Früchte als Nahrungsmittel aufspeichern, tragen zur Verbreitung derselben bei, so Hamster, Eichhörnchen, Mäuse und auch Ameisen. Endlich dienen viele Früchte Tieren zur Nahrung und werden die Samen derselben in noch keimfähigen Zustande mit dem Kote der Tiere aus 
geschieden und so weiter verbreitet; dies ist z. B. bei zahlreichen Beerenfrüchten durch die Vögel der Fall.

Der Einfluß des Menschen ist noch weit mannigfaltiger. Abgesehen davon, daß der Mensch ebenso wie die Tiere zur Verbreitung der Samen beitragen kann, übt er noch in mannigfacher anderer Weise bewußt oder unbewußt einen mächtigen Einfluß auf die Pflanzendecke aus: Durch Ausschlagen von Wäldern, Truckenlegen von Sümpfen usw. werden natürliche Pflanzenbestände vernichtet oder verändert. Durch Anlagen von Feldern, Gärten usw. werden neue Pflanzenbestünde geschaffen. Absichtlich oder unabsichtlich werden neue Pflanzenarten eingeführt, durch Forstkultur, Wiesenmahd, Beweidung usw. die natürlichen Pflanzenbestände in mannigfachster Weise beeinflußt und verändert. Dies geht so weit, daß in hochkultivierten Gebieten die Vegetation überhaupt nirgends mehr ihr vollkommen ursprüngliches Geprïge zeigt, sondern überall teils mehr, teils weniger stark den menschlichen Einfluß erkennen läßt.

\section{Die Klimate in ihren Beziehungen zur Pflanzenwelt.}

\section{A. Die Wärmezonen.}

Das Klima eines Gebietes ist durch eine ganze Reihe von Faktoren gekennzeichnet: Höhe sowie jährliche und tägliche Schwankungen der Temperatur, Intensität der Sonnenstrahlung, Menge und jahreszeitliche Verteilung rer Niederschläge, Luftdruckverhältnisse, Intensität, Richtung und jährliche Verteilung der Winde, Lufteuchtigkeit usw. Alle diese einzelnen Faktoren kommen, wie oben gezeigt wurde, auch in bezug auf die Pflanzenwelt in Betracht, die wichtigste Rolle aber spielen die Wärme und die durch die Menge des Niederschlages bedingte Feuchtigkeit des Bodens und der Luft.

Bezüglich der Temperatur kann man folgende klimatische Zonen unterscheiden :

1. Die tropische Zone mit einer jährlichen Durchschnittstemperatur von $20-28^{\circ} \mathrm{C}$ und geringen jahreszeitlichen Schwankungen derselben, die oft nur $1-5^{0}$, höchstens $10^{\circ} \mathrm{C}$ betragen und oft geringer sind als die Tagesschwankungen.

2. Die gemäßigte Zone mit einer jährlichen Durchschnittstemperatur zwischen $0^{0}$ und $20^{\circ} \mathrm{C}$. Die jahreszeitlichen Temperaturunterschiede sind meist sehr beträchtlich $\left(8-40^{\circ} \mathrm{G}\right)$. Je nach dem Verhalten der Temperatur in der kühleren Jahreszeit zerfällt die gemäßigte Zone in zwei Unterzonen:

a) die warmtemperierte Zone, in der die Temperatur auch in der kalten Jahreszeit in der Regel nicht unter den Gefrierpunkt sinkt;

b) die kalttemperierte Zone, in der die Temperatur in der kalten Jahreszeit regelmäßig eine Zeitlang unter dem Gefrierpunkte bleibt. 
3. Die kalte Zone, mit einer jährlichen Durchschnittstemperatur unter dem Gefrierpunkte.

Das Gebiet der österreichisch-ungarischen Monarchie liegt mit Ausnahme der obersten Region dés Inchgebirges durchwegs im Gebiete der gemäßigten Zone. Der jährliche Gang der Temperatur bringt es in dieser Zone mit sich, daß auch die Entwicklung der Vegetation einer regelmäßigen periodischen Schwankung unterworfen ist. In der kalttemperierten Zone, der der weitaus größte Teil der Monarchie angehürt, findet im Winter eine vollständige Unterbrechung in der Entwicklung der Vegetation statt. Die sommergrünen Laubbäume werfen ihr Laub ab, zahlreiche ausdauernde Gewächse ,ziehen ein", d. h. sie überdauern die Kälteperiode nur mit unterirdischen Organen, die einjährigen Gewächse überwintern nur als Samen und auch die übrigen Pflanzen stellen ihre Lebenstätigkeit ganz oder fast ganz ein. Auch in den warmtemperierten Gebieten, den Küstengebieten des Mittelländischen Meeres, macht sich eine solche periodische Schwankung in der Entwicklung ler Vegetation bemerkbar. Hier aber ist die winterliche Unterbrechung keine ganz vollkommene, es tritt nur eine Periode unvollkommener Vegetationsruhe ein. Die Mehrzahl der Laubgehölze ist hier immergrün, da die Gefahr der Austroclinung infolge zu starker Transpiration bei kaltem bezichungsweise gefrorenem Boden, aus dem die Wasseraufnahme sehr erschwert wäre, nicht besteht. Auch die übrigen Lebensäußerungen der Pflanzen, Wachstum und selbst Blüten- und Fruchtentwicklung, ruhen nicht ganz, sondern sind nur stark eingeschränkt. Blüht doch z. B. der Erdbeerbaum (Arbulus Unedo) gerade während der kühlen Jahreszeit und auch einjährige Arten kann man mitten im Winter blühend antreffen.

Wieder anders liegen die Verhältnisse im Hochgebirge. Der Umstand, ob die mittlere Jahrestemperatur unter oder über dem Gefrierpunkte liegt, scheint bezüglich der Einwirkung auf die Vegetation von minderer Bedeutung zu sein als die Kürze der Vegetationsperiode. Denn lange nicht die ganze Zeit, in der die Temperatur über dem Gefrierpunkte bleibt, liommt für die Pflanzenwelt in Betracht, es kommt hiervon die ganze Zeit noch in Abrechnung, die nötig ist, um die winterliche Schneedecke zum Schmelzen zu bringen. Und so kann vielfach im Gebirge nur eine Zeit von drei Monaten und etwas darüber als Dauer der Vegetationsperiode in Rechnung kommen. Die Bäume aber brauchen für die volle Entwicklung von Laub, Blüten und Früchten eine längere Vegetationsdauer, und somit ist die Kürze der Vegetationsperiode mit die Ursache für den Umstand, daß im hohen Norden und auf den Höhen der Gebirge der Baumwuchs eine obere Grenze findet. Eine zweite Ursache hiervon ist die geringe Sommertemperatur, da zum mindesten die Laubbäume einer Durchschnittstemperatur von etwa $7 \cdot 5^{\circ} \mathrm{C}$ bedürfen, um ihre Frühjahrstriebe zur Entwicklung zu bringen, eine Temperatur, die währenr des Sommers auf den höheren Gipfeln der Alpen nicht erreicht werden kann. Die dritte und Hauptursache für das Aufhören des Baumwuchses in großen Höhen liegt in der stark austrocknenden Wirkung der IVinde, in Verbindung mit der verdünnten Luft, von del weiter unten die Rede sein wird. 
Auch bezüglich der übrigen Pflanzen macht sich im Hochgebirge die Kürze der Vegetationsperiode bemerkbar. Einjährige Gewächse fehlen fast gänzlich (nur einige Gentiana- und Euphrasia-Arten kommen vor), da es für diese schwer ist, in der kurzen ihnen zu Gebote stehenden Zeit ihre ganze Entwicklung von der Keimung bis zur Samenbildung durchzumachen. Fast ausschließlich sind es ausdauernde Gewächse, die in ihrer Existenz noch nicht bedroht sind, wenn einmal infolge zu frühen Einbruchs des Winters die Samenbildung ganz unterbleibt und auch diese haben oft, wie oben gezeigt, Einrichtungen aufzuweisen, die bei ausbleibender Samenbildung für eine Vermehrung der Art auf vegetativem Wege sorgen.

\section{B. Die Niederschläge und ihre Beziehungen zur Vegetation.}

Wie oben gezeigt wurde, spielt im Leben der Pflanze kein Faktor eine so bedeutende Rolle als das Wasser. Ohne Wasser kann keine Pflanze existieren und der ganze Vegetationscharakter großer Gebiete ist von der den Pflanzen zu Gebote stehenden Wassermenge abhängig. Diese Wassermenge ist aber, abgesehen von den erst in zweiter Linie in Betracht kommenden örtlichen Verhältnissen, direkt abhängig von der Menge, Form und jahreszeitlichen Verteilung der Niederschläge. Denn das Wasser, das den Pflanzen in allererster Linie zugute kommt, ist das. Wasser, das im Boden enthalten ist, und dieses steht in direkter Beziehung zu den jährlichen Niederschlägen; das Niederschlagswasser selbst und der Wasserdampf in der Luft sind für die Pflanze erst von sekundärer Bedeutung.

Dort, wo die jährlichen Niederschlagsmengen zu gering sind, um den Boden wenigstens während der Vegetationszeit feucht zu erhalten, fehlt die Grundbedingung für den Bestand pflanzlichen Lebens, hier können nur vegetationslose Wüsten bestehen. Solche ganz vegetationslose Gebiete sind auf der Erde haum irgendwo anzutreffen, denn auch in den eigentlichen Wüstengebieten fällt ab und zu Regen und es gibt immer noch extrem xerophile Pflanzen genug, die mit der spärlichen Feuchtigkeit im Boden ihr Auskommen finden.

Aber auch dort, wo die Niederschlagsmenge hinreichend ist, um einen Pflanzenwuchs zu ermöglichen, ist die Menge und jahreszeitliche Verteilung der Niederschläge keineswegs gleichgültig in bezug auf den Gesamtcharakter der Vegetation, insbesondere in Hinsicht darauf, ob Wälder oder Grasfluren die herrschende Formation sind.

Die Bäume und die Holzgewächse überhaupt besitzen ein rech verzweigtes, in tiefe Bodenschichten dringendes Wurzelsystem, welches geeignet ist, tiefgelegene Wasservorräte auszunutzen. Anderseits ist ihre transpirierende Oberfläche, die Laubkrone, eine sehr große und ragt in Luftschichten empor, die oft schon sehr der austrocknenden Wirkung der Winde a usgesetzt sind. Der Baum benötigt demnach relativ große Wasservorräte, die aber auch in tieferen Schichten des Bodens aufgespeichert sein können. Dies ist in jenen Gegende $n$ der Fall, wo die Niederschläge im Laufe des Jahres eine bestimmte große Menge 
erreichen, so daß sich in tieferen Bodenschichten ein größerer Wasservorrat ansammeln kann. Ob diese Niederschläge zu einer bestimmten Jahreszeit fallen. ob sie zur Zeit der Tegetationsruhe oder während der Vegetationsperiode zur Erde gelangen, ist gleichgültig; ja, selbst in Gebieten mit einer ausgesprochenen Trockenheitsperiode im Jahre ist Baumwuchs möglich, Voraussetzung ist nur, daß zu irgend einer Zeit im Jahre die Niederschläge so reichlich sind, daß sich in tieferen Bodenschichten ein genügender Wasservorrat ansammeln kann. Für unsere Breiten kann eine jährliche Niederschlagsmenge von etwa $50 \mathrm{~cm}$ als die untere Grenze angenommen werden, bis zu der die Entwicklung von Baumund Strauchwuchs in der Regel noch möglich ist.

Ganz anders verhalten sich die krautigen Gewächse, besonders die Gräser. Bei diesen ist das Wurzelsystem nur schwach entwickelt und dringt nur in die oberen Schichten des Bodens, die bei einer längeren Trockenheit leicht austrocknen. Zur Ermöglichung der Ausbildung von Grasfluren ist es daher nötig, daß die oberen Borlenschichten zur Vegetationszeit ständig feucht erhalten werden, was nur durch wiederholte, wenn auch nur kurz andauernde Regenfälle möglich ist. Hier kommt es auf die absolute Niederschlagsmenge, wenigstens in gewissen Grenzen, nicht an, aber die regelmäßige Wiederholung derselben in kurzen Intervallen ist unerläBlich. In solchen Gebieten, wo also nur die oberen Bodenschichten regelmäßig durchfeuchtet sind, ist ein Baumwuchs unmöglich, außer an solchen Stellen, wo aus anderen Ursachen im Boden größere Wassermengen aufgespeichert sind, wie z. B. an Flußufern. Dies erklärt das Auftreten von Wäldern entlang der Flußufer in ausgesprochenen Grasflurgebieten, die sogenannten Galeriewälder.

Dort, wo der jährliche Niederschlag weder seiner Menge noch seiner zeitlichen Verteilung den obigen Bedingungen entspricht, also zu gering ist, um Baumwchs zu ermöglichen, und auch nicht öfter während der Vegetationszeit fällt, so daß Graswuchs möglich wird, ist die Ausbildung einer geschlossenen Vegetation unmöglich, und nur wenige an extreme Trockenheit besonders angepaßte Pflanzen können hier existieren, es kommt zur Wüstenbildung.

\section{Der Wind als klimatischer Faktor.}

Wenn auch die Menge und zeitliche Verteilung der Niederschläge im Jahre als der wichtigste Faktor angesehen werden muß, der den Vegetationscharakter ganzer Gebiete bestimmt, so kann dieser Vegetationscharakter doch noch bedeutend beeinflußt werden durch den austrocknenden Einfluß trockener Winde.

Dieser Einfluß wird sich in erster Linie in bezug auf den Baumwucls geltemr machen, da einerseits bei den Bäumen infolge ihrer großen transpirierenden Oberfläche die Wasserabgabe eine besonders große ist, anderseits aber die Intensität des Windes schon bei geringer Höhe über dem Erdboden bedeutend zunimmt, und demnach die sich beträchtlich über die Erde erhebenclen Bäume der Wirkung der bewegten Luft besonders ausgesetzt sind. Es ist daher ganz begreiflich, daß in Gebieten, in denen die jährliche Niederschlagsmenge sich 
der unteren Grenze des einen Baumwuchs ermöglichenden Quantums nähert, an Stellen, wo trockene lebhafte Winde herrschen, sich keine Bäume mehr entwickeln können, während in windgeschützter Lage bei gleicher Regenmenge noch hochstämmige Holzgewächse gedeihen.

Den mächtigsten Einfluß aber haben die Winde in bezug auf die obere Grenze des Baumwuchses im Hochgebirge. Wenn auch zugegeben werden muß, daß die Küurze der Vegetationsperiode, eventuell sogar auch die niedrigen Sommertemperaturen, allein schon dem Baumwuchse im Gebirge eine obere Grenze setzen würden, spielt doch die austrocknende Wirking der hier ständig wehenden Winde in dieser Beziehung eine ganz hervorragende Rolle. Hierfür sprechen eine Reihe von Umständen. So hören die Holzgewächse nicht alle in gleicher Höhe auf, sondern an den Waldgürtel schließt sich noch ein Strauchgürtel; in diesem kommen auch noch eine Menge von Waldbäumen vor, sie blühen und fruchten auch noch gut (z. B. Sorbus Aucuparia und die Fichte), aber sie bleiben klein, zwergig, um nicht in höhere Luftschichten, wo die Windwirkung stärker ist, zu geraten, während die ihnen zu Gebote stehende Wärme, sowohl was Dauer als was Intensität betrifft, noch hinreicht, um sie zum Blühen und Fruchtèn zu bringen. Auffallend ist ferner die Tatsache, daß in ein und demselben Gebirgsstocke oft die Baumgrenze nicht auf allen Gipfeln gleich hoch liegt, sondern in Bezichung zur absoluten Höhe der einzelnen Gipfel steht, so daß isolierte Gipfel, die nicht einmal die Höhe der Baumgrenze höherer Nachbarberge erreichen, doch schon baumlos sind, offenbar wieder eine Wirkung des Windes. Oft liegt dic Baungrenze an der dem Wind exponierten West- oder Südseite erheblich tiefer als an der windgeschützten Seite. Endlich ist es eine bekannte Erscheinung, daß in großen Massenerhebungen (Ötztaler Alpen, Dolomiten) die Baungrenz: erheblich höher liegt als auf den gegen den Rand der Ilpen zu gelegenen Ketten, was gewiß nicht darauf zurückgeführt werden kamn, rlaß das Kílima in ersteren ein wärmeres ist, da ja gerade das Entgegengesetzte der Fall ist. Schließlich ist zu bemerken, daß auch alle übrigen IIochalpenpflanzen ausgesprochene Schutzeinrichtungen gegen Trockenheit aufweisen, was, da die Niederschlagsmengen im Hochgebirge keineswegs gering sind, auch nur auf die austrocknende Wirkung der Winde zurückzuführen sein kann.

\section{Die Beeinflussung klimatischer Wirkungen durch edaphische Faktoren.}

Wird der Gesamtcharakter der Vegetation, also in der Hauptsache, ob Wald, Grasflur oder Wüste, durch das Kilima bedingt, so spielen doch noch die durch die örtliche Beschaffenheit des Bodens gegebenen, die sogenannten „edaphischen" Faktoren eine nicht geringe Rolle.

Schon oben wurde erwähnt, daß im Bereich einer Grasflurvegetation sich dort, wo der Boden weithin durchfeuchtet ist, also entlang der Flüsse, Wälder ansiedeln. Ähnliches findet auch in jedenfalls durch klimatische Verhältnisse bedingten Wüstengebieten statt, wo dort, wo Quellen zutage treten, sich Oasen 
finden. Anderseits kann wieder in Waldgebieten stark wasserdurchlässiger Boden, wie Sand, Schotter usw., einen Baumwuchs unmöglich machen oder nur sehr anspruchslosen, xerophil gebauten Bäumen (z. B. Föhren) genügen. Mangelnde Humusbedeckung macht ïberhaupt eine geschlossene Pflanzendecke unmöglich, und Felsen, Geröllhalden usw. sind daher vegetationslos oder beherbergen nur wenige Pflanzen, die in dem in den Spalten und Zwischenräumen angehäuften IJumus wurzeln. Die Mannigfaltigkeit der Pflanzendecke innerhalb beschränkterer Gebiete ist überhaupt nur auf die verschiedenen Licht-, Luft-, Wärme- und Feuchtigkeitsverhälnnisse zurückzuführen, die die Verschiedenheit des Geländen teils infolge der natürlichen Verhältnisse, teils infolge der Eingrife des Menschen bieten.

\section{E. Die Klimate Österreich-Ungarns in ihren Beziehungen zur Vegetation.}

Das Klima ist im ganzen Gebiete von Österreich-Ungarn keineswegs einheitlich. Bekanntlich weist der Osten, Ostgalizien und die Bukowina, ein ausgesprochen kontinentales Klima mit langen strengen Wintern und heißen Sommern auf, während in Vorarlberg schon sich der Einfluß des westlichen atlantischen Kilimas mit geringeren jahreszeitlichen Differenzen geltend macht und im Küstengebiet der Adria heiße trockene Sommer mit regenreichen warmen Wintern wechseln. Auch, abgesehen von diesen Extremen, sind aber die lilimatischen Erscheinungen in den einzelnen Teilen unserer Heimat verschieden. Doch soll hier nicht auf diese Verschiedenheiten vom rein lilimatologischen Standpunkt eingegangen werden, sondern nur insofern, als sie einen ausgesprochenen Einfluß auf die Vegetation haben, und in dieser Hinsicht lassen sich innerhalb ÜsterreichUngarns vier verschiedene Klimate unterscheiden: das mediterrane Klima, das mitteleuropäische Klima, das osteuropäische Steppenklima und das Hochgebirgsklima.

\section{Bas mediterrane Klima.}

Das mediterrane Klima, das in den Küstengegenden des Mittelmeeres herrscht, ist charakterisiert durch heiße trockene Sommer und niederschlagsreiche retativ warme Winter, in denen die Temperatur niemals dauernd unter den Gefrierpunkt sinkt. Die Niederschlagsmengen sind keineswegs gering, im Gegenteil, sie können eine sehr bedeutende Höhe erreichen, fallen jedoch fast ausschließlich im Herbste und Winter, während der Sommer fast regenlos ist.

Das mediterrane Klima charakterisiert sich demnach in pflanzengeographischem Sinne als ein Gehölzklima. Und tatsächlich ist im ganzen Gebiete, soweit die Bodenverhältnisse es gestatten, Baum- oder doch wenigstens Strauchwuchs entwickelt. Wegen der andauernden Trockenheit im Sommer sind aber diese Iolzgewächse fast durchwegs mit Schutzeinrichtungen gegen Trockenheit versehen, sie sind xerophil gebaut; nur die ganz jungen Blätter, die sich noch zur Regenzeit entwickeln, entbehren meist eines Transpirationsschutzes. Anrlerseits 
aber fehlt bei dem Unstande, daß die T'emperatur auch in der kühlen Jahreszeit ïber dem Gefrierpunkte bleibt und überdies gerade in dieser Zeit reichliche Niederschläge fallen, die Gefahr des Vertrocknens und Erfrierens im Winter und damit die Notwendigkeit, das Laub abzuwerfen - die meisten Holzgewächse sind immergrün.

Viel ungünstiger liegen die Verhältnisse für die krautigen Gewächse. Die lange Sommerdüre ist der Entwicklung ausdauernder Stauden und Gräser keineswegs günstig. Zahhreiche einjährige Kräuter sowie Zwiebel- und Knollengewächse blühen im ersten Frühjahre, solange im Boden noch genügend Feuchtigkeit von den Winterregen her aufgespeichert ist, dann aber tritt eine Ruheperiode in der Vegetation während des heißen trockenen Sommers ein, wo nur wenige xerophile Pflanzen blühen. Es fehlen im Nediterrangebiete auch jene Pflanzengenossenschalten, die man als Wiesen bezeichnet, abgesehen von spärlichen, dureh edaphische Verhältnisse ermöglichten Sumpfwiesen, vollständig und neben Holzgewächsen beherrschen einjährige Arten, Zwiebel- und Knollengewächse und xerophile Halbsträucher das Charakterbild der Vegetation.

Nach einer zweiten schwächeren Blüteperiode im Herbste tritt eine zweite Ruheperiode während des Winters ein, dem dann ein überaus blütenreicher Frühling folgt.

Auf die Anpassungserscheinungen der Mediterranpflanzen an das Klima soll bei Besprechung der Mediterranflora genauer eingegangen werden.

\section{Das mitteleuropäische Klima.}

Das mitteleuropäische Klima ist gegenüber dem mediterranen durch zwei Terkmale scharf charakterisiert: Die kalten Winter und die andere jahreszeitliche Verteilung der Niederschläge. Im allgemeinen sind allerdings auch die Sommertemperaturen etwas niedriger als im Mittelmeergebiete, doch ist dieser Unterschied in vielen Gebieten keineswegs so bedeutend, als man anzunehmen geneigt wäre, vor allem aber sind diese r'emperaturunterschiede im Sommer für die Pflanzenwelt von geringer Bedeutung.

Während im Mediterxangebiete gerade in der kühlen Jahreszeit reichliche Niederschläge, und zwar in tropfbarflüssiger, also zur Aufnahme durch die Pflanzen geeigneter Form fallen, demnach im Winter eine Gefahr des Vertrocknens nicht besteht, ist in Hitteleuropa ${ }^{1}$ ) gerade das Gegenteil der Fall. Es wurde bereits oben hervorgehoben, daß niedrige Temperatur dio Wasseraufnahme durch die Pflanze außerordentlich erschwert; geradezu unmöglich ist sie, wenn der Boden hart gefroren ist. Es müssen daher im Winter die Pflanzen gegen jeden stärkeren Feuchtigkeitsverlust geschützt sein. Bei den niedrigen krautign Griächsen besorght diesen Schut\% dis: cinhüllende Schneedecke, welche die Pflanzen von der Außenwelt absperrt; dies ist gewiß in viel höherem Grade die Aufgabe des Schnees als der Kälteschutz, denn obwohl der Schnee ein schlechter Wärmeleiter ist, ist es doch unter demselben infolge seiner niedrigen

1) Unter Milteleuropa ist in diesem Kapitel stets Mitteleuropa mit Ausschluß der Hochgebirgsregion zu verstehen. 
Eigentemperatur recht kalt und gegen kühle Temperaturen empfindliche Gewächse würden trotz der ,warmen" Schneebedeckung erfrieren. Anders steht es mit den hochwüchsigen Pflanzen, die der Schnee nicht ganz bedecken kann. Krautige, hochwüchsige Pflanzen ziehen im Winter ein, d. h. alle höheren Stengel usw. der Pflanze sterben $a b$ und sie überwintert entwerler nur mittels unterirdischer Organe (Wurzelstöcke. Knollen, Zwiebel) oder mit dem Borlen angedrückten und so vom Schnee bedeckten Blattrosetten. Die größte Gefalır des Vertrocknens besteht aber für die Holzgewächse, die vermöge ihrer großen

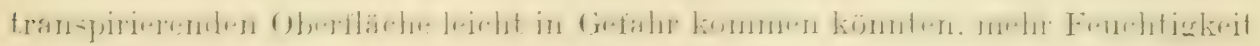
an die Luft abzugeben, als sie durch das Wurzelsystem aufnchmen können. Dies ist der Grund, warum in Mitteleuropa die weitaus größte Mehrzahl der Laubhölzer und unter den Nadelhölzern die Lärche ihre transpirierenden Organe, die Blätter, abwerfen. Die jungen Laubknospen aber sind durch trockene wasserundurchlässige Schuppen geschützt. Diese Knospenschuppen, welche oft aus lufthaltigem oder aus wasserundurchlässigem Korkgewebe bestehen, sind morphologisch entweder Niederblätter, d. h. umgestaltete, am Grunde des jungen

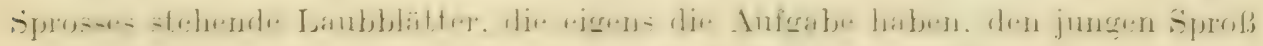
vor Vertrocknung zu schützen, oder es sind Nebenblattbildungen, welche oft bei voller Entwicklung des Blattes abfallen, wie bei der Buche. Oft sind die

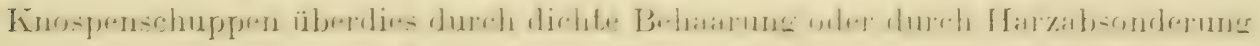
ausgezeichnet, was ihre Wasserundurchlässigkeit nur noch vermehrt.

Jene Holzgewächse aber, die im Winter ihr Laub nicht abwerfen, also die

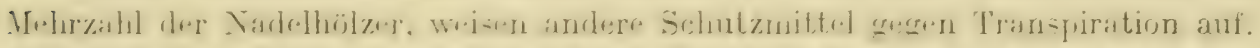

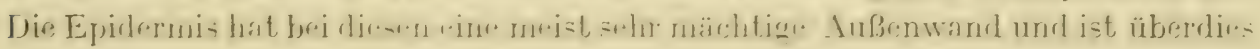
von einer dicken Kutikula bedeckt, so daß die kutikuläre Transpiration so gut wie ausgeschlossen erscheint. Die Spaltöffnungen aber, die relativ in geringer Zahl vorhanden sind, haben einen großen Vorhof, so daß sie in einer tiefen Einsenkung liegen, und der Zugang zu diesem Vorhofe ist besonders im Winter meist noch durch einen Harzpfropf verschlossen. Der Umstand, daß die Nadelhölzer im Winter ihr Laub nicht abwerfen, ist gewiß die Hauptursache des aus-

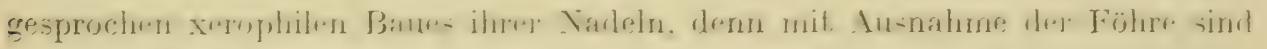
sie keineswegs Bewohner ausgesprochen trockener Standorte.

Aber nicht nur durch die Blätter transpirieren die mitteleuropäischen Bäume und Sträucher, sondern viele haben auch an den Zweigen eigene Transpirationsorgane, die sogenannten Lentizellen. Aber auch diese schließen sich im Winter durch Ausbildung einer eigenen aus Korkgewebe gebildeten Verschlußschicht.

Die Verteilung der Niederschläge während des Jahres ist in Mitteleuropa weit gleichmäßiger als im Mediterrangebiete. Relativ gering ist die Niederschlagsmenge meist im Winter und fällt noch dazu in der Form von Schnee, so $\mathrm{da} B$ er von der Pflanze nicht direkt aus dem Boden aufgenommen werden kann. Da aber die Pflanzen im Winter alle xerophil gebaut bezichungsweise durch die Schneedecke vor zu starker Transpiration geschützt sind, erwächst, dadurch der Pflanze kein Scharlen. Im Frühling, Sommer und Herbst aber 
fällt der Niederschlag meist reichlich, so daß die Notwendigkeit eines Transpirationsschutzes für die Mehrzahl der Gewächse während der Vegetationsperiode entfällt. Die jährliche Menge des Niederschlages schwankt in Mitteleuropa innerhalb sehr weiter Grenzen $(50$ bis über $200 \mathrm{~cm})$, ist aber fast überall genügend, um einen Baumwuchs zu ermöglichen.

Im allgemeinen weisen in Mitteleuropa nur Bewohner trockener Standorte Schutzeinrichtungen gegen zu starke Transpiration auf. Solche trockene Standorte sind z. B. Felsen und bei den Felsenbewohnern treffen wir auch ganz allgemein Einrichtungen, die einem zu großen Wasserverlust der Pflanzen vorbeugen sollen. Typische Sukkulenten sind z. B. die fels- und mauerbewohnenden Sedum-Arten. Dichte filzige Behaarung treffen wir z. B. beim Silberfingerkraut (Potentilla argentea), und zwar nur auf der Blattunterseite, wo sich die Spaltöffnungen befinden, derbes lederiges Laub mit dicker Kutikula haben die Kugelblumenarten (Globularia condifolia und G. Willkommii). Von Sträuchern hat der wollige Schneeball (Viburnum Lanlana) filzige Blätter; bei der Felsenbirne (Amelanchur ovalis) sind die zarten jungen Blätter, die nach oben zusammengefa!tet sind, auf der Unterseite von einem dichten weißen Filz bekleidet, der, sobald das Blatt älter geworden ist und eine dickere Oberhaut und Kutikula erhalten hat, abfällt. Auch die Bewohner von sonnigen, trockenen Stellen, Heiden, Holzschlägen, besonders aber die Pflanzen, die auf stark wasserdurchlässigem Untergrund, wie Sand, Schotter usw., wachsen, zeigen oft sehr auffällige Schutzmittel gegen zu starke Transpiration, so die Königskerzen (Verbascum) filzige Behaarung, das Heidekraut (Calluna vulgaris) kleine, nadelige, fast schuppenförınige Blätter, bei denen überdies die Spaltöffnungen in eine von Haaren ausgekleidete Spalte an der Blattunterseite münden; der Besenginster (Sarolhamnus scoparius), der im trockenen Hochsommer seine Blätter abwirft, ist ein Beispiel für die in Mitteleuropa seltenen Rutensträucher.

Die Gräser trockener Standorte zeigen in ihrem Baue große Ähnlichkeit mit den eigentlichen Steppengräsern, von denen übrigens manche auch bis nach Mitteleuropa vordringen, wie z. B. das bckannte Federgras (Stipa pennata). Die jungen Sprosse sind zumeist durch eine aus den alten Blattscheiden gehildete faserige oder strohartige Hülle, die Stroh- beziehungsweise Fasertunika, vor Austrocknung geschützt, die Blätter gehören dem Typus der ,Falzblätter" an . Diese Blätter zeigen am Querschnitt eine kreisrunde oder ovale Gestalt, in dem das Blatt längs des Mittelnerven nach oben zusammengefalzt ist, so daß die beiden Hälften der Oberseite nur durch einen schmalen Spalt voneinander getrennt sind. Meist nur auf der Oberseite sind Spaltöffnungen vorhanden, so daß diese nur in diesen Spalt münden. Das mechanische Gewebe ist stets reichlich entwickelt. Überdies weisen die Blätter jederseits des Mittelnerven, oft auch noch zwischen den übrigen Nerven in der Oberhaut sogenannte Gelenkzellen (Cellulae bulliformes) auf, die dünnwandig sind und so bei Trockenheit leicht Wasser abgeben und ihren Turgor verlieren, so daß das Blatt sich dann so weit zusammenfaltet, daß die beiden Hälften der Oberseite einander berühren und die Spaltöffnungen in einen von der Außenwelt ganz abgeschlossenen Hohlraum münden. 


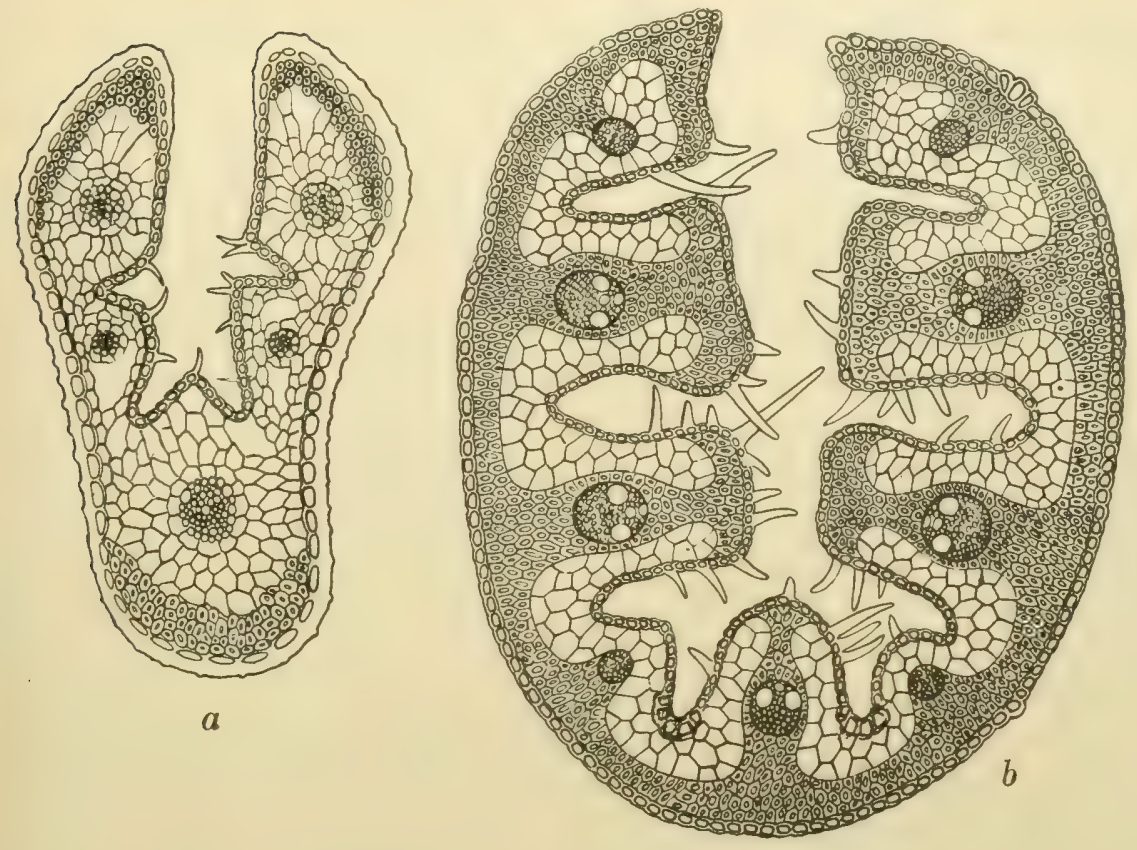

Abb. 7. Querschnitte durch die Blätter xerophiler Gräser.

$a$ Festuca sulcata. $b$ Stipa pennata.

Bei feuchter Luft hingegen steigt der Turgor in den Gelenkzellen und dadurch treten die beiden Blatthälften auseinander.

Aber auch an scheinbar feuchten Standorten wachsen Pflanzen mit ausgesprochen xerophilem Baue, und zwar vor allem in den Mooren, besonders den Hochmooren. Es ist dies, wie bereits oben (S. 11) erörtert wurde, darauf. zurückzuführen, daß die reichliche Anwesenheit von Hu mussäuren die Wasseraufnahme durch die Pflanzen sehr erschwert. Endlich sind auch, wie ebenfalls schon (S. 11) erläutert wurde, die Bewohner von salzhaltigem Boden xerophil gebaut.

\section{Das Steppenklima.}

Während in fast ganz Mitteleuropa das Klima, hauptsächlich infolge der reichen jährlichen Niederschlagsmenge, dem Baumwuchse günstig ist, gibt es in Südosteuropa ausgedehnte Gebiete, wo schon aus klimatischen Gründen Baumwuchs nicht aufkommen kann. Und in den Bereich dieses Gebietes fallen auch kleine Teile des östlichsten Galizien und der Bukowina, und auch im zentralen Teil der ungarischen Tiefebene herrschen ähnliche klimatische Verlıaltnisse.

Es wurde oben (S. 26) hervorgehoben, daß ein Baumwuchs nur dort möglich ist, wo wenigstens $\mathrm{zu}$ einer Zeit im Jahre so reichliche Niederschläge fallen, daß sich in tieferen Bodenschichten ein für das tiefgreifende Wurzelsystem der Bäume genügender Wasservorrat ansammeln kann. Wo aber die Niederschläge von geringerer Menge und in der Regel nur von kurzer Dauer sind, so daß 
nur die oberen Bodenschichten regelmäßig durchfeuchtet werden, kann sich nur eine Grasflur entwickeln.

Ein so charakterisiertes typisches Grasflurklima mit während des ganzen Jahres ziemlich gleichmäßig fallenden, aber stets nur geringen und kurz andauernden Niederschlägen, wie es z. B. im nordamerikanischen Präriegebiet herrscht, haben die Steppengebiete in Österreich-Ungarn nicht aufzuweisen. Am ehesten ist noch das Klima des ostgalizischen Steppengebietes mit dem Prärienklima zu vergleichen, hier fallen während der ganzen Sommerzeit noch, wenn auch spärliche Regen. Anders in Ungarn. Hier ist die Verteilung der Niederschläge sehr ungleich, im Spätsommer herrscht eine ausgesprochene Trockenperiode, die Gesamtmenge des Niederschlages ist aber nicht gerade unbedeutend und erreicht vielerorts eine Höhe, daß auch Baumwuchs dort gedeihen könnte. Zwei Faktoren spielen aber hier, abgesehen von der Regenmenge, eine bedeutende Rolle, die Winde und vor allem die starke Trockenheit der Luft, beides Faktoren, die die Transpiration sehr begünstigen und so bei der doch recht geringen Niederschlagsmenge einen Baumwuchs dort ausschließen.

Näheres über die klimatischen Verhältnisse und die Anpassungserscheinungen der Pflanzen an dieselben werden die über das ostgalizische Steppengebiet und das ungarische Tiefland handelnden Kapitel bringen.

\section{Das Hochgebirgsklima.}

Mit zunehmender Erhebung über den Meeresspiegel steigt in der Regel die jährliche Menge des Niederschlages, und auch die Lufteuchtigkeit wird größer, und diese Umstände bringen es mit sich, daß die Flanken der Gebirge in der Regel mit besonderes üppigen Wäldern bedeckt sind. In noch größeren Höhen aber treten sehr tief greifende Änderungen in den klimatischen Verhältnissen ein. Die Zunahme der jährlichen Regenmenge erfolgt nur bis zu einer gewissen Höhe und nimmt von da an immer mehr ab. Die Verdünnung der Luft fördert erheblich die Transpiration, noch mehr aber tun dies die hier jahraus, jahrein heftig wehenden Winde. Die Dauer der Vegetationsperiode nimmt nach oben zu immer mehr ab und ist schließlich auf eine Zeit von nur 2 -3 Nonaten beschränlit; die Bodentemperatur und insbesonders die Temperatur den aus dem Schmelzwasser des Schnees sich bildenden Grund- und Quellwassers bleibt niedrig. Hingegen ist die Lichtintensität eine sehr hohe und auch die strahlende Wärme der Sonne ist recht beträchtlich. Endlich ist auch die mechanische Wirkung der Schneedecke in Betracht zu ziehen. Das Hochgebirg:klima ist also im wesentlichen charakterisiert durch eine kurze Vegetationsperiode, geringe Niederschläge, heftige Winde, niederen Luftrick und hohe Lichtintensität sowie geringe Bodentemperatur.

Ein solches Lilina muß in erster Linie als ein ausgesprochen gehölzfeindliches bezeichnet werden. Tatsächlich fehlen auch in der Hochgebirgsregion mit Ausnahme von niedrigen ,Spaliersträuchern“ alle Holzgewächse. Da aber die gehölzfeindlichen Faktoren, geringe Niederschläge, kurze Vegetationsperiode und heftige Winde, im Gebirge nach oben zu ganz allmählich einsetzen, ist auch dis 
Aufhören der Holzgewächse ein allmähliches. Zuerst verschwinden die den Winden am meisten ausgesetzten hochwüchsigen Bäume, dann erst die höheren und zuletzt die niedrigen Sträucher.

Der Wald hört im Gebirge nach oben zu nicht plötzlich auf; er löst sich erst in einzelne Horste auf, diese in Baumgruppen und die letzten Reste bilden einzelne vom Winde usw. meist arg zerzauste ,Wetterbäume". An den Waldgürtel aber schließt sich ein in der Tirgel etwa $200-300 \mathrm{~m}$ breiter Strauchgürtel, der in zahlreichen Gebirgen aus den verschiedenen Formen der Krummholzkiefer (Pinus Mughus) oder aus Grünerlen (Alnus viridis), Zwergwacholder (Juniperus nana), Weiden usw. gebildet wird. Innerhalb dieses Strauchgürtels aber treten noch vielfach die den Waldgürtel bildenden Bäume, wie Fichten, Buchen, Ahorne, Ebereschen, aber nicht mehr als hochwüchsige Bäume, sondern in verkrüppelter strauchiger Form auf, ja, bilden in solchen Wuchsformen selbständige Formationen, wie die Buche in den illyrischen Gebirgen, die Fichte im Gesenke. Ober diesem ,Krummholzgürtel“ ist oft noch ein zweiter Strauchgürtel ausgebildet, der aber nur aus viel niedrigeren Sträuchern, wie Alpenrosen (Rhododendron), Heidelbeeren, kleinen Weidenarten u. a. besteht. Über diesem ,Zwergstrauchgürtel" herrscht aber dann die Grasflur.

Die diese I Hochgebirgsgrasflur zusammensetzenden Gewächse zeigen alle trotz der mannigfachsten Gestalt eine Reihe von gemeinsamen Eigenschaften, die auf die Einwirkung des Höhenklimas zurückzuführen sind. Die große Mehrzahl der Gebirgspflanzen ist ausdauernd, was in der kurzen Vegetationsperiode seine Erklärung findet. Der Wvehs der Alpenpflanzen ist niedrig - Anpassung an den Wind und den Schncedruck - die Blüten sind meist sehr groß und lebhaft gefärbt. Letzteres Merkmal ist wohl auf die hohe Lichtintensität zurückzuführen, kommt aber den Pflanzen insofern zugute, als dadurch die an Zahl geringen Insekten, welche doch die Bestäubung vermitteln, leichter angelockt werden. Auch eine reichliche Anhäufung der blauen oder roten Pflanzenfarbstoffe, des Anthokyans, in den Blättern und besonders in Kelchen, Blütenhüllen usw. ist häufig zu beobachten, was eine größere Ausnutzung der zur Verfügung stehenden Wärme zur Folge hat (vgl.S.6). Vor allem aber weisen/alle Hochgebirgspflanzen einen mehr oder minder deutlich ausgeprägten xerophilen Bau auf. Denn das Hochgebirgsklima ist trocken, nicht allein wegen der relativ geringen Niederschläge, sondern hauptsächlich wegen der austrocknenden Wirkung der Winde und der verdünnten Luft; auch die kühle Wasser- und Bodentemperaratur ist der Flüssigkeitsaufnahme durch die Pflanze hinderlich, was es mit sich bringt, daß auch die Bewohner feuchter Standorte, wie Ufer der Quellen, vom Schmelzwasser durchfeuchteter Boden usw., xerophil gebaut sind.

Die Transpirationsschutzeinrichtungen der Hochgebirgspflanzen sind im wesentlichen dieselben wie auch anderswo, insbesondere dichte Behaarung; dicke Kutikula, Wasserspeichergewebe, Versenkung der Spaltöffnungen und Mündung derselben in Hohlräume, bei den Gräsern Ausbildung von Falzblättern ; hingegen fehlen in der Hochgebirgsregion Mitteleuropas Rutensträucher und Dorngewächse. Zwei Vegetationsformen aber sind für die Hochgebirgspflanzen 


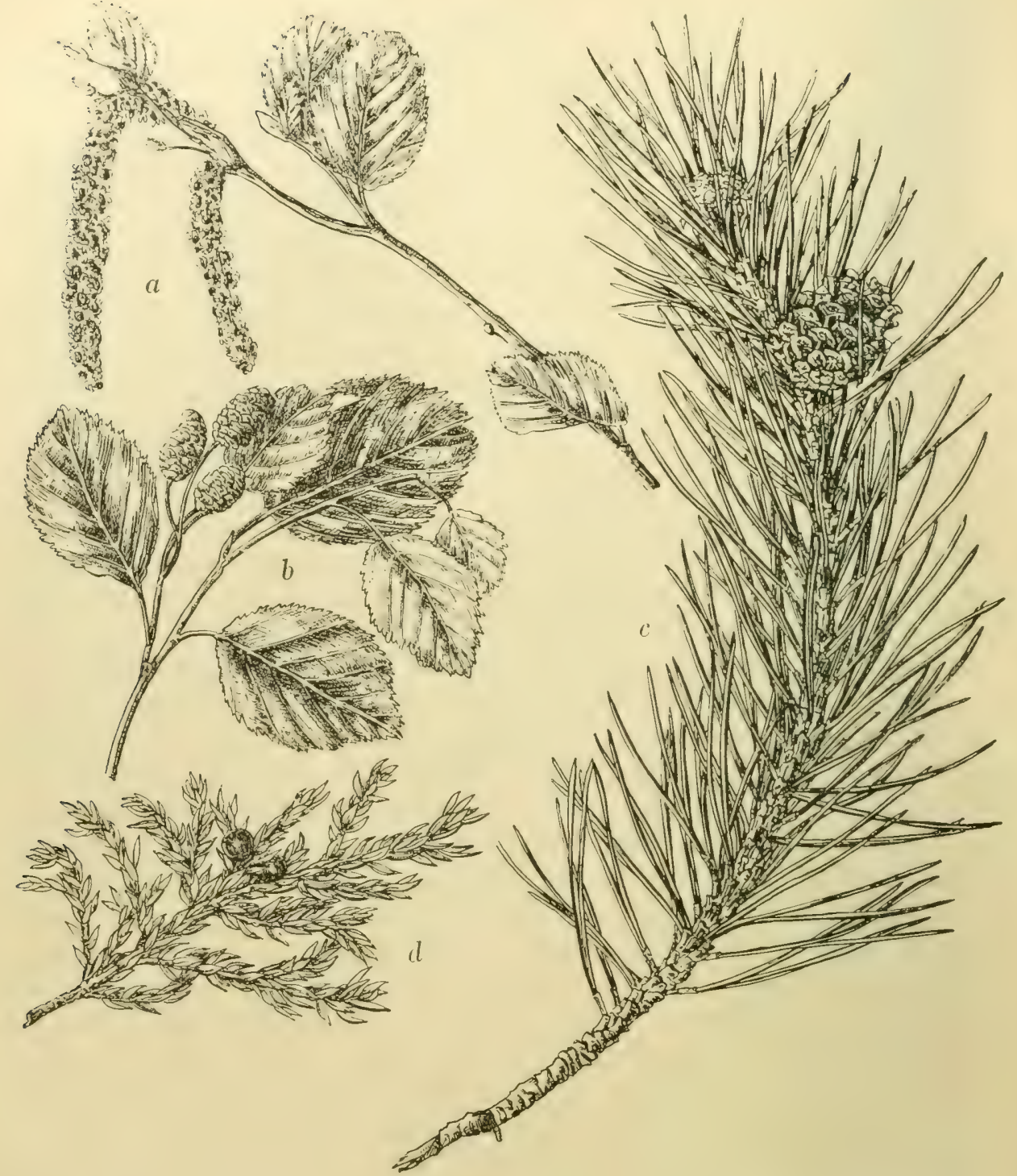

Abb. 8. Die verbreitetsten Arten des Strauchgürtels der mitteleuropăischen Hochgebirge. $a, b$ Alnus viridis. $c$ Pinus Mughus. $d$ Juniperus nana.

besonders charakteristisch, da sie anderswo, wenigstens in Mitteleuropa, fast nirgends auftreten, die Polsterpflanzen und die Spaliersträucher.

Unter Polsterpflanzen versteht man ausdauernde krautartige Gewächse, die zahlreiche dicht beblätterte Sprosse treiben, an denen die alten Blätter in der Regel nicht abfallen, sondern am Stamme allmählich verwesen, welche Sprosse dicht aneinander gedrängt stehen, so daß die ganze Pflanze einen dichte gewölbten bis halbkugeligen Polster bildet. Solche Polstergewächse sind in den verschiedensten Pflanzenfamilien vertreten, besonders häufig bei den Caryo- 


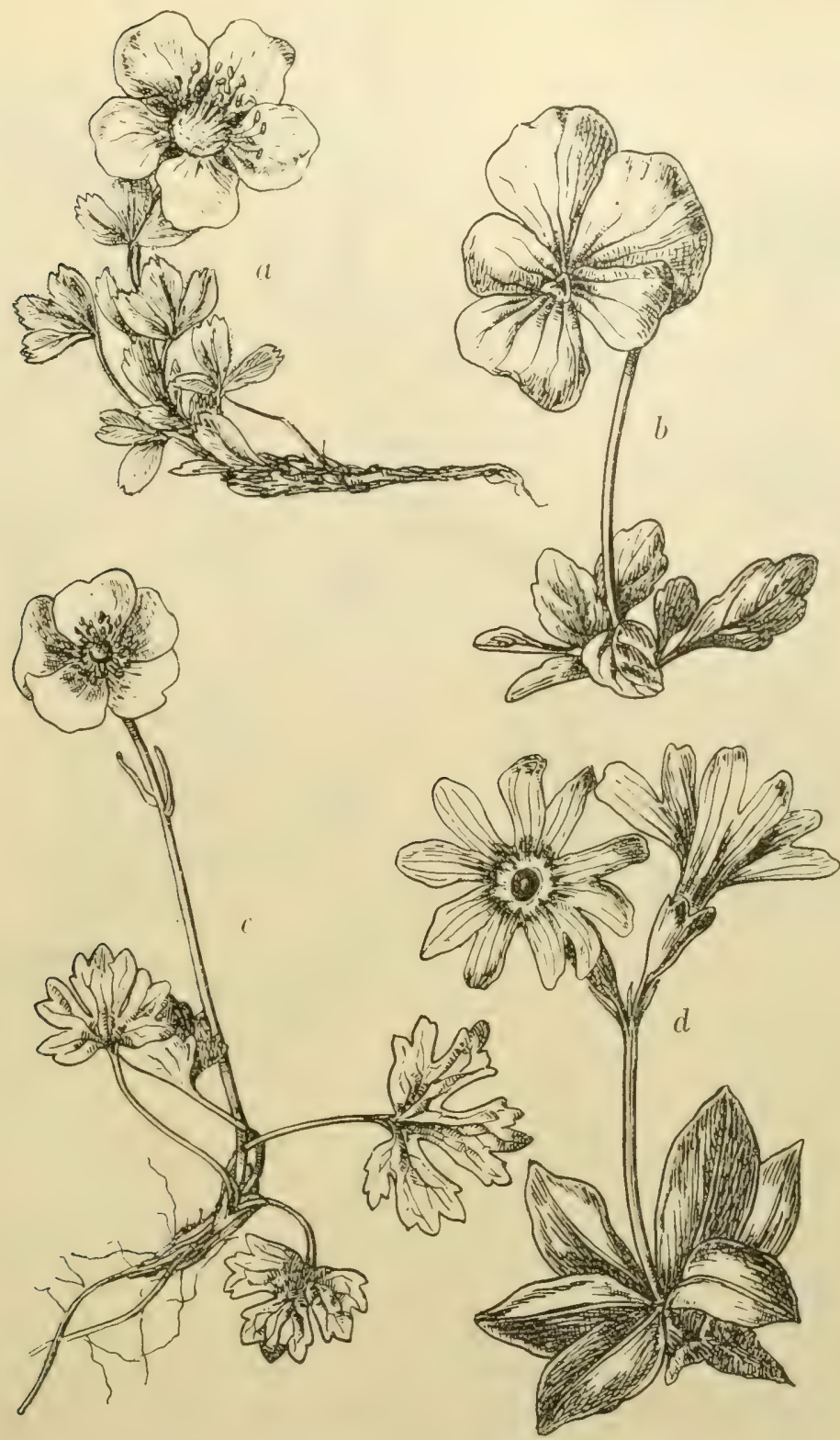

Abb. 9. Beispiele aus der Hochgebirgsflora.

$a$ Potentilla nitida. $b$ Viola calcarata. $c$ Ranunculus alpestris. $d$ Primula Clusiana.

phyllazeen (Minuartia sedoides, Silene acaulis, Saponaria pumila), Gruciferen (Petrocallis), Primulazeen (Androsace).

S p a li ersträ u cher (auch Teppichsträucher) sind Holzgewächse (Sträucher oder Halbsträucher) mit meist reich verzweigtem Stamme, dess'n Verzweigungen aber alle horizontal dem Boden angedrückt oder selbst in den Humus hinein versenkt sind, so daß nur die heurigen Triebe wenige Zentimeter 


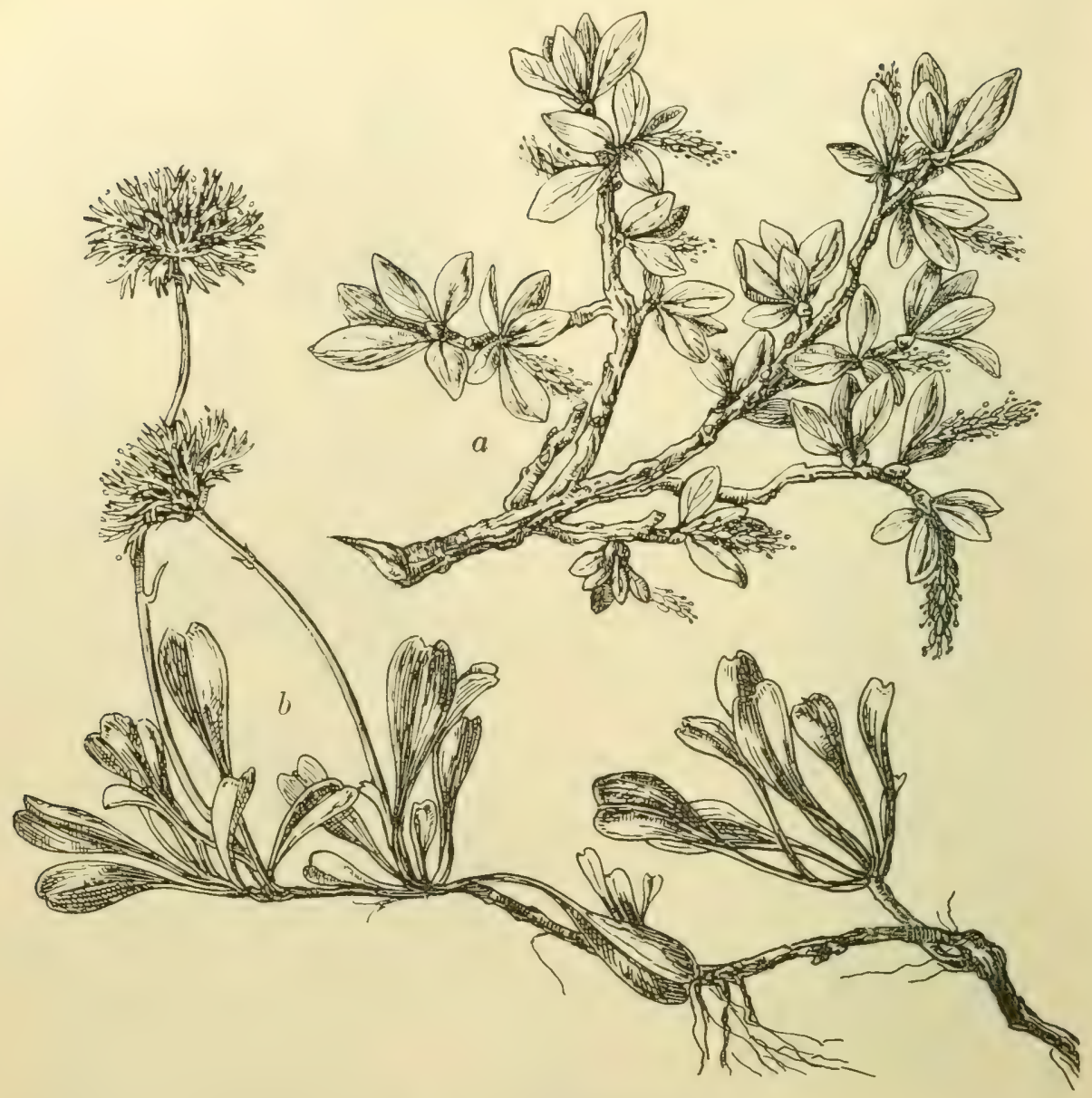

Abb. 10. Spalierstrăucher.

$a$ Salix retusa, $b$ Globularia eordifolia.

über den Boden emporragen, wie z. B. Dryas oclopelala, Salix relusa, S. herbacea, Globularia cordifolia.

Man war früher geneigt, gerade diese zwvei Vegetationsformen als Anpassungserscheinungen gegen die Kälte anzusehen, doch dürften sie, wenn auch die Einwirkung der Kälte nicht ganz ohne Einfluß auf die Ausbildung dieser Typen sein mag, doch hauptsächlich als Transpirationsschutzeinrichtungen zu deuten sein.

Andere im Hochgebirge häufig auftretende Typen sind die Rosettenstauden, die die kalte Jahreszeit mittels dem Boden angedrückter Blattrosetten überdauern und nur während der Vegetationsperiode senkrecht in die Höhe wachsende Blütensprosse entwickeln (z. B. Anemone, Primula, Gentiana, Pedicularis); auch sukkulente Formen derselben (Sempervivum, Saxifraga) kommen vor; ferner kriechende ausdauernde Pflanzen (Arenaria). Filzige Behaarung ist sehr häufig (Leontopodium, Arlemisia), doch kommen auch ganz kahle Arten nicht selten vor, bei denen aber dann die Blätter meist etwas sukkulent ausgebildet sind (Primula, Epilobium). 


\section{Die Änderungen des Klimas im Laufe der Erdgeschichte.}

Wenn auch die Verbreitung der Pflanzen auf der Erde und speziell in Mitteleuropa in großen Zügen durch die Wirkung noch jetzt tätiger äußerer Faktoren, speziell des heutigen Klimas, sich erklären, läßt gibt es doch Fälle, wo diese allein uns nicht die gewünschte Aufklärung geben. Wenn z. B. inmitten der sonndurchglühten Karstlandschaft in feuchten kühlen Schluchten oder Dolinen Alpenpflanzen vorkommen, so ist uns wohl verständlich, daß diese heute an 'diesen Standorten gedeihen können, nicht erklärlich ist es uns aber (wenn es nicht gerade Arten mit sehr leicht durch den Wind transportierbaren Samen sind), wie sie von den $50-100 \mathrm{~km}$ weit entfernt gelegenen Hochalpen dorthin gelangt sein können. Ahnlich ergeht es uns, wenn wir mitten in den Alpen, z. B. in der Umgebung von Innsbruck, an trockenen sonnigen Hängen zwar, aber in einer Meereshöhe von über $1500 \mathrm{~m}$ auf. Steppengräser stoßen, oder wenn wir im oberen Etschtal Astragalus-Arten begegnen, die ihre nächsten Standorte östlich von Wien haben. Wenn im heißen Talbecken von Raibl heute einzelne wärmeliebende Arten vorkommen, scheint uns das nicht sonderbar, aber rätselhaft wird uns ihr Vorkommen, wenn wir bedenken, daß sie von ihrer südlichen Heimat durch den hohen Predilpaß geschieden sind, der heute seinen klimatischen Verhältnissen nach nicht als Wanderstraße südlicher Formen angesehen werden kann. In den Sudeten in der kleinen Schneegrube hat die im ganzen arktischen Gebiete weit verbreitete Saxifraga nivalis ihren einzigen Standort in Mitteleuropa, wohin sie wohl kaum zufällig aus dem Norden her verschleppt sein kann. Die in den ganzen Alpen weit verbreitete Silene rupestris kommt im ganzen Karpathenzuge nur an wenigen Stellen in den Rodnaer Alpen vor, obwohl ihr zusagende Standorte auch in der Tatra und in den transsilvanischen Alpen genügend vorhanden wären. Und solcher Beispiele könnten noch zahllose angeführt werden, welche zeigen, daß einzelne Arten ganz unvermutet von ihrem geschlossenen Verbreitungsareale weit getrennte Standorte besitzen, deren Existenz durch die heute herrschenden klimatischen Verhältnisse nicht erklärt werden kann, die uns aber wohl verständlich werden, wenn wir annehmen, daß das Verbreitungsgebiet dieser Art ehedem ein weit größeres war, aber durch Änderung der klimatischen Verhältnisse unterbrochen worden ist.

Tatsächlich lehrt uns ja auch die Geologie, daß gerade in den allerletzten geologischen Epochen das Klima Mitteleuropas mehreren gewaltigen Änderungen unterworfen war; und auch die Oberflächengestalt der Erde hat in verhältnismäßig junger Zeit, in einer Epoche, in der die Pflanzenwelt in ihrer Entwicklung kaum noch Verschiedenheiten gegen jetzt zeigte, sich sehr bedeutend verändert. Die mächtigsten Gebirgszüge Österreich-Ungarns, die Alpen, die Karpathen und die Dinarischen Alpen haben sich erst zu Ende der Terziärzeit aufgetürmt, zu einer Zeit, wo die Pflanzenwelt in Mitteleuropa aus Arten bestand, die heute 
noch unverändert oder in nahe verwandten Formen auf der Erde, vielfach auch noch in Mitteleuropa existieren. Zahlreiche Fossilfunde beweisen, daß in Mitteleuropa zu jener Zeit eine Flora wohnte, die der heutigen vielfach ähnlich, aber reicher an an wärmere Kilimate gebundenen Arten war, von denen gar manche heute noch in Nordamerika, Südeuropa und Vorderasien, aber nicht mehr in Mitteleuropa selbst existieren. Daß diese wärmeliebenden Arten aus Mitteleuropa verdrängt wurden, würde uns schon die Verschlechterung des Klimas erklären, dir die Erhebung solcher mächtiger Gebirge notwendigerweise zur Folge gehabt haben muß, vollkommen verständlich aber wird sie uns durch das nun folgende Eintreten der Eiszeit.

Es ist durch zahlreiche geologische Tatsachen festgestellt, daß in der der jotzigen Erdperiodr oder besser gesagt Klimaperiode unmittelbar vorangegangenen Zeit in Nord- und Nitteleuropa ein Klima geherrscht hat, das ein derartiges Anwachsen der Gletscher mit sich brachte, daß in Nordeuropa eine geschlossene Eisdecke sich entwickelte, die nicht nur ganz Skandinavien überzog, sondern auch die Nord- und Ostsee erfültte und am heutigen mitteleuropäischen Festlande sich bis fast an den FuB rles mitteldrutschen Berglandes erstreckte; in den Alpen aber erfüllten dir Gletscher nicht nur alle großen Haupttäler, sondern bedeckten auch noch einen Teil der oberbayrischen Hochebene und nur im Südosten und Osten war die Vergletscherung geringer, und auch Sudeten, Karpathen und die illyrischen Gebirge trugen größere und kleinere Gletscher. Es ist natürlich, daß unter solchen klimatischen Verhältnissen nicht nur alle wärmeliebenden Arten in Mitteleuropa teils ausstarben, teils auswanderten - konnte doch überhaupt nur in dem schmalen Streifen zwischen den Alpen und dem nordischen Eise eine zusammenhängende Vegetation existieren, - sondern daß auch die Gebirgsflora der Alpen verdrängt wurde und sich in dem damals gewiß ein viel feuchteres und kühleres Klima als heute aufweisenden Alpenvorlande ansiedelte. Als dann die Gletscher zurückgingen und die alpine Flora nach und nach wieder sich ins Gebirge zurückzog, konnte leicht ein Florenaustausch zwischen Elementen der Flora der Alpen, der Arktis und der übrigen Hochgebirge erfolgen, da ja alle diese Arten in die gleichen räumlich so kleinen eisfreien Gebiete Mitteleuropas gedrängt worden waren. Da aber eine solche allgemeine Vergletscherung nicht einmal, sondern viermal, jedesmal durch wärmere Perioden, in denen das Klima dem heutigen ähnlich oder noch wärmer war, unterbrochen, stattgehabt hat, ist es begreiflich, daß der Einfluß dieses wiederholten Klimawechsels auf die Vegetation ein ganz kolossaler war.

Als die Gletscher sich endgültig zurückgezogen hatten, bildeten die Schottermassen, die die Gletscher selbst und die ihnen entstammenden großen Gewässer auf den den Gebirgen vorgelagerten Ebenen zurücligelassen hatten, nicht nur von Osten vordringenden Steppengevächsen geeignete Standorte, sondern viele Anzeichen sprechen dafür, daß an die letzte Vergletscherung sich eine Periode angeschlossen hat, in der das Klima wärmer und trockener war als heute und das weite Vordringen wärmeliebender Arten aus dem Süden und Osten bis in das Herz der Alpen begünstigte. 
Diese gewaltigen Klimaänderungen in den letzten Perioden lassen uns manche der eingangs angeführten Tatsachen in ganz anderem Licht erscheinen. Wir können das Vorkommen von Alpenpflanzen in den Karstschluchten als Reste aus jener Zeit deuten, wo die Alpenflora infolge der Vergletscherung der Alpen das südöstliche Alpenvorland besiedelt hatte, ebenso das Vorkommen von Steppengräsern und der genannten Astragalusarten sowie auch das Vorkommen wärmeliebender Arten bei Raibl darauf zurückführen, daß diese Arten in der der Eiszeit folgenden. Wärmeperiode daselbst eingewandert sind; das Vorkommen von Saxifraga nivalis in den Sudeten und von Silene rupestris in den Karpathen wird uns durch den während der Eiszeiten stattgefundenen Florenaustausch verständlich.

Solche Reste von Pflanzen an Standorten aus einer andern Klimaperiode pflegt man als Relikte zu bezeichnen und spricht von Glazialrelikten, wenn es sich um Úberbleibsel aus der Eiszeit, von, ,xerothermen“ oder ,aquilonaren" Relikten, wenn es sich um solche aus der postglazialen, d. h. nach der großen Vergletscherung eingetretenen Wärmeperiode, die auch als ,xerotherme Periode" bezeichnet wird, handelt.

Des näheren soll auf alle diese Verhältnisse in einem späteren Kapitel eingegangen werden.

\section{Die Pflanzengenossenschaften.}

\section{A. Das Zusammenleben der Pflanzen miteinander.}

Es wäre selbstverständlich, anzunehmen, daß an einem und demselben Standort nur solche Pflanzen vorkommen, welche unter gleichen Lebensbedingungen gedeihen und so an den betreffenden Standort gleiche Anforderungen stellen. Dies ist jedoch keineswegs ausschließlich der Fall, da auch die Pflanzen selbst die standörtlichen Einflüsse vielfach modifizieren und beeinflussen. So kann z. B. ein lichtbedürftiger Baum größere Bestände bilden, während in dem von diesem Baume gebildeten Schatten lichtscheue Gewächse vegetieren. Viele Pflanzen aber sind sogar direkt bezüglich ihrer Lebensbedürfnisse voneinander abhängig. So gibt es eine große Zahl von Pflanzen, welche nicht in der Lage sind, ihre Nährstoffe selbst zu bilden, sondern selbe in bereits ausgrebildetem Zustande anderen Pflanzen entnehmen. Zu diesen ,Parasiten“ gehört eine große Zahl von Pilzen, aber auch höhere Pflanzen, wie die Schuppenwurz (Lathraea Squamaria), die Sommerwurzarten (Orobanche), die Klee- und Flachsseide (Cuscula), die mit eigens gebauten unter- oder oberirdischen Saugorganen ihrer "Wirtspflanze" die Nährstoffe entnehmen. Die genannten Arten sind alle bleiche Pflanzen, die des Chlorophylls ganz nder fast ganz entbehren und schon aus diesem Grunde außerstande sind, die Kohlensäure der Luft zu assimilieren, doch gibt es auch grüne Schmarotzer, wie die Nistel (Viscum album) und die Leinblatt- (Thesium-) Arten. Solche Schmarotzerpflanzen können wohl 

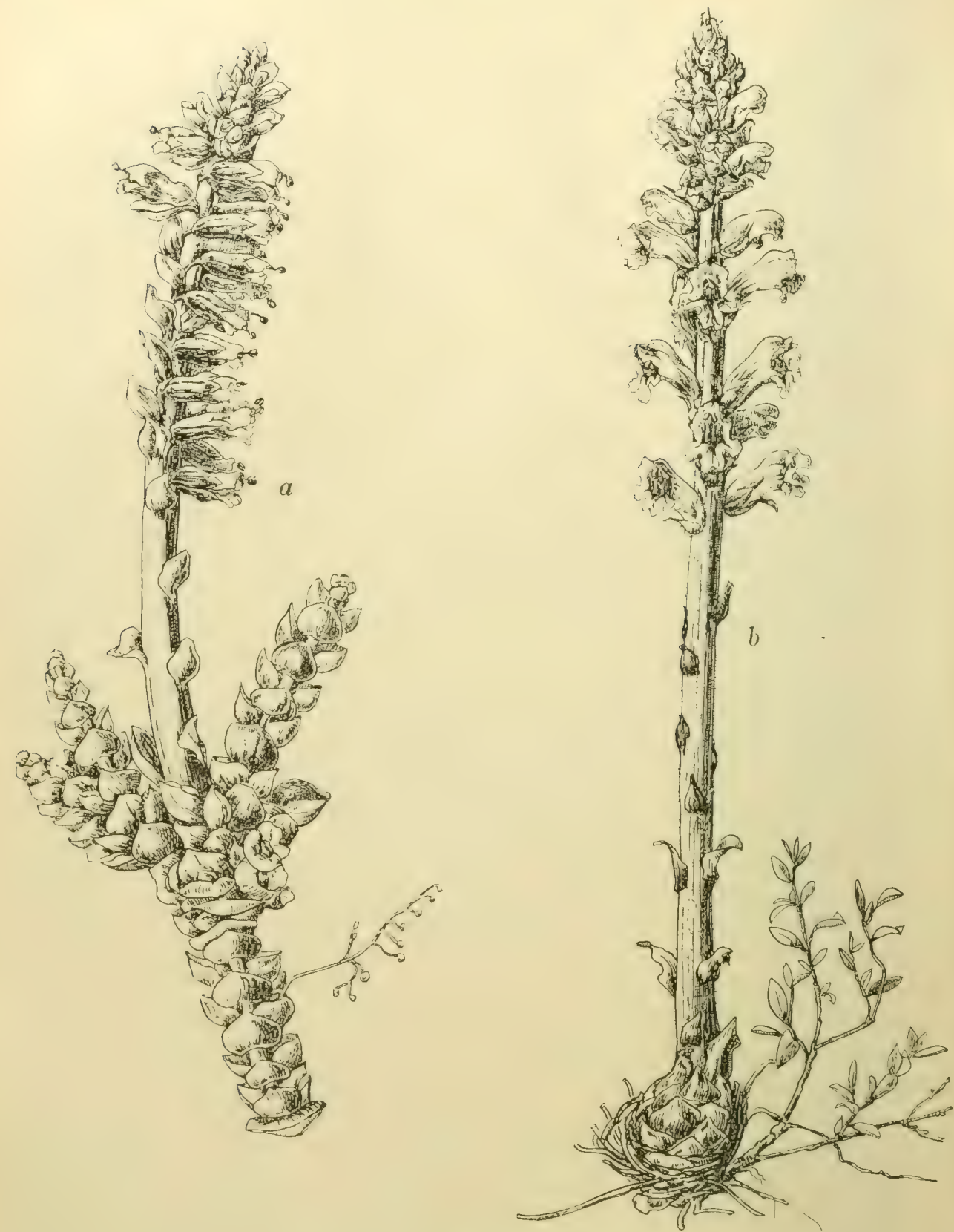

Abb. 11. Chlorophyllfreie Schmarotzerpflanzen.

$a$ Lathraea Squamaria. $b$ Orobanche lutea.

die Kohlensäure der Luft zu Nahrungsstoffen assimilieren, aber sie entnehmen die stickstoffhaltigen Nährstoffe nicht oder nur zu geringem Teile dem Humus, sonrleru hauptsächlich mittels Haustorien eigenen Wirtspflanzen. $\mathrm{Zu}$ diesen „Halbschmarotzern" gehören außer den genannten z. B. die Arten der 
Gattungen Augentrost (Euphrasir), Klappertopl (Alectorolophus), Läusekraut (Pedicularis) und Wachtelweizen (Melampyrum). Diese Schmarotzer und Halbschmarotzer können natürlich nur dort vorkommen, wo ihre Wirtspflanzen wachsen. Eine andere Reihe von Pflanzen entnimmt ihre organischen Nährstoffe zwar nicht lebenden Wirtsplanzen, wohl aber dem an pflanzlichen Zersetzungsprodukten überreichen Humus, die sogenannten "Saprophyten", von denen einige, wie Fichtenspargel (Monolropa) und Nestwurz (Veoltia Nidus avis). cbenfalls des Chlorophylls entbehren. Diese Gewächse sind natürlich ebenfalls an das Zusammenleben mit anderen Gewächsen gebunden, deren Zersetzungsprodukte ihnen die Nahrungsstoffe liefern.

Zahlreiche Pflanzen, besonders Holzgevächse, sind stets an ihren Wurzelenden von einem Pilz bewohnt, der entweder in die Wurzelspitze eindringt oder eine Kappe auf der Oberfläche der Wurzelspitze bildet — , M y c or hi za", welcher jedenfalls dazu dient, der betreffenden Pflanze organische Nährstoffe aus dem Boden zuzuführen, während der Pilz selbst vermutlich ebenfalls von der von ihm befallenen Pflanze Nutzen zieht. Bei zahlreichen Leguminosen wieder finden sich an den Wurzeln kleine Kn̈̈llchen, die aus Bakterien bestehen, welch die Fähigkeit, die den übrigen Pflanzen abgeht, besitzen, den reinen stickstoff der Luft, also auch der Bodenluft, in höher zusammengesetzte, der Pflanze notwendige Verbindungen jüberführen und so nicht nur der von ihnen befallenen Pflanze nützen, sondern direkt durch Inhäufung stickstoffhaltiger Nährstoffe den Boden verbessern ${ }^{1}$ ).

Vielfach kommt es auch vor, daß die eine Pflanze der andern als Standort dient. In unteren Breiten sind zwar in der Regel nur Moose und Flechten und (mit Ausnahme der schmarotzenden Visteln) nur ausnahmsweise Phanerogamen Bewohner der Rinde des Stammes und der Äste von Bäumen, in den Tropen aber gibt es eine große Zahl solcher "Epiphyten", die, ohne im geringsten Schmarotzer zu sein, ausschließlich auf den Stämmen und Isten anderer Pflanzen gedeihen. Endlich kommen bei Schling- und Kletterpflanzen die Nachbargewächse als natürliche Stützen in Betracht.

Diese wenigen Beispiele mögen genügen, um zu zeigen, in wie vielfacher Beziehung die einzelnen Pflanzenarten in ihrem Vorkommen gegenseitig aufeinander angeviesen sind.

\section{B. Der Begriff der „Pflanzenformation“.}

Die Pflanzen wachsen bekanntlich nicht regellos durcheinander auf der Erde, sondern schließen sich zu eigenartigen, schon ihrem äußeren Ansehen nach wohl charakterisierten Genossenschaften, wie Wälder, Heiden, Wiesen usw., zusammen. Nur sehr selten bestehen solche Genossenschaften aus nur einer einzigen Art, wie z. B. mitunter die Bestände des Teich-Schachtelhalmes (Equiselum limosum) oder manche Föhrenwälder, meist sind sie aus einer

1) Auf dieser Grundlage basiert die Kultur der Lupinen zum Zwecke der Bodenverbesserung. 
größeren Zahl von Arten zusammengesetzt, die teils durch gemeinsame Ansprüche an die äußeren Lebensbedingungen, teils durch die Wechselbeziehungen, die sie aneinander binden, an ein und denselben Standort zusammengeführt werden.

Für eine bestimmte Pflanzengenossenschaft bezeichnend sind zwei Momente: erstens die dieselbe zusammensetzenden Pflanzenarten und deren gegenseitiges Zahlenverhältnis und zweitens die äußeren Bedingungen, die das Gedeihen gerade dieser und keiner andern Genossenschaft zur Folge haben.

Von diesen äußeren Bedingungen ist für den Gesamtcharakter der Vegetation das Klima in erster Linie naßgebend; edaphische, d. h. durch die Bodenbeschaffenheit bedingte Einflüsse können die dem Kilima entsprechenden Pflanzengenossenschaften meist nur lokal beeinflussen. So ist z. B. in großen ungarischen Tiefland die Steppe die vorherrschende, durch das Klima bedingte Genossenschaft; dort aber, wo, wie an den Flußufern, sich überreichlich Feuchtigkeit im Boden befindet, treten auch Waldbestände, dort, wo der Boden salzhältig ist, Salztriften auf. Im Mittelmeergebiete ist der immergrüne Hoch- und Buschwald die klimatisch bedingte, herrschende Genossenschaft, dort aber, wo der Boden weithin von IIumus mehr oder minder entblößt ist, liönnen Holzgewächse nicht gedeihen und hier machen sich Kräuter und Stauden breit.

Es hat sich natürlich bald das Bedürfnis herausgestellt, die einzelnen Pflanzengenossenschaften voneinander $\mathrm{zu}$ unterscheiden und $\mathrm{zu}$ benennen. Schon der bloße fhỵsiognomische Eindruck führt zu einer Gliederung in Waldbestände, Buschbestände, Grasflurbestände, Wüstrn sowie einige untergeordnete Gruppen, wie Heiden, Hochmoore usw. Doch ist diese Gliederung allein nicht allen Anforderungen entsprechend, zumal sie über die die betreffende Genossenschaft bedingenden äußeren Einflüsse uns nicht aufliärt. Das Bestreben nach einer sicheren Definition einer bestimmten Pflanzengesellschaft hat zum Begrife der Pflanzenformation geführt.

Unter einer Pflanzenformation (auch Formation schlechtweg) versteht man jede aus wesentlich den gleichen Elementen zusammengesetzte und durch gleiche äußere (klimatische und edaphische) Einflüsse bedingte Pflanzengenossenschaft. Nach dieser Definition wäre z. B. eine Formation der immergrüne Buschwald des Mittelmeergebietes, die ,Macchie", oder der Gebirgsnadelwald Mitteleuropas, die mitteleuropäische Heide oder die ungarische Steppe. Weitere Verschiedenheiten innerhalb einer Formation, die durch edaphische Einflüsse von geringerer Bedeutung, oder das Torherrschen der einen oder andern der die Formation zusammensetzenden Arten oder endlich durch das geographisch begrenzte Eintreten oder Fehlen der einen oder andern Art bedingt sind, kann man als, "Fazies" der betreffenden Formation bezeichnen. So sind z. B. Steineichenwald oder Myrtengebüsch als Fazies der Nacchie, Tannen-, Fichten- oder Lärchenwalı als Fazies des Gebirgsnadelwaldes, Trespensteppe, Federgrassteppe und Goldbartflur als Fazies der ungarischen Steppe zu bezeichnen.

Gewiß ist die oben gegebene Definition der Formation ziemlich dehnbar und vielleicht auch in allen Punkten nicht ganz genau. Doch ist gerade der Begriff 
der Formation selbst ein außerordentlich dehnbarer. Wer z. B. die Pflanzengenossenschaften der ganzen Erde behandelt, wird die tropischen Regenwälder ler ganzen Erde nur als eine Formation auffassen, während der, der die Vegetation Brasiliens zum Gegenstande seiner Studien macht, vielleicht in Brasilien allein mehrere verschiedene Formationen innerhalb der Gruppe der tropischen Regenwälder unterscheiden wird. Und ebenso steht es mit anderen Formationen in anderen Gebieten. In vorliegendem Werke ist der Begriff der Formation eng, vielleicht zu eng gefaßt, beziehungsweise besser gesagt, es sind Formation und Fazies nicht immer scharf voneinander geschieden.

Die einzelnen Formationen werden dann wieder in größere Formationsgruppen, die von verschiedenen Gesichtspunkten aus gewählt werden können, zusammengefaßt, so z. B. die Wälder in sommergrüne und immergrüne Laubund Nadelwälder oder aber in xerophile, mesophile und hygrophile Wälder.

Zur Charakterisierung einer Formation ist also nötig die Angabe der Zugehörigkeit zu einer der physiognomischen Hauptgruppen (Wälder, Wiesen usw.), ferner die Angabe der dieselbe zusammensetzenden Pflanzenarten und schließlich auch die Angabe, ob es sich um eine geschlossene Formation handelt, bei der der Boden ganz von Pflanzen bedeckt ist, oder um eine offene Formation, bei dem zwischen den Pflanzenindividuen noch besiedlungsfähiger nackter Boden frei bleibt. Endlich gehört zur Charakteristik der Formation die Angabe der klimatischen und edaphischen Einflüsse, durch welche die Formation bedingt ist.

Die die einzelnen Formationen zusammensetzenden Arten sind an Individuenzahl nicht gleich. Eine oder wenige Arten bilden meist den Hauptbestand, sie sind tonangebend (sociales, abgekürzt soc. ${ }^{1}$ ), andere zwar in größerer Individuenzahl, aber zwischen die anderen nur eingestreut, häufige (copiosae, „cop.") Arten, die, wenn sie in Gruppen vorkommen, als ,gesellig“ (gregariae, ,greg.") bezeichnet werden; andere Arten sind selten (sparsae, ,sp.") oder treten nur ganz vereinzelt (solitariae, ,sol.") auf.

Eine einheitliche wissenschaftliche Nomenklatur der einzelnen Pflanzenformationen ist vorläufig noch ein frommer Wunsch der Pflanzengeographen. Meist werden die Formationen noch mit Ausdrücken aus der Landessprache nach physiognomischen Gesichtspunkten allein bezeichnet und eventuell durch Anführung charakteristischer Pflanzenarten oder besonderer ökologischer Eigenschaften genauer bestimmt. So spricht man vorn tropischen Regenwald, vom Savannenwald, Dornwald, der Tundra oder vom Eukalyptuswald, der Federgrassteppe, von Wäldern aus Quercus conferta oder Beständen von Equiselum limosum. In neuerer Zeit hat auch der Vorschlag viel Anklang gefunden, die einzelnen Formationen mit einem lateinischen Wort zu bezeichnen, das aus dem Gattungsnamen der in der Formation tonangebenden Art durch Anfügungr der Silbe -etum gebildet wird, z. B. Quercelum für Eichenwald, Callunelum für Callunaheide, Caricetum für Riedgrasmoore; will man die Spezies, die die F(nmation zusammensetzt, näher präzisieren, kann man den. Speziesnamen im

1) Die beigefügten lateinischen Bezeichnungen beziehungsweise Abkürzungen haben in zahlreichen neueren pflanzengeographischen Werken Aufnahme gefunden. 
Genitiv beifügen, z. B. Quercelum confertae für einen Waldbestand aus Quercus conferla, Caricelum elatae für ein aus Carex elata zusammengesetztes Moor. Auch für die höheren Einheiten in der Pflanzengeographie, die Formationsgruppen, wurden lateinische Bezeichnungen in Vorschlag gebracht, so Pluviisilvae für Tiegenwälder, Altoherbiprala für Hochstaurlenwirsen. Siccideserta für Wüsten usw.

\section{Allgemeine Bemerkungen über die wichtigsten Formationen.}

\section{Die Wälder.}

Alle Baumbestände pflegt man als Wälder zu bezeichnen. Trotz der mannigfachsten Unterschiede bestehen doch in den ökologischen Verhältnissen der verschiedenartigsten Waldformationen große Ähnlichkeiten. Tonangebend sind die Bäume, welche über die übrige Vegetation mehr oder minder dichtes Dach ausbreiten, so daß im Inneren des Waldes stets nur gedämpfteres Licht herrscht. Das abfallende Laub beziehungsweise auch die abfallenden Nadeln der Bäume liefern eine dicke Humusdecke.

Nur selten ist im Walde außer den dieselben zusammensetzenden Bäumen keine weitere Vegetation vorhanden. Meist kann man unter den Bäumen, dem „,Oberholze" noch zwei oder mehrere Schichten oder Stockwerke in der Pflanzenwelt unterscheiden. Auf das Oberholz folgt das ,Unterholz", aus hochwüchsigen Sträuchern und auch dem Nachwuchse des Oberholzes bestehend, dann der "Niederwuchs", den verschiedene krautige Gewächse oder niedrige Sträucher bilden. Endlich ist am Boden oft noch ein Moospolster entwickelt.

Die Wälder sind entweder xerophil, so die Föhrenwälder oder die immergrünen Wälder des Mittelmeergebietes, oder aber meso- oder hygrophil, letzteres z. B. die meisten Auenwälder. Doch sind in unseren Breiten diese Wälder nur während der Vegetationsperiode meso- beziehungsweise hygrophil, im Winter sind sie xerophil, sie sind also streng genommen als tropophil zu bezeichnen.

Infolge der Beschattung durch die Bäume können im Inneren des Waldes lichtbedürflige Pflanzen in allgemeinen nicht gedeihen, im tiefen Waldesschatten ist die Vegetation meist spärlich, und nur in Lichtungen und am Waldesrande üppiger entwickelt. In den Laubwäldern blüht die Mehrzahl der Pflanzen des Niederwuchses im ersten Frühling, noch bevor sich das Laub des Oberholzes entwickelt hat. Viel mehr als in unseren Breiten macht sich in den tief schattigen Tropenwäldern das Streben nach Licht bemerkbar, dort finden sich auf den İsten der Bäume zahllose Epiphyten und eine große líenge von Lianen strebt an den Stämmen der Bäume dem Lichte zu. Erstere Vegetationsform fehlt in unseren Breiten vollständig und auch die Lianen sind auf wenige Typen beschränkt.

$\mathrm{Zu}$ den Waldformationen im weitesten Sinne sind auch die Strauchformationen zu zählen. Im allgemeinen sind solche dort entwickelt, wo die Lebensbedingungen für Bäume minder günstige sind. So treten, wie bereits 
erwähnt, an der oberen Grenze des Baumwuchses noch Strauchformationen auf. Auch an trockeneren Standorten tritt in unseren Breiten statt Baumwuchs vielfach Strauchwuchs auf, so an felsigen Steilhängen in Mitteleuropa, besonder aber im Grenzgebiete zwischen dem Wald- und dem Steppengebiete. Endlich aber ist auch oft der Einfluß des Menschen schuld daran, wenn statt hochstämmiger Wälder sich nur Buschbestände entwickeln, unrationelles Roden des Waldes ohne entsprechenden Schutz des Nachwuchses, vor allem aber das Überlassen des Waldes, besonders des Jungwaldes an das Weidevieh richtet jeden Waldbestand zugrunde.

Obwohl der Wald in ganz Mitteleuropa unzweifelhaft eine ursprüngliche Formation ist, sind doch im Urzustande belassene Wälder, in denen nichts durch den Menschen verändert wurde, nur mehr selten anzutreffen. Solche "Urwälder“ findet man noch ab und zu im Hochgebirge an schwer zugänglichen Stellen, in Schluchten oder an Steilhängen, wo der Abtransport des, gewonnenen Holzes mit unverhältnismäßig großen Kosten und Schwierigkeiten verbunden wäre, ferner auch in einzelnen Gebieten, wo der ursprüngliche, unberührte Wald aus Absicht in seinem Urzustande als ,Naturdenkmal" belassen wird, wie auf dem Kubany im Böhmerwald und im mährischen Gesenke. Die übrigen Wälder aber sind durchweg keine Urwälder mehr, sondern sind durch den Eingriff des Menschen in „Forste" umgewandelt.

In den meisten Fällen freilich ist die Umgestaltung des Waldes durch den Forstbetrieb lieine sehr erhebliche. Sie besteht darin, daß die Bäume ihr natürliches Lebensalter nicht erreichen, sondern schon weit früher der Axt zum Opfer fallen und die gefallenen beziehungsweise gefällten Bäume aus dem Wald entfernt werden. Die Zusammensetzung des Waldes aber, die in demselben wachsenden Bäume bleiben dieselben. In solchen Wäldern wird vielfach der Plänterbetrieb durchgeführt, indem in jeden Bestande alljährlich die geeigneten Stämme gefällt werden und die Verjüngung des Waldes dem natürlichen Nachwuchs überlassen wird. Oder es werden sogenannte Besamungsschläge angelegt, indem man in einem größeren Holzschlage einzelne, reichlich Samen tragende Bäume stehen läßt, welche die natürliche Besamung des Schlages besorgen. Als rationallste Forstwirtschaft gilt allerdings der Kahlschlag, wobei ganze Waldparzellen, sobald die Mehrzahl der Bäume ein bestimmtes Alter erlangt hat, geschlagen werden und dies in regelmäßigen, je nach der Baumart verschiedenen Zwischenräumen (,Umtriebszeiten ${ }^{6}$ ) wiederholt wird. Auch in diesem Falle wird noch die Zusammensetzung des Waldes nicht verändert, wenn nur der natürliche Nachwuchs zur Verjüngung des Waldes herangezogen wird. Vielfach werden aber jetzt die Kahlschläge mit jungen, in Baumschulen gezogenen Sämlingen neu bepflanzt und auf diese Weise der ursprüngliche Waldbestanr stark verändert. Der Forstmann liebt in der Regel lieine gemischten Bestände, und so werden, wenn schon keine dem Bestande ganz fremde Arten angepflanzt werden, doch z. B. in einem ursprünglichen Mischwald nur Fichten oder nur Eichen nachgeforstet, und so der Mischbestand in einen reinen Fichten- beziehungsweise Eichenbestand umgewandelt. Ein weiteres Merkmal des liünstirh 
nachgeforsteten Waldes ist das, daß hier die Bäume nicht regellos am Boden verteilt sind, sondern in bestimmten Abständen voneinander gepflanzt sind.

Aber nicht nur durch Aufforstung allein kann der natürliche Waldbestand verändert werden. Im geregelten Forstbetriebe werden oft die eingesprengt vorkommenden Baumarten entfernt, oder aber z. B. ein Fichten-Buchen-Mischwald durch Ausschlagen der minderwertigen und lichtraubenden Buchen in einen Firhtenwald verwandelt. Aurh ein irrationaler Forstbetrieb kann zu cinemähnlichen, in diesem Falle aber nicht erwünschten Ergebnisse führen. Wenn z. B. in einem Mischwalde aus Buchen und Fichten nur die letzteren regelmäßig gefällt und verwertet werden, während man die minderwertigen Buchen stehen läßt, kann auch dieser Wald mit der Zeit zu einem reinen Buchenbestande werden. Auf diese TVeise sind z. B. in den schönen Auenwäldern der Donau und ihrer Nebenflüsse di॰ Eichen nahezu verschwunden, da selbe wegen ihres wertvollen Holzes ausgeschlagen wurden, der Nachwuchs derselben aber durch die viel rascher wachsenden Weiden, Pappeln, Erlen, Ulmen usw. unterdrückt wurde. Gewiß ist es dem regelmäßigen Forstbetriebe zuzuschreiben, daß heute in Mitteleuropa Mischwälder verhältnismäßig selten sind und reine Bestände weitaus vorherrschen.

Abgesehen von diesen Veränderungen im Walde, die der Forstbetrieb mit sich bringt, werden aber oft noch fremde Holzarten eingeführt. Es kommen hier weniger noch außereuropäische Holzarten, bei uns fast nur die Weymouthsliefer (Pinus Strobus) und die Akazic (Robinia Psendacacia) in Betracht, da selbe als fremdes Element immer leicht kenntlich bleiben. Vielmehr kann das ursprüngliche Waldbild verändert werden durch den Anbau heimischer, aber in dem betreffenden Gebiet ursprünglich nicht vorkommender Baumarten, als welche besonders die Fichte (Picea excelsa), die Lärche (Larix decidua) und die Schwarzföhre (Pinus nigra), im Hochgebirge auch Pinus Mughus, in Betracht kommen. So ist das ursprüngliche Verbreitungsgebiet von Pinus nigra in den Südalpen kaum mehr mit Sicherheit festzustellen, und ähnlich steht es mit der Verbreitung der Lärche in den Sudeten.

Wird auf diese Weise im Walde die Zusammensetzung des Oberholzes vielfach geändert, so blieben Unterholz und Niederwuchs doch meist in ihrer ursprünglichen Zusammensetzung bestehen, und somit stellt auch der Forst wenigstens eine halbnatürliche Formation dar.

Eine eigenartige Pflanzenformation verdankt überdies der Forstkultur ihre Existenz, und das ist die Flora der Holzschläge. Es ist begreiflich, daß auf dem wenig besiedelten und nun plötzlich der vollen Einwirkung des Tageslichtes ausgesetzten Boden eine große Zahl von Pflanzen einwandert. Im ersten Jahre sind im Holzschlage meist nur diejenigen Pflanzen des Niederwuchses zu finden, die gegen Licht weniger empfindlich sind, bald aber siedeln sich andere Gewächse an, vornehmlich solche, die durch den Wind leicht verbreitbare Samen besitzen, wie zahlreiche Kompositen, Epilobien usw. Zuerst gelangen natürlich die einjährigen Gewächse zur Blüte, die in einem jungen ITolzschlag stets vorherrschen, später folgen dann die mehrjährigen Arten. 


\section{Die Grasfiluren.}

Die Grasfluren stellen an die klimatischen und edaphischen Verhältnisse ganz andere Ansprüche als der Wald. Die eigentliche Heimat der Grasflur sind auch jene Gebiete, wo es keine natürlichen Wälder gibt, wie die östlichen Steppengebiete und die Hochgebirgsregion. Hier entsprechen die klimatischen Verhältnisse - häufige, wenn auch kurz dauernde Regen während der Vegetationsperiode - den Ansprüchen der Grasflur vollkommen.

Ilan kann die Grasfluren, wenn man von den zu den Heideformationen gehörigen Sandgrasfluren absieht, gliedern in Wiesen, Steppen und Triftformationen. Unter letzterem Namen verstehen wir aus ausdauernden krautigen Pflanzen mit eingemischten ein- und zweijährigen Arten gebildete Bestände, in denen die dikotylen Stauden über den Gräsern und Scheingräsern vorherrschen. Triftormationen sind vornehmlich in Waldgebicten an jenen stellen entwickelt, wo aus edaphischen Ursachen Wälder sich nicht entwickeln können, so die mediterrane Felsentrift und die Karsttrift auf steinigem, von Humus entblößtem Borlen im Gebiete der mediterranen und Kiarstflora, die blütenreichen Triften im pannonischen Waldgebiet an sonnigen, dem Winde ausgesetzten humusarmen Steilhängen. Auch im Grenzgebiete zwisehen IVald- und Steppengebiet, wie in Ostgalizien, treten an Stelle von typischen Grasfluren oft Triften auf.

Dort, wo aber das Klima ausgesprochen gehölzfeindlich, hingegen der Grasflur günstig ist, erscheint letztere als Wiese oder als Steppe. Die Wiese ist hygrophil oder mesophil, ja selbst wie im IIochgebirge xerophil, aber niemals an eine sommerliche Trockenheitsperiode angepaßt. Speziell in der Hochgebirgswiese sind die einzelnen Elemente derselben fast durchweg mit Transpirationsschutzeinrichtungen versehen, die aber ihren Grund in der geringen Wasseraufnahme wegen des kalten Bodens, der starken Transpiration wegen der verdünnten und stark bewegten Luft, aber niemals wegen einer sommerlichen Dürreperiode haben; trotz mancher Schutzeinrichtungen gegen Feuchtigkeitsverlust ist der Gesamthabitus der Alpenpflanzen kein xerophiler. Anders in der Steppe. Die Steppenpflanzen sind ausgesprochen xerophil gebaut, hier besteht eine sommerliche Dürreperiode, demnach eine zweimalige Unterbrechung der Vegetationszeit, eine im Winter und eine im Hochsommer. Die Steppe kann, muß aber nicht immer, eine offene Formation sein, in der die Gräser büschelweise wachsen und dazwischen noch nackter, unbesiedelter Boden frei bleibt; solche Formen bilden den Übergang zur Wüste und werden als W üstensteppen bezeichnet.

Obwohl Mitteleuropa ein ausgesprochenes Waldlklima besitzt, ist doch dort neben dem Walde die Wiese die weitaus häufigste Formation. Jedoch die writaus größte Mehrzahl dieser Wiesen ist keine ursprüngliche Formation, sondern verdankt ihr. Dasein dem Einflusse des\} Menschen. Ursprüngliche Wiesen sind in Mitteleuropa die Sumpfwiesen, die Triftformationen im Osten, sowie vielleicht auch einzelne WViesen in den Flußtälern an jenen Stellen, wo infolge des alljährlichen Eisganges sich kein Wald entwickeln lionnte, die 
Nehrzahl der Tal- und Bergwiesen aber ist durch den Eingriff des Menschen entstanden, entweder durch Trockenlegen der Sumpfwiesen oder durch Ausroden des Waldes. Eine sich selbst überlassene Wiese geht allmählich wieder in Wald oder in Heide über, sie wird in ihrem wiesenartigen Zustand erhalten durch einen regelmäßig einmal oder zweimal im Jahre erfolgenden Eingriff des Menschen: die Mahd.

Die Wiesen sind usprünglich gewiß nicht angepflanzt, sondern haben sich offenbar, sofern sie nicht aus Sumpfwiesen durch Trockenlegen entstanden sind, unter dem Einflusse der Nahd aus der IIolzschlagflora entwickelt. Diese regelmäßig wiederkehrende Mahd ist aber ein Faktor, der auf die Lebensbedingungen der Wiesenpflanzen auch jetzt noch einen mächtigen Einfluß ausübt.

Nach dem Schmelzen des Schnees ist die Wiese niedrig, alle höheren Stengel sind im Winter abgestorben, und nur die überwinternden Blätter der Gräser und der Rosettenstauden setzen den Grasboden zusammen. Es ist die Zeit des ersten Tiefstandes, in der einige niedrige Pflanzen, wie Veilchen, Primeln, Crocus, einzelne Carex-Arten, hlühen. Allmählich geht dieser erste Tiefstand in den ersten Hochstand über, in der die Vegetation der Wiese zur schönsten Entfaltung kommt; jetzt blüht die Mehrzahl der Gräser und übrigen Wiesenpflanzen, wie die Orchideen, Nelken, Campanula, Chrysanthemum, Ranunculus, Rumex Acetosa usw. Diesem ersten Hochstand aber wird durch die Mahd ein rasches Ende bereitet und er wird in den zweiten Tiefstand übergeführt, während welches nur wenige Arten, wie Carlina acaulis, Euphrasien, ihre Blüten entfalten. Dieser zweite Tiefstand geht allmählich in einen zweiten Hochstand über, während dessen neben neue Sprosse treibenden Pflanzen des ersten Hochstandes insbesondere Leontodon-Arten, Cirsien und Umbelliferen (Heracleum, Pastinaca) blühen. Eine zweite Mahd führt auch diesen Hochstand in einen dritten Tiefstand über, für den besonders die Blüte von Colchicum charakteristisch ist. Dieser dritte Tiefstand geht dann allmählich in den ersten Tiefstand über, seltener kommt noch ein dritter schwacher Hochstand zur Entwicklung, der durch Beweidung oder eine dritte Mahd ein Ende findet.

Es ist natürlich, daß auf den Mähwiesen nur solche Pflanzen existieren können, die diesen wiederholten gewaltsamen Eingriff ohne Gefährdung ihrer Existenz ertragen können. Von ren ausdauernden Pflanzen treiben viele nach der Malıd neuerlich frische Sprosse, andere wieder entwickeln nur während eines Hochstandes Stengel, Blätter und Blüten und überdauern die übrige Zeit nur mittels unterirdischer Organe, wie die meisten Zwiebel- und Iinollengewächse. Wieder andere bleiben bis zur ersten Wiesenmahd ganz niedrig und schießen dann zur Zeit des zweiten Ilochstandes rasch in die Höhe, wie Heracleum und die Cirsien. Einjährige Gewächse haben oft zur Zeit der ersten Mahd schon reife Früchte. Bei vielen einjährigen und zweijährigen Arten aber haben sich im Laufe der Zeiten anscheinend infolge der regelmäßigen Mahd zwei parallele Rassen entwickelt: eine vor der Mahd blühende, ,ästivale“ mit geringer Verzweigung und gestreckten Stengelinternodien und eine nach der Wiesenmahd blühende , autumnale" mit kurzen Internodien und reicher Verzweigung 
(Saisondimorphismus). Diese Erscheinung wurde u, a. bei Euphrasia, Alectorolophus, Melampyrum. Gentiana und selbst bei ausdauernden Pflanzen wir Galium und Campanula beobachtet.

Wird durch die regelmäßige Nahd der Lebensgang der Viesenpflanzen hochgradig beeinflußt, so wird die Zusammensetzung der Wiesenflora durch andere Eingriffe des Menschen verändert. Einerseits werden vielfach

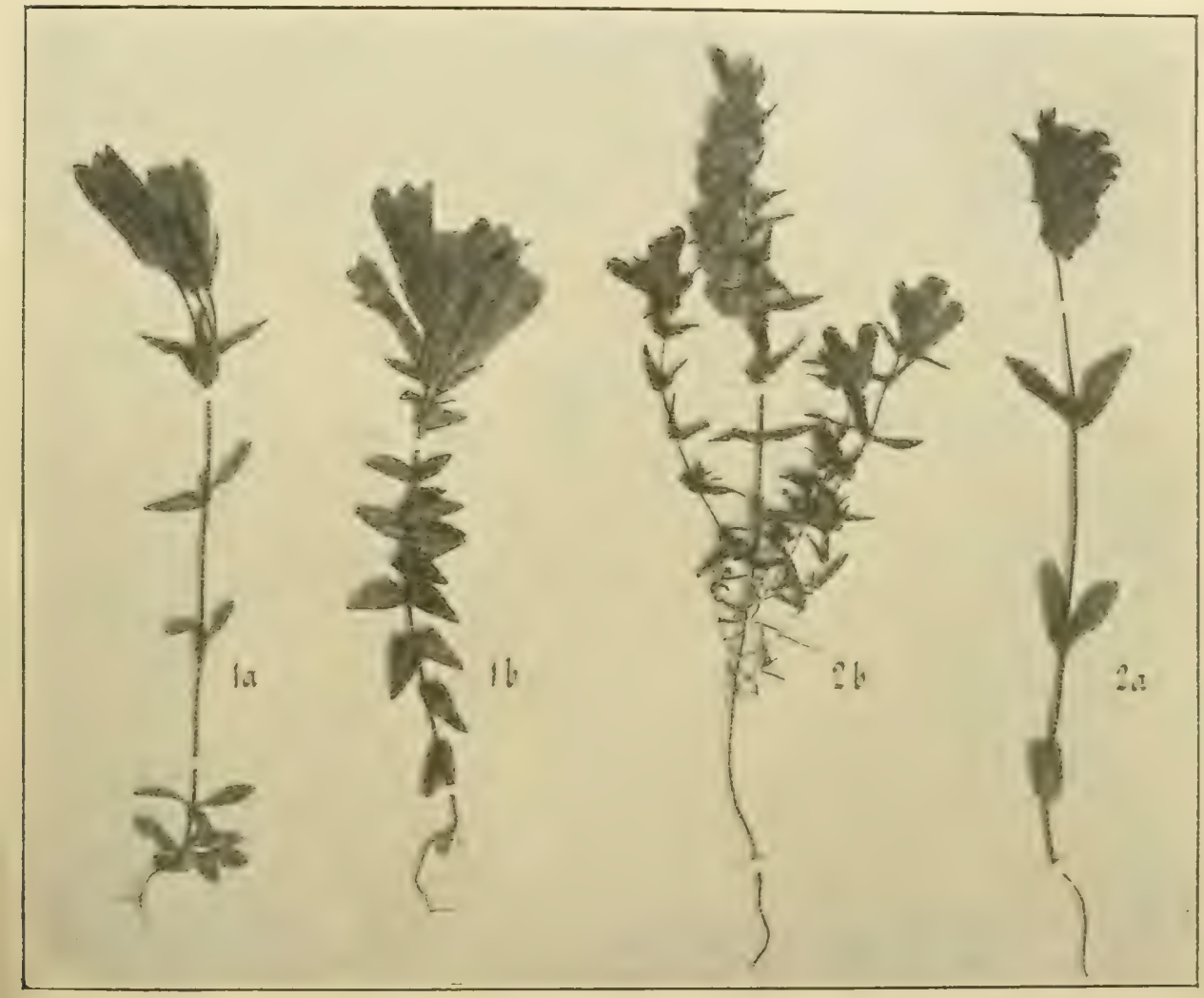

Abb. 12. Saisondimorphe Rassen.

$1 a$ Gentiana aspera Subsp. norica. $1 b$ Gentiana aspera Subsp. Sturmiana. $2 a$ Alectorolophus maior Subsp. maior. $2 b$ Alectorolophus maior Subsp. montanus, $1 a, 2 a$ blūhen vor, $1 b .2 b$ nach der Wiesenmahd.

(Nach einer Aufnahme von Prof. Amalie Mayer, Wien.)

neue Arten auf den Wiesen angebaut; vornehmlich Kleearten, aber auch verschiedene Gräser; speziell beim französischen Raygras (Arrhenatherum elatius) ist heute z. B. absolut nicht mehr festzustellen, wie weit seine ursprüngliche Verbreitung reicht und wo es ursprünglich angebaut wurde. Dieser Anbau von Wiesengräsern und anderen Futterpflanzen b'schränlst sich in neuester Z Zit. nicht allein auf die Talregion, auch im Hochgebirge werden vielfach die Wins'n und Weiden durch Anbau verschiedener Grassamen verbessert. Ein zweiter Faktor, der auf die Zusammensetzung der Wiesenflora von hervorragender Be- 
deutung ist, ist die Düngung. Es ist schon oben (S. 20 f.) hervorgehoben worden, daß die Pflanzen sich gegenüber dem Gehalte an organischen Nährstoffen nicht indifferent verhalten und daß viele Arten nährstoffreiche Böden direkt meiden. Da die Wiesen die einzige wenigstens halbwegrs natürliche Formation sind, die nnter Umständen rrgehnäßig gerlüngt wird, macht sich dieser Umstand bei diesen am deutlichsten geltend. Man kann direkt zwischen ungedüngten ,Magerwiesen" und gedüngten, ,Fettwiesen" unterscheiden. So gehören in der Talregion die Wiesen, in denen Bromus erectus, Carex montana, Festuca ovina s. I., Nardus stricla, Sesleria varia vorherrschen, zu den Magerwiesen, während auf Fettwiesen Arrhenatherum clatius, Poa trivialis, Holcus lanalus tonangebent sind. Manche Arten der Magerwiesen wie Orchideen und verschiedene Leguminosen (Anthyllis, Onobrychis, Lotus), frmer alle Heidepflanzen verschwinden bei Düngung, ja selbst saure Sumpfwiesen können durch Düngung in fruchtbare Süßviesen umgewandelt werden.

\section{Die Heide.}

Eine eigenartige, im atlantischen und auch noch im nord- und mitteleuropäischen Florengebiete häufige, im Steppengebiete völlig fehlende Formation ist die Heide. Unter Heide im engeren Sinne versteht man einen Bestand niederer Halbsträucher oder Sträucher ohne erheblichen Baumwuchs und ohne geschlossenen saftigen Graswuchs auf nährstoffarmem Boden. Eine so typische und wohl charakterisierte Formation die Heide auch ist, so steht sie doch sowohl ihrer Entwicklungsgeschichte nach als auch durch zahlreiche Übergänge init den Sandgrasfluren, den Hochmooren und den Wäldern in Verbindung.

Die typische Heide, wie sie in Böhmen und Galizien auftritt, stellt der Hauptsache nach einen dichten Bestand von Heidekraut (Calluna vulgaris) dar, in den sich von anderen Sträuchern meist nur Vaccinium Myrtillus, V. Vitis Idaea, Sarothamnus scoparius, Genista pilosa und Genista tincloria mischen. Mächtige Inospolster aus Polytrichum commune sind oft zwischen den einzelnen Heidekrautbüschen entwickelt, von den sonstigen Begleitpflanzen sind Nardus stricla, Deschampsia flexuosa, Carex leporina, Polentilla erecta, EuphrasiaRostkoviana, Anlennaria dioica und Hieracium Pilosella als wohl nie fehlende Arten zu nennen.

Obwohl die Mehrzahl der die Heide zusammensetzenden Arten gelegentlich auch auf Kalkboden auftritt (auch Calluna). kommt die typische Heide nur auf kalkarmem Boden vor, da die Heide überhaupt die typische Formation nährstoffarmer Böden ist, auf der keine andere Formation mehr zur Entwicklung kommt.

Der typische Ort dẹr Entstehung der Heide ist vom Regen ausgelaugter Sandboden. Der Sandboden bindet das Niederschlagswasser nicht, sondern es sickert in die Tiefe und löst dabei einen Teil der Nährstoffe, die so dem Boden verloren gehen. Diese nährstoffarme Schicht nimmt von Jahr zu Jahr zu, und oft bildet sich an der unteren Grenze derselben eine Schicht von durch Humusverbindungen dicht verkitteten Sandes, der ,Ortstein", der für Pflanzenwurzeln undurchdringlich ist. Dieser Ortstein ist daher ein Hindernis für den Baumwuchs und kann leicht dazu führen, daß in solchen saudigen Gegenden 


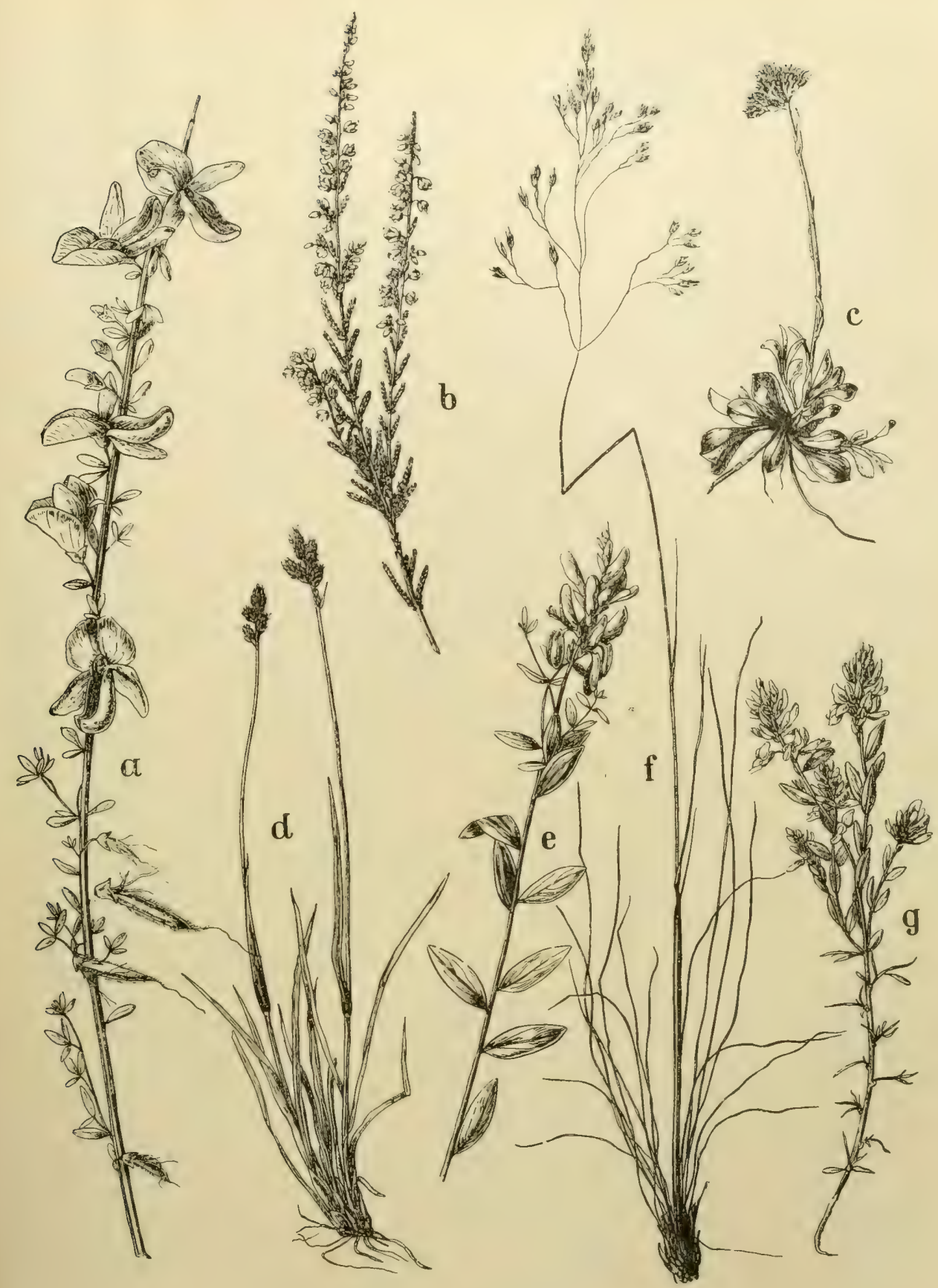

Abb. 13. Heidepflanzen.

$a$ Sarothamnus scoparius. $b$ Calluna vulgaris. $c$ Antennaria dioica. $d$ Carex leporina. $e$ Genista tinctoria. $f$ Deschampsia flexuosa. g Genista germanica.

ein Wald, wenn er einmal geschlagen worden ist, sich nicht mehr verjüngt, sondern in Heide sich verwandelt. Diese Entstehung der Heide aus Wald scheint im 
Gebiete von Österreich-Ungarn selten vorzukommen, viel häufiger ist die aus Sandfluren oder Hochmooren.

Auf Sandboden tritt Calluna gewöhnlich erst auf, wenn der Sand durch die einjährigen, seltener auch ausdauernden (Carex arenaria) Sandpflanzen gefestigt ist. In diesem Sande siedeln sich auch nicht selten Algen, Flechten und Moose an; sobald aber die Heidepflanzen, speziell Calluna, einmal festen Fuß gefaßt haben, pflegen sie sich auch rasch auszubreiten und so die Grasflur in Heide umzuwandeln.

In typischen wasserreichen Hochmooren ist Calluna gewöhnlich nicht anzutreffen. Wie aber ein Hochmoor auszutrocknen beginnt, sei es infolge von küustlicher Entwässerung, sei es infolge natürlicher Ursachen, wie Sinken des Grundwasserspiegels oder zu starkes Emporwachsen der Moordecke, siedelt sich Calluna an und verwandelt im Vereine mit Vaccinien usw. das Moor erst in eine Moorheide und schließlich in eine Heide.

\section{Die Moore.}

Unter dem Namen Moore versteht man Pflanzengenossenschaften des nassen Bodens, die das miteinander gemein haben, daß die abgestorbenen Pflanzenteile nicht verwesen und zu Humus werden, sondern unter Luftabschluß einem langsamen Verkohlungsproze $ß$ verfallen, zu Torf werden.

Was man aber als Moore bezeichnet, gehört zwei sowohl ihrer Entstehungsgeschichte als ihrer Zusammensetzung nach ganz verschiedenen Formationen an, den Flachmooren und den Hochmooren.

Das Flachmoor, auch Wiesenmoor oder Grünlandsmoor genannt, bildet sich in an mineralischen Nährstoffen reiche m Boden dort, wo der Grundwasserspiegel wenigstens zeitweise so hoch liegt, daß der Boden unter Wasser steht. Dies ist einerseits regelmäßig der Fall am Ufer stehender Gewässer, und tatsächlich finden sich in der Verlandungszone derselben stets eine Zone, die einem Wiesenmoor entspricht. Viel ausgedehnter aber sind solche auf ebenem oder wenig geneigtem Boden, wo in geringer Tiefe sich eine wasserundurchlässige Schichte im Boden findet. Dort siedeln sich in dem nassen, oft noch mit einer niedrigen Wasserschichte bedeckten Boden erst verschiedene Cyperaceen an, vornehmlich Carex-, Schoenus- und Heleocharis-Arten, von denen manche nach und nach dichte Rasen bilden, die mit der Zeit zusammenschließen und so schließlich zu einer geschlossenen Vegetationsdecke führen. Zwischen den Rasen wachsen oft verschiedene Moose, besonders Hypnum-Arten, niemals aber Sphagnum, welche die Bildung einer geschlossenen Vegetationsdecke noch beschleunigen. Von sonstigen Arten, die in den Grünlandmooren wachsen, sind Gräser (Alopecurus, Deschampsia caespilosa, Molinia coerulea), Orchidaceen (Orchis palustris, incarnata), Ranunculaceen (Thaliclrum lucidum, Ranunculus), Umbelliferen, Scrophulariaceen (Aleclorolophus maior, Pedicularis palustris), Succisa pralensis, Gompositen (Cirsium) in erster Linie zu nennen; die charakteristischen Arten der Hochmoore, vor allem die Ericaceen (Calluna, Vaccinium, Andromeda, Oxycoccos, Ledum), ferner Eriophorum vaginalum, Trichophorum, 


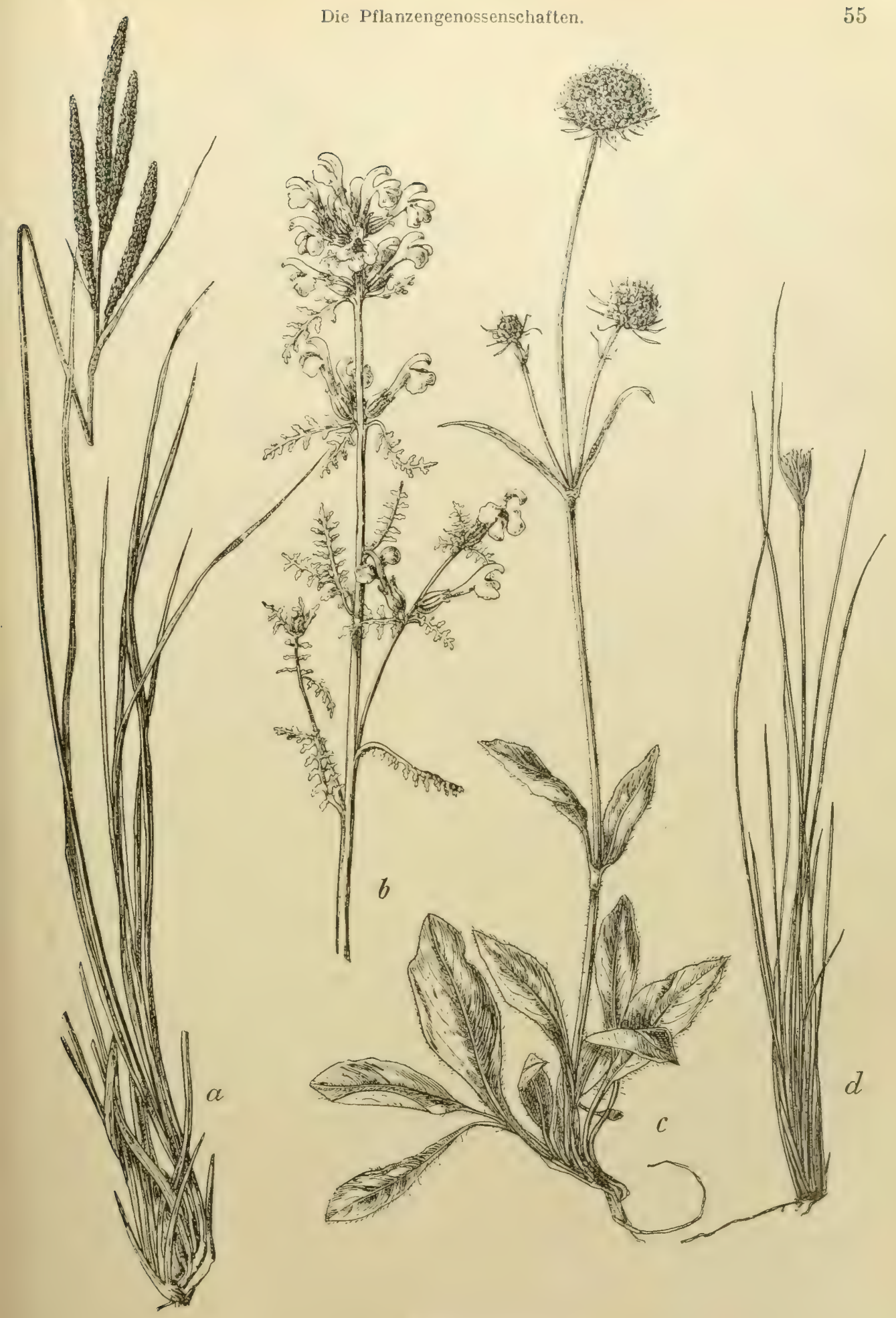

Abb. 14. Wiesenmoorpflanzen.

$a$ Carex elata (= stricta). $b$ Pedicularis palustris, $c$ Succisa pratensis. $d$ Schoenus ferrugineus. 
Carex pauciflora, G. limosa, C. chordorhiza, Belula nana fehlen vollkommen. Nur wenige Arten sind es, die im Hochmoor ebensogut wie im Wiesenmoor gedeihen, so z. B. Carex Goodenoughii, C. elongata, C. canescens, Potentilla palustris, Menyanthes Irifoliala, Pedicularis palustris, Pinguicula vulgaris.

Das Wiesenmoor ist stets flach oder nach einer Seite leicht geneigt. Denn im Wiesenmoore wächst zwar die Bodenschichte allmählich in die Höhe, aber gleichmäBig über das ganzt. Hoor hin, da das Wiesenmoor sich nicht wie das Hochmoor von einem Punkte aus nach allen Seiten hin ausbreitet, sondern in seiner Ausdehnung konstant bleibt, oder aber, wenn es sich ausbreitet, am verlandenden Ufer gegen das stehende Wasser, demnach unter diesen Verhältnissen die am Wasser liegende Seite die jüngste und niedrigste, die vom Wasser entfernte die älteste und höchste ist.

In jeder Beziehung anders verhält sich das Hochmoor. Vor allem bildet sich ein IIochmoor nur auf nährstoffarmem Boden, gleich wie die Heide. Im übrigen kann es aber auf Sandboden, im Walde oder auf alten Wiesenmooren entstehen, oder auch im Wasser, und zwar in nährstoffarmen Heidetümpeln seinen Ursprung nehmen; stets aber muß der Feuchtigkeitsgrad der Luft ein hoher sein und in trockenen Klimaten fehlen Hochmoore daher vollständig.

Am häufigsten ist bei uns die Entstehung des Hochmoores auf einem alten Wiesenmoore zu beobachten. Das Wiesenmoor troknet im Laufe der Zeit auch ohne Zutun des Menschen von selbst aus, da die Torfschicht nach oben zu immer mehr wächst, der Wiesenmoortorf aber das Wasser nur schlecht leitet. Wenn die Torfschicht so dick geworden ist, daß die Moorpflanzen nicht mehr mit ihren Wurzeln in die durchfeuchtete Bodenschicht gelangen, sterben sie ab und an ihre Stelle treten minder hygrophile Gewächse; oft siedeln sich selbst Bäume an und das Wiesenmoor verwandelt sich in Wald. Auf diesem durch die Torfschicht vom an mineralischen Nährstoffen (Kalk usw.) reichen Untergrund isolierten Boden siedeln sich nun an feuchteren, tiefer gelegenen Stellen gern Torfmoose (Sphagnum-Arten) an. Diese Sphagnum-Arten besitzen in den Blättern und auch am Stamme zahlreiche große mit Luft gefüllte Zellen, die sich reichlich mit IVasser füllen und stellen so ein großes Feuchtigkeitsreservoir dar, zumal auch die abgestorbenen Blätter nicht abfallen und auch weiter als Flüssigkeitsspeicher fungieren. Da die Sphagnumrasen nach allen Seiten sich weiter ausbreiten, entstehen bald größere Polster, die sich ringsum gleichmäßig vergrößern oder aber, wenn der Boden nach einer Seite geneigt ist und der Flüssigkeitsstrom nun besonders nach dieser Seite sich ergießt, auch zungenförmig nach dieser Seite weiter wachsen. Da die Torfmoose rasch in die Höhe wachsen, sind die zentralen älteren Teile höher als die jüngeren peripheren und daher kommt es, daß diese Sphagnumpolster in der Mitte höher sind als am Rande, also gewölbt erscheinen. Mit der Ausbildung eines solchen Sphagnumpolsters ist aber das Hochmoor bereits gegeben, denn wenn auch später andere Gewächse in den Moospolstern erscheinen und schliəßlich die Sphagnen fast ganz verdrängen können, ist die Grundlage des Hochmoores doch stets ein sich peripher immer mehr ausdehnender Rasen von Torfmoos. 


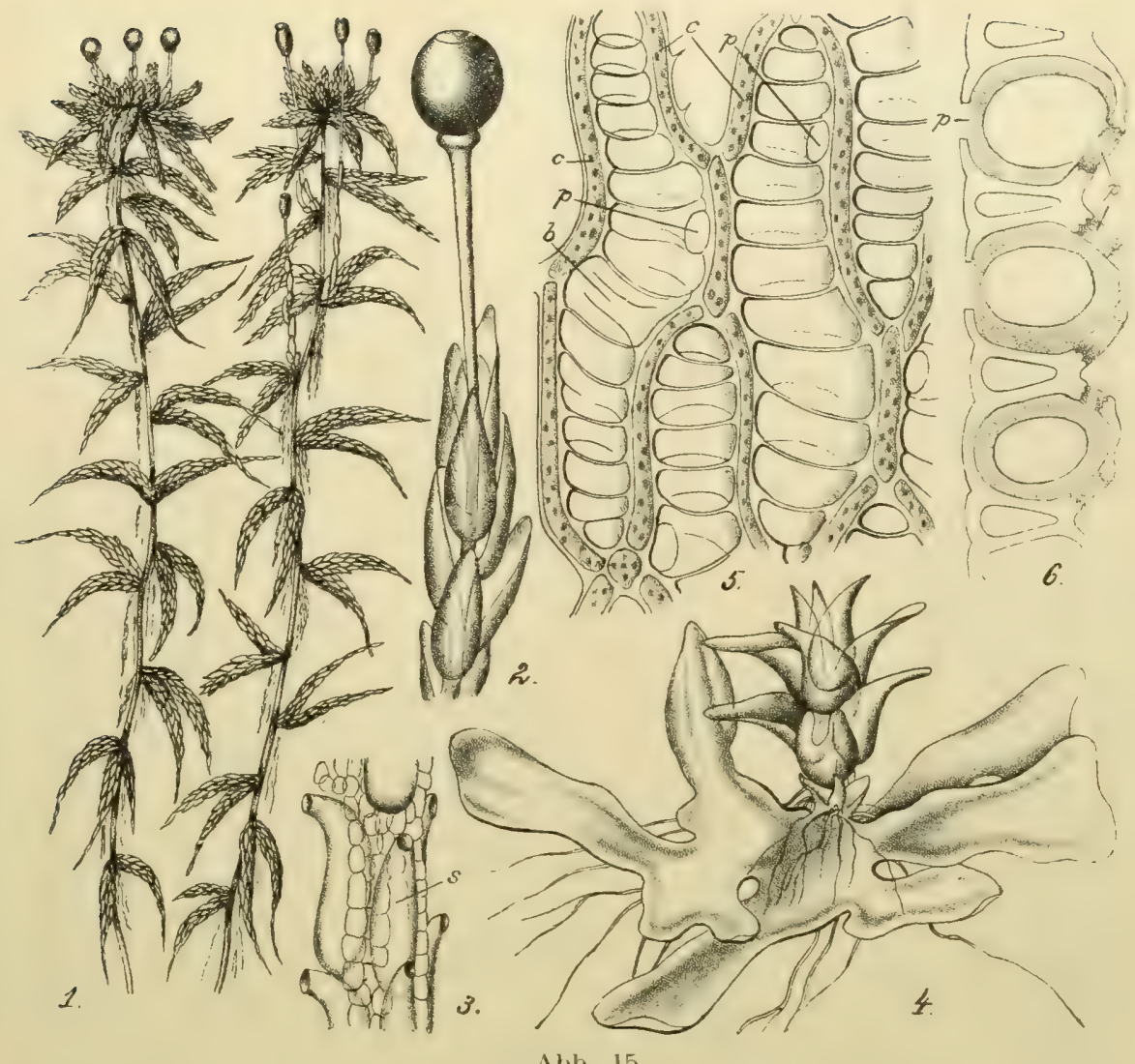

Abb. 15.

1. Sphagnum cymbifolium. 2. Sporogon davon, vergr. 3. Aststück, $s$ Ampullen, d. i. mit Luft gefüllte chlorophyllose Zellen. 4. Vorkeim. 5. Stück des Blattgewebes, $c$ chlorophylhältige, $b$ chlorophyllose luftührende Zellen mit Poren $p$ 400:1. 6. Querschnitt durch ein Blatt, $p$ Poren. $450: 1.1-5$ nach Schimper, 6 nach Russow.

Von den Pflanzen, die sich in den Sphagnumpolstern ansiedeln, sind besonders eine Anzahl von Gyperaceen und Ericaceen von Wichtigkeit. Von den ersteren sind es vor allem das scheidige Wollgras (Eriophorum vaginatum) und das Alpenwollgras (Trichophorum alpinum), weniger gewisse Carex-Arten (C. limosa, C. pauciflora, C. canescens, C. slellulata), die oft in großer Menge auftreten und, da sie dichte Rasen bilden, die Torfmoose fast verdrängen. Von Ericaceen treibt die Moosbeere (Oxycoccos quadripetala) zarte über die Woospolster hinkriechende fädliche Stengel, die übrigen Arten sind strauchig, wie die Sumpfheidelbeere (Vaccinium uliginosum), der Kienporst (Andromeda polifolia), die Heide (Calluna vulgaris); auch die zu einer ganz anderen Familie grhörige Rauschbeere (Empetrum nigrum) verhält sich ökologisch ganz wie die genannten Arten. Andere für die Flora der Hochmoore charakteristische Arten sind Scheuchzeria palustris, Juncus squarrosus, Drosera rotundifolia und anglica, Viola palustris, Trientalis europaea. Auch höhere Sträucher und selbst Bäumo: kommen im Hochmoor vor, so bildet Kru m molz (Pinus Maghus) in den Alpen, 


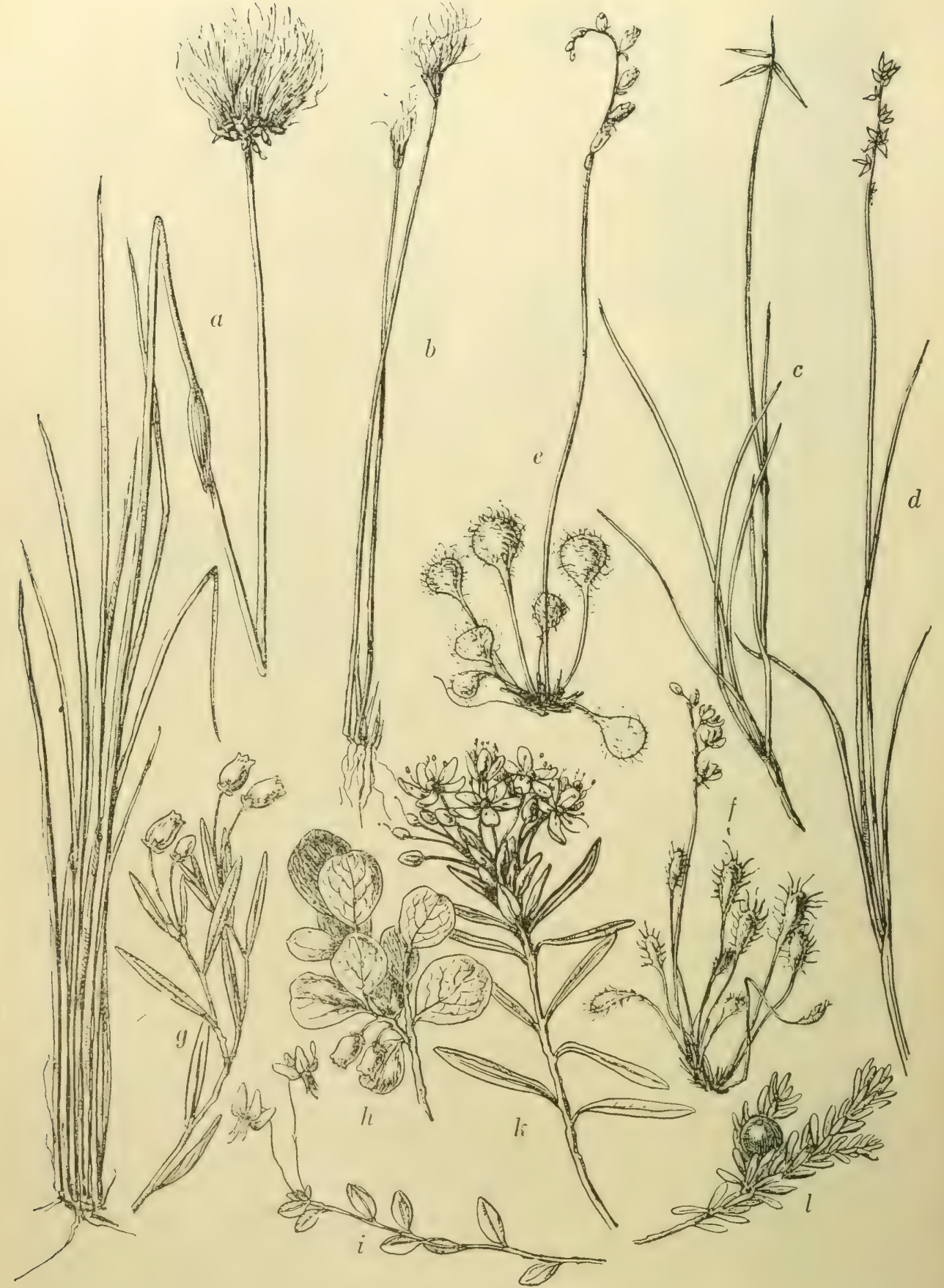

Abb. 16. Hochmoorpflanzen.

$a$ Eriophorum vaginatum. $b$ Trichophorum alpinum. $c$ Carex pauciflora. $d$ Carex stellulata. $e$ Drosera rotundifolia. $f$ Drosera intermedia. $g$ Andromeda polifolia. $h$ Vaccinium uliginosum. $i$ Oxycoccos quadripetala. $k$ Ledum palustre. $/ l$ Empetrum nigrum. 
Sudeten und Karpathen oft undurchdringliche Buschbestände, anderwärts bildet wieder die aufrechte Moosföhre (Pinus uliginosa), seltener die gemeine Föhro (Pinus silvestris) oder selbst die Fichte (Picea excelsa) Waldbestände. Auch Birken (Belula pubescens) treten gelegentlich auf, ab und zu auch strauchige Weiden (besonders Salix cinerea) oder die beiden Strauchbirken Betula humilis und Betula nana.

Die Oberfläche der Hochmoore ist meist wellig, sei es infolge von ungleichem Wachstum der Moosdecke, sei es infolge davon, daß das Moor aus einer größeren Zahl später miteinander verschmolzener Sphagnumpolster entstanden ist, es finden sich erhöhte Polster von Sphagnum, die Bulten, auf denen besonders die xerophileren Elemente der Moorflora, wie Ericaceen, Betula nana usw., freilich auch oft Drosera anglica und Drosera rolundifolia wachsen; zwischen diesen Bulten liegen die vertieften Stellen, die Kolke, in denen sich gern Scheuchzeria palustris, Carex chordorrhiza, C. lasiocarpa und C. limosa ansiedeln, während an ihrem Rande häufig Lycopodium annotinum, Drosera intermedia und Rhynchospora fusca zu finden sind.

In Heidetümpeln nimmt ein|Torfmoor seinen Ursprung, indem sich daselbst flutende Sphagnumarten ansiedeln, die schließlich den Tümpel ganz ausfüllen und so zu einer festen Moosdecke führen. Diese Verfestigung kanı auch nur in den oberen Schichten erfolgen, während in tieferen Schichten noch Wasser oder schwimmendes Sphagnum vorhanden ist und dies führt dann zur Ausbildung schwimmender Moore.

Die Bildung von Hochmooren auf Sandboden ist in Österreich nur in Zentral-Böhmen und besonders in Galizien häufig zu beobachten, nicht aber in den Gebirgsländern, und erfolgt auf ganz ähnliche Weise wie auf Flachmooren. Auch auf den nährstoffarmen wasserdurchlässigen Sanden können sich Sphagnumarten ansiedeln, sobald die Lufteuchtiglieit nur eine genügend große ist, da ja die Sphagnen die Feuchtigleit außerordentlich zäh festhalten und auch die wasserdurchlässigste Unterlage nicht ihre Austrochinung herbeizuführen imstande ist, sie anderseits, da sie die Feuchtiglieit aus der Luft und den Niederschlägen aufnehmen, auf Wasserzufuhr aus dem Boden nicht angewiesen sind. Haben sich Torfmoose einmal auf dem Sande angesiedelt, so erfolgt die Bildung der Moore ganz analog wie an anderen Stellen durch periphere Vergrößerung und schließliche Verschmelzung der einzelnen Moospolster und nachträgliches Einwandern der übrigen Moorpflanzen. Da aber das erste Auftreten von Sphagnumplanzen vom zufälligen Hingelangen von Sphagnumsporen abhängt, braucht natürlich keineswegs das ganze Sandgebiet gleichzeitig sich in Moor zu verwandeln und so kommt es, daß man z. B. in den Sandgebieten Westgaliziens oft genug feuchte Hochmoore mit trockenen Sandflächen abwechseln sieht.

Auch ohne menschliches Zutun können die Hochmoore mit der Zeit austrocknen. So lange freilich die Torfmoose, die unerschöpflichen Feuchtiglieitsreservoire, vorherrschen, kann höchstens ein rapides Sinken des Grundwassers zur Austrocknung des Moores führen; oft aber verdrängen rasenbildende Cyperaceen die Sphagna immer mehr und mehr und auf dem nummehr schon 
Lrockeneren Boden fassen Calluna, Vaccinien und selbst Strauchflechten FuB, welche bei immer mehr zunehmender Austrocknung das Moor in eine Moorheide und schließlich in eine reine Heide verwandeln.

\section{Die Wasser - und Uierflora.}

Die im Wasser wachsenden Pflanzen sind in bezug auf ihre Lebensweise und ihre Vorkommensverhältnisse sehr unghleichartig. Höhere Gewächse kommen nu in verhältnismäßig geringen Tiefen vor, soweit noch die Wirkung des Tageslichtes ziemlich erheblich ist; mikroskopische im Wasser frei schwebende Algen und im Neere auch Rotalgen sind noch in beträchtlichen Tiefen zu finden. Da die Vegetation des Meeres in einem eigenen Kapitel behandelt werden wird, soll hier nur die Vegetation des Sü $B$ wassers besprochen werden.

Die im Wasser lebenden Pflanzen sind entweder am Grunde festgewachsen oder sie schweben frei im Wasser oder schwimmen an dessen Oberfläche. Erstere bilden mit den am Boden festsitzenden oder nur am Boden lebenden Tieren das „Benthos", letztere das ,Plankton“, während die aktiv im Wasser schwimmenden Tiere das „Nekton“ bilden.

Während die im Wasser frei schwebenden und nur durch die Strömung desselben fortbewegten Tiere alle mikroskopisch oder fast mikroskopisch klein sind, gibt es Pflanzen im Wasser, die nicht im Boden wurzeln und recht beträchtliche Dimensionen erreichen. Diese Formen iverden besser aus dem Begriff des Planktons ausgeschieden und als ,Hydrochariten“" bezeichnet.

$\mathrm{Zu}$ diesen Hydrochariten, die frei an der Oberfläche des Wassers umherschwimmen, gehören eine Zahl von Grünalgen, besonders Arten der Gattungen Spirogyra und Zygnema, die größere aus hellgrünen Fäden gebildete Kolonien bilden, welche durch zwischen den einzelnen Faden hängen bleibende Luftblasen an die Oberfläche gehoben werden. Auch andere Algen (Cladophora, Oedogonium) und selbst Moose (Amblystegium) liönnen sich, wenn sie gewaltsam vom Grunde weggerissen werden, so verhalten. Von den Gefäßpflanzen gehören zu den Hydrochariten teils Formen ohne Schwimmblätter, von denen manche durch eigenartige blasenartige Blattorgane schwebend erhalten werden, wie Utricularia und Aldrovandia, teils solche, die Schwimmblätter besitzen und in der Regel auf der Oberfläche des Wassers schwimmen, wie die Farnpflanze Salvinia nalans, ferner von Blütenpflanzen die die Oberfläche stehender Ge-. wässer oft in Mass'n bedeclienden Wasserlinsen (Lemna minor, L. trisulca, Spirodela polyrrhiza) oder der Froschbiß (Hydrocharis Morsus ranae). Auch die Wasseraloe (Slratioles aloides) und die Wrasserfeder (Hollonia) wurzeln nie im Boden. Endlich können auch andere Wasserpflanzen, wenn sie abgerissen werden, im Wasser frei schwebend weiter vegetieren, sowie z. B. die Hornblattarten (Ceralophyllum).

Das Plankton besteht durchwegs aus mikroskopisch kleinen Algen, vornehmlich aus den Gruppen der Cyanoplyceen, Diatomaceen und Peridineen, ab und zu auch aus Desmidiaceen und Bakterien. Die Zusammensetzung des Planktons ist nicht nur von der Lage und Tempreratur des betreffenden Gewässers abhängig, sondern schwankt außerordentlich während der einzelnen Jahres- 


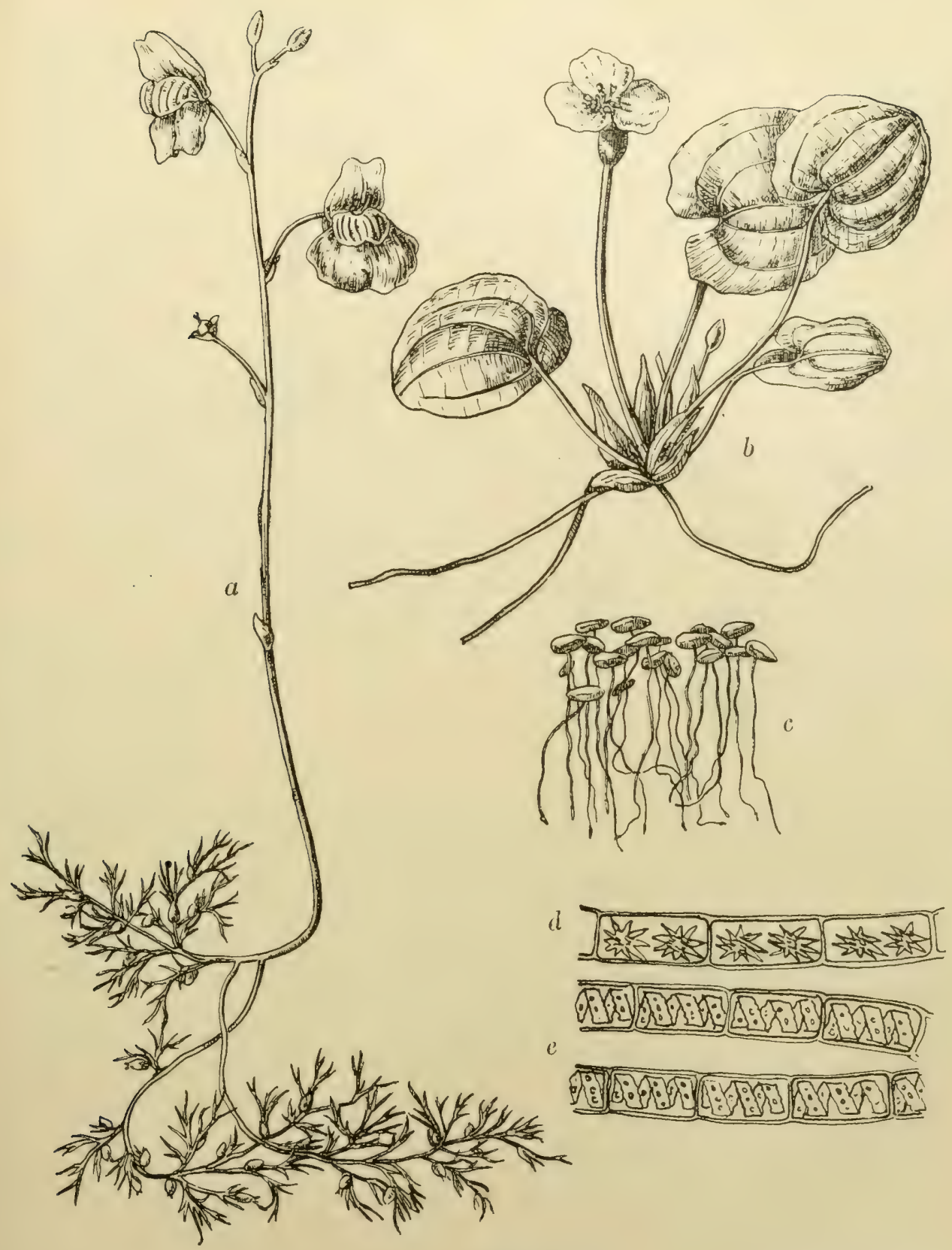

Abb. 17. Hydrachariten.

$a$ Utricularia vulgaris. $b$ Hydrocharis Morsus ranae. $c$ Lemna minor. $d$ Zygnema pectinata. $e$ Spyrogyra areta ( $d$ und $e$ stark vergrößert).

zeiten"und in den verschiedenen Tiefenschichten. Das Plankton ist für die Biologer der Gewässer von größter Wichtigkeit, da es zahlreichen Tieren, darunter selb-1 großen】Fischen, zur ausschließlichen Nahrung dient, pflanzengeographiseh ist seine Bedeutung geringer, zumal rla bis jetzt noch viel zu wenig Lntersuchungen 


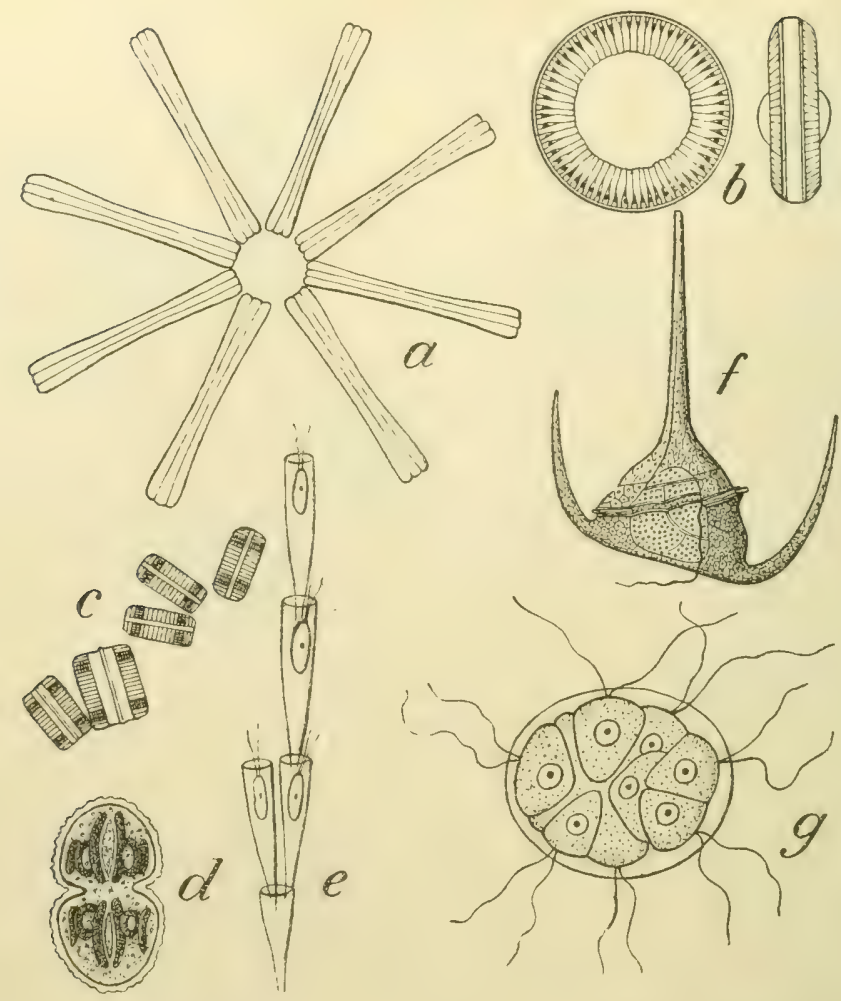

Abb. 18. Einige verbreitete Formen aus dem pflanzlichen Süßwasserplankton.

a Asterionella formosa (Diatomacee) $400: 1$. b Cyclotella comta (Diatomacee). $c$ Fragilaria virescens (Diatomacee) $400: 1$. $d$ Cosmarium Botrytis (Desmidiacee) $300: 1$. e Dinobryon divergens (Chrysomonade) $500: 1$. $f$ Ceratium tripos (Peridinee) $200: 1$. g Pandorina Morum (Volvocacee) $400: 1$.

über dasselbe vorliegen, und wird auf dasselbe in diesem Werke weiterhin nicht näher eingegangen werden. Doch sei noch hervorgehoben, daß das Plankton trotz seiner mikroskopischen Kleinheit auch auf den landschaftlichen Gharakter eines Gebietes nicht. ganz ohne Einfluß ist, da verschiedene Fïrbung der Gewässer oft auf die Zusammensetzung und Menge des Planktons zurückzuführen ist.

Von viel größerer Bedeutung als die frei schwebenden Wasserpflanzen sind die am Boden festwurzelnden Wasser- und Sumpfpflanzen. Unter Wasserpflanzen versteht man jene Gewächse, die im Wasser untergetaucht leben oder bei denen nur die Blüten sich über den Wasserspiegel erheben und höchstens die oberen Blätter oft auf der Wasseroberflïche schwimmen, während jene Gewächse, die oft mit ihren unteren Teilen im Wasser stehen, während ein größerer Teil des Stengels und der Blätter über das Wasser herausragt, zu den Sumpfgewächsen gehören. Manche Pflanzenarten zeigen sich in dieser Beziehung sehr anpassungsfähig. So ist es vom Sumpfknöterich (Polyponum amphibium) seit langem bekannt, daß er in einer Land- beziehungsweise Sumpfform und in 
riner Wasserform mit Schwimmblättern und auftauchenden Blütenähren auftritt, während anderseits verschiedene Wasserranunkeln (Ranunculus aqualilis, paucistamineus) bei zurücktretendem Vasser imstande sind, im fouchten Schlamm als Sumpfpflanzen zu vegetieren und selbst Blüten zu erzeugen. Auch wurde bei zahlreichen Sumpfpflanzen beobachtet, daß sie in tieferem Wasser flutende Wasserformen bilden, die jedoch dann meist nicht zur Blüte gelangen.

Die am Boden festsitzenden Wasserpflanzen kann man in zwei Gruppen teilen. Die einen, die "Nereiden", sitzen auf festem Boden, Felsen, Steinen usw: und sind in unseren Breiten im Süßwasser nur durch Algen und Noose vertreten, die anderen, die „Limnäen", wurzeln in lockererem Boden. Zu den Limnäen gehören sowohl Algen und Moose, als auch Farnpflanzen (z. B. Isoëtes) und Blütenpflanzen. Bei letzteren bleibt entweder die ganze Pflanze unter Wasser und entwickelt auch unter Wasser die Blüten (Ceralophyllum, Naias), meist aber tauchen die Blüten über den Wasserspiegel empor (Myriophyllum, Polamogelon) und eine große Zahl derselben entwickelt auch auf der Wasseroberfläche schwimmende, ,Schwimmblätter", die dann oft die Wasseroberfläche auf weite Strecken hin bedecken (Nuphar, Castalia).

Die Limnäen und die am Ufer wachsenden Sumpfgewächse sind darum von größter Wichtigkeit, da sie eine vom Ufer gegen das Wasser zu stetig fortschreitende Verlandung bei stehenden Gewässern verursachen und so schließlich dahin führen können, daß ein solches Wasser völlig trocken gelegt und in Land verwandelt wird. Die Anordnung der Wasser- und Sumpfgewächse gegen das Ufer zu ist eine in den meisten Fällen regelmäßige und typische.

Bei einer Tiefe von etwa 8-12 $m$ beginnen die Limnäen, zuerst nur aus Moosen und Algen bestehend, unter denen die Characeen oft Massenvegetation bilden. Erst bei etwa $6 \mathrm{~m}$ Tiefe beginnen Blütenpflanzen aufzutreten, erst Arten ohne Schwimmblätter, wie Ceralophyllum, zahlreiche Polamogeton-Arten und Myriophyllum. An noch seichteren Stellen, von etwa $4 m$ Wassertiefe an, treten dann die Wasserpflanzen mit Schwimmblättern auf, vor allem die Secrosen, ferner Polamogelon nalans und Polygonum amphibium; doch schon bald mengen sich in diesen Seerosengürtel die ersten Sumpfgewächse, und zwar ist es die Teichbinse (Schoenoplectus lacustris), die sich am weitesten ins Vasser vorwagt und bis zu einer Tiefe von $3 m$ reicht. An diesen Binsengürtel schließt sich außen ein meist breiter Schilfrohrgürtel, aus Phragmiles communis gebildet, an, der etwa die Zone von $0-2 m$ Wassertiefe einnimmt, oft von Typha-Arten, Iris Pseudacorus, ferner von Typhoides arundinacea, Glyceria aquatica usw. begleitet. Im seichtesten Wasser, bis $0-50 \mathrm{~cm}$ Tiefe, treten dann im Schilfe oft schon die hochwüchsigen Carex-Arten (Carex vesicaria, rostrala, elata, aculiformis usw.) auf, auch Equiselum limosum bildet im Seichtwasser oft große Bestände. Am Ufer bilden dann diese und kleinere Carex-Arten, Eriophorum, Gräser (Molinia) usw. die eigentliche Verlandungszone (s. Abb. 20 auf S. 65).

Die Breite dieser einzelnen Gürtel wechselt natürlich sehr mit der Neigung des See- oder Teichbodens. An den steilen Ufern der Gebirgsseen ist diese ,Verlandungszone oft sehr wenig ausgeprägt, in den flachen Seen und toten Armen 


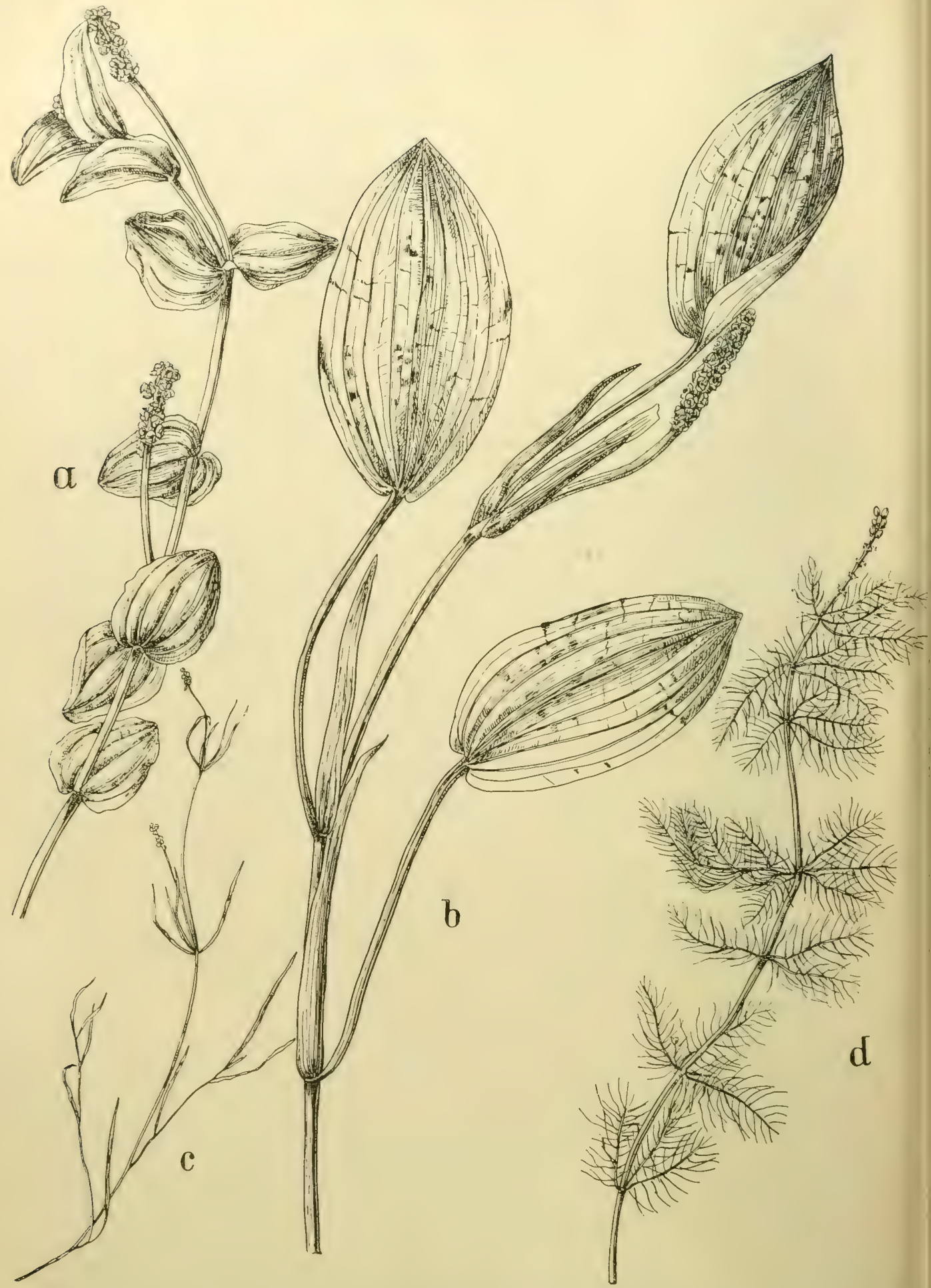

Abb. 19. Limnäen.

a Potamogeton perfoliatus. $b$ Potamogeton natans. $c$ Potamogeton pusillus. $d$ Myriophyllum verticillatum 


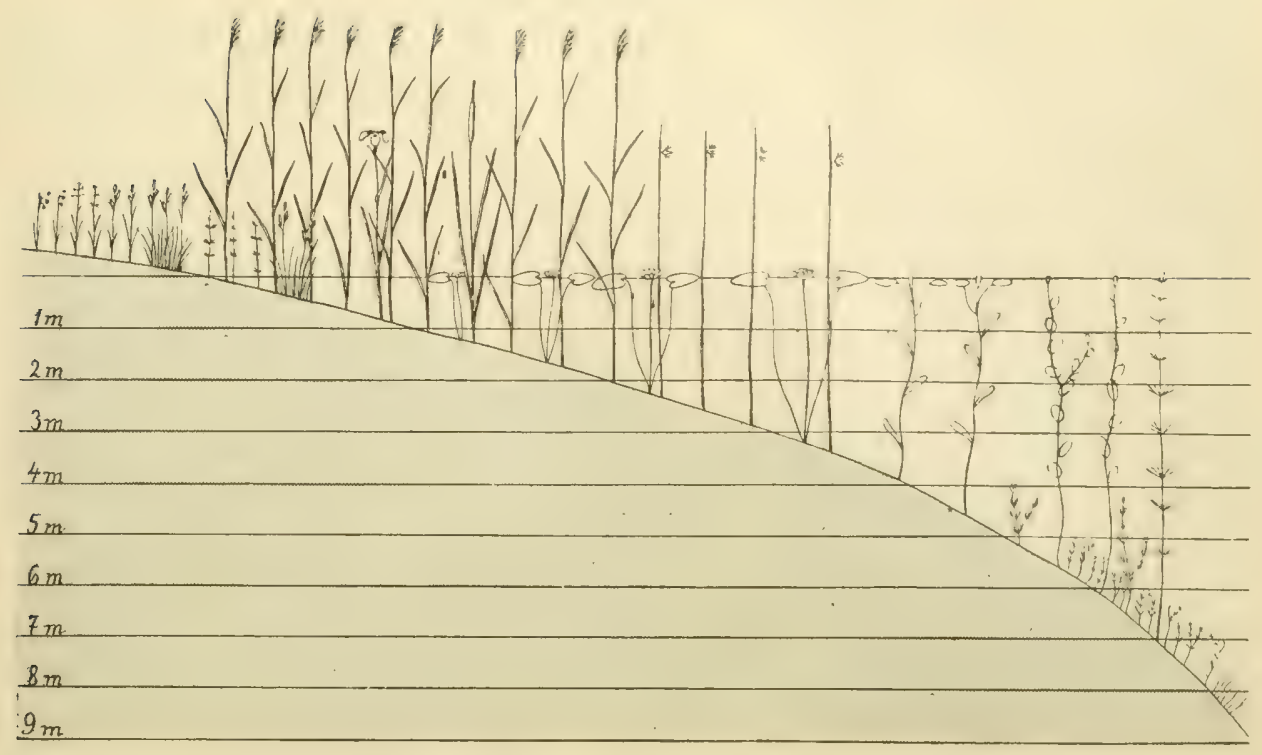

Abb. 20. Schema der Verlandungszone eines stehenden Gewässers.

(Vgl. den Text auf S, 63.)

im ungarischen Tiefland nehmen die Bestände aus Phragmites oft ungeheur: Flächen ein.

Auf sehr wenig geneigtem Boden kann die Verlandungszone oft einen sehr breiten Streifen einnehmen und hier kommt es dann zur Ausbildung vou Wiesenmooren und Sumpfwiesen.

\section{Die Flora der Felsen und des Felsschuttes.}

Auf dem chemisch unveränderten nackten Fels vermögen nur Flechten und Algen sich anzusiedeln (,Lithophyten“). Diese allerdings sind auch auf dent scheinbar ganz nackten Stellen meistens nachzuweisen, wenn man mit einem Hammer anschlägt, indem dann ein chlorophyllgrüner Fleck entsteht. Die Algen, noch mehr aber die Flechten tragen aber sehr zur Bildung des Detritus bei, in welchem auch höhere Gewächse Wurzel fassen können; die ersteren wohl nur durch ihre eigenen Verwesungsprodukte, die letzteren aber auch dadureh, daß sie mit ihren Phizoiden in den Fels eindringen und denselben chemisch verändern.

Auf diesem oberflächlich gebildeten Detritus siedeln sich zunächst Moose (die ,Exochomophyten") an, deren abgestorbene Teile den Detritus noch vermehren. Dieser wird nun durch Regen und Wind in die Ritzen und Spalten der Felsen geweht; eine große Rolle bei der Bilrlung von Humus in den Felsspalten spielen auch die Regenwürmer, die alle möglichen verwesenden Pflanzenteile in die Spalten hineinziehen und übexdies ihre Verdauungsprodulite in Innern der Felsspalten absetzen. Auch andere Tiere, wie Ameisen, Asseln usw.. spielen eine ähnliche Rolle. Dieser in den Spalten aufgesammelte Detritus orles Humus bildet nun einen geeigneten Standort für zahlreiche Farn- und Blütcn- 
pflanzen (die ,Chasmophyten“), zumal da er auch reichlich Wasser aufsaugt, aber infolge seiner geschützten Lage im Felsinnern nur sehr langsam abgibt und sehr lange feucht erhalten bleibt.

Die die Felsen bewohnenden höheren Pflanzen sind der Wirkung von Wind und Wetter, Trockenheit (wegen der mangelnden Schneedecke), der Gefahr der Verletzung durch Sturmschlag, Lawinen usw. stark ausgesetzt, hingegen im allgemeinen vor der Gefahr des Getretenwerdens und vor Viehfraß geschützt. Auch ist der Standort in Felsspalten einer mächtigen Ausbildung des Wurzelsystems hinderlich und dies gewiß mit der Grund des Mangels von Baumwuchs, denn in entsprechend breiten Felsspalten sieht man oft genug Bäume wurzeln. Hingegen macht sich natürlich der Einfluß der chemischen Zusammensetzung des Bodens in besonders hohem Maße geltend und nirgends wohl ist die Verschiedenheit der Flora auf Kalk und Schieferboden mehr in die Augen springend als bei der Felsflora. Hingegen sind die Felspflanzen in zahlreichen Fällen (z. B. Asplenium trichomanes, $A$. viride, Potentilla caulescens, Galium) bei weitem nicht so hochgradig xerophil gebaut als man vermuten würde, weil eben der in der Tiefe der Felsspalten angehäufte Humus die Feuchtigkeit lange zurückhält.

Ganz anders als am festen Fels liegen die Verhältnisse dort, wo lose Gesteinstrümmer den Boden bedecken, also auf Gerölle und Felsschutt. Wenn dieser Felsschutt den. Boden in größerer Mächtigkeit bedeckt, stellt er infolge seiner großen Wasserdurchlässigkeit immer einen trockenen Boden dar, allerdings je nach seiner weiteren Beschaffenheit in geringerem oder höherem Maße. Wenn wir vom eigentlichen Sandboden, wo die einzelnen Fragmente einen Durchmesser von $2 \mathrm{~mm}$ im Durchschnitt nicht überschreiten, absehen, findet sich von Gesteinstrümmern bedeckter Boden an folgenden Punkten:

a) Am Ufer felsiger Flachküsten im Meere. Hier werden die einzelnen Steine von der Brandung regelmäßig hin und her gerollt und allseitig glattgeschliffen und nehmen allmählich eine mehr minder genaue Kugel-oder Walzenform an - Gerölle —, zu einer Verfestigung kommt es bei der immer wieder eintretenden Bearbeitung durch die Brandung nicht, außer bei Hebungen der Küste.

b) An den Ufern fließender Gewässer. Hier werden die einzelnen Steine durch das strömenrle: Wasser hauptsächlich weiter geschoben (nicht gerollt) und nehmen cine plattige flache Form init abgerundeten Kanten an - Geschiebe. Solange das Geschiebe nuter dem stetigen Einfluß des fließenden Wassers bleibt, kann eine Verfestigung nicht eintreten, wohl aber dann, wenn infolge Änderung des Flußlaufes nur mehr ber Ilochwasser eine Überflutung mit meist nur langsam fließendem Wasser erfolgt, welches dann feinen Sand, Schlamm und Humus zwischen den Steinen einlagert.

c) Unter den Abbruchstellen verwitternder Felsen, und da solche besonders im Hochgebirge in großer Ausdehnung vorhanden, besonders daselbst. Hier werden dic einzelnen Steine nicht oder durch zeitweises Pollen und Rutschen nur wenig abgerundet, die einzelnen Trümmer sind celig — Felsschutt. Der Schutt kann in steter Bewegung begriffen sein - beweglicher Schutt - oder aber dort, 
wo er nur gelegentlich durch Hochwasser zusammengeführt wird oder wo Sand, Erde und Pflanzen ihn gefestigt haben, in Pulpe befinulich. Je nach der Größ der einzelnen Felsstücke kann man unterschiden Blockhalden (bis ?5 cm Durchmesser herab), Grobschutt (zwischen 2 und 2; $\mathrm{cm}$ Durchmesser) und Fuinschutt (zwischen $2 \mathrm{~mm}$ und $2 \mathrm{~cm}$ Durchmesser).

d) An den Moränen der Gletscher. Hier sind die einzelnen Blöcke meist kugelig gerundet, von sehr verschiedener Größe und außer an der vom Regen ausgewaschenen Oberfläche durch Sand und Lehm fest verkittet.

Das Gerölle am Meeresstrande trägt nur dort, wo es nicht regelmäßig von Flut und Brandung überflutet ist, eine spärliche Vegetatirn. Hingren ist der Fhußkies und der Felsschutt im Hochepbirge nft reichlich rom Pflanzen aller Art bewachsen.

Eine fast allen Bewohnern des Schotterbolens gemeinsam zuhornmende Eigenschaft ist die Ausbildung eines in große Tiefen reichenden Wurzelsystems, um bis in tiefere wasserreichere Bodenschichten dringen zu hönnen. Am wenigsten ist das noch bei den Bewohnern der Kïsbänke der Flußufer der Fall, da hier das Grundwasser ja in sehr geringer Tiefe zu finden ist. Die Flora der Schotterbänke bietet auch gewöhnlich nicht viel Charakteristisches. sie setzt sich aus den xrophiler gebauten Uferpflanzen zusammen, denen in der Nähe iler Gebirg: sich oft aus letzterem herabgeschwemmte Bewohner der Schutthalden des Berglandes zugesellen.

Hingegen weisen die Bewohner der Schutthalden des Hochgreirges ein Ruthe von sehr interessanten Anpassungserscheinungen auf. Abgeschen davon. daß die Bewohner dieser, Schutthalden. wie schnn rrwähnt. ein inächtig entwickeltes Wurzelsystem, welches in tiefere Bodenschichten, wo größere Feuchtigheitsmengen aufgespeichert sind, zu dringen vermag. laufen die Bewohner des beweglichen Felsschuttes stets Gefahr, von den nachrollenden Schuttmassen verschüttet zu werden und müssen Einrichtungen besitzen, die dies verhindern. Tielfach wird dies erreicht durch horizontal weiter wachsende sprosse. die entweder Wurzeln treiben und sich durch rlen Schutt durcharbeiten, bis sie wieder ans Licht gelangen (.,Schuttwanderer"), wie z. B. lor Silberhafer (Avena argentea) und das rundblätterige Täschelkraut (Thlaspi rotundifolium oder aber olıne zu wurzeln oberflächlich über den Schutt hinkriechen!.,Schuttüberkriecher" wie das Alpenleinkraut (Linaria alpina). Andere Arten wieder vermögen mittels in die Höhe wachsender Blattsprosse sich durch ren schutt durchzuarbeiten (,Schuttstrecker"), z. B. die Farne, wie Dryopteris rigida, oder die Posenwurz (Sedum roseum). Zur Festigung des Schuttes tragen die sogenannters .,Schuttdecker" bei, die über den losen Schutt eine wurzelnde Fasendecke ausbreiten, wie z. B. Saxifraga oppositifolia oder Carex firma. fermer dis ...Schutstauer" , die mit einer kräftigen Pfahlwurzel fest verankrert sind und mit kräticen Fosetten oder Polstern den nachrollenden Schutt aufstaunn. wis dit alpiom Iohne, Saponaria pumila oder Salix retusa.

Eine auffallende Erscheinung ist es, daß in den Gubirgen die Sohnthahten in allen Höhenstufen, in den Tälern so gut wie in der Hochregion, von fast den 
gleichen Arten, und zwar durchweg Hochgebirgsarten bewohnt werden. Es läßt sich dies daraus erklären, daß die Schutthalden in den Tälern den xerophil grbauten Hochgebirgsplanzen geeignete Standorte bieten und diese anderseits raselbst nicht mit den hygrophilen Talbewohnern in einen Konkurrenzkampf geraten und infolgedessen sich üppig entwickeln können.

\section{Die Adventivilora.}

An Stellen, wo der Mensch die ursprüngliche Vegetation verdrängt hat, wie in Beständen von Küulturpflanzen, an Wegen, Zäunen, Bahndämmen, Schuttplätzen, siedelt sich bald eine Flora an, die aus oft einjährigen Pflanzen sehr verschiedenartiger Herkunft besteht. Teils sind es Reste der ursprünglichen Vegetation, die sich da finden, teils andere heimische Gewächse, die von dem noch unbesiedelten Borlen Besitz ergreifen, vielfach aber sind es fremde Arten, die durch den Menschen eingeführt worden sind, teils absichtlich (verwilderte Kulturpflanzen), teils unabsichtlich.

Ursprünglich bei uns heimische Unkräuter werden als A pophyten bezeichnet, und zwar als spontane Apophyten, wenn sie als Reste der ursprünglichen Vegetation auf in Kunstbestände umgewandeltem Boden, vorliommen. ' wir z. B. Heracleum Spondylium und Melandryum silvestre auf Äckern, oder Pleridium aquilinum als Rest der Waldflora auf in Äcker umgewandelten Waldböden. Heimische Arten hingegen, die von ihren ursprünglichen Standorten auf Schutt, an Wegrändern oder in Dorfstraßen ${ }^{2}$ gewandert sind, wie z. B. Urlica dioeca oder Rumex silvesler, werden als ruderale Apophylen bezeichnet.

Den Gegensatz zu diesen Apophyten bilden jene Pflanzen, welche bei uns an primären Standorten nicht vorkommen und daher nachweisbar oder vermutlich durch den Menschen eingeführt worden sind, die sogenannten Anthropochoren. Viele davon sind schon seit undenklichen Zeiten bei uns heimisch geworden, die Archäophylen, wie z. B. Delphinium Consolida, Papaver Rhoeas, Agrostemma Githago, Antirrhinum Orontium, Anagallis arvensis, Centaurea Cyanus; auch Arten, die, wenn auch in historischer Zeit, doch schon seit Jahrhunderten, eingewandert sind, wie Erigeron canarlensis und Oenothera biennis, kann man noch zu den Archäophyten rechnen. Bei manchen der zu den Archäophyten gerechneten Arten kennt man die ursprüngliche Heimat gar nicht, doch schließt man daraus, daß sie bei uns zu Lande niemals außerhalb der Kulturbestände und Ruderalstellen an natürlichen Standorten vorkommen, daß sie fremden Ursprunges sind, wie z. B. Chenopodium album oder Veronica agrestis. Eine andere Kategorie von fremden Ansiedlern stellen die Neophyten dar, Arten, die erst in newerer Zeit in Mitteleuropa eingewandert sind, sich hier aber rasch ausbreiten und im Begriffe sind sich völlig einzubürgern. Bekannte Beispiele solcher Neophyten sind Elodea canadensis, Veronica Tournefortii, Erechtiles hieracifolius, Stenactis annua, Malricaria discoidea; in neuester Zeit beginnen sich insbesondere verschiedene amerikanische Kompositen an unseren Flußufern rasch einzubürgern, so Aster Novi Belgii, Solidago serotina und Rudbeckia laciniata. Manchmal freilich kommt es vor, daß solche fremde Arten sich 
ungeheuer rasch ausbreiten und völlig heimisch zu werden scheinen, um dann allmählich wieder zu verschwinden; das war in Vitteleuropa bei Ghrysanthemum segetum und Senecio vernalis der Fall und auch Erechtites hieracifolius verschwindet an seinen Standorten stets nach einigen. Jahren wieler, um allerdings meist an anderen wieder aufzutauchen.

Die übrigen fremden Ankömmlinge sind gewöhnlich nur vorübergehende Erscheinungen, die nach einer Generation wieder völlig verschwinden. Teils sind es zufällig verwilderte Kulturgewächse - Ergasioph y ten - z. B. Culendula officinalis, Hordeum*vulgare, Avena sativa, teils Arten, lie: zufällig eingeschleppt wurden - Ephemerophyten. Unter letzteren gibtes Arten, die fast alljährlich irgendwo erscheinen, aber ebenso rasch wieder verschwinden, ohne sich an ihren Standorten halten zu können, wie z. B. Phalaris canariensis oder Centaurea Calcitrapa, während andere Arten zufällig einmal im Verlaufe vieler Jahre einmal irgendwo aufgefunden werden. Daß aber besonders an verkehrsreichen Orten die Zahl dieser vorübergehenden Ankömmlinge ganz ungewöhnlich groß ist und die meisten nur übersehen werden, beweisen die Beobachtungen Zimmermanns, der im Laufe weniger Jahrzehnte im Hafen von Mannheim mehrere Hundert verschiedener fremdländischer Arten beobachtete, die allerdings meist nur in einem oder wenigen Exemplaren auftraten und rasch wieder verschwanden. 


\section{Verzeichnis der wichtigsten Literatur.}

\section{Werke allgemeineren Inhaltes.}

Drude O., Handbuch der Pflanzengeographie. Stuttgart, 1890.

Grisebach A., Die Vegetation der Erde nach ihrer klimatischen Anordnung. Leipzig, 1872. 2. Aufl. 1884 .

Haberlandt G., Physiologische Pflanzenanatomie. Leipzig, 1884.

Kerner v. Marilaun A., Pflanzenleben. 2. Aufl. Leipzig und Wien, 1896.

Neger F. W., Biologie der Pflanzen auf experimenteller Grundlage. Stuttgart, 1913.

Pfeffer M., Pflanzenphysiologie. 2. Aufl. Leipzig, 1904.

Schimper A. F. W., Pflanzengeographie auf physiologischer Grundlage. Jena, 1898; zweite, unveränderte Aufl. 1908.

Solms-Laubach H., Graf zu, Die leitenden Gesichtspunkte einer allgemeinen Pflanzengeographie. Leipzig, 1905.

Warming E., Lehrbuch der ökologischen Pflanzengeographie. 2. 'Aufl. d. 'deutschen Ausgabe. Berlin, 1902 .

Wiesner J. V., Elemente der wissenschaftlichen Botanik._3.-4.¿Aufl. Wien, 1902-1912.

\section{Spezialarbeiten.}

\section{Die Wirkung der einzelnen äußeren Faktoren auf die Pflanze.}

\section{A. Die Wärme.}

Detmer W., Über die Einwirkung niederer Temperaturen auf die Pflanze. Forschungen zur Agrikulturphysik. 1888.

Fischer A., Beiträge zur Physiologie der Holzgewächse. (Pringsheims Jahrb. f. wiss. Bot., XXII [1891], 73.)

Hayek A. v., Über eine biologisch bemerkenswerte Eigenschaft alpiner Kompositen. (Österr. bot. Zeitschr., L [1900], 383.)

Kny L., Zur physiologischen Bedeutung des Anthokyans. (Atti d. Congr. bot. internat. Genova, 1892.)

L idfors B., Zur Physiologie und Biologie der wintergrünen Flora. (Bot. Zentralbl., LXVIII [1896], 33.)

Maximov J., Chemische Schutzmittel der Pflanze gegen Erfrieren. (Ber. d. deutschen bot. Ges., XXX [1912], 52.)

Molisch H., Das Erfrieren der Pflanzen über dem Eispunkt. (Sitz.-Ber. d. Akad. d. Wiss., Wien, math.-nat. Kl., CV, I. Abt. [1896], 82.)

Overton E., Beobachtungen und Versuche über das Auftreten von rotem Zellsaft in den Pflanzen. (Pringsheims Jahrb. f. wiss. Bot., XXXVII [1899], 171.)

Sachs J., Kristallbildungen bei dem Gefrieren und Veränderung der Zellhäute bei dem Auftauen saftiger Pflanzenteile. (Ber, d. math.-phys. Kl, d. kgl. sächs. Gesellsch. d. Wiss., XII $[1860], 1$. 


\section{B. Das Licht.}

Bitter K., Über Chlorophyllbildung im Finstern bei Kryptogamen. (Österr. bot. Zeitschr., LV [1905], 302.)

Bonnier G. et Flahault C., Observations sur les modifications des végétaux suivant les conditions physiques du milieu. (Ann. sc. nat., Bot.6. Serie, VII [1879], p. 93.)

Frimmel F. v., Die untere Kutikula des Taxusblattes - ein Lichtreflektor. (Österr. bot. Zeitschr., LXI [1911], 211.)

Godlewski, Über die tägliche Periodizität des Längenwachstums. (Anz, d. Akad. d. Wissensch., Krakau, 1889, Nr. 6, S. XXI.)

Johow F., Über die Beziehungen einiger Eigenschaften der Laubblätter zu den Standortsverhältnissen. (Pringsheims Jahrb. f. wiss. Bot., XV [1884], 282.)

Noll F., Über das Leuchten von Schistostega osmundacea Schimp. (Arb. d. bot. Inst., Würzburg, III [1888], 477.)

Pringsheim $、$ N., Über Lichtwirkung und Chlorophyllfunktion in der Pflanze. (Pringsheims Jahrb. f. wissenseh. Bot., XII [1879-1881], 288.)

Sachs J., Über den Einfluß des Tageslichtes auf Neubildung und Entfaltung verschiedener Pflanzenorgane. (Bot. Zeitung, XXI [1863], Beil.)

- Wirkung des Lichtes auf die Blütenbildung unter Vermittlung der Laubblätter. (Bot. Zeitung, XXIII [1865], 117.)

- Wirkungen farbigen Lichtes auf die Pflanzen. (Bot. Zeitung, XXII [1864], 353.)

Stahl E., Über sogenannte Kompaßpflanzen. (Jenaische Zeitschr. f. Naturwiss., XV [1881].

- Über den Einfluß von Richtung und Stärke der Beleuchtung auf einige Bewegungserscheinungen. (Bot. Zeitung, XXXVIII [1880], 297.)

- Über den Einfluß des sonnigen und schattigen Standortes auf die Ausbildung der Laubblätter. (Zeitschr. f. Naturw., XVI, N. F., IX [1883], 1., 2.)

Wiesner J., Die heliotropischen Erscheinungen im Pflanzenreiche. (Denkschr. d. math.nat. K1. d. Akad. d. Wissensch., Wien, XXXIX [1878] und XLI [1880]).

- Beiträge zur Kenntnis des photochemischen Klimas von Wien, Kairo und Buitenzorg. (Denkschr. d. math.-nat. KI. d. Akad. d. Wissensch., Wien, LXIV [1896].)

- Photometrische Untersuchungen auf pflanzenphysiologischem Gebiet. (Sitz.-Ber. d. Akarl. d. Wissensch., Wien, math.-nat. K1., CII, 1 [1890], 291.)

- Untersuchungen über den Lichtgenuß der Pflanzen im Yellowstonegebiet und in anderen Gegenden Nordamerikas. (Sitz.-Ber. d. Akad. d. Wissensch., Wien, math.-nat. Kl., CXIV, 1 [1905], 77.)

- Der Lichtgenuß der Pflanzen. Leipzig, 1907.

\section{Das Wasser.}

Burgerstein A., Über den Einfluß äußerer Bedingungen auf die Transpiration der Pflanzen. (XII. Jahresber. d. Leopoldst. Komm.-Real- u. Obergymn., Wien, 1876.)

Gain M. E., Recherches sur la rôle physiologique de l'eau dans la végétation. (Ann. se. nat. ser., XX [1895], 63.)

Guttenberg H. v., Anatomisch-physiologische Untersuchungen über das immergrüne Laubblatt der Mediterranflora. (Englers bot. Jahrb., XXXVIII [1907], 383.)

Haberlandt G., Beiträge zur Kenntnis der Lentizellen. (Sitz.-Ber. math.-nat. Kl. d. Akad. d. Wissensch., Wien, LXXII, 1 [1875], 1.)

- Über wassersezernierende und -absorbierende Organe. (A. a. O., CIII u. CIV, 1894-1895.)

Hackel E., Über einige Eigenschaften der Gräser trockener Klimate. (Verh. zool. bot. Ges., Wien, XL [1890], 125.)

Kohl G., Die Transpiration der Pflanzen. Braunschweig, 1886.

Sauvageau C., Observation sur la structure des feuilles des plantes aquatiques. (Journ. de bot., IV [1890], 41.)

Schimper A. F. W., Über Schutzmittel des Laubes gegen Transpiration, vornehmlich in der Flora Javas. (Monatsber. d. Berl. Akad. d. Wissensch., VII, 1890.) 
Schenk II., Über die Biologie der Wassergewächse. Bonn, 1886.

Stahl E., Entwicklungsgeschichte und Anatomie der Lentizellen. (Botanische Zeitung, $1873,561$.

Über die Einwirkung des sonnigen und schattigen Standortes auf die Ausbildung der Laubblätter. (Jenaische Zeitschr. f. Naturwiss., XVI [1883], 162.)

Tschirch A., Beiträge zur Anatomie und zum Einrollungsmechanismus einiger Grasblätter. (Pringsheims Jahrb f. wiss. Bot., XIII [1882], 370.)

Wagner A., Zur Kenntnis des Blattbaues der Alpenpflanzen und dessen biologischer Bedeutung. (Sitz.-Ber. d. Akad. d. Wissensch., Wien, math.-nat. KI., CI, 1 [1892], 487.)

Wiesner J., Der absteigende Wasserstrom und dessen physiologische Bedeutung. (Bot. Zeitung, 1889.)

- Formänderungen von Pflanzen bei Kuitur im absolut feuchten Raume und im Dunkeln. (Ber. d. deutsch. bot. Ges., IX [1891], 46.)

- Über ombrophile und ombrophobe Pflanzenorgane. (Sitz.-Ber. d. Akad. d. Wissensch., Wien, math.-nat. Kl., CII, Abt. 1 [1893], 503.)

\section{Die Luft.}

Borggreve B., Über den Einfluß des Sturms auf die Baumvegetation. (Abh. d. nat. Ver., Bremen, III [1872], 251.)

Kihlmann A. O., Pflanzenbiologische Studien aus Russisch-Lappland. Helsingfors, 1890. Wieler A., Die Beeinflussung des Wachstums durch veränderte Partiärpressung des Sauerstoffs. (Arb. d. bot. Inst., Tübingen, I.)

\section{E. Die chemische Zusammensetzung des Bodens.}

Bonnier G., Quelques observations sur les relations entro la distribution des Phanérogames et la nature chimique du sol. (Bull. soc. bot. de France, XXVI [1879], 338.)

Brick C., Beiträge zur Biologie und vergleichenden Anatomie der baltischen Strandgewächse. (Schr. d. nat. Ges., Danzig, N. F., VII [1888], 108.)

Diels L., Stoif wechsel und Struktur der Halophyten. (Pringsheims Jahrb. f. wiss. Bo£., XXXII [1898], 309.)

Frank, Über die Pilzsymbiose der Leguminosen. Berlin, 1890.

Lierner A., Über das sporadische Vorkommen sogenannter Schieferpflanzen im Hochgebirge. (Verh. zool.-bot. Ges., Wien, XIII [1863], 245.)

Lesage P., Recherches expérimentales sur les modifications des feuilles chez les plantes maritimes. (Rev. gen. de bot., II [1890], 54.)

Sadebeck, Über die generationsweise fortgesetzten Aussaaten und Kulturen der Serpentinformen der Farngattung Asplenium. (Ber. über d. Sitzungen d. Ges. f. Bot. in Hamburg, III [1887], 4.)

Stebler und Schröter C., Versuch einer Gliederung der natürlichen Wiesentypen der Schweiz. (Landw. Jahrb. d. Schweiz, X, 1892.)

Unger F., Über den Einfluß des Bodens aut die Verteilung der Gewächse. Wien, 1836.

Tierhapper F., Der Kreislauf des Stickstoffs im Pllanzenreich. (Jahresb. d. ErzherzogRainer-Gymnasiums, Wien, 1904.)

\section{F. Die physikalischen Eigenschaften des Bodens.}

Gain E., Action du l'eau du sol sur la vegetation. (Revue gen. de bot., VII [1895], 15.)

Hoff mann H., Untersuchungen zur Klima- und Bodenkunde mit Rücksicht auf die Vegetation. (Beil. z. bot. Zeitschr., 1863.)

İrašan F., Über die geothermischen Verhältnisse des Bodens und deren Einfluß auf die geographische Verteilung der Pflanzen. (Verhandlungen d. zool. bot. Ges., Wien, XXXIII [1883], 587.)

Oettli M., Beiträge zur Ölologie der Felsenflora. Zürich, 1905.

Schröter C., Das Pflanzenleben der Alpen. Zürich, 1908. 


\section{G. Der Einfluß der Tiere und Menschen auf die Vegetation.}

Huth E., Die Klettpflanzen mit besonderer Berücksichtigung ihrer Verbreitung durch Tiere. (Bibl, bot., H. IX [1887].)

- Die Verbreitung der Pflanzen durch die Exkremente der Tiere. (Samml, naturwiss. Vortr., III, Berlin, 1912.)

Kinuth P., Handbuch der Blütenbiologie. Leipzig, 1898-1905.

Ludwig F., Lehrbuch der Biologie der Pflanzen. Stuttgart, 1895.

II orton F., Die Bedeutung der Ameisen für die Verbreitung der Pflanzen. (Mitt. nat. Ver. a. d. Univ., Wien [1912], 77.)

Müller H., Alpenblumen. Ihre Befruchtung durch Insekten und ihre Anpassungen an dieselben. Leipzig, 1881.

Sernander R., Versuch einer Monographie der europäischen Myrmekochoren. (Kgl. Svenska Vetinsk. Akad. Handl. XLI, Nr. 7.)

Thellung A., Die Adventiv - und Ruderalflora des Kantons Zürich. Zürich, 1905.

- La flore adventive de Montpellier. (Mitt d. bot. Mus, Zürich, LVIII, 1912.)

\section{Die Klimate in ihren Beziehungen zur Pflanzenwelt.}

\section{A. Die Wärmezonen.}

Hann, Handbuch der Klimatologie. 2. Aufl Stuttgart, 1897.

Kiöppen, Klimalehre. Leipzig, Sammlung Göschen, 1899.

- Versuch einer Klassifikation der Klimate. Leipzig, 1901.

Schimper A. F. W., Pflanzengeographie auf physiologischer Grundlage. Jena, 1898.

\section{B. Die Niederschläge und ihre Beziehungen zur Vegetation.}

Brandis D., Regen und Wald in Indien. (Meteorolog. Zeitschr., 1887, 369.)

Brockmann - Jerosch H., Der Einfluß des Klimacharakters auf die Verbreitung der Pflanzen und Pflanzengesellschaften. (Englers bot. Jahrb., XLIX [1913], Beibl., Nr. 109.)

Schimper A. F. N., Pflanzengeographie auf physiologischer Grundlage, S. 176 ff.

\section{Der Wind als klimatischer Faktor.}

Borggreve B., Über den Einfluß des Sturms auf die Baumvegetation. (Abh. d. nat. Ver., Bremen, III [1872], 251.)

Kihlmann A. O., Pflanzenbiologische Studien aus Russisch-Lappland. Helsingfors, 1890. Schröter C., Das Pflanzenleben der Alpen. Zürich, 1908.

Tanfiljew A., Die polare Grenze des Waldes in Rußland nach Untersuchungen in der Tundra der Timan-Ssamojeden. Odessa, 1911.

\section{Die Beeinflussung klimatischer Wirkungen durch edaptische Einflüsse.}

Iiraus G., Boden und Klima auf kleinstem Raum. Jena, 1911.

Radde G. v., Reisen im Süden von Ostsibirien. (Beiträge z. Kenntnis d. russischen Reiches, XXIII.)

Tanfiljew G., Pflanzengeographische Studien im Steppengebiete. Petersburg, 1908.

Volkens G., Die Flora der ägyptisch-arabischen Wüste auf Grundlage anatomisch-physiologischer Forschungen. Berlin, 1887.

\section{E. Die Klimate Österreich-Ungarns in ibren Beziehungen zur Pllanzenwelt.}

Ginzberger A., Die Pflanzenwelt Österreich-Ungarns. (Das Wissen f. Alle, II [1902], 397.) Iierner A., Österreich-Ungarns Pflanzenwelt. (Die österr.-ung. Monarchie in Wort und Bild, Übersichtsband, S. 185. Wien, 1887).

Iilimatographie von Österreich. Herausgegeben von der Direktion d. k. k. Zentralanst. f. Meteorologie und Geodynamik, Wien. Wien, 1904. 
1. Das mediterrane Klima.

Beck v. Managetta G., Die Vegetationsverhältnisse der illyrischen Länder. Leipzig, 1896. Flahault C., Les herborisations aux environs de Montpellier. II. Les Garigues. (Journal de botis in 1888], 34.)

Ginzberger A. und Maly K., Exkursion in die illyrischen Länder. (Führer zu d. wiss. Exkursionen d. II. internat. bot. Kongresses, Wien, 1905.)

Guttenberg H. v., Anatomisch-physiologische Untersuchungen über das immergrüne Laubblatt der Mediterranflora. (Englers bot. Jahrb., XXXVIII [1907], 383.)

Nikolié E., Phänologische Beobachtungen aus der Winterflora Ragusas. (Öst. bot. Zeitschr., XLVIII [1898], 451.)

Philippson A., Das Mittelmeergebiet. Leipzig, 1904.

Willkomm M., Grundzüge der Pflanzenverbreitung auf der iberischen Halbinsel. Leipzig, 1896.

2. Das mitteleuropäische Klima.

Bürgen M., Bau und Leben unserer Waldbäume. Jena, 1897.

Drude O., Deutschlands Pflanzengeographie. I, 1896.

- Der herzynische Florenbezirk. Leipzig, 1902.

Graebner P., Die Pflanzenwelt Deutschlands. Leipzig, 1909.

Mohl H. v., Über die anatomischen Veränderungen des Blattgelenks, welche das Abwerfen der Blätter herbeiführen. (Bot. Zeitung, 1860.)

WViesner J., Untersuchungen über die herbstliche Entlaubung der Holzgewächse. (Sitz.-Ber. d. Akad. d. Wiss., Wien, math.-nat. Kl., LXIV [1465] 1871.)

3. Das Steppenklima.

Gruner L., Zur Charakteristik der Boden- und Vegetationsverhältnisse des Steppengebietes und der Dniepr- und Konka-Niederung unterhalb Alexandrowsk. (Bull. soc. imp. nat. Moscou, 1872, Nr. 1.)

Hackel E., Über einige Eigentümlichkeit der Gräser trockener Klimate. (Verh. d. zool, bot. Ges., Wien, XL [1890], 125.)

Kerner A., Das Pflanzenleben der Donauländer. Innsbruck, 1863.

Krassnoff G., Geobotanische Untersuchungen in den Kalmückensteppen. (Nachr. d. k. russ. Ges., 1886).

Nehring A., Über Tundren und Steppen der Jetzt- und Vorzeit. Berlin, 1890.

Tanfiljew G., Pflanzengeographische Studien im Steppengebiete. Petersburg, 1898.

Woenig F., Die Pußtenflora der großen ungarischen Tiefebene. Leipzig, 1899.

\section{Das Hochgebirgsklima.}

Bonnier G., Influence des hautes altitudes sur les fonctions des végétaux. (Comptes rendues de l'Acad. d. sciences, Paris, 1890.)

- Etude expérimentale sur l'influence du climat alpin sur la végétation et les fonctions des plantes. (Bull. de la soc. bot. de France, XXXV [1888], 436.)

- Recherches expérimentales sur l'adaption plantes au climat alpin. (Ann. sc. nat. Journ. ser., XX [1895], 29.)

Christ H., Das Pflanzenleben der Schweiz. Zürich, 1879.

Müller H., Alpenblumen, ihre Befruchtung durch Insekten und ihre Anpassung an dieselben. Leipzig, 1887.

Pax F., Das Leben der Alpenpflanzen. (Zeitschr. d. Deutsehen und österr. Alpenver., XXIX [1898], 61.)

Rübel E., Untersuchungen über das photochemische Klima des Berninahospizes. (Vierteljahrsschrift d. nat. Ges., Zürich, LIII, 1908.)

Schröter C., Das Pflanzenleben der Alpen. Zürich, 1908.

Vierhapper F. und $\mathrm{H}$ andel-Mazzetti H. Frh. V., Exkursion in die Ostalpen. (Führer zu d. wiss. Exkursionen d. II. internat. bot. Kongresses, Wien, 1905.) 
Wagner A., Zur Kenntnis des Blattbaues der Alpenpflanzen und dessen biologische Bedeutung. (Sitz.-Ber. d. Akad. d. Wiss., Wien, math.-nat. Kl, CI, 1 [1892], 487.)

Wiesner J., Untersuchungen über den Lichtgenuß der Pflanzen im Yellowstonegebiete und in anderen Gegenden Nordamerikas. (Sitz.-Ber. d. Akad. d. Wiss., Wien, math.-nat. Kl., CXIV, 1 [1905], 77.)

\section{III. Änderungen des Klimas im Laufe der Erdgeschichte.}

Beck v. Managetta G., Die Umkehrung der Pflanzenregionen in den Dolinen des Karstes. (Sitz.-Ber. d. Akad. d. Wiss., Wien, math.-nat. K1., CXV, 1 [1906], 3.)

- Die Bedeutung der Karstflora in der Entwicklung der Flora der Ostalpen. (Result. d. Congres internat. de bot. Vienne, 1905.)

- Vegetationsstudien in den Ostalpen. (Sitz.-Ber. d. Akad. d. Wiss. Wien, math.-nat. Kl. CXVI, CXVII, 1907-1908.)

Briquet J., Recherches sur la flore du district savoisien et du district jurassique francosuisse. (Englers bot. Jahrb., XIII [1891], 47.)

Engler A., Versuch einer Entwicklungsgeschichte der Pflanzenwelt seit der Tertiärzeit. Leipzig, 1879.

- Grundzüge der Entwicklung der Flora Europas seit der Tertiürzeit. (Result. scientif. du Congrès internat. de bot. Vienne, 1905.)

Jerosch M., Herkunft und Geschichte der schweizerischen Alpenflora. Leipzig, 1903.

Kerner A. v., Studien über die Flora der Diluvialzeit in den österreichischen Alpen. (Sitz.-Ber.

d. Akad. d. WViss., Wien, math.-nat. Kl., XCVII, I [1888], 7.)

Pax F., Grundzüge der Pflanzenverbreitung in den Karpathen. Leipzig, 1898 und 1908.

Penck und Brückner E., Die Alpen im Eiszeitalter. Leipzig, 1901-1906.

Schulz A., Entwicklungsgeschichte der phanerogamen Pflanzendecke Mitteleuropas nördlicł der Alpen. Stuttgart, 1899.

Die Veränderungen des Klimas seit dem Maximum der letzten Eiszeit. Herausgegeben v. Exekutivkomitee des 11. internat. Geologenkongresses. Stockholm, 1910.

\section{Die Pflanzengenossenschaften.}

\section{A. Das Zusammenleben der Pflanzen miteinander.}

Beck v. Managetta G., Monographie der Gattung Orobanche. Bibliotheca bot. Heft 19. Kassel, 1890. !

Frank, Uber die Pilzsymbiose der Leguminosen. Berlin, 1890.

Heinricher E., Die grünen Halbschmarotzer. (Pringsheims Jahrb. f. wiss. Bot., XXXI [1898], XXXII (1898], XXXXVI [1901], XXXVII [1902], XLVI [1909].)

- Biologische Studien an der Gattung Lathraea. (Ber. d. Deutschen bot. Ges., XI (1893], 1.) Kronfeld M., Zur Biologie der Mistel (Viscum album). (Biol. Zentralbl., VII [1887], 449.)

Noack F., Über mykorhizenbildende Pilze. (Bot. Zeitung, XLVII [1889], 389.)

Stäger R., Beitrag zur schweizerischen Epiphytenflora. (Mitt. nat. Ges., Bern, 1908.)

Stahl E., Der Sinn der Mykorhizenbildung. (Pringsheims Jahrb. f. wiss. Bot., XXXIT$[1900], 539$.

\section{B. Der Begriff der Pflanzenformation.}

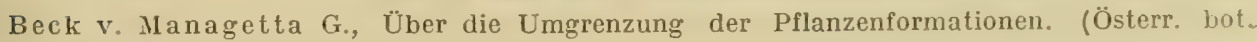
Zeitschr., XLII [1902], S. 421.)

Brockmann-Jerosch H. und Rübel E., Die Einteilung der Pflanzengesellschaften nach ökologisch-physiognomischen Gesichtspunkten. Leipzig, 1912.

Glements F. E., A system of Nomenclature for Phytogeography. (Englers bot. Jahrb., XXXI, Beibl., 70 [1903].)

Drude O., Pflanzengeographie. Aus Neumayers Anleitung zu wiss. Beobachtungen auf Reisen. Hannover, 1905. 
Drude 0. Über die Prinzipien in der Unterscheidung von Vegetationsformationen, erläutert an der zentraleuropäischen Flora. (Englers bot. Jahrb, XI [1890], 21.)

Engler A., Die Vegetationsformationen tropischer und subtropischer Länder in übersichtlicher Zusammenstellung nebst farbigen Signaturen zur Verwendung für Vegetationskarten. (Englers bot. Jahrb., XLI [1908], 367.)

Flahault C. et Schröter C., Nomenclature phytogéographique. Votes et remarques. 3me Congre̊s internat. de bot., Bruxelles, 1910.

Faunkiaer C., Types biologiques pour la géographie botanique. (Overs. over d. kgl. danske Kdensk. Selsk. Forh., 1905.)

- Livsformernes Statistik som Grundlag for biologisk Plantegeografi. (Bot. Tidskr. XXI. [1908] 42.)

\section{Allgemeine Bemerkungen über die wichtigsten Formationen.}

1. Die Wülder.

Bürgen M., Bau und Leben unserer Waldbäume. Jena, 1897.

Cieslar A., Die Rolle des Lichtes im Walde. (Mitt. d. forstl. Versuchswesens Österr., XXX.)

Höck I., Die Verbreitung der Rotbuche und ihrer Begleiter. (Bot. Zentralbl., XLIX [1892], 37.)

- Begleitpflanzen der Kiefer in Norddeutschland. (Ber. d. Deutschen bot. Gesellschaft, XI [1893], 242.)

- Die Flora der Nadelwälder Norddeutschlands. (Natur, 1892.)

Kerner A., Das Pflanzenleben der Donauländer. Innsbruck, 1863.

Roßmäßler E. A., Der Wald. 2. Aufl., durchgesehen und ergänzt v. M. Willko mm. Leipzig und Heidelberg, 1871.

Willkomm M., Forstliche Flora von Deutschland und Österreich. 2. Aufl. Leipzig, 1887.

\section{Die Grasfluren.}

Fritsch K., Über den Einfluß des Ackerbaues und der Wiesenkultur auf die Vegetation. (Mitt. d. nat. Ver. f. Steiermark [1902] 390.)

Stebler und Schröter, Beiträge zur Kenntnis der Matten und Weiden der Schweiz. (Landw. Jahrb. d. Schweiz, X, 1892.)

Wettstein R. v., Deszendenztheoretische Untersuchungen. I. Untersuchungen über den Saison-Dimorphismus im Pflanzenreiche. (Denkschr. d. math.-nat. Kl. d. Akad. d. Wiss., Wien, LXX [1900], 305.)

- Die Biologie unserer Wiesenpflanzen. (Vorträge d. Ver.z. Verbr. naturwiss. Kenntn., Wien, XLIV [1904], H. 11.)

Wönig R., Die Pußtenflora der großen ungarischen Tiefebene. Leipzig, 1899.

3. Heide und Moore.

Fischer-Benzon, Die Moore Schleswig-Holsteins. (Abh. d, naturwiss. Ver., Hamburg, XI [1891], H. 3.)

Graebner P., Studien über die norddeutsche Heide. (Englers bot. Jahrb., XX [1895], 500.)

- Die Heide Norddeutschlands. Leipzig, 1901.

Kerner A., Über die Zsombék-Moore Ungarns. (Verh. d. zool. bot. Ges., Wien, VIII [1858], 315.)

- Das Pflanzenleben der Donauländer. Innsbruck 1863.

\section{Die Wasser- und Uferflora.}

Apstein C., Das Süßwasserplankton. Kiel und Leipzig, 1896.

Behrens, Über den Einfluß der Bewegung und anderer physikalischer Verhältnisse des Wassers auf die Formen der Wasserpflanzen. (Jahresber, d. nat. Ges, Elberfeld, 1880.) Bommersheim P., Untersuchungen über Sumpfgewächse. (Beitr. z. bot. Zentralbl., XXIV, $2[1902]$, S. 504.) 
GIück H., Die Lebensweise der Uferflora. (Englers bot. Jahrb., XLII [1909], Beibl., 99, S. 104.)

- Biologische und morphologische Untersuchungen über Wasser- und Sumpfgewächse. Jena, $1905-1911$.

Hensen, Methodik der Untersuchungen bei der Plankton-Expedition, 1895.

Hildebrand F., Über die Schwimmblätter von Marsilia und einigen anderen amphibischen Pflanzen. (Bot. Zeitung, 1870.)

Schenck H., Vergleichende Anatomie der submersen Gewächse. (Bibl. bot. H. I, 1886.)

- Die Biologie der Wassergewächse. Bonn, 1886.

Schröter und Kirchner O., Die Vegetation des Bodensees. Lindau i. B., 1896.

\section{Die Pflanzen der Felsen und des Felsschuttes.}

Hess E., Über die Wuchsformen der alpinen Geröllpflanzen. (Beitr. z. bot. Zentralbl., XXVII, $2(1910]$, S. 1.)

Oettli, Beiträge zur Ökologie der Felsflora. (Jahrb. d. St. Gallener nat. Ges., 1903.)

Schade A. W., Pflanzenökologische Studien aus den Felswänden der sächsischen Schweiz. (Englers bot. Jahrb., XLVIII [1912], 119.)

Schröter C., Das Pflanzenleben der Alpen, S. 509 ff. Zürich, 1908.

\section{Die Adventivflora.}

Höck F., Ankömmlinge in der Flora Mitteleuropas während des letzten halben Jahrhunderts. (Beih. bot. Zentralbl., IX [1900], XVIII, 2 [1905].)

Laus H., Mährens Ackerunkräuter und Ruderalpflanzen. (Mitt. d. Kommission zur naturwiss. Erforschung Mährens, land- und forstw. Abt., Nr. 2, Brünn, 1898.)

Thellung G., Die Flora des Kantons Zürich. I. Die Adventiv- und Ruderalflora des Kantons Zürich. Zürich, 1905.

- La flore adventice de Montpellier. (Mitt. d. bot. Mus., Zürich, LVIII, 1912.)

Zimmermann F., Die Adventiv- und Ruderalflora von Mannheim, Ludwigshafen und der Pfalz. Mannheim, 1907. 

Spezieller Teil. 



\section{Die Sudetenlïnder.}

(Böhmen, Mähren und Schlesien mit Ausschluß der Karpathen, Ober- und Niederösterreich nördlich der Donau.)

\section{A. Die Vegetation der Sudetenländer in ihrer Abhängigkeit von Klima und Boden.}

Die Sudetenländer in dem eingangs angenommenen Umfange stellen keineswegs ein pflanzengeographisch einheitliches Gebiet dar, sondern zeigen hauptsächlich infolge ihrer orograph hischen Gliederung und der darlurch bedingten klimatischen Verhältnisse Verschiedenheiten in ihrer Flora, wie man sie nicht leicht innerhalb eines Gebietes auf so geringe Entfernungen hin wieder beobachten kann.

Böhmen stellt eine wellige, von Süden nach Norden allmählich an absoluter Höhe abnehmende Ebene dar, die an allen vier Seiten - Nordwest, Nordost, Südost, Südwest - von nicht unbedeutenden Gebirgen umgeben ist.

Von Nordost nach Südwest erstreckt sich der hauptsächlich aus Gneis und Glimmerschiefer bestehende Zug des Erzgebirges, der, an der Eulauer Schlucht beginnend, sich bis zum Tale von Schönbach erstreckt und nach Böhmen hin ziemlich steil abfällt, während sein breiter Rücken ein $10-30 \mathrm{~km}$ breites Hochplateau darstellt, das sich nach der sächsischen Seite hin allmählich senkt. Die durchschnittliche Kammhöhe beträgt $840 \mathrm{~m}$, aus der sich einzelne Gipfel bis über $1000 \mathrm{~m}$ hoch erheben (Fichtelberg $1213 \mathrm{~m}$ ) und die sich ziemlich rasch zu dem zirka $300 \mathrm{~m}$ tieferen südlichen Vorland senkt. Der westlichste Teil des Erzgebirges, von Graslitz westwärts, wird auch als Elstergebirge bezeichnet.

Parallel mit dem Erzgebirge südlich der Eger erhebt sich das aus Basalt bestehende Duppauer Gebirge und westlich von diesem das aus Gneis und Glimmerschicfer bestehende Karlsbader Gebirge mit dem Kaiserwalde. Der äußerste Westen Böhmens gehört bereits dem Fichtelgebirge an, das jedoch größtenteils außerhall der Grenzen Österreichs gelegen ist.

Vom Fichtelgebirge nach Südosten erstreckt sich der fast durchwegs aus Gneis und Granit aufgebaute Böhmerwald in einer Länge von $230 \mathrm{~km}$ bis an dir Donau und wird durch den Sattel bei Neumark in zwei Teile geschieden. Der nördliche, der Pfälzer Wald, hat eine durchschnittliche Kammhöhe von $700 \mathrm{~m}$,

\footnotetext{
Hayek, Die Pflanzendecke Österreich-Ungarns, I.
} 
seine Gipfel sind nur 900-1039 m (Čerchov) hoch, sein steilerer Abfall liegt an der böhmischen Seite; der südliche Teil erreicht im Hauptkamme 1378, in Seitenlämmen bis $1457 \mathrm{~m}$ und hat eine Kammhöhe von über $1000 \mathrm{~m}$, die nur von wenigen 685-967 $m$ hohen Pässen unterbrochen wird. Im Südosten erweitert sich das Massiv gewaltig und wird vom Oberlaufe der Moldau durchflossen, östlich dessen der Stock des Kubany und der Blansker Wald liegen. Die südlichsten Ausläufer des Böhmerwaldes sind der Linzer Wald und Greiner Wald.

Vom Böhmerwald sehr unscharf geschieden, schließt sich an ihn das Granitplateau des niederösterreichischen Waldviertels an, das eine durchschnittliche Höhe von $400-700 \mathrm{~m}$ besitzt und mehrere Gipfel von über $1000 \mathrm{~m}$ Höhe aufweist. Dasselbe geht allmählich in den böhmisch-mährischen Höhenzug über, der sich nach Nordosten erstreckt und nach beiden Seiten allmählich abfällt. Derselbe crreicht nur eine Höhe von $700-800 \mathrm{~m}$ und ist hauptsächlich aus Gneis aufgebaut. Die nordöstliche Begrenzung Böhmens bildet der Zug der Sudeten, der mit dem auf böhmischem Boden größtenteils aus Sandstein aufgebauten Lausitzer Gebirge, das an seinem Südende im Jeschken 1013 m Höhe erreicht, beginnt. Von demselben durch das Tal der Neisse getrennt, erhebt sich das aus Granit aufgebaute Isergebirge, ein massiger Gebirgsstock von einer durchschnittlichen Höhe von 900 bis $1000 \mathrm{~m}$, das im Hinterberg $1126 \mathrm{~m}$ erreicht, und an dasselbe schließt sich das ïhnlich dem Isergebirge breitrückige Riesengebirge, ebenfalls aus Granit bestehend. an, dessen höchste Gipfel die Schneekoppe $(1603 \mathrm{~m})$ und der Brumnerg $(1555 \mathrm{~m})$ sind. Südöstlich des Riesengebirges senkt sich der Kamm der Sudeten bedeutend, erhebt sich aber in dem aus Gneis aufgebauten Adlergebirge wieder bis zu $1114 \mathrm{~m}$. Südöstlich vom Adlergebirge liegt der Glatzer Schnecberg $(1422 \mathrm{~m})$ und an diesen schließt sich das Hohe Gesenke, gleich dem Glatzer Schneeberg aus Gneis und Glimmerschiefer aufgebaut, mit dem 1490 m hohen Altvater sowie das aus Karbonschiefern bestehende Niedere Gesenke an, das durch die Täler der Bečva und Oder von den Karpathen getrennt wird. Die südlichen Ausläufer des Glatzer Schneeberges stehen mit dem böhmisch-mährischen Höhenzug in Verbindung.

Zwischen den Sudeten und dem Erzgebirge endlich liegt das niedrige, von der Elbe durchbrochene Elbesandsteingebirge, das durch seine quaderförmigen Felsbildungen bekannt ist.

Das von diesen Randgebirgen umschlossene zentrale Böhmen stellt ein von Süden nach Norden sich allmählich abdachendes Hügelland dar. Der südliche Teil, im Westen bis zum Brdywald, im Osten bis fast an die Elbe, gehört noch dem böhmischen Massiv an und besteht größtenteils aus Granit und Gneis, der die beiden flachen tertiären Becken von Wittingau und Budweis umschließt. Westlich der Moldau erstreckt sich von Südwest nach Nordost der mit dem Böhmerwalde in Verbindung stehende, $857 \mathrm{~m}$ erreichende Brdywald. Der nördliche Teil Zentralböhmens besteht hauptsächlich aus Sandsteinen der Kreidezeit, die Niederungen an der Elbe sind mit Schottern diluvialen und alluvialen Alters ausgefüllt. Südlich der Beraun sowie entlang der unteren Moldau bis südlich von Prag aber sind silurische und kambrische Schichten mächtig entwickelt, unter denen in pflanzengeographischer Beziehung vor allem die silurischen Kalke der 
Prager Gegend von Wichtigkeit sind. Zu beiden Seiten der Elbe von Leitmeritz bis Tetschen endlich erhebt sich das Böhmische Mittelgebirge, das größtenteils aus Basalt besteht und im Milleschauer $725 \mathrm{~m}$ M. H. erreicht.

Nach Südosten zu senkt sich das Gneismassiv des böhmisch-mährischen Höhenzuges meist allmählich, nur im Süden etwas rascher gegen die Tiefebene an der March und unteren Thaya, deren südlicher Teil, das Marchfeld, nur durch die Karpathen von der kleinen ungarischen Tiefebene getrennt ist, während es südlich jenseits der Donau im südlichen Wiener. Becken seine Fortsetzung findet. Westlich von dieser Tiefebene erheben sich ein welliges tertiäres Hügelland und die stellenweise auftauchenden Jurakalkklippen von Staatz und Nikolsburg, zwischen Thaya und March die Flyschzüge des Steinitzer Waldes und Marsgebirges, welch letzteres das obere Marchbecken, die Hanna, im Süden begrenzt.

Die böhmischen Randgebirge und auch der Brdywald besitzen ein zwar ziemlich rauhes, aber dahei niederschlagsreiches Klima, das überall einem Baumwuchs günstig ist. Die winterliche Kälteperiode dauert 3, höchstens 4 Monate an, die Sommertemperaturen sind wenig extrem, die Niederschläge sind reichlich und betragen 600-1000 mm im Jahre, ihre größte Nenge fällt im Sommer (Juni, Juli), die geringste meist im September oder Februar. Nachfolgende Tabellen sollen ein Bild des Klimas einiger Punkte der böhmischen Randgebirge geben:

a) Mittelverte der Temperatur.

\begin{tabular}{|c|c|c|c|c|c|c|c|c|c|c|c|c|c|}
\hline $\begin{array}{l}\text { Beobachtungsstation, } \\
\text { Lage und } \\
\text { Ifeerchölte }\end{array}$ & Jahr & 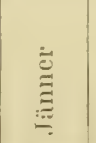 & $\stackrel{\bar{E}}{\underline{\underline{E}}}$ & $\stackrel{N}{=}$ & 可 & 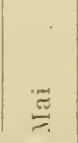 & $\stackrel{\Xi}{\Xi}$ & $引$ & $\overrightarrow{\underline{W}}$ & 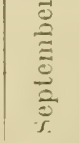 & $\frac{\vdots}{3}$ & 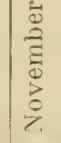 & $\frac{\grave{D}}{\stackrel{\Xi}{D}}$ \\
\hline $\begin{array}{l}\text { Oberjeutensdorf, } \\
\text { Erzgebirge, } 930 \mathrm{~m}\end{array}$ & $7 \cdot 5$ & $-2 \cdot 4$ & $-1 \cdot 1$ & $2 \cdot 4$ & $1 / 7 \cdot 7$ & $12 \cdot 4$ & $15 \cdot 6$ & $17 \cdot 3$ & 16.5 & $13 \cdot 0$ & $7 \cdot 9$ & $2 \cdot 1$ & $1-1 \cdot 2$ \\
\hline $\begin{array}{c}\text { Schlössel, Erzge- } \\
\text { birge, } 325 \mathrm{~m} . .\end{array}$ & $8 \cdot 1$ & $-2 \cdot 4$ & -0.9 & $2 \cdot 3$ & $7 \cdot 9$ & $11 \cdot 8$ & $17 \cdot 1$ & $19 \cdot 1$ & $18 \cdot 1$ & $14 \cdot 2$ & 8.5 & $2 \cdot 2$ & $-1 \cdot 6$ \\
\hline $\begin{array}{l}\text { Eger, Fichtelgebirge, } \\
\qquad 463 \mathrm{~m} \text {. . . . . }\end{array}$ & 6.7 & $-3 \cdot 2$ & $-1 \cdot 8$ & $1 \cdot 2$ & 26.5 & $11 \cdot 2$ & $15 \cdot 2$ & $17 \cdot 0$ & $16 \cdot 0$ & 12.5 & $7 \cdot 1$ & $1 \cdot 3$ & $3 \mid-2 \cdot 2$ \\
\hline $\begin{array}{l}\text { Schüttenhofen, Böh- } \\
\text { merwald, } 461 \mathrm{~m} \text {. }\end{array}$ & $7 \cdot 3$ & -2.9 & $-1 \cdot 0$ & $2 \cdot 0$ & $7 \cdot 0$ & 11.5 & $15 \cdot 4$ & $17 \cdot 2$ & $16 \cdot 7$ & $12 \cdot 9$ & $8 \cdot 0$ & $2 \cdot 2$ & $-1 \cdot 6$ \\
\hline $\begin{array}{l}\text { Krumau, Böhmer- } \\
\text { wald, } 561 \mathrm{~m} . \text {. }\end{array}$ & $7 \cdot 0$ & $-3 \cdot 2$ & -1.7 & 1.5 & $57 \cdot 0$ & 11.9 & $15 \cdot 6$ & $17 \cdot 5$ & $16 \cdot 6$ & 12.5 & $7 \cdot 1$ & $1 \cdot 2$ & $-2 \cdot 3$ \\
\hline $\begin{array}{c}\text { Taus, Böhmerwald, } \\
434 \mathrm{~m} \ldots\end{array}$ & $7 \cdot 8$ & $-2 \cdot 6$ & -0.7 & 2.4 & $17 \cdot 5$ & 12.4 & $16 \cdot 3$ & $18 \%$ & $17 \cdot 4$ & 13.5 & $8 \cdot 1$ & $2 \cdot 1$ & $1-1.5$ \\
\hline $\begin{array}{c}\text { Zwettl, Waldviertel, } \\
525 \mathrm{~m}\end{array}$ & $6 \cdot 2$ & $-3 \cdot 8$ & $-1 \cdot 3$ & 0.8 & 36.0 & $10 \cdot 6$ & $15 \cdot 1$ & $16 \cdot 5$ & $15 \cdot 3$ & 11.4 & $6 \cdot 7$ & $0 \cdot 7$ & $7-2 \cdot S$ \\
\hline $\begin{array}{c}\text { Datschitz, Böhm.- } \\
\text { mähr. Gebirge, } \\
461 \mathrm{~m} .\end{array}$ & $6 \cdot 8$ & -3.9 & $-2 \cdot 1$ & $10 \cdot 9$ & $96 \%$ & 11.8 & $16 \cdot 1$ & $17 \cdot 2$ & $16 \cdot 6$ & $12 \cdot 3$ & $7 \cdot 2$ & $1 \cdot 4$ & $1-2 \cdot 6$ \\
\hline $\begin{array}{l}\text { Iglau, Böhm.-mähr. } \\
\text { Gebirge, } 530 \mathrm{~m} \text {. }\end{array}$ & $6 \cdot 6$ & $-3 \cdot 7$ & $-2 \cdot 2$ & $0 \cdot 7$ & $76 \cdot 1$ & $11 \cdot 1$ & $15 \cdot 4$ & $16 \cdot 7$ & $16 \cdot 2$ & $12 \cdot 1$ & $7 \cdot 3$ & 1.5 & $-2 \cdot 6$ \\
\hline
\end{tabular}




\begin{tabular}{|c|c|c|c|c|c|c|c|c|c|c|c|c|c|}
\hline $\begin{array}{l}\text { Beobachlungsstation, } \\
\text { Lage und } \\
\text { Mcereshöhe }\end{array}$ & Jahrr & $\stackrel{\leftrightarrows}{\Xi}$ & 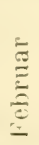 & $\stackrel{N}{=}$ & $\overline{\underline{E}}$ & $\tilde{\Xi}$ & $\Xi$ & $\Xi$ & $\stackrel{\bar{c}}{\overbrace{0}}$ & 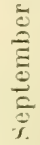 & 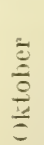 & 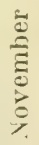 & 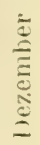 \\
\hline
\end{tabular}

Mähr.-Schönberg, Gesenke, $341 \mathrm{~m}$. 'Iroppau, Niederes Gesenke, $280 \mathrm{~m}$. Trautenau, Riesengebirge, $442 \mathrm{~m}$ Hohenelbe, Riesengebirge, $485 \mathrm{~m}$ Bodenbach, Elbesanásteingebirge, $140 \mathrm{~m}$

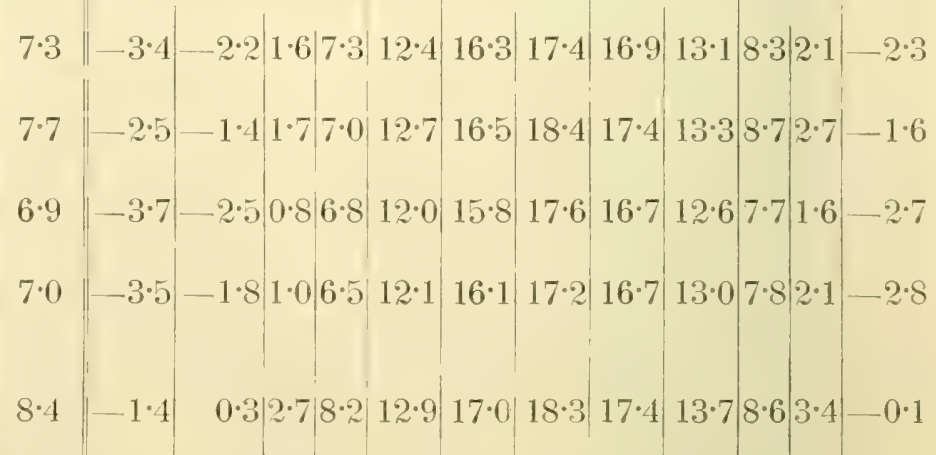

b) Mittelwerte der Niederschläge in Millimetern.

Beobachtungsstation und

Meereshöhe

\begin{tabular}{|c|c|c|c|c|c|c|c|c|c|c|c|c|}
\hline Jahx & $\frac{\grave{\Xi}}{\Xi}$ & $\stackrel{\Xi}{ٍ}$ & $\stackrel{5}{=}$ & $\overline{\mathrm{E}}$ & $\bar{z}$ & $\underline{\Xi}$ & $\Xi$ & 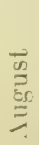 & $\frac{\stackrel{\mathscr{D}}{0}}{\stackrel{0}{\Xi}}$ & $\frac{5}{\frac{5}{5}}$ & 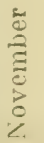 & \\
\hline
\end{tabular}

Oberleutensdorf, $930 \mathrm{~m}$

Schlössel, $325 \mathrm{~m}$.

Eger, $463 \mathrm{~m}$

Schüttenhofen, $461 \mathrm{~m}$

Irumau, $561 \mathrm{~m}$.

Taus, $434 \mathrm{~m}$

Zwettl, $525 \mathrm{~m}$.

Datschitz, $461 \mathrm{~m}$

Iglau, $530 \mathrm{~m}$

Mähr.-Schönberg, $341 \mathrm{~m}$

Troppau, $280 \mathrm{~m}$.

Trautenau, $442 \mathrm{~m}$.

Hohenelbe, $485 \mathrm{~m}$

Bodenbach, $140 \mathrm{~m}$. \begin{tabular}{|l|l|l|l|l|l|l|l|l|l|l|l|l|}
5499 & 31 & 43 & 40 & 39 & 40 & 70 & 51 & 54 & 34 & 45 & 54 & 48
\end{tabular} \begin{tabular}{l|l|l|l|l|l|l|l|l|l|l|l|l}
439 & 23 & 21 & 22 & 24 & 57 & 74 & 54 & 56 & 38 & 26 & 27 & 17
\end{tabular} \begin{tabular}{ll|l|l|l|l|l|l|l|l|l|l|l|l}
585 & 36 & 43 & 39 & 38 & 58 & 75 & 71 & 50 & 40 & 43 & 47 & 45
\end{tabular} \begin{tabular}{l|l|l|l|l|l|l|l|l|l|l|l}
765 & 63 & $39+75$ & 51 & 80 & 104 & 85 & 90 & 61 & 37 & 45 & 35
\end{tabular} \begin{tabular}{l|l|l|l|l|l|l|l|l|l|l|l|l}
606 & 30 & 33 & 46 & 49 & 72 & 89 & 92 & 99 & 58 & 33 & 34 & 34
\end{tabular} \begin{tabular}{ll|l|l|l|l|l|l|l|l|l|l|l|}
652 & 18 & 23 & 33 & 38 & 61 & 101 & 91 & 68 & 56 & 54 & 41 & 68
\end{tabular} \begin{tabular}{l|l|l|l|l|l|l|l|l|l|l|l|l}
688 & 41 & 31 & 43 & 49 & 83 & 103 & 80 & 79 & 67 & 43 & 30 & 39
\end{tabular} \begin{tabular}{l|l|l|l|l|l|l|l|l|l|l|l|l}
562 & 29 & 29 & 39 & 43 & 51 & 78 & 61 & 79 & 32 & 34 & 43 & 44
\end{tabular} \begin{tabular}{ll|l|l|l|l|l|l|l|l|l|l|l}
614 & 34 & 26 & 42 & 46 & 64 & 84 & 85 & 69 & 49 & 45 & 33 & 37
\end{tabular}

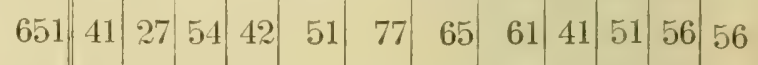
\begin{tabular}{ll|l|l|l|l|l|l|l|l|l|l|l}
630 & 20 & 56 & 38 & 46 & 60 & 88 & 74 & 89 & 59 & 36 & 37 & 34
\end{tabular} \begin{tabular}{l|l|l|l|l|l|l|l|l|l|l|l|l}
1073 & 73 & 67 & 85 & 75 & 103 & 97 & 127 & 134 & 95 & 79 & 72 & 66
\end{tabular} \begin{tabular}{l|l|l|l|l|l|l|l|l|l|l|l|l}
963 & 94 & 67 & 75 & 65 & 67 & 90 & 89 & 87 & 66 & 78 & 88 & 97
\end{tabular} \begin{tabular}{l|l|l|l|l|l|l|l|l|l|l|l|l|l|}
630 & 41 & 43 & 44 & 41 & 57 & 76 & 80 & 64 & 44 & 40 & 50 & 50
\end{tabular}

In keinem der Orte ist die Regenmenge besonders hoch, aber doch überall reichlich g’mug, un Waldbildung zu ermöglichen. Nit zunehmender Meereshöh» aber nimmt die Niederschlagsmenge bedeutend zu, so zeigt z. B. Außergefield im Böhmerwalde $(1058 \mathrm{~m})$ folgende Werte: 
Jänn. Febr. März April Mai Juni Juli August Sept. Okt. Nov. Dez. Jahr

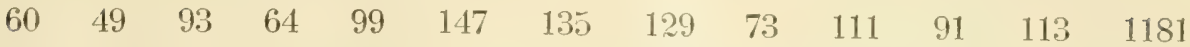

Einsiedel im Erzgebirge $(720 \mathrm{~m})$ weist $830 \mathrm{~mm}$, Eisenstein im Böhmerwalde $(800 \mathrm{~m}) 1203 \mathrm{~mm}$, Friedrichstal im Riesengebirge $(735 \mathrm{~m}) 1376 \mathrm{~mm}$, Fürstenhut im südlichen Böhmerwalde $(1105 \mathrm{~m}) 1181 \mathrm{~mm}$, Hanichen am Jeschken $(500 \mathrm{~m})$ $1062 \mathrm{~mm}$ Niederschlag auf.

Diesen klimatischen Verhältnissen entspricht auch die Vegetation an den Flanken des Gebirges, dichte Wälder sind überall reichlich entwickelt, die nach oben zu, wo die Niederschläge reichlicher werden, an Üppigkeit zunehmen. Die fast überall sehr reiche Ausbildung von Hochmooren wird durch die große Luftfeuchtigkeit begünstigt, auf der Schneekoppe treten an ?6 1 Tagen im. Jahre flarunter an $25 \mathrm{im}$ März, $23 \mathrm{im}$ Juli, 27 im Oktober) Nebel auf, bei Sebastiansberg im Erzgebirge an 100 Tagen im Jahre. In der kalten Jahreszeit werden diese Nebel durch die starke Rauhreifbildung sehr schädlich.

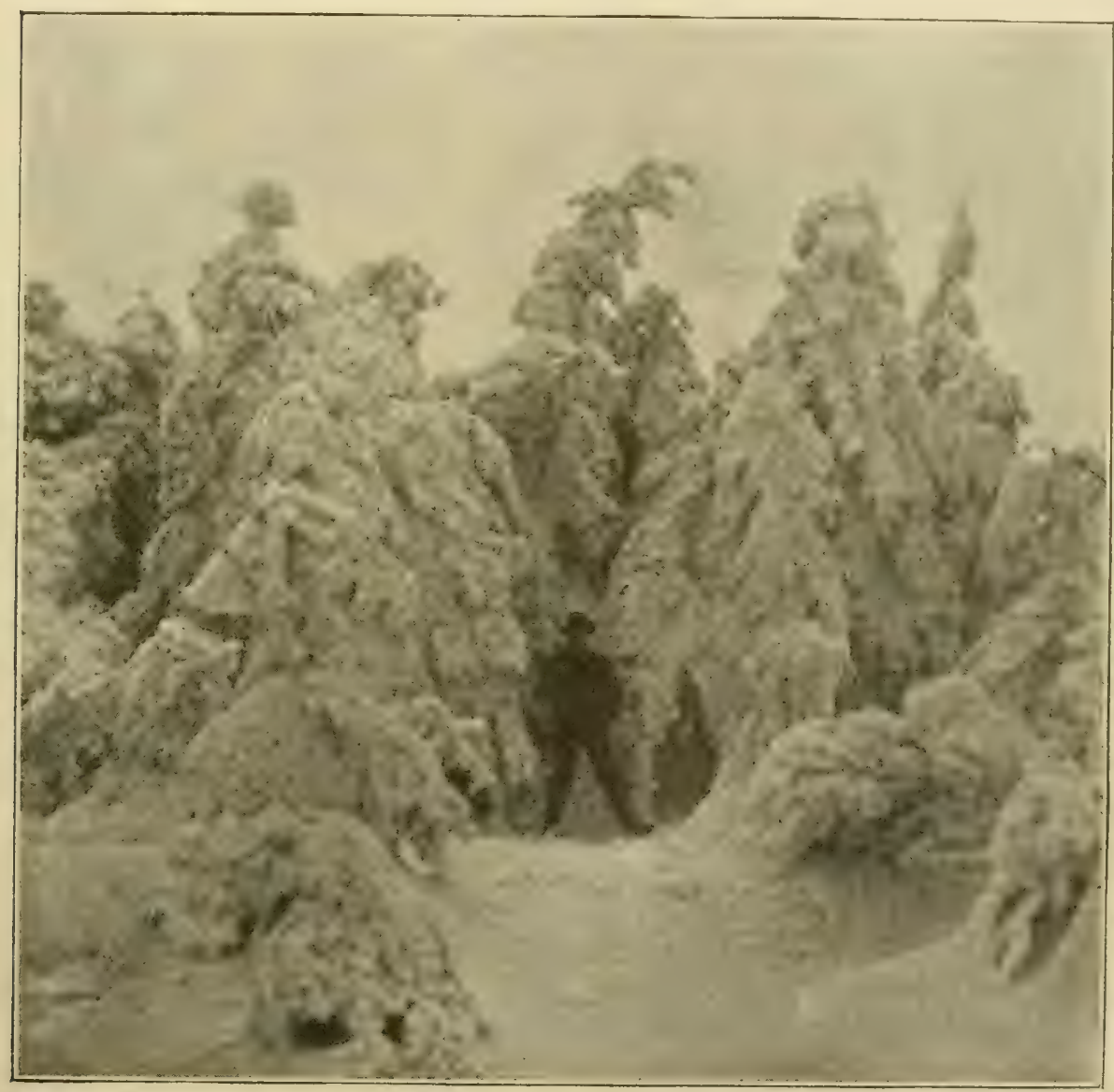

Abb. 21. Rauhreif im Erzgebirge.

(Nach einer Aufnahme von Prof. K. Domin, Prag.)

(Aus Domin, Das böhmische Erzgebirge.) 
Auch an der IValdgrenze sind die Niederschläge noch selnr reichlich, die Petersbaude im Riesengebirge $(1288 \mathrm{~m})$ weist $1600 \mathrm{~mm}$ Niederschlag im Jahre auf; auch erhält das Schmelzwasser des Schnees den Boden sehr lange feucht. Hingegen ist die Temperaturabnahme nach oben zu sehr bemerkbar, wie aus folgender Tabelle hervorgeht:

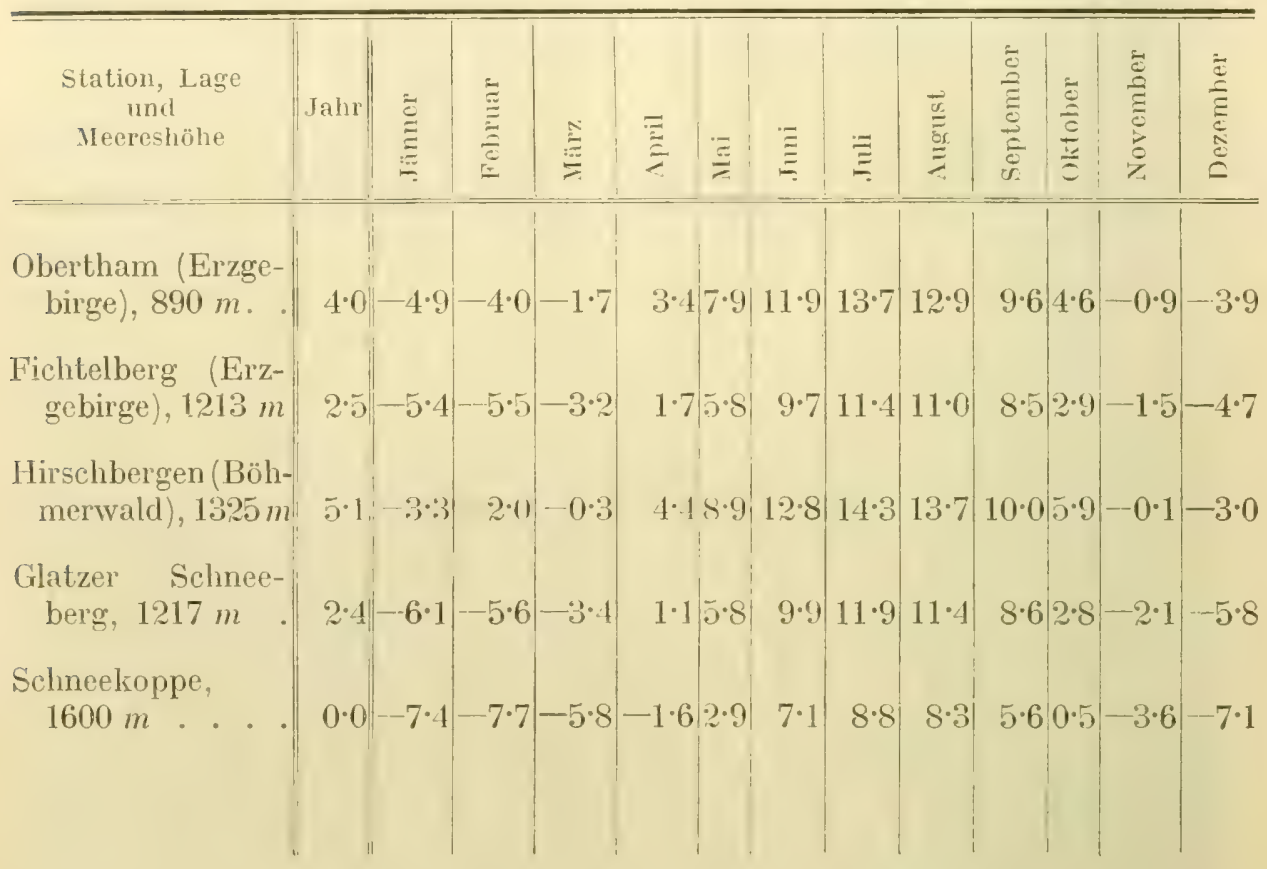

Im Erzgebirge sind demnach bei kaum $900 \mathrm{~m}$ nur mehr 7 Monate frostfrei, während im Böhmerwalde bei $1325 \mathrm{~m}$ noch 8 frostfreie Monate vorhanden sind; erst in den Sudeten, auf der Höhe der Schneeloppe, sinkt die Zahl der frostfreien Monate auf 6. Doch ist die Vegetationsperiode bedeutend kürzer, da der Schnee erst im Mai schmilzt und schon anfangs Oktober sich die Schneedecke erneuert, demnach die Vegetationsperiode auf der Schneekoppe etwa $4^{1} / 2$ Monate dauert. Die verhältnismäßig tiefe Lage der Baumgrenze ist demnach in den böhmischen Gebirgen weder auf zu geringe Niederschläge noch auf die zu kurze Vegetationsperiode zurückzuführen, sondern gewiß in erster Linie auf Windwirkung.

Es ist begreiflich, daß ein Gebiet wie Zentralböhmen, das allseitig von höheren Gebirgen umschlossen ist, relativ arm an Niederschlägen sein muß, da es im ,, Regenschatten" dieser Gebirge liegt. Dies ist auch tatsächlich der Fall. Im ganzen westlichen Trile des inmen Böhmens ereicht die jälnlichr Regenmenge (nit . Iusnahme im Brdywalde) fast nirgends mehr die Höhe von $600 \mathrm{~mm}$ und auf größere Strecken hin, so um Leitmeritz, nördlich von Prag und im mittleren Moldautale um Kamaik nicht einmal $500 \mathrm{~mm}$. Die jährliche Menge und monatige Verteilung der Niederschläge einiger Punkte Zentralböhmens, zeigt folgende Tabelle: 


\begin{tabular}{|c|c|c|c|c|c|c|c|c|c|c|c|c|c|}
\hline Beobachtungsstation & Jahr & 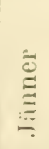 & & $\stackrel{\mathscr{B}}{*}$ & $\bar{\Xi}$ & $\vec{\Xi}$ & $\cong$ & $\equiv$ & 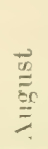 & 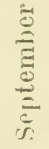 & $\frac{\frac{\partial}{0}}{\frac{1}{0}}$ & 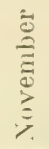 & 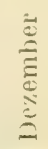 \\
\hline
\end{tabular}

Leitmeritz, $182 \mathrm{~m}$

Lobositz, $161 \mathrm{~m}$

Laun, $105 \mathrm{~m}$.

Prag, $202 \mathrm{~m}$

Bölımisch-Lrija, 271 m

Weißwasser, $304 \mathrm{~m}$.

Czaslau, 275 m.

Pilsen, 319 m

Frauenberg, $390 \mathrm{~m}$

Budweis, $425 \mathrm{~m}$

\begin{tabular}{l|l|l|l|l|l|l|l|l|l|l|l|l}
502 & 33 & 28 & 32 & 30 & 54 & 71 & 72 & 55 & 37 & 41 & 39 & 30 \\
447 & 26 & 29 & 27 & 32 & 45 & 64 & 53 & 41 & 23 & 31 & 40 & 36 \\
496 & 13 & 12 & 30 & 36 & 62 & 78 & 102 & 58 & 56 & 46 & 28 & 32 \\
469 & 23 & 21 & 28 & 38 & 52 & 72 & 60 & 55 & 37 & 27 & 31 & 25 \\
494 & 31 & 36 & 34 & 30 & 47 & 60 & .66 & 60 & 35 & 30 & 37 & 38 \\
646 & 35 & 48 & 49 & 47 & 59 & 64 & 71 & 57 & 42 & 49 & 64 & 61 \\
457 & 23 & 27 & 29 & 40 & 39 & 63 & 63 & 58 & 33 & 26 & 30 & 26 \\
504 & 23 & 26 & 25 & 46 & 64 & 76 & 58 & 59 & 38 & 33 & 30 & 26 \\
473 & 21 & 16 & 30 & 32 & 58 & 67 & 68 & 72 & 37 & 23 & 24 & 25 \\
669 & 30 & 33 & 46 & 49 & 72 & 89 & 92 & 99 & 58 & 33 & 34 & 34
\end{tabular}

Auch hier ist der Sommer zwar die regenreichste Jahreszeit, aber nur in seiner rrsten Hälfte; August und September, also der Spätsommer, sind relativ trocken; besonders in den Zahlen von Laun und Prag macht sich dies stark bemerkbar.

Auch die Temperaturverhältnisse sind andere als in den Randgebirgen. Es weisen als Mittelwerte auf:

\begin{tabular}{|c|c|c|c|c|c|c|c|c|c|c|c|}
\hline Beobachtungsstation & $i_{1} \underset{\Xi}{\Xi} \stackrel{\Xi}{\Xi}$ & $\stackrel{\Xi}{\Xi}$ & $\stackrel{N}{=}$ & $\ddot{z}$ & 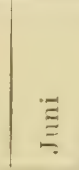 & $\Xi$ & 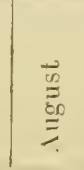 & 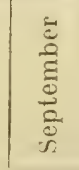 & $\left|\begin{array}{c}0 \\
0 \\
0 \\
0 \\
\frac{3}{4} \\
5\end{array}\right|$ & 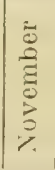 & 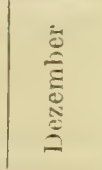 \\
\hline Leitmeritz & $|8 \cdot 7|-1 \cdot 4 \mid$ & $0 \cdot 0$ & $3 \cdot 38 \cdot 5$ & $13 \cdot 3$ & $17 \cdot 1$ & $18 \cdot 7$ & $17 \cdot 9$ & $14 \cdot 3$ & & $3 \cdot 4$ & $-0 \cdot 1$ \\
\hline Lobositz . . & $|8 \cdot 9-1 \cdot 8|$ & $-0 \cdot 1$ & $3 \cdot 39 \cdot 1$ & $14 \cdot 1$ & $17 \cdot 9$ & $19 \cdot 2$ & $18 \cdot 5$ & $14 \cdot 7$ & & $3 \cdot 2$ & -0.6 \\
\hline Laun . . . . . & $8 \cdot 4-1 \cdot 8$ & -0.8 & $58 \cdot 0$ & 12.9 & $16 \cdot 9$ & $18 \cdot 8$ & $18 \cdot 0$ & $14^{\circ}$ & 89 & $3 \cdot 4$ & -0.4 \\
\hline Prag . . . . & $8 \cdot 7-1 \cdot 6$ & $-0 \cdot 1$ & $5 \cdot 18 \cdot 4$ & $13 \cdot 4$ & $17 \cdot 2$ & $18 \cdot 9$ & $18 \cdot 2$ & $14 \cdot 6$ & $9 \cdot 2$ & $3 \cdot 1$ & -0.5 \\
\hline Bühm.-Leipa & $7 \cdot 6-2 \cdot 5$ & $-1 \cdot 3$ & $1 \cdot 97 \cdot 3$ & $12 \cdot 2$ & $16 \cdot 1$ & $17 \cdot 6$ & $16 \cdot 9$ & $10 \%$ & & $2 \cdot 4$ & $-1 \cdot 2$ \\
\hline Weißwasser . & $\mid 7 \cdot 2-2 \cdot 8$ & $-1 \cdot 6$ & $1 \cdot 56 \cdot 9$ & $12 \cdot 0$ & $16 \cdot 0$ & $17 \cdot 5$ & $16 \cdot 5$ & $12 \cdot 7$ & $7 \cdot 7$ & $2 \cdot 0$ & -1.9 \\
\hline Czaslau . . . & $8 \cdot 3-1 \cdot 8$ & -0.5 & $2 \cdot 78$ & $13 \cdot 1$ & $16 \cdot 7$ & $18 \cdot 4$ & $17 \cdot 8$ & 14 & $9 \cdot 0$ & $2 \cdot 9$ & $-1 \cdot 0$ \\
\hline Pilsen . & $8 \cdot 6 \mid-1 \cdot 8$ & $-0 \cdot 1$ & $3 \cdot 18 \cdot 5$ & $13 \cdot 4$ & $17 \cdot 2$ & $18 \cdot 9$ & $18 \cdot 3$ & $14 \cdot 4$ & & $3 \cdot 1$ & -0.5 \\
\hline Frauenberg & $8 \cdot 6-1.7$ & 0.0 & $3 \cdot 1 / 8 \cdot 5$ & $13 \cdot 2$ & $16 \cdot 8$ & $18 \cdot 5$ & $17 \cdot 9$ & $14 \cdot 7$ & & $3 \cdot 3$ & -0.7 \\
\hline Budweis & $7 \cdot 5-3 \cdot 0$ & $-1 \cdot 4$ & $1 \cdot 7 \mid 7 \cdot 5$ & $12 \cdot 5$ & $16 \cdot 1$ & $17 \cdot 7$ & $17 \cdot 1$ & $12 \cdot 9$ & & $2 \cdot 0$ & $-1 \cdot 6$ \\
\hline
\end{tabular}

Es macht sich demnach in Böhmen die auffallende Erscheinung geltend, daß im Süden das Klima rauher, d. h. kälter und meist auch niederschlagsreicher ist als im Norden, was gewiß in erster Linie auf die höhere absolute Meereshöhe zurückzuführen ist. Südböhmen (vgl. die Zahlen für Budweis) weist noch ganz 
ähnliche klimatische Verhältnisse auf wie die Randgebirge und auch die Vegetationsverhältnisse sind denen der letzteren noch sehr ähnlich; auch hier sind Nadelwälder und Noore reichlich entwickelt. Auch in Nordostböhmen (vgl. VTeißwasser) ist die Niederschlagsmenge noch reichlich genug, um überall, wo nicht edaphische Verhältnisse es verhindern, die IValdbildung zu begünstigen. Anders liegen die Verhältnisse im zentralen und nordwestlichen Böhmen. Hier sinkt die jährliche Regenmenge vielerorts unter $50 \mathrm{~cm}$ im Jahre herab und erreicht somit ungefähr den Grenzwert, bis zu welchem noch Waldentwicklung möglich ist. Tatsächlich sehen wir hier auch vielfach bereits den Wald zurücktreten und Grasflurformationen auftreten, welche entsprechend den heißen und relativ trockenen Sommern häufig Steppencharakter annehmen.

Ähnlich liegen auch die Verhältnisse im mittleren und südlichen Mähren. Soweit die Ausläufer des böhmisch-mährischen Höhenzuges reichen, sind die klimatischen Verhältnisse ähnlich denen der böhmischen Randgebirge (vgl. oben die Daten für Iglau), ebenso an den Ausläufern der Sudeten. Anders liegen die Verhältnisse am äußersten Rande des westlichen Plateaus und in der Marchebene, besonders die Niederschläge werden wieder bedeutend geringer, wie folgende Zahlen beweisen:

\begin{tabular}{|c|c|c|c|c|c|c|c|c|c|c|c|c|c|}
\hline & Jahr & 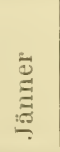 & 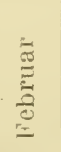 & $\stackrel{N}{\Xi}$ & $\bar{\Xi}$ & 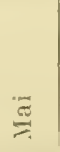 & $\Xi$ & $\vec{\Xi}$ & 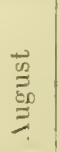 & 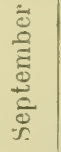 & $\begin{array}{l}\frac{b}{0} \\
\frac{0}{0} \\
\frac{3}{b}\end{array}$ & $\begin{array}{l}\vec{d} \\
\text { है } \\
\text { d } \\
\text { o } \\
z\end{array}$ & 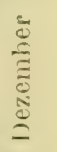 \\
\hline Brünn, 20อ̆ m & 536 & 26 & 16 & 31 & 42 & 58 & 79 & 72 & 66 & 42 & 47 & 30 & 27 \\
\hline Znaim, $265 \mathrm{~m}$ & 483 & 30 & 21 & 30 & 37 & 68 & 62 & 70 & 47 & 41 & 32 & 21 & 24 \\
\hline Göding, $170 \mathrm{~m}$. & 512 & 24 & 13 & 29 & 44 & 51 & 73 & 58 & 48 & 51 & 58 & 32 & 31 \\
\hline Nikolsburg, $176 \mathrm{~m}$ & 455 & 20 & 27 & 27 & 26 & 55 & 47 & 61 & 66 & 31 & 32 & 28 & 35 \\
\hline
\end{tabular}

Die jährliche Regenmenge sinkt bis gegen oder unter $50 \mathrm{~cm}$ im Jahre, dabei sind die Sommer verhältnismäßig trocken - in keinem Monat erreicht der Niederschlag $8 \mathrm{~cm}$ Höhe - und dabei relativ warm.

Durchschnittswerte der Monats- und Jahrestemperatur.

\begin{tabular}{|c|c|c|c|c|c|c|c|c|c|c|c|c|c|c|c|}
\hline & & & 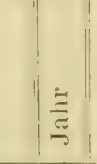 & 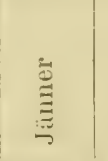 & 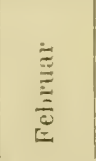 & $\stackrel{\Xi}{=}$ & 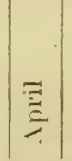 & $\bar{E}$ & $\underline{\Xi}$ & 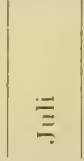 & 节 & 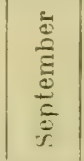 & $\frac{1}{0}$ & $\mid \begin{array}{l}\tilde{z} \\
0 \\
\text { है } \\
0 \\
z \\
0 \\
z\end{array}$ & 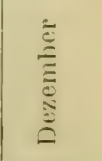 \\
\hline Brünn & & & || $8 \cdot 1 \mid$ & $|-2 \cdot 8|$ & -1 & & $8 \cdot 2$ & $13 \cdot 5$ & $17 \cdot 2$ & $18 \cdot 7$ & $17 \cdot 6$ & $13 \cdot 8$ & 8.5 & $1 \cdot 9$ & $-1 \cdot 8$ \\
\hline Znaim . & . & . & $|8 \cdot 6|$ & -25 & $0 \cdot 5$ & $3 \cdot 2$ & $8 \cdot 8$ & $13 \cdot 7$ & $17 \cdot 6$ & $19 \cdot 4$ & 18.7 & $14 \cdot 6$ & $9 \cdot 0$ & $2 \cdot 7$ & -1.5 \\
\hline Göding . . & . & . & $\cdot|9 \cdot 0|$ & $|-2.5|$ & & & 49.5 & $14 \cdot 4$ & $18 \cdot 3$ & $20^{\circ} 0$ & $19 \cdot 2$ & $15 \cdot 1$ & & $3 \cdot 3$ & $-1 \cdot 2$ \\
\hline Nikolsburg & . & . . & . $|8 \cdot 0|$ & $-2 \cdot 8$ & $-0 \cdot \delta$ & $3 \cdot 2$ & $8 \cdot 8$ & $13 \cdot 7$ & $17 \cdot 6$ & $19 \cdot 4$ & $18 \cdot 7$ & $14 \cdot 6$ & $9 \cdot 0$ & $9 \cdot 2 \cdot 7$ & \\
\hline
\end{tabular}


Die klimatischen Verhältnisse weisen hier also eine unverkennbare Ähnlichkeit mit denen von Zentralböhmen auf und auch der Vegetationscharakter ist ähnlich. Freilich ist Südmähren unvergleichlich reicher an östlichen Arten als Böhmen und die Steppenformationen sind viel üppiger entwickelt, aber das hängt hauptsächlich damit zusammen, daß Südmähren mit den großen südosteuropäischen Steppengebieten in offener Verbindung steht und demnach der Einwanderung derselben kein Hindernis im Wege steht, während das zentrale Böhmen allseitig von höheren Gebirgen umschlossen ist, die heute wenigstens für die Einwanderung wärmeliebender Typen ein unüberwindliches Hindernis bilden, so daß alle die böhmischen Steppengewächse bereits in einer früheren wärmeren Erdperiode eingewandert sein müssen.

Alınliche klimatische Verhältnisse wie in Südı̈ihren herrschen aber auch im ganzen Donautale bis an den Fuß des Granitplateaus, wie die nachfolgenden Zahlen für Krems beweisen:

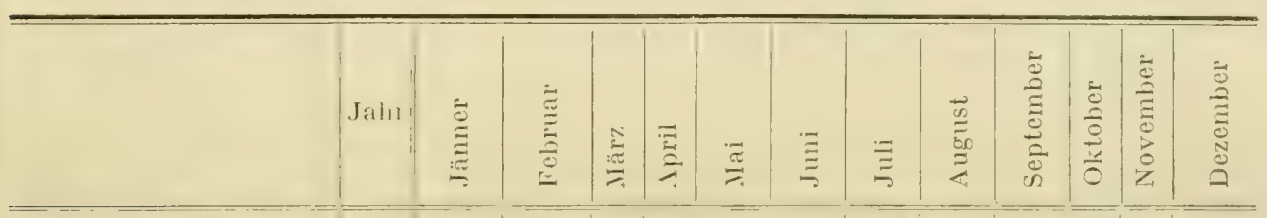

Temperatur, Mittel .| $8 \cdot 8|-1 \cdot 9|-0 \cdot 4|3 \cdot 4| 8 \cdot 9|13 \cdot 7| 17 \cdot 6|19 \cdot 4| 18 \cdot 3|14 \cdot 6| 9 \cdot 3|3 \cdot 0|-1 \cdot 0$ \begin{tabular}{l|l|l|l|l|l|l|l|l|l|l|l|l} 
Niederschläge, Mittel | 530: & 23 & 9 & 24 & 48 & 66 & 75 & 88 & 77 & 45 & 37 & 18 & 20
\end{tabular}

Dies erklärt auch uns die ganz abweichenden Vegetationsverhältnisse dieses Gebietes gegenüber dem Granitplateau des Waldviertels, das Vordringen von Steppenformationen und die Möglichkeit des Weinbaues in diesem Gebiete.

\section{B. Die Pflanzengenossenschaften des Gebietes.}

\section{Die Iflanzengenossenschaften des hepzynischen lierglandes.}

(Lausitzer-und Elhesandsteingebirge. Eız- und Elstergebirge, Böhrnerwald und dessen Ausläufer, Brdywald. B̈̈hmisch-mährischer Höhenzug.)

a) Waldbestände.

Gemischte Laubwälder. Am Fuße des Lausitzer- und Elbesandsteingebirges sowie des Erzgebirges trifft man nicht selten gemischte hainartige Laubwaldbestände, welche dem Vorlande des Böhmerwaldes gänzlich abgehen. Die herrschenden Bäume sind zumeist Eichen (Quercus Robur und Q. sessiliflora), denen sich Buchen (Fagus silvalica), Hainbuchen (Carpinus Betulus), Birken (Belula pendula), Zitterpappeln (Populus tremula), Ahorne (Acer platanoides, A. Pseudoplatanus, A. campestre), Ulmen (Ulmus glabra, U. scabra), Linden (Tilia cordala, T. plalyphyllos), Eschen (Fraxinus excelsior), Ebereschen (Sorbus 
Lucuparia, S. torminatis), Waldkirschen (Prunus avium) beimengen. Unter diesen zahlreichen Laubhölzern sind Föhren (Pinus silvestris) das einzige Nadelholz. Gewöhnlich ist in diesen Wäldern ein sehr reiches Unterholz entwickelt. das neben Haselnüssen (Corylus Avellana), Salweiden (Salix caprea), Pfaffenkäppchen (Evonymus vulgaris) und Him- und Brombeeren (Rubus Idaeus, R. nessensis, R. plicatus, R. Bellardii) auch noch Rhamnus calhartica, Cornus sanguinea, Lonicera Xylosteum, Sambucus nigra, S. racemosa und Viburnum Opulus zusammensetzen. Dort aber, wo das Unterholz Raum läßt, ist stets ein reicher Niederwuchs zu finden. Im Frühlinge schmücken Gagea lutea, Corydalis cava, Lathyrus vernus, Pulmonaria officinalis den Waldboden, später sind darin Trifolium alpestre, Astragalus glycyphyllus, Vicia sepium, Cylisus nigricans, Lathyrus niger, Geum urbanum, Polentilla erecta, Hypericum hirsutum, Aegopodium Podagraria, Anthriscus silvester, Torilis Anthriscus, Lamium maculatum, Galeopsis speciosa, Melampyrum nemorosum, Solidago Virga aurea die häufigsten Arten, doch treten gelegentlich auch Convallaria maialis, Potentilla procumbens, Vicia silvalica, Laserpilium pruthenicum, Veronica Chamaedrys sowie der seltene Dianthus silvaticus auf und die östliche Veronica spuria ist auf ihrem einzigen böhmischen Standort ebenfalls im lockeren Laubmischwalde zu finden. An anderen Stellen herrschen wieder Gräser und Scheingräser vor, von denen Molinia arundinacea, Brachypodium silvaticum, Carex silvatica und Luzula nemorosa die häufigsten sind.

In eigentlichen Erzgebirge sind solche gemischte Laubwälder auch in höheren Lagen, bis zu etwa 680 m Meereshöhe, anzutreffen, wo Lilium Martagon, Ranunculus nemorosus, Aconitum variegatum *gracile, Lathyrus montanus, Vicia silvalica, $V$. pisiformis und Arnica montana in denselben auftreten.

Birkenwälder. Ein ganz anderes Bild als diese gemischten Laubholzbestände bieten die Birkengehölze, wie sie j̈berall am Fuße der Gebirge anzutreffen sind, besonders häufig im Vorlande des Böhmerwaldes. Schon die Zusammensetzung des Oberholzes ist hier viel einfacher, nur Birken (Betula pendula) mit ihren weißen Stämmen bilden hier lockere Bestände, mitunter von einzelnen Föhren (Pinus silvestris) begleitet, während andere Baumarten, wie Buchen (Fagus silvatica) oder Fichten (Picea excelsa) nur ganz vereinzelt anzutreffen sind. Das hochwüchsige Unterho! $\mathrm{z}$ wird höchstens vom Besenginster (Sarothamnus scoparius) gebildet, wie überhaupt der Untergrund stets einen heideartigen Charakter aufweist, da stets Heidekraut (Calluna vulgaris) im Vereine mit Heidel- und Preißelbeeren (Vaccinium Myrtillus und V. Vilis Idaea) in dichtem Bestande den Boden bedeckt, dem oft in großer Menge der Adlerfarn (Pleridium aquilinum) entsproßt. Auch die Heidegräser sind im Niederwuchse nicht selten, so vor allem Nardus stricla und Sieglingia decumbens, ferner Agrostis vulgaris, Deschampsia flexuosa, D. caespilosa und Carex leporina, von dikotylen Stauden hingegen sind neben den häufigen Arten Polentilla erecta und Antennaria dioeca nur Selinum Carvifolia und Arnica montana als Bewohner der Birkenbestände zu nennen. 
Auenwälder. Auenwälder sind im herzynischen Berglande selten und last nur im Gebiete des Lausitzer Gebirges in den Talniederungen verbreitet. Wie überall, sind es ausschließlich Laubhölzer, die diese IVälder zusammensetzen, besonders Alnus glutinosa, Populus tremula, Fraxinus excelsior, ferner Quercus Robur, Carpinus Betulus, Betula pendula, Ulmus glabra, Acer campestre. Im Unterholze herrschen neben Prunus Padus, Sambucus nigra und Rhamnus Frangula verschiedene Weiden, wie Salix cinerea, S. alba, S. purpurea vor. Den Niederwuchs bilden hochwüchsige Gräser und Seggen, z. B. Fesluca giganlea, Milium effusum, Carex silvalica, $C$. remota, ferner von Stauden Leucoium vernum, Gagea lulea, Allium ursinum, Polygonatum multiflorum, Slellaria Holostea, S. nemorum, Moehringia trinervia, Alliaria officinalis, Cardamine Impatiens, C. flexuosa, Geum urbanum, Circaea Luletiana, Galeopsis speciosa, Adoxa moschalellina u. a.

Buchenwälder. Dem Böhmerwalde fehlen reine Buchenbestände, hier ist die Buche stets von der Tanne und Fichte begleitet, hingegen sind im Lausitzer Gebirge und Erzgebirge in einer Höhenlage zwischen 400 und 700 m, ja selbst bis $920 \mathrm{~m}$ Meereshöhe IVälder, die fast nur aus Fagus silvalica zusammengesetzt sind, keine Seltenheit. Nur in höheren Lagen gesellen sich auch Abies alba und Picea excelsa vereinzelt der Buche zu, sonst ist sie gewöhnlich der allein herrschende Waldbaum. Im Unterholze, das oft recht spärlich ist und streckenweise ganz fehlt, dominiert die Himbeere (Rubus Idaeus) oder der rotbeerige Hirschholler (Sambucus racemosa), seltener sind die schwarze Heckenkirsche (Lonicera nigra), Alpen-Johannisbeeren (Ribes alpinum) und Seidelbast (Daphne Mezereum) anzutreffen; hie und da umspinnt Efeu (Hedera Helix) die Buchenstämme, auf denen oft auch eine reiche Moosvegetation, hauptsächlich atus Necliera pennala. Amblyslegium sublile und Orthotrichum slramineum gebildet. entwickelt ist. Der Niederwuchs ist im Buchenwalde meist spärlich; schattenliebende, breitblätterige Gräser, wie Daclylis glomerala, Milium effusum, Hordeum europaeum, Poa nemoralis, ferner Carex silvatica und C. nemorosa bilden hie und da Kolonien und im tiefen Waldesschatten blühen Sauerklee (Oxalis Acetosella), Sanikel (Sanicula europaea), Goldnessel (Lamium luleum) und Waldmeister (Asperula odorala). Nur im ersten Frühjahr, bevor die Buchen noch belaubt sind, ist ein reicherer Blütenflor aus Anemone Hepalica, Cardamine enneaphyllos, Asarum europaeum entwickelt. An feuchten Stellen bildet Allium ursinum ab und zu Bestände, sonst sind nur noch Moehringia trinervia, Cardamine bulbifera, Impatiens Noli tangere und der Farn Athyrium Filix femina erwähnenswert. Erst in höheren Lagen wird die Flora des Buchenwaldes etwas reicher, da dann Festuca silvatica, Lilium Martagon, Polygonatum verlicillatum, Cephalanthera rubra, C. longifolia und im tiefen Waldesschatten Coralliorhiza Irifida auftreten.

Der herzynische Bergmischwald. Besonrlers in Böhmerwalre, aber auch im Lausitzer und ab und zu im Erzgebirge ist ein Hochwald entwickell, der hauptsächlich aus Buchen (Fagus silvatica) und Weißtannen (Abies alba) besteht. In tieferen Lagen finden sich auch Fichten (Picea excelsa), Föhren 
(Pinus silvestris), Hainbuchen (Carpinus Belulus) und selbst Eichen (Quercus Robur) beigemischt; das Unterholz besteht aus Hirschholler (Sambucus racemosa), Himbeeren (Rubus Idaeus), Haselnüssen (Corylius Avellana) und Salweiden (Salix Capraea), im Niederwuchs herrschen Calamagrostis varia und C. arundinacea, Aclaea spicala, Cardamine bulbifera, Petasites albus, Senecio sarracennius und Prenanthes purpurea vor.

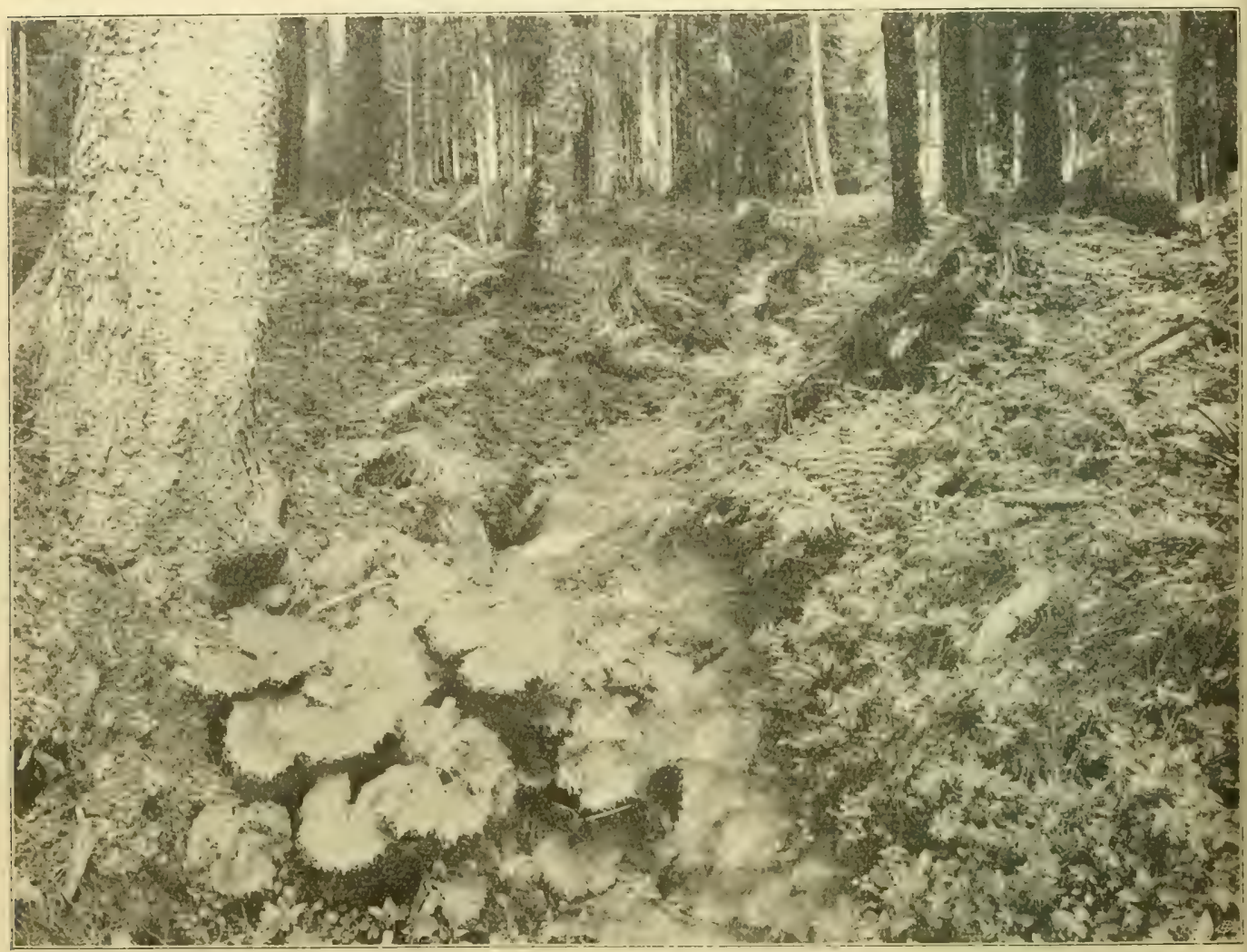

Abb. 22. Niederwuchs im Bergmischwalde auf dem Kubany im Böhmerwalde.

Im Vordergrunde links Petasites albus, rechts Dryopteris Linnaeana, dahinter hauptsächlich Dryopteris Oreopteris.

(Nach einer Aufnahme von K. Heller, Wien.)

(Aus Scharfetter, Lehrbuch der Pflanzenkunde.)

Vin üppiger ist lie Zusammensetzung lieser Vischwälder aber in höheren Lagen, wo sie besonders im Böhmerwalde die herrschende Formation bilden und hier stellenweise, so im bekannten Urwaldgebiete auf dem Kubany, im Urzustande belassen sind. Hier fehlen Eichen, Weißbuchen und Föhren im Oberholze, und den weitans dominiemenden Tanmen und Buchen misehen sich nur vereinzelt Fichten. Clmen (Llmus scabra) und häufiger der Bergahorn (Acer Pseudoplalanus) bei. In Interholze sind auch hir Sambucus racemosa und insbrsonders Fubus Idaeus tonangebend, doch treten auch Bromberen (Rubus 
Bellardii, R. hirlus,. Suilelbast (Daphne Mezereum, besunders aber Lonicera nigra und Rosa pendulina auf und bilden oft ein dichtes Gestrüpp, während Efeu (Hedera Helix) dir von Leskea nervosa. Brachythecium Starkei, Hypnum fertile, $H$. reptile und anderen Moosen belikideten Buchenbestände umspinnt.

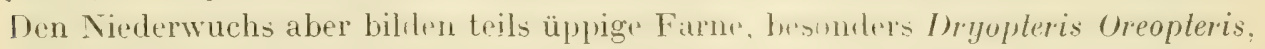
D. spinulosa, D. Filix mas, Athyrium Filix femina, A. alpestre und Blechnum Spicant, teils hochwüchsige Graspflanzen, so Calamagrostis varia, Festuca silvatica, Bromus asper, Milium effusum, Hordeum europaeum, Luzula nemorosa, L. silvatica, vor allem aber Gebirgsstauden, wie Türkenbundlilien (Lilium Martagon). Polygonalum verticillalum. Aclaea spieala, Thatictrum ayuilegifolium, der weiße Ranunculus platanifolius, Lunaria rediviva, Cardamine bulbifera, Sanicula europaea, Astrantia maior, Atropa Belladonna, Prenanthes purpurea, Lactuca muralis und der überall häufige Senecio sarracenius,. Als besonders charakteristische Pflanze dieser IVälder aber muß Petasiles albus hervorgehoben werden, der an feuchteren Strllen oft in großen Mengen auftritt. Natürlich fuhlen auch die Gharakterpflanzen der schattigen Gebirgswälder überhaupt, wie Allium ursinum, Maianthemum bifolium. Coralliorhiza Lrifida, Veotlia Vidus avis, Cardamine hirsuta, Ranunculus nemorosus, Mercurialis perennis, Veronica montana, Lysimachia nemorum, Asperula odorata usw. nicht. Den Boden des Waldes aber bedeckt vielfach ein dichler Mousasen, der insbesondere aus Hylocomium triquetrum, H.splendens, H. lorenm. Hypnum cupressiforme, Plagiolhecium undulalum, Heterocladium dimorphum, Oligotrichum her'ynicum, Mnium spinosum, M. spinulosum und Jungermannia curvifolia besteht.

Der herzynische Fichtenwald. Der weitaus wirhtigste Walıbaum in ganzen herzynischen Berglande ist jeduch die Fichte, lir nicht nur in höheren Lagen des Erzgebirges großs Bestände bildet, sondern aurh insbesondere im Brdywalde, Böhmerwalde, im böhmisch-mährischen Grenzgebirge sowohl im rigentlichen Gebirgslande als auch im Vorlande bis weit nach südböhmen, Oberund Niederösterreich hinein ausgedehnte Wälder bilctet. Das Bild dieser Fichtenbestände ist allerdings ein je nach der Höhenlage verschiedenes.

Der ,Untere herzynische Fichtenwald“, der im Vorlande des Gebirges und an seinem Fuße bis zu einer Höhe von etwa $800 \mathrm{~m}$ verbreitet ist, macht gewöhnlich einen höchst eintönigen Eindruck. Picea excelsa, oft mit Pinus silvestris vermengt, ist der herrschendr Waldbaum, nur vereinzelt finden sich Abies alba, Belula pendula oder Populus tremula eingemengt. Ein Unterholz fehlt meist ganz, den Niederwuchs aber bilden Heidelbeeren und PreiBelbeeren (Vaccinum Myrtillus und V.Vitis Idaea), die oft auf weite Strecken hin in geschlossenem Bestande den Boden bedecken und nur ab und zu sind auch Farne (Athyrium Filix femina, Dryopleris Filix mas, Blechnum Spicant) oder Luzula nemorosa, Maianthemum bifolium, Anemone nemorosa. Potentilla erecta. Ielampyrum silvaticum, M. pratense *vulgalum, Prenanthes purpurea und Hieracium murorum anzutreffen. Manchenorts aber ist auch der Boden von Moosrasen, besonders aus Hylocomium splendens. H. Iriquetrum. Hypnum un- 
cinatum und $H$. Crisla castrensis bedecht, oder es treten Polster von Polytrichum oder selbst Sphagnum-Arten auf, welch letztere manchmal so überhand nehmen. daß selbst Bewohner der Hochmoore, wie Vaccinium uliginosum, Oxycoccos quadipelala, Drosera rolundifolia orler Viola paluslris in den Fichtenwald eintreten.

Der ,Obere herzynische Fichtenwald", der in liöheren Gebirgslagen uber $800 \mathrm{~m}$, aber manchmal auch schon bei $600 \mathrm{~m}$ auftritt, bietet ein ganz anderes Bild. Den Fichten sind hier Abies alba und Fagus silvatica, vereinzelt auch Acer Pseudoplalanus und Sorbus Aucuparia beigemischt; auch ein Unterholz, vorwiegend aus Rubus Idaeus, Lonicera nigra und Sambucus racemosa zusammengesetzt, ist meist vorhanden. Im Niederwuchse sind hochwüchsige Gräser, wie Calamagroslis villosa, C. varia, Poa Chaixii, Bromus asper, Carex silvalica nicht selten, besonders aber tritt Luzula nemorosa. und zwar zumeist in der $f$. rubella, sehr häufig auf. Neben den auch hier nicht fehlenden Heidelund Preißelbeeren sind Maianlhemum bifolium, Polygonatum verficillalum, Anemone nemorosa, Epilobium monlanum, Viola silvestris, Pirola uniflora. Phyteuma spicatum, Solidago Virga Aurea, Prenanthes purpurea nirgends selten und im südlichen Böhmerwald und im böhmisch-mährischen Gebirge treten noch die zierliche Soldanella montana, Cardamine lrifolia und das leuchtend goldgelbe Doronicum auslriacum hinzu. Auch Farne sind oft sehr häufig und neben diesen ab und zu auch Bärlapparten (Lycopodium Selago, L. annotinum, L. complanatum). An feuchten Stellen ist, wie im Nischwalde, Pelasiles albus of́t tonangebend. Von sonstigen hie und da auftretenden Arten seien noch Orchis maculata, Plantanthera bifolia, Ranunculus nemorosus, Aruncus silvester, Rubus saxalilis, Pirola rotundifolia, P. chlorantha, P. minor, Trientalis europaea, Aitaga pyramidalis, Myosolis silvatica, Homogyne alpina, Mulgedium alpinum und Hieracium racemosum genannt.

Föhrenwälder. In tieferen Lagen und am Fuße der Gebirge, besonders des Böhmerwaldes, Brdywaldes und des Böhmisch-mährischen Höhenzuges bildet neben der Fichte auch die Föhre (Pinus silvestris) vielfach Waldbestände, die physiognomisch einerseits an die Birkenbestände, anderseits an den unteren herzynischen Fichtenwald erinnern. Der allein herrschende Waldbaum ist Pinus silvestris, das Unterholz, wenn überhaupt vorhanden, bilden neben Wacholder (Juniperus communis) verschiedene Brombeeren (Rubus nessensis, R. plicalus, R. Gremlii, R. Bellardii). Den Boden aber bedecken meist Calluna vulgaris, Vaccinium Myrtillus und $V$. Vitis idaea in dichtem Bestande, denen sich mitunter Genisla pilosa, G. germanica und G. lincloria beigesellen. Auch Pteridium aquilinum fehlt selten, sonst sind im Niederwuchse Sieglingia decumbens, Dianlhus delloides, Trifolium alpestre, Chimaphila umbellala, Pirola secunda, $P$. rolundifolia, P. minor, Veronica Chamaedrys, Melampyrum pratense *vulgatum, Jasione montana und Antennaria dioeca nicht selten. Unter und zwischen den Heidelbeerbüschen aber überziehen oft Noose (Hypnum Schreberi, H. cutpressiforme, Hylocomium splendens, Dicranum scoparium) und Flechten (Cladonia rangiferina, C. furcala, G. squamosa) den Boden. 


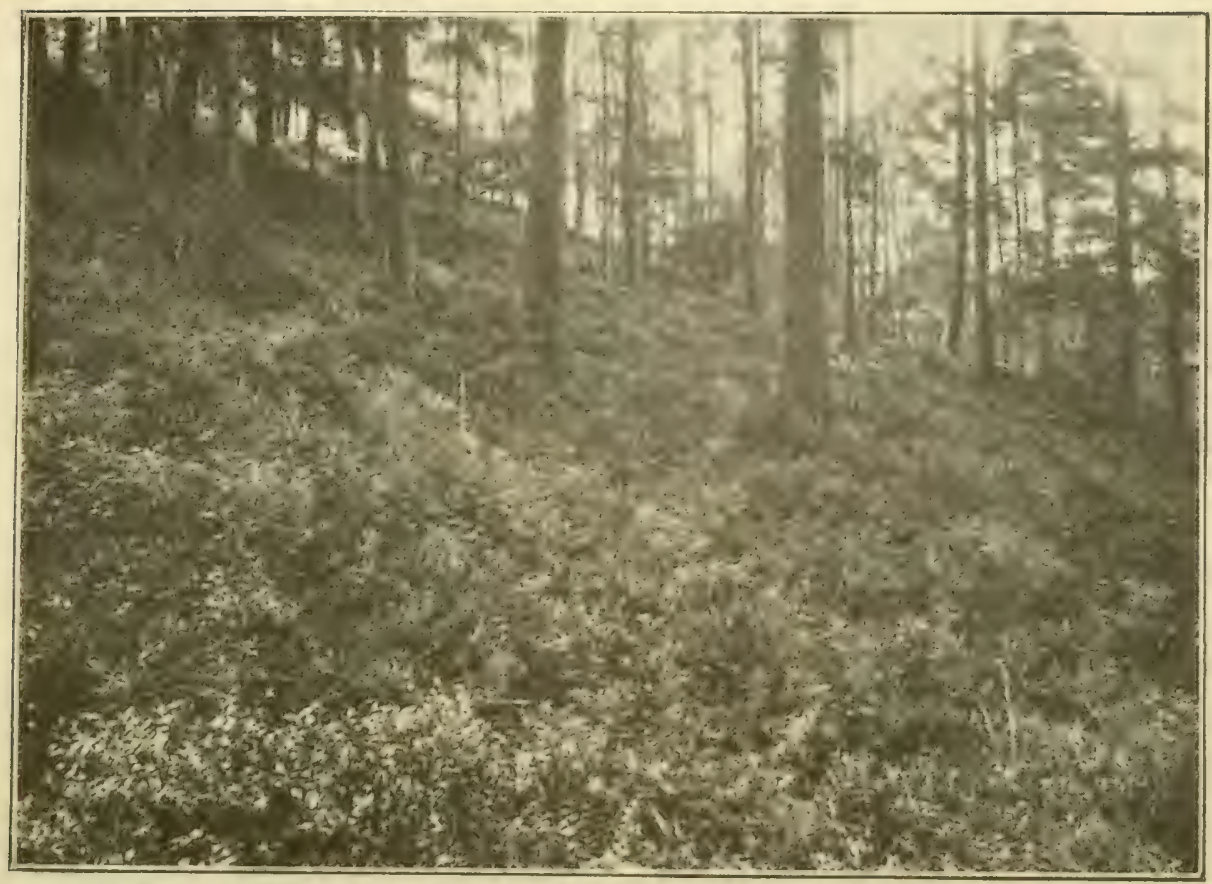

Abb. 23. Vaccinium Myrtillus und Calluna vulgaris als Niederwuchs in cinem Föhrenwald bei Karlsbad.

(Nach einer Aufnahme von Dr. K. Rechinger, Wien.)

Moorwälder. Im südlichen Böhmerwalde, besonders aber auf dessen Ausläufern im oberösterreichischen Mühl- und nierterösterreichischen Waldviertel, seltener auch im Lausitzergebirge, treten Föhrenwälder auf, deren Untergrund den Charakter eines Hochmoores trägt. Die Entstehung dieser Moorwälder kann auf zweierlei Art erfolgen, entweder ist das Hochmoor das primäre, auf dem sich Föhren, und in diesem Falle meist Pinus uliginosa, ansiedeln, oder aber in einem Föhren- oder selbst Fichtenwalde siedeln sich Torfmoose (Sphagnum) an, die sich allmählich immer weiter ausbreiten und schließlich den Untergrund res Waldes in ein Hochmoor verwandeln.

Das Oberholz dieser Moorwälder bildet demnach entweder die Moosföhre (Pinus uliginosa), ab und zu von Pinus silvestris begleitet, oder aber Pinus silvestris, der sich manchmal Picea excelsa beigesellt; sehr selten sind im Gebiete Hoorwälder, die aus Erlen (Alnus glutinosa) zusammengesetzt sind. Den Untergrund dieser Wälder aber bildet ein typisches Hochmoor, in welchem T'orfmoose, insbesondere Sphagnum medium, aculifolium, squarrosum und teres in Verein mit anderen IIoosen, wie Aulacomnium paluslre, Philonolis fontana, Polytrichum commune, Dicranum palustre, Jungermannia Taylori, den Untergrund bilden, auf dem die verschiedenen charakteristischen Hochmoorpflanzen, wie Dryopleris Thelypleris, Trichophorum alpinum, Eriophorum vaginalum, Rhynchospora alba, Carex dioica, C. pauciflora, C. canescens, C. echinala, C. limosa, Juncus filiformis, J. squarrosus, Drosera rolundifolia, Epilobium palustre, Poten- 


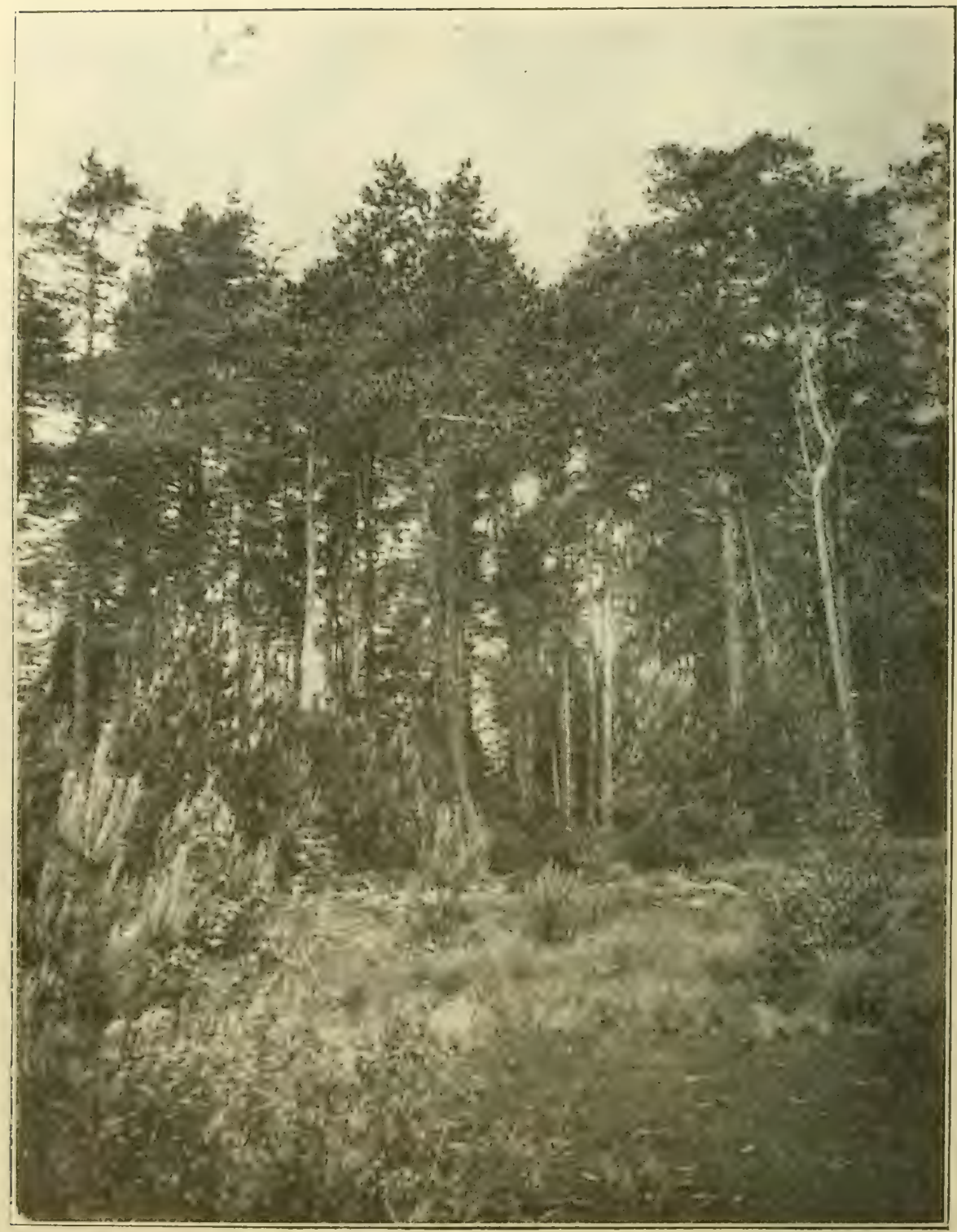

Abb. 24. Moorwald aus Pinus silvestris (Stämme hell) und Pinus uliginosa (Stämme dunkcl) am Nordende des Langenbruckerteiches bei Schwarzbach im südlichen Böhmerwald.

(Nach einer Aufnahme von Prof. J. Nabělek, Leipnik.)

(Aus der Bildersammlung des botanischen Institutes an der Wiener Universität.)

Iilla palustris, P. norvegica, Oxycoccos quadripetala, Trientalis europaea sowie die besonders im Mühlviertel häufige Calla palustris gedeihen. Besonders zahlreich aber treten gewöhnlich die halbstrauchigen Ericazeen, wie Vaccinium uliginosum, V. Vitis Idaea, Andromeda polifolia und selbst Calluna vulgaris auf und eine seltene prächtige Zierde dieser Wälder bildet Ledum palustre, das neben Salix aurita und Rhamnus Frangula ab und zu das Unterholz bildet. 
IIayek, Die Pflanzendecke Österreich-Ungarns, I.

Taf. I.

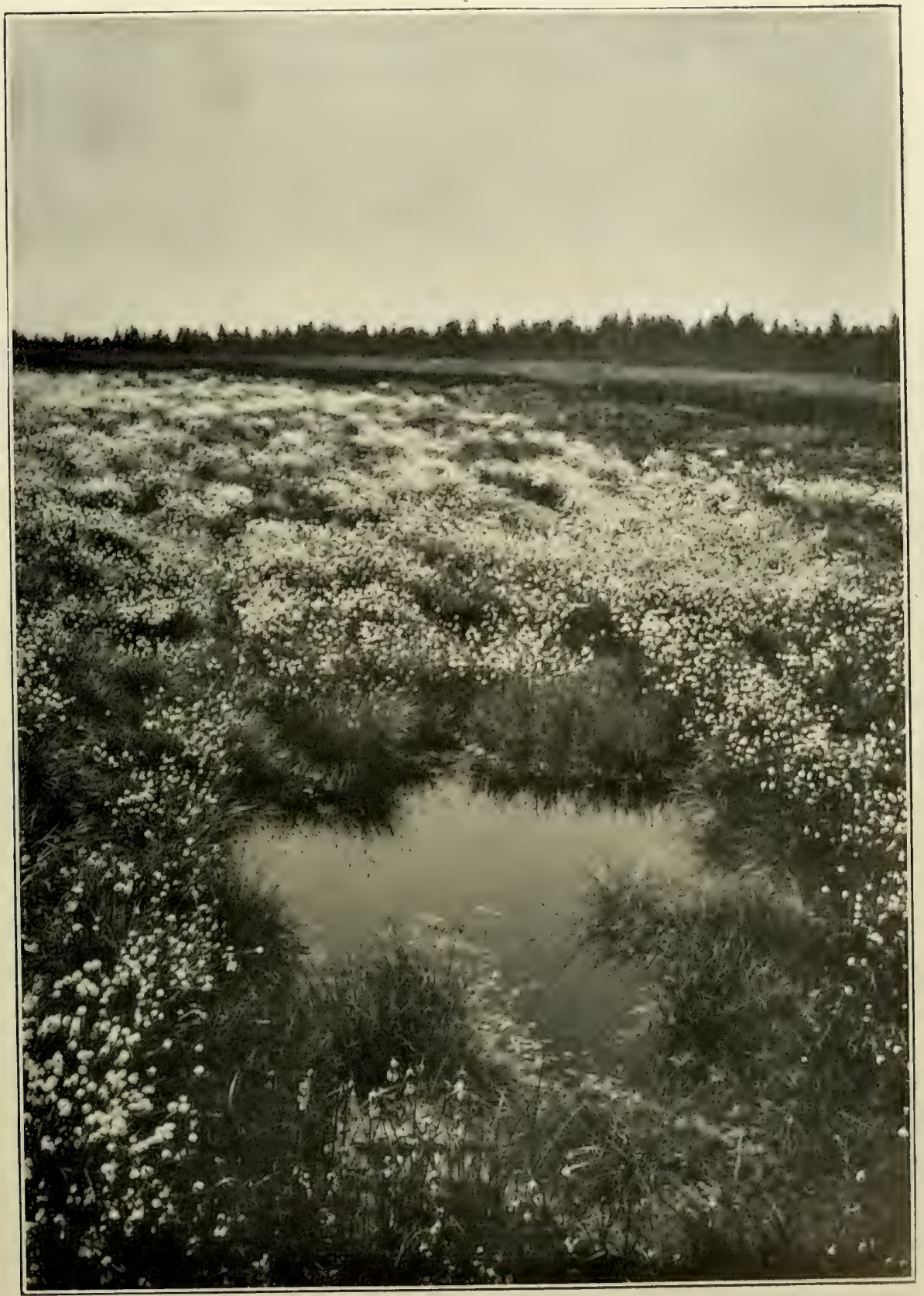

Abb. 25. Hochmoor bei Gottesgab im Erzgebirge mit Eriophorum vaginatum. (Nach einer Aufnahme von Nenke und Ostermaier in Dresden.) 



\section{b) Moore und Heiden.}

Hochmoore. Hochmoore sind sowohl im Erzgebirge als im Böhmerwald pine bis in die höchsten Lagen häufige und für ditselben ïußerst charakteristische Formation, die auch dem böhmisch-mährischen Höhenzuge nicht fehlt. Den Untergrund dieser Moore bilden hauptsächlich Sphagnum cuspidatum, S. recurvum, S. cymbifolium, S. subsecundum, S. medium, S. aculifolium im Vereine mit Aulacomnium palustre, Hypnum cuspidalum, H. stramineum, Philonotis fontana, Polytrichum commune, $P$. strictum und $P$. gracile. In diesen Moospolstern und sie stellenweise fast verdrängend, breitet vor allem das scheidige Wollgras (Eriphorum vaginatum) seine sparigen Rasen aus, seltener Juncus squarrosus und $J$.glaucus; auch das blaue Pfeifengras (Molinia coerulea) bildet manchmal fast wiesenartige Bestände. Ferner ist das zierliche Alpenwollgras (Trichophorum alpinum) manchenorts nicht selten; von sonstigen Cyperazcen seien noch Rhynchospora alba, Carex dioeca, C. pauciflora, C. stelullata C. canescens, $C$. leporina, $C$. Goodenoughii, $C$. limosa und $C$. rostrata sowie Trichophorum auslriacum genannt. Auf den Sphagnumbülten wachsen die rotdrüsigen Rosetten von Drosera rolundifolia und D. anglica, Viola palustris und die rote kriechende Stengel treibende Hoosbere (Oxycoccos palustris), während in den Kolken besonders Scheuchzeria palustris und Juncus filiformis zu finden sind. Neben den Scheingräsern aber spielen die Hauptrolle die halbstrauchigen Ericazeen Andromeda polifolia, Vaccinium Myrtillus, V. Vitis Idaea, V. uliginosum und Calluna vulgaris und mit ihnen Empetrum nigrum, während Ledum palustre auf das Elbesandsteingebirge und auf die südlichen Ausläufer des Böhmerwaldes beschränkt ist und sonst fehlt. Von krautigen Pflanzen der Hochmoore wären noch Calla palustris, Juncus alpinus, Potentilla erecta, P. norvegica, Sedum villosum und Melampyrum pratense* paludosum zu nennen. Auch höherer Strauch-oder selbst Baumwuchs ist auf den Hochmooren nicht selten anzutreffen; oft bildet Pinus Mughus dichte Buschbestände, Salix aurita und Betula pubescens sind nicht selten und besonders im Böhmerwalde tritt auch die baumförmige Moosföhre (Pinus uliginosa) auf. In Erzgebirge und im südlichen Böhmerwalde ist endlich auch Belula nana keine große Seltenheit, während Salix myrlilloides auf sehr wenige Standorte des Böhmerwaldes beschränkt ist.

Wiesenmoore sind nur vereinzelt am Fuße des Böhmerwaldes anzutreffen und unterscheiden sich in ihrer Flora wenig von den unten zu besprechenden Sumpfwiesen; als bezeichnende Arten wären Trifolium spadiceum, Gicula virosa und Pedicularis silvatica zu nennen.

Heiden. Im Böhmerwalde und Erzgebirge sowie im Böhmisch-mährischen Höhenzuge sind typische Heideformationen nur spärlich entwickelt und hauptsächlich an den Hängen des Gebirges anzutreffen, während sie im Lausitzer Gebirge auch in den Niederungen zu finden sind. 'Auf diesen Heiden bildet Calluna vulgaris ausgedehnte Bestände, oft mit Vaccinium Myrtillus und $V$. Vitis Idaea vergesellschaftet, während Sarothamnus scoparius ab und zu große, zur 
Blütezeit goldig leuchtende Büsche bildet. Sonst ist Genista germanica im Gebiete die einzige auf der Heide auftretende Ginsterart. Ab und zu bilden auf der Heide Juncus effusus, J. Leersii, Nardus stricta, Carex leporina oder Molinia coerulea auf kleine Strecken hin Bestände, Potentilla erecta, Antennaria dioica und Hieracium Pilosella sind meist nicht selten. I Iingegen sind höhere Sträucher nicht häufig und treten von solchen, abgesehen von Sarolhamnus, nur ab und zu Juniperus communis, Betula pubescens oder Salix aurita auf.

Die Knäueltrift. An den südlichsten Ausläufern des Böhmerwaldes gegen die Donau zu sowie auch am Ostrande des Böhmisch-mährischen Gebirges, ab und $\mathrm{zu}$ auch in tieferen Lagen des Böhmerwaldes selbst, tritt eine heideartige Formation auf, in der der ausdauernde Knäuel (Scleranthus perennis) dominiert. Diese besonders auf trockenem Granitboden auftretende Formation zeichnet sich meist durch große Artenarmut aus, die häufigsten Begleitpflanzen des Scleranthus sind Nardus stricta, Festuca ovina, Carex leporina, Cerastium pumilum, Rumex Acetosella, Trifolium arvense, Veronica Dillenii, Euphrasia gracilis, Antennaria dioica und Hieracium Pilosella.

Sandgrasfluren. Am Fuße res Lausitzer Gebirges und im Vorlande des Böhmerwaldes trifft man auch ab und zu auf Sandflächen heideartige Grasfluren an, auf denen das auch auf den norddeutschen Sandheiden überall häufige Keulengras (Corynephorus canescens) mit seinen blaubereiften pfriemlichen Blättern und silberigen Rispen dominiert. In seiner Gesellschaft kommen auch noch andere Gräser und Scheingräser, wie Aira caryophyllea, A. praecox, Vulpia Myurus, Agroslis vulgaris, Deschampsia flexuosa, Sieglingia decumbens, Carex verna, $G$. pilulifera und $G$. hirta vor. Von sonstigen Begleitpflanzen sind Scleranthus annuus, Spergula Morisonii, Teesdalea nudicaulis, Potentilla argentea, Trifolium arvense, Jasione montana, Helichrysum arenarium und Hieracium Pilosella die häufigsten.

\section{c) Grasflurformationen.}

Gediungte Talwiesen. Dic meist regelmäßig gedüngten Talwiesen bieten auch im Gebiete des herzynischen Berglandes dasselbe Bild wie überall in Mitteleuropa. Die häufigsten Gräser sind Alopecurus pratensis, Phleum pratense, Arrhenatherum elatius, Triselum flavescens, Dactylis glomerata, Cynosurus cristatus, Briza media, Festuca elalior und Bromus hordaceus, die eine hochhalmige Grasnarbe bilden. Von den übrigen Arten dieser Wiesen seien als besonders häufig Lychnis Flos Cuculi, Ranunculus acer, Carum Carvi, Pimpinella maior, Anthriscus silvester, Salvia pratensis, Chrysanthemum Leucanthemum, Centaurea Jacea und Crepis biennis sowie als nach der Mahd tonangebend Heracleum Spondylium, Pastinaca sativa, Girsium oleraceum, Leontodon hispidus, L. autumnalis und Colchicum autumnale genannt; neben diesen in ganz Mitteleuropa verbreiteten Arten sind für die Wiesen des Gebietes noch bezeichnend Saxifraga granulata, Sanguisorba officinalis, Geranium pratense, Silaus pralensis und Girsium canum. 
Berg- und Voralpenwiesen. Ein ganz anderes Bild bieten die Bergund Voralpenwiesen des Gebietes. Hier herrscht von Gräsern insbesondere Festuca rubra, mit der vergesellschaftet auch Anthoxanthum odoralum, Alopecurus pratensis, Avena pubescens, A. pratensis, Deschampsia flexuosa, D. caespitosa, Agroslis vulgaris, Nardus stricla, Carex pallescens, C. pilulifera und Luzula multiflora vorkommen. Als besonders bezeichnende Arten dieser Wiesen sind

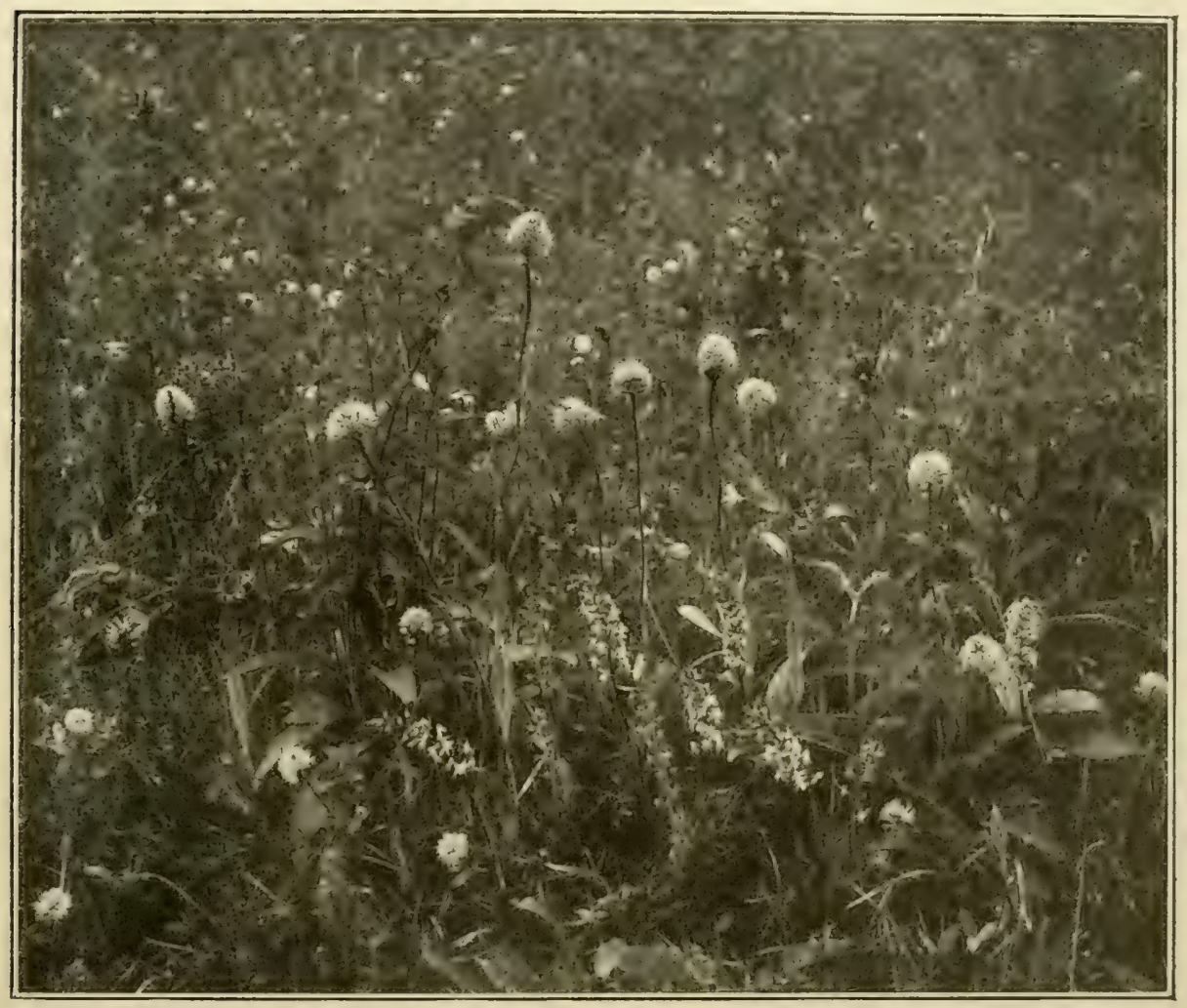

Abb. "26. Hergwiese im Erzgebirge.

Orchis globosa, Gymnadenia conopea, Listera ovata.

(Nach einer Aufnahme von Nenke und Ostermaier in Dresden.)

Polygonum Bistorta, Trollius europaeus, Arabis Halleri, Arnica monlana, Cirsium helerophyllum, Centaurea pseudophrygia, ferner im Erzgebirge Meum athamanticum, im Böhmerwalde Phyteuma nigrum hervorzubeben; doch kommen auf diesen reichblumigen Wiesen auch noch Orchis mascula, O. sambucina, o. maculata, Anacamplis pyramidalis, Gymnadenia conopea. G. albida, Coeloglossum viride, Thesium pratense, Melandryum silvestre, Aquilegia vulgaris, Thlaspi alpestre, Viola alpestris, Hypericum maculatum, Linum calharlicum, Geranium silvaticum, Trifolium monlanum, T. spadiceum, Lathyrus monlanus, Gentiana campestris, Slachys officinalis, Scorzonera humilis, Crepis succisacfolia und viele andere Arten vor; im Erzgebirge treten überdies noch Lilium bulbi- 
ferum, Orchis globosa (auch im Lausitzer Gebirge), Calamagrostis varia, Hypochoeris maculata, Gentiana Wetlsteinii und der seltene Dianthus silvaticus. im Böhmerwalde Phyteuma orbiculare und Gentiana Sturmiana hinzu.

Sumpiwiesen. Nur im Bereiche des Lausitzer Gebirges sind in tieferen Lagen, bis etwa $590 \mathrm{~m}$, Sumpfwiesen häufig anzutreffen, im übrigen Teile des herzynischen Berglandes sind sie seltener und meist nicht von großer Ausdehnung.

Über die Gräser (vor allem Holcus lanatus, Deschampsia caespitosa, Molinia coerulea, Agrostis canina, Poa trivialis) herrschen hier die Cyperazeen vor (Eriophorum anguslifolium, E. lalifolium, Scirpus silvaticus, Carex paradoxa, C. canescens, C. Goodenoughii, C. flava, C. panicea, C. hirla u. a. Carex-Arten), auch Juncazeen (besonders Juncus effusus, $J$. articulatus und $J$. filiformis) beteiligen sich an der Rasenbildung. Von den übrigen Bewohnern der Sumpfwiesen sind am bezeichnendsten Orchis incarnata, Epipactis palustris, Triglochin palustre, Lychnis Flos Cuculi, Ranunculus acer, Parnassia palustris, Trifolium spadiceum, Angelica silvestris, Myosotis scorpioides, Pedicularis palustris, P. silvalica, Valeriana dioica, Succisa pralensis, Senecio aquaticus, Cirsium oleraceum, G. palustre, $G$. canum und an salzigen Stellen Glaux maritima.

Borstengrasmatten. Die höchsten Kuppen des Erzgebirges und Böhmerwaldes und seiner Ausläufer bedeckt eine heideartige trockene Grasflur, in der das Borstengras (Nardus stricla) meist im Vereine von Calluna vulgaris, Vaccinium Myrtillus und V. Vitis Idaea in dichtem Bestande den Boden bedeckt; dicht verwebt in der Grasnarbe sind gewöhnlich Renntierflechte und isländisches Moos (Cladonia rangiferina und Celraria islandica), und verschiedene Moose, besonders Polytrichum commune. $P$. formosum, $P$. juniperum, P. piliferum und Pogonatum alpinum, bilden dazwischen dichte Polster. Die übrige Flora ist ziemlich eintönig; Anthoxanthum odoralum, Phleum alpinum, Deschampsia flexuosa, Festuca rubra, Carex leporina, C. Goodenoughii, C. pilulifera, C. pallescens, Juncus filiformis, Juncus squarrosus, Luzula nemorosa, L. multiflora und L. sudetica sind mehr oder weniger zahlreich an der Bildung der Grasnarbe beteiligt, Lycopodium alpinum, Gymnadenia albida, Cerastium vulgatum, Geranium silvalicum, Potentilla erecta, Trientalis europaea, Veronica officinalis, Melampyrum pratense *alpestre, Galium hercynicum, Homogyne alpina, Solidago alpeslris, Antennaria dioica die für die Formation am meisten charakteristischen Arten, doch treten auch noch Athyrium alpestre, A. Filix femina, Dryopteris Filix mas, Orchis maculala, Streptopus amplexifolius, Polygonum Bistorta, Sagina saginoides, Dianthus deltoides, Ranunculus acer, P. plalanifolius, Veronica Chamaedrıs, $V$. serpyllifolia, Aleclorolophus minor, Campanula rotundifolia, Gnaphalium silvaticum, G. norvegicum, Senecio subalpinus, Leontodon aulumnalis, Hieracium Pilosella,' H. Auricula, H. floribundum, $H$. murorum und $H$. vulgalum nicht gerade selten auf.

Die Federgrassteppe. Die äußersten Ausläufer des herzynischen Berglandes gegen die Donau zu, die Hänge der Wachau, und teilweise auch noch 
die Abfälle gegen das Kamptal, weisfn einen vom übrigen Teil ganz abweichenden Florencharakter auf. Hier an den heißen Granithängen hat sich vom Osten her vordringend eine wärmeliebende Flora angesiedelt, die stellenweise direkt Steppencharakter annimmt. Hier gedeihen Slipa penala *Joannis und S. capillata, Melica ciliala, Koeleria gracilis, Poa badensis, Carex humilis, Allium flavum, Iris pumila, I. variegala, Minuartia verna, Silene Otites, Erysimuin canescens, Isatis linctoria, Linum lenuifolium, Seseli Beckii, Orlaya grandiflora, Cylisus nigricans, Onosma austriacum, Thymus lanuginosus, Linaria genislifolia, Campanula sibirica, Asperula glauca, Cenlaurea rhenana, Chondrilla juncea und manche andere östliche Art.

\section{d) Xerophile Staudenformation.}

Die Felsenflora. Die Felsenflora des herzynischen Berglandes ist außerordentlich artenarm, da das Gestein fast durchwegs aus Silikatgesteinen oder sindstein besteht und demnach alle kalkliebenden Elemente fehlen. Am zahlreichsten sind die Noose vertreten, unter denen besonders liacomilrium heterosliclum weit verbreitet ist, im übrigen sind Dicranoweisia Brunloni, Dicranodonlium longirostre, Barbula muralis, Torlula ruralis, Grimmia apocarpa, G. putvinala, Orthotrichum rupestre, Bartramia ithyphylla die häufigsten Arten, denen sich in höheren Lagen Racomitrium aciculare, $R$. lanuginosum, $R$. fasciculare, Hedwigia ciliata und Andraea petrophila beigesellen. Neben den Moosen sind auch die Flechten reich vertreten; auf den Silikatgesteinen neben dem so charakteristischen und weit verbreiteten Rhizocarpon geographicum in höheren Lagen hauptsächlich noch Placodium albescens, $P$. saxicolum, Haematomma coccineum, Lecidea crustulala, Lecanora badia, L. sulphurea, L. polytropha, L. petrophila und Parmelia saxalilis, während für die Sandsteine des Lausitzer Gebirges vor allem Umbilicaria pustulala sowie Gyrophora hirsula, G. polyphylla und $G$. deusta charakteristisch sind. Neben den Moosen und Flechten treten die höheren Gewächse an Iäufigkeit zurück, am verbreitetsten sind noch die Farne Asplenium septentrionale, A. Rula muraria, A. Irichomanes und Cyslopleris fragilis, während Asplenium Adianlum nigrum minder häufig und Woodsia ilvensis auf wenige Standorte besonders im Lausitzer Berglande beschränkt ist; auf Serpentin im liaiserwalde kommen überdies noch Asplenium cuneifolium und A. adullerinum,vor! Von Phanerogamen licmmen von meist an Felsen wachsenden Arten wohl nur Anthericum ramosum, A. Liliago, Allium monlanum, Sedum album, Potentilla argenlea, Bupleurum falcalum, Libanolis montana, Stachys recta und Asperula, cynanchica als ziemlich allgemein verbreitete Arten in Betracht.

Einzelne Lokalitäten freilich sind reicher mit Felsenpflanzen bedacht; so die Basaltfelsen der Lausitz, wo Aster alpinus *hirsulus und Hieracium Schmidtii vorkommen, und die Gegend von Krumau, wo Alyssum Arduini allenthalben häufig ist.

Alpine Felsenpflanzen sind nur auf einigen Gipfeln des Böhmerwaldes anzutreffen; am häufigsten ist Juncus trifidus, doch auch Lycopodium Selago. Agrostis rupestris und Poa alpina sind nicht selten. 
Eine ganz andere Felsenflora zeigen die Abhänge der Ausläufer des niederösterreichischen Waldviertels gegen den Kamp und die Donau zu. Hier treten in großer Zahl östliche und südliche Typen auf. So finden sich an Moosen Hymenostomum torlile, Syntrichia intermedia und Barbula squarrosa, von Flechten Lecidea lurida und Dermatocarpon Michelii als ausgesprochen südlichr? Formen, daneben freilich auch hochalpine (Dicranella subulata, D. squarrosa, Grimmia Mühlenbeckii) und Voralpen-(Gyrophora cylindrica, Parmelia diffusa, Cladonia gracilis) Typen. Von Phanerogamen treten gelegentlich fast alle der oben genannten Glieder der Federgrassteppe auch an Felsen auf, häufig besonders Melica ciliala, Allium flavum, Poa badensis, Iris pumila, Alyssum Arduini, A. montanum, Seseli Beckii und Centaurea rhenana. Im Gurhofgraben bei Aggsbach hat der südliche Farn Notholaena Marantae seinen cinzigen niederösterreichischen Standort, begleitet von Sedum micranthum und Myosotis suaveolens.

\section{e) Kulturgewächse.}

Getreidebau. In den rauhen Gebirgslagen des gesamten herzynischen Berglandes, das Mühl- und Waldviertel inbegriffen, spielt der Getreidebau naturgemäß keine hervorragende Rolle. Roggen und Hafer sind die einzigen kultivierten Getreidesorten, und nur am Fuße des Erzgebirges findet man auch Gerste (Hordeum distichum) gebaut. Im Erzgebirge, wo Getreide, und zwar Sommerroggen, bis in die höchsten Lagen (Gottesgab $1030 \mathrm{~m}$ ) gebaut wird, kommt es vor, daß das Getreide noch grün von den Feldern eingefahren werden muß.

Gemüsepflanzen. Von diesen spielt die Kartoffel die Hauptrolle, die vielfach fast $50 \%$ des gesamten Bodenertrages liefert und alienthalben, besonders in dem bis hoch hinauf besiedelten Erzgebirge, im großen gebaut wird. Die übrigen Gemüsepflanzen werden fast ausschließlich in Gärten gebaut, allerdings bis zu einer Meereshöhe von $1000 \mathrm{~m}$.

Obstbau. Der Obstbau ist im herzynischen Bergland von geringer Bedeutung, obwohl Äpfel, Birnen, Pflaumen und Kirschen allenthalben bis zu einer Höhe von $750-800 \mathrm{~m}$ gedeihen. Im oberösterreichischen Mühl- und niederösterreichischen Waldviertel werden vielfach minderwertige Äpfel- und Birnsorten mit herben Früchten zur Mostgewinnung gebaut.

Vein. Von Weinbau ist natürlich im ganzen eigentlichen herzynischen Berglande keine Rede, wohl aber wird derselbe ziemlich intensiv im Donautale, besonders um Krems betrieben, wo besonders auf Löß, auf künstlich terrassiertem Boden ausgedehnte Rebenkulturen zu treffen sind.

Sonstige Nutzpilanzen. Von solchen ist in erster Linie der Flachs zu nennen, den man im Gebirge nicht selten gebaut antrifft, spärlicher ist der Anbau von Hanf. Auch der Anbau von Futterkräutern ist nicht von Bedeutung, neben Trifolium pralense und Medicago sativa kommt nur noch Anthyllis Vulneraria 
und (besonders um Krems) Onobrychis viciaefolia in Betracht. Die besonders um Loosdorf bei Melk ehedem betriebene Safrankultur ist wohl schon ganz eingegangen.

Forstwirtschait. In dem ungeheuer waldreichen Gebiete des herzynischen Berglandes findet allenthalben ein geregelter Forstbetrieb statt. Der Wold ist größtenteils im Besitze des Großgrundbesitzes, was natürlich für die Erhaltung desselben und die Durchführung einer rationellen Bewirtschaftung nur von Vorteil ist. Wo reine Fichtenbestände vorhanden sind, ist Kahlschlagwirtschaft mit 100-120jähriger Umtriebszeit vorherrschend, wo aber die Nachzucht schattenliebender Holzarten, wie Fichte und Tanne, die Kahlschlagwirtschaft ausschließt, ist geregelte Plänterwirtschaft in Anwendung. Auch in den höchsten Gebirgslagen, wo bei Kahlschlag durch die folgende Entblößung des Bodens der Waldbestand gefährdet wäre, kommt der Plänterbetrieb zur Geltung. Auch in den im Kleinbesitze befindlichen Wäldern, besonders im Böhmisch-mährischen Gebirge, wird in der Regel Plänterwirtschaft betrieben. Vor noch kaum 40 Jahren bestanden im sürlichen Böhmerwalde noch ziemlich ausgedehnte Urwälder, heute sind diese durch fortschreitende Ausnutzung und Wetterkatastrophen bis auf eine 47 ha große Fläche auf dem Kubany, die über Auftrag des verstorbenen Fürsten Johann Adolph zu Schwarzenberg für ewige Zeiten als Urwalıl erhalten bleiben soll, verschwunden.

Von Kulturen fremdländischer Forstbäume wäre vor allem die von amerikanischen Eichen, besonders Quercus rubra, bei Worlik nächst Pisek, die, sehr günstige Resultate lieferte, zu erwähnen.

\section{f) Die Adventivflora.}

Ackerunkräuter. WVie überall an vom Verkehre weniger berührten Orten ist auch im herzynischen Bergland die Adventivflora artenarm. Als Ackerunkräuter kommen insbesondere Apera Spica venta, Bromus secalinus, Polygonum Convolvulus, Spergula arvensis, Scleranthus annuus, S. perennis, Raphanus Raphanistrum, Alchimilla arvensis, Trifolium procumbens, Linaria arvensis, Cirsium arvense und Centaurea Cyanus in Betracht; mehr wärmeliebende Arten, wie Delphinium Consolida, Ranunculus arvensis, Legousia Speculum Veneris usw. fehlen gewöhnlich oder treten nur vorübergehen!t auf, selbst Agrostema Githago und Papaver Rhoeas sind nicht häufig. Hingegen hängt es mit der Art des Wirtschaftsbetriebes in den Gebirgsländern zusammen, wo oft Wechselwirtschaft zwischen Acker und Wiesen betrieben wird, daß man mitunter ausdauernde Wiesenpflanzen als Ackerunkräuter beobachten kann, wie z. B. Lilium bulbiferum, Rumex crispus, Achillea Millefolium. Im Erzgebirge ist Tiola tricolor eine Zierde der Äcker.

Ruderalflora. Ebenso arın ist auch die eigentliche Ruderalflora auf Schutt, wüsten Plätzen, in Dorfstraßen usw. Allenthalben verbreitet sind nur Polygonum aviculare, P. Persicaria, Chenopodium album, Ch. Bonus Henricus, Lrtica dioeca, U. urens, Senecio vulgaris, Carduus acanthoides, Cirsium lanceolatum, Plantago 
maior und Polentilla anserina; in neuerer Zeit zeigt sich auch schon an manchen Urten .Malricaria discoidea. Sueziell im Erzgebirge ist Malva pusilla, im Böhmischmährischen Höhenzug Chenopodium rubrum häufig.

\section{Die Pflanzengenossenschaften der Sudeten.}

\section{a) Waldbestände.}

Der siiddeutsche Eichenwald. Im Fube der Sudeten, besonders anf der schlesischen Seite, sind Eichenmischwälder nicht selten, die, mit den westungarischen und zentralböhmischen Eichenwäldern zwar nahe verwandt, sich von denselben doch durch das Fehlen der meisten östlichen Begleitpflanzen unterscheiden. Vorherrschend ist Quercus sessiliflora, seltener Q. Robur, ferner treten von Bäumen Tilia cordata und T. platyphyllos, Acer platanoides und A. Pseudoplatanus, Ulmus glabra, U. scabra und U. laevis, Prunus avium, Sorbus Aucuparia, Betula pendula, Populus tremula und Salix Caprea auf, Carpinus Belulus ist hingegen ziemlich selten. Das Unterholz besteht aus Prunus spinosa, Sorbus torminalis, Rhamnus cathartica und R. Frangula, Cornus sanguinea, Evonymus vulgaris, Slaphylea pinnata, Ligustrum vulgare, Lonicera - I ylostenm und Sambucus racemosa sowie aus zahlreichen Rosen (z. B. Rosa collina, R. glauca, $R$. canina, $R$. umbellifera) und Brombeeren (Rubus plicalus, R. Koehleri, $R$. apricus, $R$. hirtus, $R$. Bellardii usw.). Im Niederwuchs ist stellenweise Calluna vulgaris tonangebend, wo dann daneben Festuca ovina, Nardus stricta, Sieglingia decumbens, Luzula multiflora, Melampyrum nemorosum, Potentilla erecta, Antennaria dioica und Polytrichum-Arten vorherrschen; häufiger aber bilden zahlreiche Gräser und Gyperazeen, wie Dactylis Aschersoniana, Festuca helerophylla, Melica nutans, M. picta, Bromus serolinus, Brachypodium pinnatum, Carex muricala und $C$ pallescens eine reiche Grasnarbe, in der Paris quadrifolia, Lalhyrus vernus, L. niger, Primula elalior, P. veris, Convallaria maialis, Maianthemum bifolium, Dianthus superbus, Veronica Chamaedrys und Aiuga reptans den blütenreichen Niederwuchs bilden.

Gemischte Nadelwälder. Neben Eichenwäldern treten auf den Torhügeln der Sulcten besonders Nadelwälder aus Fölı ren und Fich ten zusammengesetzt auf. Neben Pinus silvestris und Picea excelsa, die die Hauptmasse des Oberholzes bilden, ist auch Abies alba nicht selten und oft mischen sich auch Laubbäume in den Nadelholzbestand, besonders Betula pendula, Quercus sessiliflora, Fagus silvatica, Tilia cordata, Ulmus scabra und in tieferen Lagen auch Carpinus Betulus. Das spärliche Unterholz besteht besonders aus Juniperus communis, Prunus spinosa, Evonymus vulgaris usw. Sehr einförmig ist der Niederwuchs; Vaccinium Myrtillus überzieht weithin in dichtem Bestande den Boden, vergesellschaftet mit Calluna vulgaris, Taccinium Titis Idaea, Pirola rolundifolia, P. chlorantha, P. minor, P. secunda und Polentilla erecla. Auch Sanicula europaea, Galium rolundifolium, G. hercynicum, Lacluca muralis, Prenanthes purpurea, Polygonatum verticillalum. Oxalis Acetosella, Melampyrum silvalicum sind in den 
Nadelwäldern anzutreffen, und an feuchteren Stellen erheben sich Cardamine enneaphyllos, Digilalis ambigua, Senecio nemorensis, Cephalanthera alba, Epipaclis latifolia, Anemone Hepatica und mächtige Farne, wie Pleridium aquilinum, Athyrium Filix femina, Dryopteris spinulosa, D. Filix mas, Equiselum silvaticum. Von Schlingpflanzen ist Vicia silvalica nicht selten.

Buchenwälder. IVenn auch Nadelwälder in den Sudeten weitaus vorherrschen, so sind doch an den Flanken derselben prächtige Buchenbestände keineswegs selten anzutreffen. Strauchartig steigt Fagus silvalica in den Sudeten bis fast an die Waldgrenze $(1300 \mathrm{~m})$ heran, größere Wälder trifft man besonders in einer Höhenlage zwischen 500 und $800 \mathrm{~m}$ an; ihre obere Grenze erreicht sie bei $830 \mathrm{~m}$; besonders auf Eruptivgesteinen ist meist die Buche der herrschende Waldbaum.

Fagus silvatica bildet entweder reine Bestände oder findet sich mit anderen Laubhölzern, besonders Ulmus scabra, Acer platanoides und A. Pseudoplatanus, Tilia cordata und $T$. platyphyllos, nicht selten auch mit der Fichte vermischt. Schöne alte Buchenwälder bieten das bekannte herrliche Bild eines alten Hochwaldes, fast ohne jegliches Unterholz, mit einem im Sommer aus nur spärlichen Schattenpflanzen bestehenden Niederwuchs, während im Frühling vor der Belaubung der Buchen zahlreiche Stauden und Kräuter erblühen. Wo aber der Wald sich etwas lichtet, sowie an Waldrändern und in Durchschlägen usw., tritt meist ein reiches Unterholz aus Salix caprea und S. silesiaca, Prunus spinosa, Rubus Idaeus und R.hirtus, Ribes Grossularia und R.alpinum, Sambucus racemosa, Lonicera Xylosteum und L. nigra auf. Der Niederwuchs der Buchenwälder besteht vorzüglich aus Hordeum europaeum, Bromus serotinus und $B$. asper, Festuca silvatica, Melica nulans, Poa Chaixii, Garex pendula und C. digilata, Luzula nemorosa, Allium ursinum, Lilium Martagon, Corallorrhiza trifida, Epipogon aphyllum, Epipactis alropurpurea, Cephalanlhera alba und C. longifolia, Anemone nemorosa und A. Hepatica, Ranunculus lanuginosus, Thalictrum aquilegifolium, Actaea spicata, Cardamine bulbifera, $C$. enneaphyllos, $C$. impatiens und C. flexuosa, Lunaria rediviva, Vicia silvatica, Aruncus silvester, Oxalis Acetosella, Circaea alpina, C. intermedia, Euphorbia dulcis, E. amygdaloides, Pulmonaria officinalis, Lamium luleum, Salvia glutinosa, Atropa Belladonna, Veronica montana, Campanula latifolia, Galium silvaticum, Asperula odorala, Homogyne alpina, Prenanthes purpurea und Lacluca muralis. Ein dichter Moospolster am Grunde des von einer dichten Schicht dürren Laubes bedeckten Bodens ist selten, hingegen überziehen Moose oft in großer. Menge den Grund der mächtigen alten Buchenstämme. An feuchten schattigen Stellen treten aber Farne oft in großer Anzahl auf, besonders Polysstichum lobatum und P. Braunii, Dryopteris spinulosa, D. dilatata, D. Filix mas, D. Oreopteris, D. polypodioides, D. Linnaeana, Athyrium Filix femina, A. alpestre und Blechnum Spicant.

Der sudetische Fichtenwald. Der weitaus wichtigste und vorherrschente Waldbaum der Sudeten ist die Fichte, die die Flanken des Gebirges bis zur 
oberen Waldgrenze $(1200-1300 \mathrm{~m})$ in dichtem Bestande bekleidet. In tieferen Lagen wird der Fichtenwald noch hie und da von Buchenbeständen unterbrochen, während in höheren Lagen geschlossene Fichtenbestände die Hänge des Gebirges bedecken, nur hie und da einen Wiesenstreifen oder kleinere Moore dazwischen freilassend. Auch in physiognomischer Beziehung unterscheiden sich die Fichtenbestände tieferer Lagen von denen höherer Regionen und es gliedert sich demnach der Fichtenwald der Sudeten in einen unteren und einen oberen sudetischen Fichtenwald.

a) Der untere sudetische Fichtenwald. Bis zu einer Höhe von etwa $1000 \mathrm{~m}$ ist die Tanne (Abies alba) ein regelmäßiger Begleiter der Fichte, die teils einzeln eingesprengt, teils in kleinen Gruppen im Walde sich findet. Im äußersten Südosten des Gebietes, im Gesenke, kommt auch die Lärche (Larix decidua) vor. Von sonstigen Begleitbäumen sind nur noch Pinus silvestris, Populus tremula, Betula pendula, Acer Pseudoplatanus zu nennen. Meist entbehrt der Nadelwald vollständig des Unterholzes und nur hie und da tritt ein Strauch von Juniperus communis, Salix silesiaca, Lonicera Xylosteum, L. nigra oder Sambucus racemosa auf. Den Boden dieser Wälder aber überziehen oft in dichtem Bestande Vaccinium Myrtillus und V. Vitis Idaea, vergesellschaftet mit Melampyrum pralense *vulgatum, $M$. silvaticum, Pirola rolundifolia, $P$. secunda, Veronica officinalis, Potentilla erecta und vereinzelten Gräsern, wie Deschampsia flexuosa, Festuca heterophylla und Luzula nemorosa. An humosen schattigen Stellen treten auch Farne auf, besonders Alhyrium Filix femina, Dryopteris Filix mas, D. Oreopleris, außerdem Cardamine enneaphyllos, Lamium luteum, Monolropa Hypopitys und selbst Bewohner des Buchenwaldes, wie Cephalanthera alba, C. Iongifolia, Sanicula europaea, Prenanthes purpurea, Lacluca muralis usw. Nur in Lichtungen und an Waldrändern wird die Flora etwas reicher und es kommen daselbst Aruncus silvester, Vicia dumetorum, V. silvatica, Digitalis ambigua, Salvia glutinosa, Senecio nemorensis, S. sarracenius und andere hochwüchsige Stauden vor.

b) Der obere sudetische Fichtenwald. Bei ungefähr $1000 \mathrm{~m} \mathrm{M.} \mathrm{H.}$ bleibt die Tanne als Begleiter der Fichte zurück und an ihre Stelle tritt ein anderer in tieferen Lagen nur selten auftretender Baum, Sorbus Aucuparia * glabrata. Im Niederwuchs sind auch hier Vaccinium Myrtillus und V. Vitis Idaea in tonangebender Menge vorhanden und in deren Gesellschaft Deschampsia flexuosa, Calamagrostis villosa, Luzula nemorosa, Maianthemum bifolium, Euphorbia amygdaloides, Pirola media, P. minor, P. chloranlha, P. uniflora, Circaea alpina, C. intermedia, Veronica officinalis, Galium rolundifolium, Homogyne alpina. Viel reichlicher als in tieferen Lagen treten hier die Farne auf und neben den oben genannten Arten kommen noch Polystichum Braunii, P. lobatum, Blechnum Spicant und Dryopleris spinulosa vor. Auch die subalpinen Hochstauden sind hier in größerer Menge vertreten, besonders nahe der oberen Waldgrenze zwischen 1100 und $1300 \mathrm{~m}$, wo die Bestände sich zu lichten beginnen, die niedrigen reich mit Flechten bewachsenen Fichtenstämme lockerer stehen und auch einem reicheren Strauchwuchs Platz marhen. Neben Sorbus Aucuparia 


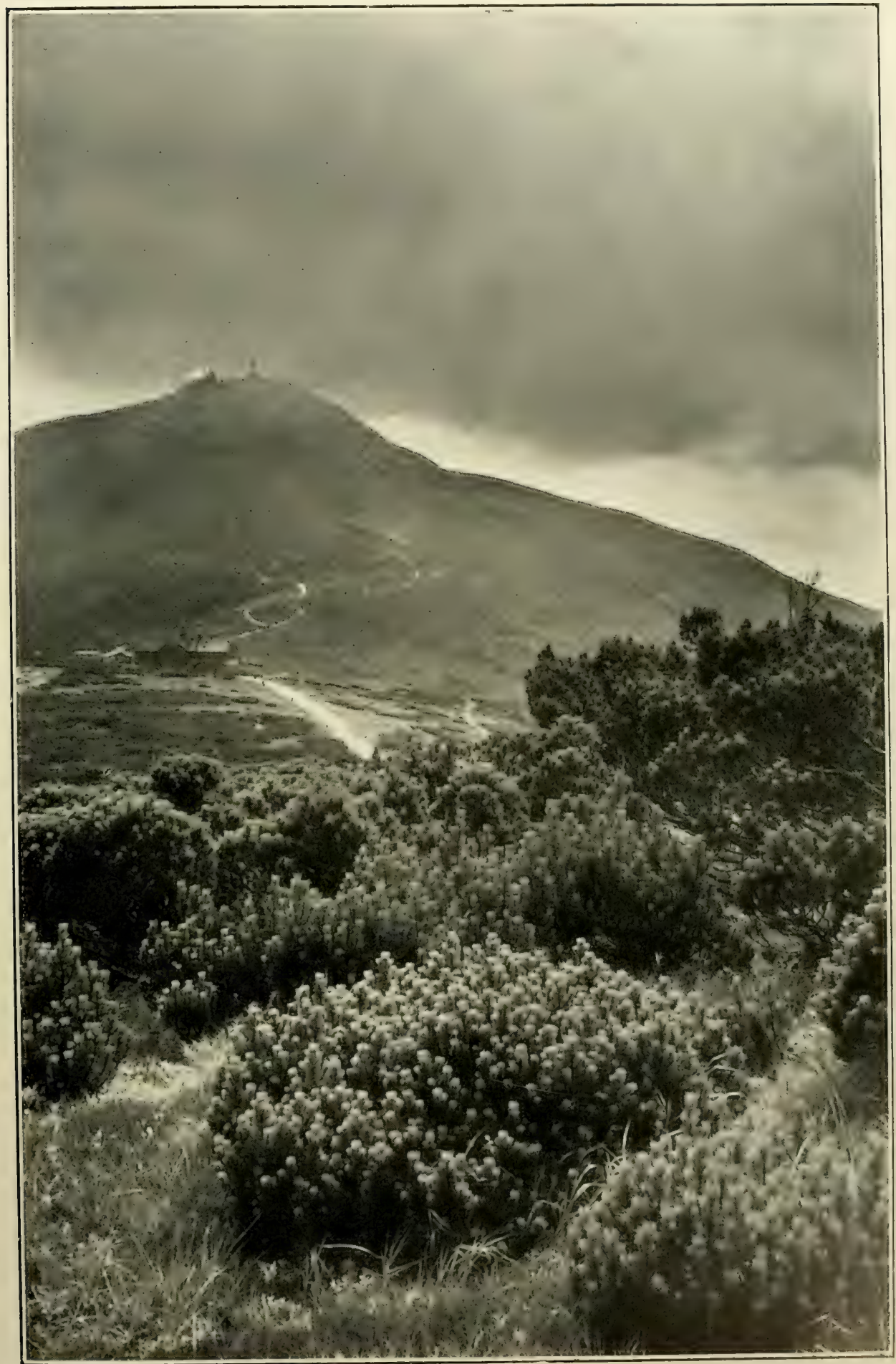

Abb. 27. Krummholzbestände auf dem Koppenplan im Riesengebirge. Im Hintergrunde die Schneekoppe.

(Nach einer Aufnahme von Nenke und Ostermaier in Dresden.)

Verlag von Franz Deuticke in Leipzig und Wien. 



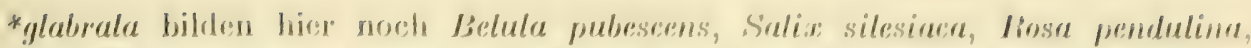
liabus Idaeus, Sorbus sudetica, Lonicera nigra, Sambucas racemosa das I nobry

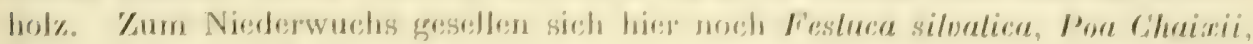
Luzula silosalica, Polygonalum officinale, S'lreplopons amplexifolins, Lianunculus: plalanifolius, Thatichum aquilegifolium, Aconilum variegalum *grarile, Aulhriscus nilidus, Chaerophyllum Gicularia, Ginaphalium norongioum, Adenoslygles Alliariae.

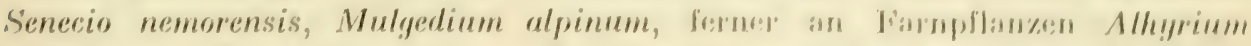

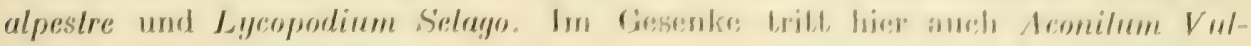
paria inf.

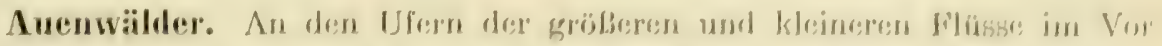

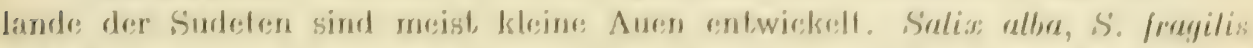
und S. pentandra, Alnus glulinosa, Ulmus glabra und U. Larvis bidalon das

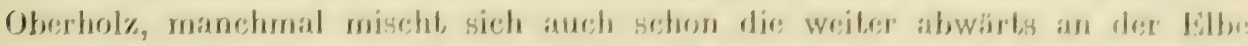

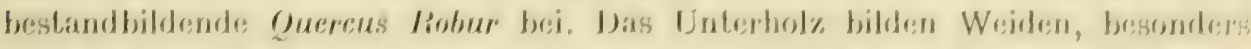
Salix triandra, S. daphnoides, S. purpurea, S. viminalis, forner lihammus: firangula, Prunus l'adus usw. Jer Niederwuchs besteht, Leils aus Gräsern, wir:

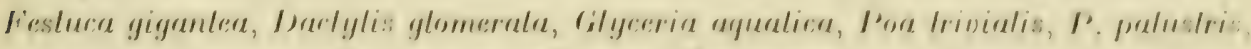
Calamagrostis lancestala, toils aus Jiumes, Mydrolapalhum, IS. aqualions, Vrtica urens, U. dioesa, Stellaria aqualica, S' media, Ciucubalas baccifer, Impaliens Noli langere, Filipendula Ulmaria, Geum urbanum, Viola elatior, Aegopodium I'oda

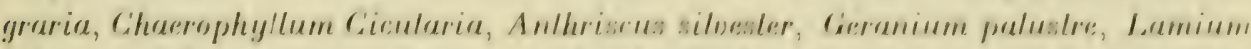

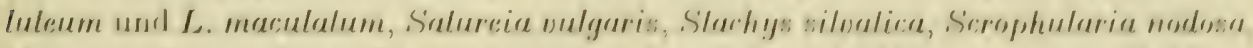

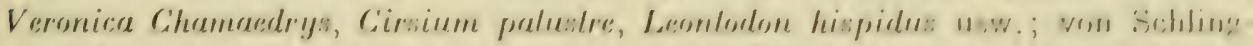

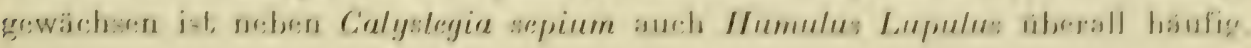

\section{b) Strauchformationen.}

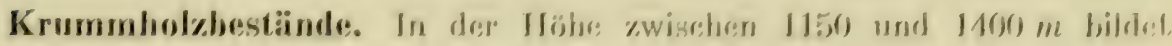
im Iser- und lhesengebirge die Krummholekicher (Pinus Mughus) and oblwas

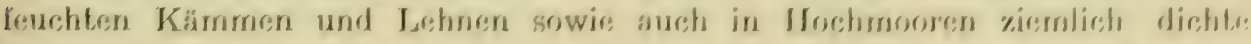

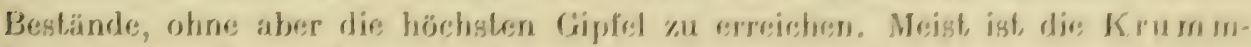
holzkiefer (Pinus Mughus) allein vertreben und bildel, mil ihren niedere-

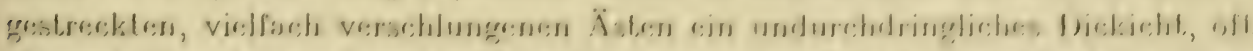

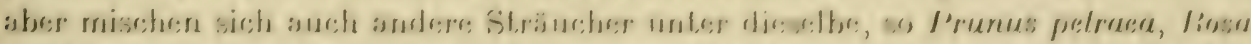

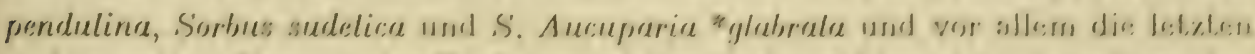

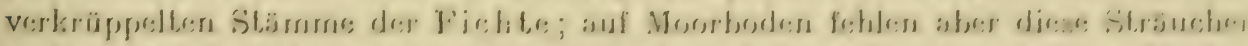

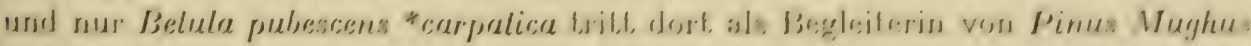
auf. Den Niederwuchs dieser Buschwalder bildsen auf nicht mosorigern Grume:

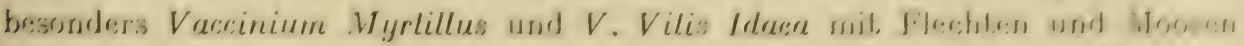

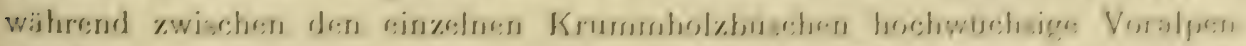

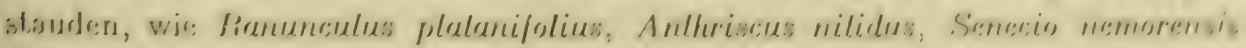

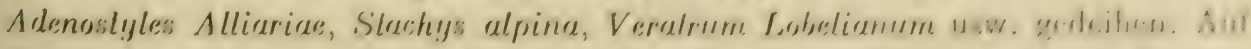

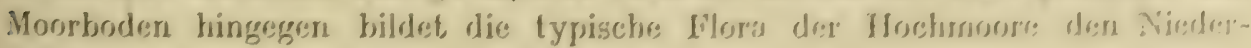
wuchs. 
Die Formation der Krippelïchten. In den Ostudeten, wo die Krumnholzkiefer wenigstens ursprünglich fehlt, treten an der oberen Waldgrenze an ihrer Stelle andere Strauchformationen auf. Vor allem sind es verkrüppelte Exemplare der Fichte (Picea excelsa) mit ganz niedrigem, an der Wetterseite astlosem Stamm und schon am Boden beginnender Beastung, die hier bis zu einer Höhe von $1400 \mathrm{~m}$ gesellig vorkommen, nach unten zu allmählich in die hochstämmigen Fichtenwälder übergehend. In jhrer Gesellschaft sind auch Buchen von ähnlichem Wuchse zu beobachten, die aber schon bei zirka $1300 \mathrm{~m}$

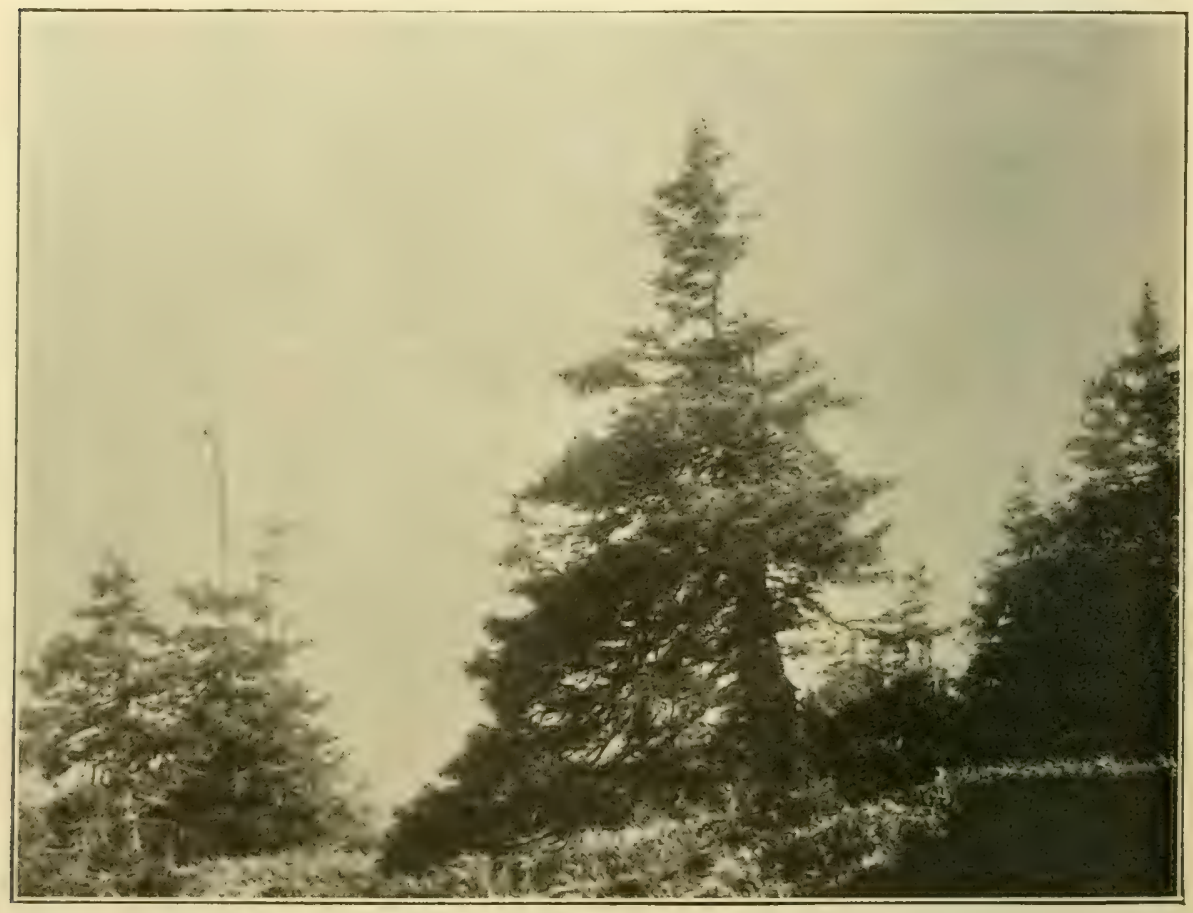

Abb. 28. Krüppelfichten im Hochgesenke.

(Nach einer Aufnahme von J. Pauer, Olmütz.)

ihre obere Grenze finden. Häufiger aber findet man in ihrer Gesellschaft Sorbus Aucuparia *glabrata in Strauchform, die stellenweise dichte Gestrüppe bildet, sowie strauchig Belula pubescens. Von sonstigen in dieser Höhenlage auftretenden Sträuchern sind Juniperus nana, Salix caprea, S. silesiaca, S. aurita, Ribes pelraeum, Tubus Idaeus, Rosa pendulina, Rhamnus Frangula und strauchförmiger Acer Pseudoplatanus zu nennen. Auch Pinus Mughus wurde in neuerer Zeit mit großem Erfolge angepflanzt. Den Niederwuchs dieser Buschbestände bildet insbesondere Vaccinium Myrlillus, das in großer Menge den Boden bedeckt, begleitet von Luzula nemorosa, Carex montana, Maianthemum bifolium, Orchis maculata, Polentilla erecta, Campanula barbata usw.; auf den von den Heidelbeeren freigelassenen Stellen siedeln sich aber gern subalpine Hochstauden an, wie Festuca silvatica, Poa Chaixii, Veralrum album *Lobelianum, Rumex arifolius, 
Polygonum Bistorta, Melandryum silvestre, Ranunculus plalanifolius, Aconitum Napellus *firmum, Delphinium elalum. Laserpilium Archangelica. Pleurospermum austriacum, Conioselinum tataricum, Geranium silvaticum, Scrophularia Scopolii, Campanula lalifolia, Adenostyles Alliarine. Doronicum auslriacum, Cirsium heterophyllum, Mulgedium alpinum und Crepis sibirica.

Zwergwacholdergestripp. Der Zwergwacholder (Juniperus nana), der auch im Iser- und Riesengebirge stellenweise anzutreffen ist, bildet besonders auf den Kuppen der Ostsudeten, denen Pinus Mughus fehlt, größere oder kleinere

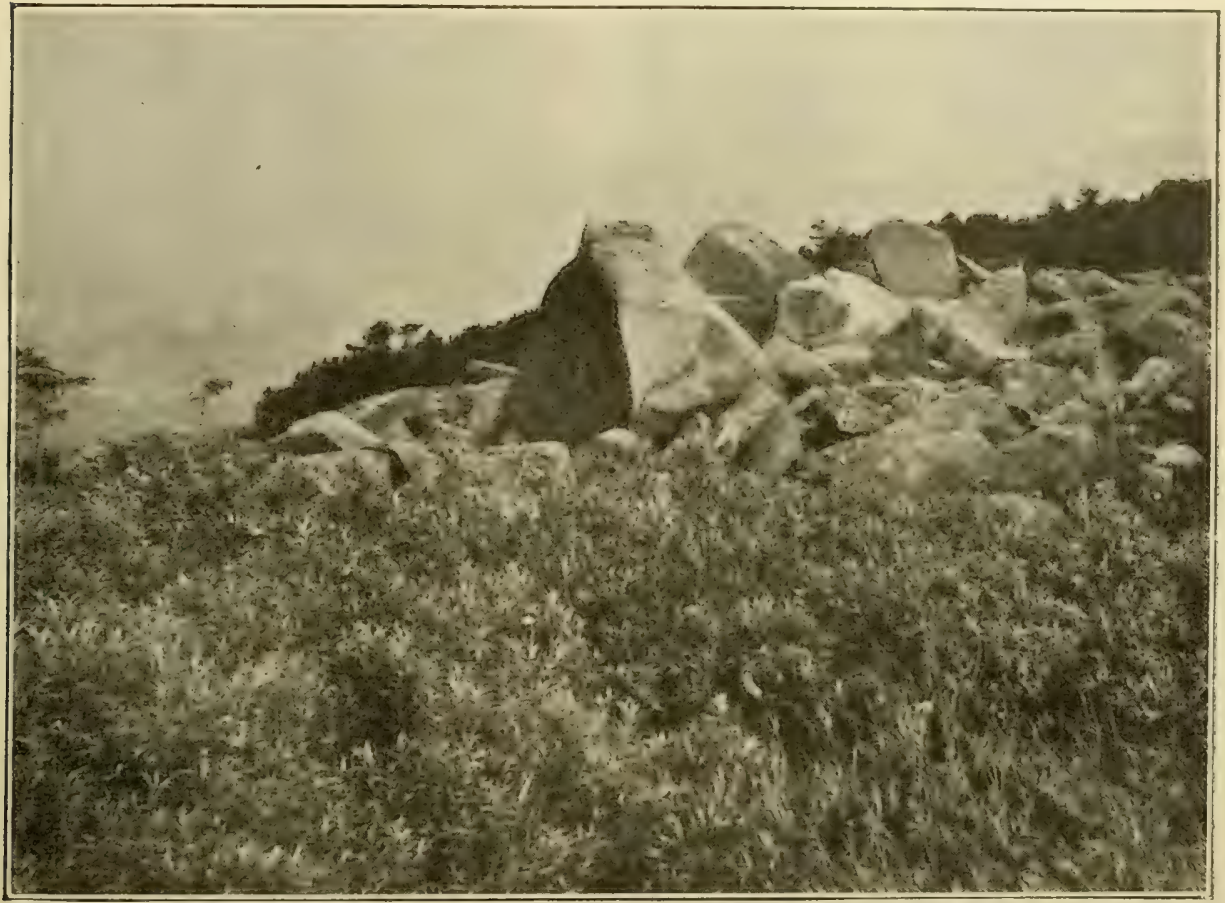

Abb. 29. Salix Lapponum bei der Prinz-Heinrich-Baude im Riesengebirge.

(Nach einer Aufnahme von Nenke und Ostermaier in Dresden.)

Gestrüppe. Neben Vaccinien tritt auch Calluna vulgaris gern in seiner Gesellschaft auf, ebenso einige Gräser, besonders NTardus stricta und Deschampsia flexuosa.

Die Formation der sehlesischen Weide. Ähnlich wie in den Karpathen bildet auch in den Sudeten die schlesische Weide (Salix siles i a $a$ ) an Bergbächen, feuchten felsigen Hängen, in Gebirgsschluchten, teils allein, teils mit anderen Sträuchern vergesellschaftet, größere oder kleinere Bestände. Vereinzelt bis $450 \mathrm{~m}$ herabsteigend, ist sie am häufigsten in der oberen Waldregion und erreicht mit dem Aufhören des IValdes oder etwas höher bei etwa 1300 m ihre obere Grenze. In tieferen Lagen mitunter noch mit anderen Uferweiden, wie Salix fragilis orler S. purpurea, vergesellschaftet, läßt sie dieselben hald unter sich zurück und bildet entweder für sich allein oder aber im Vereine mit Salix Lapponum und (im Gesenke) 


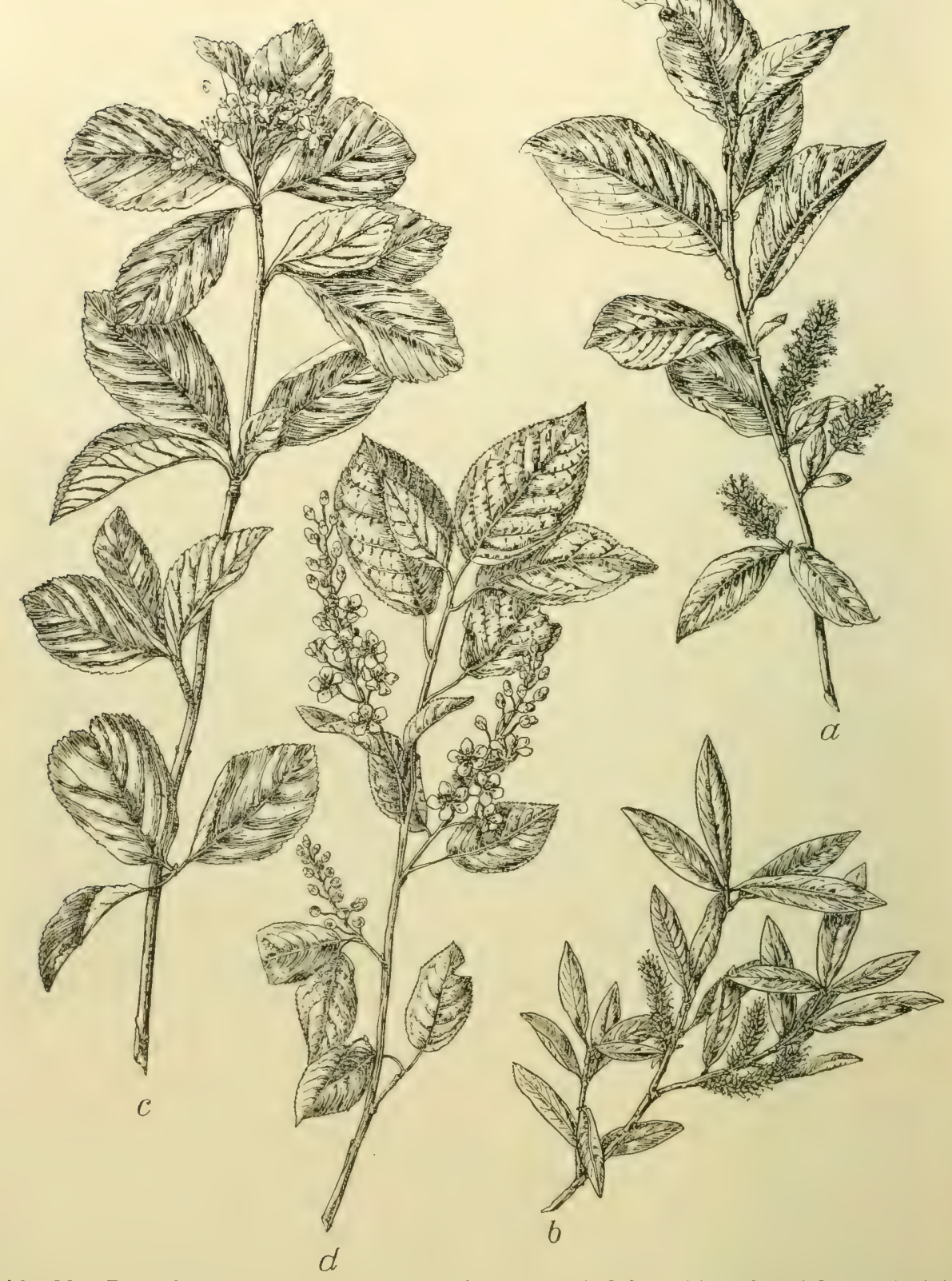

Abb. 30. Bemerkenswerte Arlen aus der Flora des subalpinen Strauchgürtels der Sudeten. $a$ Salix silesiaca. $b$ Salix Lapponum. $c$ Sorbus sudetica, $d$ Prunus petraea.

auch S. haslala, Sorbus aucuparia *glabrala und der selteneren Sorbus sudelica, Rosa pendulina, Sambucus racemosa, Lonicera nigra, Ribes pelraeum und der seltenen Felsenkirsche (Prunus petraea) Buschbestände; auch Himbeeren sind meist noch häufig anzutreff'n, hingegen fehlt die in dieser Formation zu erwartende Grünerle den Sudeten völlig. Neben dem Buschwerke siedelt sich in feuchten 
Schluchten und an felsigen Lehnen aber meist auch eine reiche Flora von subalpinen Stauden an. Der grüne Germe r (Veralrum Lobelianum), Streplopus amplexifolius, Polygonatum verlicillalum, Calamayroslis villosa, Poa Chaixii, Luzula silvalica sind fast überall anzutreffen, Lilium Martagon erhebt dort seine trübroten Blüten, Delphinium elatum seine tiefblauen Trauben; vorherrschend aber ist die gelbe Farbe, vertreten durch Aconitum Vulparia (im Gesenke), Senecio nemorensis, S. rivularis, Doronicum austriacum, Solidago Virgaurea, Ranunculus nemorosus und das seltsame Bupleureum longifolium; weiß blühen Ranunculus platanifolius und eine Reihe mächtiger Doldenpflanzen, wie Anlhriscus nitidus, Angelica Archangelica, Pleurospermum austriacum und im Osten auch Conioselinum tataricum. Adenostyles Alliariae, Cirsium helerophyllum, Epilobium alpestre, Chamaenerion angustifolium. Stachys alpina, Thalictrum aquilegifolium, Genliana asclepiadia, sind gleichfalls häufige Glieder dieser Formation. Im Schatten der Büsche aber gedeihen Chrysosplenium alternifolium, Sagina procumbens und S. saginoides, Viola biflora. Oxalis Acelosella und mancherorts die seltene nordische Linnaea borealis.

\section{c) Grasflurformationen.}

Talwiesen. Die Talwiesen des Sudetenvorlandes bieten meist die Charaktere feuchterer Wiesen dar. Neben den verbreiteten Gräsern, wie Alopecurus pratensis, Anthoxanthum odoratum, Deschampsia caespilosa, Triselum flavescens, Avena pubescens, Poa pralensis, $P$. trivialis, Festuca elatior, treten auch Cyperazeen in Menge auf, so Garex Davalliana, C. panicea, C. glauca, C. Goodenoughii, Heleocharis paluslris, Eriophorum latifolium usw. Orchis latifolia, Trollius europaeus und Cardamine pratensis bilden im Frühling eine Hauptzierde dieser Wiesen, auf denen überdies Lychnis Flos Cuculi, Ranunculus acer, 1i. repens, Sanguisorba officinalis, Angelica silvestris, Carum Carvi, Heracleum Spondylium, Parnassia palustris, Prunella vulgaris, Aiuga reptans, Glechoma hederacea, Veronica Chamaedrys, V. longifolia, Plantago media, Galium boreale, G. verum, Euphrasia Rosthoviana, Succisa pratensis, Cirsium canum, C. oleraceum, Leontodon autumnalis häufig sind und im Herbste Colchicum autumnale den Reigen der blühenden Pflanzen schließt.

Bergwiesen. Ein ganz anderes Bild bieten die Wald- und Bergwiesen der Sudeten bis zu einer Höhe von etwa $1000 \mathrm{~m}$. Hier herrschen von Gräsern Triselum flavescens, Holcus mollis, Briza media, Poa angustifolia, P. pratensis, Dactylis glomerata, Festuca duriuscula, F. rubra, F. elatior, Carex polygama, C. verna, G. pilulifera; reich sind die Orchideen (Orchis ustulata, mascula, sambucina, globosa, Gymnadenia conopea, Coeloglossum viride) vertreten und einen besonderen Schmuck der Bergwiesen bildet besonders im Osten Gladiolus imbricalus. Bei Troppau blüht im ersten Frühling Crocus Heuffelianus, an feuchteren Stellen ist überall Leucoium vernum verbreitet; später sind Primula elatior (seltener P. veris), Arabis Halleri, Trollius Europaeus meist in tonangebender Menge vorhanden. Von sonstigen bezeichnenden Arten seien genannt Polygonum Bistorta, Thesium pralense, Dianthus Armeria, Ranunculus auricomus, $R$. acer, 


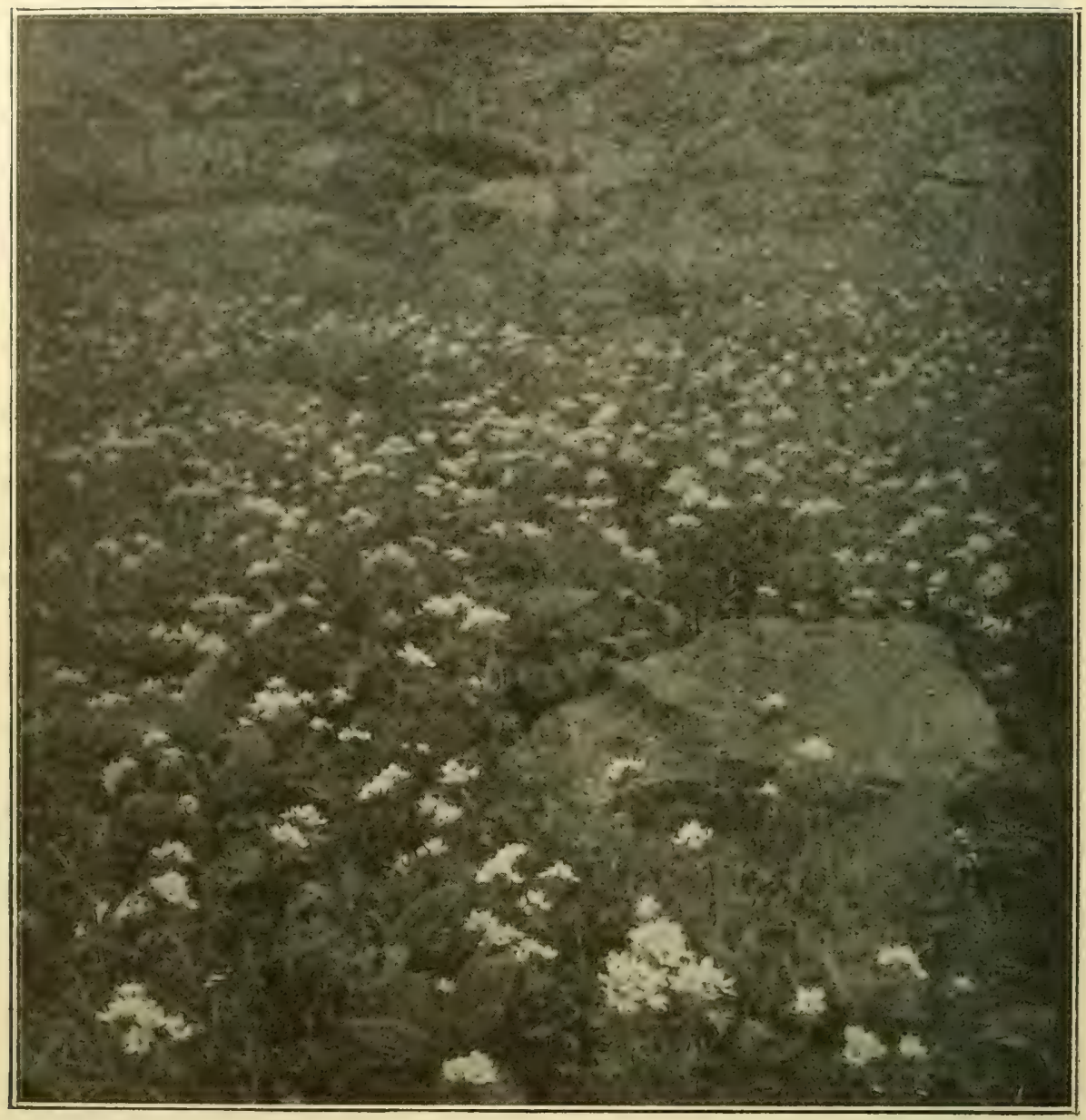

Abb. 31. Anemone narcissiflora in der Kleinen Schneegrube im Riesengebirge. (Nach einer Aufnahme von Nenke und Ostermaier in Dresden.)

R. polyanthemus, Trifolium pratense, T. monlanum, T. ochroleucum, T. spadiceum, Lolus corniculalus, Chaerophyllum aromalicum, Pimpinella major, Myrrhis odorata, Gentiana Weltsleinii, G. campestris, Euphrasia coerulea, Pedicularis silvatica, Phyleuma orbiculare, Valeriana dioeca, Arnica montana (im Gesenke lehlend), Cirsium rivulare, Cenlaurea Jacea, C. oxylepis, C. pseudophrygia, Crepis praemorsa, C. succisaefolia, Hieracium flagellare, $H$. glomeralum, $H$. suecicum, H. floribundum, H. pratense und von Farnpflanzen Botrychium Lunaria.

Voralpenwiesen. Auf sanft geneigten Hängen der Voralpenregion bis über die Waldgrenze hinaus, etwa zwischen 900 und $1400 \mathrm{~m}$, wo der Boden eine genügende Menge Feuchtigkeit aufweist, ohne gerade zu versumpfen, sind Wiesen mit mannigfaltiger Vegetation vorhanden. Alopecurus pralensis, Phleum alpinum, Calamagrostis villosa, Avena planiculmis, Deschampsia caespilosa, Poa pralensis, Carex alrata, Luzula mulliflora sind hier die häufigsten Gräser und 


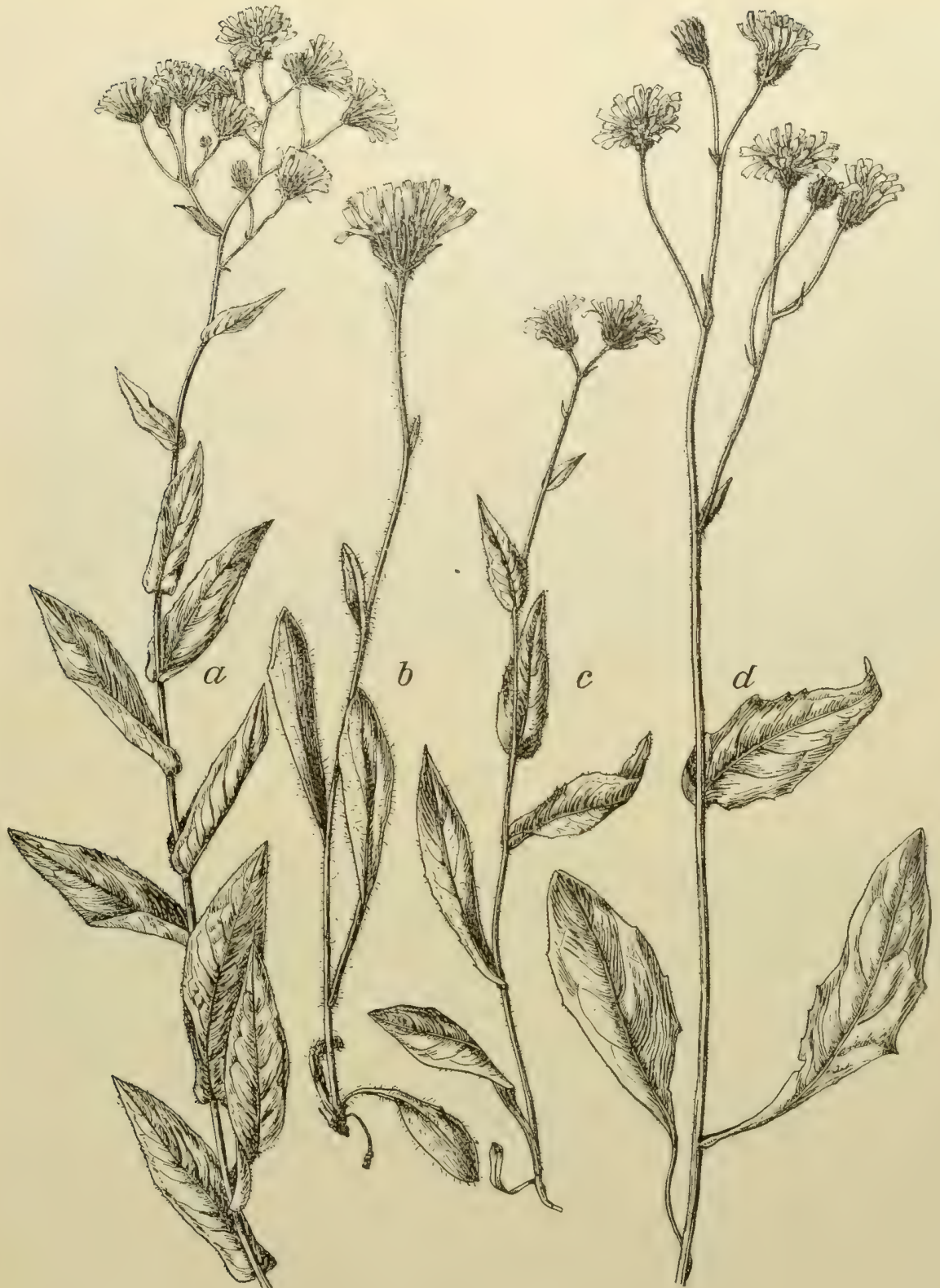

Abb. 32. Einige, ,Sudeten"-Hieracien.

a Hieracium prenanthoides, $b$ H. Fritzei. $c$ II. riphaeum. $d$ H. nigritum.

Scheingräser und zahlreiche bunte Blüten schmücken diese Wiesen. Ilier blühen Gymnadenia conopea und G. albida, Orchis mascula und O.globosa, Platanlhera monlana, Anemone narcissiflora, Ranunculus acer, Arabis Halleri, Dianlhus speciosus, Melandryum silvestre, Geum montanum, Cerast um macrocarpum, Polentilla aurea, Liguslicum Mulellina, Pimpinella maior, Peucedanum Ostruthium, Gentiana punclala, Aleclorolophus pulcher, Euphrasia coerulea, E. picla, 
Campanula barbala, Achillea sudetica, Gnaphatium norvegicum, Mulgedium alpinum, Leontodon opimus, Crepis conyzifolia, C. mollis und vor allem eine Unzahl der mannigfachsten Hieracien, an denen die Sudeten ungeheuer reich sind und eine ganze Reihe von Endemismen besitzen. Die wichtigsten Arten derselbe sind Hieracium flagellare, floribundum, aurantiacum, sudeticum, pedunculare, asperulum, nigritum, alralum, nigrescens, alpinum, Fritzei, pseudopersonalum, chlorocephalum, riphaeum, stygium, Engleri und prenanthoides.

Gedingte Voralpenwiesen. An reich gedüngten Stellen, besonders um die hier „Bauden“ genannten Sennhütten, finden sich meist üppige Wiesen, wo Alopecurus pratensis, Phleum alpinum, Avena planiculmis, Poa annua, $P$. supina und $P$. pratensis gewöhnlich sehr häufig sind. Außerdem kommen die Cardamine pratensis, Ranunculus acer, Trifolium pratense, T. repens, Melandryum silvestre, Rumex Acelosa, R. alpinus, Polygonum Bistorta, Viola sudelica, Peucedanum Ostruthium, Hieracium aurantiacum, H. floribundum, $H$. iseranum, Taraxacum vulgare, T. nigricans vor und selbst Urtica urens und $U$. dioeca wurden um die Bauden schon beobachtet.

Borstengrasmatten. Auf den wasserlosen Kämmen und Kuppen der Hochsudeten ist häufig gleichwie in den Alpen und Karpathen eine mit zahlreichen Ericazeen, Moosen und Strauchflechten untermischte und so der Formation der Heide nahestehende Grasflurformation entwickelt, in der Nardus stricta gewöhnlich tonangebend auftritt. Mit diesem Borstengras vergesellschaftet finden sich meist Festuca ovina, $F$. duriuscula und $F$. supina, Deschampsia flexuosa, Poa supina, Anthoxanthum odoratum, Carex leporina, C. rigida, Juncus trifidus, Luzula sudelica und L. multiflora. Dazwischen bilden Polytrichum juniperum und $P$. piliferum dichte Polster und in den Rasen fest verwebt finden sich mannigfache Strauchflechten, wie Cladonia pyxidaria, C. rangiferina, Cetraria islandica, Bacomyces rosens und Solorina crocea. Calluna vulgaris und Vaccinium Vitis Idaea und V. Myrlillus überziehen oft weite Flächen, fast jede andere Vegetation unterdrückend. Sonstige Blütenpflanzen treten nur wenige auf, in größerer Menge wohl nur Potentilla erecta, Melampyrum pratense *alpestre, Helianthemum grandiflorum, Antennaria dioeca. Solidago alpestris, Hieracium Pilosella und H. alpinum; ab und zu lrommen Silene vulgaris, Anemone alba, Arabis sudetica, auch Polentilla aurea, Geum montanum, Thymus alpestris, Taraxacum nigricans, Hieracium rupicolum, H. Fiekii, H. riphaeum usw, vor.

\section{d) Moore.}

Hochmoore. Zu den häufigsten und bezeichnendsten Pflanzengenossenschaften der Sudeten gehören die Moore, fast ausschließlich IIochmoore, die von einer Meereshöhe von $700 \mathrm{~m}$ an bis auf die höchsten IKämme hinauf ausgebildet sind und insbesondere im Iser- und Riesengebirge eine Fläche von etwa 1500 ha einnehmen. Minder zahlreich, aber lieineswegs ganz fehlend, sind die Moore im Mense- und Adlergebirge und im Gesenke. 


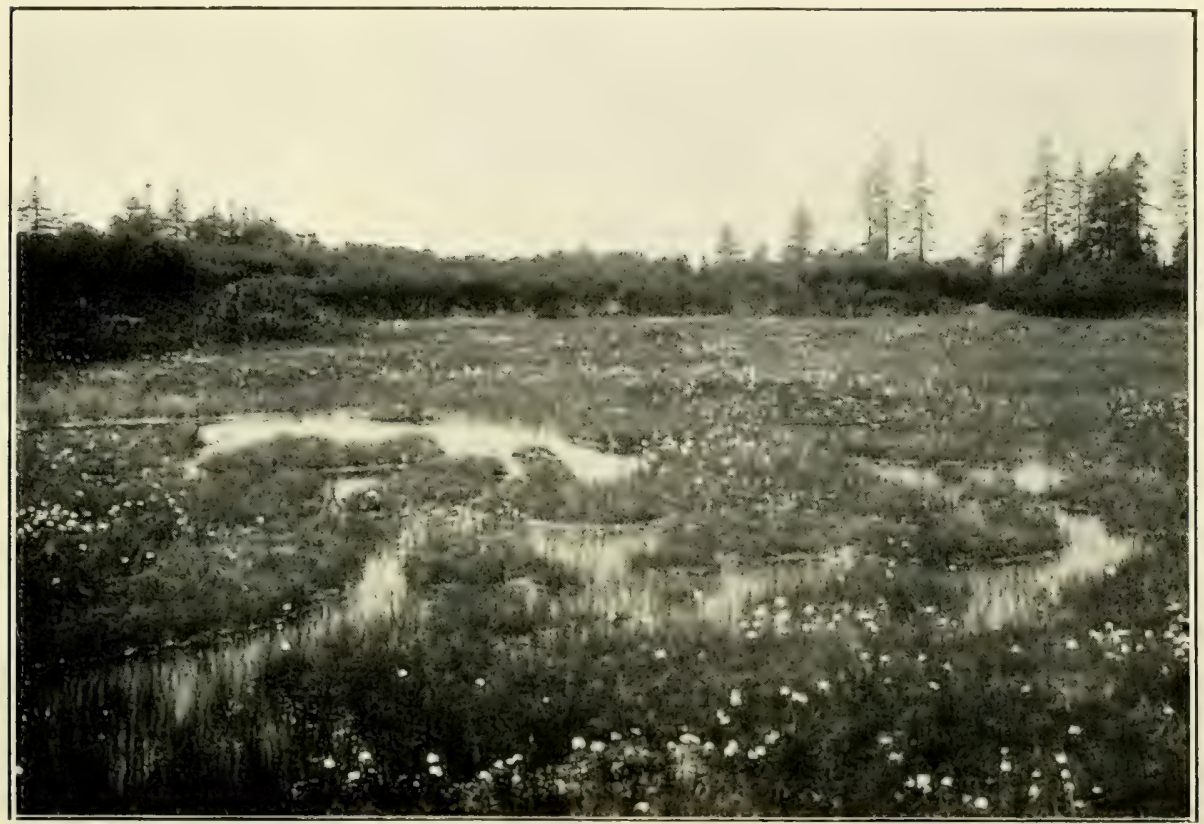

Abb. 33. IIochmoor im Isergebirge. (Das Sichübel-Moor.)

Im Vordergrunde hauptsächlich Eriophorum vaginatum; im Ilintergrunde Pinus Mughus und dahinter Fichtenwald.

(Nach einer Aufnahme des Deutschen Gebirgsvereines für das Jeschken- und Iserwebirge in Reichenberg.)

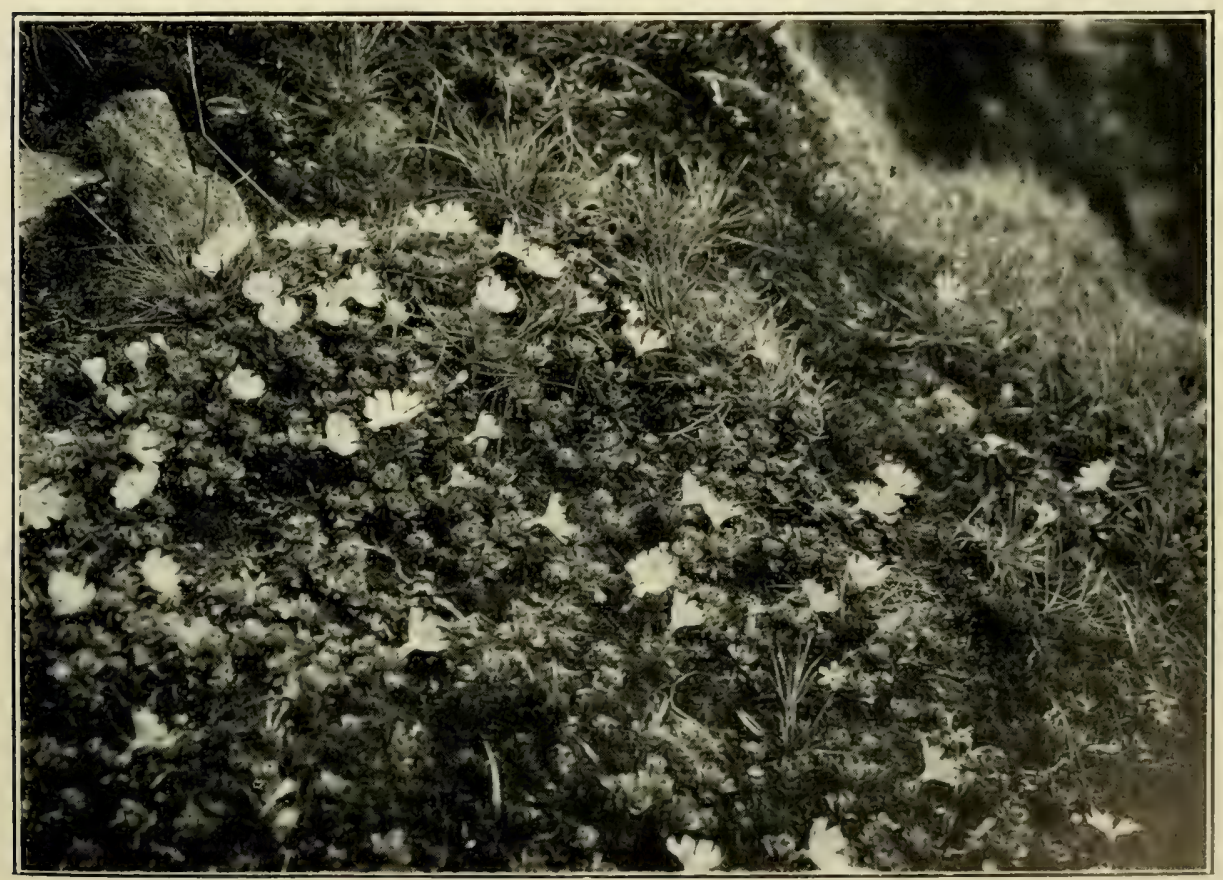

Abb, 34. Primula minima in der Kleinen Schneegrube des Riesengebirges. (Nach einer Aufnahme von Nenke und Ostermaier in Dresden.) 



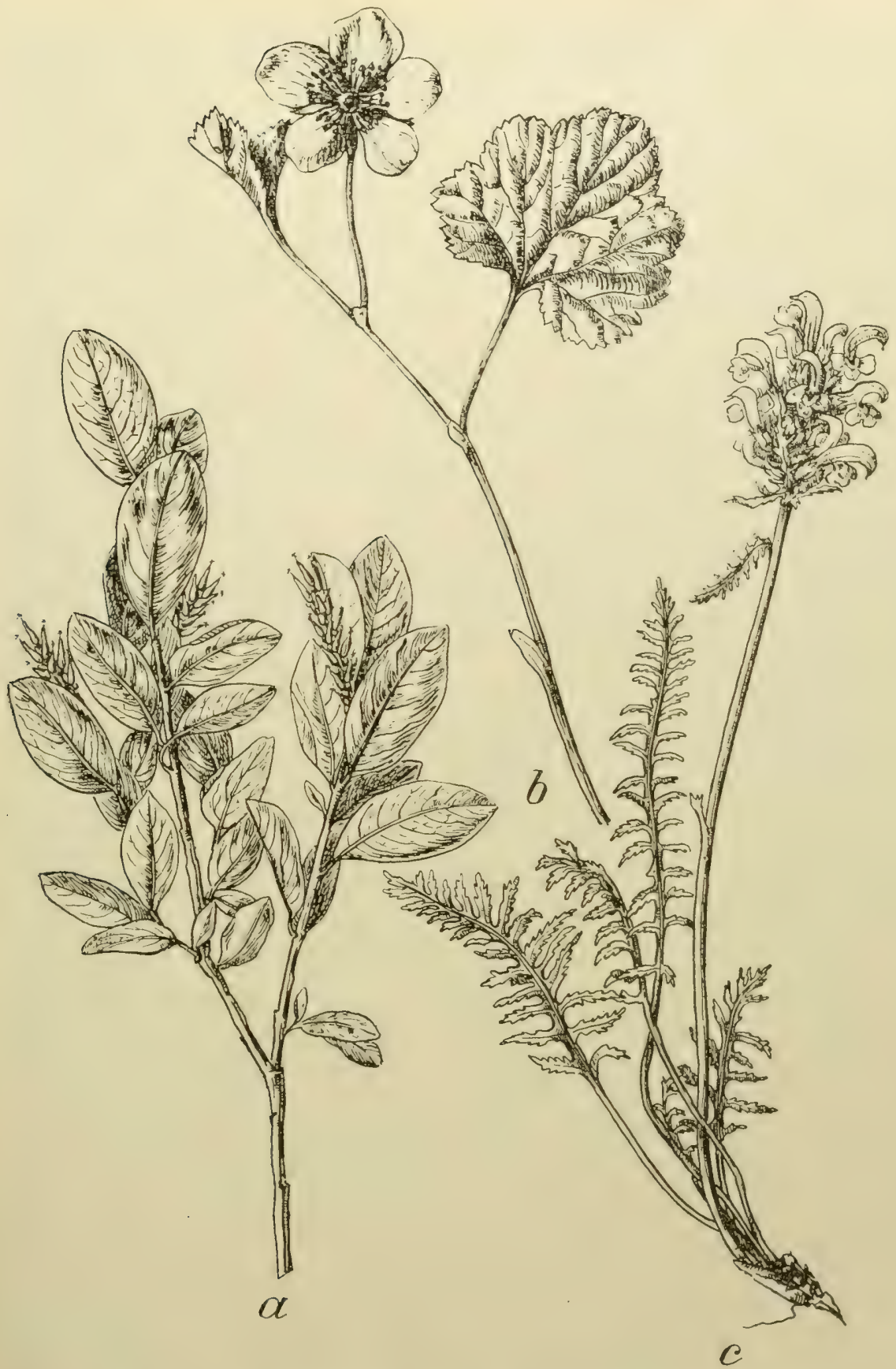

Abb. 35. Drei seltene Arten aus den Hochmooren der Sudeten.

$a$ Salix myrtilloides. $b$ Rubus Chamaemorus. $c$ Pedicularis sudetica.

Mannigfache Torfmoose, insbesondere Sphagnum aculifolium, S. Dusenii, S. molluscum, S. fuscum, S. cuspidatum, S. Lindebergii bilden im Vereine mit zahlreichen anderen Moosen (u. a. Polytrichum commune, Dicranella cerviculati, 
Dicranum Schraderi, Hypnum fluilans, H. exannulatum, Sarcoscyphus sphacelalus, Scapania undulata, Jungermannia inflata, J. Taylori) die schwankende Moosdecke, in der in mehr oder minder großer Menge vor allem Cyperazeen und Ericazeen gedeihen, so von ersteren Trichophorum austriacum, Eriophorum vaginatum, E. gracile, Rhynchospora alba, Carex chordorhiza, C. canescens, C. pauciflora, C. limosa, C. lasiocarpa, von letzteren Vaccinium uliginosum, Oxycoccos quadripelala und *microcarpa, Andromeda polifolia, Calluna vulgaris und das schneeweiß blühende Ledum palustre. Auf den feuchten Moospolstern gedeihen mit Vorliebe Drosera rolundifolia, D. anglica und D. intermedia, Scheuchzeria palustris und Polentilla palustris, an Gräben Graliola officinalis, Pedicularis sudelica und Lysimachia thyrsiflora. An kleineren Sträuchern sind neben den genannten Ericazeen auch Empetrum nigrum, Betula nana und Salix myrtilloides zu finden; meist bedeckt reiches Dickicht aus Föhren, entweder der strauchigen Pinus Mughus oder der baumförmigen Pjnus uliginosa die Oberfläche dieser Moore.

Etwas abweichend ist die Zusammensetzung der über oder nahe der Baumgrenze gelegenen Hochmoore. Von Moosen sind in dieser Höhenlage Sphagnum cymbifolium, S. cuspidatum, P. acutifolium, S. leres, S. Lindebergii, Dicranum Schraderi, Polytrichum juniperinum, Hypnum sarmentosum, Jungermannia Wenzelii u. a. häufig. Carex pulicaris, C. rigida, C. magellanica gesellen sich zu den oben genannten Cyperazeen hinzu; von Sträuchern aber bilden hie und da Belula pubescens oder Salix Lapponum, ganz allgemein aber Pinus Mughus dichte Buschbestände, in deren Schatten u. a. die Moltebeere (Rubus Chamaemorus), die in ganz Mitteleuropa nur im Iser- und Riesengebirge vorkommt, ferner Trientalis europaea und Sweerlia perennis gedeihen.

\section{e) Staudenformationen.}

Quelliluren. An quelligen Stellen, auf durchnäßtem Boden nahe der oberen Walugrenze und oberhalb derselben siedelt sich gern eine charakteristische Flora an. Carex vaginala, C. flava, Luzula silvalica, Orchis latifolia, Allium sibiricum, Slellaria uliginosa, Cardamine Opizii, Chrysosplenium allernifolium, Viola biflora, Alchimilla glaberrima, Hypericum maculalum, Epilobium nulans, $E$. alsinefolium und E. anagallidifolium, Gentiana verna, Sweertia perennis, Pedicularis sudelica, Barlschia alpina, Pinguicula vulgaris sind an solchen Stellen häufig; von Sträuchern tritt nicht selten in den Ostsudeten Salix haslala auf. Auf dem durchnäßten Boden sind auch meist reichlich Moose zu finden, wie Bryum Schleicheri, Mnium punclalum, Dicranella squarrosa, Sphagnum speclabile, Sarcoscyphus sphacelatus, während im nassen Kies mit Vorliebe Oligotrichum hercynicum, Webera Breidleri, W. Ludwigii, Polylrichum sexangulare wachsen.

Subalpine IIochstaudeniluren. Die üppigsten und farbenprächtigaten Vegetationshilder im Gebiete der Sudeten bieten die Hochstaudenfluren, die sich an den Ufern der Bäche, an Wasserfällen, auch ab und zu an Waldesrändern 
Hayek, Die Pflanzendecke Österreich-Ungarns, 1.

Taf. IV

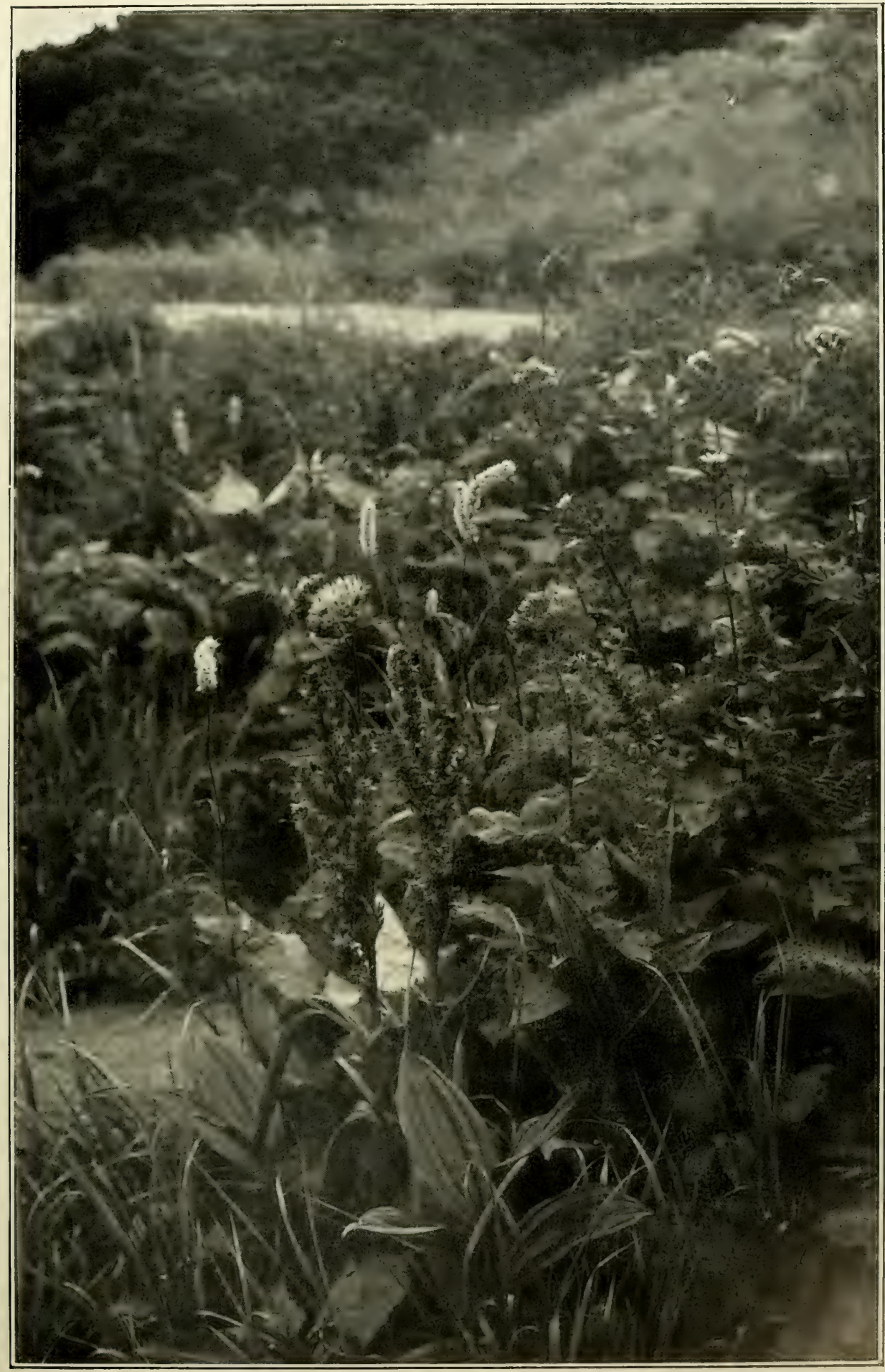

Abb. 36. Hochstaudenflur bei der Prinz Heinrich-Baude auf dem Kamme des Riesengebirges. Polygonum Bistorta, Adenostyles Alliariae, Mulgedium alpinum, Veratrum. Lobelianum.

(Nach einer Aufnahme von Nenke und Ostermaier in Dresden.) 

orler in Felsschluchten ansiedeln. Zahlreiche hochwüchsige dikotyle Stauden mit üppigem Blattwerk und meist lebhaft gefärbten Blüten herrschen hier vor; Türkenbundlilien (Lilium Marlagon), Doldenpflanzen (Anthriscus nilidus, Chaerophyllum Cicularia, Heracleum sibiricum), rote Disteln (Carduus Personala), weißer Hahnenfuß (Ranunculus platanifolius), Alpendost und Alpenlattich (Adenostyles Alliariae und Mulgedium alpinum), weiße Pestwurz (Petasiles albus), Wiesenraute (Thalictrum aquilegifolium), Natterwürz (Polygonum Bislorla), grüner Germer (Veralrum Lobelianum), hochwüchsige Gräser (Poa Chaixii, Calamagrostis villosa) wuchern üppig an solchen Stellen im Vereine mit blauem Rittersporn und Eisenhut (Delphinium elatum, Aconilum variegatum *gracile und A. Napellus *firmum), Bachnelkenwurz (Geum rivale), gelbem Fingerhut (Digitalis ambigua), Waldstorchschnabel (Geranium silvalicum), Weidenröschen (Epilobium trigonum), Ampfer (Rumex arifolius) und Alpenmilzfarn (Athyrium alpestre). Von Sträuchern treten ab und zu die schlesische Weide (Salix silesiaca), Ebereschen (Sorbus Aucuparia *glabrata), ferner im Westen Salix Lapponum, im Osten S. haslala auf. In den östlichen Sudeten (Schneeberg und Altvatergebiet) kommen überdies noch Aconilum Vulparia, Conioselinum talaricum, Laserpitium Archangelica, Doronicum austriacum und Crepis sibirica in dieser Formation vor.

Gesteinfluren. Die höchsten Gipfel der Sudeten sind fast durchwegs mit riesenhaften Felsblöcken und grobem Felsschutte bedeckt, die reich von weißen, grauen, gelben und roten Flechten überzogen sind, so von Pannaria lepidota, Ronodina biatorina, Lecanora alra, L. nigrescens, L. frustulosa, Haematomma ventosum, Aspicilia alpina, Perlusaria corallina, Bialora aenea, B. lygaea, Rhizocarpon geographicum, R. postumum, Lecidella bullala, L. nodulosa, L. marginala, L. alboflava, L. sudetica, L. lapicida, L. plana, Lecidaea cinereoalra, L. superba, L. confluens, Sagedua chlorotica, Parmelia perlata, P. saxalilis, P. encausta, Gyrophora cylindrica, G. proboscidea, G. deusta, Alectoria nigrescens, Cornicularia tristis, Stereocaulon coralloides u. a. Auch Moose, besonders die schwarzen Grimmia- und Andreaea-Arten sind reichlich vorhanden. Spärlich hingegen ist die Phanerogamenflora. Poa laxa, Carex capillaris, Luzula spicala, Salix herbacea und S. bicolor, Cardamine resedifolia, Sagina saginoides, Saxifraga bryoides, S. moschata und S. oppositifolia, Sedum alpeslre, Hedysarum obscurum, Primula minima, Thymus nummularius, Gnaphalium supinum, Galium anisophyllum *sudeticum gedeihen an den Felsen und an feuchten, von Schnee lang bedeckten Stellen, und im groben Felsschutte steht der seltene Farn Allosorus crispus.

Alpine Felsenpilanzen. In den Felsspalten der tief eingerissenen Schluchten (,Gruben“) in der Hochregion der Sudeten ist meist eine reiche Flora anzutreffen. An diesen Felsen sind zu finden: Poa nemoralis, P. laxa und P. caesia, Festuca varia, Carex rupestris, Luzula spicata, Minuarlia Gerardi, Sagina saginoides, Ranunculus acer, Arabis alpina, Sedum roseum, Saxifraga Aizoon, S. nivalis, Cotoneaster inlegerrima, Pimpinella alpina, Androsace obtusifolia, 


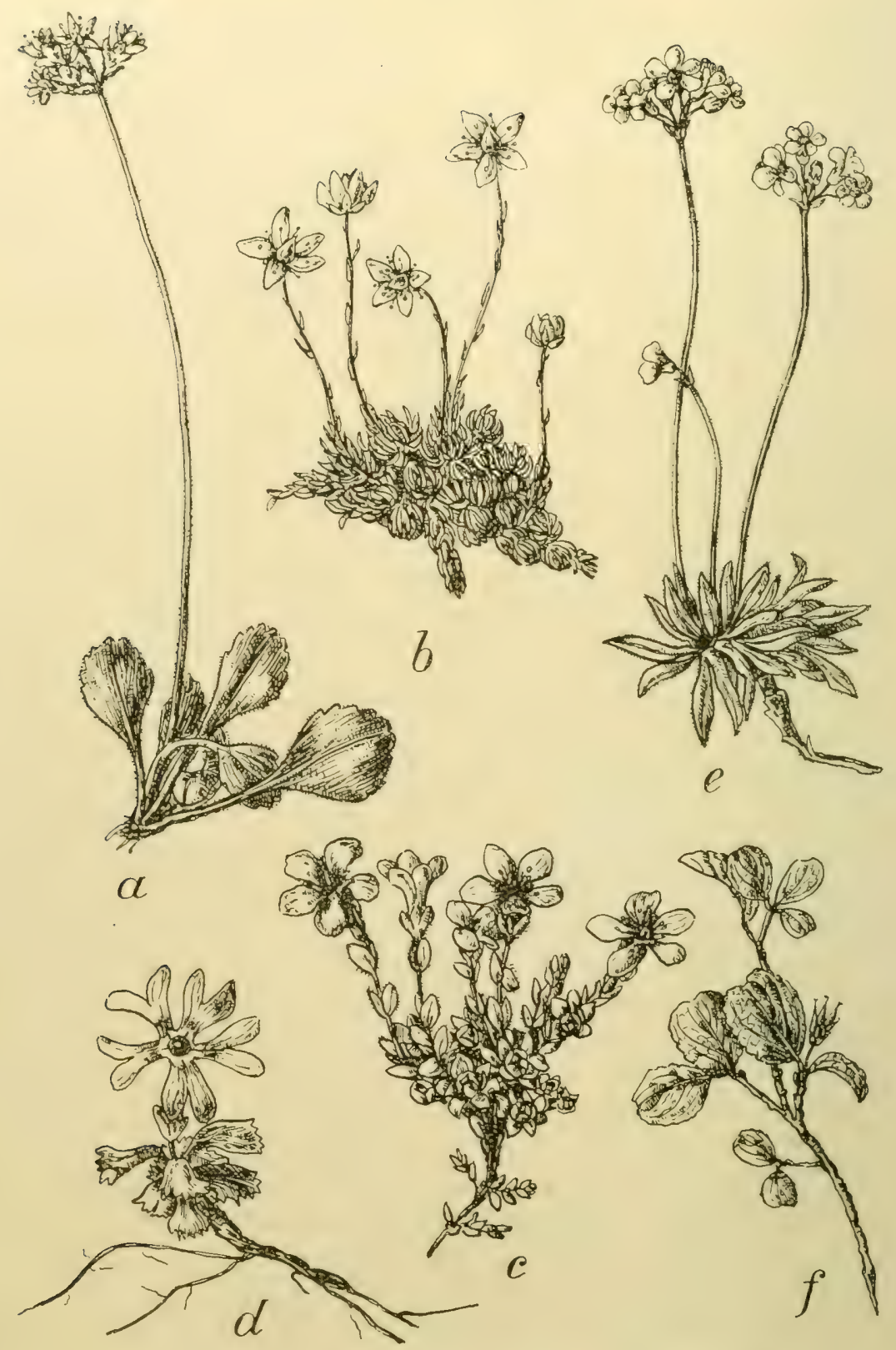

Abb. 37. Aus der Hochgebirgsflora des Riesengebirges.

$a$ Saxifraga nivalis. $b \mathrm{~S}$. bryoides. $c \mathrm{~S}$, oppositifolia. $d$ Primula minima. e Androsace obtusifolia, $f$ Salix herbacea.

Myosotis alpestris, Veronica bellidioides, Plantago montana, Campanula Scheuchzeri, Aster alpinus, Carlina longifolia, Hieracium villosum, H. plumbeum, H. Schmidtii, H. Engleri, H. chlorocephalum und zahlreiche Farne, wie Woodsia alpina, Asplenium viride, Polystichum Lonchitis, Dryopleris spinulosa, Lyco- 
podium alpinum. Von Moosen sind auf den Felsen zu finden Hypnum Heufleri, H. molluscum, Brachythecium plicatum, Leucodon sciuroides, Pseudoleskea calenulata, Grimmia sulcala, G. alpina, G. elatior, G. spiralis, Racomitrium patens, R. fasciculare, R. sudeticum, Bartramia Oederi, Bryum pendulum, B. elegans, Encalypta rhabdocarpa, Dicranum Starkei, Dicranodontium longirostre, Anoectangium compactum, Gymnostomum rupestre. Sarcoscyphus aduslus, Andraea rupestris und $A$. petrophila u. a. Reichlich sind die Felsen auch mit bunten Flechten überzogen, von denen die wichtigsten oben genannt sind.

\section{f) Kulturgewåchse.}

Getreidebau. Im dicht bevölkerten Riesengebirge wird auch der Getreidebau etwas intensiver betrieben als in den übrigen Teilen der Sudeten. Bewohnte Ortschaften reichen allerdings nur bis zu einer Höhe vou $760 \mathrm{~m}$, also lange nicht so hoch hinauf als im Erzgebirge. Gebaut wird fast nur Roggen und Hafer. Das Isergebirge ist wenig bewohnt und weist daher auch wenig Ackerbau auf; intensiver wird derselbe wierler in den Tälern des Hohen Gesenkes, besonders in Schlesien, und im Niederen Gesenke betrieben.

Gemüsepilanzen. Der Kartoffelbau ist in ken Surleten besonder's im Riesengebirge von hoher Bedeutung für die Bevölkerung. Andere Gemüsepflanzen werden nur in Gärten gebaut.

Obstbau. Dieser ist ohne Berleutung, in len ranhen Gebirgslagen findet man fast nur Kirschen, Zwetschken und mindere Äpfel- und Birnsorten. Wein wird überhaupt nicht gebaut.

Sonstige Kulturpflanzen. Auch in den Sudeten ist der Anbau von Flachs ziemlich bedeutend, sowohl in Böhmen als auch in Nähren, besonders um Römerstadt. Der Anbau von Futterkräutern ist von geringer Bedeutung, doch wird in den Sudeten der Wiesenkultur sehr viel Aufmerksamkeit zugewendet, da die Viehzucht auf hoher Stufe steht und vielfach an der Waldgrenze unil auch in der Hochregion die Einwohner Holzbauten, die sogenannten Bauden, errichtet haben, um Wiesenkultur und Viehzucht zu betreiben. Im Gegensatze zu den Alpenhütten im Alpengebiete sind diese Bauden jedoch größtenteils im Winter und Sommer bewohnt.

Forstbetrieb. In den Sudeten herrschen in bezug auf die Forstwirtschaft ähnliche günstige Verhältnisse wie im herzynischem Berglande und die gleichen Betriebsformen. Auch weisen die Sudeten ebenfalls einen kleinen Urwaldbestand auf, den fürstlich Liechtensteinschen Urwald im Altvatergebiete.

Von ausländischen Holzarten findet man am Fuße der Sudeten ab und zu die amerikanische Pinus Strobus aufgeforstet.

\section{g) Ruderalflora.}

Auch im Sudetengebiet ist die Ackerilora artenarm, aber meist inrlividuenreich. Häufige Unkräuter sind Apera Spica venti, Agropyrum repens, Bromus 
secalinus, Scleranthus annuus, Spergula arvensis Polygonum Convolvulus, Chenopodium album, Vicia hirsuta, V. segelalis, Sherardia arvensis, Mentha arvensis, Gnaphalium uliginosum, Anthemis arvensis, auch perenne Arten, wie Equiselum arvense, Stachys palustris, Achillea Millefolium, Centaurea Scabiosa sind nicht selten. Gelegentlich sieht man auch andere Arten, z. B.: Gypsophila muralis, Anagallis arvensis, Odontites rubra, Convolvulus arvensis, Silene gallica, Campanula rapunculoides usw. Auch Viola tricolor ist ebenso wie im Erzgebirge verbreitet. Auf Leinäckern wird Cuscula Epilinum oft schädlich.

In der Ruderalflora überwiegen die heimischen Arten, die „Apophyten“ entschieden über die eingeschleppten. IIäufig sinul Chenopodium album, Ch. Bonus Henricus, Atriplex palula, Rumex conglomeratus, $R$. crispus, Polygonum aviculare, Melandryum album, Capsella Bursa Pastoris, Plantago maior, Lamium album, Campanula rapunculoides, Bellis perennis, Senecio vulgaris usw., während Hordeum murinum, Conium, Onopordon, Cardaria Draba, Sisymbrium-Arten, Diplolaxis usw. an Häufigkeit sehr zurücktreten oder vielerorts ganz fehlen.

\section{Die Pflanzengenossenschaften Zentraböhmens.}

a) Waldbestände.

Fichtenwälder. Sowohl im westlichen als im südlichen Teile Böhmens bildet die Fichte oft ausgedehnte Bestände. Im wesentlichen stimmen diese Wälder mit den tiefer gelegenen herzynischen Fichtenwäldern überein. Picea excelsa ist der allein herrschende Baum, nur vereinzelt ist Abies alba oder Pinus silvestris beigesellt, noch seltener Laubhölzer, wie Fagus silvatica, QuercusArten oder Acer Pseudoplalanus. Ein Unterholz fehlt oft ganz oder besteht aus einzelnen Büschen von Berberis, Rosa canina, $R$. coriifolia, Rubus bifrons, R. Idaeus, Daphne Mezereum usw. Der Niederwuchs wird oft nur aus großen Massinn von Vaccinium Myrtillus gebildet, das auf weite Strecken hin den Boden bedeckt, meist begleitet von Vaccinium Vilis Idaea, Calluna vulgaris, Nardus stricta, Deschampsia flexuosa, Sieglingia decumbens usw. Seltenere Arten des Niederwuchses sind Dryopteris Filix mas, Athyrium Filix femina, Lycopodium complanalum, Festuca heterophylla, F. gigantea, Bromus asper, Carex remota, C. pilulifera, Lnzula nemorosa, Plalanthera bifolia, Epipaclis Latifolia, Euphorbia dulcis, Mercurialis perennis, Prenanthes purpurea, Lacluca muralis, Melampyrum nemorosum, M. pratense *vulgalum, Lamium luteum, Pirola rolundifolia, P. secunda. Actaea spicata, Viola silvestris, Sanicula europaea, Genisla tinctoria usw. Besonders im südlichen Landesteile finden sich auch Fichtenwälder mit moorigen Untergrunde, wo dann im Niederwuchs Rhamnus Frangula, Prunus Padus, Tiubus Idaeus auftreten, während im Niederwuchse neben einzelnen Sphagnumund Polylrichum-Polstern hic und da selbst Oxycoccos quadripetala, Vaccinium uliginosum, Drosera usw. sich finden.

Föhrenwälder. Eine womöglich noch wichtigere Rolle als die Fichte spielt in Zentralböhmen die Föhre als Waldbaum. Diese Bestände von Pinus silveslris 
sind meist ganz ohne Unterholz, während der Niederwuchs eine typische Heide darstellt. Calluna vulgaris, Vaccinium Myrlillus und V. Vilis Idaea bedecken oft fast ausschließlich auf weite strecken hin den Bodrn, begleitet von Deschampsia flexuosa, Luzula nemorosa, Cylisus nigricans, Convallaria maialis, Anemone nigricans, Anlennaria dioeca, Koeleria gracilis, Trifolium montanum, Veronica prostrala und Pleridium aquilinum, und verschiedene Strauchflechten, besonders Cladonia rangiferina, bilden noch mit den Heidelbeeren und der Heide ein dichtes Geflecht. Seltener sind im Unterwuchse Koeleria pyramidala, Silene nulans, Dianthus Carthusianorum, Trifolium alpestre, Brunella grandiflora, Veronica spicala, Chrysanthemum corymbosum u. a. vertreten.

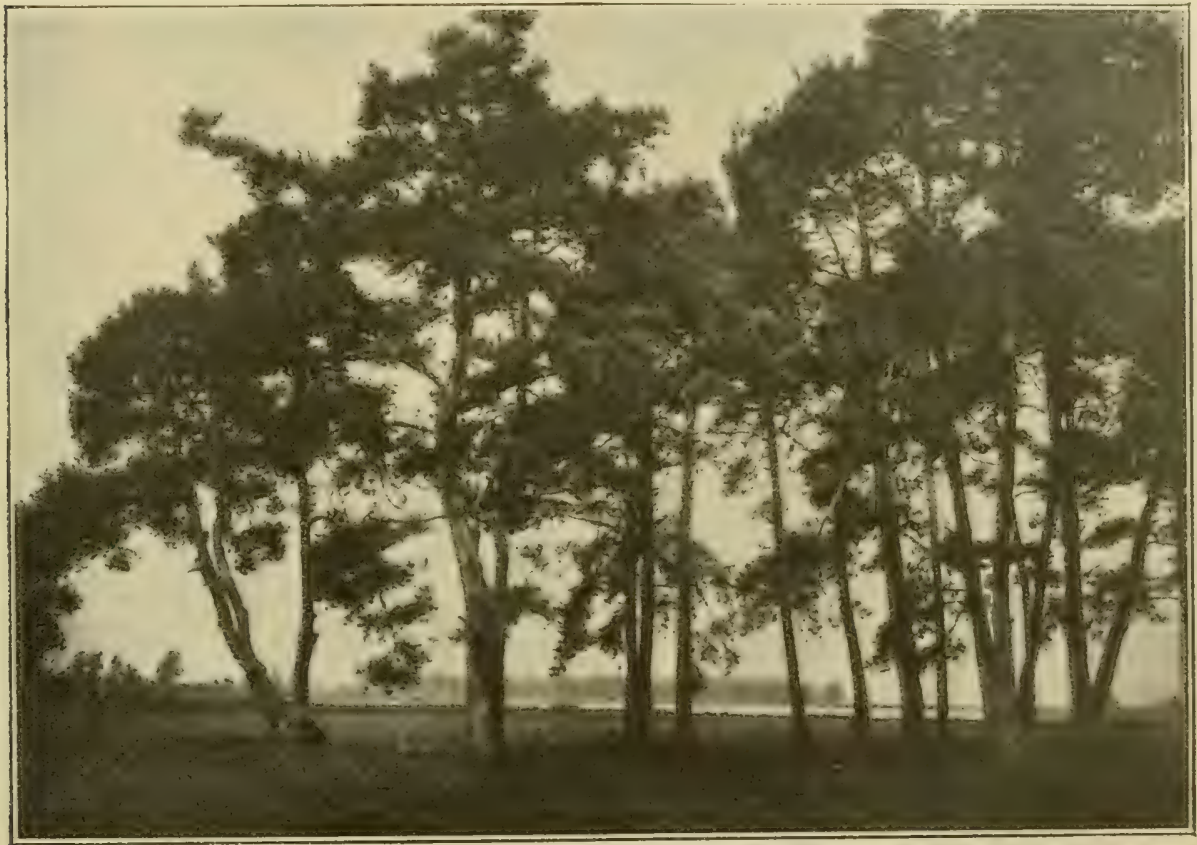

Abb. 38. Bestand von Pinus silvestris bei WVittingau, Südböhmen.

(Nach einer Aufnahme von Prof. IK. Domin in Prag.)

Im südlichsten Teile von Böhmen sowie am Fuße des böhmisch-mährischen Gebirges treten auch Föhrenwälder mit moorige un Untergrunde auf, die einen ähnlichen Aufbau wie die Moorwälder rles südlichen Böhmerwaldes und des niederösterreichischen Waldviertels zeigen. Das Oberholz bildet entweder Pinus silvestris oder Pinus uliginosa, den Untergrund des Waldes aber bildet ein typisches Hochmoor.

Birkenwälder. Auf trockenerem Boden sind in Zentralböhmen, und zwar sowohl im Norden als auch gegen die Ausläufer der Randgebirge zu aus Betulat pendula gebildete Bestände nicht gerade selten. Ein Unterholz fehlt diesın Wäldern meist ganz und auch im Oberholz sind nur selten andere Baumarten wie Pinus silveslris oder Populus lremula eingesprengt. Der Niederwuchs wirt zumeist aus Calluna vulgaris, die mit Deschampsia flexuosa, Sieglingia decumbens, 


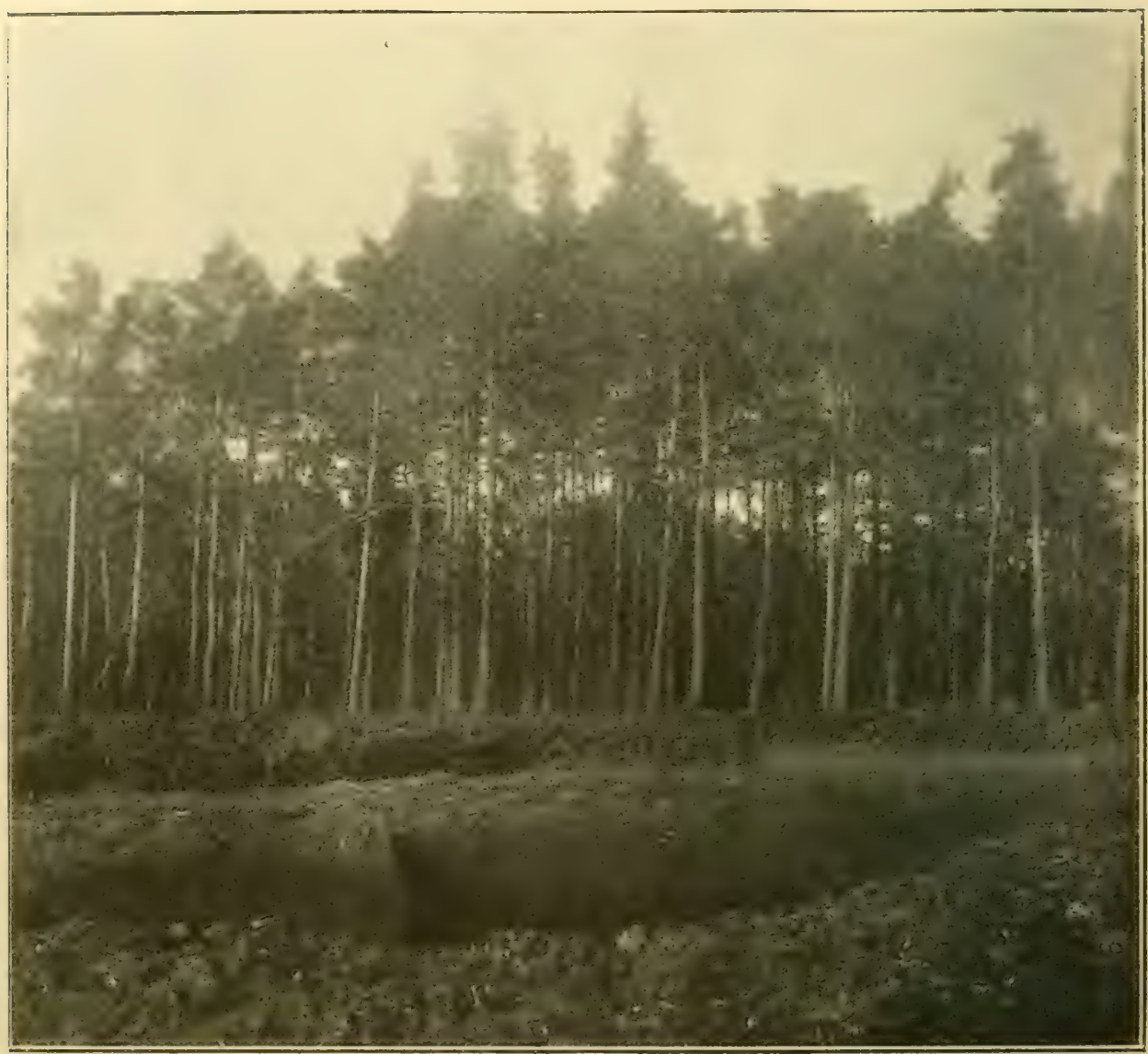

Abb. 39. Waldbestand von Pinus silvestris in einem Hochmoore bei Sichelbach in Südböhmen. (Nach einer Aufnahme von H. Schreiber, Sebastiansherg.)

Potentilla erecta, Vaccinium Myrtillus, Antennaria dioica, Hieracium Pilosella, Pleridium aquilinum vergesellschaftet ist, gebildet.

Buchenwälder. Im Gegensatze zu anderen Waldgebieten treten in Zentralböhmen die Buchenwälder sehr in den Hintergrund und finden sich fast ausschließlich in höhreren Lagen, bsonders im Mittelgebirge. Die Wälder bieten dazu absolut nichts Eigrentümliches dar und zejgen das bekannte Bild der meisten mitteleuropäischen Buchenbestände. Fagus silvalica ist der fast alleinige Waldbaum, dem nur hie und da einzelne Exemplare von Picea excelsia, Abies alba, Acer Pseudoplatanus oder Ulmus scabra beigesellt sind. Im Niederwuchse herrschen frühblühende Arten, wie Asarum europaeum, Anemone nemorosa, Cardamine bulbifera, Oxalis Acetosella, Euphorbia dulcis, oder schattenliebende Pflanzen, wie Milium effusum, Brachypodium silvalicum, Poa nemoralis, Carex silvalica, G. pendula, C. remota, Aclaea spicala, Impaliens Noli langere, Lamium luteum usw.. vor, ein Unterholz fehlt oder ist nur durch Daphne Mezereum angedeutet. 


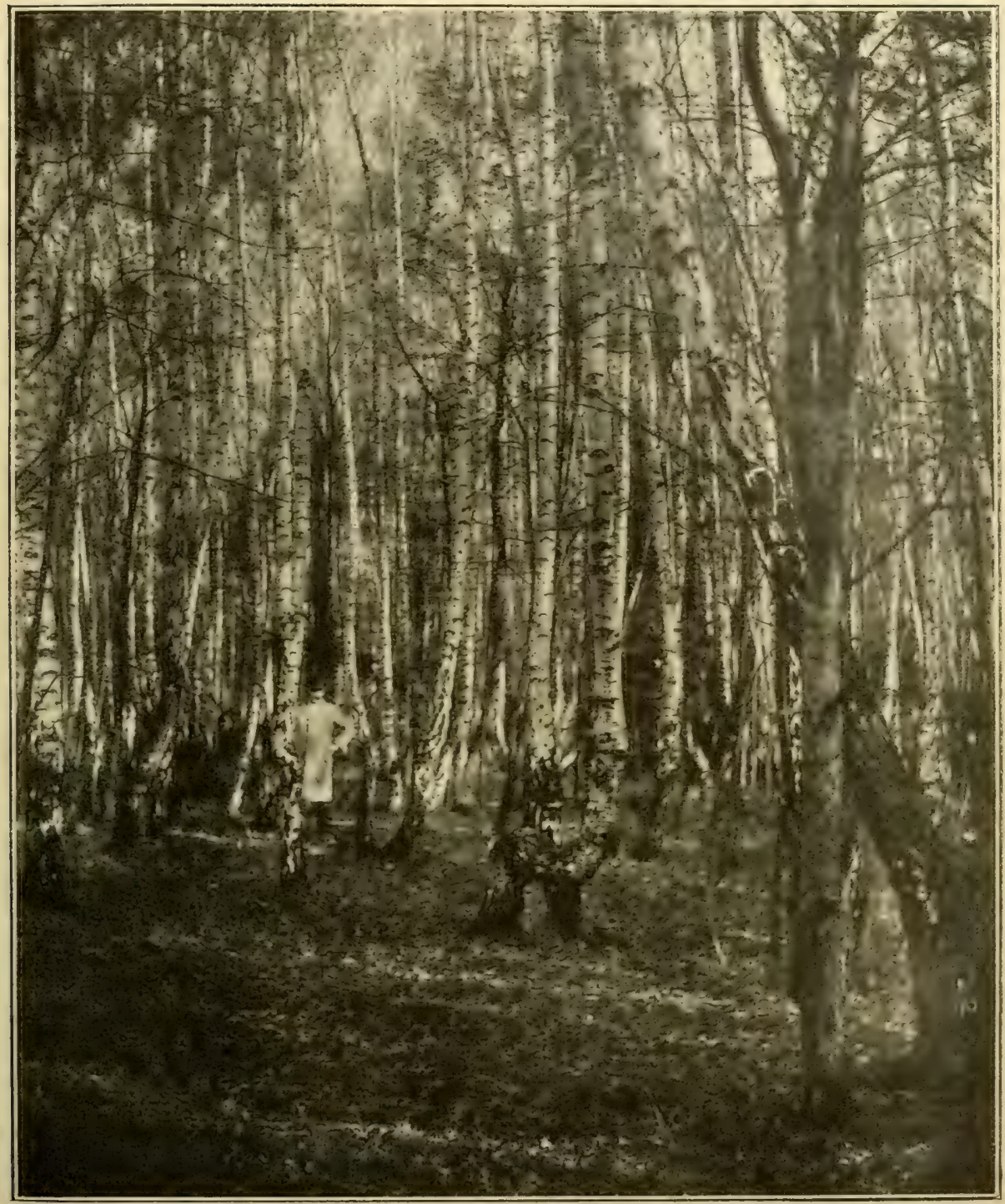

Abb. 40. Birkenwald bei Goltsch-Jenikau in Ostböhmen. (Nach einer Aufnahme von Prof. K. Domin, Prag.)

Der ostböhmische Eichenwald. Eichenhochwälder, seltener Niederwälder, sind besonders im Osten und Nordosten Böhmens sehr verbreitet. Der herrschende Baum dieser Wälder ist Quercus Robur, der in weit geringerer Zahl Quercus sessiliflora beigemischt ist, seltener finden sich Fagus silvatica, Carpinus Betulus, Acer Pseudoplatanus und A. campestre eingesprengt. Das Unterholz ist besonders an den Waldrändern und in Lichtungen reich entwickelt und besteht vornehmlich aus Salix caprea, Corylus Avellana, Crataegus Oxyacantha, Rubus dumetorum, R. Idaeus, Rosa canina, $R$. dumelorum, $R$. corifolia, $R$. rubiginosa, Prunus Padus, P. spinosa, Evonymus vulgaris, Sorbus torminalis, Rhamnus 
cathartica, R. Frangula und Cornus sanguinea. Im meist reichen Niederwuchs blühen im Frühlinge Pulmonaria angustifolia, Galium vernum, Potentilla alba, Corydalis cava, Asarum europaeum, Isopyrum thalictroides, Maianthemum bifolium, später dann zahlreiche Gräser und Scheingräser, wie Milium effusum, Hierochlö̈ australis, Melica nulans, Deschampsia flexuosa, Brachypodium silvaticum, Carex muricala, $C$. divulsa, $C$. pilosa usw.; reich sind besonders an den Waldrändern die Papilionazeen vertreten, wie Genisla germanica, Cytisus hirsulus und $G$. nigricans, Trifolium ochroleucum, T. alpestre, Coronilla varia, Astragalus danicus, Vicia cassubica, V. pisiformis, V. silvalica, Lathyrus vernus und der manchmal ganze Strecken bedeckende Sarolhamnus scoparius. Auch Platanthera bifolia, Ranunculus lanuginosus, Lilium Marlagon, Clematis recta, Hypericum hirsutum, Bupleurum falcatum, Pencedanum Cervaria, Dianthus Armeria, Veronica Chamaedrys und $V$. officinalis, Malva Alcea, Inula salicina, Serralula tincloria, Hieracium flagellare gehören zu den häufigeren Arten des Niederwuchses, wo nicht Calluna vulgaris mit ihren gewöhnlichen Begleitpflanzen, wie Sieglingia decumbens, Agrostis alba, Nardus stricta, Hypericum perforalum, Polentilla erecla, Melampyrum nemorosum, Antennaria dioeca und Hieracium Pilosella den Borl'n bedeckt. Auf den Eichen ist nichl selten Loranthus europaeus als Schmarotzer anzutreffen.

Die Eichenniederwälder. Ein ganz anderes Bild bieten jene Eichenniederwälder, die besonders auf den Kalkbergen der Umgebung von Prag, im Mittelgebirge und von da weiter gegen Ostböhmen hin an sonnigen Hängen vorherrschen. Hier tritt neben Quercus. Robur und Qu. sessiliflora auch Qu. pubescens auf und diese drei Eichen bilden in Gesellschaft von Carpinus Betulus, Ulmus glabra, Sorbus torminalis, Acer campestre, Cralaegus Oxyacantha, Tilia cordala ein meist niedriges, bis $3 m$ hohes Gebüsch, über das sich einzelne Eichenstämme mit rundlichen Kronen erheben. Zahlreiche Dornsträucher, wie Rosa gallica, $R$. canina, $R$. dumetorum, Prunus spinosa, gesellen sich ihnen gewöhnlich bei. Im Niederwuchse finden sich vor allem Carex praecox, C. humilis, G. Michelii, G. monlana, C. pilulifera, Melica picta, Orchis fusca, Asarum europáeum, Thalictrum minus, Anemone nemorosa, A. ranunculoides, A. silvestris, Corydalis solida, C. cava, Polentilla rubens, Viola mirabilis, Bupleurum falcalum, B. longifolium, Chaerophyllum bulbosum, Trifolium rubens, Lalhyrus vernus. Pulmonaria obscura, Lithospermum purpureo-coeruleum, Brunella alba, B. grandiflora, Slachys germanica, Melampyrum crislalum, Galium silvalicum, Campanula glomerata, C. Cervicaria, Asperula glauca, Cirsium acaule, C. eriophorum, $C$. arvense usw. An schattigen, feuchteren Stellen treten auch Myosotis sparsiflora, Omphalodes scorpioides, Gagea minima sowie Orchideen (Orchis pallens, Cephalanthera rubra, Platanlhera bifolia und P. montana, Neollia Nidus avis) auf.

Auenwälder. Auenwälder treten in Böhmen gegenüber den Ufergeländen der Donau, sowohl was räumliche Ausdehnung als was Reichtum der Flora betrifft, stark zurück. Neben verschiedenen Weiden, besonders Salix alba, 
S. fragilis, S. penlandra, S. caprea und $S$. purpurea, bilden in Gesellschaft von Alnus glutinosa und Betula pendula Populus tremula, P. nigra und Quercus Robur das Oberholz. Sehr reich ist gewöhnlich das Unterholz entwickelt und besteht aus Ulmus glabra, Salix purpurea, S. triandra, S. alba, S. fragilis, Prunus

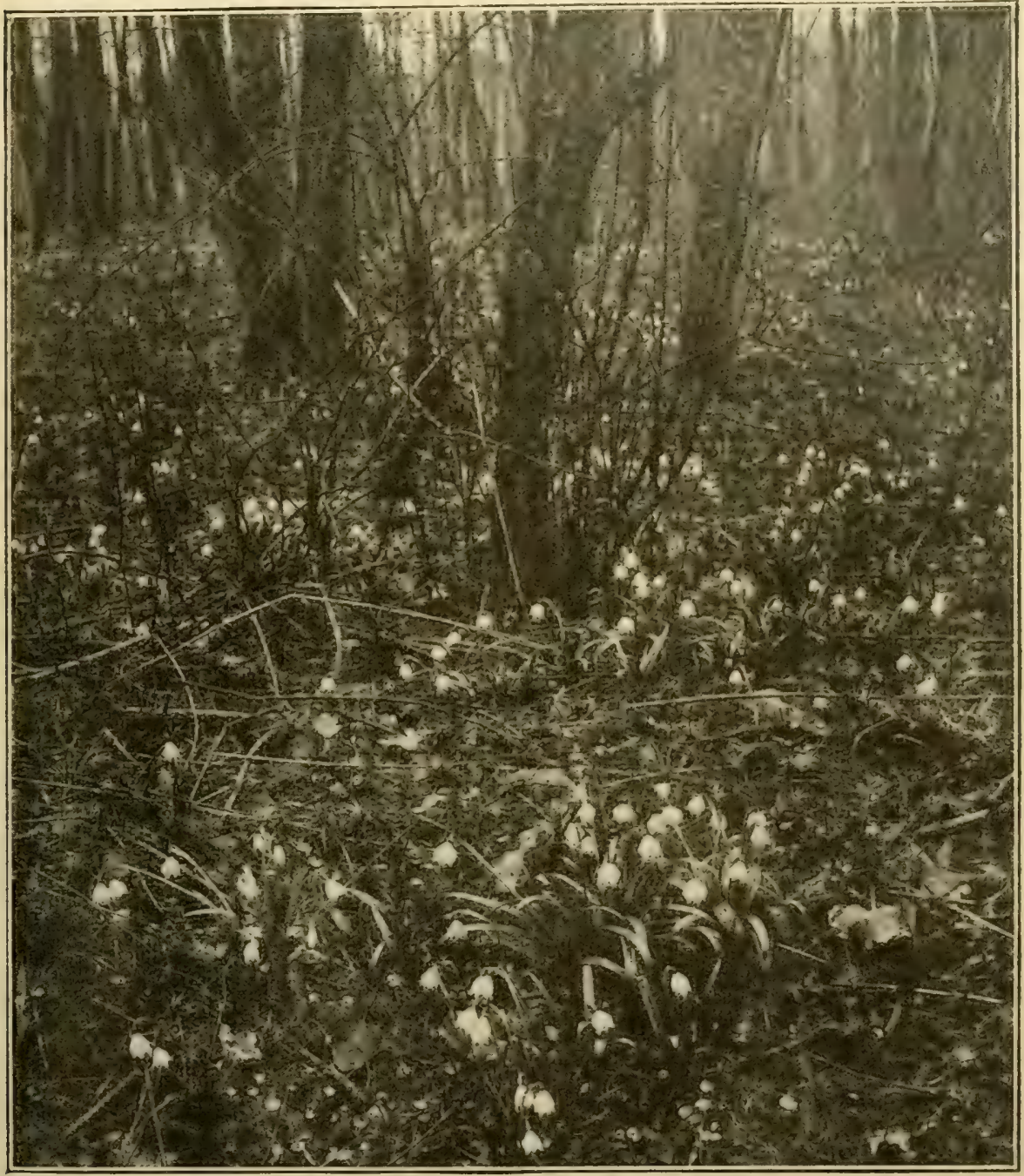

Abb. 41. Leucoium vernum in den Auen der Eger bei Budin.

(Nach einer Aufnahme von Nenke und Ostermaier in Dresden.)

Padus, " Rhamnus Frangula und R. calhartica, Cornus sanguinea, Viburnum Opulus usw. Nicht selten klettert Cucubalus baccifer im Gebüsche; im Nirierwuchse finden sich von Gräsern Deschampsia caespitosa, Milium effusum, Fesluca gigantea, Bromus asper, Agropyrum caninum, Carex brizoides, C. remule und $C$. silvatica, an Kräutern und Stauden Paris quadrifolia, Scilla hifolia, Ornithogalum tenuifolium, Leucoium vernum, Galanthus nivalis, Lislera onatx, 
Polygonum mite, Slellaria nemorum, Ranunculus auricomus, $R$. lanuginosus, Galtha palustris, Cardamine impaliens, Chrysosplenium allernifolium, Filipendula Llmaria, Oxalis Acelosella, Epilobium parviflorum, Circaea Lutetiana, Pimpinella maior. Selinum Carıifolia, Chaerophyllum Cicutaria, Lysimachia nemorum, Stachys silvatica, St. palustris, Crepis paludosa usw.

Erlenbriiche. Im südlichen Böhmen treten in dortigen Moor- und Sunı̣flande Erlenbrüche nicht selten auf. Mit den übrigen Wäldern haben sie, abgesehen vom Baumwuchs, eigentlich nichts gemein, ihr Untergrund stellt in der Regel ein typisches Flachmoor vor. Die Hauptmasse des Oberholzes bildet stets Alnus glutinosa, der nur vereinzelte Exemplare von Betula pubescens, Pinus silveslris oder Quercus Robur beigesellt sind. Das Unterholz besteht hauptsächlich aus Alnus viridis, Salix pelandra, S. purpurea, S. cinerea, Rubus Idaeus, Rhamnus Frangula, Prunus Padus. Den Niederwuchs bilden Dryopleris cristala, D. spinulosa, Athyrium Filix femina, Deschampsia caespitosa, Glyceria fluilans, Calamagrostis lanceolala, Carex elongata, C. brizoides, Calla palustris, Iris Pseudacorus, Polygonum mite, Stellaria longifolia, Caltha palustris, C. procumbens, Ranunculus Flammula, Polentilla palustris, Filipendula Ulmaria, Circaea Lutetiana, C. alpina, Angelica silvestris, Pimpinella maior, Peucedanum palustre, Lysimachia vulgaris, L. thyrsiflora, Solanum Dulcamara, Lycopus europaeus, Galium palustre, G. uliginosum, Senecio rivularis u. а. Von -Moosen finden sich vor allem Polster von Polylrichum commune, Hypnum-Arten und nicht selten selbst Torfmoose (Sphagnum cymbifolium, medium, acutifolium, quinquefarium, subsecundum, cuspidatum), die stellenweise sogar größere Strecken überzichen.

\section{b) Buschformationen.}

Sommergrüe Buschgehölze (Vorhölzer, Haine). Gleichwie im ungarischen und kroatischen Berglande sind auch in Zentralböhmen, besonders in Nittelgebirge und in der Umgebung von Prag, sommergrüne Buschgehölze eine sehr häufige Erscheinung. Die Zahl der dieselben zusammensetzenden sträucher und lileiner Bäume ist eine ziemlich große, doch treten in tonangebender Menge wohl nur Corylus Avellana, Carpinus Betulus, Quercus pubescens und Q. sessiliflora sowie Populus tremula auf, so daß man je nach dem Vorherrschen der einen oder andern Art Haselnu B-, Weißbuchen-, Eichen-oder Zitterpappelgebüsche unterscheiden kann. Die wichtigeren der an der Zusammensctzung dieser Formationen teilnehmenden Sträucher (und auch kleiner Bäume sind neben den genannten auch noch Salix aurila, S. Caprea, Ulmus glabra, Sorbus Aria, S. lorminalis, Pirus Piraster, P. acerba, Rubus tomentosus, Rosa trachyphylla, $R$. Jundzillii, $R$. gallica, $R$. vestila, $R$. dumetorum, $R$. glauca, $R$. canina, $R$. coriffolia, $R$. tomentella, $R$. sepium, $R$. rubiginosa, $R$. tomentosa, Prunus spinosa, P. fruticosa, Acer campestre, A. platanoides, A. Pseudoplatanus, Cornus mas, $G$. sanguinea, Lonicera Xylosteum, Viburnum Lantana,S ambucus nigra. Im Niederwuchs finden sich Calamagrostis arundinacea, Hierochloë australis, Koeleria pyramidala, Agropyrum glaucum, Carex praecox, Allium sphaero- 
cephalum, Polygonalum officinale, Asparagus officinalis, Orchis sambucina, Plalanthera bifolia, Mercurialis perennis, Viscaria vulgaris, Silene nulans, Ranunculus polyanthemus, Anemone Hepalica, Thaliclrum minus, Erysimum erysimoides, Berteroa incana, Arabis hirsuta, Clemalis recta, Geranium sanguineum, Diclamnus albus, Fragaria collina, Trifolium rubens, T. alpestre, T. ochroleucum, Anthyllis Vulneraria, Lathyrus versicolor, Lolus corniculatus, Viola collina, $V$. montana, $V$. arenaria, Bupleurum falcalum, Libanolis montana, Peucedanum Cervaria, P. Oreoselinum, Primula veris *anescens, Lithospermum officinale, Cynanchum Vincetoxicum, Veronica Teucrium, Digitalis ambigua, Melampyrum cristatum, Galium verum, G. Mollugo, Asperula glauca, Valeriana officinalis, Inula hirla, I. salicina, Senecio campester, Chrysanthemum corymbosum, Serratula tinctoria, Cirsium pannonicum, Crepis praemorsa, Hieracium Pilosella, H. setigerum u. v. a.

Ebenfalls in die Kategorie der sommergrünen Buschgehölze gehörig, zeigen jene Bestände, in denen die Zwergweichsel (Prunus frulicosa) vorherrscht, doch ein abweichendes Gepräge, so daß sie eine gesonderte Besprechung erfordern. Neben Prunus frulicosa treten an niederen Büschen vor allem Prunus spinosa, Rosa gallica und Sorbus Aria häufig auf. Die wichtigsten Begleitpflanzen derselben sind Carex praecox, Agropyrum glaucum, Slipa Joannis, Muscari tenuiflorum, Anthericum Liliago, A. ramosum, Anemone nigricans, Polentilla incana, Geranium sanguineum, Viola ambigua, Asperula glauca, Centaurea rhenana, Hieracium Schmidlii usw.

Uiergebiische. Ein ganz anderes Bild als die eben geschilderten xerophilen Buschbestände bieten die Gebüsche, die sich an den Ufern der Bäche, Flüsse und Teiche ansiedeln. Hier herrschen Weiden (Salix pentandra, S. alba, S. fragilis, S. triandra, S. cinerea, S. aurila, S. viminalis, S. purpurea) und Erlen (Alnus glutinosa und incana) weitaus vor, in ihrer Gesellschaft finden sich ferner Populus alba und $P$. tremula, Rhamnus cathartica und P. Frangula und Evonymus vulgaris. Der Niederuchs ist sehr mannigfach, oft herrschen rohrartige Gräser (Typhoides arundinacea, Phragmiles communis, Calamagrostis lanceolata, Festuca arundinacea, Deschampsia caespitosa) oder Binsen (Juncus effusus, glaucus) vor, oder aber dikotyle Stauden, wie Rumex marilimus, R. Limosus, Polygonum lapalhifolium, P. mile, Caltha palustris, Barbarea v'ulgaris, B. stricta, Roripa silvestris, $R$. islandica, Hypericum acutum, Cicuta virosa. Peucedanum palustre, Angelica silvestris, Heracleum Spondylium, Filipendula Ulmaria, Lythrum Salicaria, Epilobium hirsutum, E. palustre, E. parviflorum, E. obscurum, Myosotis scorpioides, Scrophularia nodosa, Solanum Dulcamara, Lysimachia vulgaris, Symphytum officinale, Bidens tripartitus usw.

Formation der Spiraea saliciolia. Eine eigentümliche Fazies der vorgenannten Formation findet sich im südlichen Böhmen im Budweiser und Wittingauer Becken. Hier bildet auf Jooren und an Ufern die prächtige Spiracu salicifolia mit ihren rosenroten Blütentrauben stellenweise ausgedehnte Be- 


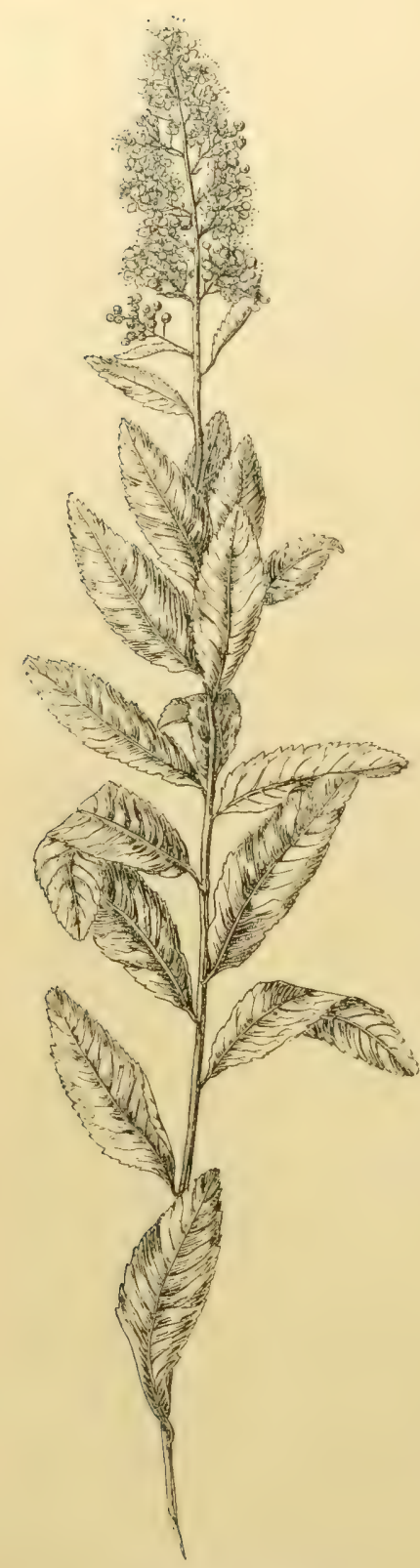

Abb. 42. Spiraea salicifolia.

stände. Spiraea salicifolia ist ein nordasiatischer Strauch, der sich bis ins europäische Rußland erstreckt und hier in Süd böh men sowie in S teiermark vorgeschobene Standorte besitzt, die zugleich seine Westgrenze darstellen. Oft bildet Spiraea salicifolia allein größere Bestände, nicht selten begleitet von der nicht unähnlichen Filipendula Ulmaria, oft aber vergesellschaftet sie sich auch mit den oben genannten Weiden- und Kreuzdornarten. Im Niederwuchse macht sich gegenüber den anderen Ufergebüschen kein Unterschied geltend.

\section{c) Heide- und Moorformationen.}

Sandfluren. Die Flugsandflächen Nordböhmens, besonders des Elbetales, tragen eine in ganz Mitteleuropa auf solchem Boden wiederkehrende charakteristische Vegetation, die im allgemeinen auch mit den später geschilderten Sandfluren Galiziens übereinstimmt und ein Bindeglied zwischen den Heide- und Steppenformationen darstellt. Das vorherrschende Gras ist stets Corynephorus canescens, etwas seltener finden sich Deschampsia flexuosa, Koeleria glauca, Festuca ovina und F. glauca var. psammophila, Aira caryophyllea und $A$. praecox. Häufig sind zwischen den Gräsern Strauchflechten und Moose angesiedelt, wie Cladonia rangiferina, Cornicularia aculeata, Polylrichum piliferum, Racomitrium canescens. Unter den Blütenpflanzen machen sich insbesondere einige einjährige Kräuter bemerkbar, wie Erigeron canadensis, Hypochoeris glabra, Planlago ramosa, Filago montana, Veronica Dillenii, Spergula penlandra, sonst aber herrschen Stauden mit oft kräftig entwickelter, tief reichender Pfahlwurzel vor, so Isatis lincloria, Armeria elongata, Anemone nigricans, Jasione montana, Hypochoeris radicala, Jurinea cyanoides; auch Thymus angustifolius, Polentilla arenaria und $P$. argentea sind für diese Sandfluren charakteristische Arten. Weite Strecken überzieht oft Scleranthus perennis und auch Herniaria hirsula, H. glabra, Dianlhus delloides, D. Carlhusianorum, Teesdalea nudicaulis, Viola arenaria, Androsace septentrionalis, Scabiosa ochroleuca, Helichrysum arenarium, Anlhemis austriaca, A. ruthenica, Senecio viscosus, Arnoseris minima, Hieracium Pilosella und $H$. echioides sind stellenweise nicht selten. 
Verlag von Franz Deuticke in Leipzig und Wien.

Die europäischen Gattungen der Farn- und Blütenpflanzen nach dem Wettsteinschen System geordnet

von

Erwin Janchen.

Zweite, verbesserte Auflage.

Preis N. $2 \cdot=$ K $2 \cdot 40$.

Waldwegebaukunde.

Von

dipl. For. Julius Marchet,

o. $\delta$. Professor an der $k$. $k$. Hochschule für Bodenkultur in Wien, Fachberichterstatter des $k$. k. Aokerbauministeriums.

I. Band: Das Trassieren und die Projelrtverfassung.

Mit 15 lithographischen Tafeln und 29 Abbildungen in Text.

Preis M. $7 \cdot 500=\mathrm{K} 8 \cdot 40$.

\section{Der Holzhandel Norddeutschlands.}

Von

dipl. For. Julius Marchet,

o. o. Professor an der k. $\mathbf{k}$. Uochschule für Bodenkultur in Wien,

Fachberichterstatter des $k$. $k$. Ackerbauministeriums.

Mit 16 Abbildungen, 1 Situationsplane und 1 Karte.

Preis N. $7 \cdot-\mathrm{K} 8 \cdot 40$.

Die Grundlagen der Bodenkunde.

Von

Dr. L. Milch,

['rivatdozent für Mineralogie und Geologie an der Universität Breslau.

Preis M. $4^{\circ}-=\mathrm{I} .4 \cdot 80$.

Flora des österreichischen Küstenlandes.

Von *

Eduard Pospichal.

Mit 25 Tabellen und einor Karte des österreichischen Kitstenlandes.

Zwei Bände in drei Teilen.

Preis eines jeden Teiles geh. M. $8 \cdot-=\mathrm{K} 9 \cdot 60$, geb. N. $10-=\mathrm{K} 12-$.

Einleitung in die experimentelle Morphologie der Tiere.

Von

Dr. phil. Hans Przibram,

Privatdozenten an der Wiener Universität.

Preis M. $4 \cdot-=\mathrm{K} 4: 80$.

\section{Experimental-Zoologie. \\ Von}

Dr. phil. Hans Przibram,

Privatdozenten an der Wiener Universität.

I. Teil. Embryogenese.

Mit 16 lithographischen Tafeln.

Preis N. $7 \cdot-=K 8 \cdot 40$.

II. Teil. Regeneration.

Mit 16 lithographischen Tafeln.

Preis Mr. $14 \cdot=\mathrm{K} 16 \cdot 80$.
III. 'Teil. Phylogenese.

Nit 24 lithographischen Tafeln.

Preis Mr. $18-=\mathrm{K} 21 \cdot 60$.

IV. Teil. Vitalität.

Mit 10 lithographischen Tafeln.

Preis II. $10^{\circ}-=\mathrm{K} 12 \cdot$. 
Verlag von Franz Deuticke in Leipzig und Wien.

\section{Lehrbuch der Pflanzenkunde}

fur die unteren Klassen der Mittelschulen

von

Dr. Rudolf Scharfetter,

k. h. Professor an der II. Staatsrealschule in Graz.

Mit 201 Abbildungen im Text und 28 farbigen Tafelu.

Preis geb. M. $3 \cdot 60=\mathrm{K} 4 \cdot$ -

\section{Vitalismus.}

\section{Elementare Lebensfunktionen.}

Von

Dr. Karl Camillo Schneider,

Privatdozent an der Universität Wien.

Preis geh. M. $11-=\mathrm{K} 13 \cdot 20$, geb. M. $12^{\circ}-=\mathrm{K} 14 \cdot 40$.

\section{Handbuch der systematischen Botanik. \\ Von}

Dr. Richard R. v. Wettstein,

Professor an der Universität in Wien.

Zweite, umgearbeitete Auflage.

Mit 3692 Figuren in 600 Abbildungen und mit einer farbigen Tafel.

Preis geh. M. $20^{\circ}-=\mathrm{K} 24^{\circ}-$, geb. M. $26^{\circ} 60=\mathrm{K} 32^{\circ}-$.

\section{Vegetationsbilder aus Südbrasilien. \\ Von}

Dr. Richard R. v. Wettstein, Professor an der Universität in Wien.

Mit 58 Tafeln in Lichtdruck, 4 farbigen Tafeln und 6 Textbildern.

Preis M. $24 \cdot-=\mathrm{K} 28 \cdot 80$.

Die Samenpflanzen.

(Blutenpflanzen, Phanerogamen.)

Systematische Übersicht ihrer Familien und wichtigeren Gattungen und Arten mit besonderer Beriicksichtigung der für Land- und Forstwirtschaft, Technik und Arzneikunde in

Betracht kommenden Gewächso

ron

Dr. Karl Wilhelm,

o. ö. Professor der Botanik an der k. k. Hochschule für Bodenkultur in Wien.

Nit einem Anhange, enthaltend eine Übersicht der wichtigsten kryptogamen Nutzptlanzen.

Preis geh. II. 5- $=$ K 6.-, geb. M. $6 \cdot 20=\mathrm{K} 7 \cdot 40$.

\section{Grundriß der Waldwegebaulehre}

nebst einer Aufgabensammlung

und neuen Hilfstafeln zur Erdmassen-Berechnung

von

Dr. Karl Wimmenauer,

o. Professor der Forstrissenschaft an der Universität Gießen.

Mit einer Waldkarte und 4 Figurentafeln.

Preis M. 4. $-=\mathrm{K} 4.80$.

Grundriß der Waldwertrechnung und forstlichen Statik nebst einer Aufgabensammlung

bearbeitet von

Dr. Karl Wimmenauer,

0. Professor der Forstwissenschaft an der Universitabt Gie Len.

Mit 1 Kurventafel.

Preis M. $3 \cdot-=\mathrm{K} 3 \cdot 60$. 


\title{
DIE PFLANZENDECKE ÖSTERREICH-UNGARNS
}

\author{
AUF GRUND FREMDER UND EIGENER FORSCHUNGEN GESCHILDERT \\ VON \\ Dr. AUGUST EDLER VON HAYEK, \\ PRIVATDOZENT FÜR SYSTEMATISCHE BOTANIK AN DER UNIVERSITÄT WIEN. \\ HERAUSGEGEBEN MIT EINEII DRUCKKOSTENBEITRAG \\ DER KAISERLICHEN AKADEMIE DER WISSENSCHAFTEN IN WIEN.
}

VOLLSTÄNDIG IN ZWEI BÄNDEN VON ETWA JE 5 LIEFERUNGEN. MIT ZAHLREICHEN ABBILDUNGEN UND TAFELN.

PREIS JEDER LIEFERUNG $6 K=5 \mathrm{Mk}$.

\section{BAND.}

2. LIEFERUNG.

LEIPZIG UND WIEN.

FRANZ DEUTICKE.

1914.

Verlags-Nr. 2110.

\section{Aus dem Vorwort.}

Im Jahre 1762 sind die beiden ersten unter dem Einflusse Linnés stehenden Werke erschienen, die speziell die Flora einzelner Gebiete Österreich-Ungarns behandeln, J acquins Flora der Wiener Umgebung und der erste Teil von Grantz' Stirpes Austriacae. Es war dies der Anfang einer intensiv einsetzenden Forschung, deren Ziel die erschöpfende Kenntnis der Pflanzenwelt unserer Heimat war, welche in den seither verstrichenen anderthalb Jahrhunderten ohne Unterbrechung mit stets sich steigernder In- und Extensität weiter arbeitete und zu den schönsten Resultaten geführt hat. Viele Hunderte von größeren und kleineren Arbeiten teils floristischen, teils pflanzengeographischen Inhaltes, zahlreiche oft umfangreiche ältere und neuere Landesfloren, eingehende pflanzengeographische MIonographien 
größerer Gebiete und kleincrer Gebietsteile geben Zeugnis von der diesbezüglichen Tätigkeit zahlreicher Forscher und enthalten eine reiche Fülle von außerordentlich wertvollem Bcobachtungsmateriale. Aber nur einmal vor bereits 62 Jahren ist der Versuch gemacht worden, wenigstens die Ergebnisse der floristischen Forschung in Form einer Aufzählung der im Bereiche des damaligen Kaiserstaates vorkommenden Pflanzen zusammenzufassen, und erst in allerneuester Zeit erscheint ein groß angelegtes kritisches Florenwerk, das neben dem übrigen Mitteleuropa auch das Gesamtgebiet der österreichisch-ungarischen Monarchie in den Umkreis seiner Darstellung gezogen hat, ein Werk, dessen Vollendung allerdings erst in vielen Jahren zu erwarten ist. Eine Flora von Osterreich-Ungarn aber bleibt nach wie vor ein frommer Wunsch der Botaniker.

Von noch größcrem allgemeinem Interesse als eine Flora im üblichen Sinne des Wortes mit einer Aufzählung und Beschreibung der im Gebiete vorkommenden Arten und Angabe ihrer Verbreitung ist eine eingehende Darstellung der Vegetation in Form einer Schilderung der Pflanzengenossenschaften und -verbände und ihrer Verbreitung in ihrer Abhängigkeit von den klimatischen und Bodenverhältnissen. Eine solche Schilderung ist nicht allein an und für sich für den Botanilier und besonders den Pflanzengeographen von hoher Wichtigkeit, sondern es bieten die gewonnenen Ergebnisse einer solchen auch den Schlüssel zur Lösung wichtiger florengeschichtlicher und somit auch erdgeschichtlicher Fragen. Aber auch in praktischer Hinsicht ist die genaue Kenntnis der Vegetationsverhältnisse von nicht geringer Bedeutung, renn dic Vegetation beeinflußt nicht allein das Landschaftsbild in hervorragendem Maße, sondern sic spicgelt auch dic klimatischen Verhältnisse in getreuestem Maße wider und ist daher die genaue Kenntnis der natürlichen Vegetationsverhältnisse eine der wichtigsten Voraussetzungen für eine rationelle Land- und Forstwirtschaft.

Eine glänzende Darstellung der pflanzengeographischen Verhältnisse der Monarchie aus berufenster Feder erschien im Jahre $1887 \mathrm{im}$ Übersichtsbande des Werkes ,Die österreichisch-ungarische Monarchie in Wort und Bild“. Diese Darstellung beschränlit sich jerloch auf eine Schilderung der Vegetation in den cinzelnen Florengebieten in großen Zügen, schon mit Rüchsicht auf die Raumverhältnisse allen Details ausweichend. Seither ist zwar eine Reihe umfangreicherer Detailarbeiten erschienen, die u. a, das illyrische Gebiet, die Karpathen und das herzynische Florengebiet betreffen, dazu eine größere Zahl kleinerer Monograplien; cine zusammenfassenile Darstellung der Vegetationsverhältnissc von ganz Österreich-Ungarn unter Verwertung des reichen in den verseliedensten Publikationen nieciergelegten Materials ist his jetzt nicht veröffentlicht worden.

Diese Lücke in der Literatur sucht das vorliegende Werk auszufüllen. Nicht eine Flora der Monarchic mit Beschreibungen der Arten und Verbreitungsangaben will es bieten, sondern cine Schilderung der Pflanzendecke in Wort und Bild, die sowohl dem Fachmann als dem gebildeten Laien die Vegetation ÖsterreichUngarns nach ihrer rüumlicien Verteilung vor Augen führt. Ein kurz gehaltener allgemeiner Teil bringt cincrseits das Wichtigste aus der allgemeinen Pflanzengeographir, soweit es auf Österrcich-Ungarn Bezug hat, um auch dem Nichtifachmann das Verständnis des Buches zu erleichtern, anderseits, um Wiederholungen zu vermeiden, Bemerkungen allgemeiner Natur über die Abhängigkeit der Pflanzengenossenscliaften von Klima und Boden und die verbreitetsten Vegetationsformationen.

Der Hauptabschnitt des Buches ist der eingehenden planzengeographischen Schilderung Österreich-Ungarns gewidmet und in folgende acht TKapitel geglierlert: 1. Die Sudetenländer. 2. Galizien und Bukowina mit Ausschluß der Karpathen. 3. Dic Karpathen. 4. Das ungarische Tiefland. 5. Das westungarische Bergland. 6. Die Alpen. 7. Nordlkroatien und Slawonien. 8. Die Karstländer. Diese Gliederung wurde gevallıt, um, ohne den Ergebnissen der Detaildarstellung vorzugreifen, 
Die Sandheide. Wenn diese Grasflur längere Zeit den Sandboden besierlelt und genügend gefestigt hat, nehmen dann Heide und Ginster Besitz vom Boden und es entwickelt sich eine typische Heide, in der entweder Calluna vulgaris oder Sarothamnus vulgaris vorherrschen. Vaccinium Myrlillus fehlt selten in dieser Gesellschaft und von Gräsern fallen vor allem die borstigen Rasen von Nardus slricta ins Auge. Daneben sind Avena pralensis und Carex ericelorum überall häufig, auch Calamagrostis arundinacea und C. Epigeios, Deschampsia flexuosa, Carex leporina sind nicht selten. Ferner treten in dieser Formalion auf: Vaccinium Vitis Idaea, Silene Olites, S. nulans, Spergula pentandra,

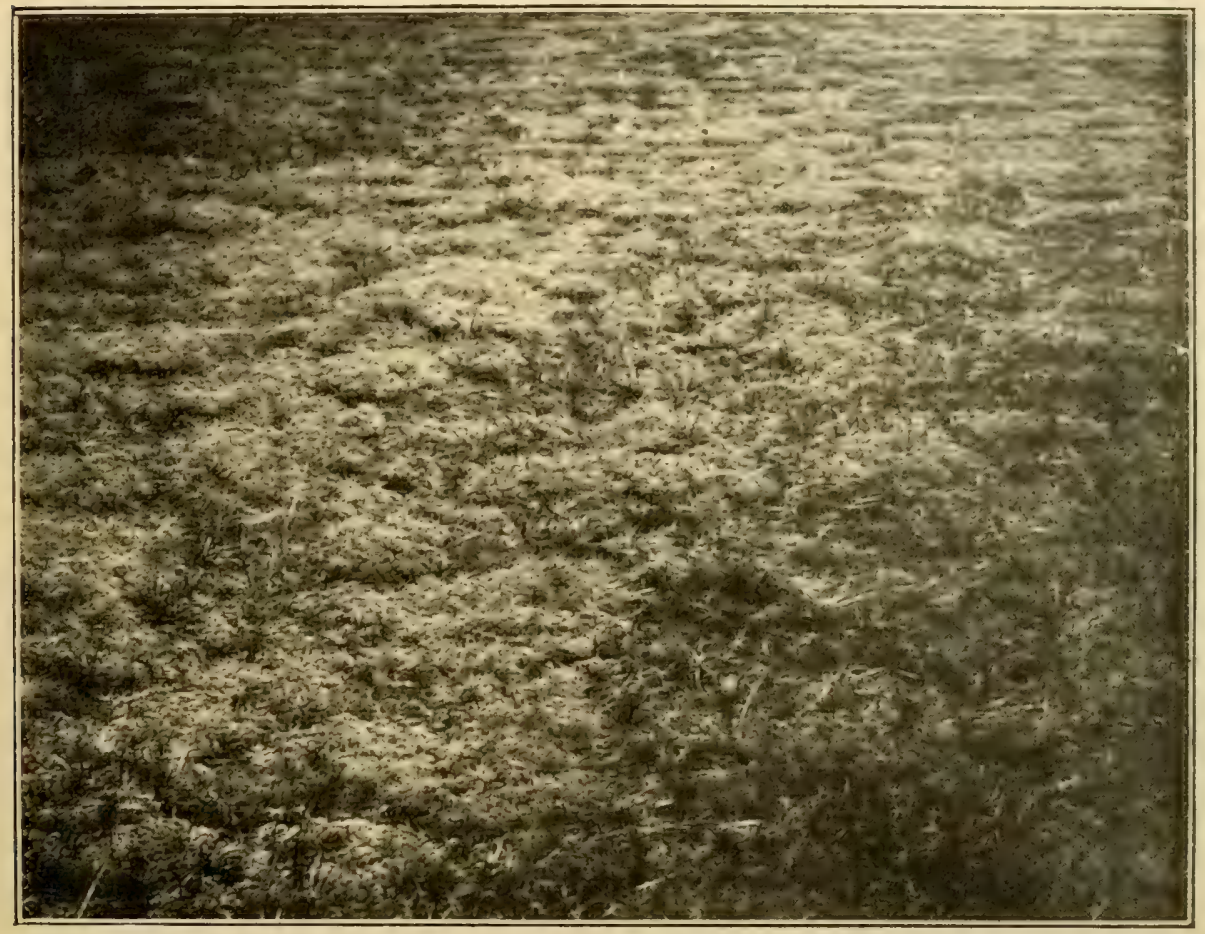

Abb. 43. Scleranthus-Sandflur am Rosenberger Teich bei Wittingau. (Nach einer Aufnahme von Prof. K. Domin, Prag.)

Anemone nigricans, Sedum acre. Polenlilla arenaria, Trifolium montanum, $T$. alpestre, Veronica prostrata, V. spicata, Scabiosa ochrolenca, S. canescens, Achillea collina, Hieracium Pilosella; überall sind Cladonien und Polytrichumarten in großer Anzahl vorhanden.

Die Moorheide. Einen Übergang der IJeiden zu den eigentlichen Inorformationen stellen dje Moorheiden dar, die besonders in Sülböhmen rech entwickelt sind. Die Entstehungsgeschichte der Moorheide ist freilich eine ganz andere wie die der Sandheide, da erstere sich aus Hochmooren bei allmählicher Austrocknung, letztere aus Flugsandfluren entwickeln; in ihrer letzten Ausbildung aber haben beide Formationen eine große Ähnlichkeit miteinander. Hayek, Die Pflanzendecke Österreiclt-Ungarns, $\mathbf{I}$. 
Auch hier herrschen Calluna vulgaris und Vaccinium Myrtillus weitaus vor, in ihrer Gesellschaft findet man aber nicht Sarolhammus, sondern zwei typische MIoorbewohner, Ledum palustre und Vaccinium uliginosum, oft in großer Anzah], auch Andromeda polifolia ist nicht selten anzutreffen, während Empelrum in Zentral- und Südböhmen fehlt. Die Sphagnumarten der Moore sind meist schon von Polylrichum- und Racomitrium-Arten verdrängt und auch die übrigen typischen Moorbewohner sind meist schon verschwunden, nur hie und da treten noch rasenbildende Gyperazeen, wie Eriophorum vaginalum, Carex Goodenoughii, C. lasiocarpa, G. leporina, Juncus filiformis auf. Hingegen fehlen Nardus stricla, Deschampsia flexuosa, ferner Polentilla erecla, Antennaria dioeca, Arnica montana und Hieracium Pilosella wohl auf keiner Moorheide.

Hochmoore. Ebenso wie in den Gebirgen Böhmens sind auch im südlichen Teile des zentralböhmischen Hochplateaus Hochmoore von großer Ausdehnung vorhanden. Die Hauptmasse des moorigen Untergrundes bilden Moose, vor allem zahlreiche Sphagnumarten, wie Sphagnum cuspidatum, S. compaclum, S. subesecundum, S. leres, S. squarrosum, S. fimbrialum, S. quinquefarium, S. aculifolium, S. medium, S. cymbifolium, ferner Hypnum- und PolytrichumArten, Philonolis fontana, Dicranum palustre, Aulacomnium palustre, Bryum pseudotriquelrum, Jungermannia Taylori und zahlreiche kleine CephaloziaArten. Überall ist auf den Moospolstern Drosera rolundifolia und D. anglica zu finden. Von rasenbildenden Cyperazeen treten vor allem Eriophorum vaginatum E. angustifolium, E. latifolium, Rhynchospora alba, Carex lasiocarpa, C. rostrala, C. vesicaria, $C$. acutiformis, $C$. elata, C. gracilis, C. Goodenoughii, C. diandra, C. canescens in Menge auf, von Gräsern Deschampsia caespitosa, Molinia coerulea und Calamagrostis lanceolata. Auch strauchige Ericazeen fehlen selten und verdrängen oft stellenweise gleich den Cyperazeen die Moosdecke fast völlig, wie Vaccinium uliginosum, V. Myrlillus, V. Vilis Idaea, Andromeda polifolia, Calluna vulgaris und das prächtige Ledum palustre, während Oxycoccus quadripetata mit seinen fädlichen Stengeln in den Moospolstern dahinkriecht. Von sonstigen krautigen Bewohnern der Moore seien insbesondere Lycopodium inundalum, Juncus filiformis, Potentilla palustris, Viola palustris, Hydrocolyle vulgare, Lysimachia thyrsiflora und Calla palustris genannt; in den Wassertümpeln aber finden sich vorzüglich Ulricularia neglecta, $U$. minor, $U$. intermedia und U. ochroleuca, am Rande derselben Menyanthes trifoliala und Myosolis caespilosa. Häufig siedeln sich auch Bäume und Sträucher auf den Mooren an, wie Belula pubescens, Alnus glutinosa, Salix cinerea, vor allem aber Pinus Mughus, die auf den Mooren oft große Bestände bildet; doch auch die baumartige Pinus uliginosa und $P$. silveslris kommen stellenweise vor und treten selbst bestandbildend auf.

Wiesenmoore. Eine ganz andere Zusammensetzung als die Hochmoors weisen die Wiesenmore auf. Sowohl die Torfmoose als die halbstrauchigen Ericazeen fehlen ihnen gänzlich; Cyperazeen, Juncazeen und Gramineen bilden die Hauptmasse der Vegetation. Carex elata (stricla) bildet hier ähnlich wie in Ungarn und in den Alpen das Hauptkontingent der dichte Rasen 
bildenden Cyperazeen, aber auch Carex Davalliana, G. aculiformis, C. vesicaria, C. rostrata, C. lasiocarpa, C. panicea, C. gracilis, C. Goodenoughii, C. dislans, Eriophorum vaginatum, E. latifolium, E. anguslifolium, Juncus effusus, J. glaucus, J. filiformis, J. alpinus, Scirpus silvalicus, Heleocharis palustris sind überall häufig. Von Gräsern treten Agrostis vulgaris und Deschampsia caespitosa oft in großer Menge auf, nicht selten sind ferner Agroslis alba, Molinia coerulea, Poa palustris, P. trivialis, Alopecurus aequalis, Glyceria plicata, Nardus stricta. Reich ist gewöhrılich der Blütenflor der Wiesenmoore. Iris sibirica, Orchis latifolia, Gymnadenia conopea, Lychnis Flos Cuculi, Callha palustris, Ranunculus acer, $R$. repens, Cardamine palustris, Parnassia palustris, Polentilla palustris, $P$. anserina, $P$. replans, Lolus corniculalus, Peucedanum paluslre, Cicula virosa, Pedicularis palustris, Alectorolophus minor, Scorzonera humilis, Cirsium paluslre, C. canum, Equiselum palustre gehören zu den gemeinsten Arten dieser Formation.

\section{d) Grasflurformationen.}

Talwiesen. Die Talwiesen Mittel- und Südböhmens sind wie fast überall keine ursprüngliche Formation, sondern teils durch Entwässerung aus Wiesenmooren, teils vielleicht auch durch Ausrodung von Wald entstanden und überdies durch Düngung verändert. Mit den Wiesenmooren sind sie naturgemäß durch zahlreiche Übsrgänge verbunden, unterscheiden sich aber von ihnen wesentlich durch das Zurücktreten der Gyperazeen und das Vorherrschen der Gräser über dieselben. Die verbreitetsten Arten derselben sind Anthoxanthum odoratum, Phleum pratense, Agrostis vulgaris, A. alba, Holcus lanatus, Arrhenalherum elalius, Trisetum flavescens, Dactylis glomerala, Cynosurus cristatus, Briza media, Poa pratensis, P. Irivialis, Festuca elalior und Bromus mollis. Auf gedüngten Wiesen blühen im Frühlinge vor allem Taraxacum vulgare und Bellis perennis, später dann Lychnis Flos Cuculi, Ranunculus acer, R. repens, Carum Carvi, im Hochsommer Trifolium pralense, T. hybridum, T. repens, Vicia Cracca, Geranium pratense, Galium verum, G. Mollugo, Veronica Chamaedrys, V. serpyllifolia, Planlago media, Knautia amensis, Campanula palula, Cenlaurea Jacea, Cirsium palustre, Crepis biennis, im Herbste blühen noch Heracleum Spondylium, Pastinaca sativa und Cirsium oleraceum und zuletzt Colchicum aulumnale.

Reicher ist die Flora auf ungedüngten Wiesen. Hier tritt manchmal Scorzonera humilis in solchen Mengen auf, daß sie fast die Gräser verdrängt; auch Trollius europaeus und Cardamine pratensis, Polygala vulgaris, im Hochsommer Dianthus deltoides, Lotus corniculatus, Silaus pratensis, Daucus Carola Slachys officinalis, Thymus ovatus, Alectorolophus minor, Achillea Millefolium, Cirsium canum und Crepis lectorum ziehen nährstoffärmere Böden vor.

Bergwiesen. Die in der Regel ungedüngten Bergwiesen treten in Zentralböhmen in verschiedenartiger Ausbildung je nach der Bodenunterlage und den klimatischen Faktoren auf. Die wichtigsten Typen derselben sind

a) Die Burstwiese. Dieser Typus der Bergwiesen ist im zentralen Bölımen besonders auf Plänerkalk sehr verbreitet. Das vorherrschende Gras 
ist hier stets Bromus ereclus, dem oft Bromus inermis beigesellt ist, ferner treten Briza media, Phleum phleoides, Fesluca elalior, Avena pratensis, Brachypodium pinnalum, Agropyrum glaucum auf. Von den dikotylen Begleitpflanzen sind insbesondere Astragalus danicus, Polygala vulgaris, Trifolium medium, T. ochroleucum, Daucus Carola, Laserpilium prulhenicum, Thymus praecox, Salvia pralensis, Galium verum, Campanula rolundifolia, Cenlaurea pannonica, Girsium acaule für diese Formation sehr charakteristisch; doch. finden sich auch Dianlhus Carthusianorum, Reseda lutea, Anthyllis Vulneraria, Medicago falcala, Onobrychis

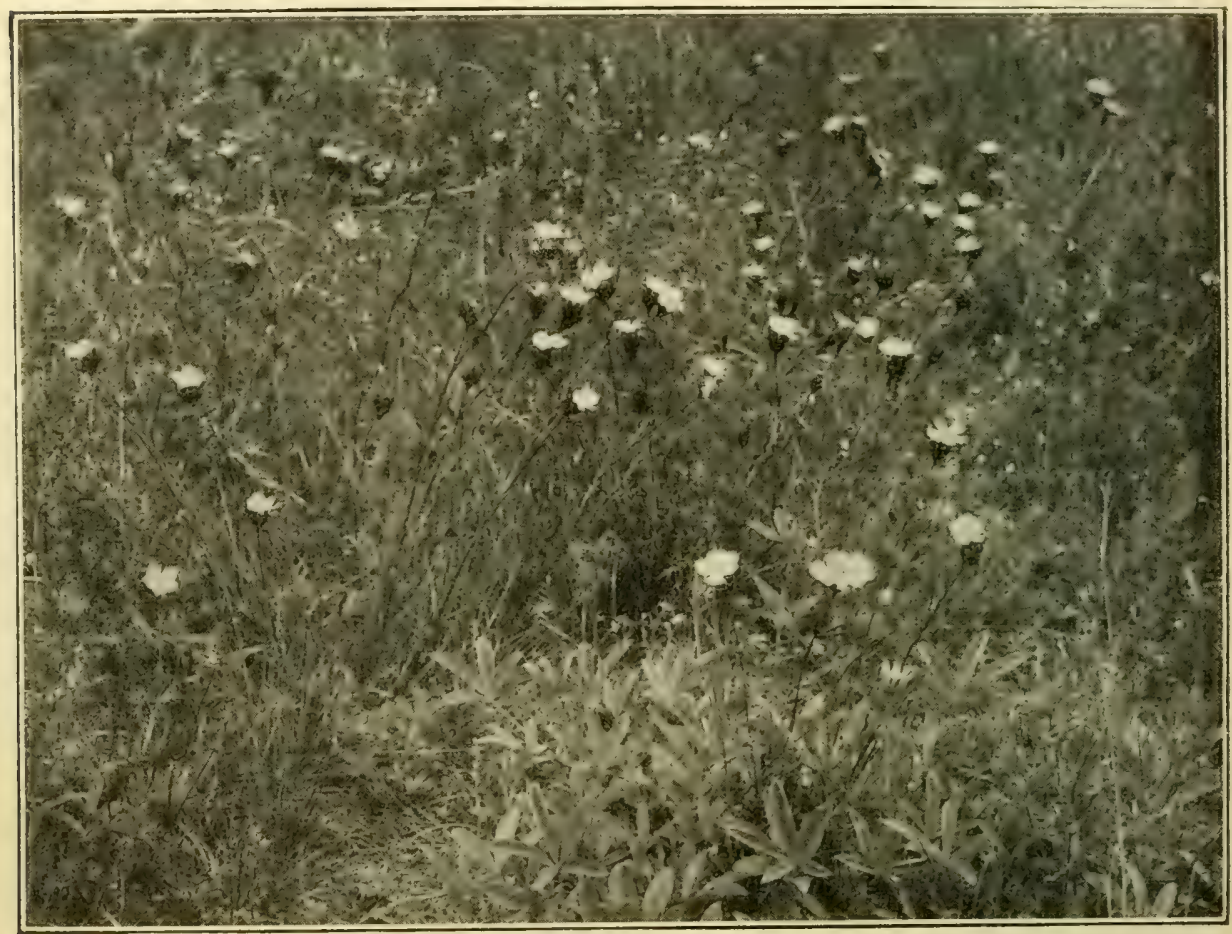

Abb. 44. Dianthus Carthusianorum auf einer Bergwiese bei Leitmeritz. Im Vordergrunde Hieracium I'ilosella und Blätter von Potentilla alba.

(Nach einer Aufnahme von Nenke und Ostermaier in Dresden.)

viciaefolia, Helianthemum nummularium, Brunella grandiflora, Scabiosa ochroleuca, Cenlaurea Scabiosa usw. nicht selten.

b) Die Formation des Wiesenhafers. Einen andern Typus der Bergwiesen stellen jene Grasfluren dar, in denen Avena pralensis vorherrscht. Daclylis glomerala, Koeleria pyramidala, Brachypodium pinnalum, Bromus inermis, Fesluca duriuscula, auch mitunter Avena pubescens und Sesleria varia, Garex flacca und $G$. monlana setzen mit Avena pralensis die Grasnarbe zusämmen. Von den Stauden und Kräutern sind besonders Labiaten oft sehr häufig, so Slachys officinalis, S. germanica, Brunella vulgaris, B. grandiflora, Teucrium Chanaedrys, Thymus praecox, Salvia pratensis, ferner finden sich Dianthus 
Carlhusianorum, Filipendula hexapelala, Agrimonia Eupaloria, Sanguisorba minor, Telragonolobus siliquosus, Ononis spinosa, Falcaria vulgaris, Bupleurum falcalum, Eryngium campestre, Planlago maior, Asperula tinctoria, A. cynanchica, Inula salicina, Centaurea Scabiosa, Scorzonera hispanica usw.

Beim Uberhandnehmen dieser Stauden geht diese Formation allmählich in die der Bergtriften über.

c) Die zentralböhmischen Orchideenwiesen. Im böhmischen Mittclgebirge ist besonders auf Basalt cin Wiesentypus sehr verbreitet, der durch den Reichtum an Orchideen sehr ausgezeichnet ist und deshalb von den Autoren als Orchideenwiese bezeichnet wird. Dieselbe stellt höchstwahrscheinlich eine ursprüngliche Formation dar, wurde aber in neuerer Zeit durch Kultur und Düngung vielfach umgestaltet. In ihrem Urzustande bietet sie eine eigenartige Mischung der gewöhnlichen Wiesenpflanzen mit Vorgebirgsarten und pontischen Elementen dar; jhr größter Blütenreichtum fällt in den Frühling und Frühsommer, im Hochsommer ist sie großenteils schon verdorrt. Von Gräsern herrschen insbesondere Anlhoxanlhum odoratum und Avena pralensis neben anderen weitverbreiteten Wiesengräsern vor; massenhaft ist stellenweise Scorzonera humilis vorhanden, auch Polentilla alba tritt hie und da in großer Menge auf. Orchideen fehlen nirgends, am verbreitetsten sind Orchis maculata, O. lalifolia, O. sambucina, O. mascula, seltener O. globosa, ferner Gymnadenia conopea und Coeloglossum viride. Aber auch sonst sind lebhaft blühende Arten verbreitet, so vor allem Polygonmm Bistorla. Dianlhus superbus, Trollius europaeus, Lathyrus monlanus, L. pratensis, Carum Carvi, Astrantia maior, Primula veris, Geranium sanguineum, Gentiana Pneumonanthe, Galium boreale, Melampyrum nemorosum, Alectorolophus monlanus, Hypericum maculalum, Hypochoeris maculata, Centaurea pseudophrygia, ferner auch Thalictrum lucidum, Anemone patens, Laserpitium pruthenicum, Peucedanum Cervaria, Pleurospermum austriacum, Chaerophyllum aureum, Anlhyllis Vulneraria, Trifolium spadiceum, Helianthemum nummularium, Campanula Trachelium, Adenophora liliifolia, Alectorolophus minor, Valeriana officinalis, Hieracium cymosum u. а.

Die Bartgrasilora. Sowrit in Zentralböhmen sich die thermophile Flora noch nachweisen läßt, ist die Formation des Andropogon Ischaemum wenigstens in Spuren noch anzutreffen. Diese Formation stellt ein Bindeglied zwischen den Bergwiesen und den eigentlichen Steppenformationen dar. Neben dem überall tonangebenden Bartgras (Andropogon Ischaemum) finden sich Slipa capillala, (selten St.pennala), Phleum phleoides, Fesluca sulcala, Lolium perenne, Carex humilis; die charaliteristischesten Begleitpflanzen derselben sind Silene Oliles, Dianthus Carthusianorum, Anemone nigricans, Ranunculus bulbosus, Alyssum alyssoides, Lepidium Draba, Sanguisorba minor, Medicago falcala, M. minima, Eryngium campestre, Falcaria vulgaris, Echium vulgare, Nonnea pulla, Veronica spicata, Euphorbia Cyparissias, Scabiosa ochrolenca, Terbascum Thapsus, V. phlomoides, Achillea nobilis, A. collina, Carlina vulgaris, Centaurea rhenana, Carduus nulans, Crepis rhoeadifolia, Hieracium Pilosella. 


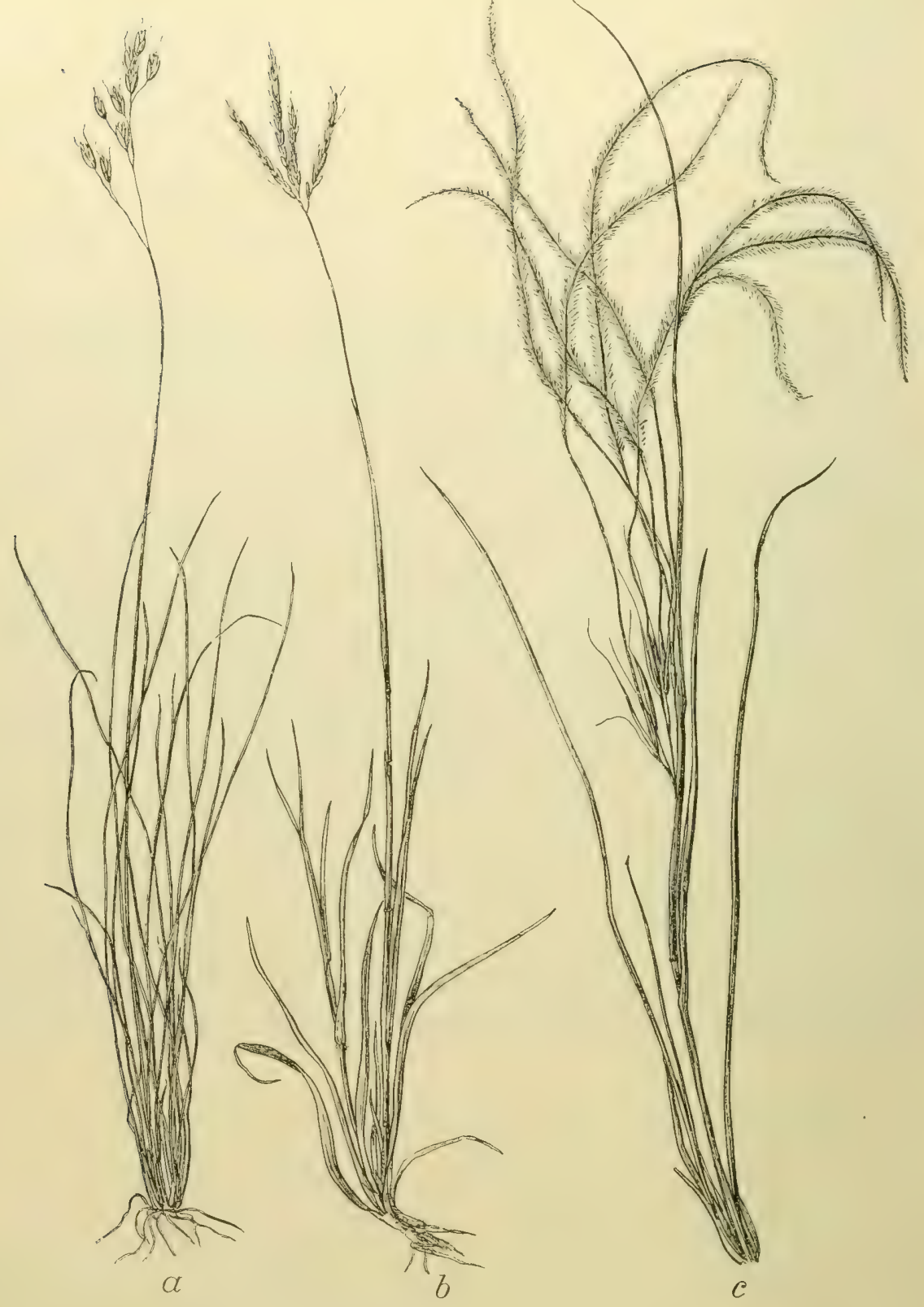

Abb. 45. Die drei wichtigsten Steppengräser Zentralböhmens.

$a$ Avena desertorum. $b$ Andropogon Ischaemum. $c$ Stipa Tirsa.

Die Schwingelsteppe. Auch diese Formation ist noch nicht als typische Steppe aufzufassen. Fesluca sulcala und Koeleria gracilis bilden entweder miteinander vergesellschaftet oder allein vorherrschend die dicht geschlossene Grasnarbe; beigemengt finden sich auch Fesluca duriuscula, F. glauca, Carex 
praecox und die seltene Koeleria nilidula. Unter den Kräutern und Stauden finden sich viele, die allen trockenen Bergiviesen gemein sind, so Dianthus Carthusianorum, Sanguisorba minor, Salvia pralensis, S. verlicillata, Scabiosa ochroleuca, Asperula cynanchica, Centaurea rhenana, Carduus nutans, aber auch schon typische östliche Arten, wie der prächtige Adonis vernalis, Polenlilla arenaria, Medicago minima, Vicia lathyroides, Thymus slenophyllus, Salvia nemorosa, Grepis rhoeadifolia, Lachuca viminea u. a., auch Sedum acre, Salureia Acinos, Bupleurum falcatum usw. kommen in dieser Formation vor. Auffallend ist oft das massenhafte Auftreten von gelbblühenden Arten, wie Rapistrum perenne, Lotus corniculalus, Medicago falcala und Sedum acre.

Die Federgrassteppe. Typisch ausgebildete Steppen, in denen die Federgräser vorherrschen, sind in Zentralböhmen nur im Nittelgebirge zu finden, und zwar gewöhnlich auf Basaltunterlage, meist auf feinschotterigem Untergrunde. Hier ist Slipa Tirsa gewöhnlich in großer Menge anzutreffen und herrscht weitaus vor; mit ihr finden sich Stipa pennata *Grafiana und *Joannis, Festuca sulcala, Koeleria gracilis, Phleum phleoides, Avena pralensis. IIassenhaft tritt oft Melampyrum arvense mit seinen purpurnen 'Trauben auf; auch Arlemisia pontica ist gewöhnlich sehr häufig. Von den übrigen Begleitpflanzen seien insbesondere Oxylropis pilosa, Aslragalus exscapus, Rapislrum perenne, Eryngium campestre, Salvia nemorosa, S. pratensis, Thymus collinus, T. stenophyllus, Verbascum phoeniceum, Cenlaurea rhenana genannt. Eine auf wenige Lokalitäten beschränkte Modifikation dieser Formation stellt die Steppe der Avena deserlorum vor, wo dieses erst in Südmähren, Ostgalizien und Südrußland wiederkehrende Gras in Gesellschaft der Avena pratensis vorherrscht. Die Begleitpflanzen sind im wesentlichen dieselben wie die der Federgrassteppe, doch ist stellenweise das häufige Vorkommen des Astragalus austriacus auffallend.

\section{e) Staudenformationen.}

Die Triftormation. Gleichwie im ungarischen und kroatischen Berglande tritt an sonnigen Abhängen in Zentralböhmen, besonders im Mittelgebirge, eine Formation auf, in der ausdauernde Stauden besonders aus den Familien der Rosazeen, Loguminosen, Labiaten und Scrophulariazeen über die Gräser und Scheingräser weitaus überwiegen und die Formation so nicht mehr den physiognomischen Eindruck einer Wiese macht. Vorherrschend sind gewöhnlich die schwarze Küchenschelle (Anemone nigricans), der sich mancherorts auch A. patens zugesellt, ferner Potentilla arenaria, Cerastium arvense, Erysimum erysimoides, Thymus praecox, $T$. lanuginosus, später dann Cylisus nigricans, Genisla germanica, Trifolium rubens, T. alpestre, Sanguisorba minor, Filipendula hexapetala, Dianthus Garthusianorum, Helianthemum nummularium, Galium verum, Inula hirla, J. salicina, Tragopogon dubius, Hieracium setigerum und in Hochsommer Salvia nemorosa, Verbascum Lychnites, Aster Amellus, Hieracium boreale sowie das für das nördliche Zentralböhmen besonders charakteristische Cirsium acaule. Sonstige häufige Arten dieser Pflanzengenossenschaft sind 
Anthericum Liliago, A. ramosum, Asparagus officinalis, Polygonalum officinale, Thesium linophyllum, Ceraslium semidecandrum, C. glulinosum, Viscaria vulgaris, Anemone silvestris, Arabis hirsula, Erysimum crepidifolium, Viola collina, Potenlilla argenlea, P. recta, P. canescens, Trifolium parviflorum, Anthyllis Vulneraria, Hypericum elegans, Bupleurum falcalum, Pimpinella Saxifraga, Salvia pralensis, Thymus Marschallianus, Verbascum phoeniceum, Veronica prostrala, $V$. dentata, Orobanche alba, Asperula lincloria, Campanula bononiensis, Aster Linosyris, Achillea selacea, A. collina, Anthemis linctoria, Cirsium pannonicum, Chondrilla juncea, Scorzonera laciniala, S. Jacquiniana, Picris hieracioides, Hieracium cymosum, $H$. pratense, $H$. florentinum, $H$. echioides. Gegenüber dieser großen Zahl von Stauden und Kräutern, deren Zahl durch Aufzählung der weniger verbreiteten Arten noch vermehrt werden könnte, treten die Gräser an Arten- und oft auch an Individuenzahl stark zurück. Hauptsächlich sind es die verbreiteten Steppengräser, die an der Zusammensetzung dieser Triften teilnehmen, wie Stipa pennala und S. Tirsa, S. capillala, Koeleria gracilis, Fesluca duriuscula, F. ovina, F. sulcala, Carex humilis, ferner auch Melica transsilvanica, Dactylis glomerata, Bromus ereclus, B. sterilis, Brachypodium pinnalum, Carex praecox u. a.

Felsenflora. Die Felsenflora Mittel- und Südböhmens ist eine je nach dem Substrat und der geographischen Lage sehr verschiedene, zumal da besonders auf Kalk und Basalt in Mittelböhmen eine Reihe östlicher Typen auftritt, die im übrigen Lande fehlt.

a) Auf Sandstein, kristallinischen Schiefern und Granit. Die Felsenflora dieser kalkfreien und ,kalten" Gesteine ist eine verhältnismäßig arme. Einige Farne, wie Asplenium trichomanes, A. Ruta muraria, A. septentrionale, Cystopleris fragilis, Polypodium vulgare, sind wohl allgemein verbreitet, ebenso Valeriana officinalis, Silene vulgaris, Allium monlanum, Polenlilla argenlea, Sedum album, Calluna vulgaris; weniger verbreitet sind Gynanchum Vinceloxicum und Dianthus gratianopolitanus. Von Moosen sind vor allem die RacomitriumArten überall häufig, ferner Barbula muralis, Tortula ruralis, Grimmia pulvinala, Barlramia ithyphylla. Von Flechten feht auf Granit und kristallinischem Schiefer wohl nirgends Rhizocarpon geographicum, während auf Sandsteinen besonders die Gyrophora-Arten und Umbilicaria ins Auge fallen.

b) Auf Kalk. Eine außerordentlich reiche Flora haben insbesondere die devonischen und silurischen Kalkfelsen der Umgebung von Prag aufzuweisen. Hier wachsen u. a. Sorbus Aria, Coloneaster inlegerrima, Slipa Tirsa, S. pennala, S. capillala, Melica ciliala, Agropyrum glaucum, Festuca glauca, Carex humilis, Anthericum Liliago, A. ramosum, Allium monlanum, Thaliclrum foelidum, Bisculella laevigala, Alyssum Arduini, Erysimum crepidifolium, Dianlhus gralianopolilanus, Seseli Beckii, S. Hippomaralhrum, Pimpinella Saxifraga, Anthyllis Vulneraria, Thymus pracox, Asperula cynanchica, Scabiosa ochroleuca, Lactuca viminea, L. perennis, Centaurea rhenana und das seltene Dracoceplkalum austriacum. An Moosen treten hier Grimmia pulvinala, Schistidium apoparpum, Gymnoslomum 
rupestre, G. calcareum, Trichostomum crispulum, T. pallidisetum, Bryum murale, Hymenostomum tortile usw. auf, von Flechten besonder's Psora-Arten (P.testacea, lurida), Endopyrenium rufescens, ferner verschiedene Gallertflechten, wie Collema multifidum, C. cheileum, C. plicatile, Omphalaria pulvinala.

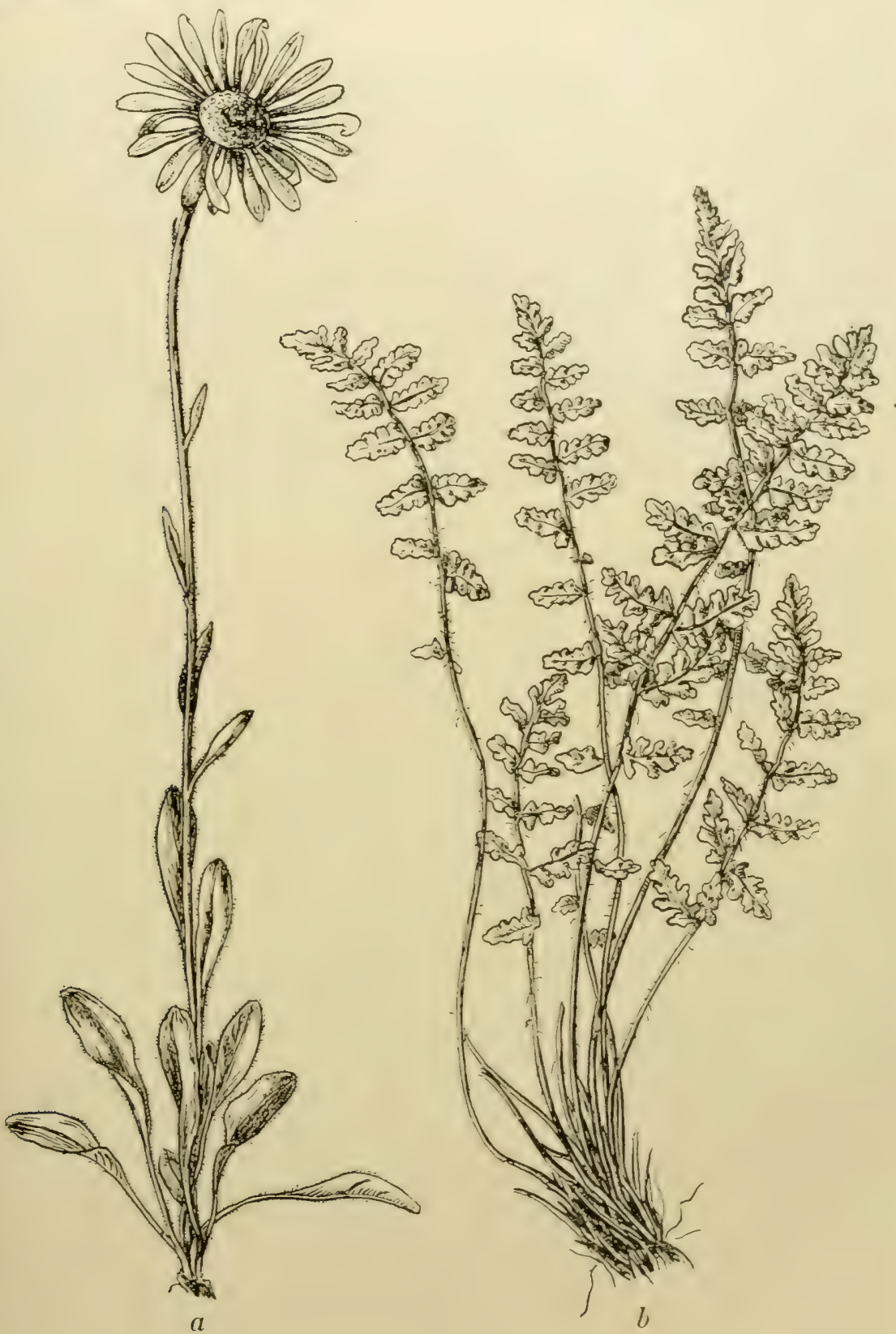

Abb. 46. Zwei Charakterpflanzen der nordböhmischen Basaltfelsen.

$a$ Aster alpinus Subsp. hirsutus. $b$ Woodsia ilvensis. 
c) Auf Basalt. Wieder anders gestaltet sich das Bild der Flora auf den warmen Basalt- und Phonolithfelsen. Thymus Marchallianum, T. praecox und Teucrium Chamaedrys sind hier meist in tonangebender Menge vorhanden, begleitet von. Potenlilla arenaria, Erysimum crepidifolium, Anemone nigricans, Adonis vernalis, Dianthus Carthusianorum, Dianthus gratianopolilanus, Sedum acre, Astragalus exscapus, Seseli Beckii, S. Hippomaralhrum, Alyssum Arduini, Lithospermum arvense, Salureia Acinos, Salvia pralensis, Artemisia campestris, Cenlaurea rhenana, Hieracium Schmidlii, H. charlaceum, H. Winkleri, Melica ciliala, Poa bulbosa, Slipa pennala, Carex humilis, G. supina, C. praecox, Iris bohemica usw.; von Sträuchern findet man insbesondere Pirus Piraster, Coloneaster inlegerrima und Carpinus Belulus, letzteren in einer zwergigen, dem Fels angeschmiegten Form. In höheren Lagen treten einige montane und subalpine Formen hinzu, besonders Gefäßkryptogamen, wie Lycopodium Selago, Asplenium trichomanes, A. seplenlrionale, Woodsia ilvensis, ferner Sesleria varia, Allium montanum, Aster alpinus *hirsulus, Bisculella laevigala, Saxifraga decipiens und S. Aizoon.

Die Formation der Ononis spinosa. An Waldrändern auf lehmigem Boden tritt stellenweise Ononis spinosa formationsbildend auf, gewöhnlich in Gesellschaft von Brachypodium pinnatum. Die wichtigsten sonstigen Begleitpflanzen dieser Formation sind Briza media, Dianthus Carthusianorum, Trifolium montanum, T. ochroleucum, Medicago falcala, Astragalus Gicer, A. glycyphyllus, Daucus Carola, Salvia pratensis, S. verticillata, Origanum vulgare, Veronica Chamaedrys, Asperula cynanchica, Cirsium eriophorum, C. acaule, Cenlaurea Scabiosa; von Sträuchern treten insbesondere Prunus spinosa, P. avium und Cornus sanguinea auf.

\section{f) Sumpf- und Wasserformationen.}

Röhricht. An stehenden und fließenden Gewässern bildet Phragmiles communis überall größere oder kleinere Bestände, nirgends aber sind diese so zahlreich und in solcher Ausdehnung anzutreffen als in dem an Teichen so reichen Gebiete Südböhmens. Neben Phragmites communis treten auch Schoenopleclus lacustris, Typha anguslifolia, T. latifolia, Glyceria aquatica, Typhoides arundinacea und Equiselum limosum stellenweise bestandbildend auf. Als Begleitpflanzen dieser Röhrichte sind in erster Linie Gräser und Seggen zu nennen, so Glyceria fluilans, Poa palustris, Molinia allissima, Deschampsia caespilosa, Scirpus marilimus, S. silvaticus, S. radicans, Carex Pseudocyperus, G. rostrata, $G$. vesicaria, $G$. gracilis, $G$. glauca, ferner hohe monokotyle Stauden, wie Alisma Planlago aqualica, Sagillaria sagillaefolia, Butomus umbellatus, Sparganium ramosum, Iris Pseudacorus. Doch auch dikotyle, meist hochwüchsige Arten mit lebhaft gefärbten Blüten sind nicht selten, vor allem Gicula virosa, die fast nirgends fehlt, Filipendula Ulmaria, Peucedanum palustre, Oenanthe aqualica und Lythrum Salicaria, ferner Lysimachia vulgaris und L. thyrsiflora, Epilobium hirsulum, Ranunculus Lingua, Menlha aqualica, M. longifolia, 


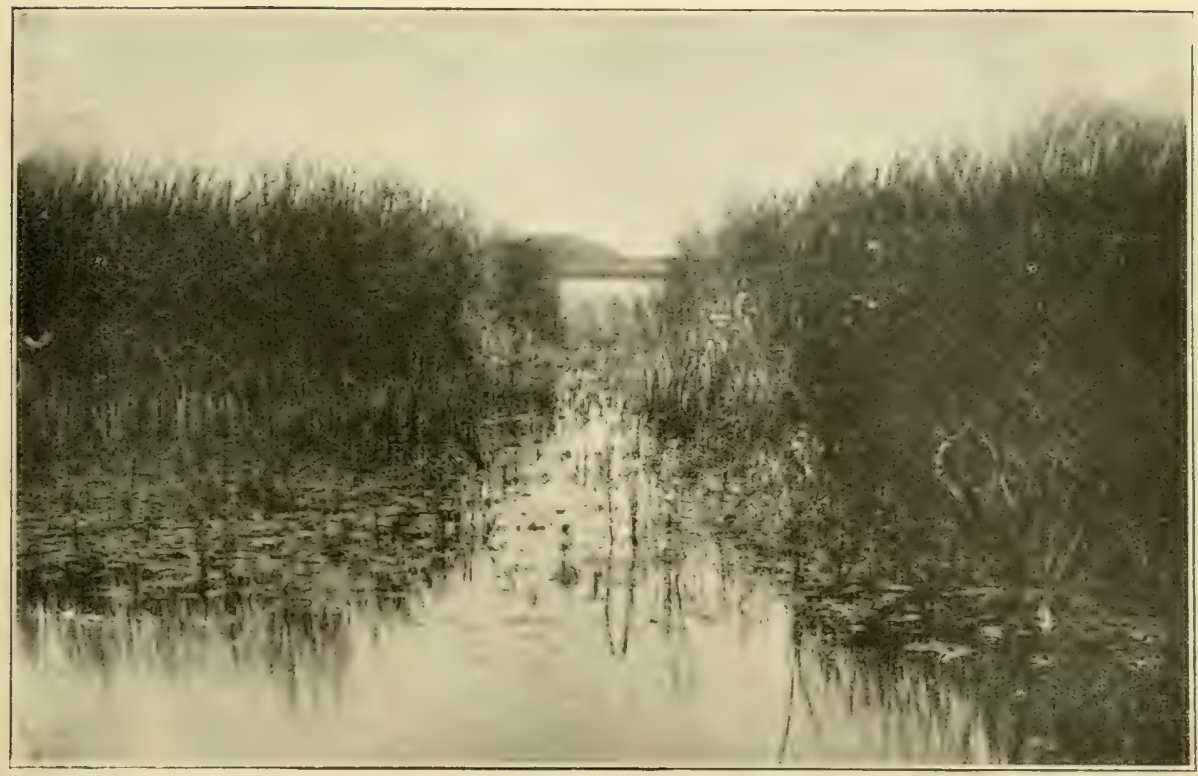

Abb. 47. Bestand von Phragmites communis mit Nuphar luteum bei Goltsch-Jenikau in Ostuöhmen.

(Nach einer Aufnahme von Prof. K. Domin, Prag.)

Solanum Dulcamara, Veronica sculellala, Sculellaria galericulata, Myosolis scorpioides und $M$. caespilosa, Bidens radialus. Menyanthes trifoliala überzieht sogar oft allein weite Strecken.

Die Formation des nackten Teichbodens. In allen groben Teichgehietrn und also auch in Südböhmen tritt eine auffallende Erscheinung auf: Sobald ein Teich abgelassen wird, erscheint wie mit einem Zauberschlage eine ganz eigenartige Flora, aus zarten, einjährigen Gewächsen bestehend, die den schlammigen Grund besiedelt und erst nach und nach von höheren ausdauernden Gewächsen verdrängt wird. Obwohl also diese eigentümliche Genossenschaft nur von ephemerer Dauer ist, muß sie wegen ihrer äußerst charakteristischen Zusammensetzung als eigene Formation betrachtet werden. Die wichtigsten Charakterarten derselben sind Heleocharis ovata, Isolepis setacea, Carex cyperoides, Elatine hexandra, E. triandra, E. Hydropiper, Limosella aqualica und Lindernia pyxidaria. Ferner finden sich daselbst Coleanthus sublilis, Heleocharis acicularis, Cyperus fuscus, C. flavescens, Juncus supinus, J. capitatus, J. Tenageia, J. bufonius, Spergularia echinosperma, S. rubra, Illecebrum verticillatum, Gypsophila muralis, Radiola linoides, Polentilla supina, P. norvegica, Callitriche verna var. caespitosa, Peplis Portula, Crassula aquatica, Plantago maior, Veronica scutellata, Bidens radiatus, Gnaphalium luteoalbum und G. uliginosum.

Die Formation der Wasserpflanzen. Trotz der großen und zahlreirhw Teiche in Südböhmen ist die Wasserflora dortselbst keine sehr reiche. Speziell die Teiche selbst sind meist ziemlich arm an Wasserpflanzen, welche mehr in 


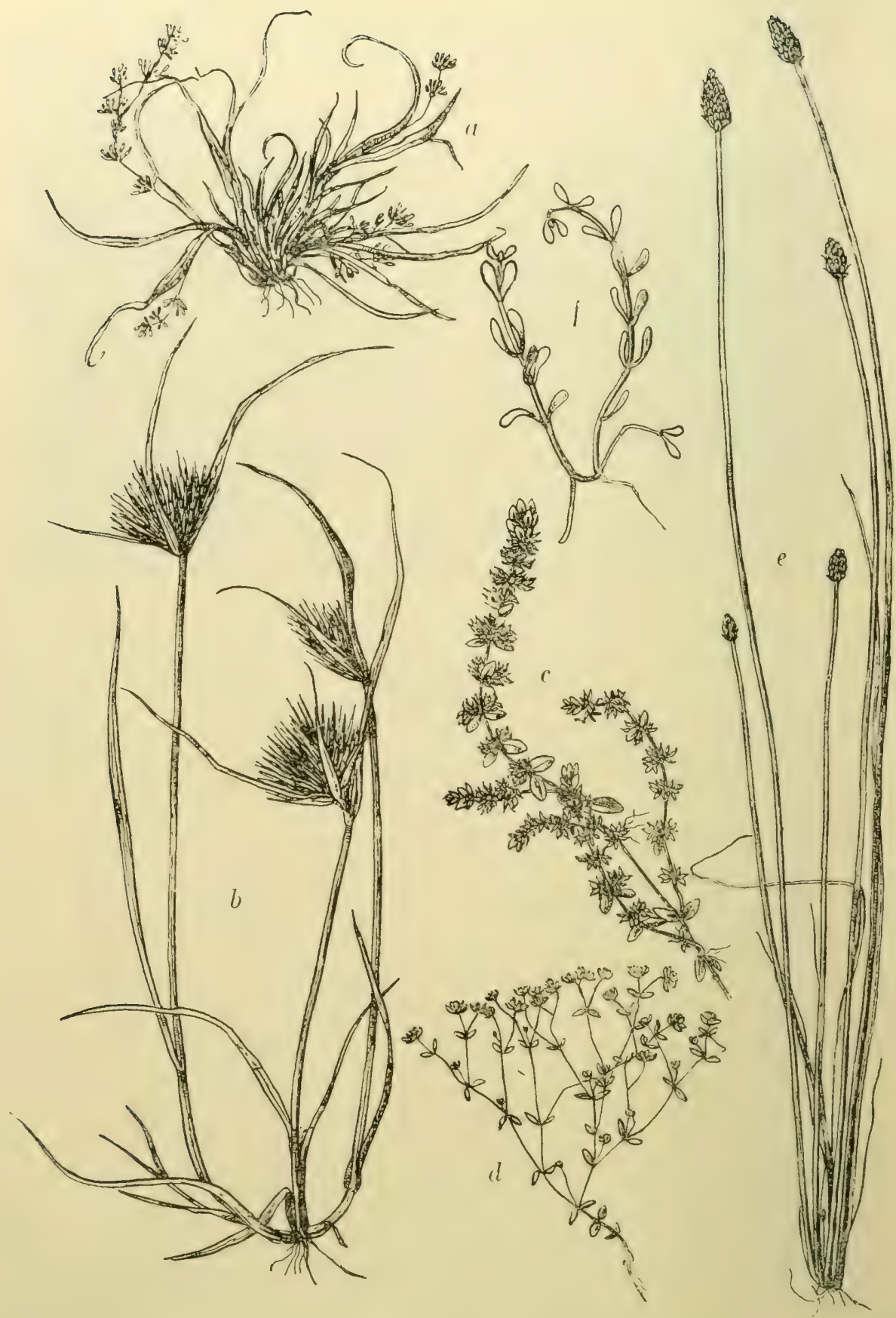

Abb. 48. Aus der Flora der nackten Teichböden Südböhmens.

$a$ Coleanthus subtilis. $b$ Carex cyperoides, $c$ Illecebrum verticillatum. $d$ Radiola linoides. e Heleocharis ovata. f Elatine Hydropiper. 
Gräben und Pfützen zu finden sind. Zu den häufigeren Arten gehören Lemna minor, Spirodela polyrhiza, Zannichelia palustris, Polamogeton nalans, P. lucens, P. crispus und P. pusillus, Elodea canadensis, Ceratophyllum demersum, Callitriche verna und $C$. hamulata, Polygonum amphibium, Utricularia minor, $U$. neglecta und U. ochroleuca, Ranunculus aqualitis, Caslalia alba, G. candida, Nuphar luteum, Montia rivularis, Myriophyllum verticillalum, Chara coronala und Nilella flexilis. Seltener sind Polamogeton alpinus, P. oblusifolius und P. Irichoides, Sparganum minimum, Isolepis selacea var. fluitans, Callitriche stagnalis, Litorella lacustris u. a.

\section{g) Kulturgewächse.}

Getreidebau. Der Getreidebau wird im Innern Böhmens sehr intensiv betrieben. Böhmen produziert jährlich über 3 Millionen Meterzentner an Weizen und an Roggen, 5.7 Millionen Meterzentner an Gerste und an Hafer, von welchen Zahlen naturgemäß der größte Anteil auf den zentralen Teil des Landes entfällt. Der rauhere Teil von Süd- und Südostböhmen sowie der äußэrste Osten und die Pilsener Gagend sind die Hauptanbaugabiete von Hafer, auch Roggen wird besonders im südöstlichen Teile und um Pilsen gebaut. In der fruchtbaren Niederung an der Elbe und unteren Moldau hingagen sind die Hauptgebiete des Weizenbaues. Gerste (fast ausschließlich Hordeum dislichum) wird in der Elbeniederung, ferner im nordwestlichen Böhmen sowie im mittleren Moldautale in großer Menge kultiviert. Mais wird in Böhmen nicht gebaut.

Gemuisepflanzen. Auch der Kartoffelbau ist in Böhmen sehr ergiebig (jährlich 29 Millionen Meterzentner) und wird fast im ganzen Lande, an wenigsten im Nordwesten, ausgaübt. Auch der Anbau von Hülsenfrüchten ist nicht unbedeutend. Von übrigen Gemüsepflanzen spielt das Kraut die hervorragendste Rolle (jährlich 577.000 Meterzentner in Böhmen), das vielfach auf freiem Felde kultiviert wird. Die übrigen Gemüsepflanzen werden hauptsächlich in Gärten gezogen.

Obstbau. Auch der Obstbau ist in Zentralböhmen nicht ohne Bedeutung. Besonders ist es Kernobst ( und auch ausgeführt werden; auch Zwetschken werden allgemein gebaut. Am Fuße des Erzgebirges, bei Komotau, baut man auch Edelkastanien (Castanea sativa).

Weinbau. Der Weinbau ist in Böhmen auf das mittlere Elbetal, besonders die Ungebung von Melnik, Leitmeritz und Lobositz beschränkt. Die Weingärten nehmen 870 ha an Bodenfläche ein, die jährliche Produktion beträgt $9450 h l$. Gebaut werden besonders Riesling, Traminer und roter Burgunder; es werden sowohl Weißweine (Czernoseker) als Rotweine. (Melniker) erzeugt.

Futterpflanzen. Die häufigste Futterpflanze, die gebaut wird, ist Rotkler. (Trifolium pratense), ferner auch Luzerne (Medicago saliva) und Esparsette (Onobrychis viciaefolia), seltener Weißklee (Trifolium repens) unil Bastarikler. (Trifolium hybridum). Das wichtigste Gebiet des Futterpflanzenbaues ist dic 
Elbeniederung. Der Anbau von Lupinen (Lupinus luteus, albus und angustifolius) ist erst seit wenigen Jahrzehnten im Gebrauche und nicht von hervorragender Bedeutung. Allgemein verbreitet ist hingegen die Kultur der Runkelrübe (Beta vulgaris) zu Futterzwecken. Als Bienenpflanze wird ab und zu Phacelia tanacetifolia angebaut.

Sonstige Nutzpilanzen. Von hoher Bedentung ist in Böhmen der Anbau der Zuckerrübe, die in ganz Nordböhmen, besonders in der Elbeniederung, ferner um Prag, Saaz, Komotau, Teplitz und Aussig betrieben wird und einen jährlichen Ertrag von über 33 Millionen Meterzentnern abwirft.

Eine zweite sehr wichtige Nutzpflanze ist der Hopfen (Humulus Lupulus), der einerseits um Saaz und von hier südwärts bis Rakonitz, ostwärts bis an den Fuß des Mittelgebirges, ferner im Gebiete der mittleren Elbe, besonders um Auschau, im großen kultiviert wird. Der jährliche Ertrag an Hopfen beträgt 72.000 Meterzentner. Auch der Flachsbau ist nicht ohne Bedeutung, besonders in Südostböhmen (Tabor, Kamenitz, Pilgram) sowie in der östlichen Umgebung von Prag und um Policzka. Ab und zu findet man auch Kulturen von Zichorie (Cichorium Inlybus).

Forstkultur. Im an Nadelwäldern reichen südlichen Teile Zentralböhmens herrschen in bezug auf die Forstkultur ähnliche Verhältnisse wie im Böhmerwalde. Hier besteht, besonders in den landtäflichen Besitzen von Wittingau und Gratzen, eine genaue Ertragsregelung der Forste, welches Beispiel jetzt allgemein Nachahmung findet. Auch wurde in diesem Gebiete reichlich aufgeforstet, besonders zahlreiche Noore sind daselbst entwässert und der Kultur zugänglich gemacht worden.

Anders liegen die Verhältnisse in Zentralböhmen und in der Elbeniederung. Hier war bis vor kurzem der Niederwald- und Nittelwaldbetrieb heimisch, beso nders zur Gewinnung von Brennholz und von Eichenrinde als Gerbmaterial. Besonders die Eichenschälwaldungen, in denen die jungen, $2-5 \mathrm{~cm}$ dicken Schößlinge meist noch auf dem Stocke geschält und erst später abgehauen werden, waren früher sehr beliebt. Seit jedoch die Einfuhr billigeren fremdländischen Gerbematerials die Eichenschälwirtschaft in ihrer Ertragsfähigkeit sehr beeinträchtigt und auch die Steinkohle die Nachfrage nach hartem Brennholze stark herabgedrückt hat, wird auch hier meist der Hochwaldbetrieb eingeführt.

\section{h) Die Adventivflora.}

Ackerunkräuter. Im südlichen Böhmen ist die'Ackerflora ähnlich zusammengesetzt wie in den Gebirgsländern. Apera Spica venti, Bromus secalinus, Scleranthus annuus, Spergula arvensis, Alchemilla arvensis, Raphanus Raphanistrum, Sinapis arvensis, Vicia villosa, Anagallis arvensis, Alectorolophus maior, Girsum arvense sind die verbreitetsten Arten, auch Agrostemma Githago, Papaver Rhoeas und Centaurea Cyanus kommen vor und stellenweise nicht selten ist Linaria arvensis. Auf Leinäckern ist Lolium remolum häufig anzutreffen. Reicher ist die Ackerflora in den nördlicheren Teilen, wo auch Bromus arvensis, 
Allium rolundum, Nigella arvensis, Caucalis daucoides, Scandix Pecten Veneris, Lathyrus luberosus, Euphorbia falcata, Kickxia spuria, Physalis Alkekengi, Slachys annua, Cerinthe minor usw. auftreten; in der Gegend von Brüx und Aussig sind auch Androsace elongala und Anthemis ruthenica, um Komotau Falcaria vulgaris und Adonis aeslivalis zu finden.|

Ruderalflora. Auch die Ruderalflora ist in Südböhmen relativ artenarm. Neben den auch in den Randgebirgen verbreiteten Arten wären besonders Conium maculatum, Malva pusilla, Alriplex rosea und $A$. hastala zu nennen. Im nördlichen Teile Zentralböhmens sind auch Digitaria filiformis, Echinochloa Crus galli, Setaria glauca, Bromus lectorum, Chenopodium glaucum, C. Vulvaria, C. rubrum, Salsola Kali, Xanthium strumarum nicht selten, besonders üppig gedeiht an manchen Orten Atriplex nitens. Im oberen Egertale ist Pastinaca opaca, in Elbetal an feuchten Stellen Pulicaria vulgaris sehr häufig.

\section{Die Pflanzengenossenschaften von Mittel- und Südmähren und dem nordöstlichen Niederösterreich.}

\section{a) Waldbestände.}

Laubmischwälder. Der häufigste Walrltypus auf den Hügeln Mittelund Südmährens sowie des nordöstlichen Niederösterreich sind gemischte Laubwälder von sehr mannigfacher Zusammensetzung. Die Hauptmasse des Oberholzes bilden Carpinus Betulus, Quercus sessiliflora, Qu. Robur, Acer campestre und Tilia cordata; eingestreut finden sich Fagus silvatica, Ulmus glabra, Salix Caprea, Sorbus lorminalis, Pirus acerba, Prunus avium, Acer platanoides, Tilia plalyphyllos und von Nadelhölzern nicht selten Pinus silvestris. Das oft sehr reiche Unterholz besteht aus Cornus Mas, C. sanguinea, Cralaegus monogyna, C. Oxyacantha, Evonymus vulgaris, Staphylea pinnata, Acer campestre, Ligustrum vulgare, Lonicera Xylosteum, Viburnum Lantana und oft auch Evonymus verrucosus. An Lianen ist Clematis Vitallea allenthalben verbreitet, seltener ist Hedera Helix. Außerordentlich mannigfaltig ist der Niederwuchs. Plalanthera bifolia, Cephalanthera alba, Gagea lulea, Anemone nemorosa, A. ranunculoides, A. Hepatica, Ranunculus auricomus, Aclaea spicala, Stellaria Holoslea, Corydalis cava, C. solida, Cardamine enneaphyllos, Viola mirabilis, V. silveslris, Genista tinctoria, G. germanica, Cylisus supinus, Trifolium ochroleucum, T. medium, Lalhyrus vernus, Vicia dumetorum, V. pisiformis, Circaea lutetiana, Torilis Anthriscus, Primula vulgaris, Pulmonaria officinalis, Lamium luleum, Melillis Melissophyllum, Veronica Chamaedrys, Melampyrum nemorosum, Asperula odorata, Campanula persicifolia, Solidago Virga aurea, Hieracium racemosum, H. umbellatum sind wohl allgemein verbreitet; dazu gesellen sich einige Gräser und Scheingräser, wie Milium effusum, Melica nutans, M. picla, Deschampsia flexuosa, Dactylis glomerata, Fesluca gigantea, Agropyrum caninum, Carex digitata, C. pilosa, C. divulsa, Luzula vernalis, die oft in reichlicher Menge vorhanden sind. Von 
Farnen ist Pleridium aquilinum stellenweise nicht selten, auch Athyrium Filix femina, Dryopteris Filix mas, D. polypodioides treten gelegentlich auf. Andere Arten des Laubmischwaldes von minder allgemeiner Verbreitung sind Scilla bifolia, Galanthus nivalis, Lilium Marlagon, Gephalanlhera longifolia, Ranunculus cassubicus, Aclaea Cimicifugia, Selinum Carvifolia, Laserpilium latifolium, Peucedanum Cervaria, Lilhospermum purpureocoeruleum, Prenanthes purpurea usw.

Buchenwälder. Reine Buchenbestände treten besonders auf den Ausläufern des Böhmisch-mährischen Höhenzuges ab und zu auf. Fagus silvalica, hie und da begleitet von Carpinus Belulus, bildet hier meist allein das Oberholz; das Unterholz fehlt meist ganz und im Niederwuchs treten die durch ganz Mitteleuropa verbreiteten Buchenwaldpflanzen auf, wie Melica nutans, Poa nemoralis, Carex digilala, C.pallescens, C.pilosa, Arum maculatum, Lilium Marlagon, Paris quadrifolia, Galanthus nivalis, Plalanthera bifolia, Neollia Nidus avis, Asarum europaeum, Mercurialis perennis, Euphorbia amygdaloides, Aclaea spicala, Geranium Robertianum, Oxalis Acelosella, Cardamine enneaphyllos, C. bulbifera, Sanicula europaea, Asperula odorala usw.

Birkenwälder. Reine Birkenbestände sind im nördlichen Niederösterreich und im westlichen Mähren liaum anzutreffen, hingegen ab und zu auf den tertiären Erhebungen des Marsgebirges und Steinitzer Waldes entwickelt. Die Zusammensetzung dieser Bestände ist die gleiche wie überall in Mitteleuropa, das Oberholz bildet Belula pendula, ab und zu von Pinus silvestris, Belula pubescens oder Populus tremula begleitet; ein Unterholz felılt gewöhnlich und den Niederwuchs bildet eine typische Callunaheide.

Fichtenwälder. Reine Fichtenbestände gehören im mittleren und südlichen Mühren zu den selteneren Erscheinungen; in ihrer Zusammensetzung erinnern sie an die herzynischen Fichtenwälder. Picea excelsa, der sich mitunter Abies alba oder Pinus silvestris beigesellt, bildet das Oberholz. Das Unterholz ist sehr spärlich und besteht hauptsächlich aus Corylus Avellana, Juniperus communis, Berberis vulgaris, Prunus spinosa. Im Niederwuchs aber herrschen Vaccinium Myrtillus und Calluna vulgaris weitaus vor, begleitet von Polentilla erecla, Melampyrum silvaticum, Pirola uniflora, P. rolundifolia, P. secunda, Deschampsia flexuosa. Von Farnen sind Pleridium aquilinum, Dryopleris Filix mas und Athyrium Filix femina nicht selten; an Moosen treten Hypnum Schreberi, H. purum, Hylocomium splendens, Dicranum scoparium und Leucobryum glaucum auf.

Föhrenwålder. Wälder aus Pinus silvestris sind in Mittel- und Sülmähren nicht selten, und zwar sowohl im Hügellande auf anstehendem Gesteine als auch insbesondere in der Ebene auf Sandboden. Die Flora der Föhrenwälder ist stets eine ziemlich dürftige, doch ist sie in den Wäldern des mährischen Hügellandes noch verhältnismäßig reich zu nennen. Im Oberholze ist Pinus silvestris meist allein vertreten, nur selten kommen Populus tremula, Belula pendula, Quercus sessiliflora, Qu. pubescens oder besonders in höheren Lagen auch Picea excelsa eingesprengt vor. Das Unterholz ist spärlich und 


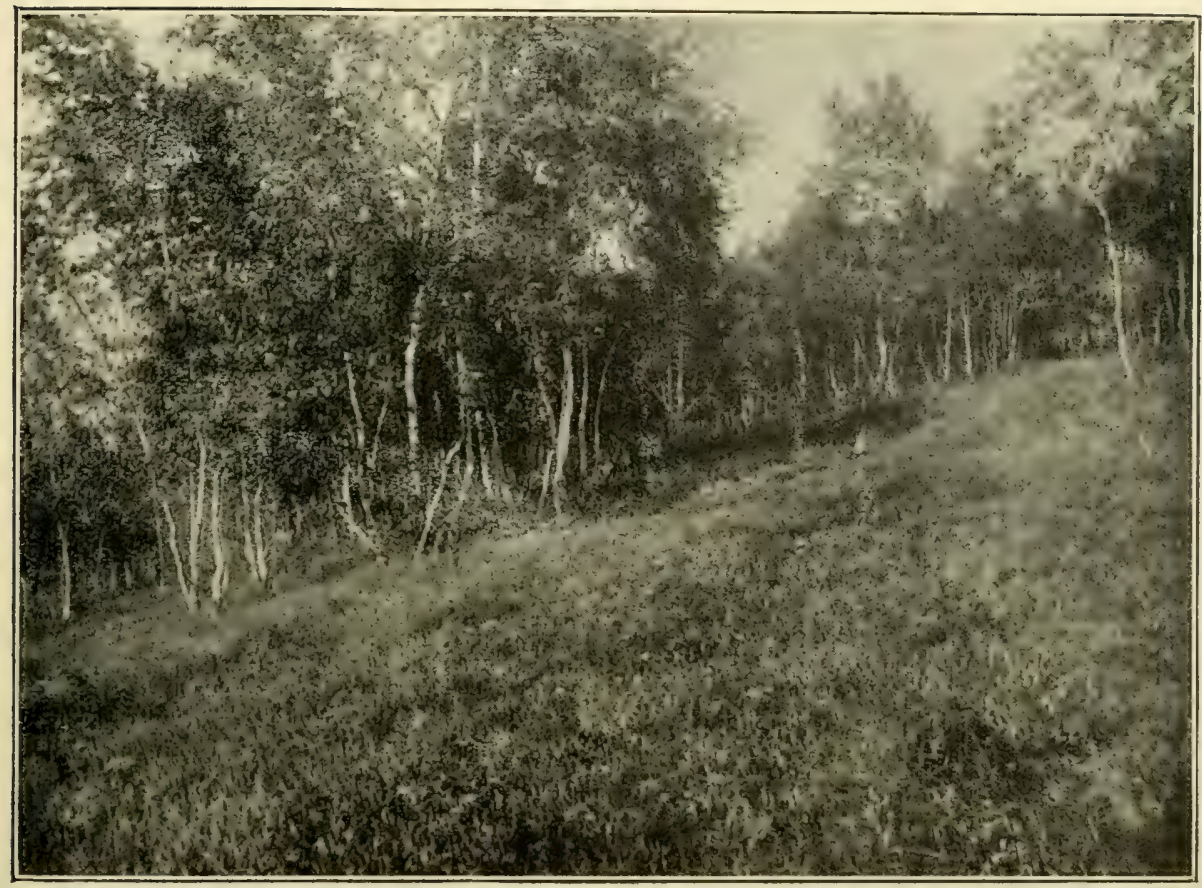

Abb. 49. Niederwuchs aus Calluna vulgaris in cinem Birkenbestande bei Četechovic im Marsgebirge.

(Nach einer Aufnahme von Prof. J. Nabělek, Leipnik.)

(Aus der Bildersammlung des botanischen Institutes der Wiener Universität.)

besteht aus Juniperus communis, Prunus spinosa, Cralaegus Oxyacantha, Berberis vulgaris, Evonymus vulgaris, E. verrucosus, Viburnum Lanlana und auf kalkfreiem Boden mitunter auch aus Sarothamnus scoparius. Der Niederwuchs ist sehr mannigfacher Art. Besonders gegen die Ausläufer des Gesenkes zu und im Böhmisch-mährischen Höhenzuge ist Vaccinium Myrlillus oft in großen Mengen vorhanden, begleitet von Calluna vulgaris, Vaccinium Vilis Idaea, Pirola rolundifolia, P. minor, Melampyrum vulgalum usw. Im wärmeren Hügellande Mährens treten aber die Heidelbeeren zurück oder fehlen vielfach auch ganz; aber auch der übrige Niederwuchs ist dann oft sehr spärlich. Carex ericelorum, C. leporina, Agrostis vulgaris, besonders aber niedrige, strauchige Leguminosen treten dann auf, wie Gylisus supinus, $C$. nigricans, Genisla pilosa, G. lincloria und G. germanica, ferner Anemone Hepalica, Viola silvestris, Potentilla erecta, Cyclamen europaeum, Solidago Virga aurea, Anlennaria dioica und noch hie und da Pirolazeen, wie Chimaphila umbellala und Pirola rolundifolia. Ton Farnen ist nur Pteridium aquilinum häufiger.

Noch dürftiger sind die meist angepflanzten trockenen Kieferwälder der' sandigen Ebenen. Hier herrscht Pinus silvestris meist ganz allein, nur in neuerer Zeit wurde auch Pinus nigra vielfach mit Erfolg aufgeforstet. Das Unterholz fehlt völlig und selbst einzelne Sträucher von Juniperus oder Sarothamnus

Hayek, Die Pflanzendecke österreich-Ungarns, I. 
sind selten. Im Niederwuchs aber trifft man die Pflanzen der Sandheiden und Sandsteppen. Koeleria gracilis, Festuca sulcala, Corynephorus canescens, Calamagrostis Epigeios, Apera interrupta, Agrostis alba, Carex ericelorum sind die Vertreter der Gräser; von sonstigen Arten findet man Luzula pilosa, L. campestris, Silene nutans, Euphorbia Cyparissias, Polentilla erecta, Viola rupestris, Helianlhemum ovalum, Thymus Marschallianus, Melampyrum nemorosum, Jasione montana, Filago montana, Gnaphalium luteo-album, Hieracium Pilosella und H. vuglalum.

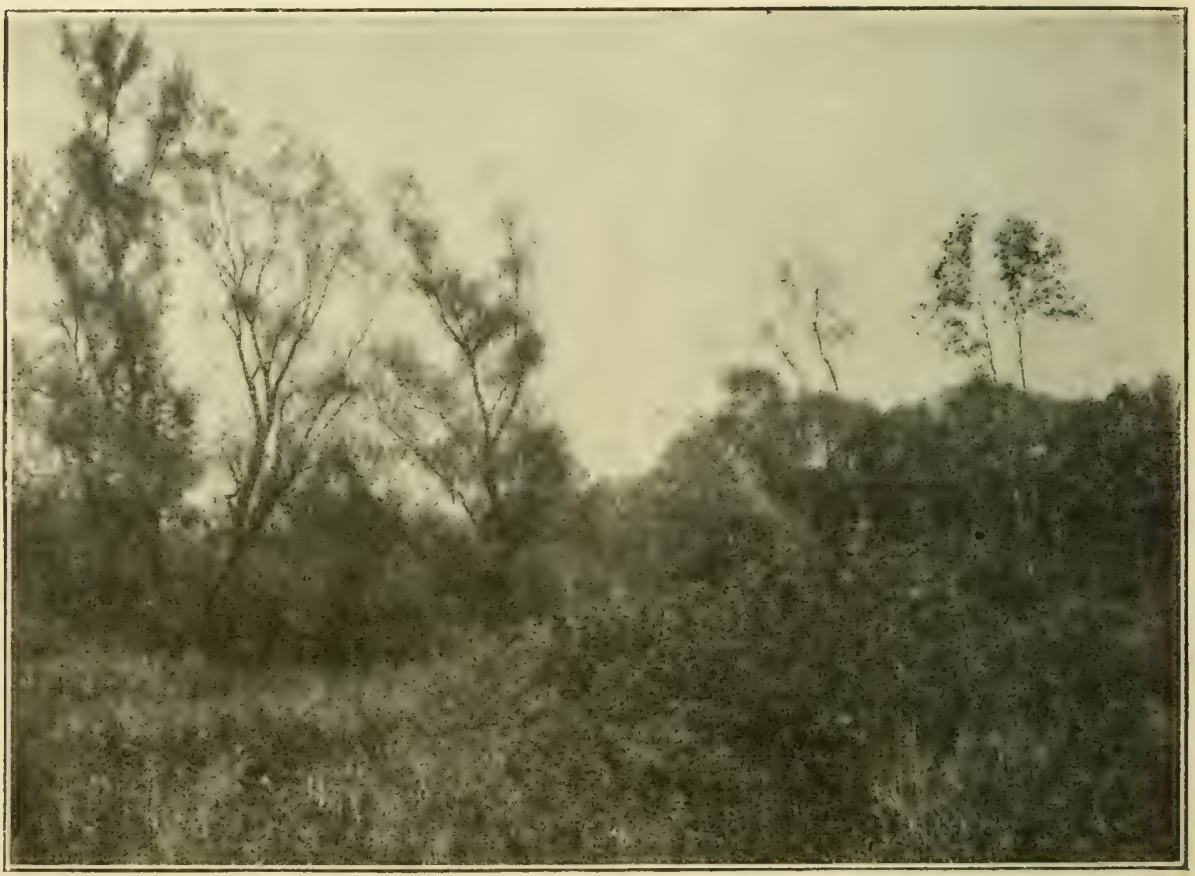

Abb. 50. Aus den Auen der March bei Baumgarten.

Links Populus nigra, daneben Salix alba, die im Hintergrunde Bestände bildet. Im Vordergrunde Glyceria aquatica und Ulmus sp.

(Nach einer Aufnahme von Dr. K. Rechinger, Wien.)

Auenwäldler. Auf den Alluvionen der größeren Flüsse, besonders der March, aber auch der unteren Thaya und Schwarzawa, sind überall ausgedehnte Auenwälder ausgebildet. Ursprünglich waren es wohl Eichen (Quercus sessiliflora), die diese Wälder hauptsächlich zusammensetzten; jetzt sind dieselben schon vielfach der Axt zum Opfer gefallen und haben anderen, rascher wüchsigen Bäumen Platz gemacht, sind aber doch noch nicht ganz geschwunden und oft noch zahlreich in prächtigen uralten Exemplaren anzutreffen. Die häufigsten Bäume der Auen sind heute Ulmus glabra und Fraxinus excelsior, ferner findet man nicht selten Acer campestre, Populus tremula, Carpinus Betulus, Betula pendula, während Populus alba und $P$. nigra nicht so häufig sind wie an der Donau. An feuchteren Stellen aber ist Alnus glulinosa, begleitet von 


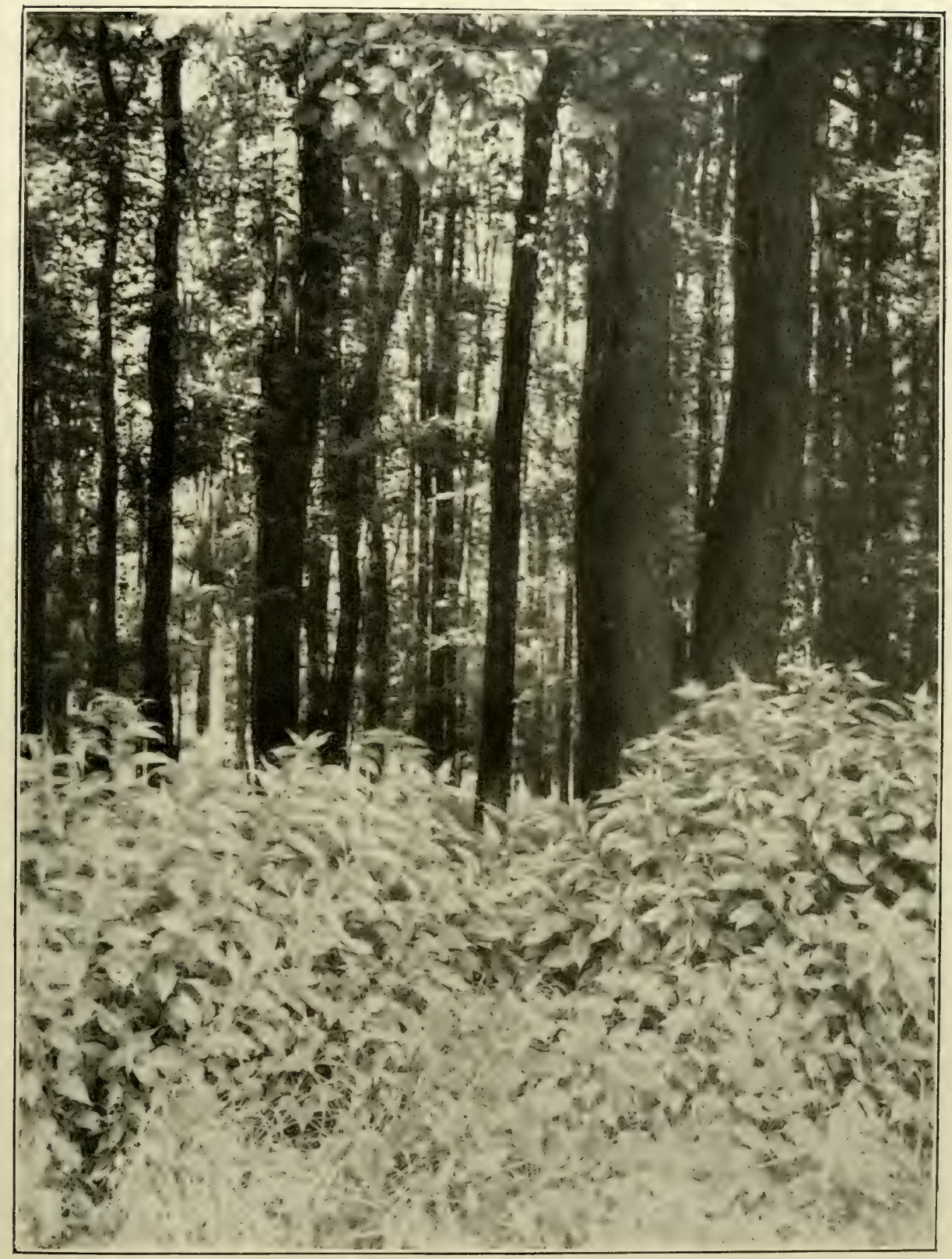

Abb. 51. Parietaria officinalis als Niederwuchs in den Donauauen der Lobau bei Wien. Das Oberholz wird von UImus laevis gebildet.

(Nach einer Aufnahme von Prof. Amalie Mayer, WVien.)

(Aus der Bildersammlung des botanischen Institutes der Wiener Universität.) 

Salix alba, S. fragilis, S. purpurea, S. viminalis und S. Iriandra der herrschende Baum. Das Unterholz ist meist sehr reich entwickelt und besteht hauptsächlich aus Sambucus nigra, Viburnum Opulus, Cornus Mas, C. sanguinea, Rhamnus calharlica, Ligustrum vulgare, Lonicera Xylosteum, ferner aus Corylus Avellana, Ribes nigrum, Evonymus vulgaris und Rhamnus Frangula. Von Schlinggewächsen ist besonders der Hopfen (Humulus Lupulus) üppig entwickelt, ferner sind Calystegia sepium, Polygonum dumetorum und lie und da auch Bryonia alba zu finden. Im Niederwuchs treten hochwüchsige Gräser oft in Menge auf, so insbesondere Deschampsia caespilosa, Poa nemoralis, Fesluca gigantea, Bromus asper, Brachypodium silvaticum und Agropyrum caninum. Von sonstigen Arten, die stellenweise Massenvegetation bilden, seien insbesondere Allium ursinum, Filipendula Ulmaria, Salvia glulinosa, Eupatorium cannabinum und an schotterigen Stellen Cirsium arvense genannt. Andere häufige und charakteristische Arten des Niederwuchses sind Athyrium Filix femina, Dryopteris spinulosa, Milium effusum, Gagea lutea, Convallaria maialis, Polygonalum multiflorum, Paris quadrifolia, Listera ovala, Stellaria Holostea, Caltha palustris, Isopyrum thatictroides, Ranunculus Ficaria, $R$. acer, R. lanuginosus, Corydalis solida, Alliaria officinalis, Viola silvestris, Lythrum Salicaria, L. virgatum, Angelica silvestris, Pimpinella maior, Aegopodium Podagraria, Lysimachia nummularia, Pulmonaria obscura, Stachys silvatica, Aiuga reptans, Salureia vulgaris, Lamium maculatum, L. luteum, Glechoma hederacea, Lycopus europaeus, L. exallatus, Scrophularia nodosa, Lathraea squamaria, Galium Aparine, Carduus crispus usw. Aber auch seltenere Arten sind gelegentlich in den Marchauen zu finden, wie Leonurus Marrubiastrum und die prächtig blaue Clemalis integrifolia.

Einen etwas andern Aufbau zeigen die Auenwälder der Donau von Krems abwärts bis zum Durchbruche durch die Karpathen bei Preßburg. Hier sind vor allem Populus alba und $P$. nigra tonangebend, neben ihnen auch Salix alba und S. fragilis und an zeitweise innundierten Stellen auch Alnus incana. Aber auch Ulmus glabra und $U$. laevis treten oft bestandbildend auf und bilden die im Gegensatze zu den aus weichen Holzarten (Salix, Populus) gebildeten „,weichen" Auen die, ,harten Auen". Ferner ist Acer campestre ein häufiger Baum der Donauau, seltener treten Belula pendula, Pirus Pirasler, Carpinus Belulus und, jetzt wenigstens, Quercus sessiliflora auf. Im Unterholze sind Sambucus nigra, Prunus Padus, Cralaegus monogyna vorherrschend; überdies finden sich auch noch Pirus Piraster, Rhamnus Frangula, R. catharlica und Weidenarten (Salix alba, fragilis, triandra, purpurea, incana). Dicse Salixarten, besonders Salix purpurea und S. incana sowie Alnus incana, Hippophä̈ rhamnoides und Myricaria germanica, bilden oft auf den Schotterbänken des Flusses eigene Gehölze.

Von Schlingpflanzen ist in den Donauauen Humulus Lupulus überall gemein, auch Clematis Vitalba ist nicht selten; von Wien abwärts aber tritt auch schon Vilis silvestris auf, die gegen Ungarn zu immer häufiger wird. Im Niederwuchs ist überall dort, wo der Boden nicht regelmäßig inundiert wird, 
Galanthus nivalis in Tausenden und Abertausenden von Exemplaren im ersten Frühling vertreten; später aber bildet Parielaria officinalis oft auf weite Strecken hin Massenvegetation. Von sonstigen Arten des Niederwuchses sind noch Arum maculatum *immaculalum, Allium ursinum, Gagea lulea, Scilla bifolia, Agropyrum caninum, Anemone ranunculoides, Cardamine Impatiens, Geum urbanum, Aegopodium Podagraria, Lysimachia nummularia, Stachys silvalica, Scutellaria galericulala, Adoxa moschalellina, Lalhraea squamaria, Carduus crispus, Dipsacus pilosus, Eupatorium cannabinum bemerkenswert.

\section{b) Buschformationen.}

Sommergrüne Buschgehölze. Von niedrigem Buschwerke bewarhsene Hänge sind im Hügellande des südlichen Mährens und des nordöstlichen Niederösterreichs eine weit verbreitete Erscheinung. Besonders am Rande und zwischen den Weingärten bildet sich diese Formation gerne aus. Die Zusammensetzung derselben ist äußerst mannigfach. Dic vorwiegenden Sträucher sind meist Quercus pubescens, Prunus frulicosa, P. Mahaleb, Cornus sanguinea und Viburnum Lantana; außerdem kommen aber von Holzgewächsen auch Juniperus communis, Corylus Avellana, Ulmus glabra var. suberosa, Acer campestre, Evonymus vulgaris, E. verrucosus, Staphylea pinnala, Rosa dumetorum, $R$. coriifolia, R. rubiginosa, R. agrestis, Coronilla Emerus, Tilia cordala, Viburnum Opulus, Cornus Mas, Lonicera Xylosleum, Lycium halimifolium nicht selten vor. Von Lianen ist Clematis Vitalba überall häufig, viel seltener ist Lonicera Caprifolium. Häufig sind auch die hohen Stauden von Sambucus Ebulus hier anzutreffen. Der Niederwuchs ist ebenfalls sehr mannigfach und gelegentlich können alle Arten der Triftformationen hier auftreten. Besonders häufig sind aber die Zwergsträucher aus der Familie der Leguminosen, wie Cytisus nigricans, C. supinus und $C$. Kilaibelii; ferner treten im Gebüsche gern auf Melica ciliala, Bromus sterilis, Aristolochia Clematilis, Sisymbrium Loeselii, Descurainia Sophia, Geranium sanguineum, Polentilla recta, $P$. canescens, Lavalera thuringiaca, Lithospermum purpureocoeruleum, Slachy; recla, Lachuca Scariola und L. viminea.

Uiergebische. Diese Formation zeight im Gebiete dieselbe Zusammensetzung wie allenthalben in Mitteleuropa. Salix alba, S. fragilis, S. triandra, S. purpurea, S. viminalis, Alnus glulinosa, Rhamnus Frangula, Sambucus nigra sind stets häufig, seltener sind Populus alba, Salix caprea, S. daphnoides und S. pentandra anzutreffen. Von Schlingpflanzen sind Polygonum dumelorum, Humulus Lupulus und Calystegia sepium allgemein verbreitet; bemerkenswerter ist die im Gebüsche kletternde seltene Asperula rivalis. Im Niederwuchs sind Festuca arundinacea, Rumex sanguineus, Callha palustris, Ranunculus repens, Filipendula Ulmaria, Lylhrum Salicaria, Mentha longifolia, M. verticillala, M. aquatica, Scrophularia alala, Veronica Anagallis aquatica, Graliola officinalis, Lycopus europaeus, Chrysanthemum vulgare, Eupalorium cannabinum, Cirsium oleraceum nirgends selten. 


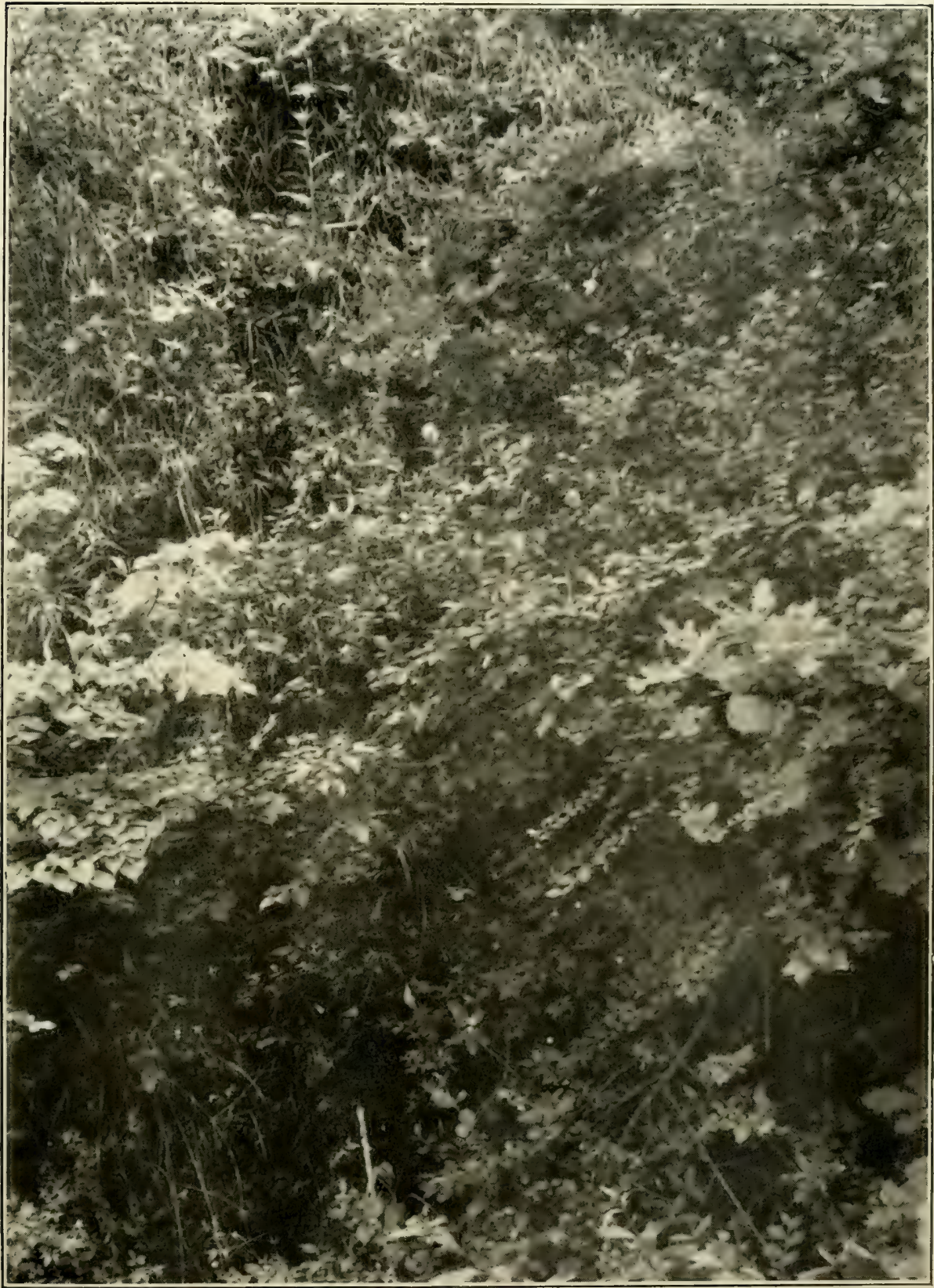

Abb. 52. Buschgehölz bei Schlapanitz nächst Brünn.

Tilia cordata, Cotoneaster integerrima, Quercus pubescens.

(Nach einer Aufnahme von Prof. H. Iltis, Brünn.) 



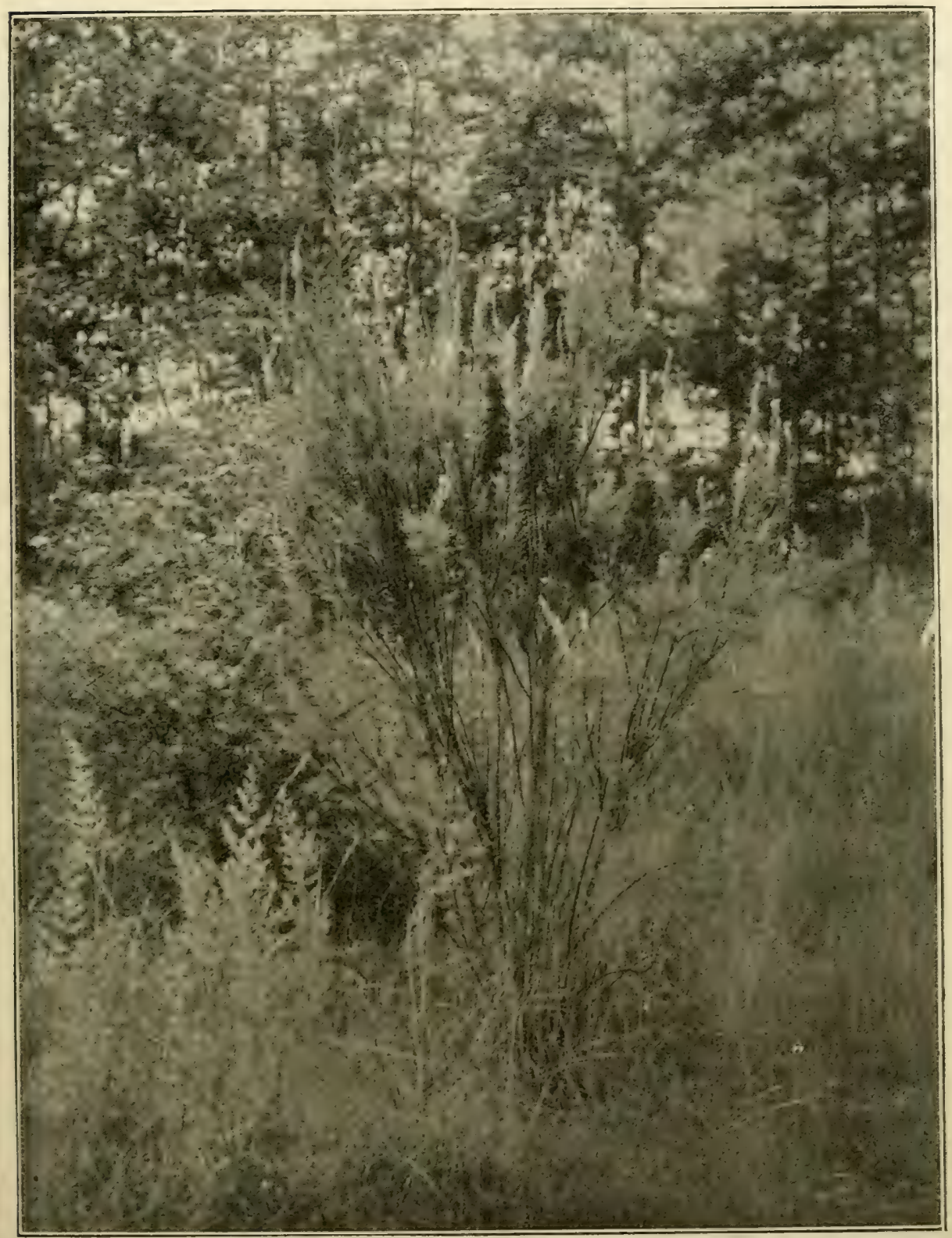

Abb. 53. Myricaria germanica und Cialamagrostis Epigeios auf Schotter in den Donauauen der Lobau bei Wien.

(Nach einer Aufnahme von Prof. Amalie Mayer, Wien.)

(Aus der Bildersammlung des botanischen Institutes der Viener Universität.)

Auf den Schotterbänken der Donau aber zeigt sich ein anders zusammengesetztes Buschwerk. Hier ist Salix incana die dominierende Pflanze, auch die im Herbste durch seine orangeroten Beeren sehr auffallende Hippophaë 
rhamnoides ist stellenweise in großer Menge anzutreffen; ferner lkommen Salix purpurea, Populus nigra, Alnus incana und Myricaria germanica als häufige Arten in Betracht. Schling- und Kletterpflanzen sind vorwiegend Cucubalus baccifer, Clematis Vilalba, Solanum Dulcamara und Humulus Lupulus. Im Niederwuchs sind-Bromus sterilis, Agropyrum caninum, Saponaria officinalis, Oenothera biennis, Eupalorium cannabinum, Inula brilannica, Carlina vulgaris, Cirsium arvense und Hicracium Pilosella häufig.

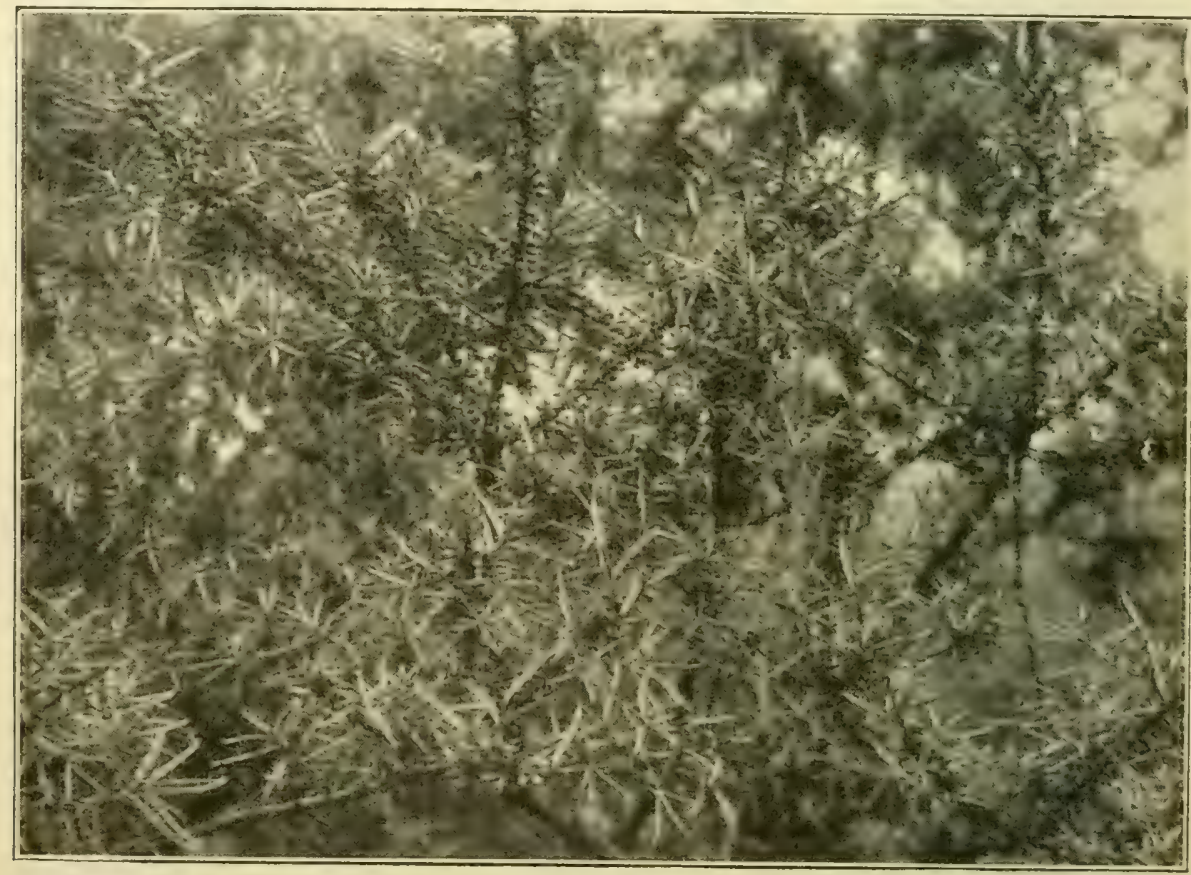

Abb. 54. Hippophaë rhammoides in der Lobau bei Wicn.

(Nach einer Aufnahme von Prof. Amalie Mayer, Wien.)

- (Aus der Bildersammlung des botanischen Institutes der Wiener Universität.)

\section{c) Heideformationen.}

Die Heidle. Am Abhange des Böhmisch-mährischen Höhenzuges und des Mannhartsberges, im Hügellande zwischen Brünn und Znaim sowie endlich auch noch im Vorlande der Ostsudeten treten auch noch stellenweise typische Heideformationen auf. Calluna vulgaris ist hier stets die tonangebende Pflanze, während andere Ericazeen fehlen oder höchstens durch Vaccinium Myrlillus vertreten sind. Hingegen sind für die Heideformation charakteristische Arten Anthoxanthum odoralum, Festuca ovina, Rumex Acelosella, Scleranthus perennis, Viscaria vulgaris, Linum catharlicum, Potentilla erecta, Thymus ovalus, Echium vulgare, Euphrasia stricta, Jasione montana, Anlennaria dioeca, Hieracium Pilosella und vor allem die halbstrauchigen Ginsterarten Genista lincloria und G. germanica. Von anderen Arten, die gelegentlich in der Heide vorkommen, 
seien Briza media, Luzula campestris, Cerastium vulgalum, Euphorbia Cyparissias, Saxifraga granulata, Polentilla argentea, Polygala vulgaris, Aiuga genevensis, Hypericum perforalum, Helichrysum arenarium, Solidago Virga aurea, Crepis lectorum genannt. Am Abhange des Berglandes gegen die Ebene treten gelegentlich auch Arten der Steppe in die Heide ein, wie Festuca sulcala, F. glauca, Dianthus Carthusianorum, Veronica spicata, Anthemis lincloria и. a.

Sandgrasiluren. Auf den Sandflächen des südlichen Mährens und des Narchfeldes sind vielfach Sandgrasfluren entwickelt, die in ihrer Zusammensetzung sehr an dic Sandgrasfluren Zentralböhmens und Galiziens erinnern und in mehreren voneinander abweichenden Typen auftreten.

a) Die Silbergrasflur. Hier ist Corynephorus canescens mit seinen borstlichen blaugrünen Blättern stets weitaus vorherrschend und bedeckt in lockerem Bestande oft weithin den Boden. Nit ihm treten von anderen Gräsern noch auf: Digilaria ciliaris, Koeleria glauca, Eragrostis pilosa, Poa compressa, Festuca vaginala, Bromus teclorum und B. hordaceus. Auch die Begleitpflanzen sind meist mitteleuropäische Arten, wie Cerastium semidecandrum, G. glulinosum, Holosleum umbellalum, Tunica prolifera, Silene conica, S. Otiles, Anemone nigricans, Alyssum alyssoides, Draba verna, Euphorbia Cyparissias, Potentilla argentea, P. arenaria, Hypericum perforalum, Cynoglossum officinale, Armeria elongata, Thymus anguslifolius, Jasione montana, Plantago ramosa, Hieracium Pilosella.

b) Die Fingergrasflur. Besonders auf gerodetem und noch nicht wieder aufgeforstetem Terrain tritt Digilaria ciliaris oft in großen Massen auf. Begleitpflanzen derselben sind Bromus lectorum, B. hordaceus, Eragrostis minor, Polygonum aviculare, Chenopodium Botrys, Salsola Kali, Polycnemum arvense, Scleranthus annuus, S. perennis, Arenaria serpyllifolia, Porlulaca oleracea, Viola arvensis, Trifolium arvense, Veronica arvensis, V. Dillenii, Crepis lectorum.

c) Die In äueltrift. Auf festerem Sandboden treten auch die ScleranthusArten, S. perennis, S. annuus und S. intermedius oft in tonangebender Menge auf. In ihrer Gesellschaft sind besonders Polenlilla arenaria, $P$. argentea und $P$. Wiemanniana oft zahlreich vorhanden und können selbst vorherrschend werden. Auch Herniaria glabra ist meist sehr häufig. Regelmäßige Begleitpflanzen sind ferner Gagea pusilla, Rumex Acelosella, Euphorbia Cyparissias, Sisymbrium Sinapistrum, Alyssum alyssoides, Viola arenaria, Sedum boloniense, Plantago ramosa, Thymus angustifolius, Jasione montana, Erigeron canadense, Taraxacum laevigalum, Hieracium seligerum. Ferner kommen ṇoch Ornilhogalum Bouchéanum, Lepidium campestre, Helianlhemum ovalum, Arenaria serpyllifolia, Sedum acre, Oenolhera biennis, Aiuga genevensis, Galeopsis Ladanum, Orobanche alba, Lappula echinala, Lycopsis arvensis, Veronica Dillenii, Linaria genistifolia, Taraxacum serolinum, Achillea collina, Anlhemis rulhenica, Carlina vulgaris, Crepis leclorum vor. 


\section{d) Grasflurformationen.}

Talwiesen. Besonders in den Niederungen an der March und Thaya sind in Mittel- und Südmähren und auch in Niederösterreich oft ausgedehnte Wiesenbestände entwickelt, die vielfach, besonders dort, wo regelmäßiger Eisgang die Entwicklung eines Baumwuchses behindert, gewiß ursprüngliche Formationen darstellen. Das vorherrschende Gras ist hier zumeist Triselum flavescens; ferner sind Alopecurus pratensis, Phleum pratense, Anthoxanthum odoralum, Holcus lanalus, Avena pralensis, Arrhenaterum elatius, Daclylis glomerala, Fesluca elatior häufig. Von den Begleitpflanzen ist besonders Cirsium rivulare meist in großer Menge vertreten, auch Gcranium pralense, Carum Carvi, Pimpinella maior, Anlhriscus silvester, Heracleum Spondylium, Campanula palula, Galium verum, G. Mollugo, Crepis biennis, Centaurea Jacea sind sehr häufig; von sonstigen Arten seien Dianthus superbus, Vicia sepium, Trifolium repens, T. pratense, T. hybridum, T. montanum, Lathyrus pratensis, Girsium cañum, G. oleraceum, Chrysanthemum Leucanthemum genannt; im nördlichsten Teile des Gebietes treten auch noch Polygonum Bistorta und Trollius europaeus auf den Talwiesen auf.

Sumpiwiesen und Wiesenmoore. Auch Sumpfwiesen sind in den Niederungen der March und Thaya sehr verbreitet, während Hochmoore im ganzen Gebiete von Mittei- und Südmähren (mit Ausnahme des Böhmisch-mährischen Gebirges und der Karpathen) ebenso wie im nordöstlichen Niederösterreich fehlen. Die Flora dieser Sumpfwiesen ist gewöhnlich sehr reich. Von Gräsern sind Agrostis vulgaris und A. alba, Alopecurus aequalis, Deschampia caespitosa, Poa palustris, P. trivialis, Molinia coerulea, Glyceria plicala und G. fluitans nicht selten; an Zahl werden sie aber meist von den Gyperazeen übertroffen, von denen Carex gracilis, $C$. elala, $C$. caespilosa gewöhnlich in tonangebender Menge vorhanden sind, begleitet von Carex Davalliana, G. paniculata, G. paradoxa, C. vulpina, $C$. canescens, $G$. elongata, $C$. dislicha, $G$. Goodenoughii, $C$. glauca, C. panicea, G. Pseudocyperus, C. flava, C. aculiformis, G. vesicaria, G. rostrata, G. lasiocarpa, C. hirla, Eriophorum anguslifolium, Scirpus silvalicus und verschiedenen Juncazeen, besonders dem stellenweise sehr häufigen Juncus alralus. Auf diesen Wiesen kommen häufig vor Equisetum palustre, Triglochin palustre, Allium angulosum, Epipactis paluslris, Orchis incarnala, Iris sibirica, Dianlhus superbus, Stellaria palustris, Thaliclrum lucidum, Ranunculus acer, $R$. repens, Cardamine pratensis, Barbaraea vulgaris, Geum rivale, Polentilla palustris, $P$. anserina, Trifolium hybridum, T. fragiferum, Lotus lenuis, Galega officinalis, Lathyrus palusler, Geranium pralense, G. palustre, Euphorbia villosa, E. palustris, Viola elalior, Lylhrum Salicaria, Silaus pratensis, Laserpilium prulhenicum, Heracleum Spondylium, Lysimachia Ihyrsiflora, Gentiana Pneumonanthe, Cenlaurium pulchellum, Slachys paluslris, Sculellaria galericulala, Teucrium Scordium, Mentha verlicillala, Aleclorolophus maior, Veronica longifolia, Galium boreale, G. palustre, Succisa pratensis, Taraxacum paludosum, Scorzonera humilis, Senecio aquaticus, Cirsium paluslre, $C$. canum, C. oleraceum, C. rivulare u. v. a. und bei Olmütz auch Oslericum paluslre. 
Bergwiesen. Ungedüngte Bergwiesen treten im mittleren Mähren fast stets in der Facies der Burstwiese auf, wo Bromus erectus das vorherrschende Gras ist. Außerdem sind besonders Festuca elatior, Dactylis glomerala, Cynosurus cristatus, Poa angustifolia stets in Menge vorhanden. Andere, nicht seltene Gräser und Scheingräser sind Phleum pralense, P. phleoides, Triselum flavescens, Avena pratensis, A. pubescens, Arrhenatherum elatius, Poa trivialis, Fesluca rubra, F. sulcata, Carex verna, C. montana, Luzula campestris. Von sonstigen häufigeren Arten der Bergwiesen seien genannt: Orchis militaris, Gymnadenia conopea, Silene nulans, S. vulgaris, Dianthus Carthusianorum, Ranunculus acer, R. bulbosus, Anemone grandis, Arabis hirsula, Polygala maior, Linum lenuifolium, L. austriacum, L. catharlicum, Geranium pratense, Sanguisorba officinalis, Trifolium alpestre, T. rubens, Anlhyllis vulneraria, Lolus corniculalus, Coronilla varia, Lathyrus silvestris, Helianthemum ovalum, Carum Carvi, Daucus Carola, Pimpinella Saxifraga, Primula veris, Salvia pralensis, Aleclorolophus maior, A. minor, Veronica Chamaedrys, Orobanche gracilis, O. lutea, Plantago media, P. lanceolata, Knaulia arvensis, Asperula glauca, Galium verum, G. Mollugo, Phyleuma orbiculare, Campanula glomerala, Inula hirla, Buphthalmum salicifolium, Carlina acaulis, Cenlaurea Jacea, C. Scabiosa, Picris hieracioides, Crepis praemorsa, Hieracium Auricula, H. Bauhini, H. pralense.

Steppenwiesen. Dort, wo die Bodenfeuchtigkrit größer und die den Burlen bedeckende Sandschichte von geringer Mächtigkeit ist, tritt oft eine Formation auf, die als Bindeglied zwischen der Formation der Talwiesen und den eigentlichen Steppen angesehen werden kann. Die vorherrschenden Gräser sind hier Phleum phleoides, Avena pratensis, A. pubescens, Arrhenatherum elatius, Holcus lanalus, Andropogon Ischaemumiund Briza media, also durchwegs andere Arten als auf den eigentlichen Steppen. Von Begleitpflanzen kommen einerseits typische Wiesenpflanzen vor, wie Rumex Acetosa, Dianthus Carthusianorum, D. Pontederae, Silene nulans, S. vulgaris, Viscaria vulgaris, Medicago lupulina, Trifolium monlanum, Lotus corniculatus, Vicia Cracca, Agrimonia Eupatoria, Pimpinella Saxifraga, Pastinaca saliva, Daucus Carota, Polygala vulgaris, Salvia pratensis, S. verlicillata, Slachys officinalis, Brunella vulgaris, Galium verum, Knautia arvensis, Centaurea Jacea, Picris hieracioides, Leontodon hispidus, anderseits aber auch Bewohner der Steppen und der Triftformation, z. B. Koeleria gracilis, Berteroa incana, Anthyllis polyphylla, Seseli annuum, Peucedanum Oreoselinum, Cytisus nigricans, Coronilla varia, Sanguisorba minor, Euphrasia stricta, Armeria elongala, Anchusa officinalis, Echium rubrum (selten), Potenlilla Wiemanniana, P. canescens, Scabiosa ochroleuca, Veronica Teucrium, Asperula cynanchica, Achillea pannonica, Verbascum Blatlaria, V. phoeniceum, Centaurea rhenana, C. Scabiosa, Hieracium florentinum, H. Bauhini. Besonders auffallend aber ist das Auftreten von Radiola linoides in dieser Formation.

Die Sandsteppe. Auf den Sandfeldern der Marchebene in Südmähren und im angrenzenden Niederösterreich sind Steppenformationen, die mit den Sandsteppen der großen ungarischen Tiefebene eine große Ủbereinstimmung 
zeigen, vertreten. Doch bestehen anderseits auch wieder starke Anklänge an die Sandheiden des Norddeutschen Tieflandes und oft genug kann man eine innige Mengung pontischer und mitteleuropäischer Florenelemente beobachten, so Corynephorus canescens neben Stipa capillala, Scleranthus perennis neben Gypsophila paniculala, Armeria elongata neben Melandryum viscosum. Man kann verschiedene Typen der Sandsteppe unterscheiden, unter denen die Federgrassteppe zwar nicht die verbreitetste, wohl aber die charakteristischeste Formation darstellt. Stipa capillata ist hier meist das tonangebende Gras, begleitet von Stipa pennala, Andropogon Ischaemum, Koeleria glauca, $K$. gracilis, Festuca vaginata und Poa compressa. Von den übrigen Arten dieser Formation seien noch Ceraslium semidecandrum, Minuarlia verna, Dianthus serolinus, Melandryum viscosum, Gypsophila paniculala, Erysimum canescens, Polentilla argentea, P. collina, Coronilla varia, Plantago ramosa, Armeria elongala, Helichrysum arenarium, Achillea setacea, Chondrilla juncea, Hieracium Pilosella und $H$. echioides genannt.

Eine andere Fazies der Sandsteppe stellt die Bartgrasflur dar, in der Andropogon Ischaemum unter den Grüsern dominiert, von Tragus racemosus, Digitaria ciliaris, Koeleria gracilis, K. glauca und Fesluca vaginata begleitet, während von sonstigen Pflanzen Gagea pusilla, Polygonum aviculare, Holosteum umbellatum, Cerastium semidecandrum, Minuarlia verna, Dianthus serolinus, Draba verna, Rapistrum perenne, Euphorbia Gerardiana, Seseli Hippomarathrum, Anchusa officinalis, Plantago ramosa, Arlemisia scoparia, Helichrysum arenarium, Achillea selacea und Hieracium Pilosella die augenfälligsten sind.

Die Formation des Steppenhaiers. An wenigen Punkten bildet auf Jurakalkhügeln in Südmähren und dem angrenzenden Niederösterreich der Steppenhafer (Avena desertorum) fast reine Bestände, in die sich von anderen Gräsern höchstens Slipa pennala, Koeleria gracilis und Fesluca sulcata und glauca einmengen, während von den sonstigen Begleitpflanzen Dianlhus Pontederae, Minuarlia selacea, Anemone grandis, Erysimum canescens, Astragalus austriacus, Cylisus ratisbonensis, Euphorbia Gerardiana, Asperula glauca und Jurinea mollis die augenfälligsten sind.

\section{e) Xerophile Staudenformationen.}

Die pannonische Triftiormation. Ähnlich wie im Vorlande der Karpathen und im westungarischen Berglande ist auch in Mähren und im nordöstlichen Niederösterreich an den Hängen des Hügellandes allenthalben eine Formation ausgebildet, die zwar den Grasflurformationen nahesteht, aber durch das starke Überwiegen der diliotylen Stauden und Halbsträucher über die Gräser von denselben abweicht und im Frühlinge und Frühsommer sich durch einen außerordentlichen Blütenreichtum auszeichnet. Im Gegensatze zu den Heideformationen fehlt aber der typische Trift Calluna vulgaris gänzlich. Hier in Südmähren freilich, wo das pannonische Florengebiet direkt an das herzynische angrenzt, kommt es allerdings vor, daß auch Typen der Heide gelegentlich in der Trift- 
formation vorkommen und so diese zwei sonst so scharf voneinander getrennten Formationen durch Übergänge miteinander verbunden sind. Dies ist insbesondere im Gebiete der oberen Thaya, in der Umgebung von Znaim und Retz mitunter der Fall.

Die Gräser der Triftformation sind hauptsächlich Steppengräser, wie Andropogon Ischaemum, Stipa pennata, Phleum phleoides, Koeleria gracilis. Bromus erectus, Festuca glauca und $F$. sulcata, auf Kalkboden ab und zu auch Sesleria varia. Dazu gesellen sich von Gyperazeen Carex verna, C. montana C. Michelii und insbesondere die charakteristische Carex humilis. Von Halb-

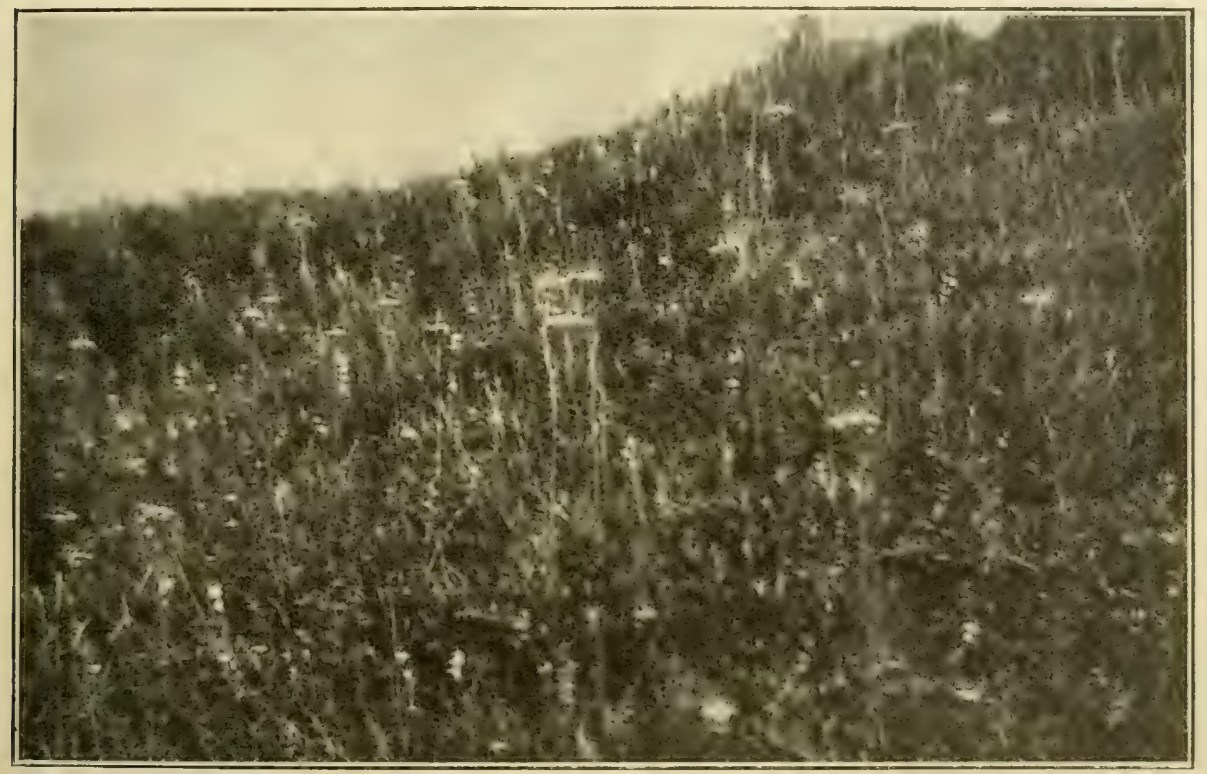

Abb. 55. Umbelliferen-Trift bei Nebotein nächst Olmütz.

Peucedanum Cervaria, P. alsaticum, Campanula glomerata, Centaurea Scabiosa, Avena pratensis.

(Nach einer Aufnahme von J. Pauer, Olmütz.)

(Nach Podpěra, Květena Hané.)

sträuchern ist besonders Cylisus Kitaibelii stellenweise in tonangebender Menge vorhanden, aber auch andere Leguminosen, wie Cytisus supinus, C. nigricans, C. albus, Genista pilosa sind keineswegs selten und ab und zu trifft man auch die kleinen Sträucher der Rosa gallica und $R$. spinosissima. Von niedrigen Stauden sind im ersten Frühling durch ihren bunten Blütenflor insbesonders Anemone nigricans, A. grandis, Adonis vernalis, Polentilla arenaria, P. Gaudini, Helianthemum canum, Globularia Willkommii in die Augen fallend, später dann Dianthus Carthusianorum, Anemone silveslris, Arabis hirsula, A. auriculata, Alyssum montanum, A. Arduini, Erysimum canescens, Diplotaxis lenuifolia, Geranium sanguineum, Linum tenuifolium, L. flavum, Euphorbia Cyparissias, Polygala maior, Dictamnus albus, Trifolium rubens, T. alpestre, T. montanum, T. ochroleucum, Anthyllis polyphylla, Astragalus Onobrychis, 
Coronilla montana. G. varia, Lathyrus silvester, Seseli annunm, S. Beckii, Libanolis montana, Bupleurum falcalum, Pencedanum Cervaria, P. alsalicum, Lithospermum purpurencoeruleum, L. officinale, Nonnea pulla, Onosma Visianii, Teucrium montanum, Sideritis montana, Stachys recta, Salvia nemorosa, S. pralensis, Thymus Marschallianus, Linaria genislifolia, Veronica Teucrium, Melampyrum cristatum, Odontites lutea, Orobanche alba, Asperula glauca, Valeriana officinalis, Campanula sibirica, Phyleuma orbiculare, Aster Amellus, Inula germanica, I. hirta, I. Oculus Christi, I. ensifolia, Buphthalmum salicifolium, Anthemis tinctoria, Achillea collina, A. pannonica, Chrysanthemum corymbosum, Arlemisia Absinthium, A. pontica, A. austriaca, Senecio campestris, Cenlaurea Scabiosa, Tragopogon dubius, T. orienlalis, Scorzonera hispanica, S. auslriaca, S. purpurea, Lacluca Scariola, Crepis praemorsa, Hypochoeris maculata, Hieracium Bauhini, H. seligerum. Einen besonderen Schmuck dieser Formation aber bilden die prächtigen Irisarten und Orchideen, wie Iris pumila, I. variegala, Orchis militaris, Gymnadenia conopea und die allenthalben seltenen Arten Himanloglossum hircinum, Ophrys fuciflora und in Niederösterreich auch $O$. aranifera und O.apifera.

Die Beifubtrift. Auf festerem Sand-und besonders auf mehr schotterigem Boden treten auch Arlemisia campestris und A. scoparia bestandbildend auf. Von Gräsern ist in dieser Formation fast nur Bromus lectorum vertreten, selten findet man noch Koeleria gracilis, Phleum phleoides, Cynodon Dactylon, Poa compressa, Carex hirla und $G$. supina. Hingegen treten andere hochwüchsige Stauden neben den Beifußarten oft in Menge auf, z. B. Asparagus officinalis, Kochia arenaria, Salsola Kali, Silene Otites, Dianthus Carthusianorum, Berteroa incana, Erysimum canescens, Coronilla varia, Hypericum veronense, Oenothera biennis, Eryngium campestre, Linaria genistifolia, Verbascum thapsiforme, V. phlomoides, Echium vulgare, Anchusa officinalis, Scabiosa ochroleuca, Centaurea rhenana, C. Scabiosa, Chondrilla juncea, Grepis rhoeadifolia, Hieracium setigerum. Ferner sind nicht selten Allium flavum, Anthericum ramosum, Papaver Argemone, Fumaria Vaillantii, Medicago falcala, Thymelaea Passerina, Thymus angustifolius, Th. Marschallianus, Salureia Acinos, Teucrium Chamaedrys, Orobanche alba, Veronica spicala, Nonnea pulla, Cuscula Epithymum, Filago montana, Helichrysum arenarium, Achillea pannonica, Scabiosa canescens, Crepis tectorum, Hieracium Pilosella.

Die Formation des rosmarinblättrigen IV eidenröschens. Auf den Schottern der Ufer und der größeren Sandbänke der Flüsse, besonders der Donau bei und unter Wien, findet man regelmäßig eine Formation ausgebildet, die mit der eben geschilderten eine gewisse Ähnlichkeit besitzt. Chamaenerion palustre (Epilobium Dodonaei) bedeckt hier den Boden oft in solcher Menge, daß zu seiner Blütezeit weite Strecken rot gefärbt erscheinen. Regelmäßige Begleiter desselben sind Oenothera biennis und Oe. muricala, ferner Erigeron canadensis, das ebenfalls oft Massenvegetation bildet. Das spärliche Buschwerk besteht aus Populus nigra, Hippophä̈ rhamnoides und Rubus caesius, zwischen dem Bromus slerilis, B. teclorum und Agropyrum repens als die Vertreter der 
Gräser gedeihen. Seltener sind kleine Bestände von Calamagroslis Epigeios. Häufige Arten der Flora dieser Schotterbänke sind ferner Erysimum canescens, Sisymbrium Sinapistrum, S. orientale, Draba verna, Arabis arenosa, Rapislrum perenne, Silene Otites, Kochia scoparia, Anchusa officinalis, Linaria genistifolia, Verbascum phlomoides, Echium vulgare, Centaurea rhenana, Crepis tectorum, Hieracium Pilosella und $H$. florentinum. Hie und da entwickeln sich auch kleine Moosrasen, vorwiegend aus Bryum argenteum und Ceralodon purpureus, zwischen denen nicht selten die von der Donau herabgeschwemmte Selaginella helvelica zu finden ist.

Die Felsenflora. Abgesehen von vereinzelten Standorten ist eine reichere Felsenflora in Südmähren besonders an den Steilabstürzen des Thayatales bei Frain und Znaim und an den Polauer Bergen bei Nikolsburg sowie in der Umgebung von Brünn, ferner im nordöstlichen Niederösterreich an den Staatzer Felsklippen entwickelt, die trotz der Verschiedenheit der geologischen Unterlage überall ziemlich die gleiche Ausbildung zeigt. Teils sind es Arten der Triftformation, die hier gedeihen, wie Stipa pennata, Iris pumila, I. variegata, Bupleurum falcalum, Alyssum monlanum, Cynanchum Vinceloxicum, Stachys recta, Achillea Neilreichii, teils typische Felsenpflanzen, wie Allium montanum, A.flavum, Seseli Beckii, Sempervivum soboliferum, Teucrium monlanum, Alyssum Arduini, endlich kommen auch einzelne Voralpengewächse daselbst vor, wie Sesleria varia, Saxifraga Aizoon und an den Polauer Bergen Arenaria grandiflora.

\section{f) Die Formationen des Salzbodens.}

Sowohl im südlichen Mähren, bei Tellnitz, Groß-Seelowitz, Pausram, Auspitz, Nikolsburg, als auch im nördlichen Niederösterreich im Pulkatale unı stellenweise im Marchfelde, ist der Boden an manchen Orten sehr reich an Salz und an solchen Stellen treten dann Halophytenfluren auf, die viel Gemeinsames mit denen des ungarischen Tieflandes haben. Die wichtigsten Typen dieser Halophytenfluren sind:

Salzwiesen. Diese Formation tritt besonders auf feuchtem, humusreichem Boden auf, sobald derselbe einen stärkeren Salzgehalt aufweist. Von Gräsern ist eigentlich nur Atropis distans in größerer Menge vertreten, seltener sind Agrostis alba, Agropyrum repens und Carex distans, während Juncus Gerardi wohl nirgends fehlt. Von dikotylen Stauden sind vor allem Asler Tripolium, Lotus tenuis und Plantago maritima überall vertreten und bilden oft Massenvegetation. Auch Melilotus dentatus und Triglochin maritimum sind stellenweise häufig. Von anderen Arten, die gelegentlich auf den Salzwiesen vorkommen, seien insbesondere Heleochloa schoenoides,! Atriplex hastatum, A. lalaricum, Spergularia media, Lolus uliginosus, L. corniculalus, Centaurium pulchellum, Ononis spinosa, Cirsium canum, Scorzonera humilis, Achillea asplenifolia, Taraxacum bessarabicum genannt.

Salzsïmpie. An den das salzhaltige Terrain durchziehenden Gräben findet sich oft eine charakteristische Vegetation, aus Schoenoplectus Tabernae- 


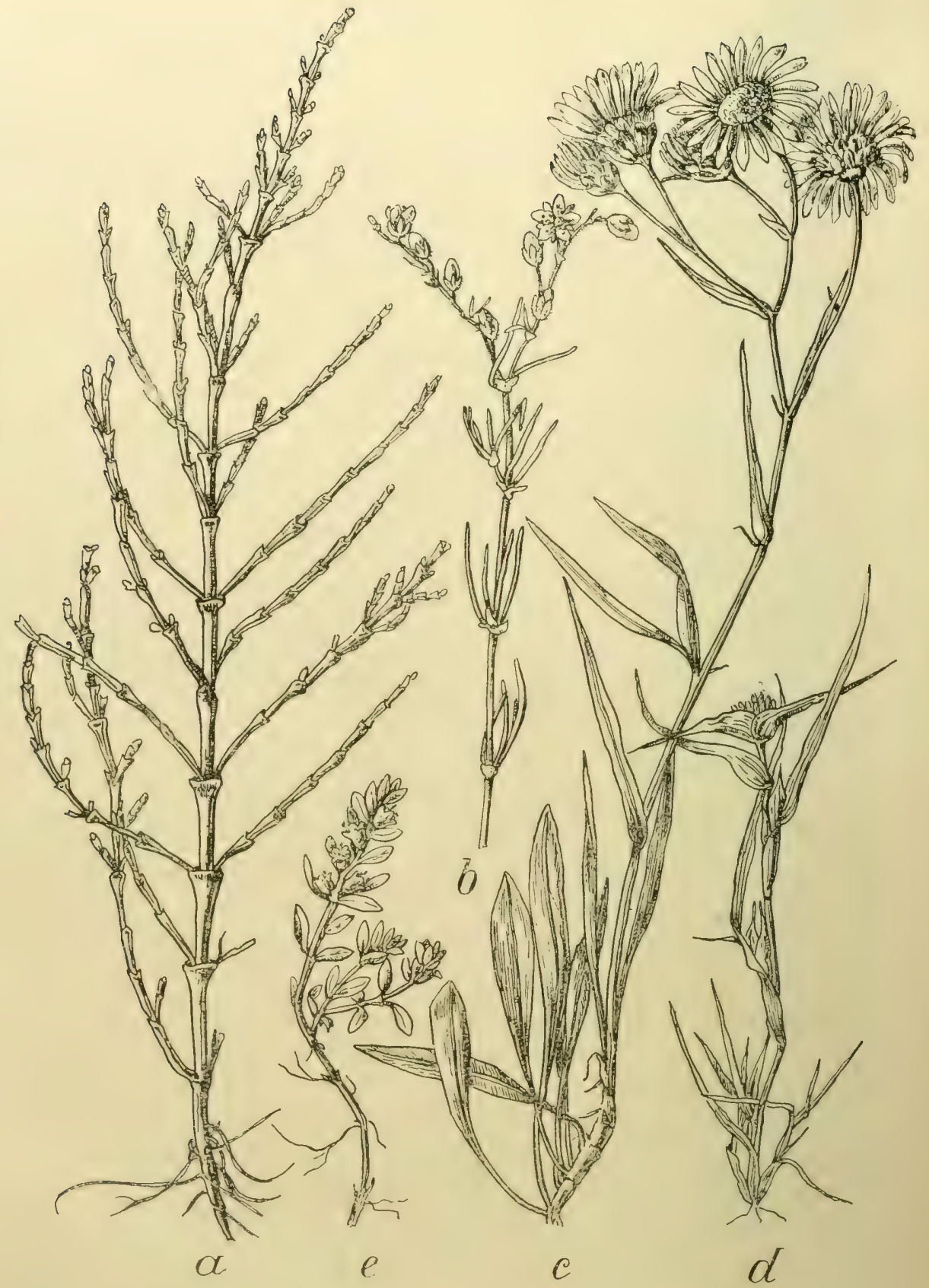

Abb. 56. Aus der südmăhrischen Halophytenflora.

$a$ Salicornia herbacea. $b$ Spergularia media. $c$ Aster Tripolium. $d$ Crypsis aculeata. $e$ Glaux maritima. 
montani, Scirpus maritimus, Phragmites communis, Pumex odonlocarpus, Lycopus europaeus und Asler Tripolium gebildet.

Die Salztriftiormationen. Auf mehr trockinem, salzreichem Borlen bildet in der Regel Salicornia herbacea Massenvegatation und bedeckt dann oft in so dichtem Bestande den Boden, daß derselbe weithin braunrot gefärbt erscheint. Begleitpflanzen der Salicornia sind in der Regel Heleochloa schoenoides, Crypsis aculeala, Atropis dislans, Carex hordeistichos, Suaeda maritima, Spergularia salina, S. media, Bupleurum tenuissimum, Althaea officinalis, Scorzonera parviflora ; ferner kommen noch ab und zu Lotus tenuis, Tetragonolobus siliquosus, Atriplex hastata, Chenopodium rubrum, Plantago maritima, Lacluca saligna, Taraxacum bessarabicum, Aster Tripolium vor. Dort, wo der Boden weniger salzreich ist, ist gewöhnlich Atropis distans tonangebend, begleitet von Cynodon Dactylon, Carex hordeistichos, G. secalina, Juncus Gerardi, Chenopodium rubrum, C. glaucum, Atriplex latifolia, Lolus angustissimus, Melilolus dentatus, Trifolium fragiferum, Althaea officinalis, Glanx maritima, Plantago marilima, Scorzonera Jacquiniana usw.

\section{g) Sumpf- und Wasserformationen.}

Uferformationen. An den Ufern stehender und langsam fließender Gewässerr, besonders der Teiche, bilden Phragmiles communis, Calamagrostis Epigeios und C. Pseudophragmiles und Schoenoplechus lacustris stellenweise kleine Bestände, in denen Typha lalifolia, Sparganium simplex, Glyceria aquatica, Schoenoplectus Tabernaemontani, Scirpus marilimus, Carex disticha, $C$. riparia, $C$. vesi-

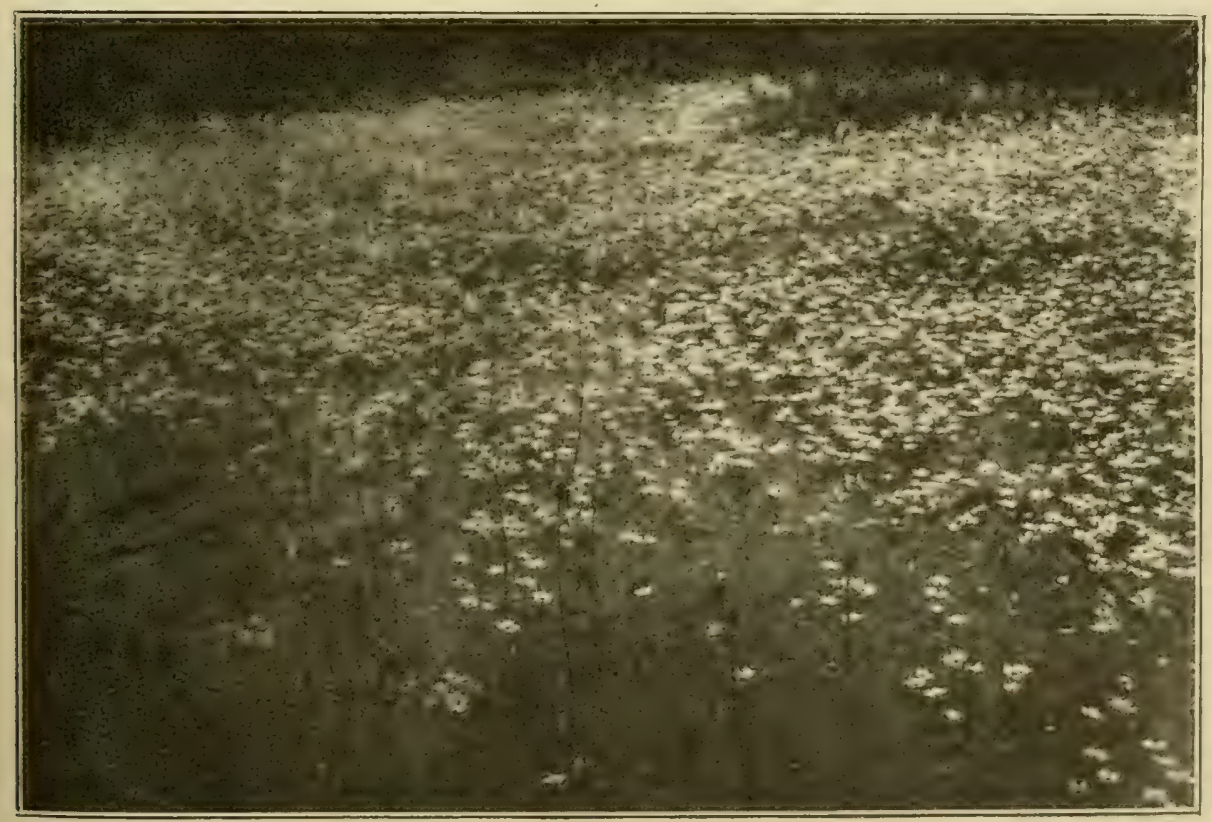

Abb. 57. Ranunculus agquatilis und Hottonia palustris in einem Tümpel bei Leipnils. (Nach ciner Aufnahme von Prof. F. Nabělek, Leipnik.) 
caria, C. Pseudocyperus, C. rostrata, C. acutiformis, Alisma Plantago aquatica, Bulomus umbellatus, Sagittaria sagittaefolia, ferner Euphorbia virgala, E. lucida, Filipendula Ulmaria, Cicula virosa, Oenanthe aqualica, Geranium palustre, Lythrum Salicaria, Gratiola officinalis, Senecio paludosus, S. fluviatilis auftreten. Auf feinsandigen Stellen der Ufer hingegen sind Heleochloa explicata, Cyperus flavescens, C.fuscus, Heleocharis acicularis, Juncus bufonius, Polentilla supina, Elatine Alsinastrum zu finden. An einigen Stellen tritt auch Marsilea quadrifolia auf.

Wasserpilanzen. Dit überall verbreiteten Wasserpflanzen, wie Polamogeton natans, P. lucens, P. crispus, P. pusillus, Lemna minor, L. trisulca, Polygonum amphibium. Tianunculus ayuatilis, Myriophyllum spicatum. Hollonia paluslris sind. natürlich auch in diesem Gebiete verbreitet. Eine besonders reiche Wasserflora aber weisen die toten Arme der March, besonders entlang ihres Unterlaufes, auf. Hier finden sich auch Polamogeton plantagineus und P. acutifolius, Hydrorharis Morsus ranae und Stratiotes aloides, Lemna gibba, Ceratophyllum demersum. Caslalia alba, Nuphar luleum und vor allem auch Trapa natans und Nymphoides pellata. Auch die toten Arme der Donau beherbergen eine reiche Flora, doch fehlt hier Trapa und (jetzt wenigstens) Nymphoides peltata, hingegen wurde daselbst neuestens Naias marina beobachtet.

\section{h) Kulturpflanzen.}

Getreidebau. Das mittlere und südliche Mähren sowie das nordwestliche Niederösterreich sind die wichtigsten Getreidebau betreibenden Gebiete Österreichs, wo vielfach auf weite Strecken hin der Boden ausschließlich mit wogenden Feldern bedeckt ist. Besonder's ist es Roggen und Weizen im Marchfelde sowic Weizen in der Hanna und im südlichen Mähren, die kultiviert werden; der Hafer- und Gerstenbau ist von geringerer Bedeutung. In Südmähren, besonders aber im Marchfelde, wird als zweite Frucht vielfach Buchweizen (Fagopyrum esculentum) gebaut. Auch Mais findet man in Südmähren und im nordöstlichen Niederösterreich nicht selten.

Gemüsebau. Kartoffeln writen allgemein kultiviert. Von großer Bedeutung aber ist der Bau von Gemüse, besonders von Kraut und Salat, in der nördlichen und östlichen Umgebung von Wien, besonders auf den Donaualluvien und im südlichen Marchfelde. In Mähren ist ferner die Kultur von Meerrettig [,,Kren“] (Armoracia rusticana) wichtig, ferner die Spargelkultur bei Eibenschitz, die übrigens auch in Niederösterreich, besonders um Langenzersdorf, betrieben wird.

Obstbau. Der Obstbau ist in den ebenen Gegenden Mährens und Niederösterreichs von geringerer Bedeutung und beschränkt sich meist auf die in den Gärten der Baurnhäus'r in den Dörfern gezogenen Zwetschken- und Birnbäume. Ausgedehnter ist der Obstbau im Hügellande, wo nicht nur Äpfel, Birnen und Zwetschken, sondern in den Weingärten auch Pfirsiche gezogen werden.

Weimbau. Sowohl in Südmähren als im nordöstlichen Niederösterreich wird im Hügellande der Weinbau intensiv betrieben. In Mähren reicht die 
Weinkultur nordwärts bis Brünn und erstreckt sich von hier bis an die March; die wichtigsten Weingebiete sind Znaim, Auspitz, Bisenz und Nikolsburg. In Niederösterreich ist das das Marchfeld im Osten begrenzende Hügelland bei Retz, Mailberg, Zellerndorf, Stinkenbrunn und von da südwärts bis an die Donau (Korneuburg, Bisamberg, Langenlois usw.), ferner das Gebiet der Hochleiten (Poysdorf, Matzen), wo Wein gebaut wird. Hauptsächlich werden leichte, etwas sauere Weißweine produziert, seltener Rotweine, wie bei Matzen. Der Weinstock wird allgemein nur auf deutsche Art kultiviert, d. h. mit ganz kurz gehaltenem Stamme und an einen Stock aufgebundenen Schößlingen.

Sonstige Nutzpilanzen. Ton sonstigen Nutzpflanzen spielt auch in Südmähren und im nordöstlichen Niederösterreich die Zuckerrübe die Hauptrolle, von der Mähren 131/2 Millionen, Niederösterreich 700.000 Meterzentner produziert, von welch letzteren die Gesamtzahl auf den nordöstlichen Landesteil entfällt, da im übrigen Teile Niederösterreichs keine Zuckerrüben gebaut werden. Von sonstigen Nutzpflanzen ist nur der Anbau von Futterkräutern (Klee, Esparsette, Luzerne und Punkelrüben) von einiger Bedeutung; ab und zu wird auch Flachs, Hanf, Mohn und Raps gebaut.

Forstkultur. Im IIügellande Südmährens finden sich schöne Nadelwälder nur an den Ausläufern des Böhmisch-Mährischen Gebirges, die vielfach, besonders im Thayatale, vorzüglich gepflegt werden. Das übrige Gebiet, speziell das Marsgebirge und der Steinitzer Wald, sind Laubwaldgebiete, in denen der Wald infolge der intensiven Bodenbebaung schon stark eingeengt ist. Nichtsdestoweniger steht auch hier die Forstiultur auf hoher Stufe, wenn auch die in letzter Zeit gemachten Versuche der Aufforstung von Nadelholz daselbst nicht als sehr glücklich bezeichnet werden kïnnen. Von viel größerer Bedeutung ist die Aufforstung der ausgedehnten Sandflächen im südlichen Mähren, besonder's um Bisenz und Göding, sowie im niederösterreichischen und ungarischen Marchfelde, die fast ausschließlich mit Föhren, und zwar mit Pinus silvestris und in Niederösterreich auch vielfach mit Pinus nigra erfolgt und zu sehr schönen Resultaten geführt hat.

\section{i) Die Adventivflora.}

Ackerunkräuter. Lnter allen Teilen der Sudetenländer sind Mittel- und Südmähren und das niederösterreichische Marchfeld entschieden an Ackerunkrüutern am reichsten, obwohl gewiß der Ackerbau auf sehr hoher Stufe steht; doch schon die geographische Lage bringt es mit sich, daß hier südliche und östliche Typen leicht Eingang fanden. Die in den Gebirgen häufigen Arten, wie Scleranthus annuus, Spergula arvensis, Alchimilla arvensis, Linaria arvensis, treten hier an Häufigkeit zurück oder fehlen wie die letztgenannte ganz. Hingegen sind Raphanus Raphanistrum, Sinapis arvensis, Papaver Rhoeas, Delphinium Consolida, Agrostema Githago, Trifolium campestre, Vicia villosa, $V$. segetalis, Anagallis arvensis, Sherardia arvensis, Sonchus arvensis, Cirsium arvense, Kickxia Elaline, $K$. spuria, Linaria vulgaris überall häufig; auch Diplo- 
laxis muralis, D. tenuifolia, Ranunculus arvensis, Nigella arvensis, Lathyrus luberosus kommen vor. Im südlichen Mähren und im Marchfelde sind auch Setaria glauca, Euphorbia acuminata, E. falcala, Bupleurum rolundifolium, Cerinthe minor, in Südmähren Allium vineale und Veronica praecox, im Marchfelde Vicia glabrescens, Stachys annua, Legouzia Speculum Veneris und Carduus nulans häufige Erscheinungen.

Ruderalilora. Das, was von den Ackerunkräutern gesagt wurde, gilt in gleichem Maße von der Ruderalflora. Chenopodium urbicum, Atriplex tatarica. Cardaria Draba, Berteroa incana sind hier neben den auch in den Gebirgs-

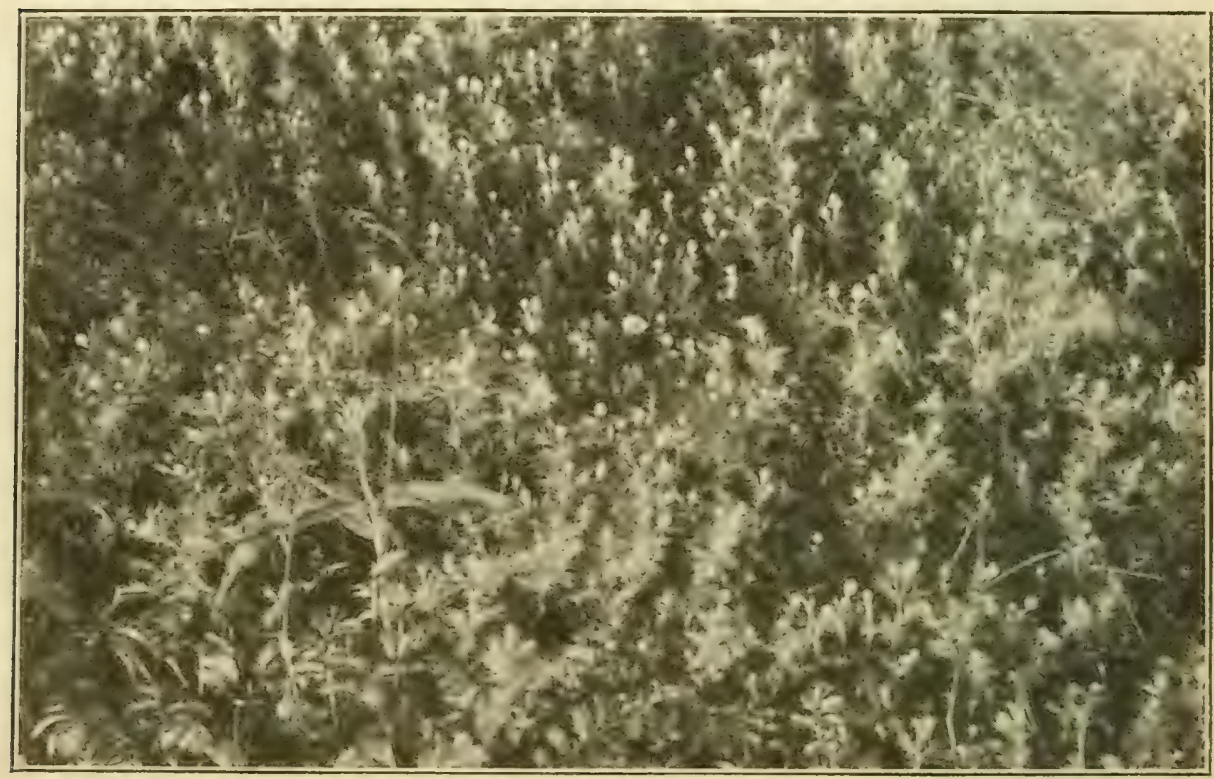

Abb. 58. Matricaria discoidea bei Schlapanitz nächst Brünn.

(Nach einer Aufnahme von Prof. H.- Iltis, Brünn.)

gegenden häufigen Arten allgemein verbreitet und meist gemein. Besonders aber ist es die Marchebene in Mähren und Niederösterreich, wo auf den Schuttplätzen und in den Straßen der Dörfer eine besonders reiche Ruderalflora anzutreffen ist. Neben allen weit verbreiteten Unkräutern trifft man hier auch allgemein Chenopodium Vulvaria, Ch. urbicum, Atriplex talarica, Marrubium vulgare, $M$. peregrinum und den Bastard beider Arten, Leonurus Cardiaca, L. Marrubiastrum, Anthemis Colula, Matricaria Chamomilla, Xanthium strumarium und oft auch $X$. spinosum, während um den unvermeidlichen Gänseteich meist Pulicaria vulgaris und Mentha Pulegium wachsen. In neuester Zeit breitet sich an Bahndämmen und auf Schuttplätzen Malricaria discoidea immer mehr aus. 


\section{Spezielle pflanzengeographische Schilderung.}

\section{Das Erzgebirge und Elstergebirge mit dem Egerland.}

Das langgestreckte, die Grenze zwischen Sachsen und Böhmen bildende Erzgebirge, aus Urgestein und stellenweise auch aus Basalten aufgebaut, stellt ein nach Norden ganz allmählich abgedachtes, nach Süden aber ziemlich rasch gegen die Nordböhmische Ebene abflallendes, wenig grgliedertes Kettengebirge von einer durchschnittlichen Tlammhöhe ron etwa $700 \mathrm{~m}$ dar, in dem sich nur wenige Gipfel, vor all'm iler Feilberg $(1244 \mathrm{~m})$, Fichtelberg $(1215 \mathrm{~m})$ und Spitzberg $(1111 \mathrm{~m}$ ) über $1000 \mathrm{~m}$ erheben. An seiner Südseite ist es bis zu einer Höhe von zirka $700 \mathrm{~m}$ mit lockeren Mischwäldern aus Pinus silvestris, Belula pendula, Ouereus Robur, Fagus silvalica usw. nnit meist reichem Unterholz und Niederwuchs beleckt, die jedoch bis weit hinauf $(700 \mathrm{~m})$ von Tiulturen, besonders von Roggen, IIafer und Kartoffeln, auch ron Buschwerk aus Rosen, Schlehen, Schneeball unıl trockenen grasigen Hängen mit Dianthus delloides, Thlaspi alpestre, Helianthemum nummularium, Genistagermanica. Pimpinella Saxifraga usw. unterbrochen sind. Im mittleren und östlichen Teile des Gebirges treten auch vielfach Buchenwälder auf, in deren Unterholze Rubus Idaeus. Daphne Mezereum, Ribes alpinum und Lonicera nigra, im Niederwuchs Festuca silvalica, Hordeum europaenm. Cardamine enneaphyllos. C. bulbifera. Anemone Hepatica, Lalhyrus vernus, Galium siluaticum. Asperula odorala, Lamium luteum. Dryopteris Filix mas, D. spinulosa besomders charakteristisch sind. In höheren Lagen aber herrscht im ganzen Zuge des Erzgebirges der Fichtenwald vor. Eingesprengt finden sich in diesen Wäldern nicht selten Belula pendula. Fagus silvatica, Sorbus -Aucuparia und insbesondere Abies alba, die ab und zu selbst in kleinen Beständen auftritt. Der Niederwuchs ist in tieferen Lagen höchst cintönig und besteht hauptsächlich aus Vaccinium Myrlillus, I. Tilis idaea, Deschampsia flexuosa, Luzula nemorosa, Sieglingia decumbens, Polentilla erecta, Melampyrum pratense *vulgalum, Hieracium murorum, ab und zu auch Polygala Chamaebuxus. In höheren Lagen aber tritt dazu eine Reihe von für las Erzgebirge charaliteristischen Arten, so insbesondere Calamagrostis villosa. C. varia, Luzula silvalica, Polygonalum verlicillatum, Mercurialis perennis, Cardamine hirsula, Pirola minor, P. uniflora, Trientalis europaea, Stachys alpina, Melampyrum silvalicum, Galium hercynicum, Prenanthes purpurea und Mulgedium alpinum. In den höchsten Lagen, über $900-1000 \mathrm{~m}$, kommen noch Athyrium alpestre, Gnaphalium nortegicum und Homogyne alpina hinzu. An Waldbächen und in feuchten Schluchten sind Leucoium v'ernum, Lunaria rediviva, Geum rivale. Aruncus silvester, Filipendula Ulmaria var. denudala, Slellaria nemorum. Thalictrum aquilegifolium, Ranunculus plalanifolius, Circaea alpina, Chaerophyllum Cicularia. Pelasites albus, Senecio rivularis und Crepis paludosa charakteristische Erscheinungen. 


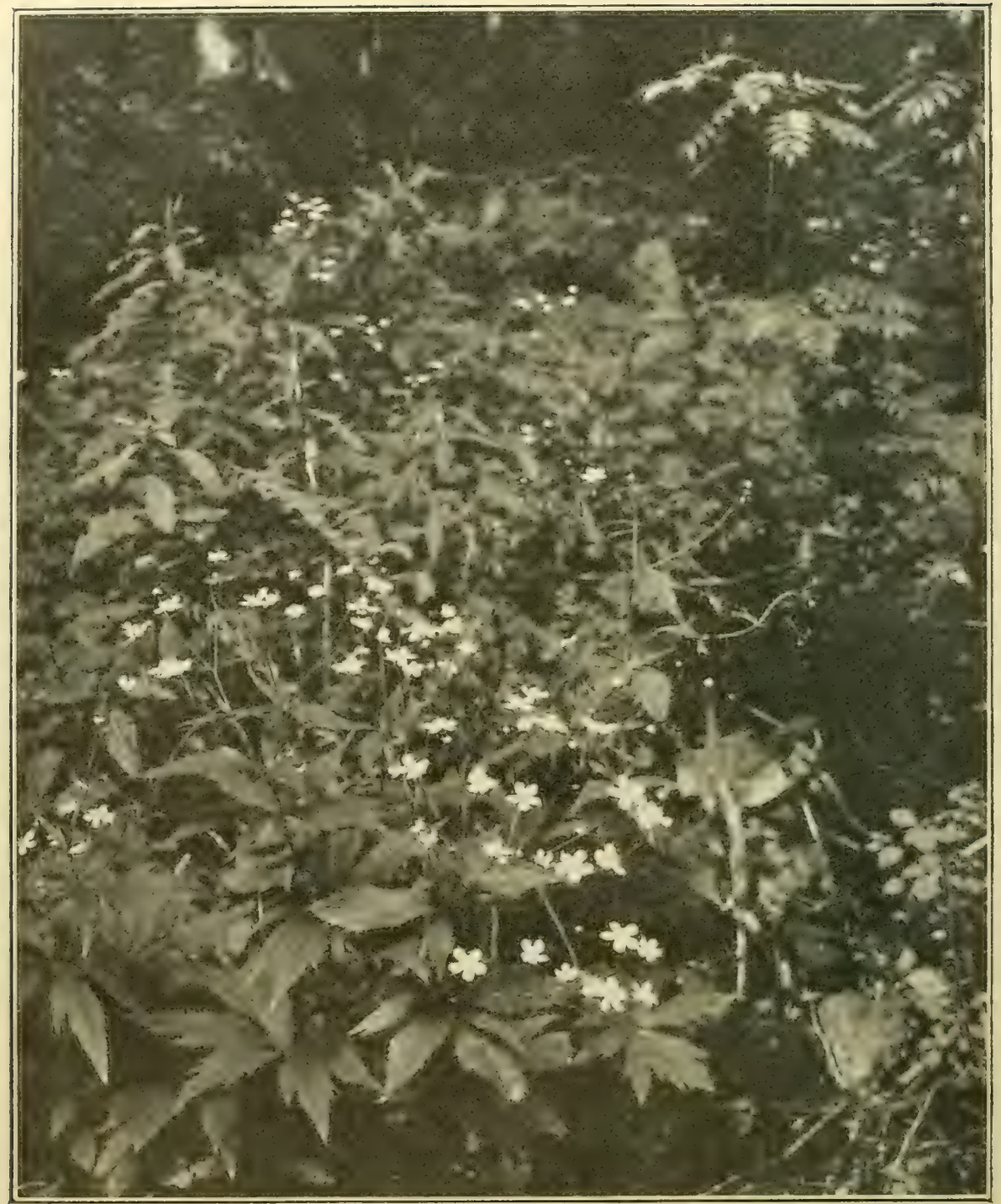

Abb. 59. Ranunculus platanifolius bei Schreiberhau im Erzgebirge.

(Nach einer Aufnahme von Nenke und Ostermaier in Dresden.)

Neben den Wäldern sind insbesondere die ausgedehnten Hochmoore, meist mit dichten Beständen von Pinus uliginosa bewachsen, sowie die Gebirgswiesen mit Luzula sudetica, Orchis globosa, Gymnadenia albida, Polygonum Bislorla, Ranunculus platanifolius, Thaspi alpestre, Dianthus silvalicus, Geranium silvaticum, Hypericum monlanum, Chaerophyllum aureum, Meum alhamanlicum, Phyleuma nigrum, Achillea sudetica, Arnica montana, Cirsium heterophyllum, Cenlaurea pseudophrygia, Hieracium floribundum für das Erzgebirge bezeichnend. 


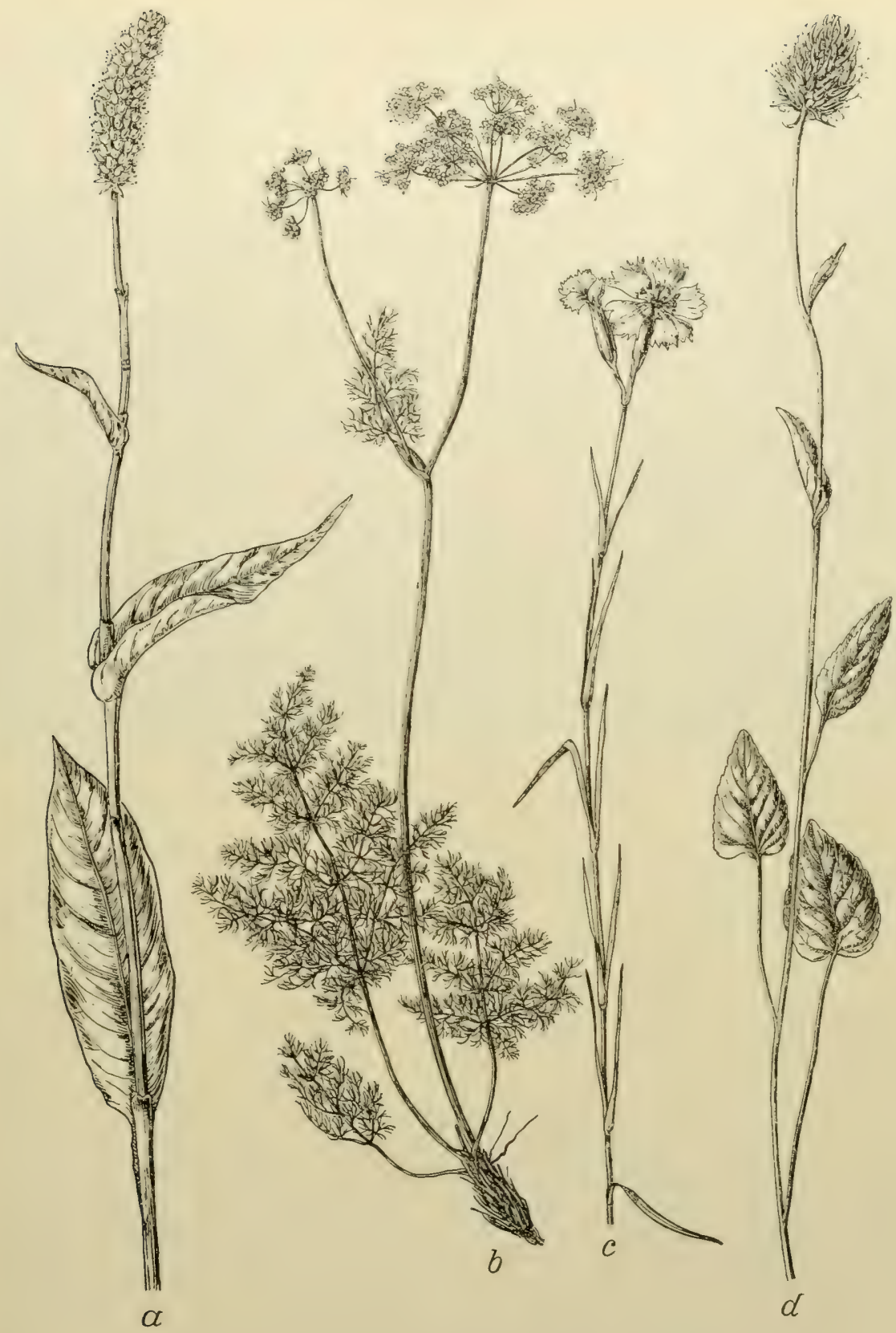

Abb. 60. Einige bezeichnende Arten der Erzgebirgswiesen.

a Polygonum Bistorta. $b$ Meum athamanticum. $c$ Dianthus silvaticus.

$d$ Phyteuma nigrum. $(1 / 2$ n. Gr.)

Von den Charakterarten des Erzgebirges sind Calamagrostis varia, Lilium bulbiferum, Teucrium Scorodonia und Senecio palustris innerhalb der Sudetenländer auf das Erzgebirge allein beschränkt, Meum alhamanlicum und Digitalis purpurea kommen außerdem noch im Lausitzer- beziehungsweise Elbesandstein- 
gebirge vor, Orchis globosa daselbst und im böhmischen Nittelgebirge, welch letzteres auch Hypochoeris maculata und Hieracium barbalum beherbergt. Dem Erzgebirge und Böhmerwalde sind Herminium Monorchis, Thesium pratense, Polygala Chamaebuxus, Oxycoccos microcarpa, Erica carnea und Phyteuma nigrum gemeinsam, fehlen aber der Sudetenflora, während anderseits vor dem Böhmerwalde das Erzgebirge durch den Besitz von Polystichum Lonchitis, Botrychium ramosum, Orchis mascula, Trollius europaeus, Potentilla procumbens, Geum rivale, Epilobium alpestre, Galium hercynicum, die auch in den Sudeten verbreitet sind, sich auszeichnet. Betula nana, Pinus uliginosa, Rumex arifolius, Gymnadenia albida, Polygonatum verticillatum, Calamagrostis villosa, Arabis Halleri, Mulgedium alpinum, Crepis succisaefolia, Cirsium helerophyllum, Cenlaurea pseudophrygia und Arnica montana sind im Böhmerwalde und den Sudeten ebenso wie im Erzgebirge zu Hause.

Nollendorf. Die Senkung zwischen Nollendorf (nördlich von Aussig) und Peterswald bezeichnet die Grenze zwischen dem Elbesandsteingebirge und dem Erzgebirge. Telnitz. Südlich von Telnitz breitet sich hier de̊r ,breite Busch“ aus, ein mit Buchen und Eichen durchsetzter und von zahlreichen kleinen VViesen mit Selinum Carvifolia und Cirsium acaule unterbrochener Fichtenbestand. Die Höhe des Graupen. Gebirges von Nollendorf bis gegen Graupen ist von Fichten- und Buchenwäldern und von Wiesen bedeckt, welche bereits die für das Erzgebirge bezeichnenden Arten Meum athamanticum, Arnica montana, Centaurea pseudophrygia und Cirsium helerophyllum aufweisen. An der sächsischen Grenze erhebt spitzberg. sich die Basaltkuppe des $1111 \mathrm{~m}$ hohen Spitzberges mit Bergwiesen mit Orchis globosa, Dianthus silvalicus und Scorzonera humilis.

Eichwald. Bei Eichwald sind die westeuropäischen Arten Teucrium Scorodonia und Digitalis purpurea anzutreffen. Zwischen Eichwald und Zinnwald ist Zinnwald. in den Wäldern die Buche vorherrschend; bei Zinnwald, besonders zwischen Niklasberg und Moldau, sind auch größere Hochmoore mit Eriophorum vaginalum, Drosera rotundifolia, Oxycoccos palustris und O. microcarpa sowie Beständen aus Pinus uliginosa ausgebreitet; auch üppige Bergwiesen init Ranunculus platanifolius, Geranium silvalicum, Mulgedium alpinum und den oben genannten Charakterarten des Erzgebirges sind um Moldau schön entwickelt. Weiterhin nach Westen zu wechseln Fichten- und Buchenwälder mit subalpinen Wiesen

Strobnitz- mit Meum athamanticum usw. ab; auf dem Gipfel des Strobnitzberges stehen
berg. schöne alte Bergahorne neben gepflanzten Lärchen und Eschen; an den Mauern

Riesen-

burg.

Göttersdorf.
dotter divaricatum. Vom $956 \mathrm{~m}$ hohen Wieselstein bis gegen Göttersdorf ist die Buche der fast allein dominierende Waldbaum, von Göttersdorf bis Komotau aber herrschen Eichenniederwälder mit Corylus, Populus tremula, Belula und einem Niederwuchs aus Luzula nemorosa, Convallaria maialis, Cylisus nigricans, Lathyrus monlanus, Melampyrum nemorosum, Vaccinium Myrtillus, Hypochoeris maculala usw., nur stellenweise durch feuchte Waldtäler mit Fichten- und Buchenbeständen unterbrochen. Ober Komotau liegt das prachtvolle Waldtal Komotauer des Komotauer Grundes, von prächtigen Buchenwäldern erfüllt, die im
Grund. 


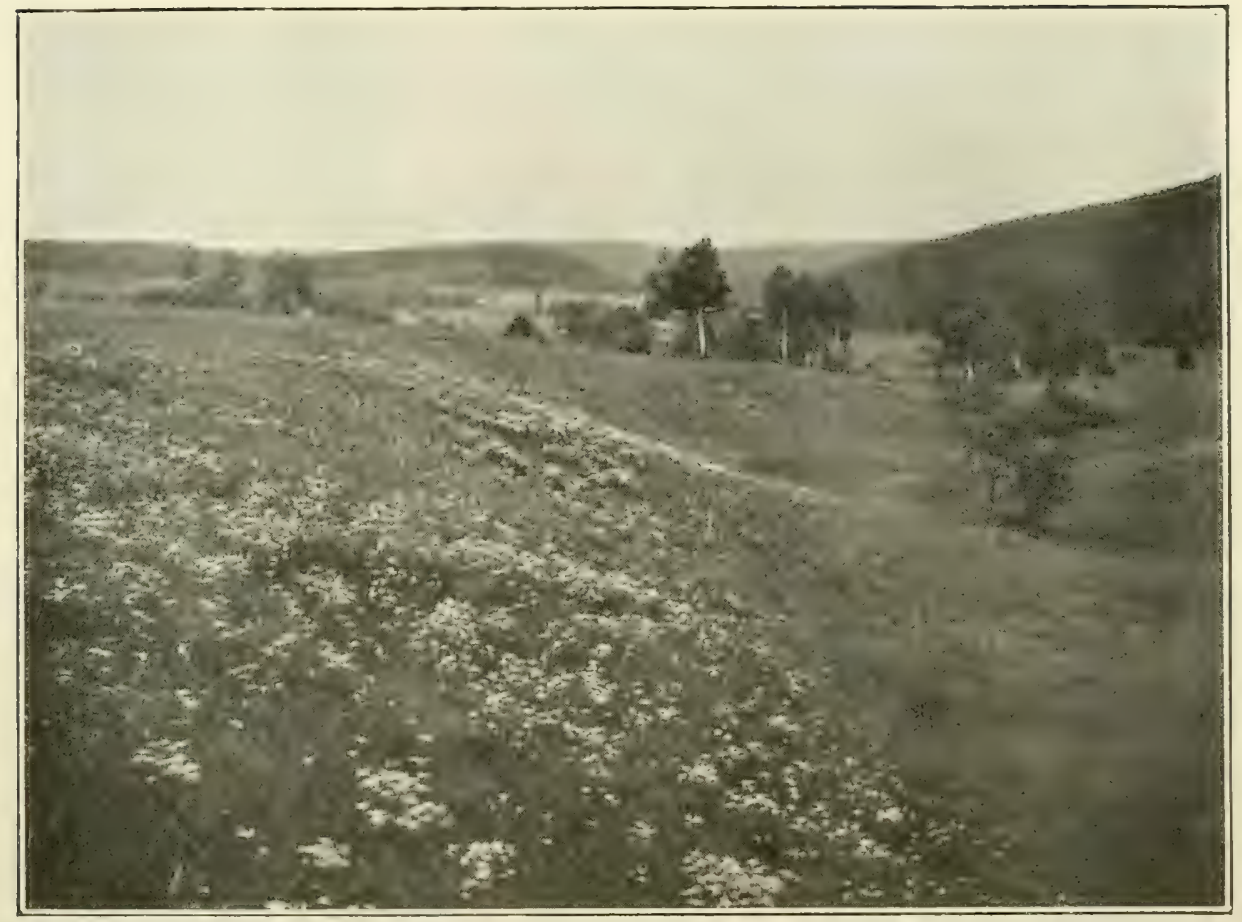

Abb. 61. Wiese im Erzgebirge bei Altenberg nächst Zinnwald mit Mcum athamanticum. (Nach einer Aufnahme von Nenke und Ostermaier in Dresten.)

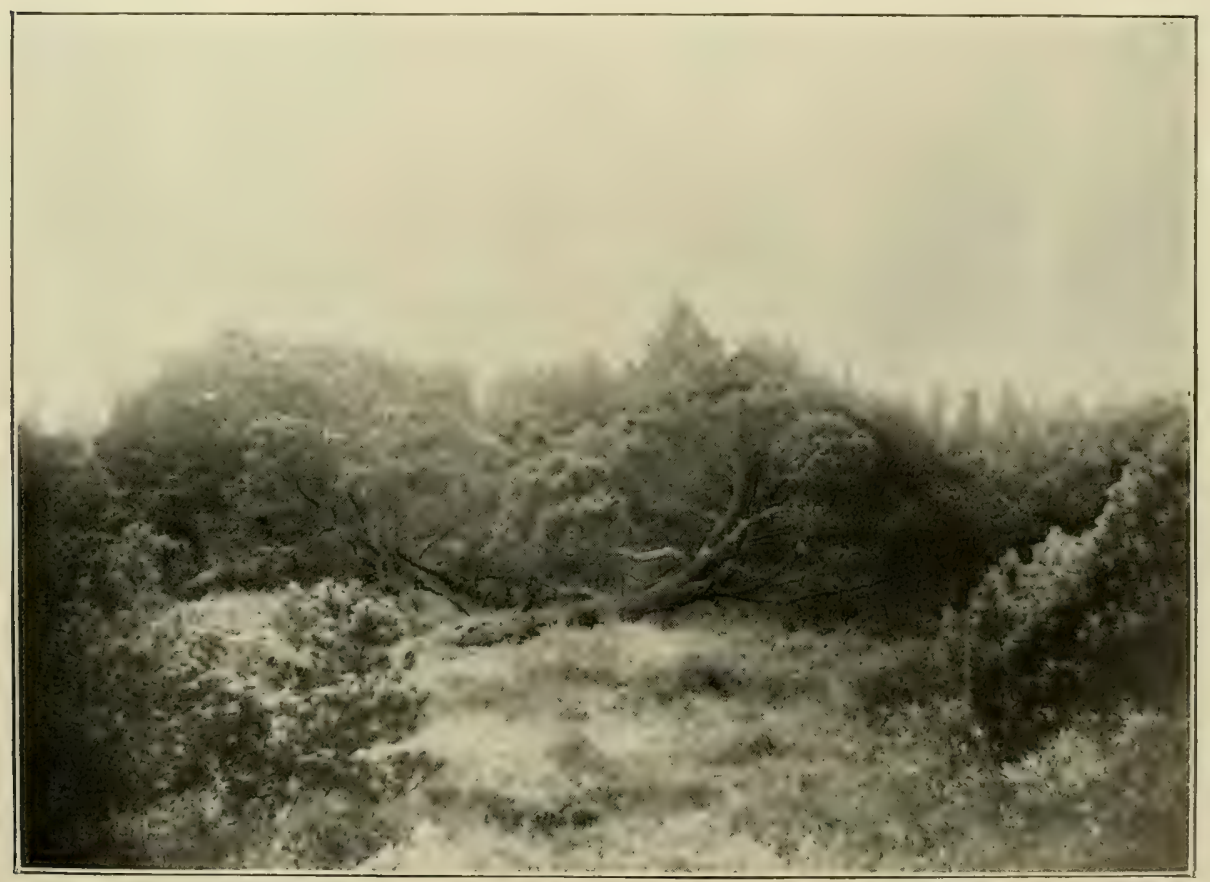

Abb. 62. Hochmoor mit 100jährigem Bestande von Pinus uliginosa bei Moldau. (Nach einer Aufnahme von Prof. IK. Domin, Prag.)

Verlag von Franz Deuticke in Leipzig und Wien. 



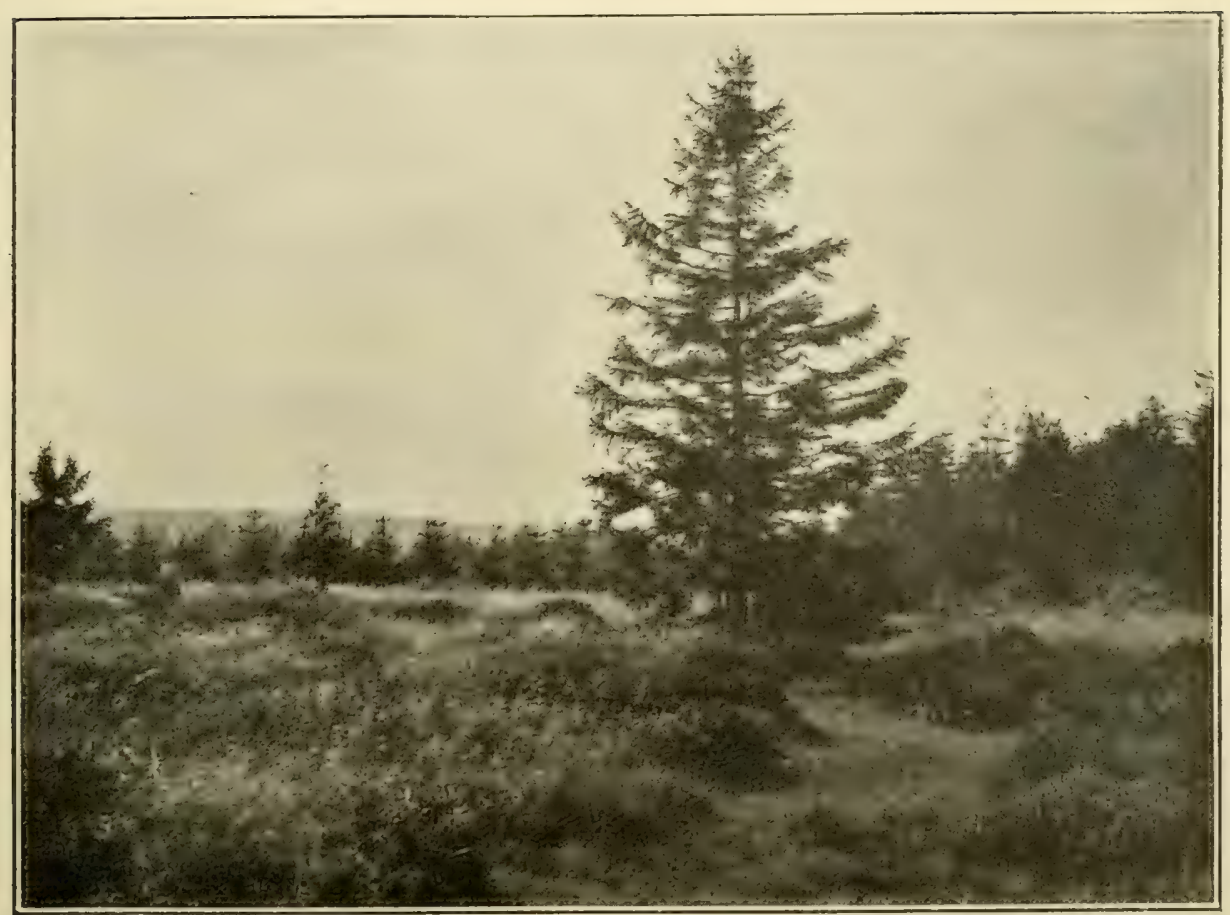

Abb. 63. Der Kamm des Erzgebirges bei Zinnwald.

Borstengrasmatte mit Deschampsia flexuosa (links) und Hochmoor (rechts), dahinter Fichtenwald.

(Nach einer Aufnahme von Nenke und Ostermaier in Dresden.)

Tale weit gegen die Ebene sich hinziehen, während an den Hängen darüber noch eine thermophile Flora mit Clematis recla, Anemone palens, Viola mirabilis, Chrysanthemum corymbosum usw, anzutreffen ist. Bei Sebastiansberg aber Sebastiansliegen schon ausgedehnte Hochmoore, die sich nach Westen zu bis gegen Sonnenberg erstrecken. Vom Komotauer Grunde an westwärts tritt in den Wäldern die Buche stark zurück und ausgedehnte Fichtenbestände bekleiden die Hänge des Gebirges, während den Kamm bis gegen den Spitzberg Wiesen und Hochmoore bedecken, welch letztere auch zwischen Schmiedeberg und Preßnitz Schmiedeauftreten. Reich ist die Flora des $1244 \mathrm{~m}$ hohen Keilberges. Fichtenwälder, Keilberg. in denen nur ganz vercinzelt Buchen oder Tannen vorkommen, bedecken seine Hänge; in ihrem Niederwuchs sind Galium hercynicum, von $900 \mathrm{~m}$ an auch Melandryum silvestre, Homogyne alpina, Luzula maxima, Ranunculus nemorosus, Lycopodium complanatum, Deschampia flexuosa, Calamagrostis villosa, Ranunculus platanifolius und Rumex arifolius die auffälligsten Typen. In der Gipfelregion findet man kleine Wiesen und Torfmoore mit Polytrichum commune, Carex Goodenoughii, G. stellulala, Juncus filiformis, J. squarrosus, Viola paluslris, Trientalis europaea, Gymnadenia albida usw. Gegen Gottesgab zu aber er-Gottesgab. strecken sich;ausgedehnte Bergwiesen mit Tausenden von Meum alhamanticum 
und Arnica montana, mit Polygonum Bistorta, Chrysanthemum Leucanthemum, Phyteuma spicalum, Mulgedium alpinum, Centaurea pseudophrygia, Cirsium helerophyllum, Thlaspi alpestre, Achillea sudelica, Lychnis Flos Cuculi usw. Bei Gottesgab selbst sind wieder ausgedehnte Hochmoore, u. a. mit Carex pauciflora, C. lasiocarpa, C. limosa, Juncus supinus, Andromeda, Eriophorum vaginalum und Belula nana anzutreffen, während gegen die Landesgrenze zu'.Swertia perennis zu Tausenden den Boden bedeckt. Ober der Straße nach Hofberg wächst das seltene Bolrychium ramosum.

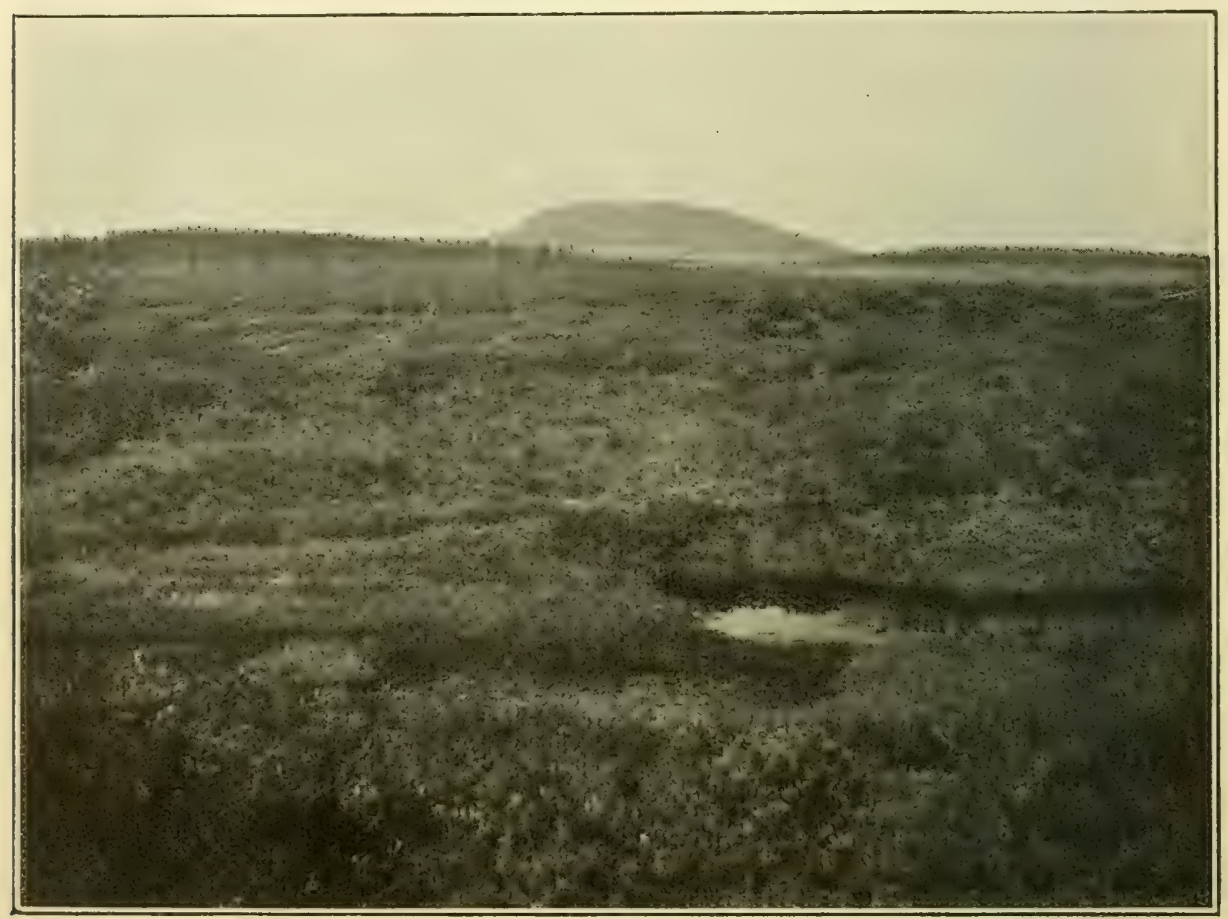

Abb, 64. Hochmoor bei Gottesgab im Erzgebirge. Im Vordergrunde Pinus Mughus.

(Nach einer Aufnalıme von Nenke und Ostermaier in Dresden.)

Spitzberg. Der dem Keilberg benachbarte $1111 \mathrm{~m}$ hohe Spitzberg trägt auf seinem Gipfel Wälder aus Picea excelsa mit Acer Pscudoplatanus, Sorbus Aucuparia, Blechnum Spicant, Lycopodium Selago, an seiner Südseite aber ausgedelnte Voralpenwiesen, auf denen u. a. Aconilum "Napellus" (wohl *hians) und Colchicum autumnale, an sumpfigen Stellen auch die im Erzgebirge sonst fehlende Platten. Scheuchzeria palustris vorkommen. Nach Westen zu gegen Platten erstrecken Abertham. sich wieder ausgedehnte Fichtenwälder und ober Abertham auch Hochmoore mit zahlreicher Andromeda und Oxycoccos microcarpa. Ober Schlackenwert ist auch Aiuga pyramidalis nicht selten.

Auch im westlichsten Teile des Erzgebirges, zwischen den Tälern der Wistintz und Zwodau, herrschen Fichtenwälder oft mit sehr üppigem Niederwuchs, unterbrochen durch kleine Waldwiesen mit Thlaspi alpestre, Cirsium 
helerophyllum und Meum alhamanticum, vor, doch treten in den tieferen Tälern, wie bei Neudeck, auch Mischwälder aus Birken und Föhren mit Cytisus nigricans, Jasione montana und Carlina vulgaris auf; bei Neudeck ist auch Bolrychium ramosum und auf einem Holzschlage bei Hammerhäuser Erica carnea zu finden. Zwischen Neudeck und Kohling. sind schöne Bergwiesen (auf diesen u. a. Kohling. auch Dianthus silvaticus) entwickelt, im Teiche südwestlich von Kohling ist in $631 \mathrm{~m}$ Meereshöhe noch Castalia candida anzutreffen. Hochmoore sind in diesem Teile des Erzgebirges besonders zwischen Neudeck und Schönlinde entwickelt. An den Hängen gegen Annaberg sind wieder Birken- und Fichtengehölze mit oft massenhaftem Sarothamnus scoparius häufig, im Zwodautale finden sich Wiesenmoore und Wiesen mit Silaus pratensis.

Das westlich vom Graslitzer Sattel sich rhebende Elstergebirge ist in bezug auf seine Vegetation vom Erzgebirge nicht auffallend verschieden. Auch hier herrscht als Waldbaum die Fichte vor, in welchen Beständen vor allem das stellenweise massenhafte Auftreten von Erica carnea sowie das Vorkommen von Polygala Chamaebuxus, Homogyne alpina, Prenanthes purpurea, Calamagrostis villosa und Ranunculus platanifolius bemerkenswert ist. Auf Bergwiesen treten gleichwie im Erzgebirge Cirsium helerophyllum, Thlaspi alpestre und Meum athamanticum, die beiden letzteren doch minder häufig, auf.

Am Fuße des Erzgebirges zwischen Schlackenwerth und Karlsbar Schlackenfinden sich vielfach gemischte Laubwälder und insbesondere oft ziemlich ausgedehnte Birkenbestände. Die meist gedüngten Wiesen bieten wenig auffallende Typen, wie Trollius europaeus und Polygonum Bislorta, an trockeneren Abhängen tritt oft Anthemis tincloria und Anthyllis Vulneraria in großen Massen auf; gegen Lichtenstadt zu bildet Carex disticha auf Wiesen größere Bestände. An den Waldrändern hinter Schlackenwerth sind jedoch schon die typischen Vertreter der Erzgebirgsflora, wie Melandryum silvestre, Dianthus silvalicus und Girsium helerophyllum zu finden; eine sehr charaliteristische Pflanze dieser Gegend jst auch die überall häufige Pastinaca opaca. In den zalılreichen Teichen des Gebietes ist Caslalia candida häufig, ferner Polamogelon nalans, lucens, acutifolius und gramineus, am Röderteiche kommen Sparganium minimum, am Ottenteiche Lysimachia thyrsiflora vor.

Weiter flußaufwärts, in der Umgebung von Eger, finden sich teils Föhrenwälder, teils gemischte Bestände aus Föhren, Fichten, Eichen und Hainbuchen, aus deren Niederwuchs Primula elatior, Jasione montana, Cytisus nigricans erwähnt seien. Auf Wiesen sind Polygonum Bislorla, Saxifraga granulata, Phyteuma nigrum und Arnica montana häufige Arten. Auch ausgedehnte Heiden mit Calluna vulgaris, Scleranthus perennis, Potentilla erecta, Filago arvensis, Girsium acaule, Jasione montana sind im Egerland eine häufige Erscheinung und bedecken auch den erloschenen Vulkan Kammerbühel bis zur Spitze. In der Umgebung von Franzensbad sind die Wälder hauptsächlich FranzensBirkengehölze, vor allem aber ist in der Umgebung dieser Stadt das Auftreten ausgedehnter Moore von Bedeutung. Das größte derselben ist das Franzensbader Moor, ein teilweise von Hochmoor überdecktes Wiesenmoor, aus dessen 
Flora Carex canescens, $C$. diandra, C. elala, C. limosa, Rhynchospora alba, Chrysosplenium oppositifolium, Cicula virosa, Peucedanum palustre, Lysimachia thyrsiflora, Andromeda polifolia, Pinguicula vulgaris, Senecio palustris beziehungsweise in Gräben Utricularia intermedia und Glaux maritima zu nennen sind, welch letztere den im Moor entspringenden Mineralquellen ihre Existenzfähigkeit verdankt. Nördlich von Franzensbad erstreckt sich das ähnliche Katharinen-

Soos. berger Moor oder ,Soos", auf dem auch Schoenopleclus Tabernaemontani und angeblich Ledum palustre vorkommen. Auf beiden Mooren sind Salix pentandra und Belula pubescens nicht selten. Auch Salzwiesen mit Atropis dislans, Glaux marilima und Scorzonera parviflora kommen um Franzensbad vor.

Asch. Auch weiter nördlich um Asch sind noch einzelne Moore vorhanden, so unmittelbar bei der Stadt selbst, ebenfalls Wiesenmoore, teilweise von Hoch-

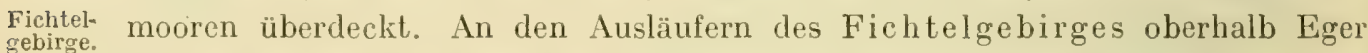
ist das häufige Auftreten von Sempervivum soboliferium an Felsen sowie das von Dianlhus silvalicus und Cytisus nigricans bemerkenswert. Bezeichnend für das Egerland sind schließlich die auch zahlreichen Teiche, in denen zumeist Castalia candida sehr häufig ist.

\section{Der Kaiserwald und Böhmerwald mit dem ober- österreichischen Mühlviertel.}

Südlich der Eger von Karlsbad bis Marienbad erstreckt sich der Kaiserwald, ein Bergland von einer durchschnittlichen Höhe von $600-750 m$ Höhe. In den Tälern dieses Gebirges und an seinem Fuße trifft man teils Föhrenwälder, teils Birkenbestände, besonders aber Heiden mit Nardus stricla, Juncus squarrosus, Arnica montana usw. In höheren Lagen jedoch herrschen üppige IVälder vor. So reichen bei Karlsbad Mischwälder aus Fichten, Tannen, Buchen und selbst Eichen, mit reichlichem Niederwuchs aus Sambucus racemosa und Rubus Idaeus bis direkt an die Stadt heran und auch im übrigen Teile des Gebirges herrschen teils Fichten-, teils Nischwälder mit Calamagrostis villosa, Lilium Martagon, Polygonatum verlicillatum, Listera cordala, Cardamine enneaphyllus, Aclaea spicala, Erica carnea, Lonicera nigra, Senecio rivularis vor; auf dem Glatzberge tritt auch Ranunculus platanifolius auf. Die Bergwiesen des Kaiserwaldes sind durch Polygonum Bistorla, Thesium pratense, Dianthus silvaticus, Lathyrus montanus Geranium silvalicum, Phyleuma nigrum, Arnica monlana, Girsium acaule, Scorzonera humilis ausgezeichnet. Im nordwestlichen Teile des Gebirges erstreckt Glatzberg. sich ein $15 \mathrm{~km}$ langer und $10 \mathrm{~km}$ breiter Moorkomplex vom Glatzberge bis gegen Kohling, der nur stellenweise durch einzelne höhere Gipfel unterbrochen wird und an charaliteristischen Arten Carex pulicaris, $C$. canescens, C. diandra, C. flava, Juncus squarrosus, Eriophorum vaginalum, Trichophorum alpinum, Ledum palustre, Andromeda polifolia, Oxycoccos quadripetala, Empetrum nigrum, Utriculara vulgaris und Crepis succisaefolia aufweist und größtenteils mit Pinus uliginosa, teilweise auch mit verkrüppelten Fichten bewachsen ist. An Felsen an der Tepl

Petschau. bei Grün und Petschau kommt der seltene Farn Woodsia ilvensis, zwischen 


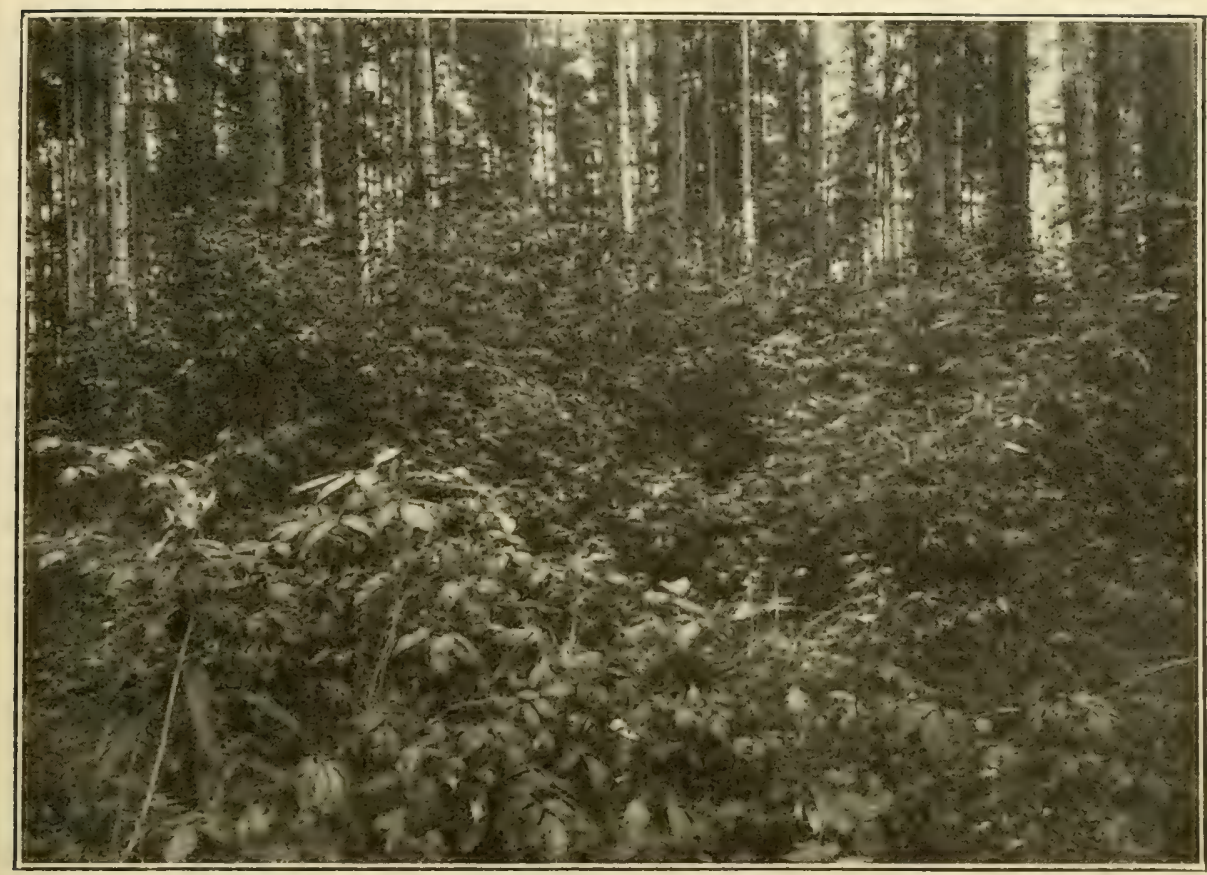

Abb. 65. Sambucus racemosa und Rubus Idaeus als Unterholz in einem Miscluwalde bei Karlsbad.

(Nach einer Aufnahme von Dr. K. Rechinger, Wien.)

Petschau und Grünhart die zierliche Liliazee Erylhronium Dens canis vor, auf der Rauschenbacher Heide bei Einsiedl finden sich die beiden Serpentinfarne Asplenium adulterinum und A. cuneifolium. Bei Königswart tritt Pinus silvestris in größeren Beständen auf, in denen neben Deschampsia flexuosa auch KöniçsAira caryophyllea häufig ist; auch Crepis praemorsa und Arnoseris minima gehören der dortigen Flora an. Marienbad ist gleichwie Karlsbad ringsum von dichten Marienbad. Wäldern umgeben, teils von reinen Fichtenwäldern, teils von Mischbeständen aus Fichten, Tannen, Buchen, Birken und Eichen, in denen im Unterholze Rubus Idaeus und Sambucus racemosa, im Niederwuchs Festuca silvatica, Melandryum silvestre, Aruncus silvester, Actaea spicata, Pelastes albus, Prenanthes purpurea und Lactuca muralis charakteristische Arten sind.

Der von den Quellen der Wald-Nab sich bis-an die Donau bei Linz und Grein erstreckende Böhmerwald, ebenfalls aus Granit und Gneis aufgebaut, Böhmerzeigt in seinem Aufbaue und in seiner Flora viel Ähnlichkeit mit dem Erzgebirge. Wenn auch reicher gegliedert, ist er doch nur von zwei tieferen Sätteln, dem Taus-Further Sattel und dem Neumarker Sattel durchschnitten und weist im nördlichen Teil eine etwa $700 \mathrm{~m}$, im südlichen eine über $1000 \mathrm{~m}$ hohe Kammhöhe auf, die nur wenige unbedeutende Einsattelungen besitzt, während die Gipfel vielfach 1300 , ja über $1400 \mathrm{~m}$ erreichen und somit die bei zirka $1400 \mathrm{~m}$ gelegene Baumgrenze überragen. Nadel- und Mischwälder bedecken in dichtem Bestande 
das im Gegensatze zum Erzgebirge nur am Fuße besiedelte Gebirge, Hochmoore sind ebenfalls, besonders im südlichen Teile des Gebirges reich entwickelt, allerdings mehr in den Tälern und Mulden als auf dem Kamme des Gebirges, hingegen sind üppige Wiesen selten.

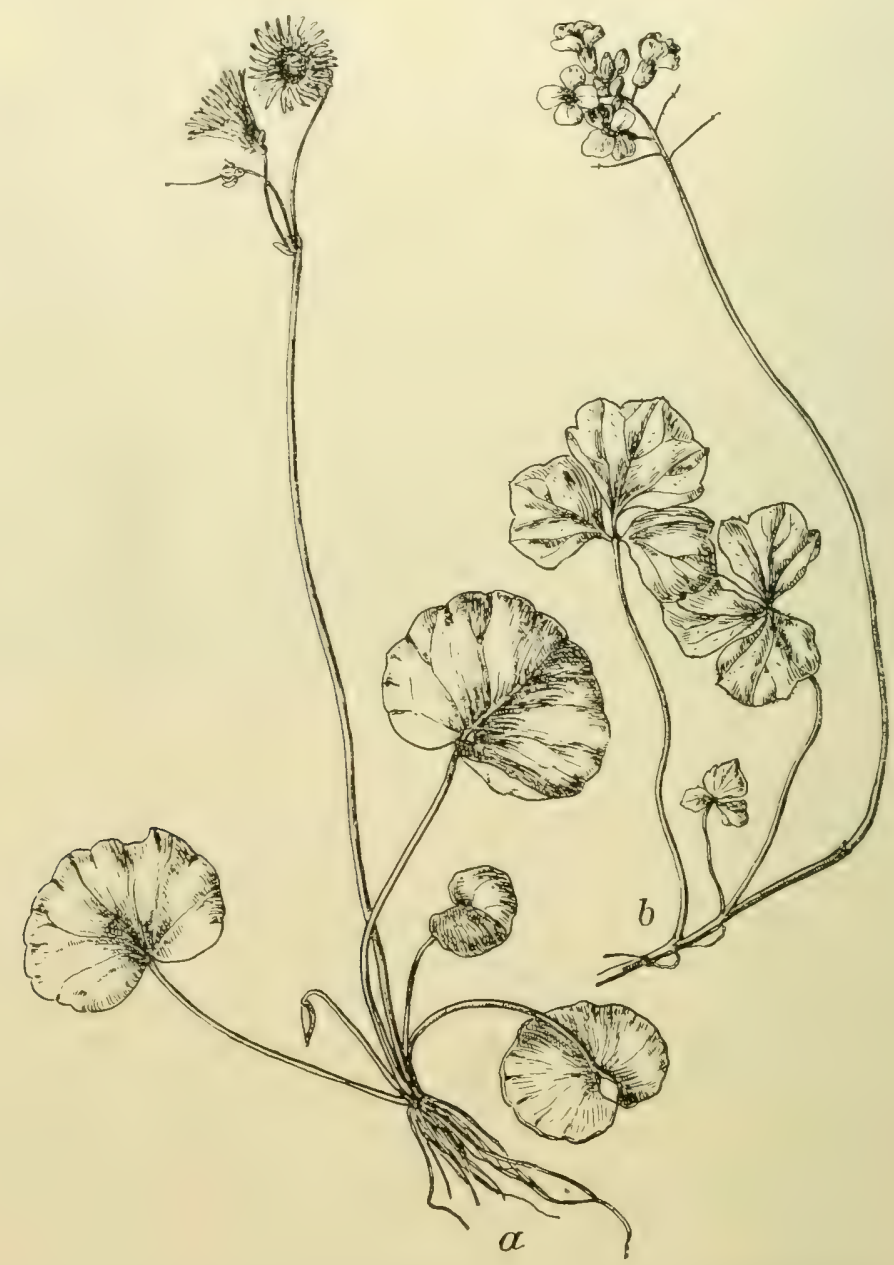

Abb. 66. Zwei Charakterpflanzen des südlichen Böhmerwaldes. a Soldanella montana. $b$ Cardamine trifolia.

Von den bezeichnenden Arten des Erzgebirges fehlen im Böhmerwalde Calamagroslis varia, Lilium bulbiferum, Orchis globosa, Thlaspi alpestre, Meum athamanticum und Digitalis purpurea gänzlich, obwohl Thlaspi alpestre auch im Brdywalde auftritt. Hingegen ist für den ganzen Böhmerwald Soldanella montana eine sehr charakteristische Pflanze, die sich von hier bis ins niederösterreichische Waldviertel und das Böhmisch-Mährische Gebirge erstreckt. Ferner finden sich im südlichen Böhmerwalde häufig Cardamine trifolia, Doronicum austriacum und Alnus viridis, die alle auch dem Piesengebirge (Doronicum jedoch im Gesenke häufig) fehlen. Auch Salix grandifolia, Senecio subalpinus, 
Willemetia slipitata, Lonicera coerulea und in der Hochgebirgsregion Poa alpina, Ligusticum Mutellina und Gentiana pannonica fehlen sowohl den Sudeten als dem Erzgebirge, es sind alpine Arten, die in den Sudetenländern nur im Böhmerwalde auftreten. Juncus trifidus, Trichophorum alpinum, Carex magellanica, Agrostis rupestris, Salix myrtilloides, Hieracium aurantiacum und der Farn Allosorus crispus sind den Sudeten und dem Böhmerwalde gemeinsam eigen. Im südlichsten Böhmerwald ist die auch auf den südböhmischen Mooren verbreitete Calla palustris häufig.

Im nördlichen Böhmerwalde oder Pfälzerwalde von Eger bis Furth ist die Vegetation noch recht eintönig. Föhrenwälder mit massenhaftem PlePfälzerwald. ridium aquilinum, mit Juniperus communis, Dianthus delloides, Helianthemum nummularium, Jasione montana, im nördlichsten Teile auch Polygala Chamaebuxus, reichen vielfach bis gegen $550 \mathrm{~m}$ aufwärts und darüber hinaus herrschen eintönige Fichtenwälder mit Vaccinien, Deschampsia flexuosa, Rubus Idaeus, Pelasites albus, Senecio nemorensis. Doch schon oberhalb Plan kommen auch Coralliorhiza lrifida, Ranunculus platanifolius, Aruncus silvester, Astrantia maior, Pirola uniflora, Soldanella montana und Lonicera nigra in den Wäldern vor; und am Kamme des Gebirges sind vielfach ausgedehnte Moore entwickelt, die hier den Namen ,Lohen“ führen. Die bedeutendsten derselben sind die Tillenlohe und Pfarrlohe ober Tachau, die Bärenlohe und Herrenlohe, ferner ober Pfraumberg die Schwarzlohe, Tiefenlohe und Schenkellohe, alle in einer Meereshöhe von 500-700 $\mathrm{m}$ gelegene Hochmoore.

Der höchste Gipfel dieses Zuges, der $1039 \mathrm{~m}$ hohe Gzerkov, trägt Wälder Czerkov. aus Buchen und Tannen mit eingestreuten Fichten und Bergahornen und im Niederwuchs treten bereits einzelne subalpine Arten, wie Polygonalum verticillalum, Ranunculus platanifolius und Circaea alpina auf; auch ein Hochmoor, die ,große Lohe“", ist an seinem Abhang entwickelt.

Interessanter ist die Flora in dem südlich der Linie Furth-Taus gelegenen eigentlichen Böhmerwald. In tieferen Lagen herrscht hier freilich auch noch vielfach die Föhre und die Birke vor, oft unterbrochen durch feuchte Wiesen mit Trifolium spadiceum und Pedicularis silvalica. Bei einer Höhe von im Durchschnitte $650 \mathrm{~m}$ aber beginnen die Fichtenwälder, in denen auch die Tanne (Abies alba) sehr häufig auftritt. Im Unterholze der Wälder kommt ab und zu Rosa pendulina vor, im Niederwuchs ist neben den auch hier sich findenden weit verbreiteten Arten, wie Vaccinium Myrtillus, Deschampsia flexuosa, Senecio nemorensis auch Pelasites albus allgemein verbreitet, ferner Inaulia silvalica und Mulgedium alpinum. In höheren Lagen, von etwa 900-1000 $\mathrm{m}$ an, mischt sich die Buche vielfach in den Nadelwald, oft in großer Menge und stellenweise selbst tonangebend werdend. In diesen Mischwäldern findet man häufig die Zierde des Böhmerwaldes, die niedliche Soldanella montana, ferner Calamagrostis villosa, Prenanthes purpurea und an tiefmoosigen feuchten Stellen Listera cordata und Willemetia stipitata. Bei $1150 \mathrm{~m}$ Höhe erreicht die Buche und ungefähr in gleicher Höhe auch die Tanne ihre obere Grenze und dichte Fichtenwälder mit üppigem Heidelbeerenniederwuchs und schönen Farntrichtern aus Dryop- 
leris Filix mas, D. Oreopleris, Alhyrium Filix femina und A. alpestre reichen bis zu der bei $1350 \mathrm{~m}$ gelegenen Waldgrenze, welche auf österreichischem Boden nur die Gipfel der Seewand, des Lakaberges, Mittagsberges, Lusen, Plöckenstein und Hochfichtel überragen, welche dann von Krummholz bewachsen und von Felstrümmern bedeckt sind. Nur stellenweise sind die Wälder von subalpinen Wiesen mit Peucedanum Ostrulhium, Ligusticum Mutellina, Phyleuma nigrum, Cirsium helerophyllum, Arnica monlana, Crepis succisaefolia und (selten) Gentiana pannonica, aber ohne Thlaspi alpestre und ohne Meum athamanticum, unterbrochen.

Vollnau. Im Further Sattel bei Vollmau trifft màn Föhren- und eintönige Fichtenwälder sowie Sandheiden mit Scleranthus perennis usw. an; bei Neumark auf den feuchten Wiesen und um die Teiche ist Gicula virosa eine häufige Erscheinung. Von hier südwärts aber beginnen prachtvolle Fichten- und in höheren Lagen osser. auch Mischwälder, die bis gegen Eisenstein hinziehen. Der $1283 \mathrm{~m}$ hohe Osser, an dessen Abhang in einem Moor ober Schauern bei 1180 m Viola epipsila einen isolierten Standort hat, trägt bis zu seinem Gipfel prächtige Fichtenwälder mit Homogyne alpina und auf seinem von Felstrümmern bedeckten Kamm wachsen neben üppigem Heidelbeergestrüppe Lycopodium Selago und Juncus Seewand. lrifidus. Auch die $1343 \mathrm{~m}$ hohe Seewand ist bis zu ihrem mit Krummholz bewachsenen Gipfel bewaldet, am Fuße ihres von Fichten bekleideten Steil-

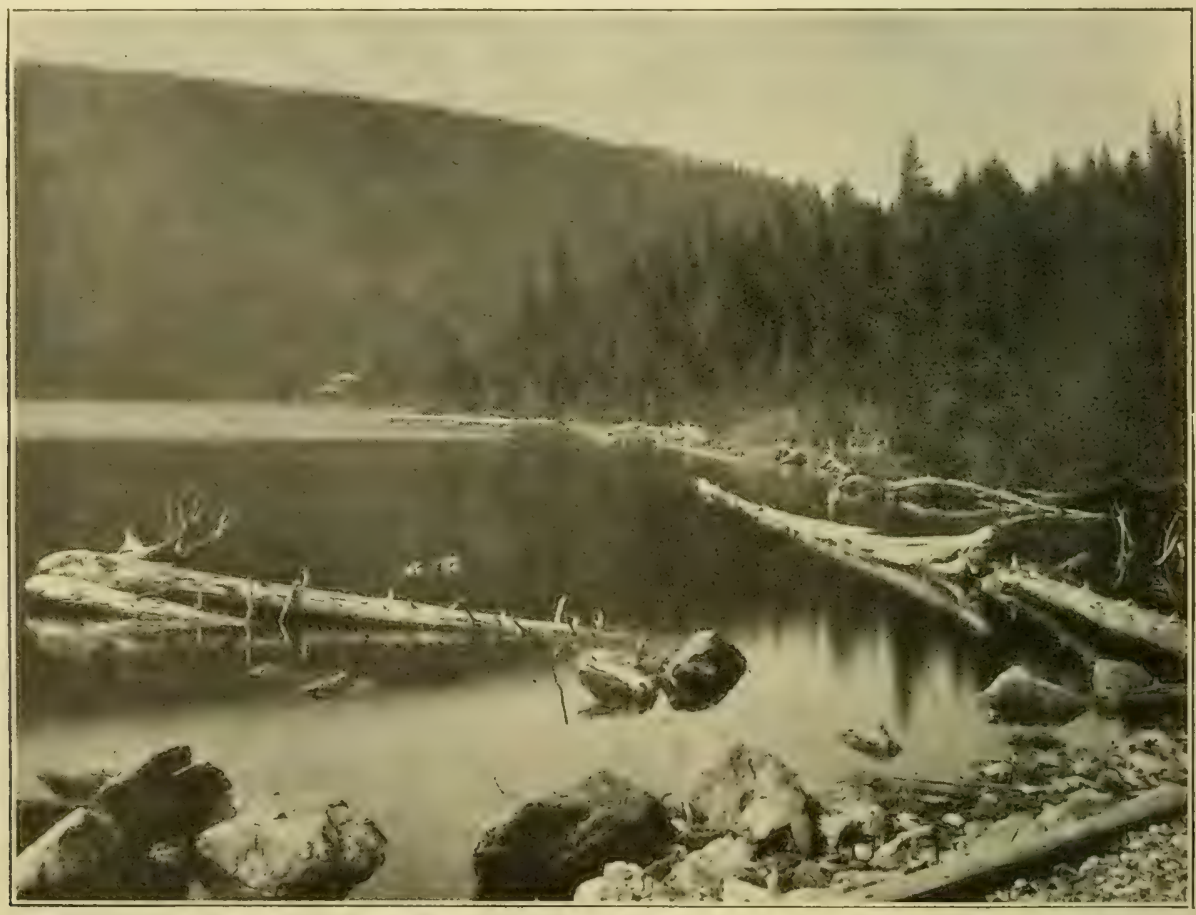

Abb. 67. Der Schwarzensee im Böhmerwald mit der Seewand. Am Seeufer Pinus Mughus, dahinter Fichtenwald.

(Nach H. Eckert, Landschaftsbilder aus Böhmen.) 
absturzes liegt in $1000 \mathrm{~m}$ Höhe der Schwarze See und unweit davon bei $1020 \mathrm{~m}$ Schwarzer der kleinere Teufelssee, beide von Krummholz umrahmt und als Standorte von Isoëles lacustris und ersterer auch von Sparganium affine bekannt. Der benachbarte höchste Gipfel des Böhmerwaldes, der $1485 \mathrm{~m}$ hohe Arber, mit seinen den Gipfel krönenden Borstengrasmatten, mit Ranunculus platanifolius, Gcnliana pannonica, Slreplopus amplexifolius und dem in $934 \mathrm{~m}$ Höhe inmitten eines Moores gelegenen Arbersee mit Nuphar luleum liegt bereits jenseits der

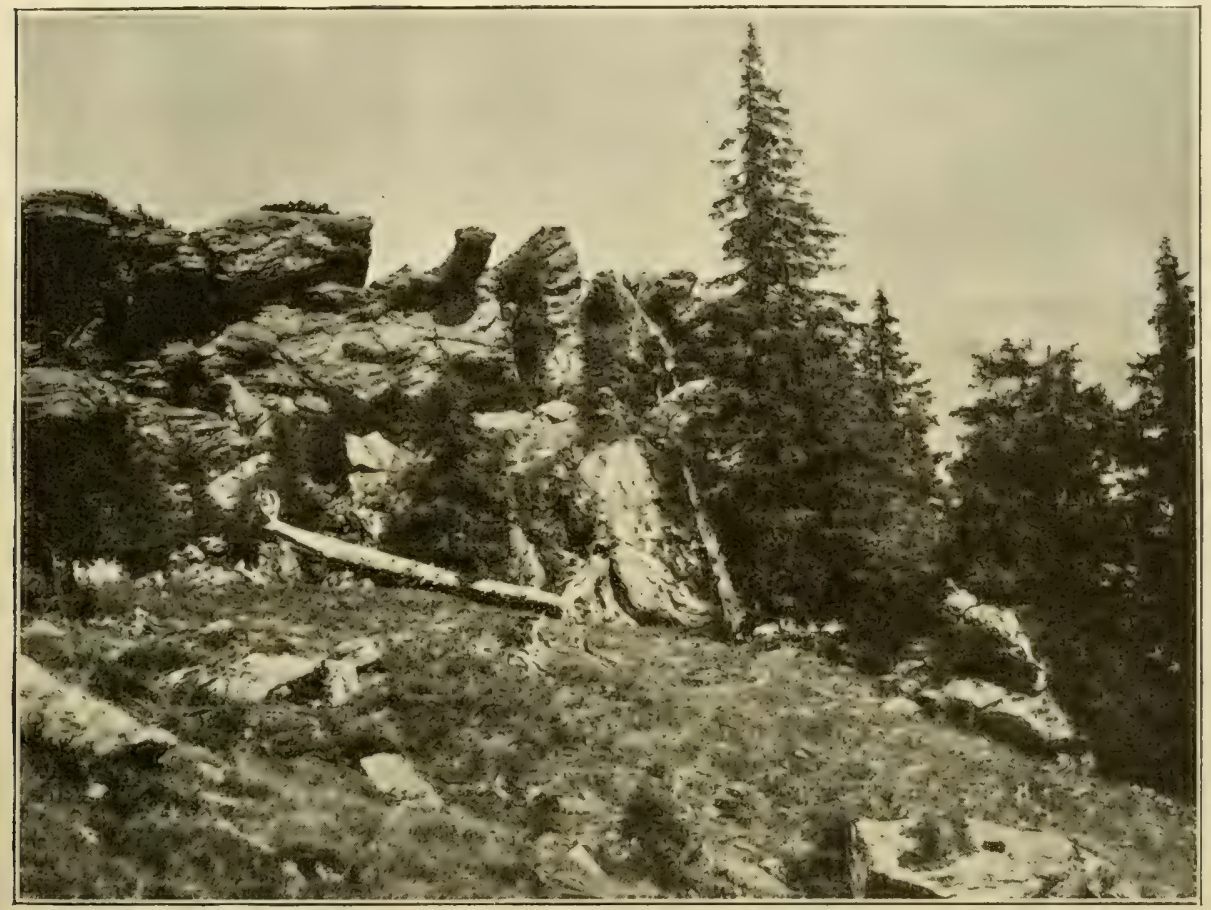

Abb. 68. Aus der Gipfelregion des Arber.

Borstengrasmatten mit Juncus trifidus, Vaccinien und Calluna sowie Fichtenwald.

(Nach einer käuflichen Photographie.)

(Aus der Bildersammlung des botanischen Institutes an der Wiener Universität.)

Reichsgrenze. Bei Eisenstein senkt sich der Kamm des Gebirges bis unter Eisenstein. $1000 \mathrm{~m}$, doch auch hier besteht noch der Wald aus Fichten, Buchen, Acer Pseudoplatanus und besonders aus manchmal $4-5 \mathrm{~m}$ Umfang messenden Tannen; im Unterholze sind Brombeeren, besonders Rubus Bellardii, häufig, im Niederwuchs tritt aber stellenweise selbst noch bei 700-800 $m$ Höhe Pleridium aquilinum in Menge auf. Südöstlich von Eisenstein erhebt sich der die Waldgrenze nur um weniges überragende und Krummholz tragende Lakaberg, an Lakaberg. dessen Nordseite inmitten eines schwimmenden Moores mit Trichophorum alpinum der kleine Lakasee liegt. Südöstlich vom Lakaberg, hart außerhalb der Reichsgrenze steht der $1450 \mathrm{~m}$ hohe Rachel, aus dessen Flora Doronicum Rachel. auslriacum und Gentiana pannonica genannt seien, und rer durch das Auftreten 
lileiner, hochgelegener Hochmoore mit Trichophorum auslriacum, Eriophorum vaginatum, Carex pauciflora, $G$. limosa und $C$. magellanica ausgezeichnet ist. Platten- Auch der Gipfel des benachbarten, $1368 m$ hohen Plattenhausen ist von
hausen. kleinen Hochmooren mit der gleichen Flora und ebenfalls ohne Moorkiefern,

Lusen. umgeben. Das gleiche gilt von den Mooren des $1372 \mathrm{~m}$ hohen Lusen, der durch das häufige Vorkommen von Aconilum variegatum und Geranium silvaticum in der obersten Waldregion sowie durch Voralpenwiesen mit Streplopus amplexifolius, Ligusticum Mulellina, Gentiana pannonica und Willemetia slipitala ausgezeichnet ist, während auf seinem mit Felstrümmern bedeckten Gipfel Hieracium gothicum die tonangebende Pflanze ist. Am Nordostabhange des Rachel und Lusen bei Mader breiten sich ausgedehnte Hochmoore, mit Pinus uliginosa bewachsen, aus und auch im Quellengebiete der Moldau sind reichlich Hochmoore entwickelt, die zwar der Moorkiefern entbehren, hingegen aber bei Fürstenhut und AuBergefild Betula nana und bei ersterem Orte auch die seltene Salix myrlilloides aufweisen.

Solche kleine Hochmoore, daselbst ,Filze" genannt, durchwegs Sphagneta mit zahlreichem Trichophorum austriacum, mit Calluna, Vaccinium aliginosum, Andromeda, Empetrum, Pinguicula vulgaris und Carex pauciflora setzen sich an OberMoldau. der oberen Moldau über Ober-Moldau, Kuschwarda, Salnau bis UnterIIoldau fort; oft sind sie von Pinus uliginosa, Ledum palustre oder Belula carpatica Kusch- bewachsen. Südöstlich von Kuschwarda erhebt sich zwischen der kalten und warmen Tussetberg. Moldau der $1065 \mathrm{~m}$ hohe T'ussetberg, in dessen dichten Wäldern noch Thalictrum aquilegifolium, Aclaea spicata, Innautia silvalica und Doronicum austriacum gedeilien. Letztere Pflanze ist im ganzen Zuge des südlichsten Böhmerwaldes eine häufige Erscheinung, doch erst im Stocke des DrePlöcken-
stein. tretén die charakteristischen Formationen des Böhmerwaldes noch einmal in voller Entwicklung auf. Buchen- und Mischwälder mit Athyrium alpestre, Luzula silvalica, Soldanella montana, Arnica und Homogyne alpina reichen hier bis zum Gipfel und auch diesen selbst krönen noch reichlich fruchtende Fichten. Der kleine Plöckensteinsee aber beherbergt die größte Seltenheit der Böhmerwaldflora, die erst in den

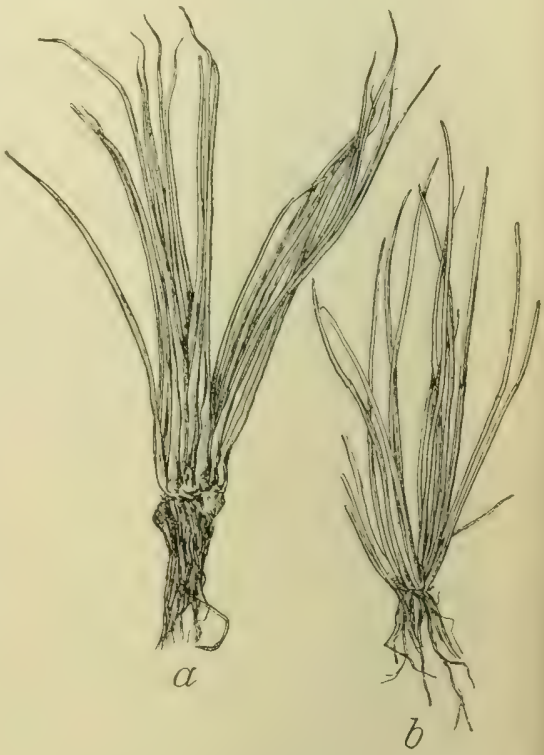

Abb. 69. Die beiden Isoëtesarten der Böhmerwaldseen.

$a$ Isoëtes echinospora. $b$ I., lacustris. $(1 / 2$ n. Gr. $)$ Vogesen und im Schwarzwalde wiederkehrende Isoëles echinospora.

Die Böhmerwaldflora mit ihren Charakterarten breitet sich auch auf den Klattau. Vorbergen weit gegen die Böhmische Ebene hin aus. Noch bei Klattau finden 


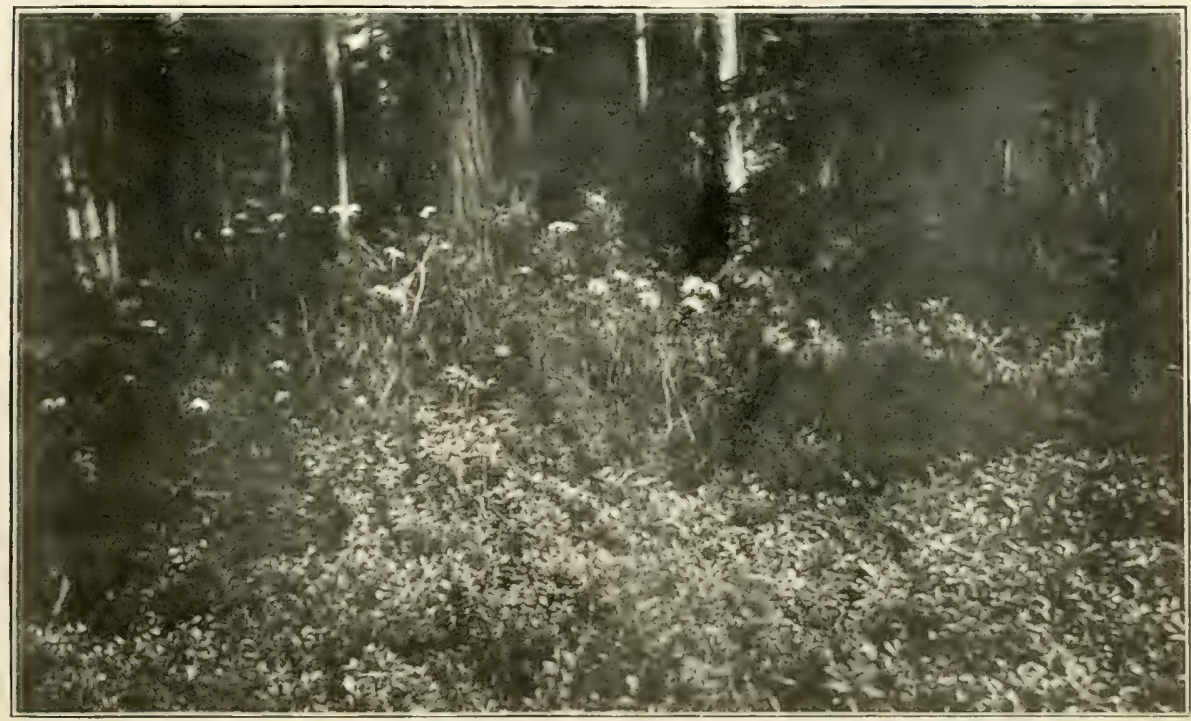

Abb. 70. Ledum palustre und Vaccinium uliginosum im Moore am Nordende des Langenbruckerteiches hei Schwarzbach im südlichen Böhmerwald.

(Nach einer Aufnahme von Prof. Fi. Nabèlek, Leipnik.)

(Aus der Bildersammlung des botanischen Institutes der Wiener Universität.

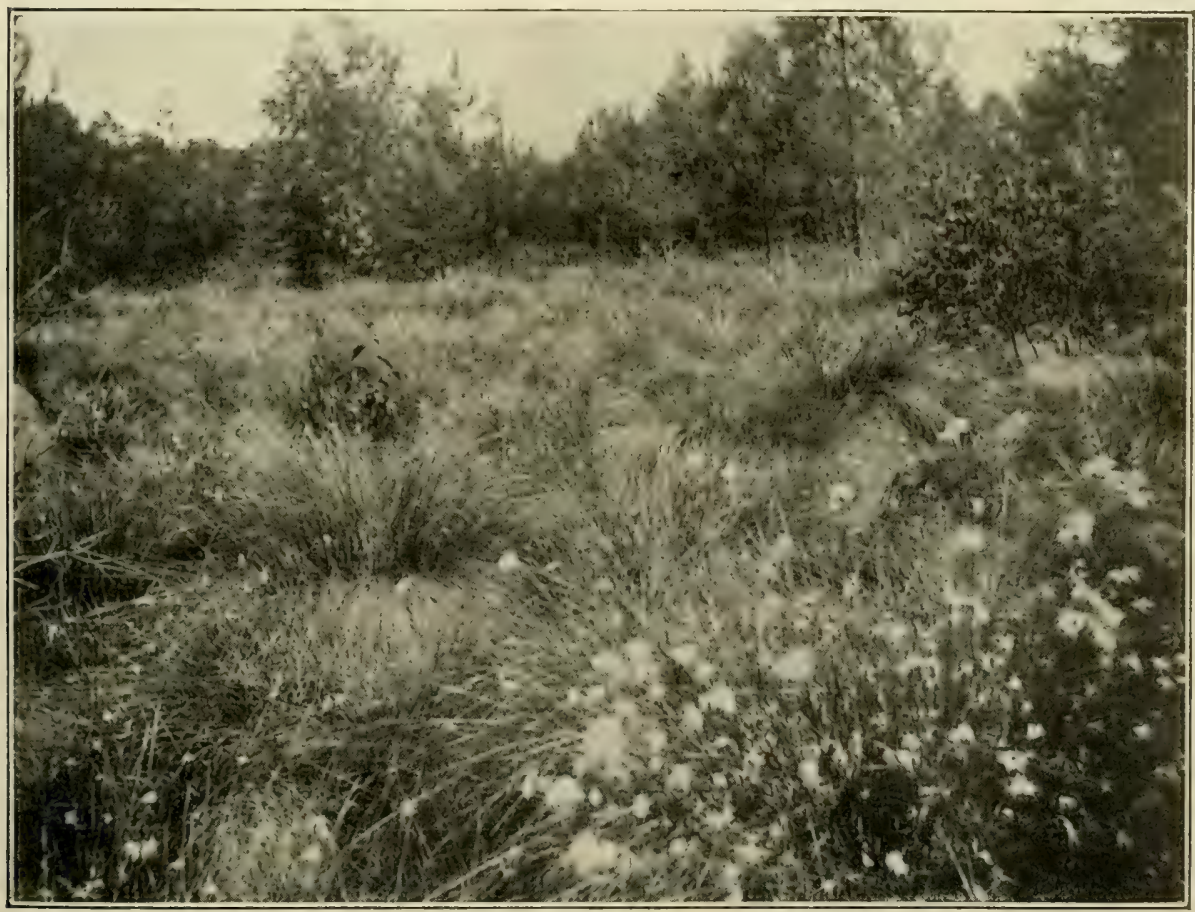

Abb. 71. Eriophorum vaginatum im Hochmoore am Nordende des Langenbruckerteiches bei Schwarzbach im südlichen Böhmerwalde.

(Nach einer Aufnahme von Prof. F. Nabělek, Leipnik.

(Aus der Bildersammlung des botanischen Institutes der Wiener Universität.)

Verlag von Franz Deuticke in Leipzig und Wien. 

sich vielfach Fichten- und Buchenwälder mit Actaea spicala, Thalictrum aquilegifolium, Vaccinium Myrlillus, V. Vilis Idaea, Soldanella monlana, Trientalis europaea, Mulgedium alpinum, Prenanthes purpurea sowie Wiesen mit Primula veris, $P$. elatior, Scorzonera humilis, Arnica monlana und Moore mit Vaccinium uliginosum, Pedicularis palustris, P. silvalica, Menyanthes trifoliala, Achillea Plarmica usw., auch soll hier schon die weiter im Südosten verbreitete Alnus viridis vorkommen. Doch treten in der Umgebung von Klattau auch schon lichte Laubwälder aus Belula pendula, Quercus Robur, Qu. sessiliflora, Fagus silvalica auf, in deren Niederwuchs Calluna vulgaris, Anemone Hepalica, Digitalis ambigua, Jasione monlana, Hypochoeris radicala usw. vorliommen. Auf Eichen wurde hier auch Loranthus europaeus beobachtet.

Auch der nördlich der Moldauquellen zwischen Schüttenhofen und Winterberg liegende Teil des Böhmerwaldes bietet genug des Interessanten. Fichten- und Föhrenwälder herrschen vor, auf Wiesen sind Phyleuma nigrum und Arnica montana überall häufig. Südlich von Winterberg erhebt sich der $1362 m$ hohe Kubany, bekannt durch seinen prachtvollen, 46 ha umfassenden fürstlich Schwarzenbergschen Urwald. Jieser Wald besteht aus Fichten, Buchen und Tannen zu ziemlich gleichen Teilen, meist prächtigen, uralten, dicht von Flechten bewachsenen Stämmen; zahlreiche gestürzte Baumriesen bedecken den Boden, das üppige Unterholz besteht aus jungen Buchen, Fichten und Tannen sowie aus Rubus Idaeus, Sambucus racemosa, Lonicera nigra, Corylus und hier in höheren Lagen auch aus der weiter südwärts häufigeren Grünerle (Alnus viridis); im Niederwuchs ist besonders Petasiles albus durch sein stellenweise massiges Auftreten auffallend, doch auch Thaliclrum aquilegifolium, Ranunculus platanifolius, Soldanella montana, Senecio nemorensis, Homogyne alpina, Prenanthes purpurea sind nirgends selten.

Vom Kubany südostwärts setzt sich der Böhmerwald bis an die Moldau fort und endigt im Blanskerwalde bei Krumau. Auch hier treten in tieferen Lagen eintönige Fichten- und Föhrenwälder mit einem Niederwuchs aus $D e$ Blanskerschampsia flexuosa, Vaccinium Myrlillus, Melampyrum pratense *vulgatum usw. auf, doch finden sich hier einige sonst im Böhmerwalde fehlende Arten, vor allem Cyclamen europaeum. In höheren Lagen herrschen Buchen und Fichten und im Niederwuchs findet man noch zahlreiche typische Böhmerwaldpflanzen, wie Actaea spicata, Soldanella monlana, Lamium luleum, Luzula nemorosa, Polygonatum verticillalum, Lonicera nigra. An den Hängen des Gebirges gegen Budweis und Krumau aber treten schon eine Menge von Arten der Hügelflora in den lichten Misch- und Laubwäldern auf, so Dianthus deltoides, Genista lincloria, G. germanica, Coronilla varia, Salvia pralensis, Melampyrum nemorosum; an Felsen kommen Bupleurum falcalum und Alyssum Arduini vor. An den Hängen gegen die Moldau treten Buchenwälder auf, zwischen Goldenkron und Krumau aber auch Buschformationen aus Quercus Robur, Qu. sessiliflora, Krumau. Berberis vulgaris, Tilia cordala und Rosen, in denen Fesluca glauca, Brachypodium pinnalum, Allium montanum, Alyssum Arduini, Cytisus nigricans, Salvia verticillala und Achillea nobilis zu finden sind. Diese Buschformationen gehen 
nach oben zu in Eichen- oder Buchenbestände über, in denen dann in feuchten Schluchten wieder Aruncus silvester, Daphne Mezereum, Lilium Marlagon usw.

Turkowitz. vorkommen. Auf Kalkboden, wie bei Turkowitz, findet man Anthericum Liliago, Anemone silvestris, Coloneaster integerrima, Brunella grandiflora, Stachys recta, Asperula glauca, Libanotis montana und das in ganz Böhmen nur hier vorkommende Verbascum austriacum, ober dem Bahnviadukt auch Andropogon Ischaemum gesellig auftreten, während an den Felsen des Schloßberges ron Krumau. Krumau Alyssum Arduini in Menge gedeiht.

Im Moldautale sind auch von Unter-Wuldau abwärts noch reichlich Moore entwickelt, doch machen die Hochmoore allmählich reinen Wiesenmooren Platz. Südlich der Moldau treten im Böhmerwalde zwei weitere weiter nördlich

Hohenfurth.

Kaplitz. daselbst fehlende Arten auf, Cardamine trifolia, die bei Hohenfurth ihre nördlichsten Standorte hat und von da südwärts im Mühl- und Waldviertel verbreitet ist, und Erica carnea, die bei der Teufelsmauer bei Hohenfurth zu finden ist. Auch noch westlich der Moldau, wie bei Kaplitz, behalten die Wälder den Charakter der Hochgebirgswälder des Böhmerwaldes bei. Auf dem $1050 \mathrm{~m}$ Hochwald. hohen Hochwald an der niederösterreichischen Grenze kommen noch Luzula silvatica, Polygonatum verticillalum, Cardamine trifolia, Thalictrum aquilegifolium, Homogyne alpina und Willemetia stipitala vor.

Auch auf oberösterreichischer Seite ist auf den Hochgipfeln des PlöckenHochfichtel.

Doronicum austriacum, Prenanthes purpurea, Lilium Martagon, Lonicera nigra usw. die herrschende Formation, auch Moore mit Andromeda polifolia und Oxycoccos quadripetala treten daselbst auf. Ebenso sind im übrigen Zuge des Böhmerwaldes, über den Sternstein bis zum Tafelberg und zur niederösterreichischen Grenze Mischwälder aus Fichten, Tannen und Buchen und cingesprengten Exemplaren von Acer platanoides und A. Pseudoplatanus, mit Lonicera nigra, Sambucus racemosa und Rosa pendulina im Unterholze und Luzula silvatica, Polygonalum verticillatum, Lunaria rediviva, Ranunculus platanifolius, Aruncus silvesler, Soldanella montana, Pelasiles albus und Crepis paludosa im Niederwuchs entwickelt. Auch Hochrnoore sind nicht selten, wie z. B. bei

Weißenbach.

Schlägel.

Rohrbach.
Kirchschlag.
Weißenbach, wo neben Carex dioica, $C$. pauciflora, Eriophorum vaginatum und Homogyne alpina auch Calla palustris vorkommt und bei Schlägel, Schwarzenbach und Rohrbach, wo Pedicularis silvatica anzutreffen ist. Auf Bergwiesen sind im ganzen Mühlviertel noch Phyleuma nigrum und Arnica montana häufig, auf den niedereren Bergen aber finden sich ausgedehnte Fichtenund Föhrenwälder mit massenhaften Heidelbeeren als Niederwuchs. Bei Kirchschlag, Hellmonsödt und von da abwärts ist Alnus viridis überall häufig. Auch Moore sind noch allenthalben verbreitet; so bei Kirchschlag Hochmoore mit Eriophorum vaginatum, Trichophorum alpinum, Carex dioiea, Juncus filiformis, J. quarrosus, Drosera rolundifolia, Vaccinium uliginosum, Andromeda polifolia; bei Zwettl nächst Hellmonsödt und Freistadt tritt Calla palustris auf, die überhaupt im oberösterreichischen Mühlviertel ziemlich verbreitet ist. Bei Schloß Neuhaus an der Donau kommt an Felsen Alyssum 


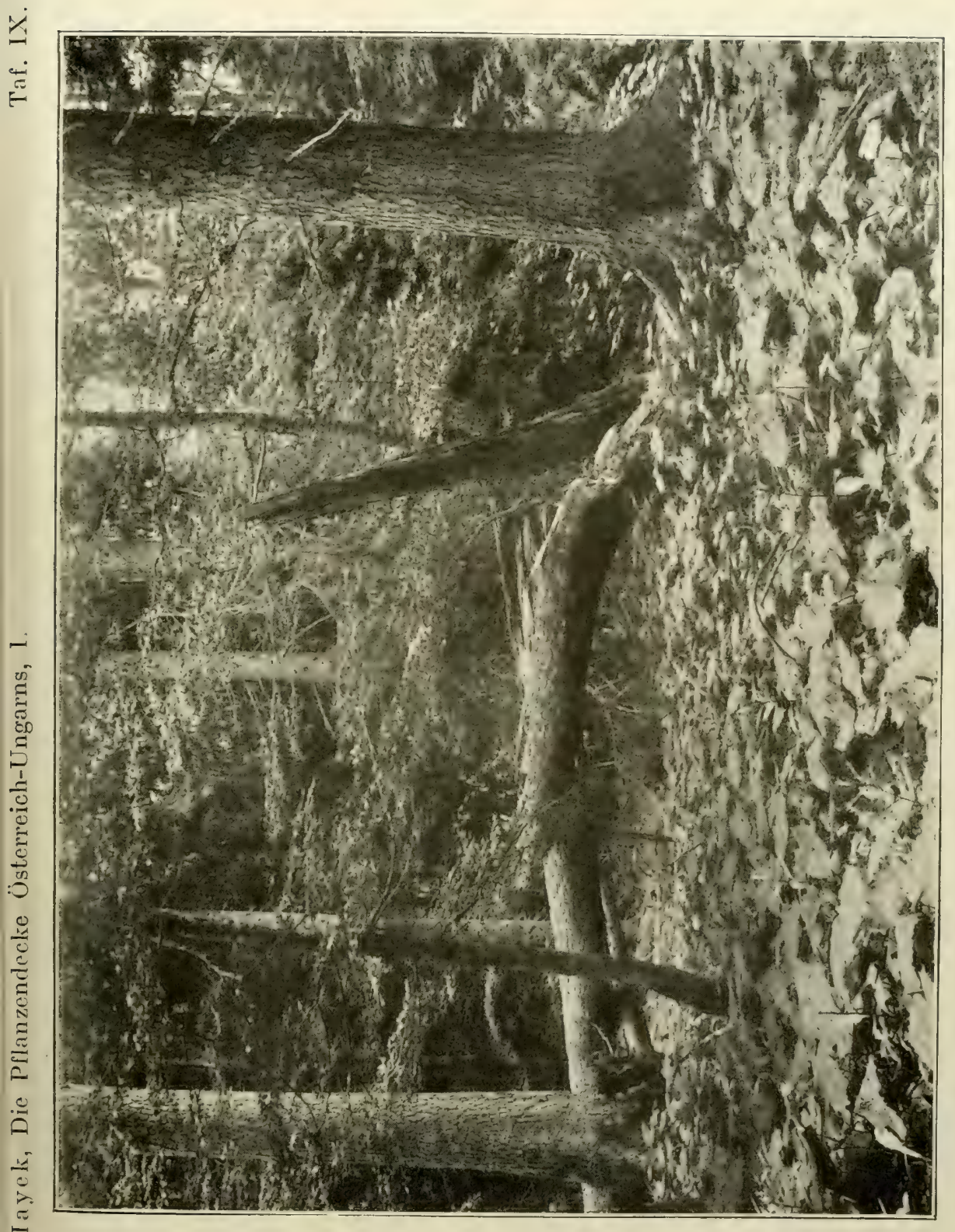

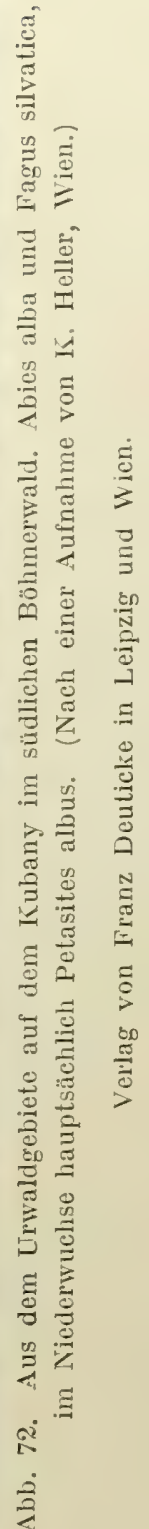



Arduini, in Mooren Hypericum Elodes vor. Erst bei Linz kommen einige Linz. fremde Typen hinzu, so im Haselgraben Buphthalmum salicifolium und auf dem Pöstlingberg und Pfennigberg Cylisus nigricans. Noch einmal treten typische Hochgebirgswälder im östlichen Teile Oberösterreichs auf, bei Grein, wo in großem Haßstabe gelungene Aufforstungsversuche mit fremdländischen Nadelhölzern gemacht wurden und bei Waldhausen, wo auch Hochmoore mit Carex pauciflora, $C$. dioica, C. limosa und Calla palustris nicht selten sind; Alnus viridis und Arnica montana sind hier im ganzen, Greiner Walde" noch häufig und bei Sophienschloß kommt auch Malaxis paludosa vor.

\section{Zentralböhmen.}

Das zentrale Böhmen ist in pflanzengeographischer Beziehung eines der interessantesten Gebiete von ganz Europa, da es kaum irgendwo vorkommen dürfte, daß in einem relativ so kleinen Gebiete sich so verschiedenartige Florenelemente finden. Der südliche Teil erinnert in seiner Vegetation lebhaft an die Vegetation des südlichen Böhmerwaldes und des Böhmisch-mährischen Gebirges und es kommen daselbst auch mit Ausnahme der Hochgebirgspflanzen, wie Agrostis rupestris, Poa alpina, Juncus trifidus, Cardamine resedifolia, Genliana pannonica fast alle Arten der Böhmerwaldflora vor. Im Moldautale und seinen Seitentälern sowie im Böhmischen Mittelgebirge treten an sonnigen Hängen, an trockenen grasigen Stellen in großer Zahl östliche TYyen auf, wie sie im westungarischen Berglande, auf den Vorbergen der Karpathen, auch in Mittel- und Südmähren und in Niederösterreich zu Hause sind, dem Gebiete der ,pannonischen" Flora. Außerdem trifft man sogar typische Steppenpflanzen, wie sie erst in Südmähren oder in der Ungarischen Tiefebene wieder vorkommen, auch einzelne Arten aus Südrußland oder Polen. Von diesen Steppenpflanzen sind vor allem jene von Interesse, die in Südmähren und Niederösterreich fehlen und erst in der ungarischen Tiefebene sich wieder finden; solche Arten der böhmischen Flora sind Silene longiflora, Anemone palens, Erysimum crepidifolium, Lalhyrus pisiformis und Koeleria nilidula; auch Avena deserlorum hat in Böhmen einen weit nach Westen vorgeschobenen Standort, wurde jedoch kürzlich auch in Südmähren und Niederösterreich entdeckt. Außerdem ist die böhmische Sandflora durch zwei den norddeutschen Sandgebieten eigentümliche Arten ausgezeichnet, Astragalus arenarius und Jurinea cyanoides; hingegen fehlen der böhmischen Flora wieder einige Steppenpflanzen, die im südlichen Mähren oder wenigstens im nordöstlichen Niederösterreich schon anzutreffen sind, so z. B. Andropogon Gryllus, Tragus racemosus, Festuca vaginata, Gagea pusilla, Iris pumila, I. arenaria, Kochia arenaria, Silene multiflora, Dianthus serotinus, Erysimum canescens, Saxifraga bulbifera, Prunus nana, Cytisus Kilaibelii, Medicago prostrala, Linum hirsutum, Polygala maior, Salvia austriaca, S. Aethiopis, Campanula sibirica, Scorzonera austriaca, Taraxacum serotinum. Endlich wäre noch das Vorkommen des südöstlichen Erythronium Dens canis und des südlichen Farnes Ceterach officinarum in Böhmen zu erwähnen. 
Was die Gebirge Zentralböhmens betrifft, so zeigt der Brdywald große Übereinstimmung mit dem Böhmerwalde, wenn ihm auch naturgemäß die Hochgebirgsarten und die Arten der Bergseen fehlen; doch weist der Brdywald auch noch drei Arten der Erzgebirgsflora, die dem Böhmerwalde fehlen, auf, nämlich Thlaspi alpestre, Pastinaca opaca und Dianthus silvalicus. Das Böhmische Mittelgebirge hat nur in seinen höchsten Lagen eine ausgesprochene Gebirgsflora, die aber ziemlich artenarm ist, da ihr sowohl die Mehrzahl der Charakterarten des Erzgebirges, wie Meum alhamanticum, Lilium bulbiferum, Phyleuma nigrum, Luzula maxima, als auch die Böhmerwaldpflanzen Soldanella montana, Doronicum austriacum und Alnus viridis fehlen; auch die typischen Sudetenpflanzen der Waldregion, wie Aconilum Napellus *firmum, Adenostyles Alliariae, Delphinium elatum, Salix silesiaca, Poa Chaixii, Laserpitum Achangelica fehlen hier, doch kommt Pleurospermum austriacum im Mittelgebirge vor.

Der südlichste Teil von Zentralböhmen, zwischen Kaplitz, Budweis und Wittingau, erinnert in seiner Flora noch sehr an die der niedrigen Teile des Böhmerwaldes. Föhren- und Fichtenwälder sind die herrschenden ForElexnitzer mationen, vielfach von Hochmooren unterbrochen, wie an den Elexnitzer
Teiche. Teiche.

Teichen bei Schweinitz und die ,Pflanzen" nächst Kaplitz. Die Fichtenwälder weisen noch zahlreiche Arten des Böhmerwaldes auf, wie Luzula nemorosa, Maianthemum bifolium, Pirola minor, $P$. rolundifolia, Soldanella montana, Senecio rivularis und Prenanthes purpurea, natürlich aber sind zumeist $V a c$ Gratzen. cinium Myrlillus und $V$. Vitis Idaea tonangebend; auch bei Gratzen trifft man noch Aruncus silvester, Circaea alpina, Cirsium heterophyllum und Petasites albus; im nahegelegenen Theresientale kommt Genista pilosa und (verwildert) Doronicum caucasicum vor.

Wittin-
gauer $\quad$ Bei Gratzen beginnt das große Tertiärbecken von Wittingau, das sich Becken. nordwärts bis Weseli erstreckt und insbesondere durch seine zahlreichen Teiche und ausgedehnten Moore ausgezeichnet ist.

Schon bei Gratzen finden sich einige Teiche mit der ihnen eigentümlichen Flora, auf deren Dämmen Viscaria vulgaris eine häufige Erscheinung ist und bei Chlumetz gedeihen am Stankauer Teich Juncus Tenageia und Crassula Georgen- aquatica. Zwischen Georgenthal und Bor dehnt sich das ,Rote Moos“ aus,
thal. cin großes Moor, in ?dem besonders die ausgedehnten Bestände von Pinus uliginosa mit massenhaftem Ledum palustre als Unterholz bemerkenswert sind. Bor. Hinter Bor befinden sich große Waldwiesen mit Briza media, Holcus lanalus, Festuca rubra, Carex leporina, Orchis latifolia, Lychnis Flos Cuculi, Dianthus deltoides, Chrysanthemum Leucanthemum, Scorzonera humilis, Crepis succisaefolia usw. Weiter nach Nordosten zu treten Wälder aus Föhren mit eingestreuten Fichtenbeständen und kleinen Mooren, auf denen Juncus squarrosus Wittingau. vorkommt, auf. Die Umgebung von Wittingau selbst stellt ein weites Wiesenland dar, doch bieten diese Kulturwiesen außer dem seltenen Phyleuma nigrum, Cirsium palustre und $C$. canum nichts Besonderes, in den Gebüschen tritt bereits Spiraea salicifolia häufig auf. Das ,Schloßrevier" besteht aus Wäldern, und zwar auf Sandboden aus Föhrenwäldern, auf feuchtem Boden 
aus Erlenbrüchen mit Dryopteris crislata, D. Thelypteris, Calla palustris, Goodiera repens, Stellaria palustris und Gircaea alpina. Von besonderem Interesse sind aber in der Umgebung Wittingaus die zahlreichen großen Fischteiche, von denen der Světteich, der Rosenberger Teich und der Steinröhrenteich die größten sind. Diese Teiche sind fast durchwegs von dichten Beständen aus Phragmiles communis, Glyceria aquatica, Typhoides arundinacea, Schoenoplectus lacustris, Typha anguslifolia, Sparganium ramosum, Iris Pseudacorus und Equisetum limosum umgeben, in welchen Rührichtbeständen Glyceria fluitans, Bulomus umbellatus, Scirpus maritimus, S. silvaticus, S. radicans, Filipendula Ulmaria, Lythrum Salicaria, Cicula virosa, Peucedanum palustre, Menyanthes trifoliala u. a. Sumpfpflanzen häufig auftreten. Hingegen ist die Wasserflora, besonders der größeren Teiche nicht reich und besteht hauptsächlich aus Caslalia alba, $C$. candida, Polamogeton nalans, $P$. lucens, $P$. crispus und Polygonum amphibum. Reicher ist die Flora der Wassergräben und Bäche, in denen vor allem Elodea canadensis, Holtonia palustris, Myriophyllum verticillatum, Zannichelia palustris, an einzelnen Stellen auch Utricularia minor, neglecla und ochroleuca vorkommen. Sehr. bezeichnend für das Wittingauer Teichgebiet sind auch die prächtigen alten Eichen, die überall auf den Dämmen der Teiche stehen, wo übrigens auch das im Gebiete sonst seltene Gras Andropogon Ischaemum wächst. Wird einer der Teiche abgelassen, entwichelt sich auf dem schlammigen Grunde sehr rasch die oben (S. 139) geschilderte Flora des nackten Teichbodens, aus der als für das Gebiet besonders bezeichnend Isolepis selacea, Heleocharis ovala, H. acicularis, Cyperus flavescens, C. fuscus, Juncus tenageia, Spergularia echinosperma, Radiola linoides, Limosella aquatica, Lindernia pyxidaria, Bidens radialus und das seltene Gras Coleanthus sublilis hervorzuheben sind.

Neben den Teichen sind für das Gebiet von Wittingau besonders die ausgedehnten Moore von Bedeutung, teils Wiesenmoore mit Carex Davalliana, pulicaris, panicea, vesicaria, rostrala, Iris sibirica, Orchis latifolia, O. angustifolia (hinter dem Svètteiche), Lychnis Flos Cuculi, Peucedanum palustre, Menyanthus trifoliala, Centaurium pulchellum, Parnassia palustris, Senecio aqualicus usw., teils aber, und zwar hauptsächlich Hochmoore mit Eriophorum vaginalum, Trichophorum alpinum, Carex lasiocarpa, C. Pseudocyperus, Rhynchospora alba, Vaccinium uliginosum, V. Vitis Idaea, Oxycoccos quadripetala, Andromeda polifolia, Calluna vulgaris, die oft mit Pinus uliginosa bestanden sind, unter deren Schatten Ledum palustre mit seinen weißen, duftenden Blüten das Unterholz bildet. Seltenere Arten dieser Moore sind Hydrocotyle vulgare, Salix myrtilloides (beim Svět-Teich) und bei St. Veith Carex chordorrhiza und C. pauciflora, hingegen fehlt Empetrum nigrum hier durchgängig. Auch Erlenbrüche sind nicht selten, in denen Salix pentandra, S. cinerea, Alnus viridis, Prunus Padus, Rhamnus Frangula das Unterholz bilden, während für den Niederwuchs Dryopteris spinulosa, D. cristata, Deschampsia caespitosa, Calla palustris, Ranunculus flammula, Caltha palustris, Potentilla palustris, Filipendula Ulmaria, Peucedanum paluslre, Lysimachia vulgaris, L. thyrsiflora, Lycopus 


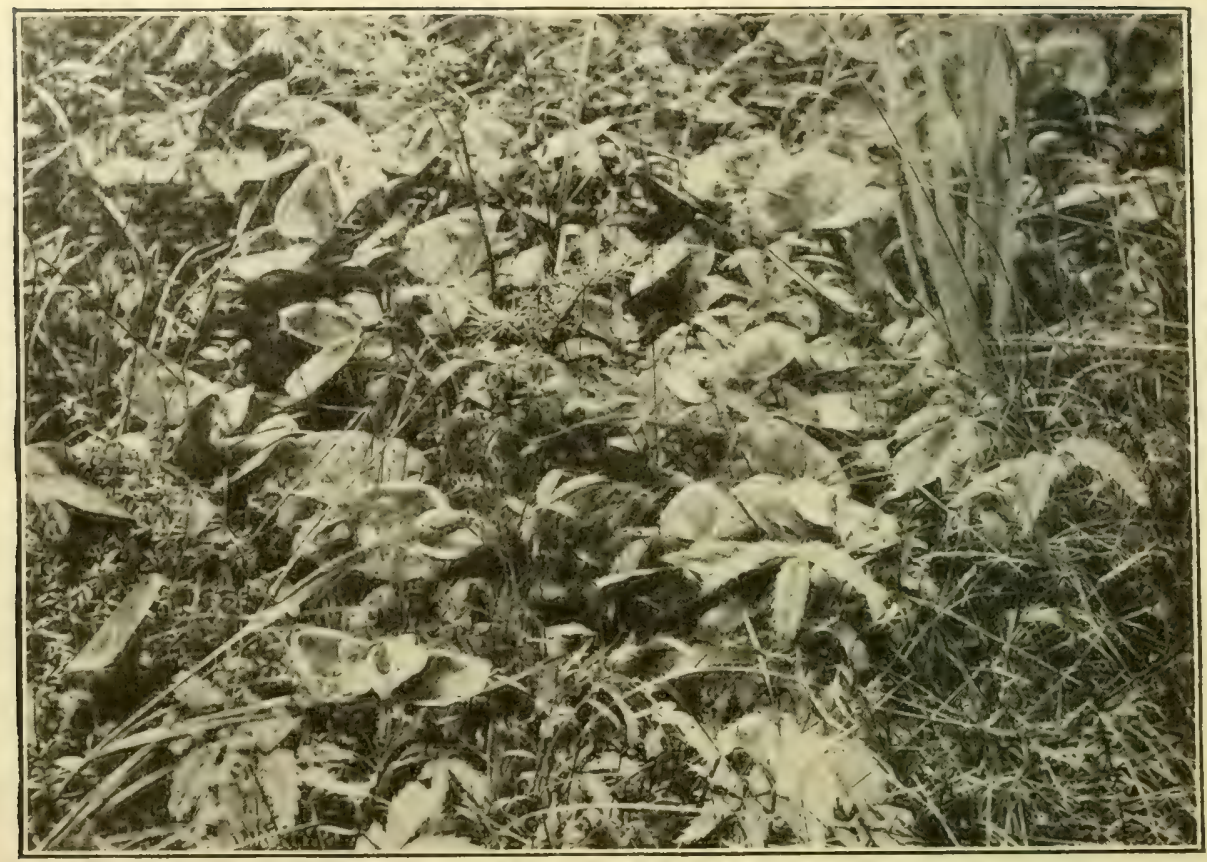

Abb. 73. Aus einem Erlenbruche zwischen Leština und Baština nächst Wittingau. Calla palustris mit Potentilla palustris, im Vordergrunde die Blätter von Peucedanum palustre, rechts oben Iris Pseudacorus.

(Nach Domin, Die Vegetationsverhältnisse von Vesely, Wittingau usw.)

europaeus und Galium palustre charakteristisch sind. An trockeneren Stellen treten im Gebiete vornehmlich Heideformationen mit Calluna vulgaris, Nardus stricta, Festuca ovina, $F$. capillata, Scleranthus perennis usw., im Süden des Gebietes auch Heidewiesen mit massenhafter Arnica montana auf.

Die Wälder des Gebietes sind meist Bruchwälder, auf trockenem Sandboden aber treten auch Föhrenbestände mit höchst eintönigem Niederwuchs aus Vaccinien, Pteridium aquilinum, Cytisus nigricans und (selten) Cytisus ratisbonensis auf.

Auch im westlich von Wittingau gelegenen Budweiser Becken sind zahlreiche, wenn auch meist kleinere Teiche und Moore vorhanden, so besonders Budweis. am Teiche bei Hackelhof westlich und am Fellinger, Czernitzer und Neuen Teiche nördlich von Budweis. Interessantere Pflanzen dieser Moore sind Carex dioica, C. paradoxa, C. diandra, C. elala, Polygala amarella, Hydrocotyle vulgare und Lysimachia thyrsiflora, während in Erlenbrüchen Dryopteris Thelypteris, Calla palustris, Polentilla palustris und Peucedanum palustre auftreten. In Wassergräben kommt Sparganium minimum, in den Teichen die bei Wittingau fehlende Trapa natans vor. Im übrigen zeigt die Flora der Umgebung von Budweis noch starke Anklänge an die Böhmerwaldflora. Die Wälder sind meist Fichtenwälder mit Vaccinien, Prenanthes purpurea, Solda- 
nella montana usw., auf den Wiesen sind überall Phyteuma nigrum und Arnica montana sehr häufig; an der Moldau bildet Spiraea salicifolia ganze Bestände. Auch nördlich von Budweis, bei Frauenberg. sind noch interessante Wiesenmoore mit Carex gracilis, C. Lurfosa, C. diandra, C. Psendocyperus, Lysimachia thyrsiflora, Peucedanum palustre und Lotus uliginosus, jedoch von geringerer Ausdehnung, entwickelt.

Das Gebiet nördlich vom Budweiser Teichgebiet bis gegen Přibram ist ein ehemaliges Sumpf- und Waldgebiet, das heute weithin kultiviert und von zahlreichen Teichen bedeckt ist. Die Wälder sind zumeist Fichtenwälder, auf den Wiesen sind Trollius europaeus, Chaerophyllum aureum, Primula elatior und stellenweise, wie bei Pisek, auch Phyleuma nigrum häufig. In den Teichen des Gebietes findet man neben der überall hüufigen Castalia alba stellenweise auch Trapa nalans und Nymphoides pellata, auch die Flora der nackten Teichböden bietet manche interessante Art, wie Coleanthus sublilis, Carex cyperoides, Heleocharis ovala, Limosella aquatica und Bidens radialus. Auch Noore, sowohl Wiesen- als Hochmoore, sind ab und zu anzutreffen, auf denen bei Putim Carex Buekii, Polentilla palustris, Menyanthes trifoliala und Cicula virosa vorkommen, während in Moorgräben bei Z átav Utricularia vulgaris und $U$. minor zu finden sind. Östlich von Pisek, bei Strakonitz, sind nur kleine Wiesen-Strakonitz. moore entwickelt, und auch um Blatna sind wieder sowohl Hoch-als Wiesenmoore kleiner $n$ Umfanges vorhanden, auf denen u. a. bei Mackow Crepis succisaefolia, bei Bratonitz Carex polygama, am Kořensky-Teiche bei Lažan Sedum villosum vorkommen; das größte Noor ist das am Thořowitzer Teiche bei Lnár, wo sich Carex diandra, C. elata, C. limosa, C. Pseudocyperus, C. riparia, Juncus alpinus *fuscoaler, Sparganium minimum, Hypericum humifusum und Potentilla norvegica finden. Am Ropitzer Teich bei Blatna ist wieder die Flora der nackten Teichböden mit Coleanthus subtilis, Carex cyperoides, Heleocharis ovata, H. acicularis, Limosella ayuatica, Peplis Portula und Bidens radiatus in schöner Ausbildung anzutreffen. Im Tale der Wottawa von Pisek bis Strakonitz sind an sonnigen Hängen auch Triften mit Andropogon Ischaemum, Hierochloë australis, Dianthus delloides, Polygala Chamaebuxus, Jasione monlana, Artemisia scoparia, Centaurea rhenana usw. entwickelt.

Einen ganz andern Charakter hat die Vegetation auf dem Höhenzuge östlich von Pisek gegen die Moldau zu. Hier sind schöne Fichtenwälder noch heute in großer Ausdehnung vorhanden, in denen manche Gebirgsarten anzutreffen sind, so vor allem zwischen Kamaik und Klingenberg in großer Menge Salvia glutinosa, ferner Festuca silvatica, Rubus saxatilis, Lunaria rediviva und Polygala Chamaebuxus. In einer kühlen Schlucht bei Klingenberg kommt sogar Doronicum austriacum vor, während nur $8 \mathrm{~km}$ weiter nördlich in einer Schlucht bei Schloß Worlik Doronicum Malthioli beobachtet wurde. Die Bergwiesen dieser Gegend bieten ebenfalls eine Reihe interessanter Arten, wie Orchis ustulata, Trollius europaeus, Melandryum silvestre, Thlaspi alpestre; Ghaerophyllum aureum, Trifolium spadicum, Scorzonera humilis; an feuchteren Stellen auch Spiraea salicifolia. Die gegen die Moldau selbst gerichteten Ab-Moldautal. 
hänge aber zeigen ein ganz anderes Bild. An Stelle der Fichtenwälder treten trockene Föhrenbestände, in denen bei Worlik Arabis Turrita anzutreffen ist. oder Buschwerk aus Carpinus Belulus, Prunus spinosa, Sorbus Aria, Rosa Jundzilli, trachyphylla, tomentosa, Ligustrum vulgare, Lonicera Xylosteum; an den felsigen Hängen über dem Flusse aber hat sich eine reiche thermophile Vegetation angesiedelt, bestehend aus Stipa pennala, S. capillala, Fesluca glauca,

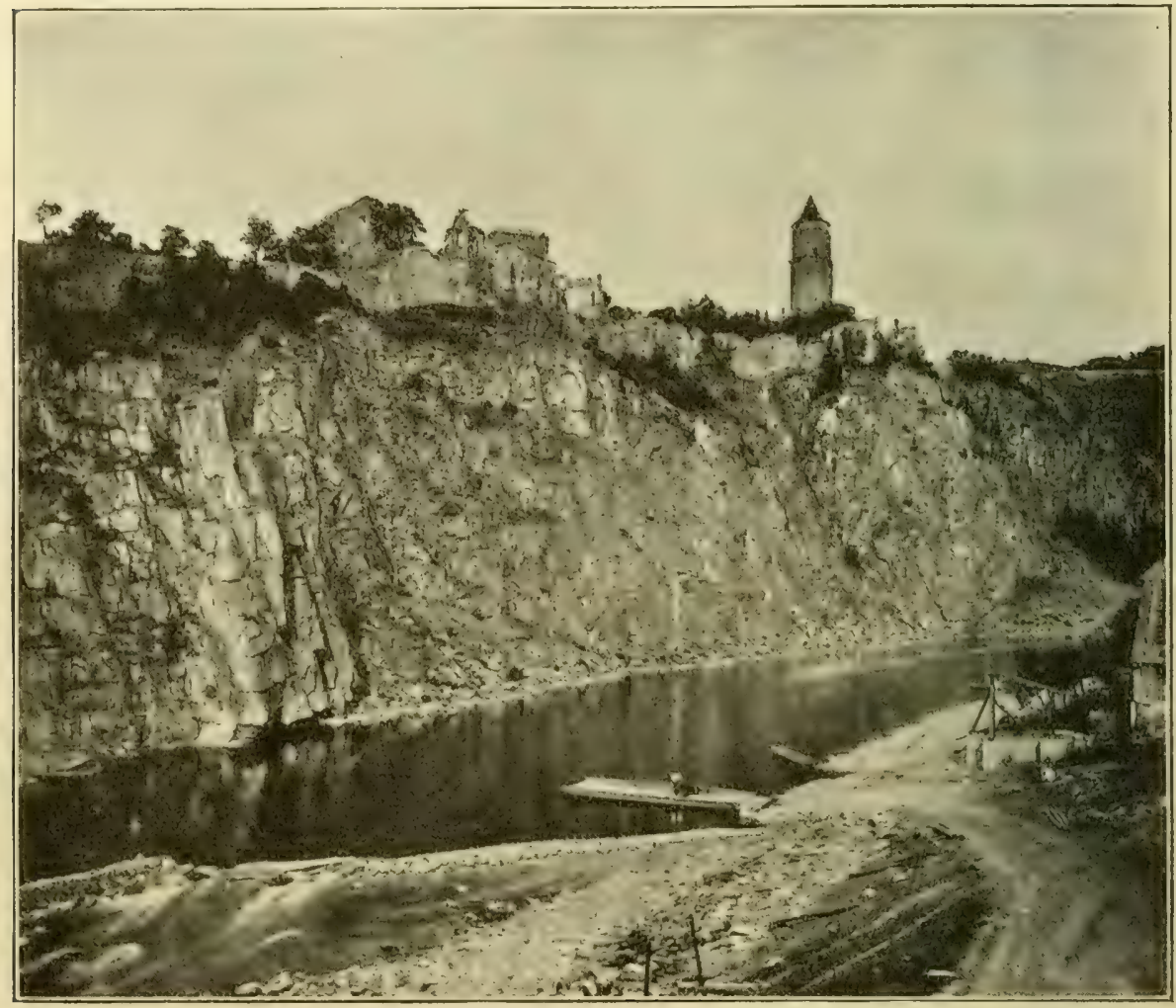

Abb. 74. Das Moldautal bei IKlingenberg.

(Nach H. Eckert, Landschaftsbilder aus Böhmen.)

(Aus der Bildersammlung des geographischen Institutes der Wiener Universität.)

Carex humilis, Anemone nigricans, Arislolochia Clemalitis, Saxifraga decipiens, Potentilla arenaria, P. canescens, Alyssum Arduini, Seseli Beckii, Diclamnus albus, Salvia nemorosa, Scabiosa ochroleuca, Asperula cynanchica, Centaurea variegala, Lactuca perennis, L. viminea usw., hie und da auch Buschwerk von Sarothamnus scoparius oder Bestände von Verbascum Lychnites und V. phlomoides.

Das Gebiet rechts von der Moldau, zwischen Wittingau und Tabor, bietet wenig Interessantes. Soweit nicht Äcker den Boden bedecken, herrschen Föhrenwälder mit Vaccinien und Pteridium aquilinum oder Sandheiden mit Festuca ovina, Nardus stricta, Carex leporina, Scleranthus perennis, 
Rumex Acetosella, Teesdalea nudicaulis, Jasione montana und Hieracium Pilosella vor.

In der Umgebung von Tabor treten in Wäldern Lilium Marlagon, AcoTabor. nitum variegatum, A. Vulparia, Actaea spicata, Cardamine enneaphyllos, Soldanella montana, Lunaria rediviva, Symphylum luberosum, Senecio nemorensis und auch Melica picta auf; auf Wiesen und Heiden Leucoium vernum, Arabis Halleri, Viola collina, Armeria vulgaris. An felsigen sonnigen Hängen wie im Tale der Pintycka, aber sind mehrere wärmeliebende Arten, wie Rosa trachyphylla, Alyssum Arduini, Cenlaurea rhenana und an den Felsen der Ruine Pribenitz auch Hieracium Schmidlii zu finden.

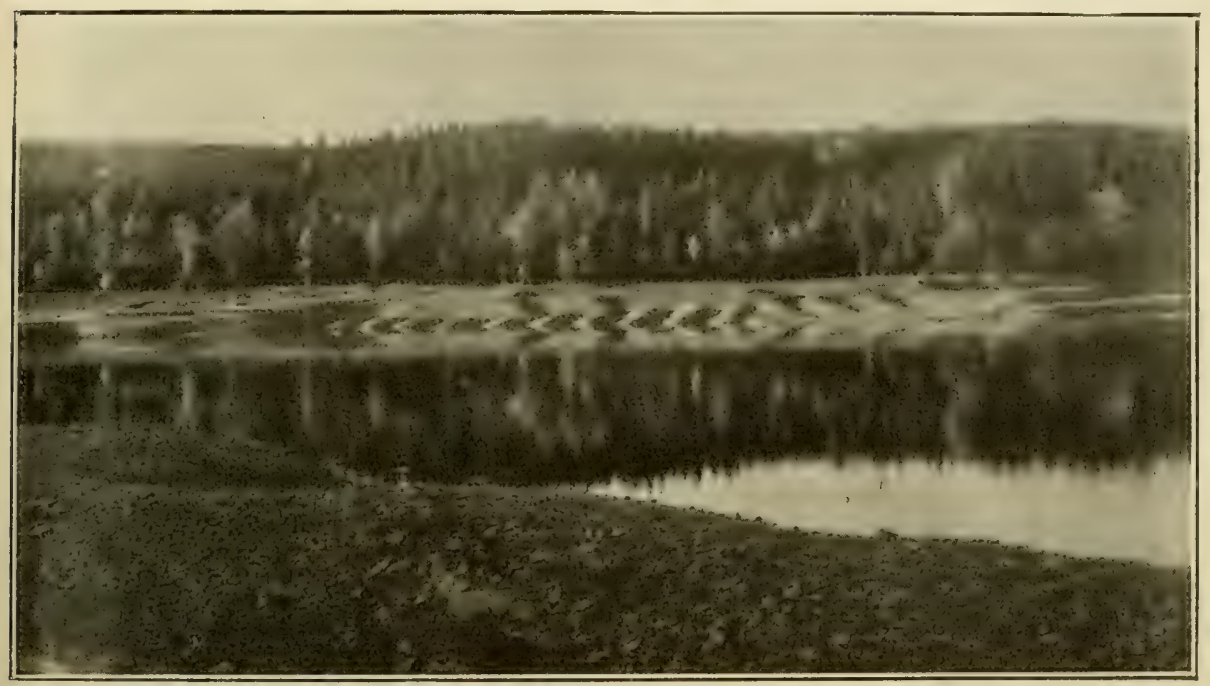

Abb. 75. Fichtenbestände am Sophienteiche im Brdywalde.

(Nach einer Aufnahme von Prof. K. Domin, Prag.)

In der Umgebung von Přibram sowie im ganzen Vorlande des Brdy- Přibram. waldes sind Föhren- und Fichtenwälder reich entwickelt. Die Föhrenbestände zeigen eine höchst eintönige Flora ; ein Unterholz fehlt entweder ganz oder besteht aus Juniperus communis, Sarothamnus scoparius, Crataegus oxycantha und Prunus spinosa, im Niederwuchs sind Deschampsia flexuosa, Sieglingia decumbens, Carex digitala, Cylisus nigricans, Melampyrum vulgatum, besonders aber Vaccinium Myrlillus und Calluna vulgaris die tonangebenden Pflanzen; ab und zu lommt auch Polygala Chamacbuxus vor. Auch die Fichtenwälder, die auch die Hänge des Brdywaldes bekleiden, sind nicht viel artenreicher. Unter die Brdywald. Fichten mischen sich Föhren, Buchen, Birken, hie und da auch Quercus sessiflora und Sorbus Aucuparia; im Niederwuchs sind auch hier Vaccinium Myrtillus und Calluna vorherrschend, doch kommen daneben auch Festuca giganlca, Milium effusum, Bromus asper, Luzula nemorosa, Carex brizoides, Anemone nemorosa, Ranunculus lanuginosus, Potentilla erecla und procumbens, Merctirialis perennis, Lathyrus vernus, Sanicula europaea, Pirola uniflora, P. rotundifolia, 
secunda, minor und chlorantha, Alhyrium Filix femina, Dryopleris Filix mas und D. spinulosa vor. Viel reicher ist die Flora des Brdygebirges erst in höheren Lagen, in über 600-700 m Meereshöhe. In den dichten Fichten- und Mischseltener Buchenwäldern treten da Calamagrostis villosa, Fesluca silvatica, Luzula nemorosa, Polygonalum verlicillalum, Thalictrum aquilegifolium, Actaea spicata Arabis Halleri, Polygala Chamaebuxus, Chaerophyllum Cicularia, Aruncus silvester, Rubus saxatilis, Soldanella montana, Trientalis europaea, Veronica montana, Centaurea pseudophrygia, Pelasites albus, Solidago Virga aurea, Prenanthes purpurea, Phyleuma orbiculare und als Seltenheiten auch Poa sudelica, Chrysosplenium opposilifolium, Cirsium helerophyllum und Homogyne alpina auf. Seltener sind im Brdywalde reine Buchenbestände mit Polystichum spinulosum, Milium effusum, Hordeum europaeum, Allium ursinum, Sanicula europaea, Vicia sillatica, Anemone Hepatica, Prenanthes usw. Die Bergwiesen des Gebietes sind durch Coeloglossum viride, Dianlhus silvaticus, Polentilla alba, Arabis Halleri, Thlaspi alpestre, Trollius europaeus, Saxifraga granulata, Chaerophyllum aureum, Primula elalior, Gentiana verna, G. Pneumonanthe, G. Weltsteinii, Trifolium spadiceum, Centaurea pseudophrygia, Arnica montana, Scorzonera humilis und Phyteuma orbiculare ausgezeichnet, während auf Sumpfwiesen Lotus uliginosus häufig ist Hochmoore sind im Brdywalde selten und von geringer Ausdehnung, das größte liegt beim Padrter Teiche. Die höchsten Kämme des Gebirges aber bedecken Bergheiden aus Nardus stricta, Deschampsia flexuosa, Calluna vulgaris, Vaccinium Myrtillus und Cladoniaarten, in denen nur wenige interessantere Arten wie Polygala Chamaebuxus und Trientalis europaea anzutreffen sind. In den Horowitz. nach Norden und Osten sich öfnenden Tälern des Gebirges, wie bei Horowitz Dobriš. Rejkovits und Dobriš, haben sich mehrere wärmeliebende Arten angesiedelt wie Erysimum crepidifolium, Trifolium ochroleucum, Vicia pisiformis, Medicagc minima, Laserpitium pruthenicum, Lythrum Hyssopifolia, Caucalis daucoides Salvia verlicillala, Veronica spicata, Crepis rhoeadifolia und bei Řidlia aucl Anemone patens.

Auch auf den Ausläufern des Brdywaldes gegen Pilsen zu ist noch di Fichte der herrschende Waldbaum, in deren Beständen Paris quadrifolia, Poly. gonalum verlicillalum, Plalanthera montana, Goodiera repens, Daphne Mezereum Bukova Vinca minor und Prenanthes purpurea vorkommen; die Bukova hora be Pilsen. Ždirec trägt sogar Buchenbestände. In der Umgebung von Pilsen selbs herrschen jedoch Föhrenwälder mit Anemone vernalis, Polygala Chamaebuxus Lalhyrus montanus, Chimaphila umbellata, Pirola chlorantha, Erica carnea um. Chrysanlhemum corymbnsum weitaus vor; gegen Westen zu, bei Malesitz un Ratschitz, trifft man auch Mischbestände aus Eichen und Weißbuchen, ir denen u. a. Hierochloë australis, Carex digilata, Vicia pisiformis, V. cassubicu und Lathyrus monlanus zu finden sind. Der ,H aj" ist ein Mischwald aus Föhren Eichen und Weißbuchen, in welchem einige seltenere Arten, wie Melica picla Lilium Martagon, Anthericum ramosum, A. Liliago, Arabis brassicaeformis Dianthus silvalicus, Myosotis sparsiflora, Melillis Melissophyllum vorkommen Bolowetz. In den Teichen der Umgebung, besonders bei Bolowetz, ist wieder die Flor: 
der nackten Teichböden mit Cyperus flavescens, Coleanthus sublitis, Elatine Hydropiper und E. hexandra, Crassula aquatica, Potentilla norvegica, Radiola linoides, Centunculus minimus, Limosella aquatica, Gnaphalium luteoalbum und Bidens radiatus in schöner Ausbildung anzutreffen, während in den dieselben umgebenden Jooren Lycopodium inundalum, Eriophorum vaginatum, Rhynchospora alba, Carex lasiocarpa, Peucedanum palustre, Trientalis europaea, Vaccinium uliginosum und Oxycoccos quadripelala auftreten. In den Tälern der Flüsse Beraun, Nies, Radbusa und Angel aber finden sich auf sonnigen Hängen und an den Uferböschungen zahlreiche wärmeliebende Arten vor, wie insbesondere.Andropogon Ischaemum, Anthericum Liliago, Dianthus gralianopolilanus, Alyssum Arduini, Medicago minima, Trifolium strialum, Bupleurum falcalum, Peucedanum Oreoselinum, Stachys germanica, S. recla, Scabiosa ochroleuca, Artemisia scoparia und Centaura rhenana. Manche dieser Arten rücken bis an den Fuß des Böhmerwaldes vor; so kommen auf dem Bühl bei Plan noch Anthericum Liliago und A. ramosum, Bupleurum falcatum und Laserpitium pruthenium, auf dem Wolfsberge daselbst Aster Linosyris vor. Im Zliner Reviere bei Lukawitz, unweit Pilsen, wurde Thesium rostratum beobachtet. Anderseits aber ist auch wieder das Vorkommen der subalpinen Moehringia muscosa im Kličavatale bei Bürglitz, ihrem einzigen böhmischen Standorte, von hervorragendem Interesse. Auch bei Beraun treten noch Bergwälder mit Rubus Idaeus, Lilium Marlagon, Aconilum Vulparia, Senecio nemorensis und Wiesen mit Dianthus delloides, Gentiana Pneumonanthe und Achillea ptarmica auf, doch fehlen auch die pannonischen Elemente keineswegs ganz, wie Veronica spicala bei Autrozin.

Einen ähnlichen Charakter hat die Vegetation auch im rechts der Moldau gelegenen Landesteile im Gebiete der unteren Sazawa. Auch hier sind auf trockenem Boden xerophile Föhrenwälder mit Pleridium aquilinum die tonangebende Formation, während Fichtenwälder die kühleren Täler vorziehen. Auch Heideformationen mit Nardus stricta, Anthoxanthum odoralum, Koeleria gracilis, Calluna vulgaris, Genista germanica, G. tinctoria, Scleranthus perennis, Silene nutans, Viscara vulgaris, Helianthemum ovalum, Veronica Chamaedrys, Chrysanthemum corymbosum usw. sind nicht selten. In den tief eingeschnittenen Quertälern aber treten häufig Laubmischwälder aus Quercus, Carpinus und Corylus auf, in denen manche interessante Pflanze, wie Melica nutans, M. picta, Hierochloë australis, Cephalanthera alba, Polentilla alba, Euphorbia angulala, Lathyrus niger, Melittis Melissophyllum und bei Daole auch Erylhronium Dens canis $\mathrm{zu}$ finden ist; in Holzschlägen ist Myosolis versicolor häufig. An den felsigen Hängen gedeihen thermophile Arten, wie Anthericum Liliago, Dianthus Carthusianorum, Polentilla arenaria, P. canescens, Veronica Dillenii, Hieracium Schmidtii und $H$. candicans; bei Kostelec auch Phleum phleoides, Melica ciliala, Kostelec. Falcaria vulgaris, Seseli Beckii, Brunella grandiflora, Lactuca viminea, im Tale von Konopischt Carex pediformis; an grasigen Stellen sind allenthalben Thlaspi alpestre und Draba muralis vertreten. Anderseits treten in den külıleren dieser Schluchten wieder subalpine Arten auf, wie z. B. in der Zahořaner Zahoraner 


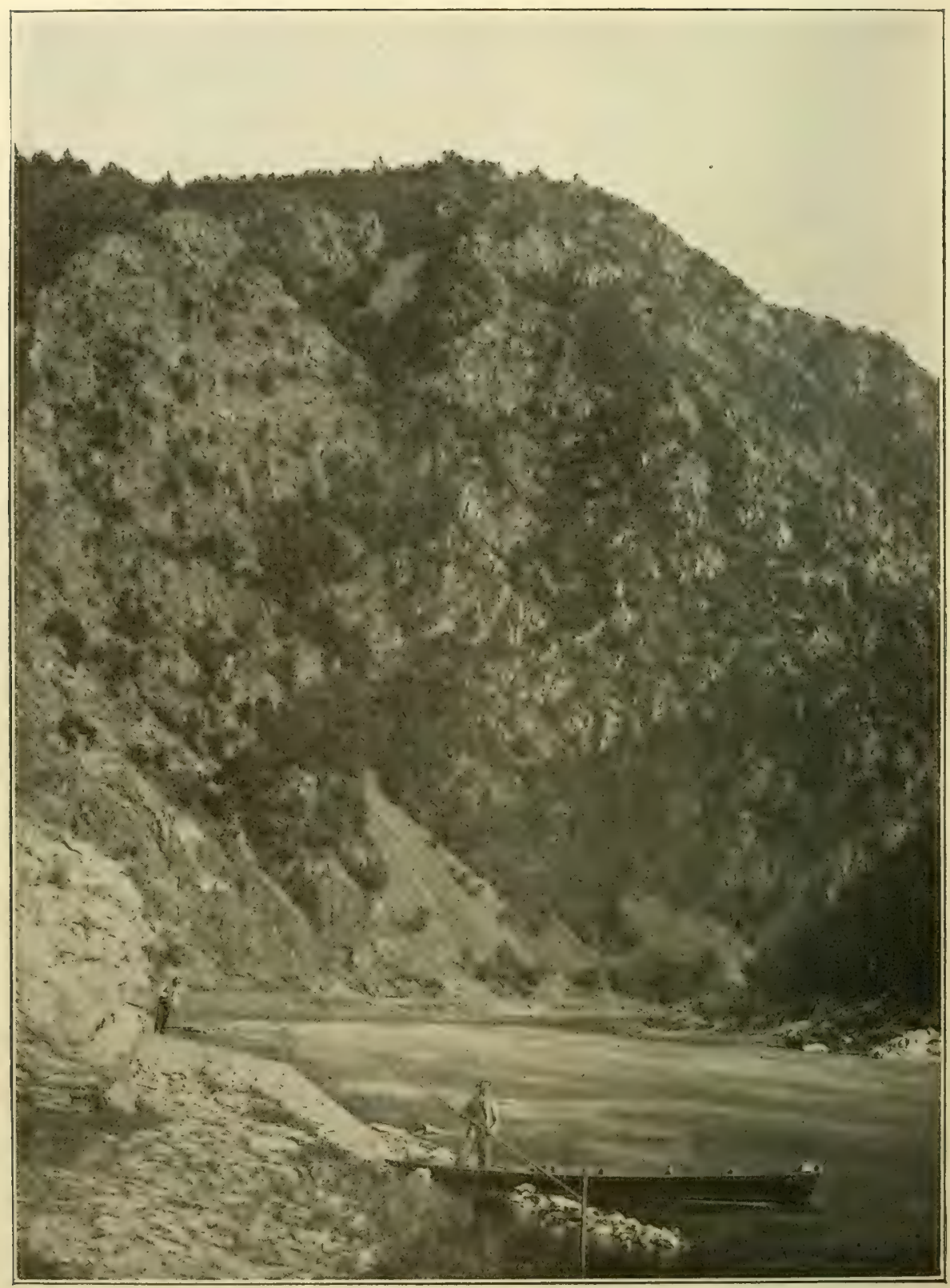

Abb. 76. Phyllitfelsen am Moldauufer bei Stěchowitz.

Buschwerk aus Carpinus Betulus, Corylus Avellana, Acer campestre, Cornus usw. und reiche Felsenflora (Festuca glauca, Dianthus gratianopolitanus, Alyssum Arduini, Seseli Beckii, Hieracium Schmidtii usw.)

(Nach H. Eckert, Landschaftsbilder aus Böhmen.)

(Aus der Bildersammlung des geographischen Institutes der Wiener Universität.) 
Schlucht Aruncus silvester, Geranium silvaticum, Rubus saxatilis, Vicia silvatica und von Moosen Webera elongala, besonders aber ist dort an den Felsen am Bache eine sehr reiche Moosflora (u. a. Bryum alpinum, Gymnostomum curvirostre, G. rupestre, Cynodontium virens, Encalypta contorta) entwickelt.

Die Umgebung von Prag ist zwar heute größtenteils kultiviert und insPrag. besondere von ausgedehnten Rübenfeldern bedeckt, doch bietet nichtsdestoweniger selbst die südliche Umgebung der Stadt, vor allem die Steilhänge der tief eingeschnittenen Täler der Moldau und Beraun infolge des Auftretens zahlreicher wärmeliebender, besonders östlicher Arten, eine sehr reiche Flora. Die Wälder sind hauptsächlich gemischte Laubwälder aus Quercus Robur, Q.pubescens, Carpinus Belulus, Sorbus torminalis, S. Aria, mit eingesprengten Föhren und Buchen und meist reichlichem Unterholze aus Cralaegus Oxyacantha, Prunus spinosa, Ligustrum vulgare, Cornus mas, C. sanguinea usw,, aus deren Niederwuchs Melica picta, Cypripedium Calceolus, Orchis fusca, Neollia Nidus avis, Epipactis latifolia, Cephalanthera alba, C. rubra, Aconitum Vulparia, Cardamine impatiens, Sanicula europaea, Pirola secunda, P. minor, Astrantia maior, Digitalis ambigua, Phyteuma spicalum, Asperula odorala hervorzuheben sind. An den steilen Phyllit- und Silurkalkhängen an der Moldau und Beraun aber ist allenthalben eine reiche, fast steppenartige thermophile Triftformation anzutreffen. So sind an der Mündung des Berauntales Stipa pennala und S. capillala, Festuca glauca, Andropogon Ischaemum, Allium fallax, Alyssum Arduini, Erysimum erysimoides, Asperula glauca, Lactuca viminea häufig. Die Velika hora bei Karlstein Karstein. trägt Laubmischwälder, in denen Cardamine bulbifera und Adenophora liliifolia vorkommen, sowie Bergwiesen mit Trollius europaeus, Anacamplis pyramidalis, Anemone nigricans, Inula salicina, Scorzonera humilis, Crepis praemorsa, an den Steilhängen der Südseite aber kommen neben zahlreichen der oben genannten Arten auch Adonis vernalis, Arabis auriculata, Linum flavum, Helianthemum canum, Sempervivum soboliferum, Bupleurum longifolium, Lathyrus versicolor, Daphne Cneorum, Stachys germanica und das prächtige Dracocephalum austriacum vor. Diese thermophile Flora dringt auch durch das Kačaktal bis Unhoscht vor, wo Andropogon Ischaemum, Trifolium strialum und Lactuca viminea noch häufig sind. In unmittelbarer Nähe von Prag ist in erster Linie Kuchelbad wegen Kuchelbad. seiner reichen Flora zu nennen; hier kommen u. a. an Felsen Stipa Tirsa, St.pennala, St. capillata, Carex Michelii, Allium montanum, A. rolundum, Anthericum Liliago, Iris bohemica, Thalictrum minus, Alyssum Arduini, Erysimum erysimoides, Sempervivum soboliferum, Teucrium Chamaedrys, Asperula glauca, Aster Linosyris sowie Buschwerk aus Quercus pubescens, Crataegus Oxyacantha, Rosa gallica, R. rubiginosa, Viburnum Lantana, Pulmonaria mollis und Bergtriften mit Avena pratensis, Koeleria gracilis, Anemone patens, A. nigricans, Potentilla rupestris, $P$. recla, Silene nemoralis, S. nutans, Trifolium alpestre, T. rubens, Vicia pisiformis, Oxytropis pilosa, Salvia austriaca, Teucrium Botrys, Hieracium echioides, H. setigerum u.h. a. vor, während bei Dvorce Erucastrum elongalum nicht selten ist. Bei St. Ivan finden sich u. a. auch Minuarta setacea, st. Ivan. Biscutella laevigata, Saxifraga Aizoon und S. tridaclylites. Auch sonst sind in 


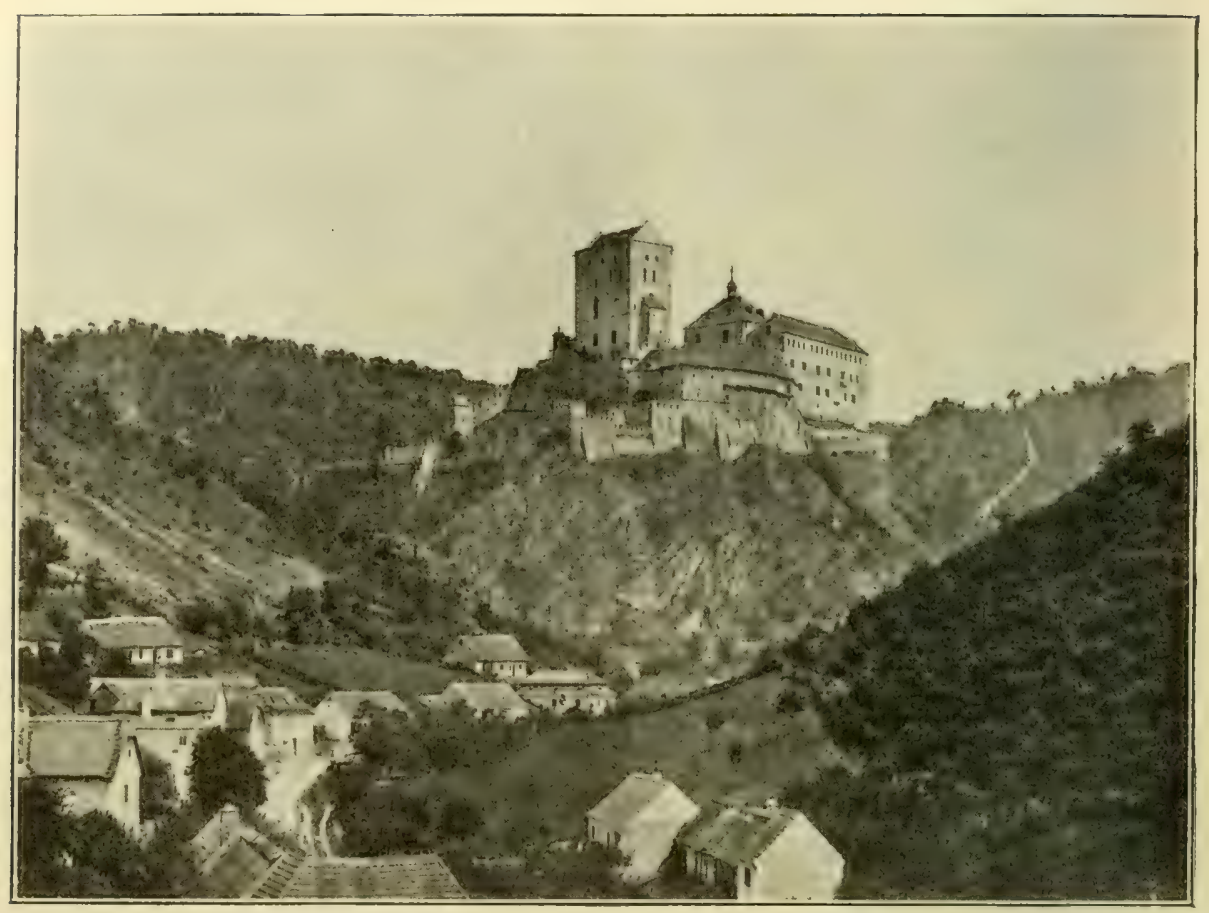

Abb. 77. Burg Karlstein bei Prag.

Gemischter Laubwald, auf dem Burghügel Felsenflora, insbesondere Sesleria varia, Carex humilis, Alyssum Arduini, Potentilla arenaria, Helianthemum canum, Stachys recta usw.

(Nach Eckert, Landschaftsbilder aus Böhmen.)

(Aus der Bildersammlung des geographischen Institutes der Wiener Universität.)

der Gegend von Prag pannonische Florenelemente nicht selten, so bei St. Prokop Iris bohemica, Helianthemum canum und Thaliclrum foelidum, während wieder Kopanina. bei Kopanina einige Gebirgspflanzen, wie Bupleurum longifolium, Galium vernum, Gentiana ciliala und Cirsium pannonicum anzutreffen sind.!

Auch im Westen von Prag ist diese östliche Flora verbreitet, so kommen

Roblin. bei Roblin an felsigen Abhängen Sesleria varia, Anthericum Liliago, A. ramosum, Arabis auriculala, Oxylropis pilosa, Dictamnus albus, Cynanchum Vinceloxicum, Veronica dentala, Asperula glauca, Inula hirla und (bei Wran) Dracocephalum austriacum, in Wäldern Lilium Marlagon, Euphorbia dulcis, Viola mirabilis, Omphalodes scorpioides, Myosolis sparsiflora, im Tale gegen Wonoklas auch Melica picla, Orchis fusca, Prunus frulicosa, Lalhyrus versicolor, Cirsium pannonicum und Asperula tinctoria vor.

Am reichsten sind die thermophilen Arten aber im Norden der Stadt anzuPodbaba. treffen, so in der Podbaba Slipa pennala, St. capillata, Melica ciliala, Festuca glauca, Silene Oliles, Adonis vernalis, Clemalis recla, Prunus frucliosa, Sempervivum soboliferum, Diclamnus albus, Androsace elongala: bei Troja Yeranthemum annuum, bei Homale Bupleurum junceum, bei Setz sind Inula germanica, Arlemisia 


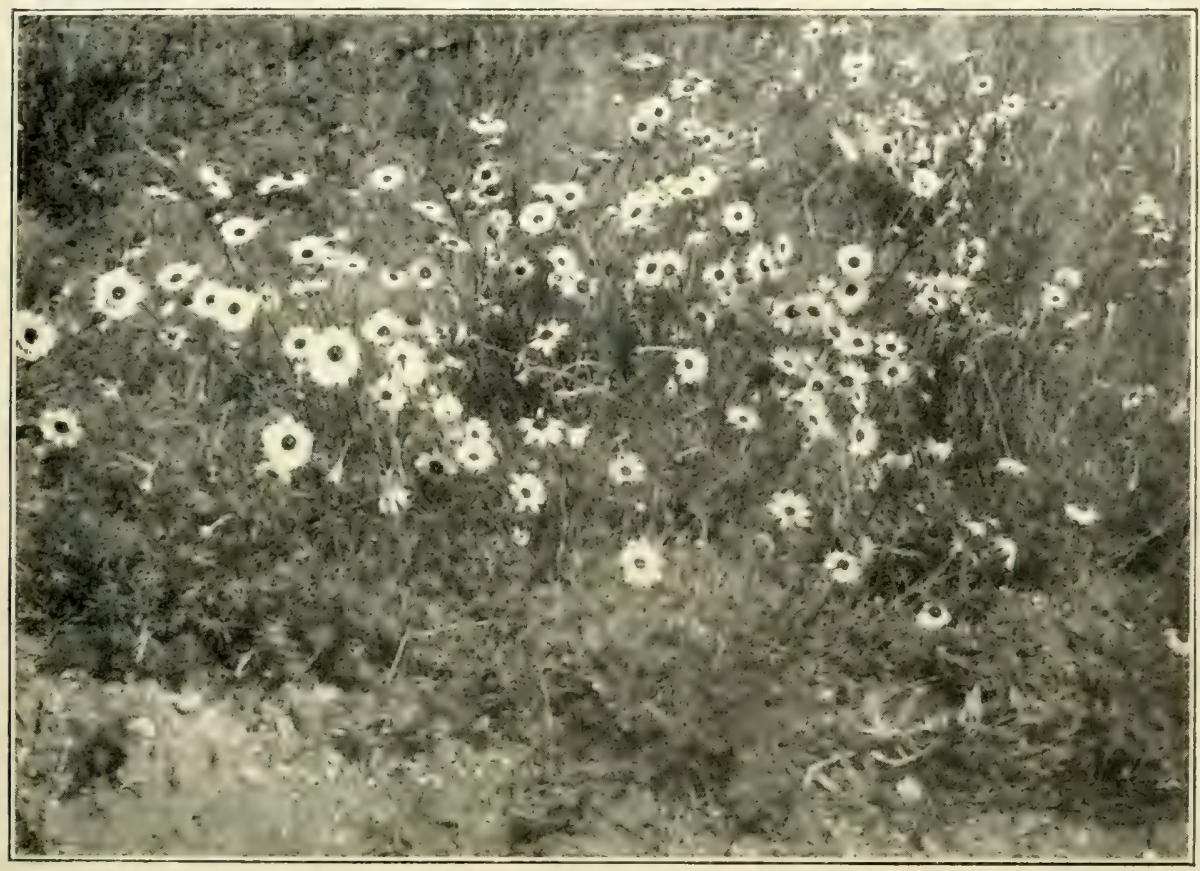

Abb. 78. Anthemis montana bei Zlin

Nach einer Aufnahme von J. Homolka, I'rag.)

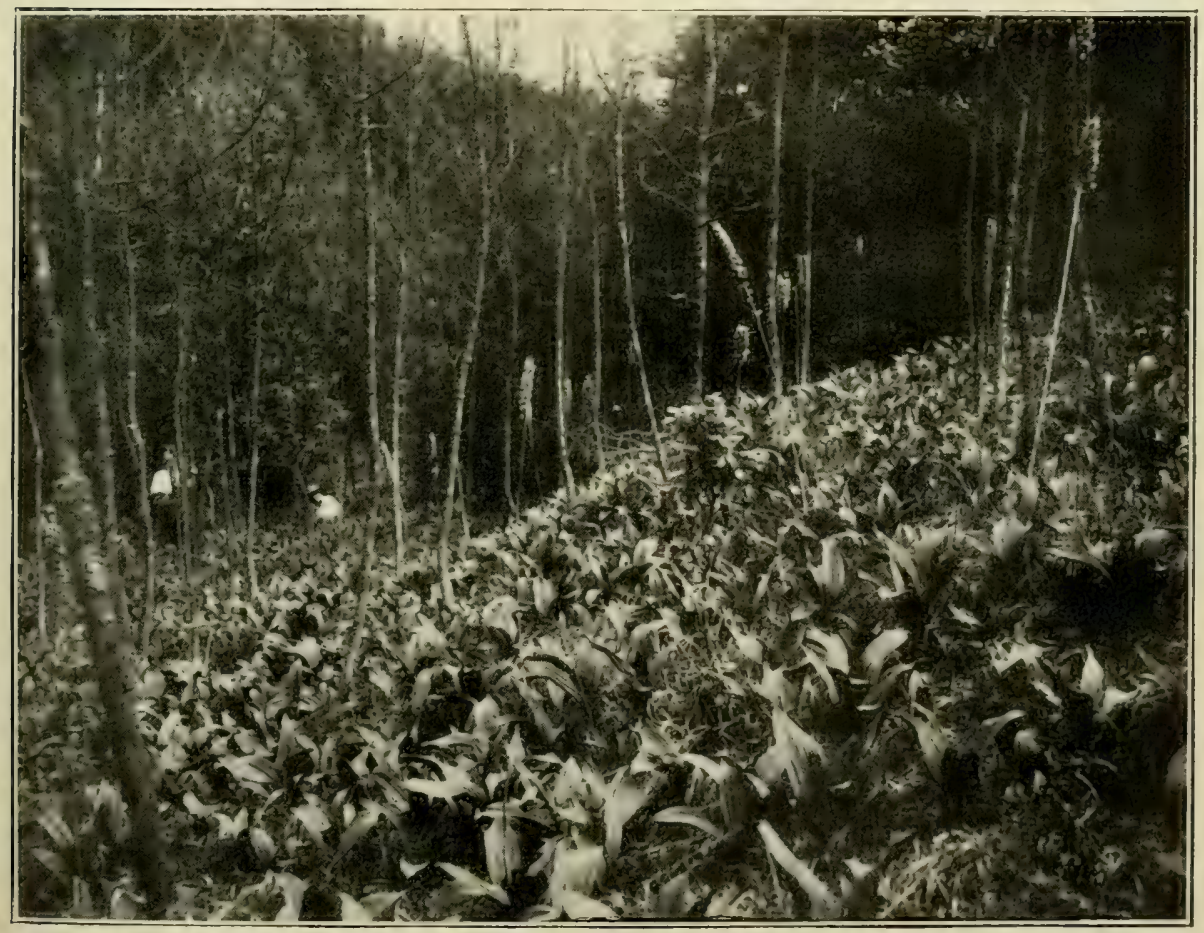

Abb. 79. Veratrum nigrum im Laubmischwalde im Bilichover Tale bei Smečno. (Nach einer Aufnahme von Prof. K. Domin, Prag.) 

Absynlhium und A. pontica, im Scharkatale Melica ciliata, Andonis vernalis und Salvia nemorosa, bei Vraune Bisculella laevigata, Orobanche arenaria, Scharkatale. Asperula glauca, Centaurea variegala und Hieracium setigerum anzutreffen. Im obersten Scharkatale liegt auch einer der wenigen größeren Waldbestände der Umgebung von Prag beim Schlosse Stern, in dem Lilium Martagon, Cephalanthera longifolia, Thlaspi alpestre, Cytisus nigricans, C. supinus, Coronilla varia, Vicia pisiformis, V. dumetorum, Lathyrus vernus, Pirola rolundifolia, Calluna vulgaris, Veronica prostrala, Prenanthes purpurea teils jetzt noch zu finden sind, teils ehemals vorkamen. Nördlich von Prag, bei Zlin nächst Weltrus, ist der weit nach Norden vorgeschobene Standort von Anthemis montana hervorzuheben, die hier in Gesellschaft von Carex Pairaei, Allium montanum, Anthericum ramosum, Sedum album, Polentilla recta, Seseli Beckii, Centaurea variegala und Hieracium candicans gedeiht.

In der Umgebung von Schlan sind auf Sandstein Föhrenwälder, auf Schlan. Tialk Mischwälder aus Föhren, Fichten, Buchen, Eichen, Ahornen vorherrschend. Diese Vischwälder weisen eine ziemlich reiche Flora auf; im Unterholze hommen Corylus Avellana, Ligustrum vulgare, Ribes alpinum, Slaphylea pinnala, im Niederwuchs Lycopodium clavalum, L. complanatum, Blechnum Spicanl, Fesluca helerophylla, Luzula nemorosa, Lilium Martagon, Cephalanlhera rubra, C. alba, Cypripedium Calceolus, Anemone Hepatica, Polygala Chamaebuxus, Sanicula europaea, Astrantia maior, Phyleuma spicalum, Prenanthes purpurea und natürlich auch Vaccinium Myrtillus, V. Vitis Idaea und Calluna vulgaris vor. Die Wiesen des Gebietes bieten außer Polygonum Bislorla und Adenophora liliifolia wenig Bemerkenswertes, ebensowenig die hie und da auftretenden Wiesenmoore mit Carex Davalliana, dioica, paradoxa, slellulala, canescens, Pedicularis palustris usw., hingegen ist auch hier an sonnigen Hügeln das Auftreten einer Triftformation mit Andropogon Ischaemum, Slipa pennata, St. capillala, Phleum phleoides, Koeleria gracilis, Carex humilis, Allium monlanum, Anlhericum ramosum und Liliago, Alyssum Arduini, Geranium sanguineum, Clemalis recla, Glaucium corniculatum, Erysimum erysimoides und durum, Bupleurum longifolium, Inula germanica, Anthemis tincloria, Artemisia Absynthium, Cirsium acaule und pannonicum, Centaurea variegata und rhenana, Lactuca perennis bemerkenswert; zwischen Welwarn und Schlan kommt auch Reseda Phyteuma, bei Dymokury Lathyrus pisiformis, bei Sternberg Coronilla vaginalis vor. Ähnliche Verhältnisse herrschen auch bei Smečno. Auch hier ist auf Sandstein die Föhre smeěno. tonangebend, während auf Plänerkalk Laubmischwälder mit Hierochlö̈ odorala, Lilium Martagon, Veralrum nigrum und im Tale von Nemčich auch Cyprepedium Calceolus sowie mannigfaches Buschwerk und Bergtriften mit Anthericum Liliago, Clemalis recta, Anemone silveslris, Saxifraga granulala, Coronilla vaginalis, Rubus saxatilis, Lithospermum purpureocoeruleum, Centaurea variegala, Asperula tinctoria und der seltenen Carex pediformis auftreten. Auf Sandstein sind aber neben den Föhrenwäldern auch typische Heiden mit Calluna, Vaccinium, Lycopodium clavatum, Antenaria dioica usw. reichlich entwickelt. 
Nicht weit westlich von Schlan aber findet die thermophile Flora ihre Rakonitz. Grenze. Schon bei Rakonitz sind selbst an sonnigen, felsigen Hängen nur mehr wenige thermophile Arten, wie Anthericum ramosum, Daphne Cneorum, Diclamnus albus, Cytisus nigricans, Arlemisia Absynthium, Aster Amellus usw. zu finden; die Wälder sind meist Föhren- oder Mischwälder mit einem Niederwuchs, der schon an das Tepler Gebirge und den Kaiserwald erinnert, denn es finden sich Athyrium Filix femina, Lycopodium annotinum, Lilium Marlagon, Cephalanthera rubra, alba und longifolia, Mercurialis perennis, Actaea spicala, Anemone Hepatica, Pirola uniflora, secunda und chlorantha, Omphalodes scorpioides, Calluna vulgaris, Vaccinium Myrtillus und V. Vitis Idaea, Campanula persicifolia, Phyleuma spicalum; auf Wiesen aber lommen bereits Coeloglossum viride, Trollius europaeus, Trifolium spadiceum, Genliana Pneumonanthe, Arnica monlana und Scorzonera humilis, daneben freilich auch noch Anemone nigricans und Girsium acaule vor.

Duppauer
Gebirge. Das östlich von Rakonitz sich erhebende Duppauer Gebirge, das sich bis gegen Karlsbad hin erstreckt, trägt hauptsächlich Mischwälder aus Föhren, Fichten, Tannen, Iainbuchen und Eichen, mit Rubus Idaeus und Sambucus racemosa im Unterholze und Aruncus silvester, Actaea spicala, Vaccinium Myrtillus, Senecio nemorensis und Lactuca munalis im Niederwuchs.

Kaaden. In der Umgebung von Kaaden ist auf Wiesen das Vorkommen von Trollius europaeus, Thlaspi alpestre, Parnassia palustris und anderer Erzgebirgspflanzen bemerkenswert; an buschigen Hängen wachsen Bromus erectus, B. inermis, Phleum phleoides, Dianthus Carlhusianorum, Falcaria vulgaris, Eryngium campestre, Tragopogon dubius und Centaurea rhenana. Besonders reich an thermophilen Arten ist aber die Flora der einzeln stehenden BasaltGoldberg. berge, wie des Goldberges, auf dem Stipa pennata, Anthericum ramosum und Burberg. Orobanche arenaria und des Burberges, wo Slipa pennala, Silene Otites, Dianthus gratianopolitanus, Alyssum Arduini, Erysimum crepidifolium, Bupleurum falcalum, Asperula glauca, Lactuca perennis und andere Arten vorkommen.

Komotau. Im Kohlenbecken von Komotau sind lichte Wälder aus Quercus sessiliflora, die oft von Carpinus Betulus begleitet wird, die bemerkenswerteste Erscheinung. Der interessanteste dieser Wälder ist der Eidlitzer Eichbusch, in welchem außer Luzula pallescens, Allium rolundum, Dianthus Armeria, D. deltoides, Polentilla canescens, P. Bouquoyana, Lathyrus montanus, Trifolium ochroleucum, Bupleurum falcatum, Veronica spicala, Campanula bononiensis, Cenlaurea Pseudophrygia usw. auch die in Böhmen nur hier wachsende Veronica spuria vorkommt. Neben diesen Eichenwäldern sind in der Umgebung von Komotau besonders die feuchten Wiesen mit Carex polygama, Juncus silvalicus, Stellaria palustris, Sanguisorba officinalis, Mimulus luteus und dem oft massenhaften Silaus pratensis sowie die zahlreichen Teiche hervorzuheben; auch die Ruderalflora von Komotau" ist sehr reich (u. a. Coronopus procumbens, Erysimum repan-

Saidschitz. dum, Reseda luteola, Lappula echinala, Asperugo procumbens). Bei Saidschitz finden sich noch einige Halophyten auf den dortigen nassen Wiesen, so Spergularia marina, Melilotus dentatus, Glaux maritima und Bupleurum tenuissimum; 
letztere Art wurde auch bei Püllna beobachtet, doch ist es sehr fraglich, ob diese Pllanze jetzt noch dort zu finden ist. In der Umgebung von Brüx sind die Sumpfwiesen mit Stellaria paluslris, Trifolium fragiferum, Lolus uliginosus, Potentilla palustris, Cirsium canum und palustre sowie die zahlreichen Teiche, an deren Ufern Carex Pseudocyperus, Equisetum limosum, Calla palustris, Rumex Hydrolapathum, Ranunculus Lingua, Cicula virosa, Oenanthe aquatica, Menyanlhes trifoliata gedeihen, die auffallendste Erscheinung in der dortigen Flora; außerdem kommen aber gegen den Galgenberg zu auch Salzwiesen mit Glaux maritima und Planlago maritima sowie besonders auf dem Schloßberge pannonische Typen, wie Allium vineale, Cytisus nigricans, Tunica prolifera, Diclamnus albus, Crepis praemorsa, auf dem Schlarlringer Berge Aslragalus auslriacus und Dianthus gralianopolitanus, bei Zlatnik Paeonia peregrina, Thalictrum lucidum, Aslragalus exscapus und Scorzonera purpurea, vor. Auch bei Dux trifft man zahlreiche Teiche, so den großen Barbarateich, wo unter anderen alle vier böhmischen Elatine-Arten (E. Hydropiper, lriandra, hexandra und Alsinastrum), ferner Lysimachia lhyrsiflora und Rumex aquaticus zu finden sind, während in Erlenbrüchen nächst der Teiche Calla palustris wächst. Auch einige thermophile Arten kommen bei Dux vor, so Lavalera thuringiaca, Salvia verlicillata, Lacluca saligna und an Ruderalstellen Crepis rhoeadifolia.

Das südlich und östlich von Brüx und Dux sich erhebende Böhmische IIttelgebirge ist insbesondere durch die Ausbildung von typischen Steppenformationen ausgezeichnet. Schon in der Umgebung von Sa a und Postelberg, die weithin von Getreidefeldern und Hopfenkulturen bedeckt ist, treten besonders an der Südseite der Basaltliuppen der Ausläufer des Mittelgebirges FedergrasSteppen mit Slipa pennala, St. Tirsa, St. capillala, Phleum phleoides, Avena pralensis, Koeleria gracilis, Carex humilis, Dianthus Carthusianorum, Adonis vernalis, Erysimum crepidifolium, Thymus Loevyanus, Artemisia ponlica, Aster Linosyris, Centaurea rhenana und Buschbestände aus Prunus spinosa, P. fruticosa, Rosa gallica, R. trachyphlla, Cralaegus Oxyacantha, Ligustrum vulgare, Viburnum Lantana usw. auf. Reichlicher noch sind die Steppen in der Umgebung von Laun entwickelt, wo neben den genannten Arten auch noch Potentilla arenaria, Viola ambigua, Linum auslriacum und Astragalus exscapus, vor allem aber auf lem Berge Pann a die erst wierter in Südmähren, Ostgalizien und Südrußland vorkommende Avena desertorum auftritt. Besonders im Launer und Saazer Mittelgebirge ist auf den Plänerkalklehnen (IVeiße Leiten) eine eigenartige Triftformation verbreitet, als deren Charakterarten Andropogon Ischaemum, Stipa capillata, Sesleria varia, Bromus erectus, Potentilla arenaria, Trifolium striatum, Adonis vernalis, Thymus praecox, Salvia pratensis, Inula germanica genannt seien; im Stradonitzer Tale bei Perutz liommt in diesen Triften auch Carex pediformis vor. Die Wälder dieses Gebietes sind vornehmlich gemischte Laubwälder aus Quercus sessiliflora, Qu. pubescens, Carpinus Belulus, Populus tremula, mit Unterholz aus Corylus, Cornus, Viburnum, Pirus Piraster, Prunus spinosa und fruticosa usw., in deren Niederwuchs Hierochloë australis, Cylisus nigricans, Lalhyrus versicolor, L. montanus, Geranium sanguineum, Primula veris, Digitalis 


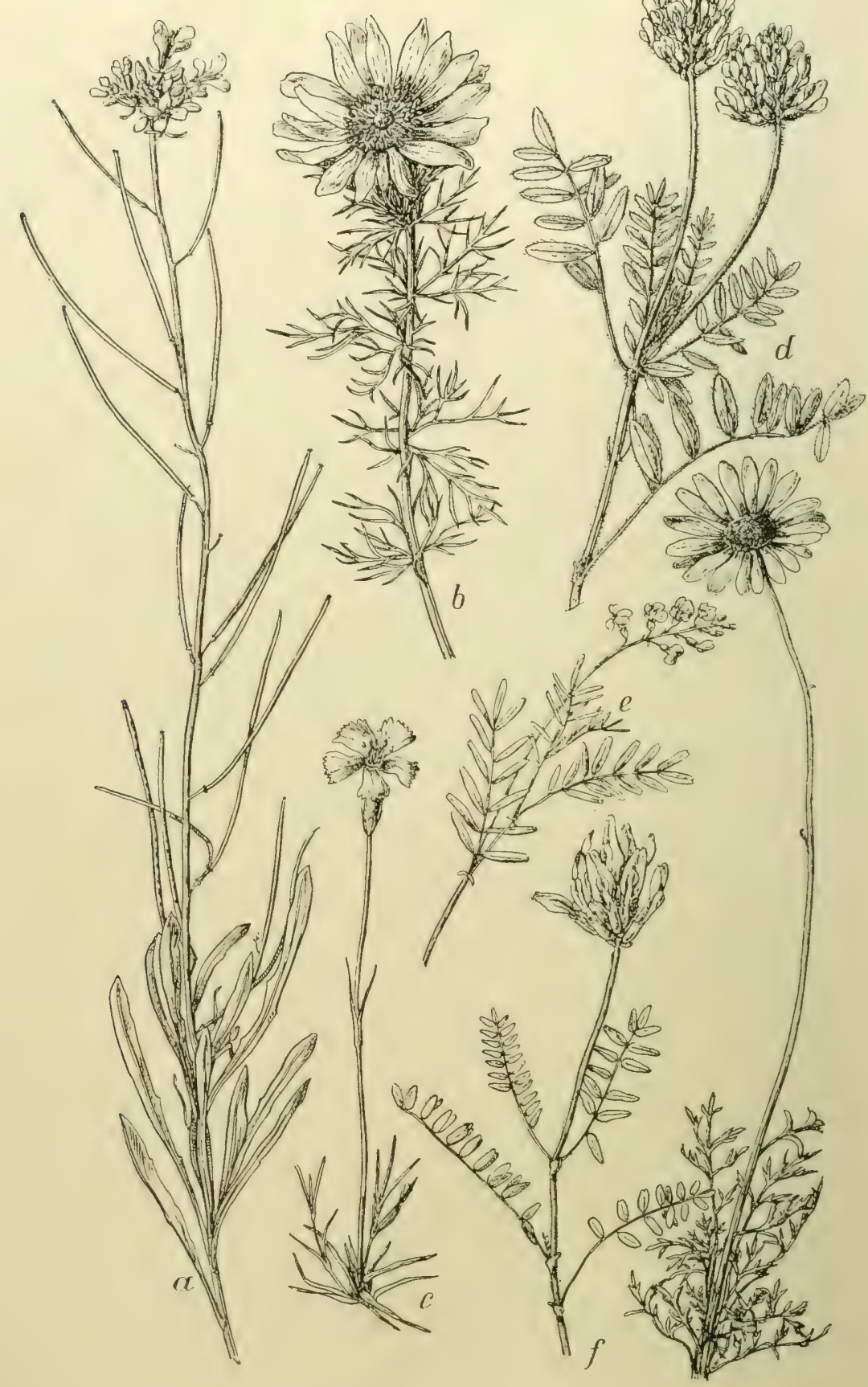

Abb. 80. Aus der Flora Zentralböhmens, besonders des Böhmischen Mittelgebirges. $a$ Erysimum crepidifolium. $b$ Adonis vernalis. $c$ Dianthus gratianopolitanus. $d$ Oxytropi pilosa. $e$ Astragalus austriacus. $f$ Astragatus danicus. $g$ Anthemis montana. 


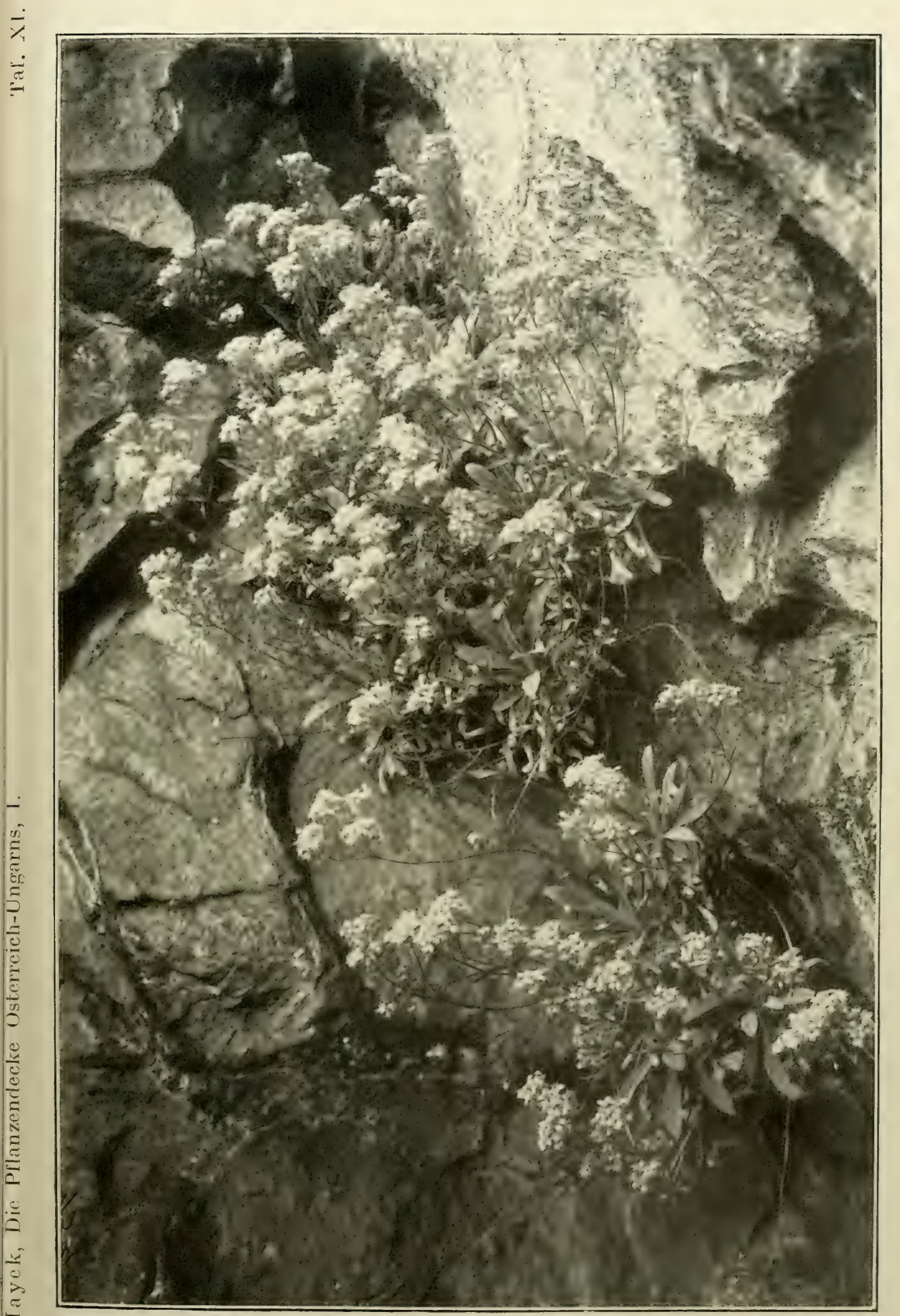

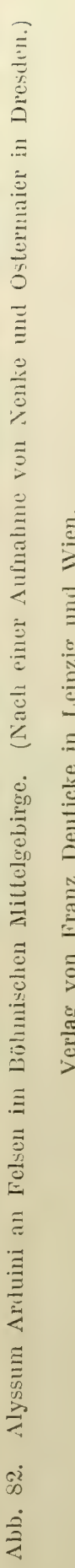



ambigua, Veronica Teucrium, V. spicata, Valeriana officinalis, Chrysanthemum corymbosum usw. bemerkenswert erscheinen. Besonders an den Nordhängen des Gebirges bei Potscherad bis gegen Brüx sind in den Tälern auch nasse Wiesen anzutreffen, die durch das Auftreten zahlreicher Halophyten besonders ausgezeichnet sind. Auf solchen Wiesen finden sich Heleocharis uniglumis, Scirpus maritimus, Schoenopleclus Tabernaemontani, Carex vulpina, disticha, nutans, secalina, riparia, Juncus Gerardi, Orchis palustris, Thalictrum lucidum, Spergularia marginata, S. salina, Melilotus dentalus, Trifolium fragiferum, Lolus

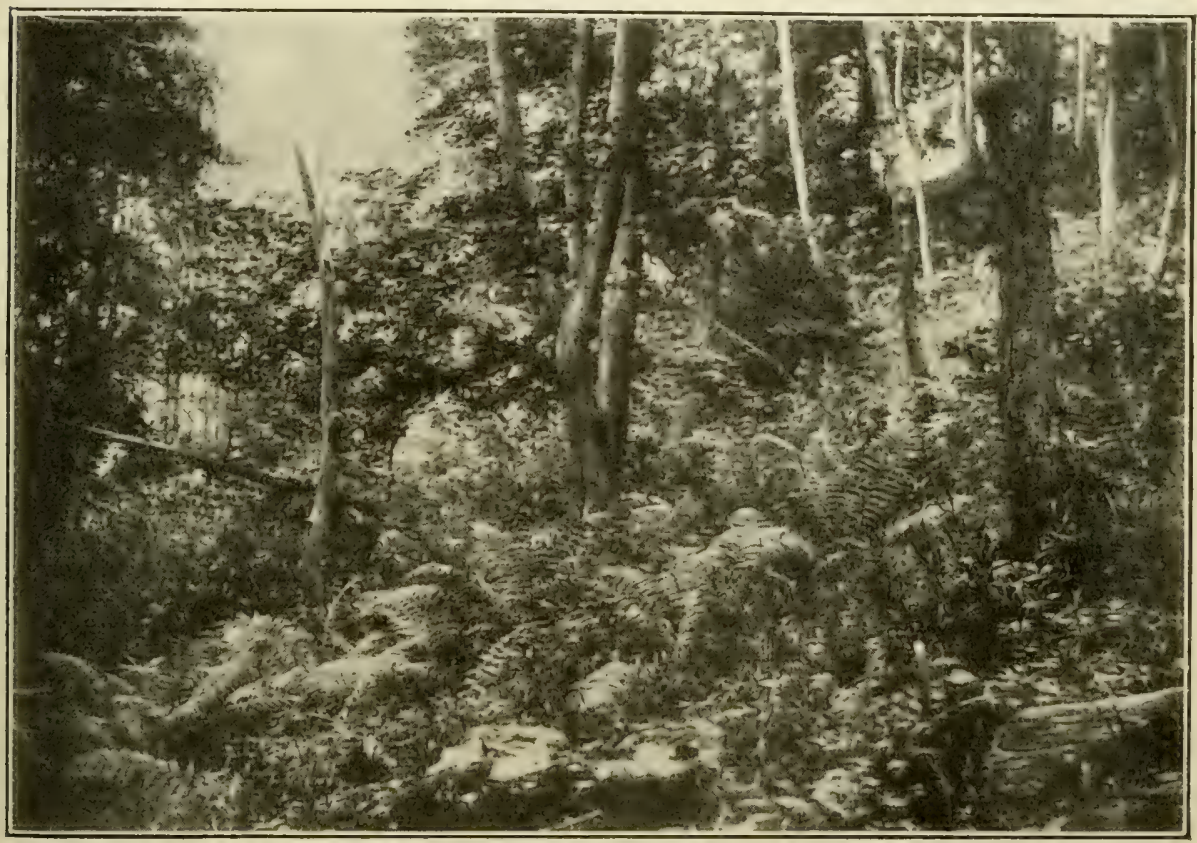

Abb. 81. Gemischter Laubwald auf dem Klettenberge im Böhmischen Mittelgebirge. Das Oberholz besteht hauptsächlich aus Fagus silvatica, Ulmus scabra und Acer Pseudoplatanus. Im Niederwuchs Dryopteris Filix mas mit Melica nutans, Senecio Sarracenius, Mercurialis perennis usw.

(Nach einer Aufnahme von Prof. K. Domin, Prag.)

siliquosus, Lathyrus palustris, Elaline Alsinastrum, Allhaea officinalis, Scorzonera parviflora, Taraxacum bessarabicum und (ehemals) auch Bupleurum tenuissimum. Gegen das Elbetal zu, bei Saaz, Laun usw., kommen auch Auenwälder Egertal. aus Ulmus laevis, Fraxinus excelsior, Acer Pseudoplalanus, Populus lremula, Prunus Padus, Salix cinerea, Rhamnus Frangula usw., mit Festuca gigantea, Bromus asper, Deschampsia caespilosa, Paris quadrifolia, Scilla bifolia, Galanthus nivalis, Ranunculus auricomus, Cardamine impaliens, Slellaria nemorum, Chaerophyllum Cicularia, Slachys silvalica usw. zur Ausbildung, im Šebinwalde bei Stradonitz kommt auch Polygonalum latifolium vor.

Die geschilderten Steppen-, Busch- und Waldformationen sind im ganzen Gebiete des niedrigeren Teiles des Mittelgebirges bis gegen die Elbe zu ver- 
breitet, freilirh besonders auf Kïieselgestein und sand oft ron Föhrenformationen Raudnitz, und Heiden unterbrochen. So treten z. B. bei Raudnitz Föhrenwälder und Sandheiden mit Corynephorus canescens, Teesdalea nulicaulis, Teronica praecox, Jurinea cyanoides und Arnoseris pusilla auf, während südlich dieser Stadt bei Kleneč. Kleneč besonders auf Plänerkalk Steppenformationen mit Slipa capillata, Andropogon Ischaemum, Dianthus Carthusi.nnorum, Adonis vernalis, Polentilla arenaria, Verbascum phoeniceum, Veronica spicala, Arlemisia Absynthium und dem seltenen Dianthus plumarius erscheinen; auch hier trifft man aber Föhrenwälder oder Heiden aus Corynephorus; an Rainen ist Rapistrum perenne häufig. Der Vinek. Berg Vinek trägt Eichen- und Föhrenwälder mit Linum tenuifolium und AstraŘip. galus austriacus, der Řip (Georgsberg) Föhrenwälder mit Silene nutans, S. Otites, Euphorbia Gerardiania, Astragalus auslriacus und Heiden init Linum tenuifolium, Silene Otites, Erysimum durum, Chrysanthemum corymbosum, Inula hirta, in der Gipfelregion kommt Hypericum elegans vor und an sonnilurchglühten Felsen der südlichen Farn Ceterach officinarum.

Der zentrale Teil des östlichen Mittelgebirges vom Horaberge und Radelstein bis zum Milleschauer ist hauptsächlich von Fichtenwäldern bedeckt, in deren Niederwuchs Equisetum silvalicum, Festuca giganlea, Bromus asper, Leucoium vernum, Ranunculus nemorosus, Aclaea spicala, Aruncus silvester, Genista tinctoria, G. germanica, Bupleurum longifolium, Chaerophyllum Cicutaria, Pirola rolundifolia, P. uniflora, Lamium luteum, Senecio sarracenius, Prenanthes purpurea die bezeichnendsten Arten sind, während im Basalt- und Phonolithgeröll der Gipfel sich manche interessante Art findet, vor allem die hier verbreitete Woodsia ilvensis und Saxifraga decipiens auf dem Radelstein und

Bořen. Milleschauer und auf dem Bořen bei Bilin Aster alpinus *hirsutus und sille- Dianthus gratianopolitanus. Der Milleschauer beherbergt außerdem noch Lycopodium Selago, Veronica montana, Orobanche alsalica und Achillea distans sowie einige interessante Moose, u. a. Dicranella subulala, Oreoveisia Brunloni. Ditrichium homomallum, Grimmia Mühlenbeckii und Grimaldia fragrans, während Radelstein.der Radelstein auf seinem Plateau prächtige Wiesen mit Luzula campestris Lilium Martagon, Orchis mascula, O. globosa, O. sambucina, O. maculata, Gymnadenia conopea, Anemone palens, Trollius europaeus, Potentilla alba, Chaerophyllum aureum, Pulmonaria anguslifolia, Centaurea montana und Hypochoeris maculata trägt.

Am Nordrande des Gebirges aber stellen sich wieder die wärmeliebenden Bilin. Typen ein. So finden sich im Mönchsbusch bei Bilin Allium vineale, Thesium linophyllum, Dianlhus superbus, Lalhyrus versicolor und monlanus, Laserpilium latifolium, Pencedanum Cervaria, Pulmonaria angustifolia, Asperula tincloria. Aster Linosyris, Cirsium pannonicum und Scorzonera humilis. Ja, selbst jenseit: des Bielaflusses norh sind die pannonischen Arten anzutreffen. Der Wacholder

Teplitz. berg, südlich von Teplitz, trägt Eichenbestände mit reichlichem Loranthus europaeus, bei Turn treten in Eichenhainen Bromus asper, Genista germanica Bupleurum longifolium, Laserpilium lalifolium, Dipsacus lacinialus, Hieraciun racemosum auf, und selbst auf dem Schloßberge von Teplitz triff mar 


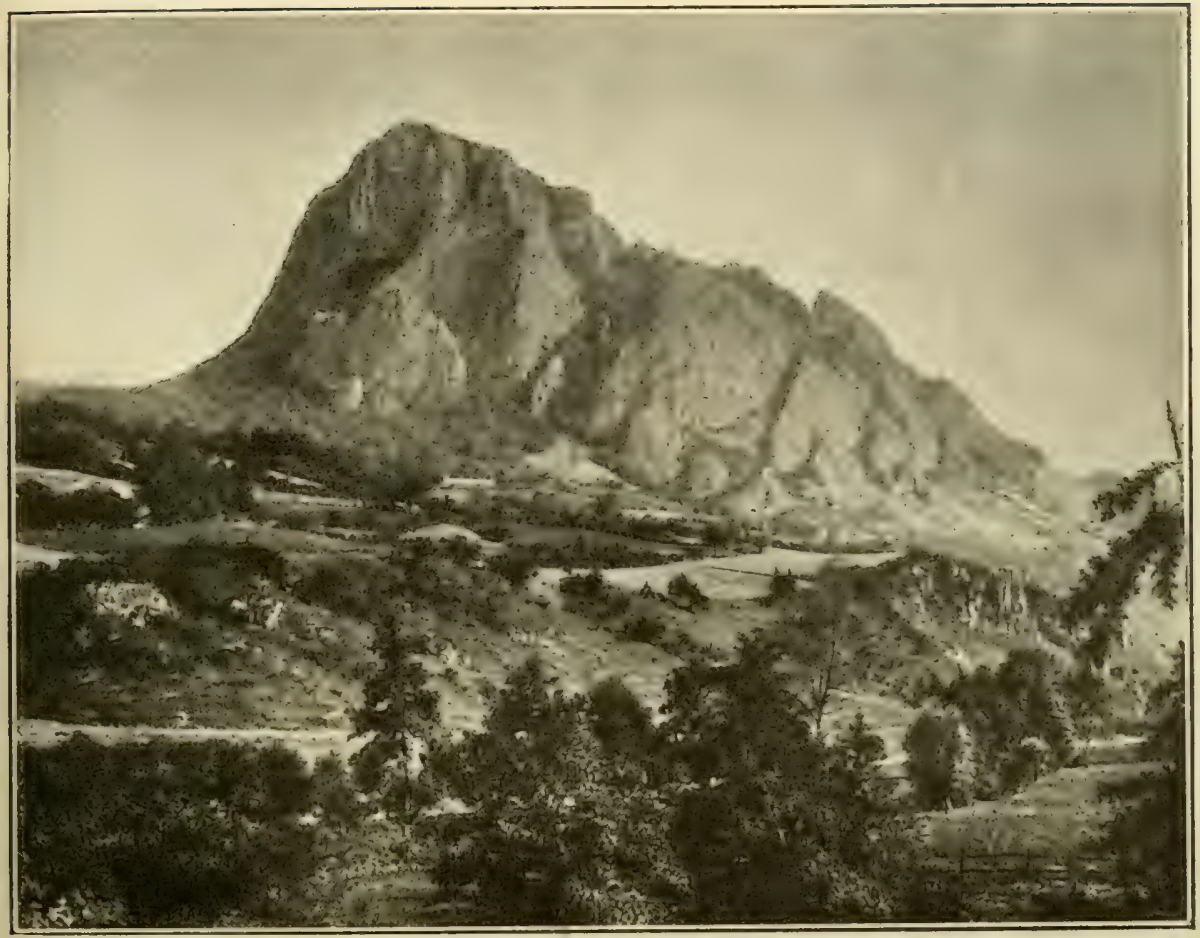

Abb. 83. Der Bořen bei Bilin.

Am Fuße des Berges gemischter Laubwald und stellenweise Basaltgerölle mit Cornus Mas, Cotoneaster integerrima, Sedum rupestre, Saxifraga decipiens usw., an den Felsen Festuca glauca, Allium montanum, Dianthus gratianopolitanus (sehr zahlreich), Aster alpinus Subsp. hirsutus u. a. Im Vordergrunde Kulturland und trockene Grasfluren.

(Nach H. Eckert, Landschaftsbilder aus Böhmen.)

(Aus der Bildersammlung des geographischen Institutes der Wiener Universität.)

noch Anthericum Liliago, Adonis vernalis, Erysimum durum, Polentilla arenaria, Trifolium slrialum, Medicago minima, Androsace elongala, Thymus Loevyanus, T. lanuginosus, Seseli annuum, Asperula glauca, Hieracium Schmidtii, auf dem benachbarten Galgenberge Koeleria gracilis und Melica ciliala. Bei Karbitz kommen Silaus pralensis, Scorzonera humilis und Campanula latifolia, bei $\mathrm{Kulm}$ Teucrium Scorodonia und Omphalodes scorpioides, bei Mariaschein Orchis ustulata, Muscari bolryoides und Aristolochia Clemalitis vor; bei Aussig treten an den heißen Felswänden Tragopogon pralensis und die auch jenseits der Elbe bei Groß-Priesen vorkommende Carex slenophylla, bei Burg Schreckenstein auch Celerach officinarum auf. Sonst tragen die Steilhänge des Mittelgebirges gegen die Elbe größtenteils Buschformationen aus Quercus pubescens, Juniperus communis, Prunus spinosa, P. fruticosa, Cralaegus oxyacantha, C. monogyna sowie Felstriften mit Andropogon, Stipa, Anemone patens, Erysimum crepidifolium, Medicago minima, Astragalus austriacus, Salvia nemorosa, Verbascum phoeniceum, Arlemisia pontica usw.; in den tiefer eingeschnittenen Seiten-

Karbitz. Kulm. Mariaschein. Aussig. 
tälern sind zumeist Fichtenwälder entwickelt. Die Ufer der Elbe aber umsäumen Weidengebüsche (Salix alba, fragilis, viminalis, purpurea), oder Piöhrichte, auch Hierochloë odorala, Allium Schoenoprasum, Eupatorium cannabinum, Mentha Pulegium, Isatis tincloria, Oenothera biennis, Oe. muricala, Lycopus europaeus, Xanthium ilalicum treten an ihren Ufern auf; im feuchten Ufersande aber kommen Heleocharis acicularis, Isolepis setacea, Scleranlhus annuus, Corrigiola litoralis, Herniaria glabra, Spergularia rubra, Polentilla supina, Peplis Porlula, Limosella aqualica, Gnaphalium uliginosum und andere Arten, wie sie auch in der Formation der nackten Teichböden zu finden sind, vor.

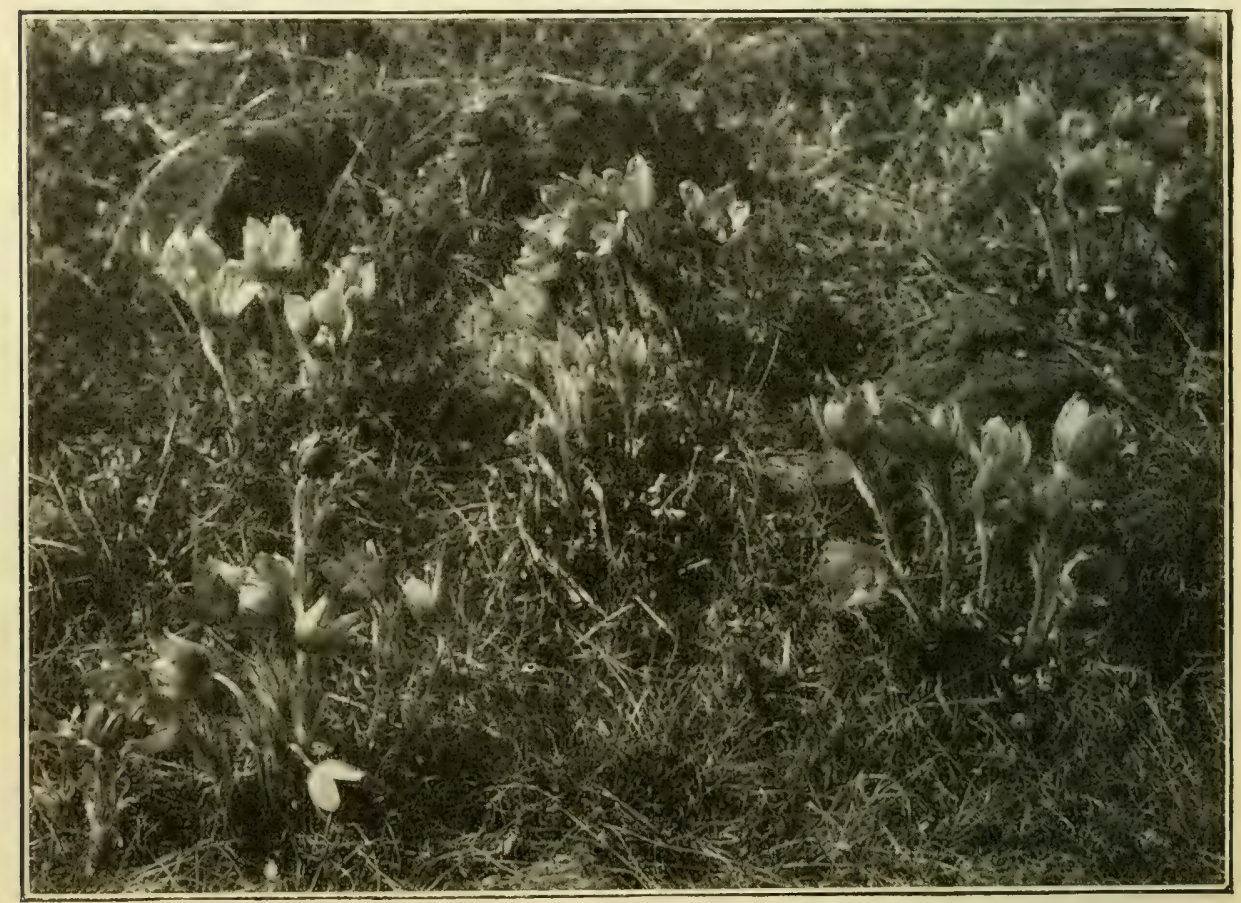

Abb. 84. Anemone patens bei Leitmeritz im Böhmischen Mittelgebirge.

(Nach einer Aufnahme von Nenke und Ostermaier in Dresden.)

Rechts von đer Elbe sind die pannonischen Trift- und Steppenformationen Leitmeritz. besonders um Leitmeritz stark entwickelt. Aus der dortigen Flora seien genannt: Slipa pennala, St. capillala, Sesleria varia, Melica transsilvanica, Silene longiflora, Adonis vernalis, Anemone patens, A. nigricans, Arabis auriculata, Linum flavum, Coronilla vaginalis, Astragalus auslriacus, Lalhyrus helerophyllus, Diclamnus albus, Lavathera thuringiaca, Androsace septentrionalis, Verbascum phoeniceum, Orobanche coerulescens, O. Picridis und Hieracium echioides. Auf Radobyl. dem Radobyl kommt auch Trigonella monspeliaca, auf dem Langen Berge Skalitz. bei Skalitz die seltene Koeleria nitidula vor.

Nördlich von Leitmeritz sind Eichenwälder die herrschende Formation, in der manche interessante Art anzutreffen ist, so bei Nemschen Aconilum 
variegalum, Pleurospermum austriacum, Laserpilium latifolium, Melillis Melissophyllum und Pulmonaria angustifolia. Eine besondere Zierde dieses Teiles des Ilittelgebirges aber sind die prachtvollen blütenreichen Bergwiesen, wie sie sich insbesondere bei Babina, Nemsehen und Tavosch finden. Auf diesen Wiesen Babina. sind Anthoxanthum odoratum, Avena pubescens, Luzula nemorosa, Thesium monlanum, Trollius europaeus, Polygonum Bislorla, Geranium sanguineum, Potentilla alba, Anthyllis Vulneraria, Lalhyrus pralensis, L. montanus, Helianthemum ovalum, Centaurea pseudophrygia, Iypochoeris maculata und Scorzonera humilis rie häufigsten Arten, einen besonderen Schmuck derselben aber bilden die nie

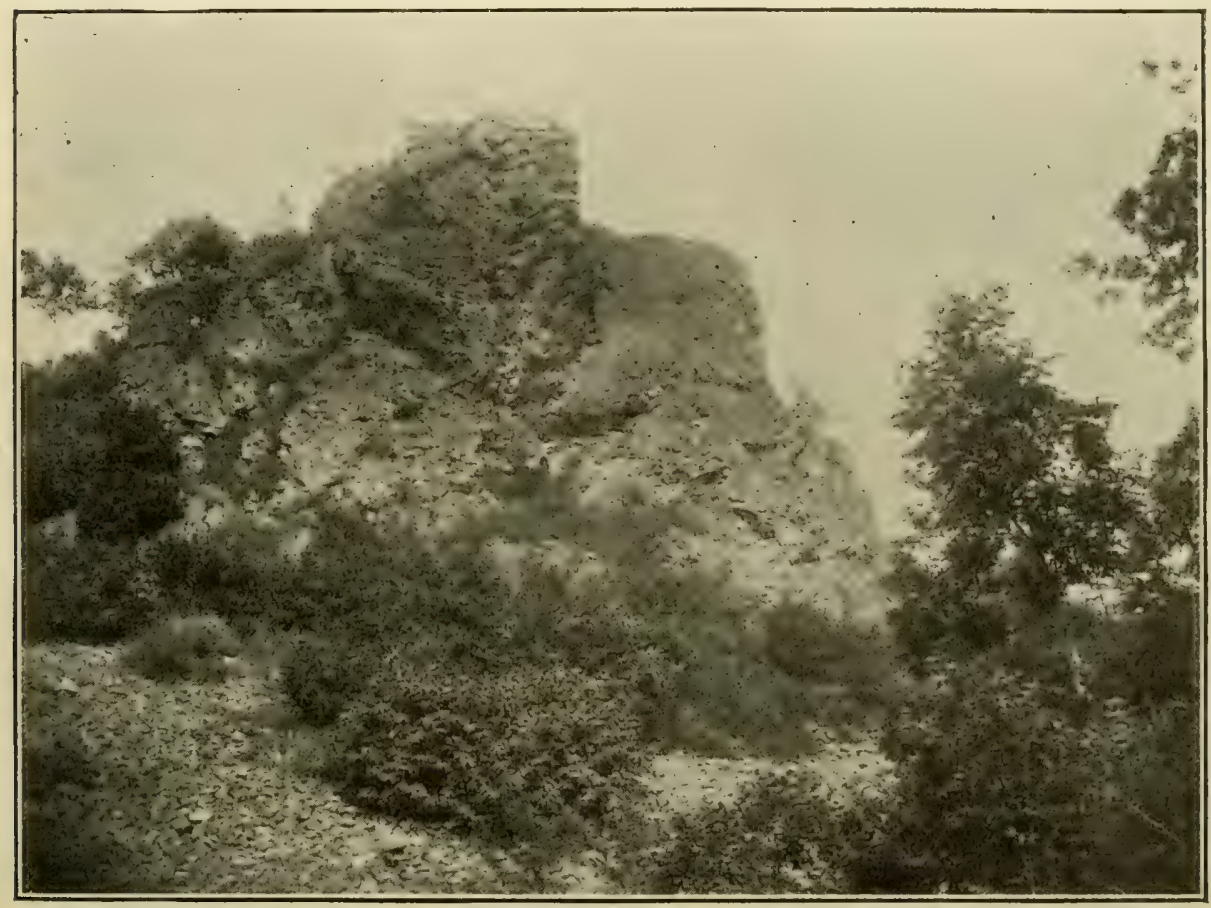

Abb. 85. Der Gipfel des Richterstein im Böhmischen Mittelgebirge. (Basalt.)

Im Felsgerölle Tilia platyphyllos, T. cordata, Acer platanoides, Prunus fruticosa usw.; rechts einige Eichen.

(Nach einer Aufnahme von Prof. K. Domin, Prag.)

fehlenden zahlreichen Orchideen, insbesondere Orchis sambucina, O. mascula, O. maculala, Gymnadenia conopea und die seltene O. globosa; gegen den Sandberg und Spitzberg zu treten. auch Thlaspi alpestre und Arnica montana auf diesen Wiesen auf; bei Winterberg kommt an buschigen Stellen Adenophora liliifolia vor. Während in tieferen Lagen im östlichen Mittelgebirge Laubmischwälder vorherrschen, ist auf den höheren Kuppen die Fichte der tonangebende Waldbaum, in deren Beständen hier auch Calamagrostis villosa vorkommt. An Felsen und im Felsgeröll der höheren Berge aber findet man Asplenium lrichomanes, A. germanicum, Alyssum Arduini, Woodsia ilvensis, Saxifraga decipiens, Coloneaster integerrima, Libanotis montana, auf dem Dreiberge bei Triebsch Triebsch. 
Geltsch. auch Saxifraga Aizoon, auf dem Geltsch Aster alpinus *hirsulus, Cephalanthera longifolia und Lanaria rediviva. Unter dem Geltschberge liegt ein kleines Waldmoor mit Carex canescens, Eriophorum vaginalum, Drosera rolundifolia und Trienlalis europaea. Auf dem Zinkenberge trifft man schöne Buchenbestände mit Milium effusum, Poa nemoralis, Calamagroslis arundinacea, Brachypadium silvalicum, Festuca silvatica, Carex silvatica, C. pendula, Polygonatum mulliflorum, Asarum europaeum, Aclaea spicala, Cardamine bulbifera, Oxalis Acetosella, Euphorbia dulcis, Lamium luteum, L. maculatum, Asperula odorata usw. Im öst-

Auscha. lichsten Teile des Mittelgebirges bei Auscha sind insbesondere die Triftformationen auf Plänerkalk schön entwickelt und weisen einige weniger verbreitete Arten auf, wie Gymnadenia conopea, Epipactis alroviolacea, Globularia Willkommii und bei den ,Fuchslöchern" häufig Ophrys muscifera. Auch Wiesenmoore mit Molinia coerulea, Deschampsia caespitosa, Carex Davalliana, C. panicea und Rhynchospora fusca sind bei Auscha vorhanden.

Bōhmisch Leipa.

In der Umgebung von Böhmisch-Leipa, das schon außerhalb des Mittelgebirges an den Ausläufern des Lausitzer Gebirges gelegen ist, ist Pinus silvestris der vorherrschende IValdbaum, in dessen Beständen Sarothamnus scoparius gewöhnlich in großer Menge auftritt; auch Pirola rolundifolia, minor, chloranlha und Chimaphila umbellata sind nicht selten. Hie und da trifft man auch Mischwälder aus Quercus Robur, Qu. sessiliflora mit Acer campeslre und anderen Laubhölzern, in denen dann Genista germanica und tinctoria häufige Erscheinungen sind. Auch Heidewiesen mit Corynephorus canesens, Aira praecox, Scleranthus perennis, Armeria elongala sind nicht selten. An den Ausläufern des Lausitzer Gebirges sind Wiesen mit Iris sibirica, Orchis ustulata, Dianthus silvalicus, Arnica montana und Cirsium helerophyllum anzutreffen und erstreclien

Niemes. sich bis gegen Niemes. Westlich dieser Stadt erhebt sich der Rollberg, ein isolierter, $696 \mathrm{~m}$ hoher Basaltliegel, der schöne Buchenwälder mit Ribes alpinum, Sambucus racemosa, Allium ursinum, Cephalanthera longifolia, C. rubra, Neollia Nidus avis, Chrysosplenium allernifolium, Lunaria rediviva, Sanicula europaea, Trientalis europaea trägt, während im Felsgerölle und an Felsen Woodsia ilvensis. Allium striclum, Sedum purpureum, Digilalis ambigua und Asler alpinus *hirsulus Höflitz. wachsen. Bei Höflitz treten auch Moore mit Eriophorum vaginalum, Carex diandra, C. lasiocarpa, Rhynchospora alba, Juncus squarrosus, Drosera rolundifolia, Polenlilla palustris, Andromeda polifolia, Oxycoccos quadripelala, Ledum palustre, Menyanthes trifoliala und Hydrocolyle vulgare auf. Südlich von Böhmisch-Leipa und Hirsch- Niemes liegen die durch ihre reiche Flora seit langem bekannten Hirschberg. berger Teiche; in den dortigen Sümpfen findet man neben Carex cyperoides, Rhynchospora fusca, Calla palustris, Sparganium minimum, Triglochin paluslre, Potentilla norvegica, Melilotus macrorrhizus, Elatine Hydropiper, E. hexandra, Lysimachia thyrsiflora, Bidens cernuus, B. tripartilus und B. radialus auch die Bösig. prächtige Ligularia sibirica; auf dem Burghügel von Bösigkommen an Felsen Dianthus gratianopolitanus und Potentilla recta vor; zwischen Weißwasser und Münchengrätz beim Forsthause Rečko liegen wieder Sümpfe, in denen Ligularia'sibirica ihren zweiten böhmischen Standort hat. 


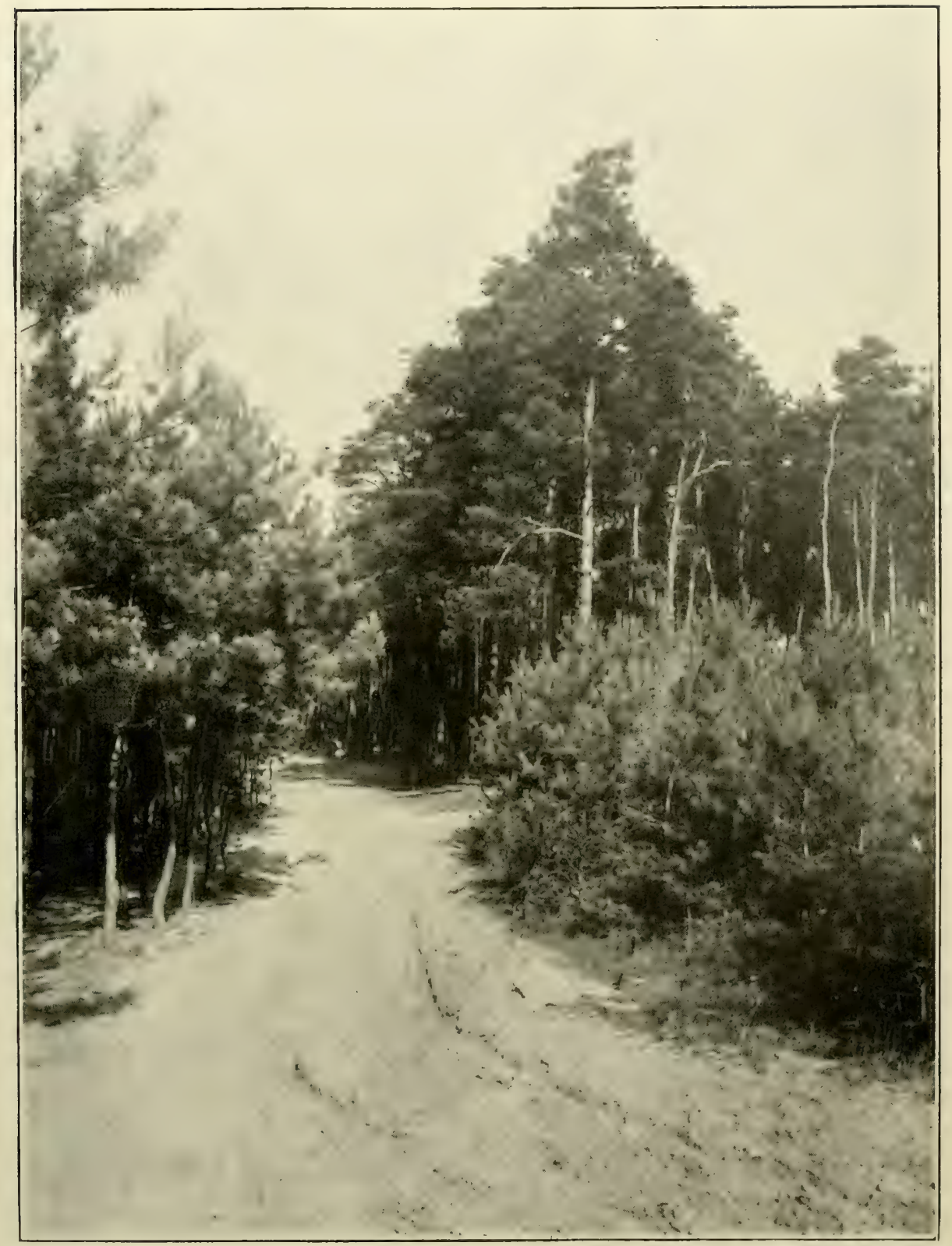

Ab). 87. Föhrenwald auf Sandboden im mittleren Elbetal bei Čelakowitz. Charakteristisch der fast fehlende Niederwuchs.

(Nach Daněk, Fytogeogr. nástin ěesk. středního polabí.) 

In der Umgebung von Münchengrätz treten auf Sand Föhrenwälder Münchenund Sandheiden mit Aira caryophyllea, Scleranthus perennis, Dianlhus deltoides. Silene nulans, Veronica proslrata, Cirsium acaule usw. auf; auf Basalt aber sind Laubwälder mit Lilium. Marlagon, Plalanlhera bifolia, Corydalis cava, Ranunculus polyanthemus, R. lanuginosus, Lalhyrus niger, Vicia cassubica, Viola mirabilis, Melampyrum nemorosum, M. pralense *uulgalum, Galium silvalicum,

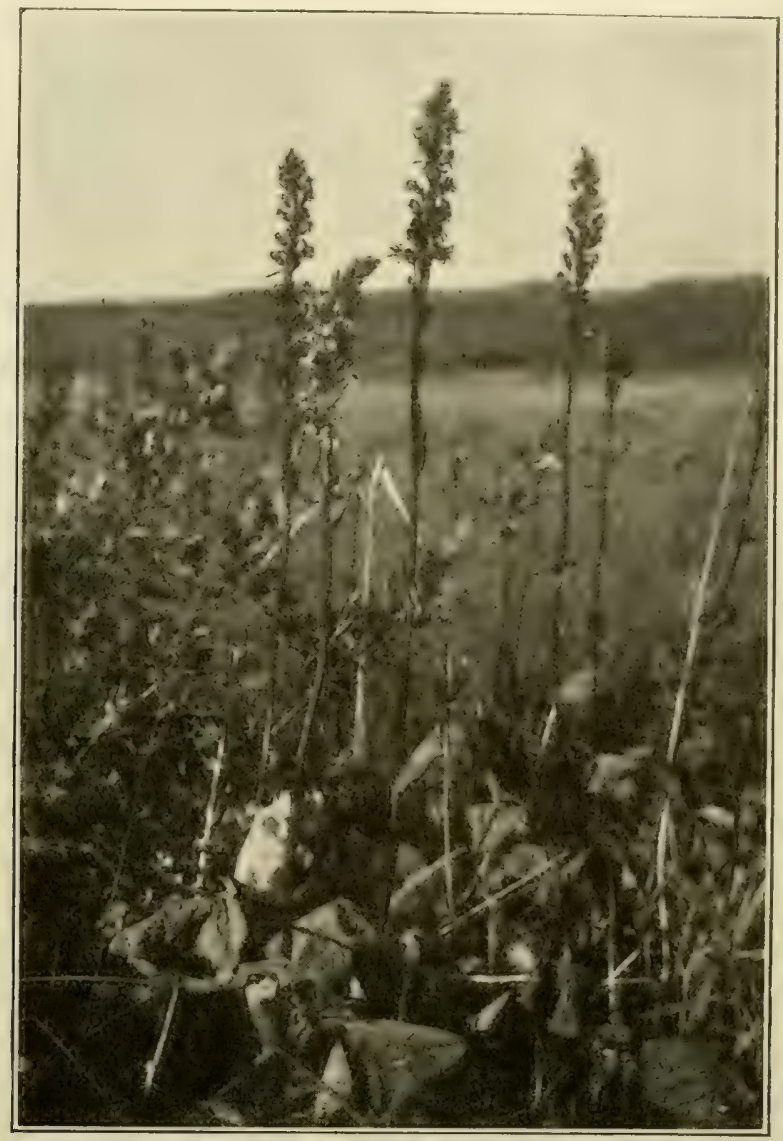

Abb. 86. Ligularia sibirica an den Hirschberger Teichen. Links Rhamnus Frangula und Glyceria sp.

(Nach einer Aufnahme von Prof. A. Pascher, Prag.)

Meliltis Melissophyllum, Inula hirla sowie Buschbestände und Bergtriften mit Thesium linophyllum, Trifolium montanum, Polenlilla canescens, P. recla, Cylisus nigricans, Peucedanum Oreoselinum, Asperula glauca, Chrysanthemum corymbosum usw. vorherrschend, seltener sind Bergwiesen mit Trollius, Phyteuma orbiculare und Crepis succisaefolia. Noch reicher entwickelt sind die pannonischen Formationen in der Umgebung von Jung-Bunzlau. Zwar sind auch hier JungFöhrenwälder mit eingesprengten Fichten mit Sarothamnus scoparius in Lnter- 
holz und Carex ericetorum und Calluna, Vaccinien, Pirolaarten im Niederwuchs häufig anzutreffen, daneben treten aber auch, besonders bei Chlum, Eichenwälder mit Hierochloë australis, Cytisus nigricans, Vicia cassubica, Omphalodes scorpioides, vor allem aber besonders an den Lehnen des Isertales schon sehr an Steppen gemahnende T'riften mit Andropogon Ischaemum, Stipa pennata, St. capillata, Iris bohemica, Dianthus Carthusianorum, Aristolochia Clemalilis, Anemone patens, A. nigricans, Clematis recla, Trifolium rubens, T. montanum, Aslragalus Onobrychis, Geranium sanguineum, Seseli annuum, Verbascum phoeniceum, Veronica orchidea, Odontites lutea, Asler Linosyris, A. Amellus, Anthemis tinctoria, Artemisia Absynthium, A. pontica, und A. Scoparia auf; auf feuchten Wiesen kommen Dianthus superbus, Veronica longifolia und Gentiana Pneumonanthe vor. Bemerkenswert ist auch das jedenfalls auf cinstige Einschleppung zurückzuführende Torkommen von Ciirsium bulbosum im Loučiner Park bei Jung-Bunzlau.

Weiter nach Süden zu sind Föhrenwälder, die auf Sandboden oft des Niederwuchses ganz entbehren, und Sandfluren mit Corynephorus canescens, Nardus stricla, Deschampsia flexuosa, Spergula Morisonii, Alyssum monlanum, Polentilla arenaria, Calluna vulgaris, Thymus angustifolius, Helichrysum arenarium die herrschende Formation; hie und da ist die Ebene durch kleine somige, aus Silikatgesteinen aufgebante Hügel unterbrochen, auf welchen dann wieder pannonische Triftormationen auftreten. So tritt bei Hoch-Lieben Kojetitz. Cylisus auslriacus auf und zwischen Kojetitz und Lobkowitz sind Festuca sulcala, Koeleria gracilis, Andropogon Ischaemum, Slipa capillala, Carex humilis, Anthericum Liliago, Dianthus Carthusianorum, Bisculella Laevigata, Sedum rupestre, Polentilla arenaria, P. argentea, Filipendula hexapelala, Trifolium 'montanum, T. striatum, Anthyllis Vulneraria, Salvia pratensis, Thymus Loevyanus, Verbascum phoeniceum, Centaurea rhenana die vorherrschenden Typen. In den Niederungen der Elbe aber treten neben Röhrichtformationen insbesondere üppige Sumpfwiesen mit tiefgründigem schwarzen Humus auf, so bei L ys a, Vrutitz und V̌̌etat, wo sie leider schon durch künstliche Austrocknung fast vernichtet sind.

Lysa. Bei Lysa sind auf diesen Wiesen Schoenus nigricans und ferrugineus, Cladium Mariscus, Carex distans, G. lepidocarpa, C. paniculala, Molinia coerulea, Triglochin palustre, Orchis incarnala, O. palustris, Parnassia palustris, Potenlilla erecla, Linum calharticum, Polygala amarella, Peucedanum palustre, Genliana Pneumonanthe, Euphrasia Rostkoviana, Aleclorolophus montanus, Pinguicula vulgaris, Stachys palustris, Cirsium palustre, C. acaule, Cenlaurea Jacea, ChryVełenka. sanlhemum Leucanthemum die auffälligsten Typen; bei Velenka bildet Sesleria uliginosa große Rasen. Eine ähnliche Zusammensetzung zeigen auch die MoorJelenitz. wiesen zwischen Jelenitz und Vrutitz, wo überdies noch Orchis coriophora, O. militaris, O. uslulala, O. latifolia, Gymnadenia conopea, Thesium ebractealum

Vštat. und Lalhyrus palusler vorliommen. Auch bei vesetat finden sich dieselben Arten, überdies noch Gymnadenia odoralissima und Oslericum paluslre, und auf Brachen nicht selten Carex secalina, während zwischen Neratowitz und Oužitz Reste von Salzwiesen mit Glaux maritima, Melilolus dentatus und Scorzonera humilis 


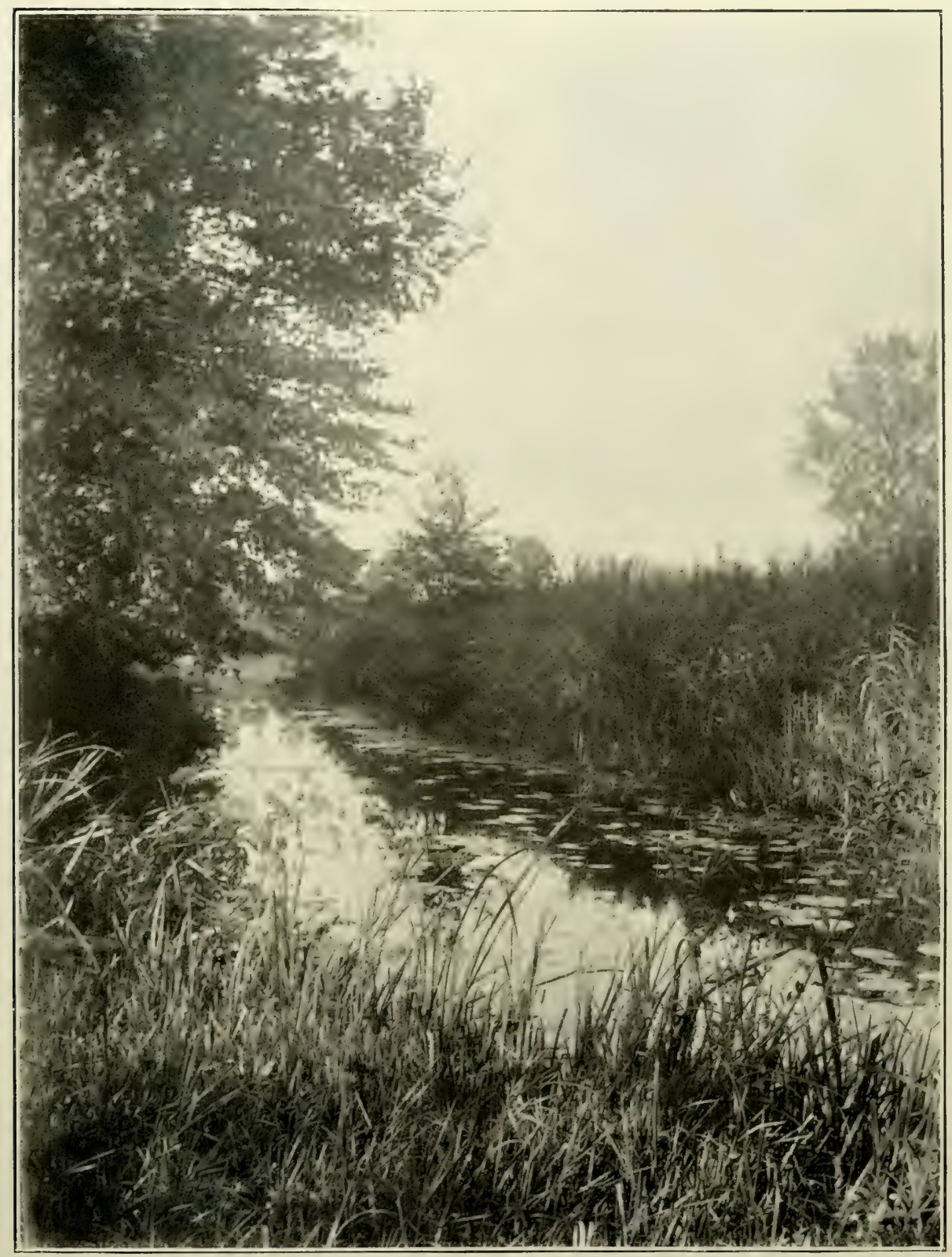

Abb. 88. Wassertümpel bei Bysičky nächst Lysa.

Am Ufer Bestand von Phragmites communis mit Typha, Schoenoplectus lacustris, in Wasser Nuphar luteum, Castalia candida und Hydrocharis Morsus ranae.

(Nach Daněk, Fytogeogr. nástin česk. střediního polabí.) 

erhalten sind. Das diese Wiesen umgebende Hügelland trägt größtenteils eintönige Heiden und Föhrenwälder, in denen Chimaphila umbellata, Carex montana und Luzula pallescens nicht selten auftreten. Auch einzelne östliche Arten trifft man in diesen Wäldern an, so bei Lieblitz Stipa pennala und zwischen Přivor und Vavřinetz Gytisus austriacus. Diese Formationen erstrecken Vavrinetz. sich bis gegen Melnik, dem einzigen Orte in Böhmen, wo in größerem Maß- Melnik. stabe Wein gebaut wird. Im Tale der Elbe bei Melnik aber sind Wiesenmoore mit Schoenus nigricans, S. ferrugineus, Cladium Mariscus, Orchis palustris, O. coriophora, Epipactis palustris, Menyanthes lrifoliala, Inula salicina und (bei Wrutik) Drosera anglica entwickelt, während am Ufer der Elbe bei Elbe-Kosteletz die in Böhmen seltene Calamagroslis Pseudophragmites wächst. Auch im weiten Talbecken der Elbe bei Podiebrad waren ehemals den oben Podiebrad. geschilderten ähnliche Moorwiesen mit Schoenus ferrugineus, Allium angulosum, Thalictrum flavum, Galega officinalis, Lylhrum Hyssopifolia, Genliana Pneumonanthe usw. entwickelt; heute sind dieselben größtenteils trockengelegt und haben Äckern oder eintönigen Kulturwiesen Platz gemacht, doch finden sich stellenweise auch heute noch größere Bestände von Galega officinalis oder sumpfige Wiesen, wie die Blatowiese bei Podiebrad, wo Schoenoplectus Tabernaemontani, Cnidium venosum, Centaurium linearifolium, C. pulchellum und Scorzonera humilis vorkommen.

Das niedere Hügelland zwischen Podiebrad und Jičin ist ein Laubwaldgebiet, in dem Eichenbestände aus Quercus Robur und Ou. sesseliflora mit Carpinus Betulus, Populus tremula, Ulmus glabra, Sorbus lorminalis und Prunus avium dominieren. Unterholz und Niederwuchs sind in diesen Wäldern sehr reich entwickelt, die wichtigsten Typen sind Corylus Avellana, Cralaegus Oxyacantha, Liguslrum vulgare, Prunus Padus, Evonymus vulgaris, Hierochloë auslralis, Platanthera bifolia, Polygonalum mulliflorum, Maianthemum bifolium, Corydalis cava, Hesperis runcinala, Cylisus nigricans, Lalhyrus vernus, Vicia pisiformis, Aslrantia maior, Bupleurum longifolium, Laserpilium prulhenicum, Melillis Melissophyllum, Cynanchum Vincetoxicum, Melampyrum vulgalum, Campanula persicifolia und Phyteuma spicatum. Hie und da treten auch Buschbestände aus Corylus Avellana, Acer campestre, Cornus sanguinea, Ligustrum vulgare, Viburnum Opulus und $V$. Lantana auf, am südlichen Rande des Gebietes auch Triftformationen, wie bei Dymokur, wo in denselben Anemone silvestris, Geranium sanguineum, Linum flavum, Trifolium rubens, T. ochroleucum, Lalhyrus versicolor, Campanula Cervicaria, Scorzonera hispanica und S. purpurea wachsen, während in dem nahe gelegenen Komarover Waldtale Allium Scorodoprasum, Astragalus Cicer, Vicia pisiformis und Crepis praemorsa vorkommen; am Jakobiteiche bei Dymokur ist Hippuris vulgaris zu finden. Auch bei Roždalowitz, wo am Zamostteiche $C y$ perus fuscus, Limosella aquatica und Lythrum Hyssopifolia gedeihen, sind einige seltenere Arten, wie Iris sambucina, Gladiolus imbricatus und Cytisus austriacus anzutreffen. Auf dem Ghotucberge bei Krinetz ist Orchis fusca auffallend häufig. Westlich von Roždalowitz, wie bei Wlkava, herrschen jedoch schon wieder Föhrenwälder mit Sarothamnus im Unterholz vor. Auch weiter nördlick, 
wie in der Umgebung von Jičin selbst, sind Föhren- und Fichtenbestände mit eintönigem Niederwuchs aus Calluna, Vaccinium Myrtillus, Luzula nemorosa und Polentilla erecta die vorherrschende Formation, in denen nur an lichteren und feuchteren Stellen Festuca gigantea, Senecio nemorensis, Oxalis usw. sowie die seltene Carex brevicollis die GleichmäBigkeit des Niederwuchses unterbrechen. Nur bei Veseč treten einige seltenere Arten, wie Thalictrum anguilegifolium, Pulmonaria angustifolia, Polentilla alba und Campanula lalifolia auf und bei

Sobotka. Sobotka wachsen an einer feuchten Stelle bei der Šlejfirna-Mühle Calla palustris, Orchis lalifolia und Menyanthes trifoliala. Zwischen Königstadl

NeuBydžow. und Neu-Bydžow breiten sich Sumpfwiesen mit massenhaftem Allium angulosum aus; am Ufer des $\mathrm{R} i \mathrm{~h}$ ateiches daselbst kommen Elaline Alsinastrum und Lindernia pyxidaria vor, zwischen $\mathrm{Habrina}$ und Velichovky bei J a romer hat Adenophora liliiflora seinen einzigen Standort in Ostböhmen. Auch in der König-
grätz. Umgebung von Königgrätz sind die Sumpfwiesen mit Carex stellulata, C. tomenlosa, C. Buekii, Teucrium Scordium und dem hier seine vorläufige Nordwestgrenze erreichenden Girsium rivulare sowie die Teiche mit Polamogelon alpinus, P. aculifolius, P.gramineus, Hydrocotyle vulgare, Lindernia pyxidaria, Menyanthes lrifoliata, an deren Ufern Dryopteris cristata und Hierochloë odorala vorkommen, die bemerkenswertesten Formationen. Im übrigen treten Föhren- und Eichenwälder sowie Sandheiden mit Corynephorus, Aira caryophyllea, Trifolium ochroleucum, Peucedanum Cervaria, Melampyrum cristatum, Gnaphalium luteoalbum, Arnoseris minima usw. daselbst auf. Bei Opočno findet man Eichenwälder mit Lilium Martagon, Cephalanthera alba, Corydalis cava, Ranunculus cassubicus, Viola mirabilis, Lathyrus vernus, Chrysanthemum corymbosum und feuchte Wiesen, auf denen stellenweise Hippocrepis comosa wächst; in den Wäldern um Pardubitz und Ghrudim ist das Vorkommen von Euphorbia amygdaloides und Melamplyrum bohemicum bemerkenswert. Weiter im Süden Caslau. gegen die Ausläufer des böhmisch-mährischen Gebirges bei Časla u und GoltschJenikau herrscht eine höchst eintönige Flora; Föhren- und Birkenbestände unterbrechen hie und da die ausgedehnten Äcker und ab und zu trifft man auch noch Schilfrohrbestände an den kleineren Sümpfen.

Reichenau Auch in der Umgebung von Reichenau a. d. Knežna herrschen WäIder Knežna. aus Quercus sessiliflora, Qu. Robur, Carpinus Belulus mit eingesprengten Buchen und Birken vor, in deren Niederwuchs neben Corylus auch Sambucus racemosa und Lonicera nigra auftreten, während im Niederwuchs Vaccinium Myrtillus, V. Vilis Idaea, Calluna vulgaris, Melampyrum nemorosum, M. vulgalum und M. silvaticum, Sanicula curopaea, Phyteuma spicalum usw. die häufigsten Arten sind. Auf Wiesen aber treten hier Saxifraga granulata, Salvia pratensis, Arnica montana, Cirsium canum und $C$. rivulare auf, daneben kommen auch noch triftartige Formationen mit Sesleria varia, Phleum phleoides, Andropogon Ischaemum, Eryngium campestre, Salvia nemorosa, S. verticillata, Jasione montana, Artemisia Absynthium, Girsium canum usw. und kleine Noore mit Oxycoccos quadripelala, Pedicularis palustris und $P$. silvalica vor, während auf Sandheiden bei AdlerKosteletz Astragalus arenarius wächst. Im östlichsten Teile von Böhmen, 


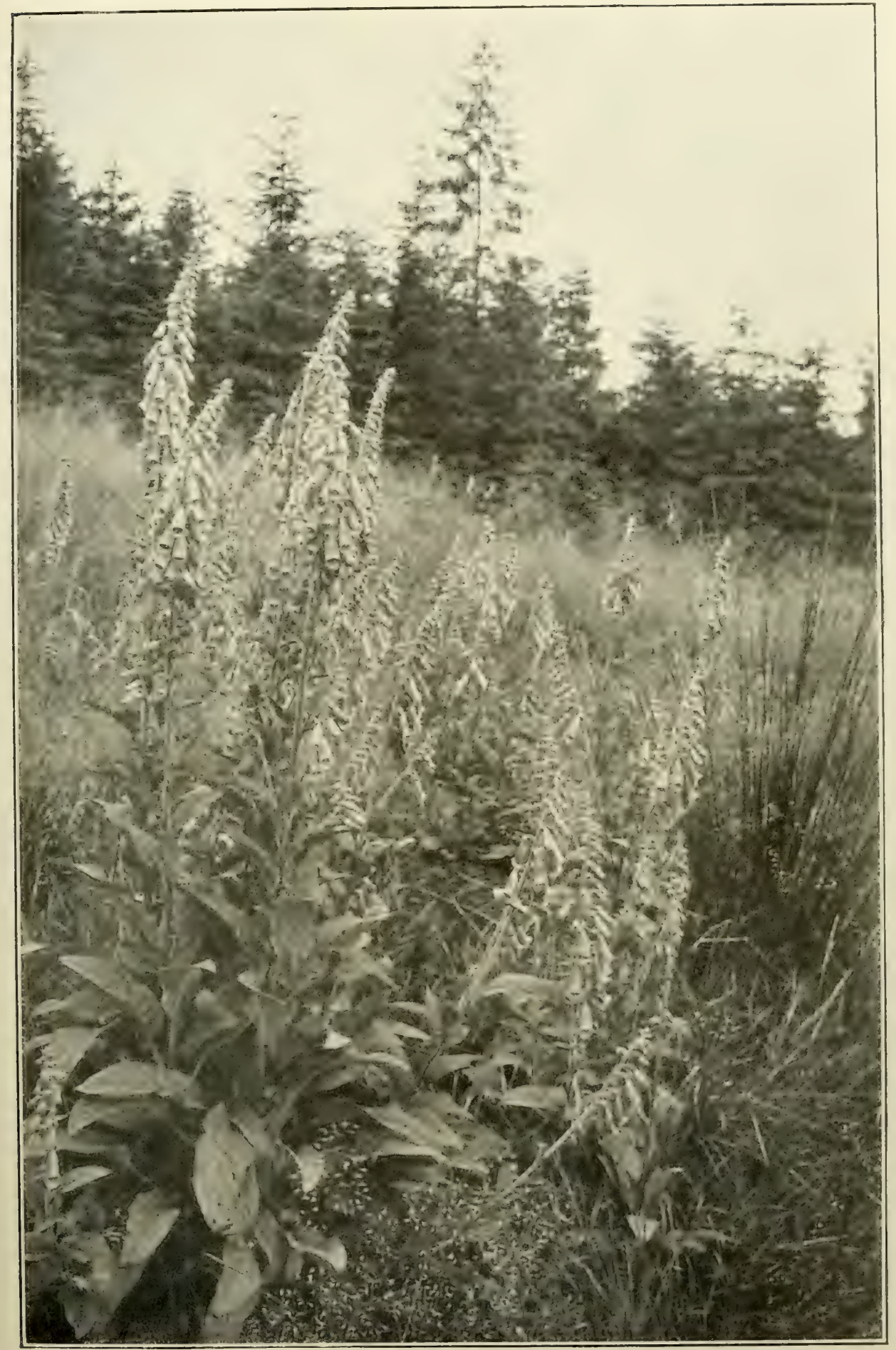

Abb. 89. Digitalis purpurea auf dem Zschirnstein an der böhmisch-sächsischen Grenze. (Nach einer Aufnahme von Nenke und Ostermaier in Dresden.) 

um Hohenmauth und Leitomischl, ist das häufige Vorkommen von Cirsium rivulare und auch von Centaurea oxylepis charakteristisch; bei Leitomischl hat überdies die seltene Pilularia globulifera ihren einzigen böhmischen Standort und in Bergwäldern tritt hier die sudetische Salix silesiaca auf.

\section{Das Elbesandstein- und Lausitzer Gebirge.}

Das Elbesandsteingebirge mit seinen Steilabhängen gegen die Elbe, seinen eigenartigen quaderförmigen Felsbildungen, seinen Felstoren und den nur wenige hundert Meter über die Elbe sich erhebenden Gipfeln weist in seiner Flora eine große Ähnlichkeit mit dem Erzgebirge auf. Von den Charakterarten des Erzgebirges fehlen dem Sandsteingebirge zwar Dianthus silvalicus, Orchis globosa und vor allem Meum alhamanticum, hingegen sind Calamagrostis villosa, Slreplopus amplexifolius, Thlaspi alpestre. Arabis Halleri, Phyleuma nigrum usw. hier so häufig wie dort. Die wichtigsten Formationen des Gebirges sind Wälder, und zwar fast ausschlieBlich Narlelwälder; Föhren und Fichtenbestände mit Vaccinien und Calluna im Niederwuchs sind charakteristisch für das Gebiet, ferner auch das stellenweise nicht seltene Auftreten von Digitalis purpurea in Holzschlägen westlich der Elbe, das sich bis gegen Niedergrund und auf dem Plateau um die Königshütte gegen den Schneeberg erstreckt. Auch der $721 \mathrm{~m}$ erreichende Hohe Schneeberg trägt dichten Nadelwald aus Fichten und Tannen, in dem Vaccinium Myrtillus und Calluna vulgaris weithin den Boden bedecken; an feuchteren Stellen treten auch Blechnum Spicant und Calamagrostis villosa auf, ferner Oxalis Acelosella, Mercurialis perennis, Anemone nemorosa usw. Hochmoore fehlen, auf kleinen Wiesenmooren ist Juncus squarrosus anzutreffen. Reicher ist die Flora in dem östlich der Elbe gelegenen Teile des Gebirges. Auf Wiesen bei Tetschen sind Arabis Halleri und Thlaspi alpestre Tetschen. eine häufige Erscheinung, am Ufer der Elbe selbst liommt Allium Schoenoprasum vor. In den Wäldern bei Herrnskretschen tritt an den Steilhängen der Täler an moosigen feuchten Felsen hie und da Ledum palustre auf; in den Schluchten der Böhmischen Schweiz bei Herrnskretschen, Dittersbach und Hohenleipa sind neben Onoclea Struthiopleris und Aruncus silvester auch Streptopus amplexifolius und Viola biflora nicht selten. Der an der Landesgrenze sich erhebende $556 \mathrm{~m}$ hohe Große Winterberg besteht in seinen oberen Partien aus Basalt und trägt daher eine etwas abweichende Flora. Der Waldbaum ist hier die Buche, in deren Beständen Hordeum europaeum, Lilium Marlagon, Cardamine enneaphyllos und das seltene Botrychium Matricariae vorkommen. Zwischen dem Winterberg und Böhmisch-Kamnitz hat sich in neuerer Zeit ebenfalls Digilalis purpurea angesiedelt, auch Mimulus gullatus bürgert sich an der Kamnitz ein. Der Rosenberg bei Böhmisch-Kamnitz weist eine ähnliche Flora wie der $\begin{gathered}\text { Böhmisch- } \\ \text { Kamnitz. }\end{gathered}$ Winterberg mit Polystichum lobatum, Cardamine enneaphyllos, C. bulbifera, Fesluca silvalica, Hordeum europaeum, Circaea alpina und Ribes alpinum auf. Viel interessanter ist die Vegetation des eigentlichen Lausitzer Gebirges Lausitzer mit seiner wechselnden geologischen Unterlage aus Sandstein, Glimmerschiefer

Herrnskretschen.

\section{Herrns-} kretschen. 
Rumburg. und Basalt. Schon bei Nixdorf und Rumburg wechseln Fichtenbestände mit Blechnum Spicanl, Luzula nemorosa, Vaccinium Myrlillus und V. Vitis Idaea, Pirola chlorantha, rolundifolia und secunda, seltener auch Chimaphila umbellata mit Laubholzbestïnden aus Fagus silvalica, Belula pendula, Acer Psendoplalanus. Ulmus scabra, in denen Milium effusum, Luzula maxima, Carex digilala, C. silvatica, C. pendula, Actaea spicala, Lathyrus vernus, Oxalis Acetosella, Monotropa Hypopitys, Lunaria rediviva wachsen, ab; auf Bergwiesen gedeihen Bolrychium Lunaria, Ophioglossum vulgalum, Orchis lalifolia, Saxifraga granulala, Primula elatior, Arnica montana, Cirsium helerophyllum und bei Georgswalde und Nixdorf auch noch Orchis globosa und Meum athamanticum. Daneben treten in den Tälern auf Schieferboden auch Heiden mit Aira caryophyllea; A. praecox, Calluna vulgaris, Cirsium acaule usw. auf; Hochmoore fehlen, doch sind Wiesenmoore mit Carex lasiocarpa, C. flava, C. rostrala, C. slellulata, C. gracilis, Eriophorum vaginatum, Drosera rolundifolia, Polentilla palustris, Pedicularis palustris und silvatica in der Rumburger Gegend nicht selten. Den Bergzug vom Kalten-

Großer Buchberg. Hohe

Lausche. berg und Großen Buchberg bei Zwickau bis zur $791 \mathrm{~m}$ hohen Basaltkuppe der Hohen Lausche bedecken ausgedehnte Buchenwälder, in denen Festuca silvalica, Hordeum europaeum, Lilium Marlagon, Senecio nemorensis und prächtige Farne, vor allem Polyslichum lobalum, Dryopteris Oreopteris und D. Filix mas sowie Blechnum Spicant häufig sind. Auch Circaea alpina und Petasiles albus fehlen nicht und im Basaltgerölle bildet Ribes alpinum das Unterholz. An Waldbächen aber sind Calamagrostis villosa, Senecio rivularis und Mulgedium alpinum charakteristische Erscheinungen, seltener ist Trientalis europaea. Die Bergwiesen der Lausche bieten außer Orchis globosa kaum etwas Bemerkenswertes, Nardus stricla, Agrostis vulgaris, Anthoxanthum odoratum und Fesluca ovina sind neben Luzula multiflora die wichtigsten Rasenbilder, Arnica montana fehlt nirgends und an feuchteren Stellen treten Juncus squarrosus und $J$. filiformis auf. An den Felsen der Burg Tollenstein bei St. Georgental gedeiht

Haida. der Farn Woodsia ilvensis, der auch an den Felsen des Kleis bei Haida in Gesellschaft von Allium sibiricum, Asler alpinus *hirsulus, Viscaria vulgaris, Cystopleris fragilis, Sedum maximum, Cynanchum Vincetoxicum, Digitalis ambigua usv. anzutreffen ist, während ober den Felsen im Gebüsche Inula salicina häufig ist. Am Südrande des Lausitzer Gebirges gegen Böhmisch-Leipa treten wieder Fichtenwälder auf, auf den Wiesen sind auch hier noch Arnica montana und Cirsium helerophyllum häufig.

Der Zug des Jeschken trägt in seiner nordwestlichen Hälfte neben Fichtenauch ausgedehnte Laubwälder, während im südlichsten Teile Wiesen mit Sanguisorba officinalis, Heracleum Spondylium, Chaerophyllum aromalicum usw. bis über $700 \mathrm{~m}$ ansteigen. Den I Iauptgipfel aber bedecken ausgedehnte Fichtenwälder, in denen Slreptopus amplexifolius, Listera cordala, Ranunculus platanifolius, Thalictrum aquilegifolium, Senecio rivularis und von zirka $900 \mathrm{~m}$ an auch die sonst im Lausitzer Gebirge fehlende Homogyne alpina auftreten. Doch bald schon zeigen die Fichten verkrüppelte, vom Winde zerzauste Formen und schon bei $985 \mathrm{~m}$, zirka $25 \mathrm{~m}$ unter dem $1010 \mathrm{~m}$ hohen Gipfel, liegt die Waldgrenze. 


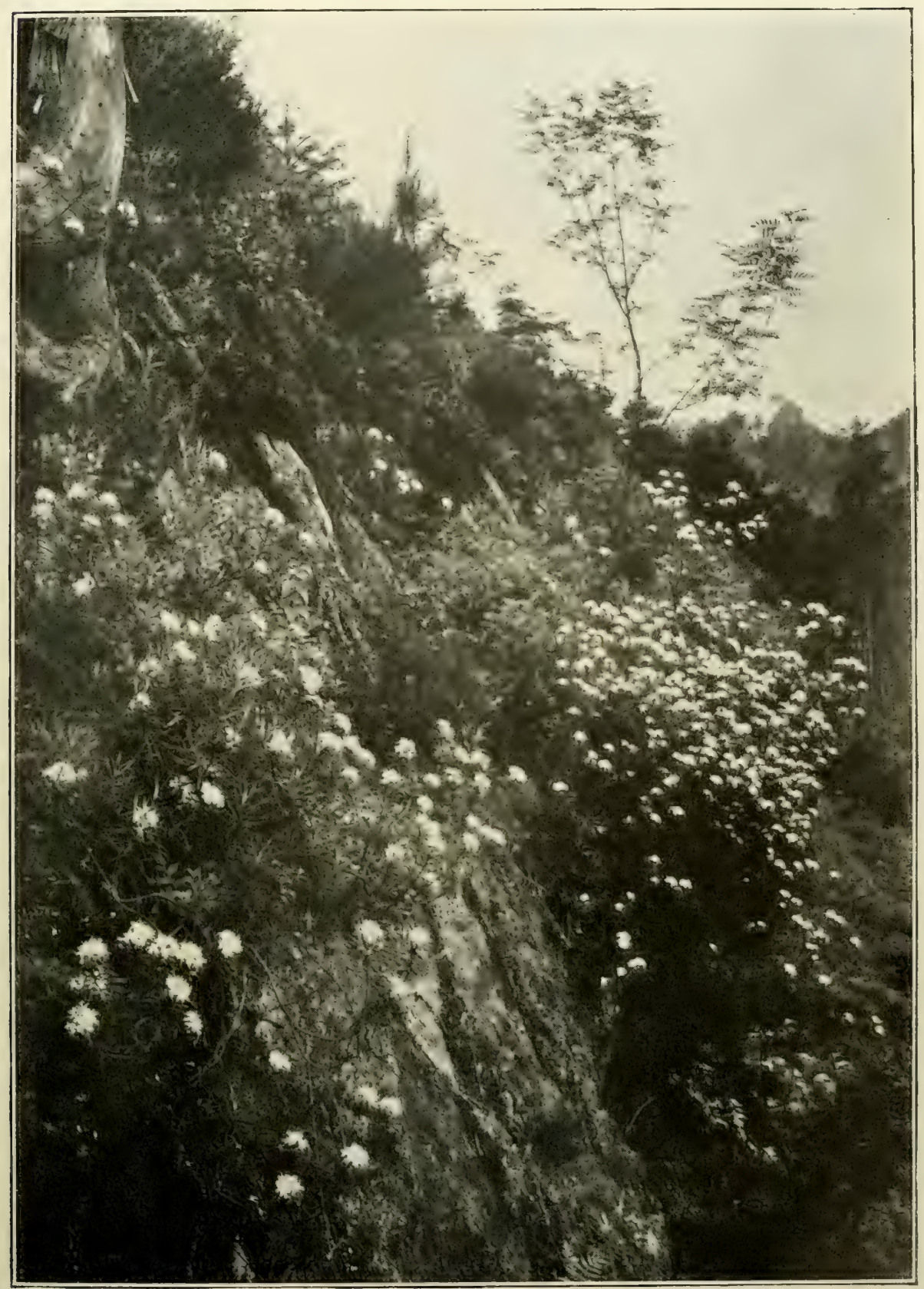

Abb. 90. Ledum palustre an feuchten FeIsen im Elbesandsteingebirge.

(Nach einer Aufnahme von Nenke und Ostermaier in Dresden) 

Der mit Felsgeröll bedeckte Gipfel aber trägt lockere Bergheide aus Deschampsia flexuosa, Calluna vulgaris, Vaccinium Myrtillus und V. Vitis Idaea, Solidago alpestris, Homogyne alpina, Prenanthes purpurea, Lycopodium Selago und einzelnen verkrüppelten Exemplaren von Fichten oder Sorbus Aucuparia.

Im Tale der Neiße bei Reichenberg sind an den Hängen des Jeschlienzuges hauptsächlich Laubmischwälder entwickelt, deren Niederwuchs vornehmlich aus Deschampsia flexuosa, D. caespitosa, Milium effusum, Polygonatum mulliflorum, Mercuralis perennis, Pulmonaria officinalis usw. besteht. Auf den zahlreichen Wiesen des Gebietes sind Leucoium vernum, Gagea lulea, Dianthus deltoides, Primula veris. Sanguisorba officinalis. Euphrasia curla. Jasione monlana Achillea plarmica häufig; auch Heiden aus Calluna usw. und Buschwerk aus Sarolhamnus scoparius sind oft anzutreffen.

\section{Die Sudeten.}

Die reichste Flora unter den böhmischen Randgebirgen weisen die Sudeten auf, und zwar besonders das Riesengebirge, das Glatzer Gebirge und das Hochgesenke, während die übrigen Teile derselben, speziell das Isergebirge und Adlergebirge, an Hochgebirgsarten ärmer sind. Es fehlen zwar den Sudeten von den im Erzgebirge vorkommenden Arten Calamagrostis varia, Eriophorum gracile, Dianthus silvaticus, Thlaspi alpestre, Teucrium Scorodonia, Aiuga pyramidalis, Digitalis purpurea, Hypochoeris maculala, Senecio palustris, von den Arten des Böhmerwaldes Salix grandifolia, Alnus viridis, Cardamine trifolia, Polygala Chamaebuxus, Soldanella montana, Gentiana pannonica, doch treten dafür wieder in den Sudeten zahIreiche andere Arten auf, so z. B. in der Waldregion Polystichum Braunii, Salix silesiaca, Delphinium elatum, Anthriscus nilidus, Pleurospermum austriacum, Adenoslyles Alliariae, Pelasiles Tablikianus, auf IIochmooren Trichophorum alpinum, Carex magellanica, Rubus Chamaemorus, Pedicularis sudelica, besonders aber in der Hochgebirgsregion, aus deren Flora nur Allosorus crispus, Carex capillaris, Salix haslala, S. Lapponum, S. herbacea, Cerastium macrocarpum, Anemone alba, A. narcissiflora, Cardamine resedifolia, Sedum roseum, S. alpestre, Saxifraga moschala, S. bryoides, S. nivalis, S. oppositifolia, Sorbus sudetica, Polentilla aurea, Alchimilla glaberrima, Hedysarum obscurum, Viola sudelica, Primula minima, Teronica bellidioides, Euphrasia picta, Campanula barbala genannt seien. Besonders charakteristisch sind für die Sudeten die vier nordischen Arten Salix bicolor, Saxifraga nivalis, Rubus Chamaemorus und Pedicularis sudetica, die nicht nur den übrigen böhmischen Gebirgen, sondern auch den Karpathen und Alpen fehlen; den Alpen fehlen ferner auch Cyslopteris sudelica, Angelica Archangelica, Avena planiculmis und Crepis sibirica.

Das Is ergebirge stellt eine hauptsächlich aus Glimmerschiefer aufgebaute Isergebirge. wenig gegliederte Bergkette mit ziemlich gleichmäßig in einer Höhe von sog his $900 \mathrm{~m}$ verlaufender Kammhöhe dar, die die wenig scharf begrenzten höheren Gipfel (Tafelfichte $1124 \mathrm{~m}$, Sieghübel $1120 \mathrm{~m}$, Schwarzenberg $1084 \mathrm{~m}$ ) 
nur tvenig überragen. Das ganze Isergebirge ist dicht bewaldet und selbst an seinem Fuße ist von Äckern oder Kulturen wenig zu sehen. Gleich ober dem Neißetale bei Reichenberg beginnen die ausgedehnten Fichtenwälder, die in

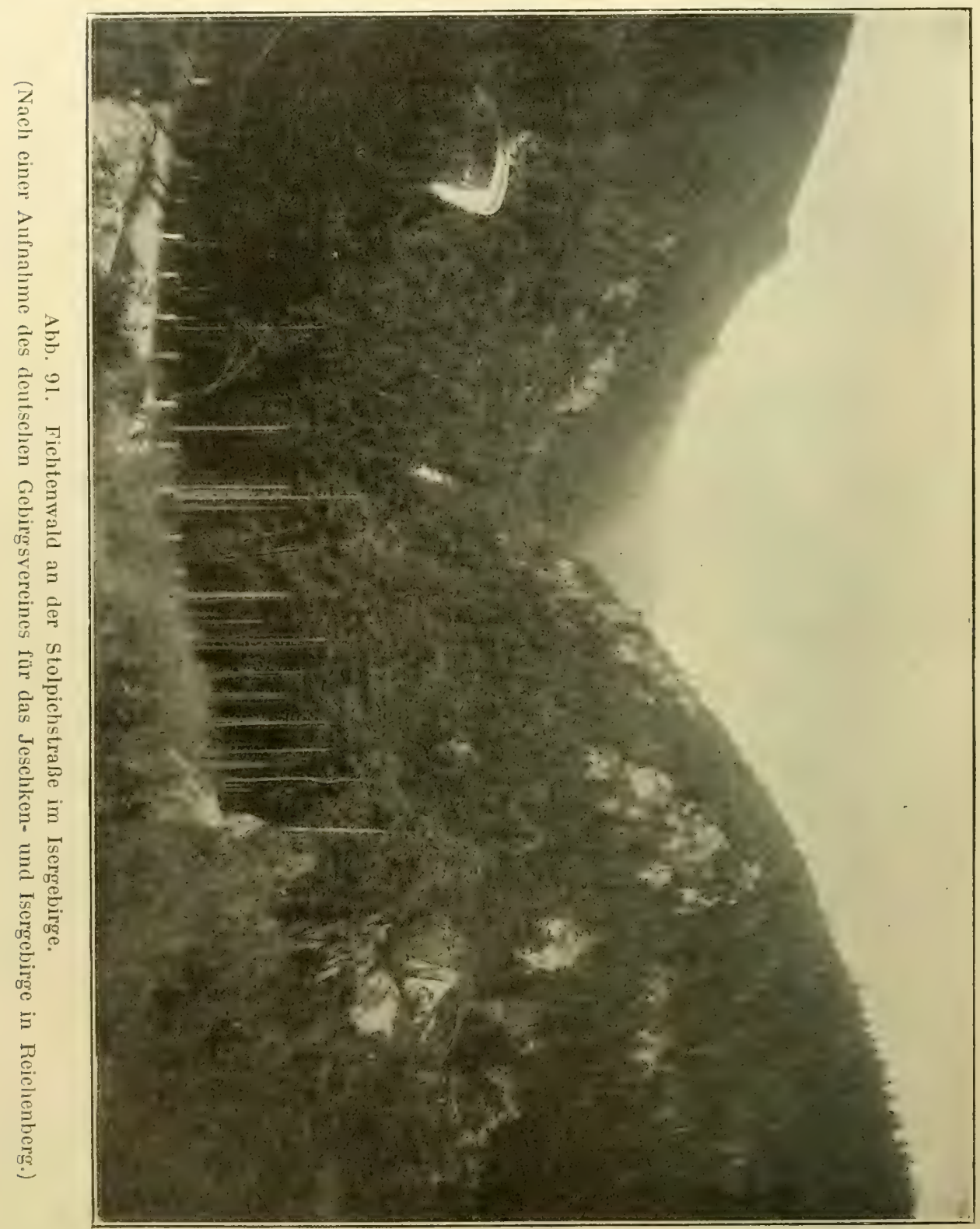

tieferen Lagen noch sehr eintönig sind und deren Boden oft weithin von Heidelbeeren, Heidekraut, untermischt mit Luzula nemorosa, oder von Moosen, wie Leucobryum glaucum, Dicranum scoparium und Hylocomium triquelrum und splendens bedeckt ist. In höheren Lagen aber treten auch die Charakterarten 
der Sudetenwälder, wie Polystichum lobatum, Dryopteris Filix Mas, Athyrium Filix femina, Polygonatum verlicillatum, Lilium Marlagon, Euphorbia dulcis, Ranunculus platanifolius, Lamium vulgare, Veronica montana, Senecio nemorensis, Homogyne alpina usw. häufig auf. Diese Fichtenwälder reichen bis auf die höchsten Gipfel des Gebirges und lirönen noch die Kuppe der Tafelfichte, Tafelfichte. wo in Lichtungen der Waldbestände Gentiana asclepiadea häufig auftritt, und

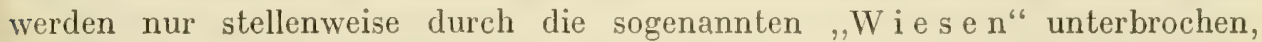
welche in einer Höhe zwischen 830-1015 $\mathrm{m}$ auf oder nahe dem Kamme auftretende Hochmoore darstellen, auf denen gewöhnlich Krummholz (Pinus Mughus) dichte Bestände bildet, welches im Isergebirge nur unter dem Gipfel des Sieghübels auch an Felsen auftritt.

Sieghübel.

Die höchste dieser ,Wiesen“ ist die am Hauptkamme in $1010 \mathrm{~m}$ Meereshöhe gelegene, dicht von Fichtenwald umgebene Wolfswiese, die ein von fast undurchdringlichen Krrummholzbeständen bedecktes Sphagnummoor darstellt, auf dem Empetrum nigrum, Andromeda polifolia und Vaccinium uliginosum häufig sind. Die am Abhange des Schwarzenberges gelegene Tschihadlwiese ist hingegen nur spärlich von Pinus uliginosa bewachsen, hingegen reich an Moortümpeln (,,Teiche“), die besonders von flutenden Formen von Sphagnum Dusenii, S. papillosum, Lophozia inflata und von Hypnum fluilans erfült sind. Auf der Kammhöhe liegt die „Wiese unter dem Börndlhause," der das Lirummholz fehlt, hingegen bilden hier Eriophorum vaginalum, Trichophorum austriacum und Carex Goodenoughii dichte Bestünde. Die „Große Knieholz-Große und riese" une wiese und die ,Kleine Knieholzwiese" tragen dichte Legföhrenbestände, Kinieholzerstere ist auch durch das Vorkommen von Juniperus nana und Trientalis europaea ausgezeichnet. Die „Schwarzen Teiche“ am Abhange der Tafel- Sehwarze fichte sind nur am Rande dicht von Knieholz bewachsen, in der Mitte treten zahlreiche kleinere Tümpel, an deren Rande Carex limosa und Scheuchzeria palustris wachsen, sowie zwei größere (die, ,Schwarzen Teiche ${ }^{66}$ ), die von Lophozia inflala und Cephalozia fluitans erfüllt sind, auf. Die ,Schöne Wiese“, inmitten eines urwaldartigen Fichtenbestandes gelegen, ist von auffallend regelmäßig angeordneten Knieholzbüschen bewachsen. Die größten dieser Moore aber sind die am Oberlaufe der Iser gelegene Große und Kleine Iserwiese. $\begin{gathered}\text { Große } \\ \text { Iserwiese }\end{gathered}$ Erstere, fast $500 \mathrm{~m}$ lang und über $1000 \mathrm{~m}$ breit, in einer Meereshöhe von $830 \mathrm{~m}$ gerade an der Reichsgrenze gelegen, ist besonders gegen den Pand zu von dichten Legföhrenbeständen bedeckt, während besonders längs der Iser auch Juniperus nana bestandbildend auftritt. Auf den von Gebüsch freien Stellen sind besonders Eriophorum vaginalum, Carex pauciflora, Trichophorum austriacum und Juncus squarrosus, an trockeneren Stellen auch Carex canescens und C. stellulata tonangebend, in deren Rasen Trientalis europaea, Polentilla erecta usw. auftreten. Von besonderem Interesse aber ist das Vorkommen von Betula nana, Salix myrlilloides und Rubus Chamaemorus auf der großen Iserwiese. Gegen Südosten zu verliert die Wiese ihren moorartigen Charakter und hier treten dann mit Nardus slricla, Agroslis vulgaris usw. einige interessantere Arten auf, wie Gnaphalium norvegicum, Hieracium crocalum und $H$. aurantiacum. 


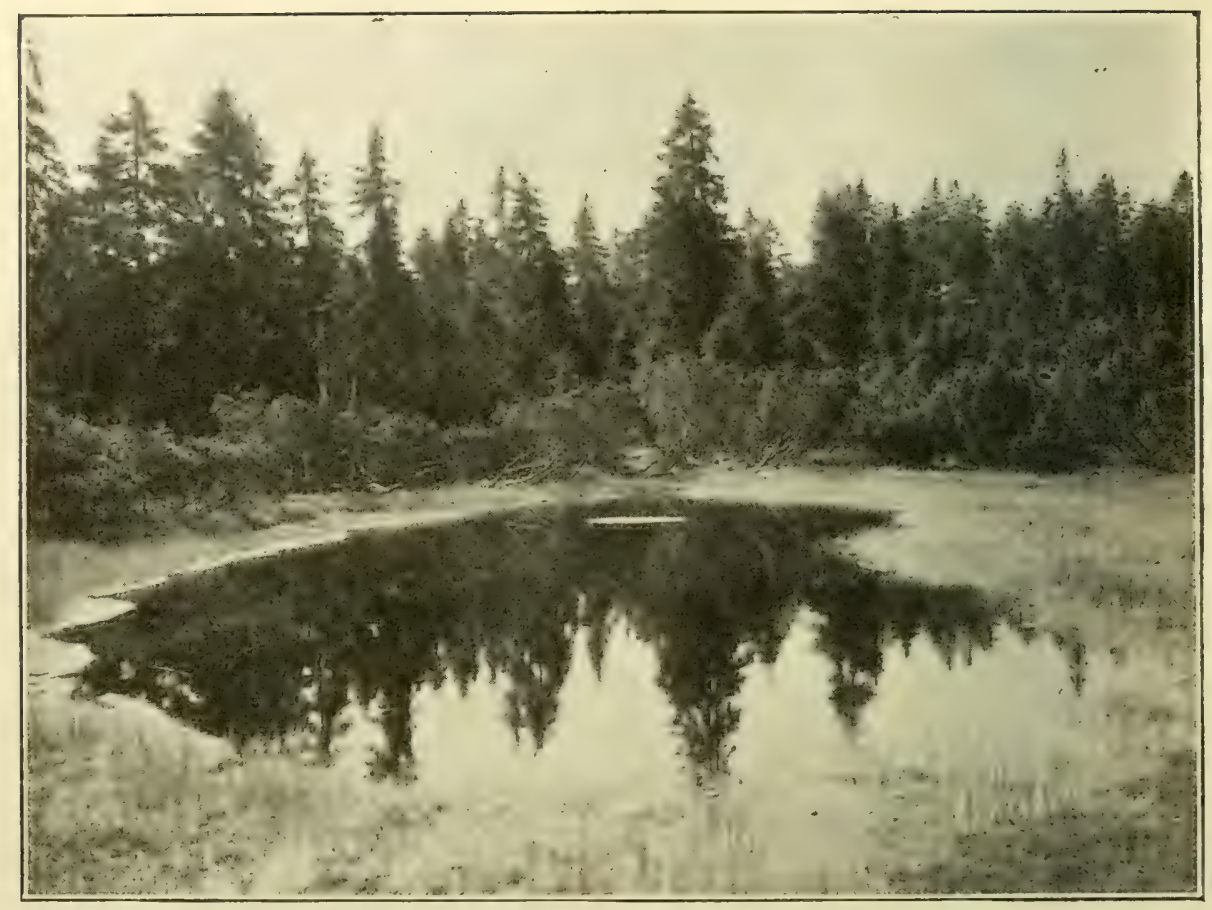

Abb. 92. Die, ,Schwarzen Teiche ${ }^{6}$ im Isergebirge.

Im Hintergrunde Pinus Mughus und Fichtenwald.

(Nach einer Aufnahme des deutschen Gebirgsvereines für das Jeschken- und Isergebirge in Reichenberg.)

Kleine

Iserwiese. Trichophorum austriacum, Eriophorum vaginalum und Carex echinala Bulten (,,Kaupen“) bilden; auch schwimmende Moore und kleine mit Lophozia Floerkei und $L$. inflata erfüllte Tümpel sind nicht selten. Die kleine Iserwiese überragt Buchber. der aus Basalt aufgebaute Buchberg, der prächtige Buchenbestände, in denen Anthriscus nilidus gedeiht, sowie überhaupt eine reichere Flora, wie Poa Chaixii, Veratrum Lobelianum, Geranium silvaticum, Arnica montana, Girsium helerophyllum, Mulgedium alpinum aufweist.

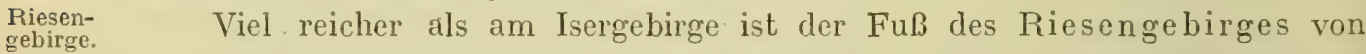

Wohnstätten und Kulturen eingenommen. Hier sind bis zu einer Höhe von $800 \mathrm{~m}$ noch Ortschaften anzutreffen und die ursprünglichen Waldbestände aus Eichen und Buchen sind auf weite Strecken von Kulturen unterbrochen. Diese Buchenwälder, die bis $830 \mathrm{~m}$ ansteigen, weisen von charakteristischen Arten insbesondere Hordeum europaeum, Bromus asper, Poa Chaixii, Luzula nemorosa, Thalictrum aquilegifolium, Cardamine bulbifera, C. enneaphyllos, Lunaria rediviva, Circaea alpina, Euphorbia amygdaloides, Galium silvalicum, Homogyne alpina, Prenanthes purpurea auf, während im Oberholz sich unter die Buchen gern Acer plalanoides und A. Pseudoplalanus mischen. An Bergbächen bildet Salix 


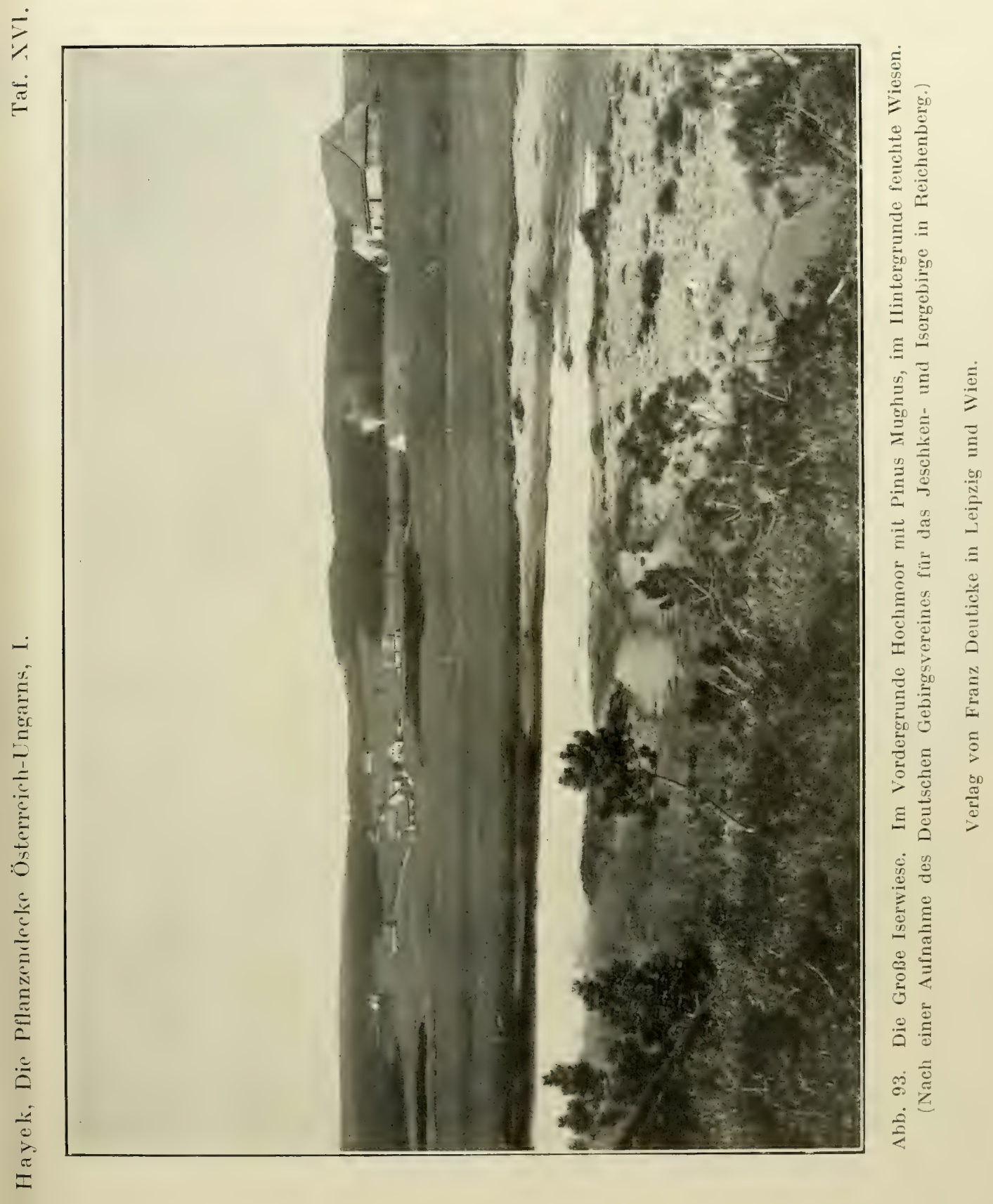



silesiaca mit S. purpurea und S. fragilis Bestände; auf Wiesen sind Trollius europaeus, Gladiolus imbricatus, Primula elatior, Arabis Halleri, Polygonum Bistorta, Arnica montana, Centaurea Pseudophrygia, Hieracium flagellare die auffallendsten Typen. Ober der Buchenzone aber bedecken Wälder aus Picea excelsa, anfangs noch von Fagus silvalica und Abies alba begleitet, in dichtem Bestande die Flanken des Gebirges bis zu einer Höhe von 1200-1300 m. Anfangs freilich ist der Niederwuchs dieser Wälder noch ziemlich eintönig und bestcht hauptsächlich aus Vaccinien, Luzula nemorosa und Farnen, doch bald treten auch die Charakterarten der Sudeten, wie Polyslichum Braunii, Thalictrum aquilegifolium, Ranunculus plalanifolius, Anthriscus nitidus, Adenostyles Alliariae, Senecio nemorensis und Mulgedium alpinum immer häufiger auf. Schon von $900 \mathrm{~m}$ an wird der Wald vielfach von Voralpenwiesen und Hochmooren unterbrochen, und von der Baumgrenze bis zu einer Höhe von $1400 \mathrm{~m}$ bedecken dichte Bestände von Pinus Mughus, oft von Sorbus Aucuparia *glabrata begleitet, die Kämme.

Schon bei Lhota, nördlich von Jičin, trifft man in den Laubwäldern einige Gebirgspflanzen, wie Rubus saxatilis, Vicia silvalica, Circaea alpina, Digilalis ambigua und Lacluca muralis; der Tabor bei Lomnitz ist von Buchen- Lomnitz. wäldern bedeckt, in denen Aclaea spicala, Hordeum europaeum, Cardamine enneaphyllos, C. bulbifera, Astrantia maior, Stachys silvalica, Atropa Belladonna, Senecio nemorensis usw. und auch noch die höher im Gebirge fehlende Primula veris gedeihen, und auf feuchten Wiesen bei Swietla wächst bereits Cirsium helerophyllum. An der Elbe bei Pelsdorf ist Equiselum pralense häufig und in der Umgebung von Hohenelbe schmückt schon Polygonum Bistorla zu Tausenden die Wiesen, auf denen auch Gymnadenia conopea, Leucoium vernum, Laserpitium prulhenicum, Myrrhis odorata, Euphrasia curla und Gentiana campestris *ballica zu finden sind; und oberhalb Hohenelbe sind schon in relativ tiefen Lagen einzelne Gebirgspflanzen zu finden, so bei Harta Cirsium heterophyllum, Homogyne alpina und Pelasites Kablikianus und am Ufer des Weißwassers in nur $800 \mathrm{~m}$ Höhe Trichophorum alpinum, Allium sibiricum und Sweertia perennis. Auch in der Umgebung von Trautenau sind auf den Wiesen Leu-Trautenau. coium vernum und Arnica montana, in den Wäldern Allium ursinum, Ranunculus plalanifolius, Adoxa moschalellina, Corydalis inlermedia und Sanicula europaea verbreitet und schon bei Parschnitz findet man Gebirgspflanzen in größerer Zahl, wie Polygonalum verlicillalum, Cardamine enneaphyllos, C. bulbifera, Thalictrum aquilegifolium, Senecio rivularis und Carduus Personala. Der Plesser Teich bei Trautenau ist durch das Vorkommen von Hollonia palustris und Utricularia minor ausgezeichnet.

Erst Buchen-, dann Fichtenwälder bedecken die Südosthänge des Böhmischen Kammes, dessen Höhen reichlich mit Krummholz bewachsen sind, zwischen dessen Beständen Rasenflächen mit Fesluca supina, Agroslis rupestris Kamm. Deschampsia flexuosa, Calluna vulgaris und massenhaftem Hieracium alpinum auftreten, auf denen jedoch auch Anemone alba, Sedum repens, Polentilla aurea, Solidago alpestris, Anlennaria dioeca, Gnaphalium supinum vorkommen. Auch 
die charakteristischen Gebirgswiesen mit zahlreichen Hieracien sind hier ent-

liesselkoppe. deticum, H. pedunculare, H. chlorocephalum, H. Wimmeri, H. albinum, H. rupicolum, H. atratum, insbesondere Dianthus speciosus und im Felsschutt Allosorus crispus durch ihre Häufigkeit auffallen. Besonders üppig ist die Vegetation Kesselgrube. aber in der nach Nordost steil abfallenden Felsschlucht der Kesselgrube, wo üppige Hochstaudenfluren mit Ranunculus platanifolius, Delphinium elatum, Aconilum variegalum *gracile und A.Napellus *firmum, Anthriscus nilidus, Veralrum

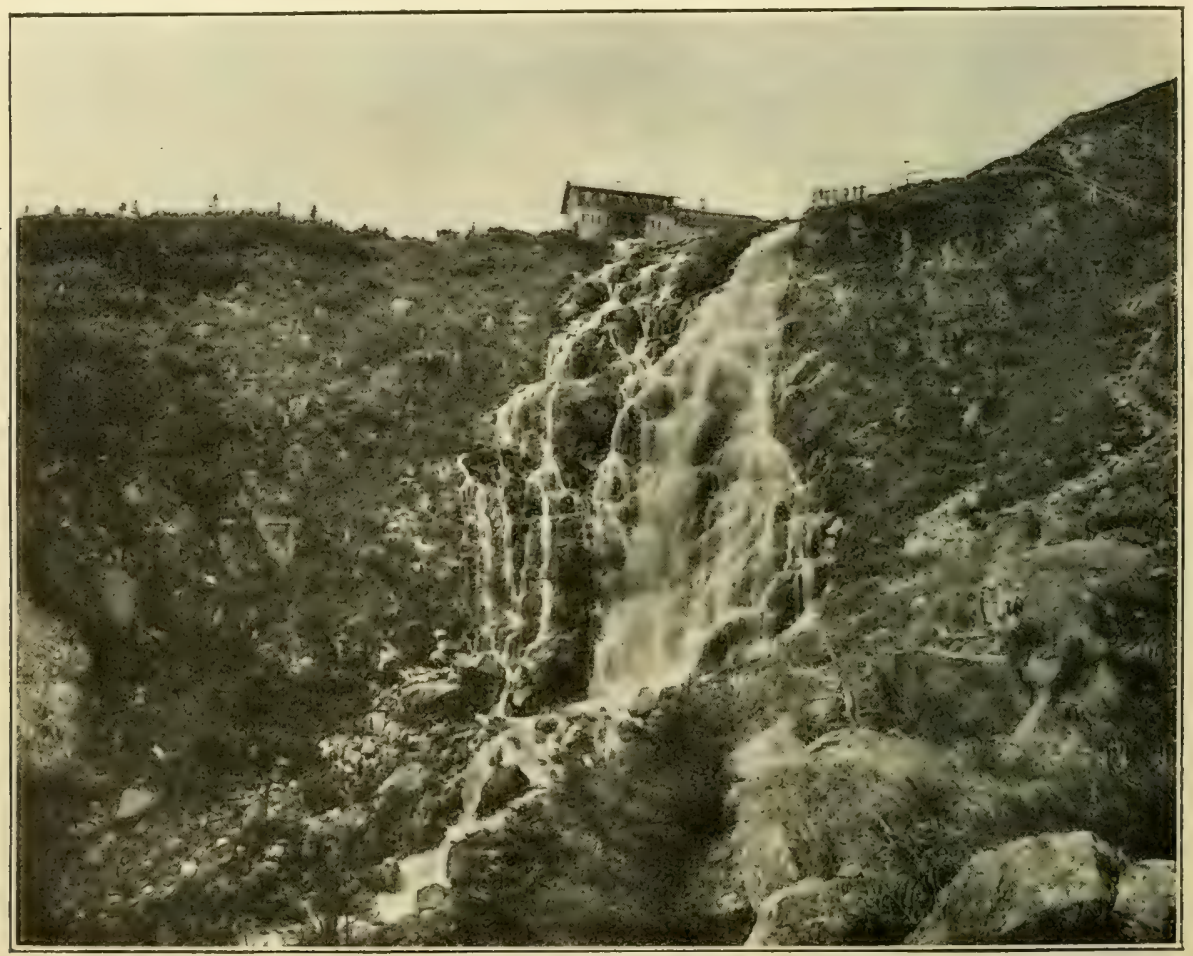

Abb. 94. Der Elbefall im Riesengebirge.

(Nach H. Eckert, Landschaftsbilder aus Böhmen.)

Lobelianum, Dianlhus speciosus, Adenostyles Alliariae, Bupleurum longifolium, Crepis mollis sich finden und an den felsigen Hängen eine Reihe von Hochgebirgsarten, wie Polystichum Lonchilis, Asplenium viride, Allosorus crispus, Festuca varia, Carex capillaris, G. vaginala, Salix herbacea, Prunus petraea, Alchimilla glaberrima, Saxifraga opposilifolia, Galium anisophyllum, Hieracium Krkonosch. alpinum und $H$. inuloides gedeihen. Auch der benachbarte Krkonosch trägt neben Krummholzbeständen Wiesen mit den oben genannten Hierazien und dem seltenen $H$. corconticum. Zwischen Krkonosch und dem Hauptkamm liegt Elbgrund. die tiefe Schlucht des Elbgrundes, die ebenfalls prächtige Hochstaudenfloren mit den oben genannten Arten aufweist. Daneben treten an den steilen Fels- 
hängen um den Pantsche- und Elbfall Ribes pelraeum, Sorbus sudetica, Angelica Archangelica, Hieracium Schmidtii mit Aconilum variegalum *gracile und Delphinium elalum auf und an den oberen grasigen Hängen sind neben zahlreichen Hieracien, besonders $H$. sudeticum und $H$. pedunculare, auch Salix Lapponum, Hypochoeris uniflora und Carex magellanica zu finden.

Am Verbindungskamm zwischen Krkonosch und dem Hauptkamm liegen zwei der größten Gebirgsmoore des Riesengebirges, die Pantsche- Pantschewiese und die Elbwiese. Diese Moore sind ziemlich dicht mit Pinus Mughus Ellwiese.

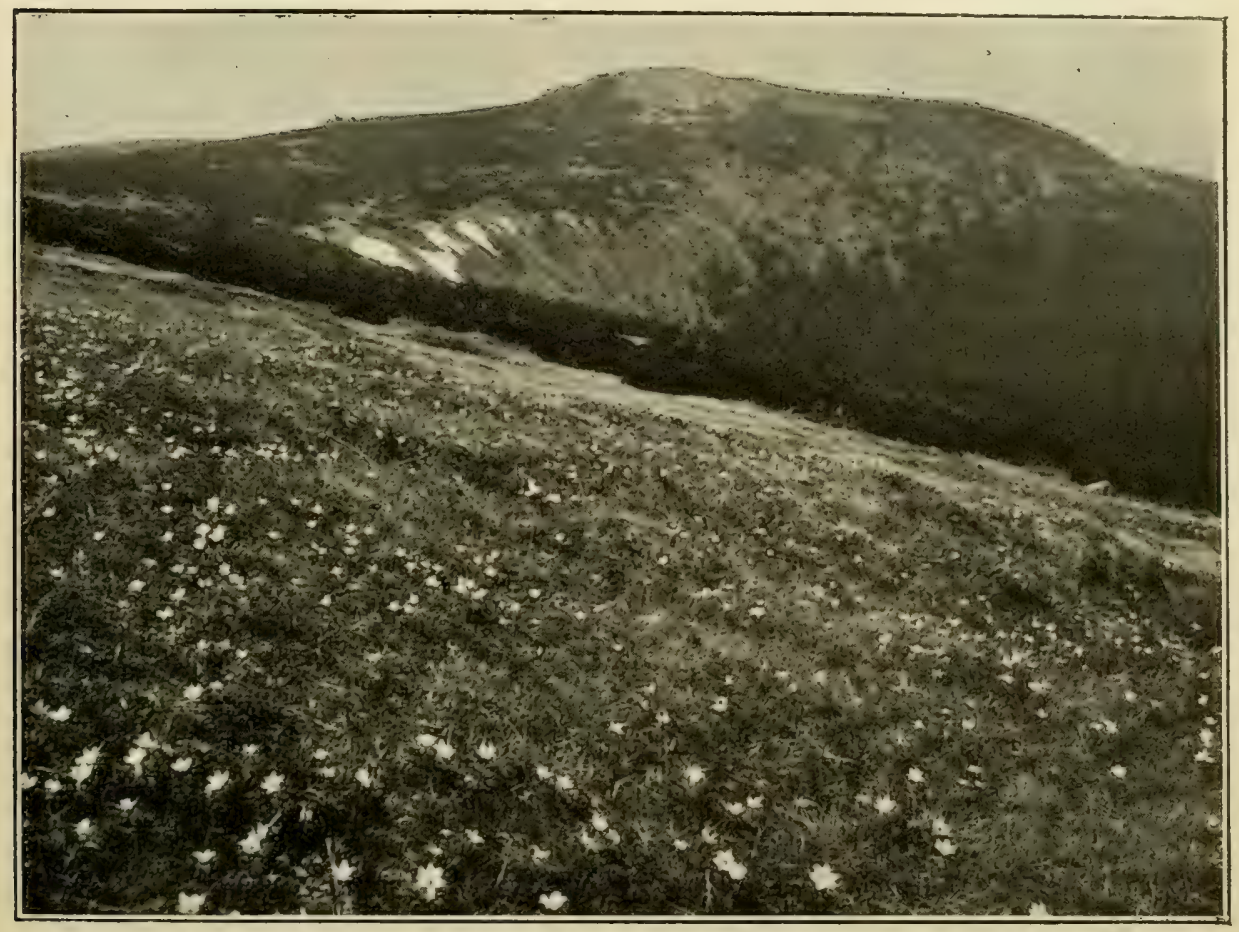

Abb. 95. Borstengrasmatte mit Anemone alba und Krummholzbestände auf dem Kamme des Riesengebirges.

(Nach einer Aufnahme von Nenke und Ostermaier in Dresden.)

bewachsen, zwischen der auf der Pantschewiese auch Juniperus nana auftritt, im übrigen sind es typische Sphagnummoore, auf denen zahlreiche Cyperazeen, besonders Eriophorum vaginalum, Trichophorum alpinum, T. austriacum, Carex stellulata, C. canesens, $C$. pauciflora, C. rigida, C. magellanica die Hauptmasse der Pflanzendecke bilden. Doch auch Ericazeen, besonders Vaccinium uliginosum, Oxycoccos quadripetala und Andromeda polifolia, sowie Empelrum nigrum, Viola palustris, Pedicularis sudetica und Chrysosplenium allernifolium sind nicht selten, während im Schatten der Krummholzkiefern Rubus Chamaemorus, Trientalis europaea und Homogyne alpina gedeihen. Am Rande der Noortümpel aber bilden Carex rostrala und auf der Elbwiese auch C.lasiocarpa dichte Bestände. 
Der Hauptkamm des Riesengebirges trägt ober dem Krummholzgürtel trockene Bürstengrasmatten mit Nardus stricla, Agrostis rupestris, Carex rigida, Anemone alba, Calluna vulgaris, Polenlilla aurea, Vaccinum Vilis daea, V. Myrlillus, Hieracium alpinum, H. Fritzei usw. Die höchsten Gipfel, so der Reifträger, sind aber mit zahlreichen kolossalen Felstrümmern bedeckt, auf denen zwar eine reiche Flechtenflora (siehe oben Seite 117), aber nur eine spärliche PhanerogamenHohes Rad. flora zu finden ist. Auch das Hohe Rad (1509 $\mathrm{m})$ ist mit solchen Felstrümmern bedeckt, an seiner Nordseite aber, hart jenseits der Landesgrenze, öffnet sich Kleine die Felsschlucht der Kleinen Schneegrube, die seit langer Zeit bekannt ist

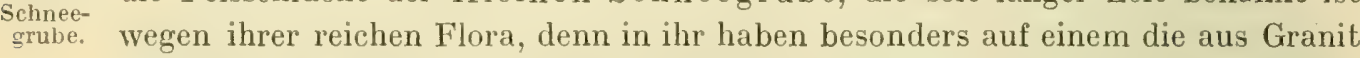
aufgebaute Westwand durchziehenden Basaltgang eine Reihe von Gebirgspflanzen ihren einzigen Standort in den Sudeten, so Saxifraga bryoides, S. moschata, Arabis alpina, Androsace oblusifolia, Pimpinella alpina und die hochnordische; in Mitteleuropa nur hier vorkommende Saxifraga nivalis, die hier in Gesellschaft von Poa laxa, Festuca varia, Luzula spicala, Saxifraga oppositifolia, Sedum roseum, Allium Victorialis, Alchimilla glaberrima, Primula minima,

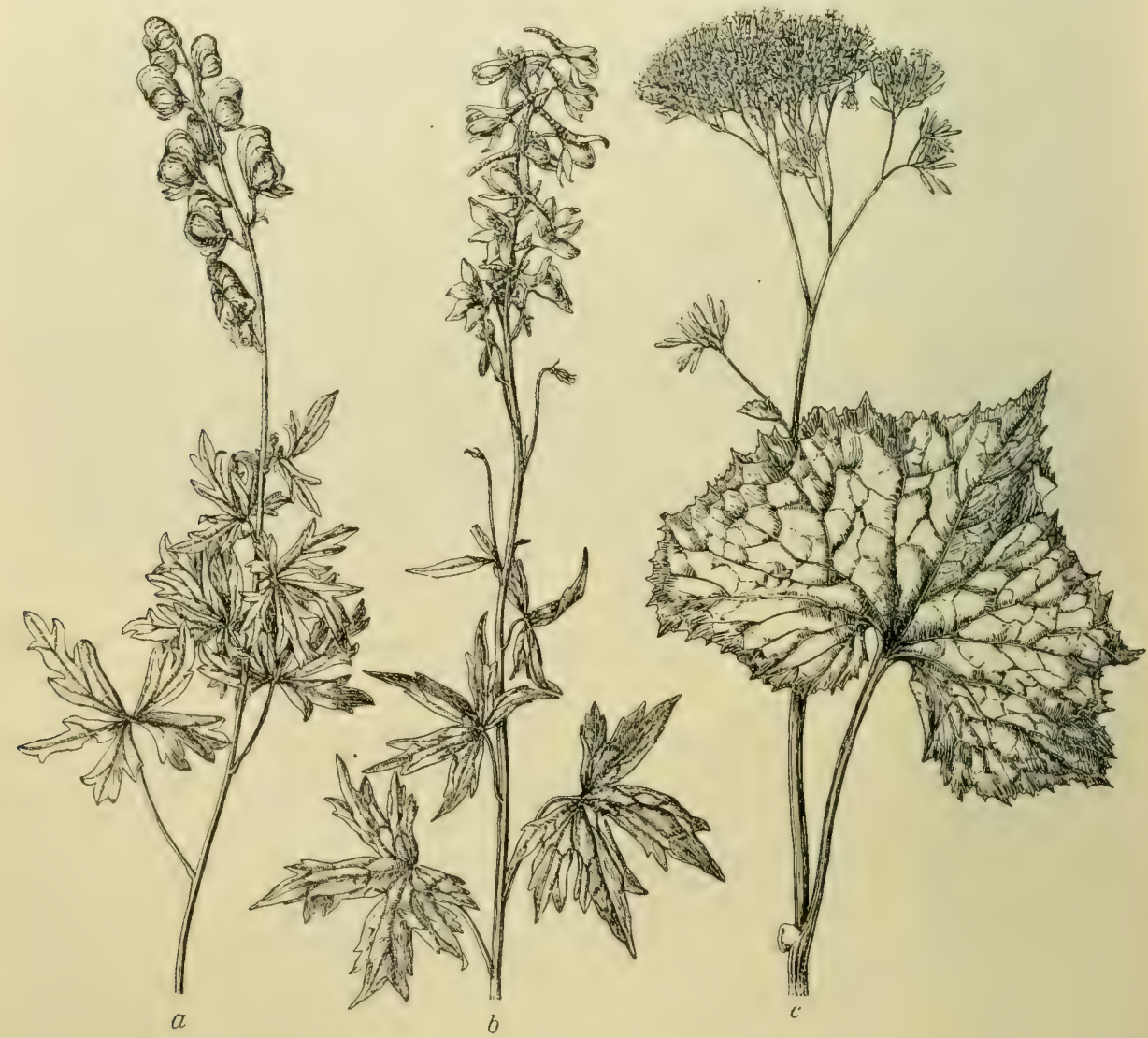

Abb. 96. Drei Charakterarten der Hochstaudenfluren der Sudeten.

$a$ Aconitum Napellus Subsp. firmum, $b$ Delphinium elatum. $c$ Adenostyles Alliariae. 


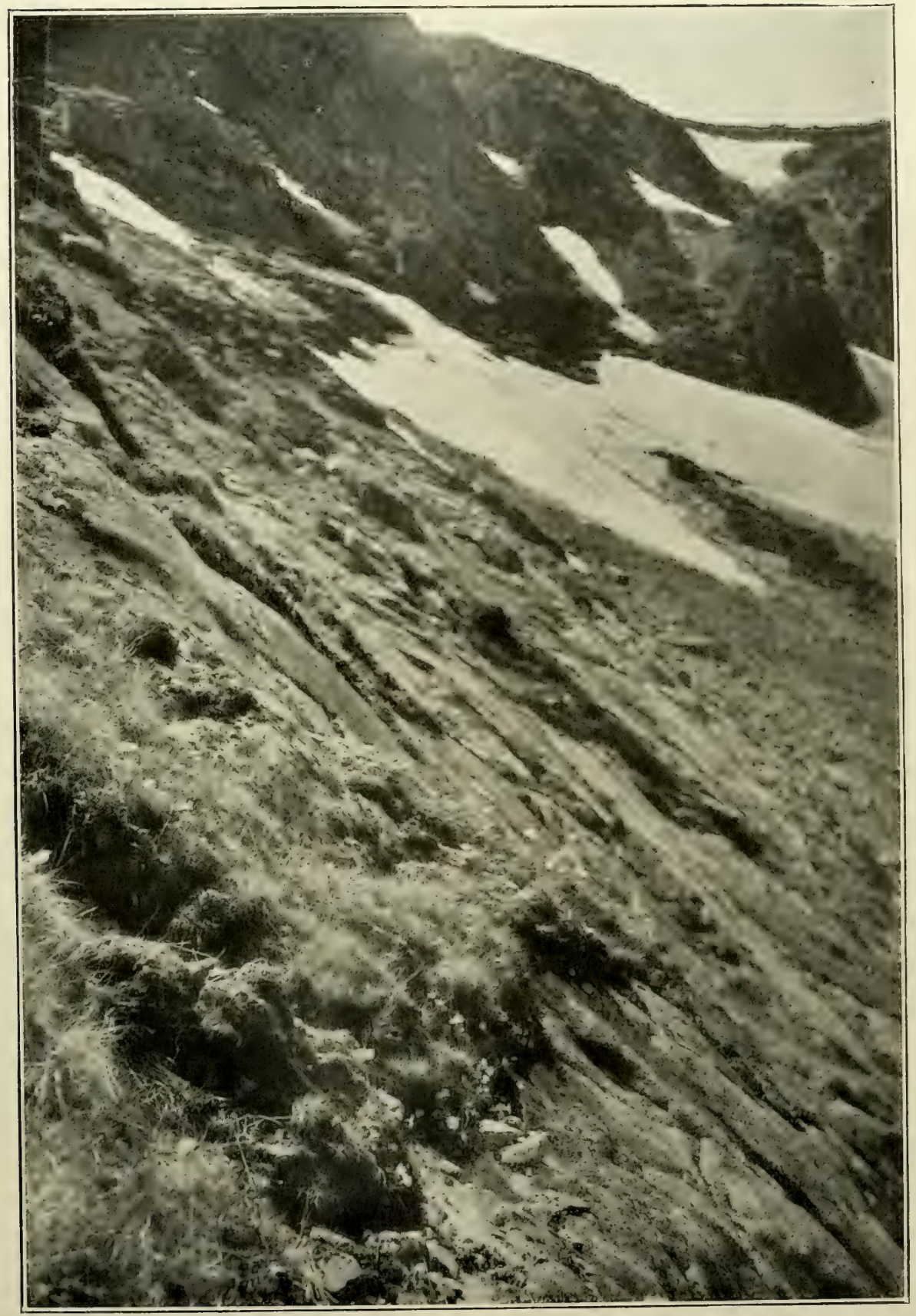

Abb. 97. Die Kleine Schneegrube.

Im Vordergrunde Anemone alba und Primula minima.

(Nach einer Aufnahme von Nenke und Ostermaier in Dresden.) 

Sagina saginoides, Hieracium Engleri, Galium anisophyllum, Woodsia alpina, Asplenium viride usw, anzutreffen sind. Auch weiterhin sind am Kamme des Piesengebirges auf der Höhe Bürstengrasmatten, auf denen gegen Osten zu Geum monlanum immer häufiger wird, an den Hängen Wiesen mit zahlreichen Hieracien und hie und da auch Noore ausgebildet, an den zahlreichen Quellen

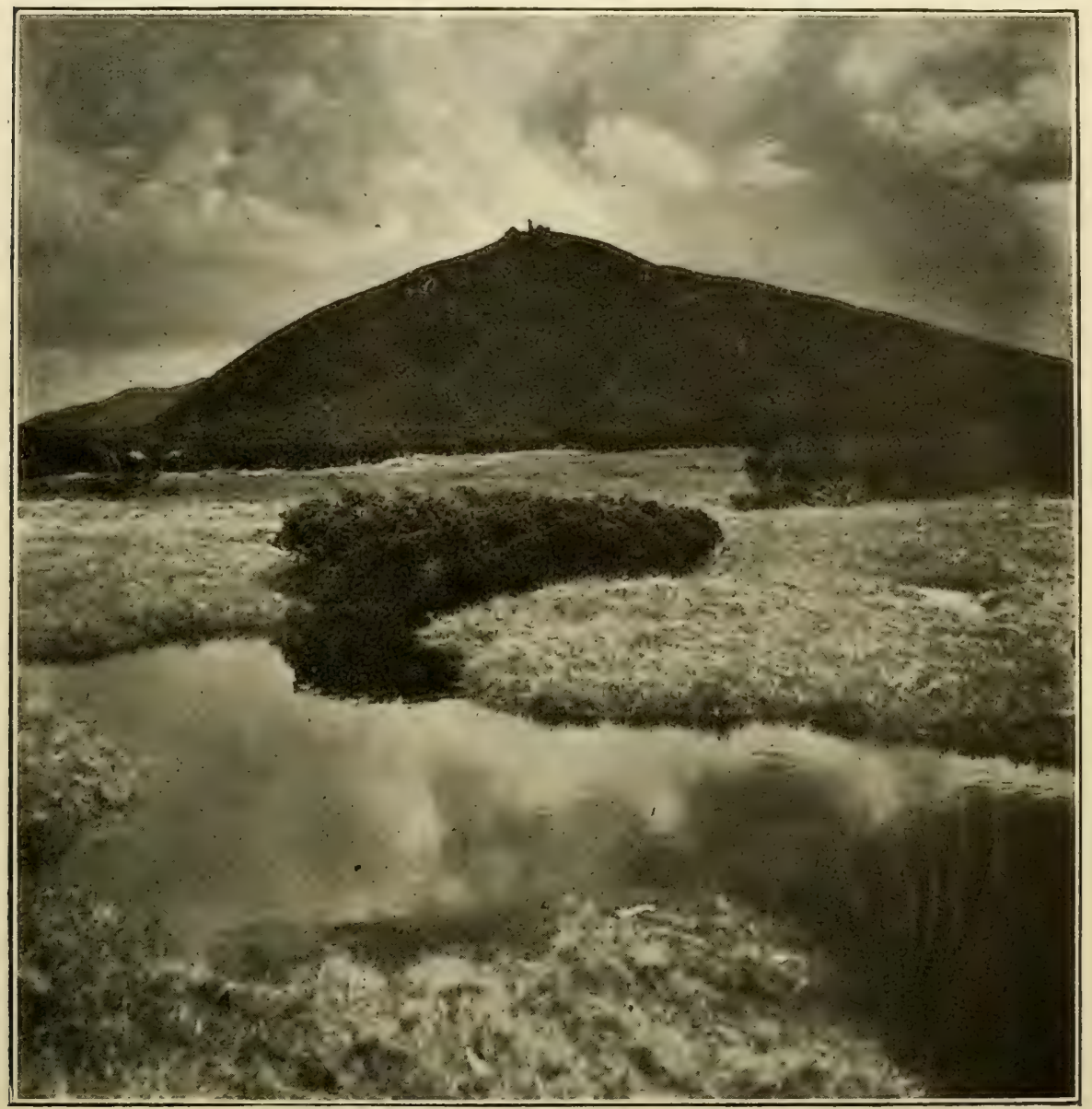

Abb. 98. Hochmoor mit Pinus Mughus auf dem Kamme des Riesengebirges.

(Nach einer Aufnahme von Nenke und Ostermaier in Dresden.)

und Bächlein der ,Sieben Gründe“ aber treten besonders reichlich üppige Bergwiesen mit Crepis conyzifolia und Crepis blallarioides sowie Quellfluren mit Ranunculus plalanifolius, Aconitum Napellus *firmum, Bartschia alpina, Sweertia perennis, Senecio rivularis, Rumex arifolius, Adenoslyles Alliariae, Prenanlhes purpurea, Veralrum album *Lobelianum, Athyrium alpestre usw. auf. Die Hochgipfel der Großen und Kleinen Sturmhaube und auch der Schneekoppe $(1603 \mathrm{~m})$ sind wieder mit einem Gewirre gigantischer Felsblöcke bedeckt, doch beherbergt letztere zwei seltenere Arten, Anemone vernalis und die nur hier 


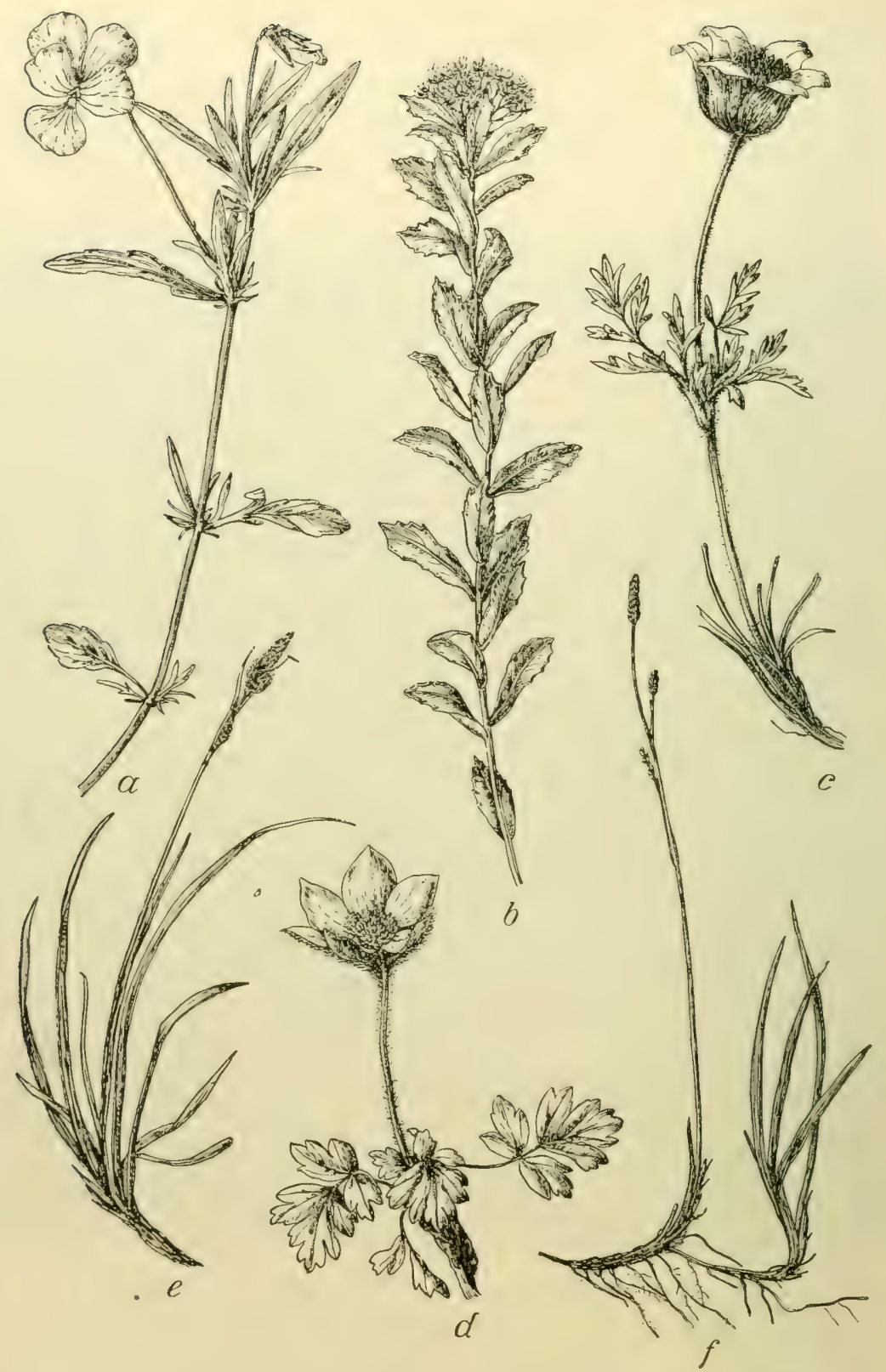

Abb. 99. Aus der Flora der alpinen Wiesen und Matten der Sudeten.

$a$ Viola sudetica. $b$ Sedum roseum. $c$ Anemone alba. $d$ Anemone vernalis, $e$ Carex rigida. $f$ Carex vaginata.

in den Sudeten auftretende Veronica bellidioides und selbst auf ihrem Gipfel wachsen noch Poa laxa, Carex alrala, Deschampsia caespitosa, Geum montanum, Sedum roseum, Primula minima, Homogyne alpina und Hieracium alpinum. 
Zwischen Schneekoppe, Koppenplan und Brunnberg liegt die „Weiße

Wiese" $^{\text {, }}$ ein reichlich mit Krummholz bewachsenes und von Hochmooren vielfach unterbrochenes Wiesenplateau, wo auch einige Hochgebirgsarten, wie Agrostis rupestris, Geum monlanum und Primula minima in dem die trockeneren Stellen bedeckenden Rasen aus Nardus stricla wachsen. Südlich der Weißen Wiese erhebt sich der 1560 m hohe Brunnberg, eine der pflanzenreichsten Lokalitäten Brunners. des Riesengebirges. Auf seinen grasigen Hängen wachsen u. a. Carex pallescens, C. vaginala, Allium Victorialis, Trollius europaeus, Ranunculus nemorosus, Viola sudelica, Campanula Scheuchzeri, Hieracium glandulosodenlalum, H. decipiens. H. alralum, H. riphaeum und an felsigen Stellen Polyslichum Lonchitis, Allosorus crispus, Selaginella selaginoides und Salix herbacea sowie am sogenannten Schneegraben die seltene Salix bicolor. Von seinen südlichen Ausläufern trägt der $1363 \mathrm{~m}$ hohe Fuchsberg noch Krummholzbestände sowie Bergwiesen mit Fuchsberg. Hieracium auranliacum usw., hingegen ist der nur 1299 m hohe Schwarzen berg Schwarzenauf seinem Gipfel noch von verkrüppelten Fichten bewachsen, während an berg. seinem Nordabhange die Bohnwiese liegt, eine der niedrigst gelegenen Voralpenwiesen des Piesengebirges, auf der aber noch Phleum alpinum, Polygonum Bistorta, Melandryum silvestre, Empetrum nigrum, Crepis succisifolia und Hieracium aurantiacum gedeihen.

Im Riesengrund, besonders um den Aupafall, findet man wieder zahlreich die prachtvollen Voralpenstauden der Sudeten, ferner auch Carex capillaris, Slreplopus amplexifolius, Sagina saginoides, Cardamine resedifolia, Saxifraga opposilifolia und Sorbus sudetica; auch auf dem Kiesberge wachsen Carex capillaris, Festuca varia, Minuarlia Gerardi und Sorbus sudetica sowie in tieferen Lagen zwischen Fichten und Krüppelbuchen Sagina saginoides, Bupleurum longifolium, Scabiosa lucida, Hieracium albinum, H. glandulosodentalum, H. nigritum, H. riphaeum, Polystichum Lonchilis, P. lobatum und Dryopteris Oreopleris. Auch die nach Südosten offene Schlucht des Teufelsgärtchens (RübezahlGarten) ist wegen ihrer reichen Hochgebirgsflora seit langem bekannt. Hier wachsen an den felsigen Hängen u. a. Allosorus crispus, Selaginella selaginoides, Dianthus speciosus, Minuartia Gerardi, Anemone alba, A. vernalis, Cardamine resedifolia, Sorbus sudelica, Hedysarum obscurum, Saxifraga oppositifolia, Viola sudetica, Petasiles albus, Hieracium chlorocephalum. Auf dem benachbarten Ziegenrücken ist die übrigens auch sonst nirgends seltene Viola sudetica zahlreich anzutreffen.

Das nördlich von Schatzlar sich erhebende, nur $1052 m$ hohe Rehhorn Rehhorn. weist trotz seiner geringen Höhe eine ziemlich reiche Flora auf. Bis zirka $780 \mathrm{~m}$ Höhe bedecken Buchenwälder seine Hänge, von zahlreichen üppigen Wiesen mit Leucoium vernum, Veralrum album *Lobelianum, Saxifraga granulata, Geranium pralense, Myrrhis odorata, Senecio rivularis, Arnica montana usw. unterbrochen; auf eingesprengten Kalklagern treten Anthyllis Vulneraria, Gentiana ciliala und Galeopsis anguslifolia auf. Darüber folgt die Fichtenwaldzone, in der Gipfelregion über $950 \mathrm{~m}$ aber findet man zahlreiche Hochgebirgsarten, wie Trichophorum alpinum, Allium Victorialis, Anemone alba, A. narcissiflora, Del- 


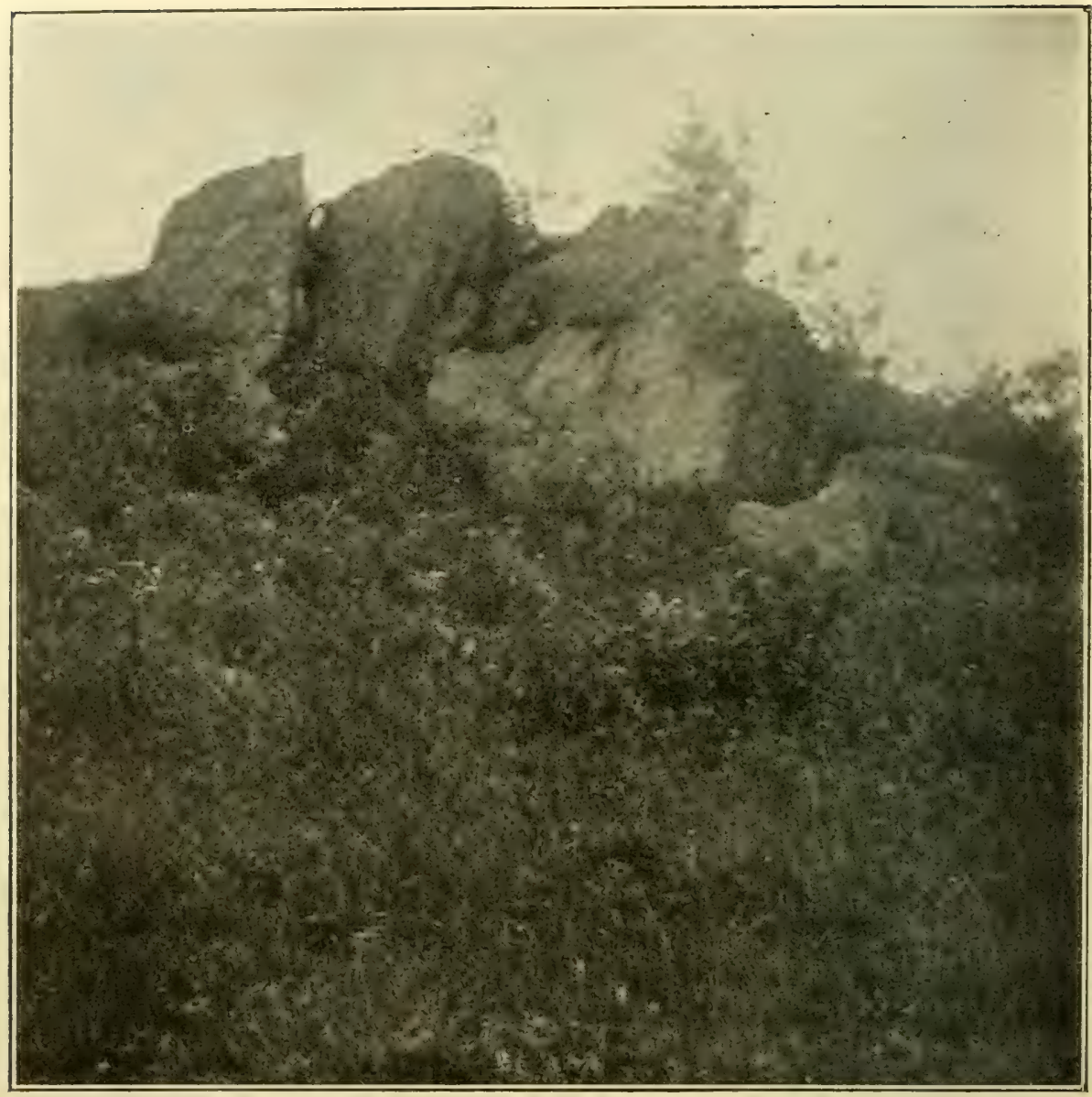

Abb. 100. Bergwiese auf dem Rehhorn bei Schatzlar. Arnica montana und Orchis maculata.

(Nach einer Aufnahme von J. Jonasch, Schatzlar.)

phinium elalum, Epilobium alsinefolium, E. alpeslre, Euphrasia picla, Hieracium lubulosum, H. Frilzei, H. nigrescens, H. decipiens, H. bohemicum, H. inuloides, H. prenanlhoides, hingegen fehlt hier sowohl Krummholz als auch mehrere sonstige charakteristische Sudetenpflanzen, wie Geum montanum und Adenoslyles Alliariae.

Der weitere Zug der Sudeten enthält bis zum Glatzer Schneeberg keinen die Waldregion überragenden Gipfel. Buchenwälder in tieferen, Fichtenwälder in höheren Lagen reichen bis auf den Kamm, stets begleitet von den charakteristischen Waldpflanzen der Sudeten, wie Poa Chaixii, Fesluca silvalica, Lilium Marlagon, Polygonalum verlicillalum, Cephalanthera longifolia, Thaliclrum aquilegifolium, Aconilum variegalum *gracile, Cardamine enneaphyllos und bulbifera, Lunaria rediviva, Aruncus silvester, Anthriscus nilidus, Pelasiles albus, Homogyne alpina, Prenanthes purpurea. 
An der Nordostseite des Gebirges bei Adersbach und Weckelsdorf sind kleinere Hochmoore entwickelt, die neben Drosera rolundifolia und Meny anthes trifoliata insbesonders einige seltenere Moose beherbergen. Die $1083 \mathrm{~m}$ hohe Hohe Mense weist außer den eben genannten Arten der Gebirgswälder auch noch Aconilum variegatum *gracile, Rosa pendulina, Salix myrlilloides und Epilobium nulans auf. Das Adlergebirge zeichnet sich wieder durch reichere Ausbildung von Mooren aus, die sich teils in Vertiefungen und Einsenkungen des Plateaus, teils in tieferen Lagen unter dem Hauptkamme finden, wie bei Batzdorf, Bärenwald und Rokytnitz. Meist sind es auf Wiesenmoorgrund ruhende Hochmoore, in denen Trichophorum alpinum, Salix repens und Epilobium nutans vorkommen. Im Adlergebirge besonders in den Gebirgswäldern läufige Arten sind ferner Alhyrium alpestre, Luzula sudelica, Veralrum Lobelianum, Slreplopus amplexifolius, Ranunculus plalanifolius, Solidago alpestris und Mulgedium alpinum; auf dem Kamme des Gebirges treten Aconilum gracile, Rosa alpina und Epilobium nutans auf.

Erst an der dreifachen Landesgrenze von Böhmen, Mähren und Schlesien treten wieder höhere, die Waldgrenze überragende Gipfel auf, so vor allem der $1424 \mathrm{~m}$ hohe Glatzer (oder Spieglitzer) Schneeberg. Der Fichtenwald, in welchem oft prächtige Exemplare von Acer Pseudoplatanus vorkommen, steigt hier bis $1320 \mathrm{~m}$ hoch an, also 50-150 $\mathrm{m}$ höher als im Riesengebirge, die häufigsten Pflanzen des Niederwuchses an lichteren Stellen sind Melandryum silvestre, Circaea alpina, Lunaria rediviva, Digilalis ambigua, Prenanthes purpurea, Senecio nemorensis, während im Unterholz Salix silesiaca, Rosa pendulina und Lonicera nigra nicht selten sind. In der Nähe der Waldgrenze treten noch Calamagrostis villosa, Luzula silvalica, Veralrum Lobelianum, Streplopus amplexifolius, Rumex arifolius, Ranunculus platanifolius, Aconitum gracile, A. firmum, Delphinium elatum, Epilobium alpestre, Adenoslyles Alliariae, Doronicum auslriacum, Gnaphalium norvegicum, Mulgedium alpinum hinzu, während Gentiana asclepiadea hier fehlt. Ober der Waldgrenze aber fehlt das Krummholz gänzlich und wird durch einen Strauchgürtel aus verkiüppelten Exemplaren von Picea excelsa und Sorbus Aucuparia *glabrala, untermischt mit Ribes alpinum und Juniperus nana ersetzt. Darüber breiten sich auf dem Gipfelplateau üppige Wiesen mit Poa Chaixii, Rumex arifolius, Arabis Halleri, Anthriscus nitidus, Trientalis europaea, Cirsium heterophyllum, Hieracium prenanthoides, H. inuloides usw. aus, während an quelligen Stellen Cardamine Opizii, Viola biflora, Epilobium alsinefolium, E. nutans und Doronicum austriacum zu finden sind. Der eigentliche Gipfel weist noch Phleum alpinum, Avena planiculmis, Carex rigida, Juncus filiformis, Gymnadenia albida, Thesium alpinum, Dianthus speciosus, Cerastium nemorale, Polentilla aurea, Viola sudetica, Ligusticum Mutellina, Hypochoeris uniflora, Crepis conyzaefolia, Hieracium alpinum, alratum, nigrescens und decipiens auf.

Aus der Flora des Riesengebirges fehlen dem Glatzer Schneeberge außer zahlreichen Hieracien auch Allosorus crispus, Pinus Mughus, Fesluca varia, Poa laxa, Agroslis rupestris, Carex magellanica, Trichophorum auslriacum, 
Salix bicolor, S. Lapponum, Anemone alba, Arabis alpina, Saxifraga nivalis, S. opposilifolia, S. moschata, S. bryoides, Sorbus sudetica, Rubus Chamaemorus, Alchemilla glaberrima, Primula minima, Androsace oblusifolia, Veronica alpina, Euphrasia minima, Pedicularis sudetica, Gnaphalium supinum und Petasites Kablikianus, hingegen kommen Luzula spicata, Rumex alpinus und Geum monlanum, die dem Gesenke fehlen, noch vor. Von den im Riesengebirge fehlenden, aber im Gesenke vorkommenden Arten findet man auf dem Schneeberge bereits Cerastium macrocarpum, Conioselinum lataricum, Campanula barbata und Hieracium slygium.

Nordöstlich vom Glatzer Schneeberge beziehungsweise dem sich an dasIVeidenau. selbe anschließenden Reichensteiner Gebirge gehört bei Weiden a u ein kleiner Teil der schlesischen Ebene dem österreichischen Gebiete an. Obwohl nur von geringer Ausdehnung, weist dieses Gebiet doch eine vom übrigen Schlesien abweichende Vegetation auf. Auf Äckern und sandigen Heiden treten hier Scleranthus perennis, Illecebrum verticillalum, Teesdalea nudicaulis, Jasione montana, Arnoseris minima und Hypochoeris glabra auf; an nassen Stellen Centunculus minimus, Centaurium pulchellum, Pulicaria vulgaris; auf Moorwiesen sind Menyanthes trifoliata, Pedicularis palustris und P. silvalica nicht selten und in Wassergräben findet sich Hollonia palustris. Die Wälder sind vornehmlich Eichenwälder, aus deren Niederwuchs Chimaphila umbellala, Symphylum luberosum, Pulmonaria obscura und Campanula Cervicaria hervorzuheben sind, auf der Nesselkoppe kommt auch schon Prenanthes purpurea

Reichensteiner

Hochgesenke.

Zuckmantel.

Jågerndorf.

vor. Auch in den Hängen des Reichensteiner Gebirges sind noch Laubmischwälder vorherrschend, in denen bei Friedeberg Asperula cynanchica, Campanula Cervicaria und Prenanlhes purpurea vorkommen.

In den Vorbergen des Hochgesenkes sind Laubwälder aus Quercus sessiliflora, begleitet von Ulmus glabra, U. laevis, Populus tremula, Betula pendula, Acer Pseudoplalanus, A. plalanoides, Tilia cordala usw., besonders in tieferen Lagen bis gegen $400 \mathrm{~m}$ am Abhange gegen die Ebene entwickelt, so bei Zuckmantel, wo Scrophularia Scopolii, Asperula cynanchica, Centaurea oxylepis, C. Pseudophrygía und Prenanthes purpurea in diesen Wäldern auftreten. Auch Jägerndorf liegt noch im Gebiete des Laubwaldgürtels. Bezeichnende Waldpflanzen aus der Gegend von Jägerndorf sind Galanthus nivalis, Isopyrum thaliclroides, Corydalis solida, Trifolium rubens, Vicia pisiformis, Astrantia maior, Hypericum monlanum, Euphorbia amygdaloides, Pirola minor, Pulmonaria angustifolia, Symphylum tuberosum, auf dem Burgberge auch Cytisus nigricans und Melillis Melissophyllum; auf Wiesen sind Trollius europaeus, Viscaria vulgaris, Dianthus Carthusianorum, Saxifraga granulala und Geranium pratense häufig; auch bei Freudenthal kommt noch Cylisus nigricans vor. Doch schon bei Jägerndorf tritt auch die Fichte mit der Lärche auf und die Hänge des eigentlichen Hochgesenkes bei Freiwaldau bis Würbenthal sind mit dichten Nadelwäldern bedeckt. Die Fichte ist zwar hier wie überall in den Sudeten der herrschende Waldbaum, doch gesellt sich bis zu einer Höhe von zirka $1000 \mathrm{~m}$ die Tanne und auch die in den übrigen Sudeten fehlende Lürche (Larix decidua) hinzu, die aber 
nicht bis zu der hier bei zirka $1200 \mathrm{~m}$ liegenden Waldgrenze aufsteigt. In höheren Lagen, zwischen 1000 und 1200 m, ist von Nadelhölzern Picea excelsa allein vertreten, von Fagus silvatica, Sorbus Aucuparia, Acer Pseudoplalanus, Populus tremula und Betula pubescens begleitet. Im Niederwuchs dieser Wälder sind verschiedene Farne, wie Dryopteris Filix Mas, D. dilatala, Blechnum Spicant, Athyrium Filix femina, A. alpestre, Polystichum Braunii, ferner Calamagroslis villosa, Festuca silvatica, Luzula nemorosa, Polygonalum verlicillatum, Maianthemum bifolium, Coralliorhiza trifida, Thalictrum aquilegifolium, Carda-

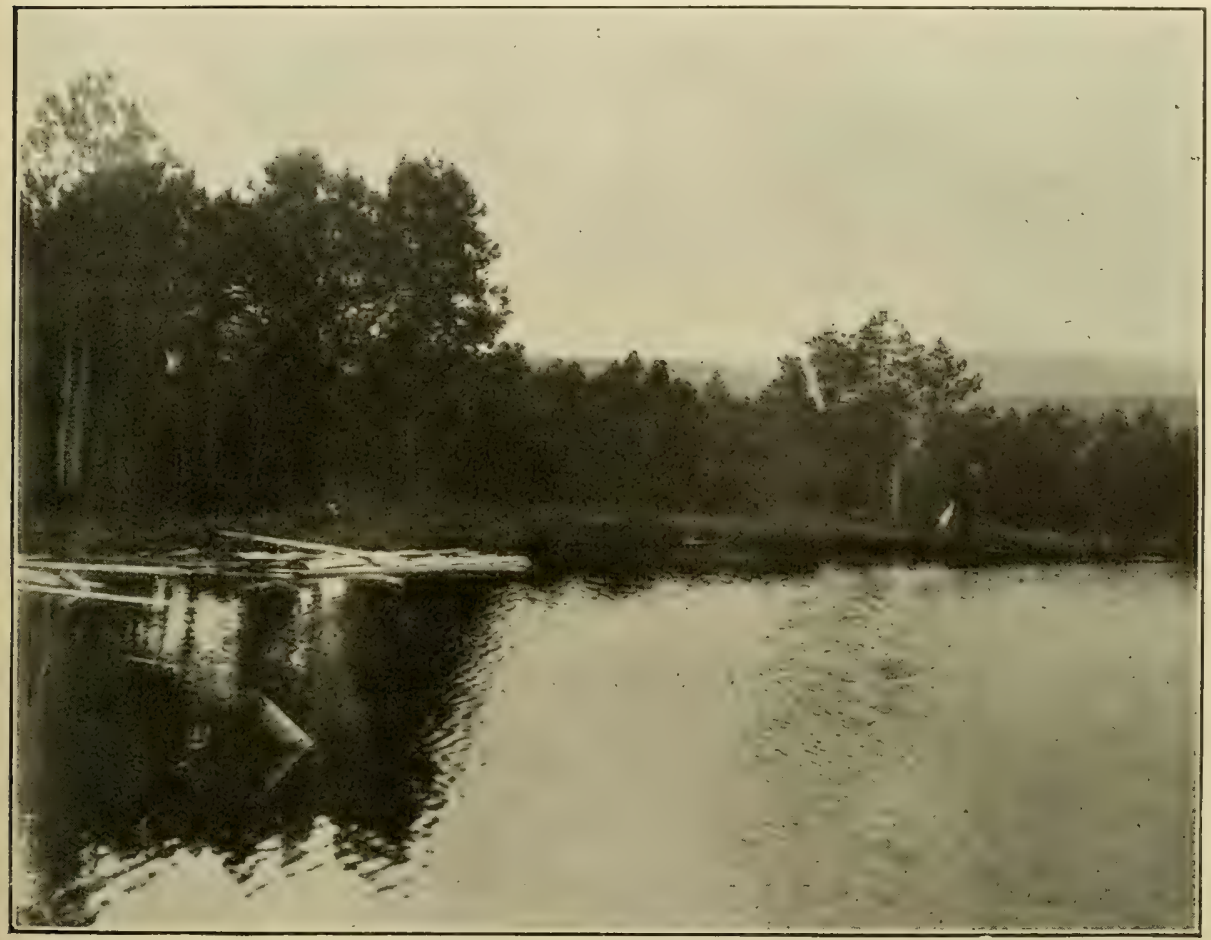

Abb. 101. Bestand von Pinus uliginosa im Moosebruch bei Reiwiesen.

(Nach einer Aufnahme von Dr. Z. v. Szabó, Budapest.)

mine bulbifera, $G$. enneaphyllos, Euphorbia amygdaloides, Aruncus silvester, Vaccinum Myrtillus, V. Vilis Idaea, Pirola uniflora, P. chlorantha, Circaea alpina, Lamium vulgare, Aiuga pyramidalis, Doronicum austriacum, Adenoslyles Alliariae, Senecio sarracenius häufige Erscheinungen, bei Würbenthal kommt auf dem Leitersberge auch Campanula latifolia, bei Gräfenberg Carex pilosa vor. Unweit Freiwaldau, bei Reiwiesen, liegt in $740 \mathrm{~m}$ Höhe der Moosebruch, Reiwiesen. ein ausgedehntes Torfmoor, das mit der in den Sudeten sonst nicht vorkommenden Pinus uliginosa bewachsen ist und von sonstigen interessanteren Arten Carex pauciflora, C. limosa, C. lasiocarpa, Eriophorum vaginalum, Scheuchzeria palustris, Polentilla palustris, Vaccinium uliginosum, Oxycoccos quadripetala, O. microcarpa, Andromeda polifolia und Ledum palustre aufweist. Bei Freiwaldau wrei- 
kommen in den Wäldern auch Thaliclrum aquilegifolium, Delphinium elatum, Rosa pendulina und Angelica Archangelica vor; auch bei Karlsbrunn sind Aruncus, Delphinum elatum, Scrophularia Scopolii und Carduus personalus nicht

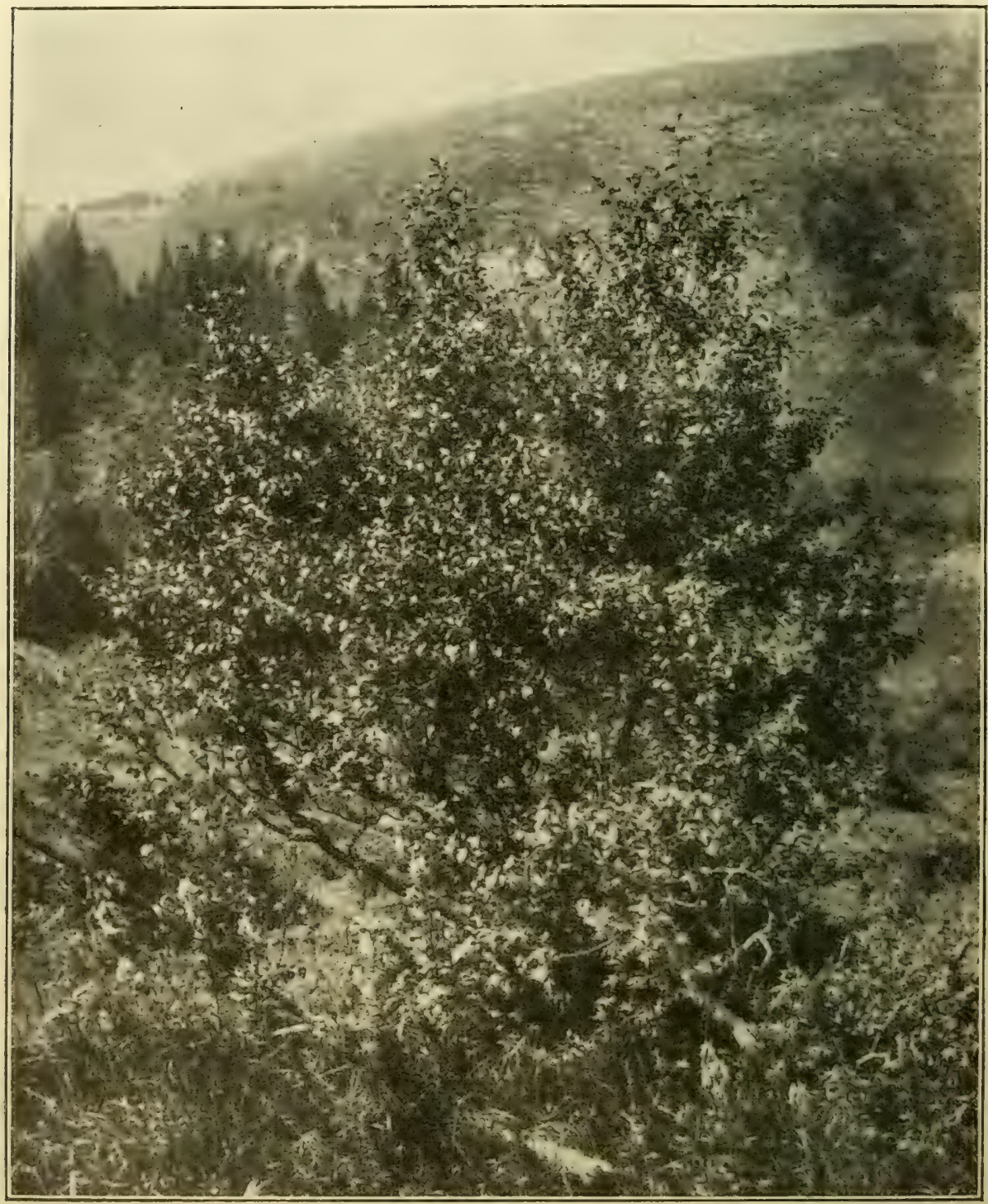

Abb. 102. Betula pubescens Subsp. carpatica im Großen Kessel im Gesenke.

(Nach einer Aufnahme von J. Pauer. Olmütz.)

selten. Am Athange des Hochschar gegen Lindewiese findet man an felsigen Stellen den seltenen Farn Cyslopleris sudelica, der auch a,m Leitersberge ober Waldenburg, am Weißen Seifen und zwischen Hirschwiesen und Tho masdorf vorkommt. 
Über der Waldgrenze bilden im Gesenke Picea excelsa, Belula pubescens *carpalica, Sorbus Aucuparia *glabrala, untermischt mit strauchigen Exemplaren von Fagus silvalica, Ribes pelraeum, Rosa pendulina, Rubus Idaeus, Juniperus

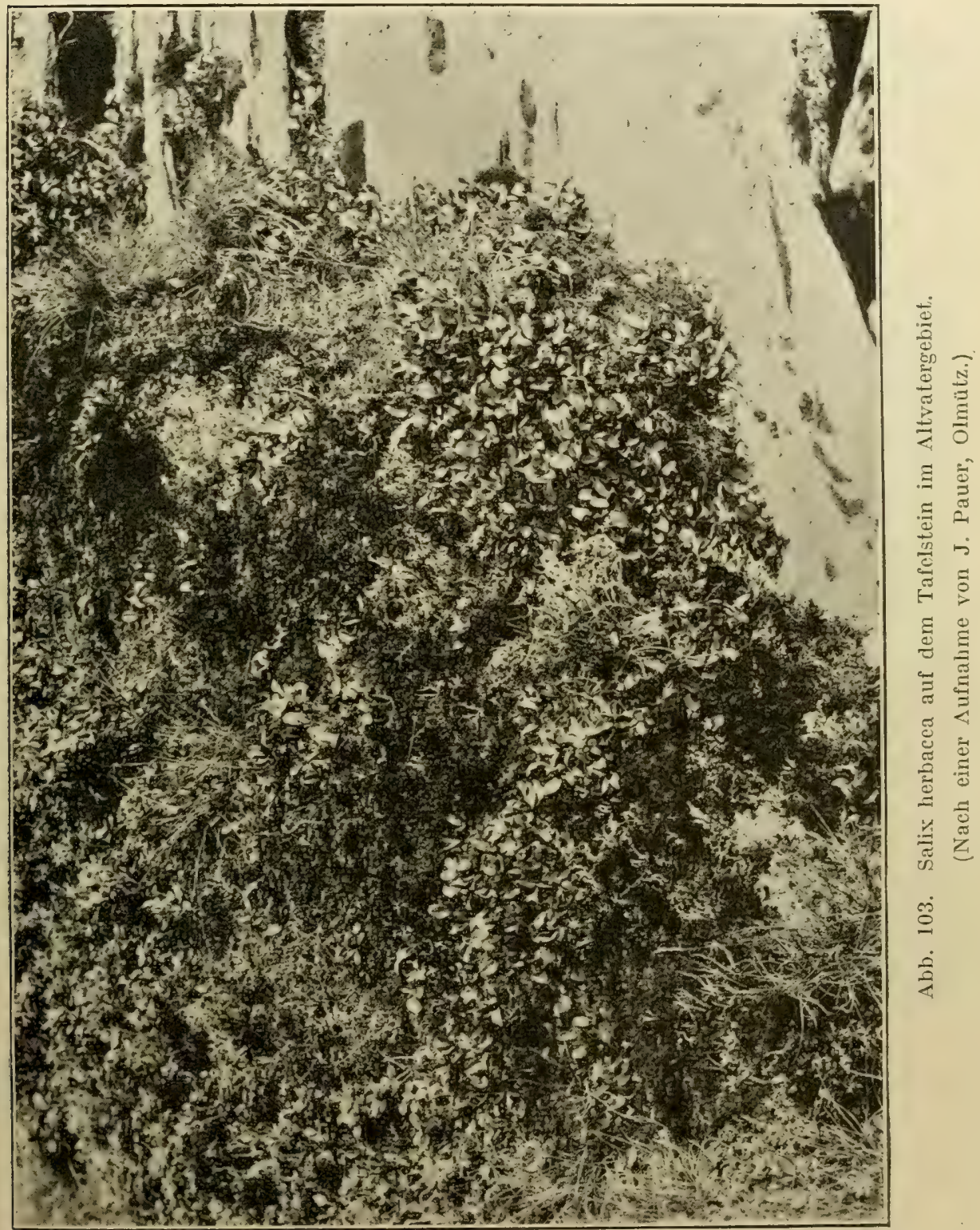

nana und der in neuerer Zeit vielfach angepflanzten Pinus Mughus einen dichten Krummholzgürtel; dazwischen bilden verschiedene Hochstauden, wie Rumex arifolius, Ranunculus plalanifolius, Aconitum Napellus *firmum, Delphinium elatum, Pleurospermum austriacum, Laserpitium Archangelica, Conioselinum 
talaricum, Geranium silvalicum, Scrophularia Scopolii, Adenostyles Alliariae, Doronicum Auslriacum, Cirsium heterophyllum, Mulgedium alpinum oft üppige Bestände, während im Schatten der verkrüppelten Fichten Athyrium alpestre Massenvegetation bildet. An quelligen Stellen treten besonders Salix silesiaca,

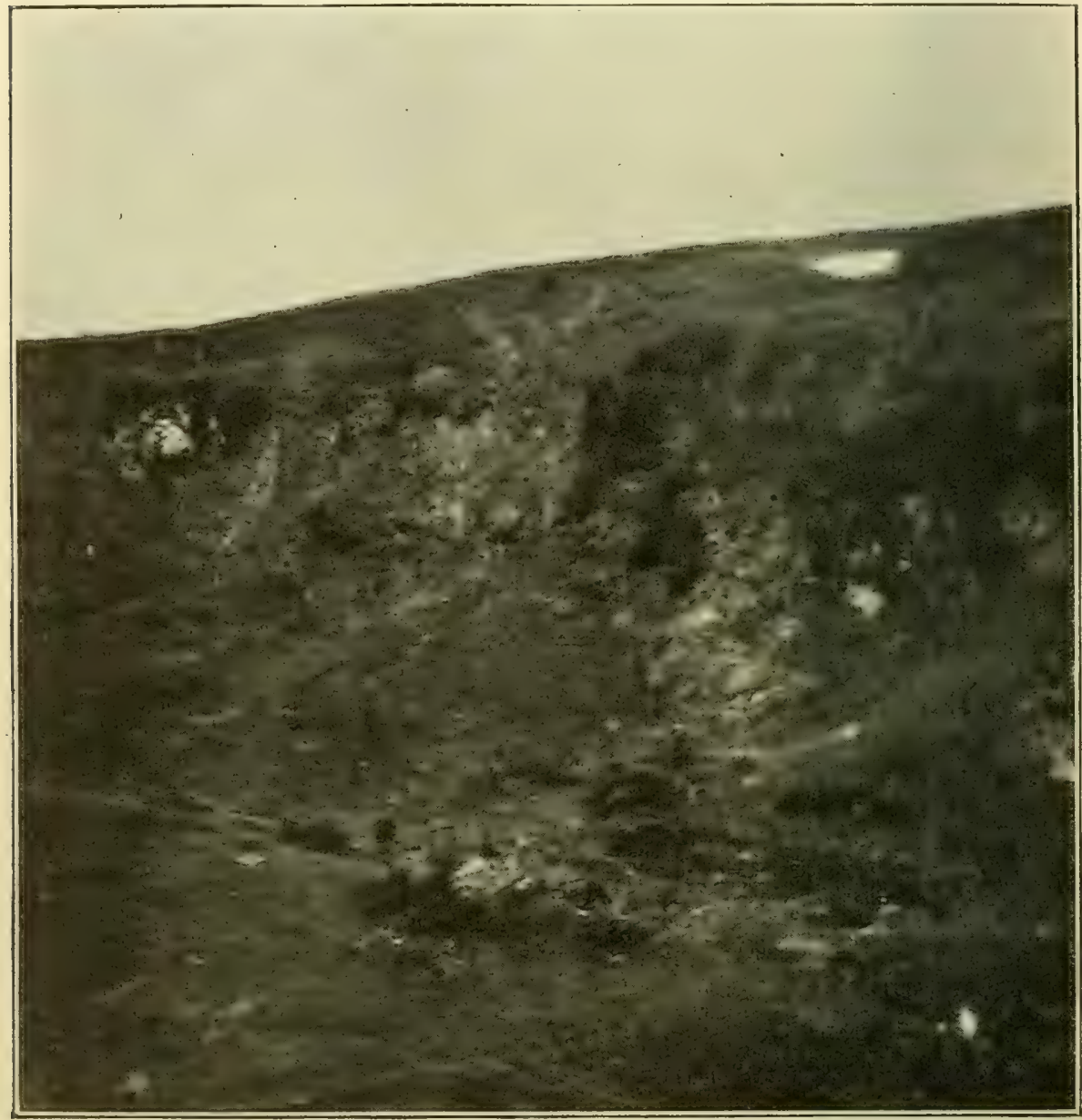

Abb. 104. Der Große Kessel im Gesenke.

Im Talgrunde WViesen, an den Steilhängen Krüppelfichten, Hochstaudenfluren und Hochgebirgspflanzen.

(Nach einer Aufnahme von Dr. Z. v. Szabó in Budapest.)

S. hastata, Carex flava, C. canescens, C. slellulala, Allium sibiricum, Trollius europaeus, Arabis Halleri, Viola biflora, Geum rivale, Epilobium nutans, E. anagallidifolium, E. alpestre, Chaerophyllum Cicutaria, Bartschia alpina, Adenoslyles Alliariae auf. Viel seltener als im Riesengebirge trifft man Hochmoore, wie am Fichtling, am Bärenkamm und die ,Seefelder" am Köpernik, die durch das Vorkommen von Ledum palustre ausgezeichnet sind. 
Die Kuppen der höheren Gipfel des Gesenkes bedecken größtenteils Borstengrasmatten mit Fesluca supina, Anthoxanthum odoratum, Deschampsia flexuosa, D. caespilosa, Potentilla aurea, P. erecla, Vaccinium Myrtillus, V. Vitis Idaea, Calluna vulgaris, Campanula barbala, Melampyrum silvaticum und zah!reichen Hieracien, besonders $H$. slygium, $H$. alpinum, $H$. prenanthoides und H. silesiacum. Diese Rasen sind vielfach von Moosen und Flechten, wie Dicranum scoparium, D. undulalum, Racomilrium sudelicum, Polylrichum alpinum, P. juniperinum, P. strictum, Cladonia rangiferina, C. silvatica, Stereocaulon alpinum, Cetraria islandica, $C$. nivalis, $C$. cucullata u. v. a. durchwirkt. Auch die Gipfe] selbst sind meist grasige, gerundete Kuppen, auf denen im Gegensatze zu den Westsudeten die Felsbildung stark zurücktritt. Die Brünnelheide ist durch das Vorkommen von Carex rupestris, Aconilum Vulparia, Saxifraga Aizoon, Gentiana punctala und G. verna ausgezeichnet; auf dem Köpernik Köpernik. kommen Poa caesia, Carex vaginala und Saxifraga Aizoon, auf dem $1490 \mathrm{~m}$ hohen Altvater Juncus trifidus, Carex rigida, Salix Lapponum, S. herbacea, Altvater. Saxifraga Aizoon, Gentiana punctala und Valeriana tripteris vor; der Hochschar ist durch Juncus trifidus, Gentiana punctata und Cystopleris sudetica Hochschar. ausgezeichnet. Die reichste Flora unter den Gipfeln weist wohl der dem Altvater benachbarte Peterstein auf, der an seinen Abhängen üppige sub-Peterstein. alpine Wiesen mit Phleum alpinum, Anthoxanthum odoratum, Poa alpina, Gymnadenia conopea, Polygonum Bistorta, Viola sudetica, Hypericum maculatum, Crepis mollis, C. conyzaefolia, Campanula barbala, Genliana verna, G. punctata usw. trägt, während sein Gipfel von mächtigen Felsmassen gekrönt ist, die nicht nur einzelne interessantere Phanerogamen, wie Salix herbacea. Poa caesia und Juncus trifidus, sondern vor allem eine sehr reiche Moos- und Flechtenflora (u. a. Desmalodon latifolius, Encalypla rhabdocarpa, Pohlia polymorpha, Myurella julaca, Scapania albicans) beherbergen. Unstreitig der interessanteste Punkt des Gesenkes aber ist die Hohe Heide mit dem an ihrer Südseite gelegenen Großen Kessel. Den Talboden des Großen Kiessels nehmen üppige Wiesen, die Kesselwiesen; ein, die neben zahlreichen subalpinen Elementen, wie Phleum alpinum, Thesium alpinum, Liguslicum .Mulellina, Arabis sudetica, Bupleurum longifolium, Achillea sudetica, Crepis mollis, C. conyzaefolia usw., auch Talpflanzen, wie Dianthus deltoides, D. Carthusianorum, Trifolium repens, Brunella grandiflora, Veronica Chamaedrys, Leontodon autumnalis, Scorzonera humilis $u$. a. beherbergen. Umgeben sind diese Wiesen von dunkeln Fichtenwäldern, Buschwerk aus verkrüppelten Buchen und Fichten mit Sorbus Aucuparia *glabrata, Lonicera nigra, Rosa pendulina, Salix hastala, S. silesiaca, Belula carpalica usw. Zwischen diesen Gebüschen und an den Ufern der Bäche aber bilden subalpine Hochstauden, wie Polygonatum verticillalum, Streplopus amplexifolius, Rumex arifolius, Ranunculus platanifolius, Aconilum Vulparia, A. firmum, A. gracile, Delphinium elalum, Lunaria rediviva, Aruncus silvester, Geranium silvaticum, Anthriscus nilidus, Pleurospermum austriacum, Bupleurum longifolium, Laserpilium Archangelica, Valeriana sambucifolia, Adenoslyles Alliariae, Doronicum austriacum, Senecio sarracenius, Carduus personalus sowie das 
seltene Conioselinum lalaricum und die in den Sudeten nur hier vorkommende Grepis sibirica ein üppiges Gestäude. An den Felsabstürzen der Hohen Heide gegen den Kessel gedeihen u. a. Woodsia alpina, Polyslichum Lonchitis, Carex atrala, C. capillaris, Dianthus Carthusianorum, Anemone vernalis, Cardamine resedifolia, Hedysarum obscurum, Saxifraga Aizoon, Valeriana tripteris, Veronica bellidioides, Hieracium Engleri sowie die in den Sudeten nur hier vorkommenden Arten Plalago monlana, Aster alpinus und Hieracium villosum, während Carlina longifolia auch im Kleinen Kessel beobachtet wurde.

Auch an der Südseite des Hochgesenkes und des Glatzer SchneeMährisch- berges bis nach Mährisch-Schönberg
schönberg. herab sind Fichtenwälder mit eingesprengten Buchen, Tannen und Lärchen die herrschenden Wälder, in denen u. a. Dryopleris spinulosa, Lycopodium annotinum, Carex silvalica, Luzula nemorosa, Polygonatum verticillatum, Euphorbia dulcis, Thalictrum aquilegifolium, Vaccinium Myrtillus, V. Vitis Idaea, Pirola

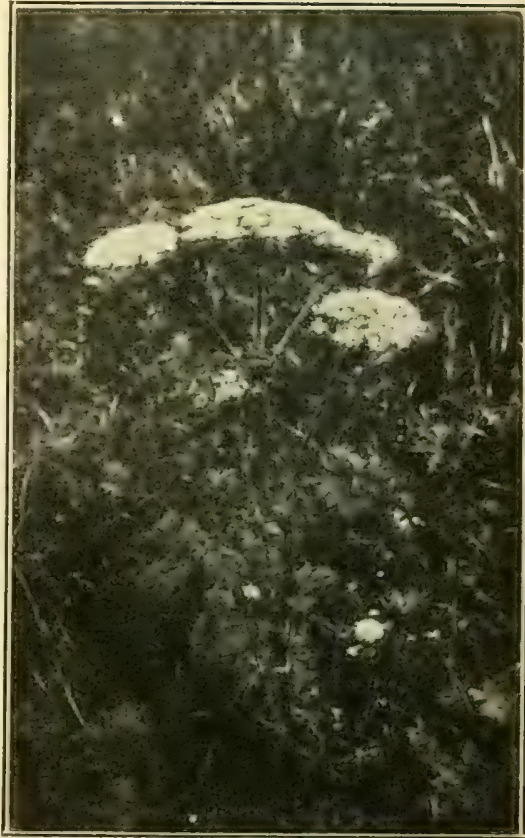

Abb. 105. Laserpitium Archangelica im Großen Kessel des Gesenkes.

(Nach einer Aufnahme von J. Pauer, Olmütz.)

uniflora, P. minor, P. secunda, Senecio sarracenius und Prenanthes purpurea, bei Goldenstein und Waldenburg auch Scrophularia Scopolii, häufig sind, während für die Wiesen Polygonum Bislorta, Melandryum silvestre, Dianthus deltoides, Chaerophyllum Gicularia, Cirsium rivulare die bezeichnendsten Arten sind. An zwei Stellen, am Berge Zdiar bei Eisenberg und am Baudenberge zwischen Grumberg und Nikles, tritt hier Serpentin zutage, wo dann die charakteristischen Serpentinfarne Asplenium adullerinum und A.cuneifolium und auch ziemlich zahlreich die Lärche vorkommen.

Niederes Gesenke.

Auch im Niederen Gesenke sind neben Laubwäldern noch vielfach Fichten- und Föhrenwälder anzutreffen, in denen so manche Gebirgsart

Bärn, gedeiht. So kommen bei Bärn und Rautenberg in den Wäldern noch Melandryum silvestre, Thalictrum aquilegifolium, Aclaea spicata, Aconitum Vulparia, Corydalis cava, Rosa pendulina, Circaea intermedia, Trientalis europaea, Pirola minor, Melampyrum silvaticum, Doronicum austriacum, Pelasites albus, auf Wiesen Veratrum Lobelianum, Orchis mascula, Iris sibirica, Polygonum Bistorta, Fulnek. Senecio rivularis und Cirsium heterophyllum vor. Um Fulnek sind die Gebirgsarten wie Aruncus silvester, Pedicularis silvatica und auf dem Schloßberge auch Lunaria rediviva weniger zahlreich, hingegen treten in Föhren- und Laubwäldern hier häufig Sarothamnus scoparius, Cylisus supinus, Genista germanica, an sonnigen felsigen Stellen Melica ciliata, Salvia verticillata und Artemisia scoparia auf, 


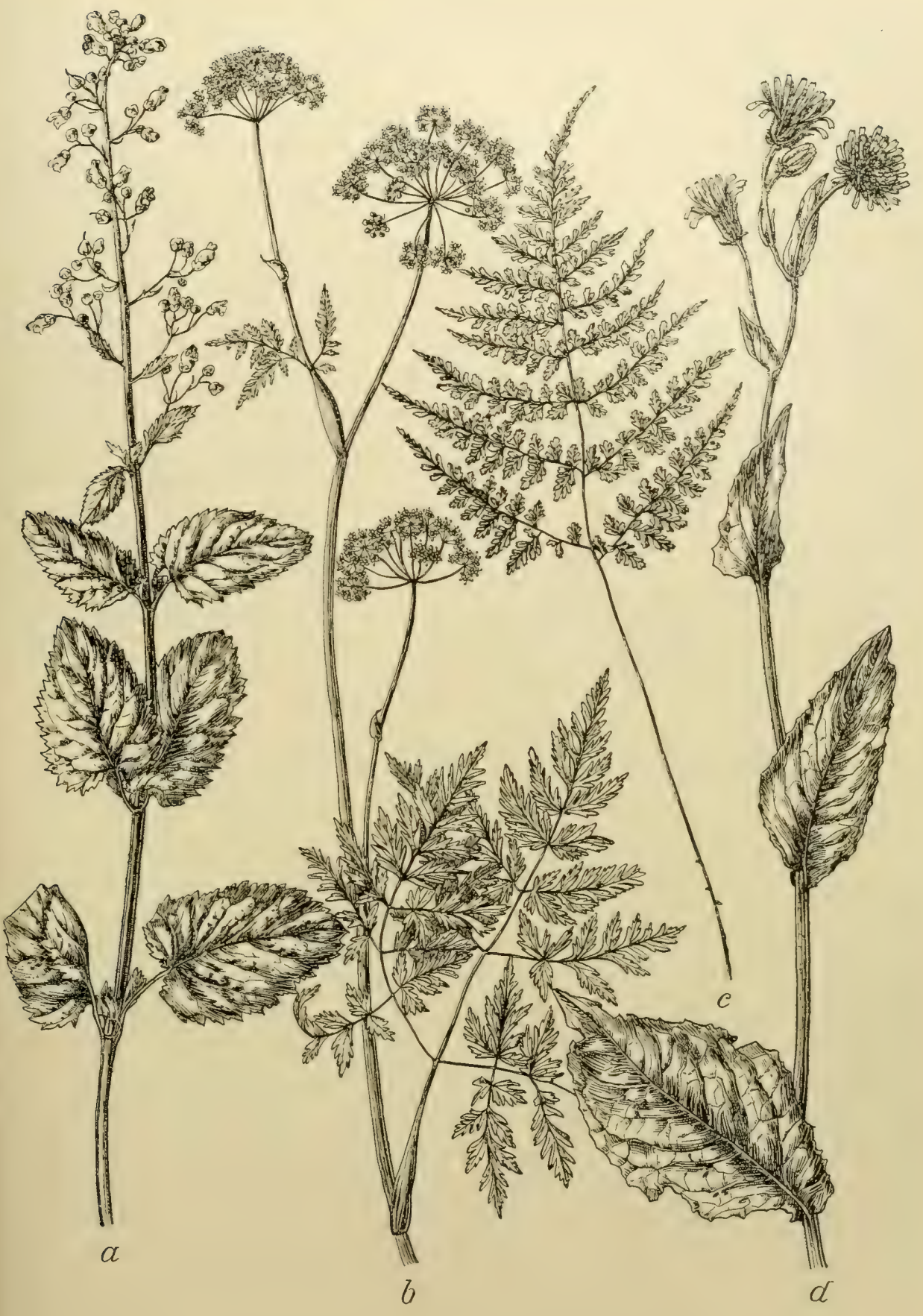

Abb. 106. Einige Pflanzen des Gesenkes, die dem Riesengebirge fehlen.

a Scrophularia Scopolii. b Conioselinum tataricum. $c$ Cystopteris sudetica. d Crepis sibirica. 
an Wegrändern kommt hier schon Xanthium strumarium vor. Im nördlichen

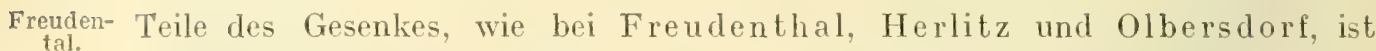
auch die Lärche nicht selten. In der Umgebung von Troppau sind Eichen-

Troppau. wälder mit Carex pilosa, Galanthus nivalis, Isopyrum thalictroides, Corydalis solida, Cylisus supinus, C. ratisbonensis, Astrantia maior, Galium vernum vorherrschend, doch kommen bei Schloß Grätz auch schöne Buchenwälder vor; dortselbst sind übrigens auch Geranium sanguineum, Cylisus nigricans und Trifolium rubens zu finden. Auf Waldwiesen am Horzinabache, zwischen Groß-Herlitz und Braunsdorf ist Crocus Heuffelianus sehr häufig und im ersten Frühling ein schöner Schmuck der Troppauer Flora; auch Gladiolus imbricalus ist im Gebiete nicht selten. Bei Groß-Herlitz, wo neben Laubbeständen auch schon Lärchengehölze auftreten, sind in ersteren Cytisus nigricans, Trifolium rubens, Hypericum montanum, H. hirsulum, Pulmonaria angustifolia, Melitlis Melissophyllum, Asperula cynanchica die bemerkenswertesten Arten; von Gebirgspflanzen ist Veratrum Lobelianum bei Groß-Herlitz anzutreffen; bei Przerowetz nächst Troppau kommt die in den Sudetenländern höchst

Freuden- seltene Polentilla slerilis vor. Auch bei Freudenthal sind noch östliche
tal. Arten, wie Cytisus nigricans, zuhause. Hoore sind im Niedrigen Gesenke seltener und meist nur von geringer Ausdehnung; bemerkenswert ist nur das Vorkommen von Saxifraga Hirculus bei Stablowitz nächst Troppau, das von Juncus squarrosus bei Lichten und Benisch und das von Juncus alpinus beim Zattinger Hofe nächst Groß-Herlitz.

\section{Das Böhmisch-mährische Gebirge mit dem niederöster- reichischen Waldviertel.}

Das Böhmisch-mährische Gebirge steht im Nordosten mit den Sudeten in engem Zusammenhang und zeigt auch in seiner Flora hier vielfach Beziehungen zu diesen. Vornehmlich sind es Fichten-, seltencr Buchenbestände, die hier Hohen- um Landskron und Hohenstadt dominieren, in denen noch manche Art
stadt. des Gebirges, wie Lilium Martagon, Paris quadrifolia, Galanthus nivalis, Cephalanthera longifolia, Cardamine enneaphyllos, Corydalis solida, Vicia silvalica, Pirola uniflora, Galium silvaticum und Campanula latifolia gedeihen, während auf Wiesen Leucoium vernum, Orchis uslulala, O. mascula, O. sambucina, Trollius europaeus, Cirsium heterophyllum und Hieracium fiugellare vorkommen. Bei Landskron. Landskron sind auch mehrfach Hochmoore anzutreffen, von denen die an den ,Landskroner Teichen" mit Calla palustris, Juncus squarrosus, Trifolium spadiceum und Ledum palustre die interessantesten sind. An den Ostabhängen

Müglitz. des Gebirges, zwischen Hohenstadt und Müglitz, aber bildet Pinus silvestris größere Bestände, in denen Dianthus delloides, Sarothamnus scoparius, Vaccinium Myrtillus, V. Vitis Idaea, mehrere Pirolaarten und Jasione monlana häufig sind. Sazawatal. Reich an Gebirgspflanzen ist das oberste Sazawatal, wo Blechnum Spicant, Polystichum lobalum, Lycopodium annolinum, Polygonalum verlicillalum, Aconilum Napellus *firmum und Pelasiles albus in den Fichten- und Buchenbeständen 
angetroffen werden. Auch um Mährisch-Trübau ist die Fichte der dominierende Waldbaum, doch kommen ausgesprochene Gebirgspflanzen nur vereinzelt, so (bei Uttigsdorf) Lilium Marlagon, Aruncus silvester und Orchis mascula *speciosa und (bei II ariakron) Epipogium aphyllum vor; auf dem Horn berge finden sich auch Lycopodium annolinum, Allium ursinum und an einem Steilhange zwischen Schlegelwasser und Silberwasser Actaea Cimicifugia, in den Hermersdorfer Wäldern Taxus baccata, Lilium Marlagon, Aslranla maior und Campanula Cervicaria. Bei Hermersdorf wächst auch das seltene Bolrychium rulaefolium, im Trübetale unterhalb Mährisch-Trübau Isopyrum thaliclroides, Trollius europaeus und Gylisus nigricans. Reicher an Gebirgspflanzen sind die Wälder um Abtsdorf, wo auch Blechnum Spicanl, Bolrychium Malricariae, Carex pendula, Polygonalum verlicillatum, Thaliclrum aquilegifolium und Veronica montana auftreten, während dort auf Sumpfwiesen Carex disticha wächst. In der Umgebung von Zwittau sind die ausgedehnten Moore, die sich von Absdorf bis Greifendorf erstrecken, durch ihre reiche Flora bekannt; Carex Davalliana, C. dioica, C. stelluluta, G. paniculala, G. diandra, C. elala, C. flava, Potentilla paluslris, Viola palustris, Menyanthes Irifoliala, Drosera rotundifolia, Senecio rivularis sind hier allgemein verbreitet. Im Lotschnauer Moore kommen auch Carex cyperoides, C. Pseudocyperus (jetzt anscheinend verschwunden), Juncus squarrosus, Leucoium vernum, Trollius europaeus, Rumex maritimus, Ranunculus sceleralus und, wahrscheinlich eingeschleppt, Primula farinosa vor, auf die Nikler Moorwiesen sind Juncus supinus, Gladiolus imbricalus, Iris sibirica und Hypericum humifusum beschränkt; sehr selten ist auch Drosera anglica, die bisher nur von Dittersdorf bekannt ist. Nicht ohne Interesse ist es, daß man südöstlich von $\mathrm{Z}$ wittau schon auf einige wärmeliebende Arten stößt, so bei Gewitsch auf Cypripedium Calceolus und Anemone grandis, bei Ghrostau an Kallifelsen auf Melica ciliala.

Die Höhen auf der böhmischen Seite des Gebirges, zwischen Polička Polička. und Kamenitz, sind nicht nur durch ihren Reichtum an Vorgebirgsarten, sondern auch durch das Auftreten einiger im übrigen Teile des Böhmischmährischen Höhenzuges fehlender Arten aus den Ostsudeten bemerkenswert, wie Aconitum Vulparia und Rubus saxalilis bei Polička und Senecio rivularis auf der Žakova hora; Polygonatum verlicillalum, Lonicera nigra und Sambucus racemosa sind hier überall verbreitet. Auf feuchten Wiesen ist Trifolium spadicum sehr häufig, am Großen Teich bei Kamenitz kommen auch Calla palustris, Viola palustris und Menyanthes trifoliata vor. Doch dringen auch thermophile Arten oft ziemlich tief ins Gebirge ein, wie Melica ciliala bis Ingrowitz und Asperula cynanchica und Anthemis tinctoria auf die Kalkabhänge südlich von Polička; bei Oels und Kunstadt kommt in den Wäldern Melampyrum bohemicum vor. Auch um Saar treten in Wäldern Streplopus amplexifolius, Geranium phaeum und Mulgedium alpinum, auf Mooren Oxycoccos quadripelala auf. Die Gegend von Deutsch-Brod ist reich bewaldet, ab und $\mathrm{zu}$ findet man auch kleine Moore mit Sedum villosum, Polentilla paluslris und Menyanthes Irifoliala. 
GroßMeseritsch.

Föhrenwälder mit Sarothamnus scoparius, Vaccinium- und Pirolaarten, teils, und zwar vorherrschend, Fichtenwälder mit eingesprengten Tannen, Lärchen und Buchen, in denen Viburnum Opulus, Sambucus racemosa, Lonicera Xylosteum und Daphne Mezereum das Unterholz bilden, während im Niederwuchs neben Corydalis cava, Chrysosplenium alternifolium, Lysimachia nemorum, Asperula odorala, Lactuca muralis, Prenanthes purpurea auch noch Gebirgspflanzen, wie Rubus saxalilis, Aconitum Vulparia, Senecio sarracenius und Polygonalum verli-

Slileny Radeschin. cillatum gedeihen. An den Teichen um Skleny, Radeschin und Pikaretz sind auch Wiesenmoore und stellenweise, besonders am Sklener Teich, Hochmoore mit Drosera rolundifolia, Potentilla palustris, Callha procumbens, Crepis paludosa, Sedum villosum usw. entwickelt. Die Wiesen des Gebietes hingegen weisen nur eine sehr arme Flora (u. a. Polygonum Bistorla, Geranium pratense und Sanguisorba officinalis) auf und auf sonnigen Heiden findet man in Callunavulgaris-Beständen Dianlhus delloides, Sarolhamnus scoparius, Gentiana carpatica. Jasione montana, Campanula rolundifolia usw. Auf Serpentin ist um Radeschin Viscaria vulgaris eine charakteristische Erscheinung.

Iglau. In der Umgebung von Iglau bedecken ausgedehnte Fichtenwälder die Hänge der Berge. Begleitet wird Picea excelsa hier von Abies alba, Larix decidua und Pinus silvestris, seltener von Laubhölzern, wie Betula pendula, Populus tremula und Acer Pseudoplatanus. Das Unterholz bilden in tieferen Lagen und an Waldrändern Sarothamnus scoparius, Genista finctoria und Pubusarten, in höheren Lagen Daphne Mezereum, Rosa pendulina, Lonicera nigra und Sambucus racemosa. Im Niederwuchs sind Calluna vulgaris, Vaccinium Myrtillus und Vilis Idaea vorherrschend, ferner treten Athyrum Filix femina, Dryopteris Filix mas, D. spinulosa, Polystichum lobalum, Lycopodium annolinum, Carex digitata, Luzula nemorosa, Maianthemum bifolium, Anemone Hepalica, Ranunculus lanuginosus, Actaea spicata, Cardamine enneaphyllos, G. bulbifera, Pirola rolundifolia, P. minor, P. chlorantha, P. uniflora, Chimaphila umbellata, Melampyrum nemorosum, Lamium luteum, Galium rolundifolium, G. silvaticum, Serralula tincloria, Senecio nemorensis, Prenanthes purpurea nicht selten auf und dazu zwei von hier bis in den südlichen Böhmerwald verbreitete Arten, Cardamine lrifolia und Soldanella monlana. Ifie und da findet man um Iglau aber auch Buchenbestände, wie auf dem Schatzberge, dem Spitzberge, bei Poppitz und auf dem Hohenstein, in welchen an letzterer Örtlichkeit Carex silvatica, Hordeum europaeum, Polygonatum v'erlicillatum, Cephalanthera longifolia, Coralliorhiza trifida und Symphytum tuberosum vorkommen. Sehr artenarm sind die Wiesen des Gebietes, auf denen von bemerkenswerteren Arten nur Orchis sambucina, Gymnadenia conopea, Thaliclrum aquilegifolium, Arabis Halleri, Saxifraga granulata, Heracleum Spondylium, Pastinaca saliva und Cirsium oleraceum vorkommen, während Arnica und Colchicum fehlen. Die Flora der Bergheiden besteht hauptsächlich aus Agrostis vulgaris, Festuca ovina, Nardus stricta, Scleranthus perennis, Dianthus delloides, Taccinium Myrtillus, V. Vitis Idaea, Calluna vulgaris, Gentiana Slurmiana, Jasione monlana, Carlina acaulis und Hieracium 
Pilosella. Selbst die wenigen Torfmoore der Umgebung weisen von bemerkenswerteren Typen nur Carex stellulala, G. canescens, Juncus filiformis, Trifolium spadiceum, Polenlilla palustris, Stellaria nliginosa, Tiola palustris, Drosera rotundifolia, Sedum villosum, Oxycoccos quadripetala, Pedicularis palustris, $P$. silvatica und Menyanthes trifoliata auf; auf trockenen Grasplätzen sind Jasione montana und Nardus stricta gemein, auf nassen IViesen Girsium rivulare; auch Calla palustris ist stellenweise, wie bei Sachsental, am Ranzersteiche und Igelbach anzutreffen. Wärmeliebende Arten hingegen sind selten, wie Andropogon Ischaemum bei der Schwimmschule, Melica ciliata und Anthemis tinctoria im Iglawatale.

Auch im weiteren Zuge des Gebirges, bis Teltsch und gegen Trebitsch, ist die Fichte der weitaus herrschende Waldbaum, der, begleitet von der Tanne und Föhre, hie und da, wie zwischen Modes und Rosenau, auch von der Lärche, ausgedehnte Bestände bildet. Um Trebitsch bildet Vaccinium Myr-Trebitsch. lillus die Hauptmasse des Niederwuchses, in dem u. a. auch Dryopteris spinulosa, D. Fili $x$ mas, Athyrium Filix femina, Pirola uniflora, P. chlorantha, P. secunda, Chimaphila umbellata, Senecio sarracenius, S. rivularis und an feuchteren Stellen auch Pedicularis silvalica und Crepis paludosa vorkommen. Auf Wiesen trifft man hier Leucoium vernum, Hieracium flagellare und bei Litý auch den seltenen Senecio aurantiacus. Vereinzelt begegenet man bei Trebitsch auch wärmeliebenden Arten, wie Andropogon Ischaemum, Melica ciliata, Artemisia Absynthium und Tragopogon dubius. Zwischen Pirnitz und Teltsch bildet Carpinus Betulus ein kleines Wäldchen, sonst ist im ganzen südwestlichen Mähren bis Datschitz und Zlabings die Fichte der herrschende Waldbaum. Hochmoore sind hier nur von geringer Ausdehnung und recht artenarm, die kleinen Moore von Modes, Hermannschlag, Walterschlag und Rosenau weisen von interessanteren Arten nur Juncus alpinus, Calla palustris, Betula pubescens, Drosera rotundifolia und Epilobium palustre auf. Drosera anglica findet sich nur am Rande des großen Kohlteiches bei Zlabings, in dessen Umgebung überhaupt die Flora an interessanteren Arten reicher ist; an den zahlreichen Teichen findet man hier Alopecurus aequalis, Carex cyperoides, Elaline triandra, Polentilla palustris, im Wostesteiche ferner Sparganium minimum, am Reckenteiche Sedum villosum; auf dem Kohlberge liommt Crepis succisaefolia vor, auf feuchten Wiesen Iris sibirica, Pedicularis palustris und $P$. silvatica, im Gilgenberger Walde und am Stallecker Teiche Arnica montana, die gleichwie Andromeda polifolia und Ledum palustre. weiter nördlich im Gebiete von Iglau völlig fehlt. Bei Datschitz sind besonders im Tale gegen Dobrohost Wiesenmoore Datschitz. mit Cicula virosa, Galium boreale und Veronica longifolia entwickelt, an der Thaya bei Datschitz kommt Nuphar pumilum vor. Um Neubystritz zeigen sich wieder reichlicher Hochmoore mit Calla palustris, Drosera rotundifolia und $D$. anglica, von größerer Ausdehnung aber ist das Gatterschlager Moor bei Neuhaus, das zum großen Teil mit Pinus uliginosa dicht bewachsen ist und Neuhaus. u. a. auch Stellaria palustris, Hypericum humifusum und Lysimachia thyrsiflora beherbergt. Auf Heiden bei Neuhaus kommt ferner die in Böhmen so seltene Anemone vernalis vor. 
Solche Moorwälder aus Pinus uliginosa, wie bei Neuhaus, treten auch im Gmünd, Waldviertel bei Litschau, Erdweis und zwischen Gmünd und Platz auf. Erdweis. Den Untergrund dieser Wälder bilden typische Hochmoore aus Sphagnum acutifolium, cymbifolium, squarrosum und subsecundum mit Meesea longisela, Aulacomnium palustre, Polytrichum commune, P. juniperum, P. gracile, Splachnum ampullaceum usw. Auf diesem Moorboden gedeihen als Unterholz Alnus glulinosa, Belula pubescens und verkrüppelte Exemplare von Picea excelsa sowie oft

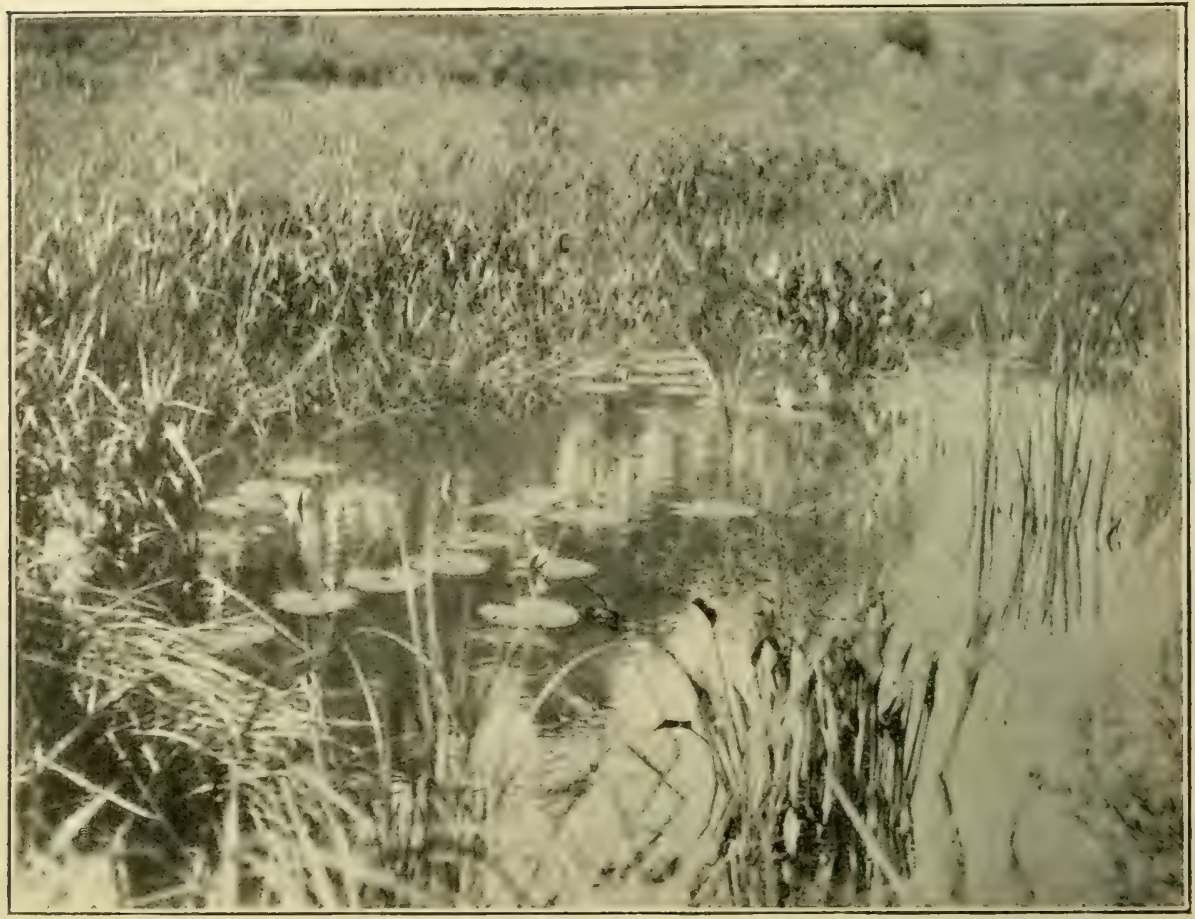

Abb. 107. Sumpf bei Litschau im niederösterreichischen Waldviertel.

Alisma Plantago aquatica, Sparganium sp., Castalia alba.

(Nach einer Aufnahme von Prof. L. Linsbauer, Flosterneuburg.)

(Aus der Bildersammlung des botanischen Institutes der Wiener Universität.)

sehr häufig Ledum palustre, während der krautige und halbstrauchige Niederwuchs aus Cyperazeen, Junkazeen, Gramineen, Callha palustris, Drosera rolundifolia, Sedum villosum, Polentilla palustris, Trifolium spadiceum, Gicula virosa, Menyanthes trifoliala usw. sowie den in allen Mooren verbreiteten Ericazeen

Litschau, besteht. Bei Litschau kommt in Holzschlägen Digitalis purpurea (aber wohl schwerlich ursprünglich) und auf Bergwiesen bei Schönau und Reichenbach Anemone vernalis, die auch bei Gmünd und Niederschrems wächst, vor. Bei Hoheneich sind aus der Flora der dortigen Teiche Coleanthus sublilis, Juncus Tenageia, Rumex marilimus, Crassula aqualica, Utricularia intermedia, U. minor hervorzuheben, während in der Umgebung derselben Agrostis scabra und Panicum 
Hayek, Die Pflanzendecke Österreich-Ungarns, I.

Taf. XVIII.

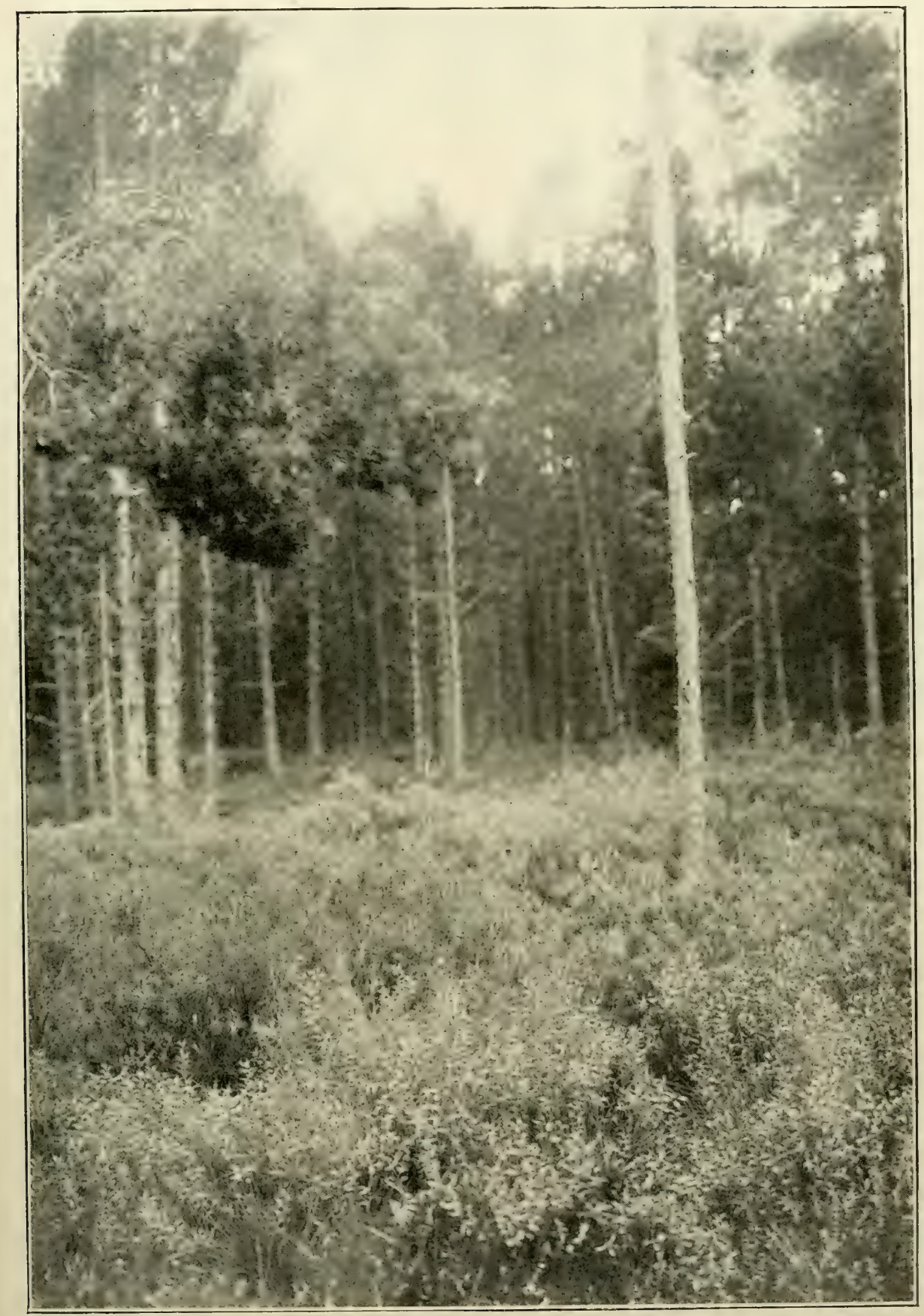

Abb. 108. Moorwald aus Pinus uliginosa bei Kößlersdorf im Waldviertel. Im Niederwuchse vorn Vaccinium uliginosum und Calluna vulgaris, hinten Ledum palustre.

(Nach einer Aufnahme von Prof. L. Linsbauer in Ǩlosterneuburg.)

(Aus der Bildersammlung des botanischen Institutes der Wiener Universität.)

Verlag von Franz Deuticke in Leipzig und Wien. 

capillare sich immer mehr auszubreiten scheinen. Auch bei Zwettl liegen einige Teiche, an denen Juncus Tenageia, Elatine triandra, E. hexandra und das seltene Gras Coleanthus sublilis sich finden. Sonst treten bei Zwettl ab und zu Buchenbestände mit Maianthemum bifolium, Cephalanthera longifolia, Corydalis solida, Gardamine bulbifera, Lunaria rediviva usw., hauptsächlich aber Föhren- und Fichtenwälder mit massenhaftem Vaccinium Myrtillus und V.Vitis Idaea, aber auch mit Soldanella montana und Senecio nemorensis auf, die sich in gleicher Zusammen-

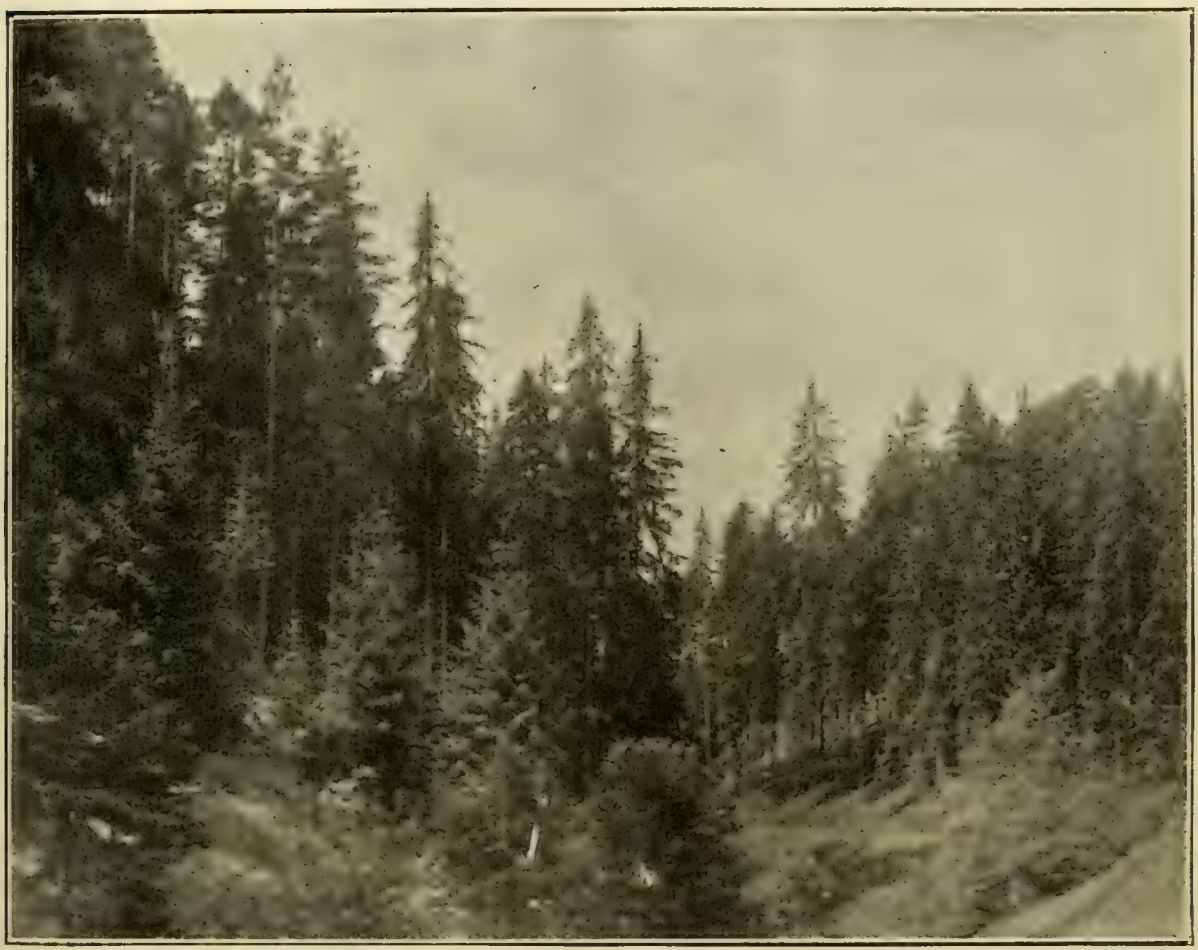

Abb. 109. Fichtenwald bei Zwettl.

(Nach einer Aufnahme von Dr. J. van Linthoudt, Wien.)

setzung bis Schrems, W aidh ofen und Raabs erstrecken. Auch südwestlich von Zwettl, gegen die oberösterreichische Grenze zu, sind Fichten- und Föhrenwälder mit einem Niederwuchs aus Vaccinium. Myrtillus und V.Vilis Idaea die herrschende Formation; auch Thaliclrum aquilegifolium, Ranunculus platanifolius, Senecio nemorensis, Doronicum austriacum sind noch verbreitet und im Frühjahre sind Cardamine trifolia und Soldanella montana eine Zierde der Wälder. Daneben sind auch Hochmoore mit Trichophorum alpinum, Eriophorum vaginatum, Carex dioica, G. pauciflora, Juncus filiformis, J. squarrosus, Galla palustris, Drosera rolundifolia, Oxycoccus quadripetala verbreitet. Bei Harmannschlag kommt auf Bergwiesen Crepis succisaefolia vor, bei Silbersberg Phyteuma nigrum. Eine Reihe interessanter Arten trifft man bei Karlstift unweit der oberöster- Karlstift. 
reichischen Grenze, so Epilobium nutans, Trientalis europaea, Phyleuma nigrum, Homogyne alpina, Carduus personalus und in Moorwäldern auch Pinus uliginosa,

GroßGerungs.

Peilstein.

Gföhl. ferner Cirsium heterophyllum, das sich von hier bis Groß-Gerungs und Ottenschlag erstreckt. Auch bei Alt-Melon und im Gebiete des Peilstein bei Gutenbrunn tritt Trientalis noch auf, im Gföhler Walde bei Grünbach und Gföhl Crepis succesaefolia.

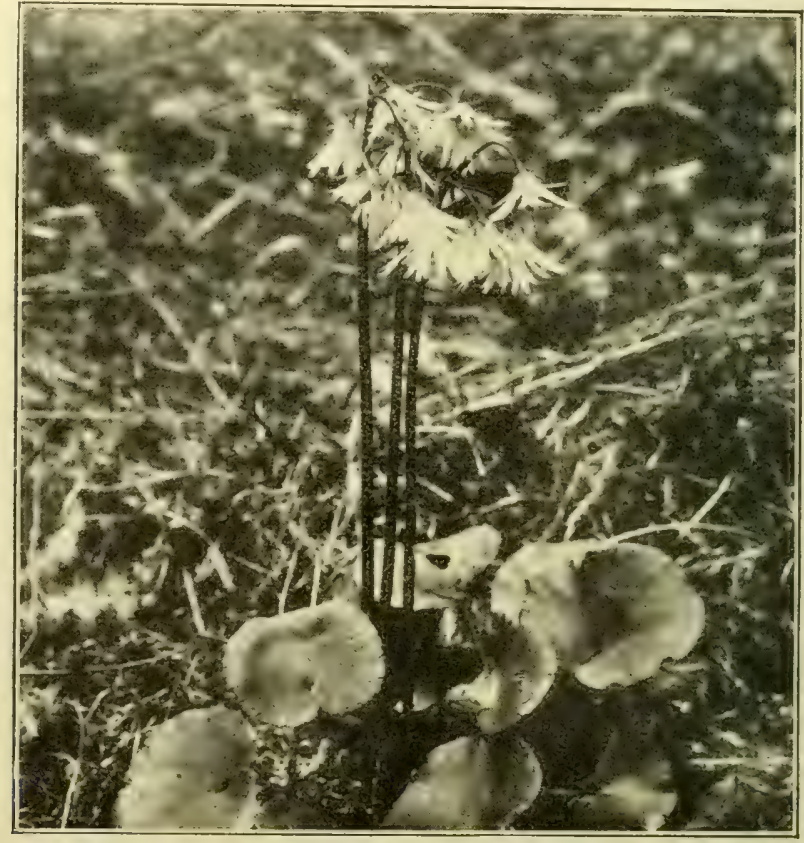

Abb. 110. Soldanella montana im niederösterreichischen Waldviertel.

(Nach einer Aufnahme von Prof. F. Müller, Kŕrems.)

Die letzten Ausläufer des Berglandes gegen die Donau zu sind der Ostrong Jauerling. mit dem $1060 \mathrm{~m}$ hohen Peilstein und der $959 \mathrm{~m}$ hohe Jauerling. Die Hänge des letzteren sind in tieferen Lagen mit Mischwäldern aus Buchen, Fichten, Tannen und Föhren, in höheren Lagen mit Fichtenwäldern und eingesprengtem Acer Pseudoplatanus bedeckt, in denen neben Vaccinium Myrtillus und V. Vitis Idaea insbesondere Cardamine enneaphyllos, C. bulbifera, C. trifolia, Rubus saxalilis, Sarothamnus scoparius und Soldanella montana als charakteristische Elemente des Niederwuchses auffallen. Ab und $\mathrm{zu}$ finden sich auch noch kleine Moore mit Trichophorum alpinum, Eriophorum vaginatum, Carex dioica, C. limosa, Drosera, Viola palustris, Sedum villosum, aber ohne Oxycoccos und Andromeda. Auf den Bergwiesen sind Primula elatior, Thesium pratense, Orchis globosa, Senecio rivularis, Scorzonera humilis, Centaurea pseudophrygia, Campanula rotundifolia *solstitialis und Arnica montana die augenfälligsten Erscheinungen; die Kúuppen des Gebirges aber bedecken Nardus- und Gallunaheiden und Buschwerk aus Corylus Avellana, Alnus viridis, Rosa pendulina und Sorbus Aucuparia. Diese 
Wälder reichen bis an dic Donau und zwischen Melk und Mautern selbst über die Donau hinüber; hier treten aber auch noch einige weitere subalpine Arten auf, die die Donau hier nordwärts nicht mehr überschreiten, wie bei Mlelk Erica Melk. carnea auf dem Hiesberge und Cirsium Erisithales bei Gerolding und bei der Ruine Wolfstein, und bei Oberbergern Salix grandifolia. Eine sehr interessante Flora bietet auch der Gurhofgraben bei Aggsbach, wo an den Agrsbach.

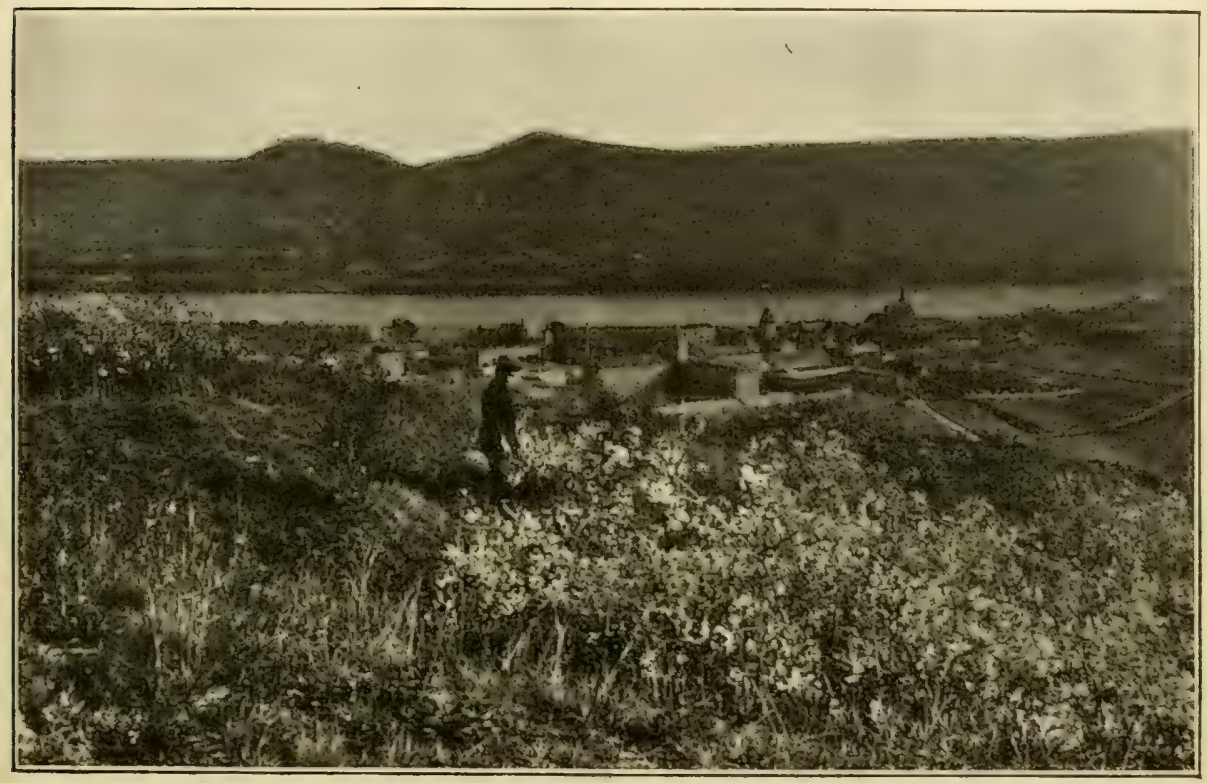

Abb. 111. Buschwerk von Prunus fruticosa und Triften an den Abhängen ober Krems.

(Nach ciner Aufnahme von Prof. F. Müller, Krems.)

Serpentinfelsen die Farne Asplenium cuneifolium und Nolholaena Marantae, ferner Polentilla slerilis, Silene vulgaris *bosniaca, das westeuropäische Seclum micranthum und die illyrische Myosotis suaveolens wachsen. Das Donautal selbst von Melk bis nach Kirems, die Wachau, weist von der ganzen Umgebung ab- Wachau. weichende Vegetationsverhältnisse auf. Freilich finden sich an den teils aus Granit bestehenden, teils von Löß überlagerten Steilhängen noch ab und zu trockene Föhrenwälder oder Scleranthusheiden, zum größten Teile aber sind die Hänge, besonders in Südexposition, von reichen Weingärten bedeckt, die hier bis $425 \mathrm{~m}$ Meereshöhe hinanreichen, dazwischen aber treten steppenartige Triftformationen mit Stipa pennata, St. capillata, Diplachne serolina, Carex humilis, Silene Ostites, Erysimum canescens, Viola ambigua, Linum flavum, Seseli Beckii, S. varium, Orlaya grandiflora, Cylisus nigricans, C. ralisbonensis. Onosma austriacum, Salvia auslriaca, Linaria genislifolia, Aster Amellus, Inula ensifolia, I. hirla, Artemisia austriaca usw. auf; unterbrochen von Buschwerk aus Quercus pubescens, Qu. Cerris, Prunus frulicosa und Colulea arborescens. An Felsen ist Alyssum Arduini überall häufig, auch Isatis tincloria und verwilderte 
Iris germanica ist nicht selten; ferner ist das Vorkommen ausgesprochen südlicher Moose (Hymenostomum lortile, Syntrichia intermedia, Grimaldia fragrans, Asterella fragrans) und Flechten (Lecidea lurida, Dermalocarpon Michelii) daselbst bemerkenswert. Bei Krems selbst gedeihen noch zwischen den Weingärten Hypericum elegans und Reseda Phyleuma sowie einige prächtige Rosen, wie Rosa Jundzillii und R. Kremsensis.

\section{Nittel- und Südmähren und das nordöstliche Nieder- österreich.}

MährischSchönberg.

In Nordmähren dringt die Sudetenflora weit gegen die Ebene vor. So treten um Mährisch-Schönberg noch vielfach Fichtenwälder mit eingesprengten Lärchen auf, in denen Lilium Martagon, Cephalanthera longifolia, Melandryum silvestre, Thalictrum aquilegifolium, Aclaea spicala, Cardamine enneaphyllos, Pirola rolundifolia, P. media, P. minor, Pelasiles albus, Senecio nemorensis und Prenanthes purpurea noch ziemlich häufig sind; daneben finden sich auch trockene Föhrenbestände und Wiesen mit Colchicum autumnale, Polygonum Bislorla und Girsium heterophyllum sowie Heiden mit Nardus stricla, Sarothamnus scoparius und Jasione montana; auf Äckern ist Arnoseris minima ein häufiges Unkraut.

Stemberg. $\quad$ Auch um Sternberg bestehen, besonders an der Ostscite der Stadt an den Ausläufern des Gesenkes die Wälder größtenteils aus Abies alba, mit eingesprengter Picea excelsa und Larix decidua, in denen Polygonatum multiflorum, Anemone Hepatica, Cardamine enneaphyllos, C. bulbifera, Pirola media, P. chlorantha, Asperula odorala, Pelasiles albus und Lactuca muralis häufig auftreten, in höheren Lagen, wie im Aleschtale findet man auch Cephalanlhera longifolia, Euphorbia amygdaloides, Campanula latifolia und Prenanthes purpurea, im Pohlhammerwalde Polygonalum verticillatum und Orchis fusca, bei Lippein Scrophularia Scopolii und in der „Henne" Gladiolus imbricatus. Am Rande des Gebirges und im Hügellande gegen die Ebene zu sowie im Ober- und Niedergrunde trifft man auch gemischte Laubwälder aus Quercus Robur, Qu. sessiliflora, Fagus silvalica usw., mit Melica uniflora, Euphorbia dulcis, E. angulala, Dianthus Armeria, Gentiana ciliata usw. sowie trockene Triften, auf denen u. a. Verbascum phoeniceum, Hypochaeris maculala, Trifolium ochroleucum, Cytisus Kitaibelii, Cylisus nigricans, Digitalis ambigua usw, wachsen. Bemerkenswert ist auch das angebliche Vorkommen von Polygola Chamaebuxus bei „Ecce homo" ober Sternberg.

Odergebirge.

Auch im Odergebirge, östlich von Olmütz, bilden Fichten und Tannen den Wald, hie und da von kleinen Laubholzbeständen aus Belula pendula, Acer plalanoides, A. Pseudoplatanus, Fagus silvalica oder Carpinus Belulus unterbrochen. In diesen Wädern gedeihen Poa nemoralis, Melica nulans, Carex digilala, Maianthemum bifolium, Cephalanthera alba, Neoltia Nidus avis, Aclaea spicala, Cardamine enneaphyllos, C. bulbifera, Selinum carvifolia, Pulmonaria obscura, Galium silvalicum, Pirola minor, P. secunda, Pelasiles albus, Senecio nemorensis, Gnaphalium 
silvalicum, Lactuca muralis; das Unterholz bilden besonders Rosa pendulina und Sambucus racemosa; an Felsen der Schieferbrüche ist Sarolhamnus scoparius sehr häufig. Auf Wiesen sind in tieferen Lagen Saxifraga granulala, Knaulia carpalica und Cirsium rivulare, höher oben, bei 400-600 m Orchis sambucina, o. mascula, Phyleuma orbiculare, Hypochoeris maculala, Crepis succisaefolia charakteristische Erscheinungen. Borstengrasmatten mit Nardus, Calluna vulgaris, Hypochoeris maculala und Scorzonera humilis treten an sanft geneigten Abhängen auf, seltener sind Moorwiesen mit Agrostis canina, Gymnadenia conopea, Trifolium montanum und $T$. spadiceum. Hie und dd trifft man in den Wäldern auch kleine Sphagnummoore, auf denen unter Carex canescens, G. stellulata, Eriophorum anguslifolium auch Veratrum album *Lobelianum vorkommt.

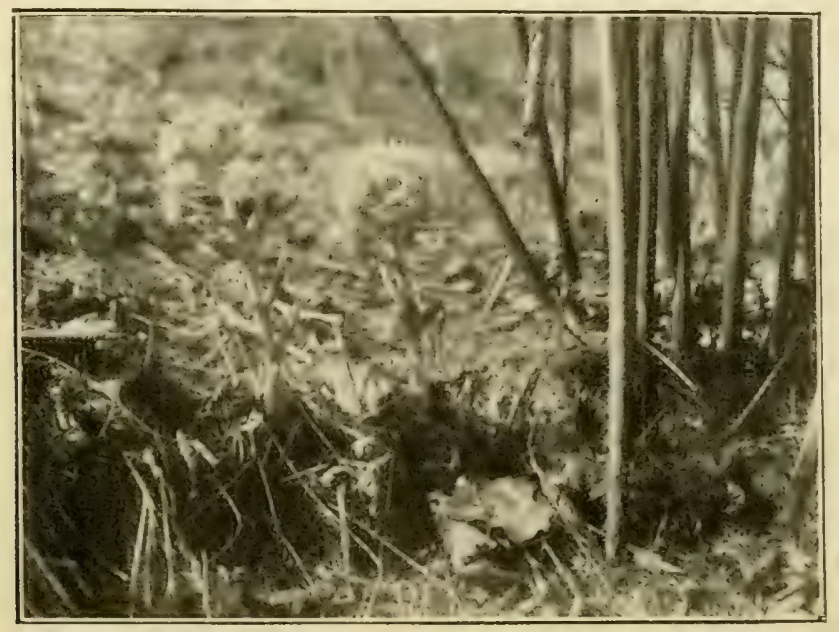

Abb. 112. Petasites albus im Walde des Odergebirges bei Leipnik in Mähren.

(Nach einer Aufnahme von Prof. J. Nabělek, Leipnik.)

Ähnliche Verhältnisse zeigt auch die Vegetation in der Umgebung von Mährisch-Weißkirchen. Hier kommen in den Wäldern Carex silvatica, MährischFestuca silvatica, Lilium Martagon, Cephalanthera alba, Cardamine bulbifera, kirchen. Aconilum Vulparia, Salvia glulinosa, Pirola uniflora, P. secunda, P. rolundifolia, P. chlorantha, Vaccinium Myrlillus, Phyleuma spicalum, Prenanthes purpurea usw. vor, die Wiesen schmücken Orchis Morio, O. Latifolia, Ranunculus acer, Melandryum silvestre, Cardamine pratensis, Heracleum Spondylium, Pastinaca sativa, Campanula Rapunculus, Girsium rivulare, C. canum u. a., auf Sumpfwiesen treten u. a. Pedicularis silvatica, Centaurium pulchellum, in Wassergräben Hollonia palustris auf, die auch bei Leipnik vorkommt. An den Teichen bei Hustopetsch sind Glyceria aquatica, Carex cyperoides, Hippuris vulgaris, Oenanthe aqualica, ferner im Wasser Potamogeton natans, P. lucens, $P$. aculifolius, Hotlonia palustris und in einem derselben auch Salvinia natans zu finden. 
Oitran.

Im Odertale bei Odrau. Neutitschein und flußabwärts bis zur Pieichsgrenze sind insbesondere die üppigen Wiesen mit Anthoxanlhum odoralum, Holcus lanalus, Rumex Acelosa, Lychnis Flos Cuculi, Trifolium pratense, Hypericum maculatum, Chrysanthemum Leucanthemum, Cirsium pannonicum, Girsium canum

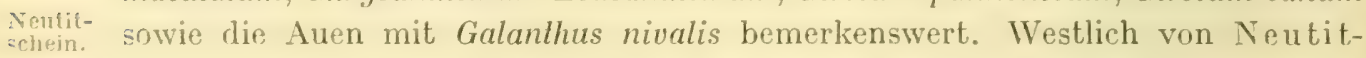
stramberc. schein besitzen vor allem die Kalkberge bei Stramberg eine interessante Flora, besonders der $5.54 \mathrm{~m}$ hohe, gegen Süden steil abstürzende Kotouc, auf welchem an der Nordseite Larix decidua einen kleinen Bestand bildet, während an den felsigen Abhängen Melica ciliala, Allium monlanum, Anthericum ramosum, Dianthus Carthusianorum, Biscutella laevigata, Arabis arenosa, Saxifraga Aizoon, Peucedanum Cervaria, Libanolis monlana, Sedum album, Cynanchum Vinceloxicum, Slachys germanica, S. recla, Scabiosa lucida, Inula squarrosa sowie rlas crst kürzlich daselbst entdeckte Geranium lucidum vorkommen. Weniger reich ist die Flora des Schloßberges von Stramberg mit Arabis arenosa, Sedum album, Polentilla arenaria, Cynanchum Vinceloxicum und Arlemisia Nessels- scoparia sowie der Piskowna bei Nesselsdorf, die überdies Cotoneasler in-
dorf. legerrina und Meliera ciliala be herberest, wihend Arlemisia scoparia daselbst fehlt.

Von Mährisch-Schönberg bis Kremsier breitet sich längs der March

Hanna. die weite fruchtbare Talebene der Hanna aus, die, heute vortrefflich kultiviert und von wogenden Gersten- und Weizenfeldern bedeckt, ehedem wohl ihrer ganzen Länge nach von jenen Auenwäldern und Wiesen bedeckt war, deren Pieste auch jetzt noch vielfach erhalten sind. Im nördlichen Teile der Hanna, Littau. wie um Littau, bestehen diese Avenwälder vorherrschend aus Alnus glutinosa, Fraxinus excelsior, Quercus Robur, Ulmus glabra, Salix fragilis, selbst herabgeschwemmten Lärchen; das Unterholz bilden Salix fragilis, S. purpurea, S. Caprea, Prunus Padus, Rhamnus Frangula, Acer campestre, Sambucus nigra, im Niederwuchs sind Allium ursinum, Galanlhus nivalis, Leucoium vernum, Lislera ovala, Arum macnlalum, Mercurialis perennis, Circaea luleliana, Galeopsis speciosa charakteristisch. Die Wiesen, die alljährlich im Frühjahre von der Nareh überflutet werlen, bieten u. a. Agroslis vulgaris, Holcus lanalis, Triselum flavescens, Deschampsia caespilosa, Poa pralensis, P. trivialis, Carex caespilosa, (:. Flaura, Polygonum Bislorla, Callha paluslris, Ranunculus acer, Cardamine praIensis, Lychnis Flos cuculi, Geranium paluslre, Sanguisorba officinalis, Saxifraga granulala, Lalhyrus pralensis, Herarleum Spondylium, Primula elalior, Chrysanlhemum Leucanthemum, Cenlaurea Jacea, Cirsium oleraceum, Tragopogon pralensis und im IIrrbste Colchicum aulumnale. An den Abhängen der Hügel um I ittau herrschen gemischte Laubwälder mit vorhersehenden Birken, in renen sich Maianlhemum bifolium, Paris quadrifolia, Anemone IIepalica, Panunculus auricomus, Isopyrum lhaliclroides, Corydalis cava, C. inlermedia, Cardamine impaliens, Hypericum montanum, Cylisus supinus, Astrantia maior finden, vor;

Milkov, bei Milkow kommen auch Fichten- und Föhrenbestände mit Genista lincoria, Vaccinum Myrtillus, Calluna vulgaris, Pirola minor, P. media, P. uniflora vor. Lautsch. Bri Lautsch treten Andropogon Ischaemum und Rosa Gallica als die cinzigen. wärmeliebenden Arten des Gebietes auf. 
Ähnlich, aber artenreicher ist die Vegetation des Talbodens in der Umgebung von $01 \mathrm{mütz}$. Die Auenwälder bilden hier neben Alnus glulinosa, Ulmus glabra, Fraxinus excelsior auch Populus alba, P. nigra und Quercus Robur, im Unterholz treten zahlreiche Weiden, Prunus Padus, Cornus sanguinea, Rhamnus Frangula, Sambucus nigra-usw. auf, Humulus Lupulus ist eine überaus häufige Liane. Im Niederwuchs sind besonders Deschampsia caespitosa, Gagea lulea, Slellaria nemorum, Tirnunrulus auricomus. Filipendula T lmaria. Ciralega offirinalis, Viola odorala, Peucedanum palustre, Selinum Carvifolia, Dipsacus pilosus und Enpaloriam cannabinum, an morrign stellen anrh Lrynpleris Thelypleris anffallend. Auf den Wiesen, unter denen insbesondere das Olmützer Moor im Norden der Stadt bemerkenswert ist, ist meist Molinia coerulea, seltener Deschampsia caespitosa das tonangrbende Gras; solche Wiesn treten besonders an feuchteren, noch wenig entwässerten Stellen auf und weisen von charakteristischen Arten Carex Davalliana, G. slellulala, G. diandra, C. paniculala, C. vulpina, C. leporina, C. caespilosa, C. panicea, C. hirla, G. vesicaria, Triglochin paluslre, Epipactis palustris, Orchis uslulala, O. incarnala, Dianthus superbus, Stellaria palustris, Thalirlrum lucidum, Geum riuale, Lalhyjus palustris, Euphorbia pilosa. E. palustris, Lylhrum Saliraria, Laserpilium pruhthenirum. Lyssimachia Ihyrsiflora, Genliana Pneumonanthe. Teucrium Sromlinm, Pedicularis palustris, Taraxacum paludosum, Girsium canum, $C$. rivulare und $G$. oleraceum auf. An von Natur aus etwas trockeneren oder künstlich entwässerten Stellen aber herrschen an Gräsern Triselum flavescens und Avena pubescens vor, in deren Gescllschaft Aloperurus pratensis, Phleum pralense, Deschampsia caespilosa, Holcus lanalus, Polygonum Bislorlı, Trollins puropaens, Polenlilla anserina *sericer, Sanguisorlor officinalis, Linum calharlirum, Heracleum Spondylium, Pastinaca saliva, Symphylum offirinale, Cienlanter subjacea, Cirsinm rivulare, C. canum und das in Mähren nur hier wachsende Oslericum palustre gedeihen.

Die Wälder der Umgebung von Olmütz sind an den Ausläufern des Odergeboreres Fichten- und Tannenwälder mit eingesprengten Laubleslzbeständen,

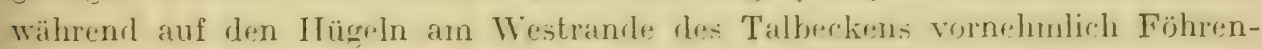
wälder mit Venlenala dubia, Cylisus supinus, Ci. ralisbonensis. Genisla germanica, Polenlille arenaria und Antennaria dioica vorherrschen. Von weit größerem Intresesse aber sind in der Olnützr. Fiora die Trift- und Steppenformationen, wie sie auf den Hügeln am Westrande der Olmützer Ebene, besonders bei Nebrotein, auftreten. Hier kommen u. a. vor: Phleum phlenides, Koeleria gracilis, Nebotein. Melica lranssilvanica, Gare.s humilis, Allium montanum. Dianthus Carthusianorum *hannensis, Silene Oliles, Anemone grandis, Prunus frulicosa, Cylisus ralisbonensis, C. Kilaibelii, Astragalus ranicus, Lavalera thuringiaca. Falcaria vulgaris, Verbascum phoeniceum, Asler Amellus und Arlemisia Absynthium. Auch östlich von Olmütz, bei Grügau, treten steppenartige Formationen mit Andropogon Ischaemum, Slipa capillala, Phleum phleoides, Cares humilis, Anemone grandis, Veronica spicala, Asler Amellus sowie Triften mit Polenlilla arenaria, Trifolium alpesire, Salvia pralensis, Verbascum phoeniceum, Cenlaurea rhenana, Cirepis praemorsa usw. auf. 


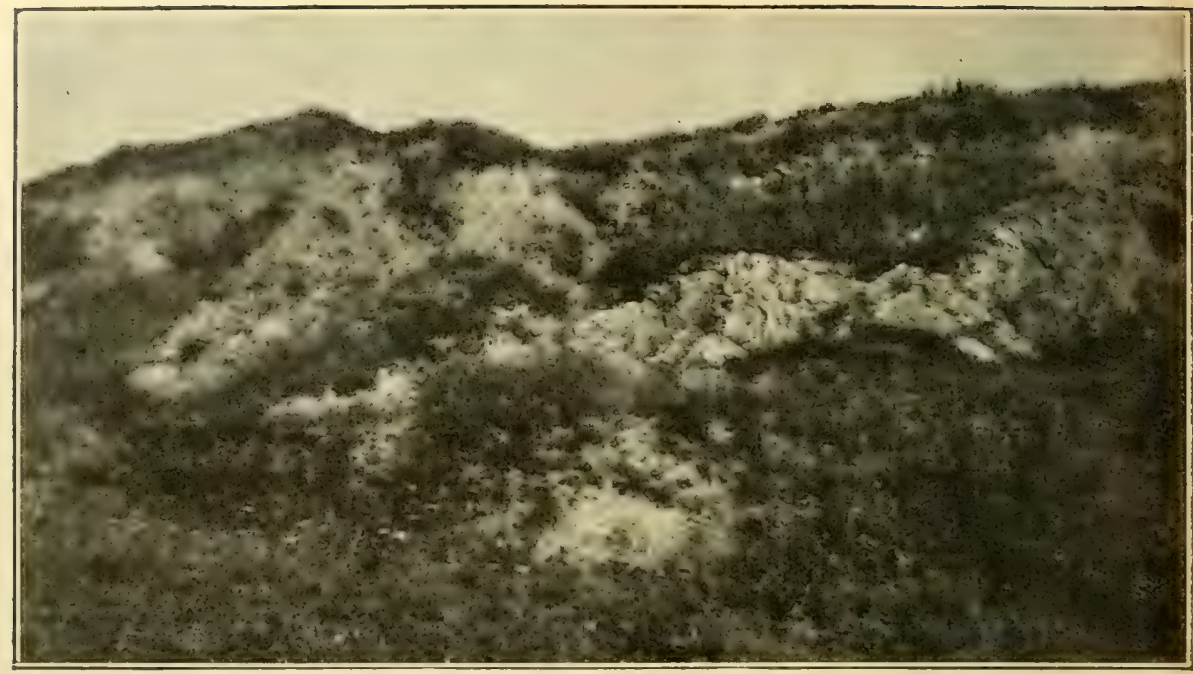

Abb. 113. C̈bergang zwischen Grassteppe und Felsentrift bei Nebotein nächst Olmütz (dev. Kalk).

Andropogon Ischaemurn, Brachypodium pinnatum, Bromus erectus, Koeleria gracilis, Dianthus Carthusianorum, Linum flavum, Asperula cynanchica, Achillea collina usw.

(Nach einer Aufnahme von J. Pauer, Olmütz.)

Solche Triftformationen finden sich auf fast allen Vorhügeln des Drahaner Proßnitz. Plateaus über Proßnitz bis gegen Kremsier zu. Bei Proßnitz findet man neben der Mehrzahl der eben genannten Arten auch Poa bulbosa, Carex Michelii, Anthericum ramosum, Ranunculus illyricus, Sempervivum soboliferum, Peucedanum alsaticum, Armeria elongata und Asperula glauca. Aber auch auf den Vorhügeln

Holleschau. der Karpathen, zwischen Prerau und Holleschau, treten ähnliche Triftformationen auf, in denen z. B. Andropogon Ischaemum, Phleum phleoides, Anthericum ramosum, Rosa gallica und Cytisus austriacus anzutreffen sind.

Kremsier. Am Südende der eigentlichen Hanna liegt die Stadt Kremsier. Auch hier sind auf den Hügeln der Umgebung gemischte Laubwälder aus Eichen, Hainbuchen, Linden und Ulmen, mit Unterholz aus Corylus Avellana, Crataegus Oxyacantha, Colutea arborescens, Cornus sanguinea und Ligustrum vulgare die herrschende Formation, in deren Niederwuchs Carex digilala, C. pilosa, C. Michelii, Brachypodium pinnatum, Convallaria maialis, Orchis militaris, Lathyrus vernus, L. niger, Trifolium alpestre, Stachys officinalis, Melampyrum nemorosum, Campanula persicifolia, C. Cervicaria, Inula salicina, Crepis praemorsa, Hieracium murorum die bezeichnendsten Arten sind. Seltener sind Buchenbestände; im Sternwalde und Ratayer Walde liommen auch Lïrchen vor. Reich sind auch him die pannonischen Triftformationen auf den Hügeln entwickelt, wo Carex Michelii. Adonis vernalis, Anemone grandis, Dictamnus albus, Lavalera Ihuringiaca, Polygala maior und Asler Amellus die auffallendsten Typen sind. Im Talboden der March aber sind auch hier Auenwälder aus Quercus Robur, Alnus glutinosa und Fraxinus excelsior mit Leucoium vernum, Galanthus nivalis, Allium ursinum, 
doch natürlich abgegrenzte und in pflanzengeographischer Bezichung halbwegs einheitliche Gebiete zur Grundlage zu wählen. Jedes dieser Kapitel enthält, nach Erfordernis mitunter in weitere Unterabschnitte zerlegt, eine Besprechung der klimatischen und Bodenverhältnisse in ihren Beziehungen zur Vegetation, an welche sich eine Schilderung der Zusammensetzung der einzelnen im Gebiete auftretenden Pflanzengenossenschaften unter steter Rüclisichtnahme auf ihre Abhängigkeit von den klimatischen und Bodenverhältnissen anschließt. Sodann folgt eine eingehende topographische Schilderung der Vegetation, Tal für Tal, Bcrgkelte für Bergliette, soweit deren Kenntnis von allgemeinerem Interesse ist, wobei sowohl dem Auftreten bestimmter Pflanzenbestände als auch den Verbreitungsgrenzen bezeichnender Arten und dem Vorkommen charakteristischer Typen entsprechende Aufmerksamkeit geschenkt wird. Eine große Zahl photograplischer Vegetationsbilder und Einzeldarstellungen von wichtigen oder bezcichnenden Arten wird diese Schilderung illustrieren.

Auf Grund der so auf induktivem Wege gewonnenen Resultate wird ein wciteres Kapitel unter Heranzichung paläontologischer Tatsachen die Entwicklungsgeschichte der Pflanzendecke Österreich-Ungarns seit der Tertiärzeit zum Gegenstande haben. Ein Schlußkapitel endlich wird den Versuch machen, eine Gliederung der Monarchic in cinzelne pflanzengeographische Gebiete durchzuführen, deren Resultat auf einer Florenkarte zum Ausdrucli gुebracht werden soll.

Der Text des Werkes ist so gehalten, daß er ohne die Grenzen streng wissenschaftlicher Darstellung zu überschreiten, für jeden nur lalbwegs mit der Pflanzenwelt Vertrauten verständlich ist. Die Kenntnis der wissenschaftlichen Namen der verbreitetsten Pflanzen muß allerdings bei jedem Leser des Buches vorausgesetzt werden, dies bringt schon die nach dem Inhalt des Werlies unvermeidliche Aufzählung von Pflanzenlisten mit sich; alle bemerkenswerteren weniger bekannten Arten jedoch werden bildlich dargestellt werden, da ja doch selbst dem Fachmann nicht alle Arten eines fremden Florengebietes geläufig sein können.

Eine so ins Detail gehende Darstellung der pllanzengeographischen Verhältnisse, wie sie im vorlicgenden Werke zu geben versucht wird, ist noch über kein Gebict von einer älınlichen Ausdehnung veröffentlicht, worden. Da aber ÖsterreichUngarn vermöge seiner geographischen Lage in Zentrum Europas und scines Übergreifen auf Gegenden von ausgesprochen ost- und südeuropäischem Charaliter, seines Anteiles sowohl an dem höchsten Gebirge Europas als an den großen östlichen und südlichen Ebenen in pflanzengeographischer Beziehung zu den interessantesten und wichtigsten Gebieten gehört, glaubt der Verfasser, daß gurade dieses Gobiet infolge der Mannigfaltigkeit seiner Flora sich zu einem ersten Versuche in diescr Hinsicht eignet. Die detaillierte Schilderung der Vegetation der kleinsten Gebiete aber soll nicht allein auf indulitivem WVege die Grundlage zu allgemeineren Ergebnissen bieten, sondern sic soll das Buch auch zu cincm crwünschten Nachschlagewerk für jeden, der sich über die Flora einer bestimmten Gegend rasch orientieren will, machen. Es wird auch die Lücken zeigen in unserem Wissen und darauf hinweisen, wo weitere Forschung einzusetzen hat, um unsere Kenntnis von der Pflanzendecke Österreich-Ungarns zu vervollständigen.

Das Buch stellt jedoch keine bloße Kompilation aus der sehr reichen, aber auch sehr zerstreuten und oft nur schwer zugänglichen Literatur dar, sondern der Verfasser hat auch den größten Teil des Gebietes aus eigener Anschauung kennen zu lernen Golegenheit gehabt, was allein ihn in den Stand setzte, die Forschungsergebnisse so vicler zu einem einheitlichen Ganzen zusammenzufïgen, was aber auch zur Folge hat, daß in dem IVerke eine Reihe von eigenen Beobrichtungen des Veriassers eingestreut ist, ganz abgesehen davon, daß sowohl die $A b$ grenzung der einzelnen Formationen als auch die beiden Kapitel über die Entwicklungsgeschichte der Flora und über die pflanzengeographische Gliederung des Gebietes die persönlichen Anschauungen des Verfassers wiedergeben. 
Die Erscheinung der Anisophyllie. Eine morphologisch-physiologische Studie von Dr. Wilhelm Figdor, Privatdozent für Anatomie und Physiologie an der k. k. Universität in Wien. Mit 23 Abbildungen im Text und 7 Tafeln in Lichtdruck.

Preis M. $7 \cdot \rightarrow=K 8.40$.

Führer zu den wissenschaftlichen Exkursionen des II. internationalen Kongresses Vien 1905. Herausgegeben vom Organisationskomitee des II. internationalen botanischen Kongresses unter Mitwirkung von A. Cieslar, A. Ginzberger, H. Freih. V. Handel-Mazzetti, A. V. Hayek, K. Maly, V. Schiffner, F. Vierhapper und E. Zederbauer. Mit 52 Lichtdrucktafeln, 1 Titelbild und 12 Textabbildungen.

Preịs in Mappe $M .20^{\circ}-=K 20^{\circ}$.

Einhïhrung in die Biochemie für Naturhistoriker und Mediziner. Von Dr. Viktor Grafe, Privatdozent an der Wiener Universität. Mit 41 Abbildungen im Text.

Preis M. $13^{-}-=K \quad 15 \cdot 60$.

Monographie der Gattung Taraxacum. Von Dr. Freih. v. Handel-Mazzetti, Assistent am botanischen Institut der k. k. Universität in Wien. Mit 2 Tafeln in Lichtdruck, 3 lithographischen Tafeln und 2 Karten.

Preis M. $15^{\circ}-=K 18^{\circ}-$.

Flora von Brixen a. E. Ein mit Standorts- und Höhenangaben versehenes Verzeichnis der im weiteren Gebiete von Brixen a. E. (Südtirol) beobachteten wildwachsenden höheren Sporen- und Samenpflanzen, der Nutzgewächse und Ziergehölze. Verfaßt von Dr. Anton Heimerl. Mit einer aus dem Legate Scholz gewährten Unterstützung der kaiserl. Akademie der Wissenschaften in Wien.

Preis M. $8 \cdot-=K 9 \cdot 60$.

Die curopäischen Gattungen der Farn- und Blütenpilanzen nach dem Wettsteinschen System geordnet von Erwin Janchen. Zweite, verbesserte Auflage. Preis M. $2 \cdot-=K 2 \cdot 40$.

Flora des österreichisehen Küstenlandes. Von Eduard Pospichal. Mit 25 Tafeln und einer Karte des österreichischen Küstenlandes. Zwei Bände in drei Teilen. Preis eines jeden Teiles geh, M. $8^{\circ}-=K 9 \cdot 60$, geb. M $10^{\circ}-=K 12-$.

Lehrbuch der Pilanzenkunde für die unteren Klassen der Mittelschulen von Dr. Rudolf Scharfetter, k. k. Professor an der II. Staatsrealschule in Graz. Mit 201 Abbildungen im Text und 48 farbigen Tafeln.

Preis geb. M. $3 \cdot 60=K 4 \cdot$.

Handbuch der systematisehen Botanik. Von Dr. Richard R. v. Wettstein, Professor an der Universität in Wien. Zweite, umgearbeitete Auflage. Mit 3692 Figuren in 600 Abbildungen und mit einer farbigen Tafel.

Preis geh. M. $20:-=K 24^{\circ}-$, geb. M. $26 \cdot 60=K 32 \cdot-$.

Vegetationsbilder aus Südbrasilien. Von Dr. Richard R. v. Wettstein, Professor an der Universität in Wien. Mit 58 Tafeln in Lichtdruck, 4 farbigen Tafeln und 6 Textbildern.

Preis in Mappe M. $24 \cdot-=K 28 \cdot 80$.

Die Samenpilanzen. (Blü tenpflanzen, Phanerogamen.) Systematische Ưbersicht ihrer Familien und wichtigeren Gattungen und Arten mit besonderer Berücksichtigung der für Land- und Forstwirtschaft, Technik und Arzneikunde in Betracht kommenden Gewächse von Dr. Karl Wilhelm, o. ö. Professor der Botanik an der k. k. Hochschule für Bodenkultur in Wien. Mit einem Anhange, enthaltend eine Úbersicht der wichtigsten kryptogamen Nutzpflanzen. $\quad$ Preis geh. M. $5 \cdot-=K 6 \cdot-$, geb. M. 6.20 $=K 7 \cdot 40$ 


\section{DIE PFLANZENDECKE ÖSTERREICH-UNGARNS}

AUF GRUND FREMDER UND EIGENER FORSCHUNGEN GESCHILDERT

VON

Dr. AUGUST EDLER voN HAYEK,

PRIVATDOZENT FÜR SYSFEMATISCHE BOTANIK AN DER UNIVERSITÄT WIEN.

HERAUSGEGEBEN MIT EINEM DRUCKKOSTENBEITRAG

DER KAISERLICHEN AKADEIIE DER WISSENSCHAFTEN IN WIEN.

VOLLSTÄNDIG IN ZWEI BÄNDEN YON ETWA JE 5 LIEFERUNGEN.

MIT ZAHLREICHEN ABBILDUNGEN UND TAFELN.

PREIS JEDER LIEFERUNG $6 K=5 \mathrm{Mk}$.

I. BAND.

3. LIEFERUNG.

LEIPZIG UND WIEN.

FRANZ DEUTICKE.

1914.

Verlags-Nr。2110. 
Verlag von Franz Deuticke in Leipzig und Wien.

\section{Die Erscheinung der Anisophyllie.}

Eine morphologisch-physiologische Studie

$$
\text { von }
$$

Dr. Wilhelm Figdor,

Privatdozent für Anatomie und Physiologie der Pflanzen an der k. k. Universität in Wien.

Mit 23 Abbildungen im Text und 7 Tafeln in Lichtdruck.

Preis M. $7 \cdot-=\mathrm{K} 8 \cdot 40$.

\section{Landwirtschaftliche Pflanzenzüchtung} und ihre Stätten in Österreich.

Dargestellt von

Prof. C. Fruhwirth,

diplomierter Landwirt, Dozent an der $k_{0} \mathrm{k}$. Hochschule für Bodenkultur. Preis M. $1 \cdot 80=\mathrm{K} 2$. .

\section{Führer zu den wissenschaftlichen Exkursionen}

des II. internationalen Kongresses Wien 1905.

Herausgegeben rom

Organisationskomitee des II. internationalen botanischen Kongresses unter Mitwirkung von

A. Cieslar, A. Ginzberger, H. Freih. v. Handel-Mazzetti, A. v. Hayek, K. Maly,

V. Schiffner, F. Vierhapper und E. Zederbauer.

Mit 52 Lichtdrucktafeln, 1 Titelbild und 12 Textabbildungen.

Preis in Mappe M. $20^{\circ}-=$ K 20.

\section{Einführung in die Biochemie}

für Naturhistoriker und Mediziner.

$$
\text { Von }
$$

Dr. Viktor Grafe,

Privatdozent an der Wiener Universität.

Mit 41 Abildungen im. Text.

Prois M. $13 \cdot-=\mathrm{K} 15 \cdot 60$.

\section{Die Forstbetriebseinrichtung.}

Fuir Studierende und ausuibende Fachmänner dargestellt von

Dr. Adolf Ritter. $\nabla$. Guttenberg,

k. k. Hofrat und o. ö. Professor an der $k$. k. Hochschule für Bodenkultur in Wien.

Zweite Auflage.

Mit 3 Tafeln in Farbendruck und 41 Figuren im Text.

Preis geh. M. $10-=\mathrm{K} \mathrm{12}-$, geb. M. $11 \cdot 20=\mathrm{K} 13 \cdot 40$.

\section{Monographie der Gattung Taraxacum.

$$
\text { Von }
$$

Dr. Heinrich Freiherr v. Handel-Mazzetti,

Assistent am botanischen Institut der $\mathbf{k}$; $\mathbf{k}$, Universität in Wien.

Mit 2 Tafeln in Lichtdruck, 3 lithographischen Tafeln und 2 Karten.

Preis M. 15: = K 18.

\section{Flora von Brixen a. E.}

Ein mit Standorts- und Höhenangaben versehenes Verzeichnis der im weiteren Gebiete von Brixen a. E. (Siidtirol) beobachteten wildwachsenden höheren Sporen- und Samenpflanzen, der Nutzgewächse und Ziergehölze.

Verfaßt von

Dr. Anton Heimerl.

Mit einer aus dem Legate Scholz gewährten Unterstützung der kaiserl. Akademie der Wissenschaften in Wien.

Preis MI. $8 \cdot-=\mathrm{K} 9 \cdot 60$. 


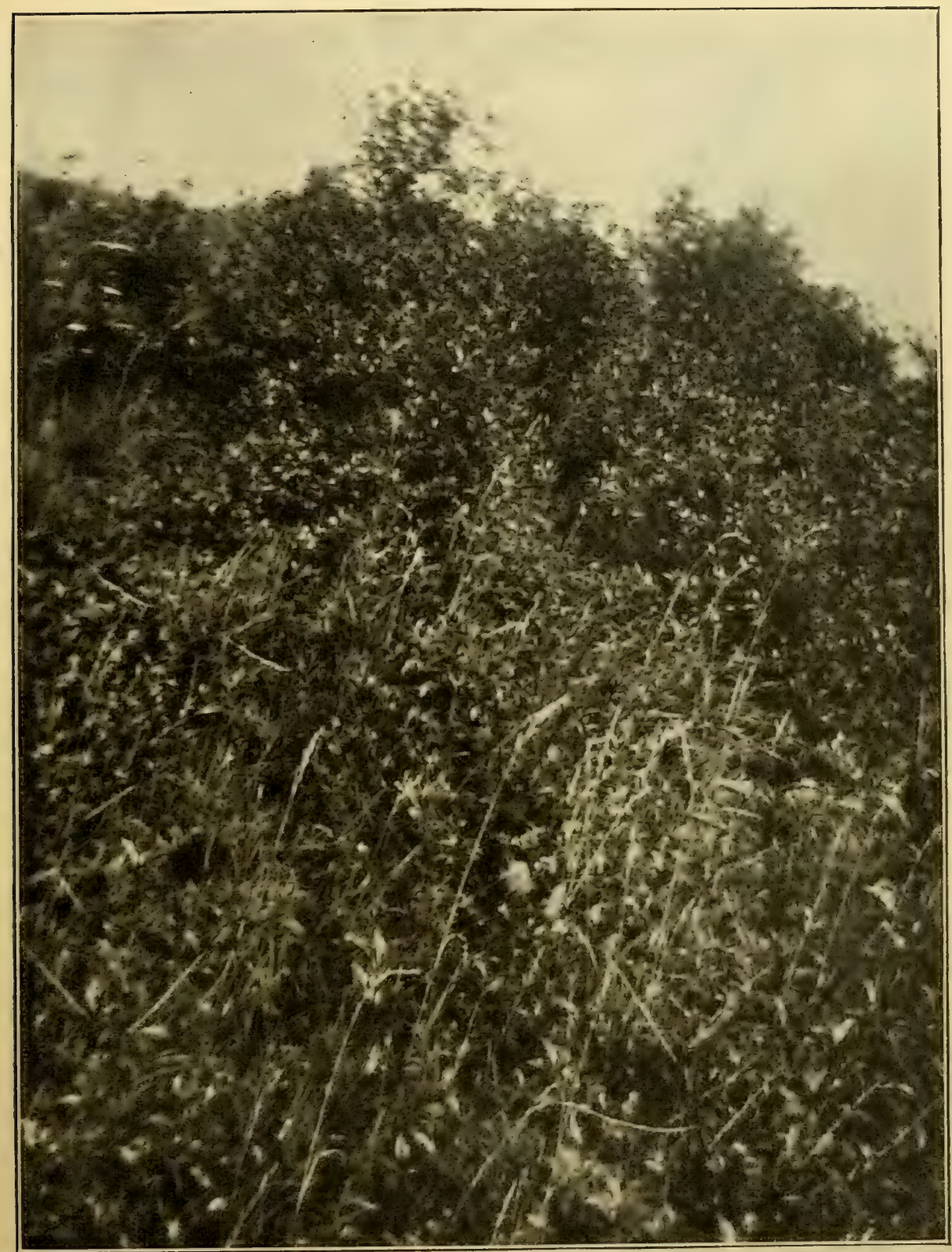

Abb. 114. Buschwerk aus Prunus fruticosa, P. spinosa und Rosa glauca bei Grügau südlich von Olmütz.

Im Vordergrund Steppe mit Bromus erectus, Brachypodium pinnatum, Stachys recta, Achillea collina usw.

(Nach einer Aufnahme von J., Pauer, Olmütz.)

Paris, Anemone ranunculoides, Urtica dioica, Alliaria officinalis, Aegopodium Podagraria, Leonurus Marrubiastrum sowie Wiesen mit Colchicum, Allium angulosum, Euphorbia palustris, Cardamine pratensis, Lychinis Flos Cuculi. Panunculus

Hayek, Die Pflanzendecke Österreich-Ungarns, I. 
acer, Trifolium fragiferum, Teucrium Scordium, Cirsium canum usw. entwickelt; in stehenden Gewässern bei Bilan kommt Holtonia palustris vor.

Nordwestlich von Kremsier dringt die pannonische Flora durch das Wischau. Tal der Hanna bis nach Wischau vor und zeigt sich gerade dort in reichster Entwicklung, da sich hier, besonders an der ,Bílá skála“ bei Drysic neben anderen verbreitetern Arten Phleum phleoides, Dianthus Carthusianorum, Prunus frulicosa, Polentilla arenaria, Seseli austriacum, Linum flavum, Scabiosa canescens, Brunella grandiflora, Asler Linosyris und Aster Amellus vorfinden. Auch im Süden der Stadt, bei V ě tr n ík und D r a žo v i c, treten steppenartige Formationen mit Andropogon Ischaemum, Stipa capillala, Allium montanum, Iris variegata, Anemone grandis, Adonis vernalis, Oxytropis pilosa, Peucedanum Cervaria, Polygala maior, Phlomis tuberosa, Campanula sibirica, Asperula cynanchica, Aster Amellus, Hypochoeris maculata usw. auf.

Das von den Ausläufern des Böhmisch-mährischen Höhenzuges gegen

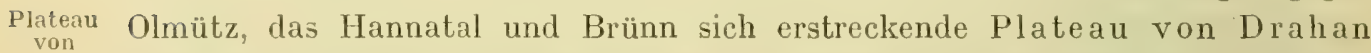
Drahan. ist fast durchwegs ein Laubwaldgebiet, in welchem gemischte IVälder aus Eichen, Hainbuchen, Ahornen, Linden und eingesprengten Föhren, in deren Niederwuchs neben Anemonen und Leberblümchen (Anemone nemorosa und A. Hepatica) insbesondere die gelbblühenden Gaisklee- und Ginsterarten, wie Genista tincloria, G. germanica und Cylisus ralisbonensis, Wachtelweizen (Melampyrum nemorosum und M.vulgatum), die pfirsichblätterige Glockenblume (Campanula persicifolia) und Waldmeister (Asperula odorala) die bezeichnendsten Typen sind. Die IViesen des Gebietes bieten außer dem häufigen Vorkommen von Saxifraga granulata Proti- kaum etwas Bemerkenswertes; doch kommt bei Protiwanow noch der sudeto-
wanow. karpathische Gladiolus imbricalus und in Wäldern daselbst Polygonalum vertiZwittawa- cillalum vor. Im Z wittaw atale reichen manche Arten des Böhmisch-mährischen
tal. tamsthal. Höhenzuges bis Adamsthal und selbst bis in die Gegend von Brünn herab, so in den Wäldern Polygonalum verticillatum, Cephalanthera alba, C. longifolia und C. rubra, Melittis Melissophyllum, Pleurospermum austriacum, Sorbus torminalis, Ribes alpinum, auf Wiesen Phyteuma orbiculare, Gentiana Pneumonanthe und Cirsium rivulare; in feuchten Gebüschen sind Omphalodes scorpioides und Asperula rivalis häufige Erscheinungen. Von besonderem Interesse

Sloup. aber ist die Flora der Urkalkfelsen bei Blansko und Sloup, wo sogar subalpine Arten vorkommen, wie Saxifraga Aizoon und Sesleria varia, die hier neben Melica ciliata, Anthericum ramosum und Artemisia Absynllium gedeihen; auch

Blansko. kommen bei Blansko die karpathische Actaea Cimicifugia sowie das in Mähren nur hier anzutreffende Cynoglossum germanicum vor. Auch die Felsen der

Mazocha. Mazocha bei Willimowitz beherbergen eine ähnliche Flora, da auch hier Asplenium viride, Sesleria varia, Alyssum Arduini, Biscutella laevigata, Actaea Cimicifugia, Thalictrum aquilegifolium, Sedum album und Saxifraga Aizoon gedeihen.

Lomnitz. Auch in der Gegend von Lomnitz und Tischnowitz, wo ebenfalls gemischte Laubwälder, aber auch reine Buchenbestände vorkommen, treten noch einzelne Gebirgsarten auf, wie Cardamine enneaphylla, C. bulbifera, Vicia 


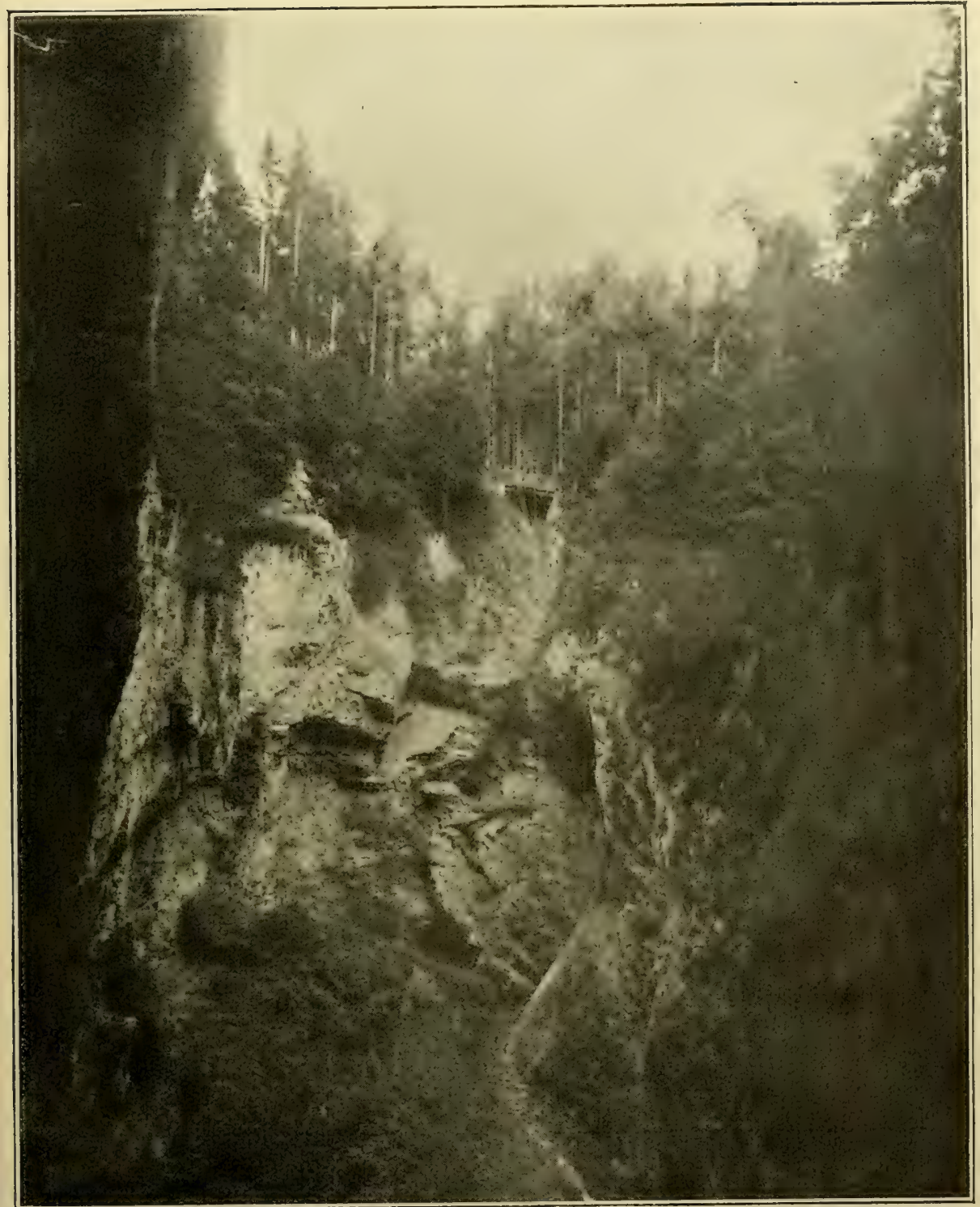

Abb. 115. Die Mazocha.

Auf den Höhen Mischwälder, an den Hängen diverse Felsenpflanzen.

(Nach einer Aufnahme von M. Eisler.)

(Aus der Bildersammlung des geographischen Institutes der Wiener Universität.)

silvatica, Ribes alpinum, Sanicula europaea sowie besonders im Schwarzawatale Cyclamen europaeum; auf der Květnitza nächst Tischnowitz an Kalk- Tischfelsen trifft man wieder Saxifraga Aizoon an. Von Tischnowitz abwärts aber treten im Schwarzawatale immer häufiger Arten der pannonischen Triftformation auf, so insbesondere Andropogon Ischaemum, Clematis Vitalba, Anemone 
nigricans, Cytisus nigricans, C. ralisbonensis, Artemisia Absynthium und auch Quercus Cerris und Qu. pubescens, ferner die subalpine Sesleria varia. Typisch entwickelt aber trifft man diese Bergtriften in der Umgebung der Landeshaupt-

Brünn. Hadiberg. stadt Brünn an, besonders im Nordwesten der Stadt auf dem Hadiberge. Hier ist besonders im Frühling ein reicher Blütenflor seltener Arten anzutreffen, so von Gräsern neben Carex Michelii und Andropogon Ischaemum auch das zarte Waisenmädchenhaar (Stipa pennata), häufig ist die große blauviolette Küchenschelle (Anemone grandis), die im Vereine mit goldgelben Fingerkäutern (Potentilla arenaria) und Ginster (Cylisus procumbens) die Hauptmasse der

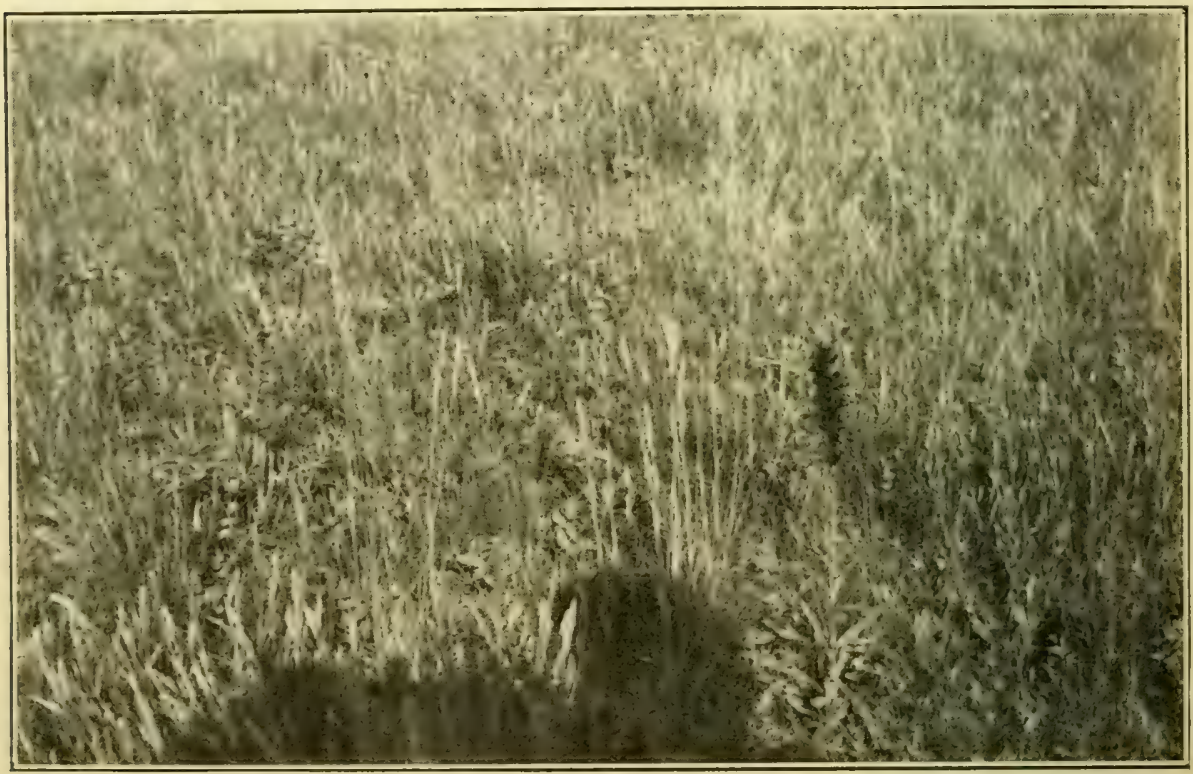

Abb. 116. Steppenwiese bei Schlapanitz nächst Brünn mit Phleum phleoides und Echium rubrum.

(Nach einer Aufnahme von Prof. H. Iltis, Brünn.)

Tegetation bildet, ferner kommen hier der prächtige Diclamnus albus, Scorzonera purpurea, Sideritis montana, Lithospermum purpureo-coeruleum, Geranium sanguineum. Coloneaster inlegerrima und als Seltenheit Himantoglossum hircinum und Iris variegata an den kahlen Hängen vor, während im Walde u. a. Hierochlö̈ australis, Pulmonaria mollissima und Euphorbia angulata anzutreffen .sind. Kuhberg. Auch der Kuhberg birgt einige seltene Arten, wie Gagea bohemica und auch Lateiner-
berg. montana und das seltene Thesium Dollineri und östlich von Brünn, bei Schlapanitz, treten neben Buschgehölzen auch steppenartige Wiesen auf, auf denen u. a. Echium rubrum vorkonmt. Ziemlich weit dringt die pannonische Flora Oslawatal. durch das Iglawa- und Oslawatal ins Bergland ein. Bis Oslawan reichen Eiben- Lavalera thuringiaca, Geranium sanguineum, Linum lenuifolium und Adonis

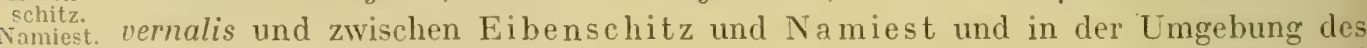


letzteren Ortes treten an felsigen Hängen Slipa capillata, Allium flavum, Clematis recta, Alyssum Arduini, A. montanum, Silene Oliles, Trifolium rubens, Prunus Mahaleb, Seseli Hippomaralhrum, S. austriacum, Inula hirta usw. auf, während Oslawan. zwischen Sennohrad und Oslawan in Gesellschaft von Saxifraga Aizoon auch Saxifraga decipiens sich findet. An den Kammerteichen bei Namiest kommt das seltene Gras Coleanthus sublilis vor. In den IVäldern der Umgebung ist neben Vaccinien, Pirolaarten, Astrantia maior usw, auch Cyclamen europaeum überall häufig. Im Iglawatale bei II ohelno treten auch Serpentinfelsen zutage, Mohelno. die eine interessante Flora beherbergen; hier gedeihen Carex humilis, Euphorbia Gerardiana, E. polychroma, Bisculella laevigala, Prunus Mahaleb, Armeria clongala, Aster Linosyris, Senecio erucifolius, Linaria genistifolia sowie der Serpentinfarn Asplenium cuneifolium und die südliche, hier ihre Nordgrenze erreichende und im Norden oft auf Serpentin auftretende Notochlaena Marantae. Auch bei Mährisch - Kromau sind wärmeliebende Arten in ziemlich beträchtlicher Anzahl anzutreffen, so Allium flavum, Anemone nigricans, Ranunculus Mähr.-
Kromau. illyricus, Aconilum Anthora, Sempervivum soboliferum, Saxifraga Aizoon, Alyssum monlanum, Verbascum phoeniceum, Melampyrum cristalum, Linaria genislifolia usw.

Schon bei Namiest treten neben gemischten Laubwäldern auch Buchenund Nadelholzbestände auf und nehmen nach Westen und Süden zu immer mehr überhand. Bei Mährisch-Budwitz sind aus Föhren, Fichten und Lärchen zusammengesetzte Wälder, in deren Niederwuchs Ventenala dubia und Sarolhamnus bemerkenswert sind, die herrschende Formation; an sonnigen Hängen treten hier nur mehr Andropogon Ischaemum, Allium monlanum, Dianthus Carthusianorum und Scabiosa ochroleuca auf. Gegen das Thayatal zu aber, wie um Frain und Hardegg, nehmen die Wälder immer mehr den Charakter von Gebirsgwäldern an. Föhren, Fichten und Lärchen, mit eingesprengten Exemplaren von Fagus silvalica und Sorbus Aria bilden hier das Oberholz, in dem bei Hardegg auch Taxus baccala auftritt; im Unterholz findet sich stellenweise Staphylea pinnala, für den Niederwuchs aber sind insbesondere Melica nutans, M. picta, Carex digitata, Lilium Martagon, Isopyrum thalilroides, Aconitum Vulparia, Cardamine bulbifera, Hypericum hirsutum, Astrantia maior, Salvia glutinosa, Cyclamen europaeum, Senecio nemorensis und die karpathische Actaea Cimicifugia bezeichnend. Im auffallenden Gegensatz zu diesen ernsten Bergwäldern ist die große Zahl östlicher und thermophiler Arten, die an den Felshängen des Thayatales gedeihen, wie bei Frain Andropogon Ischaemum, Stipa capillata, Melica ciliata, Allium montanum, Iris variegata, Anemone grandis, A. nigricans, Aconitum Anthora, Biscutella laevigata, Bupleurum falcalum, Libanotis monlana, Cotoneaster integerrima, Rosa gallica, Stachys germanica, St. recla, Linaria genistifolia, Cynachum Vinceloxicum, Asperula glauca, Achillea Veilreichii, Centaurea rhenana, C. variegata, Hieracium echioides; bei Hardegg neben den Hardegg. meisten der genannten Arten auch Aconitum variegatum, Alyssum Arduini, Saxifraga decipiens, Genliana Sturmiana, Primula veris var. hardeggensis, Inula Oculus Chrisli und Buphthalmum salicifolium, bei Schloß Neuhäusel Verbascum Neuhäusl. 
speciosum, Echinops sphaerocephalus und Arabis hirsula; auch am Geisteige bei Luggau ist die Mehrzahl der genannten Arten zu finden.

Znaim.

Weiter talabwärts, gegen Znaim zu, nimmt das Laubholz wieder überhand und Bestände aus Quercus Robur, Qu. sessiliflora und Carpinus Belulus sind dortselbst an den Hängen des Thayatales und im Hügellande vorherrschend. Reich ist auch die pannonische Triftformation im Znaimer Hügellande entwickelt, besonders im Thaya- und Leskatale, bei Poppitz, Esseklee und auf dem Kuhberge. Besonders häufig sind hier Stipa pennata, Poa bulbosa,

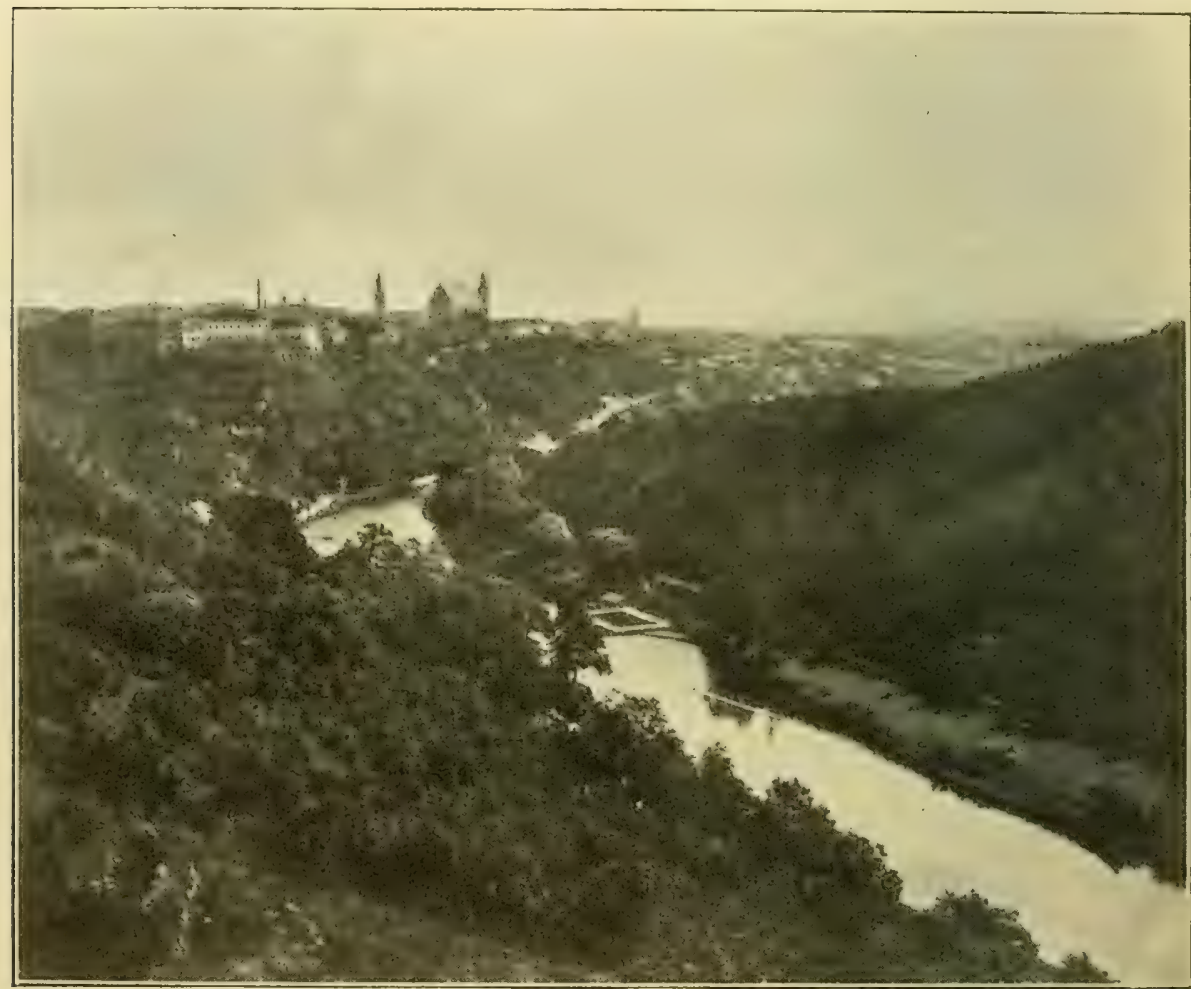

Abb. 117. Das Thayatal oberhalb Znaim.

An den Hängen sommergrünes Buschwerk und Triftormationen.

(Nach einem Diapositiv aus der Sammlung des geographischen Institutes an der Wiener Universität.)

Alyssum Arduini, Anemone silvestris, A. grandis, Stachys recta, Nonnea pulla, Odontites lutea, Artemisia Absynthium, Inula Oculus Christi, Centaurea rhenana, Thayatal. Hieracium cymosum, H. echioides, ferner im Thay atale Allium sphaerocephalum Granitztal. und Echinops sphacrocephalus, im Granitztale Echinops, Ranunculus illyricus und Minuarlia selacea. Nicht selten tritt auf Granit und Gneißboden eine eigenartige Mischung von Elementen der mitteleuropäischen Sandheide und der pontischen Steppe auf, so im Thayatale, auf dem Pelzberge bei Mühlfraun und zwischen $\mathrm{Zn}$ a im und $\mathrm{T}$ a $\beta \mathrm{witz}$, wo neben Corynephorts canescens, $F$. glauca, 
Scleranthus perennis, Calluna vulgaris, Armeria elongala, Androsace elongata, Veronica Dillenii, Jasione monlana und Helichrysum arenarium auch Stipa capillala, Festuca sulcala, Silene Otites, Dianthus Carthusianorum, Anemone grandis, Ranunculus illyricus, Nonnea pulla, Hieracium cymosum, H. echioides, $H$. setigerum und bei II ühlfraun auch Echium rubrum vorkommen.

Mühlfraun.

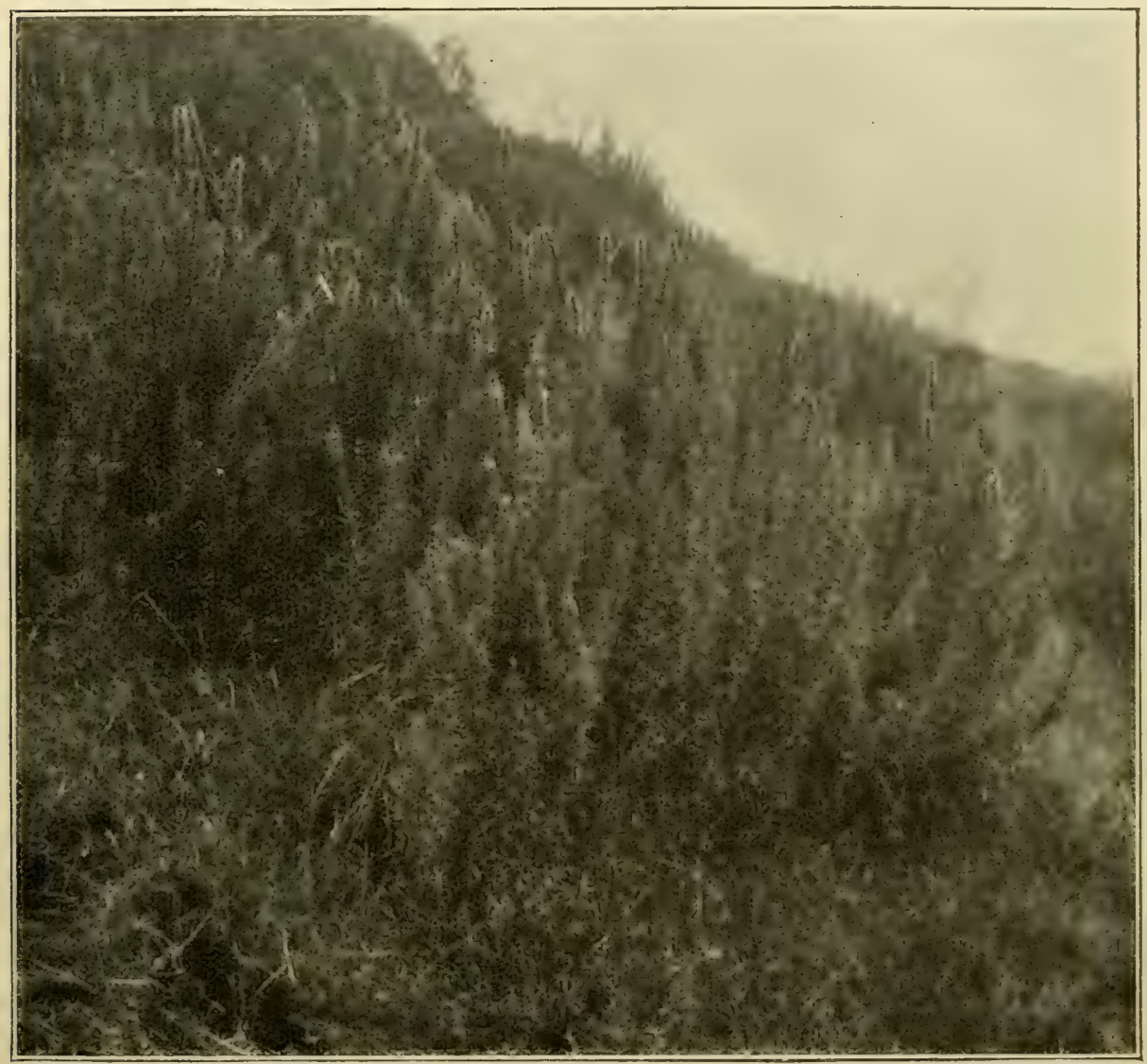

Abb. 118. Eurotia ceratoides auf den Steppen bei Goggendorf nächst Eggenburg.

(Nach einer Aufnahme von Dr. A. Ginzberger, Wien.)

(Aus der Bildersammlung des botanischen Institutes der Wiener Universität.)

Auch weiter siidwestlich, bei Retz und Pulkau herrschen auf den kahlen Abhängen diese eigenartigen Heiden vor, in denen bei Retz auch Carex supina, Gagea bohemica und Achillea Neilreichii, bei Pulkau auch noch Iris Retz. arenaria auftreten, während die Wälder daselbst hauptsächlich Föhrenwälder mit eingemischten Fichten und Ventenala dubia im Nicderwuchs darstellen. Auch nach Süden zu erstrecken sich bis gegen Eggenburg Föhrenbestände, von Tul-Ezxenlurg. turen und eintönigen Heiden mit Koeleria gracilis usw. unterbrochen, bei Goggendorf, zwischen Eggenburg und Sitzendorf aber treten Steppenformationen Eqenlurg. mit Iris pumila, Eurolia ceraloides, Reseda Phyleuma, Astragalus exscapus, 
Oxylropis pilosa, Phlomis luberosa, Aster Linosyris, Echinops ruthenicus und Horn. Jurinea mollis auf. Um Horn sind wieder Nadelwälder aus Fichten und Föhren tonangebend, in denen bei Kotzendorf noch Thalictrum aquilegifolium, bei Siegmundsherberg Pelasiles albus auftritt; ab und zu trifft man auch kleine Buchenbestände, wie im Spitalwalde, Hornerwalde und Eibenbachgraben; auf trockenen Grasplätzen sind Scleranthus perennis, Dianthus Carthusianorum, Anemone silvestris, Veronica prostrala und Jasione monlana häufig; an den Steilhängen der aus dem Granitplateau des Waldviertels sich herabziehenden Täler aber hat sich eine reiche thermophile Flora angesiedelt, wie im Mödringergraben und Taffatale, wo u. a. Gagea bohemica, Allium flavum, Tunica Saxifraga, Aconitum Anthora, Geranium sanguineum, Astragalus Onobrychis, Cyclamen europaeum, Pulmonaria mollissima und Aster Amellus, ferner bei Mödring Dictamnus albus wachsen. Ähnliche Verhältnisse herrschen auch im Kamptale, wo an den Hängen Buschwerk aus Quercus Robur und Carpinus Belulus, ferner Allium flavum, Bupleurum falcalum und vor allem das prächtige Aconitum Anthora, beim „Öden Schloß" auch Stipa pennata gedeihen.

Das Tiefland an der unteren Iglawa und Schwarzawa sowie die Abfälle der am linken Ufer der letzteren gelegenen Hügel stellen ein Gebiet dar, in welchem der Boden an vielen Stellen Salz auswittert und wo dann eine charakteristische Tellnitz. Halophytenflora anzutreffen ist. Schon zwischen Tellnitz, Mönitz und Ottmarau liegt ein solches Gebiet, doch mußte die ehemals sehr reiche Halophytenflora dort fast ganz der Kultur weichen und nur auf Hutweiden und ottmarau. an Gräben findet man noch hie und da, wie bei Ottmarau, Crypsis aculeata, Heleochloa schoenoides, Carex hordeistichos, Spergularia salina, Althaea officinalis, Bupleurum tenuissimum, Planlago maritima, Taraxacum bessarabicum usw.; auch zwischen GroB-Seelowitz und NuBlau kommen einige dergenannten Pausram. Arten vor. Bei Pausram ist besonders das häufige Vorkommen von Aster Tripolium in den Gräben längs der Bahn auffallend, auf dem Kolben bei Auerschitz hingegen sind typische Stipasteppen mit Iris pumila, Polygala maior, Dictamnus atbus usw. entwickelt. Reicher ist die Halophytenvegetation Auspitz. um Auspitz. Schon um den Bahnhof herum sind Atropis distans, Juncus Gerardi, Plantago maritima usw: nicht selten, nicht weit davon aber liegt ein ausgesprochenes Halophytenterrain, wo Salicornia herbacea, begleitet von Suaeda maritima, Spergularia salina, S. media, Atriplex hastala, Plantago maritima, Asler Tripolium und Scorzonera parviflora Bestände bildet, während an Gräben Scirpus maritimus, Schoenopleclus Tabernaemonlani, Phragmites communis, Rumex odonlo-

Saitz. carpus und Aster Tripolium gesellig auftreten. Auch bei Saitz treten besonders an den Bahngräben die genannten Arten auf, hingegen ist die reiche HalophytenCzeitsch. flora der Uferwiesen am Kobyli- und Cizeitscher See bis auf wenige Arten, wie Crypsis aculeata, Salicornia herbacea, Suaeda maritima, Spergularia salina, Samolus Valerandi, Glaux maritima Asler Tripolium infolge der Umwandlung Grußbach. des Bodens zu Kulturland verschwunden. Endlich sind auch zwischen Grußbach und Nikolsburg, bei Neu-Prerau, Fröllersdorf usw. mehrere Stellen mit typischer Halophytenflora (u. a. Heleochloa schoenoides, Salicornia 
herbacea, Suaeda marilima, Spergularia salina, Sp. media, Trifolium fragiferum, Bupleurum lenuissimum, Glaux marilima, Samolus Valerandi, Plantago marilima, Scorzonera parviflora erhalten. Bei Kobyli trifft man feuchte Wiesen mit Kobyli. Triglochin palustre, Rumex maritimus, Inula salicina und Senecio Doria sowie Eichenwälder.

Der Zug des Hradiskoberges und der Steinitzer Wald sind besonders Steinitzer an ihren nördlichen und westlichen Hängen hauptsächlich von gremischten Laubwäldern aus Eichen, Hainbuchen, Linden, Ahornen, Ulmen usw. bedeckt, deren Unterholz Cralaegus Oxyacantha, Prunus spinosa, Cornus-, Evonymus-, ViburnumArten, Staphylea pinnata usw. bilden, während im Niederwuchs Melica nutans, M. uniflora, Fesluca gigantea, Luzula campestris, L. nemorosa, Polygonatum multiflorum, Convallaria maialis, Neoltia Nidus avis, Anemone Hepalica, Isopyrum thalictroides, Aconilum Vulparia, Cardamine bulbifera, Euphorbia amygdaloides, Pulmonaria obscura, Digitalis ambigua, Lamium luteum, Asperula odorala, Hieracium murorum allgemein verbreitet sind. An den Süd- und Osthängen aber breiten sich Trift-und Steppenformationen, unterbrochen von niedrigem, sommergrünem Buschwerke, aus. So treten am Südabhange des Steinitzer Waldes Klobouk. bei Klobouk, besonders bei Grumir̆, Slipa pennala, Carex humilis, Iris pumila, I. variegata, Thesium Dollineri, Melandryum viscosum, Astragalus austriacus, A. asper, Seseli varium, Echium rubrum, Phiomis tuberosa, Arlemisia auslriaca, Senecio campestris, Girsium pannonicum, Jurinea mollis, an etwas salzhaltigen Stellen Lepidium latifolium und Taraxacum bessarabicum und an feuchten Gräben Senecio Doria auf. Reicher noch ist die Flora dieser Steppen um Nikolěic zwischen Auspitz und Klobouk, wo auch Crambe latarica, Nepeta nuda und die hier ihre Westgrenze erreichende Crepis rigida, die auch bei Boschowitz nächst Klobouk vorkommt, angetroffen werden. Auch um Czeitsch treten ähnliche Steppenformationen auf, die u. a. Poa bulbosa, Adonis vernalis, Linum austriacum, Astragalus exscapus, A. danicus, A. Onobrychis, Oxylropis pilosa, Euphorbia Gerardiana, Daphne Cneorum, Trinia vulgaris, Verbascum phoeniceum, Globularia IVillkommii, Campanula sibirica, Scorzonera austriaca aufweisen.

Ähnliche Verhältnisse weist auch das Marsge birge auf. In tieferen Lagen, besonders gegen die March zu, treten hier Föhrenwälder mit Calamagrosls Epigeios, Sieglingia decumbens, Sarothamnus scoparius, Cylisus nigricans usw. auf; hauptsächlich aber sind die Wälder Birkenbestände oder gemischte Laubholzbestände aus Fagus silvatica und Carpinus Belulus mit eingesprengten Eichen, Ahornen, Linden und in höheren Lagen, wie bei Welehrad, Schwabenitz usw. auch nicht selten Tannen und der vielfach angepflanzten Lärche. Im Niederwuchs dieser Wälder gedeihen Carex silvatica, C. pilosa, Allium ursinum, Maianthemum bifolium, Neoltia Nidus avis, Cephalanthera alba, C. longifolia, Euphorbia amygdaloides, Isopyrum thalictroides, Corydalis cava, Cardamine bulbifera, Astranlia maior, Lathyrus vernus, Pulmonaria obscura, Melampyrum nemorosum sowie zahlreich die jenseits der March in den Karpathen sehr häufige und charakteristische Hacquetia Epipactis. in höheren Lagen, wie auf dem Brdo, wachsen auch Hordeum europaeum, Carex 
muricala, Pirola minor und Vaccinium Myrlillus, während $V$. Vilis Idaea bereits fehlt, und als Seltenheit wurde bei Vlčak,nächst Strílek auch Epipogium aphyllum beobachtet. Am Fuße des Gebirges, besonders gegen die March zu, sind aber Napajedl. auch hier Triften entwickelt, auf denen bei N a pajedl und We le hrad Andropogon Ischaemum, Koeleria gracilis, Carex praccox, C. Michelii, Anthericum ramosum, Dianthus Carthusianorum, Silene Otites, Clemalis recta, Adonis vernalis, Linum

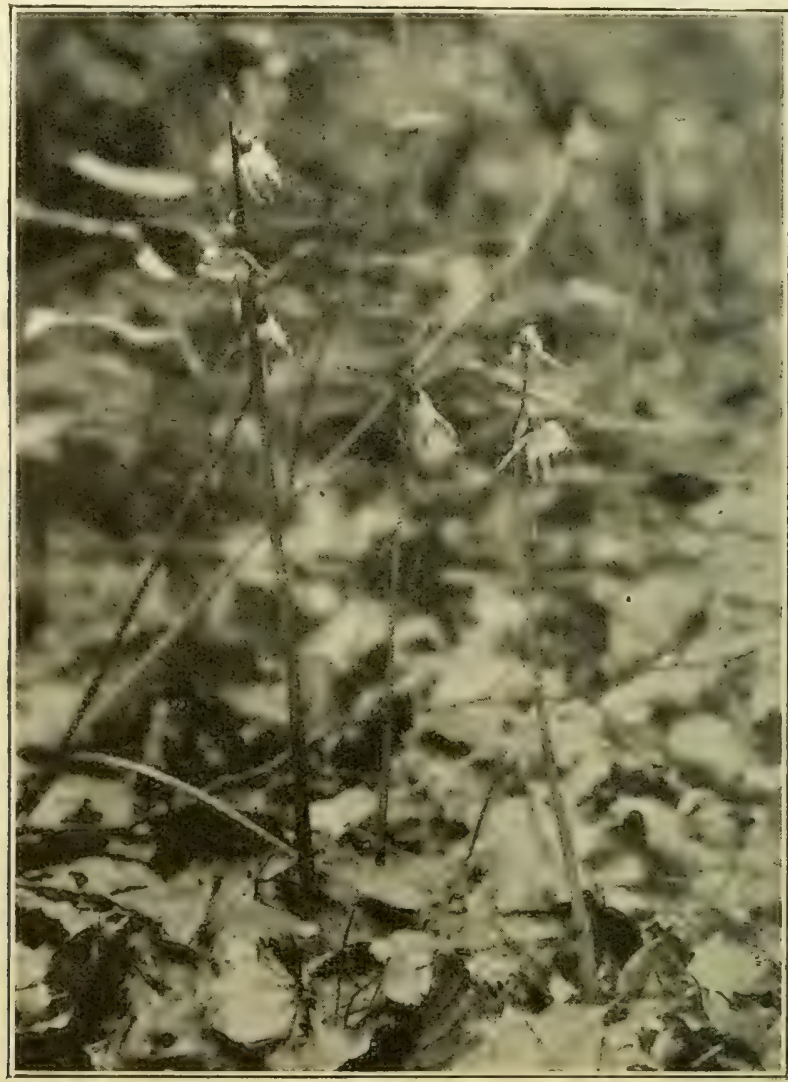

Abb. 119. Epipogon aphyllum bei Vlčak nächst Stř́lek im Marsgebirge.

(Nach einer Aufnahme von Prof. F. Nabělek, Leipnik.)

austriacum, Helianlhemum oualum, Cytisus nigricans, Trifolium alpestre, T. ochroleucum, Globularia Willkommii, Verbascum auslriacum usw. gedeihen.

Marchtal. Im Marchtale, von der Talenge bei $\mathrm{Napajedl}$ angefangen bis Bisenz und darüber hinaus, sind schöne Auenwälder aus Quercus sesseliflora, Fraxinus excelsior, Ulmus glabra, Acer campeslre, Carpinus Betulus, Populus tremula usw. entwiclielt, in deren Niederwuchs insbesonders Deschampsia caespilosa, Bromus asper, Festuca gigantea, Milium effusum, Gagea lulea, Allium ursinum, Polygonalum officinale, Ranunculus Ficaria, Anemone ranunculoides, Corydalis solida, Alliaria officinalis, Salvia glutinosa, Stachys silvatica, Lycopus europaets, 
Crepis paludosa usw. gedeihen. Diese Auen wechseln mit üppigen Wiesen ab, deren Hauptbestandteile Alopecurus pralensis, Phleum pralense, Holcus lanalus, Festuca elatior, Cynosurus cristatus, Allium angulosum, Colchicum aulumnale, Lychnis Flos Cuculi, Ranunculus acer, Cardamine pralensis, Sanguisorba officinalis, Pastinaca saliva, Heracleum Spondylium, Carum Carvi, Salvia pralensis, Cirsium canum, C. oleraceum, Centaurea Jacea, Crepis biennis und Hieracium pratense

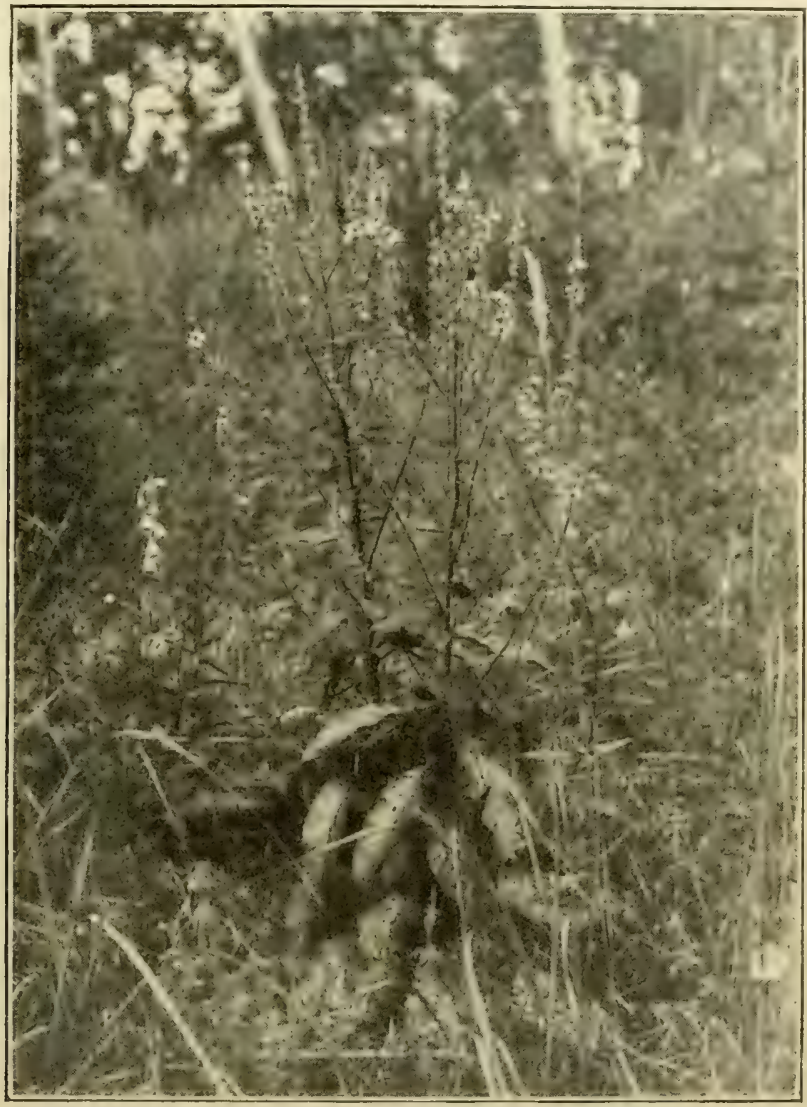

Abb. 120. Verbascum austriacum bei Brdo nächst Rostin im Marsgebirge.

(Nach einer Aufnahme von Prof. F. Nabèlek, Leipnik.)

(Aus der Bildersammlung des botanischen Institutes an der Wiener Universität.)

sind. In Sümpfen an der March bei Ungarisch-Hradisch treten Carex Ung.cyperoides, Cyperus fuscus, Dichostylis Micheliana, Potentilla supina, Peplis Portula, Lythrum Hyssopifolia, Lindernia pyxidaria, Limosella aquatica usw. auf. Solche Auenwiesen, wie die eben geschilderten, finden sich auch weiter abvärts im Tale bei Ungarisch-Ostra; nach Osten gegen die Karpathen zu aber werden die Wiesen allmählich trockener und nehmen schließlich einen steppenartigen Charakter an, wie bei Klein - Blatnitz und Lippau, wo dann Dianthus Pontederae, Adonis vernalis, Anemone grandis, Clematis recta, Lalhyrus pannonicus, Bupleurum falcalum, Peucedanum Cervaria, Cirsium pannonicum, Iris variegata 
usw. auf diesen Steppenwiesen auftreten, die ganz allmählich in die Bergtriften der Karpathenvorberge übergehen.

Bisenz. Bei Bisenz treten auch noch in der Ebene trockene Laubwälder auf, so der sogenannte ,H a j", in welchem u. a. Ranunculus illyricus, Saxifraga bulbifera, Cylisus ralisbonensis, Crepis praemorsa, Melampyrum cristalum und als Seltenheit auch Gladiolus illyricus vorkommen. Westlich von Bisenz liegt an Stelle des verlandeten Čaganow - Teiches eine große Moorwiese, die durch das Vorkommen von Carex diandra, C. paradoxa, C. limosa, Stellaria glauca und in Tümpeln Sparganium minimum ausgezeichnet ist. Von Bisenz bis Göding erstreckt

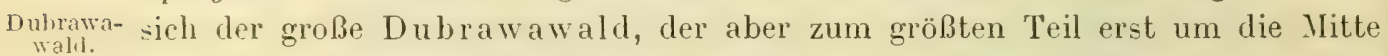
des 19. Jahrhunderts angepflanzt wurde, um die losen Flugsandmassen des Gebietes zu festigen. Der nördliche Teil desselben, der Bzinekwald bei Bisenz, ist ein wohl ursprünglicher Eichenbestand, in dessen Niederwuchs jedoch zahlreiche typische Sandbewohner, wie Slipa capillala, Phleum phleoides, Carex ericelorum, ferner Ranunculus cassubicus, Melampyrum cristatum, Cenlaurea slenolepis, an feuchten Stellen sogar Senecio fluvialilis und Crepis paludosa gedeihen. Der größte Teil des übrigen Valdes aber ist ein Bestand aus Rot- und (durchwegs angepflanzten) Schwarzföhren, deren Niederwuchs der sonst für die Föhrenwälder so charakteristischen Vaccinium- und Pirolaarten ganz entbehrt und in dem selbst Calluna selten ist. Hingegen kommen im Niederwuchs typische Bewohner der Sandheide, wie Corynephorus canescens, Festuca ovina, Scleranthus perennis, Thymus Marschallianus, Jasione montana, ferner Anthoxanlhum odoralum, Deschampsia flexuosa, Euphorbia Cyparissias, Silene nutans, Potentilla erecta, Helianthemum ovatum, Verbascum Lychnites, $V$. phoeniceum, V. thapsiforme, Veronica spicata, Onosma Visianii, Cylisus nigricans, Sarothamnus scoparius, Solidago Virga Aurea, Scorzonera purpurea vor. Wo aber der Boden nicht von Wald bedeckt ist, treten im ganzen Gebiete, der Dubrawa bis über Göding hinaus Sandsteppen, in denen meist Corynephorus canescens oder Festuca vaginata, manchmal aber auch Digitaria ciliaris, Stipa pennata, S. capillata, Potentillen oder Artemisien tonangebend sind, auf, in denen von interessanteren Arten Kochia arenaria, Scleranthus perennis, Melandryum viscosum, Gypsophila paniculata, G. fasligiala, Erysimum canescens, Polentilla rubens, $P$.arenaria, P.Wiemanniana, $P$. argentea, $P$. patula, Onosma arenarium, Thymus angustifolius, Linaria genistifolia, Veronica verna, Plantago arenaria, Erigeron canadensis (massenhaft), Anlhemis ruthenica, Hieracium seligerum u. a. gedeihen, während die weiter südwärts auftretenden Arten Koeleria glauca und Apera interrupta fehlen beziehungsweise höchst selten sind.

Die Niederung an der unteren Thaya, nahe ihrer Mündung in die March,

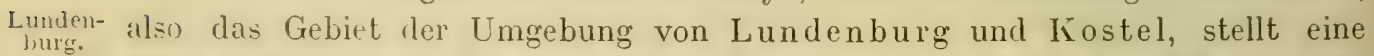
weite, teils trockene und selbst sandige, teils sumpfige Ebene dar, die von zahlreichen Wassergräben und Sümpfen durchzogen ist und teils kleinere Auenwälder, teils aber WViesen trägt, für die Molinia coerulea, Cyperus fuscus, Juncus atratus, Allium angulosum, Iris sibirica, Euphorbia lucida, E. palustris, ThalicIrum galioides, Galega officinalis, Eryngium planum, Cnidium venosum, Silaus 


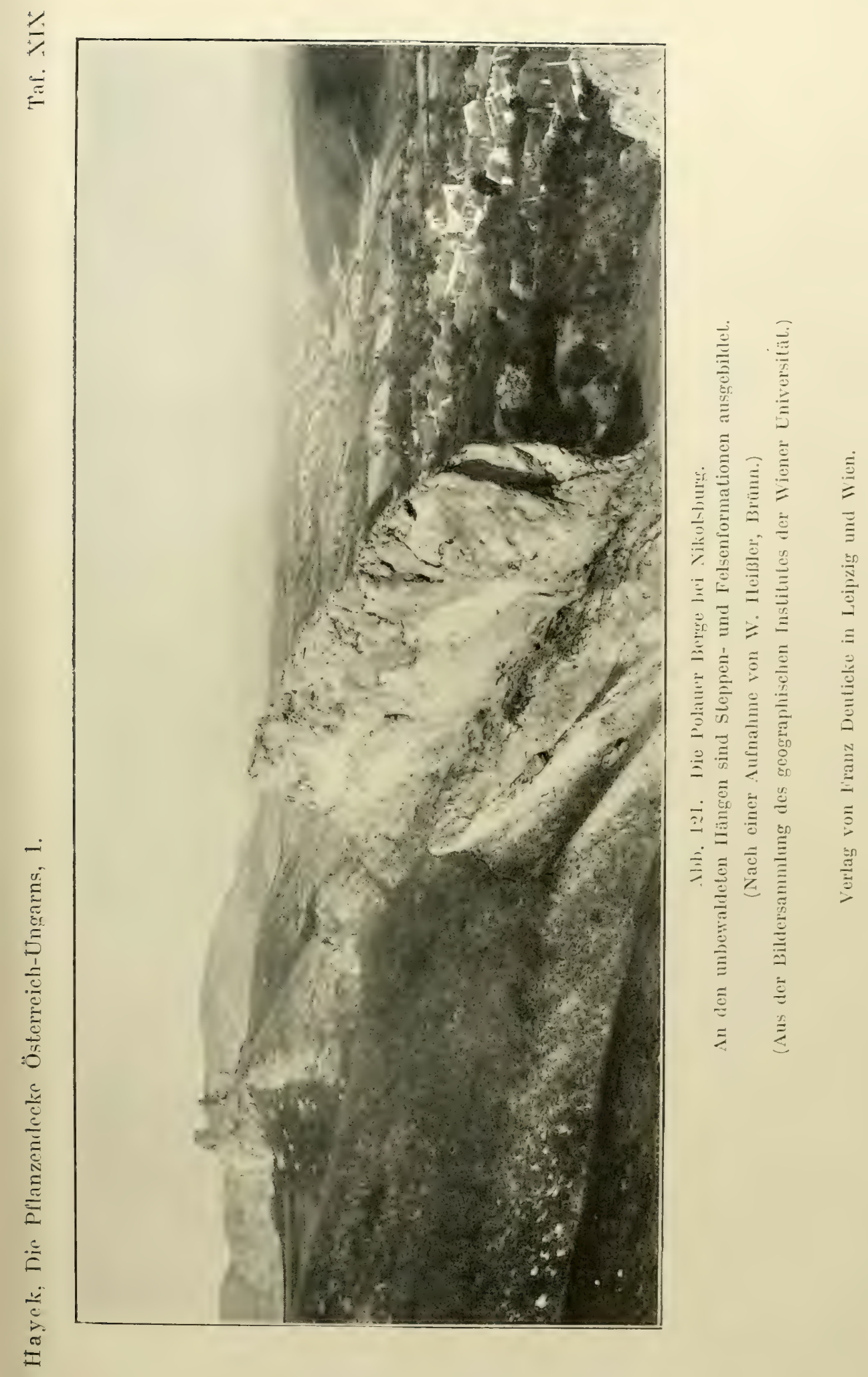



pratensis, Gentiana Pneumonanthe, Armeria elongala, Inula salicina die bezeichnendsten Arten sind. Bei der Haltestelle Rakwitz nächst Kostel findet sich übrigens noch eine salzauswitternde Stelle mit Crypsis aculeala, Heleochloa schoenoides, Spergularia marginala, Salicornia herbacea, Glaux marilima, Melilotus dentatus, Scorzonera parviflora und anderen Halophyten.

Südlich der Thaya erheben sich nördlich der Stadt Nikolsburg die aus Jurakalk aufgebauten, im Maydenberge $546 \mathrm{~m}$ Meereshöhe erreichenden Polauer Berge, die am Nordabhange mit Laubwäldern, in denen u. a. Cardamine enneaphyllos, Lunaria rediviva, Aconitum Vulparia, Peucedanum alsaticum und Glechoma hirsula vorkommen, bedeckt sind, während an ihrer felsigen geröllreichen Südseite sich eine sehr reiche steppenartige Triftflora angesiedclt hat. Hier wachsen Festuca glauca, $F$. valesiaca, Carex supina, Allium monlanum, A. flavum, Iris pumila, I. bohemica (ob noch?), Minuartia selacea, M. Jacquini, Alyssum montanum, A. Arduini, Hesperis tristis, Sempervivum soboliferum, Dictamnus albus, Seseli Beckii, Astragalus Onobrychis, A. austriacus, Phlomis luberosa, Teucrium Botrys, Cynanchum Vinceloxicum, Scorzonera austriaca und mit ihnen vereint auch subalpine Typen, wie Poa badensis, Sesleria varia, Dianthus plumarius, Sorbus Aria, ja selbst Saxifraga Aizoon und Arenaria

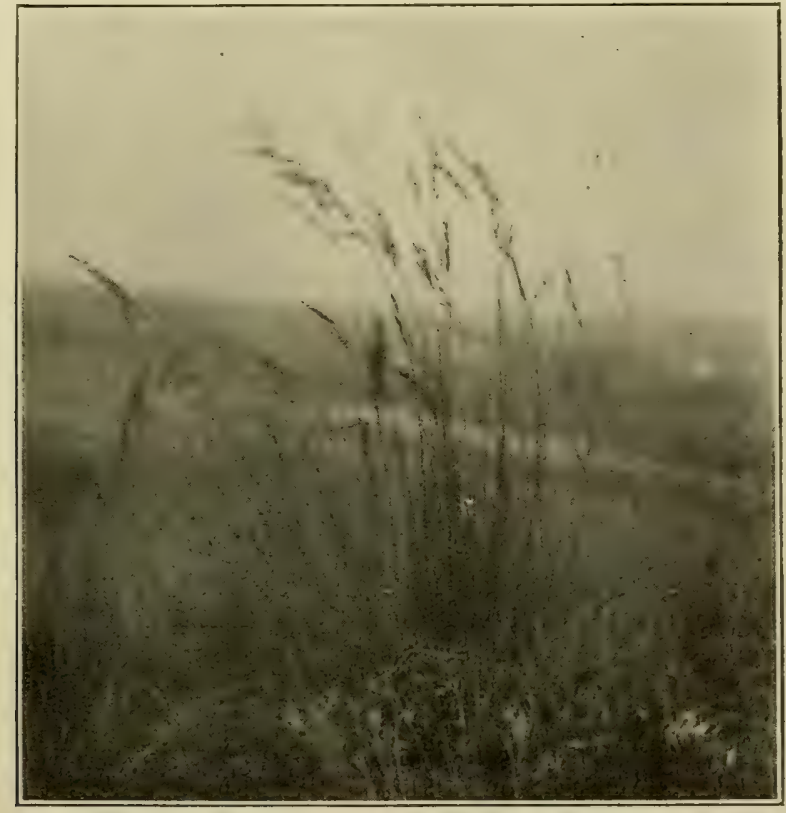

Abb. 122. Avena desertorum auf dem Galgenberge bei Nikolsburg.

(Nach einer Aufnahme von A. v. Hayek, Wien.)

grandiflora. Auf dem südlich von Nikolsburg gelegenen Galgenberge findet man auch typische Steppen mit Stipa pennala, Koeleria gracilis, Phleum phleoides. Silene Otiles, Anemone grandis, Adonis vernalis, Medicago minima, Potentilla 
arenaria, Seseli Hippomarathrum, Globularia Willkommii, Verbascum phoeniceum, Asperula glauca, Jurinea mollis und massenhaft der südrussischen, auch im Böhmischen Mittelgebirge vorkommenden Avena desertorum.

L:a: Am Unterlaufe der Pulka bei Zwingendorf und Laa in Niederösterreich treten wieder Halophytenformationen auf, besonders Salzwiesen mit Carex disticha, Scirpus marilimus, Spergularia marina, Lepidium latifolium, Galega "fficinalis, Telragonolobus siliquosus, Allhaea officinalis, Glaux marilima, Plantago marilima, Scorzonera parviflora usw. Weiter östlich, unweit der mährischen

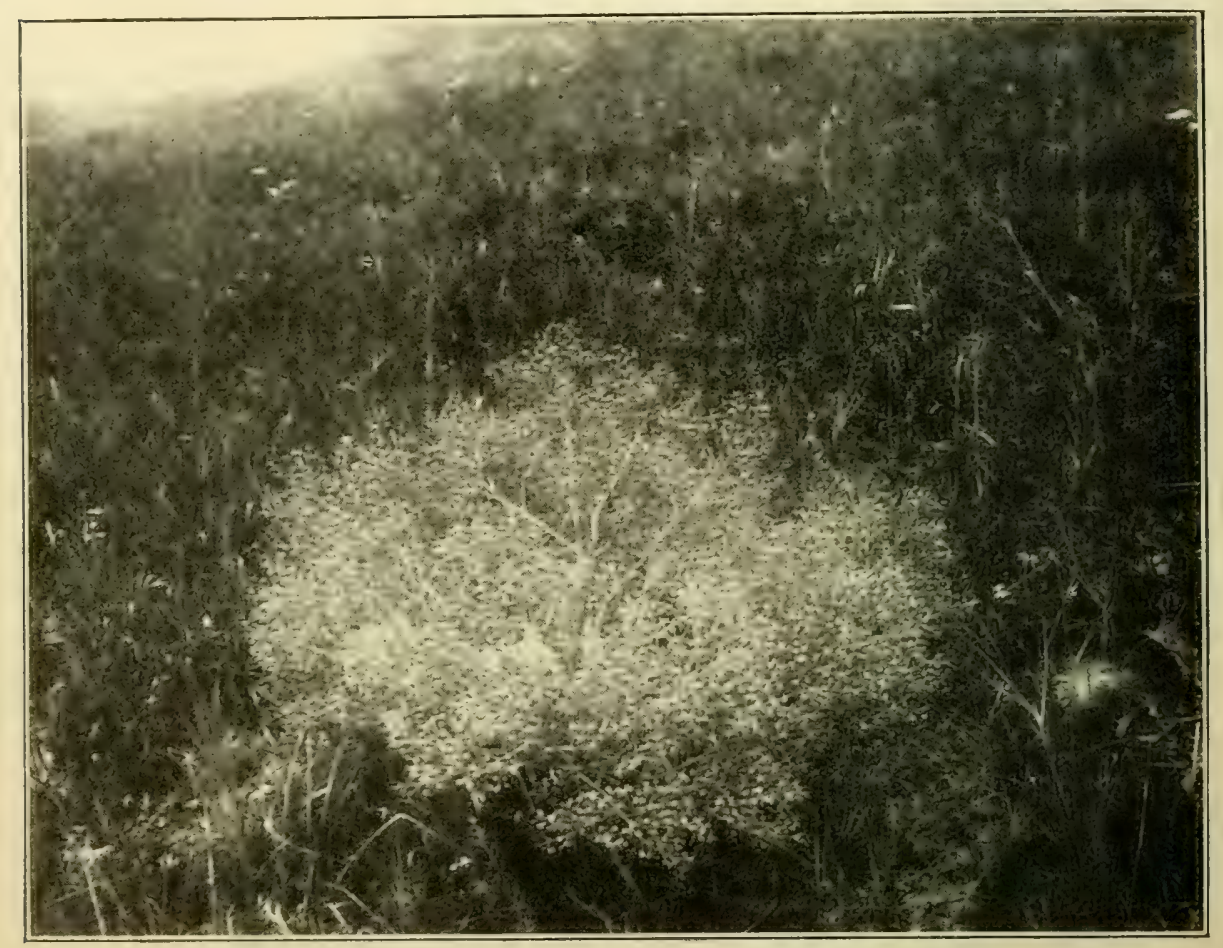

Abb. 123. Crambe tatarica bei Ottenthal.

(Nach einer Aufnahme von Dr. A. Ginzberger, Wien.

(Aus der Bildersammlung des botanischen Institutes an der Wiener Universität.)

Grenze, stellt die Kaller Heide bei Drasenhofen wieder ein kleines Steppengebiet dar, wo neben Melica ciliala, M. Iranssilvanica, Silene conica, Vicia striala auch Avena desertorum und Erysimum durum gedeihen. Im Theimwalde zwischen Feldsberg und Lundenburg ist Corynephorus canescens an sandigen Stellen häufig.

Das niedrige Hügelland zwischen Nikolsburg, Staatz und Retz ist heutzutage sehr intensiv liultiviert und von Äckern und Weinbergen bedeckt, so daß nur ganz vereinzelt Reste der ursprünglichen Vegetation vorhanden sind. Ottenthal. So ist bei Ottenthal an einem sonnigen Abhang eine Triftformation mit Bunias orientalis, Oxylropis pilosa, Phlomis tuberosa und zahlreicher Crambe lalarica 
Hayek, Die Pflanzendecke Österreich-Ungarns, I. Taf. XX.

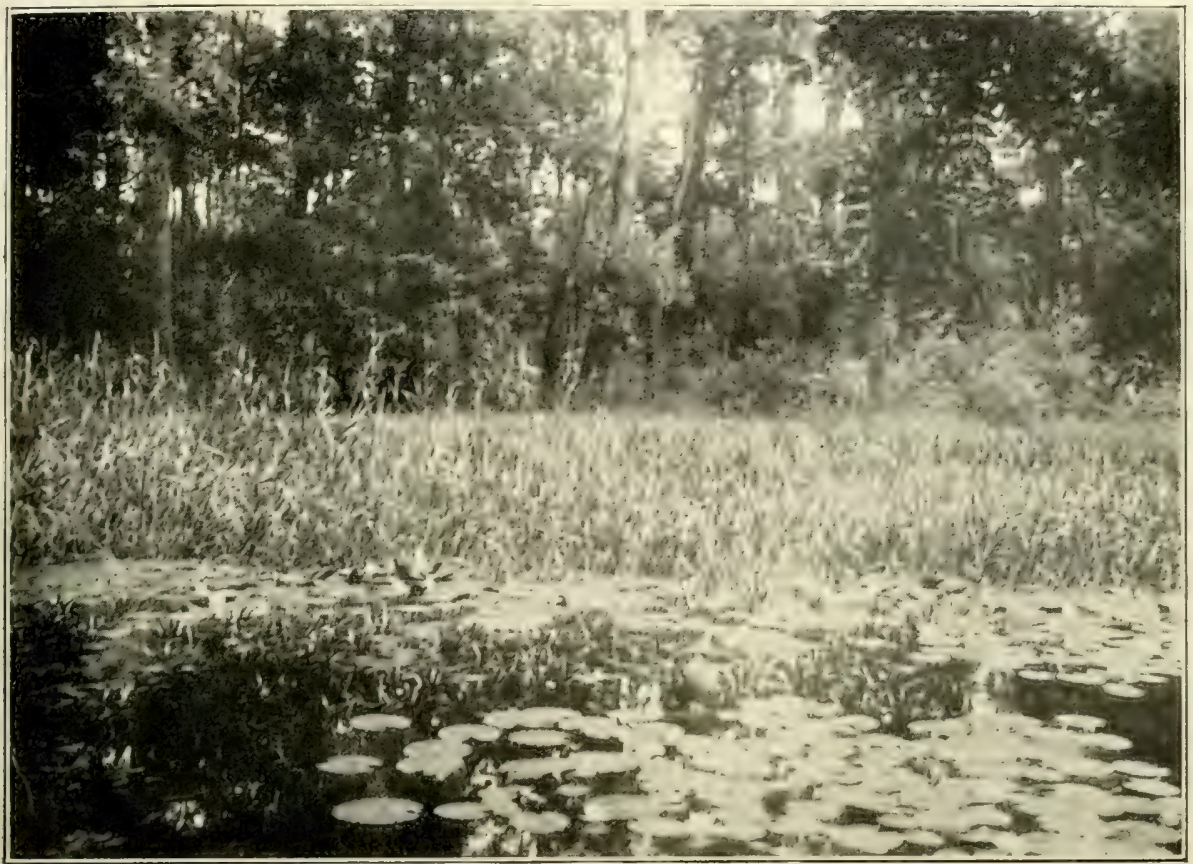

Abb. 124. Aus den Marchauen bei Hohenau.

Im Vordergrunde Castalia alba und Stratiotes aloides, dahinter Phragmites communis und Glyceria aquatica. Im Hintergrunde Waldbestand aus Populus alba und Quercus Robur.

(Nach einer Aufnahme von Dr. A. Ginzberger, Wien.)

(Aus der Bildersammlung des botanischen Institutes der Wiener Universität.)

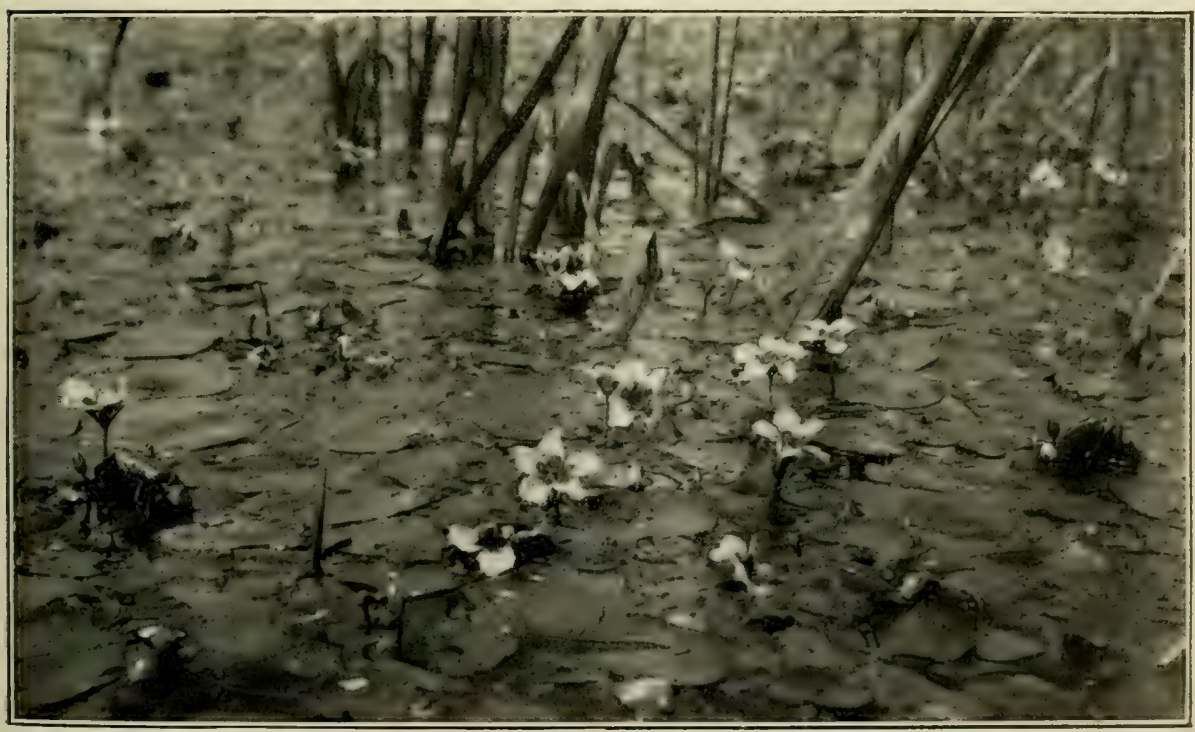

Abb. 125. Nymphoides peltata in einem Tümpel der March bei Magyarfalva.

(Nach einer Aufnahme von F. v. Wettstein, Wien.)

Verlag von Franz Deuticke in Leipzig und Wien. 

erhalten und auch bei Jetzelsdorf nächst Haugsdorf ist noch ein kleiner Komplex der ursprünglichen Steppe mit Slipa capillala, Kochia prostrala, Reseda Phyleuma, Astragalus vesicarius, A. austriacus, A. Onobrychis, A. exscapus, Seseli Hippomarathrum, Echinops rulhenicus, Taraxacum serolinum usw. zu sehen.

Bei Staatz treten wieder Jurakalkklippen zutage, die eine der der Polauer Berge ähnliche, aber viel ärmere Flora tragen, bemerkenswert sind hier insbesonders Minuartia selacea, M. Jacquini sowie der hier einen seiner nördlichsten Standorte erreichende Cotinus Coggygria. Das Waldgebiet der Leisser Berge, der ,Ernstblunner Wald", ist ein Laubmischwald, in dem Quercus Robur und Qu. sessiliflora meist vorherrschen, in dessen Niederwuchs neben Festuca helerophylla, Milium effusum, Lilium Martagon, Platanthera bifolia, Trifolium rubens, Cylisus nigricans, Euphorbia angulala, Digilalis ambigua, Senecio nemorensis und anderen Eichenwaldpflanzen auch seltenere Arten, wie Cypripedium Calceolus und Pulmonaria angustifolia vorkommen. Auch der bis gegen Stockerau sich erstreckende Rohrwald ist ein Laubmischwald, in welchem Rohrwald. Eichen und Linden vorherrschen und der sich insbesonders durch den Reichtum an seltenen Orchideen, wie Orchis fusca, O. mililaris und Cypripedium, auszeichnet. Auch im ganzen Hügelzuge über Schleinbach bis zum Bis a m berge Bisamberw. bei Wien treten solche Laubmischwälder, in denen meist Cypripedium nicht selten ist, auf; der Bisamberg selbst aber ist überdies durch die seine Abhänge gegen die Donau bekleidenden Bergtriften mit Koeleria gracilis, Slipa pennata, Iris pumila, Ophrys muscifera, O. fuciflora, O. aranifera, O. apifera, Himantoglossum hircinum, Anemone silvestris, Cytisus Kitaibelii, Geranium sanguineum, Polygala maior, Vinca herbacea, Phyleuma orbiculare, Buphthalmum salicifolium, Scorzonera hispanica, Hieracium pannonicum usw. ausgezeichnet. Weiter westlich, im Hügellande bei Wolkersdorf, Mistelbach, Zistersdorf usw., ist der Boden weithin von Weingärten und Ackern bedeckt und nur hie und da haben sich, wie bei Gaunersdorf und Poisdorf, einzelne Laubwaldbestände erhalten; bei Hohenruppersdorf kommen im Eichenwalde Echium rubrum, an der Hochleiten, zwischen Wolkersdorf und Pyrawarth, an buschigen Stellen Peucedanum officinale, Iris variegala, Prunus nana, Lavalera thuringiaca, Polygonalum multiflorum vor:-

Die March begleiten auch entlang der Grenze zwischen Niederösterreich Marchtal. und Ungarn schöne Auenwälder, in denen noch vereinzelte prächtige Exemplare uralter Eichen (Quercus Robur) anzutreffen sind; neben Parietaria officinalis sind in diesen Auen besonders Clematis integrifolia, Lylhrum virgatum, Leonurus Marrubiastrum und Lycopus exaltalus charakteristische Arten; an sumpfigen Stellen sind Oenanlhe silaifolia, Mentha Pulegium und Pulicaria vulgaris, auf Wiesen Armeria elongala häufig. Eine reiche Wasserflora beherbergen die toten Arme und Tümpel der March, in denen neben zahlreichen verbreiteten Arten auch Polamogeton polygonifolius, Stratiotes aloides, Trapa nalans und Nymphoides peltala vorkommen. Am linken Ufer der March sind noch bei Magyarfalva Sandheiden mit Corynephorus canescens, Thymus angustifolius, Armeria elongala 
Miava dehnt sich der große, sandige, ehedem angepflanzte, aus Pinus silvestris gebilde Burwald aus, an dessen Rändern, besonders bei Stampfen Sarothamnus scoparius in ausgedehnten Beständen auftritt. Der ganze niederösterMarch- reichische Anteil des. Marchfeldes gehörte zweifellos ehemals in seiner ganzen Ausdehnung dem Steppengebiete an, heute ist dasselbe von ausgedehnten Weizenfeldern bedeckt und nur an wenigen Stellen, wie bei Baumgarten, Gänserndorf und Wagram, trifft man noch Reste der Sandsteppe mit Stipa capillala, Koeleria glauca, Festuca vaginata, Gypsophila paniculala, Silene conica, Dianthus serotinus, Rapistrum perenne, Potentilla arenaria, Helichrysum arenarum, Hieracium echioides; im Narchtale, bei Angern und Baumgarten

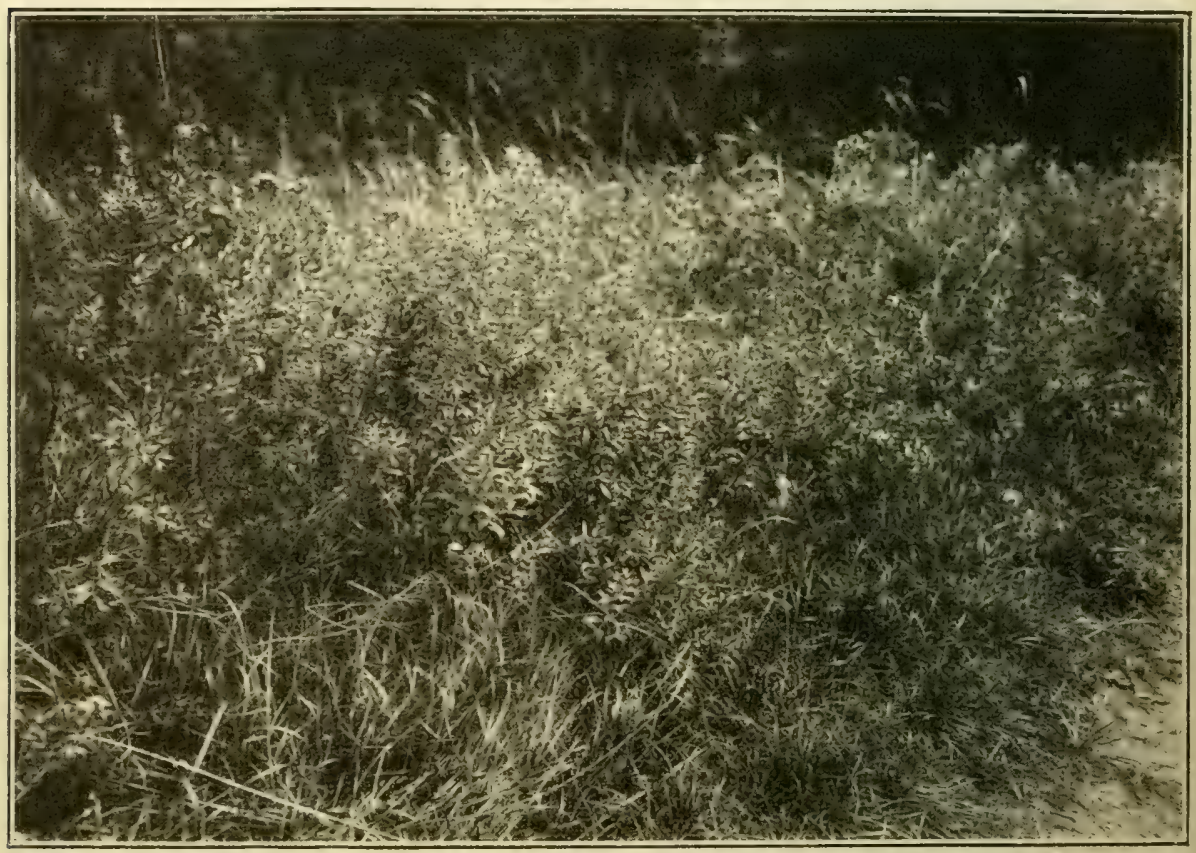

Abb. 126. Aster canus in den Marchauen bei Baumgarten.

(Nach einer Aufnalime von Dr. IK. Rechinger, Wien:)

kommt auch Melandryum viscosum, bei Wagram-und GroB-Enzersdorf Silene mulliflora, bei Magyarfalva, SchloBhof und Marchegg Ranunculus illyricus vor. Auch Salztriften mit Bupleurum tenuissimum, Planlago marilima, Sconzonera parviflora und Aster Tripolium sind stellenweise, besonders bei Baum- Baumgarten, Siebenbrunn und Breitensee anzutreffen und bei Baumgarten.

Breitens garten trifft man in den Auen auch den östlichen Asler canus sowie Pencedanum officinale. Bei Weikendorf und Gänserndorf sind größere Partien der Sandflächen mit Pinus silvestris und P. nigra aufgeforstet, in diesen Wäldern kommt ab und zu die seltene Apera interrupla vor. Im südlichsten Teile des Kagran. Machfeldes, zwischen Kagran und Marchegg, ist Eryngium planum cine häufige Erscheinung, auf Sumpfwiesen zwischen Groß-Enzersdorf und 


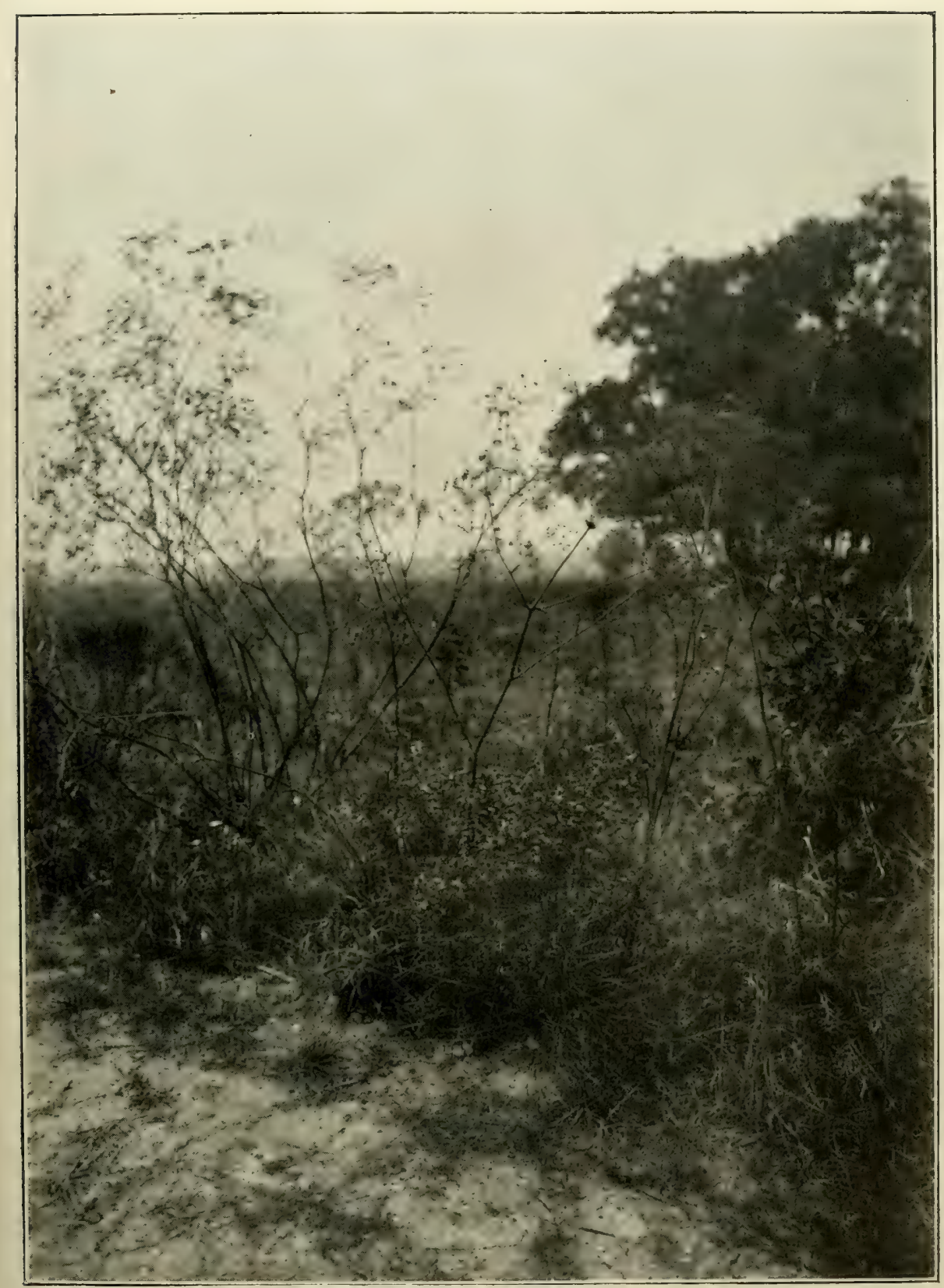

Abb. 127. Peucedanum officinale in den Marchauen bei Baumgarten.

(Nach einer Aufnahme von Dr. Ki. Rechinger, Wien.) 

Marchegg Senecio Doria und auf der Heide bei Lassee hat die höchst seltene, Lassee. erst wieder in Oeland, Thüringen und Nordasien vorkommende Arlemisia laciniata einen isolierten Standort.

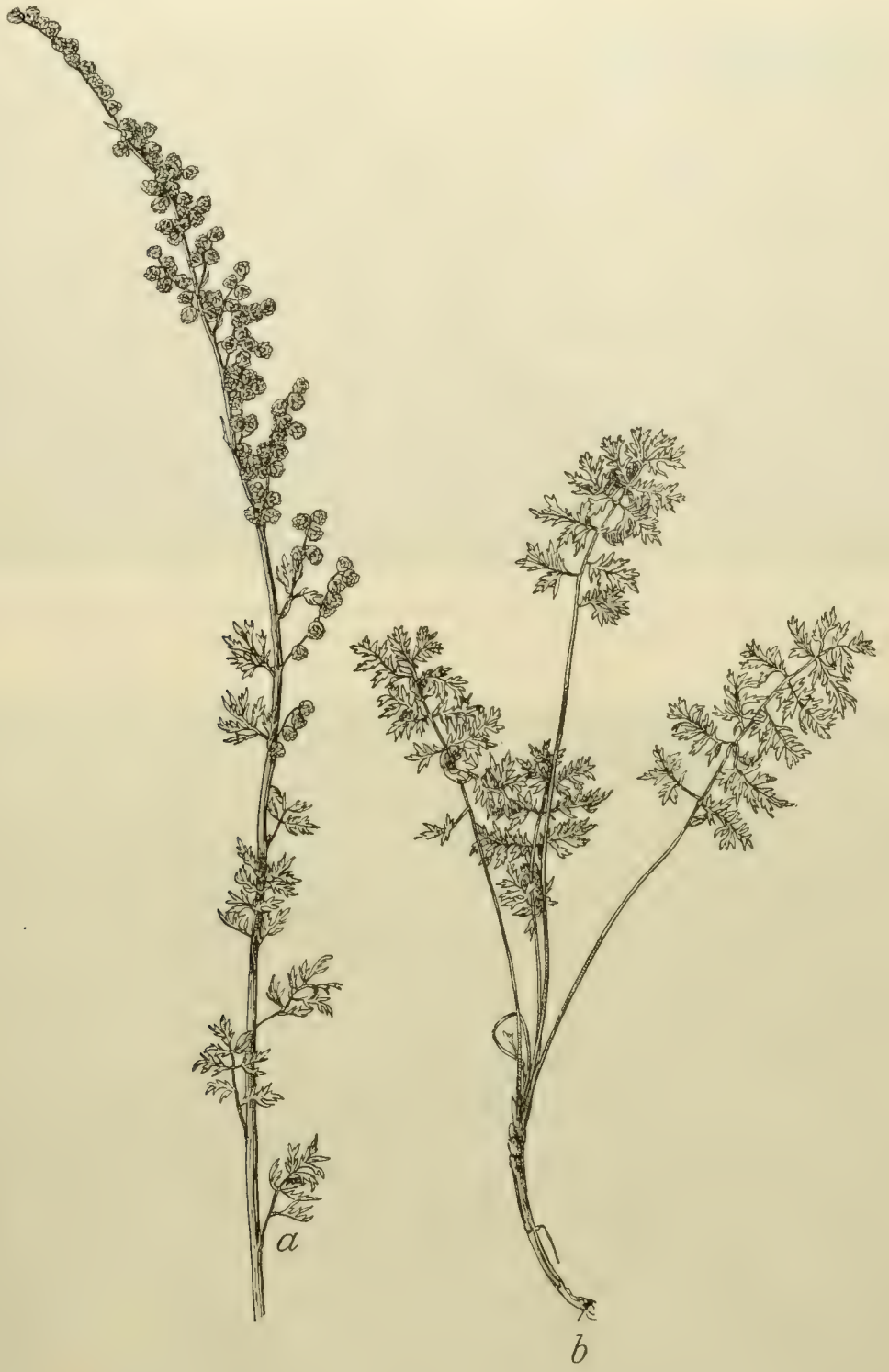

Abb. 128. Artemisia laciniata.

Entlang des nördlichen Donauufers, von Krems abwärts bis gegen Absdorf, trifft man mächtige Lößablagerungen, auf denen terrassenförmig Weingärten angelegt sind. Die Donau selbst aber begleiten ausdedehnte Auenwälder, die hauptsächlich aus Populus alba und Populus nigra zusammengesetzt sinr, doch kommen eingesprengt oder gruppenweise auch Salix alba, S. fragilis, Alnus

Hayek, Die Pflanzendecke Österreich-Ungarns, I. 


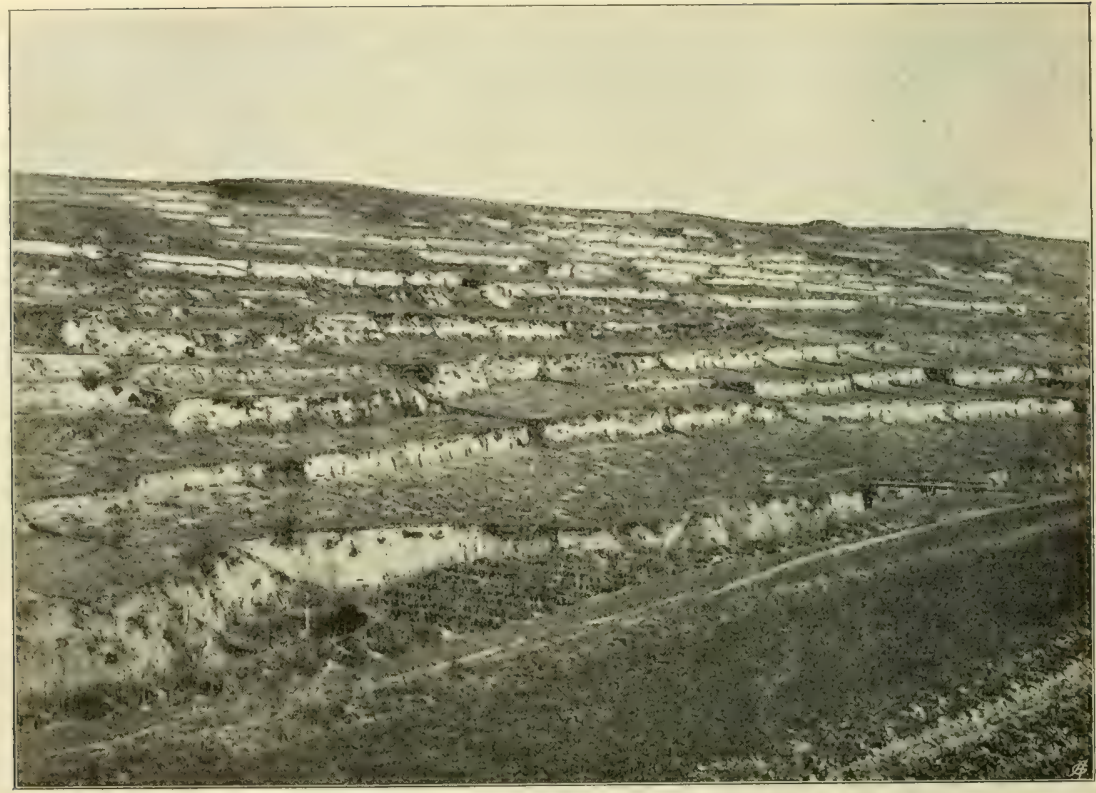

Abb. 129. Weingärten auf Lößterrassen am Gobelsberg östlich von Krems. (Nach einer Aufnahme aus der Bildersammlung des Geographischen Institutes der Wiener Universität.)

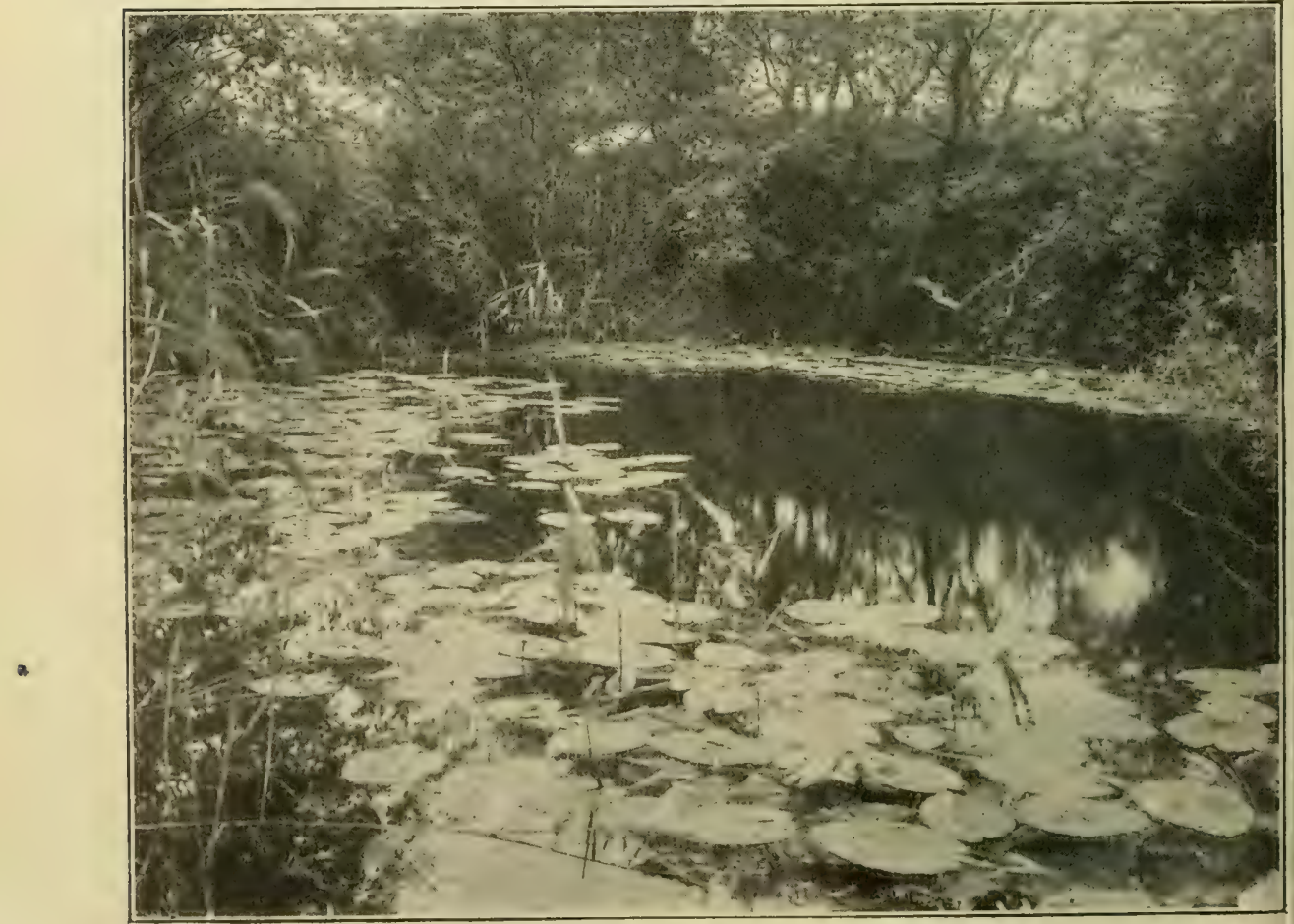

Abb. 130. Donausumpf in der Lobau bei Wien.

Nuphar luteum, im Hintergrunde Buschwerk aus Alnus incana.

( Nach einer Aufnahme von Prof. Amalie Mayer in Wien.)

(Aus der Bildersammlung des botanischen Institutes der Wiener Universität.) 


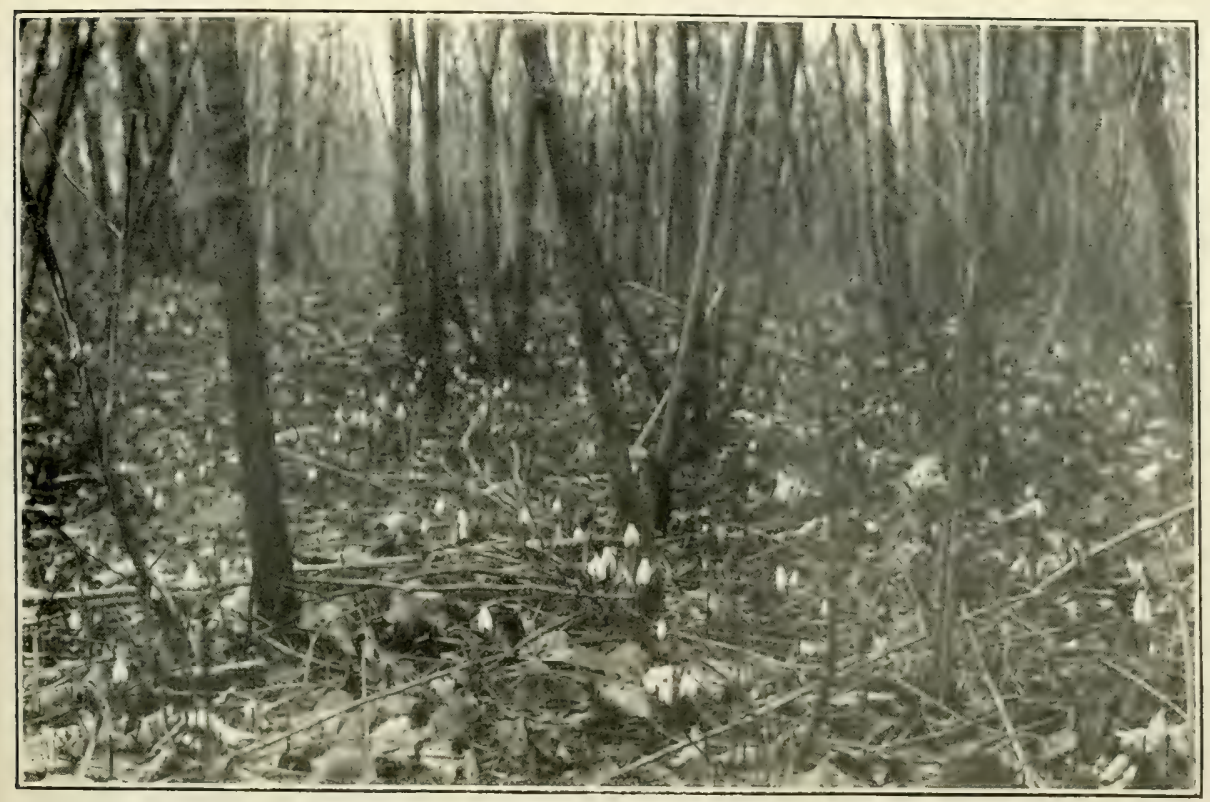

Abb. 131. Galanthus nivalis in den Donauauen bei Spilern. (Nach einer Aufnahme von A. v. llayek.

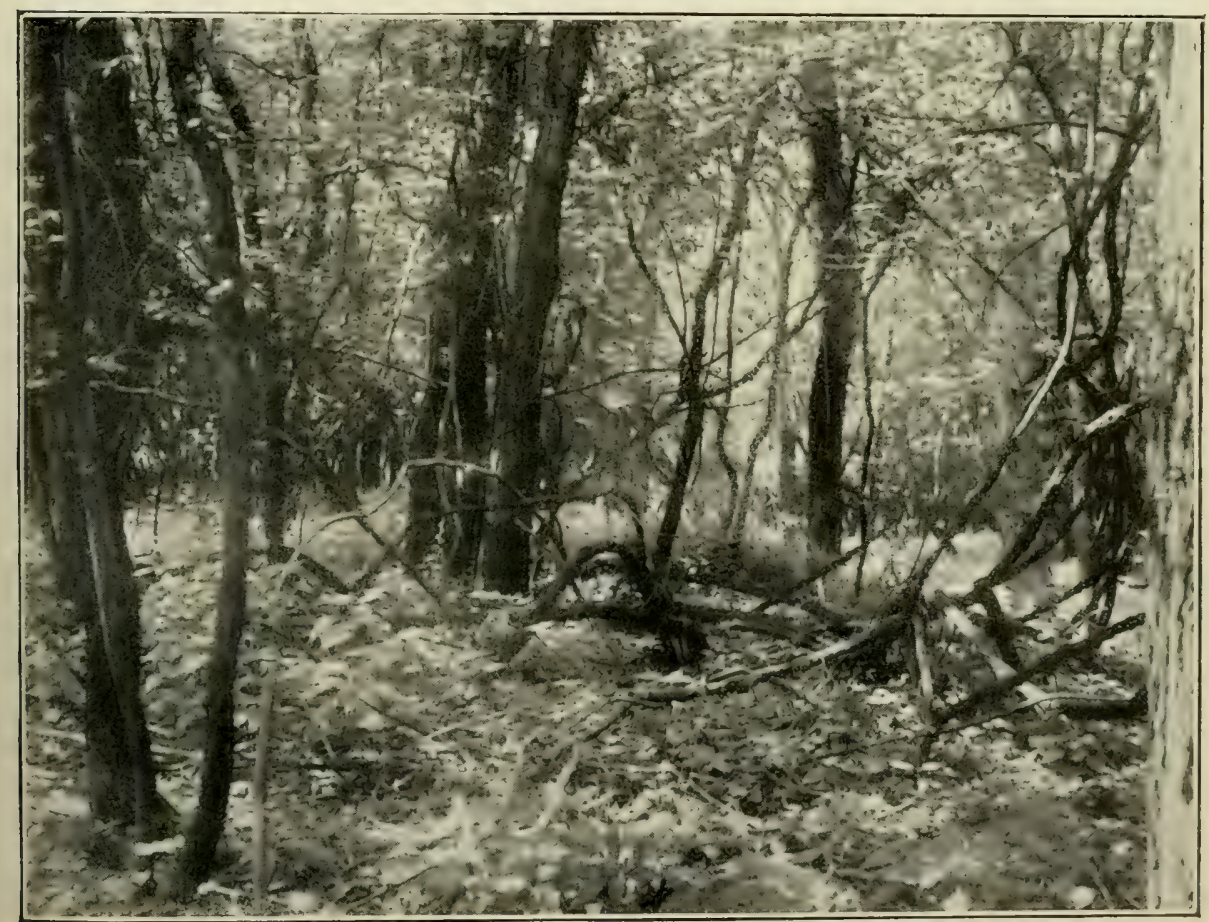

Abb. 132. Vitis silvestris in den Donauauen der Lobau bei Wien.

(Aus der Bildersammlung des botanischen Institutes an der Wiener Universität.)

(Nach einer Aufnal me von Prof. Amalie Mayer, Wien.) 

incana, Ulmus glabra, U. laevis, selten auch Quercus Robur vor. Im Niederwuchs dieser Wälder ist im ersten Frühling das massenhafte Auftreten von Galanthus nivalis, später das von Parietaria officinalis, ab und zu auch von Senecio fluviatilis, Cirsium arvense und Urtica dioeca bemerkenswert; als Liane ist Humulus Lupulus überall häufig, von Wien abwärts, so in der Lobau, vereinzelt sogar schon im Wiener Prater, tritt auch Vitis silvestris, die dann weiter ostwärts immer häufiger wird, auf. Auf den Schotterbänken an der Donau sind Salix purpurea, S. incana, Myricaria germanica und. Hippophaë rhamnoides. häufig, oft bildet auch Chamaenerion palustre, begleitet von Oenothera biennis, O. muricata, Linaria genistifolia, Verbascum phlomoides, Rapistrum perenne, Sisymbrium Sinapistrum usw. Massenvegetation. An den toten Armen der Donau findet man Weidengebüsch oder Bestände aus Phragmiles communis, Schoenoplectus lacuslris, S. triqueter und S. carinatus mit Sagittaria sagillaefolia und Butomus umbellatus, in den Gewässern neben Geratophyllum demersum, Potamogeton lucens, Myriophyllum verlicillalum und Hippuris vulgaris, auch Straliotes aloides, Hydrocharis Morsus ranae, Lemna lrisulca, Nuphar luteum, Hotlonia palustris; in der Alten Donau bei Wien kommt auch Naias, marina vor. 


\section{Verzeichnis der benutzten Literatur.}

\section{a) Arbeiten iiber das ganze Gebiet oder cinen größeren Teil desselben.}

Čelakovský L., Prodromus einer Flora von Böhmen. (Prag, 1867.)

- Resultate der botanischen Durchforschung Böhmens. (Sitz.-Ber. d. kgl. böhm. Ges. d. Wissensch. in Prag, 1882-1890.)

Laus H., Mährens Ackerunkräuter und Ruderalpflanzen. (Mitt. d. Kommiss. z. nat. Durchf. Mährens. Brünn, 1908.)

Oborny A., Flora von Mähren und Österreichisch-Schlesien. (Brünn, 1885.)

Podpèra J., Über den Einfluß der Glazialperiode auf die Entwicklung der Flora der Sudetenländer. (1. Ber. d. naturw. Sektion d. Ver. ,Botanischer Garten ${ }^{6}$ in Olmütz, 1905.)

Sitensky F., Über die Torfmoore Böhmens in naturwissenschaftlicher und nationalökonomischer Beziehung, I. (Archiv f. d. naturw. Landesdurchforschung. v. Böhmen, VI. Nr. 1 [1889].)

Velenovský J., Mechy České. (Prag, 1897.)

\section{b) Erzgebirge, Elstergebirge und Fichtelgebirge.}

Čelakovský L., Flora der Umgebung von Osseg. (Lotos, XII [1862], S. 66.)

Dalla-Torre K. v., Beiträge zur Phyto- und Zoostatistik des Egerlandes. (Lotos, XXVII [1877], Abh. S. 7.)

Domin K., Vierter Beitrag zur Kenntnis der Phanerogamenflora von Böhmen. (Sitzungsber. d. K. böhm. Ges. d. Wissensch. in Prag, 1905.)

- Das böhmische Erzgebirge und sein Vorland. (Arch. f. d. naturw: Landesdurchforschung v. Böhmen, XII, Nr. 5 [1905].)

Drude O., Der herzynische Florenbezirk. (Engler und Drude, Die Vegetation der Erde, Leipzig, 1902.)

Freyn J., Ein kleiner Beitrag zur Flora des Erzgebirges. (Deutsche bot. Monatsschr., IV [1886], S. 33.)

Koehler F., Die pflanzengeographischen VerhäItnisse des Erzgebirges. (Schneeberg, 1889.) Koehler T., Eine Kenntnis des politischen und Schulbezirkes Eger. (Eger, 1905.)

Ortmann A., Flora Carlsbads und seiner Umgebung. (In Mannl, Führer v. Carlsbad, 1850.)

Roth. A., Verzeichnis derjenigen Pflanzen, die bisher in dem böhmischen Erzgebirge und in der Gegend von Rothenhaus und Umgebung aufgefunden worden sind. (Österr. bot. Wochenbl., VII [1857], S. 39.)

\section{c) Kaiserwald, Böhmerwald und Mühlviertel.}

Brehm V., Beiträge zur Flora des Kaiserwaldes in Böhmen. (Deutsche bot. Monatsschr., XV [1897], S. 244.)

Dalla-Torre K. v., Beiträge zur Phyto- und Zoostatistik des Egerlandes. (Lotos, XXVII [1877], Abh., S. 7.)

Detmer V., Zur Charakteristik einiger Vegetationsformen. (Naturw. Wochenschr., XIII [1898], S. 601.) 
Drude O., Der herzynische Florenbezirk. (Engler und Drude, Die Vegetation d. Erde, Leipzig, 1902.)

Duftschmied J., Flora von Oberösterreich. (Linz, 1870-1883.)

Hillard C., Zur Flora des südlichen Böhmens. (Österr. bot, Wochenbl., IV [1854], S. 143.) Hinteröcker J., Botanische Mitteilungen. (Verh. d. zool. bot. Ges. Wien, VIII [1858], S. 333.)

Jungbauer J., Flora des Schöninger im Blansker Walde. (Lotos, IV [1854], S. 245.)

Kerner A., Beitrag zur Flora des Mühlviertels. (Verh. d. zool. bot. Ver., Wien, IV [1854], S. 213.)

Mardetschläger F., Beitrag zur Flora des Budweiser Kreises in Böhmen. (Lotos, XIX [1869], S. 150.)

Ondrák F., Rostliny semenné v okoli kr. města Klatov samorostlé i obecně pěstované. (Progr. c. k. stát. realn, vy̌̌šiho gymn, v Klatovech, 1890-1891.)

Peter A., Ein Beitrag zur Flora des böhmisch-bayrischen Waldgebirges. (Österr, bot. Zeitschr., XXXVI [1886], S. 11.)

Podpěra J., Bryologische Beiträge aus Südböhmen. (Sitzungsber. d. böhm. Ges. d. Wiss., Math.-nat. Abt., XLVI [1899].)

Polak K., Die Flora des Schwarzen Sees und Teufelssees und ihrer Umgebung. (Arch. f. d. naturw. Landesdurchforschung v. Böhmen, X, 1891.)

Progel A., Einige Beiträge zur Flora des oberbayrischen und Böhmerwaldes. (Deutsche bot. Monatsschr., IV [1886], S. 68.)

Ritzberger E., Prodromus einer Flora von Oberösterreich; (Jahresber. d. Mus. FranciscoCarolinum in Linz, $1904 \mathrm{ff}$.)

Rodler W., Verzeichnis der auf der Domäne Krumau in Böhmen wildwachsenden, verwilderten und gewöhnlich kultivierten Pflanzen. Krumau, 1873.

Schiedermayer C. B., Versuch einer Darstellung des Vegetationscharakters der Umgebung von Linz. (Wien, 1850.)

Schmidt F. W., Versuch einer Topographie der Stadt Plan. (Abh. d. böhm. Ges. d. Wissensch. [1788], S. 34.)

Schott A., Die Torfmoorflora des oberen Geinerwaldes. (Allg. bot. Zeitschr. [1896], S. 198.) Sendtner O., Die Vegetationsverhältnisse des bayrischen Waldes. (München, 1860.)

\section{d) Zentralböhmen.}

Ascherson P., Ein Ausflug ins nördliche Böhmen. (Österr. bot. Zeitschr., XIX [1869], S. 292.)

Bílek F., Soustavní přehled rostlin cevnatých v okolí Slaného samorostlých a obecně pěstovaných. (Čtvrtá rcění zpráva obecného vyššího gymn. v Slaném, 1884/85.)

Čelakovský L., Mitteilungen zur Flora von Böhmen. (Lotos, XII [1862], S. 18.)

- Neue Beiträge zur Flora Böhmens. (Lotos, XIV [1864], S. 58.)

- Bericht der botanischen Sektion. (2. Jahresber. über. d. Wirksamkeit d. beiden Komitees f. d. naturw. Durchforschung v. Böhmen im J. 1865 u. 1866. Prag, 1867.)

- Einige neue Beiträge zur Flora von Böhmen. (Lotos, XVIII [1868], S. 117.)

Conrath G., Floristisches aus Böhmen. (Österr. bot. Zeitschr., XXXVI [1886], S. 276.)

Daně k G., Fytogeografický nástin českého středního polabí. (Sborník klubu přrrodovědeckého v Praze, 1912, V.)

Dědeček J., Bericht über die Novernbervegetation bei Pisek im Jahre 1872. (Österr. bot. Zeitschr., XXIII [1873], S. 21.)

- Zur Flora von Südböhmen. (Österr. bot. Zeitschr., XXIV [1874], S. 152.)

Dichtl A., Floristisches aus der Teplitzer Gegend. (Österr. bot. Zeitschr., XXIX [1879], S. 121.)

Domin K., Beiträge zur Kenntnis der Phanerogamenflora von Böhmen. (Sitzungsber. d. Kgl. böhm. Ges. d. Wissensch., 1902-1905.)

- Das böhmische Mittelgebirge. (Englers bot. Jahrb., XXXVII, H. 1 [1903], S, 1.) 
Domin K., Brdy. Studie fytogeografická. (Knihovna česk. společn. zeměvědné v Praze, 2, 1903.)

- Die Vegetationsverhältnisse des tertiären Beckens von Veselí, Wittingau und Gratzen in Böhmen. (Beih.z. hot. Zentralbl., XVI, H. 2, 1904.)

Freyn J., Beiträge zur Kenntnis der Vegetationsverhältnisse des Brdygebirges in Böhmen. (Verh.zool. bot. Ges. Wien, XXIII [1873], S. 169.)

Haenke T., Tagebuch einer botanischen Reise in einigen Bezirken des Rakonitzer und Berauner Kreises in Böhmen. (Abh. d. böhrn. Ges. d. Wissensch. [1786], S. 31.)

Hansgirg A., Floristisches aus der Königgrätzer Gegend in Böhmen. (Österr. bot. Zeitschr., XXX [1880], S. 15.)

Hanu š J., Soustavný přehled a stanoviska rostlin cevnatých v okoli Plznè samorostlých a obecně pěstovaných. (XXX. Zpráva c. k. ěes. stát. výššiho realného gymn. v Plzni, $1885 / 86$.

Hoffmann F., Seznam rostlin jevnosnubných v nejbližšmí okolí Mladoboleslavském samorostlých i obecněji pěstovaných. (Progr. c. k. státn. výššího gymn. v Mladé Boleslavi 1885-1887.)

Hora P., Versuch einer Flora von Pilsen. (Lotos, N. F., III., IV. [1883], S. 81.)

Kopecký K., Analytická květana okoli města Rychnova nad Kněžnou. (Výroční zpráva c. k. stát. vyššího gymn, v Rychnově n. K., 1887.)

Maloch F., Beiträge zur Flora von Pilsen und seiner weiteren Umgebung. (Magy. bot. Lapok $\mathrm{X}[1911]$, S. 215.)

Nickerl O., Beiträge zur Flora von Prag. (Lotos, XIII [1863], S. 91.)

'Podp ěra J., Pflanzengeographische Studien in Böhmen. (Beihefte z. bot. Zentralbl., XVII, 2 [1901], S. 234.)

- Über das Vorkommen von Avena desertorum in Böhmen. (Österr. bot. Zeitschr., LII [1902]; S. 333.)

- Studien über die thermophile Vegetation Böhmens. (Englers bot. Jahrb., XXXIV [1904], S. 333.)

- Weitere Beiträge zur Phanerogamen- und Gefäßkryptogamenflora Böhmens. (Verh. d. zool. bot. Ges., Wien, LIV [1904], S. 313.)

- Über das Vorkommen von Ostericum palustre Bess. in Mähren. (Österr. bot. Zeitschr., LIV [1904], S. 387.)

Poech J., Die Vegetation von St. Ivan in Böhmen. (Flora, XV [1842], S. 410.)

Pospichal G., Flora des Flußgebietes der Cidlina und Mrdlina. (Arch. f. d. naturw. Landesdurchforschung Böhmens. IV, 5 [1881].)

Reichardt H. W., Verzeichnis aller von Herrn J. Ch. Neumann in Böhmen gesammelten Pflanzen. (Verh. zool. bot. Ver., Wien IV. [1854], S. 253.)

Reuss A.; Beiträge zur Flora Böhmens. (Lotos, XI [1861], S. 223, XII [1862], S. 213.)

- Die Flora der Salzstellen, insbesondere Böhmens. (Lotos, XIII [1863], S. 11.)

Schauta J., Zur Flora der Stadt! Niemes und deren Umgebung. (Lotos, XI [1861], S. 27.)

Sekera W., Eine Exkursion in die Gegend des Řip oder Georgsberges. (Österr. bot. Zeitschr., XVIII [1868], S. 122.)

- Flora der Basaltformation um Münchengrätz in Böhmen. (Österr. bot. Zeitschr., XIX [1869], S. 209.)

Schmidt F. W., Verzeichnis der um Wosetschan und der benachbarten Gegend an den Ufern der Moldau im Berauner Kreise wachsenden, seltenen Pflanzen. (Abh. d. böhm. Ges. d. Wissensch. [1791], S. 1.)

Velenovský J., Bericht über seine jüngsten Entdeckungen in der böhmischen Flora. (Bot. Zentralbl. XV·[1883], S. 254.)

Watzel C., Die im Horizont von Böhm.-Leipa vorkommenden Moose und Gefäßkryptogamen. (X. Jahresber. d. Komm. Ober-Realsch. in Böhm.-I.eipa, 1874.)

— Die phanerogame Flora des Gebietes von Böhm.-Leipa. (XIV. Jahresber. d. Komm: OberRealsch. in Böhm.-Leipa,1878.)

Wild A.; Aus der Flora von Kladno und dessen Umgebung. (Lotos, I884-1885.) 
Wurm F., Phänologische Beobachtungen und Beiträge zur Flora der Umgebung von Böhm.Leipa. (XXVI. Jahresber. d. Komm. Ober-Realsch. in Böhm.-Leipa, 1889.)

Zouplna J., Einige Fundorte seltener böhmischer Pflanzen. (Lotos, IX [1859], S. 119.)

\section{e) Elbesandstein- und Lausitzer Gebirge.}

Dědeček J., Ein kurzer Ausflug auf den Jeschken und Milleschauer. (Österr. bot. Zeitschr., XXVIII [1878], S. 322.)

Drude O., Der herzynische Florenbezirk. (Leipzig, 1902.)

Karl W., Nordböhmen und seine Flora. (Österr. bot. Wochenbl., II [1852], S. 233.)

- Auch eine Exkursion. Ebenda, IV [1854], S. 41.)

Matauschek F., Ergänzung der, Flora der nächsten Umgebung Reichenbergs" von Anton Schmidt. (Mitt. d. Ver. d. Naturfreunde in Reichenberg, XXV [1894], S. 1.)

- Floristisches aus der näheren und weiteren Umgebung von Reichenberg. (Sep. aus Mitt. d. Ver. Naturfr. Reichenberg.

- Bryologisch-floristische Beiträge aus Böhmen. Ebenda, XXVII [1896].

Reichardt.H. W., Verzeichnis aller von Herrn J. Ch. Neumann in Böhmen. gesammelten Pflanzen. (Verh. zool. bot. Ver., Wien, IV [1854], S. 253.)

Watzel C., Die phanerogame Flora des Gebietes von Böhm.-Leipa. (XIV. Jahresber. d. Komm.-Ober-Realsch. in Böhm.-Leipa, 1878.)

\section{i) Sudeten.}

Brandeis R., Kurzer Bericlit über eine botanische Exkursion ins Riesengebirge. (Lotos, XXII [1872], S. 96.)

Cypers V.v., Beiträge zur Flora des Riesengebirges und seiner Vorlagen. (Österr. bot, Zeitschr, XLVIII [1898], S. 185, LIX [1909], S. 302.)

Fiek E., Flora von Schlesien preußischen und österreichischen Anteiles. (Breslau, 1881.) Formánek E., Ein Beitrag zur Flora des, böhmisch-mährischen und des Glatzer Schneegebirges. (Österr. bot. Zeitschr., XXXV [1885], S. 153.)

- Beitrag zur Flora des nördlichen Mährens und des Hochgesenkes. (Ebenda, XXXVII [1887], S. 234.)

Haenke F., Botanische Beobachtungen auf einer Reise nach dem Riesengebirge. (Dresden, 1781.)

Hans W., Botanischer Ausflug in das mährische Gesenke im Juli 1867. (Österr. bot. Zeitschr., XVIII [1868], S. 352.)

Hansgirg N., Dodatky ku květeně české: (Sitz.-Ber. d. böhm. Ges. d. Wissensch., [1882], S. 123.)

Kreisel H., Die Samenpflanzen der Umgebung Jägerndorfs. (12. und 13. Jahresber. d. Staatsrealschule Jügerndorf.)

Laus H., Der große Késsel im Hochgesenke. (Beih. z. bot. Zentralbl., XXXI, 2, [1909], S. 103.) Limpricht G., Ergebnis einiger botanischer Wanderungen durchs Isergebirge. (Abh. d. schles. Ges. f. vaterl, Kultur $[1869-1872]$, S. 34.)

Müncke R., Der große Kessel im böhmisch-mährischen Gesenke. (Österr. bot. WochenbI., $\mathrm{V}[1855]$, S. 225.)

- Der Blaugrund im. Riesengebirge. (Ebenda, S. 378.)

Òborny A., Zur Flora von Mähren. (Österr. bot. Zeitschr., XXIV́ [1874], S. 23.)

Pax F., Die Flora des Rehhorns bei Schatzlar. (Flora, LVI [1883], S. 177.)

Petrak, Die alpine Flora der mähr.-schles. Sudeten. (Allg. bot. Zeitschr., XIV [1908], S. 59.)

Rohrer R., und Mayer A., Vorarbeiten zu einer Flora des mährischen Gouvernements. (Brünn, 1835.)

Schauer, Über die Flora des böhm.-mähr. Gesenkes.-(Flora, XXIII [1840], 1, S. 17.)

Schiffner V., Ökologische Studien über die sogenannten ,Knieholzwiesen“ des Isergebirges. (Wiesner-Festschrift, Wien, 1908, S. 542.) 
Szabó Z., A Sudeták növényföldrajzának vázlatos foglalata. (Földrajzi Közlem. XXXV [1907].)

Traxler R., Einige neue Standorte für Böhmen. (Österr. bot. Zeitschr., XXIX [1879], S. 395.)

Vierhapper F. sen., Flora des Bezirkes Freiwaldau und seines angrenzenden Gebietes. (Weidenau, 1880.)

Weitenweber W. R., Zur Flora des böhmischen Riesengebirges. (Lotos, IX [1859], S. 169.) Wimmer F., Geographische Übersicht der Vegetation Schlesiens in Wimmer, Flora von Schlesien, Ergänzungsband. (Breslau, 1845.)

Zeiske M., Die Pflanzenformationen der Hochsudeten. (Beih. z. bot. Zentralbl., XI [1901], S. 418 .)

\section{g) Böhmisch-mährisches Gebirge und IValdviertel.}

Beck v. Managetta G., Flora von Niederösterreich. Wien, 1890-1893.

- Die Wachau. Eine pflanzengeographische Skizze aus Niederösterreich. (Blätter d. Ver. f. Landesk. v. Niederösterreich. [1898].)

Hansgirg N., Ein Beitrag zur Flora, des böhmisch-mährischen Grenzgebietes. (Österr. bot. Zeitschr., XXXII [1882] S. 14.)

Hruby J., Flora des Mähr.-Trübauer Berglandes. (XXIX. Jahresber. d. k. k. Staatsgymnasiums in Mähr.-Trübau [1905/06].)

Iltis H., Die Umgebung von Radeschin mit besonderer Berücksichtigung ihrer Flora. (Jahresbericht d. deutschen Staatsgymn. Brünn, 1910-11.)

Kerner A., Die Flora des Donautales von Melk bis Hollenburg. (Verh. d. zool.-bot. Ver. Wien, I $[1851]$, S. 27.)

- Der Jauerling; eine pflanzengeographische Skizze. (Verh. d. zool.-bot. Ver. Wien, V [1855], S. 521.)

- Das Pflanzenleben der Donauländer. (Innsbruck, 1863.)

Kovář F., Př́spěvek ku květeně lišejniků a jevnosnubných rostlin. (Věstník klubu př́rodovědeckého v Prostějově, IV [1904], S. 55.)

Linsbaver, Über das Vorkommen von Botrychium rutaefolium A. Br. in Niederösterreich. (Österr. bot. Zeitschr., LIV [1904], S. 332.)

Neilreich A., Flora von Niederösterreich. (Wien, 1859.)

Novák J., Klíč k určování rostlin krytosemenných okolí města Německého Brodu. (3. roění zpráva realn. a vyšš. gymn. Něm. v Brodě, 1878-1880.)

Oborny A., Beiträge zu den Vegetationsverhältnissen der oberen Thayagegenden. (Österr. bot. Zeitschr., XXX [1880], S. 384, XXXI [1881], S. 16.)

Pokorny A., Die Vegetationsverhältnisse von Iglau. (Wien, 1852).

- Beiträge zur Kenntnis des böhmisch-mährischen Gebirges. (Verh. d. zool.-bot. Ver., Wien, I [1851], S. 59.)

Reichardt H. W., Nachtrag zur Flora von Iglau. (Verh. d. zool.-bot. Ver. Wien, V [1855], S. 485.)

Schreiber G., Die Moore des Zwittauer Bezirkes. (Mitt. d. Komm. z. naturw. Durchforschung Mährens. Brünn [1907].)

- Beiträge zur Flora des Zwittauer Gebietes. (Zeitschr. d. mähr. Landesmuseume, VIII [1908], S. 139.)

Teyber A., Über einige interessante floristische Funde in Niederösterreich. (Verh. d.zool.-bot. Ges. Wien, LVI [1906], s. 70.)

Zederbauer E., Exkursion in die niederösterreichischen Alpen und das Donautal. (Führer zu d. Exkursionen d. II. internat. bot. Kongresses, Wien, IV [1905].)

\section{h) Mittel- und Südmähren mit dem nordöstlichen Niederösterreich.}

Bachinger A., Beiträge zur Flora von Horn. (XV. Jahresber. d. nied.-öst. Landes-Real- und Obergymn., Horn, 1887.) 
Beck v. Managetta G. V. Flora von Niederösterreich. (WVien, 1890-1893.)

Bil ý A., Beitrag zur Flora von Mähren. (Verh. d. naturw. Ver. Brünn, XXXV [1896], S. 157.) Bubela J., Verzeichnis der um Bisenz. in Mähren wachsenden Pflanzen. (Verh. d. zool.-bot. Ges., Wien, XXXI [1881], S. 775.)

- Nachtrag zum Verzeichnis der um Bisenz in Mähren wildwachsenden Pflanzen. (Ebenda, XXXII [1882], S. B., S. 42.)

- Floristisches aus der Umgebung von Čejč in Mähren. (Österr. bot. Zeitschr., XXXII [1882], S. 117.)

Ċoka F., Příspěvky ku květeně moravské. (Věstník klubu př́rodovědeckého, Proßnitz, IX [1906], S. 88, [1908], S. 132.)

Formánek E., Korrespondenz, (Österr.bot. Zeitschr., XXXIV [1884], S. 144, XXXVIII [1888], S. 36, 75, 103, 186, 321.)

Frank L., Beiträge zur Flora der Umgebung von Olmütz. (Verh. d. naturf. Ver. Brünn, XLV. [1906], S. 175.)

Ginzberger A., Exkursion in die Donauauen unterhalb Wiens. (Führer zu d. wissensch. Exkursionen d. II. internat. bot. Kongresses, Wien, 1905.)

Gogela L., Květana na dolnim toku Rusavy v okolí Střebětic. (Věstník klubu př́rodovědeckého, Proßnitz, XI [1908], S. 43.)

Hochstetter G. F., Übersicht des Merkwürdigsten aus Mährens Flora. (Flora [1825], S. 513.)

Kalbrunner H., Beitrag zur Flora des V. U. M. B. (Verh. d. zool.-bot. Ver. Wien, V [1855], S. 683.)

Keller L., Bericht über Pflanzenfunde. (Verh.d.zool.-bot. Ges., Wien, LIV [1904], S. 620.)

Laus H., Die Halophytenvegetation des südlichen Mährens und ihre Beziehungen zur Flora der Nachbargebiete. (Mitt. d. Komm, zur naturw. Durchforschung Mährens. Bot. Abt. Nr. 3, Brünn, 1907.)

- Beiträge zur Flora Mährens. (Verh. d. naturf. Ver., Brünn, XLVII [1908].)

- Die Vegetationsverhältnisse der südmährischen Sandsteppe zwischen Bisenz und Göding und des Nachbargebietes. (Bot. Zeitung, LXVIII, 2 [1910], S. 177 ff.)

- Die pannonische Vegetation der Gegend von Olmütz. (Verh. naturf. Ver., Brünn, XLVIII [1909], S. 195.)

Laus H. und Schierl A., Pflanzenformationen und Pflanzengenossenschaften im südlichen Mähren. (II. Ber. d. Lehrerklub f. Naturkunde für 1899. Brünn, 1900.)

Makowsky A., Die Sumpf- und Uferflora von Olmütz. (VI. Jahresber. d. k. k. Staats-Oberrealschule, Olmütz, 1860.)

- Die Flora des Brünner Kreises. (Brünn, 1863.)

Neilreich A., Das Marchfeld. Eine botanische Skizze. (Verh. d. zool.-bot. Ver. Wien, III [1853], Abh., S. 392.)

- Flora von Niederösterreich. Wien, 1859.

Niessl G. v., Über die Flora der Eisleiten bei Frain. (Verh. d. naturf. Ver. Brünn, VI [1867], Sitzungsber., S. 62.)

Oborny A., Zur Flora von Mähren. (Österr. bot. Zeitschr., XXIV [1874], S. 23.)

- Beiträge zur Flora des südlichen Mährens. (Österr. bot. Zeitschr., XXV [1875], S. 64.)

- Beiträge zur Flora von Niederösterreich. (Österr. bot. Zeitschr., XXIX [1879], S. 9.)

- Die Flora des Znaimer Kreises. (Verh. d. naturf. Ver. Brünn, XVII, 1879.)

Ortmann J., Über eine in dem ehemaligen Viertel ob dem Mannhartsberge unternommene botanische Exkursion. (Verh. d. zool.-bot. Ver., Wien, I [1851], S. 78.)

Palla J., Die Flora von Kremsier in Mähren. (Österr, bot.Zeitschr. XXXVI [1886] S. 86.)

Picbauer R., Floristické poznámky z okolí Kroměřiže. (Věstník klubu př́rodovědeckého, Proßnitz, X [1908], S. 77.)

- Př́spěvek ku poznání květeny okolí Třebiče a některých míst okresu Velko-Mleziřičského a Námèstského. (Vèstník klubu prírodovèdeckého, Proßnitz, IX [1907], S. 3.)

Pluskal F. S., Phanerogamenflora der Gegend von Lomnitz in Mähren. (Verh. d. zool.-bot. Ver., Wien, III [1853], S. 1.) 
Podpèra J., Geranium lucidum, nová na Moravě rostlina jevnosnubná. (Časopis mor. mus., IV, 1, 2 [1904].)

- Über das Vorkommen von Ostericum palustre Bess, in Mähren. (Österr. bot. Zeitschr., LIV [1904], S. 387.)

- Irvětana Hané. (Archiv na př́rod. prozkoumání Moravy. Odd. bot. I, Brünn, 1911.)

- Über das Vorkommen von Avenastrum dersertorum (Less.) Podp. in Mähren. (Österr. bot. Zeitschr., LXII [1912], S. 249.)

Reis A., Die Flora von Auspitz. (V. Jahresber. d. deutschen Landes-Unterrealschule in Auspitz, 1875.)

Reisseck S., Beiträge zur Flora von Mähren. (Flora [1841],S. 673.)

Römer C., Beiträge zur Flora von Namiest in Mähren. (Österr. bot. Zeitschr, V [1855], S. 233.)

Sapetza J., Beitrag zur Flora von Mähren und Schlesien .(Verh. d. zool, bot. Ges., Wien, VI $[1856]$, S. 471

- Beitrag zur. Flora von Mähren. (Ebenda, X [1860], S. 686.)

- Die Flora von Neutitschein. (Abh.d. naturf. Ges., Görlitz, XII [1865], S. 1.)

Schlögl L., Die Flora von Ung.-Hradisch und Umgebung. (Progr. d. k. k. Real- u. Obergymn. Ung.-Hradisch, 1874/5 und 1875/6.)

Slavícek F. J., Beitrag zur Flora von Mähren. (Verzeichnis der in der Umgebung von Littau beobachteten phanerogamen Pflanzen.) (Verh. d. naturf. Ver., Brünn, XXXV [1897], S. 3.)

Spitzner W., Korrespondenzen. (Österr. bot. Zeitschr., XXXVI (1886), S. 213, 238, 433; XXXVII [1887], S. 332 ; XXXVIII (1888) S. 144, 394, 430.)

Steiger R., Verzeichnis der im Bezirke von Klobouk beobachteten phanerogamen Pflanzen. (Abh. d. naturf. Ver., Brünn, XVIII [1880], S. 87.)

Stranák F., Kvètána propasti Macochy. (Časopis vlast. mus. Olmütz, 1906, S. 105.)

- Die Dunkelflora der Slouper Höhlen. (Sitzungsber. d. böhm. Ges. d. Wissensch., 1907.)

Teyber A., Interessante,floristische Funde in Niederösterreich. (Verh. d. zool. bot. Ges. Wien, LII [1902], S. 593.)

- Neues aus der Flora Niederösterreichs. (Verh. d. zool. bot. Ges. Wien, LIII [1903], S. 564.)

- Uber interessante Pflanzen aus Niederōsterreich und Dalmatien. (Verh. d. zool. bot. Ges. Wien, LIX [1909], S. 160.)

Tkany F., Die. Vegetationsverhältnisse der Stadt Olmütz und ihrer Umgebung. (Progr. d. k. k. deutschen Staats-Obergymn., Olmütz, 1879/80.)

Vogl A., Flora von Olmütz. (Österr. bot. Wochenbl., IV [1854], S. 244.)

- Flora von Weißkirchen in Mähren. (Österr. bot. Wochenbl., VI [1856], S. 211.)

Wawra H., Vorarbeiten zu einer Flora von Brünn. (Verh. d. zool. bot. Ver. Wien, I [1851], S. 161.)

Wildt A., Beitrag zur Flora von Mähren. (Abh. d. naturf. Ver., Brünn, XLII [1903], S. 178.)

- Beiträge zur Flora von Mähren. (Ebenda, XLVI [1907], S. 1, 94.). 


\section{Galizien und die Bukowina}

\section{und das östliche Schlesien mit Ausschluß der Karpathen.}

\section{A. Die Vegetation in ihrer Abhängigkeit von Klima und Boden.}

Galizien und die Bukowina stellen ein ausgedehntes, welliges Tiefland von einer durchschnittlichen Höhe von $200-300 m$ dar. Im Süden erheben sich die aus eozänen Sandgesteinen aufgebauten Vorhügel der Karpathen, im Nordwesten finden sich Jura- und Kreidekalke der Tarnowitzer Platte und im Osten am Dnjestr und seinen Zuflüssen sind die Kallie und Gipse der podolischen Hochebene, die sich bis über Lemberg hinaus nach Westen erstreckt, aufgeschlossen; das ganze übrige Land ist von Alluvien und diluvialen Sandmassen bedeckt, die oft als mächtige Flugsandschichten den Boden bedecken.

Klimatisch ist das Land durch seine große Entfernung vom Meere, durch seinen Abschluß gegen Süden zu durch die Karpathenkette und durch seine nach Norden offene Lage ausgezeichnet, welche Umstände es mit sich bringen, dả dieses Gebiet :unter allen Landstrichen Österreich-Ungarns das ausgesprochenste Kontinentalklima aufweist. Besonders im Osten machen sich die lang dauernden kalten Winter sehr bemerkbar, die Temperatur bleibt über vier Monate unter dem. Gefrierpunkt, die durchschnittliche Januartemperatur sinkt oft unter $-5^{0} \mathrm{C}$. Dazu kommt noch, daß das Land den kalten Nord- und Nordostwinden schutzlos ausgesetzt ist. 'Im Gegensatze zu diesen langen und kalten Wintern sind die Sommer sehr heiß und relativ trocken.

Genauere Werte über die Temperaturen an verschiedenen Orten Galiziens und der Bukowina zeigt nachstehende Tabelle. (Siehe S. 268.)

WWas die Niederschläge betrifft, so sind sie 'in ganz. Galizien nicht unbeträchtlich und sinken nur an wenigen Orten unter $60 \mathrm{~cm}$ im Jahre. An den nahe am Fuße der Karpathen gelegenen Orten sind sie sogar oft recht beträchtlich und fallen besonders reichlich in den Sommermonaten; in der Ebene hingegen sind sie ziemlich gleichmäßig auf dos Jahr verteilt und im Sommer relativ gering. 
Mittelwerte der Temperatur.

\begin{tabular}{|c|c|c|c|c|c|c|c|c|c|c|c|c|c|}
\hline $\begin{array}{l}\text { Beobachtungsstation } \\
\text { und Meereshöhe }\end{array}$ & $\frac{3}{\pi}$ & $\underset{\stackrel{E}{E}}{\stackrel{E}{\Xi}}$ & & $\sum_{2 \pi}^{N}$ & $\overline{\frac{\pi}{\varepsilon}}$ & $\tilde{\pi}$ & $\underline{\Xi}$ & $\Xi$ & 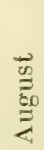 & 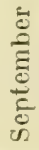 & $\frac{5}{\frac{5}{0}}$ & 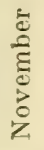 & 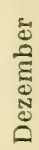 \\
\hline
\end{tabular}

Bielitz, $343 \mathrm{~m}$. . . $7 \cdot 6-2.5-1 \cdot 6|1 \cdot 87 \cdot 2| 12 \cdot 2|15 \cdot 9| 17 \cdot 6|17 \cdot 2| 13 \cdot 58 \cdot 9|2 \cdot 7|-1 \cdot 7$

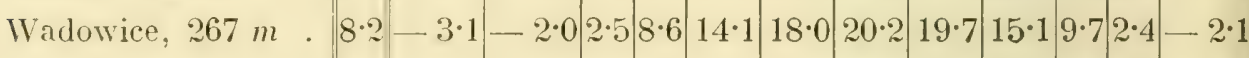
Krakau, $220 m$. . $7 \cdot 9-3 \cdot 3-2 \cdot 02 \cdot 08 \cdot 013 \cdot 5 \quad 17 \cdot 2 \quad 18 \cdot 8$ 17.9 $14 \cdot 18 \cdot 92 \cdot 3$ - $2 \cdot 2$

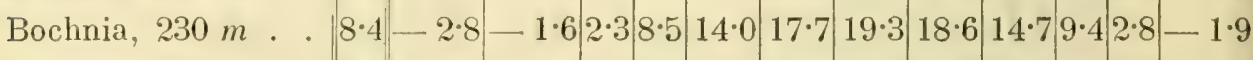

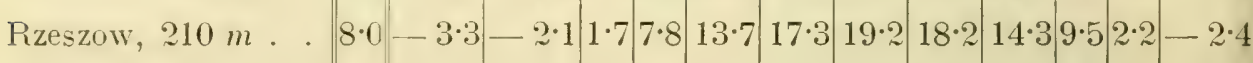

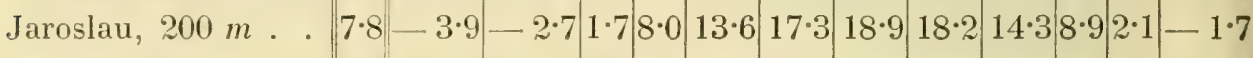
Lemberg, $300 \mathrm{~m}$. . $8 \cdot 0 \cdot-3 \cdot 6-2 \cdot 7|2 \cdot 2 \cdot 1| 14 \cdot 1 \quad 17 \cdot 8$ 19.4 $18 \cdot 6$ 14.2 $9 \cdot 02 \cdot 3-2 \cdot 3$ Zloczow, $275 m$. . $7 \cdot 4-4 \cdot 4-3 \cdot 70 \cdot 77 \cdot 8 \quad 13 \cdot 9$ 17.4 $18 \cdot 8$ 17.8 $13 \cdot 48 \cdot 41 \cdot 6$ - $3 \cdot 1$

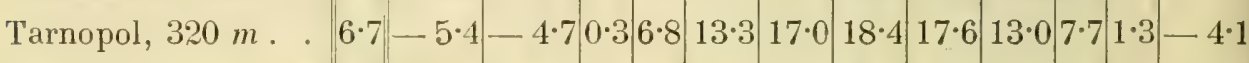
Drohobycz, $310 m$. $7 \cdot 4-4 \cdot 2-2 \cdot 60 \cdot 97 \cdot 4 \quad 13 \cdot 617 \cdot 018 \cdot 1 \quad 18 \cdot 013 \cdot 78 \cdot 61 \cdot 8-3 \cdot 4$

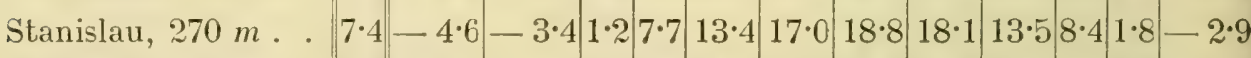

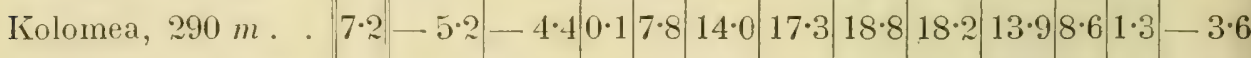
Czernowitz, $225 \mathrm{~m} \cdot|7 \cdot 9|-5 \cdot 1|-4 \cdot 0| 1 \cdot 0|8 \cdot 6| 14 \cdot 7|18 \cdot 3| 20 \cdot 1|19 \cdot 4| 14 \cdot 8|9 \cdot 0| 1 \cdot 5 \mid-3 \cdot 5$

Mittelwerte der Niederschläge in Millimetern.

\begin{tabular}{|c|c|c|c|c|c|c|c|c|c|c|c|c|c|}
\hline & Jahr & 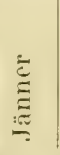 & $\frac{\bar{E}}{\stackrel{E}{\bar{E}}}$ & 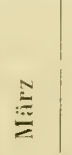 & $\overline{\bar{E}}$ & $\tilde{\Xi}$ & $\Xi$ & $\vdots$ & 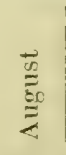 & 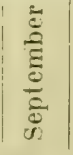 & $\frac{\frac{4}{0}}{\frac{0}{0}}$ & 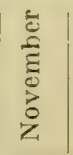 & 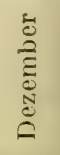 \\
\hline & 792 & 41 & 51 & 54 & 61 & 79 & 101 & 98 & 88 & 68 & 48 & 50 & \\
\hline Wadowice (K.), $267 \mathrm{~m}$ & 1052 & 45 & 57 & 86 & 86 & 133 & 116 & 131 & 97 & 106 & 65 & 58 & 72 \\
\hline $900 \mathrm{~m}$ & 630 & 27 & 31 & 35 & 42 & 62 & 82 & 91 & 83 & 55 & 45 & 38 & 39 \\
\hline Bophnis 930 m & 741 & 42 & 45 & 39 & 58 & 75 & 104 & 95 & 94 & 62 & 38 & 44 & 45 \\
\hline zeszow, $210 \mathrm{~m}$ & 598 & 31 & 33 & 44 & 46 & 61 & 67 & 91 & 76 & 47 & 38 & 31 & 33 \\
\hline Toroclou & 670 & 29 & 27 & 33 & $5 \%$ & 81 & 89 & 96 & 72 & 70 & 35 & 39 & 47 \\
\hline $\mathrm{g}, 300 \mathrm{~m}$ & 684 & 38 & 32 & 46 & 48 & 78 & 97 & 94 & 77 & 50 & 40 & 42 & $4^{5}$ \\
\hline ow, $275 \mathrm{~m}$. . & 663 & 31 & 38 & 43 & 46 & 64 & 91 & 90 & 71 & 64 & 42 & 41 & $4 \%$ \\
\hline หา & 574 & 25 & 31 & 38 & 41 & 62 & 84 & 80 & 63 & 48 & 40 & 33 & 32 \\
\hline R.), $310 \mathrm{~m}$ & 934 & 33 & 29 & 55 & 61 & 116 & 170 & 156 & 94 & 73 & 63 & 46 & 38 \\
\hline & 637 & 23 & 27 & 33 & 42 & 69 & 87 & 97 & 82 & 60 & 51 & 35 & 31 \\
\hline (JK) 200 & 745 & 34 & 38 & 47 & 46 & 113 & 124 & 102 & 76 & 56 & 43 & 27 & 39 \\
\hline Czernowitz (K.), $225 \mathrm{~m}$ & 605 & 18 & 26 & 41 & 48 & 79 & 95 & 89 & 61 & 51 & 43 & 32 & 22 \\
\hline
\end{tabular}

1) Die mit (K.) bezeichneten Orte liegen am Fuße der Karpathen. 
Weit größer als man nach der Verschiedenheit des Klimas erwarten könnte, ist die Verschiedenheit der Vegetation in den verschiedenen Teilen Galiziens. Der ganze Westen ist ein Waldgebiet, in welchem auf anstehendem Gesteine Laubhölzer, auf dem trockenen Flugsand Föhren die waldbildenden Bäume darstellen; der nährstoffarme Quarzsand bietet Gelegenheit zur Ausbildung von Heideformationen, die große Lufteuchtigkeit ist der reichlichen Hochmoorbildung günstig. Ganz anders im Osten. Hier herrscht der Laubwald vor, Nadelhölzer fehlen (einschließlich des Wacholders) ganz. Hier spielen die lange dauernden kalten Winter und die herrschenden Stürme gewiß die Hauptrolle, die jährliche Niederschlagsmenge ist ja groß genug, um Baumwuchs zu ermöglichen, aber hier können nur jene Bäume (und auch andere Gewächse) existieren, die der winterlichen Trockenheit vollkommen standzuhalten in der Lage sind, und das sind nur jene, welche im WVinter gar keine transpirierenden Organe mehr aufweisen, die laubabwerfenden Bäume. Es fehlen auch in Ostgalizien in der Ebene nicht nur alle immergrünen Laubhölzer, es fehlen auch die immergrünen Sträucher und Halbsträucher unserer Wälder, die Erikazeen und Pirolazeen, da offenbar auch diese im Winter gleich wie die Nadelhölzer durch das überdauernde Laub so stark transpirieren, daß sie der andauernden winterlichen Trockenheit nicht widerstehen könnten. In jenen Gebieten aber, wo die jährliche Niederschlagsmenge noch tiefer sinkt wie: an der Ostgrenze des Gebietes (Tarnopol hat nur mehr $574 \mathrm{~mm}$ Niederschlag!), dort ist auch den Laubhölzern in der Verbreitung eine Grenze gesetzt und hier findet sich nur mehr Grasflur in Gestalt von blumenreichen Triften oder Steppen.

Galizien und die Bukowina außerhalb der Karpathen gehört demnach in bezug auf seine Flora drei verschiedenen Gebieten an: im Westen und Norden einem Waldgebiete, in dem sich Laub- und Nadelwälder finden und das sich an das Waldgebiet Ostdeutschlands eng anschließt, im Osten einem Waldgebiete, in welchem aber Nadelhölzer sowie immergrüne Gewächse (mit Ausnalıme von Hedera Helix, vgl. unten) fehlen, und endlich dem äußersten Osten, der sich schon als ein Vorposten des großen südrussischen Steppengebietes darstellt.

\section{B. Die Pflanzengenossenschaften des Gebietes.}

\section{Die Pflanzengenossenschaften West- und Nordgaliziens.}

\section{a) Waldbestände.}

Laubmischwälder. fln der nördlichen Ehene Galiziens sind Laubmischwälder im allgemeinen nicht häufig und auf anstehendes Gestein beschränkt. Eichen (Quercus Robur), Buchen (Fagus silvatica), Hainbuchen (Carpinus Betulus), Linden (Tilia cordata und platyphyllos), Zitterpappeln (Populus tremula), Erlen (Alnus rotundifolia) und Ahorne (Acer platanoides) setzen den meist sehr gemischten Bestand zusammen; ab und zu gesellen sich auch einzelne Nadelhölzer 
(Pinus silvestris, Picea excelsa, Abies alba) hinzu. Das meist reiche Unterholz bilden Wacholder (Juniperus communis), Weiden (Salix caprea und aurita), Haselnüsse (Corylus Avellana), Pfaffenküppchen (Evonymus vulgaris und verrucosus), ferner Crataegus monogyna, Prunus spinosa und im Westen Acer campestre. Der reiche Niederwuchs bietet dasselbe Bild wie allenthalben in lichten Laubwäldern; im ersten Frühling blühen Galanthus nivalis, Anemone Hepalica, A. nemorosa, A. ranunculoides, Viola hirla, $V$. odorata, $V$. silvestris, $V$ : mirabilis, Stellaria holostea, Oxalis Acelosella, Lamium vulgare, Lathyrus vernus, später dann sind besonders grasartige Pflanzen zahlreich anzutreffen, wie Milium effusum, Agrostis canina, Calamagrostis lanceolata, C. neglecta, Deschampsia flexuosa, Sieglingia decumbens, Daclylis glomerala, Bromus asper, Brachypodium pinnatum, Carex muricala, C. brizoides, $C$. remota, C. 'leporina, C. umbrosa, C. digitata, G. silvatica. Ferner gedeihen in diesen Wäldern Maianthemum bifolium, Polygonatum officinale, $P$. multiflorum und $P$. verlicillatum, Listera ovata, Neottia Nidus avis, Ranunculus auricomus, R. cassubicus, Dianthus Armeria, Silene nulans, Viscaria vulgaris, Hypericum montanum, H. hirsutum, Epilobium monlanum, Potentilla erecta, Genista germanica, G. tinctoria, Gytisus hirsulus (im Osten C. ruthenicus), Trifolium medium, T. alpestre, Vicia cassubica, Sanicula europaea, Vaccinium Myrlillus, V. Vitis. Idaea, Galluna vulgaris, Scrophularia nodosa, Digitalis ambigua, Veronica officinalis, Asperula odorata, Galium Schullesii, G. rotundifolium (nur im: Westen häufig), |Phyleuma spicatum, Gnaphalium silvaticum, Chrysanthemum corymbosum, Centaurea austriaca und im Herbste blühen noch Origanum vulgare, Carlina vulgaris, Solidago Virga aurea und Serralula tincloria.

Föhrenwälder. Der wichtigste und vorherschende Waldbaum der nordund westgalizischen Ebene ist die Rotföhre (Pinus silvestris), die sowohl auf Sand- als auch auf Moorboden große Bestände bildet. Auf Sandboden speziell ist Pinus silvestris der einzige Baum, der, mitunter in verkrüppelter Form, weite Strecken bedeckt. Das Unterholz fehlt in diesen Wäldern oft ganz oder besteht aus Juniperus communis, Sarothamnus scoparius und Calluna vulgaris, die oft in dichtem Bestande den Boden bedecken. Im Niederwuchs finden sich vor allem die Gräser des Sandbodens, wie Corynephorus canescens, Aira caryophyllea, Deschampsia flexuosa, D. caespitosa, Koeleria glauca, Calamagrostis Epigeios, Nardus slricta, auch Pleridium aquilinum tritt oft in großer Menge auf. Ferner kommen Alhyrium Filix femina, Dryopteris Filix mas, Equiselum pratense, E. silvaticum, Genista germanica, Daphne Cneorum, Chimaphila umbellala, Pirola rotundifolia, P. chlorantha, P. minor, P. secunda, Viola rupestris, Gentiana asclepiadea, Jasione montana, Gnaphalium luteoalbum, Serratula tinctoria usw. vor. Nicht selten aber fehlen auch Unterholz und Niederwuchs vollständig und der von einer dichten Schicht abgefallener Nadeln bedeckte sandige Boden ist ganz vegetationslos.

Fichtenwälder. $\mathrm{Ab}$ und $\mathrm{zu}$, besonders längs der Weichsel, treten auf Sandboden auch Fichtenbestände in größerer Ausdehnung auf. Mit Picea excelsa 


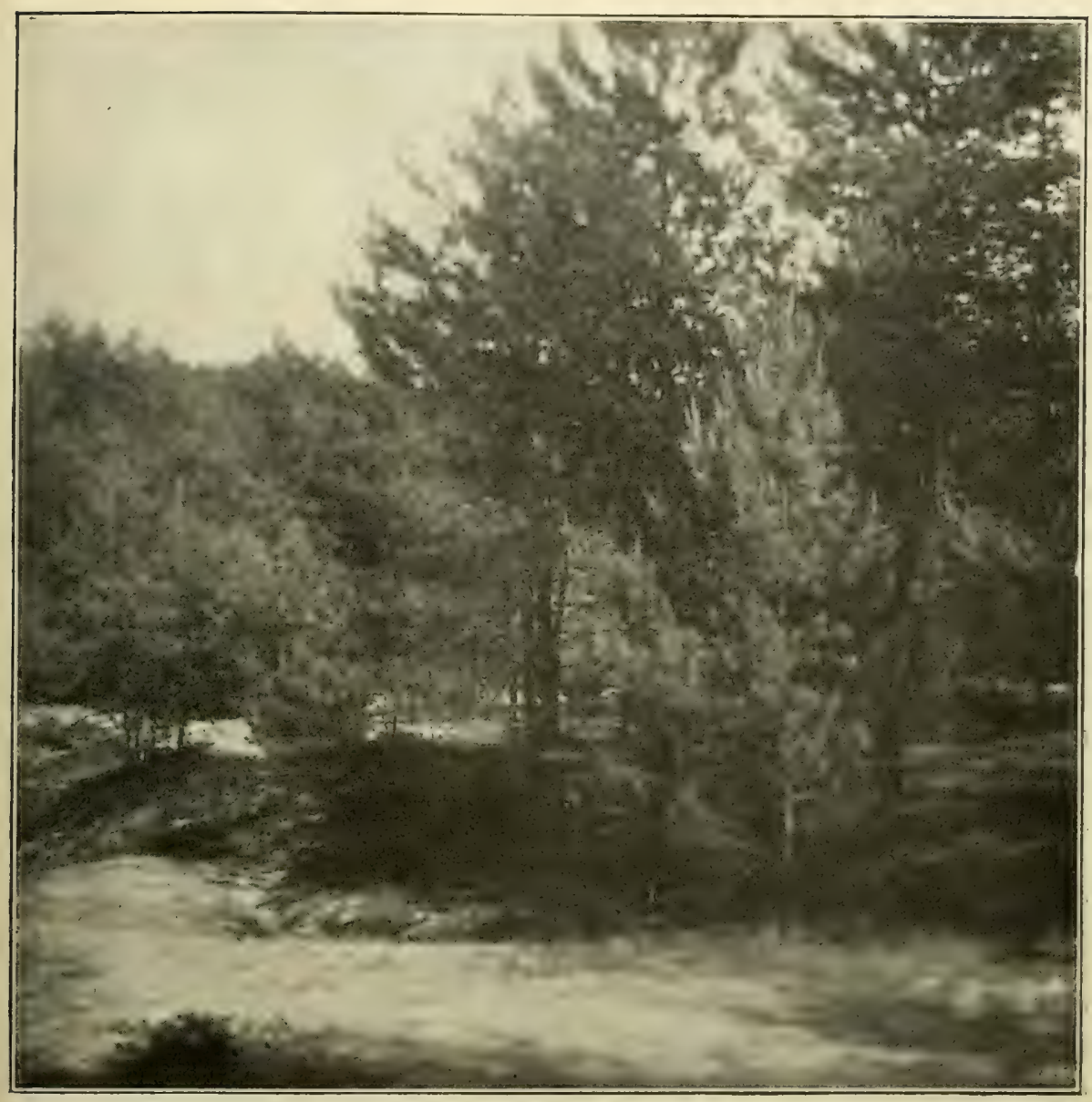

Abb. 133. Föhrenwald auf Flugsand bei Trzebinja in Westgalizien. Der Untergrund fast vegetationslos.

(Nach einer Aufnahme von A. v. Hayek).

ist gewöhnlich Abies alba und Pinus silveslris vergesellschaftet, von Laubhölzern trifft man ab und zu Populus tremula und Betula pendula (an der schlesischen Grenze auch B. *obscura) eingesprengt. Physiognomisch unterscheiden sich diese Wälder von den Nadelwäldern der Gebirge sehr bedeutend durch die geringe Stammdicke der meist sehr dicht stehenden Bäume. Ein Unterholz fehlt in diesen Wäldern meist ganz oder besteht aus einzelnen Strüuchern von Juniperus communis, Prunus spinosa, Crataegus monogyna oder Sarolhamnus. scoparius. Im Niederwuchs herrschen gewöhnlich Vaccinium Myrlillus und $V$. Vitis Idaea vor und bedecken weithin in dichtem Bestande den Boden; nur hie und da treten einzelne Gräser, wie Nardus stricta, Deschampsia flexuosa und Sieglingia decumbens oder Calluna vulgaris und Genista pilosa dazwischen auf;im Osten findet sich auch als Seltenheit Gymnadenia, cucullala. 
Birkenbestainde. Auf Heiden bildet auch Betula pendula ab und zu kleine Bestände. Im Niederwuchs ist gewöhnlich die typische Heideflora entwickelt, besonders Calluna vulgaris und Pleridium aquilinum treten meist in Menge auf.

Moorwälder. Ein ganz anderes Bild als diese Heidewälder bieten die Föhrenwälder auf moorigem Untergrunde, die sich in Westgalizien vielfach direkt neben den Sandwäldern finden und sich auch aus solchen durch Auftreten und Überhandnehmen von Torfmoosen entwickeln. Die reiche Vegetation, besonders der Baumwuchs, bringt es mit sich, daß der Boden meist etwas weniger naß ist als in nicht von Wald bestandenen Mooren, nichtdestoweniger erweist sich der Untergrund doch noch als ein typisches Hochmoor. Das Oberholz bildet meist Pinus silvestris allein, ab und zu treten auch Betula pubescens und Alnus rolundifolia eingesprengt auf. Im Unterholze ist besonders das oft massenhafte Auftreten von Ledum palustre bemerkenswert, auch Calluna vulgaris, Vaccinium Myrtillus, V. Vitis Idaea und V.uliginosum, seltener Betula humilis bedecken oft den Boden. Den Untergrund aber bildet ein typisches Sphagnummoor, in welchem von Holzgewächsen noch Andromeda polifolia und Salix repens vorkommen, während Empetrum hier fehlt. Im Niederwuchs sind Eriophorum vaginatum, Carex canescens, Molinia coerulea, Nardus stricta, Juncus squarrosus, J. effusus, Polentilla erecta, Oxycoccos quadripelala, Melampyrum pratense. *paludosum, M. silvaticum nicht selten, ferner kommen Dryopteris Thelypteris, D. cristala, Trientalis europaea, Sweertia perennis, Polemonium coeruleum, Pedicularis silvatica und im Osten auch P. Sceptrum Carolinum vor.

Auenwälder. An den Ufern der größeren Flüsse, besonders der Weichsel, sind oft ausgedehnte Auen entwickelt. Pappeln, besonders Populus nigra und $P$. alba, ferner Weiden (Salix alba, S. pentandra, S. fragilis) bilden dort die Hauptmasse der Laubbäume, denen sich Ulmus glabra, U. laevis sowie Alnus glutinosa zugesellen, während Fraxinus excelsior anscheinend fehlt. Das meist sehr reiche Unterholz bilden neben dem Nachwuchs des Oberholzes vor allem zahlreiche Weiden, wie Salix purpurea, S. viminalis, S. pentandra, S. cinerea, ferner Rhamnus Frangula; Viburnum Opulus, Sambucus nigra sowie an den aus den Karpathen kommenden Flüssen Alnus incana. Auch Ribes nigrum kommt ab und $\mathrm{zu}$ in den Auen vor, während Prunus Padus nur selten auftritt. Im Niederwuchs dieser Auen finden sich im allgemeinen die in Mitteleuropa in Uferwäldern verbreiteten Arten, wie. Calamagrostis lanceolata und C. Epigeios, Agrostis alba, Deschampsia caespitosa, Poa trivialis, Daclylis glomerata, Festuca gigantea und F. arundinacea, Gagea lulea, Paris quadrifolia, Urtica urens und $U$. dioeca, Parietaria erecta, Rumex Hydrolapathum, R. aquaticus, Ranunculus Ficaria, Alliaria officinalis, Viola odorata, Potentilla erecta, Geum urbanum, Dipsacus pilosus, Stenaclis annua, Carduus crispus, Mentha longifolia, M. aquatica, $M$. arvensis u. a., Lycopus europaeus, Stachys palustris und S. silvatica, Aiuga reptans, Physalis Alkeliengi, Solanum Dulcamara, Scrophularia nodosa, Aegopodium Podagraria, Cnidium venosum, Chaerophyllum lemulum, Adoxa moschatellina usw. 


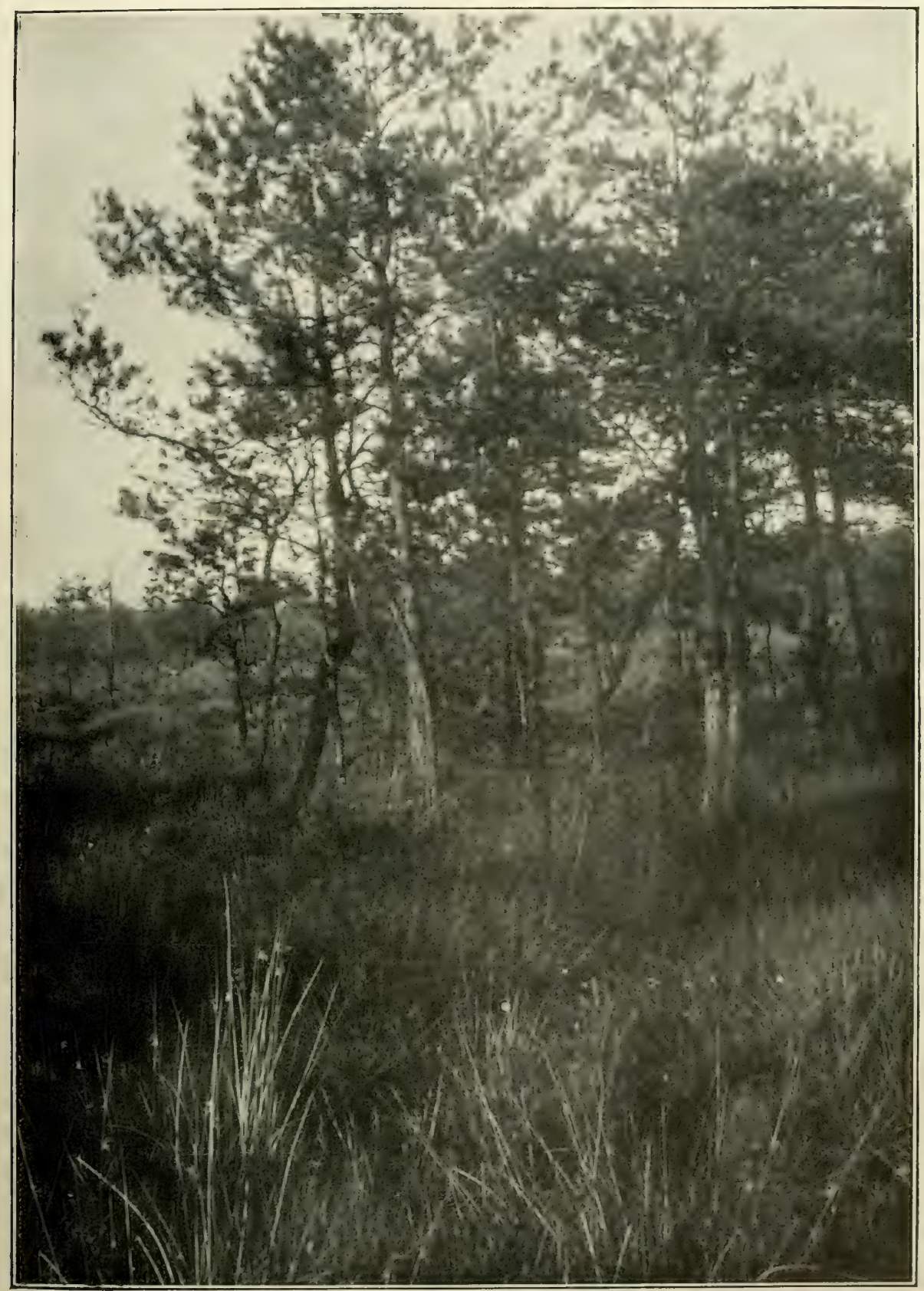

Abb. 134. Moorwald bei Trzebinja in Westgalizien.

Im Niederwuchs hauptsächlich Eriophorum vaginatum und Juncus effusus.

(Nach einer Aufnahme von A. v. Hayek.) 



\section{b) Moore und Heiden.}

Hochmoore. Hochmoore sind in allen Teilen der nordgälizischen Ebene häufig und zeigen den bekannten Aufbau derselben. Ein dichter Polster aus Sphagnumarten, besonders Sphagnum cuspidatum und S. subsecundum,

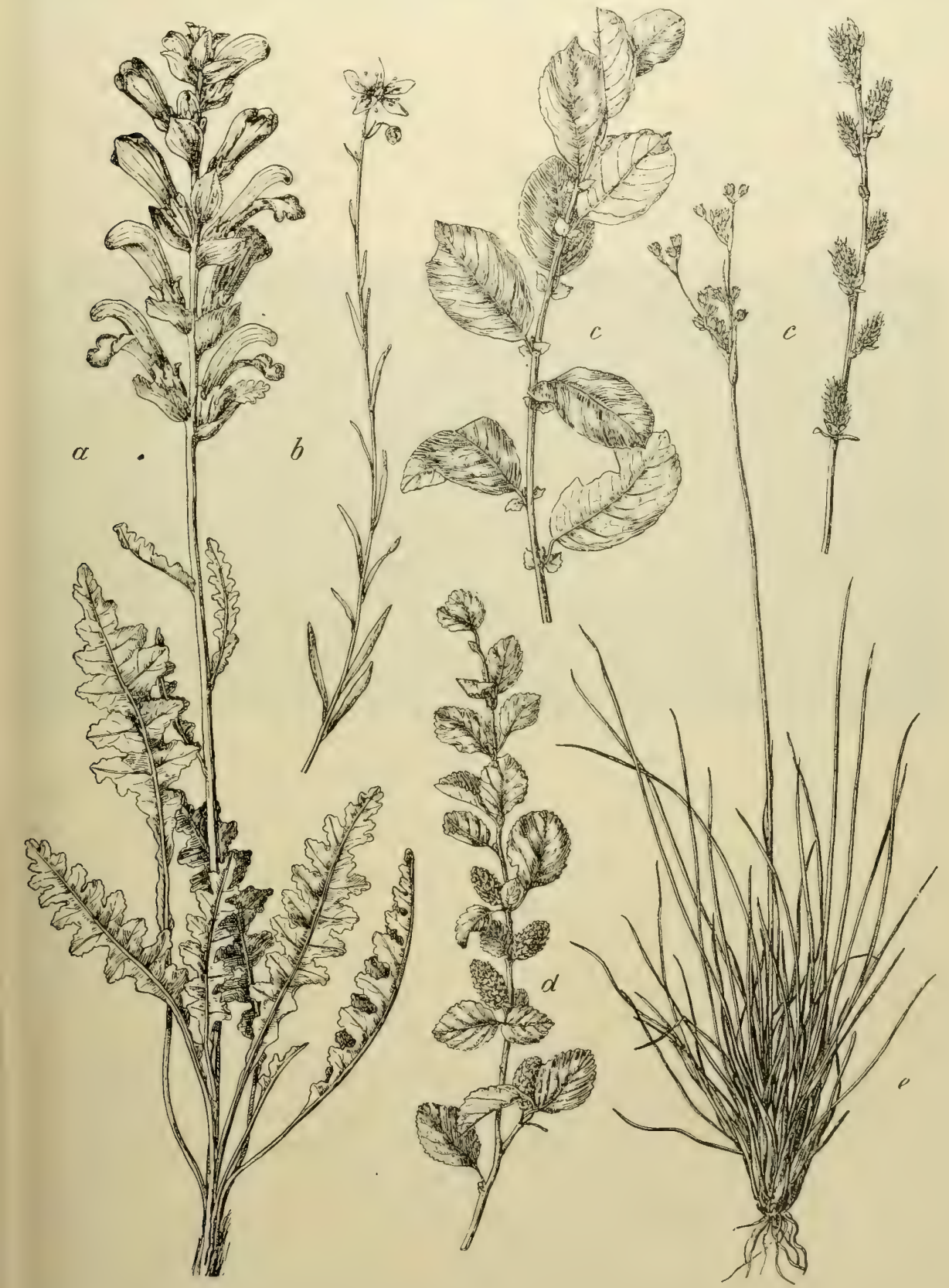

Abb. 135. Einige bemerkenswerte Arten aus den galizischen Mooren.

a Pedicularis Sceptrum Carolinum. b Saxifraga Hirculus, $c$ Salix livida. $d$. Betula humilis. $e$ Juncus squarrosus.

Hayek, Die Pflanzendecke Österreich-Ungarns, I. 
bedeckt weithin den Boden, in den tieferen Schichten längst in T'orf umgewandelt, nach oben zu weiter wachsend und einen gewölbten schwellenden Untergrund bildend. In Gesellschaft der Sphagnumarten treten auch andere Moose auf, so Dicranella cerviculala, Dicranum palustre und undulalum, Campylopus torfaceus, Leucobryum glaucum, Splachnum ampullaceum, Tremalodon ambiguus, Bryum pendulum und bimum, Meesea uliginosa, M. tristicha und M. longisela, Aulocomnium palustre, Philonotis marchica, P. caespitosa, Hypnum stellalum, $H$. aduncum, H. exannulalum, $H$. Sendtneri, H. purum, H. scorpioides, besonders aber Polytrichum commune und $P$. gracile, die an trockeneren Stellen ab und zu große Polster bilden. Von torfbildenden Gewächsen kommt neben den Sphagnumarten vor allem Eriophorum vaginatum in Betracht, das stellenweise

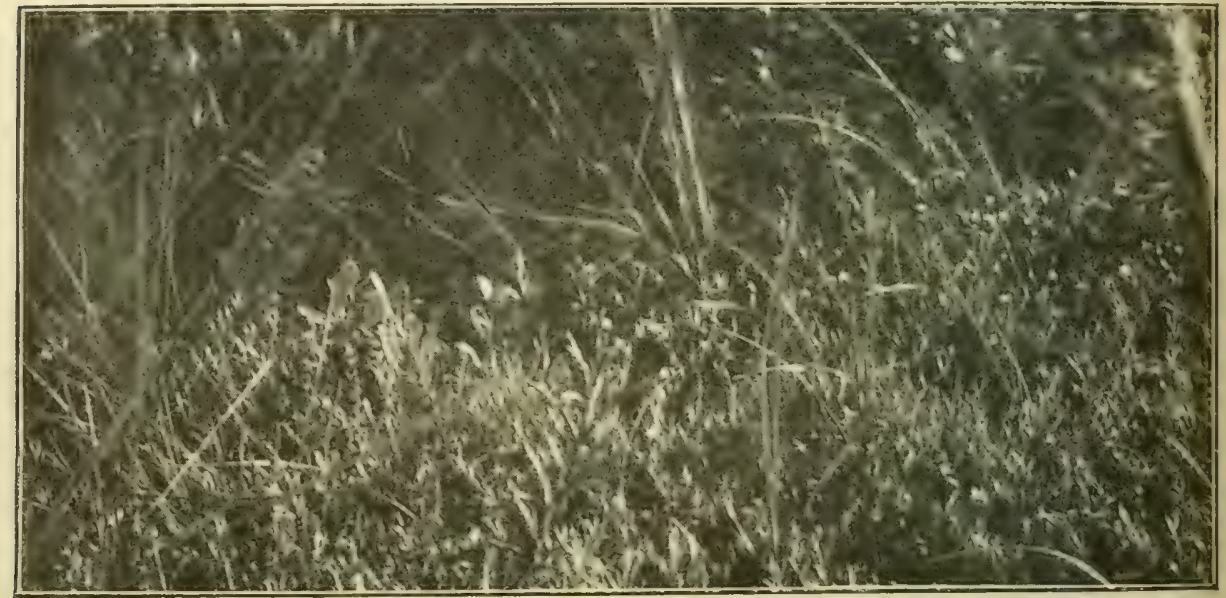

Abb. 136: Dętailbild aus einem Hochmoor bei Trzebinja.

Calluna vulgaris, Vaccinium uliginosum, Oxycoccos quadripetala, Andromeda polifolia.

(Nach einer Aufnahme von A. v. Hayek.)

in großen Massen auftritt, weniger die torfbildenden Carices, wie Carex Davalliana, C. canescens und $G$. stellulala, auch Rhynchospora alba kommt vor, hingegen fehlen den Mooren der Ebene Trichophorum alpinum und T. austriacum. Von die Moore bewohnenden Gramineen und Gyperazeen sind noch Molinia coerulea, Carex dioica, $C$. pulicaris, $C$. diandra, $C$. flava, C. lasiocarpa, C. canescens, C. vesicaria, Heleocharis pauciflora zu nennen. Von krautigen Pflanzen sind häufig Calla paluslris, Malaxis paludosa, Drosera rolundifolia, D. anglica, Viola palustris, Polentilla erecla, Hydrocolyle vulgare, Saxifraga Hirculus, Lysimachia thyrsiflora, Trientalis europaea, Sweerlia perennis, Pinguicula vulgaris, Veronica sculellata, Pedicularis palustris, P. Sceptrum Carolinum sowie die mit ihren fädlichen Stengeln weithin kriechende Oxycoccos quadripelala. Von Farnpflanzen kommen Lycopodium inundatum und Dryopleris cristata vor und an wenigen Orten auch Osmunda regalis. Aber auch kleine Halb- und Zivergsträucher sind auf den Hooren überall zu finden, vor allem Galluna vulgaris, die beim Austrocknen des Moores gewöhnlich so überhand nimmt, daß eine 
Moorheide und schließlich eine Heide sich aus dem Hochmoor entwickelt. Auch Vaccinium Myrtillus, V. uliginosum und Andromeda polifolia treten nicht selten auf. Von höheren Sträuchern ist insbesondere Ledum palustre auf den westund nordgalizischen Mooren ungemein charakteristisch und stellenweise häufig; ferner ist Belula humilis ab und zu nicht selten; von Weiden sind Salix aurila, S. cinerea und S. repens und selten S. myrtilloides und S. livida zu finden. Auch Betula pubescens und Alnus rolundifolia treten in Strauchform auf den Mooren ab und zu auf. Bemerkenswert ist ferner das Auftreten von Pinus Mughus auf den Mooren bei Zorniska nächst Lemberg. Selten ist Baumwuchs auf den Mooren, nur Betula pubescens und Pinus silvestris sind auf Hochmooren zu finden, letztere allerdings mitunter so häufig, daß aus dem Moor ein Moorwald entsteht. Für die Flora der Moortümpel ist neben verschiedenen Algen das Vorkommen von Sparganium minimum, Utricularia vulgaris und (selten) $U$. minor bezeichnend.

Moorheide. Durch das Überhandnehmen von Calluna vulgaris entsteht aus den Sphagnum mooren die Moorheide. Stets trockener als die Sphagneta werden hier die Sphagnumarten zum Teil durch andere Moore, besonders durch Polylrichum commune, verdrängt. Die Hauptmasse der Vegetation bilden aber Zwerg- und Halbsträucher, vor allem Calluna vulgaris, dann Andromeda polifolia, Vaccinium uliginosum, $V$. Vitis Idaea und V. Myrlillus, auch Ledum palustre ist nicht selten. Auf den zwischen den Heiden und Heidelbeeren erhaltenen Sphagnumpolstern aber finden sich noch überall die typischen Moorpflanzen, vor allem die Droseraarten und Oxycoccos quadripetala, von Cyperazeen sind Carex stellulata, C. leporina, C. elongata und $C$. caespitosa vorherrschend.

Viesenmoore. Von ganz anderem Charakter als die Hochmoore und doch wieder in diese vielerorts übergehend, sind die Wiesenmoore. Hier fehlen die charakteristischen Sphagnumarten und viele ihrer Begleitpflanzen völlig und die übrigen sich häufig findenden Moose, wie Aulacomnium palustre, Camplothecium nitens, Hypnum cuspidalum, aduncum, nitens, cordifolium, Mnium palustre usw. spielen bei weitem nicht die Rolle wie die Sphagnumarten in den Hochmooren. Die torfbildenden Pflanzen sind hauptsächlich Garexarten, vor allem Carex Davalliana, G. elata, G. caespilosa, C. Goodenoughii, G. flava, $C$. Oederi, $C$. panicea, ferner $C$. canescens, $C$. elongata, C. limosa, C. diandra, C. hirta, C. lasiocarpa, C. vesicaria, C. acutiformis, C. rostrata usw. Dazu gesellen sich Alopecurus aequalis, Poa lrivialis, Heleocharis palustris, Blysmus compressus, Eriophorum vaginalum, E. lalifolium und anguslifolium, Schoenus nigricans und Sch. ferrugineus, selten auch Rhynchospora alba usw. Häufige Bewohner der Wiesenmoore sind Triglochin palustre, Iris sibirica, Stellaria uliginosa, S. palustris, Dianthus superbus, Ranunculus flammula, Polentilla palustris, Lalhyrus palustris, Epilobium palustre, E. adnalum,. Sweerlia perennis, Peucedanum palustre, Laserpilium pruthenicum, Pedicularis palustris und P. Sceplrum Carolinum, Veronica scutellata, Gratiola officinalis, Myosotis scorpioides, Galium uliginosum, Bidens cernua usw. 
Die Heide. Eine in den Ebenen Mitteleuropas weit verbreitete und für dieselben sehr charakteristische Formation ist die Heide, die auch im nördlichen Galizien überall häufig anzutreffen ist. Die Heide ist ein dichter Bestand von Calluria vulgaris, der sowohl aus Hochmooren als aus Sandfluren sich entwickeln kann, indem Calluna die übrige Vegetation allmählich verdrängt und unterdrückt. Sie stellt einen dichten geschlossenen Buschbestand von Calluna vulgaris dar, wo die Büsche des Heidekrautes jede andere Vegetation fast völlig unterdrücken. Nur Sarolhamnus scoparius tritt stellenweise mit der Galluna in erfolgreiche Konkurrenz und bietet zur Blütezeit mit seinen mit goldgelben Blüten überladenen rutenförmigen Ästen ein prächtiges Bild. Genista tincloria und im Westen auch G. pilosa treten gern in seiner Begleitung auf. Von sonstigen Arten, die teils zwischen den Heidekrautbüschen, teils auf den mächtigen Moospolstern aus Polytrichum commune sich finden, sind Agrostis vulgaris, A. canina, Deschampsia flexuosa, D. caespitosa, Sieglingia decumbens, Carex leporina, $C$. pallescens und $C$. pilulifera, Juncus squarrosus, J.effusus, J.bulbosus, Salix repens, Stellaria graminea, Silene vulgaris, Potenlilla erecla, P. replans, Lysimachia vulgaris, Armeria elongata, Centaurium umbellatum, Gentiana Pneumonanthe, Euphrasia Rostkoviana, Gnaphalium silvalicum, Antennaria dioeca, Helichrysum arenarium, Hieracium Pilosella und H. Auricula zu nennen.

Sandgrasfluren. Auf den weiten Flugsandflächen der nordgalizischen Ebene ist eine eigenartige Grasflurformation von steppenartigem Charakter weit verbreitet, die in ihrer Zusammensetzung von den Sandsteppen Ungarns und Polodiens weit verschieden ist, hingegen eine große Übereinstimmung mit den Sandfluren Norddeutschlands zeigt. Das bezeichnendste Gras für diese Formation ist Corynephorus canescens, das an entsprechenden Standorten wohl nirgends fehlt. In seiner Gesellschaft treten Aira caryophyllea, Digitaria linearis, Setaria verlicillata, Vulpia Myurus und V. bromoides, Koeleria glanca, Elymus arenarius und stellenweise auch Psamma arenaria, letztere beide wohl nur zur Bindung des Flugsandes gepflanzt, auf. Auch Nardus stricta ist auf diesen Sandflächen häufig, seltener sind Phleum pratense var. nodosum, Bromus tectorum, Blysmus compressus und Carex hirta zu finden, im östlichen Teile tritt auch Fesluca vaginata auf. Von sonstigen Arten der Flugsandflächen sind Herniaria glabra und H. hirsuta, Spergula pentandra, Spergularia campestris, Scleranthus: perennis, Cerastium semidecandrum, Gypsophila fastigiala, Tunica prolifera, Dianthus delloides und D. borussicus, Silene Otites, S. chlorantha, S. gallica, Draba nemorosa, Potentilla procumbens, Viola arenaria, Medicago minima, Radiola linoides, Hypericum humifusum, Armeria elongata, Androsace septentrionalis, Centunculus minimus, Teucrium Botrys, Galeopsis angustifolia, Linaria arvensis, Plantago ramosa, Jasione montana, Helichrysum arenarium, Erigeron canadensis, Gnaphalium luteo-album, Filago montana, Senecio vernalis, Crepis foetida zu nennen, zu denen sich im Westen noch Illecebrum verticillatum, Teesdalea nudicaulis und Chondrilla juncea gesellen. Von Zwergsträuchern treten Salix repens und Calluna vulgaris stellenweise auf den Sandflächen auf, von Bäumen 
sind nur Pinus silvestris und Betula pendula zu finden, die allerdings manchmal in solcher Menge auftreten, daß die Grasflur in einen Waldbestand umgewandelt wird.

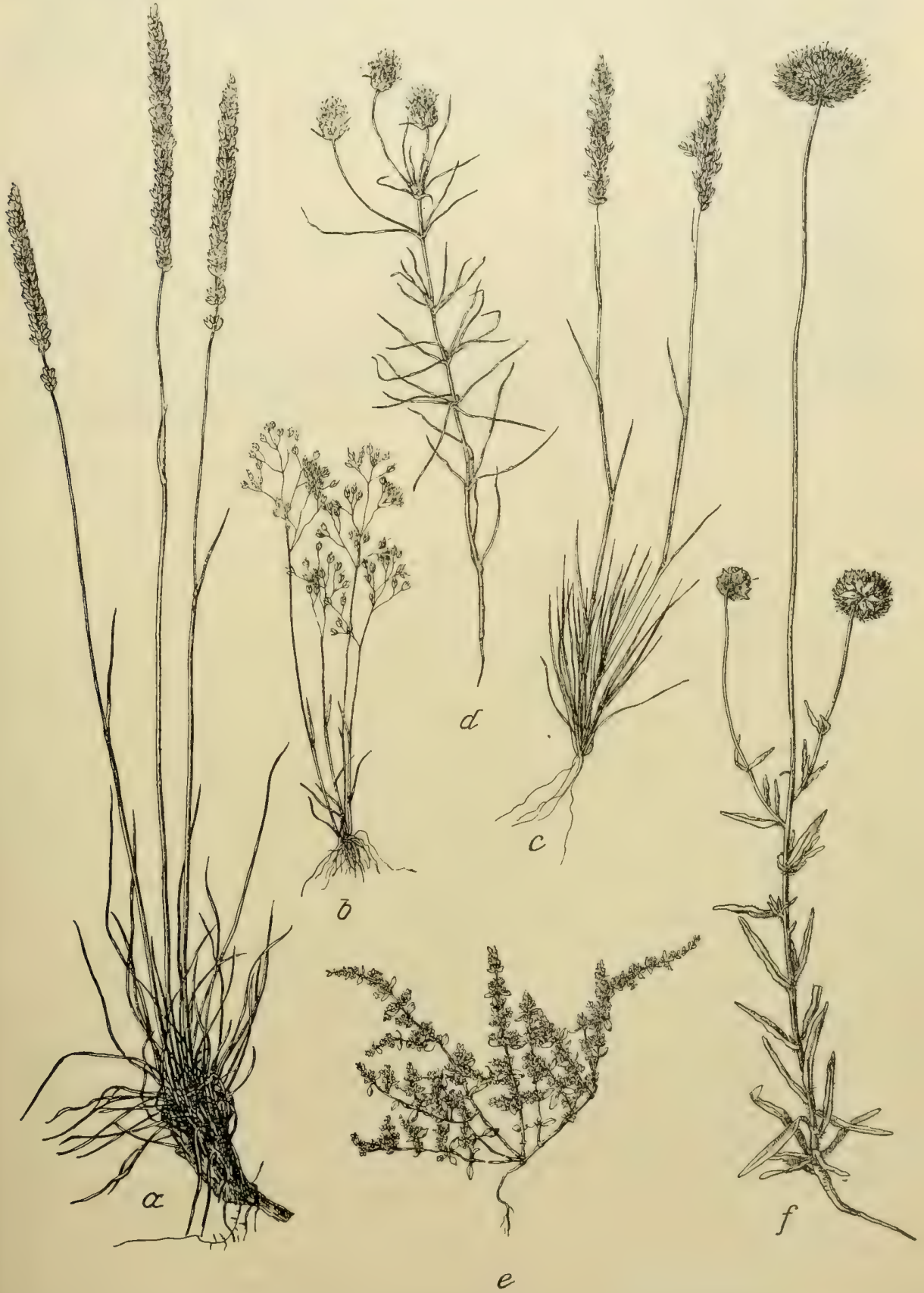

Abb. 137. Einige Charakterpflanzen der galizischen Sandheide.

$a$ Koeleria glauca. b Aira caryophyllea. $c$ Corynephorus canescens. $d$ Plantago ramosa. $e$ Herniaria hirsuta. $f$ Jasione montana. (1/2 nat. Gr.) 


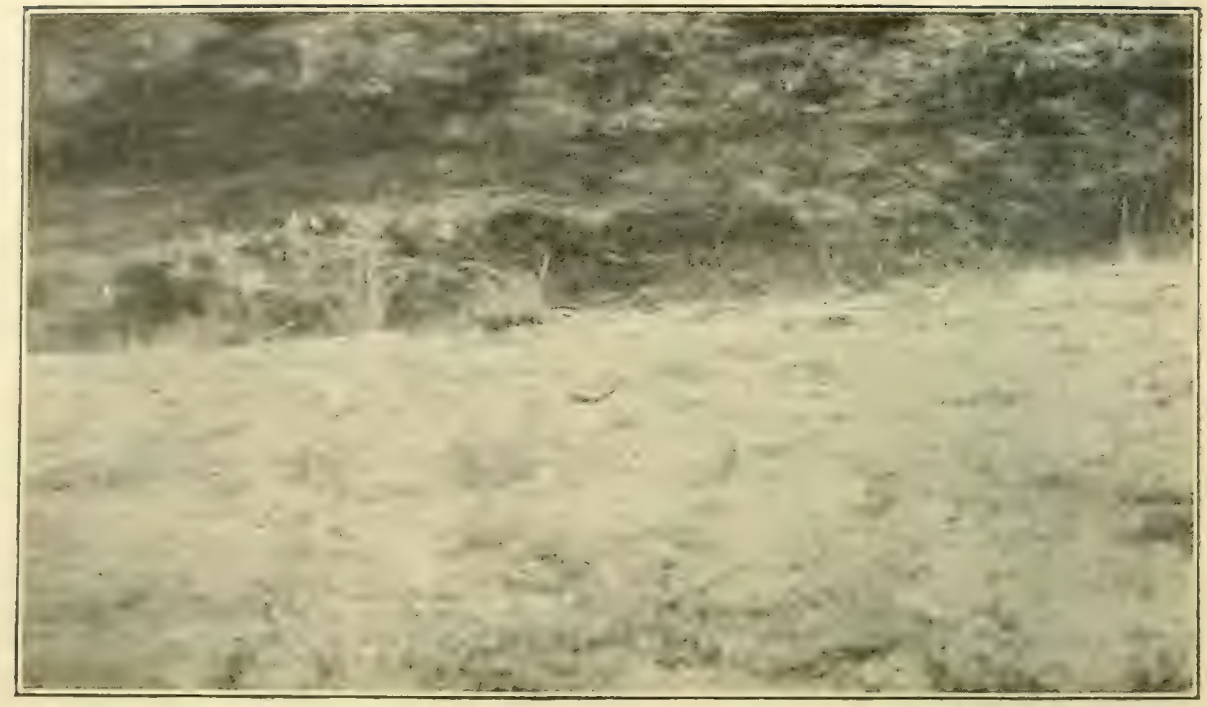

Abb. 138. Corynephorus canescens als erster Ansiedler auf Flugsand bei Trzebinja. (Nach einer Aufnahme von A. v. Hayck.)

\section{c) Wiesenformationen.}

Talwiesen. Die Talwiesen der nördlichen Ebene Galiziens bieten wenig Bemerkenswertes und stimmen im wesentlichen mit denen Mittrleuropas überein. Die Grasnarbe setzen Alopecurus pratensis, Phleum pratense, Holcus lanalus, Anthoxanthum odoratum, Agrostis vulgaris, Avena pubescens, A. pratensis, Arrhenatherum elalius, Poa pratensis, P. trivialis, Festuca rubra, F. elalior, Lolium perenne zusammen. Von Kräutern und Stauden sind Colchicum aulumnale, Orchis Morio (). ustulata, (). Latifolia, O. maculala, Gymnarlenia conopea, Listera ovala, Dianthus Carthusianorum, D. delloides, Ranunculus auricomus, R. acer, R. bulbosus, Arabis hirsula, Euphorbia Esula, Polentilla Tabernaemonlani, Alchimilla silveslris, Filipendula hexapelala, Anthyllis Vulneraria, Medicago falcata, M. lupulina, Trifolium pratense, T. monlanum, T. repens, T. hybridum, Lolus corniculatus, Virin Cracca, Lathyrus pratensis, Primula veris, Lysimachia nummularia, Carum Carvi, Pimpinella maior, P. Saxifraga, Silans pratensis, Pastinaca saliva, Daucus Carola, Anthriscus silvester, Saxifraga granulata, Gentiana Pneumonanthe, Symphylum officinale, Salvia pratensis, Prunella vulgaris, Slachys officinalis, Aiuga replans, A. genevensis, Verbascum Blallaria, Veronica Chamaedrys, V. spicala, Euphrasia Roslkoviana, E. slricla, Alectorolophus hirsulus, A. maior, A. minor, Orobanche lulea, O. caryophyllacea, Galium Cruciata, G. boreale, G. verum, G. Mollugo, Campanula rotundifolia, G. patula, Planlago media, P. lanceolala, Knautia arvensis, Succisa pratensis, Scabiosa ochroleuca, Bellis: perennis, Inula brilannica, Achillea Millefolium, Chrysanthemum Leucanlhemum, Senecio Jacobaea, Cenlaurea Jacea, C. Scabiosa, Cirsium rivulare, G. oleraceum, Leontodon aulumnalis, L. hispidus, Tragopogon orientalis, Scorzonera humilis, 
Taraxacum vulgare, Crepis biennis, Hieracium Pilosella, H. Auricula ebenso verbreitet wie im übrigen Mitteleuropa. Dazu gesellen sich als auffallendere Typen Ononis hircina, Viola stagnina, Heracleum sibiricum und Inula salicina.

Sumpiwiesen. Durch das Zurücktreten der torfbildenden Gyperazeen und das reichlichere Auftreten von Gramineen unterscheiden sich die Sumpfwiesen von den Wiesenmooren. Alopecurus aequalis und pralensis, Agrostis alba und vulgaris, Phragmites communis, Deschampsia caespilosa, Poa trivialis und palustris, Molinia coerulea, Carex Davalliana, C. vulpina, C. paniculata, C. paradoxa, C. elongala, C. caespilosa, C. gracilis, C. Goodenoughii, C. glanca, C. panicea, C.flava, C.distans, C.aculiformis, C.hirta, Heleocharis palustris, Scirpus silvaticus, Eriophorum angustifolium, E. lalifolium, Cyperus fuscus, C. flavescens, Juncus effusus, J. conglomeratus, J. glaucus, J. arliculatus, J. atralus, J. compressus bilden die Hauptmasse der grasähnlichen Gewächse. Equiselum paluslre und limosum sind gleichfalls stellenweise nicht selten, ferner Tofieldia calyculala, Veratrum album, Iris sibirica, I. Psendacorıs, Gladiolus paluslris, Orchis coriophora, O. latifolia, Epipaclis paluslris, Llisma Planlago anuatica. Von Dikotylen finden sich Stellaria palustris und S. aquatica, Dianthus superbus, Lychnis Flos cuculi, Thalictrum lucidum, Ranunculus flammula, $R$. Lingua, R. acer, R. repens, Caltha palustris. Trollius curopaeus. Cambunine pratensis, Roripa islandica und R. amphibia, Euphorbia palustris, Lylhrum Salicaria, Filipendula Ulmaria, Cicula virosa, Sium lalifolium, Berula anguslifolia, Oenanthe fistulosa, Selinum carvifolia, Ostericum palustre, Peucedanum palustre, Pastinaca saliva, Heracleum Spondylium, Laserpilium pruthenicum, Gentiana Pneumonanthe, G. axillaris, Sculellaria galerieulala, Tencrium Sirntinm. Myosolis scorpioides, Symphylum officinale, Gratiola officinalis. Termica scutellalu, Teronica marilima, Euphrasia Rosthoviana, Pedicularis palustris, Alectorolophus maior, A. hirsutus, Galium uliginosum, G. palustre, Succisa pratensis, Succisella inflexa, Valeriana dioeca, Inula britannica, Achillea Plarmica, Senecio palustris, Cirsium canum, C. rivulare, C. oleraceum, Scorzonera humilis, Crepis paludosa u. a.

\section{d) Sumpf- und Wasserformationen.}

Sümpfe. An stehenden Gerwässern, Teichen, den toten Armen der Flüsse bildet sich rine reiche Sumplflorat aus. Phragmites communis und Schocnoplectus lacustris treten hier bestandbildend anf, mit ihnen Leersia oryzoides, Typhoides arundinacea, Calamagrostis lanceolala, Carex vulpina, C. gracilis, C. vesicaria, C. aculiformis, G. riparia, Heleocharis palustris, H. ovala, Schoenoplectus Tabernaemonlani, Scirpus marilimus und S. silvalieus; ferner Llisma Planlago annalica. Sagillaria sagillacfolia, Butomus umbellatus, Iris Psendacorus. Typha lalifolia und T. anguslifolia, Sparganium simplex und S. ramosum, Equiselum palustre und E. limosum, Polygonum mite, P. Hydropiper, Rumex maritimus, R. conglomeralus, R. atualicus, R. Hydrolapalhum, Slellaria apualica, Ranunculus Lingua, R. flammula und R. repens, Filipendula Limaria, Cienla virosa, Sium lalifolium, Berula anguslifolia, Peucedanum palustre, Lylhrum Salicaria, Epilobium hirsulum, 
E. parviflorum, Thalictrum lucidum, Stachys palustris, Veronica Anagallis,

V. Beccabunga, Hippuris vulgaris, Myosotis scorpioides, Galium palustre, Senecio palustris und S. paludosus, Sonchus paluster.

An überschwemmten Stellen, Teichrändern, im feuchten Sande finden sich besonders Heleocharis ovala, Schnenoplectus supinus, Peplis Portula, Lindernia pyxidaria, Limosella aquatica, Elatine hexandra, E. Alsinastrum, Pulicaria vulgaris.

Wasserpflanzen. In den toten Armen der Weichsel und des Bug, in den Teichen bəi Zator, Jaworow, Grodek, Brody usw. sowie in anderen stehenden und langzam fließenden Gowässern Galiziens ist eine reiche Wasserflora entwickelt. Die verbreitetston Arten derselben sind Potamogeton nalans, P. alpinus, $P$. crispus, $P$. perfolialus, $P$. pusillus, P. pectinatus, Zannichelia palustris, Lemna minor, L. trisulca, L. gibba, Spirodela polyrrhiza, Hydrocharis Morsus ranae, Stratiotes aloides, Polygonum amphibium, Castalia candida, Nuphar luteum, Ranunculus aqualilis, $R$. circinnatus, Ceratophyllum demersum, Callitriche verna, C. hamulata, Myriophyllum verticillatum, M. spicatum, Hottonia palustris. Doch sind außer diesen weitverbreiteten Arten auch andere nicht selten, so Naias minor, Ceratophyllum submersum, Nymphoides peltata; ziemlich häufig ist in Galizien Potamogeton praelongus, auch Naias maior ist verbreitet und hie und da kommt auch Trapa natans vor.

\section{Die Pflanzengenossenschaften 0stgaliziens und der Bukowina.}

a) Waldbestände.

Der podolische Eichenwald. Die Wälder der podolischen Hochebene stellen Laubmischwälder mit sehr reich zusammengesetztem Obərholze, in dem die Eichen meist vorherrschen, dar, während Nadelholz vollständig fehlt. Der herrschende Waldbaum ist Quercus sessiliflora, in deren Gesellschaft auch Quercus Robur auftritt; andere Eichenarten abər fehlen. Sehr häufig sind ferner die oft tonangebende Hainbuche (Carpinus Belulus), die Kirsche (Prunus avium) sowie die beiden Lindenarten (Tilia cordata und $T$. platyphyllos) und mancherorts die spitzfrüchtige Esche (Fraxinus oxycarpa). Auch Fagus silvalica ist nicht selten. Überdies finden sich eingesprengt fast alle mitteleuropäischen Laubbäume, so insbesonders Ulmus glabra, U. scabra, Sorbus torminalis, Acer platanoides, A. campestre. Das Unterholz fehlt oft vollständig oder besteht auch Corylus Avellana, Acer campestre, Evonymus vulgaris, E. verrucosus, Rhamnus catharlica, R. Frangula, Slaphylea pinnala, Cornus sanguinea, Berberis vulgaris, Crataegus monogyna sowie Rosen und Brombeeren; seltener sind Acer talaricum und Cornus Mas. Der $\mathrm{Ni}$ e d e r w u $\mathrm{ch} \mathrm{s}$ ist meist reichlich und besonders bildet sich gewöhnlich an lichteren Stellen eine riche Grasnarbe, bestehend aus Milium effusum, Melica nulans, M. altissima, Poa nemoralis, Dactylis glomerala, Fesluca giganlea, F. heterophylla, Brachypodium silvaticum, 


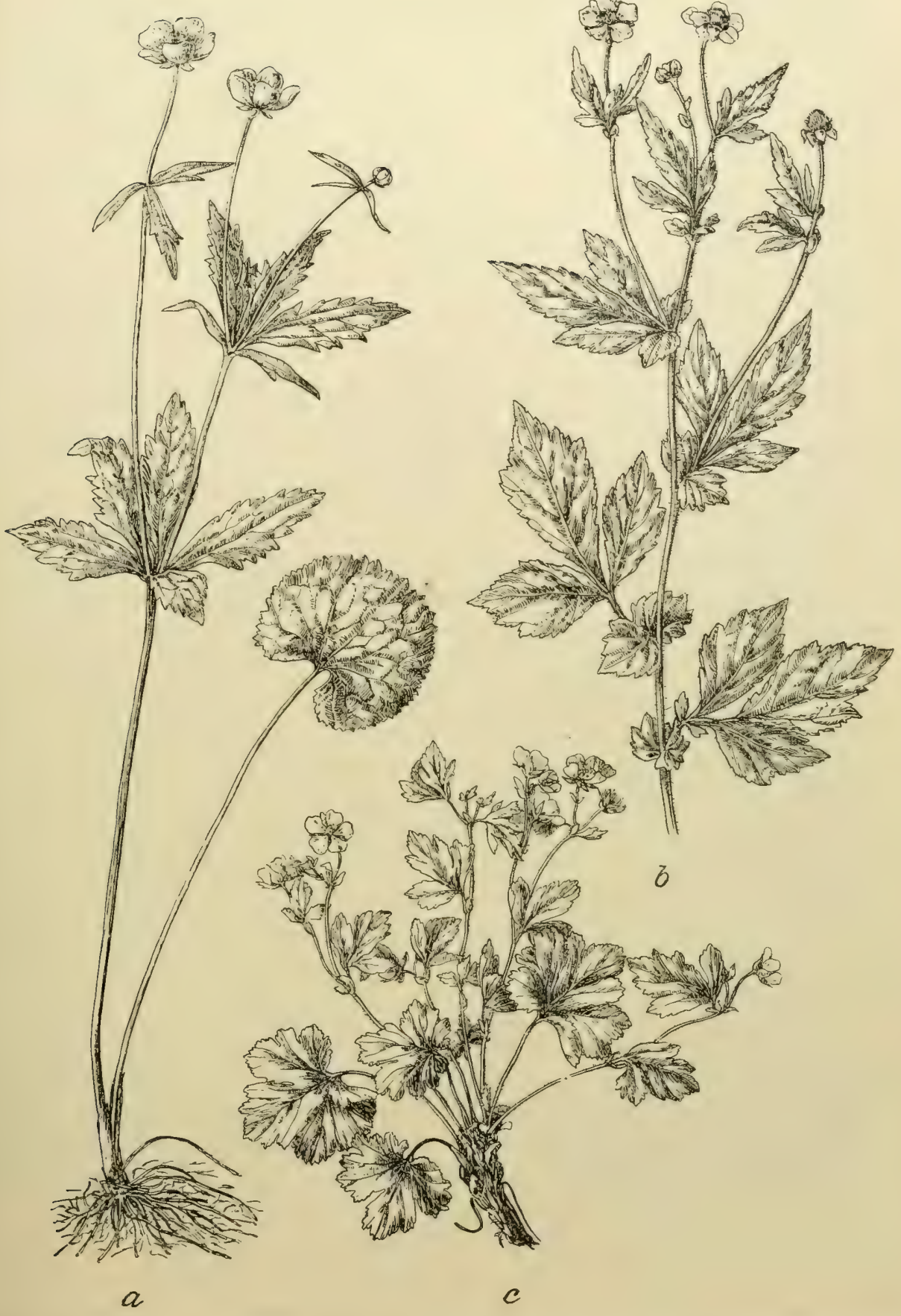

Abb. 139. Einige bezeichnende Arten aus dem Niederwuchs der podolischen Eichenwälder. $a$ Ranunculus cassubicus, $b$ Geum aleppicum. $c$ Waldsteinia geoides.

$(1 / 2$ nat. Gr.) 
B. pinnalum, Carex muricala, G. silvalica, Luzula nemorosa usw. aus. Von den den übrigen Niederwuchs zusammensetzenden Arten seien noch genannt: Scilla bifolia, Polygonatum officinale, $P$. latifolium, Gymnadenia conopea, Epipactis latifolia, Cieraslium silvaticum, Silene chlorantha, Trollius europaeus, Ranunculus auricomus, R. cassubicus, R. Steveni, Helleborus purpurascens, Actaea Cimicifugia, IValdsleinia geoides, Agrimonia pilosa, Geum aleppicum, Lathyrus vernus, L. niger, L. laevigalus, Vicia pisiformis, Ferulago silvalica, Digilalis ambigua, Veronica Teucrium, V. officinalis, Campanula bononiensis, Adenophora liliifolia, Senecio umbrosus, S. nemorensis, Centaurea stenolepis, Crepis sibirica usw. Auch Farne, besonders Dryopteris Filix mas, D. spinulosa, Athyrium Filix femina, sind stellenweise nicht selten und mancherorts finden sich sogar hochwüchsige, an eine subalpine Vegetation erinnernde Stauden, wie Lilium Marlagon, Cardamine bulbifera, Senecio rivularis und Cirsium Erisithales. Besonders charakteristisch für den podolischen Eichenwald ist aber das Fehlen aller Nadelhölzer, auch des Wacholders, sowic aller immergrünen Sträucher, besonders der Erikazeen und Pirolazeen. Einzig und allein Hedera Helix ist der Vertreter der immergrünen Gewächse.

Der Hainbuehenwald. Auf tiefgründigem Lehmboden tritt in Ostgalizien und der Bukowina stellenwe ise ein fast ausschlie Blich aus $\mathrm{H}$ a in bue hen gebildeter Waldbestand auf, der allerdings auch vielfach aus den Eichenwäldern durch Ausschlagen der Eichen sich gebildet hat. Neben Carpinus Belulus finden sich in diesen Wäldern vereinzelt Quercus Robur, Ulmus laevis, Prunus avium, Acer campestre, A. platanoides, Fraxinus oxycarpa. Das Unterholz fehlt ganz oder besteht aus Acer campestre, A. tataricum, Evonymus verrucosus usw. Der Niederwuchs ähnelt in seiner Zusammensetzung dem des Eichenwaldes, ist aber weniger reich; Silene chlorantha, Cucubalus baccifer, Actaea Cimicifugia, Helleborus purpurascens, Agrimoniäpilosa, Astragalus glycyphyllos, Lathyrus vernus, L. niger, Vicia silvatica, V. dumelorum, V. pisiformis, Laserpitium latifolium, Ferulago silvalica, Lysimachia punclata, Salvia glutinosa, Pulmonaria mollissima, Asperula tincloria, A. glauca, Solidago Virga aurea und Cetaurea stenolepis sind die verbreitetsten Typen desselben.

Der podolische Buchenwald. Nur an wenigen Stellen, wo günstige Feuchtigkeitsverhältnisse herrschen, tritt in Ostgalizien die hier ihre Ostgrenze erreichende Rotbuche waldbildend auf. Fagus silvatica ist hier der herrschende Waldbaum, hie und da begleitet von Carpinus Betulus oder Acer platanoides. Das Unterholz fehlt meist ganz, als Liane tritt aber der hier ebenfalls die Ostgrenze seiner Verbreitung erreichende Efeu (Hedera Helix) auf. Der Niederwuchs ähnelt ganz dem der mitteleuropäischen Buchenwälder und wird hauptsächlich aus Melica uniflora, Brachypodium silvalicum, Carex monlana, C. digilala, Allium ursinum, Galanthus nivalis, Gymnadenia conopea, Listera ovata, Mercurialis perennis, M. ovata, Anemone Hepalica, Ranunculus lanuginosus, Cardamine impaliens, G. bulbifera, Daphne Mezereum, Viola mirabilis, Sanicula europaea, Pirola minor, Lathraea Squamaria zusammengesetzt. 


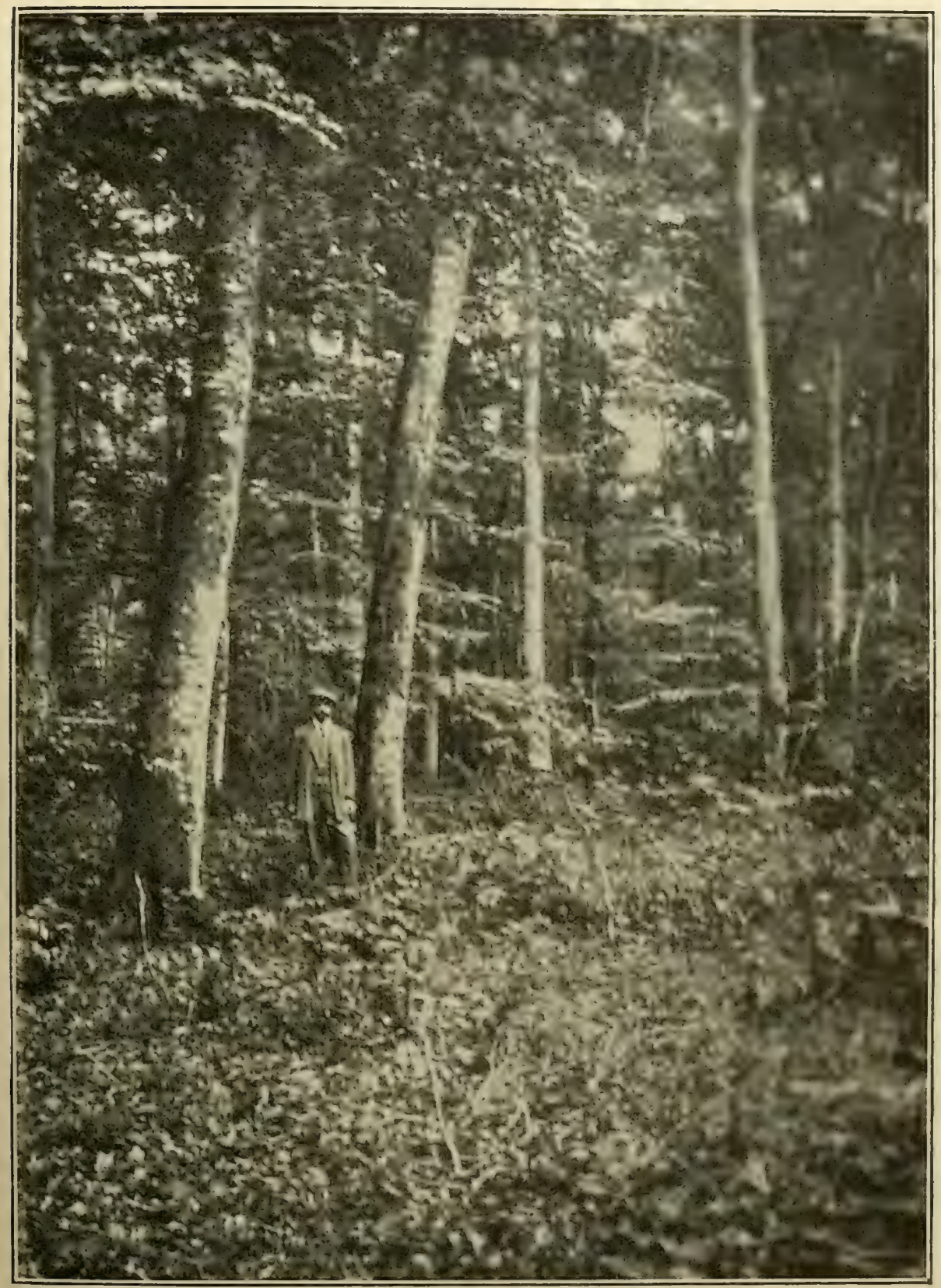

Abb. 140. Podolischer Buchenwald bei Pieniaky.

(Nach einer Aufnahme von Dr. W. Szafer, Lemberg.)

b) Strauchformationen.

Die Formation der Zwergweichsel. Auf trockenmen Anhöhen, an I'aldrändern, besonders aber an den Böschungen der tief eingeschnittenen Flußtäler 
findet sich überall eine Strauchformation ausgebildet, in der gewöhnlich die Zwergweichsel (Prunus fruticosa) in tonangebender Menge auftritt. In ihrer Gesellschaft bilden Prunus spinosa, Crataegus monogyna, Cotoneaster nigra, Ribes Grossularia, Cornus Mas, C. sanguinea, Evonymus vulgaris, E. verrucosus, Cytisus nigricans, C. leucanthus, C. ruthenicus, Acer tataricum, Rubus caesius, R. Idaeus, Viburnum Lantana, Sambucus nigra und zahlreiche Rosen, darunter viele prächtige Arten, wie Rosa Blockiana, $R$. gypsicola, $R$. thyraica, R. Jundzillii, R. Klukii, ein reiches Buschwerk. Im Schatten derselben aber entwickelt sich eine ungemein reiche Flora meist prächtig blühender Stauden. Besonders Clematis recta, Aconitum Anlhora *Jacquini, A. eulophium, Sanguisorba officinalis, Seseli annuum, Primula veris *canescens, Gentiana ciliata, Myosotis sparsiflora, Lithospermum officinale, L. purpureocoeruleum, Nepeta pannonica, Phlomis tuberosa, Adenophora liliifolia, Inula salicina, Chrysanthemum corymbosum, Carlina simplex, Serratula lincloria, S. lycopifolia, Hieracium umbellalum treten oft in großen Massen auf: daneben finden sich Melica altissima, Hierochloë borealis, Asparagus tenuifolius, Iris nudicaulis, Aristolochia Clematilis, Silene chlorantha, Melandryum viscosum, Helleborus purpurascens, Arabis Turrita, Sisymbrium.orientale, Waldsteinia geoides, Agrimonia pilosa, Oxytropis pilosa, Vicia pisiformis, Hypericum perforalum, H. elegans, Euphorbia lrislis, Pencedanum alsalicum, Laserpilium podolicum, Anchusa Barellierii, A. procera, Aiuga Laxmanni, Scutellaria altissima, S. lupulina, Dracocephalum auslriacum, D. Ruyschiana, Salvia dumetorum, Leonurus Marrubiastrum, Veronica incana, V. Jacquinii, Asperula thyraica, Scabiosa ochroleuca, Campanula bononiensis, Asyneuma canescens, Aster Amellus, Artemisia Absynthium, Echinops sphaerocephalus, Jurinea arachnoidea, Centaurea orientalis, G. Marschalliana, Crepis foetida, C. sibirica usw.

Ufergebiische. An den gewöhnlich tief in die Hochebene eingeschnittenen Flüssen ist meist nur eine spärliche Strauchvegetation, gebildet aus Salix alba, S. fragilis, Alnus rolundifolia, Ribes nigrum, Sambucus nigra und Myricaria germanica anzutreffen. Humulus Lupulus und Calystegia sepium sind häufige Schlinggewächse, während Clemalis Vitalba im Gebiete fehlt. Auf Sandbänken siedeln sich gern Phragmiles communis und Calamagrostis Epigeios an, und in diesen Schilfbeständen finden sich dann Filipendula Ulmaria und seltener Senecio fluvialilis. Im Ufergebüsch aber treten die auch sonst in Mitteleuropa häufigen Uferpflanzen auf, wie Saponaria officinalis, Euphorbia virgata, Lythrum Salicaria, Myosolis scorpioides, verschiedene Mentha-Arten, Slachys silvalica, S. arvensis, Erigeron canadensis, Stenactis annua und Inula britannica; ferner noch Scutellaria allisima und stellenweise Inula Helenium.

\section{c) Stauden- und Grasflurformationen.}

Die podolische Felsenflora. Eine reiche und interessante Flora weisen die zahlreichen Kalk- und Gipsfelsen der podolischen Hochebene auf. Teils sind es typische Felsenpflanzen, die diese Formation zusammensetzen, teils 


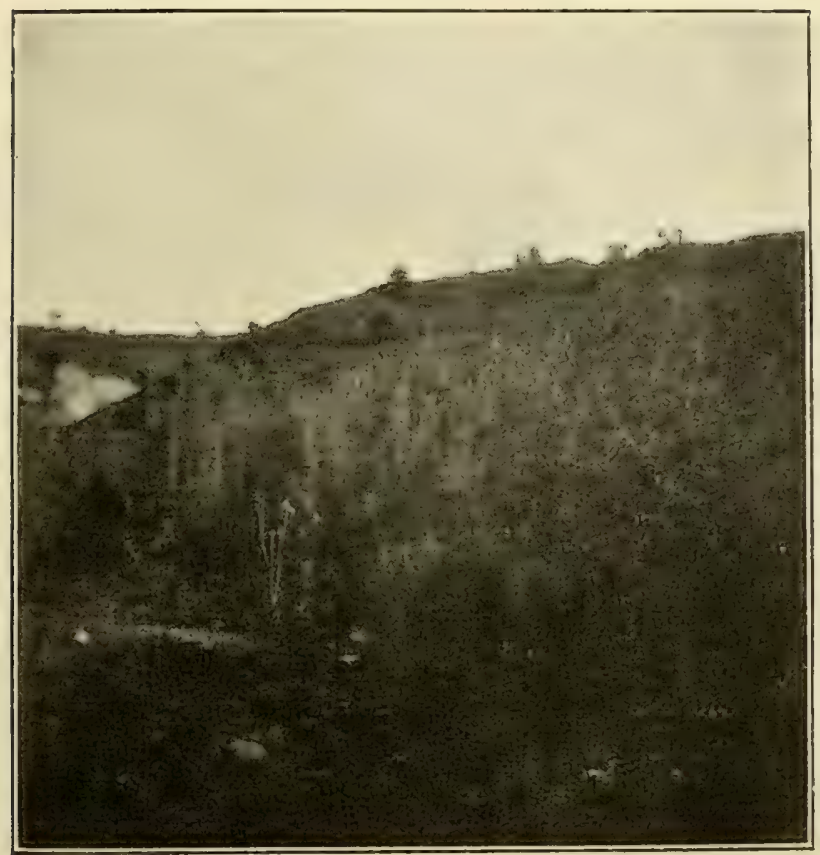

Abb. 141. Ufervegetation am Serezelbache in der Bukowina.

Im Vordergrund Myricaria germanica und Dipsacus silvestris, rechts von Saponaria officinalis; dahinter Weidengebüsch. Im Hintergrund die künstlich entwaldeten Hänge des Runc.

(Nach einer Aufnahme von C. Frh. v. Hormuzaki, Czernowitz.)

aber auch Glieder der eben geschilderten Buschformation, teils endlich Bewohner der Steppen und Triften. Von typischen Felsenpflanzen sind zu nennen Sesleria Heufleriana, Melica ciliata, Allium flavescens, A. montanum, Minuartia setacea, Dianthus capitalus, Erysimum pallescens, E. erysimoides, Alyssum Arduini, Coloneaster nigra, Bupleurum falcalum, Trinia Henningii, Dracocephalum austriacum, Aster Amellus, Artemisia Absynthium; zu diesen gesellen sich aber Stipa pennata, S. capillata, Hierochloë borealis, Fesluca valesiaca und die seltene Avena desertorum, Carex humilis, Hyacinthella leucophaea, Iris nudicaulis, Dianthus Carthusianorum, Silene chlorantha, S. Pseudotites, die zierliche Gypsophila altissima, Anemone patens, Lepidium Draba, Arabis arenosa, Arabis Turrita, Isatis tinctoria, Sisymbrium pannonicum, S. Irio sowie die für die podolische Flora sehr charakteristische Schievereckia podolica, Draba nemorosa, Sedum polonicum, Hypericum perforatum, Libanotis montana, Peucedanum alsalicum, Mercurialis ovata, Androsace septentrionalis, Anchusa Barellierii, Veronica spicata, V. Jacquini, V. incana, Asperula thyraica, Cephalaria uralensis, Campanula sibirica, Asyneuma canescens, Echinops ruthenicus, E. sphaerocephalus, E. commulalus, Jurinea arachnoidea, Centaurea Marschalliana usw. 


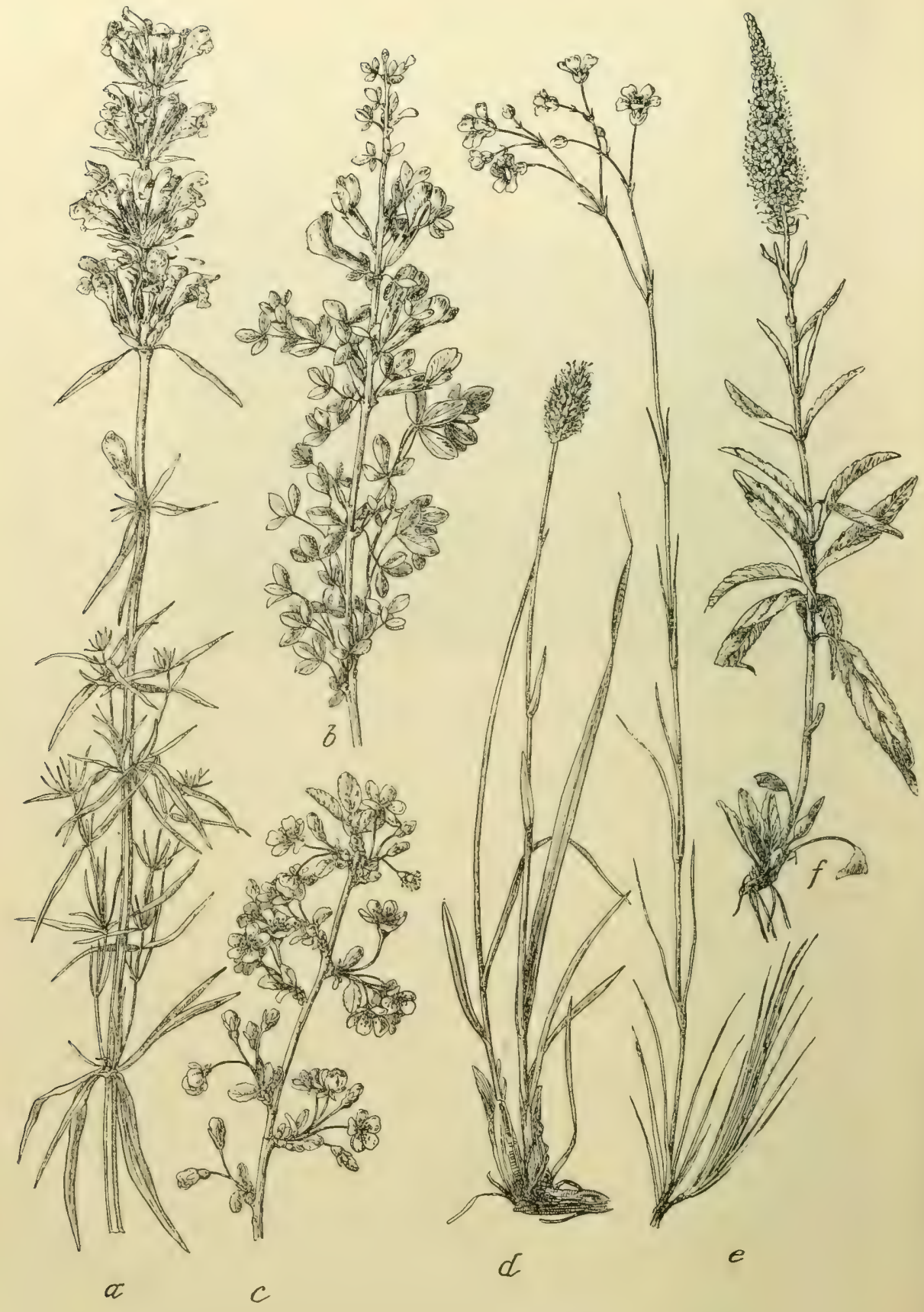

Abb. 142. Aus der ostgalizischen Felsen- und Triftlora.

$a$. Dracocephalum Ruyschiana. $b$ Cytisus ruthenicus. $c$ Prunus fruticosa. $d$ Sesleria Heufleriana. e Arenaria graminifolia. $f$ Veronica incana. (1/2 nat. Gr.)

Die podolische Triftiormation. Die häufigste Formation der Grasflur in Ostgalizien und in der Bukowina ist die Triftormation, eine üppige, blütenreiche 
Wiese, in der Kräuter und Stauden über die Gräser weitaus dominieren. Andropogon Ischaemum, Cynosurus cristatus und Koeleria polonica bilden die Hauptmasse des Graswuchses, überdies sind noch Stipa capillata, Phleum phleoides, Avena pubescens, Arrhenalherum elatius, Deschampsia caespitosa, Poa sterilis, Carex humilis und Juncus alralus häufige Erscheinungen. Hochwüchsige Stauden mit lebhaft gefärbten Blüten, wie Veratrum nigrum, Muscari tenuiflorum, Iris nudicaulis, Dianthus capitalus, Clematis recta, die hier im Osten in den Steppen der Ebene auftretende, jetzt allerdings schon sehr seltene Anemone narcissiflora,

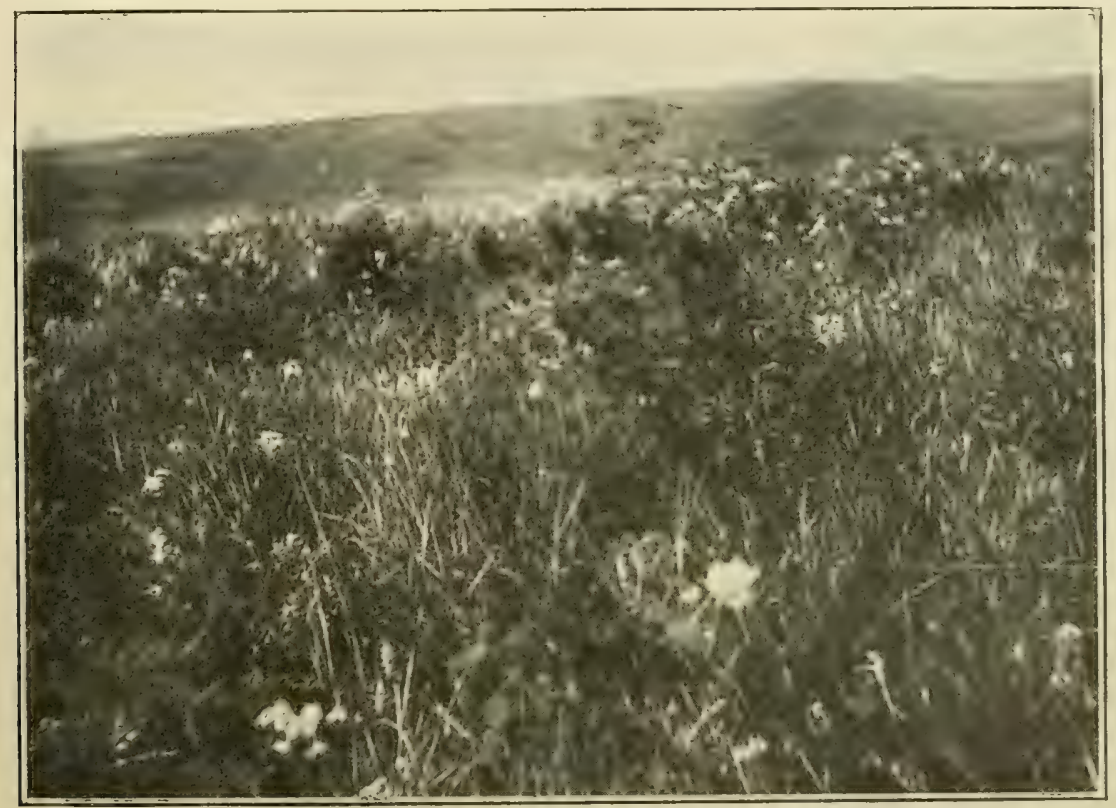

Abb. 143. Trift auf dem Okruh bei Czernowitz.

Filipendula hexapetala und Trifolium pannonicum, dazwischen die großen Büsche von Clematis recta. Hinten in der Mitte Ferulago silvatica, ganz vorne links Digitalis ambigua.

(Nach einer Aufnahme von Dr. K. Rudolph, Prag.)

Potentilla patula, Cytisus nigricans, C. albus, Lathyrus pannonicus, Linum flavum, Diclamnus albus, Ferulago silvalica, Echium rubrum, Salvia nutans, Stachys recta, Verbascum phoeniceum, Pedicularis campestris, Senecio campestris, Cirsium pannonicum, Scorzonera purpurea, Hieracium echioides herrschen weitaus vor und bieten ein abwechslungsreiches farbenprächtiges Bild. Doch ist damit del Artenreichtum dieser Formation noch lange nicht erschöpft, es finden sich hier u. a. auch noch Anthericum ramosum, Crocus banaticus, Iris caespitosa, Arenaria graminifolia, Dianthus collinus, Silene vulgaris, S. chlorantha, S. dichotoma, Anemone patens, A. polonica, A. silvestris, Adonis vernalis, Clemalis integrifolia, Draba nemorosa, Helianthemum ovalum, Polygala maior, Ononis hircina, Trifolium rubens, T. ochroleucum, T. pannonicum, T. pralense, Astragalus Onobrychis, A. Cicer, Peucedanum Cervaria, P. Oreoselinum, Heracleum sibiricum, 
Carum Carvi, Eryngium planum, Salvia dumetorum, S. nutans, Aiuga Laxmanni, Slachys germanica, S. recla, Phlomis tuberosa, Nonnea pulla, Anchusa procera, Veronica longifolia, V. spuria, V. spicala, V. Teucrium, Campanula palula, C. Cervicaria, C. sibirica, Achillea Plarmica, Ligularia sibirica, Senecio Biebersteinii, Jurinea arachnoidea, Cirsium canum, Centaurea Jacea, Hypochoeris radicala, H. maculala. Von Sträuchern aber treten nur hie und da einzelne Individuen von Prunus spinosa und $P$. fruticosa auf.
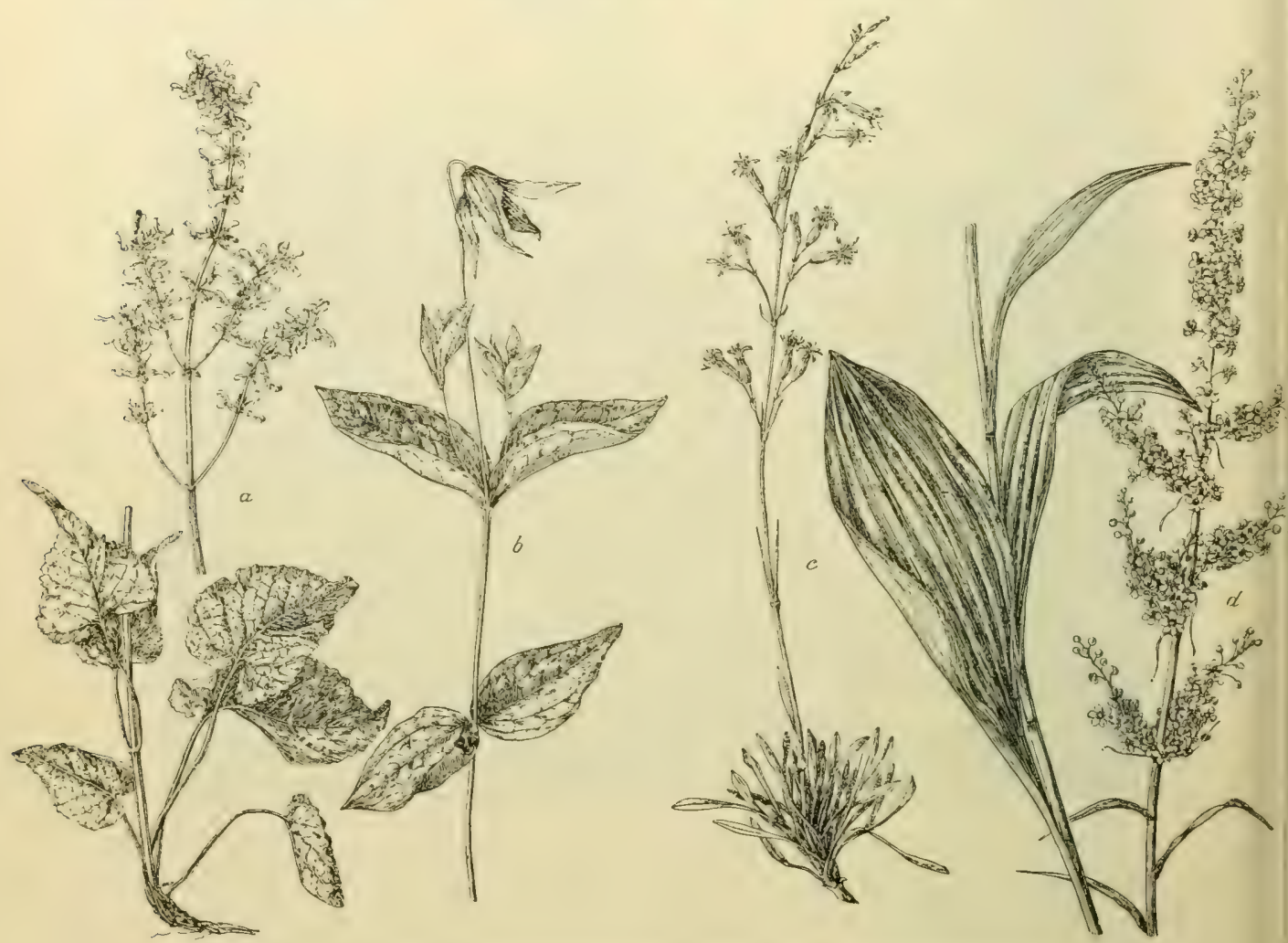

Abb. 144. Einige charakteristische Arten der podolischen Triften.

$a$ Salvia nutans. $b$ Clematis integrifolia. $c$ Silene chlorantha. $d$ Veratrum nigrum.

( $1 / 3$ nat. Gr.)

Die podolische Vorsteppe. Viel seltener als Trift tritt die Grasflur in Ostgalizien als ausgesprochene Steppe auf. Doch auch diese/ Steppen, wenn auch weit artenärmer, als die Triften, sind, obwohl sie eine offene Formation darstellen, in der zwischen den einzelnen Pflanzenindividuen noch nicht aller verfügbarer Raum von Vegetation bedeckt ist, doch viel üppiger und von mehr wiesenartigem Charakter als die eigentlichen, noch weit mehr xerophiles Gepräge aufweisenden eigentlichen Steppen Südrußlands, weshalb sie besser noch als "Vorsteppen“ zu bezeichnen sind.

Stipa pennata, St. capillata, Koeleria polonica, Agropyrum intermedium und der stellenweise in großer Menge auftretende Andropogon Ischaemum bilden 


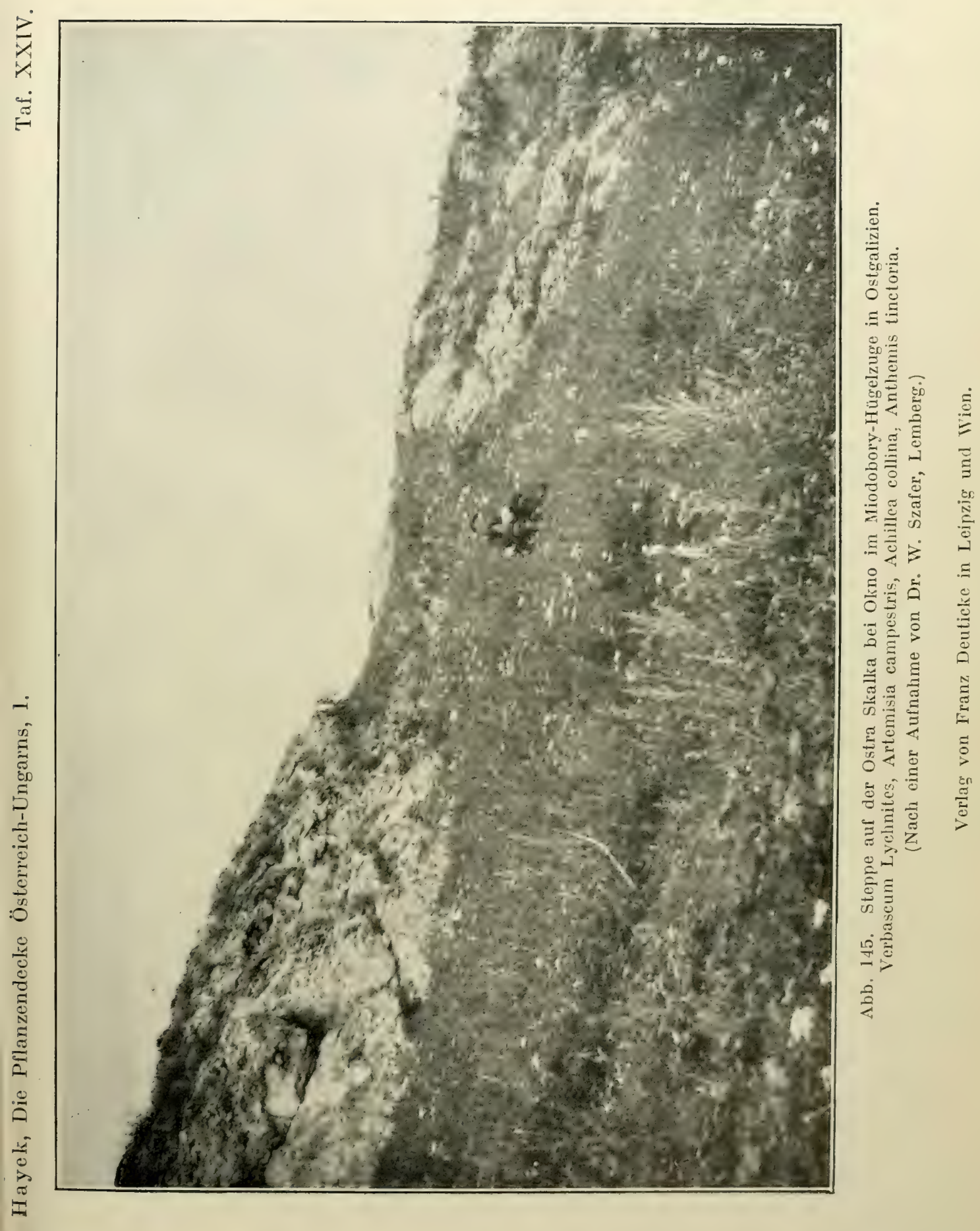



die Hauptmasse der Gräser, zu denen sich Bromus inermis, Fesluca elatior, Carex Michelii und auf Sandboden auch Poa slerilis, P. polonica und Carex praecox gesellen. Vertreter der monokotylen Zwiebel- und Wurzelstockgewächse sind Anthericum ramosum, Fritillaria Meleagris, Hyacinthella lencophaea, Muscari tenuiflorum, Allium paniculalum, Iris nudicaulis. Von dikotylen Krräutern und Stauden sind Kochia scoparia, Atriplex nitens, Thesium linophyllum, Arenaria graminifolia, Gypsophila fastigiata, G. altissima, Silene dichotoma, S. Pseudolites, Anemone patens, A. silvestris, Adonis vernalis, Thalictrum flexuosum, Ceratocephalus testiculalus, Lepidium Draba, L. perfolialum, Euclidium syriacum, Viola rupestris, Linum flavum, Euphorbia Gerardiana, E. glareosa, Astragalus Onobrychis, Oxylropis pilosa, Eryngium campestre, E. planum, Trinia Henningii, Echium rubrum, Nonnea pulla, Anchusa procera, A. Barellierii, Salvia pralensis, S. nemorosa, S. nutans, Thymus Marschallianus, Th. lanuginosus, Veronica prostrata, Asperula cynanchica, Campanula sibirica, Helichrysum arenarium, Achillea setacea, Artemisia campestris, A. ponlica, A. scoparia, Echinops commutalus, Jurinea arachnoidea, Cirsium lanceolatum, C. Boujarti, Carduus hamulosus, Scorzonerea purpurea, Sc. laciniala die wichtigsten Bestandteile dieser mit den Triften durch allmähliche Übergänge verbundenen Steppenformation.

Talwiesen. In den Niederungen der größeren Flüsse, besonders des Sereth und Pruth, treten in der Bukowina auch Talwiesen auf, die von denen Mitteleuropas in ihrem Gepräge nur wenig abweichen. Avena pubescens, Arrhenatherum elatius, Briza media, Cynosurus cristatus, Poa trivialis, Festuca elatior sind die häufigsten Wiesengräser; von den zahlreichen Begleitpflanzen sind Rumex Acetosa, Lychnis Flos Cuculi, Dianthus deltoides, Stellaria graminea, Ranunculus acer, R. polyanthemus, Arabis hirsuta, Hypericum perforatum, Polygala vulgaris, Filipendula hexapelala, Trifolium pratense, T. monlanum, T. repens, Astragalus Cicer, Lotus corniculatus, Coronilla varia, Onobrychis viciaefolia, Lathyrus pratensis, Carum Carvi, Primula veris, Symphylum officinale, Brunella vulgaris, Aiuga genevensis, Salvia pratensis, S. verticillata, Alectorolophus maior, Veronica Chamaedrys, Plantago media, P. lanceolata, Galium verum, Valeriana officinalis, Campanula patula, C. glomerata, Cirsium pannonicum, Crepis biennis, Leontodon hispidus, Taraxacum vulgare, Chrysanthemum Leucanthemum, Centaurea Scabiosa ebenso häufig wie im übrigen Mitteleuropa; an feuchteren Stellen treten noch Barbarea vulgaris, Euphorbia villosa, E. lucida, Viola pumila, Aiuga reptans hinzu. Auffallend sind nur Dianthus pseudoserotinus und Salvia nemorosa als östliche TTypen und das häufige Vorkommen von Peucedanum alsaticum.

Sumpiwiesen. Bei dem im allgemeinen trockenen Charakter der podolischen Hochebene sind Sumpfwiesen selten und von meist nur geringer Ausdehnung. Alopecurus aequalis, Anthoxanthum odoratum, Molinia coerulea, Poa trivialis, Carex tomentosa, C. disticha, C. vesicaria, C. rostrata, C. acutiformis, C. riparia, Heleocharis paluslris, Scirpus silvalicus, Eriophorım angustifolium sind die wichtigsten Gräser und Scheingräser auf diesen Wiesen. Ferner finden 
sich daselbst Triglochin palustre, Epipaclis palustris, Polygonum Bistorta, Lychnis Flos Cuculi, Caltha palustris, Barbaraea vulgaris, Lythrum Salicaria, Cicuta virosa, Alectorolophus maior, Scutellaria galericulata, Lysimachia nummularia, Cirsium palustre, C. oleraceum, Grepis paludosa usw.

\section{d) Sumpf- und Wasserpflanzen.}

Sumpipflanzen. Eine ausgesprochene Sumpfflora ist in Ostgalizien kaum anzutreffen und auch in der Bukowina nur wenig am Ufer von Teichen und anderen stehenden Gewässern entwickelt. Hier kommen vor Phragmiles communis, Schoenoplectus lacustris, Carex aculiformis, C. rostrata, C. vesicaria, Typha latifolia, Butomus umbellatus, Sagiltaria sagitlifolia, Iris Pseudacorus, Polygonum Persicaria, Sium latifolium, Berula angustifolia, Scrophularia alala, Veronica Anagallis, V. Beccabunga, Pedicularis palustris, Menyanthes trifoliata.

Wasserpflanzen. Auch die Wasserflora ist arm. Als häufigste Arten kommen Lemna minor, L. trisulca, L. gibba, Spirodela polyrhiza, Polamogeton natans, $P$. crispus, $P$. pusillus, Hydrocharis Morsus ranae, Ranunculus aquatilis, Castalia candida, Nuphar luteum, Callitriche verna, Ceratophyllum demersum, Myriophyllum spicalum, Hollonia palustris und Ulricularia vulgaris in Betracht.

\section{Die Kulturgewichse Galiziens und der Bukowina.}

Getreidebau. Von Getreidesorten werden in Galizien hauptsächlich Hafer (18\% der Anbaufläche) und Roggen (16\%), weniger Gerste $(9.5 \%)$ gebaut. Die Kultur des Weizens und des Maises ist fast ausschließlich auf den Südosten des Landes, die podolische Hochebene, beschränkt. Im nördlichen Podolien und in Nordostgalizien gehört auch der Buchweizen zu den verbreiteten Kulturpflanzen. Während im Gebirge der Getreidebau sehr 'geringfügig ist, wird derselbe im IIügellande und der Ebene eifrig gepflegt. Ein großer Teil des Landes ist in den Händen des Großgrundbesitzes; in jeder Ortschaft besteht ein herrschaftlicher Besitz in der Ausdehnung von 100-500, ja selbst bis 1000 ha. Daneben spielt nur der sehr zerstückelte Kleinbesitz eine bedeutende Rolle, während Besitztümer mittlerer Größe äußerst selten sind. Während auf dem Eigentum der Großgrundbesitzer, wenigstens in neuerer Zeit, ein moderner rationeller Landwirtschaftsbetrieb eingeführt ist, liegen beim Kleinbesitz diese Verhältnisse noch ziemlich im Argen. Zwar wurde die bis in die Mitte des vorigen Jahrhunderts allgemein gepflegte Dreifelderwirtschaft jetzt fast überall verlassen und die Wechselwirtschaft (Getreide und Kartoffel) eingeführt. Aber landwirtschaftliche Maschinen sind noch sehr wenig im Gebrauche und vielfach wird noch mit den althergebrachten sehr primitiven Werkzeugen gearbeitet. Gedüngt werden die Äcker nur in Podolien allgemein, Kunstdünger ist wohl nur auf herrschaftlichen Besitzungen in Westgalizien in Gebrauch.

Weinbau. In Galizien wird kein Wein gebaut, denn die spärlichen Weingärten bei Bilcze fallen nicht ins Gewicht, nur in der Bukowina trifft man bei 
Czernawka, Zurin, Czernowitz, Bobestie, Bossancze, Sekuriczeny, Reusseny, Pawalar und Chiliczeny Weinkulturen.

Gemuisebau. Auch der Gemüsebau spielt keine hervorragende Rolle. Die wichtigste Gemüsepflanze ist die Kartoffel, auf die über $10 \%$ der Gesamtanbaufläche fallen. Auch die Kultur von Hülsenfrüchten ist noch einigermaßen von Bedeutung.' Weniger ins Gewicht fallen Kohl, Kraut, Rüben, Kürbisse und in der Bukowina auch Eierpflaumen (Solanum Melongena). Zwiebel, Knoblauch und andere Küchengewürze werden fast nur in Gärten kultiviert.

Obstkultur. Man baut Obst fast nur in Gärten, und zwar Zwetschken, Ïpfel und Birnen, ferner auch Melonen und Wassermelonen; Aprikosen müssen schon im Winter gedeckt werden.

Forstwirtschait. Trotz der ehemals ausgedehnten Waldbedeckung fast des ganzen Landes und des jetzt noch immer großen absoluten Waldreichtums ist in Galizien nur $24.8 \%$ des Bodens mit Wald bedeckt, so daß das Land relativ waldärmer ist als sogar Dalmatien. Besonders Westgalizien bis zum San ist heute außerordentlich waldarm. Abgesehen von der Lichtung der Wälder zum Zwecke der Urbarmachung des Bodens, trägt an dieser Entwaldung des Landes die besonders in früheren Jahren stattgehabte grauenhafte Holzverschwendung schuld, die trotz der bestehenden Forstgesetze auch jetzt noch, wenn auch in geringerem Grade, fortbesteht. Die zunehmende Verarmung der Bevölkerung, sowohl des Adels als des Bauernstandes, brachte es mit sich, daß jährlich große' Bestände an Spckulanten verkauft und geschlagen wurden, ohne daß für entsprechenden Nachwuchs gesorgt wurde. Nur auf den Grundstücken der wohlhabenden Großgrundbesitzer kann von einer geregelten Forstwirtschaft gesprochen werden, doch muß hervorgehoben werden, daß auch dort der Nachwuchs meist nur der natürlichen Besamung überlassen wird und nur selten künstlich aufgeforstet wird, so daß die Waldbestände fast durchwegs in ihrer ursprünglichen Gestalt erhalten sind. In neverer Zeit wird auch die Aufforstung der weiten Flugsandflächen Nordgaliziens, insbesonders durch Föhren und Birken, energischer in Angriff genommen.

Sonstige Nutzpilanzen. Von solchen spielt vor allem der Tabak eine. wichtige Rolle, der in Ostgalizien (südliches Podolien und Pokutien) und der Bukowina, fast ausschließlich von den Kleinbauern, gebaut wird. In Galiziens werden alljährlich zirka 25.000 Pflanzen gezogen. Ein wichtiges Kulturgewächs Galiziens ist ferner der Hopfen, der besonders bei Brody, Kamionka und Zloczow, aber auch bei Lemberg, Zolkiew, Jaroslau und Rzeszow gebaut wird und dessen Kultur entschieden im Zunehmen begriffen ist. Der Anbau von Raps! hingegen geht merklich zurück. Flachs und Hanf werden insbesondere in der nördlichen Sandebene gebaut. Der Anbau von Futterkräutern ist geringfügig, aber in Zunahme begriffen; auch der Bau von Zuckerrüben ist besonders. in Westgalizien und der Bukowina nicht unbedeutend. 


\section{Die Adventivflora.}

Ruderaliflora. Die Flora der wüsten Plätze, Straßenränder, Dorfplätze usw. ist in Galizien zwar individuenreich, bietet aber trotzdem nicht viel Besonderes. Die häufigeren Ruderalpflanzen sind fast dieselben wie in ganz Mitteleuropa, so Panicum Crus galli, Selaria viridis und S. glauca, Lolium perenne, Hordeum murinum, Urtica dioeca und U. urens, Atriplex palula, Chenopodium Bonus Henricus, C. urbicum, C. album, C. glaucum und C. polyspermum, Amaranthus viridis und $A$. retroflexus, Polygonum aviculare, Rumex obtusifolius, $R$. conglomeralus und R. crispus, Arenaria serpyllifolia, Ranunculus sardous, Capsella Bursa pastoris, Alyssum alyssoides, Malva silvestris und M.neglecta, Solanum nigrum, Ballota nigra, Lamium amplexicaule, L. purpureum, L. maculalum und L. album, Leonurus Cardiaca, Marrubium vulgare, Cynoglossum officinale, Salvia verticillata, Verbena officinalis, Linaria vulgaris, Dipsacus fullonum, Erigeron canadensis, Galinsoga parviflora, Anthemis Colula, Onopordon Acanthium, Girsium lanceolatum, Arctium Lappa, A. minus und A. tomentosum, Gichorium Intybus, Sonchus oleraceus, Crepis tectorum. Von in Mitteleuropa selteneren Arten seien genannt Sicyos angulatus, der besonders im östlichen Teile häufig ist, aber auch schon bei Krakau vorkommt, Impatiens parviflora, die sowohl in Lemberg als bei Krakau eingebürgert ist, Senecio vernalis, Brassica nigra, ferner Atriplex nitens und A. rosea, Xanthium strumarium und spinosum, Nepeta Cataria, Scrophularia Scopolii; im Osten gesellt sich noch Salvia nutans und Atriplex tatarica hinzu.

Ackerunkräuter. Von den Ackerunkräutern gilt dasselbe. Auch hier sind fast alle in Mitteleuropa verbreiteten Arten weit verbreitet; erwähnenswert ist nur das nicht seltene Auftreten von Gladiolus imbricatus auf Äckern, das häufige Vorkommen von Falcarin vulgaris und der auf Ostgalizien beschränkte Hibiscus ternatus.

\section{Spezielle pflanzengeographische Schilderung.}

Im nördlichen Teile des Teschener Kreises Schlesiens zeigt die Flora oderberg. schon einen ähnlichen Charakter wie in Westgalizien. Schon östlich von Oderberg sind Erlenbrüche sowie Mischwälder aus Fichten, Föhren und Eichen, in denen Fesluca heterophylla allenthalben häufig ist, verbreitet; auch Heiden mit Sarolhamnus scoparius, Genisla pilosa, Calluna vulgaris, typische Sandfluren mit Aira caryophyllea, Corynephorus canescens, Digilaria filiformis, Scleranthus perennis, Dianthus delloides, Armeria elongata, Myosotis micrantha, bei Riegersdorf auch Gypsophila fastigiata, sowie Wiesen mit massenhaftem Cirsium rivnlare bedecken den Boden, soweit er nicht von Äckern und Zuckerrübenfeldern eingenommen ist. An der Weichsel und unteren Biala aber gedeihen in Menge Calamagrostis lanceolata, Leersia oryzoides, Carex caespitosa, Scirpus radicans, Gladiolus imbricatus, Thalictrum lucidum, Cucubalus baccifer, Agrimonia odorata, 
Armeria elongata, Hippuris vulgaris, Sculellaria hastifolia, Veronica longifolia, Bielitz. Senecio aquaticus. Bei Bielitz reichen die Nadelwälder der Karpathen mit Picea und Larix bis an die Stadt heran, in denen auch noch am Rande der Ebene Anemone Hepatica, Ranunculus platanifolius, Lunaria rediviva, Sambucus racemosa, Lonicera nigra, Salvia glutinosa, Pelasites albus und andere Gebirgspflanzen nicht selten sind; Conioselinum lalaricum wurde sogar am Bahndamme unter Bielitz beobachtet. Auch Galanlhus nivalis ist häufig und an mehreren Stellen, wie am Salzberg bei Bielitz und am Josefsberg und Haislik bei Biala, ist Digilalis purpurea zu finden. Auf den Wiesen wachsen hier u. a. Ononis hircina, Geranium phaeum und G. pratense, während Colchicum aulumnale auffallenderweise fehlt; am Leibnitzbache ist Mimulus gullatus verwildert. Ebenso herrscht auch um Wadowice und Landskron die Karpathenflora, Nadel- und Buchen-Wadowice. wälder, in denen noch Cardamine trifolia und Symphytum cordatum vorkommen, sind nicht selten. Weiter nördlich in der Ebene aber treten schon bei Oswieczim Oswieczim. Föhrenwälder mit teils sandigem, teils moorigem Untergrunde auf, die sich hier längs der Weichsel ausdehnen. Nicht uninteressant ist auch die Sumpfflora entlang der Weichsel und besonders der Przemsza, wo u. a. Salvinia natans, Garex dioica, Elatine Hydropiper, Hydroctolye vulgare, Lindernia pyxidaria, Senecio paludosus und bei Kaniow und Skavina auch Aldrovandia vesiculosa vorkommen. Bei Szczakowa ist das Vorkommen von Anemone vernalis bemerkenswert. Nördlich der Weichsel, bei Trzebinja und Ghrzanow, Trzebinja: liegt bereits ein Flugsandgebiet, wo dichte Föhrenwälder, in denen ein spärlicher Niederwuchs, aus dem Equisetum pratense und Koeleria glauca und Corynephorus canescens bemerkenswert sind, den tief sandigen Boden bedecken, während das Unterholz stellenweise von Sarothamnus scoparius gebildet wird, oft unterbrochen von Moorwäldern, ebenfalls aus Pinus silvestris gebildet, in denen Ledum palustre im Unterholz dominjert, während im moorigen Niederwuchs neben

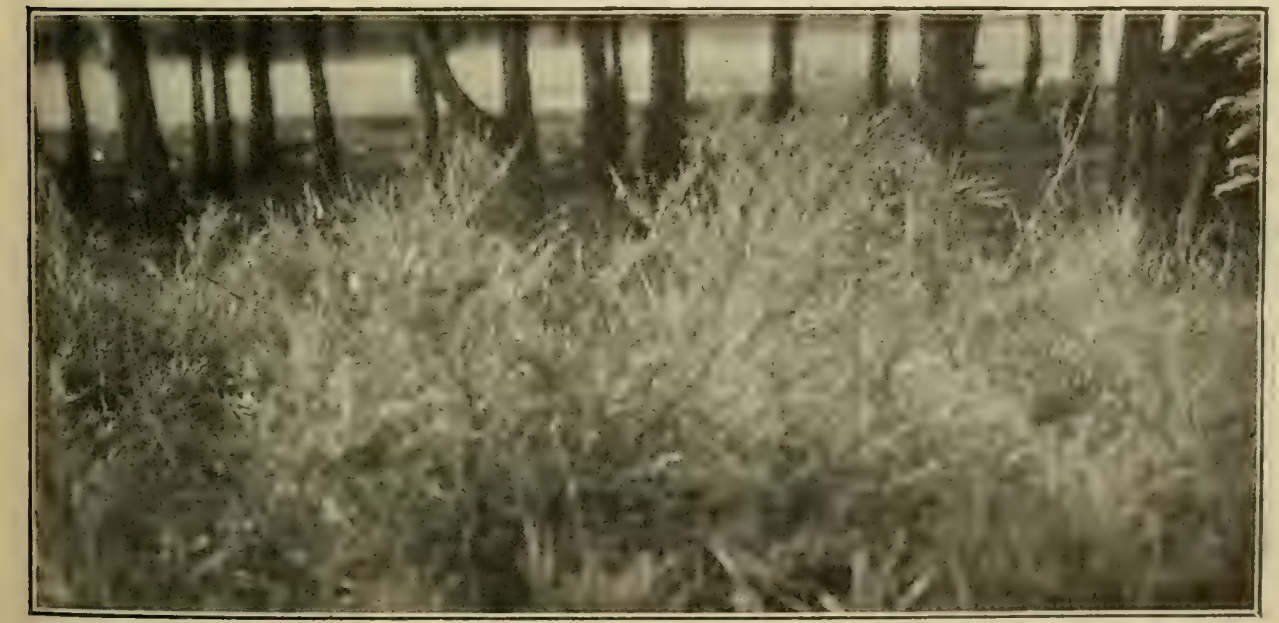

Abb. 146. Sarothamnus scoparius als Unterholz in einem Föhrenwald bei Trzebinja. (Nach einer Aufnahme von A. v. Hayek.) 
Vaccinium Myrtillus und $V$. uliginosum auch Juncus squarrosus, Oxycoccos quadripetala, Andromeda polifolia und mancherorts auch Lycopodium annotinum und Calla palustris auftreten.

Krakau. Auch in der Umgebung von Krakau treten auf Sandboden noch Föhrenwälder auf, während auf anstehendem Gestein sich Laubmischwälder aus Buchen, Birlien, Eichen und Linden, in den tief eingeschnittenen Kalkschluchten Mischwälder aus Buchen mit Eichen, in denen u. a. Cypripedium Calceolus und Cephalanthera alba vorkommen, sich finden. Die wichtigste Formation der Umgebung von Krakau, soweit sie nicht von Äckern bedeckt ist, sind die ausgedehnten Wiesen, auf denen Galium verum, Valeriana simplicifolia und Cirsium arivulare die tonangebenden Arten sind; hie und da treten auch Erlenbrüche mit Iris Pseudacorus, Calla palustris, Oenanthe aquatica usw. oder kleine Hochmoore auf, in denen Lycopodium annotinum, Juncus supinus, als Seltenheiten Sielicha. sogar Belula humilis und Saxifraga Hirculus vorkommen; im Teiche bei Dziekanowice, südlich von Wielicka, ist auch Salvinia natans zu finden, bei Niepolemice der seltene Farn Osmunda regalis.

Tarnow. Weiter nach Osten zu nimmt der Sand immer mehr überhand und besonders die Umgebung von Tarnow ist durch weite Flugsandflächen, unterbrochen von spårlichen Föhrenwäldern, ausgezeichnet, doch kommen auch hier noch Moore vor, wie bei Radlow und Poreba, bei welch letzterem Orte auch Osmunda regalis einen Standort hat. Die Vorhügel der Karpathen, südlich von Tarnow, tragen bereits Mischwälder aus Pinus silvestris, Abies alba, Fagus silvatica und Carpinus Betulus mit einem Niederwuchs aus Gebirgspflanzen, wie Gentiana asclepiadea, Salvia glutinosa und Digitalis ambigua.

Entlang der Weichsel in Nordgalizien herrschen trockene Nadelwälder, teils aus Fichten, teils aus Föhren zusammengesetzt, vor; an den toten Armen der Weichsel ist eine reiche Sumpfflora, durch das häufige Vorkommen von Euphorbia palustris und Butomus umbellatus ausgezeichnet, entwickelt.

Grobiet zwischen TVeichsel jand Sin. Flugsandgebiet mit weiten, sandigen, fast vegetationslosen Flächen, Heiden und Misch- und Föhrenwäldern. Auf Sandheiden treten hier neben Corynephorus canescens, Koeleria glauca und Digitaria filiformis auch Festuca vaginata, Calamagrostis neglecla, Elymus arenarius, Gypsophila fastigiala und Dianthus borussicus auf, bei Dabrowicza kommt auch, wahrscheinlich zur Festigung des Flugsandes angepflanzt, Ammophila arenaria vor, bei Orlisk finden sich auch Anemone patens und Alyssum montanum, bei Trzésiń Eryngium planum; auf Sumpfwiesen kommen Dryopleris crislata, Oenanthe fistulosa, Euphorbia lucida, Soholniki. E. villosa und Veronica longifolia vor; bei Sokolniki überdies auch Iris sibirica: Dianthus superbus und Galium uliginosum. Die Wälder des Gebietes waren ehedem gewiß von weit größerer Ausdehnung als jetzt und bildeten einen Teil sandomirer des großen Sandomirer Urwaldes. Auf Lehmboden sind es Laubwälder aus Quercus Robur, Carpinus Belulus, Fagus silvalica, Acer platanoides, A. Pseudoplatanus, Tilia cordata mit eingemischten Föhren, Fichten und Tannen, mit Maianthemum bifolium, Polygonatum latifolium, Clematis recta, Thalictrum 


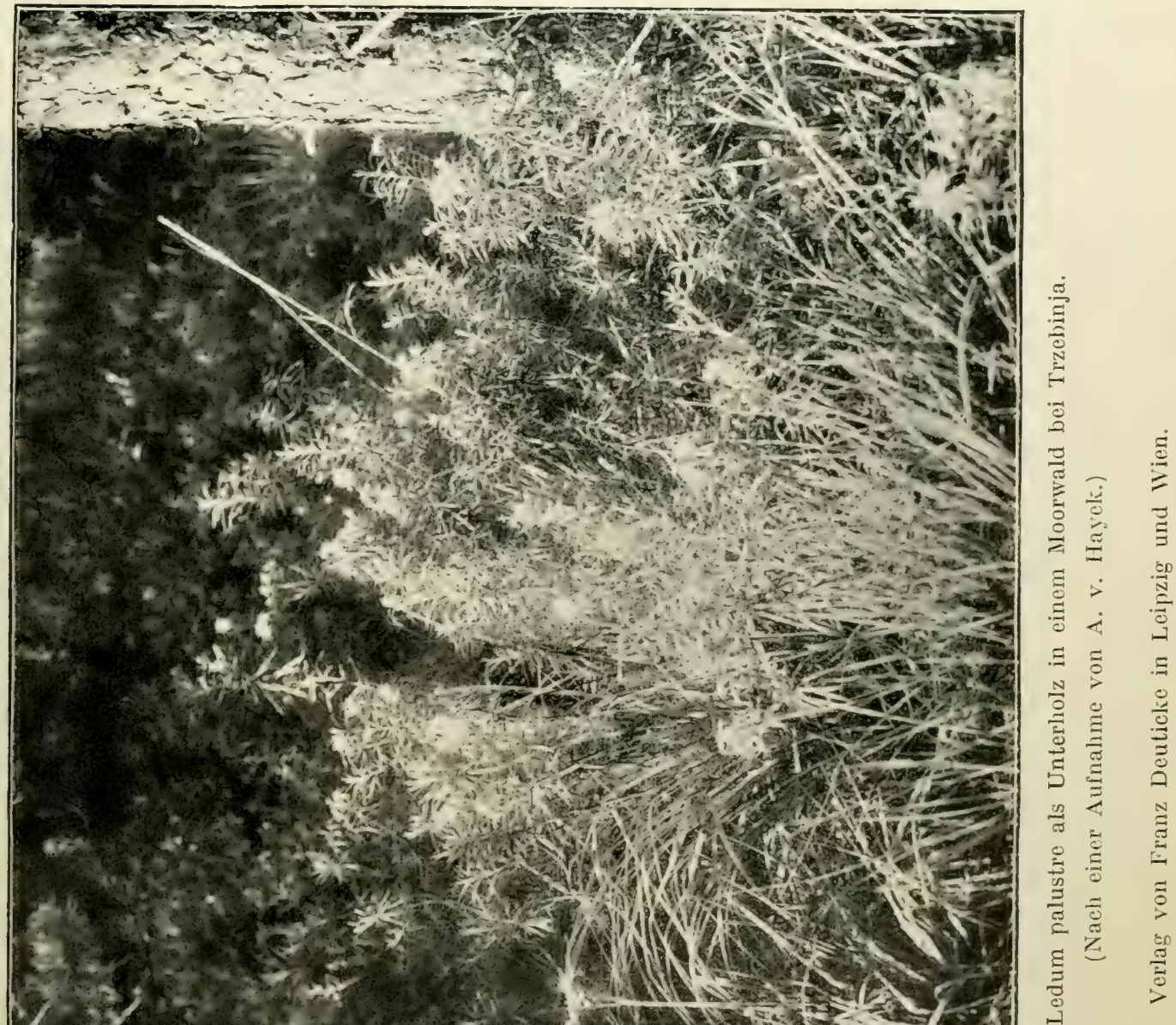





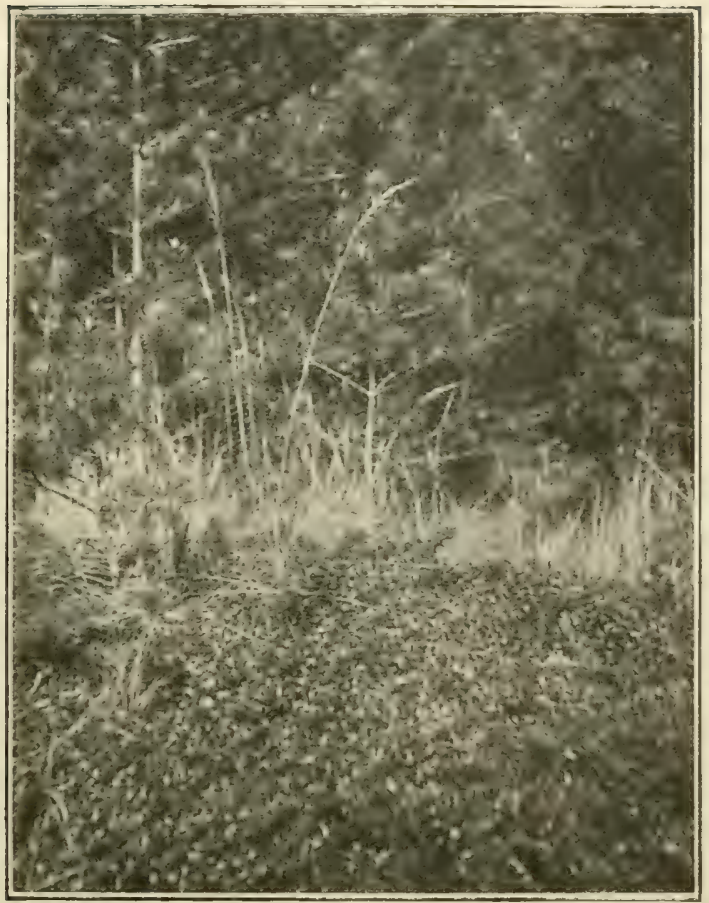

Abb. 148. Arctostaphylos Uva ursi als Niederwuchs in einem Föhrenwald bei Szydlowiec nächst Mielec im Sandomirer Urwaldgebiet.

(Nach W. Szafer, O niektórich zradszych roślinach nizu Galicyjskiego.)

aquilegifolum, Cylisus nigricans usw. im Niederwuchs; auf Sandboden aber herrschen Föhrenwälder mit einem Niederwuchs aus Pleridium aquilinum, Lycopodium clavatum, Calluna vulgaris, Taccinium Vitis Idaea, Chimaphila umbellata, Pirola secunda, Scorzonera humilis und stellenweise massenhaftem Arclostaphylos Uva ursi vor. Von besonderem Interesse aber ist das Auftreten des erst $285 \mathrm{~km}$ weiter östlich in Volhynien wieder auftretenden, durch seine großen gelben Blüten ausgezeichneten Rhododendron flavum (Azalea pontica), das bei ITola Zarczycka als Unterholz im lockeren Föhrenbestand auf Sandboden auftritt, während im Niederwuchs daselbst Kochia arenaria wächst. Auch Hochmoore sind im Gebiet des Sandomirer Urwaldes nicht selten, auf denen neben Andromeda polifolia, Ledum palustre, I accinium Vitis Idaea und V. uliginosum, Drosera rotundifolia und $D$. anglica bei Majvan (Bezirk Kolbuszow) auch $D$. intermedia und Viola epipsila gedeihen, während bei Jeziorki auch Carex limosa, C. dioica, Juncus capilalus, J. filiformis, Scheuchzeria palustris, Malaxis paludosa, Calla palustris und Hydrocotyle vulgare auftreten. Auch Erlenbrüche mit Calla palustris, Dryopteris crislata sind stellenweise nicht selten und bei Gwozdziec (Bezirk Gwożdzic. Nisko) wachsen in solchen Bruchwäldern Dryopleris Thelypleris, Molinia coerulea, Ranunculus flammula, Lysimachia vulgaris, Drosera rolundifolia, Ledum palustre sowie der seltene Farn Osmunda regalis. 


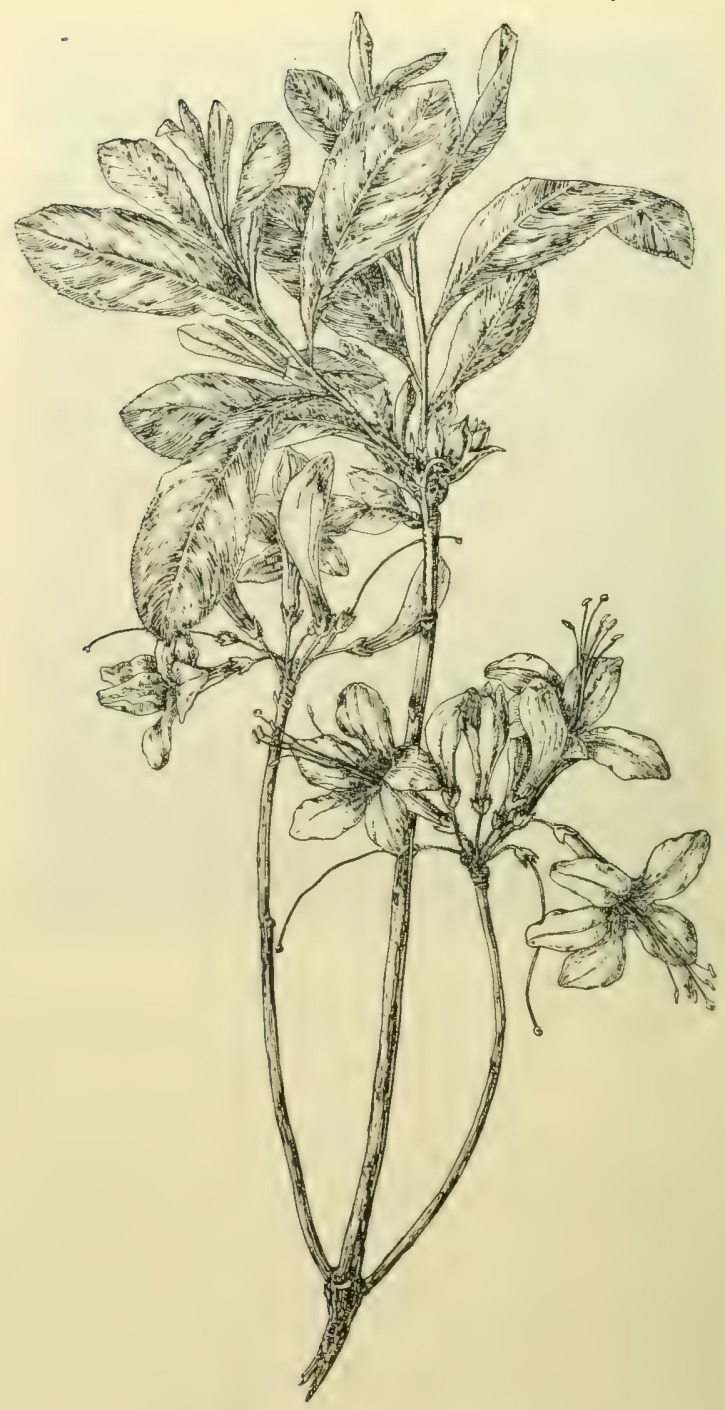

Abb. 149. Rhododendron flavum.

( $1 / 2$ nat. Gr.)

Lezaiska.

Auch um Lezaisk herrschen ähnliche Verhältnisse, auch hier dominieren Föhrenbestände, seltener sind gemischte Laubwälder mit Cytisus supinus, G. nigricans, Pirola secunda, Salvia glulinosa, Thalictrum aguilegifolium usw.; auf Sandheiden kommen neben Corynephorus, Nardus, Scleranthus, Herniaria, Jasione usw. auch Plantago ramosa, Salsola Kali und Verbascum speciosum vor; an und in den Teichen Acorus Calamus, Typha latifolia, Glyceria aquatica, Castalia candida, Trapa natans, auf Sumpfwiesen Peucedanum palustre und Succisa inflexa.

Dieses Flugsandgebiet erstreclit sich entlang des San über Jaroslau bis Przemysi. in die Gegend von Przemysl. Die Sandheiden bei Przemysl bilden haupt- 



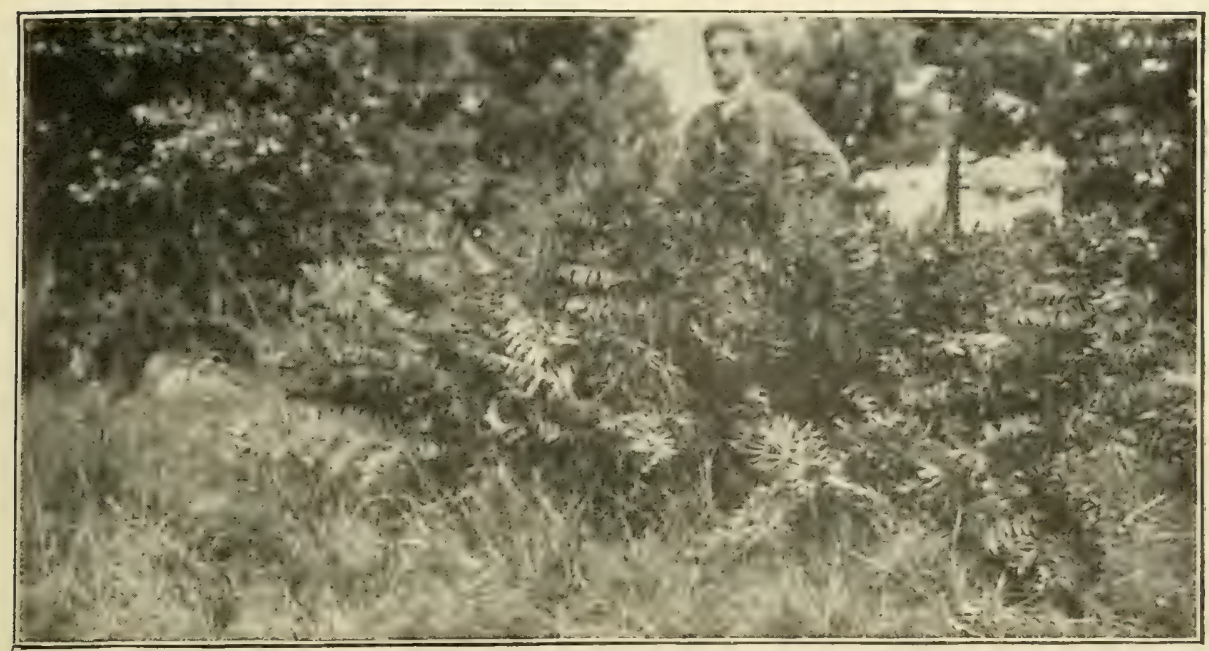

Abb. 151. Osmunda regalis in einem Bruchwald bei Gwozdziec in Nordgalizien.

(Nach W. Szafer, O niektórich rzadszych roślinach niz̉u Galicyjskiego.)

sächlich Corynephorus canescens, Scleranthus perennis, Herniaria glabra, H. hirsuta, Silene Otites, S. vulgaris, Planlago ramosa, Helichrysum arenarium, Jasione montana und Hieracium echioides. Im Tale rles San aber finden sich ausgedehnte feuchte Wiesen mit Allium angulosum, Fritillaria Meleagris, Iris sibirica, Dianthus superbus, Euphorbia villosa, E. lucida, E. palustris, Cnidium venosum, Gentiana Pneumonanthe, Veronica longifolia usw.; die Sümpfe sind durch Salix livida, Calla palustris, Elatine Hydropiper, Lathyrus palustris, Peucedanum palustre, Hottonia palustris, Teucrium Scordium und Senecio paludosus ausgezeichnet. Die Wälder des Hügellandes um Przemysl sind vorwiegend Eichenwälder mit einem Niederwuchs aus Carex pilosa, Hordeum europaeum, Gagea minima, Scilla bifolia, Cephalanthera longifolia, Goodiera repens, Corydalis cava, C. solida, Cardamine glandulosa, Vinca minor, Aposeris foetida, dazwischen aber treten an kahlen Hängen Triften auf, die schon lebhaft an die ostgalizischen Vorsteppen erinnern und hauptsächlich aus Carex Michelii, Thaliclrum simplex, Th. flexuosum, Anemone silvestris, Linum flavum, Geranium sanguineum, Potentilla arenaria, $P$. canescens, $P$. recta, Stachys recta, Veronica spicala, Campanula bononiensis, Aster Amellus, A. Linosyris, Scorzonera purpurea bestehen und in denen sogar schon Prunus fruticosa vorkommt.

Auch weiter nach Nordosten zu bis Jaworow und Grodek dehnt sich Groders. das Heidegebiet mit Föhren- und Fichtenwäldern aus. Bei Jaworow sind noch Jaworow. weite mit angepflanztem Elymus arenarius bestandene Flächen vorhanden; von IVäldern herrschen Föhrenwälder vor, doch trifft man auch Laubmischwälder an, in denen neben Fagus silvatica und Betula pendula auch Quercus Pobur keineswegs selten ist. Auch Moore sind noch häufig; vor allem aber verdient die reiche Teichflora mit Leersia oryzoides, Acorus Calamus, Naias maior, N. minor, Cicuta 
virosa ụsw., bei Grodek auch Salvinia natans hervorgehoben zu werden und bei Lubien maly hat Carex arislata einen weit nach Süden vorgeschobenen Standort.

Ein ganz anderes Bild bietet die Vegetation weiter südlich im Tale des Dnjester und in dem südlich dieses Flusses gelegenen Hügellande. Bei Sambor. Sambor finden sich längs des Dnjester Moore mit Eriophorum gracile, Carex diandra, C. limosa, C. panicea, C. vesicaria, C. lasiocarpa, C. riparia, Lalhyrus paluster, die sich weiter flußabwärts zu einem weiten Sumpflande verbreitern, wo neben Beständen aus Schoenoplectus lacustris und Phragmites communis auch Wiesenmoore mit Carex gracilis, C. vesicaria, C. rostrata, Alopecurus geniculatus, Iris Pseudocorus, Potentilla palustris, Hippuris vulgaris, Lysimachia lhyrsiflora, Menyanthes trifoliala, Pedicularis palustris, Dryopleris Thelypteris usw., bei Kalinow auch mit Fritillaria Meleagris, auftreten. Die Tümpel und stehenden Gewässer sind reich an verschiedenen Polamageton-Arten (u. a. auch $P$. acutifolius und P. pectinatus), an Castalia candida, Nuphar luteum, Myriophyllum verticillatum, Stratiotes alö̈des, an Teichufern tritt Senecio paludosus, an schlammigen Stellen Pulicaria vulgaris auf; in den toten Armen des Dnjester bei Zurawno wächst Salvinia nalans. Die Wälder um Drohobycz sind gemischte Laubwälder aus Fagus silvalica und Carpinus Belulus mit eingesprengten Eichen, in deren Niederwuchs Melica nutans, Carex brizoides, C. silvatica, C. digitala, Polygonalum mulliflorum, Stellaria holostea, Ranunculus auricomus, $R$. cassubicus, $R$. nemorosus, Potentilla alba, Lathyrus vernus, $L$. niger, L. laevigatus, Peucedanum Cervaria, Laserpitium pruthenicum, Pleurospermum austriacum, Aposeris foetida usw. wachsen; auf den Wiesen sind Orchis latifolia, Anacamptis pyramidalis, Gladiolus imbricalus, Arabis Halleri, Campanula patula, Chrysanthemum Leucanthemum, Hypochoeris maculala häufig. Zwischen Stebnik und Drohobycz treten sogar einige Halophyten, wie Salicornia herbacea, Atri-

Stryi. plex hastata und Spergularia salina auf. Auch bei Stryi zeigen sich ähnliche Anklänge an die Karpathenflora, die Wälder bestehen aus Fichten und Buchen Stanislau. und beherbergen schon zahlreiche Gebirgspflanzen; bei Stan islau aber herrschen Laubwälder aus Eichen und Hainbuchen, in denen Galanthus nivalis, Lilium Martagon, Actaea Cimicifugia, Cardamine glandulosa und Aposeris foetida gedeihen, vor. Doch finden sich auch stellenweise Moore, so bei Krechovce, wo Lysimachia thyrsiflora, Calla palustris und Trapa natans vorkommen, bei Wolcyniec hingegen auch schon podolische Triften mit Adonis vernalis, Anemone polonica, Erysimum erysimoides, Eryngium planum, Libanotis monlana, Cylisus nigricans, Asperula cynanchica, Campanula sibirica, Aster Amellus usw.

Östlich von Jaworow wird die Sandfläche durch einen von Lemberg nach Nordwesten gegen Rawa ruska hinziehenden Höhenrücken, der einen Ausläufer der podolischen Hochebene darstellt, unterbrochen. Dies macht sich auch

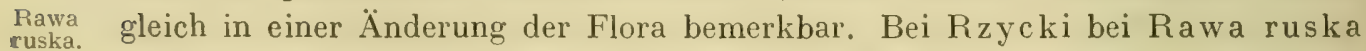
sind noch Moore mit Salix repens, IS. livida, Ostericum palustre, Pinguicula vulgaris, Pedicularis palustris und $P$. Sceptrum Carolinum anzutreffen, aber 


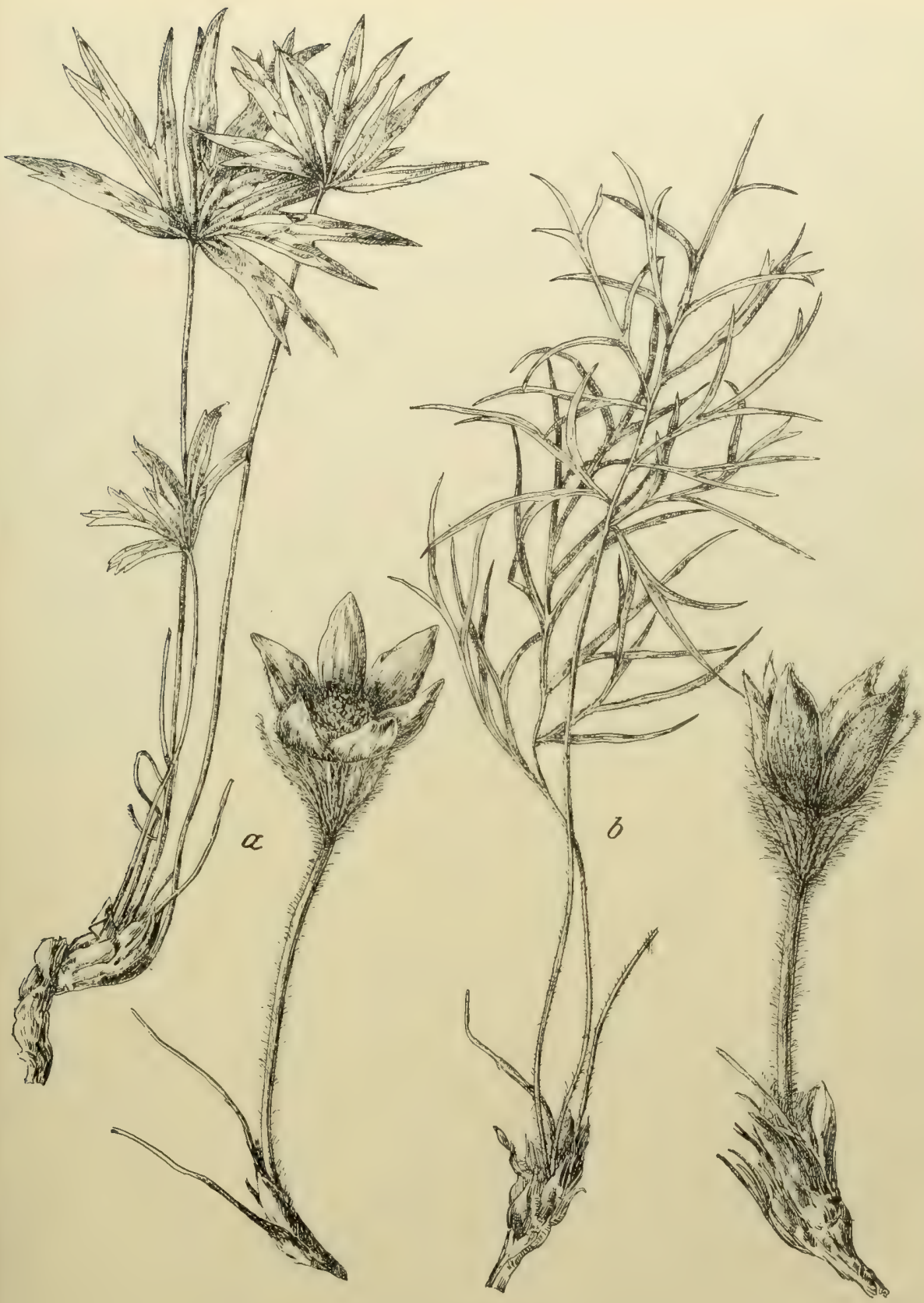

Abb. 152. Die beiden galizischen Küchenschellen.

$a$ Anemone patens. $b$ A. polonica.

schon bei Siedliska und Prusie nächst Rawa ruska treten podolische Laubmischwälder mit Bolrychium Matricariae und Circaea alpina und östliche Steppenpflanzen, wielCylisus ruthenicus, auf, obwohl auch noch Bewohner der Sandheiden wie Koeleria glauca nicht fehlen. 
Lemberg. Reich und mannigfaltig ist die Flora der. Umgebung von Lemberg. An der Grenze zwischen der podolischen Hochebene und dem nördlichen Tieflande und unweit der letzten Ausläufer der Karpathen gelegen, besitzt die Umgebung dieser Stadt eine Flora, in der die Formationen aller dieser Gebiete vertreten Janow: Sind. So ist der Janower Wald ein typischer podolischer Laubwald mit Geum aleppicum, Anemone patens, Aconitum Janoviense, Dracocephalum Ruyschiana, Veronica spuria, Scrophularia Scopolii, Centaurea austriaca und einzelnen Karpathenpflanzen, wie Onoclea Struthiopleris, Gladiolus imbricatus und Salix silesiaca; an sumpfigen Stellen im Walde kommt Carex Buekii, an Felsen Cotoneaster nigra und Iris nudicaulis vor; in Mooren zwischen Lelechovski und Stawki findet sich Salix myrlilloides. Besonders reich ist die Umgebung Lembergs an Mooren; teils sind es Hochmoore, auf denen Drosera rolundifolia, D. anglica, Saxifraga Hirculus, Trientalis europaea und Pedicularis Sceptrum Rzesna Carolinum und bei Rzesna ruska auch Pinus Pseudopumilio vorkommen, teils, wie besonders längs des Peł $ł \mathrm{ew}$ gegen den $\mathrm{Bug}$ zu Wiesenmoore mit Schoenus nigricans, S. ferrugineus, Carex diandra, G. paradoxa, C. limosa, Pseudorchis Loeselii, Lathyrus palustris. Ebenso sind typische Heiden und Sandfluren mit Corynephorus canescens, Koeleria glauca, Festuca ovina, Bromus tectorum, Scleranthus perennis, Dianthus borussicus, Teesdalea nudicaulis, Thymus angustifolius, Plantago ramosa, Jasione montana, Filago montana und Hieracium echioides nicht selten und schon in unmittelbarer Nähe der Stadt, wie bei Lesienice (ehemals auch am Sandberge) anzuKrzyw- treffen. Doch schon auf den Hügeln zwischen Zniesienie und Krzywczycze
czycze. tritt eine Triftformation mit Linum flavum, Geranium sanguineum, Anemone palens, Stachys germanica, Campanula sibirica, Crepis praemorsa, Cirisum pannonicum, Inula hirta, I. ensifolia auf, die schon eine verarmte Form der podolischen

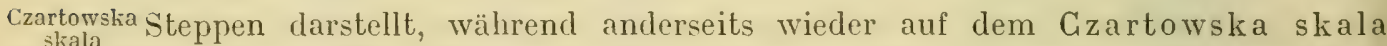
(Teufelsfelsen) bei Lesienice Cardamine glandulosa, Aposeris foelida und andere Karpathenpflanzen, beim jüdischen Friedhofe und an anderen Stellen Carex pediformis und $C$. ericetorum auftreten. Die zahlreichen Teiche in der Umgebung Lembergs sind meist mit einem dichten Gürtel aus Phragmites umgeben, im Wasser sind Potamogeton-Arten, Naias maior, N. minor, Elatine Hydropiper und Charazeen (besonders Tolypellopsis slelligera) zumeist in großer Menge anzutreffen, bei Czerlany wächst auch Wolffia arrhiza.

Der nordöstlichste Teil Galiziens, zwischen Rawa ruska, Lemberg Zolkiew. und Zloczow, also die Umgebung von Zolkiew, Kamionka und Brody, stellt wieder ein ausgedehntes Flugsandgebiet dar. Sandfluren und Heiden wechseln mit Föhrenwäldern, in denen Daphne Cneorum sehr häufig ist, und dürftigen Laubholzbestïnden aus Eichen, Ulmen und Erlen, aus deren Niederwuchs Carex digitala, C. montana, Paris quadrifolia, Crocus. Heuffelianus, Anemone Hepatica, Isopyrum lhaliclroides, Cardamine glandulosa,! Fragaria vesca hervorKrystyno- zuheben sind, ab. Im Norden dieses Lanflesteiles bei Krystynopol erreicht die
nol. Buche (Fagus silvatica) ihre Nordostgrenze, welche nur hier auf ein kurzes Stück die Grenzen Österreichs durchschneidet. Auch Moore treten stellenweise 


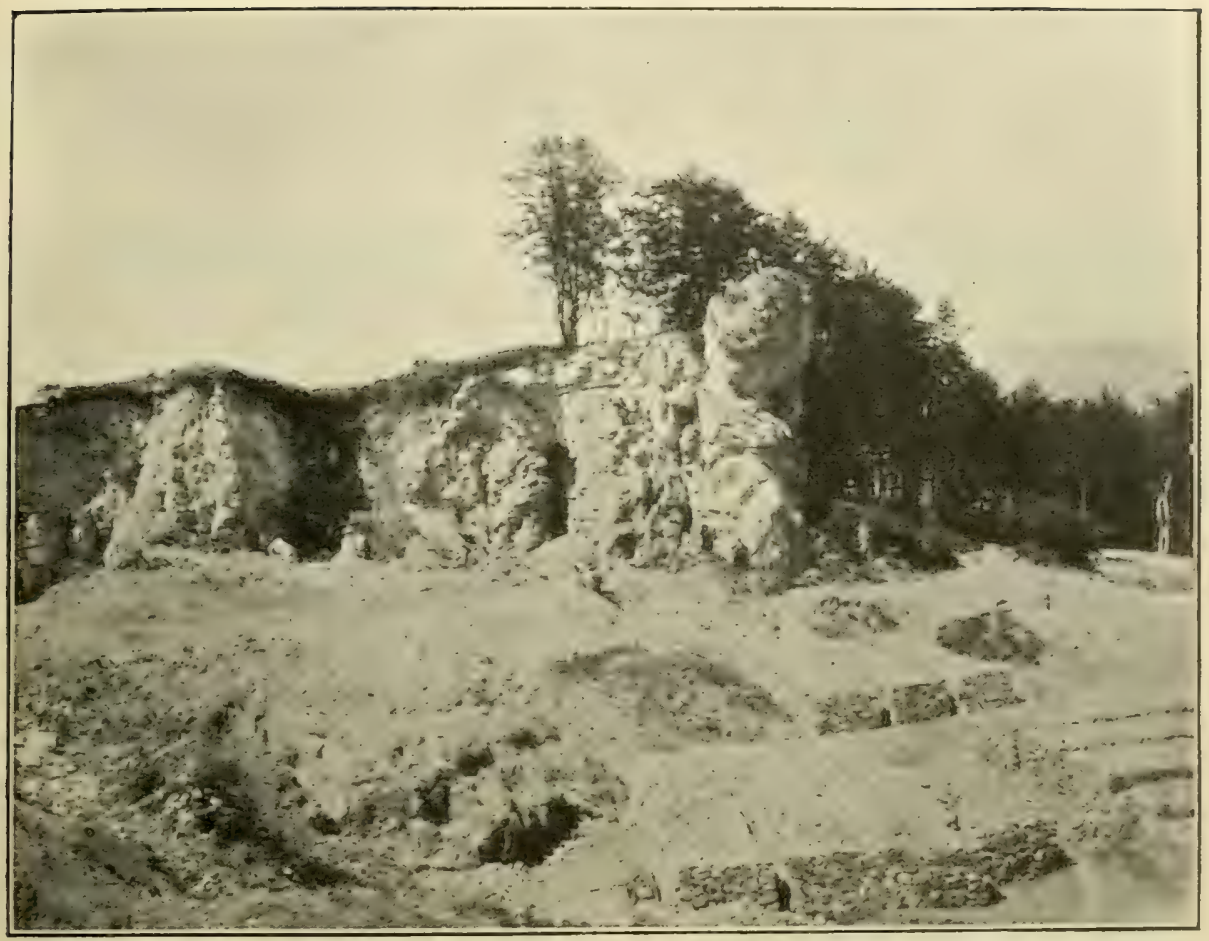

Abb. 153. Die ,Czartowska skala" bei Lemberg.

(Nach einer Aufnahme aus der Bildersammlung des geographischen Institutes der Wiener Universität.)

auf; so liegt im äußersten Norden bei Poturycza, unweit Sokal, das Hochmoor Kopytowicz, welches eine außerordentliche interessante Flora aufweist, da daselbst neben Schoenus ferrugineus, Salix cinerea, S. aurita, S. purpurea, S. repens, Pinguicula vulgaris, Pedicularis Sceptrum Carolinum auch Salix myrlilloides und die erst in den Karpathen wiederkehrende S. Lapponum sowie S. nigricans wachsen. Am Ufer des Bug aber wächst hier in Gesellschaft von Euphorbia lucida die nordosteuropäische Achillea salicifolia. Bei Skomorochy kommen auch schon Triften mit Muscari comosum, Linum flavum, Stachys germanica, Anthemis tinctoria und Potentilla recla* fallacina vor. Reicher an östlichen Florenelementen ist schon die Umgebung von Brody, wo in Laubmischwäldern bei Zalozce Hierochloë odorata, Anemone silvestris, Clemalis recla, Turritis glabra, Fragaria viridis, Rosa spinosissima, Teucrium Chamaedrys, in Föhrenwäldern Gymnadenia cucullata, auf Triften Peucedanum carvifolia, Arlemisia anslriaca und Dracocephalum Ruyschiana auftreten.

Südlich von Brody erhebt sich dann die podolische Hochebene mit ihren tief eingeschnittenen Schluchten der Flüsse, ihren zahlreichen Gips- und Kalkfelsen und ihren eigentümlichen Gipstrichtern. Von den diese Hochebene ursprünglich bedeckenden Eichenwäldern ist freilich jetzt nicht mehr viel zu sehen und besonders im Nordwesten, bei Zloczow und Brzezany, bedecken heute 
wogende Weizenfelder den Boden, von der ursprünglichen Vegetation nur Spuren übrig lassend. Bei Pieniaky, südlich von Brody, hat jedoch Graf Wladimir Zdieduczicki eine $2 \cdot 3$ ha große Parzelle als Naturpark in seinem Urzustande erhalten lassen, hauptsächlich einen Buchenbestand, in dessen Nieder-

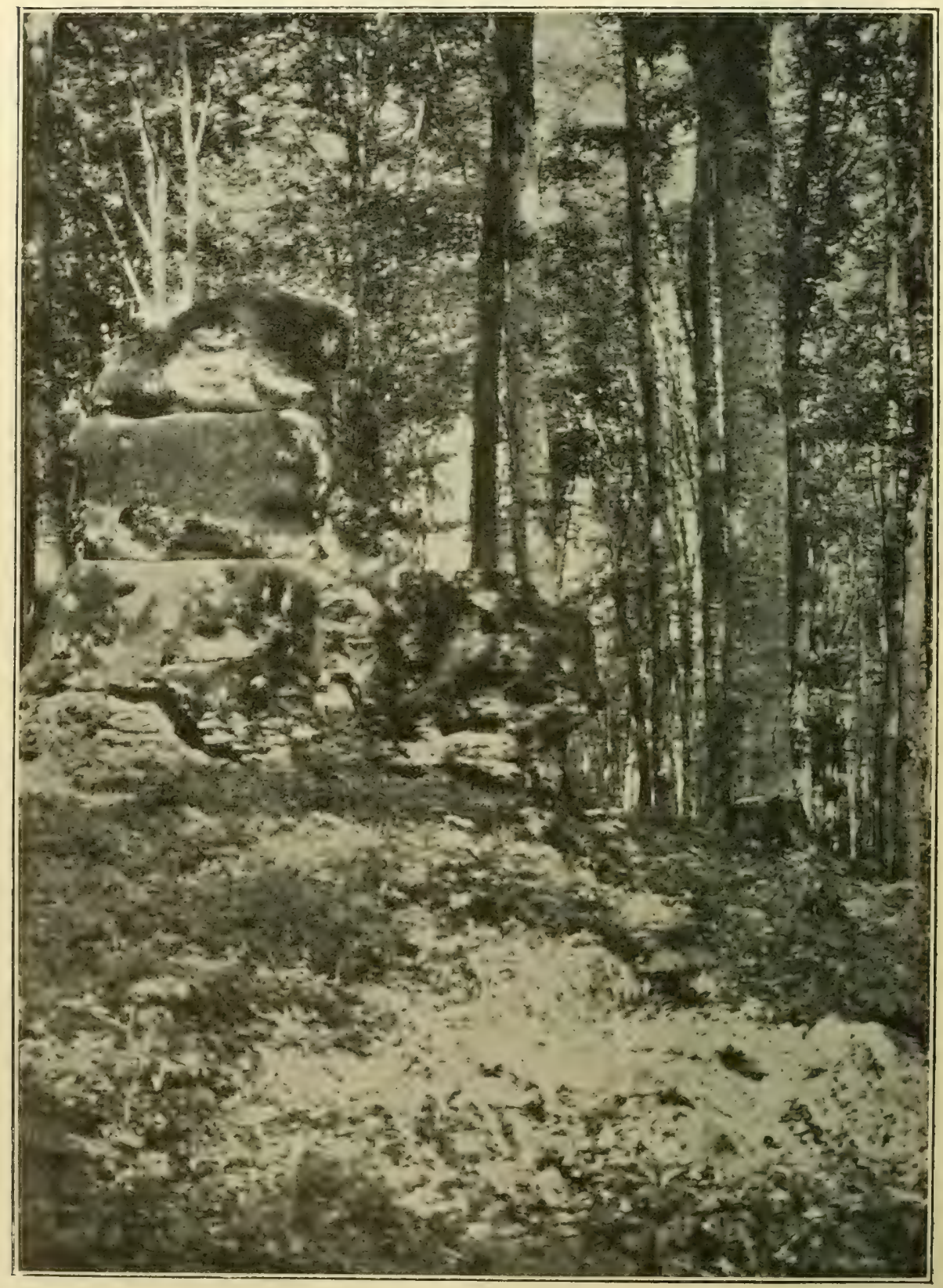

Abb. 154. Aus dem gräflich Dzieduczickischen Urwaldgebiet bei Pieniaky. (Nach einer Aufnahme von Dr. W. Szafer, Lemberg.) 
wuchs Milium effusum, Carex silvalica, C. digilata, Paris quadrifolia, Plalanthera bifolia, Neollia Nidus avis, Asarum europaeum, Ranunculus lanuginosus, Cardamine glandulosa, Oxalis Acelosella, Lamium vulgare, Asperula odorala die bezeichnendsten Arten sind. Aber auch schon bei Pieniaky, findet Pieniaky? man schöne Triften mit Anemone narcissiflora, A.patens, Cytisus leucanthus, Linum flavum, L. austriacum, Anchusa Barellierii usw. und Eichenwälder mit Cypripedium Calceolus, Cardamine bulbifera, C. glandulosa, Agrimonia odorata, Lathyrus laevigatus, Pulmonaria mollissima, Galium Schullesii. Bei Brzezany ist das Vorkommen von Fritillaria Meleagris und Salix depressa, bei Zlotnik das von Gynoglossum montanum zu erwähnen. Auch bei Uhorce sind auf Triften Anemone narcissiflora, Adonis vernalis, Ferulago silvatica und Veratrum nigrum zu finden. Bei Pantalicha, wo östliche Florenelemente, wie Hyacinthella Pantalicha. leucophaea, Rumex confertus, Ranunculus polyphyllus, Senecio Doria und Scorzonera purpurea ehedem schon in größerer Zahl zu finden waren, bedecken jetzt Weizenfelder weithin den Boden und von der ursprünglichen Vegetation sind kaum mehr Spuren vorhanden.

Die Westgrenze des eigentlichen Steppengebietes bildet das tief eingeschnittene Tal des Strypaflusses. In der Umgebung von Tarnopol, wo heute nahezu jedes Fleckchen Erde urbar gemacht und von Weizenfeldern eingenommen ist, sind noch Grasfluren von steppenartigem Charakter mit Poa slerilis, Salvia nutans, S. pendula, Dracocephalum austriacum, Veronica incana, Pedicularis campestris, Jurinea arachnoidea in spärlichen Resten zu finden. Nordöstlich von Tarnopol, bei Zbaraz, treten aber wieder Välder aus Quercus Robur mit Prunus avium, Lonicera Xylosteum, Maianthemum bifolium, Actaea Gimicifugia, Geum urbanum, Chaerophyllum aromalicum, Astrantia maior, Sanicula europaea, Vicia silvatica, Salvia glutinosa, Campanula Trachelium usw. auf. Südlich davon liegt der durch seine reiche Flora berühmte Höhenzug der Miodobory. Auch hier trifft man auf dem Rücken des Gebirges noch Välder Miodobory. aus Quercus Robur, Carpinus Betulus, vermischt mit Prunus avium, Fraxinus oxycarpa und zahlreichen anderen Laubbäumen, im reichen Niederwuchs sind Milium effusum, Festuca helerophylla, F. gigantea, Galanthus nivalis, Scilla bifolia, Lilium Martagon, Trollius europaeus, Actaea Cimicifugia, Aconitum paniculatum, Agrimonia pilosa, Geum aleppicum, Vicia silvalica, V. pisiformis, Laserpilium latifolium, Digitalis ambigua, Pulmonaria mollissima, P. officinalis, Salvia glutinosa, Centaurea slenolepis die auffallendsten Typen. Am Ostfuße des Gebirges, am Durchbruche des Zbrucz, treten reine Buchenbestände mit dem für dieselben charakteristischen Niederwuchs auf ; bei Kecilow wächst auch der auf benachbartem russischem Gebiete häufigere, dann erst wieder in der Bukowina und im Kaukasus vorkommende Evonymus nana. An den Abhängen der Hügel aber trifft man die podolische Strauchvegetation mit Prunus fruticosa, Crataegus melanocarpa, Spiraea media, Rosa spinosissima, R. gallica, Cylisus nigricans, G. ruthenicus, Viburnum Lantana usw., zwischen denen Aconitum Anthora* Jacquini, A. eulophium, Clematis recla, Phlomis luberosa, Nepela pannonica, Genliana ciliala, Adenophora liliifolia, Chrysanthemum corymbosum, Serratula tinc- 
Ioria, S. lycopifolia wachsen, sowie Steppenwiesen aus Avena pubescens, Koeleria polonica, Poa sterilis, P. polonica, Festuca pseudovina, F. elatior, Bromus erectus mit Dianthus capitalus, Silene Pseudotites, Arenaria graminifolia, Adonis vernalis, Anemone silvestris, Clematis integrifolia, Schiewereckia podolica, Erysimum erysi-

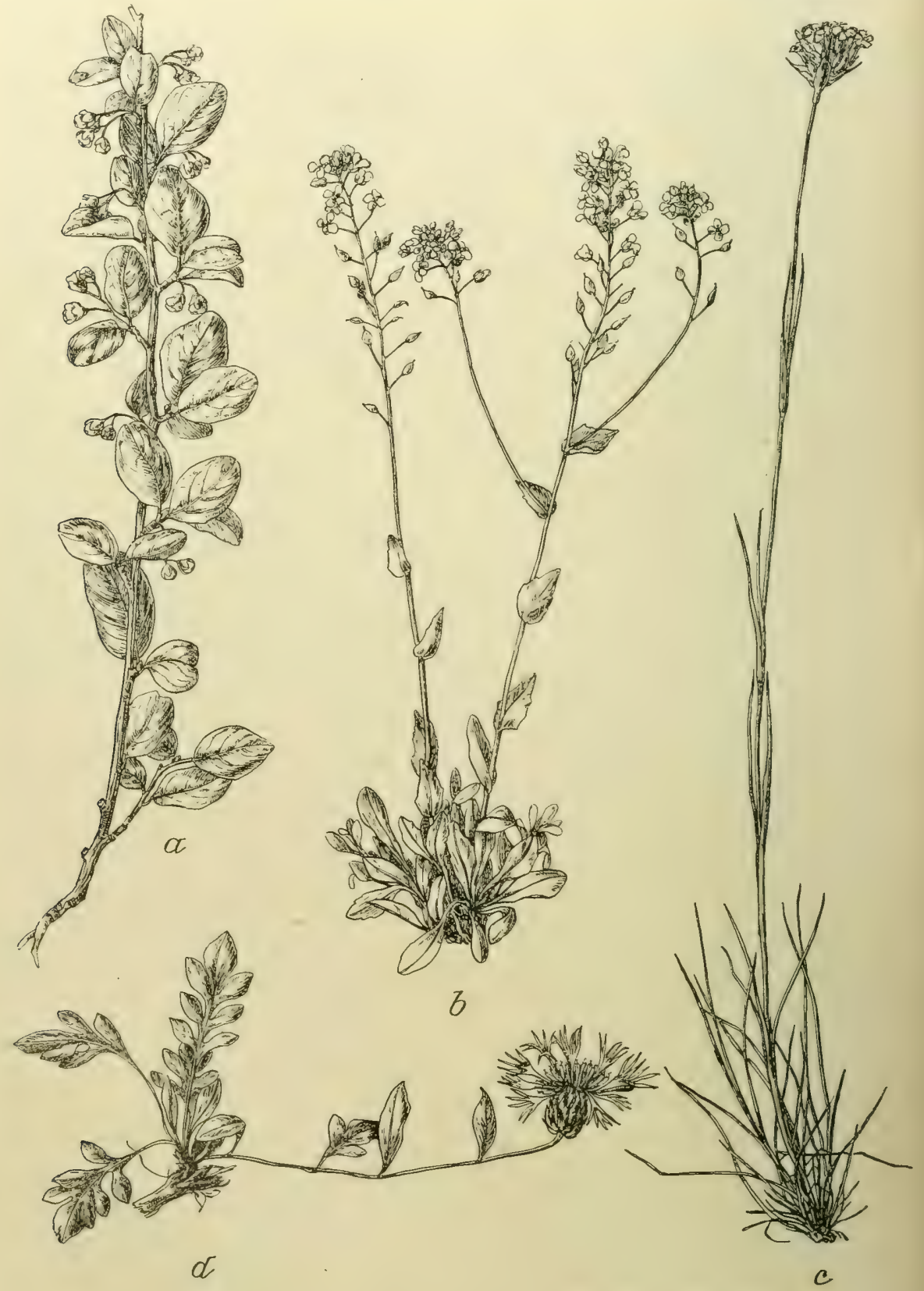

Abb. 155. Steppen- und Felsenpflanzen der Miodobory-Hügel. $a$ Cotoneaster nigra. $b$ Schiewereckia podolica. $c$ Dianthus capitatus. $d$ Centaurea Marschalliana. 


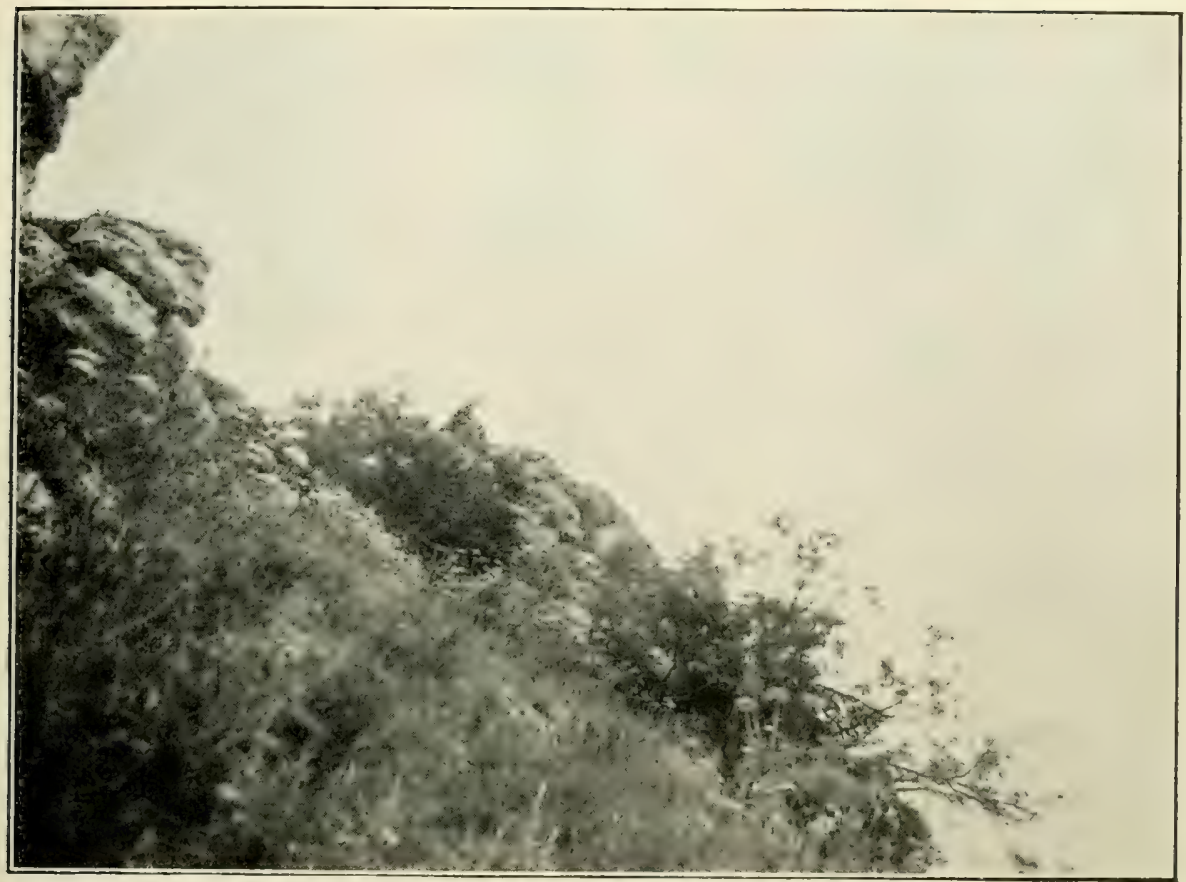

Abb. 156. Die Ostra Skatska bei Okno im Mydobory-Hügelzuge.

Schievereckia podolica, Rhamnus cathartica, Libanotis montana. (Nach einer Aufnahme von Dr. W. Szafer, Lemberg.)

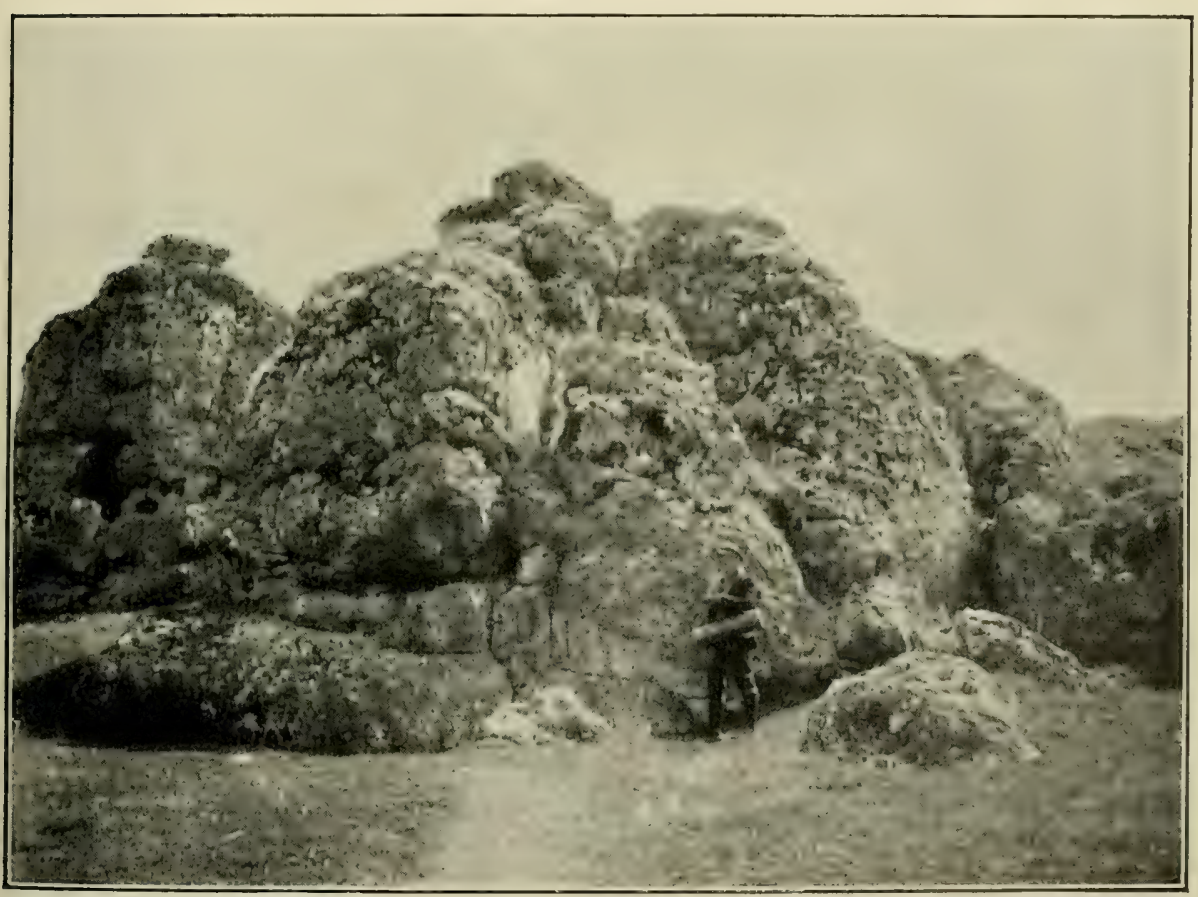

Abb. 157. Der Monasterz-Felsen im Miodobory-Hügelzuge.

Alyssum Arduini, Allium podolicum, Sempervivum globiferum, Asplenium trichomanes usw. (Nach einer Aufnahme von Dr. W. Szafer, Lemberg.) 

moides, Euphorbia tristis, E. Gerardiana, Linum flavum, Cylisus ruthenicus, C. leucanthus, Salvia nulans, Echium rubrum, Verbascum phoeniceum, Veronica Jacquini, Linaria genistifolia, Pedicularis campestris, Asyneuma canescens, Campanula sibirica, Centaurea rhenana, Jurinea arachnoidea, Hieracium virosum in schönster Entwicklung; auch Felsenpflanzen, wie Asplenium trichomanes, A. Rula muraria, Allium podolicum, Alyssum Arduini, Sempervivum globiferum, sind an den eigenartig geformten Kalk- und Gipsfelsen in großer Zahl anzutreffen.

Auch südlich der Miodoboryhügel herrscht vom Tale der Zlota lipa ostwärts, soweił nicht Kulturen sie verdrängt haben, die Steppenflora. So findet man zwischen Buczacz und Monosterzyska u. a. schon Rumex con- Buczacz. ferlus, Clematis recta, Aclaea Gimicifugia, Helleborus purpurascens, Ranunculus Steveni, Agrimonia odorata, Laserpitium prulhenicum, Bupleurum falcatum, Ferulago silvalica, Stachys germanica, Thymus Marschallianus, Asperula glauca, Campanula bononiensis, Chrysanthemum corymbosum, Artemisia austriaca, Cirsium pannonicum, G. spathulatum, Echinops commulatus und Crepis sibirica.

Südlich und westlich von Buczacz sind auch noch gemischte Laubholzbestände vorhanden, in denen sich noch manche westliche oder karpathische Gebirgspflanze findet, wie Allium ursinum, Polygonatum verticillatum, Dianthus Carthusianorum, Oxalis Acetosella, Pirola rotundifolia, P. secunda, Aruncus silvester, Rubus Idaeus, Waldsteinia geoides, Lunaria rediviva, Symphylum cordalum, Pulmonaria mollissima, Centaurea austriaca und Aposeris foetida, und auch bei Nizniow begleiten den Dnjester dichte Laubholzbestände.

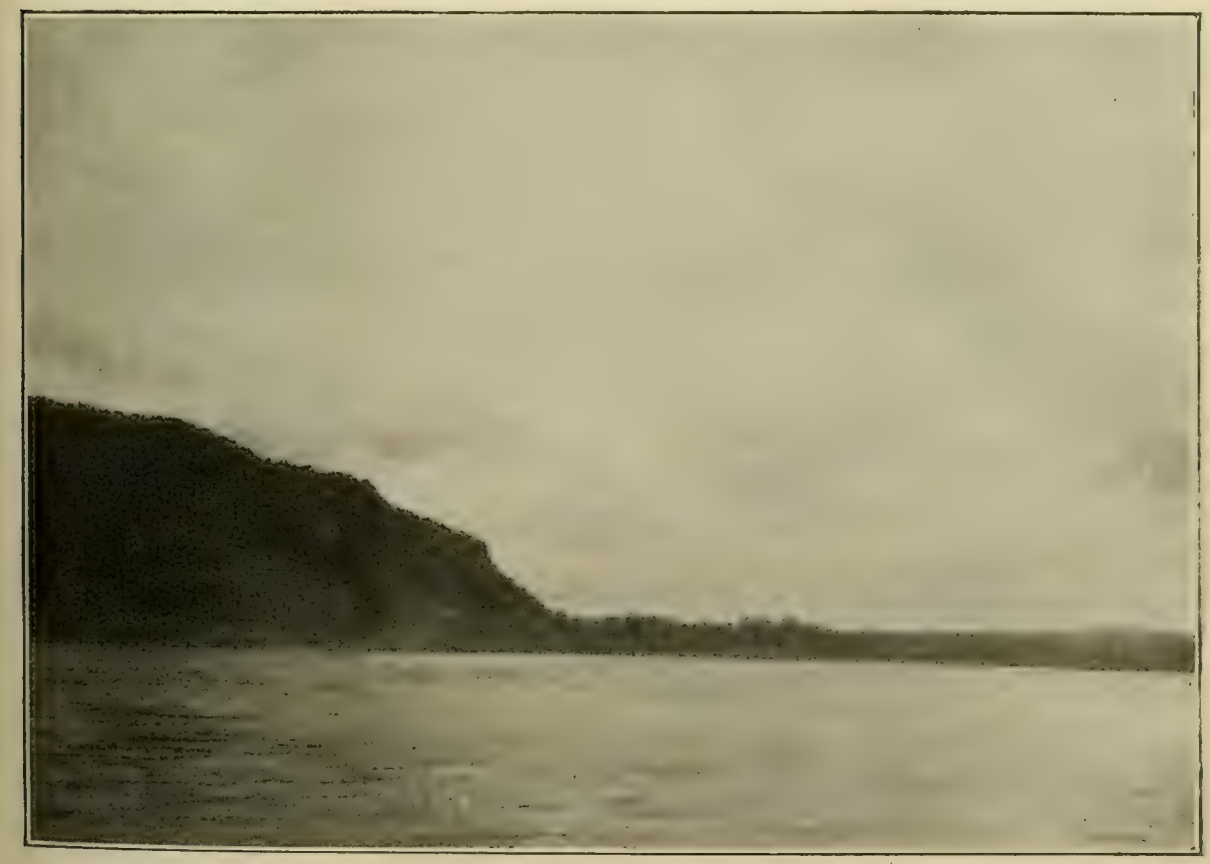

Abb. 158. Buchen- und Laubmischwälder an den Ufern des Dnjester bei Nizniów. (Nach einer Aufnahme von Dr. W Szafer, Lemberg.)

Hayek Die Pflanzendecke Österreich-Ungarns, I. 
Östlich vom Strypaflusse findet man keine Wälder mehr, sondern ausczortkow, schließlich blumenreiche Triften und Steppen, wie bei Gzortkow, wo Silene chlorantha, Dianthus pseudoserotinus, Aconitum Anthora *coeruleum, Adonis vernalis, Helleborus purpurascens, Ononis hircina, Linum flavum, Dictamnus albus, Phlomis tuberosa, Anchusa Barellierii, Echium rubrum, Veronica prostrata, V. Jacquinii, Asyneuma canescens, Aster Amellus, A. Linosyris, Inula Helenium, I. ensifolia, Senecio erucifolius, Echinops sphaerocephalus und an felsigen Hängen Prunus fruticosa und Cotoneasler nigra die bezeichnendsten Arten sind. Solche Steppenformationen sind auch weiterhin durch das ganze südöstliche Galizien verbreitet und besonders durch Andropogon Ischaemum, Stipa pennata, Silene Oliles, Dianthus capitalus, Adonis vernalis, Anemone patens, Geranium sanguineum, Linum flavum, Eryngium planum, E. campestre, Bupleurum falcatum, Ferulago silvatica, Heracleum sibiricum, Primula veris, Aiuga Laxmanni, Salvia pratensis, S. nemorosa, S. dumetorum, Slachys germanica, Nepela nuda, Verbascum phoeniceum, Veronica spuria, V. spicala, V. incana, V. Jacquinii, Melampyrum cristalum, Adenophora liliifolia, Asyneuma canescens, Campanula sibirica, Helichrysum arenarium, Artemisia campestris, A. austriaca, A. procera, Inula ensifolia, I. hirta, Echinops sphaerocephalus, E. commulalus, Cenlaurea variegata, Tragopogon dubius Bilcze. usw. charakterisiert, wozu sich auf den Gipsbergen bei Bilcze und Cygan nächst Borszczow noch Avena compressa, Melica altissima, Muscari comosum, Asparagus tenuifolius, Oxylropis pilosa, Astragalus austriacus, Hypericum elegans, Erysimum erysimoides, Bunias orientalis, Salvia nulans, Inula germanica, Crepis rigida und Hieracium virosum gesellen. Nur hie und da, besonders an den Flußufern, ist diese Steppenvegetation durch sumpfige Stellen unterbrochen, an welchen sich bei $\mathrm{O}$ k e $\mathrm{n}$ y n e boło to Marsilea quadrifolia findet.

Besonders reich ist die podolische Flora aber an den steilen Hängen des Zaleszczyki.Dnjesterdurchbruches bei Zaleszczyki sowie des unteren Strypa entwickelt. Sesleria Heufleriana, Festuca valesiaca, Minuartia selacea sind an allen Felsen gemein, die steilen Hänge bedeckt Buschwerk aus Prunus fruticosa und anderen Laubhölzern und dazwischen finden sich allenthalben Allium podolicum, Iris graminea, Silene chlorantha, Dianthus pseudoserotinus, Gypsophila altissima, Clematis integrifolia, Sisymbrium junceum, S. strictissimum, Mercurialis ovata, Euphorbia gracilis, Lalhyrus versicolor, Hypericum elegans, Heracleum sibiricum, Laserpilium latifolium, Verbascum phoeniceum, Pedicutaris campestris, Veronica Jacquinii, Asyneuma canescens, Jurinea arachnoidea, Centaurea Marschalliana und die prächtige gelbe $C$. orientalis, Lacluca saligna usw., während die Steppengräser insbesondere durch Stipa capillala, Hierochloë odorata, Poa pannonica, Alopecurus nigricans und bei Ostapie auch durch Avena desertorum vertreten sind. Wenige Kilometer östlich von Zaleszczyki kommen am Dnjesterufer auch Ephedra dislachia und Prunus nana* Besseriana vor. Ähnliche Steppen und Triften treten auch bei Ostrowce nächst Horodenka auf, wo unter anderem Avena pralensis* slepposa, Avena Besseri, Carex montana, C. Michelii, Hyacinthella Leucophaea, Thaliclrum uncinatum, Adonis vernalis, Lathyrus pisiformis, Oxylropis 


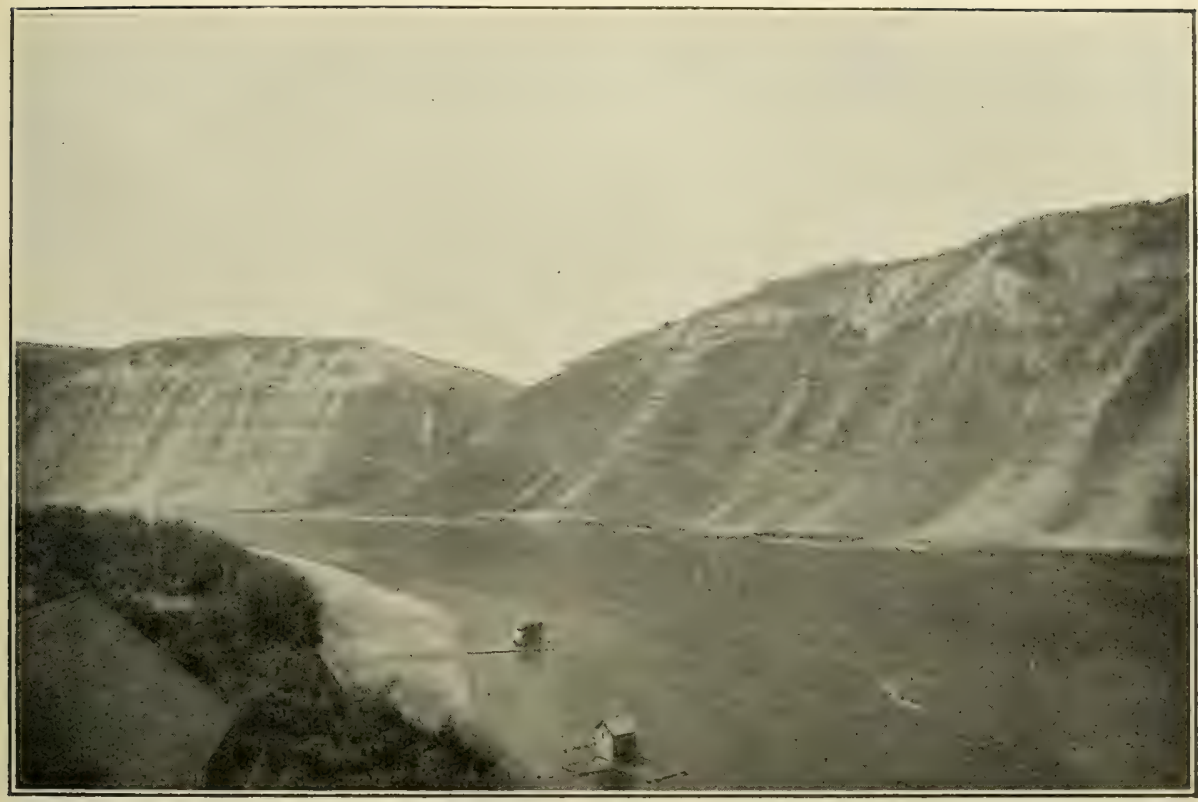

Abb. 159. Das Dnjestertal bei Zaleszczyki.

Zu unterst oberstes Silur, dann rote Schiefer, zu oberst Miozäner Nulliporenkalk (31 $\mathrm{m}$ ) und Gips $(6 \mathrm{~m})$.

An den Steilhängen Steppen- und Felsformationen, am Flußufer Weidengebüsch.

(Nach einer Aufnahme aus der Bildersammlung des geographischen Institutes der Wiener Universität.)

pilosa, Astragalus austriacus und A. Onobrychis wachsen. Südlich des Dnjester nimmt die Steppenflora in Galizien nur mehr einen schmalen Streifen ein. Bei Stanislau treten, wie schon erwähnt, Laubwälder auf, die ganz allmählich in stanisau. die Karpathenwälder übergehen, doch kommen auch noch steppenartige Triften mit Clematis recta, Eryngium planum, Digilalis ambigua, Melampyrum cristalum, Artemisia Absynthium, Xanthium spinosum, Serralula tincloria usw. vor. Reicher ist die Flora an östlichen Elementen bei Obertyn, wo an steinigen Hängen Slipa Ohertyn. pennala, Allium montanum, Arenaria graminifolia, Filipendula hexapetala, Ononis hircina, Cylisus nigricans, Astragalus austriacus, Geranium sanguineum, Linum flavum, Sempervivum globiferum, Veronica spicata, Stachys recta, Salvia nutans, Campanula bononiensis, Laserpitium lalifolium, Aster Amellus und A. Linosyris sich finden, während in den Gipstrichtern unter üppig wuchernder Urtica dioica besonders Geranium pralense, Malva Alcea, Potenlilla hirla, Stachys officinalis, Scabiosa ochroleuca, Nepela nuda und Campanula rapunculoides auftreten. Auch bei Kolomea kommen noch, besonders nördlich des Pruth, wie bei Werziac Kolomen und Okrzesińce, steppenartige Formationen mit Andropogon Ischaemum, Iris pumila, Cytisus ruthenicus, Clematis recta, Lavalera thuringiaca, Hypericum elegans, Veronica spuria, V. prostrala, Salvia nutans, S. nemorosa, Aster Amellus 


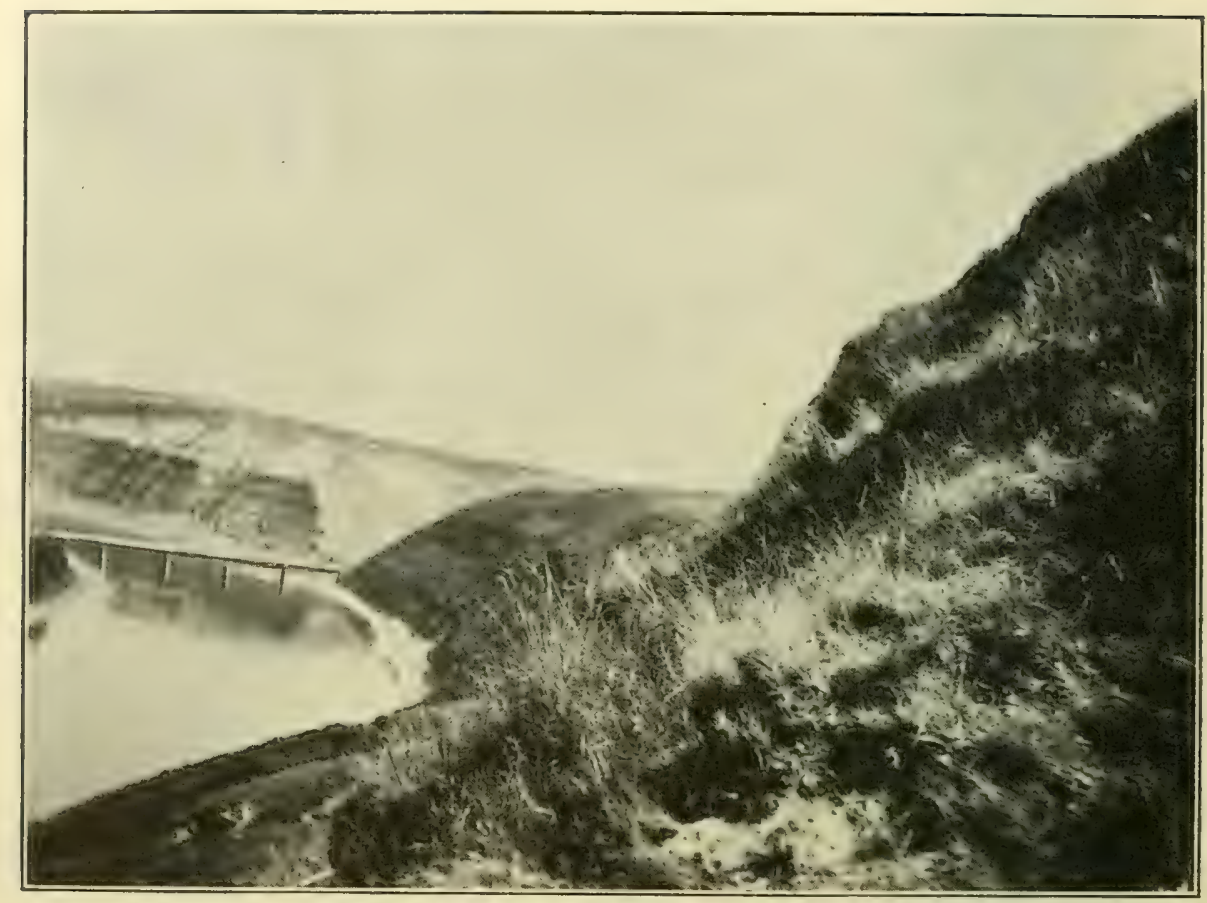

Abb. 160. Stipa-Steppe auf den Gipsfelsen am Dnjester bei Zaleszezyli. Stipa pennata, St. capillata, Poa pannonica, Melica transsilvanica.

(Nach eincr Aufnahme von Dr. K. Rudolph, Prag.)

usw. vor, und an den steilen Ufern des Pruth wachsen Phleum phleoides, Calamagrostis silvalica, Asparagus officinalis, Eryngium planum, Aslragalus Onobrychis, Scabiosa ochroleuca und Inula Helenium. Auf Wiesen um Kolomea kommen Lencoium vernum, Gladiolus imbricatus, Fritillaria Meleagris und Primula elalior vor, hie und da, wie bei Okrzesińce, trifft man auch Hochmoore mit Gicula virosa, Trientalis europaea, Ledum palustre usw. Die Wälder des Gebietes sind teils Buchen-, teils Fichtenwälder, deren Niederwuchs Scilla bifolia, Galanthus nivalis, Lilium Martagon, Anemone Hepalica, Ranuncutus lanuginosus, R. cassubicus, Corydalis cava, C. solida, Cardamine glandulosa, Cerastium silvalicum, Doronicum austriacum usw. aufweist und die ganz allmählich in die Karpathenwälder übergehen. Auch um Sniatyn treten noch schöne Wiesen mit. Dianthus deltoides, D. Carlhusianorum, Geranium pralense, Coronilla varia usw. auf, an den Ufern des Pruth sind Senecio fluvialilis und Lycopus exallatus nicht selten.

In der nördlichsten Bukowina herrscht ebenfalls die Steppenflora. An okna. den steilen Dnjesterufern bei Brodek, Okna und Doroszowe wachsen u. a. Muscari tenuiflorum, Cylisus leucanthus, Euphorbia tristis, Thymus lanuginosus, Galium Schullesii, Inula salicina, I. ensifolia, Centaurea stenolepis, in den Gipstrichtern findet man Dianthus capilatus, Erysimum exallatum, Astragalus 


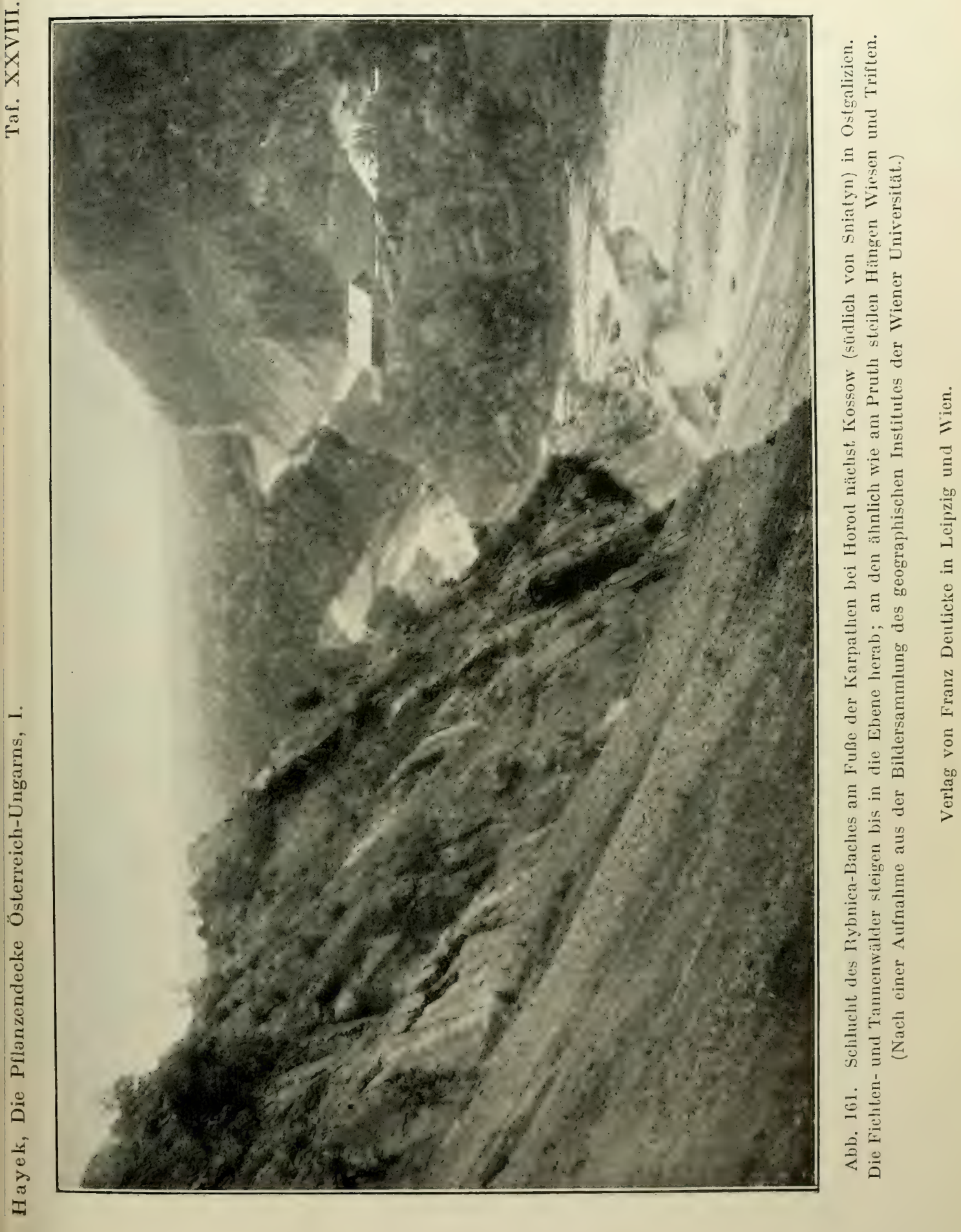





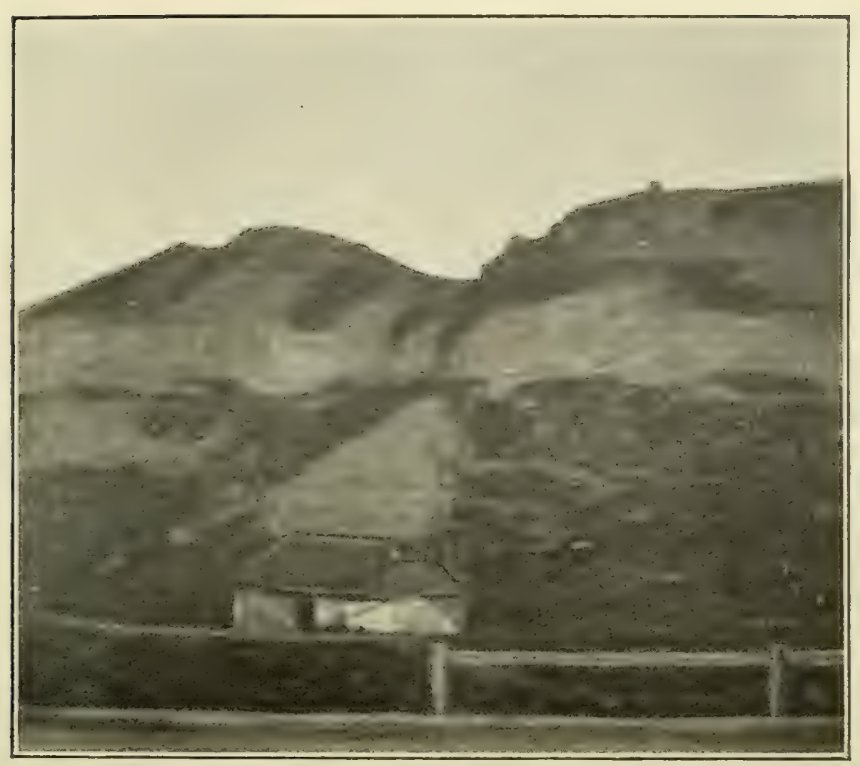

Abb. 162. Mit Steppe bedeckte Felsabhänge (Silur und Devon) bei Zwiniacza in der Bukowina.

(Nach einer Aufnahme von C. Frh. v. Hormuzaki, Czernowitz.)

austriacus, Veronica spuria, Asyneuma canescens, Aster Amellus, Inula germanica, Arctium nemorosum und Hieracium virosum. Auch südlich des Dnjesters sind zum Teil noch Wiesen und Triften erhalten, auf denen neben anderen charak-

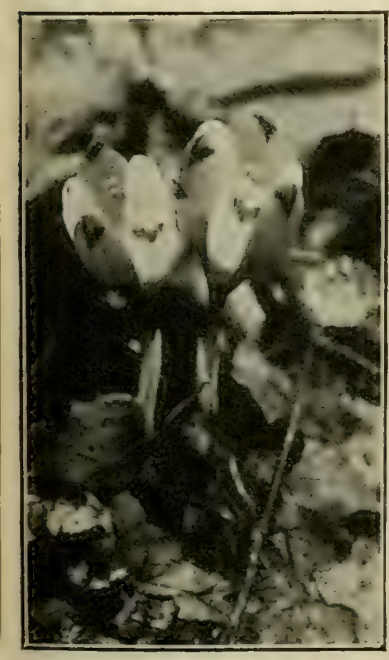

Abb. 163. Crocus Heuffelianus im Buchenwalde auf der Cecina bei Czernowitz. (Nach einer Aufnahme von Dr. Fudolph, Prag.) teristischen Arten auch Alopecurus nigricans, Fritillaria Meleagris, Polygala maior, Linum perenne und (ob noch?) Laserpitium Winkleri vorkommen. Die Buchenwälder der Karpathen reichen bis weit ins Innere des Landes, bis an den Sereth, bis Fontina alba, Volovlet und Gapu Campului; aber auch im übrigen Teile der Bukowina herrschen Waldformationen vor, die stark an die mitteleuropäischen Wälder erinnern. So finden sich auf den Höhen bei Cizernauka nächst Sadagora Buchenwälder mit Czernauka Oxalis Acelosella, Pirola rolundifolia, P. minor, Lycopodium Selago und $L$. complanatum. Im Tale des Pruth treten typische Talwiesen auf, vor allem aber Sumpfwiesen mit Carex vulpina, $C$. riparia, Glyceria fluitans, Phragmites communis, Sparganium ramosum, Iris Pseudacorus, Euphorbia villosa, Sium erectum, Scutellaria hastifolia usw., den Fluß selbst umsäumen Weidengebüsche, untermischt von Populus alba, Evonymus vulgaris usw. Die Wälder der Umgebung von Cizernowitz sind größtenteils Laub-Czernowitz. 


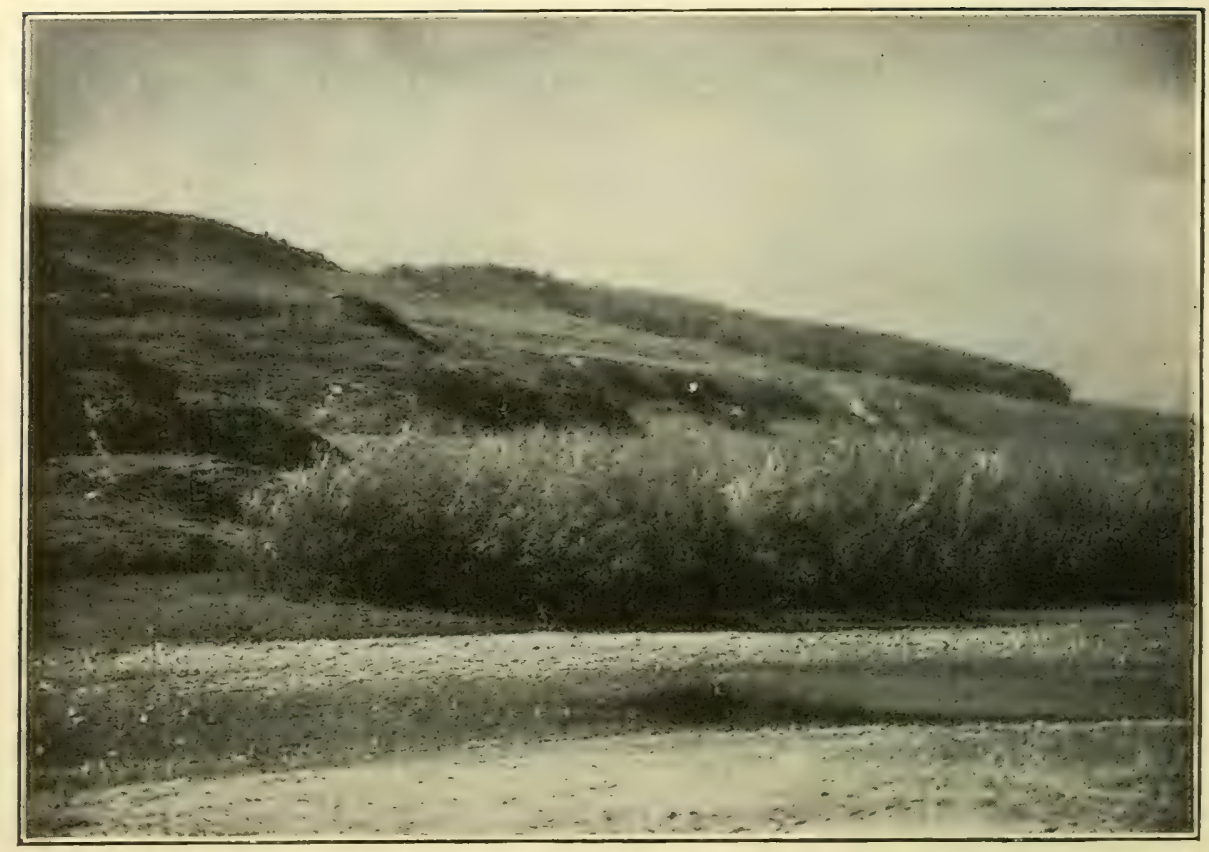

Abb. 164. Das Ufer des Pruth bei Czernowitz.

Im Vordergrund Weidengebüsch, dann Viehweide, im Hintergrund Buchenwald.

(Nach einer Aufnahme von Dr. K. Rudolph, Prag.)

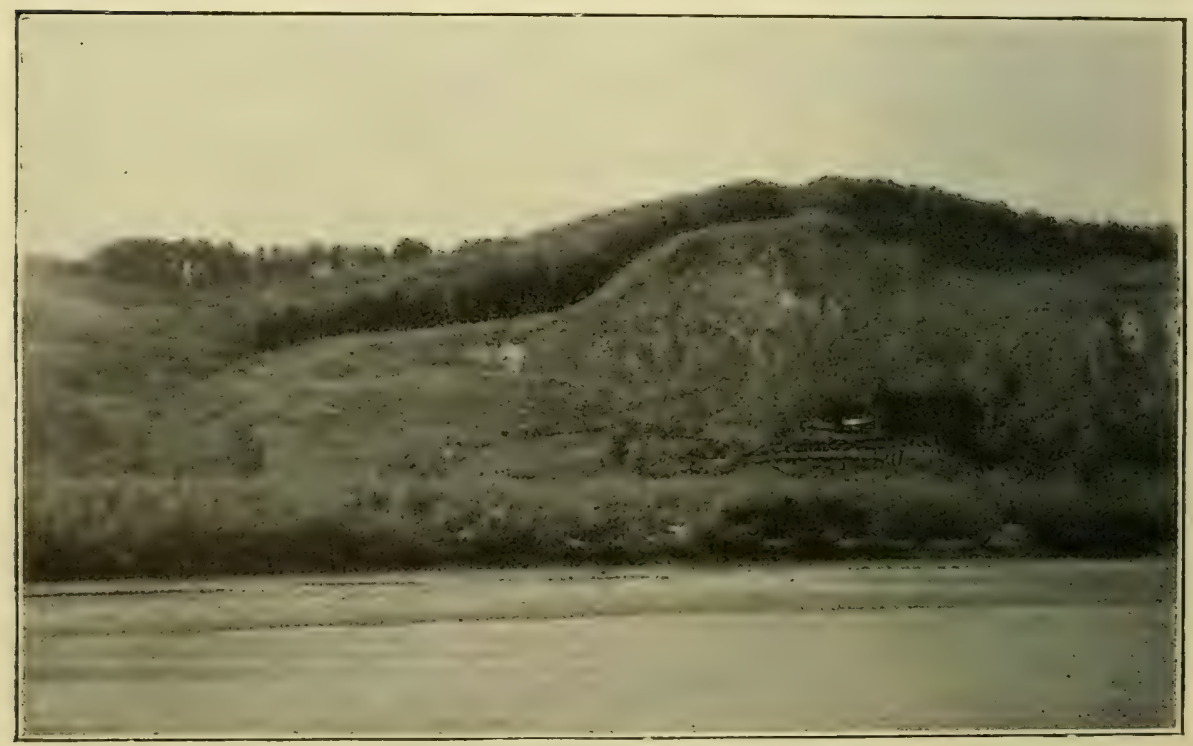

Abb. 165. Laubwälder bei Rewna nächst Czernowitz. Im Vordergrund am Ufer des Pruth Weidengebüsch. (Nach einer Aufnahme von Dr. K. Rudolph, Prag.) 
mischwälder aus Fagus silvatica, Carpinus Betulus, Quercus Robur, Qu. sessiliflora, Acer Pseudoplatanus, A. plalanoides, Ulmus glabra, Belula pendula, Populus tremula, Prunus avium, P. Padus, Tilia platyphyllos, T. cordala. Im Unterholz dieser Wälder finden sich Corylus Avellana, Salix caprea, Acer campestre, Rhamnus Frangula, R. catharlica, Evonymus vulgaris, E. verrucosus, Cornus sanguinea, G. Mas, Sambucus racemosa, S. nigra, Viburnum Opulus usw.; im Niederwuchs sind Gagea lutea, Crocus Heuffelianus, Neollia Nidus avis, Stellaria holostea, Anemone ranunculoides, A. nemorosa, A. Hepatica, Thalictrum aquilegifolium, Corydalis cava, $C$. solida, Cardamine bulbifera, Euphorbia amygdaloides, Oxalis Acelosella, Viola mirabilis, Aruncus silvester, Astrantia maior, Sanicula europaea, Pirola rotundifolia, P. secunda, Myosotis sparsiflora, Omphalodes scorpioides, Salvia glutinosa, Melitlis Melissophyllum, Lamium vulgare, Pulmonaria officinalis, P. mollissima, Asperula odorata, Aposeris foetida häufig. Seltener sind um Gzernowitz reine Eichenwälder mit Anemone silvestris, Lalhyrus niger, Campanula persifolia, Chrysanthemum corybosum usw.

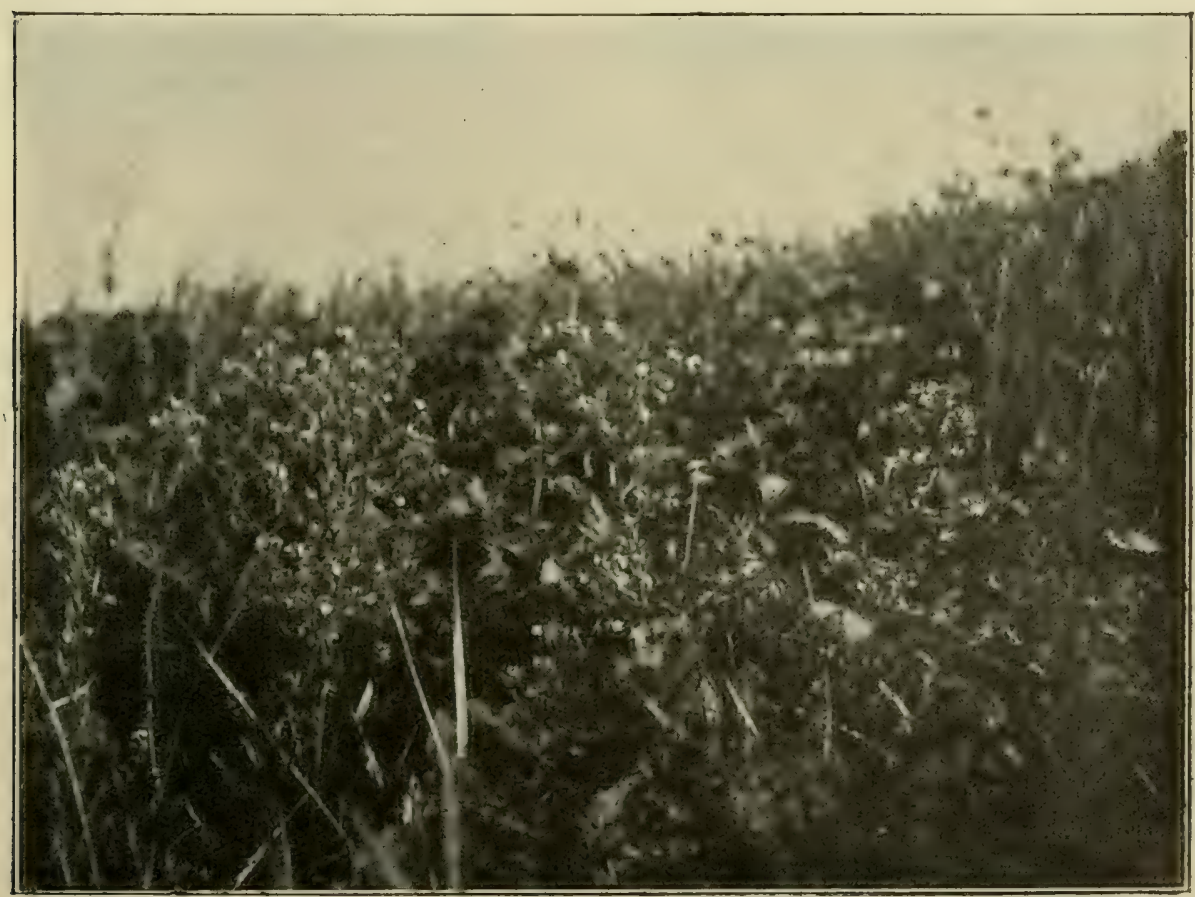

Abb. 166. Trift auf dem Okruh bei Czernowitz.

Anchusa Barellieri und Salvia dumetorum (?)

(Nach einer Aufnahme von Dr. K. Rudolph, Prag.)

Die Höhen des Okruh und der Cecina bedeckt niedriges Buschwerk aus Quercus Robur, Prunus fruticosa, P. spinosa, Acer campestre usw., an den Hängen dieser Hügel und an einigen anderen Stellen in der Umgebung von 
Gzernowitz sind auch Triften entwickelt, deren bezeichnendste Arten Triselum flavescens, Koeleria pyramidala, Phleum phleoides, Stipa pennata (nur auf der Cecina), Carex Michelli, C. montana, Orchis purpurea, Anemone patens, A. Pulsalilla (*polonica?), A. silvestris, Polentilla alba, Anthyllis Vulneraria, Trifolium alpestre, Cylisus leucanthus, C. Heuffelianus, C. Rochelii, Linum flavum, L. austriacum, Anchusa Barellierii, Echium rubrum, Nepeta pannonica, Phlomis tuberosa, I'eronica Jacquinii, Asperula cynanchica, Hypochoeris maculala, Anthemis tinctoria und Chrysanthemum corymbosum sind; auf dem Okruh kommt auch Senecio macrophyllus und merkwürdigerweise die alpine Polentilla Crantzii vor; und bei Zirin und Ostritza findet sich die in Galizien fehlende Anchusa ochroleuca. An den Niederungen des Pruth aber treten Wiesen von ganz mitteleuropäischem Gepräge mit Rumex Acetosa, Euphorbia villosa, E. lucida, Trifolium pratense, Onobrychis viciaefolia, Primula veris, Salvia pratensis, Campanula patula, Cirsium pannonicum, Chrysanthemum Leucanlhemum und ausgedehnte Hutweiden auf. Auch nördlich des Sereth findet man noch Steppen mit Kochia scoparia, Clematis recta, Anemone patens, Gypsophila muralis, Linum flavum, Genista ovata, Cytisus hirsulus, C. leucotrichus, Lathyrus megalanthus, Polentilla alba, Prunus spinosa, Inula Helenium, Anthemis tinctoria, Serratula tinctoria, Centaurea solstilialis, Adenophora liliifolia, Verbascum phlomoides usw., zwischen slobodzia. Slobodzia und Pris acareni auch Eichenwälder mit massenhaftem Sarothamnus scoparius. Nach Süden zu bildet der Sereth auf dieser Strecke eine scharfe Grenze der östlichen Vegetation und an seinem rechten Ufer treten sofort karpathische Tannenwälder mit Gentiana asclepiadea, Telekia speciosa usw. auf. Weiter flußabwärts nehmen die Talebene des Sereth ausgedehnte Sumpfwiesen mit verschiedenen Carex- und Juncus-Arten, mit Iris Pseudacorus, Spiraea salicifolia, Gentiana Pneumonanthe, Veronica longifolia, Achillea Plarmica usw. ein. Jenseits des Sereth sind wieder Eichenwälder vorherrschend, südlich der

Horaica. Stadt Sereth liegt die große Steppeninsel der Horaica, die jetzt zwar fast ganz von Äckern bedeckt ist, aber doch noch stellenweise Reste der ehemaligen Triften mit Carex humilis, Anthericum ramosum, Veratrum nigrum, Iris nudicaulis, Orchis ustulata, Thesium linophyllum, Dianthus capitatus, Anemone patens, A. silvestris, Aconitum lasianthum, Clematis recta, Potentilla patula, Cytisus nigricans, C.albus, Dictamnus albus, Echium rubrum, Senecio campestris, Cirsium pannonicum, Hieracium echioides aufweist. Südlich von der Horaica treten wieder IVälder auf, und zwar meist Bestände aus Carpinus Betulus mit eingestreuten anderen Laubhölzern und mannigfachem Niederwuchs, aus dem Polygonalum multiflorum, Cypripedium Calceolus, Cephalanthera alba, Anemone Hepalica, Ranunculus cassubicus, Isopyrum thalictroides, Cardamine glandulosa, Aruncus silvester, Melampyrum nemorosum, Telelia speciosa hervorzuheben sind, teils besonders an der Reichsgrenze bei Petroutz und Mitoka auch Wälder aus Fagus silvatica. Im äußersten Südosten der Bukowina, bei Suczawa, liegt abermals eine Steppeninsel. Zwar hat auch hier die Kultur die ursprüngliche Vegetation fast ganz vernichtet, doch trifft man hie und da, Suczawa. besonders bei Ipostie und auf der Pojana bei Suczawa, teils Buschgehölze 


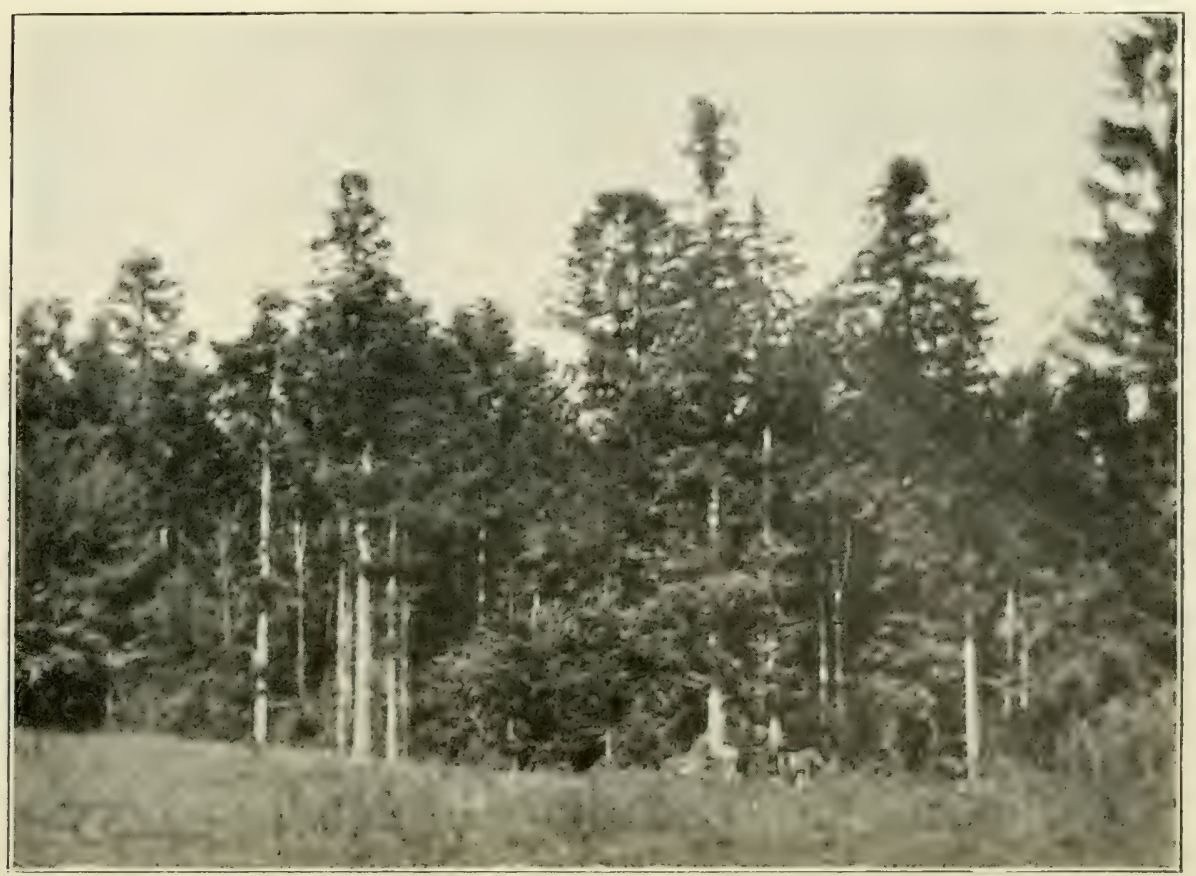

Abb. 167. Tannenwald mit eingesprengten Fichten am rechten Ufer des Sereth bei Pop̧cea in der Bukowina.

(Nach einer Aufnahme von C. Frh. v. Hormuzaki, Czernowitz.)

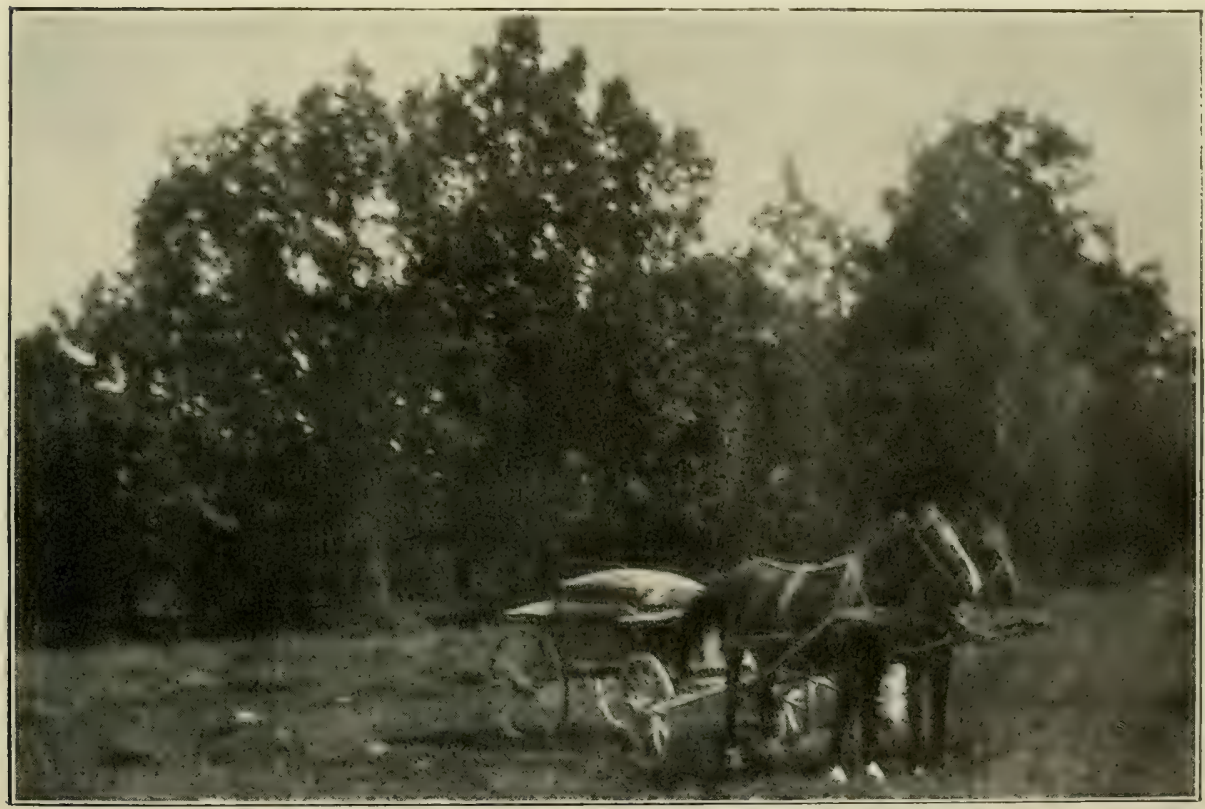

A b. 16S. Eichenwald am linken Ufer des Sereth bei Ropcea in der Bukowina. (Nach einer Aufnahme yon C. Frh. v. Hormuzaki, Czernowitz.) 

aus Tilia cordata, Acer campestre, Prunus fruticosa, Staphylea pinnala, Evonymus vulgaris, Carpinus Belulus usw., teils blumenreiche Triften, auf denen besonders Anthericum ramosum, Muscari tenuiflorum, Iris nudicaulis, Iris ruthenica, Clematis recta, Anemone nigricans, A. silvestris, Sisymbrium strictissimum, Silene dubia, Linum flavum, L. austriacum, Geranium sanguineum, Astragalus Onobrychis, Seseli annuum, Lithospermum purpureocoeruleum, Nonnea pulla, Aiuga Laxmanni, Scabiosa ochroleuca, Inula salicina, Anthemis tinctoria, Senecio macrophyllus, Scorzonera purpurea, Jurinea arachnoidea und die seltene Centaurea Marschalliana bezeichnend sind. 


\section{Verzeichnis der benutzten Literatur.}

Baier A., Zur Flora der Umgebung von Bielitz und Biala. (Österr. bot.. Zeitschr., XXXVII [1887], S. 88.)

Berdau F., Flora Cracoviensis. (Cracoviae, 1859.)

Besser W., Primitiae flora Galiciae Austriacae utriusque. (Viennae, 1809.)

Blocki B., Rošlinność lentina i jesienna okolic Bilcza i Cygan. (Kosmos, Lemberg, V [18s0], S. 222.)

- Korrespondenzen. (Österr. bot. Zeitschr., XXXIII [1883], S. 272, XXXV [1885], S. 107, $144,184,329$, XXXVI [1886], S. 36, XXXVII [1887], S. 369, 406, 442, XXXVIII [1888], S. $70 \mathrm{ff}$, )

- Veronica multifida, eine klimatisch-geographische Rasse von V. austriaca. (Österr. bot. Zeitschr., XXXIII [1883], S. 283.)

- Neue Bürger der Flora von Galizien. (Deutsche bot. Monatsschrift., III, [1885], S. 29.)

- Zur Flora von Galizien. (Österr. bot. Zeitschr., XXXVI [1886], S. 367.)

- Zur Flora von Ostgalizien. (Österr. bot. Zeitschr., XXXVII [1887], S. 17.)

- Ein weiterer Beitrag zur Flora von Ostgalizien. (Österr. bot. Zeitschr., XXXVII [1887], S. 128.)

- Ein Beitrag zur Flora von Galizien und der Bukowina. (Deutsche bot. Monatsschr., XIII. [1895], S. 67.)

- Versuch einer genetischen Erklärung des Charakters der Flora von Lemberg. (Magy. bot. Lapok, VII [1908], S. 281.)

Borowiczka K., Flora miasta Stanislawowa i jego okolicy. (FIora der Stadt Stanislau und deren Umgebung). (Sprawozd. dyrekcyi c. k. wyszéj szkoly realnéj w Stanislawowie za rok 1881.)

Gregorczek A., Flora von Tarnow. (Österr. bot. Wochenbl., III [1853], S. 121.)

Habdank-Hankiewicz., Korrespondenz. (Österr. bot. Zeitschr., XXXIV [1884], S. 379.)

Herbich F., Botanischer Ausflug in die galizisch-karpathischen Alpen des Sandezer Kreises. (Flora XVII [1834], S. 561.)

- Pflanzengeographische Bemerkungen über die Wälder Galiziens. (Verh. d. zool. bot. Ges. Wien, X [1860], Abh., S. 359.)

- Beiträge zur Flora von Galizien. (Ebenda, X [1860], Abh., S. 607.)

- Ein Blick auf die pflanzengeographischen Verhältnisse Galiziens. (Ebenda, XIV [1864], Abli. S. 125.)

- Przyezynek do geografiï roślin w Galicyi. (Rocznik ces. král. towarzystwa naukowego Krakowskiego, XXXIII [1865], S. 70.)

Hormuzaki K., Frh. v., Die Schmetterlinge der Bukowina. (Verh. d. zool. bot. Ges., Wien, XLVII [1897], S. 70, XLIX [1899], S. 32.)

- Nachtrag zur Flora der Bukowina. (Österr. bot. Zeitschr., LXI [1911], S. 59.)

Iryniewiecki B., Wschodnia granica buka w Europie. (Kosmos, XXXVI [1911], S. 225.)

II ückel F., Uber die Flora der Umgebung von Drohobycz. (Verh. d. zool. bot. Ges. Wien, XVI [1866], S. 237.) 
Jablonski V., Roślinność oliolic Ležajska. (Sprawozd. komisy fizyogr. c. k. towazystwa nauk. Krakowskiego, I [1867], S. 206.)

Jachno J., Rośliny zebrane w okolicy Sokolnik w puszczy Sandomierskiéj. (Sprawozd. komisy fizyogr. c. k. towazystwa nauk Krakowieskiego, I [1867], S. 228.)

- Sprawozdanie z naukowéj wycieczki odbytej r. 1867 w polnocnym cyplu Galicyi, od potowy kwietnia do koňca lipca. (Sprawozd. komisy fizyogr. c. k. towazystwa nauk. Krakowieskiego, II [1868], S. 10.)

Janota E.; Dodatek do flory okolic Białéj i Žywca. (Sprawozd. Komisy fizyogr. c. k. nauk tow. Krakowieskiego, VI [1872], S. 27.)

Kloeber E., Wykaz roślin z okolicy Brodów. (Sprawozd. komisy fizyogr. c. k. tow. nauk. Krakow., III [1869], S. 113.)

Knapp J. A., Przyczynek do flory obwodów jasielskiego i sanockiego. (Sprawozd. komisy fizyogr. c. k. tow. nauk. IKrakow., II [1869], S. 74.)

- Die bisher bekannten Plfanzen Galiziens und der Bukowina. (Wien, 1872.)

Knauer B., Die Flora von Suczawa und seiner Umgebung, eine pflanzengeographische Skizze. (Progr. d. k. k. gr. n. un. Obergymn. in Suczawa, 1863.)

Kolbenheyer K., Dodatek do flory okolic Białéj i Žywza. (Sprawozd. komisy fizyogr. c. k. tow. nauk. Krakow., II [1868], S. 15.)

Kotula B., Spis roślin nacznyniowych z okolic górnego Strwiąza i Sanu, z uwzględnieniem pionowego zasiagu gatunkow. (Sprawozd. kom. fizyogr. tow. c. k. Krakow., XVII [1883], S. 105.)

Krupa J., Przyczynek do florystyki roślin naczyniowych. (Sprawozd. kom. fizyogr. tow. Krakow., XVI [1882], S. 205.)

Paczoski J., Skic flory i spis roślin zetranych we wschodniej Galicyi, na Bukowinie i w Komitacie Marmaroskim na Wegrzech. (Sprawozd. kom. fizyogr. tow. Krakow., XXXII [1890], S. 1.)

Procopianu-Procopovic ́,, Zur Flora von Suczawa. (Verh. d. zool. bot. Ges., Wien, XLII [1892], S. 63.)

- Zur Flora der Horaiza. (Ebenda, XLIII [1893], S. 54.)

Raciborski M., Przyczynek do flory roślin naczyniowych wadowickiego i myslenickiego. obwodu. (Sprawozd. kom. fizyogr. c. k. tow. Krakow., XVIII [1854], S. 239.)

- Zapiski floristyezne zebral. (Sprawozd. kom fizyogr. c. k. tow. Krakow., XIX [1885], S. 71).

- Rosliny zebrane przez A. J. Sleńdzińskiego w r. 1880. (Sprawozd, kom fizyogr. c. k. tow. Krakow., XX [1886], S. 1.)

- Azalea pontica im Sandomirer Wald und ihre Parasiten. (Bulletin de l'acad. d. sciences de Cracovie, Class. d. sc. math. et nat. Juillet, 1909, S. 385.)

- Roślinność wód stojących okolicy Łwowa. (Wasservegetation der Umgebung von Lemberg.) (Kosmos, Lemberg, XXXV [1910], S. 44.)

- Rośliny poIskic. (Plantae polonicae.) (Kosmos, XXXV [1910], S. 739, XXXVI [1911], S. 995 .

Rehmann A., Sprawozdanie z wycieczki botanicznéj w zachodnią ezcść Galicyi. (Sprawozd. kom. fizyogr. c. k. tow. Krakow., II [1868], S. 1.)

- O formacyach roślinnych w Galicyi. a) Obwód Zołkiewski. (Sprawozd. kom. fizyogr. c.k.tow. Krakow., IV [1870], S. 186.)

- Botanische Fragmente aus Galizien. (Verh. d. zool. bot. Ges., Wien, XVIII [1868], S.479.)

- Schiewereckia podolica Andrz. in Galizien. (Österr. bot. Zeitschr., XXII [1872], S. 34.)

Rudolph K., Vegetationsskizze der Umgebung von Czernowitz. (Verh. d. zool, bot. Ges. Wien, LXI [1911], S. 64.)

Szteinbock K., Flora okolic Kazimierka nad Wisła. (Sprawozd. kom. fizyogr. c. k. tow. Krakow., XLIV [1901], S. 3.)

Slendzinski A. J., Rośliny dolnego miedzyrzecza Seretu i Zlotéj Lipy, oraz killu miejscowości temu miedzyrzeczu przyległych z wyciecki w roku 1879. (Sprawozd. kom. fizyogr tow. Krakow., XV [1881], S. 91.) 
Szafer W., Geo-botanickiego stosunki Miodoborów galicyiskich. (Rozpr. widzialu math. przyr. Akad. umiet. Krakau, Ser. 3, X, S. 64 [1911]).

- „Pamiątka" pieniacka. (O rezerwacie leśnym w Pieniakach.) (Sylwan, 1912.)

- O niektórych rzadszych roślinach niz̉u galicyjskiego. (Sprawozd. kom. fizyogr. Akad. umiet. Krakau, XLVII, S. 41 [1913.])

Tinyecki L. v., Forstwirtschaft, Jagd und Fischerei in Galizien. (Die österr.-ung. Monarchie in Wort und Bild. Galizien, 1898, S. 819.)

Tokarski T., Botanische Fragmente aus Ost-Galizien. (Sprawozd. kom. dyrekcyi c. z. wyzs. Gimn. w Rzeszowie, 1879.)

Tomaschek A., Zur Flora der Umgebung Lembergs. (Verh. d. zool.-bot. Ges., Wien, IX [1859], S. 43, X [1860], S. 93.)

- Dritter Beitrag zur Flora der Umgebung Lembergs, (Ebenda, XII [1862], S. 63.)

- Vierter Beitrag zur Flora der Umgebung Lembergs. (Ebenda, XII [1862], S. 869.)

Trusz, Przyczynek do flory Galicyi a względnic Buczacza okoli. (Kosmos, Lemberg, IX [1884], S. 13.)

Turczynski E., Przyczynek do flory wschodniej Galicyi i Bukowiny. (Beitrag zur Flora von Ostgalizien und Bukowina.) (Sprawozd. dyrekcyi c. k. realn. gimnas. w Drohobyczu za rok 1877.)

TVajgel L., Flora miasta Kolomyi i jego okolicy. (Sprawozd. dyrekcyi c. k. wizsjego gimn. w Kolomyi za rok 1882.)

Wilczyński T., O paru rzadsych roslinnach potudni owozachodniego Podola. (Sprawozd. kom. fizyogr. c. k. tow. Krakow., XLVI [1913].)

Wodzinska J., W sprawie godnych ochrony zbiorowisk roślinnych. (Über Eichenwald in Mietnow.) (Kosmos, XXXVI [1911], S. 232.)

Woloszczak E., Zur Flora von Jaworow in Galizien. (Verh. d. zool.-bot. Ges., Wien, XXIV [1874], S. 529.)

- Zur Flora von Galizien. (Österr. bot. Zeitschr., XXXVII [1887], S. 178.)

Zipser G., Rosliny stryjskie. (Sprawozd. kom. fizyogr. tow. Krakow., I [1867], S. 224.) 


\section{Die Karpathen.}

\section{A. Der Einfluß der geographischen, klimatischen und Bodenverhältnisse auf die Vegetation der Karpathen.}

In weitem, nach Süden offenem Bogen umsäumt das Ungarische 'Tiefland im Norden und Osten ein mächtiger Gehirgszug, der, im Südosten an der Donau scharf nach Süden umbiegend, sich jenseits dieses Stromes in die Gebirge der Balkanhalbinsel fortsetzt. Es sind die Karpathen, nach den Alpen das mächtigste Gebirge Mitteleuropas, dessen Gipfel sich vielfach über die Grenzen des Baumwuchses erheben und fast in die Region des ewigen Schnees reichen. Höchst mannigfach ist der geologische Bau dieses Gebirges. Außen bildet ein mächtiger Sandsteinzug eine fast ununterbrochene Kette; an der Miava beginnt derselbe mit den Weißen Karpathen, setzt sich dann in die eigentlichen, in der Babiagora $(1725 \mathrm{~m})$ kulminierenden Beskiden fort, die, am Dunajecdurchbruch durch den Kalkstock der Pieninen unterbrochen, östlich des Jablonicapasses in den Waldkarpathen ihre Fortsetzung finden und hier eine Reihe von die Höhe von $2000 \mathrm{~m}$ übersteigenden Gipfeln, wie die Hoverla und Gsernahora, aufweisen. Nach Süden bezichungsweise Westen ziemlich rasch abfallend, lösen sich auf galizischer Seite die Waldkarpathen in ein weit gegen die Ebene ausgreifendes welliges Hügelland auf. Sanft gerundete Kuppen, selbst in den höheren Regionen ohne oder mit nur geringer Felsbildung, wasserreiche Täler und reichbewaldete Hänge bilden sowohl im Westen in den Beskiden als im Osten in den Waldkarpathen den landschaftlichen Gharakter.

Im Quellgebiete der Thei $B$ aber und südlich desselben zeigt der Sandsteinzug eine Unterbrechung durch den mächtigen, aus kristallinischen Schiefern und Gneisen mit eingesprengten Kalklagern aufgebauten Gebirgsstock der Rodnaer Alpen, die im Vrf Pietroszu $2305 \mathrm{~m}$, im Ineu $2280 \mathrm{~m}$ erreichen. Südlich derselben liegt die Trachytkette des Kelemen und erst im Gebiete der Csik-Gyergyoer Alpen wird wieder das Sandsteingebirge vorherrschend, allerdings mehrfach, gleich wie die Rodnaer Alpen, durch Kalkklippen unterbrochen, von denen auf österreichisch-ungarischem Gebiete der Rareu sowie der Sttock des Nagy-Hagymas und Öcsem teteje die wichtigsten sind. Den Ostrand Siebenbürgens bildet wieder ein wenig gegliederter, nirgends $2000 \mathrm{~m}$. Meereshöhe erreichender Sandsteinzug, an den sich aber südlich von Kronstadt an eng das aus einem eigenartigen Kalkkonglomerat gebildete, wild zerrissene Burzenländer Bergland mit dem $2509 m$ hohen Bucsecs und dem $2241 \mathrm{~m}$ 
hohen Königstein anschließt. Von hier an verschwindet die Sandsteinzone der Karpathen fast gänzlich und ist nur in einzelnen Schollen auf rumänischem Boden nachweisbar, die direkte Fortsetzung der Burzenländer Berge gegen Westen bildet die gewaltige Gebirgsmauer der Fogarascher Alpen, des gewaltigsten Zuges der Ostkarpathen, die durchwegs aus Gneis und kristallinischen Schiefern aufgebaut sind und zahlreiche Gipfel von einer Höhe über 2000, ja über $2500 \mathrm{~m}$ aufweisen, wie den Vrfu Urlei (2474 $\mathrm{m}$ ), die Vènatorea $(2598 \mathrm{~m})$ und den höchsten Gipfel Siebenbürgens, den Negoi $(2544 \mathrm{~m})$. Bis zur tiefen, aber weder in geologischer noch in pflanzengeographischer Beziehung bedeutsamen Senkung des Rotenturmpasses behält das Gebirge seinen wilden Hochgebirgscharakter bei und fällt besonders nach Norden zu gegen die Fogarascher Hochebene ziemlich steil ab; westlich des Rotenturmpasses zeigt die Kette sanftere, gerundete Formen und löst sich gegen Norden allmählich in ein niedrigeres Bergland auf, um erst noch weiter im Westen in der Retyezatgruppe $(2427 \mathrm{~m})$ noch einmal jäh aufstrebende steile Hochgipfel und ausgedehnte Hochkare mit einsamen Gebirgsseen zu zeigen. Westlich der Retyezatgruppe aber sinkt die Kammhöhe rasch und in dem sich jäh südwärts wendenden Zuge treten vielfach, besonders um Herkulesbad und an den Steilhängen des Donaudurchbruches, jurassische Kalke im Gneisgebirge auf.

Der enge Bogen, den die Ostkarpathen im Osten bilden, wird durch einen Bergzug von sehr mannigfachem geologischem Aufbau im Westen zu einem völligen Kreise geschlossen, der das jungtertiäre siebenbürgische Hochland umschließt. Das teils aus jungvulkanischen Gesteinen, hauptsächlich aber aus Kreidekalken aufgebaute Siebenbürgische Erzgebirge und das aus kristallinischen Schiefern und Granit bestehende Bihariagebirge sind die wichtigsten Glieder dieser vom Quellengebiete der Theiß bis ans Marostal reichen den Verbindungskette.

Während also im Westen und auch noch im mittleren Teile der Karpathen der Sandsteinzug einen gewaltigen Bogen bildet, tritt derselbe im Südosten ganz zurück und der zentrale Gneis tritt hier an seine Stelle. Aber auch im Westen fehlen die kristallinen Schiefer und der Granit nicht. An der Südseite der Sandsteinzone, mit den größtenteils aus Granit bestehenden Kleinen Karpathen beginnend, erheben sich hier zahlreiche mächtige Gebirgsketten, teils aus kristallinen Massengesteinen und Schiefern gebildet, wie die Niedere und die Hohe Tatra, welch letztere auf relativ beschränktem Raume die höchsten Erhebungen in den Karpathen überhaupt (Gerlsdorfer Spitze $2634 \mathrm{~m}$ ) aufweist, teils aus Kalken hauptsächlich triassischen Alters aufgebaut, wie das Galgoczgebirge, der Klein-Krivan, die Fatra, die Belaer Kalkalpen usw. Am Innenrande dieser kristallinen Zone aber treten vielfach jungvulkanische Gesteine auf, wie besonders im Ungarischen Erzgebirge und, weit nach Süden vorgeschoben, im Bükkgebirge und der Matra sowie endlich im Neograder Gebirge. Dieser vulkanische Zug läßt sich auch weiter nach Osten verfolgen. Vom Vihorlat bis zum Guttin erhebt sich eine ganze Kette solcher Trachytberge und ihre Fortsetzung finden dieselben in dem gewaltigen Bergzug der Hargita, der sich an der Innen-(West-) Seite der Cziker Alpen erhebt. 
In einem Gebirge von so gewaltiger Längenausdehnung, so bedeutenden Höhenunterschieden und so wechselndem geologischem Aufbaue, der hier nur in den allergröbsten Zügen skizziert werden konnte, muß naturgemäß auch die Vegetation viel mannigfacher sein als auf den relativ einförmigen böhmischen Randgebirgen, da nicht nur die Änderungen der klimatischen Verhältnisse mit zunehmender Meereshöhe, sondern auch die wechselnde geologische Unterlage, die Beziehungen zu den Floren der benachbarten Gebirge und Ebenen und endlich der Unterschied im Klima an der Außen- und Innenseite des selbst eine Klimascheide bildenden Gebirges eine Rolle spielen.

Wie in jedem Gebirge, ändern sich auch in den Karpathen mit zunehmender Meereshöhe die Temperatur- und Niederschlagsverhältnisse, wie nachfolgende Tabellen zeigen.

Mittelwerte der Temperatur.

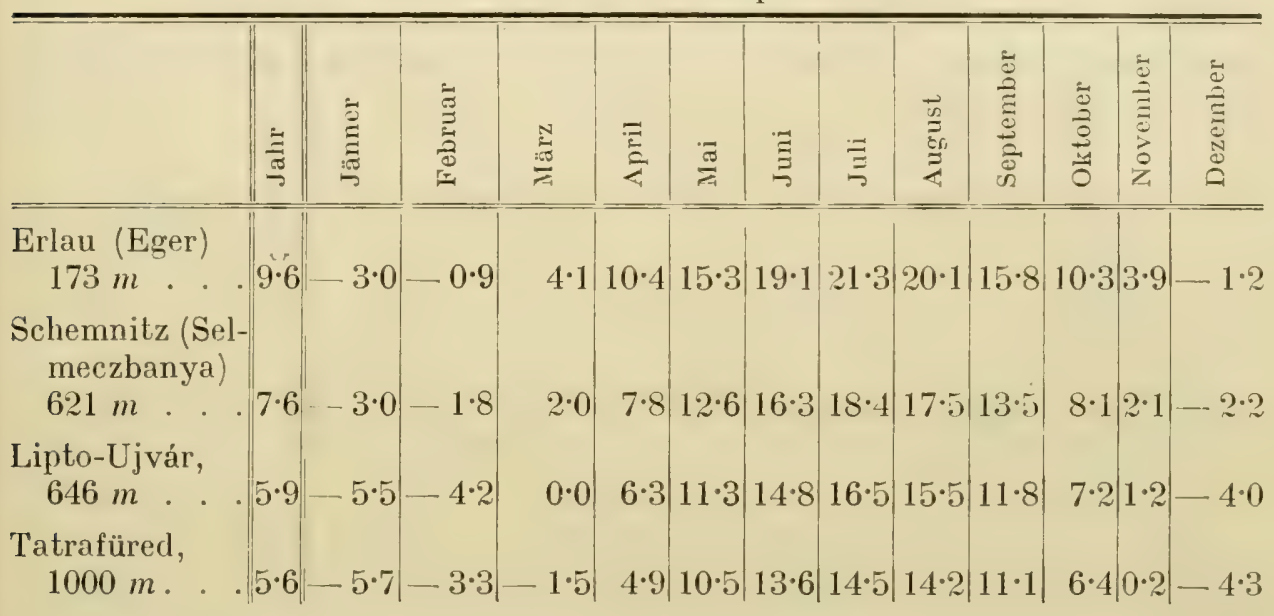

Mittelwerte der Niederschläge in Millimetern.

\begin{tabular}{ll||c|c|c|c|c|c|c|c|c|c|c|c|c}
\hline \hline & \\
\hline
\end{tabular}

Das sind die Daten für vier möglichst auf gleicher geographischer Länge liegende Orte der Westkarpathen. Die Tabellen zeigen vor allem eine beträchtliche Temperaturabnahme bei zunehmender Meereshöhe, wobei der großc Unterschied zwischen dem gegen Süden offenen Schemnitz und dem zwischen zwei hohen Bergketten gelegenen, fast gleich hohen Lipto-Ujvár besonders auffällt. Ferner ist die bedeutend größere Regenmenge in den höheren Gebirgs- 
lagen gegenüber dem am Rande der Ebene gelegenen Erlau sehr in die Augen fallend. Nichtsdestoweniger sind die Daten nur wenig gecignet, einen Einblick der kTimatischen auf die Vegetationsverhältnisse zu gewähren. Wie in allen Gebirgen, so sind auch in den Karpathen in höheren Lagen die Wälder hauptsüchlich infolge der größeren Niederschlagsmengen üppiger entwickelt, aber auch am Fuße des Gebirges am Rande der Ebene sind die Niederschläge noch recht ausgiebig (fast $600 \mathrm{~mm}$ im Jahre), so daß auch hier noch Baumwuchs möglich ist. Von einer ausgesprochenen Hitze- oder Dürreperiode im Sommer kann aber auch hier noch kaum die Rede sein. Über die klimatischen Verhältnisse in den Regionen über $1000 \mathrm{~m}$ aber liegen keinerlei meteorologische Daten vor.

Für die Ostkarpathen sind insbesondere cine Anzahl Daten aus der Marmaros gut zu verwerten.

Mittelwerte der Temperatur.

$=0$

Huszt, $168 m . \cdot 8 \cdot 8 \mid-4 \cdot 8-2 \cdot 7$

Bustyaháza, $200 \mathrm{~m}$. . . $8 \cdot 7-4 \cdot 8-2 \cdot 7$

Dombó, $383 \mathrm{~m} \cdot 8 \cdot 0-4 \cdot 0-2 \cdot 0$

Akna-Sugatag, $490 \mathrm{~m}$. . . $8 \cdot 2-3 \cdot 7-1.9$

\begin{tabular}{ll|l|l|l|l|l|l|l}
$3 \cdot 2$ & $10 \cdot 0$ & $15 \cdot 0$ & $18 \cdot 1$ & $20 \cdot 1$ & $19 \cdot 1$ & $15 \cdot 0$ & $10 \cdot 2$
\end{tabular} $3 \cdot 2-2 \cdot 6$

Körömezö, 652 $m 6 \cdot 0 \cdot 6 \cdot 0-3 \cdot 9$

\begin{tabular}{lllll|l|l|l}
$2 \cdot 7$ & $10 \cdot 1$ & $15 \cdot 2$ & $18 \cdot 5$ & $20 \cdot 3$ & $19 \cdot 2$ & $15 \cdot 0$ & $9 \cdot 9$
\end{tabular} $3 \cdot 0-2 \cdot 5$ \begin{tabular}{llll|l|l|l|l|l|l|l}
$2 \cdot 3$ & $8 \cdot 8$ & $13 \cdot 9$ & $17 \cdot 0$ & $18 \cdot 7$ & $17 \cdot 8$ & $13 \cdot 9$ & $9 \cdot 0$ & $0 \cdot 8$ & $-2 \cdot 1$
\end{tabular}

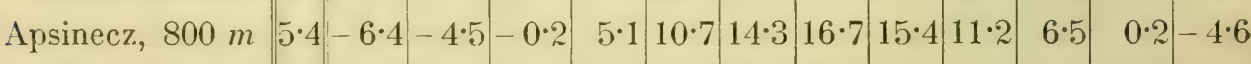
Turbat, $1140 m \cdot|3 \cdot 2|=8 \cdot 2|-6 \cdot 2|-2 \cdot 8|2 \cdot 7| 8 \cdot 4|12 \cdot 0| 14 \cdot 4|13 \cdot 3| 9 \cdot 3|4 \cdot 7|-1 \cdot 6 \mid-6 \cdot 4$

Mittelwerte der Niederschläge in Millimetern.

\begin{tabular}{|c|c|c|c|c|c|c|c|c|c|c|c|c|c|c|}
\hline & & 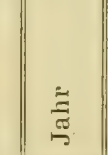 & 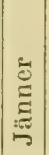 & 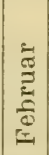 & $\stackrel{N}{z}$ & $\frac{\bar{\Xi}}{\bar{\Omega}}$ & E & $\underset{\Xi}{\Xi}$ & 急 & 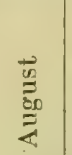 & 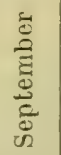 & $\frac{\dot{0}}{\frac{0}{0}}$ & 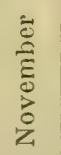 & 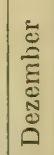 \\
\hline Huszt, $168 \mathrm{~m}$. . . & & 1071 & 73 & 62 & 83 & 68 & 85 & 134 & 101 & 87 & 71 & 120 & & 92 \\
\hline Bustyaháza, 200 m & & 904 & & 49 & 64 & 55 & 79 & 116 & 98 & 89 & 63 & 95 & & 68 \\
\hline Dombó, $383 \mathrm{~m}$. & & 1313 & 77 & 75 & 101 & 78 & 107 & 164 & 138 & 119 & 94 & 150 & 117 & 93 \\
\hline Akna-Sugatág, $490 \mathrm{~m}$ & & 753 & & 33 & 52 & 45 & 81 & 116 & 95 & 74 & 54 & 76 & 47 & 43 \\
\hline Körömezö, $652 \mathrm{~m}$ & & 1002 & 33 & 41 & 56 & 59 & 103 & 149 & 129 & 123 & 78 & 112 & & 55 \\
\hline Apsinecz, $800 \mathrm{~m}$ & & 863 & & 26 & 48 & 50 & 95 & 132 & 122 & 112 & 68 & 95 & & 39 \\
\hline Turbat, $1140 \mathrm{~m}$... & & 1266 & 53 & 53 & & & 127 & 178 & $|141|$ & 141 & 101 & 154 & & 74 \\
\hline
\end{tabular}


Die Temperaturabnahme mit zunehmender Meereshöhe ist hier deutlich erkennbar, keineswegs aber die Zunahme der Niederschläge, die mehr von der Nähe des Gebirges als von der absoluten Höhenlage des betreffenden Ortes abhängt. So liegen Bustyaháza und Akna-Sugatág am Rande des Gebirges beziehungsweise im weiten gegen die Ebene offenen Tal. Die geringe Regenmenge des ganz im Gebirge Jiegenden Apsinecz allerdings ist durch die Lage nicht erklärbar. Hingegen lassen alle höher gelegenen Orte eine Zunahme des Regens in den Sommermonaten gegenüber den Wintermonaten erkennen.

Über die klimatischen Verhältnisse in den höheren Regionen über $1100 \mathrm{~m}$ liegen keine Beobachtungen vor, so daß der Einfluß des Klimas auf die Vegetation sich unserer Beurteilung entzieht. Dnch zeigen die Karpathen in dieser Bezichung gewiß analoge Terhältnisse wie die übrigen mitteleuropäischen Gebirge, besonders die Alpen, wie ja auch rlie Vegetationsverhältnisse ebenfalls analoge Verhältnisse zeigen. Um ein beträchtliches höhrr als in den böhmischen Grenzgebirgen liegt in den Karpathen die Waldgrenze. Während im Böhmerwalde diese bei $1400 \mathrm{~m}$, im Riesengebirge bei $1300 \mathrm{~m}$ liegt, findet der Wald eine obere Grenze:

Auf der Babiagora (Beskiden) bei. . . . . . $1330 \mathrm{~m}$
In der Hohen Tatra bei . . . . . . . . . . . . . . $1510 \mathrm{~m}$
Auf dem Nagy-Hagymas bei . . $1850 \mathrm{~m}$

Nur im Gebiete der Waldkarpathen scheint die Waldgrenze auf $1200 \mathrm{~m}$ zu fallen, dies rührt aber daher, daß hier die Fichte vielfach in den höheren Lagen fehlt und die Buche überhaupt stets viel weniger hoch hinaufreicht als diese. Sehr beträchtliche Flächen sind es demnach, die in den Karpathen über die Grenze des Baumwuchses sich erheben. Ein 200-300 m breiter Strauchgürtel, in den Westkarpathen fast nur aus der Krummholzkiefer, in den Ostkarpathen neben dieser aus der Grünerle gebildet, schließt sich an den Waldgürtel an und darüber herrscht dann die Grasflur der Hochgebirgsregion. Daß diese nicht in geschlossenem Bestande bis auf die höchsten Gipfel reicht, daran ist aber wohl lediglich die Kionfiguration des Bodens, rie einer gleichmäßigen Humusbedeckung nicht günstig ist, schuld und nicht die Ungunst der klimatischen Verhältnisse. Denn dort, wo auch die höheren Gipfel flache, gerundetere Formen zeigen, wie in den Rodnaer Alpen und den Fogarascher Alpen, z. B. auf dem Szuru, bedeckt auch die höchsten Kuppen noch ein geschlossener Rasen. Die Hochgipfel der Tatra überragen zwar die für dieses Gebiet auf $2300 \mathrm{~m}$ berechnete Schneegrenze um 200 - $300 \mathrm{~m}$, doch kommt es hier wegen der steilen Bergspitzen nirgends zu Gletscherbildung und diese Steilheit der Hänge ist auch schuld daran, daß hier sich nirgends eine zusammenhängende Humusdecke, die Grundbedingung einer geschlossenen Vegetation, bilden kann; allerdings muß zugegeben werden, daß, nach den analogen Verhältnissen in den Alpen zu schließen, auch bei entsprechender. Konfiguration des Bodens hier etwa in der Höhe der höchsten Gipfel auch der geschlossene Pflanzenwuchs eine obere Grenze finden würde.

Hayek, Die Pflanzendecke Österreich-Ungarns, I. 
Was die Zusammensetzung der Hochgebirgsflora betrifft, so weicht diese in den Westkarpathen von der der Alpen nur wenig ab. Die Hohe Tatra weist nur sehr wenige Arten (z. B. Salix Lapponum, Delphinium oxysepalum, Saxifraga

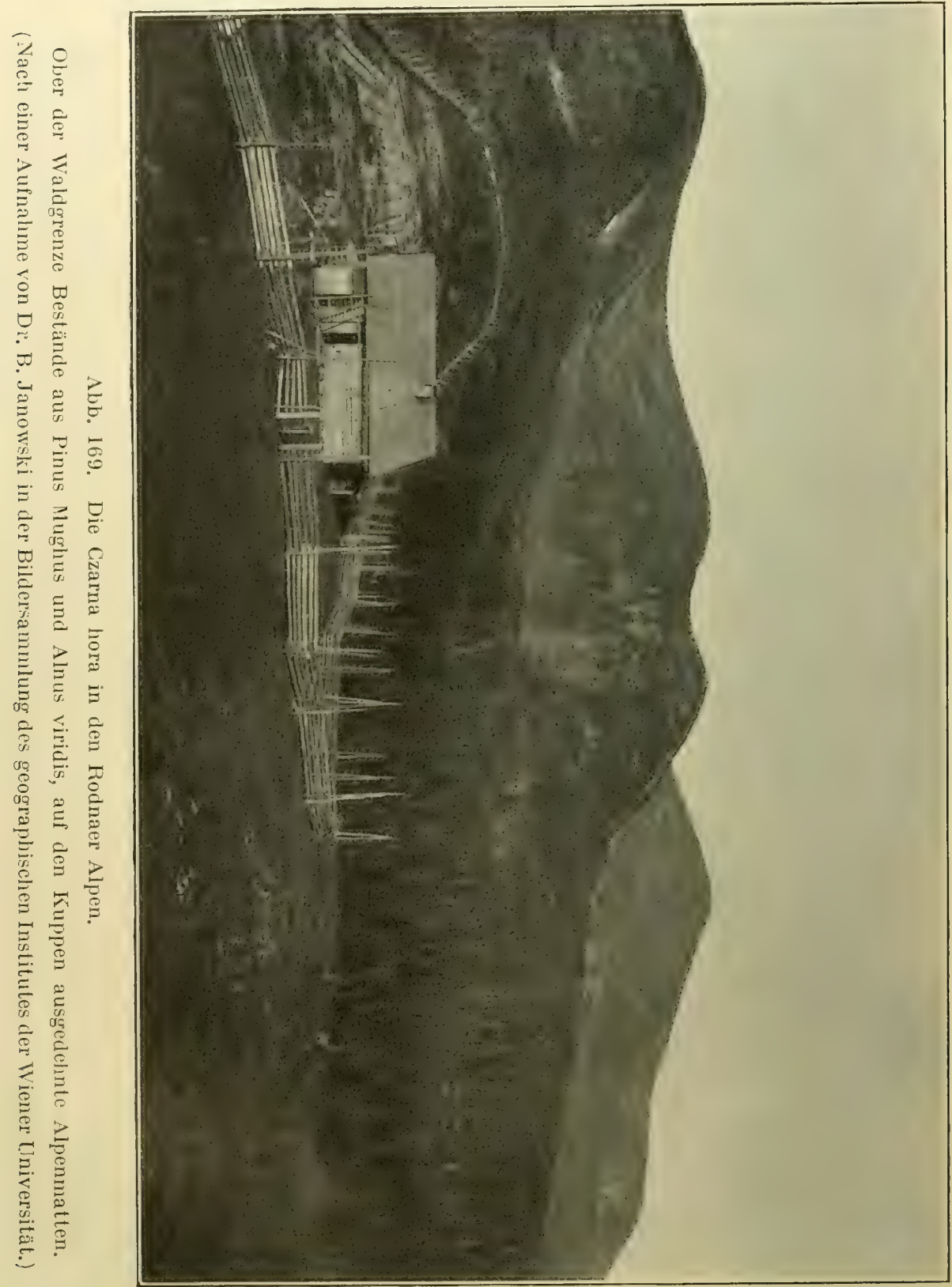

carpalica. S. perdurans, Leontodon clavalus) auf, die den Alpen ganz fehlen, wenn auch einige Gharakterpflanzen derselben, wie Ranunculus pygmaeus, Arabis neglecla, Cochleria excelsa, Saxifraga Wulfeniana, Gentiana frigida in den Alpen 
eine sehr beschränkte Verbreitung besitzen. Doch ist die Flora der Alpen weit reicher und das Fehlen der rotblühenden Primeln aus der Sektion Auriculastrum, der meisten Pedicularis- und Gentiana-Arten ist, in der Tatra sehr in die Augen fallend. Geringer sind die Beziehungen zur Hochgebirgsflora der Surleten. Wenn auch aus der alpinen Flora des Riesengebirges wohl nur Saxifraga nivalis der Tatra fehlt, so ist es doch auffallend, daß die den Sudeten zunächst gelegenen Hochbeskiden eine von jener stark abweichende Hochgebirgsflora aufweisen. Mehr Gemeinsames weist die Flora der Waldregion in beiden Gebirgen auf. Anders liegen die Verhältnisse in den Ostkarpathen, von den Waldkarpathen ostwärts. Weniger das Fehlen von Carex firma, Saxifraga caesia, Satureia alpina und anderer alpiner Typen ist es, das den abweichenden Charakter der Flora bedingt, als das Auftreten neuer, oft sehr charakteristischer Formen, als deren augenfälligste hier Sesleria coerulans, Alopecurus laguriformis, Silene nivalis, Dianthus gelidus, Ranunculus crenalus, Alyssum repens, Saxifraga luleoviridis, Bupleurum diversifolium, Rhododendron myrlifolium, Soldanella pusilla, Satureia Baumgartenii, Veronica Baumgartenii, Planlago gentianoides, Phyleuma confusum, Achillea Schurii, Anthemis carpatica, Doronicum carpalicum genannt seien, deren Auftreten der Flora einen eigenartigen fremden Gharakter verleiht. Teils sind es endemische Arten der Ostkarpathen, teils Typen, die sie mit den Gebirgen der nördlichen Balkanhalbinsel gemein haben und von denen einige von den Südostkarpathen über jene bis in die Alpen zu verfolgen sind, wie z. B. Ranunculus crenalus, Soldanella pusilla und Phyteuma confusum.

Was hier von der Flora der Hochgebirgsregion gesagt wurde, gilt auch im wesentlichen für die der oberen Waldregion. In den Westkarpathen sind besonders im südwestlichen Teile derselben noch zahlreiche Arten der Alpen zu Hause, von denen manche, wie Cardamine enneaphyllos, Primula vulgaris und Cyclamen europaeum schon die Tatra nicht mehr erreichen; den Alpen fremde Typen sind neben einigen Formen von Federnelken insbesondere Cardamine glandulosa, Campanula carpalica, Aclaea Cimicifugia und die erst in den Südalpen heimische Hacquetia Epipactis. Den Alpen fehlen ferner Sali:s silesiaca und Crepis sibirica, zwei Typen, die den Sudeten und Karpathen gemeinsam sind, auch zahlreiche der Sudetenhierazien treten im Karpathengebiete wieder auf, die den Alpen entweder fehlen oder daselbst zu den größten Seltenheiten gehören. In den Ostkarpathen macht sich aber auch in der Waldregion gegenüber dem Wester und den Alpen ein bedeutender Unterschied geltend. Zahlreiche Charakterpflanzen der Buchen- und Nadelwaldregion der Ostkarpathen, die auch den Westkarpathen entweder ganz fehlen oder nur vereinzelt daselbst auftreten, fehlen den Alpen ganz, so Ranunculus carpaticus, Helleborus purpurascens, Anemone transsilvanica, Laserpilium alpinum, Symphylum cordatum, Pulmonaria rubra, oder lassen sich von den Ostkarpathen über die Gebirge der Balkanhalbinsel mit Umgehung der Westkarpathen bis ins Gebiet der Ostalpen verfolgen, wie Scopolia carniolica, Cirsium pauciflorum, Scorzonera rosea, Hieracium transsilvanicum und vielleicht auch Telekia specinsa, deren Indigenat im Alpengebiete nicht üher alle Zweifel erhahen scheint. 
Dieselben Unterschiede, die sich in der oberen Waldregion geltend machen, zeigen sich auch in der Waldflora am Fuße des Gebirges, wenn auch einige der ¿stlichen Typen sich bis in die südlichen Vorlagen der Westkarpathen, die Matra und das Bükkgebirge, verfolgen lassen. In der untersten Region macht sich aber noch ein sehr bedeutender Unterschied bemerkbar in der Flora am Außenund am Innenrande des Gebirges, der neben entwicklungsgeschichtlichen Gründen auch in den verschiedenen klimatischen Verhältnissen seine Erklärung findet. Im nachfolgenden sind die Temperatur- und Niederschlagsverhältnisse einiger Orte am AuBen-(Nord-) und Innen- (Südrand) der West- und Waldliarpathen gegeben.

a) Nordrand. Mittelwerte der Temperatur.

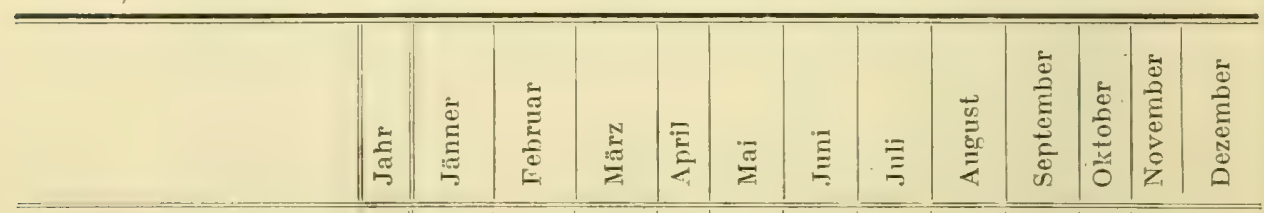

Bielitz, $343 m \quad . .|7 \cdot 6|-2 \cdot 5|-1 \cdot 6| 1 \cdot 8|7 \cdot 2| 12 \cdot 2|15 \cdot 9| 17 \cdot 6|17 \cdot 2| 13 \cdot 5|8 \cdot 9| 2 \cdot 7 \mid-1 \cdot 7$ Wadowice, $267 m$. . $8 \cdot 2-3 \cdot 1-2 \cdot 0|2 \cdot 58 \cdot 6| 14 \cdot 1|18 \cdot 0| 20 \cdot 2.19 \cdot 7|15 \cdot 1| 9 \cdot 7|2 \cdot 4|-2 \cdot 1$ Zakopane, $840 m$. . $|5 \cdot 0|-5 \cdot 9-5 \cdot 1-1 \cdot 4|4 \cdot 7| 10 \cdot 1|14 \cdot 1| 16 \cdot 0|15 \cdot 0| 11 \cdot 36 \cdot 30 \cdot 3-4 \cdot 5$ Szczawnica, $480 m \quad .6 \cdot 5|-5 \cdot 1|-3 \cdot 9|0 \cdot 56 \cdot 8| 12 \cdot 1|15 \cdot 5| 17 \cdot 0|16 \cdot 4| 13 \cdot 0|8 \cdot 3| 1 \cdot 4 \mid-3 \cdot 7$

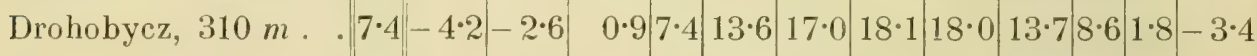

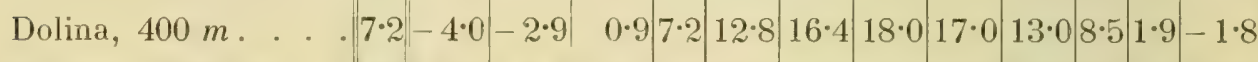

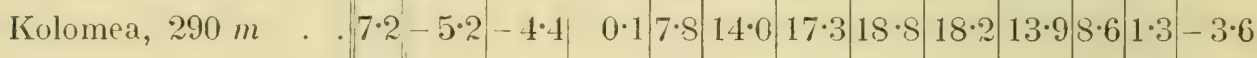
Czernowitz, $225 \mathrm{~m} . \cdot|7 \cdot 9|-5 \cdot 1|-4 \cdot 0| \quad 1 \cdot 0|8 \cdot 6| 14 \cdot 7|18 \cdot 3| 20 \cdot 1|19 \cdot 4| 14 \cdot 8|9 \cdot 0| 1 \cdot 5 \mid-3 \cdot 5$ b) Südrand.

\begin{tabular}{|c|c|c|c|c|c|c|c|c|c|c|c|c|c|}
\hline & 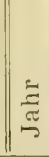 & 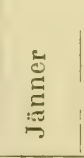 & 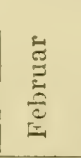 & $\stackrel{N}{=}$ & $\overline{\bar{E}}$ & $\ddot{E}$ & $\stackrel{\Xi}{\Xi}$ & 豆 & $\frac{\overrightarrow{w D}}{\sum_{\bar{E}}}$ & 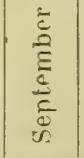 & $\frac{5}{\frac{5}{0}}$ & 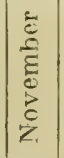 & 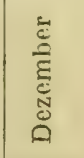 \\
\hline $\begin{array}{c}\text { Preßburg (Pozsony), } \\
153 \mathrm{~m}\end{array}$ & $9 \cdot 5$ & $-1 \cdot 8$ & $0 \cdot 3$ & $4 \cdot 5$ & $10 \cdot 4$ & $15 \cdot 0$ & $18 \cdot 9$ & $21 \cdot 0$ & $20 \cdot 1$ & $16 \cdot 2$ & $10 \cdot 5$ & $4 \cdot 2$ & -0.4 \\
\hline $\begin{array}{l}\text { Neutra (Nyitra), } \\
190 \mathrm{~m} \text {..... }\end{array}$ & & $-2 \cdot 2$ & $-0 \cdot 2$ & $4 \cdot 4$ & $10 \cdot 8$ & $15 \cdot 5$ & $19 \cdot 0$ & $21 \cdot 1$ & $20 \cdot 2$ & $16 \cdot 1$ & $10 \cdot 8$ & $4 \cdot 5$ & -0.8 \\
\hline $\begin{array}{c}\text { Neusohl (Besztercze- } \\
\text { banya), } 371 \mathrm{~m} .\end{array}$ & & $-3 \cdot 8$ & $-1 \cdot 9$ & $2 \cdot 8$ & $9 \cdot 1$ & $4 \cdot 1$ & $17 \cdot 7$ & $19 \cdot 3$ & $18 \cdot 5$ & $14 \cdot 5$ & $9 \cdot 1$ & $2 \cdot 8$ & $-2 \cdot 2$ \\
\hline $\begin{array}{c}\text { Schemnitz (Selmecz- } \\
\text { banya), } 621 \mathrm{~m} .\end{array}$ & & $-3 \cdot 0$ & $-1 \cdot 8$ & $2 \cdot 0$ & $7 \cdot 8$ & $12 \cdot 6$ & $16 \cdot 3$ & $18 \cdot 4$ & $17 \cdot 5$ & $13 \cdot 5$ & $8 \cdot 1$ & $2 \cdot 1$ & $-2 \cdot 2$ \\
\hline Eperies, $246 \mathrm{~m}$... & & $-3 \cdot 5$ & $-1 \cdot 9$ & $2 \cdot 8$ & $9 \cdot 1$ & $14 \cdot 2$ & $17 \cdot 8$ & $19 \cdot 7$ & $18 \cdot 8$ & $14 \cdot 6$ & $9 \cdot 5$ & $3 \cdot 2$ & $-1 \cdot 8$ \\
\hline Erlau (Eger), $173 \mathrm{~m}$ & $9 \cdot 6$ & $-3 \cdot 0$ & $-0 \cdot 9$ & $4 \cdot 1$ & $10 \cdot 1$ & $15 \cdot 3$ & $19 \cdot 1$ & $\because 1 \cdot 3$ & $20 \cdot 1$ & $15 \cdot 8$ & $10 \cdot 3$ & $3 \cdot 9$ & $-1 \cdot 2$ \\
\hline Ungvár, $128 \mathrm{~m}$. . & $9 \cdot 1$ & $-3 \cdot 0$ & $-1 \cdot-1$ & $3 \cdot 7$ & $10 \cdot 2$ & $15 \cdot 0$ & $18 \cdot 1$ & $20 \cdot 0$ & $19 \cdot 0$ & $15 \cdot 0$ & $10 \cdot 2$ & $3 \cdot 9$ & $-1 \cdot 3$ \\
\hline Nagybanya, 227 m & & 0 & $-1 \cdot 2$ & & $10 \cdot 0$ & $14 \cdot 8$ & $\mid 17 \cdot 8$ & $|20 \cdot 0|$ & $|19 \cdot 2|$ & $15 \cdot 0$ & $|10 \cdot 2|$ & $|3 \cdot 7|$ & $-1 \cdot 1$ \\
\hline
\end{tabular}


Mittelwerte der Niederschläge in Millimetern.

a) Nordrand.

\begin{tabular}{l|r|r|r|r|r|r|r|r|r|r|r|r|r}
\hline \hline & \\
\hline
\end{tabular}

b) Südrand.

\begin{tabular}{|c|c|c|c|c|c|c|c|c|c|c|c|c|c|}
\hline & $\stackrel{\Xi}{\Xi}$ & 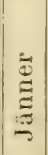 & 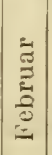 & $\stackrel{N}{=}$ & $\bar{\vdots}$ & $\ddot{\tilde{z}}$ & $\stackrel{\Xi}{\Xi}$ & $引$ & 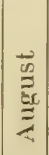 & 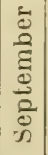 & $\frac{\frac{\mathscr{D}}{0}}{\frac{\partial}{0}}$ & 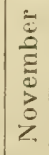 & $\begin{array}{c}\tilde{D} \\
\tilde{D} \\
\tilde{D} \\
\tilde{D} \\
\tilde{D} \\
\tilde{U}\end{array}$ \\
\hline Preßburg (Poszony), $153 \mathrm{~m}$. . & 699 & 43 & 37 & 54 & 62 & 74 & 71 & 69 & 63 & 52 & & 54 & 5 \\
\hline Neutra (Nyitra), $190 \mathrm{~m}$. . . . & 597 & 29 & 29 & 39 & 50 & 72 & 72 & 62 & 56 & 46 & 62 & 44 & 44 \\
\hline Neusohl (Beszterzebanya), $371 \mathrm{~m}$ & 899 & 56 & 49 & 67 & 72 & 90 & 86 & 84 & 68 & 75 & 99 & 80 & 77 \\
\hline Schemnitz (Selmeczbanya), $621 \mathrm{~m}$ & 909 & 54 & 58 & $6 ?$ & 74 & 97 & 96 & 81 & 73 & 72 & & 74 & 74 \\
\hline Eperies, $246 \mathrm{~m} \quad \ldots . .$. & 642 & 27 & 23 & 30 & 51 & 69 & 93 & 94 & 77 & 57 & & 32 & 34 \\
\hline Erlau (Eger), $173 \mathrm{~m}$. . . . & 599 & 28 & 24 & 35 & 56 & 68 & 74 & 70 & 56 & 46 & 62 & 42 & 38 \\
\hline Ungvár, $128 \mathrm{~m}$. . . . & 775 & 44 & 38 & 44 & 52 & 73 & 102 & 86 & 73 & 57 & & 63 & 59 \\
\hline Nagybanya, $227 \mathrm{~m}$. . . . . & 1031 & 63 & 64 & 76 & 66 & 102 & 132 & 106 & 82 & 7 & 101 & 79 & 85 \\
\hline
\end{tabular}

Überall, mit Ausnahme des Ostens (Czernowitz, Ungvár, Nägybanya), zeigt es sich, daß am Nordrande die Sommer kühler und relativ niederschlagsreicher sind als am Südrande, auch bei ungefähr gleicher Höhenlage (vgl. die Zahlen für Bielitz und Szczawnica einerseits, für Neusohl und Schemnitz anderscits), wenn auch die Differenzen in den Gesamtniederschlägen und selbst in der jährlichen Durchschnittstemperatur nicht sehr erhebliche sind. Diese Differenzen machen sich aber noch in viel höherem Grade durch den Umstand geltend, daß der Südrand um rund 100-200 m tiefer liegt als der Nordrand. Diese Unterschiede im Klima aber bedingen auch bedeutende Verschiedenheiten in der Vegetation. Am Nordrande reichen die Nadelwälder des Gebirges bis 
weit ins vorgelagerte Hügelland hinaus, die Ausbildung von Mooren, selbst von Hochmooren, ist keine Seltenheit und typisch xerophile Formationen fehlen fast ganz. Anders am Südrande. Hier findet der Gebirgsnadelwald bald eine untere Grenze, an seine Stelle treten sommergrüne Laubhölzer, ja selbst Buschgehölze, und an trockeneren sonnigen Hängen machen sich Triftformationen, ja selbst xerophile Steppenformationen breit, die aus dem benachbarten Tieflande leicht einwandern konnten; von der Ausbildung hygrophiler Formationen, besonders von Hochmooren, ist lkeine Rede. Selbst mitten im Gebirge haben solche Änderungen in den Niederschlagsverhältnissen eine Änderung des Florencharakters zur Folge. Késmark, am Südostfuße der Hohen Tatra in $623 \mathrm{~m}$ Meereshöhe gelegen, weist eine von den übrigen in der Nähe gelegenen Orten um rund $200 \mathrm{~mm}$ geringere jährliche Niederschlagssumme auf $(652 \mathrm{~mm}$ gegen $895 \mathrm{~mm}$ in Árvaváralya, $825 \mathrm{~mm}$ in Tatrafüred, $748 \mathrm{~mm}$ in Dobsina), mit einem Maximum im Mai von nur $127 \mathrm{~mm}$ und tatsächlich trifft man hier unmittelbar am Fuße der Hohen Tatra schon Triftformationen, die gegenüber denen an den Südhängen gegen die Ebene zu liaum Verschiedenheiten zeigen.

Anders liegen die Verhältnisse im Nordosten, hier macht sich an den Nordosthängen schon der Einfluß des podolischen Steppengebietes geltend und auf eine weite Strecke hin bildet, wie schon im vorigen Abschnitt erwähnt, der Sereth eine scharfe Grenze für den Gebirgsnadelwald, während anderseits das Gebiet am Oberlaufe der Theiß eines der regenreichsten Gebiete der Tiefebene darstellt.

Im nördlichen Teile des zentralen Siebenbürgens liegt ein großes Gebiet, die Mezöseg, die des ursprünglichen Baumwuchses ganz entbehrt und mit üppigen Wiesen und Triften, seltener mit Steppen bedeckt ist, und auch die Ebenen von Fogaras und des Burzenlandes dürften ursprüngliches Grasland darstellen. Wenn natürlich auch regenärmer als die umgebenden Gebirge, weist dieses Gebiet doch keineswegs so geringe Niederschlagsmengen auf, daß dieser Umstand allein uns das Fehlen eines Baumwuchses und das Auftreten von Grasfluren erklären würde. Freilich liegen meteorologische Daten nur von den Grenzen dieses Steppengebietes vor, doch dürften die Differenzen gegen das Innere desselben nicht so gewaltige sein, als man dies auf Grund der Vegetationsverhältnisse voraussetzen könnte. Es weisen als mittlere Regenmengen auf:

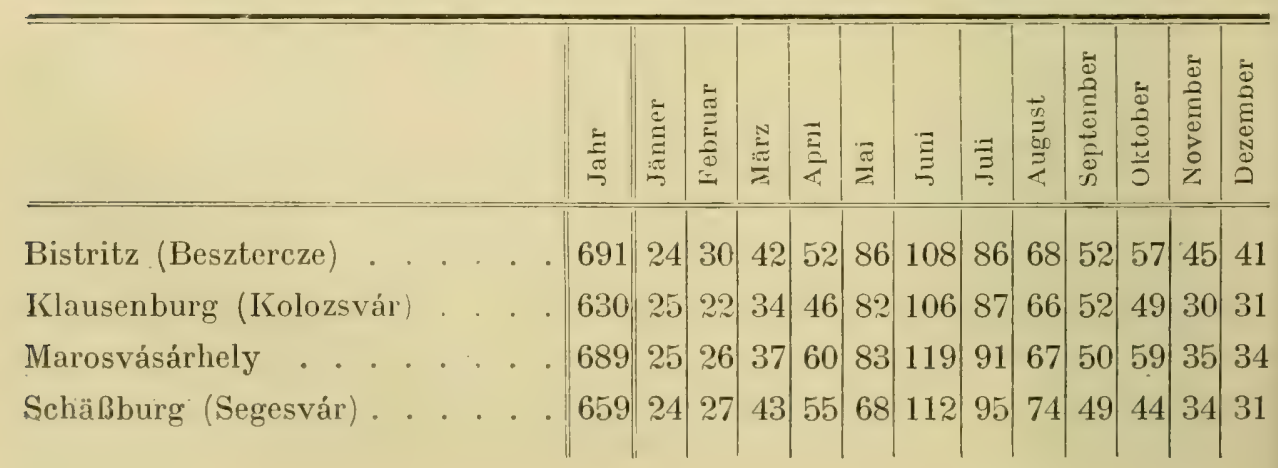


Die Regenmenge sinkt also nirgends unter $60 \mathrm{~cm}$ im Jahre und kann, da in Mitteleuropa selbst Gebiete mit unter $50 \mathrm{~cm}$ Niederschlag im Jahre noch Baumwuchs und selbst Wälder aufweisen, nicht die Ursache des Baummangels sein. Weit eher mag diese zu suchen sein in der Verteilung der Niederschläge; langdauernde Regengüsse sind hier selten, unr wenn in den umgebenden Gebirgen Regenwetter herrscht, so fallen auf der Hochebene meist nur wiederholte, aber kurz dauernde Regen, die zwar die oberflächlichen Bodenschichten genügend durchfeuchten, aber nicht genügen, um in tieferen Bodenschichten einen hinreichenden Wasservorrat sich ansammeln zu lassen. Auch die Lufttrockenheit mag eine Rolle spielen. Jedenfalls liegen hier die Verhältnisse ähnlich wie in der großen Ungarischen Tiefebene, von der ein großer T'eil ebenfalls des ursprünglichen Baumwuchses entbehrt, obwohl auch dort die jährliche Niederschlagsmenge nicht unbedeutend ist. Bezüglich ihrer floristischen Zusammensetzung stimmen diese zentralsiebenbürgischen Grasfluren viel mehr mit denen Ostgaliziens und der Bukowina als mit denen der großen Lngarischen Tiefebene überein.

Einen abweichenden Florencharakter weist endlich der südöstlichste Teil der Karpathen, das Banater Bergland, auf, der sich besonders in den Hügelregion geltend macht, indem hier eine große Zahl südlicher und südöstlicher Typen, die im ganzen übrigen Zuge der Karpathen fehlen, vorkommen. Die Niederschlagsverhältnisse weisen in diesem Gebiete nichts Auffallendes auf (Orsova hat $890 \mathrm{~mm}$ Niederschlag), hingegen sincl die Temperaturen hier höher als irgendwo in den Karpathen. Der Jahresdurehschnitt beträgt in Orsova $10 \cdot 8^{0}$, in Dravicza gar $11 \cdot 2^{0}$, das Julimaximum $22 \cdot 4^{0}$ beziehungsweise $22 \cdot 7^{\circ}$, während im ganzen übrigen Karpathengebiet diese Zahlen $10^{\circ}$ beziehungsweise $21^{\circ}$ kaum übersteigen oder meistens gar nicht erreichen. Aber auch im Winter ist der Unterschied nicht unbedeutend, da in beiden Orten nur im Jänner die Durchschnittstemperatur unter dem Gefrierpunkte bleibt.

Schon eingangs (S. 18) ist erwähnt worden, daß der Einfluß der chemischen Zusammensetzung des Bodens auf die Vegetation sich in der Hochgebirgsregion in viel höherem Maße geltend macht als in tieferen Lagen. Dies hat auch für die Karpathen volle Geltung, da auch hier, besonders in der Region ober der Waldgrenze, weniger ausgeprägt auch in der Waldregion, die Flora, je nachdem die Bodenunterlage aus kalkreichem oder kalkfreiem Gesteine besteht, einen ganz verschiedenen Charakter aufweist. So sind in den Westkarpathen von verbreiteten Arten Carex firma, C. atrata, C. capillaris, Ranunculus Thora, Saxifraga caesia, Gypsophila repens, Astragalus oroboides, A. australis, Linum extraaxillare, Bupleurum ranunculoides, Veronica aphylla, V. fruticans, in der Waldregion Minuarlia laricifolia, Dianlhus hungaricus, Kernera saxalilis, Hippocrepis comosa, Gentiana Clusii, Leontodon incanus und Hieracium bupleuroides auf Kalk beschränkt, während Fesluca picla, Poa laxa, Ciarex fuliginosa, Ranunculus glaciatis, R. pygmaeus, Saxifraga hieracifolia, S. bryoides, Geum reptans, Dianthus glacialis, Gentiana frigida, Hieracium alpinum nur auf kalkfreiem Boden gedeihen. In den Ostkarpathen sind insbesondere Gypsophila petraea, 
Draba compacla, Ranunculus alpestris, Saxifraga luteoviridis (ob immer?), Veronica Baumgartenii, Gentiana phlogifolia als ausgesprochene Kalkpflanzen zu nennen und auch Dianthus spiculifolius, Saxifraga demissa, Salureia Baumgartenii, Achillea Schurii ziehen den Kalk entschieden vor, während Polygonum alpinum, Ranunculus crenatus, Silene dinarica, Sempervivum montanum, Plantago gentianoides, Symphyandra Wanneri, Phyleuma confusum, Erigeron uniflorus den Kalk meiden. Zahlreiche verbreitete Arten sind wieder bodenvag, wie z. B. Carex sempervirens, Poa alpina, Lloydia serotina, Silene acaulis, Dianthus gelidus, Saxifraga moschata, Viola alpina, Pedicularis verticillata, ja, selbst Arten, die in den Alpen auf Kalk oder auf Urgestein beschränkt sind, wie Carex curvula, Sesleria disticha, Pedicularis Oederi und Cirsium Erisithales sind im Karpathengebiete in bezug auf die Unterlage nicht wählerisch.

Schließlich sei hervorgehoben, daß im zentralen Siebenbürgen auf der Hochebene an zahllosen Stellen Salz zutage tritt, wo dann eine reiche Halophytenflora anzutreffen ist.

\section{B. Die Pflanzengenossenschaften des Gebietes.}

\section{Die Westkarpathen.}

\section{Die Pflanzengenossenschaften der Hügel und der niederen Bergregion.}

a) IValdiormationen.

Eichenmischwälder. Ganz reine Eichenbestände sind im Gebiete der Westkarpathen eine seltene Erscheinung, hingegen treten auf den Vorbergen und in der Hügelregion sehr häufig reich zusammengesetzte Laubmischwälder auf, in denen doch die Eichenarten tonangebend sind. Besonders die Traubenund Zerreiche (Quercus sessiliflora und Qu. Cerris) sind es, die den Hauptbestandteil des Oberholzes bilden, seltener sind die flaumharige Eiche ( $Q u$. pubescens) und die mehr den Niederungen angehörige Sticleiche (Qu. Robur). Vergesellschaftet mit diesen Eichen finden sich fast stets Hainbuchen (Carpinus Belulus), Linden (Tilia ulmifolia), Schwarz- und Zitterpappeln (Populus nigra und P. tremula), Waldkirschen (Prunus avium), Holzäpfel und Holzbirnen (Pirus silvestris und P. Piraster), Birken (Belula pendula) und Ulmen (Ulmus glabra und $U$. laevis). Ein dichtes Unterholz ist stets vorhanden, das neben Sahl- und Ohrweiden (Salix caprea und S. aurita), Pfaffenkäppchen (Evonymus vulgaris und $E$. verrucosus), Hartriegel (Cornus Mas), Sauerdorn (Berberis vulgaris), Kreuzdorn (Rhamnus calharlica), wolliger Schneeball (Viburnum Lantana), Hollunder (Sambucus nigra), vor allem die strauchartigen Pflaumenarten (Prunus fruticosa, P. spinosa, P. Mahaleb, P. nana), zahllose Rosen und Brombecformen (Rosa, Rubus) sowie halbstrauchartige, gelbblühende Ginster- 
und Gaiskleearten (Genista tinctoria, Cylisus nigricans, C. supinus) zusammensetzen; auch Pimpernuß (Staphylea pinnata) und tatarischer Ahorn (Acer (utaricum) sind stellenweise nicht selten und am Südrande des Gebietes gesellt sich der Perückenstrauch (Cotinus Coggygria) hinzu. In diesem Gestråuche aber klettert überall Hopfen (Humulus Lupulus) sowie die weiße Waldrebe (Clematis Vitalba). Dort, wo die Sträucher in der Bodenbedeckung zurücktreten, ist allenthalben ein reicher krautiger Niederwuchs entwickelt. Im ersten Frühling blühen Leberblümchen (Anemone Hepalica), weiße und gelbe Anemonen (Anemone nemorosa und A. ranunculoides), Lerchensporn (Corydalis cava), Lungenkraut (Pulmonaria officinalis) und im ganzen westlichen Teil des Gebietes die stengellose Schlüsselblume (Primula vulgaris). Später aber treten verschiedene Gräser, wie Hordeum europaeum, Agropyrum caninum, Brachypodium silvaticum, Melica nutans und altissima, oft $\mathrm{zu}$ einer dichten Grasnarbe zusammen, zwischen der Salomonssiegel (Polygonalum latifolium), die braune Nestwurz (Neollia Nidus avis), Nelkenwurz (Geum urbanum), Wolfsmilch (Euphorbia amygdaloides), Wirbeldost (Salureia vulgaris), Gundelrebe (Glechoma hirsula), ferner Sculellaria allissima, Salureia inlermedia und vor allem Wicken und Platterbsen mit oft lebhaft violetten, roten oder gelben Blüten (Vicic dumetorum, $V$. pisiformis, Lathyrus niger, $L$. venetus) sowie Dost (Origanum vulgare), stinkender Storchschnabel (Geranium Roberlianum) und die ans Gebirge mahnende klebrige Salbei (Salvia glulinosa) sich erheben, während im Herbste der gelbe und violette Wachtelweizen (Melampyrum nemorosum) oft in dichtem Bestande den Boden bedeckt. In Lichtungen und an Waldrändern aber tritt ein dichtes Gestäude aus Wasserdost (Eupatorium cannabinum). Dolden (Chaerophyllum bulbosum), Judenkirschen (Physalis Alkeliengi), aus Cytisus-Arten, Coronilla varia, Lalhyrus megalanthus, Chrysanthemum corymhosum, Cephalaria transsilvanica, Dipsacus pilosus, Picris hieracioides und den im Herbste blühenden Habichtskräutern (Hieracium boreale) auf. Hingegen fehlt diesen Laubholzbeständen der dichte Moospolster des Nadelwaldes und nur Catharinea undulata und Polytrichum-Arten bedecken stellenweise den Boden.

Birkenbestände. Die beiden Birkenarten, Belula pendula und B. pubescens, sind auf den Bergen und Hügeln des Karpathenvorlandes allgemein verbreitet und finden sich teils eingesprengt in Laub- und Föhrenwäldern, teils in kleineren Gruppen an Waldrändern; selten jedoch bilden sie kleinere Waldbestände, deren Boden dann zumeist von Heidekraut (Calluna vulgaris), Heidelbeeren (Vaccinium Myrtillus) und Adlerfarn (Pleridium aquilinum) dicht bedeckt ist.

Buchenwålder. Die in der höheren Bergregion der Karpathen ausgedehnte Bestände bildende Buche tritt auch schon im Karpathenvorlande in höheren Lagen waldbildend auf. Doch sind diese Buchenbestände meist nicht rein, sondern mit Fagus silvatica vermischt treten auch Weißbuchen (Carpinus Betulus), Eichen (Quercus sessiliflora und Qu. Cerris), Ahorne (Acer platanoides) und Linden (Tilia cordata und platyphyllos) auf. Ein Unterholz fehlt oft ganz, oft aber setzen es auch Hirschholler (Sambucus racemosa), Himbeeren (Rubus 
Idaeus) und Ebereschen (Sorbus Aria und torminalis) im Vereine mit Weißdornarten (Crataegus Oxyacantha und monogyna), Pfaffenkäppchen (Evonymus verrucosus und vulgaris) und Heckenkirschen (Lonicera Xylosleum) zusammen. In Niederwuchs sind neben zahlreichen Arten der Mischwälder auch typische Buchenwaldpflanzen, wie Schneeglöchchen:(Galanthus nivalis), Goldstern (Gagea lutea), Arum maculatum, Cardamine impatiens, Aconitum Vulparia, Mercurialis perennis, Campanula persicifolia, sowie die großen gelben Sterne der für die Iiarpathen sehr charakteristischen Schaftdolde (Hacquetia Epipactis) nicht selten, und Baldrian (Valeriana officinalis) sowie die tiefblauen Blütentrauben der Gentiana asclepiadea mahnen schon an die Nähe des Gebirges.

Föhrenwälder. Während fast im ganzen südwestungarischen Berglande Nadelhölzer, also auch Föhren, vollständig fehlen, ist Pinus silvestris in den Westkarpathen ein weit verbreiteter Baum, der am Saume des Gebirges sowohl an der Süd- als an der Ostseite häufig ist, allerdings meist nur in kleineren Truppen oder Beständen auftretend und nur selten größere Wälder bildend. In Gesellschaft von Pinus silvestris treten nicht selten Laubhölzer, besonders Betula pendula, Populus tremula oder selbst Eichen auf. Sehr reich ist oft in den lockeren Beständen das Unterholz entwickelt, das aus den die unten geschilderten Buschformationen zusammensetzenden Sträuchern besteht, so daß es oft sich mehr um einzelne, die Buschbestände überragende Kiefern als um eigentliche Wälder handelt. Besonders sind es Juniperus communis, Cylisus nigricans und supinus, Cralaegus- und Evonymus-Arten, Prunus fruticosa usw., die dieses Strauchwerk zusammensetzen. An anderen Stellen wieder, besonders an der Nordwestseite des Gebirges, ist der Boden der Kiefernwälder mehr sandig und im Niederwuchse gedeihen dann auch typische Sandbewohner, wie Corynephorus canescens, Armeria elongala, Jasione montana usw.

Fichtenwälder. Die in der höheren Voralpenregion tonangebenden Fichtenwälder rücken in den Westkarpathen stellenweise bis in die Hügelregion herab, wo sich ihnen auf Kalkboden häufig die Tanne beigesellt. Unterholz ist in diesen Wäldern gewöhnlich gar keines vorhanden oder besteht aus Rubus Idaeus und anderen Brombeerarten, Salix silesiaca, Spiraea chamaedryfolia, Berberis vulgaris, Corylus Avellana usw. Im Niederwuchse ist vor allem Vaccinium Myrtillus meist weitaus vorherrschend, zu welcher sich Deschampsia flexuosa und D. caespitosa, Luzula nemorosa, Digilalis ambigua, Melampyrum silvaticum, Gentiana asclepiadea, Hieracium Pilosella, H. murorum und $H$. vulgatum mengen. Oft ist am Boden ein reicher Moosrasen aus Hylocomium-, Hypnum-, Brachythecium- und Mnium-Arten ausgebreitet, auch Farne (Dryopteris Filix mas, D. Oreopteris, Athyrium Filix femina) sind stellenweise nicht selten.

Auenwälder. An den im Frühjahre oft überschwemmten Ufern der Flüsse sind fast überall Auenwälder entwickelt. Vorwiegend sind es Salix-Arten, wie S. alba, S. fragilis, $S$. pentandra, S. daphnoides, die in Gesellschaft von Alnus rolundifolia und A. incana, Fraxinus excelsior, Quercus Robur, Populus nigra, seltener Ulmus glabra und U. laevis, Tilia cordala, Pirus Piraster das 
Oberholz bilden. Das Unterholz besteht aus den verschiedenartigsten Weiden, wie Salix amygdalina, S. viminalis und $S$. purpurea und namentlich der überall sehr håufigen S. incana, ferner aus Prunus Padus, Rhamnus Frangula, Viburnum Opulus, Sambucus racemosa, Rubus caesius usw. Massenhaft tritt stellenweise Onoclea Slrulhiopteris mit seinen großen trichterförmigen Wedelbüschen auf; von sonstigen Arten des Niederwuchses seien Calamagrostis Epigeios und C. Pseudophragmites, Festuca giganlea und F. arundinarea, Daclylis glomerala, Urlica dioeca, Parietaria officinalis, Clemalis integrifolia, Aegopodinm Podagraria, Euphorbia stricla, Salureia vulgaris, Eryngium campestre, Eupatorium cannabinum, Galium Aparine, Girsium lanceolatum, C. paluslre und C. arvense, Carduus nulans und $C$. crispus genannt, während von Schlingpflanzen Humulus Lupulus, Calystegia sepium und Cuscuta europaea häufig sind.

\section{b) Strauchiormationen.}

Ufergebïsche. Auf schotterigem Boden der Flüsse und auf Sandbänken siedelt sich neben Salix incana und S. purpurea auch Myricaria germanica gern an, mit derselben dichte oder lockere Gebüsche bildend. Auch Chamaenerion palustre ist an solchen Stellen oft in Masse zu finden, ferner Herniaria glabra, Sagina procumbens, Saponaria officinalis, Draba verna und oft genug auch Cirsium arvense und $C$. lanceolatum.

Wachholdergebuisch. An trockenen Abhängen ist in den Westkarpathen überall sehr häufig eine eigentümliche Buschformation zu finden, die man wegen des fast nie fehlenden Juniperus communis als Wachholdergebüsch bezeichnen kann und die dem später geschilderten Buschwerk des westungarischen Berglandes entspricht. Leider nur zu oft stellt dieses Buschwerk die Reste eines ehemaligen Waldes dar, wie das Vorkommen von Waldbewohnern, z. B. Anemone Hepalica, Primula vulgaris, Pulmonaria officinalis, usw. in denselben beweist. Neben Juniperus communis setzen dieses Buschwerk vor allem zahlreiche Rosenformen aus der Verwandschaft der $R$. coriifolia, $R$. canina, $R$. dumelorum, $R$. sepium, $R$. rubiginosa usw. zusammen, ferner Prunus frulicosa und $P$. spinosa, Berberis vulgaris, Corylus Avellana, Cornus Mas und C. sanguinea, Ligustrum vulgare, Genista tincloria, Cytisus nigricans usw. Dazwischen finden sich zahlreiche Stauden und Kräuter der Bergtrift, wie Coronilla varia, Inula squarrosa, Hypericum perforalum, Slachys recla und germanica, Geranium sanguineum, Cephalaria transsilvanica u. a.

\section{c) Staudenformationen.}

Die pannonische Bergtrift. Gleichwie im westungarischen Berglande und im Hügellande Südmährens ist auch in den Westkarpathen an sonnigen Hängen der Vorhügel eine außerordentlich reich zusammengesetzte, besonders im Frühlinge durch große Blütenpracht ausgezeichnete Triftformation entwickelt. Die Gräser, wie Agrostis vulgaris, Stipa pennata, Andropogon Ischaemum, Poa anguslifolia, P. bulbosa, Festuca sulcala, Bromus erectus und B. hordaceus treten gegen die große Zahl lebhaft blühender Stauden und Halbsträucher 
stark zurück. Im Frühlinge sind es vor allem Anemone grandis (beziehungsweise A. slavica), Alyssum montanum, Helianthemum canum, Polentilla arenaria, Viola hirta, die mit ihren gelben und violetten Blüten tonangebend sind; später dann sind es Silene Otiles, Arenaria graminifolia, Ranunculus illyricus, Helianthemum ovalum, Genista lincloria, Gylisus Kitaibelii, C. pallidus, C. nigricans, Anthyllis vulgaris, Trifolium alpestre, T. medium, T. rubens, Astragalus Gicer, Onobrychis viciaefolia, Vicia cassubica, V. sepium, Coronilla varia, Hippocrepis comosa, Potentilla canescens, P. argentea, Sanguisorba polygama, Filipendula hexapelala, Diclamnus albus, Polygala maior, Geranium sanguineum, Linum flavum, L. hirsulum, Seseli Hippomarathrum, Slachys recla, Verbascum phoeniceum, Campanula sibirica, Inula cordala, I. hirla, I. ensifolia und deren Bastarde, Anthemis tinctoria, Scorzonera purpurea, S. hispanica, Tragopogon dubius, Hieracium Pilosella, H. auriculoides. Im Hochsommer aber blühen Allium flavum, Dianthus Carthusianorum, D. collinus, Tunica prolifera, Lychnis Coronaria, Ononis spinosa, Trifolium ochroleucum, Hypericum perforatum, Pimpinella Saxifraga, Bupleurum falcatum, Peucedanum alsaticum, P. Cervaria, P. Schotlii, Lavatera thuringiaca, Echium vulgare, E. rubrum, Salureia vulgaris, Origanum vulgare, Thymus montanus, Stachys germanica Linaria vulgaris, L. genislifolia, Veronica spicala, Verbascum austriacum, V. thapsiforme, Digitalis ambigua, Odontites lutea, Orobanche alba, O. caryophyllacea, Galium Mollugo, Scabiosa agrestis, Aster Amellus, Artemisia campestris, Achillea collina, A. Neilreichii, Centaurea Jacea, C. rhenana, C. Scabiosa, Carduus collinus, Picris hieracioides, Cichorium Intybus, Hieracium echioides u. a.

Felsenformationen. Die Flora der Felsen in der Tal- und Hügelregion zeigt je nach der Bodenunterlage eine sehr verschiedene Zusammensetzung, so daß eine getrennte Besprechung der Vegetation der Kalkfelsen und der der Felsen aus kalkfreiem Substrate, besonders Sandstein, erforderlich ist.

a) Auf kalkarmen Felsen. Hier sind besonders einige Arten aus der Flora der Bergtriften, die gern auch die Felsen besiedeln, wie Cylisus nigricans, C. Kitaibelii, Hypericum perforatum, Linum catharticum, Lolus corniculatus, Helianthemum ovalum, Anthemis linctoria, Picris hieracioides, Galium vertum und $G$. erectum, Campanula rotundifolia und $C$. sibirica, Origanum vulgare, Odontites lutea, Thymus montanus, Stachys recta, Cynanchum Vincetoxicum usw. vertreten. Dazu treten dann noch eine Reihe von Farnen, wie Asplenium septentrionale, A. Ruta muraria und A. trichomanes, Woodsia ilvensis, Moose und Flechten und außerdem gesellen sich neben einer Reihe typischer Felsenpllanzen, wie Sedum album, S. acre und S. boloniense, Sempervivum hirtum und S. soboliferum, Salureia Acinos, Arabis petrogena, Asperula cynanchica, Arlemisia Absynthium, Lactuca perennis, Thatictrum minus, Melica ciliata, auch noch ab und zu Viola collina, Galium vernum, Libanolis montana, Laserpitium latifolium, Astragalus glycyphyllos und Aconitum Anthora hinzu.

b) Auf Kalkfelsen. Eine viel artenreichere Flora zeigen die Kalkfelsen. Selten fehlen hier die blaue Sesleria varia und Festuca glauca, Draha lasiocarpa, 
Bupleurum falcalum, Seseli Beckii usw., ferner finden sich Carex humilis, Alyssum Arduini, Arabis arenosa und A. alpina, Corydalis capnoides, Helianthemum canum und $H$. ovalum, Hippocrepis comosa, Lotus corniculalus, Parnassia palustris, Teucrium montanum, Globularia Willkommii, Allium flavum und A. montanum, Gentiana cruciala, Sedum album und S. acre, Campanula carpalica, Pinguicula vulgaris, Hieracium Pilosella, H. ramosum u. а.

\section{d) Grasfilurformationen.}

Bergwiesen. Die Bergwiesen auf den Vorhügeln der Westkarpathen entsprechen meist dem Typus der ungedüngten Burstwiese, in der Bromus erectus das tonangebende Gras ist, neben dem noch Festuca elatior, Daclylis glomerata, Briza media, Avena pratensis, minder zahlreich meist Anthoxanthum odoralum, Arrhenalherum elalius, Avena pubescens, Trisetum flavescens, Festuca sulcata und F. ovina auftreten; auch Carex montana und Luzula campestris sind meist an der Bildung der Grasnarbe beteiligt. Im Frühlinge schmücken diese Wiesen Tausende von gelben Schlüsselblumen (Primula veris *anescens und $P$. elatior) und blauen Veilchen (Viola hirla), später sind besonders die Leguminosen, wie Medicago falcata, M. lupulina, Trifolium pratense, $T$. alpestre, T. campestre, Anthyllis vulgaris, Vicia Cracca, reich vertreten. Von sonstigen bezeichnenden Arten dieser Bergwiesen sind noch Orchis ustulala, Linum catharlicum, Viola alpestris, Hypericum perforalum, H. elegans, Carum Carvi, Chaerophyllum aromalicum, Anthriscus silvester, Polygala amara, P. maior, Veronica Chamaedrys, Alectorolophus minor, A. maior, A. hirsutus, Campanula rotundifolia, Achillea Millefolium, Cirsium pannonicum, Centaurea Scabiosa, Hypochoeris maculala, Hieracium Pilosella, H. Auricula, H. flagellare, H. pratense, H. Bauhini und stellenweise Knaulia carpalica hervorzuheben.

Die Pusztaweide. Dort, wo die Ebene hart an den Fuß der Berge herantritt, bildet sich öfter eine eigentümliche Formation aus, die den Übergang zwischen den Steppen des Tieflandes und den Bergwiesen darstellt und die man nach dem Vorgange von Pax am zweckmäßigsten als Pusztaweide bezeichnen kann. Vor den Steppen Zentralungarns zeichnen sich dieselben vornehmlich durch die längere Vegetationszeit aus, da die vom Gebirge kommenden Gewässer und die reichlicheren Niederschläge eine größere Durchfeuchtung des Bodens ermöglichen. Trockenheit liebende Gräser, wie Andropogon Ischaemum, Stipa pennata, Cynodon Dactylon, Selaria glauca und S. viridis, Festuca ovina, $F$. sulcata und $F$. vaginata, Bromus tectorum, B.hordaceus und B. arvensis, setzen die meist eine nicht völlig geschlossene Decke bildende Grasnarbe zusammen. Dazwischen gedeihen zahlreiche niederwüchsige, oft am Boden hinkriechende Arten, wie z. B.Polygonum aviculare, Erodium cicutarium, Convolvulus arvensis, Filago germanica, $F$. apiculala, $F$. arvensis und $F$. montana, Leonlodon aulumnalis usw., und dazwischen erheben sich vereinzelte hochwüchsige Stauden und Kräuter, wie Reseda lutea, Ononis spinosa, Melilotus albus und M. officinalis, Verbena officinalis, Salvia nemorosa, Stachys germanica, Erigeron canadensis, 
Xanthium spinosum, Cirsium lanceolatum, Cenlaurea rhenana, Cichorium Intybus.

Talwiesen. Die Talwiesen des Gebietes zeigen ein ausgesprochen mitteleuropäisches Gepräge und nur wenige Arten derselben sind fremdere Erscheinungen. Die Zusammensetzung derselben ist der Hauptsache nach folgende: Alopecurus pratensis, Phleum pratense, Arrhenatherum elatius, Dactylis glomerala, Gynosurus crislalus, Poa pratensis und P. trivialis, Festuca elatior, Colchicum aulumnale, Iris sibirica, Crocus Heuffelianus, Galanthus nivalis, Orchis latifolia, Lychnis Flos Cuculi, Ranunculus acer und R. auricomus, Cardamine pratensis, Sanguisorba officinalis, Trifolium pratense, T. repens, T. hybridum, Vicia sepium, Lathyrus pratensis, Geranium pratense, Linum calharticum, Angelica silvestris, Heraclum Spondylium, Aegopodium Podagraria, Daucus Carola, Anthriscus silvester, Myosotis scorpioides, Veronica Chamaedrys, Aleclorolophus minor und A. maior, Euphrasia Rostkoviana, Campanula patula, Chrysanthemum Leucanthemum, Centaurea Jacea, Cirsium oleraceum, C. rivulare, C. canum, Tragopogon orientalis, Taraxacum vulgare, Leontodon aulumnalis, Crepis biennis.

\section{e) Formationen des nassen Bodens.}

IViesenmoore. Wiesenmoore sind lim niederen IIügellande der Karpathen zwar nicht selten, aber meist von nur geringer Ausdehnung. Ihre Zusammensetzung ist im wesentlichen folgende: Alopecurus aequalis und $A$. geniculalus, Agrostis canina, Deschampsia caespitosa, Poa trivialis, Molinia coerulea, Carex Davalliana, C.vulpina, C. disticha, C. Goodenoughii, C. gracilis, C. elata, C. panicea, C. tomentosa, C. flava, G. rostrata, C. acutiformis, Heleocharis palustris, Eriophorum angustifolium und $E$. latifolium, Juncus conglomeratus, $J$. effusus, J. filiformis, Triglochin palustre, Iris sibirica, Orchis maculata, Lychnis Flos cuculi, Ranunculus Flammula, Caltha palustris, C. cornuta, Cardamine pratensis, Roripa silvestris, Geum rivale, Lotus uliginosus, Epilobium palustre, Gentiana Pneumonanthe, Brunella vulgaris, Pedicularis silvatica und P. palustris, Valeriana dioeca und $V$. polygama, Succisa pratensis, Cirsium palustre und C. oleraceım. Zwischen den Gräsern und Seggen aber bilden verschiedene Moose, besonders Hypnum- und Polytrichum-Arten (nicht aber Sphagnum) kleine Teppiche.

Formation der Ufer. An den Ufern stehender oder langsam fließender Gewässer pflegt meist Phragmites communis Bestände zu bilden, ohne daß dieselben auch nur annähernd jene Ausdehnung erreichten wie im Tieflande. In Gesellschaft des Schilfrohres finden sich häufig Schoenoplectus lacustris, Typha anguslifolia und $T$. latifolia, Sparganium simplex, Cladium Mariscus, Carex vulpina, G. vesicaria, C. aculiformis, Equisetum palustre und E. limosum, Iris Pseudacorus, Alisma Plantago aquatica, Ranunculus Lingua, Oenanthe aquatica, Lythrum Salicaria usw. Wo Phragmites fehlt, bilden andere Gräser, wie Typhoides arundinacea, Calamagrostis litorea, Glyceria fluitans, Festuca arundinacea, Bestände; zu den häufigeren Uferpflanzen gehören ferner Filipendula Ulmaria, 
Lythrum Salicaria, Mentha longifolia, M. aquatica, M. verticillata, M. austriaca, Lycopus europaeus, Eupalorium cannabinum u. a.

Wasserpflanzen. Die Wasserflora ist in den Karpathen naturgeinä $\Omega$ viel weniger reich entwickelt als im benachbarten Tieflande. Zu den verbreitetsten Arten gehören: Lemna minor, Polamogeton nalans und P. perfolialus, Hydrocharis Morsus ranae, Castalia alba, Nuphar luteum, Ranunculus aqualilis und R. paucistamineus, Myriophyllum spicalum, Gallitriche verna, Hollonia palustris.

\section{Die Pflanzengenossenschaften der höheren Berg- und Voralpenregion.}

\section{a) Waldiormationen.}

Der Buchenhochwald. In den Westkarpathen tritt die Buche vornehmlich am Nordabhange der Tatra, ferner auf der Veterna Hola, in der Niederen Tatra, in den Belaer Kalkalpen und im Braniszkostocke auf. Sie steigt aber hier nirgends bis zur Waldgrenze, sondern erreicht bei $1200 \mathrm{~m}$, an der Nordseite sogar schon bei $1000 \mathrm{~m}$ ihre obere Grenze. Die in der niederen Bergregion sie begleitenden Bäume, wie Weißbuchen, Eichen usw., bleiben bald zurück und in höheren Lagen ist es Fagus silvatica fast allein, die ausgedehnte, prächtige Hochgebirgswälder bildet. Nur Acer Pseudoplatanus und Ulmus scabra sind in vereinzelten Exemplaren zu finden, noch seltener Sorbus Aria und S. Aucnparia; häufig aber ist stellenweise die Tanne, die auch in. kleineren Gruppen oder Beständen vorkommt. Das Unterholz bilden vor allem Salix caprea und S. silesiaca, Spiraea chamaedryfolia, Daphne Mezereum, Evonymus verrucosus, Ribes Grossularia, $R$. alpinum und $R$. petraeum, Rosa pendulina, Rubus Idaeus, Lonicera Xylosleum und L. nigra, Sambucus racemosa. Im Niederwuchse herrschen wie überall im Buchenwalde Arten vor, die im Frühjahre, vor Entwicklung des Buchenlaubes, ihre Blüten entfalten, oder aber typische Schattenpflanzen. Milium effusum, Festuca gigantea, Carex silvatica, Arum *immaculatum, Scilla bifolia, Allium ursinum, Paris quadrifolia, Neoltia Nidus avis, Anemone Hepatica und A. nemorosa, Corydalis cava, Cardamine impaliens, C. enneaphyllos, G. glandulosa, Asarum europaeum, Oxalis Acelosella, Mercurialis perennis, Hedera Helix, Sanicula europaea, Hacquetia Epipactis, Pirola rotundifolia, P. minor und P. secunda, Geranium Robertianum, Circaea lutetiana, Lamium vulgare, Prenanthes purpurea, Lacluca muralis, Asperula odorala sind solche typische Buchenwaldbewohner. Dazu gesellen sich aber auch typische Voralpenstauden, wie die Farne Polystichum aculealum, P. lobatum, P. Lonchilis und selten auch Phyllites Scolopendrium, ferner Polygonalum verticillalum, Cardamine glandulosa, Ranunculus cassubicus, Veronica montana, Lamium cupreum, Galium Schullesii, Geranium phaeum, Cyclamen europaeum, Goodiera repens, Coralliorhiza lrifida, Luzula flavescens, Symphylum cordalum, Buphthalmum salicifolium, Senecio umbrosus usw. 


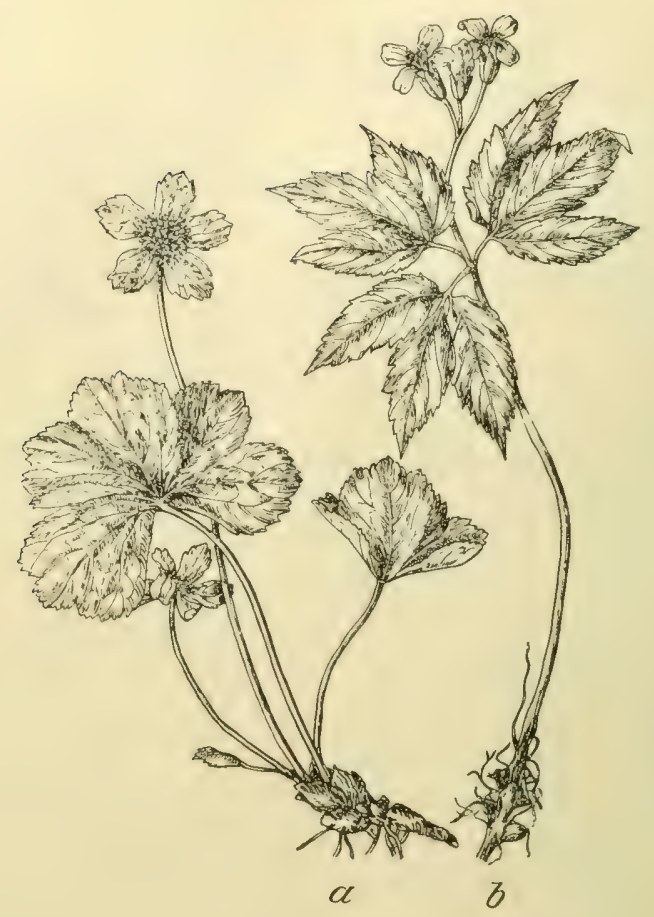

Abb. 170. Aus der. Waldflora der Beskiden.

$a$ Hacquetia Epipactis, $b$ Cardamine glandulosa.

(Zirka 1/1 n. Gr。)

Fichtenwälder. Der vorherrschende Waldbaum der Tatra und der Beskiden ist die Fichte (Picea excelsa), die bis zu einer Höhe von 1500 bis $1560 \mathrm{~m}$, an der Nordseite sogar nur zirka $1300 \mathrm{~m}$, reiche Bestände bildet. Bis etwa in einer Höhe von $1100 \mathrm{~m}$ ist die Tanne (Abies alba) eine treue Begleiterin der Fichte, während an der Waldgrenze auch die Lärche und in der Tatra die Zirbelkiefer (Pinus Cembra) im Fichtenwalde eingesprengt vorkommen.

Dort, wo die mit Flechten, besonders Usnea-Arten, reich bewachsenen Fichten im dichtem Bestande den Boden bedecken, fehlt ein Unterholz im Fichtenwalde fast gänzlich und der eintönige Niederwuchs wird fast nur aus Vaccinium Myrtillus und V. Vitis Idaea, Calluna vulgaris, Luzula nemorosa, Deschampsia caespilosa und D. flexuosa, Calamagrostis Halleriana, Melampyrum pratense *ulgalum und M. silvalicum gebildet, denen sich hie und da Hieracium murorum, H. vulgalum, Homogyne alpina, Digilalis ambigua, Gentiana asclepiadea usw. beigesellen; von Moosen ist im dichten Waldesschatten besonders Leucobryum glaucum häufig. An feuchteren, humösen Stellen finden sich auch Oxalis Acelosella, Listera cordala, Circaea alpina, Soldanella carpalica, Lysimachia nemorum und die seltene Linnaea borealis.

Wo aber die Bestände sich etwas lichten, tritt auch ein Unterholz aus Salix silesiaca, Rubus Idaeus, Spiraea chamaedryfolia, Evonymus verrucosus auf und hochwüchsige Stauden siedeln sich an, wie Luzula silvatica, Digitalis 


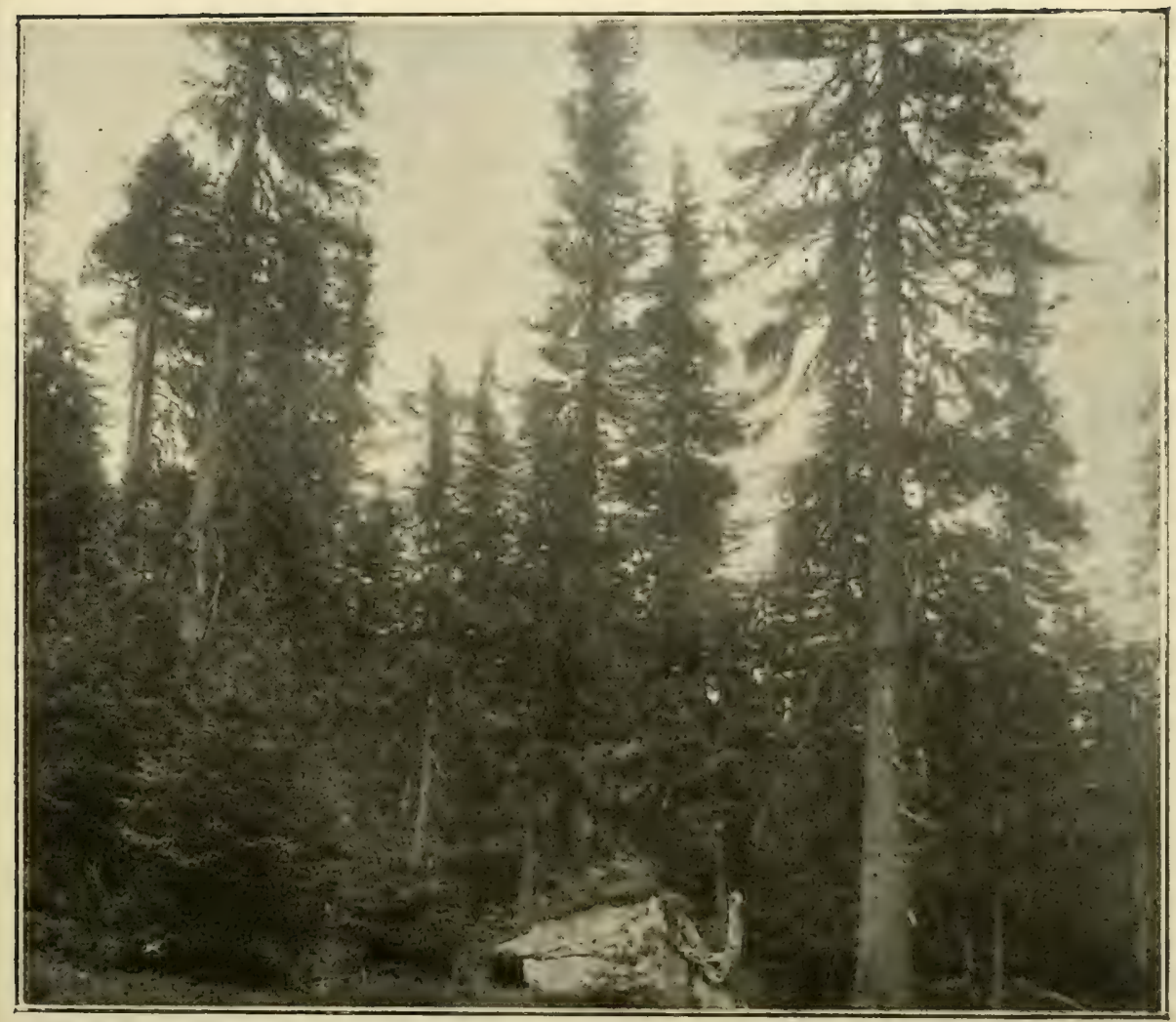

Abb. 171. Fichtenwald im Bialkatale der Hohen Tatra.

(Nach einer Aufnahme von A. V. Hayek.)

ambigua, Stachys silvatica und S. alpina, Circaea intermedia, Chrysanthemum rotundifolium und Farne (Dryopteris Filix mas, D. Oreopteris, D. spinulosa, Cystopleris sudetica); und in höheren Lagen, wo die Bäume locker stehen, da treten überall die unten genannten, prächtigen Voralpenstauden auf.

\section{b) Strauchiormationen.}

Der subalpine Buschwald. An der oberen Grenze der Buchenregion tritt insbesondere in jenen Bergzügen, wo die Nadelwälder zurüclitreten, die Buche nicht mehr im hochstämmigen, geschlossenen Walde auf, sondern bildet als Strauch oder verkrüppelter Baum im Vereine mit Corylus Avellana, Sorbus Aria, S. Aucuparia, Rubus Idaeus, Rosa pendulina, Sambucus nigra und S. racemosa lockere Bestände, zwischen denen sich sich eine aus üppigen Hochstauden gebildete Voralpenvegetation breit macht, die sich an Waldrändern, auf Blößen und an Bächen auch schon in tieferen Lagern findet. Calamagrostis villosa und C. varia, Poa Chaixii, Luzula nemorosa und $L$. silvalica bilden die Hauptmasse der ziemlich spärlichen grasartigen Gewächse; hingegen bilden Chaerophyllum Cicutaria, C. aromaticum, Laserpitium latifolium, Anthriscus 
nilidus, Heracleum flavescns, Torilis Anlhriscus, Astrantia maior, Aclaea spicala und A. Cimicifugia, Digitalis ambigua, Stachys alpina und S. silvatica, Salvia glutinosa, Campanula latifolia, Senecio nemorensis, Valeriana sambucifolia mächtige blütenreiche Büsche; daneben finden sich Aconilum moldavicum, Lilium Marlagon, Scrophularia Scopolii, Lunaria rediviva, Hesperis inodora, Silene nutans, Geum striclum, Rubus saxalilis, Hypericum montanum und H. hirsutum, Aquilegia vulgaris, Delphinium clatum und D. oxysepalum, Euphorbia polychroma, Gentiana asclepiadea, Knautia silvatica, Melittis Melissophyllum, Campanula persicifolia, Adenophora liliifolia, Chrysanthemum corymbosum, Cephalanthera rubra, Cypripedium Calceolus u. a.

Ufergebüsche. Während in tieferen Lagen noch Salix incana und S. purpurea in Gesellschaft von Alnus incana und $A$. rotundifolia die Bachufer umsäumen, tritt bei etwa $1200 \mathrm{~m}$ Salix silesiaca an deren Stelle, die gewöhnlich von Belula pubescens * carpalica, Acer Pseudoplatanus, Ribes Grossularia, Sorbus Aucuparia, Lonicera nigra und manchmal selbst von Pinus Mughus begleitet wird. Neben und zwischen diesem Buschwerke aber vegetieren in großer Üppigkeit hochwüchsige Voralpenstauden. Veralrum album, Caltha laeta, Thalictrum aquilegifolium, Chaerophyllum Cicularia, Anthriscus nilidus, Salvia glutinosa, Mentha longifolia, Pelasiles albus, Adenostyles Alliariae, Senecio

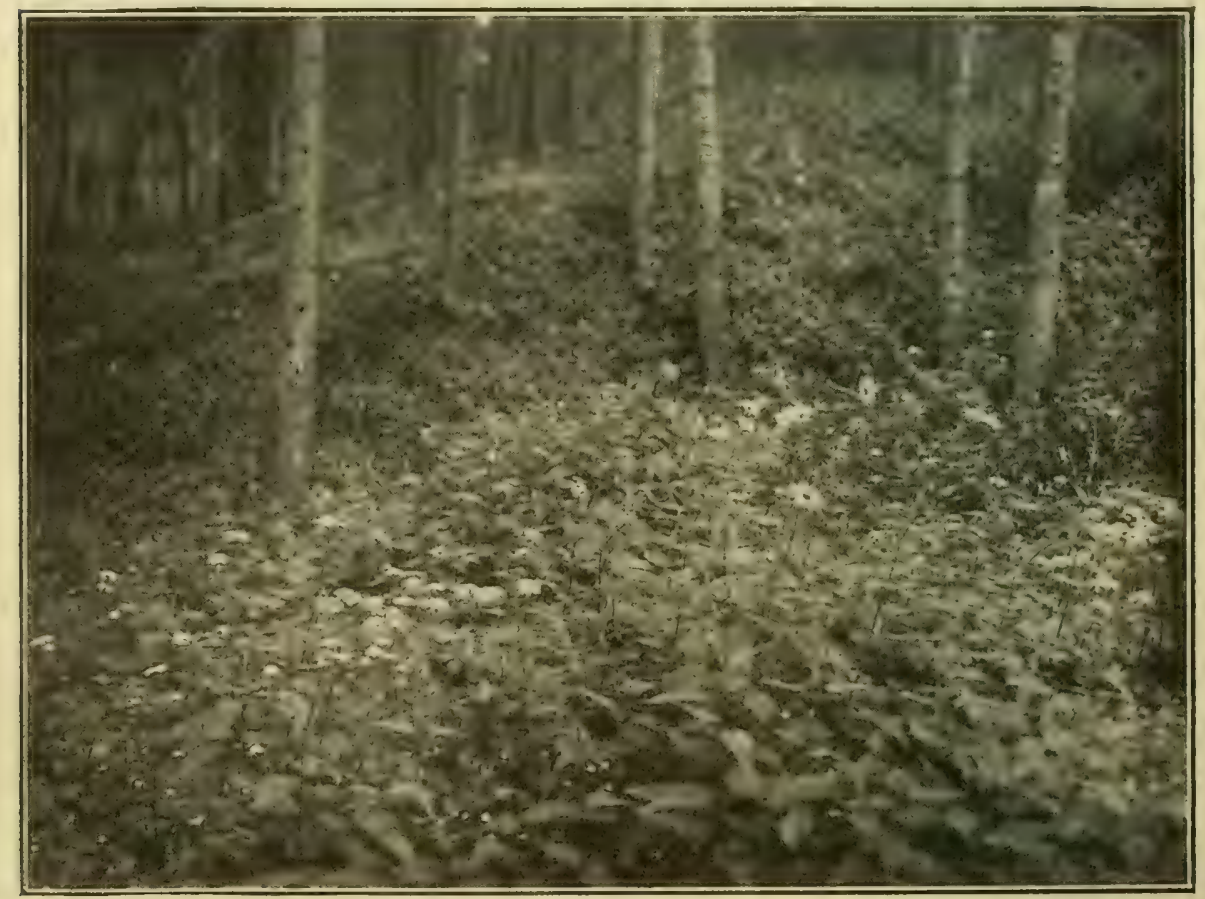

Abb. 172. Bachufervegetation bei Uj-Tatrafüred:

Chaerophylum Cicutaria, Doronicum austriacum, Geranium Robertianum.

(Nach einer Aufnahme von A. V. Hayek.) 
nemorensis, S. subalpinus und Doronicum austriacum sind an solchen Stellen allgemein verbreitet und überall begleiten die mächtigen Wedeltrichter des Straußenfarns (Onoclea Slruthiopleris) den Lauf der Bergbäche. Auch Stellaria nemorum, Aconitum firmum, Delphinium clatum, D. oxysepalum, Ranunculus platanifolius, Angelica Archangelica, Carduus Personala, Girsium heterophyllum, Crepis paludosa und die auf die südlichen Zentralkarpathen beschränkte Saxifraga rolundifolia gehören dieser Formation an. Im feuchten Sande der Bäche aber gedeihen Heliosperma quadrifidum, Arabis alpina, Cardamine Opizii, Saxifraga aizoides und Epilobium alsinefolium und die Felsblöcke sind oft von den blutroten Krusten von Chroolepus iolithus überzogen.

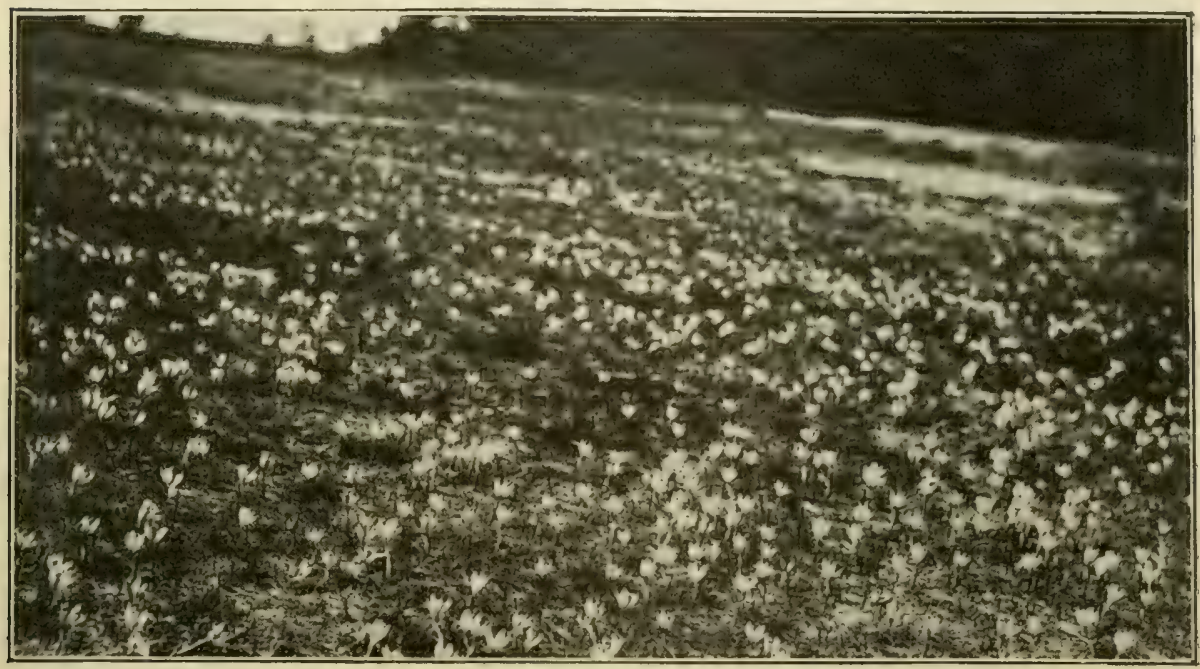

Abb. 173. Grocus Heuffelianus auf einer Bergwiese bei Löcse.

(Nach einer Aufnahme von G. Nyaradyi, Maros-Vasarhely.)

\section{c) Grasflurformationen.}

Voralpenwiesen. Ein farbenprächtiges Bild bieten die Voralpenwieser der Westkarpathen. Anthoxanthum odorolum, Agroslis vulgaris, Phleum commutatum, Deschampsia caespitosa, Trisetum flavescens, Fesluca rubra sind hier die vorherrschenden Gräser, während einige Arten tieferer Lagen, insbesondere Arrhenalherum, fehlen. Aber noch lange bevor die Gräser entwickelt sind, im. ersten Frühling nach dem Schmelzen des Schnees, schmückt Crocus Heuffelianus: in Unzahl den braungrünen Boden, oft mit Leucoium vernum vergesellschaftet. Später sind es besonders die zahlreichen Orchidazeen, wie Orchis globosa, O. mascula *signifera, O. sambucina, O. maculata, Gymnadenia conopea und Platanthera bifolia, ferner Gladiolus imbricatus, Polygonum Bistorta, Trollius europaeus, Silene vulgaris, Trifolium montanum, Hypericum maculatum, Geranium silvaticum, Pimpinella maior, Heracleum flavescens, Alectorolophus maior, Gentiana carpatica, Campanula pseudolanceolata, G. patula, Chrysanthemum 
Leucanthemum, C. corymbosum, Centaurea austriaca, Hieracium aurantiacum, H. umbellatum, die auf den Voralpenwiesen der Westkarpathen zumeist häufig sind, zu denen auf Kalkboden sich noch Scabiosa lucida und Cirsium Erisithales gesellen. Hingegen kommt Arnica montana nur in den südwestlichen Beskiden vor und fehlt dem übrigen Teil der Westkarpathen.

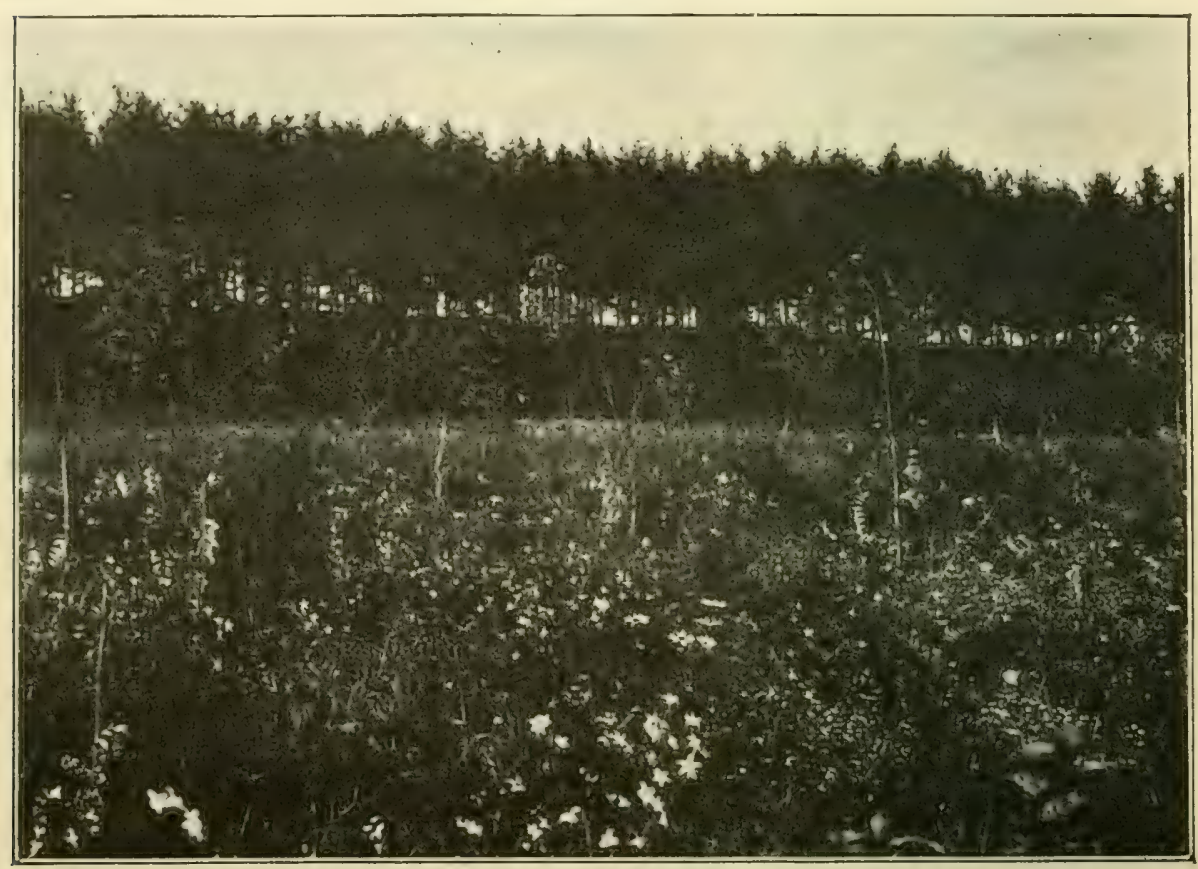

Abb. 174. Wiese bei Hoszuerdö.

Gladiolus imbricatus, Campanula patula, Chrysanthemum Leucanthemum.

(Nach einer Aufnahme von G. Nyarádyi, Maros-Vasarhely.)

\section{d) Moore.}

Wiesenmoore. Wenn auch größere Wiesenmoore in höheren Lagen der Westkarpathen kaum vorhanden sind, trifft man kleinere moorige Stellen und sumpfige Wiesen allenthalben bis zur Baumgrenze an. Im wesentlichen bieten diese dasselbe Bild wie die Sumpfwiesen tieferer Lagen, verschiedene Cyperazeen, besonders Carex Goodenoughii, G. flava, G. panicea, Heleocharis paluslris, Eriophorum latifolium und $E$. anguslifolium, bilden mit Deschampsia caespitosa und Molinia coerulea die Grasnarbe, in der Orchis maculata, Callha laeta, Geum rivale, Epilobium palustre, Pedicularis palustris, Girsium palustre, Senecio rivularis, Crepis succisaefolia, $G$. paludosa nicht selten sind, auch Cirsium rivulare ist noch stellenweise häufig und am Nordostrande der Niederen Tatra kommt auch Schoenus ferrugineus vor.

Hochmoore. Hochmoore sind in den Westkarpathen eine nicht seltene Erscheinung und liegen größtenteils in einer Höhe zwischen 500 und $1000 \mathrm{~m}$. 
In ihrer Zusammensetzung weichen sie von denen der Alpen durch das Auftreten von Ledum palustre und Trienlalis europaea ab und zeigen eine große Übereinstimmung mit den Mooren der Sudeten. Zahlreiche Sphagnum-Arten (S. Girgensonii, S. fusum, S. teres, S. molluscum, S. aculifolium), im Vereine mit Thuidium lamariscinum, Amblyodon dealbatus, Meesea lrigrala und anderen Arten bilden einen dichten Moosrasen, in welchem Drosera rolundifolia, Pinguicula vulgaris, Viola palustris und Oxycoccos palusiris sich finden. Ferner treten verschiedene Cyperazeen, wie Carex pauciflora, C. slellulata, C. canescens und C. limosa, Eriophorum vaginalum und $E$. Scheuchzeri auf; und an Ericazeen neben Oxycoccos noch Calluna vulgaris, Vaccinium uliginosum, Andromeda polifolia und das nicht

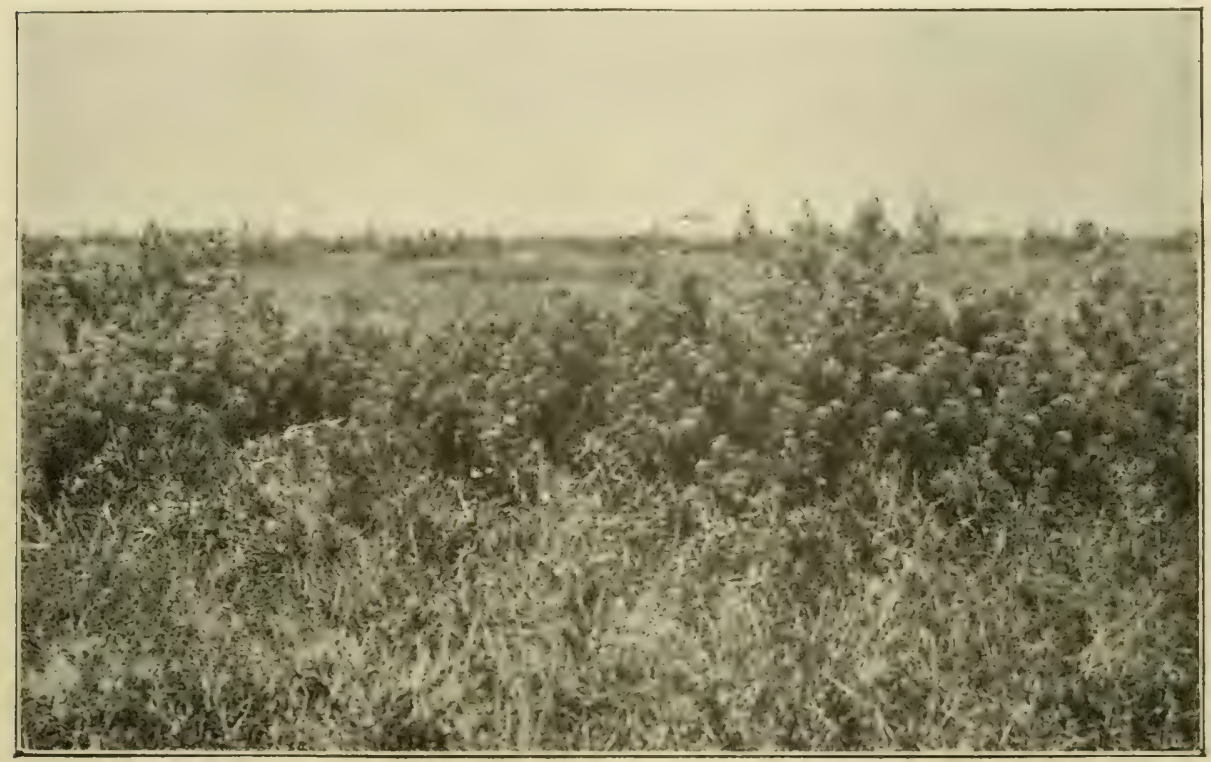

Abb. 175. Pinus Pseudopumilio in den Borysümpfen im Arvaer Komitat.

(Nach einer Aufnahme von G. Nyarádyi, Maros-Vasarhely.)

häufige Ledum palustre. Ferner kommen in den Hochmooren Trienlalis europaea, Empetrum nigrum und die prächtige Pedicularis Sceptrum Carolinum vor; im großen Kohlbachtale auch Trichophorum alpinum. Manchmal findet sich auch Strauchwuchs, wie Salix aurila und S. repens, seltener bildet, wie in den Borysümpfen und auf den Mooren bei Neumarlit, Pinus Psendopumilio Bestände.

\section{e) Stauden- und Kräuterformationen.}

Subalpine Hochstaudenfluren. Dieselben prächtigen Stauden, die im Buschwerke an den Ufern der Bergbäche vorkommen, treten in den Westkarpathen auch an Waldrändern und steinigen Stellen nicht selten gesellig auf. Freilich fehlen hier die ausgesprochenen Bewohner des nassen Bodens, wie Caltha laeta und Cardamine Opizii. Hingegen sind Melandryum silvestre, Ranun 
culus platanifoilus, Delphinium elatum, Aconitum firmum, Anthriscus nilidus, Stachys alpina, Gentiana asclepiadea, Adenoslyles Alliariae, Senecio nemorensis, Doronicum austriacum, Carduus Personala, Crepis succisaefolia an solchen Stellen häufige Erscheinungen, zu denen auf Kalkboden sich noch Cirsium Erisithales gesellt.

Flora der Holzschläge. Nach dem Ausschlagen des Waldes verschwinden auch die charakteristischen Gewächse dessen Niederwuchses und nur vereinzelte Exemplare von Lacluca muralis, Senecio nemorensis oder Stachys alpina bleiben übrig. Hingegen siedelt sich rasch ein Heer ein- oder zweijähriger Arten an, deren Früchte oder Samen durch einen Haarschopf ausgezeichnet und so für die Verbreitung durch den Wind besonders ausgerüstet sind, so Senecio silvaticus und S. viscosus, Gnaphalium silvalicum, Solidago Virga aurea, Girsium eriophorum, $C$. lanceolalum und $G$. arvense, Senecio nemorensis, Chamaenerion anguslifolium und Epilobium montanum. Auch Gräser treten oft in großer Menge auf, vor allem Agrostis vutgaris, Deschampsia flexuosa und D. caespitosa, Nardus stricta, mit ihnen Carex leporina, Luzula campestris und L. nemorosa. Farne, besonders Pteridium aquilinum und Dryopteris Filix mas, sprossen oft wieder aus den im Boden verbliebenen Rhizomen hervor. Später siedeln sich dann noch andere Arten an, wie Veronica officinalis und $V$. Chamaedrys, Lolus corniculalus, Hypericum perforalum, vor allem aber beerentragende Stauden und Sträucher, wie Fragaria vesca, Atropa Belladonna, Sambucus racemosa und insbesondere Rubus-Arten, wie z. B. R. szepusiensis, $R$. Guentheri, R. Bayeri usw., und oft in größter Menge Rubus Idaeus.

Subalpine Felsenflora. a) Auf kalkarmem Substrat. Dic Flora der Sandstein- und Schieferfelsen in der Voralpenregion der Westkarpathen bietet wenig Interessantes. Einige Farne (Cystopteris fragilis, Asplenium Rula muraria, A. trichomanes und A. septentrionale), Arabis arenosa, Campanula glomerala, Erigeron acer und das prächtige purpurrote Sedum carpaticum fehlen selten, dazu gesellen sich Carex digitala, Arabis Turrila, Chrysanthemum corymbosum, Thalictrum minus, Dianthus Carthusianorum, Galium vernum, Euphrasia stricta usw.; in höheren Lagen treten noch Saxifraga adscendens und S. Aizoon hinzu.

b) Auf Kalkfelsen. Viel reicher ist die Flora der Kalkfelsen. Zu den Farnen gesellt sich Phegopteris Robertiana und Asplenium viride; an Gräsern sind Sesleria varia, Melica ciliata, Fesluca glauca und Calamagrostis villosa nicht selten. Häufigere Arten sind ferner Anthericum ramosum, Allium montanum, Minuarlia laricifolia, Dianthus hungaricus, Silene nemoralis, Moehringia muscosa, Biscutella laevigala, Kernera saxalilis, Draba aizoides, Amelanchier ovalis, Coloneaster integerrima, Sorbus Aria, Hippocrepis comosa, Saxifraga Aizoon *robusta, Bupleurum falcalum, Primula Auricula, Gentiana Clusii, G. cruciata, Euphrasia salisburgensis, Asperula cynanchica, Scabiosa lucida, Valeriana Iripteris, Campanula carpatica, C. cochleariaefolia, Aster alpinus, A. Bellidiastrum, Carduus glaucus, Centaurea montana *mollis, Leontodon incanus, Hieracium bupleuroides; seltener sind Stipa pennata, Anemone slavica, Coloneaster lomentosa, Minuartia verna, 


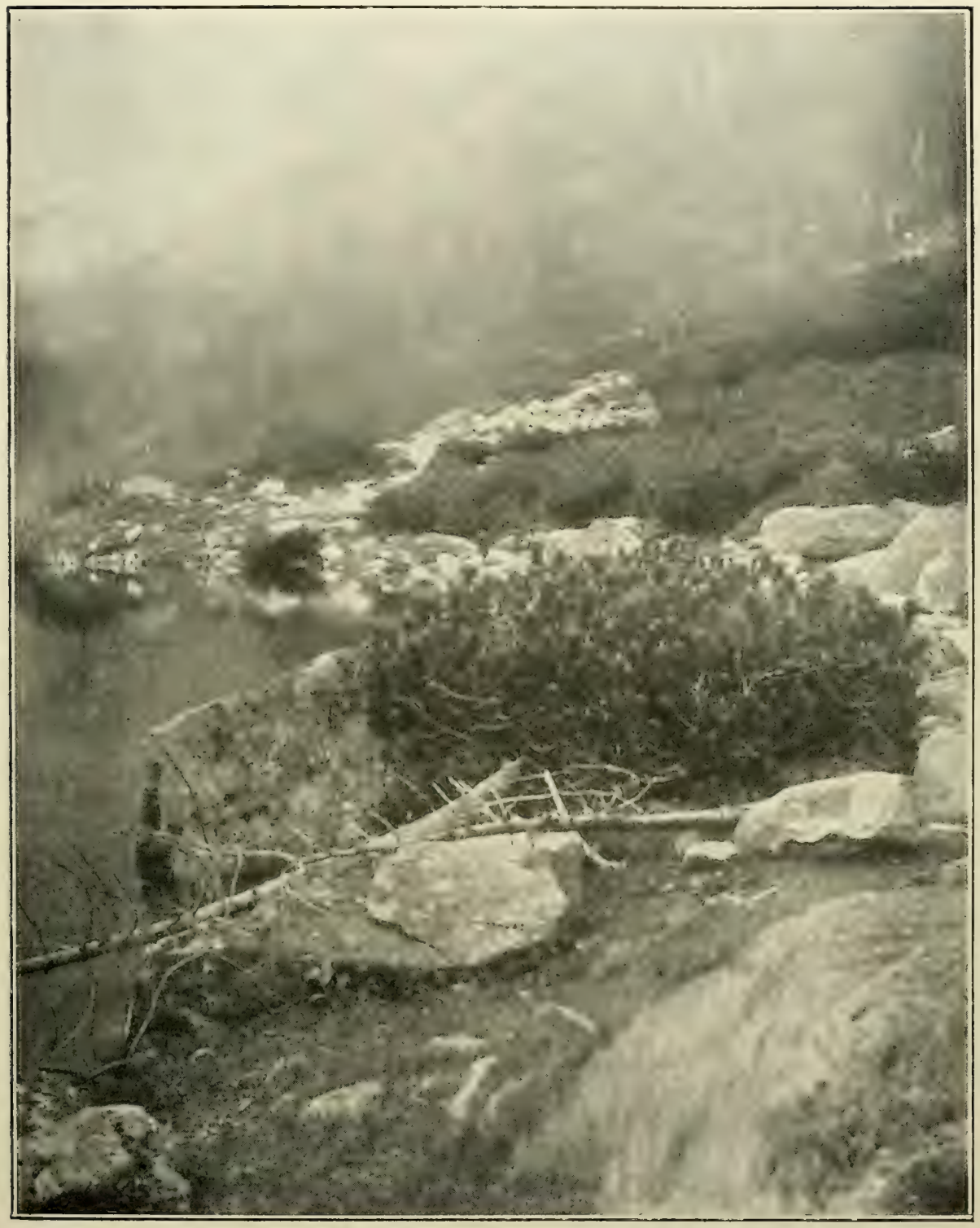

Abb. 176. Krummholzbestand am Großen Fischsee in der Hohen Tatra. (Nach einer Aufnahme von A. v. Hayek.) 

Globularia Willkommii, Crepis Jacquini, Erysimum Wittmanni, Inula ensifolia, Aconitum moldavicum, u. a., ferner nur in den Pieninen Juniperus Sabina und das durch seine hellblauen Strahlblüten auffallende Chrysanthemum Zawadskii. An feuchten Felsen finden sich vornehmlich Cystopleris fragilis, Tofieldia calyculala, Heliosperma quadrifidum, Parnassia palustris und Pinguicula vulgaris.

\section{Formationen der Hochgebirgsregion.}

\section{a) Strauchiormationen.}

Krummholzbestände. Während sowohl die Grünerle (Alnus viridis) als auch Alpenrosen (Rhododendron) den Westkarpathen fast völlig fehlen, bildet in höheren Lagen die Krummholzkiefer (Pinus Mughus) allenthalben ausgedehnte Buschwälder. Dichte Bestände von Legföhren beginnen bei etwa $1450 \mathrm{~m}$ und reichen bis etwa $1800 \mathrm{~m}$ hinan, einzeln aber steigt Pinus Mughus bis über $2000 \mathrm{~m}$ an und bis $1300 \mathrm{~m}$, ja, selbst noch bis $690 \mathrm{~m}$ herab. Als Mittelwert für den Krummholzgürtel kann in den Beskiden die Höhenzone zwischen 1330 und $1660 \mathrm{~m}$, in der Hohen Tatra zwischen 1450 und $1800 \mathrm{~m}$ gelten.

Pinus Mughus bildet in dieser Höhenlage dichte undurchdringliche Buschwälder, zwischen deren Geäst nur Juniperus nana in größerer Menge sich findet; nur an der unteren Grenze kommt Sorbus Aucuparia nicht selten vor; auch verkrüppelte Exemplare von Picea excelsa, Larix decidua und Pinus Cembra trifft man an; nur vereinzelt finden sich Sorbus Chamaemespilus, Rosa pendulina oder Salix silesiaca. Als Niederwuchs im Legföhrenwald stellen sich oft Vaccinium Myrlillus und V. Vilis Idaea, begleitet von Rubus saxalilis ein, oder es bedecken Moose (Sphagnum compactum, Dissodon Froelichianus, Pogonatum alpinum, Oligotrichum hercynicum) und Flechten (besonders Cetraria islandica) den Boden. An freien Stellen, zwischen den Büschen, stellen sich gerne subalpine Stauden, wie Geranium silvaticum, Aconitum firmum, Adenostyles. Alliariae, Cirsium Erisithales, Mulgedium alpinum, ein.

Alpine Quelliluren. Gleichwie in der Voralpenregion ist auch in der Krummholzregion Salix silesiaca cine stete Begleiterin der Bachrinnsale, der sich gerne Sorbus Aucuparia, Sambucus racemosa, Ribes pelraeum, Rosa pendulina und hie und da auch andere Weidenarten (Salix nigricans, S. bicolor, S. glauca) zugesellen, während $S$. grandifolia den Karpathen fehlt. Neben und zwischen diesen Sträuchern aber finden sich meist üppige, lebhaft blühende Stauden und Farne, so vor allem Athyrium alpestre, Dryopleris spinulosa, Phyllites Scolopendrium; dann Deschampsia caespilosa, Calamagrostis villosa, Poa Chaixii, Aconilum firmum, Delphinium elatum und D. oxysepalum, Ranunculus platanifolius, Trollius europaeus, Cardamine Opizii, Arabis alpina, A. neglecta, Heliosperma quadrifidum, Chaerophyllum Cicutaria, Anthriscus nitidus, Heracleum flavescens, Angelica Archangelica, Rumex scutalus, Pedicularis sumana, Senecio subalpinus, Doronicum austriacum, Adenoslyles Alliariae, Carduus Personatus, Valeriana tripteris, Epilobium alpestre und $E$. anagallidifolium, Viola biflora, Saxifraga aizoides, Pinguicula vulgaris, Allium victoriale. 


\section{b) Grasiluriormationer.}

Hochhalmige Alpenwiesen. Hochhalmige Alpenwiesen, von den Voralpenwiesen nur wenig verschieden, sind in der Krummholzregion der Westkarpathen auf tiefgrundigem Humus keineswegs selten. Die wichtigsten Gräser, die diese Wiesen zusammensetzen, sind Agroslis alba und A. canina, Phleum alpinum und P. Michelii, Deschampsia caespitosa, Triselum fuscum und T. macrotrichum, Poa alpina, Fesluca Talrae, F. alpina und F. varia, Carex alrata, C. sempervirens, Luzula sudelica. Dazwischen finden sich Gymnadenia albida und G. odoratissima, Orchis globosa, Polygonum Bistorta, Thesium alpinum, Cerastium macrocarpum, Anemone alba und A. narcissiflora, Ranunculus monlanus, Geum monlanum, Viola sudelica, Liqusticum Mutellina, Geranium silvaticum, Gentiana asclepiadea, G. punclala und G. carpalica, Primula elalior, Phyteuma orbiculare, Aleclorolophus pulcher, Campanula glomerata *elliptica und C. pseudolanceolata, Achillea distans, Chrysanthemum corymbosum, Solidago alpestris, Crepis conyzifolia, Hypochoeris uniflora, Hieracium aurantiacum, H. nigritum, H. stygium, H. carpalicum, H. Wimmeri, H. prenanthoides usw.

Die Formation des zweizelligen Kammgrases. (Oreochloa disticha.) In höheren Lagen, besonders auf einer minder mächtigen Humuslage treten im Gebiete der Zentralkarpathen Alpenmatten auf, die, im allgemeinen den Krummseggenrasen (Carex curvula) der Ostalpen und Ostkarpathen entsprechend, sich von diesem vor allem durch das Fehlen der genannten Leitart unterscheiden, an deren Stelle vor allem Oreochloa dislicha, ferner Agrostis rupestris und Avena versicolor treten. Die genannten drei Gramineen bilden im Vereine mit Poa alpina, Phleum alpinum, Nardus stricla, Festuca varia und F. supina, Carex sempervirens und C. fuliginosa, Luzula spadicea und L. spicala die Grasnarbe, in der niederliegende Spaliersträucher, wie Salix herbacea und S. retusa ihre Zweige ausbreiten. In tieferen Lagen (in der Krummholzregion) treten auch Vaccinium Myrtillus und V. Vilis Idaea stellenweise in Mengen auf. Häufig finden sich auch Strauchflechten (Cetraria islandica, C. cucullala, Thamniola vermicularis, Alectoria ochroleuca), die oft dichte Rasen bilden oder mit den Gräsern und Zwergsträuchern sich zu einem Teppiche verweben; auch Moose (Pogonatum alpinum, Dicranum albicans) bilden oft dichte Polster. Von den zahlreichen, alpinen Stauden sind ob ihrer Häufigkeit vor allem zu nennen Silene acaulis, Ranunculus montanus, Veronica alpina, Campanula alpina, Homogyne alpina, Hieracium alpinum und H. Auricula; ferner Botrychium Lunaria, Coeloglossum viride, Gymnadenia albida, Polygonum viviparum, Anemone alba, A. narcissiflora, Ranunculus alpestris, Arabis sudelica, Dianthus glacialis, Linum extraaxillare, Trifolium badium, Geum montanum, Potentilla aurea, Saxifraga hieracifolia, Ligusticum Mulellina, L. simplex, Gnaphalium norvegicum, Antennaria carpalica, Senecio capitalus, S. carniolicus, Hieracium tatrense, Campanula Scheuchzeri, Gentiana Chusii, Veronica aphylla, Pedicularis verlicillata und P. Oederi, Barlschia alpina, Euphrasia salisburgensis, Thymus pulcherrimus usw. 


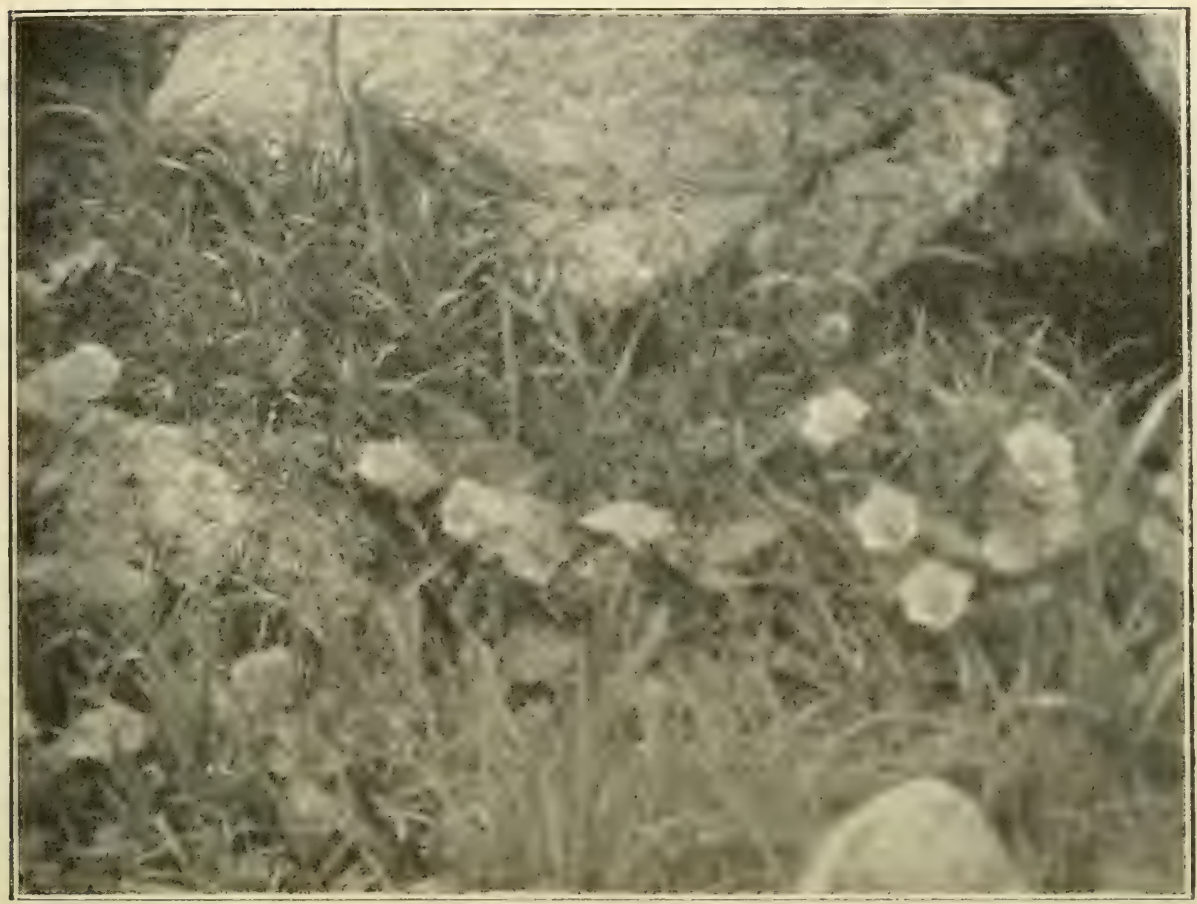

Abb. 177. Geum montanum am Meerauge in der Hohen Tatra. (Nach einer Aufnahme von A. v. Hayck.)

Die Formation der Polstersegge. (Carex firma.) Auf Kalliboden treten in der alpinen Region ein Gras, Sesleria varia, und eine Segge, Carex firma, gewöhnlich in tonangebender Menge auf. Mit ihnen findet man auch $P$ oa alpina, Phleum alpinum, Festuca varia, Carex sempervirens, C. alrala und C. capillaris, und selbst Oreochloa disticha meidet den Kalk nicht ganz. Von Spaliersträuchern finden sich neben Salix reticulala und $S$. relusa auch Salix Jacquini, Loiseleuria procumbens und vor allem Dryas oclopetala. Ferner treten häufig Ranunculus Thora, Saxifraga Aizoon und S. caesia, Gypsophila repens, Bisculella laevigala, Helianthemum alpestre, Minuartia Gerardi, Oxytropis Halleri und $O$. carpatica, Astragalus alpinus, A. australis und A. oroboides, Hedysarum obscurum, Polentilla aurea, Sedum atralum, Bupleurum ranunculoides, Aster alpinus, Leontopodium alpinum, Antennaria carpatica, Gentiana Clusii, Primula Auricula, Androsace Chamaeiasme, Veronica alpina, V. aphylla und V. fruticans, Euphrasia salisburgensis, Pedicularis Oederi,P. verlicillala, Gymnadenia albida, G. odoratissima, Tofieldia calyculata usw. auf.

Lägerflora. Die Weidewirtschaft mit ihren Sennhütten (,Stinen“) bringt manche Veränderung in der Alpenflora mit sich. Auf stark beweideten Wiesen und Matten, besonders in der Nähe der Sennhütten, siedeln sich zahlreiche Gewächse tieferer Lager an, so vor allem Stellaria graminea, Ranunculus acer, Capsella Bursa pastoris, Geum urbanum, Trifolium pratense und T. repens, 
Prunella vulgaris, Veronica officinalis, $V$. Chamaedrys und $V$. serpyllifolia, Planlago maior und P. media, Leontodon danubialis und L. aulumnalis, Hieracium Pilosella usw. Auf dem stets feuchten und überdüngten Boden in der nächsten Umgebung der Sennhütten findet man eine eigentümliche Flora, die man als „Lägerflora" bezeichnet. Rumex alpinus bildet da in der Regel die Hauptmasse der Vegetation und erscheint gewöhnlich in solcher Masse, daß jeder andere Pflanzenwuchs ersticlit wird. Urtica dioeca ist ebenfalls oft nicht selten, ferner Senecio subalpinus und S. rivularis, Aconilum firmum und üppig wuchernde Alchimillen.

\section{c) Hygrophile Staudenformationen.}

Apine Quellfuren. An feuchten quelligen Stellen in der Kirummholzregion pflegen niedere alpine IVeiden, wie Salix retusa, S. Jacquini, seltener S. hastata, L. arbuscula und S. Lapponum in Menge aufzutreten, mit ihnen Empetrum nigrum und Vaccinium uliginosum. Häufig sind an solchen Stellen Pedicularis verlicillata und P. Oederi, Sweertia perennis, Epilobium alsinefolium, Polygonum viviparum, Heliosperma quadrifidum, Bartschia alpina, Pinguicula alpina, ferner einzelne Gyperazeen, wie Eriophorum Scheuchzeri und Carex Goodenoughii und $C$. Oederi, die erst genannte besonders dort, wo der Boden durch reichliches Auftreten von Torfmoosen einen moorartigen Gharakter annimmt.

Schneetälchenrasen. Auf dem vom kalten Schmelzwasser der Schneeflecken stets durchfeuchteten, tief humösen Boden findet sich in den Karpathen gleichwie in den Alpen eine äußerst charaliteristische Vegetation, die besonders auf liallfreiem Substrate typisch ausgebildet ist. Sehr charaliteristisch für dieselbe sind vor allem die Alpenglöckchen (Soldanella carpalica), die dicht am Schnee oder denselben selbst durchwachsend zu Hunderten ihre blauen Glöckchen erheben. Gern gesellen sich ihr die tiefrote Primula minima sowie die weißen Alpenranunkeln (Ranunculus alpestris und R. glacialis, Callianthemum coriandrifolium) bei. Manche Moose, vor allem Polytrichum sexangulare, bilden oft cinen dichten Polster, in dem Arenaria biflora, Ceraslum cerastioides und die zierliche Saxifraga carpatica sowie $S$. androsacea ihre weißen Blüten erheben. Auch Oxyria digyna, Polygonum viviparum, Arabis neglecta, Epilobium anagallidifolium, Lloydia serolina und der seltene Ranunculus pygmaeus gehören dieser Genossenschaft an und auch Salix herbacea kriecht gern in dem durchfeuchteten Boden umher.

\section{d) Xerophile Staudenformationen.}

Felsschuttiloren. a) Auf Kalk. Im Kalkschutte der Hochgebirge siedelt sich bald eine eigenartige Tegetation an. Tielfach sind es Stauden mit verzweigtem, Stämmchen treibendem Rhizom, die, vom Schutte verschüttet, weiter fortwachsen, um bald wieder ans Tageslicht zu gelangen. Hierher gehört z. B. Silene alpina, Gypsophila repens, Rumex sculatus, Papaver Burseri, Scabiosa lucida, Poa cenisia; ferner finden sich auf den Schutthalden gern Ranunculus 


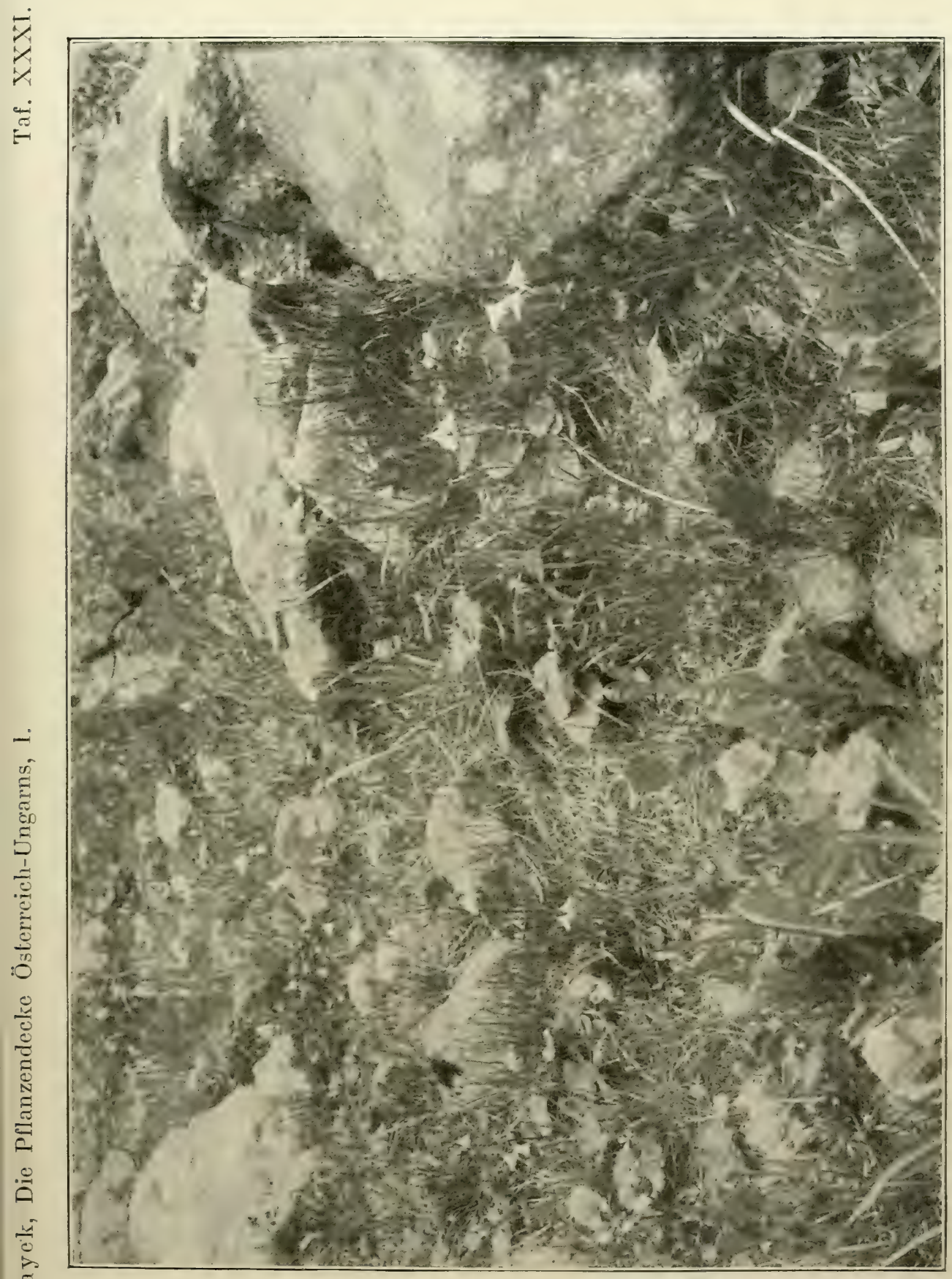

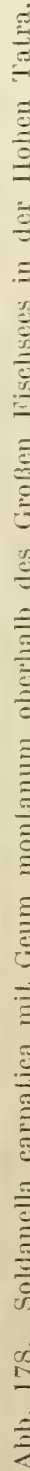



Thora, Biscutella laevigala, Arenaria ciliala, Minuartia Gerardi, Linum extraaxillare, Oxytropis carpatica, Hedysarum obscurum, Dryas octopetala, Saxifraga caesia, S. aizoides, S. perdurans, Carduus glaucus, Leontodon clavatus, Crepis Jacquini, Hieracium glaucum, H. bupleuroides, H. villosum, H. dentatum, Veronica fruticans, Euphrasia salisburgensis, Tofieldia calyculala.

b) Auf Urgestein. Viel artenärmer ist die Flora des meist aus großen Blöcken bestehenden Gerölles der Urgebirge. Rumex sculalus, Senecio carpaticus,

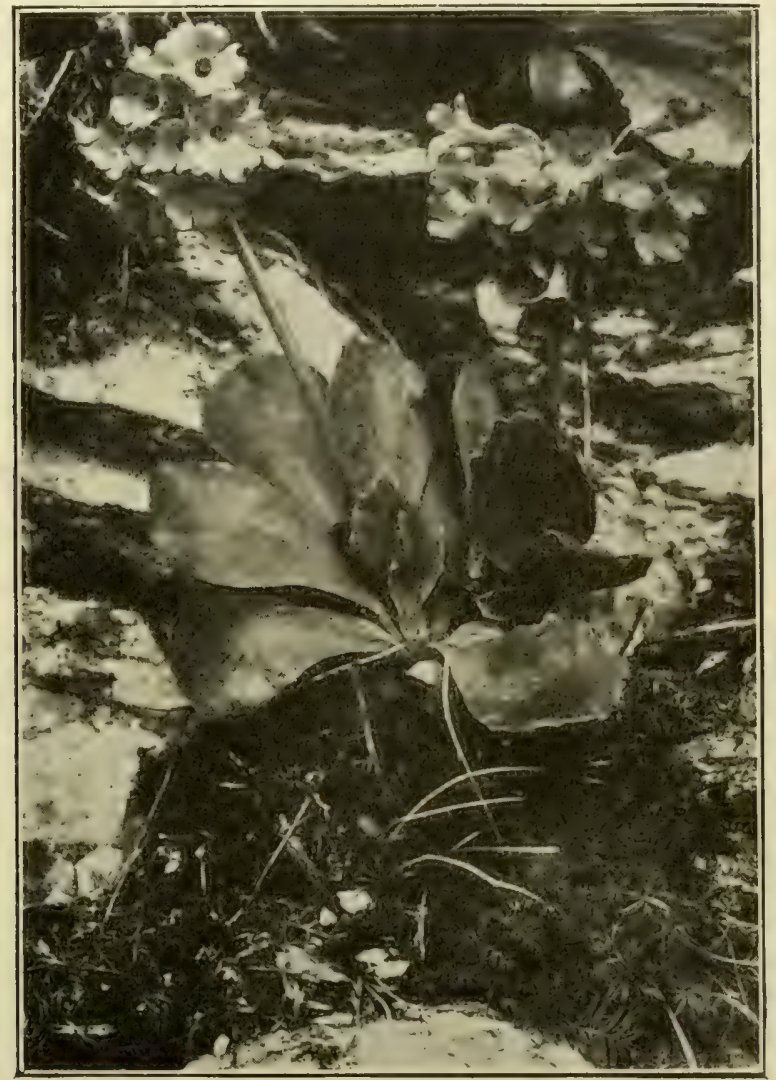

Abb. 179. Primula Auricula und Astragalis australis an Kalkfelsen in den Belaer Kalkalpen.

(Nach einer Aufnahme von G. Nyarádyi, Maros-Vasarhely.)

Chrysanthemum alpinum, Cerastium villosum mit Poa alpina, Oreochloa disticha und Agrostis rupestris sind die wichtigsten Vertreter dieser Flora, während der an ähnlichen Standorten in den Zentralalpen so verbreitete Allosorus crispus den Westkarpathen fehlt.

Alpine Felsenflora. a) Auf Kalk. An Kalkfelsen der alpinen Region ist meist eine reiche Flora entwickelt. Sesleria varia, Oreochloa disticha, Carex capillaris, C. alrata, C. firma, C. sempervirens sind von grasartigen Gewächsen die häufigsten. Häufig sind ferner Saxifragen, wie S. Aizoon, S. caesia, 
S. perdurans, S. moschata, und Leguminosen, vor allem Hedysarum obscurum, Oxytropis sericea, O. campestris, O. carpatica, Hippocrepis comosa, Astragalus alpinus, A. australis und A. frigidus, Anthyllis alpestris sowie das EdelweiB (Leonlopodium alpinum); außerdem finden sich Gypsophila repens, Asler alpinus, Erigeron hungaricus und E. alticus, Hulchinsia alpina, Sedum alratum, Sempervivum carpaticum, Hieracium villosum, $H$. denlatum, Veronica frulicans, Primula Auricula usw.

An feuchten Felsen aber siedeln sich gern mannigfache Moose (Bryum elegans, Amblyodon dealbatus, Homalothecium Phillippeanum, Leptotrichum. flexicaule) an, ferner Selaginella selaginoides, Polygala alpestris, Heliosperma quadrifidum, Asler Bellidiastrum, Campanula cochleariaefolia, Arabis sudetica, Corlusa Malthioli, Campanula carpatica u. a.

b) Auf Gneis und Granit. Auf Gneis- und Granitfelsen fallen vor allem die zahlreichen, lebhaft gefärbten Flechten sehr ins Auge, in erster Linie das ungemein häufige Rhizocarpon geographicum, ferner Gyrophora cylindrica, G. tornala, Cornicularia aculeala, auch Thamniola vermicularis und Celrarien. Von Moosen sind Andraea pelrophila und A. rupestris sowie Pogonalum alpinum häufig. Im übrigen ist die Flora im Verhältnisse zu der der Kalkfelsen arm und besteht aus Carex alrala, C. fuliginosa und $C$. sempervirens, Poa alpina und P. laxa, Oreochloa dislicha, Agrostis rupestris, Festuca picla und F. varia, Lycopodium Selago, Saxifraga perdurans und S. aizoon, Sempervivum soboliferum und S. carpalicum, Senecio carpalicus und S. carniolicus, Hieracium alpinum, Saxifraga hieracifolia usw. An feuchten Felsen, wo von Moosen insbesonders Oligolrichum hercynicuin oft in Masse auftritt, finden sich auch Sweertia perennis, Primula minima, Myosolis alpestris, Barlschia alpina, Alchimilla glaberrima, Arabis alpina und $A$. neglecla, Cardamine resedifolia und die seltene Saxifraga cernua.

Gesteinfluren. Auf den höhchsten Gipfeln der Tatra fehlt eine zusammenhängende Pflanzendecke: zerstückelte Rasenflächen bedecken die Felsschrofen, und im Gesteinsgrus und in den Felsspalten siedeln sich überall Vertreter der subnivalen Flora an. Poa laxa ist in dieser Höhenlage das weitaus häufigste Gras, ihr gesellen sich noch Agrostis rupestris, Oreochloa disticha und Carex fuliginosa zur. Nicht selten sind Luzula spadicea und L. spicala, an feuchten Stellen überall Primula minima und Ranunculus glacialis. Auch Juncus trifidus ist stellenweise im Gefels zu finden, Salix herbacea und $S$. relusa steigen bis an die höchsten Gipfel an; Minuarlia sedoides und Silene acaulis bilden oft mächtige Polster und ihnen im Wuchse ähnlich sind die kleinen Saxifragen S. perdurans und S. moschata; Barlschia alpina, Pedicularis verlicillata, Myosotis alpestris, Gentiana frigida, Doronicum Clusii, Senecio capilatus, S. carniolicus und S. carpaticus, Hieracium alpinum, Saussurea alpina und S. pygmaea, Gnaphalium supinum, Antennaria carpatica, Sempervivum carpaticum, Sedum roseum, Geum replans, Saxifraga hieracifolia, Cochlearia excelsa, Dianthus glacialis, Anemone alba und $A$. narcissiflora, Ranunculus montanus schmücken im buntesten 


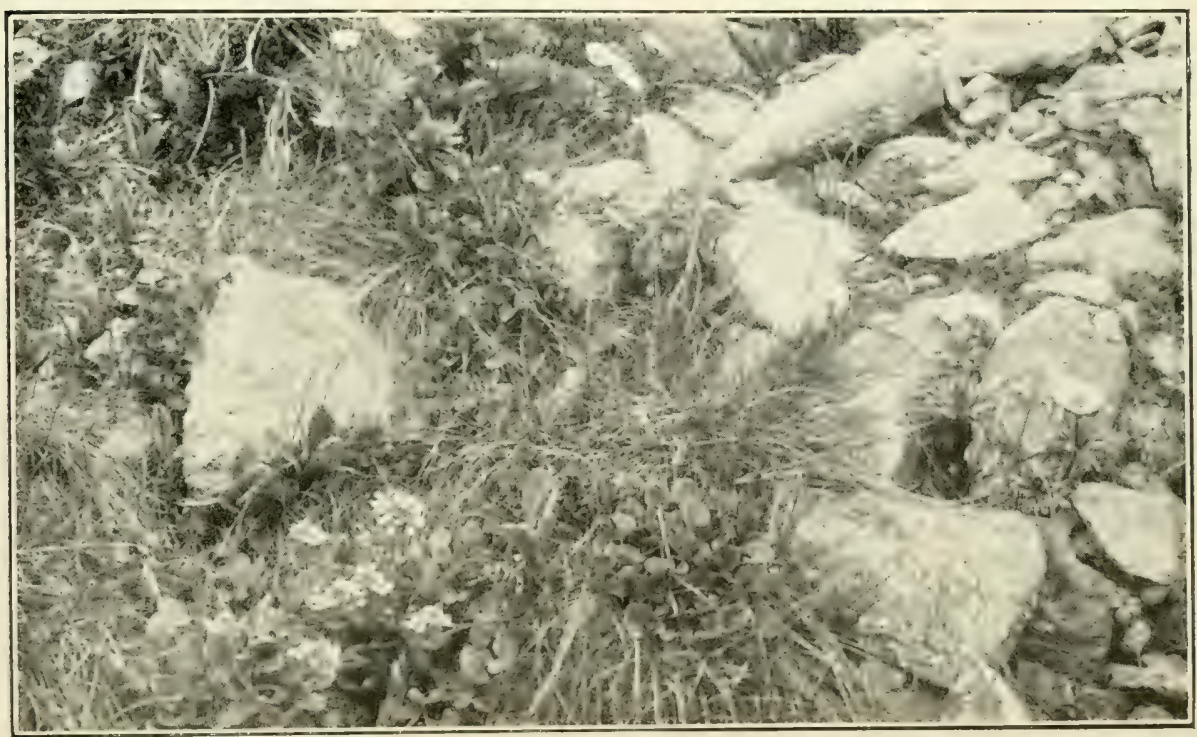

Abl. 180. Gesteinsflur auf dem Polnischen Kamm in der Hohen Tatra. Ranunculus glacialis, Cochlearia excelsa, Lloydia serotina.

(Nach einer Aufnahme von A. v. Hayel.)

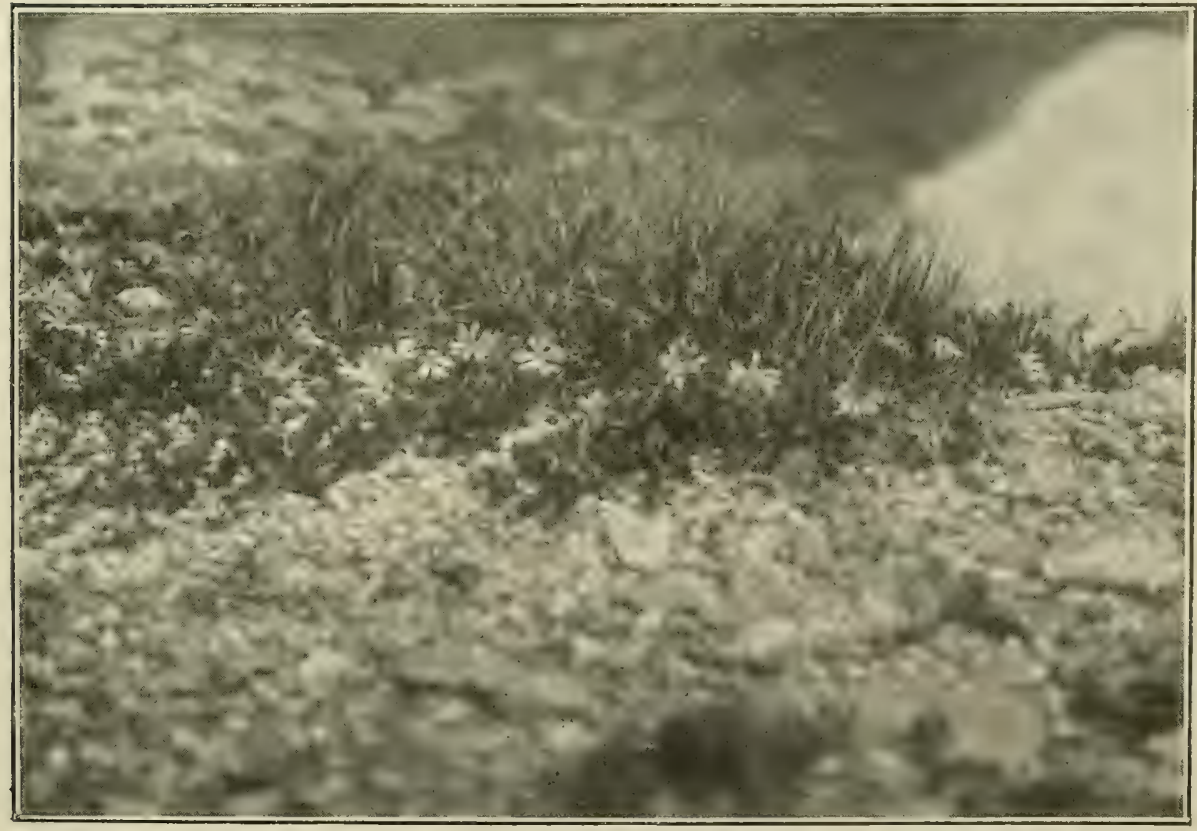

Abb. 181. Primula minima unterhalb des Gefrornen Sees in der Hohen Tatra.

(Nach einer Aufnahme von A. V. Hayek.) 

Farbengemisch das nackte Gestein. In den höchsten Regionen, von $2300 \mathrm{~m}$ aufwärts, wird aber diese Zahl rasch reduziert. Poa laxa, Ranunculus glacialis, Cerastium villosum, Myosolis alpestris, Senecio carniolicus, Primula minima aber steigen bis zu den höchsten Gipfeln an und zu ihnen gesellen sich die kleinen Saxifragen, S. carpatica, S. moschala, S. bryoides, S. oppositifolia und S. Wulfeniana.

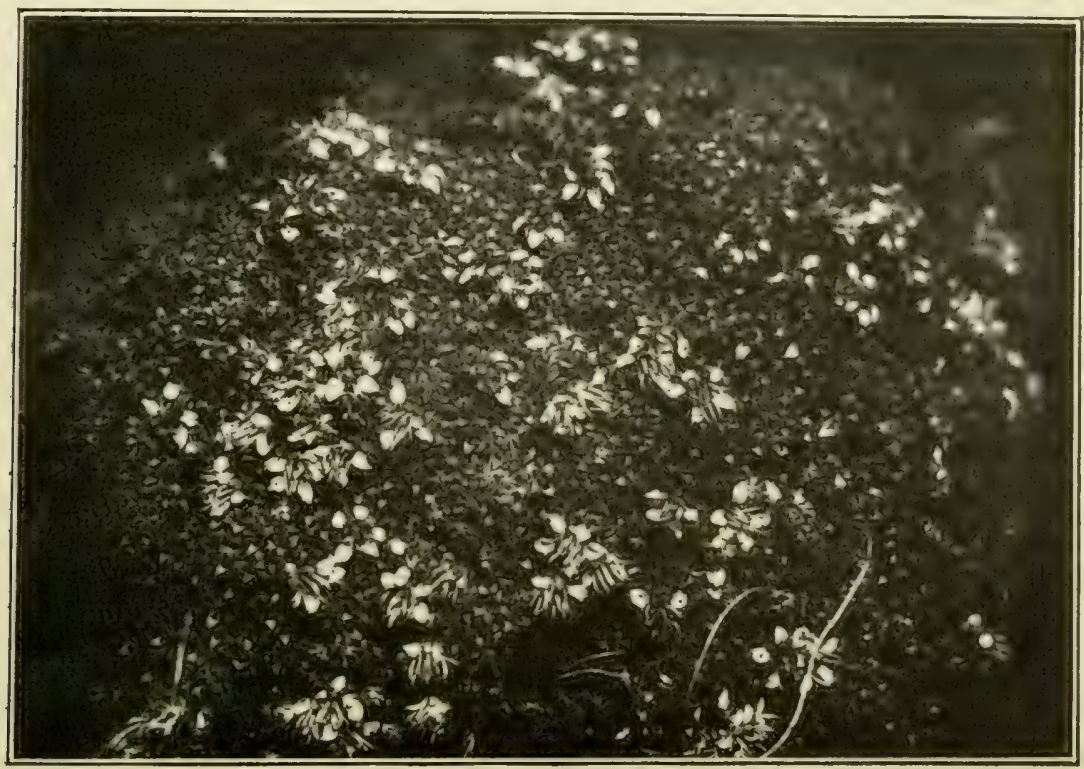

Abb. 182. Blühender Polster von Saxifraga Wulfeniana in der Hohen Tatra. (Nat. Gr.)

(Nach einer Aufnahme von G. Nyarádyi, Maros-Vasarhely.)

\section{Die Ostkarpathen.}

\section{Die Pflanzengenossenschaften der Hügel und der niederen Bergregion.}

\section{a) Waldiormationen.}

Der dazische Eichenwald. Im ganzen zentralsiebenbürgischen Hügellande, mit Ausnahme des waldlosen Gebietes der Mezöség, sowie fast überall am Fuße der Randgebirge sind Laubmischwälder, in denen Eichen vorherrschen, oder selbst reine Eichenbestände sehr verbreitet. In ihrer Zusammensetzung weichen sie im allgemeinen nicht sehr wesentlich von denen der Westkarpathen ab, wenn auch speziell in den Arten des Niederwuchses sich Unterschiede zeigen. So fehlen Hacquetia Epipactis und Primula vulgaris in Siebenbürgen ganz und Anemone Hepatica ist auf den westlichen Teil der Landschaft beschränkt. Hingegen sind als im Westen fehlende Arten Veratrum nigrum, Melandryum nemorale, Polentilla chrysantha, Hieracium transilvanicum und der im Westen nur im Bükk- 
gebirge und der Mátra vorkommende Helleborus purpurascens mit seiner Form Baumgarlenii zu nennen, ferner von minderverbreiteten Arten Carex transilvanica, Ferula silvalica, Veronica Bachofenii, Cirsium furiens usw.; auch das westliche Melampyrum nemorosum wird im Osten durch das verwandte M. bihariense vertreten. Im südwestlichen Teile Siebenbürgens und im Banate aber treten neue fremde Elemente im Eichenwalde auf. So tritt zu Quercus Robur, Qu. sessiliflora, Qu. pubescens und Qu. Cerris eine neue fünfte Eichenart hinzu, die durch ihr prachtvolles großes Laub ausgezeichnete Zigeunereiche (Quercus conferla). Auch die Silberlinde (Tilia tomentosa) mit ihrem zweifarbigen Laub ist dem Westen fremd. Im Unterholze werden nach Südwesten hin die im östlichen und nordöstlichen Teile Siebenbürgens meist fehlenden Arten Acer lataricum und Colinus Coggygria immer häufiger und im Banat gesellen sich Fraxinus Ornus und Carpinus orientalis hinzu; eine wahre Zierde der Wälder aber bieten im Westen und Südwesten Siebenbürgens, von der Marmaros bis ins Banat, die beiden prächtigen heimischen Fliederarten Syringa Josikaea und S. vulgaris, von denen die erstere vom Innenrande der Waldkarpathen bis ins Bihariagebirge, die letztere von den Tälern der Parenggruppe bis ins Banat sich erstreckt. Im äußersten Süden des Banates wird die Zusammensetzung des Waldes noch reicher. Im Oberholze tritt hie und da die Baumhasel (Corylus Colurna) und die wilde Waldnuß (Juglans regia) auf, im Niederwuchse findet man manche südliche Art, wie Ruscus aculealus, R. Hypoglossum, Oxyzopsis virescens, Trifolium Molineri, T. expansum, Digilalis lanala, Acanthus hungaricus und als Lianen treten neben Clematis Vitalba auch Calystegia silvalica, Vitis silvestris und Tamus communis auf.

Die obere Grenze der Eichen liegt in Siebenbürgen durchschnittlich höher als in den Westkarpathen, die obere Grenze von Quercus sessiliflora kann in Siebenbürgen auf $850 \mathrm{~m}$ veranschlagt werden, während im Bihariagebirge Quercus Robur schon bei $300 \mathrm{~m}$, Qu. Cerris bei $690 \mathrm{~m}$, Qu. sesseliflora bei $820 \mathrm{~m}$ ihre obere Grenze finden, obwohl letztere in einzelnen Exemplaren bis $1200 \mathrm{~m}$ ansteigt.

Birkenbestände treten in den Ostkarpathen, besonders am Südfuße der Waldkarpathen, als Fortsetzung der Birkenwälder der dem Tieflande angehörenden "Nyirgegend" auf. Charakteristisch für dieselben ist insbesondere das massenhafte Auftreten von Pleridium aquilinum.

Buchenwälder. Die reich entwickelten Buchenwälder Siebenbürgens und rles Banates, die im Bihariagebirge bei etwa 500 m auftreten, im südlichen Banate aber bis ins Tal herabsteigen, sind vor denen der Westkarpathen durch den Besitz einer Reihe von Charakterpflanzen ausgezeichnet. $\mathrm{Zu}$ diesen gehört vor allem das sich nach Westen bis Kroatien und Südsteiermark erstreckende weichhaarige Hieracium transsilvanicum, der schon oben genannte braunrote Helleborus. purpurascens, die rotblühende Pulmonaria rubra; in den Waldkarpathen ist Aposeris foelida ein bis in die Hügelregion herabsteigender Buchenbegleiter und auch Melandryum nemorale und Telekia speciosa fehlen im Buchenwalde selten. 


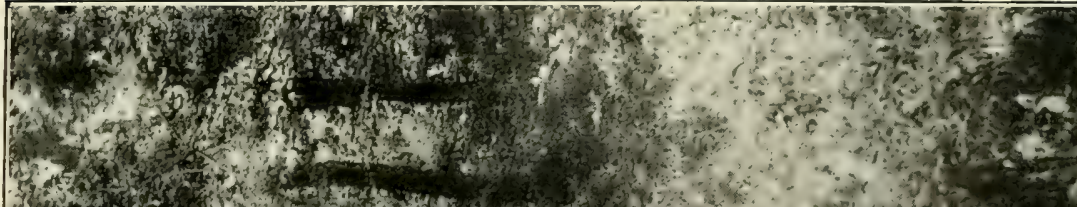

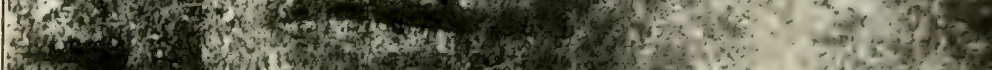

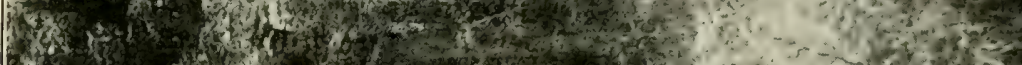

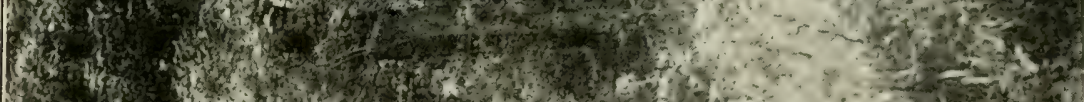

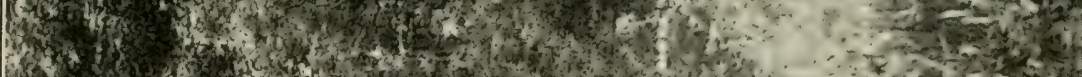

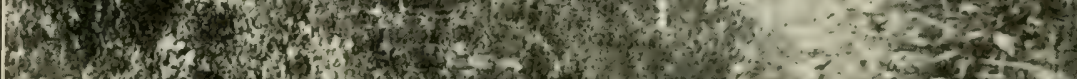

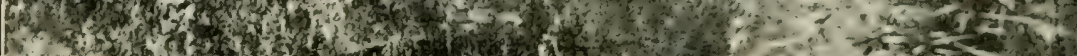

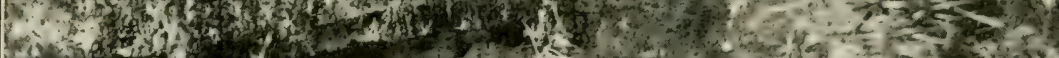

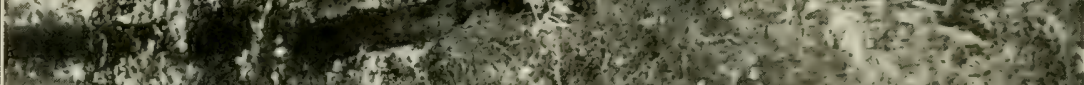

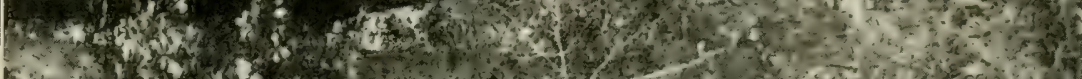

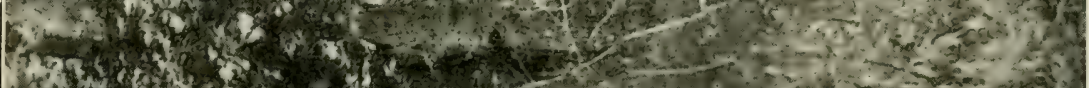

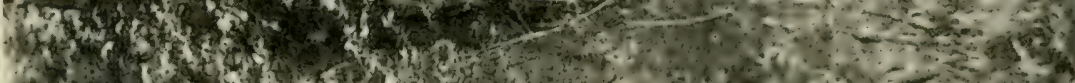

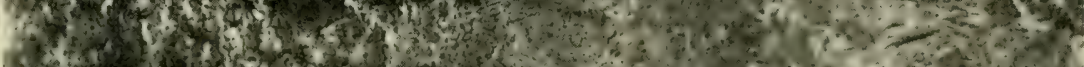

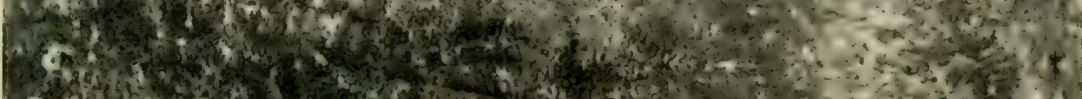

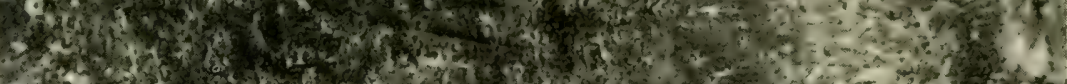
Q

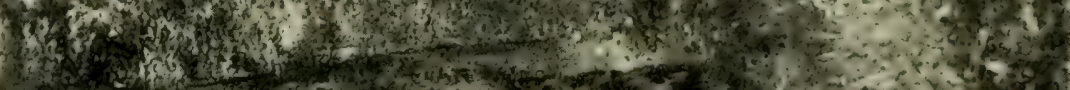

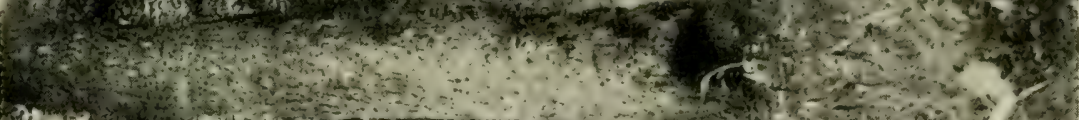

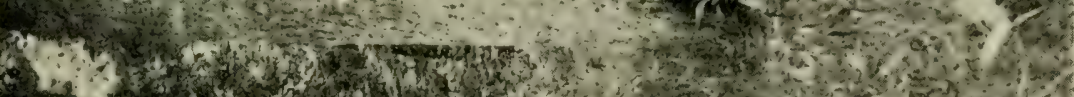

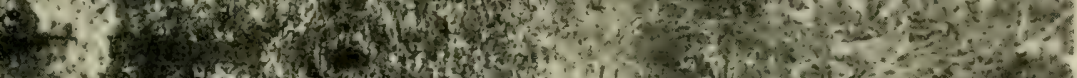

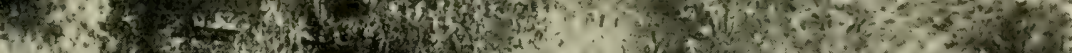

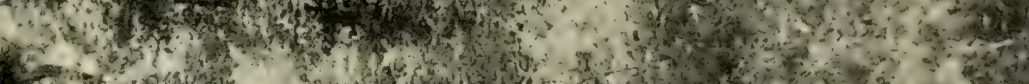

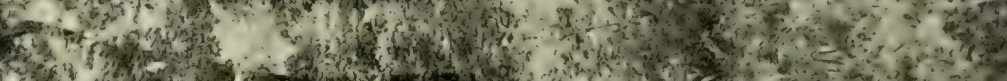

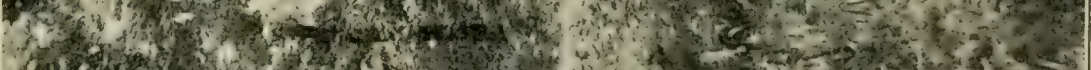

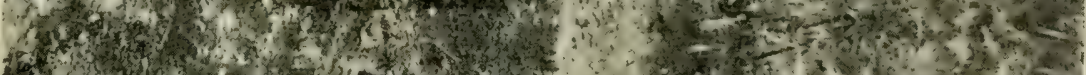

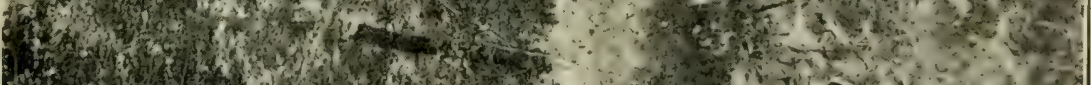

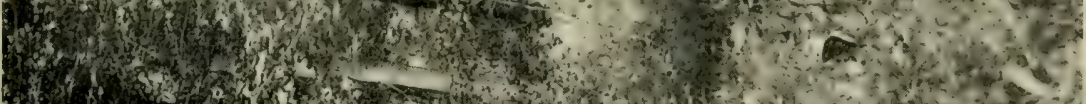

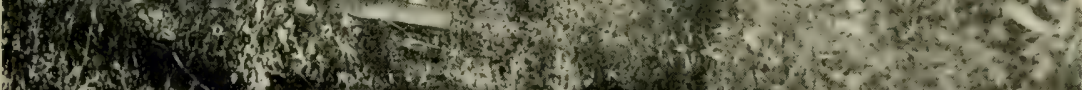

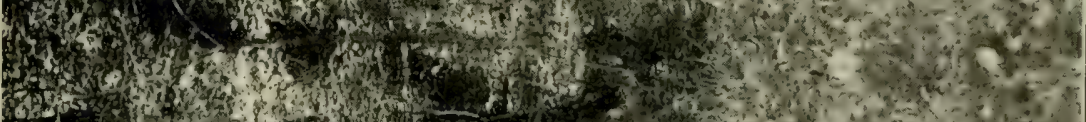

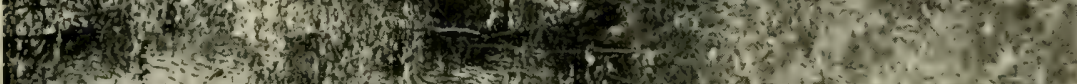

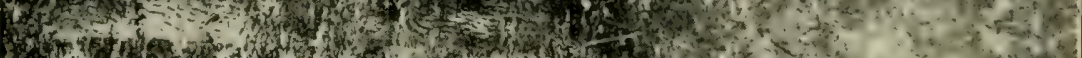

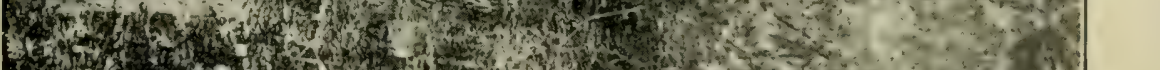



Ferner ist im größten Teile von Sicbenbürgen Anemone transilvanica im Buchenwalde zu finden und Cardamine glandulosa und C. bulbifera sind allgemein verbreitet, während $G$. enneaphyllos dem Osten fehlt.

Föhrenwälder. Wälder aus Pinus silveslris treten in den Ostkarpathen hauptsächlich im nördlichen Siebenbürgen auf. Als charakteristische Pflanze derselben kann nur Hieracium Pavichii (Fussianum) genannt werden.

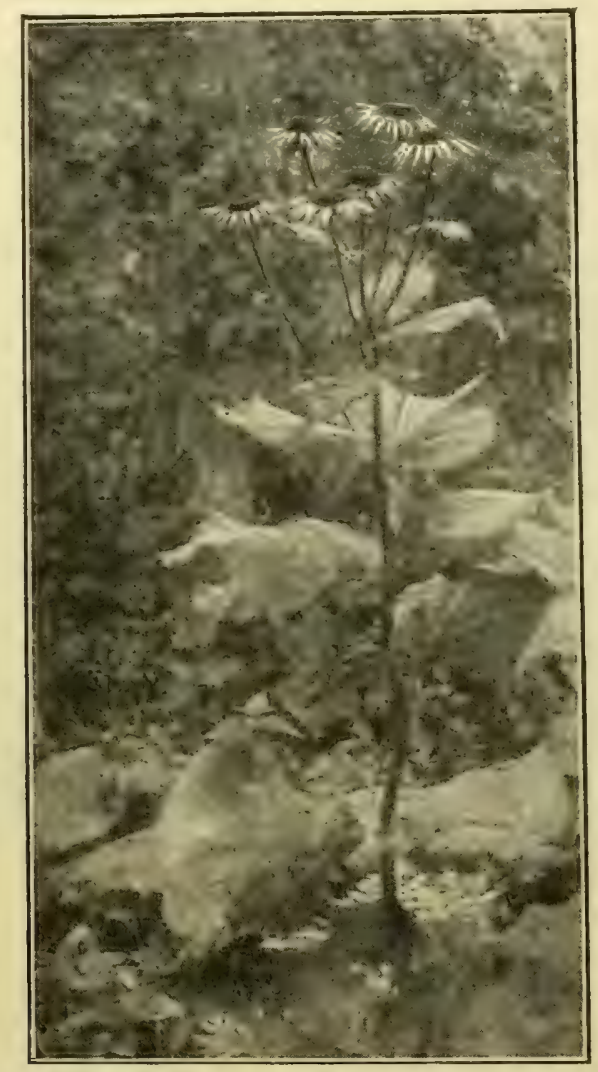

Abb. 184. Telekia speciosa im Ufergebüsch des Großen Weidenbachtales bei Rosenau nächst Kronstadt.

(Nach einer Aufnahme von A, v. Hayek.)

Auenwälder und Ufergebüsche sind in den Ostkarpathen in tieferen Lagen ebenso häufig anzutreffen wie im Westen, bieten aber wenig Eigentümliches. Doch ist zu bemerken, daß Salix incana, die in der Marmaros noch häufig ist, weiter östlich und südlich fast vollkommen fehlt und nur vereinzelt im Gebiete des Bucsecs auftritt. Auch tritt an Stelle von Calyslegia sepium die $C$. silvalica und in den Ufergebüschen ist die stattliche Inula Helenium nicht selten und auch Telekia speciosa tritt nicht selten schon in der Talregion auf. 


\section{b) Strauchiormationen.}

Wacholdergebüsche treten in den Wallkarpathen und in Siebenbürgen viel seltener auf als in den Westkarpathen, sind aber doch stellenweise, wie auf den Trachytstöcken der Hargila und des Kelemen, mächtig entwickelt und noch bei einer Höhe von $1400 \mathrm{~m}$ anzutreffen. Neben den Wacholdergebüschen aber tritt in Siebenbürgen und im Banat eine andere Buschformation auf, die, fast durchwegs aus laubabwerfenden Sträuchern bestehend, am besten als

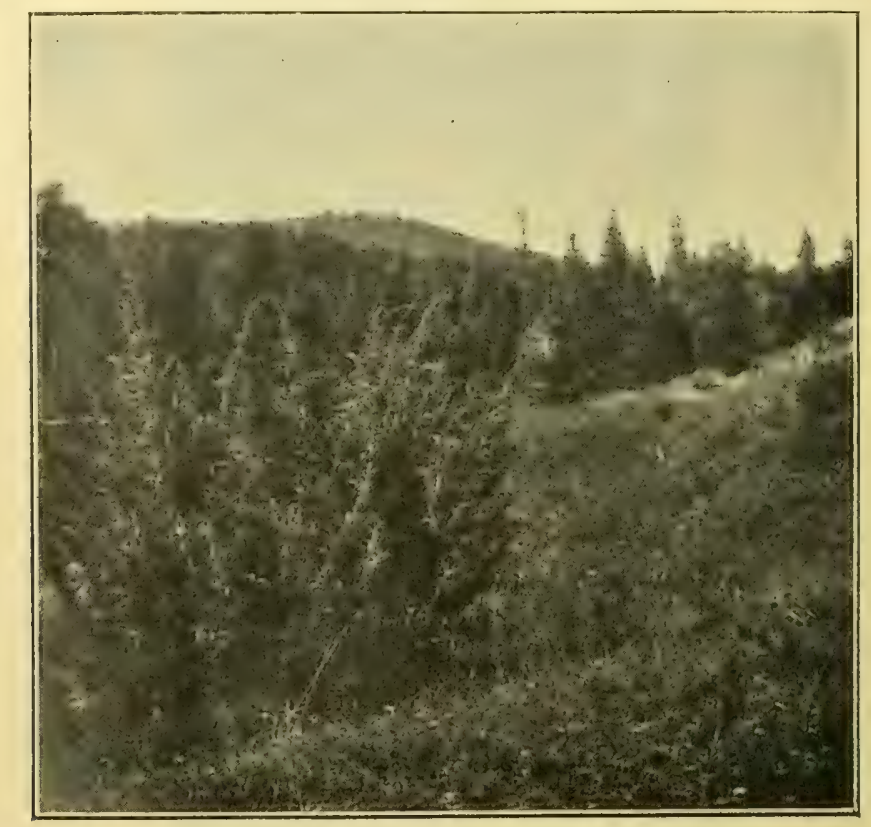

Abb. 185. Wacholdergebüsch auf einer Voralpenweide auf dem Runc bei Krasna-Ilska nächst Czernowitz.

(Nach einer Aufnahme von C. Frh. v. Hormuzaki, Czernowitz.)

Formation des Perückenstrauches bezeichnet wird. Eichengestrüpp, vor allem Quercus pubescens, verschiedenartige Rosen, Cralaegus, Ligustrum, Evonymus vulgaris und $E$. verrucosus, Slaphylea pinnata sind weit verbreitete Bestandteile dieses Buschwerkes; dazu aber gesellten sich als südliche Elemente der Perrückenstrauch (Colinus Coggygria), dis Mannaesche (Fraxinus Ornus), die orientalische Hainbuche (Carpinus orientalis) und eine flaumblätterige Schlehe (Prunus dasyphylla): auch Acer tataricum tritt nicht selten in diese Formation cin. Dazu gesellen sich zahlreiche strauchige Leguminosen, besonders Cylisus-Arten ( $C$. nigricans, pallidus, albus, banalicus), ferner Genista Malyeri, Dorycnium herbaceum u. a. Clematis Vilalba und Calystegia silvalica sind überaus häufige Schlinggervächse; im Gebüsche aber wachsen zahlreiche Stauden und Kräuter der Bergtrifte, besonders Verbascum-Arten ( $V$. banaticum, nigrum, phoeniceum usw.), Anchasa Barellierii, Orlaya grandiflora, Echinops 
Die europäischen Gattungen der Farn- und Blütenpflanzen nach dem Wettsteinschen System geordnet

von

Erwin Janchen.

Zweite, verbesserte Auflage.

Preis M. $2 \cdot-=\mathrm{K} 2 \cdot 40$.

\section{Waldwegebaukunde.}

Von

dipl. For. Julius Marchet,

o. o. Professor an der k. k. Hoohsohule für Bodenkultur in Wien, Fachberichterstatter des k. k. Ackerbauministeriums.

I. Band: Das Trassieren und die Projektverfassung.

Nit 15 lithographischen Tafeln und 29 Abbildungen im Text.

Preis M. $7 \cdot 50=\mathrm{K} 8 \cdot 40$.

\section{Der Holzhandel Norddeutschlands.}

Von

dipl. For. Julius Marchet,

o. ö. Professor an der k. k. Hochschule für Bodenkultur in Wien,

Fachberichterstatter des k. k. Ackerbauministeriums.

Mit 16 Abbildungen, 1 Situationsplane und 1 Karte.

Preis M. $7 \cdot-=K 8 \cdot 40$.

\section{Die Grundlagen der Bodenkunde.}

Von

Dr. L. Milch,

Privatdozent für Mineralogie und Geologie an der Universität Breslau.

Prois N: $4:=\mathrm{K} 4: 80$.

Flora des österreichischen Küstenlandes.

$$
\text { - Von }
$$

Eduard Pospichal.

Mit 25 Tabellen und einer Karte des österreichischen Küstenlandes.

Zwei Bände in drei Teilen.

Preis eines jeden Teiles geh. M. $8^{\circ}-=\mathrm{K} 9 \cdot 60$, geb. M. 10 $-=\mathrm{K} 12 \cdot$.

Einleitung in die experimentelle Morphologie der Tiere.

$$
\text { Von }
$$

Dr. phil. Hans Przibram,

Privatdozenten an der Wiener Universitait.

Preis M. $4 \cdot-=\mathrm{K} 4 \cdot 80$.

\section{Experimental-Zoologie. \\ Von \\ Dr. phil. Hans Przibram, \\ Privatdozenten an der Wiener Universität.}

\section{Teil. Embryogenese.}

Mit 16 lithographischen Tafeln.

Preis M. 7:- $=\mathrm{K} 8.40$.

II. Teil. Regeneration.

Mit 16 lithographischen Tafeln.

Preis M. $14^{\circ}-=\mathrm{K} 16 \cdot 80$.
III. 'Teil. Phylogenese.

Mit 24 lithographischen Tafeln.

Preis M. 18- = K 21.60.

$$
\text { IV. Teil. Vitalităt. }
$$

Mit 10 lithographischen Tafeln.

Preis M. 10 - = K 12. 


\section{Verlag von Franz Deuticke in Leipzig und Wien.}

\section{Lehrbuch der Pflanzenkunde}

fur die unteren Klassen der Mittelschulen

von

Dr. Rudolf Scharfetter,

k. k. Professor an der II. Staatsrealschule in Graz.

Nit 201 Abbildungen im Text und 28 farbigen Tafeln.

Preis geb. M. $3 \cdot 60=\mathrm{K} 4 \cdot$.

\section{Vitalismus.}

Elementare Lebensfunktionen.

Von

Dr. Karl Camillo Schneider,

Privatdozent an der Universität Wien.

Preis geh. M. $11-\doteqdot \mathrm{K} 13.20$, geb. M. $12 .=\mathrm{K} 14.40$.

Handbuch der systematischen Botanik.

Von

Dr. Richard R. v. Wettstein, Professor an der Universität in Wien.

$\mathrm{Z}$ weite, umgearbeitete Auflage.

Mit 3692 Figuren in 600 Abbildungen und mit einer farbigen Tafel.

Preis geh. M. $20^{\circ}-=\mathrm{K} 24^{\circ}-$, geb. M. $26^{\circ} 60=\mathrm{K} 32 \cdot$.

\section{Vegetationsbilder aus Südbrasilien.}

Von

Dr. Richard R. v. Wettstein,

Professor an der Universität in Wien.

Nit 58 Tafeln in Lichtdruck, 4, farbigen Tafeln und 6 Textbildern.

Preis M. $24-=\mathrm{K} 28 \cdot 80$

\section{Die Samenpflanzen.}

\section{(Blutenpflanzen, Phanerogamen.)}

Systematische Übersicht ilırer Familien und wichtigeren Gattungen und Arten mit besonderer Beruicksichtigung der fiir Land- und Forstwirtschaft, Techuik und Arzneikunde in

Betracht kommenden Gewächso

$$
\text { von }
$$

Dr. Karl Wilhelm,

o. ö. Professor der Botanik an der k. $k$. Hochschule für Bodenkultur in Wien.

Mit einem Anhange, enthaltend eine Übersicht der wichtigsten kryptogamen Nutzpflanzen.

Preis geh. M. 5- $=\mathrm{K} 6 \cdot-$, geb. M. $6 \cdot 20=\mathrm{K} 7 \cdot 40$.

\section{Grundriß der Waldwegebaulehre}

nebst einer Aufgabensammlung

und neuen Hilfstafeln zur Erdmassen-Berechnung

von

Dr. Karl Wimmenauer,

o. Professor der Forstwissenschaft an der Universităt Gießen.

Mit einer Waldkarte und 4 Figurentafeln.

Preis M. $4 \cdot-=\mathrm{K} 4: 80$.

\section{Grundriß der Waldwertrechnung und forstlichen Statik} nebst einer Aufgabensammlung

bearbeitet von

Dr. Karl Wimmenauer,

o. Professor der Forstwissenschaft an der Universităt Gießen.

Mit 1 Kurventafel.

Preis M. $3 \cdot-=\mathrm{K} \cdot 3 \cdot 60$. 


\section{DIE PFLANZENDECKE ÖSTERREICH-UNGARNS}

AUF GRUND FREMDER UND EIGENER FORSCHUNGEN GESCHILDERT

VON

Dr. AUGUST edler von HAYEK,

PRIVATDOZENT FÜR SYSTEMATISCIE BOTANIK AN DER UNIVERSITÄT WIEN.

HERAUSGEGEBEN MIT EINEII DRUCKKOSTENBEITRAG

DER KAISERLICHEN AKADEMIE DER WISSENSCHAFTEN IN WIEN.

VOLLSTÄNDIG IN ZWEL BÄNDEN VON ETWA JE 5 LIEFERUNGEN. MIT ZAHLREICHEN ABBILDUNGEN UND TAFELN.

PREIS JEDER LIEFERUNG $6 K=5 \mathrm{Mk}$.

\section{BAND.}

4. LIEFERUNG.

LEIPZIG UND WIEN.

FRANZ DEUTICKE.

1915.

Verlags $-\mathrm{Nr} .2110$ 


\section{Verlag von Franz Deuticke in Leipzig und Wien.}

\section{Die Erscheinung der Anisophyllie.}

Eine morphologisch-physiologische Studie von

Dr. Wilhelm Figdor,

Privatdozent für Anatomie und Physiologie der Pflanzen an der k. k. Universität in Wien.

Mit 23 Abbildungen im Text und 7 Tafeln in Lichtdruck.

Preis M. $7 \cdot-=\mathrm{K} 8 \cdot 40$.

\section{Landwirtschaftliche Pflanzenzüchtung} und ihre Stătten in Österreich.

Dargestellt von

Prof. C. Fruhwirth,

diplomierter Landwirt, Dozent an der k. k. Hochschule für Bodenkultur.

Preis M. $1 \cdot 80=$ K 2.-.

Führer zu den wissenschaftlichen Exkursionen

des II. internationalen Kongresses Wien 1905.

Herausgegeben vom

Organisationskomitee des II. internationalen botanischen Kongresses unter Mitwirkung von

A. Cieslar, A. Ginzberger, H. Freih. v. Handel-Mazzetti, A. v. Hayek, K. Maly,

V. Schiffner, F. Vierhapper und E. Zederbauer.

Mit 52 Lichtdrucktafeln, 1 Titelbild und 12 Textabbildungen. Preis in Mappe M. $20^{\circ}=\mathrm{K} 20^{\circ}$.

\section{Einführung in die Biochemie}

fur Naturhistoriker und Mediziner.

Von

Dr. Viktor Grafe,

Privatdozent an der Wiener Universität.

Mit 41 Abildungen im 'Text.

Preis M. $13 \cdot-=$ K $15 \cdot 60$.

\section{Die Forstbetriebseinrichtung.}

Fiir Studierende und ansiibende Fachmänner

dargestellt von

Dr. Adolf Ritter v. Guttenberg

k. k. Hofrat und 0. ö. Professor an der k. k. Hoclischule für Bodenlzultur in Wien. Zweite Auflage.

Mit 3 Tafeln in Farbendruck und 41 Figuren in Text.

Preis goh. M. $10^{\circ}=\mathrm{K} \mathrm{12}$-, geb. M. $11 \cdot 20=\mathrm{K} 13.40$.

\section{Monographie der Gattung Taraxacum. \\ Von}

Dr. Heinrich Freiherr v. Handel-Mazzetti,

Assistent am botanischen Insitut der $k$. $k$. Universität in Wien.

Mit 2 Tafeln in Lichtdruck, 3 lithographischen Tafeln und 2 Karten. Preis M. $15-=\mathrm{K} 18$.

\section{Flora von Brixen a. E.}

Ein mit Standorts- und Hühenangaben versehenes Verzeichnis der im veiteren Gobiete von

Brixen a. E. (Siditirol) beobachteten willwachsenden höheren Syloren- und Samonptlanzen, der Nutzgewächse und Ziergehölze.

Verfaßt von

Dr. Anton Heimerl.

Mit einer aus dem Legate Scholz gewährten Unterstiitzung der kaiserl. Akademie der Wissenschaften in Wien.

Preis M. $8 \cdot-=\mathrm{K} 9 \cdot 60$. 
banalicus und E. ruthenicus, Paeonia banalica, Helleborus purpurascens, Salvia Iranssilvanica u. а.

\section{c) Staudenformationen.}

Die dazische Bergtrift. Die durch das Überwiegen der hochwüchsigen, meist blumenreichen Stauden über die Gräser ausgezeichnete Formation sonniger Hänge, die Trift (auch Bergheide), tritt in Siebenbürgen und im Banat ebenso reich entwickelt auf wie auf den Vorbergen der westlichen Karpathen, aber in wesentlich anderer floristischer Zusammensetzung. Wenn auch hier Leguminosen, wie Cylisus nigricans, G. banaticus, C. elongatus, C. albus, G. pallidus, Genisla pilosa, G. pubescens, G. virgala, G. lasiocarpa, Medicago falcala, Trifolium pallidum, T. pralense, T. medium, T. szarosiense, T. alpeslre, T. rubens, T. ochroleucum, T. pannonicum, T. Molinerii, T. montanum, T. strictum, Dorycnium herbaceum, Lotus corniculalus, Aslragalus Rochelianus, A. monspessulanus, Coronilla Emerus, C. varia, Onobrychis alba, Vicia serralifolia, V. Cracca, Lathyrus pralensis, L. Hallersleinii, L. silvestris meist überwiegen, gesellen sich dazu eine große Zahl anderer Gewächse, darunter viele östliche und südliche Typen. Charakteristische Arten, teils Siebenbürgens, teils des Banates, sind Danlhonia calycina, Andropogon Ischaemum und A. Gryllus, Fesluca valesiaca, Bromus fibrosus, B. barcensis, Iris variegata, I. spuria, Kohlrauschia prolifera, Dianthus banalicus, Adonis vernalis, Erysimum canescens, Syrenia cuspidala, Isalis paecox, Linum nervosum, L. flavum, L. tenuifolium, Geranium sanguineum, Polenlilla recta, $P$. tuberosa, Orlaya grandiflora, Tordylium maximum, Peucedanum longifolium, Onosma virescens, Anchusa Barrelierii, Slachys germanica, Thymus comosus, Salvia nulans, Sculellaria Columnae, S. allissima, Aiuga Laxmanni, Salureia Calamintha, S. hungarica, Verbascum Lychnites, V. phlomoides, V. speciosum, V. banalicum, V.phoeniceum, V. Blallaria, Linaria dalmatica, Digitalis. ambigua, Veronica orchidea, $V$. crassifolia, V. dentala, Odontites lulea, Melampyrum barbatum, Cephalaria radiata, Campanula lingulala, Asyneuma canescens, Galium flavescens, G. ereclum, Asperula laurina, Achillea pannonica, A. crithmifolia, A. compacta, Anthemis tincloria, Malricaria tenuifolia, Inula cordala, I. bifrons, Centaurea Scabiosa*spinulosa, C. micrantha, Carduus candicans, Serralula radiata, S. nitida, Echinops ruthenicus, E. banaticus, Picris hieracioides, Scorzonera purpurea, S. hispanica u. v. a.

Felsenpflanzen. a) Auf kalkarmem Substrat. Gleich wie in den Westkarpathen, ist auch im Osten die Flora kalkarmer Felsen verhältnismäßig arm. Von den westlichen Arten fehlt vor allem Semperivum hirtum, hingegen treten Dianthus giganteus und D. trifasciculatus, Silene Armeria und wenigeandere Arten auf. Viel reicher ist die Felsenflora

b) a f Kalk entwickelt. Von den im Westen häufigen Arten fehlt Sedum album, Minuarlia laricifolia, Hieracium bupleuroides und vor allem Sesleria varia, welche durch $S$. Heufleriana ersetzt wird. Dafür treten in Siebenbürgen. Avena decora, Dianthus spiculifolius, Alyssum murale, Sempervivum assimile, Viola Jooi, Anchusa Barellierii, Thymus comosus, Scrophularia lasiocaulis, Lcon- 
lodon asper usw. hinzu. Noch reicher aber wird die Flora der Kalkfelsen im äußersten Süden, wo neben dem südlichen Ceterach officinarum zahlreiche subalpine Arten, wie Fesluca flavescens, Arabis procurrens, Moehringia pendula, Minuartia banatica, Silene petraea, Dianthus petraeus, Sedum glaucum, Salureia Pulegium, Mercurialis ovala usw. ins Tal herabsteigen und insbesondere an den Felsen des Donaudurchbruches zwischen Bazias und Orsova eine große Zahl seltener Arten sich angesiedelt hat, z. B. Fumaria Reuteri, Cardamine graeca, Alyssum microcarpum, Dianthus Balbisii, Ruta patavina, Peucedanum longifolium, Campanula crassipes, C. Welandii, Lithospermum pelraeum, Asplenium lepidum $\mathrm{u}$. a.

Die Halophytenflora. Siebenbürgen ist außerordentlich reich an Salzstellen, an denen sich eine eigenartige Halophytenflora entwickelt hat. So findet man an sumpfigen Stellen, Gräben usw. häufig Atropis limosa, A. transsilvanica, Scirpus maritimus, Schoenoplectus Tabernaemontani, Juncus Gerardi, Triglochin maritimum, Spergularia media, S. marginala, Trifolium fragiferum, T. striatum, Melilolus dentalus *perfrondosus, Telragonolobus siliquosus, Bupleurum tenuissimum, Stalice Gmelini, Glaux maritima, Centaurium pulchellum, Plantago marifima; ferner von für die siebenbürgische. Halophytenflora bezeichnenden Arten die südrussische Pelrosimonia Volvox, Suaeda salinaria, das stattliche Peucedanum latifolium und Plantago Cornuli. An mehr trockenen, lehmigen, salzauswitternden Stellen ist Plantago maritima, oft von P. Schwarzenbergiana begleitet, meist in Beständen zu finden, vergesellschaftet mit Chenopodium rubrum, C. glaucum und der seltenen Alriplex microsperma. Die Ränder von Salzwassertümpeln und Teichen umsäumt oft in dichtem Bestande Salicornia herbacea, begleitet von Suaeda salsa, Spergularia marina, Gypsophila muralis, Planlago maritima und Scirpus maritimus. Hingegen fehlen Camphorosma ovata, Crassula Magnolii und Asler dracunculoides den siebenbürgischen Halophytenfluren. A's salzliebende Ruderalpflanze ist das bei Torda auftretende Chenopodium Wolffii zu nennen.

\section{d) Grasiluriormationen.}

Bergwiesen. Die Bergwiesen Siebenbürgens, die mit der Trift durch alle Übergänge verbunden sind, zeigen in ihrer Zusammensetzung gegenüber denen der Westkarpathen gleichfalls Abweichungen. Von Gräsern sind Arrhenatherum clatius, Triselum flavescens, Phleum phleoides, Danthonia calycina, Fesluca elatior, Poa pratensis, P. anguslifolia häufig; ferner finden sich Carex monlana, Iris hungarica, I. spuria, Bulbocodium ruthenicum, Orchis mililaris, O. ustulala, O. Iridentata, O. Morio, Gymnadenia conopea, Silene chlorantha, S. Otites, Dianthus banalicus, Linum nervosum, L. tenuifoliam, L. flavum, L. catharticum, Anemone patens, A. grandis, A. montana, Ranunculus auricomus, $R$. acer, R. Sleveni, Arabis hirsula, Hypericum elegans, H. maculalum, H. perforalum, Lolus corniculatus, Ononis hircina, Trifolium pratense, T. montanum, T. ochroLencum, Medicago falcala, M. Lupulina, Lathyrus pratensis, Potentilla palula, 


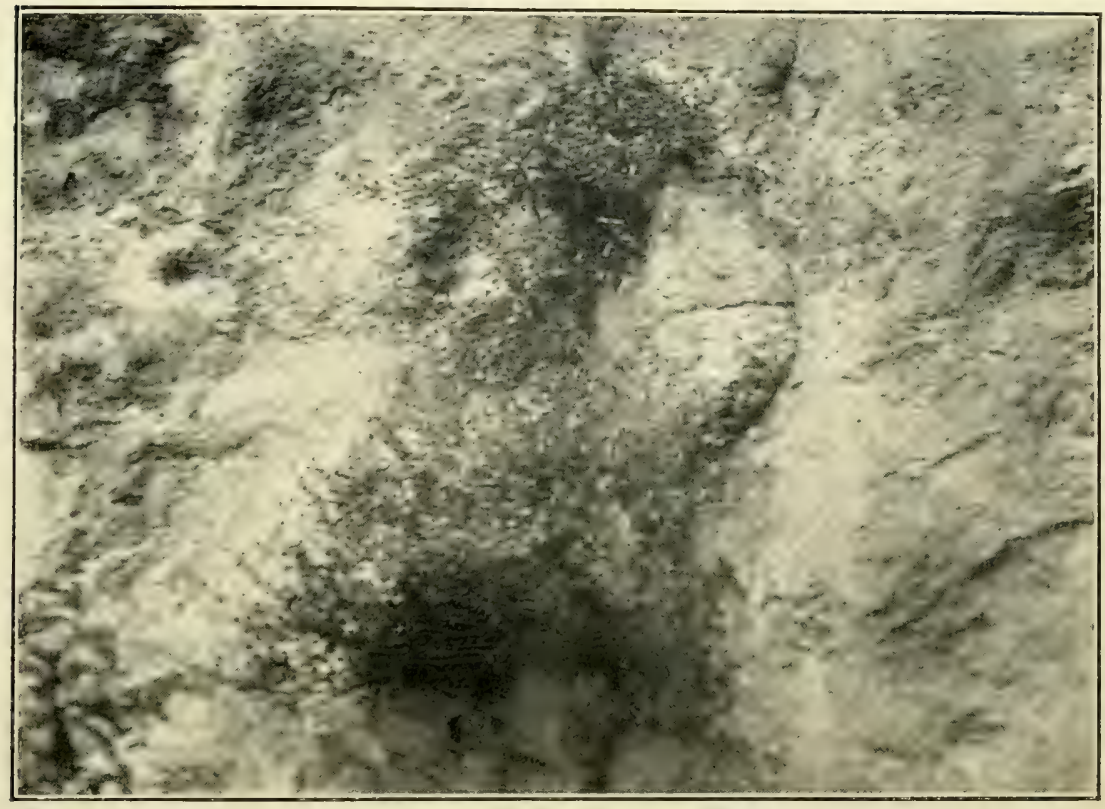

Abb. 186. Serophularia lasiocaulis an kalkfelsen in der Tordaer Schlucht. (Nach einer Aufnahme von A. v. Iayek.)

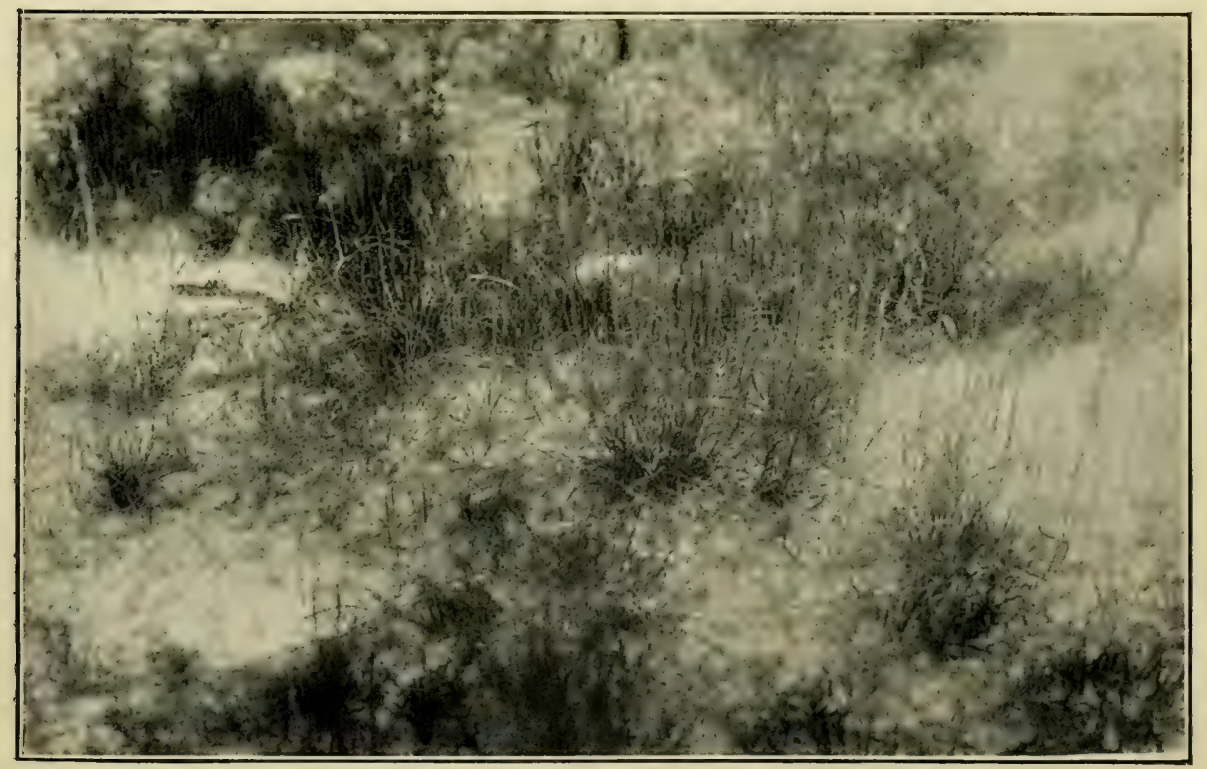

Abb. 187. Plantago maritima auf Salzboden bei Salzburg (Vizakna) nächst Hermannstadt. (Nach einer Aufnahme von A. v. Hayek.) 



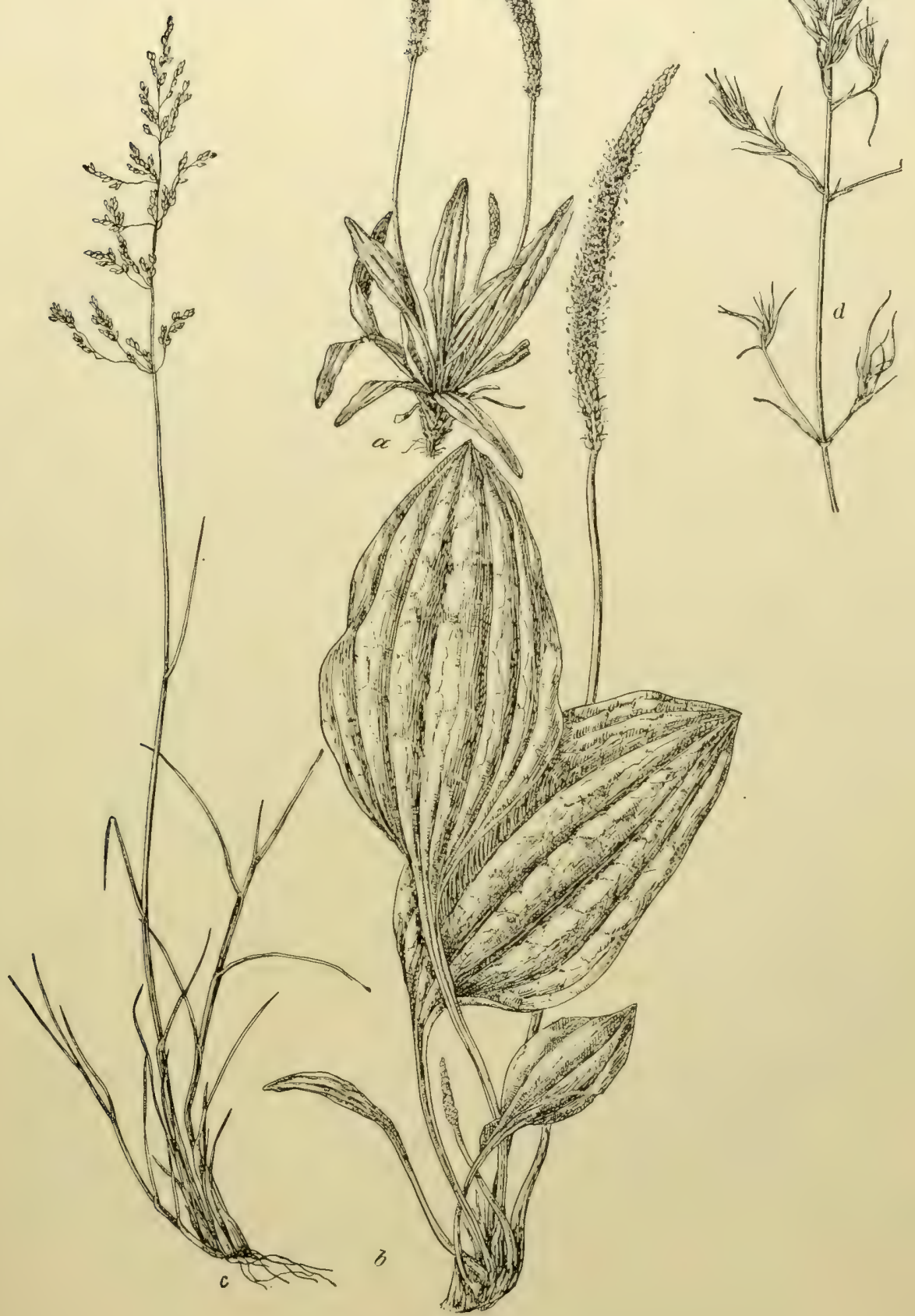

Abb. 188. Siebenbürgische Halophyten.

$a$ Plantago Schwarzenbergiana. $b$ Plantago Cornuti. $c$ Atropis imosa. $d$ Petrosimonia Volvox. 
P. Thuringiaca, Filipendula hexapelala, Polygala comosa, P. amarella, Daucus Carola, Carum Carvi, Salvia nemorosa, S. pratensis, S. nulans, Thymus transilvanicus, Primula elatior, Genliana carpatica, Campanula palula, C. rolundifolia, Galium verum, G. erectum, Phyleuma Vágneri, Scabiosa ochroleuca, Centaurea Jacea* banatica, C. spinulosa, Tragopogon orientalis, Crepis praemorsa, Leontodon autumnalis, L. hispidus, L. danubialis, Hypochoeris maculata, Hieracium Pilosella, H. Bauhini usw.

Die siebenbürgische Grassteppe. Im zentralen Siebenbürgen, im Gebiete der Mezöség, tritt eine eigenartige xerophile Grasflurformation auf, die vielfach an die Steppen Zentralungarns, mehr vielleicht aber noch an die Steppen SüdruBlands und Ostgalizien erinnert. Slipa Tirsa, St. pulcherrima, Sl.Lessingiana, Andropogon Ischaemum, A. Gryllus, Fesluca elatior, Gynodon Daclylon, Carex humilis sind die Pflanzen, welche hauptsächlich die Grasnarbe derselben zusammensetzen, welche aber an Zahl beinahe übertroffen werden durch oft schön blühende Stauden. Allium flavescens, A. flavum, Gypsophila fastigiala, Dianthus Carlhusianorum, Silene Otites, S. chlorantha, Arenaria graminifolia, Adonis vernalis, A. wolgensis, Anemone monlana, Ranunculus illyricus, Berteroa incana, Crambe aspera, Filipendula hexapelala, Onobrychis arenaria, Oxylropis pilosa, Aslragalus dasyanthus, A. vesicarius, A. transsilvanicus, Dorycnium herbaceum, Diclamnus albus, Linum flavum, L. hirsulum, L. nervosum, L. tenuifolium, Euphorbia Gerardiana, Althaea pallida, Onosma arenarium, O. viride, Anchusa Barellierii, Echium rubrum, Nonnea pulla, Digilalis lanata, D. ferruginea, Sideritis montana, Teucrium Chamaedrys, Nepela pannonica, Phlomis tuberosa, Asperula cynanchica, Cephalaria Iranssilvanica, C. radiala, C. laevigala, Asyneuma canescens, Inula hirta, Artemisia pontica, A. campestris, Anthemis ruthenica, Xeranthemum annuum und X. cylindraceum, Carduus hamulosus, C. candicans, Serralula nifida, S. radiala, S. Wolffii, Jurinea transsilvanica, Carthamus lanalus, Centaurea ruthenica, C. trinervia, C. micrantha, Leonlodon asper, Hieracium echioides seien aus der Unzahl der hier vorkommenden Stauden besonders hervorgehoben.

Talwiesen, Wiesenmoore und die Ufer- und Wasseriormationen bieten in ihrer Zusammensetzung gegenüber den Westkarpathen kaum nennenswerte Unterschiede dar.

\section{Formationen der höheren Berg- und Voralpenregion.}

\section{a) Waldiormationen.}

Der Buchenhochwald. Noch weit mehr als in der Hügelregion macht sich in höheren Lagen der Unterschied zwischen west- und ostkarpathischer Flora geltend. So bietet der subalpine Buchenwald in Siebenbürgen eine ganze Reihe von Charakterpflanzen, die dem Westen fehlen. Zu diesen Arten gehört das bis Kroatien und Südsteiermark verbreitete, durch seine weichhaarigen Blätter ausgezeichnete Hieracium transsilvanicum, die braunrote Nieswurz (Helleborus purpurescens), die durch ihre rot bleibenden Blüten ausgezeichnete 


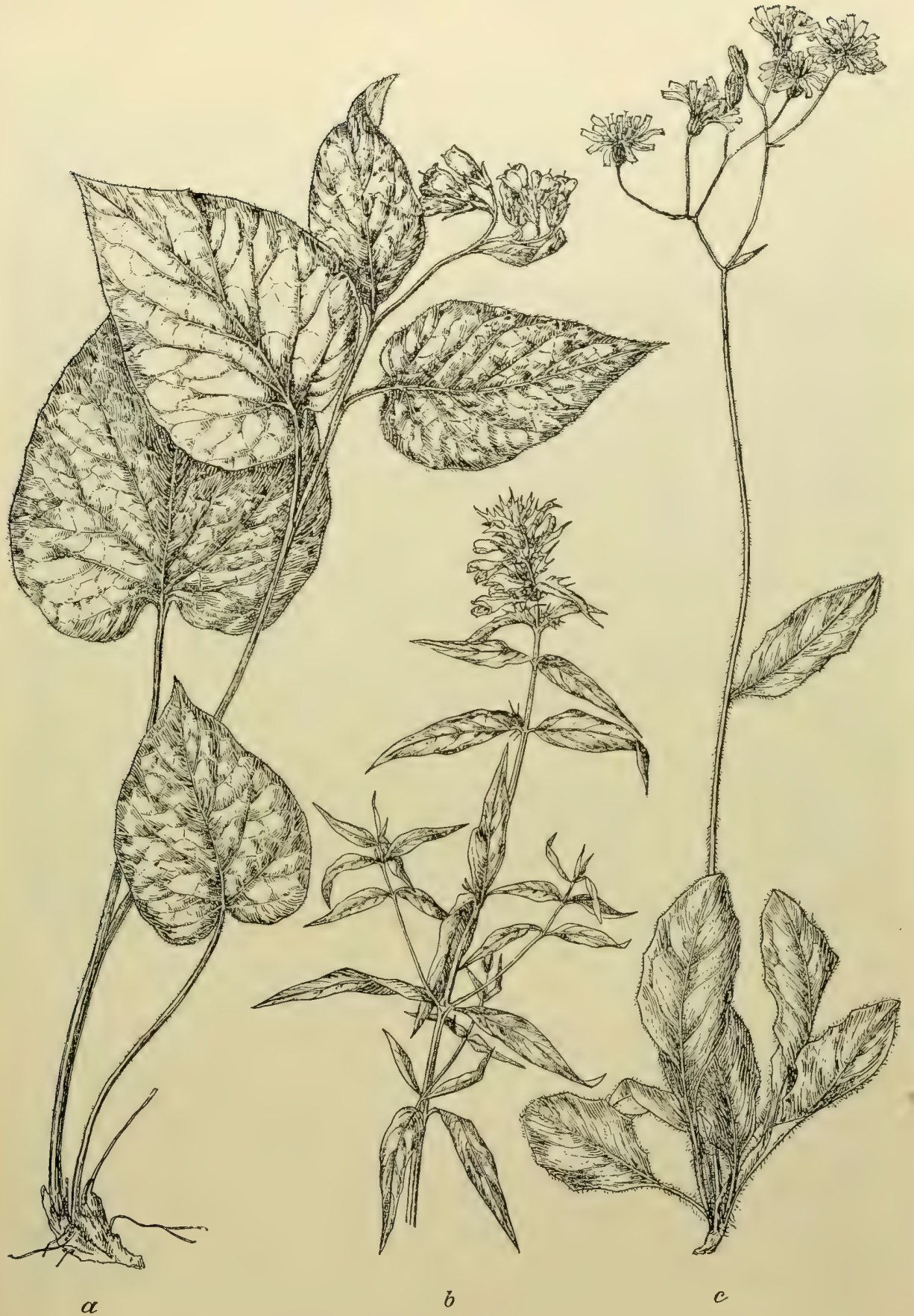

Abb. 189: Aus der Waldflora der Ostkarpathen.

$a$ Symphytum cordatum. $b$ Melampyrum bihariense. $c$ Hieracium transsilvanicum. 
Pulmonaria rubra sowie die zierliche Anemone transsilvanica. Auch die für Siebenbürgen so bezeichnende Teletia speciosa fehlt den Westkarpathen fast gänzlich. Hingegen fehlen den Ostkarpathen Cyclamen europaeum und $B u$ phthalmum salicifolium. Andere Bewohner des siebenbürgischen Buchenwaldes sind ferner noch Allium ursinum, Galanthus nivalis, Gagea lulea, Paris quadrifolia, Scilla bifolia, Slellaria nemorum, Silene viridiflora, Cardamine glandulosa, C. Irifolia, C. bulbifera, Ranunculus Steveni, R. carpalicus, Lamium vulgare und L. cupreum, Geranium macrorrhizum, Saxifraga heucherifolia, S, rotundifolia,

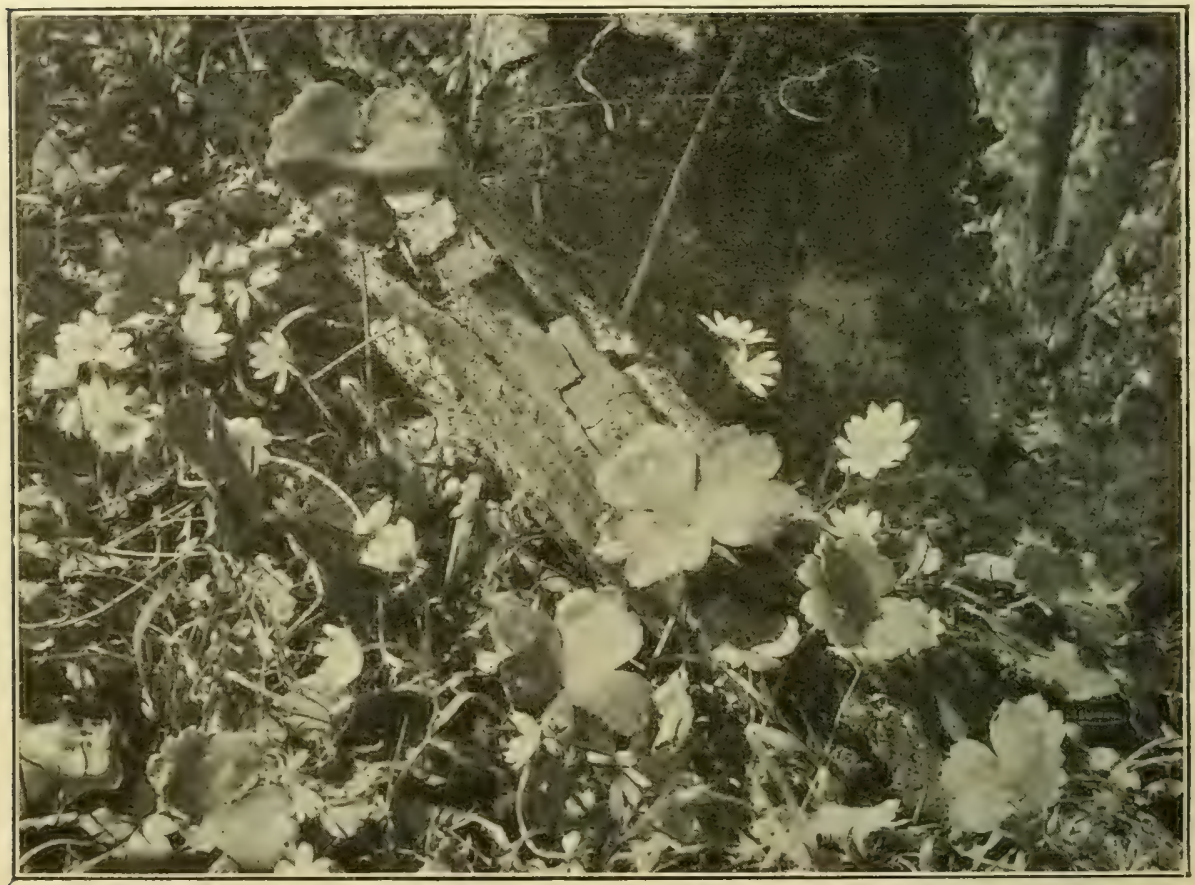

Abb. 190. Anemone transsilvanica im Buchenwald auf der Zinne bei Kronstadt. (Nach einer Aufnahme von H. Lehmann.)

(Aus der Bildersammlung des botanischen Institutes der Wiener Universität.)

*Heuffelii und S. cuneifolia, Vicia cassubica, Doronicum cordalum, Hieracium pseudofasligiatum, Melampyrum bihariense, Campanula Grosseckii, im Banate ist sogar Ruscus aculeatus im Buchenwalrle zu finden und als große Seltenheit das prächtige Botrychium virginianum. Im Unterholze ist Spiraea ulmifolia nicht gerade selten, und dem Oberholze ist mitunter auch Tilia tomentosa beigemengt.

Der dazische Fichtenwald weist ebenfalls einige eigentümliche Arten auf. Dazu gehört vor allem die bis in die Waldkarpathen weit verbreitete Campanula abietina, ferner die erst in höheren Lagen, bei ungefähr $1000 \mathrm{~m}$, auftretende Primula carpalica. Auch die zierliche Ericazee Bruckenthalia spiculifolia kommt, obwohl hauptsächlich der Krummholzregion angehörig, nicht 
政

ह

-

E $\div$

$\Xi \equiv$

满

롤

$\equiv$

$\div \div$

三

$\div$

ㄴ.

-

อ

-

$\frac{3}{4}$ 



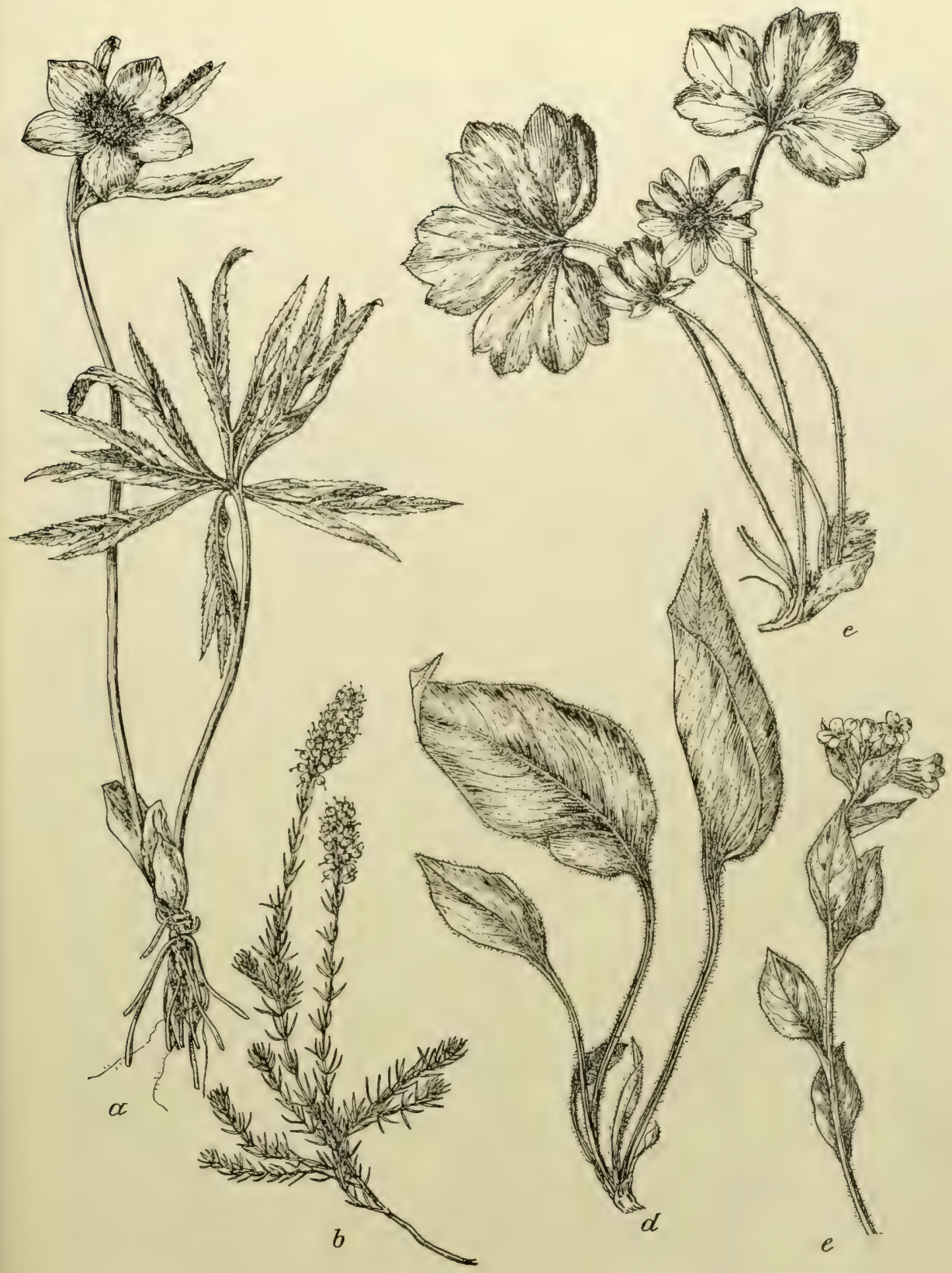

Abb. 192. Aus der Waldflora der Ostkarpathen.

$a$ Helleborus purpurascens. $b$ Bruckenthalia spiculifolia. $c$ Anemone transsilvanica. $d$, e Pulmonaria rubra. ( $1 / 2$ nat. Gr.)

selten im Fichtenwalde vor. Als Bewohner desselben sind ferner Orchis saccifera, Cardamine glandulosa, Adenostyles orientalis und Hieracium transsilvanicum zu nennen. 


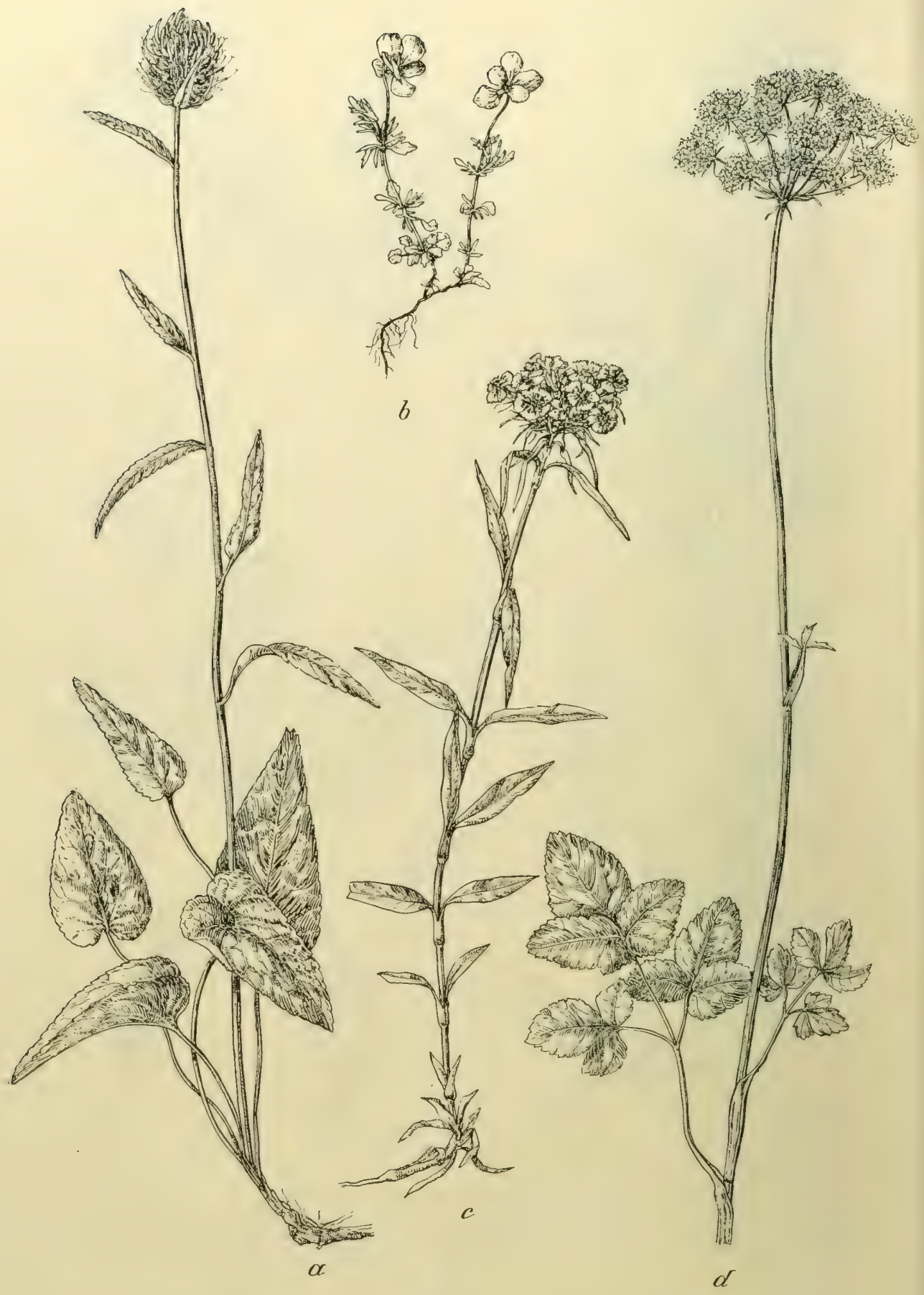

Abb. 193. Charakteristische Arten der Voralpenwiesen der Ostkarpathen.

a Phyteuma Vágneri. $b$ Viola declinata. $c$ Dianthus compactus. $d$ Laserpitium alpinum. 



\section{b) Strauchformationen.}

Der subalpine Buschwald. Auch im subalpinen Buschwalde treten im Osten neue Typen auf. In erster Linie ist die bis mannshohe, mit goßen gelben Blüten ausgestattete Komposite Telekia speciosa als Charakterpflanze der ganzen Ostkarpathen bis ins Banat zu nennen, die dann in Bosnien wiederkehrt. Neben Aconitum moldavicum treten auch A. lasianthum, A. Anthora und A. toxicum auf, die prächtige Centaurea Kolschyana erhebt stellenweise ihre schwarzroten Blütenköpfe und Hesperis nivea fällt durch ihre schneeweißen Bläten auf. Auch Silene dubia, S. Cserei, Ranunculus platanifolius, Physocaulos nodosus, Satureia Baumgartenii und Phyteuma Vágneri gehören dieser Formation an.

Strahlenginstergebuische. Im Banater Berglande tritt in der höheren Bergregion ein neues Buschformationen bildendes Element auf, der Strahlenginster (Genista radiala), der mit seinen sparrig ästigen, fast blattlosen Zweigen und seinen leuchtend goldgelben Blüten nicht selten niederes Buschwerk bildet.

Ufergebüsche. Auch die subalpinen Quellfluren und Ufergebüsche bieten im Osten ein anderes Bild als im Westen. Neben Salix silesiaca treten häufig Spierstauden (Spiraea crenifolia, S. chamaedryfolia) auf und in höheren Lagen mischt sich Alnus viridis darunter. Nirgends fehlt das bis mannshohe $B u$ phlhalmum speciosum, dem sich mancherorts das prächtige Cirsium pauciflorum beigesellt, in dessen Gesellschaft oft auch $C$. oleraceum und $C$. helerophyllum sich finden. Häufig sind zahlreiche Aconiten (A. moldavicum, A. Baumgarlenianum, A. paniculatum, A. lasianthum), die im Vereine mit Thalictrum aquilegifolium, Doronicum austriacum, Senecio nemorensis, Heracleum palmalum und H. Spondylium, Conioselinum talaricum, Campanula abietina, Pelasites hybridus und P. albus, Chrysanthemum corymbosum usw. ein farbenprächtiges Bild bieten.

\section{e) Wiesenformationen.}

Voralpenwiesen. Vielleicht in keiner andern Formation macht sich der Unterschied zwischen Ost- und westkarpathischer Flora stärker bemerkbar als auf den Voralpenwiesen. Das Fehlen von Phyleuma spicalum, Viola sudetica, Hieracium latrense und der meisten ,Sudeten“-Hieracien der Westliarpathen im Osten würde noch weniger ins Auge fallen. Aber die Wiesen der Ostkarpathen sind durch drei ungemein charakteristische und fast nirgends fehlende Arten besonders ausgezeichnet, den durch dunkel überlaufene Kelche und tiefpurpurne Blüten ausgezeichneten Dianthus compactus, ein reizendes bunt gefärbtes Stiefmütterchen, Viola declinata, und endlich die blaß rosenrote Scorzonera rosea, denen sich meist auch die hellgelbe Primula carpatica beigesellt. Gleich im Westen ziert im Frühlinge Crocus Heuffelianus die Wiesen, im Herbste aber entfaltet der eigenartige Crocus banaticus (= iridiflorus) seine Blüten. Von weiteren verbreiteten Arten der ostkarpathischen Voralpenwiesen seien noch Cerastium Lerchenfeldianum, Ranunculus carpaticus, Thlaspi dacicum, T. Ko- 


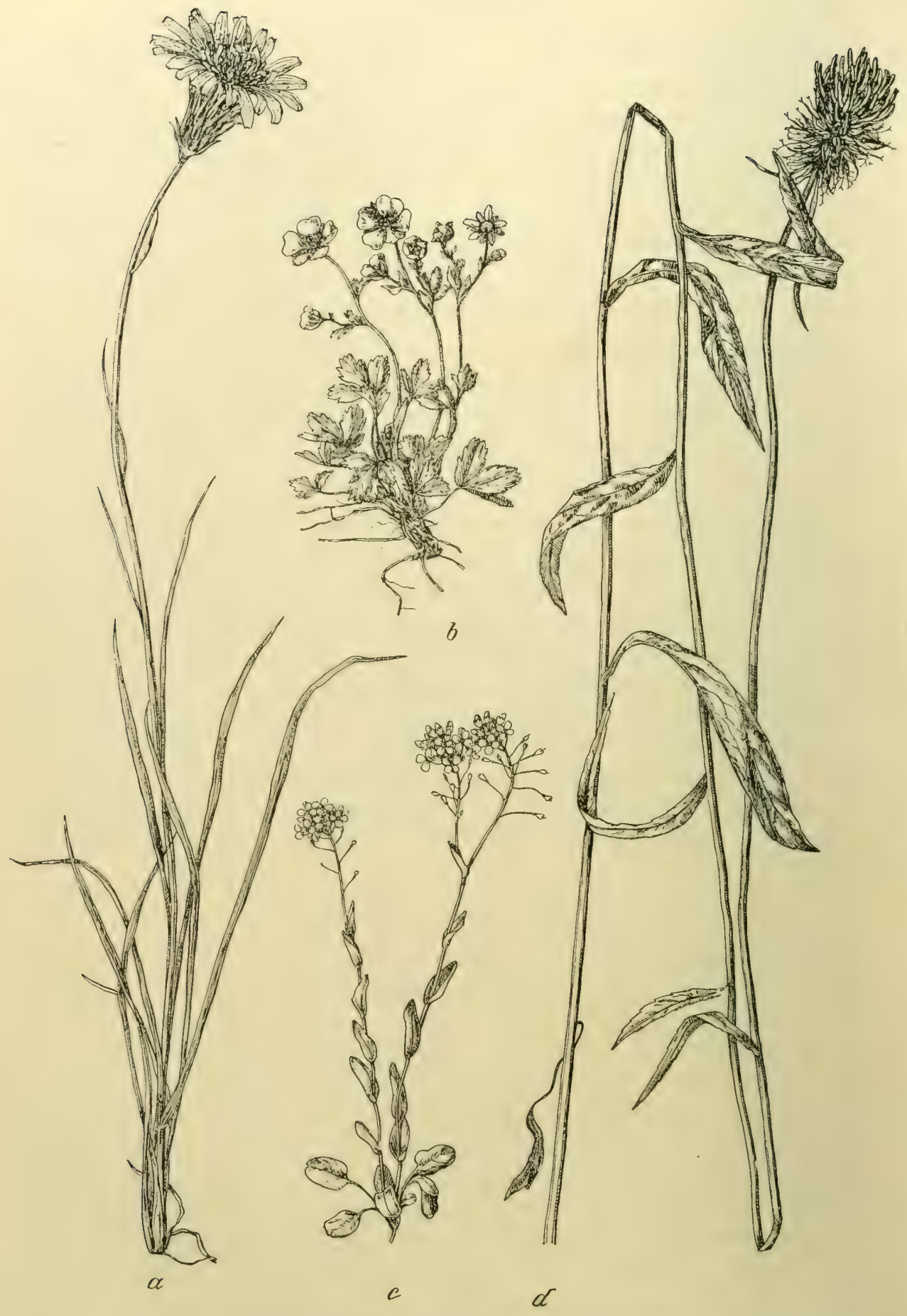

Abb. 195. Charakteristische Arten der Voralpenwiesen der Ostkarpathen. $a$ Scorzonera rosea. $b$ Potentilla ternata. $c$ Thlaspi Kovacsii. $d$ Phyteuma tetramerum. 
vacsii, Arabis ovirensis, Hypericum alpigenum, Phyleuma Vágneri, P. tetramerum und Hieracium auranliacum zu nennen; auch die der Krummholzregion angehörige Potentilla lernata steigt nicht selten in die Waldregion herab.

\section{d) Moore.}

Hochmoore. Hochmoore sind in den Ostkarpathen relativ selten entwickelt und stimmen bezüglich ihrer floristischen Zusammensetzung im wesentlichen mit denen der Westkarpathen überein, doch fehlt ihnen das im Westen nicht seltene Ledum palustre, hingegen ist hier Belula humilis keine seltene Erscheinung; auch Carex dacica ist auf die Ostkarpathen beschränkt.

\section{e) Staudenformationen.}

Subalpine Hochstaudenfluren. Gleichwie in den Westkarpathen sind auch im Gebiete der Ostkarpathen in Waldschluchten, an Bergbächen und Vald-

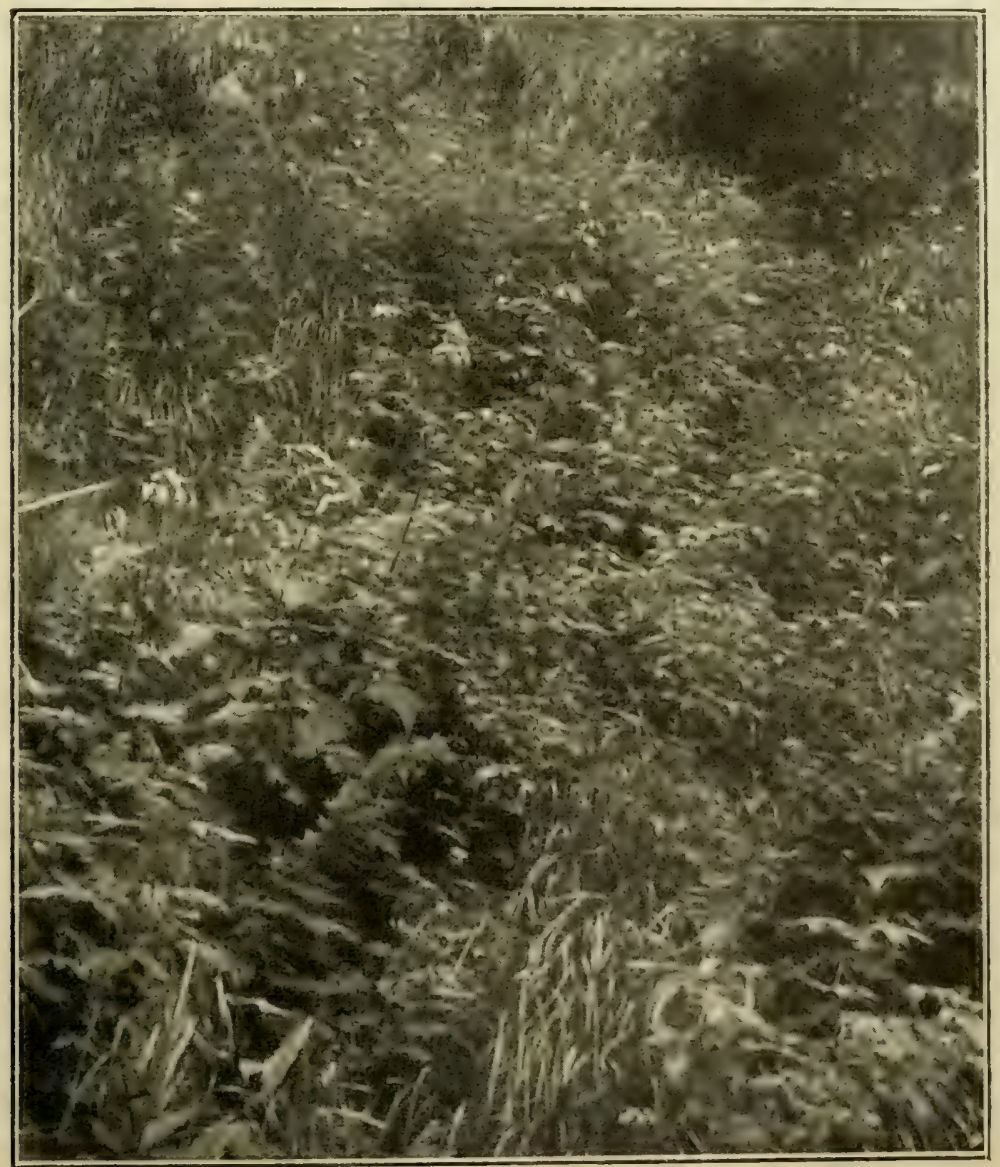

Abb. 196. Hochstaudenflur in einer Waldschlucht im Buleatale der Fogarascher Alpen. Dryopteris Filix mas, Senecio nemorensis, Doronicum austriacum, Mulgedium alpinum.

(Nach einer Aufnahme von A. v. Hayek.) 
rändern üppige Hochstaudenfluren entwickelt, die auch in ähnlicher Weise, doch meist reicher zusammengesetzt sind. Veralrum album, Lilium Martagon, Ranunculus platanifolius, Aconitum moldavicum, Chaerophyllum Cicutaria, Genliana asclepiadea, Digilalis ambigua, Senecio nemorensis, Doronicum austriacum, Cirsium Erisilhales, Mulgedium alpinum sind im allgemeinen ebenso verbreitet wie im Westen. Ein für die ganzen Ostkarpathen bis an die Westgrenze der Waldkarpathen sehr bezeichnendes Glied der Hochstaudenfluren ist die bis über mannshohe Telekia speciosa, mit ihren leuchtend gelben Blüten. Andere dem Osten eigentümliche Formen sind das prächtige Cirsium pauciflorum mit dunkelroten nickenden Blütenköpfen, die schwarzrote Cenlaurea Kolschyana, Lamium cupreum, Adenostyles orienlalis und besonders auf Kalkboden ist das auch dem Westen nicht fehlende Delphinium elalum häufig. Conioselinum lalaricum ist auf die Rodnaer Alpen und den Königstein beschränkt, im Siebenbürgischen Erzgebirge ist stellenweise in tieferen Lagen Cnidium apioides nicht selten.

Subalpine Felsenfilora. a) Auf kalkarmem Substrate. In tieferen Lagen bieten die Gneis-, Granit- und Sandfelsen der Ostkarpathen in der Voralpenregion nicht viel Bemerkenswertes; nahe der Baumgrenze und über derselben aber sind einige interessantere Arten zu nennen, so die nur in der Marmaros sich findende Silene rupestris, ferner die prächtige Campanulazee Symphyandra Wanneri und der eigenartige Scleranthus uncinalus.

Eine viel reichere Flora ist aber

b) an Kalkfelsen entwickelt. Eine zierliche Federnelke, Dianthus spiculifolius, ist in fast ganz Siebenbürgen weit verbreitet und wird im Südwesten durch den nahe verwandten $D$. Kitaibelii vertreten. An Stelle der Sesleria varia des Westens treten Sesleria rigida und S. Heufleriana, auch Festuca xanthina ist stellenweise häufig. Campanula carpalica ist gleichwie im Westen überall gemein, fehlt aber dem südwestlichen Tril des Gebirgszuges; Biscutella laevigala, Kernera saxalilis, Saxifraga Aizoon sind häufig. Viola Jooi, Silene dubia. (im Süden auch S. flavescens), Centaurea alropurpurea, Leontopodium alpinum, C. cochlearifolia, Draba lasiocarpa, Saxifraga cuneifolia usw. sind weit verbreitet. Dazu kommen noch Arten von geringerer Verbreitung, wie Saxifraga Rocheliana. Sempervivum assimile, S. blandum, Erigeron racemosus, Allium obliquum, Alyssum murale, Arabis procurrens, Hieracium Herculis. Auch Hypericum alpigenum, Linum tauricum, Athamanta hungarica, Campanula divergens, Silene petraca, Hedraeanthus graminifolius, Geranium lucidum, Ferula Heuffelli usw. kommen an Kalkfelsen der Voralpen vor und bei Herkulesbad krönt die Schwarzföhre (Pinus nigra) die felsigen Hänge.

\section{Formationen der Hochgebirgsregion.}

\section{a) Strauchiormationen.}

Krummholzbestände. Obwohl Pinus Mughus in den siebenbürgischen Karpathen ebenso verbreitet ist wie in der Tatra, bildet es doch keineswegs 


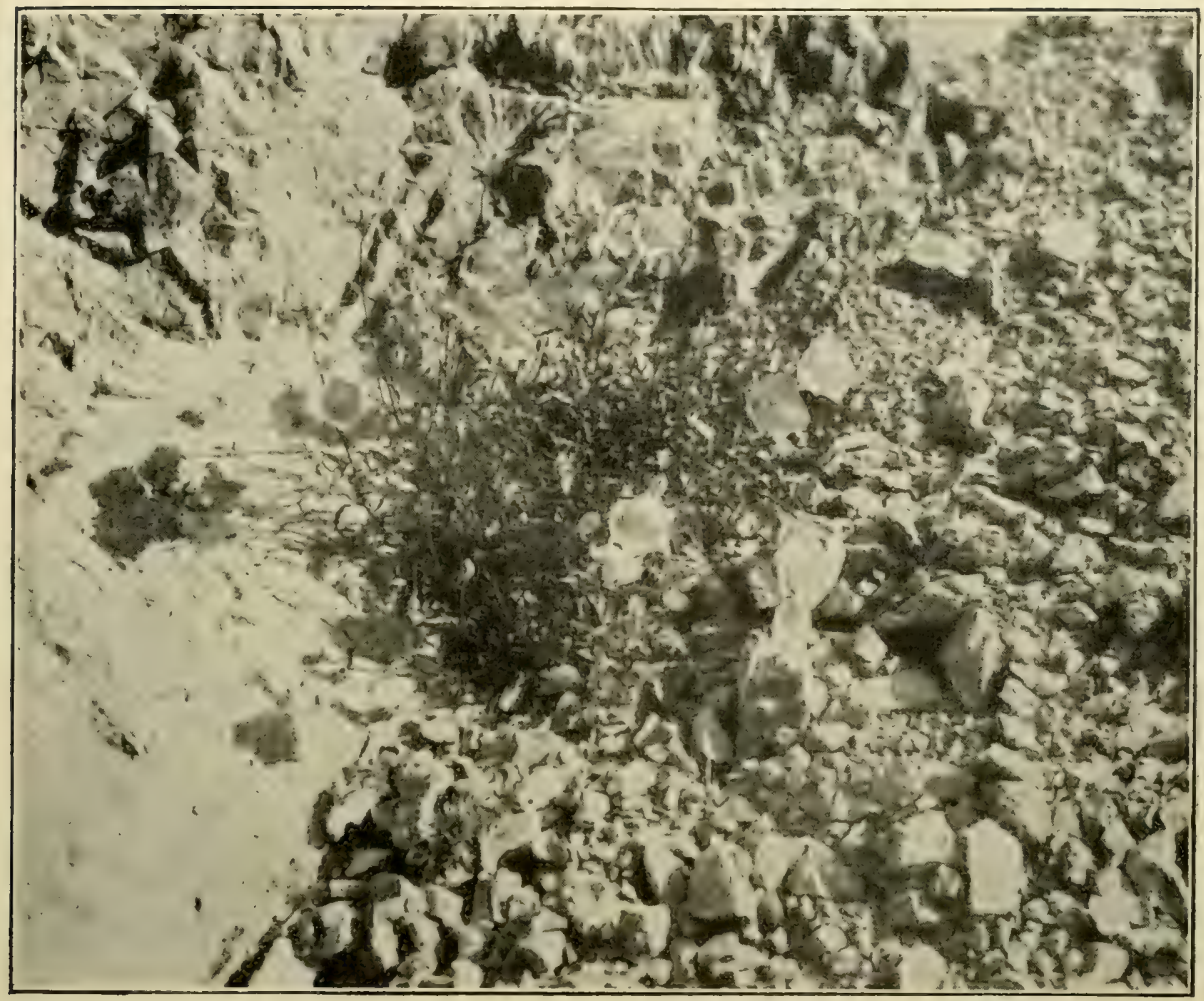

Abb. 198. Campanula carpatica im Kalkschutt des Deala Cailor bei Pozorita. (Nach einer Aufnahme von Prof. K. Linsbauer, Graz.)

(Aus der Bildersammlung des botanischen Institutes der Wiener Universität.)

so dichte Bestände wie dort. Schuld daran trägt wohl vor allem die ausgedehnte Veidewirtschaft, die in den siebenbürgischen Hochgebirgen betrieben wird, wobei die Krummholzbestände, um Weideland zu gewinnen, mit Axt und Feuer schonungslos vernichtet werden, eine die alpine Vegetation sehr schädigende Maßregel, da dem Krummholze eine wichtige Rolle bei der Bindung des Humus und dem Verhüten von Lawinenstürzen zukommt. Der Krummholzgürtel erstreckt sich in den Rodnaer Alpen von 1600-1900 m, in den Transsylvanischen Alpen von $1850-2200 \mathrm{~m}$. Häufig gesellt sich der Krummholzkiefer auch die im Westen fehlende Grünerle (Alnus viridis) bei und zu den sie begleitenden Vaccinien gesellt sich mitunter die zierliche Bruckenthalia spiculifolia, während die Alpenrose (Rhododendron myrthifolium) meist erst ober der Krummholzgrenze auftritt. Hochwüchsige Voralpenstauden und Gräser (Poa Chaixi, Calamagrostis villosa, Luzula nemorosa, Aconilen, Gentiana lulea, Senecio nemorensis, Adenoslyles albifrons) wuchern meist üppig am Rande und an weniger dicht bewachsenen Stellen der Legföhrenwälder.

Grünerlenbestände. Die Grünerle (Alnus viridis) ist in den Ostkarpathen gegenüber der Legföhre entschieden vorherrschend und bildet besonders an 
feuchten, felsigen I ängen größere oder kleinere Bestände, von wo sie in feuchten, schattigen Schluchten bis $1400 \mathrm{~m}$ hinabsteigt. Glcich Pinus Mughus ist auch Alnus viridis in den Karpathen völlig bodenvag und kommt oft genug mit letzterer vergesellschaftet vor.

Zwergwachholdergebisch. Wenn Juniperus nana auch überall als Begleitpflanze der Krummholzkiefer auftritt, bildet er doch nur selten, wie im Bihariagebirge und in den Rodnaer Alpen, an trockenen, sonnigen Stellen einigermaßen größere Bestände. Zwischen den meist dichte, inselförmige Gruppen bildenden Beständen finden sich häufig Vaccinium Vilis Idaea, Bruckenthalia spiculifolia, Lycopodium Selago, L. alpinum, Anemone alba, Geum montanum, Hypericum alpigenum usw.

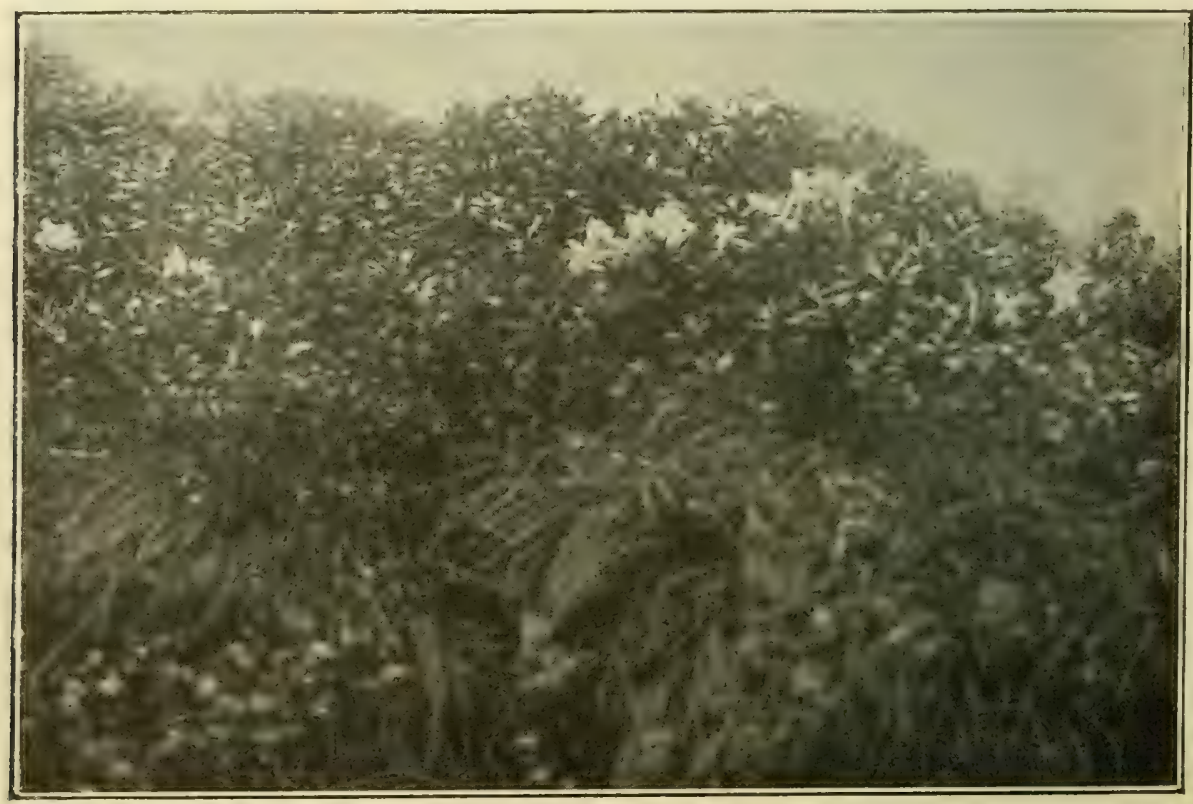

Abb. 199. Rhododendron myrtifolium am Buleasee in den Fogarascher Alpen. (Nach einer Aufnahme von A. v. Hayek.)

Alpenrosenbestände. Obwohl Rhododendron myrlifolium! das' von den Waldkarpathen ostwärts überall verbreitet ist, zu den häufigsten und bezeichnendsten Arten der Ostkarpathen gehört, tritt es doch viel seltener als seine Schwesterarten in den Alpen in größeren Beständen auf. Nur an den Steilhängen der Transsylvanischen Alpen bildet sie stellenweise vorzüglich in einem Höhengürtel von $1800-2000 \mathrm{~m}$ größere Felder, steigt aber einzeln bis über $2200 \mathrm{~m}$ an. Mit Rhododendron myrtifolium vergesellschaftet sich gern Juniperus nana, Saxifraga heucherifolia, Ranunculus nemorosus, Carduus Kerneri; und auch die prächtige Centaurea Kotschyana ist neben Leonlodon pyrenaicus, Senecio carpaticus und Bruckenthalia spiculifolia häufig zwischen den Alpenrosenbüschen $\mathrm{zu}$ finden. 



\section{b) Grasflurformation.}

Alpenwiesen. Die hochhalmigen Alpenwiesen der Ostkarpathen sind namentlich durch drei fast überall wiederkehrende Arten gekennzeichnet, ein

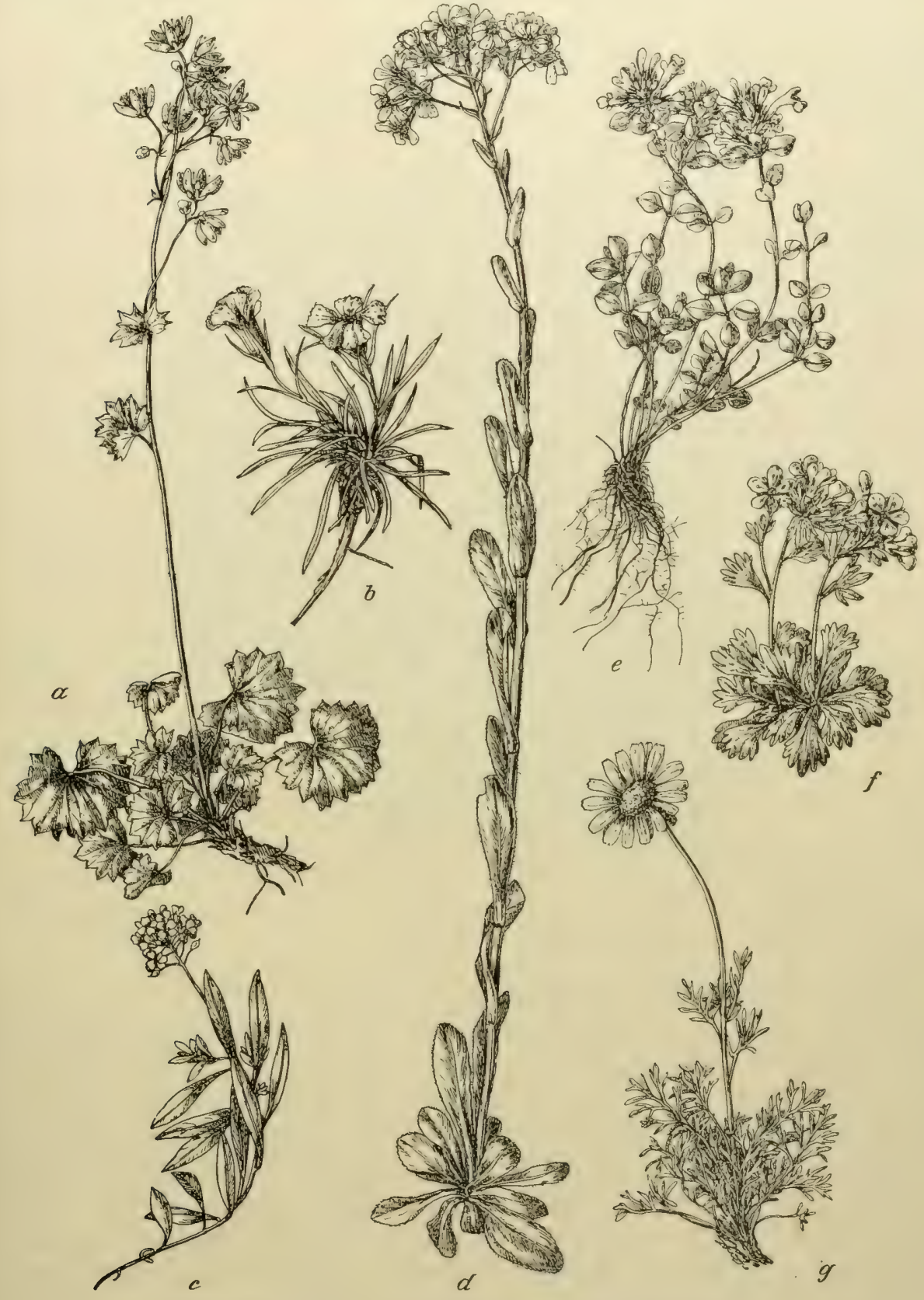

Abb. 200. Aus der siebenbürgischen Hochgebirgsflora.

$a$ Saxifraga heucherifolia. $b$ Dianthus gelidus. $c$ Alyssum repens, $d$ Achillea lingulata. e Satureia Baumgartenii. f Saxifraga cymosa. $g$ Anthemis carpatica. (1/2 nat. Gr.) 
reizendes, buntfarbiges Stiefmütterchen, die Viola declinala, eine große blutrote Nelke, Dianthus compactus, und eine rosenrote Komposite, die in den südöstlichen Kalkalpen wiederkehrende Scorzonera rosea. Dazu gesellen sich Achillea dislans und Chrysanthemum corymbosum, die die Polentilla aurea vertretende $P$. ternata und Leontodon pyrenaicus; an Gräsern Alopecurus laguriformis und die prächtige, auf die Rodnaer Alpen beschränkte Festuca Porcii; Primula carpalica, Thlaspi dacicum uns Kovacsii, Genliana lulea, Hypericum alpigenum, Cerastium Lerchenfeldianum, Laserpitium alpinum, Centaurea variegala, Grepis viscidula, Heracleum palmatum sind ebenfalls bezeichnende. Arten der siebenbürgischen Alpenwiesen, während Armeria alpina, Campanula transilvanica, Centaurea nervo:a, Geranium coerulalum и. а.' eine nur beschränkte Verbreitung zeigen.

Borstengrasmatten. Nardus slricla, in der ganzen Karpathenkette weit verbreitet und überall als Bestandteil alpiner Matten auftretend, bildet besonders auf kalkfreiem Boden, wie in den Waldkarpathen und im Bihariagebirge, in der Krummholzregion Alpenmatten von ganz eigenartigem Gepräge. Neben Nardus stricla ist besonders Deschampsia llexuosa *montana an der Zusammensetzung der trockenen Grasnarbe beteiligt, in der noch Carex leporina, C. brunnescens und Luzula sudelica häufig auftreten. Häufig sind kleine Ericazeen, besonders Vaccinium Myrtillus, V. Vitis Idaea und V. uliginosum, Loiseleura procumbens und mancherorts Bruckenthalia spiculifolia, von denen besonders die ersteren oft in einer die Gräser fast verdrängenden Masse auftreten. Verhältnismäßig arm sind diese Matten an schön blühenden Alpenpflanzen. Neben dem im ersten Frühlinge blühenden Crocus Heuffelianus sind besonders Geum montanum, Polentilla lernata, Alectorolophus alpinus, Homogyne alpina, Hieracium auranliacum und $H$. alpinum häufig; ferner sind, gleichwie auf den Alpenwiesen, Viola declinala und Scorzonera rosea mitunter in Massen vorhanden; in den Waldkarpathen ist auch Gentiana Vagneri häufig; hingegen treten in den Graspolstern Krustenflechten, besonderss Cladonia rangiferina und Celraria-Arten in Masse auf und bilden mit dem Borstengrasrasen und den kleinen Vaccinien- und Loiseleuria-Rasen ein dichtes Gefilz.

Die Formation der Krummsegge (Carex curvula). Während Carex firma auf die Westkarpathen beschränkt ist und dem Osten feblt und $C$. sempervirens nicht gerade häufig ist, ist auf den Hochalpenmatten der Ostkarpathen eine andere, auch in den Alpen weit verbreitete Segge, und zwar sowohl auf Kalkals auf Kieselboden, meist in tonangebender Menge anzutreffen, nämlich die Krummsegge $(C$. curvula), die vergesellschaftet mit Oreochloa disticha, ferner mit Poa alpina, Avena versicolor, Agrostis rupestris, Festuca supina, Luzula spadicea und L. spicata, die höheren Kuppen und Weideflächen mit einem blütenreichen, im Herbste durch die absterbenden Carexblätter oft rötlichgelb schimmernden Rasen überzieht. Ranunculus monlanus, Potentilla ternata, Taraxacum alpinum, Senecio carpaticus, Leontodon pyrenaicus, Hieracium alpinum und Pedicularis Oederi schmücken diese Rasen mit gelben Blüten, 
massenhaft findet man meist die tiefvioletten Blumen der Viola alpina, auch $V$. declinala steigt oft bis in diese Höhen hinauf, Silene acaulis bildet oft große, mit rosenroten Blütensternen geschmückte Polster und Pedicularis verlicillata, Dianthus gelidus und in den Rodnaer Alpen Silene nivalis fallen durch rote Blüten auf. Gentiana Kochiana, G. verna, G. orbicularis, Campanula alpina (hier im Gegensatze zu den Alpen mit, dunkelvioletten Blüten), Phyteuma confusum, Erigeron uniflorus, Myosolis alpestris sind neben den Violen die Vertreter der blauen oder violetten Farbe. Von sonstigen, verbreiteteren Arten

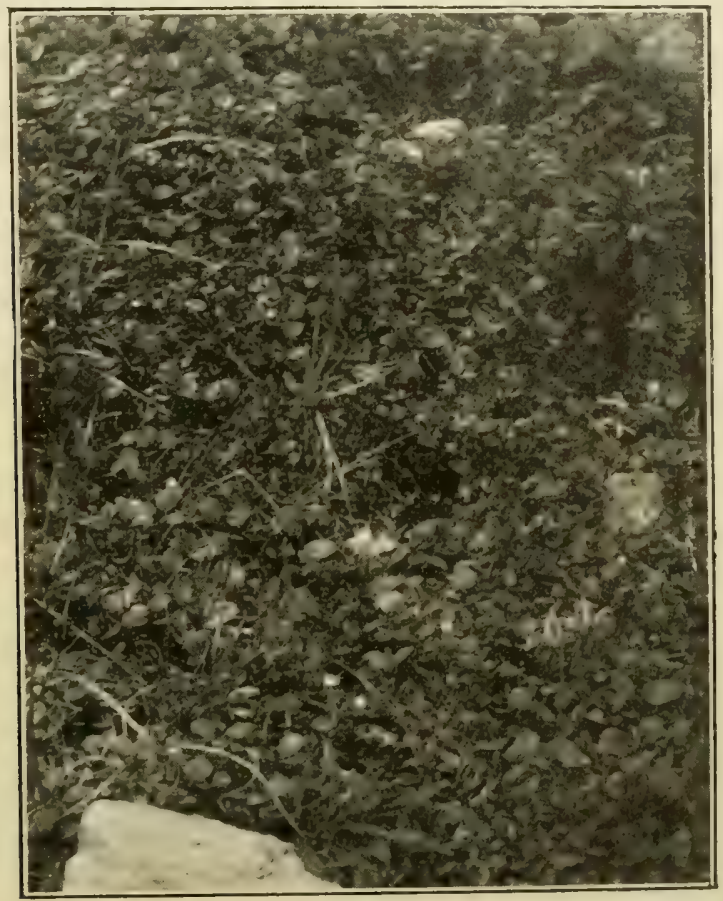

Abb. 201. Krummseggenrasen mit Salix reticulata, Soldanella hungarica und Pedicularis Oederi auf dem Bucsecs.

(Nach einer Aufnahme von A. V. Hayek.)

sind noch Minuartia sedoides, Arenaria biflora, Arabis ovirensis, Sedum alpestre, Saxifraga moschata, S. bryoides, S. hieracifolia, Ligusticum Mutellina, L. simplex, Veronica alpina, V. Baumgartenii, Gentiana frigida, Anthemis carpatica und in den Fogarascher Alpen Plantago gentianoides zu nennen. Von geringerer Verbreitung sind u. a. Nigitella rubra, Silene dinarica und Campanula transsilvanica.

\section{c) Hygrophile Staudenformationen.}

Alpine Quellíluren. Von den alpinen Weiden fehlt Salix Jacquini den Ostkarpathen östlich von den Rodnaer Alpen, hingegen ist S. Lapponum häufiger als im Westen. Häufig sind an alpinen Quellbächen Epilobium alsinefolium und E. nulans, Vaccinium uliginosum, Empetrum nigrum, Heliosperma 
quadrifidum, Bartschia alpina, Polıgonum viviparum, Pedicularis verticillala, Pinguicula alpina, dann die für Siebenbürgen charakteristischen Arten Chrysosplenium alpinum, Sweerlia punctala, Cardamine rivularis sowie die in den Alpen und in der Arktis so verbreitete, aber in den Westkarpathen fehlende Saxifraga slellaris. Auch Saxifraga carpalica und S. heucherifolia sind an feuchten, quelligen Stellen nicht selten; im Bihariagebirge auch Carex magellanica.

Schneetälchenrasen. In dieser Formation tritt in Sicbenbürgen vor allem auch die in den Alpen häufige Soldanella pusilla auf, ferner der den Westkarpathen fehlende und im Osten auf Urgestein den Ranunculus alpestris vertretende Ranunculus crenalus sowie Chrysoplenium alpinum und die zierliche Saxifraga cymosa. Auch Gardamine rivularis und Doronicum carpalicum sind an Schneefeldern zu finden und natürlich auch die an solchen Stellen überall anzutreffenden Arten, wie Polygonum viviparum, Oxyria digyna, Primula minima, Lloydia serolina, Salix herbacea, Saxifraga androsacea usw.

\section{d) Xerophile Staudenformationen.}

Alpine Felsenflora. a) Auf Kalk. Die Flora alpiner Kalkfelsen in den Ostkarpathen ist außerordentlich reich an eigentümlichen Formen. In erster Linie ist da wohl Gypsophila pelraea (Banffya pelraea) als solche zu nennen, mit ihren grasartigen Blattbüscheln und ihren weißen Blütenköpfchen, die in den Siebenbürger Karpathen an Kalkfelsen zwischen 1000 und $2400 \mathrm{~m}$ weit verbreitet ist. Ferner gehört hierher die schon oben genannte Saxifraga luteoviridis und die ihr ähnliche, aber kräftigere $S$. demissa, dann das stattliche Bupleurum diversifolium, Salureia Baumgarlenii, Draba compacla, Anlhemis carpalhica, Achillea lingulala, Achillea Schurii und Artemisia petrosa. Von den häufigeren Arten der Westkarpathen fehlen Saxifraga caesia, Gypsophila repens, Draba aizoides, Salurea alpina und Bupleurum ranunculoides; Primula Auricula kehrt erst im äußersten Süden bei Herkulesbad, und zwar in tieferen Lagen wieder. Hingegen finden sich in den Ostkarpathen noch eine Reihe anderer, auf wenige Standorte beschränkte Arten, wie Sempervivum blandum und S. Heuffelii, der so seltene Dianthus callizonus, Draba Haynaldi und D. carinthiaca, Asperula capitala, Veronica Baumgarlenii usw.

b) Auf Urgestein. Aus Urgestein aufgebaute Hochgipfel finden sich in den Ostkarpathen hauptsächlich in der langen Kette der. Transsylvanischen Alpen und weisen auch eine nicht uninteressante Flora auf. Weit augenfäliger als auf Kalkboden sind hier die charakteristischen Flechten, insbesonders Rhizocarpon geographicum, ferner Lecidea confluens und andere Lecidea-Arten, Cornicularia lristis usw. In den Felsspalten finden sich Agrostis rupestris, Poa laxa, Oreochloa disticha, Sempervivum monlanum, Saxifraga bryoides, S. moschala, Erigeron uniflorus, Campanula alpina, Primula minima usw., durchwegs auch in den Alpen verbreitete Arten, zu denen sich nur wenige den Karpathen eigentümliche Formen gesellen, wie Scleranthus uncinatus, Senecio carpaticus, S. glaberrimus und Doronicum carpaticum. 


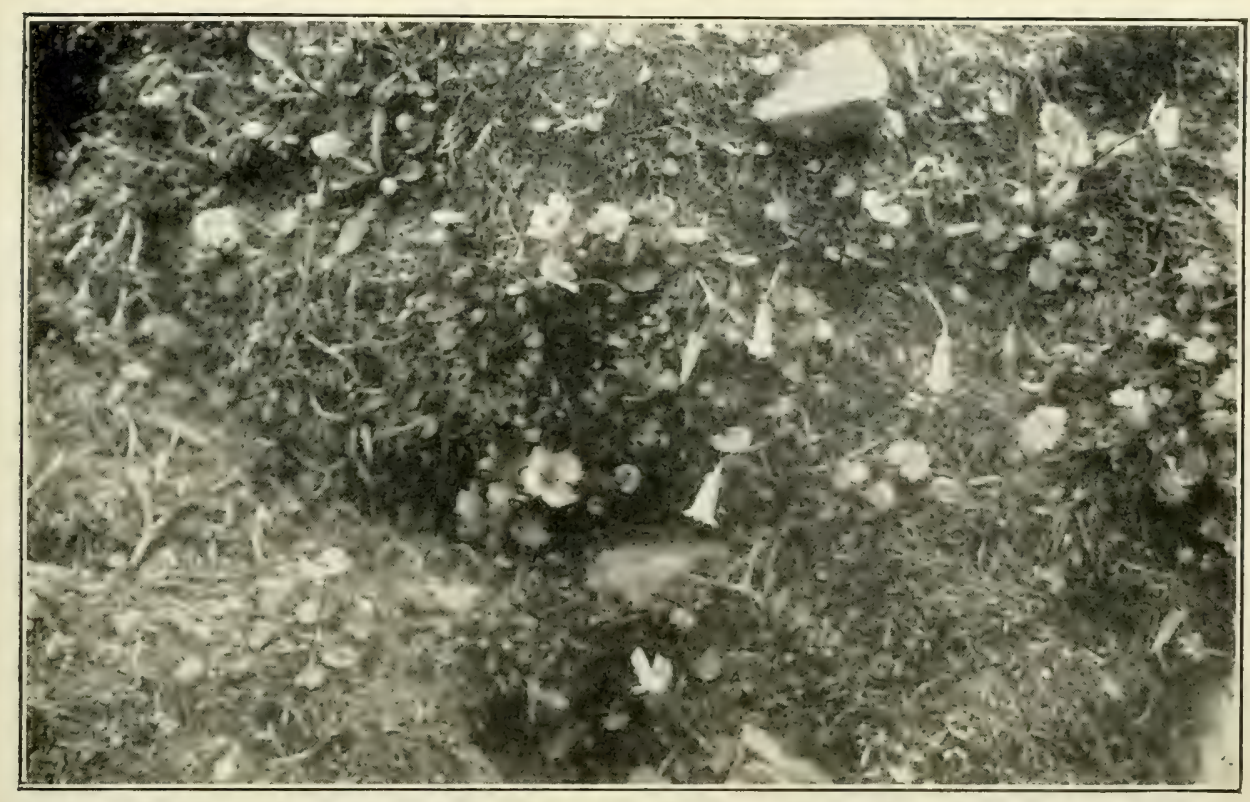

Abb. 202. Sehnectalchenrasen oler dem Buleasee in den Fogarascher Alpen, zirka $2200 \mathrm{~m}$. Ranuneuhs crenatus und Soldanella pusilla.

(Nach einer Aufnahme von A. v. Hayek.)

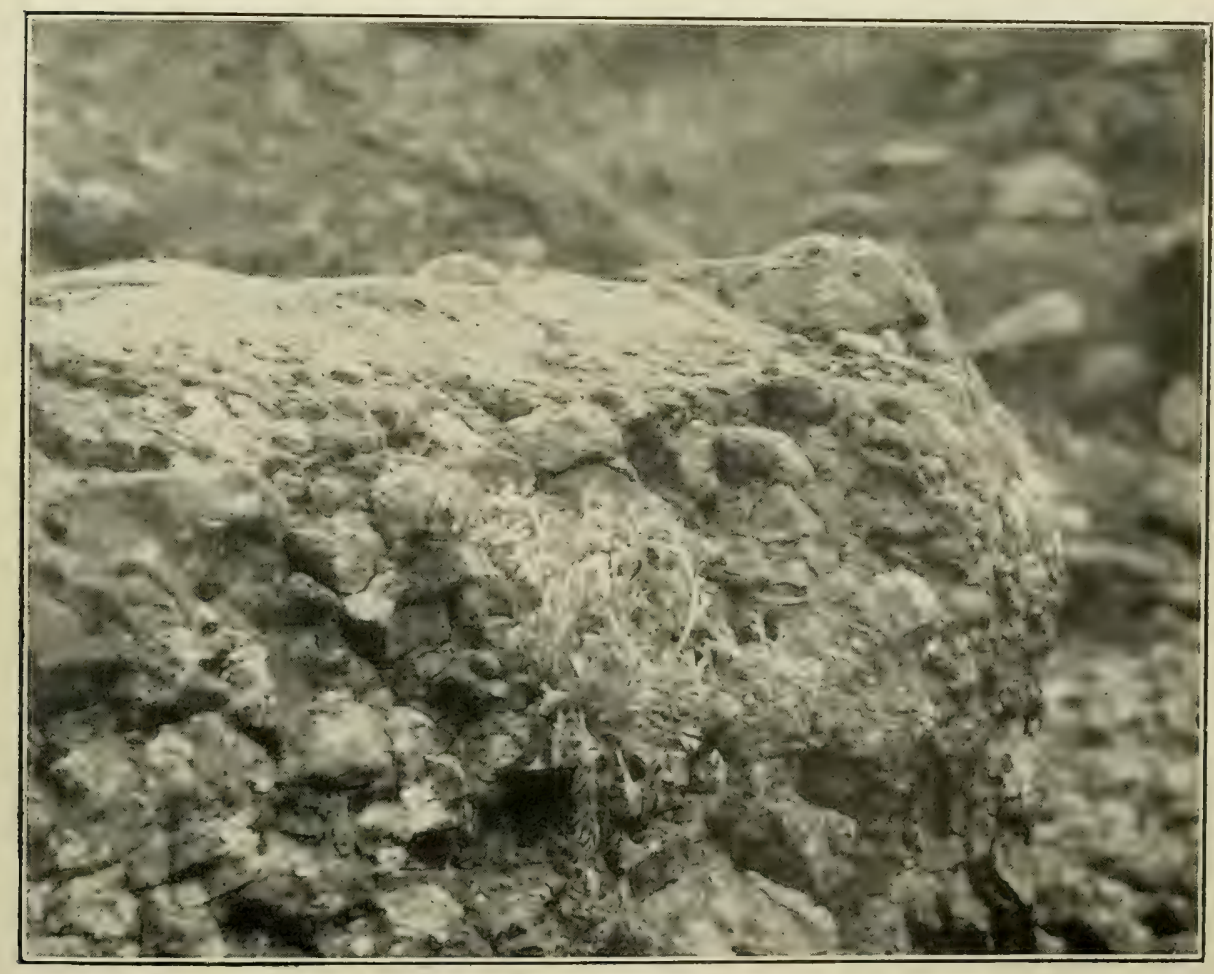

Abb. 203. Artemisia petrosa an Felsen im Malajestatale des Bucsecs.

(Nach einer Aufnahme von A. v. Hayek.) 

Gesteinfluren. Die Ilochgipfel der Rodnaer, Burzenländer und Fogaraser Alpen beherbergen eine reiche und hochinteressante Flora. Carex curvula, Poa laxa, Agrostis rupestris, Oreochloa disticha bilden im Gesteine und Felsschutt noch dürftige Rasen, auch Carex pyrenaica und $G$. bicolor treten an feuchten Stellen stellenweise auf. Dazwischen gedeihen kleine Saxifragen (S. moschala, S.bryoides, S.luleoviridis), Sedum alpestre, verschiedene seltene Draben (Draba compacla, D. Haynaldi, D. Kolschyi, D. carinthiaca), das goldgelbe Alyssum repens, Androsace oblusifolia und A. arachnoidea, Eritrichium terglouense, Gypsophila petraea, Primula minima, Gnaphalium supinum, Veronica Baumgarlenii, Arlemisia Baumgartenii, Campanula alpina, Saxifraga Wulfeniana und S. opposilifolia, aie die letzten Vorposten der phanerogamen Flora darstellen.

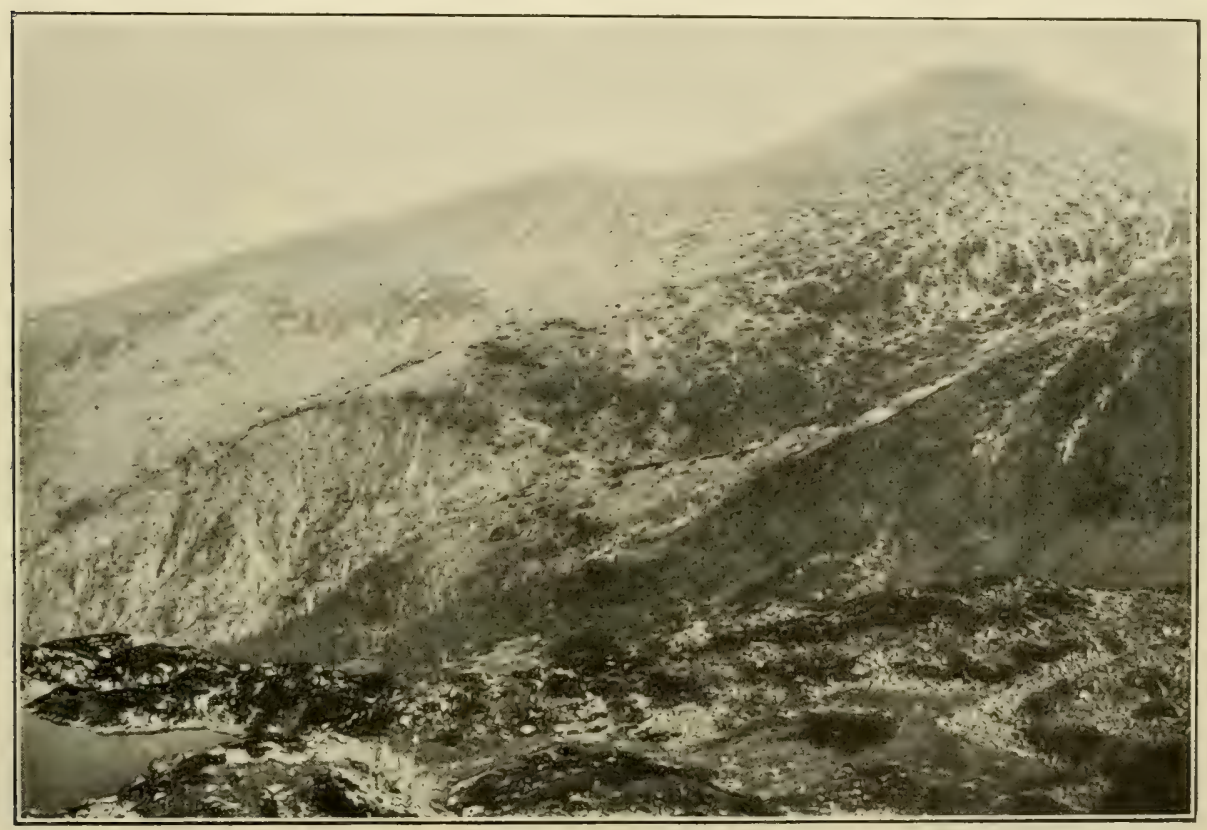

Abb. 204. Der Gipfel des Retyezat.

Im Vordergrunde Krummholzbüsche, dahinter Alpenmatten, die allmählich in zerstückelte Rasen und Gesteinsfluren übergehen.

(Nach einer Aufnahme von Ing. Hanak, Hermannstadt, im XXVI. Band der Jahrbücher des Siebenbürgischen Karpathenvereines.)

Felsenschuttfiluren. Während in den Westkarpathen das schneeweiße Papaver Burseri eine Zierde der Kalkschutthalden bildet, tritt im Osten das leuchtend goldgelbe, erst beim Trocknen sich orangegelb verfärbende Papaver aurantiacum an seine Stelle. Von sonstigen häufigeren Arten der Schutthalden sind Ranunculus Thora, Alyssum repens, Bisculella laevigala, Arabis alpina, Oxytropis carpathica, Dryas octopetala, Saxifraga luteo-viridis, Sedum atratum, Thymus nummularius und $T$. pucherrimus, Cerastium villosum, C. L.erchenfeldianum, Melandryum Zawadzkii, Achillea Schurii usw, zu nennen. 


\section{Kulturpflanzen der Karpathen.}

a) Getreide. Wie in den meisten Gebirgsländern, spielt auch in den Karpathen der Getreidebau gegenüber der Viehzucht eine untergeordnete Rolle. Besonders im Westen, wo an den Hängen des Gebirges gegen die Ebene zu der Weinbau intensiv betrieben wird, tritt der Getreidebau stark zurück und nur in den Tälern der Waag, Neutra, Eipel und Gran findet man Kulturen von Weizen, Roggen und besonders von Mais, wảhrend in den höheren Gebirgstälern der Zips sowie in Galizien vorzugsweise Roggen und Hafer gebaut wird. Besonders von den deutschen Bauern in der Zips, weniger von den Slowaken und Huzulen, wird dem Getreidebau große Sorgfalt zuteil und Düngung und Maschinenbetrieb entsprechen oft allen modernen Ansprüchen. Die abweichende Siedlungsweise jedoch bringt es mit sich, daß das Landschaftsbild in den Karpathen in ganz anderer Weise beeinflußt wird als in den Sudeten und insbesondere in den Alpen. Nirgends sieht man an den Hängen bis hoch hinauf ins Gebirge mitten im Walde die von Ärkern und Wiesen umgebenen isolierten Bauernhöfe, nur im Talboden liegen die Siedlungen und Felder und in unterbrochenem Zusammenhange bedeckt der Wald die Hänge des Gebirges bis fast zur Talsohle, denn schon in etwa $600 \mathrm{~m}$ Meereshöhe liegt hier die obere Grenze des Getreidebaues.

Die wichtigsten Getreidebaubezirke im Karpathengebiete liegen jedoch in Siebenbürgen. IIier sind es die ausgedehnten Hochebenen der Gyergyo, der Gsik, Ies Burzenlandes, von Fogaras und das breite Marostal, ferner ausgerlehnte Gebiete im Bereiche der Mezöség, wo viel Getreide gebaut wird, und zwar sowohl Mais und Weizen als auch Roggen und Hafer, seltener Gerste. Leider ist dort der Wirtschaftsbetrieb ein vielfach inrationeller. Die ausgedehnte Viehzucht bringt es mit sich, daß ein großer Berlarf an Weideflichen besteht, und so sind jene Wirtschaftsformen vorherrschend, wo ein Teil des Ackerlandes zeitweise als Viehweide benutzt werden kann, die Dreifelderwirtschaft und die Eggartenwirtschaft. Die Dreifelderwirtschaft mit dem Turnus: IVintergetreide - Sommergetreide - Brache oder oft auch Wintergetreide - Hanf - Brache ist vornehmlich in den Ebenen, so im Burzenlande und auf der Fogarascher Hochebene im Schwange, wobei die Brache als Viehweide dient; die Eggartenwirtschaft ist besonders in den Gebirgstälern, so im Bihariagebirge und Erzgebirge, zu Hause und besteht darin, daß in regelmäßigem Turnus durch 2-4 Jahre Getreide gebaut und dann ebensolang derselbe Grund als Wiese genutzt wird.

b) Wein. Wenn auch auf den Südrand beschränkt, spielt der Weinbau in den Karpathen doch eine ziemlich bedeutende Rolle. In den breiten Tälern der Westkarpathen, an den Abhängen der Kleinen Karpathen, besonders aber auf den Trachytbergen der Hegyalja bei Szantó; Tokaj, SárosPatak, Sátoralja-Ujhely wird überall Wein gebaut, ferner im Bereiche der Ostkarpathen auf dem Guttiner Trachytzuge sowie am Westrande des Siebenbürger Berglandes, im Maros- und Kokeltale. Im allgemeinen werden mit Vorliebe weiBe Traubensorten kultiviert, so im Tokajer Revier besonders 
„Furmint", „Mehlweißer", „Lindenblätteriger" und gelbe Muskatellertrauben; besonders aus der erstgenamnten Sorte wird durch schrumpfenlassen der Traube am Stocke der Ausbruchwein gewonnen. Bei Arad und Menes zieht man auch Rotwein, besonders die „Kadarka"-Traube. Die Stöckie werden, wie in Ungarn, kurz zugeschnitten; die Weinlese findet, besonders wenn man Ausbruch gewinnen will, sehr spät, oft selbst erst im November, statt.

Leider hat die Reblaus die berühmten Weinbezirke von Tokaj in letzter Zeit fast ganz vernichtet.

c) Gemiisebau. Die Hauptrolle spielt die Kartoffel, die besonders in höheren Lagen in Menge auf Feldern gebaut wird. In tieferen Lagen kultiviert man auch Kürbisse, Gurken und Bohnen auf freiem Felde. Die übrigen Gemüsesorten werden fast nur in Gärten gezogen.

d) Obstbau. Der Obstbau spielt im Bereiche der Karpathen nur eine untergeordnete Rolle, obwohl in tieferen und wärmeren Lagen fast alle Obstsorten gebaut werden; besonders ist die Kultur von Pfirsichen hervorzuheben.

e) Sonstige Nutzpilanzen. Von solehen werden nur Flachs und II anf, besonders in rauheren Lagen, häufiger gebaut, soltener der Itohn. Auf Ackern und in Weingärten findet man nicht selten Sonnenblumen (Helianlhus annuus) als Ölpflanze angebaut. Der Anbau von Futterkräutern ist gering und beschränkt sich fast ausschließlich auf Klee und Luzerne. Tabakbau fimlet man vornehmlich in niederen Lidgen des Gölnilzagebirges, seltener im zentralen Siebenbürgen.

\section{Die Adventivflora des Karpathengebietes.}

Ruderalilora. Wie in den meisten Gebirgsgegenden ist auch in den Karpathen die Riuderalflorat verhältnismälig artenarm, obwohl besonders im Hügellande auch einige Arten aus dem Ungarischen Tieflande auftreten. In Dörfern, an Straßen, auf Schuttplïtzen u. d@l. finden sich vornehmlich Urlica dioeca und U. urens, Polygonum aviculare, Chenopodium Bonus Henricus, C. album, C. polyspermum und $C$. capilatum, Rumex cripus und R. conglomeralus, Stellaria media, Capsella Bursa pasloris, Sisymbrium officinale, Descurainia Sophia, Chelidonium maius, Glaucium corniculalum, Polenlilla replans und P. anserina, Euphorbia helioscopia, Solanum nigrum, Lamium purpureum, L. maculalum und L. album, Verbena officinalis, Leonurus Cardiaca, Plantago maior, Erigeron Canadensis, Xanlhium spinosum und ... slrumarium, Senecio vulgaris, Carduns acanthoides, Cirsium lanceolalum, Sonchus oleraceus usw. An Büchen hat sich Oenothera biennis überall eingebürgert, auch liulbeckia laciniala ist stellenweise (Komitat Gömör, Siebenbürgen) sehr häufig; obrehall) Mrény ist Mimulus gutlalus verwildert; in der Marmaros ist stellenweise Chenopodium ambrosioides nicht selten. In höheren Lagen, besonders um die Alpenhütten, sind insbesondere Urlica dioeca, Slellaria graminea, Lanunculus acer, Capsella Bursa pasloris, Geum monlanum, Trifolium repens und T. pralense, Euphorbia Cypa- 
rissias, Brunella vulgaris, Veronica officinalis und V. Chamaedrys, Plantago media, Leontodon hispidus und L. autumnalis, Hieracium Pilosella, häufige, besonders durch das Vieh aus tieferen Lagen eingeschleppte Unkräuter.

Ackerunkräuter. Auch die Flora der Ackerunkräuter ist keineswegs reich. In höheren Lagen sind Bromus secalinus, Lolium lemulentum, Stenophragma Thalianum, Sinapis arvensis, Thlaspi arvense, Neslia paniculala, Raphanus Raphanistrum, Viola arvensis, Vicia saliva, Lalhyrus luberosus, Euphorbia helioscopia und E. exigua, Anagallis arvensis, Galeopsis Telrahit, Veronica arvensis, V. Tournefortii, Myosotis arvensis, Campanula rapunculoides, Knautia carpatica, Anthemis arvensis, Cirsium arvense, Cenlaurea Cyanus, Hypochoeris glabra, Sonchus arvensis die häufigsten Ackerunkräuter; im Hügellande gesellen sich noch Silene gallica, Papaver Phoeas, Bupleurum rolundifolium, Aiuga Chamaepilys, Chaenorrhinum minus, Kickxia Elatine, Melampyrum arvense und M. barbatum u. a. hinzu; in Siebenbürgen, besonders im Gebiete der Mezöség und im Marostale, ist Ornithogalum pyramidale häufig.

\section{Spezielle pflanzengeographische Schilderung der Karpathen.}

\section{Die Westkarpathen.}

a) Die kleinen Karpathen.

Am Donaudurchbruche bei Theben erhebt sich als südlichster Punkt Thebener der Kleinen Karpathen der Thebener Kogel, der an seinen kahlen Süd- und
Kogel.

Osthängen Bergtriften mit Stipa pennala, Andropogon Gryllus, Anemone grandis, A. nigricans, Polentilla arenaria, Polygala maior, Linum tenuifolium, Seseli Beckii, S. Hippomaralhrum, Peucedanum arenarium, Inula Oculus Christi, an felsigen Stellen auch Allium flavum, Iris pumila und Alyssum Arduini trägt, während seine Kuppen mit dichtem Laubmischwalde aus Buchen und Eichen bedeckt sind, in dem insbesondere das häufige Auftreten von Smyrnium perfolialum auffällt. Auch das kühle Waldtal des Eisenbrünnels bei Pre $\beta$ burg ist von schattigen Buchenwäldern, in denen eine Anzahl interessanter Brombeerformen Gemsen- vorkommt, bestanden und auch der Gemsenberg trägt teils gemischte Laub-
berg. holzbestände mit Lilium Marlagon, Orchis sambucina, Cardamine bulbifera, Vicia cassubica, V. pisiformis, Salvia glulinosa, Digitalis ambigua, teils wahrscheinlich künstlich aufgeforstete Föhrenbestände, in denen u. a. Aira caryophyllea und das seltene Limodorum abortivum wachsen. Im Weidritztale ist Impatiens parviflora seit langem eingebürgert.

Preßıurg. Der ganze Ostfuß des Gebirges von Preßburg bis gegen Modern ist von ausgedehnten Weingärten eingenommen, in deren Geröll Asplenium septentrionale, Gagea bohemica, Atriplex rosea, Linaria genistifolia, Odontiles lutea, Lactuca saligna und im Gesträuch kletternd Lonicera Caprifolium 


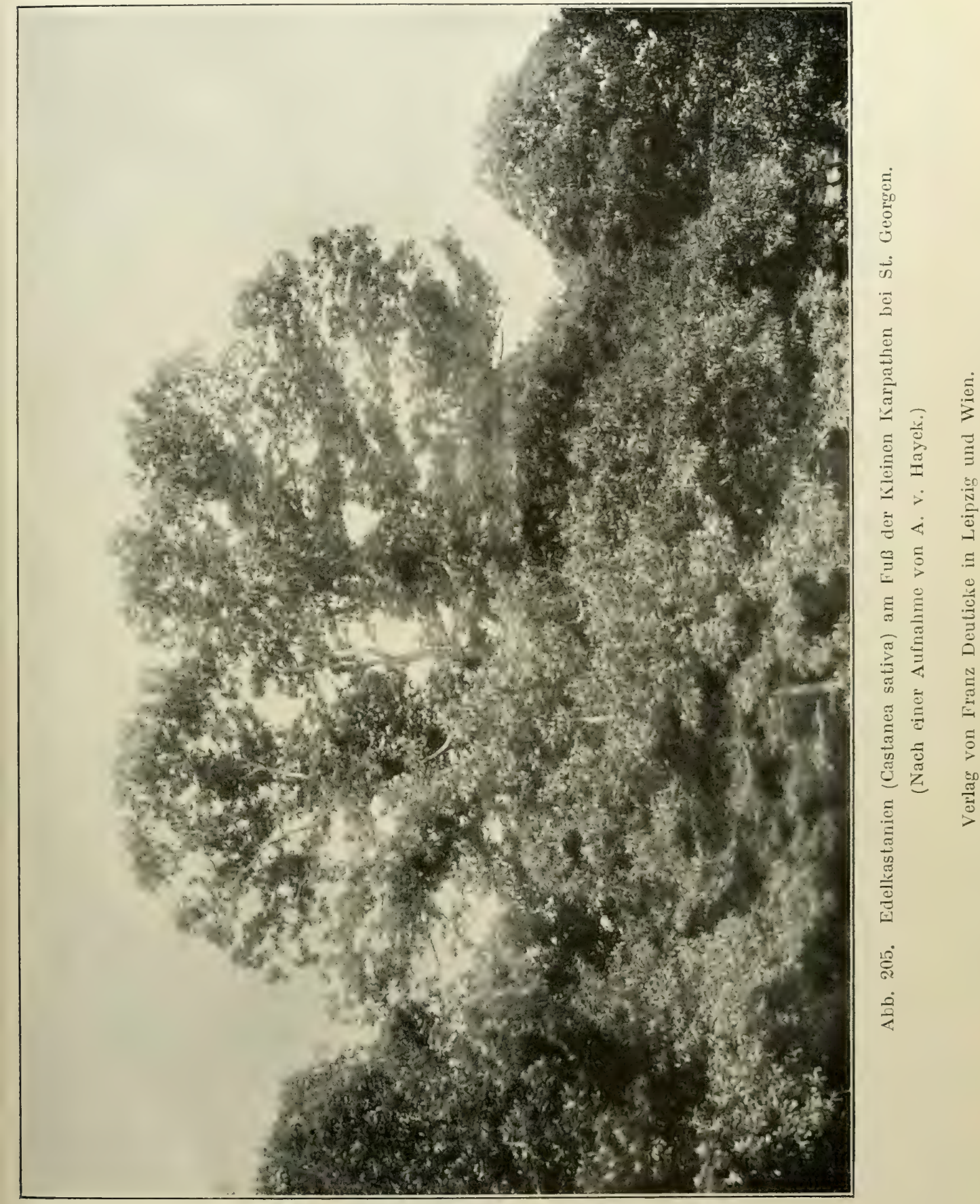



nicht selten sind; zwischen SL. Georgen und Modern sind am oberen Rande der Weingärten noch kleine Bestinde uralter Edelkastanien (Ciastanea saliva) als lieste eines zweifellos ursprïnglichen Kastanienwaldes erhalten. Hie und da begegnet man sowohl am Ost- als am Westube des Gebirges zwischen den Weinbergen auch 'I'riftormationen mit Phleam phleoides, Melica ciliala, Kohlrauschia prolifera, Genisla pilosa, Linaria genistifolia, Aster Linosyris usw. den Kamm des Gebirges aber bedecken lichenmischwilder und darüber Buchenbestande, in deren Niederwuehs oryzopsis virescens, Ventenala dubia, Carex pilosa, Lanaria rediviva, Digilalis ambigua, Vaccinium Myrlillus, Sabvin

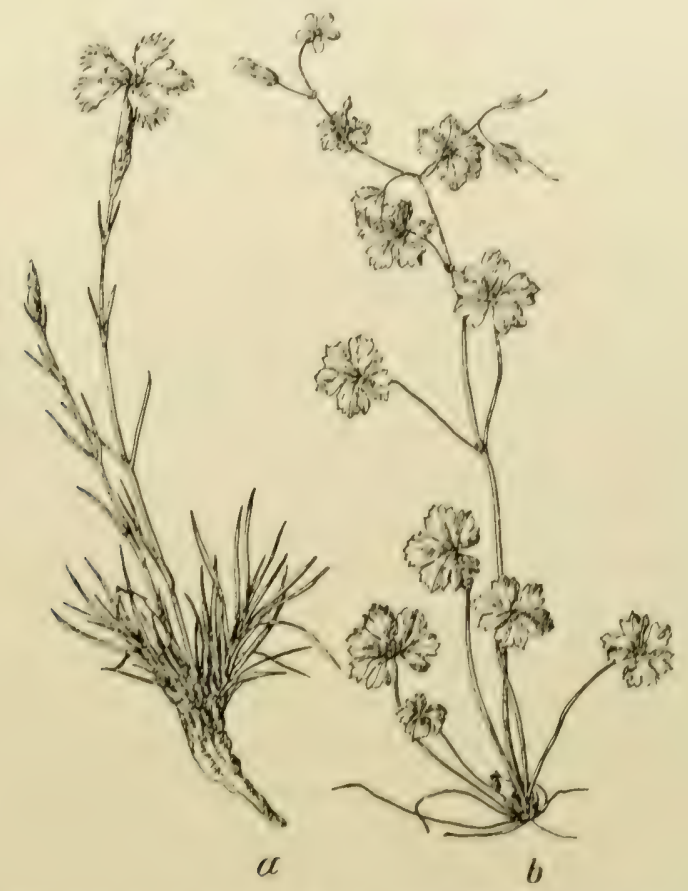

Abb. 206. Zwei charakteristische Felsenpflanzen der Kleinen Karpathen. a Jianthus Jumnilori. " Goranium Jucidum. (Kirka 1/2 nat. Gir.)

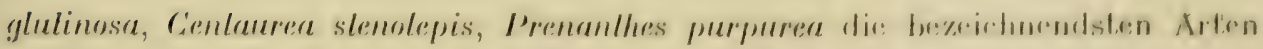
sind; zwischen St. Georgen und Modern tritt ferner, besonders an der unteren Grenze des Buchenwaldes, Ruscus IIypoglossum nicht selten auf, während

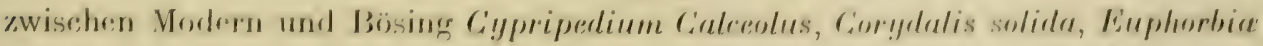

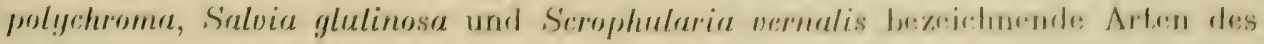
Niederwuchses sind. In höheren Lagen, wie ober Modern, treten immer zahl-

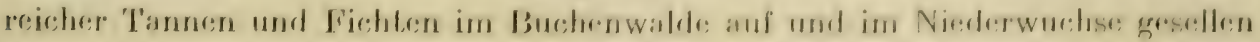

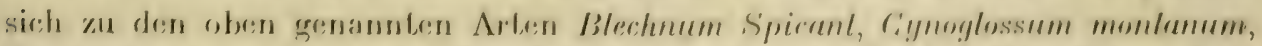
Scrophularia vernalis und selbst. Phyllitis Seolopendrium und I'olystichum Lanchilis hinzu. An Felsen ober Szomolany sind Dianthus Lumnilzeri, Alyssum

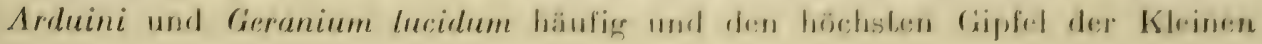


Visoka. Kirpathen, dir Visoka $(754 \mathrm{~m})$, bedecken prächtige Buchenbestände mit Lilium Marlagon, Aclaea spicala, Aconitum Vulparia, Mercurialis perennis, Aslrantia maior, Siler trilobum, Pirola minor, Salvia glutinosa, Scrophularia vernalis, Digilalis ambigua, Atropa Belladonna, Prenanthes purpurea und angeblich sogar Delphinium elalum, während auf der höchsten Spitze üppiges Gestäude aus Parielaria officinalis, Sisymbrium strictissimum, Hesperis nivea und Cynanchum Vincetoxicum vegetiert.

Rachsturm.

Wetterlin. blößen Girsium eriophorum zahlreich wächst, und auf dem WV t terlin gedeihen an sonnigen felsigen Stellen Iris variegala, Alyssum Arduini, Geranium lucidum, Siler lrilobum und Lactuca perennis, während in dessen Buchenbeständen Lunaria rediviva, Euphorbia amygdaloides, Hacquetia Epipactis und Scrophularia vernalis sowie in Bachschluchten angeblich auch Delphinium elalum zu finden sind.

\section{b) Die Beskiden und Pieninen.}

Weiße Karpathen.

Nördlich der Miava erheben sich aus der Ebene die Weißen Karpathen als das erste Glied der fast durchwegs aus Karpathensandstein aufgebauten

Velka. Beskiden. An ihrem Westfuße zwischen Velka und Ung.-Ostra, so bei Lipau und GroB-Blatnitz, finden sich ausgedehnte Steppenwiesen mit Koeleria gracilis, Iris variegala, Anthericum ramosum, Adonis vernalis, Anemone grandis, Clematis recla, Trifolium montanum, Lalhyrus pannonicus, Cytisus supinus, Aslragalus danicus, Bupleurum falcalum, Peucedanum Cervaria, Alectorolophus montanus, Asperula cynanchica, Cirsium pannonicum, die in höheren Lagen, wie bei Borschitz, Lucha und Neu-Lhota in Triften mit Dianthus Pontederae, Geranium sanguineum, Linum flavum, Lathyrus megalanthus, Laserpitium lalifolium, Veronica orchidea, Inula hirla und ensifolia übergehen, auf denen bei Velka auch die seltene Pedicularis exallata vorkommt. Ähnliche Triften mit Andropogon Ischaemum, Anthericum ramosum, Muscari comosum, Himanloglossum hircinum, Diclamnus albus, Linum lenuifolium, Lithospermum purpureo-coeruleum, Digilalis ambigua, Asperula glauca, Scabiosa ochroleuca, Inula hirla, Crepis praemorsa, Cirsium pannonicum treten auch an Vägh- der Ostseite des Gebirges ober Vág-Ujheli (Waag-Neustadtl) auf. Die Höhen des Gebirges aber bedecken teils Föhren-, teils gemischte Laubwälder, in denen Convallaria maialis, Corydalis cava, Hacquelia Epipaclis und Digitalis ambiguu bezeichnende Arten des Niederwuchses sind, während gegen Osten zu Eichenwälder mit cingemischten Buchen, mit Cephalanthera alba, C. longıtolia, C. rubra, Isopyrum thaliclroides, Melillis Melissophyllum usw. vorherrschen. Die höchsten

Javorina. Gipfel der Weißen Karpathen, wie die $968 m$ hohe Javorina, tragen Fichtenund Buchenbestände, in denen Orchis pallens, O. sambucina, Carex pilosa, Allium ursinum, Euphorbia amygdaloides, Aclaea spicala, ja, selbst Polyslichum aculealum, Epilobium alpestre und Mulgedium alpinum vorkommen. An der Ostseite der Weißen Karpathen tritt stellenweise auch Kalk zutage, wie am 
Löwenstein bei Puchov, wo sich dann eine sehr reiche Flora, aus Elementen der pannonischen Trift mit subalpinen Felsenpflanzen gemischt vorfindet, so Asplenium viride, Allium flavum, Arabis Turriia, Alyssum Arduini, Draba lasiocarpa, Seseli Beckii, Saxifraga Aizoon, Sempervivum hirlum, Valeriana tripleris usw.

Im weiteren Zuge der Beskiden ist die Fichte, vermischt mit der Tanne, iler herrschende IValdbaum; eingesprengt kommen auch Fagus silvatica, Acer platanoides und A. Pseudoplatañus vor. Neben den Wäldern sind besonders die prächtigen Bergwiesen mit Gladiolus imbricalus, Orchis globosa, O. sambucina usw. bezeichnend. In der Umgebung von Wsetin treten Eichen, und zwar Quercus Robur wieder häufiger auf; auch kommen um Wsetin einige seltenere Arten vor, wie Anacamptis pyramidalis auf der Wiese nade Mziky, Cirsium acaule auf der Dušná und in Wäldern Melampyrum nemorosum *moravicum. Noch weiter westlich, im Hosteiner Zuge zwischen Wsetin, Bistritz und Holleschau, sind die Wälder fast ausschließlich Laubwälder aus Buchen, Hainbuchen und Eichen, in deren Niederwuchs Melica uniflora, Festuca silvalica, Hordeum europaeum, Carex brizoides, Polygonatum verlicillalum, Euphorbia dulcis, E. amygdaloides, Isopyrum lhalictroides, Hypericum hirsulum, Hacquelia Epipactis, Astrantia maior, Salvia. glutinosa usw. nicht selten sind, während Anemone Hepatica hier auffallenderweise fehlt. Auf Wiesen sind Dianthus deltoides, Primula veris sowie Orchideen (Orchis militaris, Morio, sambucina, latifolia, globosa, Gymnadenia conopea) häufig, bei Rottalowitz kommt auch Gladiolus imbricalus vor. Die höheren Gipfel, wie der 865 mohe Javornik bei Rajnochowitz, tragen neben Buchenbeständen auch Nadelholzwälder. Im Javornikgebirge erhebt sich als erster $1000 m$ überschreitender Gipfel der J avornik ${ }^{\mathbf{1}}$, auf dem in den Wäldern schon Lonicera nigra, Lunaria rediviva, Javornik. Ranunculus planifolius, Aruncus silvester, Aconitum firmum, Campanula latifolia und Petasiles albus auftreten.

Nördlich und östlich vom Javornik erstreckt sich das mehrmals die Höhe von $1000 \mathrm{~m}$ überschreitende Jablunkagebirge. Während in den Tälern kleine Auen aus Alnus glutinosa, $A$. incana, Salix-Arten usw., an den Flüssen of t massenhaft Onoclea Struthiopleris, Myricaria germanica und Chamaenerion palustre, und IViesen mit Slellaria graminea, Dianthus deltoides, Cardamine pratensis, Hypericum maculatum, Carum Carvi, Campanula patula, Galium Mollugo, Chrysanthemum Leucanthemum, Cirsium palustre usw. anzutreffen sind, bedecken seine Hänge Fichtenwälder mit eingesprengten Tannen und Lärchen, in deren Niederwuchs Dryopleris Filix mas, D. spinulosa, Athyrium Filix femina, Deschampsia flexuosa, Luzula nemorosa, Polygonalum verlicillatum, Lamium vulgare, Stachys silvalica, Asperula odorata, Prenanthes purpurea, Hieracium murorum häufig sind; an Waldrändern treten Aruncus silvester, Genliana asclepiadea, ScrophuLaria Scopolii, Senecio sarracenius und an feuchten Stellen Pelasites albus auf. Die Kammhöhe der Gipfel aber bedecken zumeist Borstengrasmatten mit massenhaften Vaccinien. Doch schon auf dem 1138 m hohen Radhost tritt 


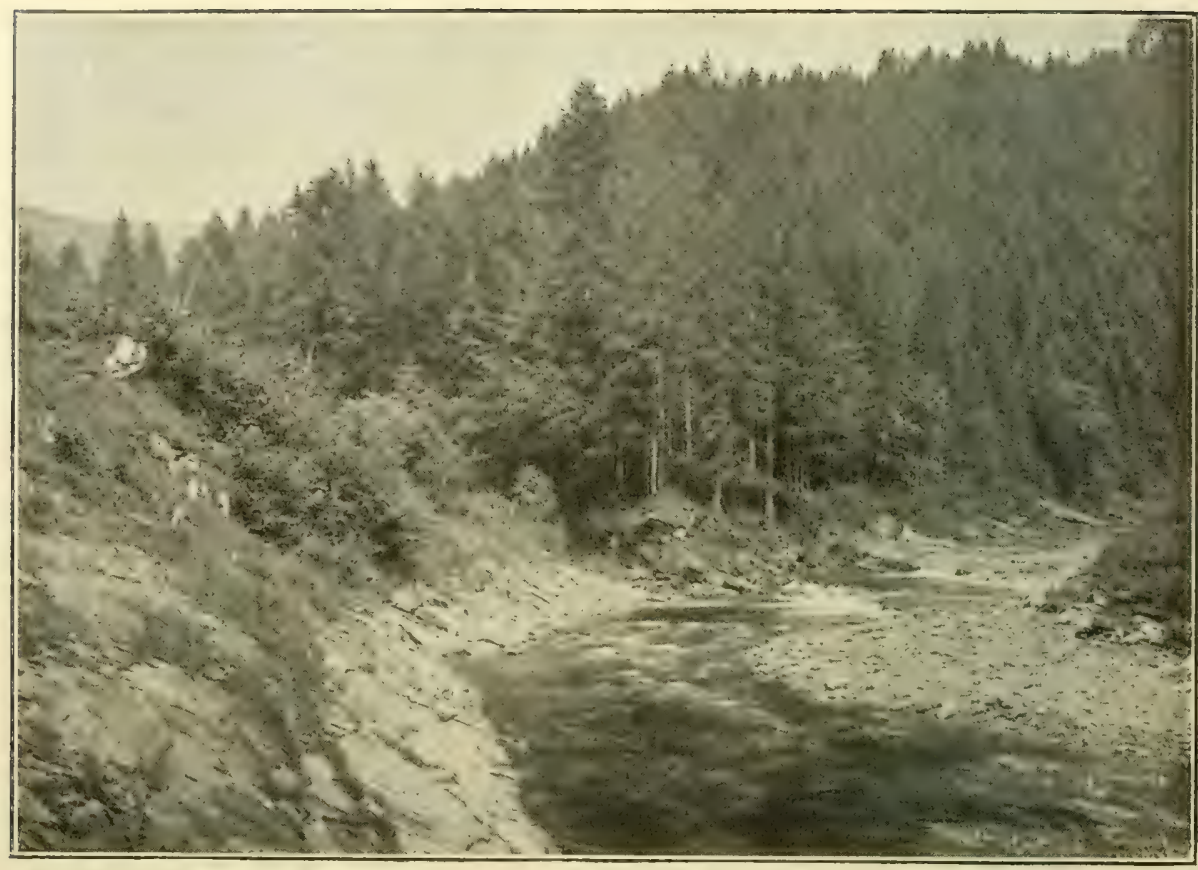

Abb. 207. Fichtenwälder an der Ostrawitza nächst Althammer im Jablunkagebirge. (Nach einer Aufnahme von W. Schlesinger, Biala.)

(Aus der Bildersammlung des geographischen Institutes der Wiener Universität.) Smrk.
Lysa hora.

in diesen Borstengrasmatten Polentilla aurea, auf Wiesen Gladiolus imbricatus, an feuchten Stellen Achroanthes monophyllos und im Walde Ribes alpinum auf, und auf dem $1282 m$ hohen Smrk und der $1325 m$ hohen Lys a hora trifft man im Walde Lycopodium annolinum, Ribes alpinum, R. pelraeum, Rosa pendulina, Thalictrim aquilegifolium, Ranunculus plalanifolius, Genliana asclepiadea und Valeriana tripteris und an Bachufern Salix silesiaca, und die Lysa hora trägt auch schon subalpine Wiesen mit Phleum alpinum, Gymnadenia albida, Polentilla rupestris, Arnica montana und dem seltene Bolrychium Matricariae. Am Nordfuße Friedland. des Jablunkagebirges bei Friedland kommen auch Hochmoore mit Carex canescens, Drosera rolundifolia, Andromeda polifolia, Oxycoccos palustris usw. vor.

Teschen. Auf den Vorbergen der Beskiden von Friedek bis Teschen tritt das Nadelholz allmählich zurück und Laubwälder aus Eichen, Buchen und Hainbuchen, oft mit Föhren gemischt, bilden die herrschende Waldformation, in denen, wie z. B. an der Ols a bei Teschen und weiter aufwärts bis Konska, Bromus asper, Arum maculalum, Allium ursinum, Veratrum Lobelianum, Euphorbia stricla, E. amygdoloides, Isopyrum thaliclroides, Corydalis solida, Arabis hirsuta, Lunaria rediviva, Cardamine glandulosa, C. enneaphyllos, Cucubalus baccifer, Geranium phaeum, Hypericum hirsulum, Cylisus supinus, Melilolus allissimus, Vicia dumelorum, Anthriscus nilidus, Salvia glutinosa, Stachys alpina, Symphytum luberosum, Galium cruciata, Lonicera Xylosteum usw. vorkommen. 
An buschigen Abhängen findet man hauptsächlich Sanguisorba minor, Ononis hircina, Salvia verticillata, Gentiana ciliala, G. cruciala, Anthemis tinctoria und bei Konska auch Diclamnus albus; noch reicher wird diese Flora gegen den Rand der Ebene zu, wie bei Poln isch-Ostrau, wo auch Clemalis Vilalba, bei Fre is tadt, wo Aster Amellus, und bei Friedek, wo Chrysanthemum corymbosum und Chenopodium Bolrys vorkommen. Besonders aber ist der südöstlich von T'eschen gelegene $620 \mathrm{~m}$ hohe Tul wegen seiner reichen Flora berühmt; hier kommen neben Gladiolus imbricatus, Iris graminea, Muscari comosum, Dianthus Carthusianorum, Trifolium rubens, Gentiana asclepiadea, Stachys alpina insbesondere eine große Zahl prächtiger Orchideen vor, u. a. Orchis militaris, O. tridentala, O. globosa, O. mascula, O. sambucina, Anacamplis pyramidalis, Plalanthera montana, Cephalanthera alba, $C$. longifolia und Cypripedium Calceolus. Gegen das höhere Gebirge zu, wie bei Konska und Mönchhof, ireten in den Wäldern auch Orchis pallens, Cypripedium Calceolus, Ranunculus cassubicus, Aruncus silvesler, Cenlaurea mollis und C. Pseudophrygia auf. Im Flußkies der Olsa, Weichsel und Biala bilden Salix incana, S. daphnoides und andere Weidenarten neben Myricaria germanica Bestände, außerdem kommen hier Chamaenerion palustre, Oenothera biennis, Saponaria officinalis und Euphorbia slricla häufig vor.

Reicher wird die Flora im östlichen Teile der Beskiden. In den Wäldern des Bielitzer Gebirges treten Thaliclrum aquilegifolium, Cardamine enneaphyllos, C. glandulosa, C. bulbifera, Aruncus silvesler, Geranium phaeum, Asperula odorala, Atropa Belladonna, Homogyne alpina, Pelasiles albus, Doronicum austriacum, auf Bergwiesen Trollius europaeus, Polygonum Bislorta, Trifolium spadiceum, Geranium silvalicum, Primula elalior, Senecio rivularis, Crepis paludosa, C. praemorsa, Orchis globosa, Gladiolus imbricalus auf. Auf der Kamitzer Platte kommen auch Polygonatum verlicillalum und Gymnadenia albida, auf der Magura Polygonatum verlicillatum und Achroanthes monophyllos vor. Auffallend ist auch das Vorkommen der westlichen Digitalis purpurea an mehreren Standorten um Bielitz und Biala, wie auf dem Klimczok, Kotarz, der Magura, dem Salzberge bei Bielitz und dem Josefsberge und Haislik bei Biala. Auf den gegen die Ebene vorgeschobenen Bergen trifft man auch häufig Galanthus nivalis, Corydalis cava, C. solida, Astrantia maior, Hacquetia Epipactis, Galium vernum, G. Cruciala, usw. In höheren Lagen, wie auf der Baranya und dem Baranya. Cizartory treten noch Aconitum firmum, Panunculus plalanifolius, Valeriana tripteris, Streptopus amplexifolius und Rumex alpinus auf auf; der Baranya die auf den Gipfeln Moore mit Juncus filiformis, Eriophorum vaginalum, Empetrum nigrum und Menyanthes trifoliala trügt, kommen überdies noch Salix silesiaca, Viola biflora, V. sudetica, Centaurea mollis, Hieracium antantiacum vor, hier und auf dem Malinow trifft man ferner Adenoslyles Alliariae, Tozzia carpatica und Malinow Poa Chaixii, die Rownica ist durch Asplenium viride ausgezeichnet.

Die Wälder der Hochbeskiden bestehen aus Fichten, denen nur in tieferen Lagen Tannen und vereinzelte Buchen beigemischt sind, im Niederwuchse sind Cardamine flexuosa, C. enneaphyllos, C. glandulosa, C. bulbifera, Lunaria 
rediviva, Aruncus silvester, Circaea alpina, C. Luletiana und Asperula odorala als charakteristisch hervorzuheben. Doch reicht von den Gipfeln nur dic Babiagora. Babiagora $(1725 \mathrm{~m})$ über die Waldregion hinaus. Die Waldgrenze liegt hier bei $1330 \mathrm{~m}$, darüber findet sich ein dichter Krummholzgürtel, der bis $1660 \mathrm{~m}$ reicht und darüber breiten sich dann alpine Matten mit Selaginella selaginoides, Festuca varia, Poa laxa, Phleum alpinum, Carex atrala, Luzula spadicea, Polygonum viviparum, Cerastium alpinum, Anemone alba, A. narcissiflora, Ranunculus montanus, Saxifraga adscendens, Polentilla aurea, P. Crantzii, Geum montanum, Liguslicum Mutellina, Soldanella carpalica, Genliana punclala, Veronica aphylla, Alectorolophus pulcher, Pedicularis summana, Bartschia alpina, Galium anisophyllum, Senecio subalpinus, Hypochoeris uniflora, Hieracium aurantiacum und H. alpinum aus, während an quelligen Stellen Allium sibiricum, Viola biflora, Oxyria digyna, Epilobium alsinefolium, E. alpestre, Sweerlia perennis, an Felsen Lycopodium alpinum, Sempervivum carpaticum, Saxifraga Aizoon, Sedum roseum zu finden sind.

Trotz dieses Reichtums an Gebirgspflanzen fehlen der Babiagora doch zahlreiche Arten, die in den Zentralkarpathen, und zwar nicht nur in der Hohen Tatra, sondern zum Teil auch in der Fatra, Niederen Tatra und auf dem Chocs verbreitet sind, wie z. B. Sesleria disticha, Carex firma, Salix Jacquini, Ranunculus glacialis, Arabis neglecla, Draba aizoides, Saxifraga moschala, S. perdurans, S. caesia, Dryas octopelala, Gentiana Clusii, G. verna, Primula Auricula, Aster Bellidiastrum, Girsium Erisithales, Leontodon lalricus, L: incanus u. a.

Polhora. Am Fuße der Babiagora bei Polhor a treten Hochmoore mit Carex dioica, C. pauciflora, Juncus squarrosus, Drosera rolundifolia, Oxycoccos quadripelala, Trientalis europaea, Valeriana polygama usw. auf. Im Zusammenhange mit diesen Bory-
sumpe. Mooren stehen dann die bekannten Borys ümpfe, deren Flora reicher ist. Hier bilden teils strauchige Pinus Pseudopumilio, teils aufrechte Pinus uliginosa Bestände, in welch, letzteren dann Ledum paluslre das Unterholz bildet; hie und da sind auch Erlenbrüche mit Calla palustris anzutreffen. Eriophorum vaginalum und E. gracile bilden im Vereine mit Juncus squarrosus, Rhynchospora alba und verschiedenen Carex-Arten dichte Bestände und an trockeneren Stellen finden sich heideartige Bestände aus Calluna vulgaris mit Vaccinium Myrlillus, V. Vitis Idaea, Lycopodium clavalum usw.; an Wassergräben sind Iris Pseudacorus, Lysimachia thyrsiflora und Cicuta virosa nicht selten. Diese Moore finden auf Novy Targ. galizischer Seite in den Mooren bei Novy T arg ihre Fortsetzung, welche ebenfalls dichte Bestände von Pinus Pseudopumilio tragen und wo die in dieser Gegend seltene Scheuchzeria palustris vorkommt. Sonst ist in der Umgebung von Novy Targ nur das häufige Vorkommen von Salvia glulinosa und Equiselum maximum in den Wäldern und das stellenweise massenhafte Auftreten von Gladiolus imbricalus auf Äckern und von Cirsium rivulare auf Wiesen bemerkenswert. Auf der Palenica bei Zakopane wurde kürzlich die in den Westkarpathen sonst fehlende Alnus viridis entdeckt.

Pieninen. Der an die. Beskiden sich ostwärts anschließende Kalkzug der Pieninen ist trotz seiner geringen Höhe durch eine sehr interessante Flora ausgezeichnet. 


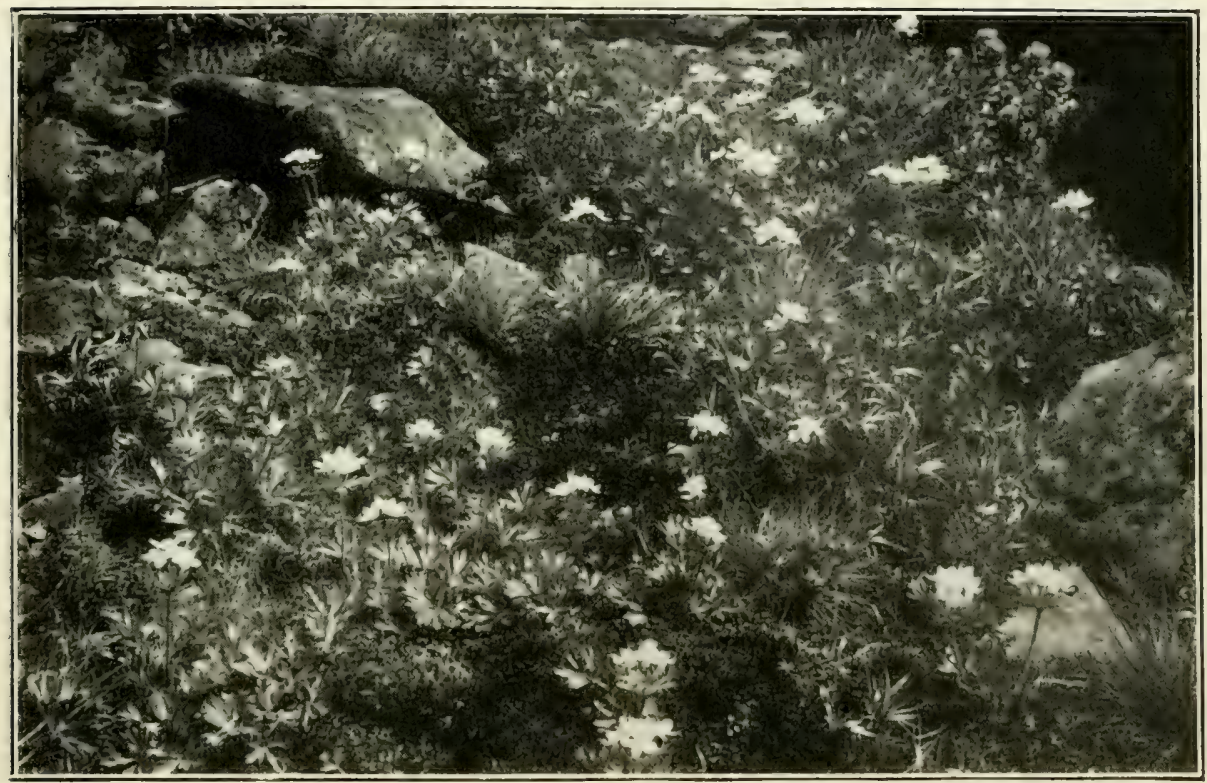

Abb. 208. Anemone narcissiflora in der Gipfelregion der Babiagora.

(Nach ciner Aufnahme von Prof. II. Baer, Trient.)

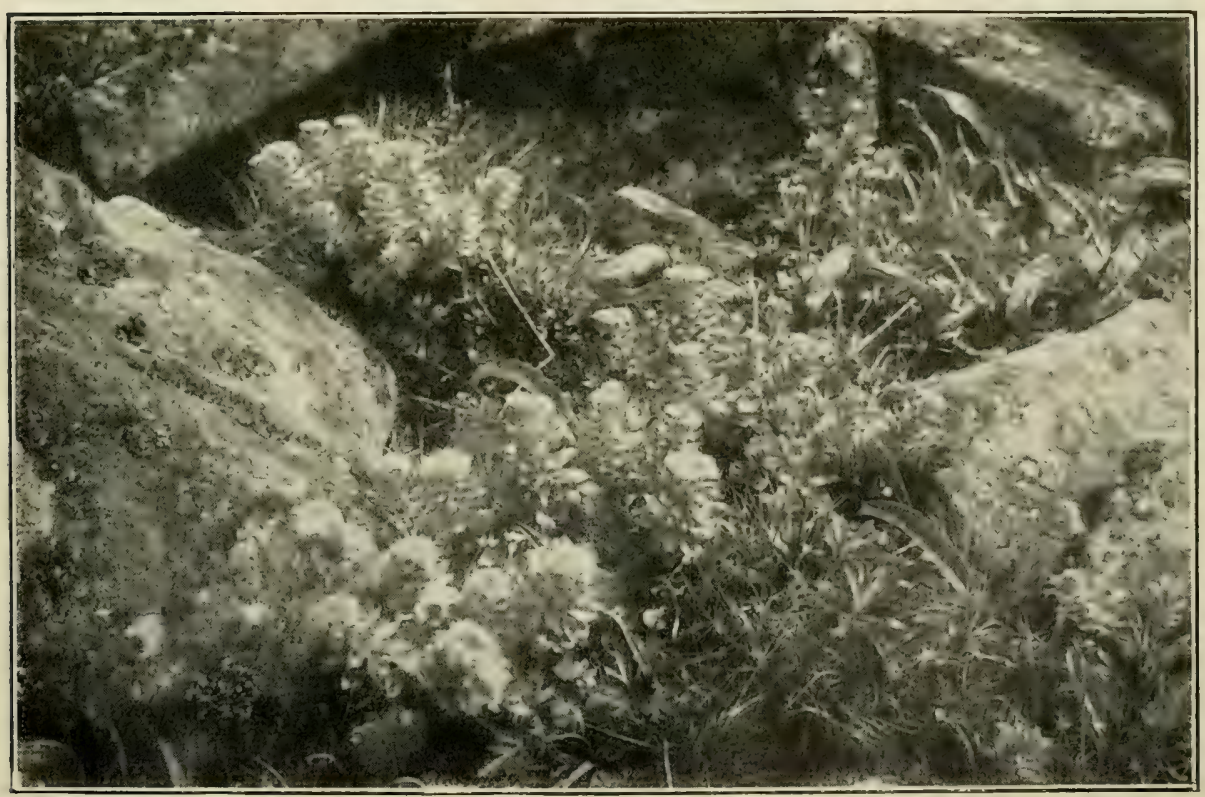

Abb. 209. Sedum roseum in der Gipfelregion der Babiagora.

(Nach einer Aufnalime von Prof. H. Baer, Trient.) 



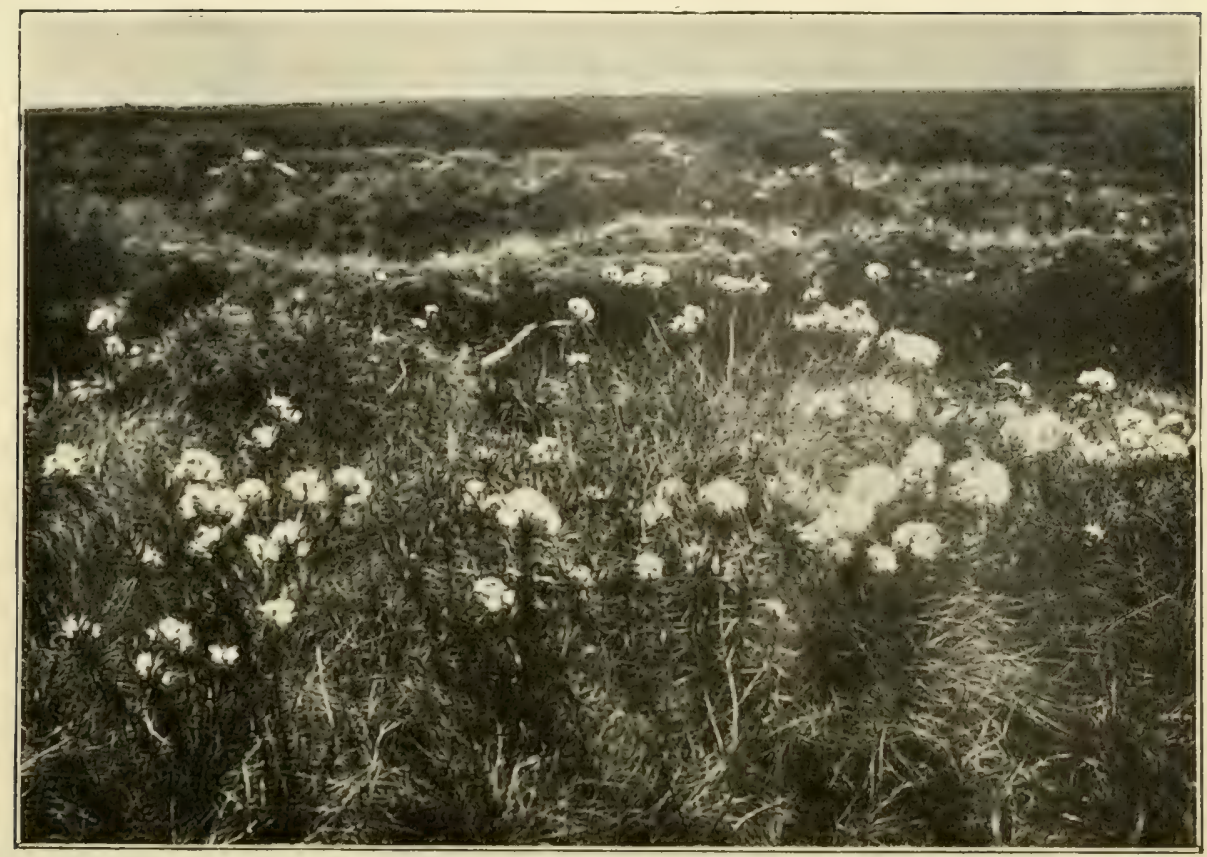

Abb. 210. Ledum palustre in den Borysümpfen.

(Nach einer Aufnahme von G. Nyarádyi, Maros-Vasarhely.)

Die sanfteren Hänge und Kuppen des Gebirges bedecken Fichten- und Buchenwälder, in deren Niederwuchs nicht nur Phyllites Scolopendrium, Alhyrium Filix femina, Dryopleris Filix mas, Cyslopteris sudelica sowie Clematis alpina, Thalictrum aquilegifolium, Circaea alpina, Homogyne alpina und andere Voralpenpflanzen gedeihen, sondern auch einzelne ostkarpathische Typen, so Scopola carniolica und Symphytum cordatum nicht selten auftreten. Die Ufer des D anajcc umsäumt Gebüsch aus Alnus glutinosa, A. incana, Salix purpurea und S. incana, auf den Schottern des Flusses wachsen Myricaria germanica, Euphorbia slricla, Herniaria glabra, Sagina procumbens und Chamaenerion paluslre. Die Bergwiesen bieten Botrychium Lunaria, Ophioglossum v'ulgatum, Veratrum album *Lobelianum, Orchis uslulata, Gymnadenia conopea, Gentiana cruciala, G. carpalica, Scabiosa lucida, Knautia carpatica, Cirsium eriophorum, Hieracium bupleuroides *Tatrae usw. Die reichste Flora aber findet man an den Felsen des Kronenberges und der Golicza, und zwar sowohl in der Gipfelregion als an den Steilhängen gegen den Dunajecdurchbruch bei Kroscienko. Hier wachsen Asplenium viride, Allium monlanum, Ophrys muscifera, Minuarlia laricifolia, M. selacea, Ranunculus Hornschuchii, Alyssum Arduini, Arabis alpina *pieninica, Lunaria rediviva, Sempervivum hirlum, Saxifraga Aizoon, Astragalus australis, Bupleurum falcatum, Androsace laclea, Teucrium montanum, Euphrasia salisburgensis, Aster alpinus, A. Bellidiastrum, Artemisia Absynthium *alcigena, Inula ensifolia und auf den höchsten Felszinnen auch Pinus Mughus und in 
fast unzugänglichen Spalten Juniperus Sabina. Hier sind endlich auch die Standorte der berülımten Seltenheiten der Pieninen, des blaßgelben Erysimum Wittmanni, der prachtvollen tiefblauen Aquilegia Ullepitschii und des durch seine bläulichen Strahlblüten ausgezeichneten Chrysanthemum Zawadskii.

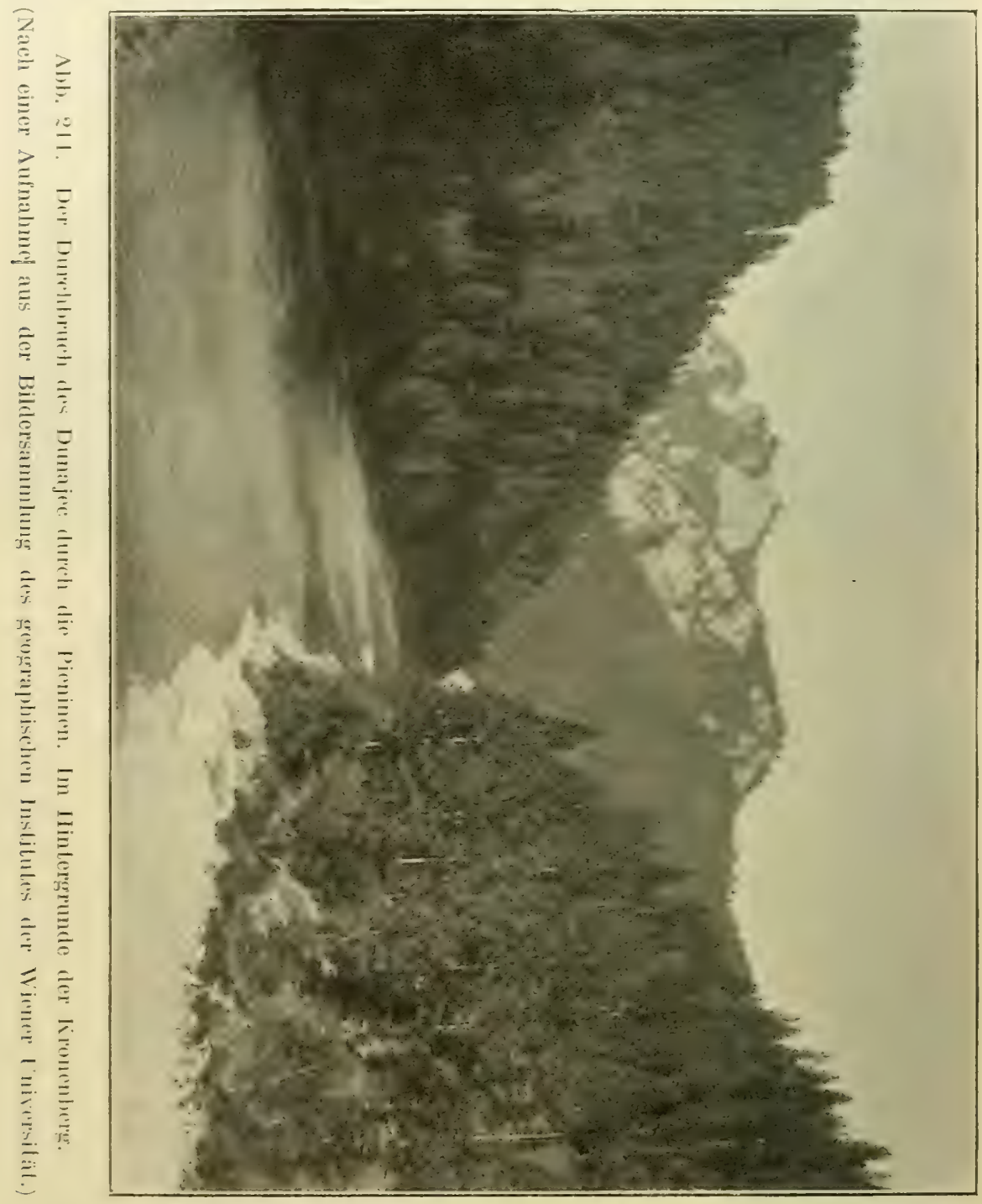

An die Pieninen ostwärts schließt sich ein niederes Sandsteingebirge an, dessen höchste Gipfel Černahora und Pasiku nicht mehr die Höhe von $900 \mathrm{~m}$ Bartfa, erreichen. Hier in der Ungebung von Bartfa (Bartfeld) herrschen Buchenund Fichtenwälder vor, auch Pinus silvestris ist nicht selten. In den Wäldern wachsen Carex pilosa, C. digitala, Lilium Marlagon, Cephalanthera longifolia, Actaea spicala, Corydalis cava, Cardamine glandulosa, Artncus silvester, Mer- 


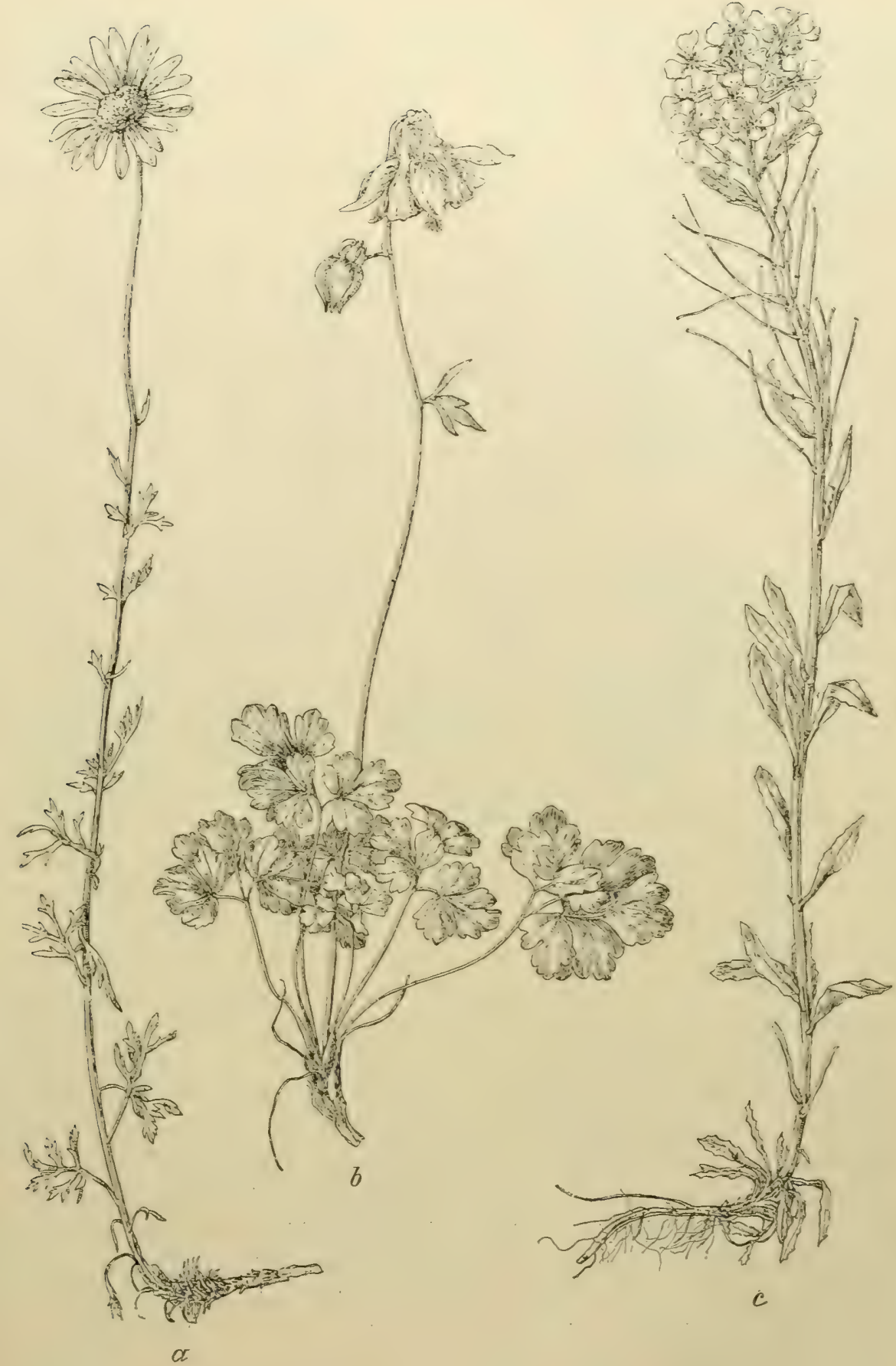

Abb. 212. Die drei bezeichnendsten Arten aus der Flora der Pieninen.

a Chrysanthemum Zawadskii. b Aquilegia Ullepitschii. c Erysimum Wittmanni. 
curialis perennis, Circaea luteliana, Chimaphila umbellata, Pirola minor, im Unterholze treten auch Evonymus verrucosus und Sambucus racemosa auf. Auch Sumpfwiesen, aus deren Flora nur Scirpus maritimus, Stellaria uliginosa und Ranunculus flammula hervorzuheben sind, sind häufig und einzig die Bergwiesen sind durch einige Gebirgspflanzen, wie Veratrum album *Lobelianum, Orchis mascula *signifera, O. sambucina, Gymnadenia conopea, Gentiana carpalica und Cenlaurea austriaca ausgezeichnet.

\section{c) Die Westkarpathen südöstlich der Waag.}

Waagtal.

Das die Beskiden von der Inoveczgruppe trennende Tal der Waag ist ein weites mit Ackern reich bedecktes Wiesental, in dem besonders die zahlreichen Girsiumarten (C. canum, G. pannonicum, G. rivulare, C. oleraceum) mit ihren Hybriden auffallen; an den Ufern der Wag finden sich hie und da Sumpfpflanzen oder kleine Sumpfwiesen mit Carex Davalliana u. dgl., auf Sandbänken

Inoveczgebirge.

Bán.

Becsko.

Temetveny. ist Myricaria germanica nicht selten. Die Ausläufer des Inoveczgebirges tragen steppenartige Triften mit Cynodon Daclylon, Adonis vernalis, Alyssum montanum, Potentilla arenaria, Thymelaea Passerina, Androsace maxima, Sideritis montana, Cephalaria transsilvanica, Inula Oculns Christi usw. sowie Buschwerk aus Quercus Cerris und Qu. pubescens, unter das sich bei Trebichnia und Timoracz nüchst B á n sogar Colinus Coggygria mischt. Reicher an Gebirgsarten sind die Hügel bei Becsko, wo auch Cerastium glulinosum, Thalictrum foetidum, Hippocrepis comosa, Trigonella monspeliaca gedeihen. Besonders reich ist aber die Flora der Kalkfelsen, wie am Te metveny, wo u. a. Sesleria varia, Poa badensis, Carex Michelii, Ophrys fuciflora, Bisculella laevigata, Alyssum montanum, Draba lasiocarpa, Saxifraga Aizoon, Rhamnus saxalilis, Bupleurum falcalum, Teucrium monlanum, Globularia Willkommii, Campanula sibirica, Inula squarrosa zu finden sind, auch auf dem Burghügel der Stadt Trencsin kommen Allium flavum. Aconitum Vulparia, Alyssum Arduini, Corydalis solida, Sedum album, Torilis helvetica, Lilhospermum purpureo-coeruleum, Teucrium Chamaedrys, Gynanchum Vincetoxicum und Aster Amellus vor. Über diesen kahlen Felshängen treten dann Eichenwälder aus Quercus Cerris und Qu. sessiliflora auf, mit dem für die Westkarpathen charakteristischen Niederwuchs aus Lilium Marlagon, Neoltia Nidus avis, Actaea spicata, Saxifraga bulbifera, Astranlia maior, Hacquelia Epipactis, Genisla pilosa, Lithospermum purpureo-coeruleum usw. und in höheren Lagen, wie auf dem Inovecz selbst, finden sich auch Buchenbestände. Auch das Zjar-Tribecz-Gebirge ist größtenteils mit Wäldern aus Quercus sessiliflora und Carpinus Belulus berleckt, an sonnigen Hängen trifft man Saxifraga bulbifera, Thymus monlanus, Galium pedemontanum, Cirsium eriophorum, Aster Linosyris und in Tale der Zoitra bei Aranyosmarót am linken Talgehänge ziemlich häufig Calluna vulgaris und Jasione montana, während dem Andesitboden an der rechten Talseite insbesondere Asplenium septentrionale, Isopyrum thalicIroides, Saxifraga granulala, Cynoglossum montanum und Scrophularia vernalis eigentümlich sind. 
Das Tal der Neutra zeigt große Ähnlichkeit mit dem der Waag, auch hier sind vornehmlich Wiesen mit Leucoium vernum, Thalictrum lucidum, Clematis integrifolia, Roripa austriaca, Cardamine pratensis usw. verbreitet.

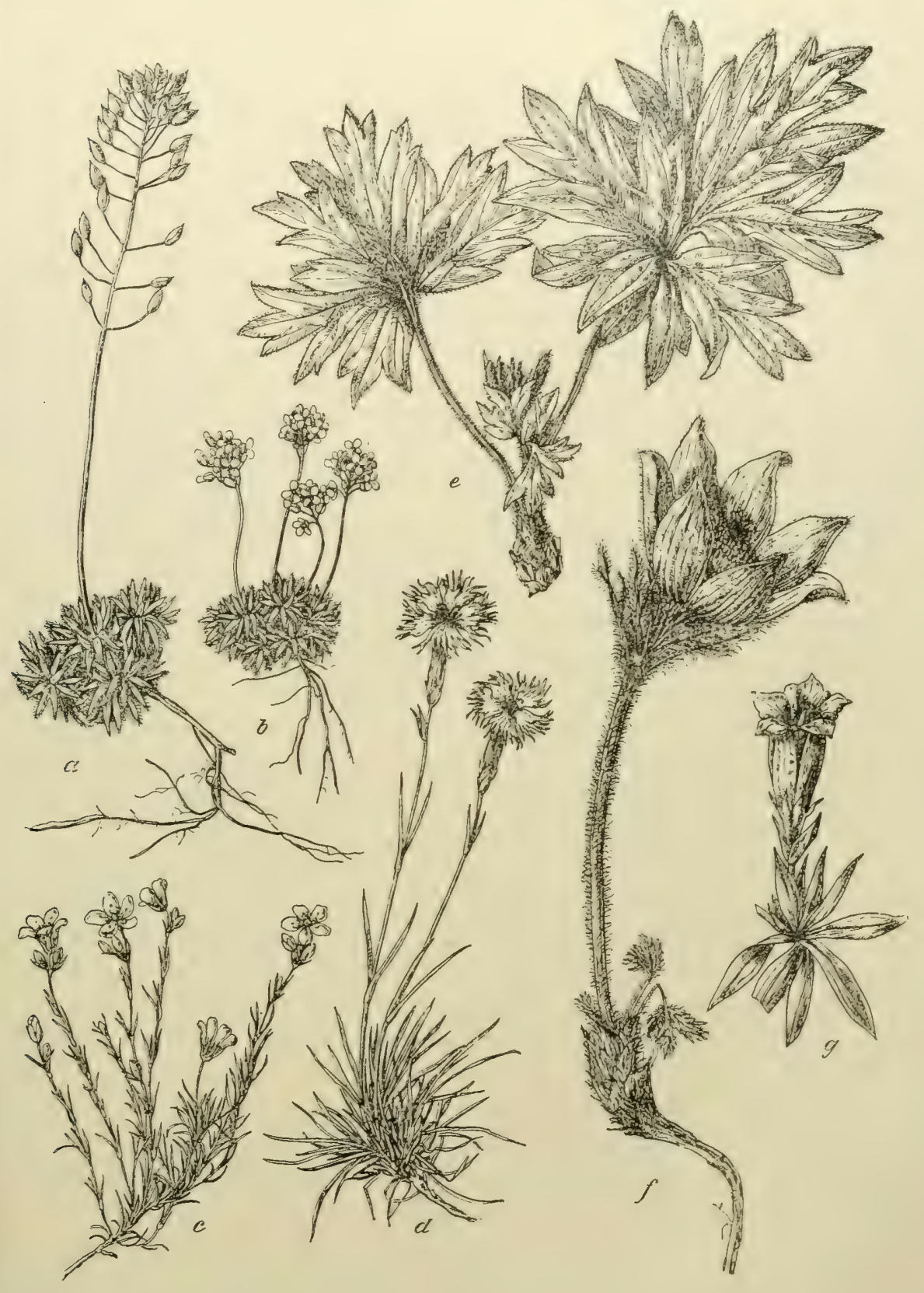

Abb. 213. Aus der Flora der Kalkberge der Südwestkarpathen.

$a, b$ Draba lasiocarpa. $c$ Minuartia laricifolia. $d$ Dianthus hungaricus, $e, f$ Anemone slavica. $g$ Gentiana Clusii var. Rochelii. 
Eine sehr reiche und interessante Flora bietet das sich nördlich an dcn Galgocz- Inovecz anschließende Galgocz-Gebirge (Veterna hola), besonders in seincm Gebirge. südlichen Teile, wo an den zahlreichen Kalkfelsen sich in großer Zahl auswesprochene Voralpenpflanzen in Gesellschaft von Bestandteilen der pannonischen

Sulov. Triftformation findet. So kommen im Talkessel von Sulov Slipa pennala, Melica nutans, Anthericum ramosum, Moehringia muscosa, Anemone slavica, Kernera saxalilis, Draba lasiocarpa, Bisculella laevigata, Saxifraga Aizoon, Hippocrepis comosa, Viola collina, Primula Auricula, Gentiana Clusii *Rochelii, Euphrasia salisburgensis, Globularia Willkommii, Asperula cynanchica, Valeriana tripteris, Aster alpinus, A. Bellidiastrum, Inula ensifolia, Centaurea mollis, Leonlodon incanus, Hieracium bupleuroides und bei der Ruine des Schlosses selbst Dianthus nilidus

Maninschlucht. in buntem Gemische vor, und an den Felsen der Maninschlucht bei VágTepla findet man Alyssum Arduini, Draba lasiocarpa, Bisculella laevigala, Saxifraga Aizoon, Sempervivum hirlum, Digitalis ambigua und Arlemisia Absynthium; bei Malenicza im Prusinskaer Tale Allium monlanum, Minuartia laricifolia und Campanula cochleariaefolia. Die Wälder des Gebietes bestehen nur am Fuße des Gebirges aus Quercus sessiliflora mit Qu. Cerris und Carpinus Belulus, sonst ist Fagus silvatica, oft von Picea excelsa begleitet, der herrschende Waldbaum, in deren Beständen Asarum europaeum, Cardamine bulbifera, Aruncus silvester, Aclaea spicata, Astrantia maior, Atropa Belladonna und Cirsium Eristhales gedeihen. Im nördlichen Teile des Gebietes treten auch ausgedehnte Bergwiesen mit Phleum alpinum, Deschampsia flexuosa, D. caespilosa, Agrostis vulgaris, Anthoxanthum odoratum, Polygonum Bistorta, Geranium silvaticum, Ligusticum Mutellina, Soldanella maior, Campanula pseudolanceolala, Solidago alpestris, Hypochoeris uniflora, Hieracium aurantiacum auf und auf solchen findet man Revan. auf dem Revan bei Gaidel auch die seltene Crepis sibirica. Der Gipfel der Velka Volka Lukna $(1477 \mathrm{~m})$ trägt sogar Krummholz und Buschwerk aus Fichten, Lukna. darunter der Picea excelsa var. ellipsoconis.

Schemnitz. Krem-

Das Schemnitz-Kremnitzer-Erzgebirge trägt auf seinen hügeligen, von Weingärten bedeckten Ausläufern Buschwerk aus Quercus pubescens, Cralaegus oxyacantha, Prunus spinosa, P. Mahaleb, Evonymus verrucosus, Acer lalaricum, Rosen usw. und stellenweise auch Eichenwälder. Im zentralen Teile des Erzgebirges aber treten die Elemente der Hügelflora bald zurück. Schon bei Schemnitz (Selmeczbanya) tritt Pinus silvestris waldbildend auf, daneben kommen aber auch gemischte Laubwälder aus Quercus Robur, Carpinus Belulus, Pirus acerba, Sorbus Aria, S. torminalis, Tilia cordala und selbst Fagus silvatica, mit Unterholz aus Corylus Avellana, Evonymus verrucosus, E. vulgaris, Cytisus nigricans, Lonicera Xylosteum, L. nigra und zabllosen Rubusarten vor, während aus dem Niederwuchse dieser Wälder Cardamine bulbifera, Vicia pisiformis, V. silvalica, Lathyrus megalanthus, L. silvester, Aruncus silvesler, Sanicula europaea, Lamium vulgare, Lilium Marlagon, Arum maculatum und die in der Tatra schon fehlenden Arten Cardamine enneaI hiyllos und Primula vulgaris hervorzuheben sind. Der durch seine reiche Posenflora (u. a. Rosa pendulina und $R$. tomentosa in verschiedenen Formen sowie die für das 


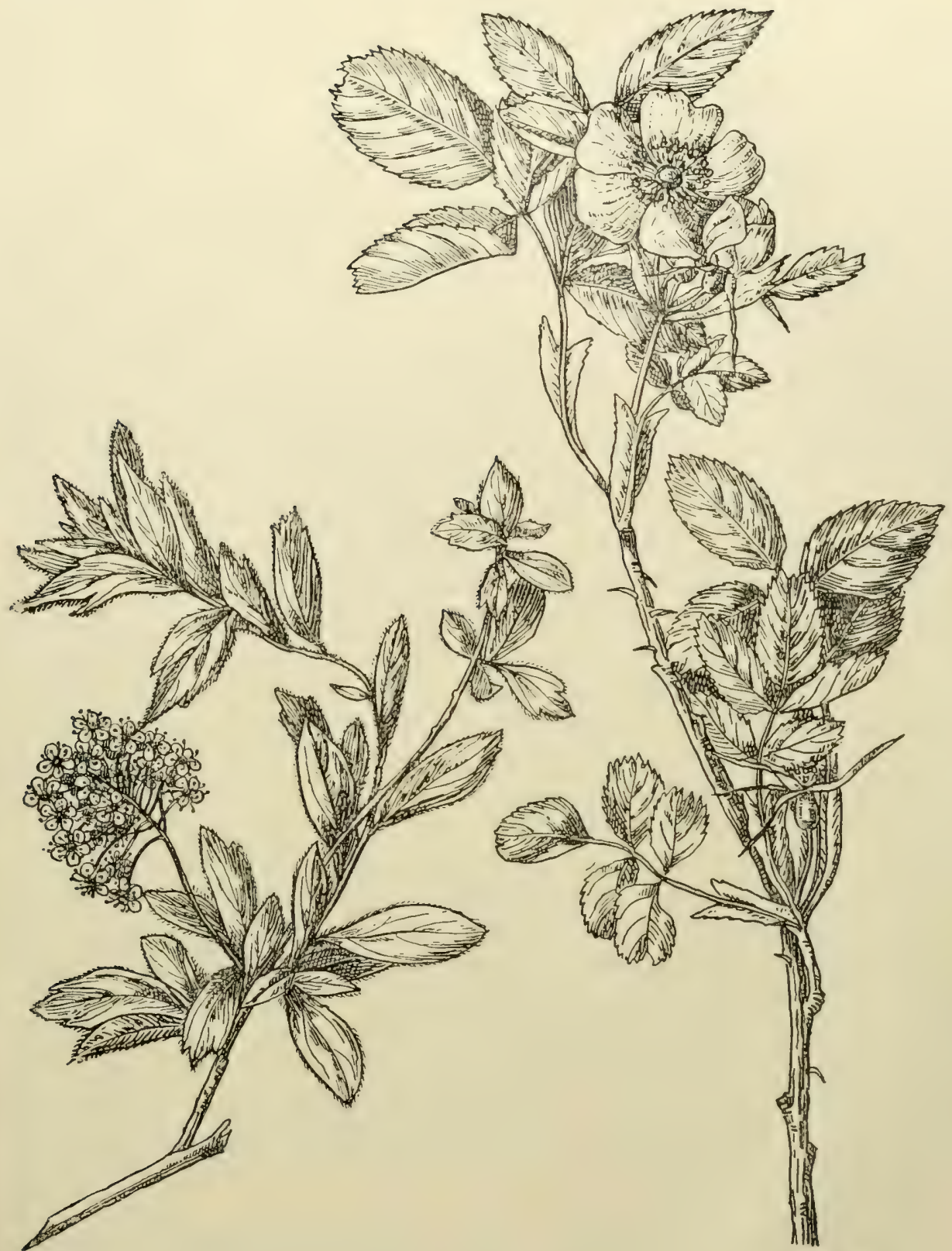

Abb. 214. Rosa glauca Subsp. Ilseana und Spiraea chamaedryfolia, zwei charakteristische Sträucher des ungarischen Erzgebirges.

ganze Gebict sehr charakteristische Rosa glauca *Ilseana) bekannte $1140 \mathrm{~m}$ hohe Sytn a beherbergt an Felsen Anemone slavica, Minuartia frulescens, Sempervivum hirlum, Coloneaster inlegerrima, Spiraea chamaedryfolia, in höheren Lagen Woodsia ilvensis, Saxifraga Aizoon und Lycopodium Selago. Im höheren Teile des Erzgebirges aber, wie auf der Poljana und dem Vjepor, treten dichte Buchen-, Poljana. 
Tannen- und Fichtenwälder auf, an deren Rändern schon manche subalpine Hochstauden, wie Thaliclrum aquilegifolium, Geum striclum, Doronicum austriacum, Senecio sarracenius, Mulgedium alpinum, Adenoslyles Alliariae, Luzula silvalica zu finden sind, während an Waldbächen bereits Salix silesiaca, Rosa pendulina, Ribes alpinum und Lonicera nigra Gebüsche bilden; und auch die Bergwiesen des Gebietes sind durch mancherlei Gebirgspflanzen, wie Gymnadenia conopea, Polentilla aurea, Viola sudetica, Gentiana asclepiadea, Gnaphalium norvegicum, Solidago alpestris, Crepis conyzaefolia und Hieracium floribundum ausgezeichnet. Auf Moorwiesen bei Breznobanya aber wurde kürzlich die seltene Viola epipsila entdeckt.

Grantal. Das Tal der Gran, das das ungarische Erzgebirge von der Fatra und Niederen Tatra trennt, zeigt bis über Neusohl (Beszterczebanya) hinauf keinerlei subalpine Anklänge. Erlen und Weiden umsäumen die Ufer des Flusses und Fatra. im Tale finden sich Äcker und eintönige Wiesen. Auch am Fuße der Fatra sind noch Bergtriften mit Carex alba, Bisculella laevigala, Euphorbia polychroma, Polygala amara, Hippocrepis comosa, Daphne Cneorum, Centaurea variegata und Leontodon incanus entwickelt und über denselben Buchenwälder, in deren Niederwuchs Cephalanthera rubra, C. alba, Cypripedium Calceolus, Plalanthera bifolia, Cardamine enneaphyllos, C. bulbifera, Aremonia agrimonioides, Cyclamen europaeum gedeihen; an Bachufern und in Waldschluchten findet man Ribes petraeum, Laserpitium Archangelica, Valeriana montana, Senecio umbrosus, Hieracium inuloides und im Lubochnatale ober Fenyöhaza auch Telelia speciosa, deren Indigenat jedoch etwas fraglich scheint, während sie auf dem Klak tatsächlich ursprünglich zu sein scheint. Auf den Bergwiesen der Fatra wachsen Silene nutans, Aquilegia vulgaris *longisepala, Thalictrum aquilegifolium, die hier endemische Knautia lurocensis, Hieracium Falrae, Gymnadenia conopea, G. odoratissima, Coeloglossum viride usw., an felsigen Stellen ist Amelanchier ovalis allenthalben häufig. An sumpfigen Stellen im Raksaertale aber findet man das seltene Trichophorum oliganthum. Von den Gipfeln ist die $1575 m$ hohe

Križna. Križna von Buschwerk aus Krüppelbuchen umsäumt und beherbergt überdies noch Anemone narcissiflora, Linum extraaxillare, Saxifraga adscendens, Leontopodium alpinum und Hieracium villosum sowie die hier endemische Hypochoeris Cserni- carpalica; der Gsernikamen ist von Beständen von Pinus Mughus bewachsen, kamen.- zwischen denen Salix silesiaca, Galanthus nivalis, Gagea minima, Allium vicloriale, Corydalis solida, Isopyrum thalictroides, Pleurospermum austriacum und Empetrum nigrum $\mathrm{zu}$ finden sind.

Östlich von der Fatra und nördlich vom Erzgebirge erstreckt sich die lange Nieder- Kette der Niederen Tatra, ein ausgedehnter Urgebirgsstock, dem im Norden Tatra. mächtige Kalkmassen vorgelagert sind und dessen Gipfel die Höhe von $2000 \mathrm{~m}$ überragen oder doch fast erreichen. Auf den kristallinischen Schiefern ist der herrschende Waldbaum die Fichte, die hier ausgedehnte Bestände mit einlünigem Heidelbeerniederwuchs bildet, auf Voralpenwiesen gedeihen Luzula sulelira, Gentiana punctala, Hieracium alpinum, H. Wimmeri und H. stygium. Dic höheren Gipfel aber, wie den Djumbir und die Kralova Hola, umgürtet 
ein dichter Bestand von Pinus Mughus und darüber breiten sich alpine Matten aus Avena versicolor, Sesleria disticha, Carex sempervirens, Juncus lrifidus, Salix retusa, S. herbacea, Silene acaulis, Geum monlanum, Sempervivum carpaticum, Saxifraga hieracifolia, S. androsacea, S. carpatica, Viola sudetica, Primula minima, Ligusticum Mulellina, Doronicum Clusii, Chrysanthemum alpinum, Senecio carpalicus, Leontodon clavalus aus, so daß die Flora schon lebhaft an die der Hohen Tatra erinnert. An der Nordseite aber ändert sich das Bild der Vegetation, sofort wie der Kalkboden sich einstellt. So treten schon am D ju m bir, Djumbir. jenseits des Ufers der Bysztra, Ranunculus alpestris, Callianthemum coriandrifolium, Veronica aphylla, V. fruticans, Euphrasia salisburgensis, Leonlopodium alpinum und andere Kalkpflanzen auf und auf dem Gipfel der Poludnic a bilden Poludnica. Sorbus Aria und S. Chamaemespilus Buschbestände. An den Nordabhängen der Niederen Tatra auf Kalkboden ist Fagus silvatica der herrschende Waldbaum, in deren Beständen Spiraea chamaedryfolia das Unterholz bildet, während im Niederwuchse Cardamine bulbifera, $C$. glandulosa und $C$. enneaphyllos häufig sind. An den Kalkfelsen gegen das Waagtal zu kommen aber Genista pilosa, Erysimum Wiltmanni, Linum extraaxillare, Daphne Cneorum und Crepis alpestris, an der Poludnica auch Anemone slavica, Ranunculus alpestris, Aconilum moldavicum und Leontopodium alpinum vor. Den östlichsten Ausläufer der Niederen Tatra bilclet die $1943 \mathrm{~m}$ hohe Ir ralova hola, wo der bisher einzige Standort von Carex rigida in den Karpathen liegt und wo auch Leontodon clavalus einen isolierten Standort besitzt. In Sümpfen am Nordfuße der Kralova hola kommt auch Ligularia sibirica vor, die im Gebiete der Niederen Tatra noch einen zweiten Standort im Straczen at a le besitzt, wo sie mit Sweerlia perennis vergesellschaftet auftritt. Die nördlichen Vorberge der Kralova hola gegen Poprad zu, der Ganocs-Lucivnaer Höhenzug, trägt Nadelwälder, in denen u. a. Cephalanthera rubra, Clematis alpina, Aconitum moldavicum, Actaea Cimicifugia, Euphorbia amygdaloides, Pirola chlorantha, Digilalis ambigua, Gentiana asclepiadea vorkommen, auf den Kalkbergen bei Teplic und Lucsivna, besonders der Baba, finden sich überdies Cypripedium Calceolus, Anemone slavica, Dianthus hungaricus. Linum flavum, Bupleurum falcatum, B. longifolium, Senecio aurantiacus, Centaurea mollis u. a., auf dem Schlößchen noch Astragalus danicus, Spiraea chamaedryfolia, Artemisia Absynthium und Soldanella maior und auf dem Smolnik und dem Kienberge bei Lucsivna auch das seltene Geranium bo- Lucsivna. hemicum. Nordöstlich von diesen Vorbergen gegen Poprad zu breiten sich Wiesenmoore aus, aus deren Flora Schoenus ferrugineus, Primula farinosa und Menyanthes trifoliata hervorzuheben sind.

\section{d) Die Zentralkarpathen nördlich der Waag.}

Das obere Wagtal, die Liptau, ist besonders in seinem östlichen Teil vielfach versumpft und von Wiesenmooren eingenommen, auf denen besonders Eriophorum latifolium und E. angustifolium, Carex vulpina, C. paradoxa, C. elala, G. Goodenoughii u. a., Primula farinosa, Pedicularis palustris, Menyanthes 
Irifoliala häufig sind; im westlichen Teil ist es teils von Wäldern, teils von prächtigen Wiesen mit Trollius europaeus, Viscaria vulgaris, Trifolium monlanum, Genisla tincloria, Knaulia carpalica, Girsium rivulare, Hypochoeris maculala usw. bedeckt.

Die westlichste Berggruppe nördlich der Waag ist die wenig ausgedehnte, teils aus Quarzit, teils aus Kalk aufgebaute Klein-Krivan- Gruppe, die besonders auf Kalkboden eine reiche Hochgebirgsflora aufweist. Der vorherrschende Waldbaum ist hier Fagus silvalica, in deren Beständen Saxifraga rolundifolia nicht selten ist und wo auch schon Epipogium aphyllum gefunden wurde; hingegen fehlt hier die südlich der Waag so verbreitete Cardamine enneaphyllos fast vollständig und ist nur als Seltenheit zwischen dem Roszudec und der Zazrina zu finden; unterhalb Medzihole kommt auch Aremonia agrimonioides vor. Über den Buchen tritt auch die Fichte und Tanne waldbildend auf, in deren Beständen Actaea spicala, Aruncus silvesler, Pirola uniflora, Soldanella maior, Gentiana asclepiadae zu finden sind; nicht ohne Interesse ist es ferner, daß in der Belska dolina die in den Sudeten heimische Prunus pelraea subalpine Buschbestände bildet. Über dem Walde breitet sich ein vielfach zerrissener Krummholzgürtcl aus und darüber Alpenmatten mit Nardus slricla, Lycopodium alpinum, L. Selago, Vaccinium Myrtillus, Potentilla anrea, Liguslicum Mulellina, Gentiana asclepiadea, Soldanella carpalica und Hieracium alpinum und selbst die höheren Quarzitgipfel, wie der $1711 \mathrm{~m}$ hohe Kleine Krivan, bieten von interessanteren Arten nur Anemone narcissiflora, Sedum roseum, Saxifraga aizoides und Allium vicloriale. Viel reicher und mannigfacher ist die Flora auf Kalkboden. Schon in tieferen Lagen findet man im Vratnatale an Felsen Asplenium viride, Draba aizoides, Kernera saxalilis, Minuartia laricifolia, Sempervivum hirtum, Gentiana Clusii, Rubus saxalilis, Aster Bellidiastrum, Cirsium Erisilhales usw. und auf dem Gipfel des 1606 m hohen Roszudec bildet Carex firma Alpenmatten, die lebhaft an die der nördlichen Kalkalpen erinnern und u. a. Gypsophila repens, Silene acaulis, Dianthus nilidus, Delphinium oxysepalum, Saxifraga caesia, S. aizoides, S. Aizoon, S. perdurans, Dryas oclopelala, Primula longiflora, Pedicularis verlicillata und Aster alpinus aufweisen und auch der benachbarte 1608 w hohe

stoch. Stoch besitzt Ranunculus alpestris, Saxifraga aizoides, S. Aizoon, Androsace lactea, Corlusa Malthioli, Gentiana Clusii, Veronica aphylla, Euphrasia salisburgensis und Allium victoriale.

Durch das Tal der Arva von ihr getrennt, erhebt sich östlich von der Choč. Klein-Krivan-Gruppe der isolierte, $1613 m$ hohe Dolomitstock des Ghoč. Die Hänge desselben sind mit dichten Buchenwäldern bekleidet, in denen Carex alba, Cardamine trifolia, C. enneaphyllos, Aruncus silvester, Hacquelia Epipaclis, Pulmonaria mollissima, Campanula pseudolanceolala, Senecio umbrosus sowie Buphthalmum salicifolium nicht selten sind, über dem Buchenwalde dehnt sich ein breiter Krummholzgürtel aus, in dem auch Delphinium elalum, Cirsium Erisithales und Mulgedium alpinum vorkommen, auf Bergwiesén ist die seltene Crepis sibirica anzutreffen, an Felsen in der Waldregion findet man Kernera saxalilis, Dianthus hungaricus, Minuartia laricifolia, Mochringia muscosa, und 


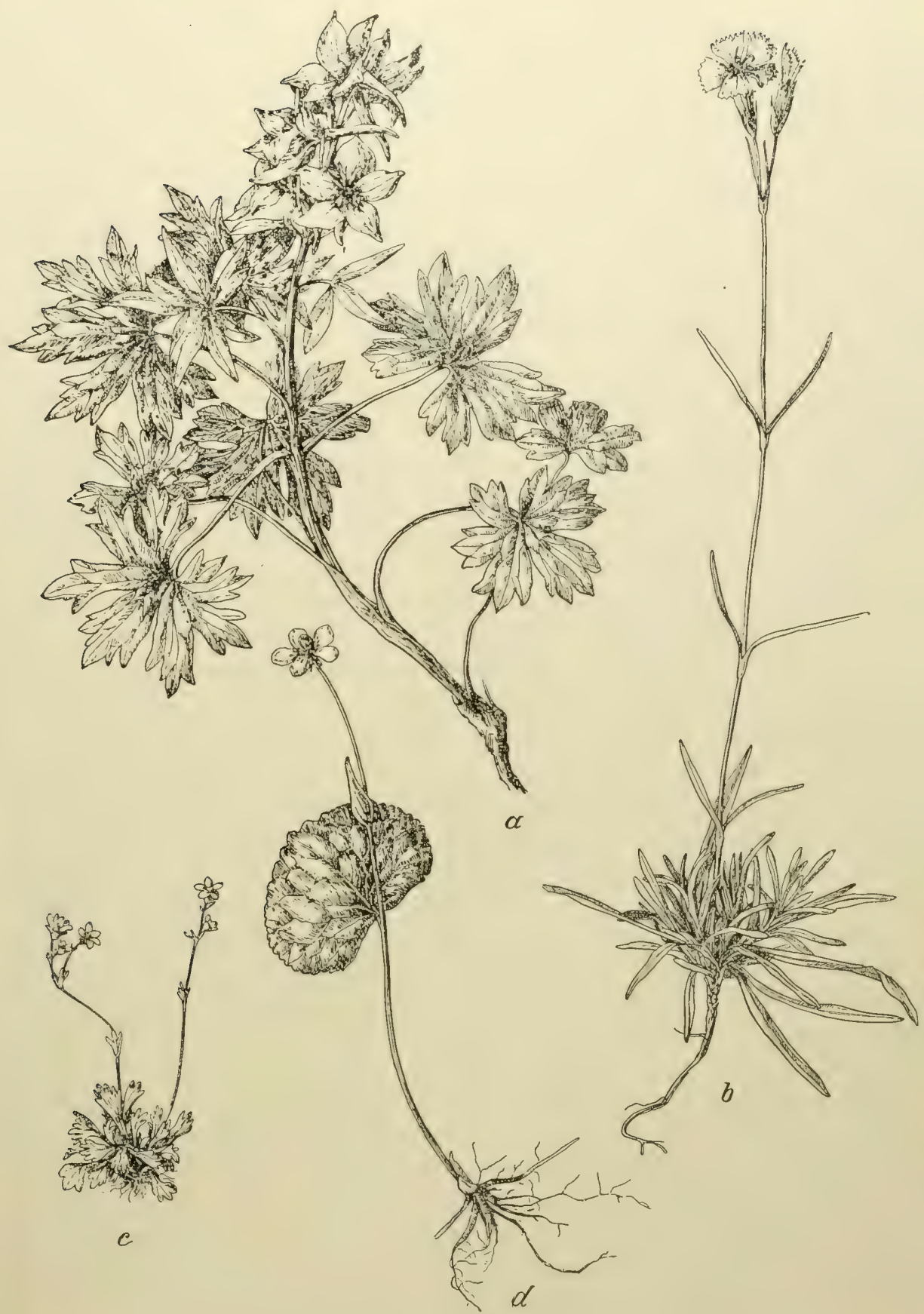

Abb. 215. Aus der Hochgebirgsflora der Kalkberge der Westkarpathen.

$a$ Delphinium oxysepalum. $b$ Dianthus nitidus. $c$ Saxifraga perdurans. $d$ Ranunculus Thora.

trotz seiner geringen Höhe hat dieser Gipfel auch eine reiche alpine Flora aufzuweisen, aus der Saxifraga caesia, S. perdurans, S. androsacea, S. moschata, 
Viola alpina, Androsace laclea, Cortusa Mathioli, Gentiana frigida und Pedicularis verlicillala hervorzuheben sind. Die heißen Südhänge des Choč sind auch der Originalstandort der Borraginee Rochelia slellulala, doch wurde diese Pflanze nie mehr wieder daselbst beobachtet. Am Fuße des Ghoč liegt der Badeort Lucski, dessen Flora durch Sümpfe mit Cladium Mariscus, Salix pentandra und Senecio paludosus ausgezeichnet ist, während in lichten Wäldern daselbst Senecio umbrosus auftritt.

Liptaver Alpen.

Vom Kvacsanpa $B$ bis zum Lilijowepa $B$ erstrecken sich die Liptauer Alpen, größtentëls aus Granit aufgebaut, dem in Norden mächtige Kalkmassen vorgelagert sind. In ihrer Flora erinnern die Liptauer Alpen schon sehr lebhaft an die Hohe Tatra, doch fehlen ihnen noch eine Reihe von Gharakterpflanzen der letzteren, wie Ranunculus pygmaeus, Cochlearia excelsa und Saxifraga Wulfeniana. Die Hänge des Gebirges bekleiden subalpine Fichten- und Tannenwälder mit Streplopus amplexifolius, Aruncus silvester, Salvia glutinosa, Pirola uniflora, Digitalis ambigua, Chrysanthemum rotundifolium und massenhaftem Vaccinium Myrlillus und V. Vilis Idaea, an Bergbächen tritt Salix silesiaca mit Veratrum album *Lobelianum, Aconilum firmum, Cardamine Opizii, Senecio subalpinus usw. auf. Auch an der Südseite des Gebirges bestehen die Wälder aus Picea excelsa, in denen im Tale der Demanova Goodiera repens, Adenostyles Alliariae, Senecio nemorensis und Cirsium Erisithale vorkommen; auf Wiesen zwischen Hradek und Vichodno findet man Polemonium coeruleum und Cirsium heterophyllum, im Bobrócer Tale an den Abhängen des Banikov Vrh, ober Liptó-Szt. Miklos, tritt in Gesellschaft von Carex alrala, C. leporina, Tofieldia calyculala, Ranunculus plalanifolius, Geum rivale, Geranium silvalicum, Linum extraaxillare, Phyleuma orbiculare, Aster Bellidiaslrum, Doronicum auslriacum, Mulgedium alpinum u. a. das nordosteuropäische, im Karpathenzuge sonst nur auf der Nemira auf rumänischem Boden vorkommende Trifolium Lupinaster auf. Über dem Waldgürtel bildet Pinus Mughus, begleitet von Juniperus nana und Sorbus Aucuparia *glabrala Bestände und darüber ist allent-

Rohač. halben eine reiche Alpenflora entwickelt. So bietet der $2126 \mathrm{~m}$ hohe Rohač Sesleria disticha, Poa alpina, P. laxa, Luzula spicala, Lloydia serotina, Salix relusa, S. herbacea, Oxyria digyna, Anemone alba, A. narcissiflora, Saxifraga hieracifolia, S. moschala, S. androsacea, Ligusticum Mulellina, Pedicularis Oederi, Gentiana punclala, Antennaria carpalica, Leonlopodium alpinum, Chrysanthemum alpinum, Senecio carpaticus, Hypochoeris uniflora, Hieracium alpinum, der beVolovec. nachbarte Volovec $(2065 \mathrm{~m})$ auch noch Carex fuliginosa, Ligusticum simplex Bystra. und Leonlodon clavalus. Auch auf der Bystra $(2189 \mathrm{~m})$ liommt die Mehrzahl der genannten Arten, ferner Dianthus glacialis, Saxifraga oppositifolia, S. bryoides, S. perdurans, S. carpatica, Gentiana frigida, Campanula alpina und Doronicum Kameništa. Clusii vor und die Kameništa $(2173 \mathrm{~m})$ besitzt überdies Ranunculus glacialis und Primula minima.

Ganz anders gestaltet sich das Bild der Vegetation im Nordosten auf den Kioscie- Kalkbergen der galizischen Tatra. An den Kalkfelsen des Koscieliskotales
liskotal. treten in einer Meereshöhe von nur 1000-1200 m eine große Anzahl alpiner und 


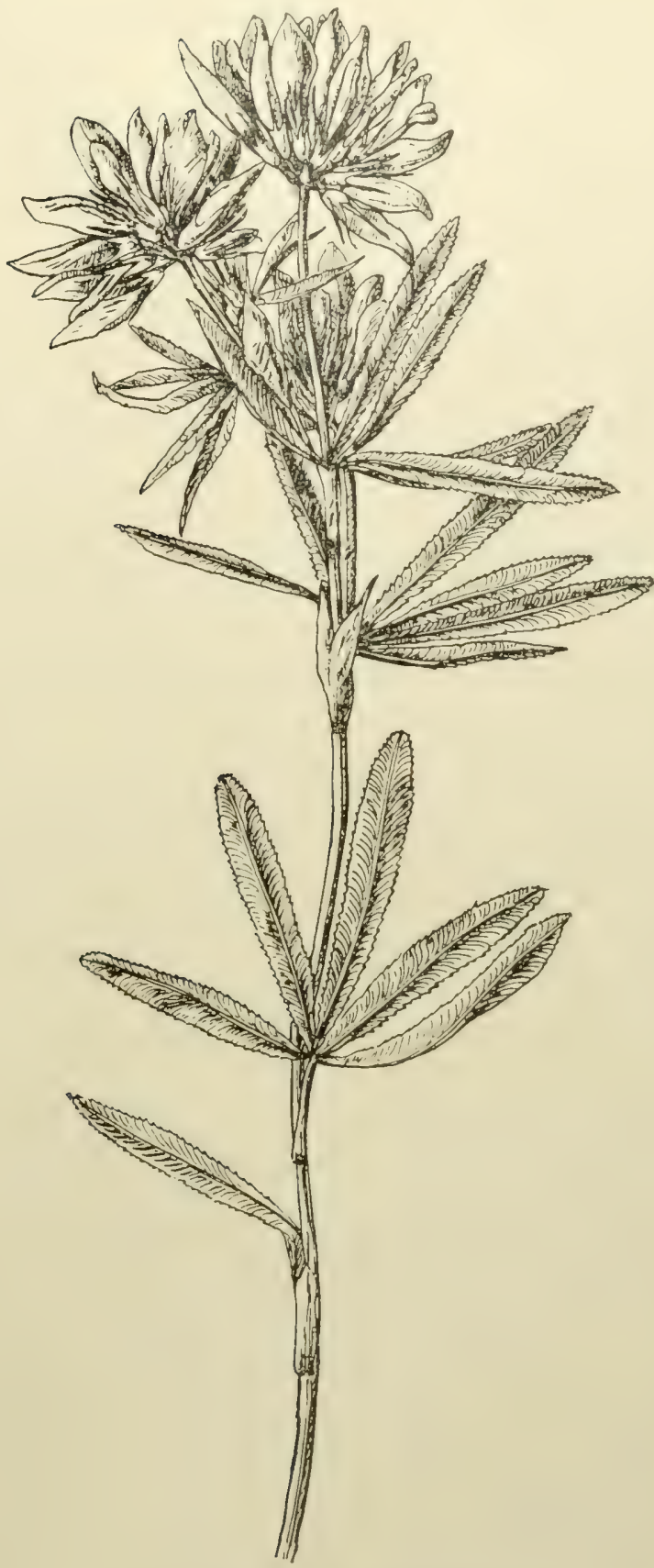

Abb. 216. Trifolium Lupinaster.

subalpiner Arten auf, wie Gypsophila repens, Cerastium villosum, Dianthus hungaricus, Silene acaulis, Minuarlia laricifolia, Sedum alralum, Saxifraga aizoides, S. caesia, Androsace laclea, Primula Auricula, Gentiana Clusii, Pedicularis verlicillala, Veronica aphylla, V. frulicans und selbst Saxifraga moschata und Leonto- 
podium alpinum, eine besondere Zierde der Felswände aber sind die weißen Blütentrauben der Saxifraga Aizoon *robusla. Auch die am Eingange des Tales liegende,

Mietusia. nur $1295 \mathrm{~m}$ hohe Mietusia soll u. a. Silene acaulis, Saxifraga oppositifolia, S. cernua, Bupleurum ranunculoides, Aster alpinus, Leontopodium alpinum usw. aufweisen. In den Wäldern, die vielfach aus Buchen bestehen, sind hier auf Kalk Clematis alpina und Asler Bellidiastrum nicht selten; von den höheren Gipfeln aber Czerwony sind insbesondere der Gizerwony vrh (Krzezanica) $(2125 \mathrm{~m}$ ) und der Giewont
vrh. $(1897 \mathrm{~m})$ bemerkenswert. Aus der Flora des Czerwony vrh sind Sesleria varia, S. disticha, Carex sempervirens, Ranunculus Thora, R. alpestris, Biscutella laevigata, Viola alpina, Arenaria ciliala, Cerastium villosum, Linum exlraaxillare, Dryas octopetala, Saxifraga perdurans, Bupleurum ranunculoides, Leontopodium alpinum, Giewont. Androsace Chamaejasme hervorzuheben. Auf dem Giewont sind in den Wäldern und an Felsen in der WValdregion Polystichum Lonchitis, Cystopteris sudelica, Carex firma, C. fuliginosa, Clematis alpina, Viola alpina, Saxifraga opposilifolia, S. perdurans, Hieracium bupleuroides *Talrae nicht selten; in der Gipfelregion findet man Fesluca pumila, Poa alpina, Avena versicolor, Triselum fuscum, Lloydia serotina, Salix relusa, S. reticulata, Ranunculus alpestris, $R$. Thora, Papaver Burseri, Hulchinsia alpina, Viola alpina, Minuartia laricifolia, M. Gerardi, Cerastium latifolium, $C$. villosum, Oxytropis carpalica, Hedysarum obscurum, Sedum alratum, Saxifraga androsacea, S. hieracifolia, S. moschala, S. caesia, S. Aizoon, S. opposilifolia, Bupleurum ranunculoides, Androsace Chamaeiasme, Myosolis alpestris, Gentiana Clusii, Pedicularis summana, P. verticillala, P. Oederi, Veronica aphylla, V. alpina, Leontopodium alpinum, Chrysanthemum alpinum, Senecio capilalus, Saussurea alpina, Leontodon clavalus, Crepis Jacquinii, Hicracium villosum, $H$. alpinum, $H$. prenanthoides und in einem einzigen Exemplar wurde vor vielen Jahren hier auch Rhododendron hirsutum var. glabratum beobachtet.

Der Lilijowepaß trennt die Liptauer Alpen von dem mächtigen Granitstock der Hohen Tatra, dem in pflanzengeographischer Beziehung unstreitig interessantesten Teile der Westkarpathen. Ein durch zahlreiche Taleinschnitte reich gegliedertes mächtiges Hochgebirge, von dessen jäh aufragenden Gipfeln viele die Höhe von $2500 \mathrm{~m}$ überschreiten, mit ihren zahlreichen Hochgebirgsseen und Wasseradern ist sie nicht nur in landschaftlicher Bezichung das prächtigste Schaustück der Westkarpathen, sondern bietet auch eine sehr reiche Wald- und insbesondere Hochgebirgsflora, die eine große Zahl von Arten aufweist, die den benachbarten Liptauer Alpen noch fehlen.

Am Nordfuße des Gebirges breitet sich der weite Talkessel von Zakopane aus, der von ausgedehnten üppigen Wiesen bedeckt ist, die nur selten von Äckern unterbrochen sind, und als deren bezeichnendste Arten Phleum pratense, Daclylis glomerala, Gladiolus imbricalus, Gymnadenia conopea, Polygonum Bislorla, Ranunculus acer, Carum Carvi, Aleclorolophus minor, A. maior, Campanula palula und Girsium rivulare genannt werden können. Die Wälder sind auch an der Nordseite fast ausschließlich Fichtenwälder mit cingesprengten Tannen, während die Lärche nur sehr vereinzelt auftritt. In diesen Wäldern bilden Vaccinium 
Myrlillus und V.Vitis Idaea auf weite Strecken hin fast allein den Niederwuchs, in den sich nur hie und da Cardamine glandulosa, Thaliclrum aruilegifolium, Circaea alpina, Pirola uniflora, P. secunda, Galium vernum, Homogyne alpina, Chrysanthemum rolundifolium, Pelasiles albus oder Hieracium murorum cinmengen; im Poduplaskitale, unter dem Mlynarz, kommt auch Linnaea borealis vor. Nur in tieferen Lagen, höchstens bis $1200 \mathrm{~m}$ ansteigend, tritt ab und zu, wie bei Javorina und im Strazyskatale bei Zakopane, auch Fagus Javorina. silvatica bestandbildend auf. An der Südseite fehlt die Buçhe vollständig und ein breiter, fast nirgends durch Kulturen und Wiesen unterbrochener Waldgürtel aus Picea excelsa, mit eingesprengten Exemplaren von Abies alba und Larix decidua, bekleidet die Flanken des Gebirges bis ins Waagtal herab. In diesen Wäldern sind Melandryum silvestre, Clemalis alpina, Ranunculus plalanifolius, Actaea spicala, A. Cimicifugia, Cardamine glandulosa, C. bulbifera, Aruncus silvester, Melampyrum silvaticum, M. saxosum neben den auch hier tonangebenden Vaccinien die häufigsten Arten. Ab und zu treten auch kleine Hochmoore auf, wie im Belatale, wo Pedicularis Sceplrum Carolinum, Trienlalis europaea und Pinguicula vulgaris vorkommen, und im Schwarzwassertale, wo neben Pedicularis paluslris und Oxycoccos quadripelala ebenfalls Pedicularis Sceplrum Carolinum anzutreffen ist. Reicher ist die Moorbildung bei Also-Tátrafüred, be-Tátrafüred.

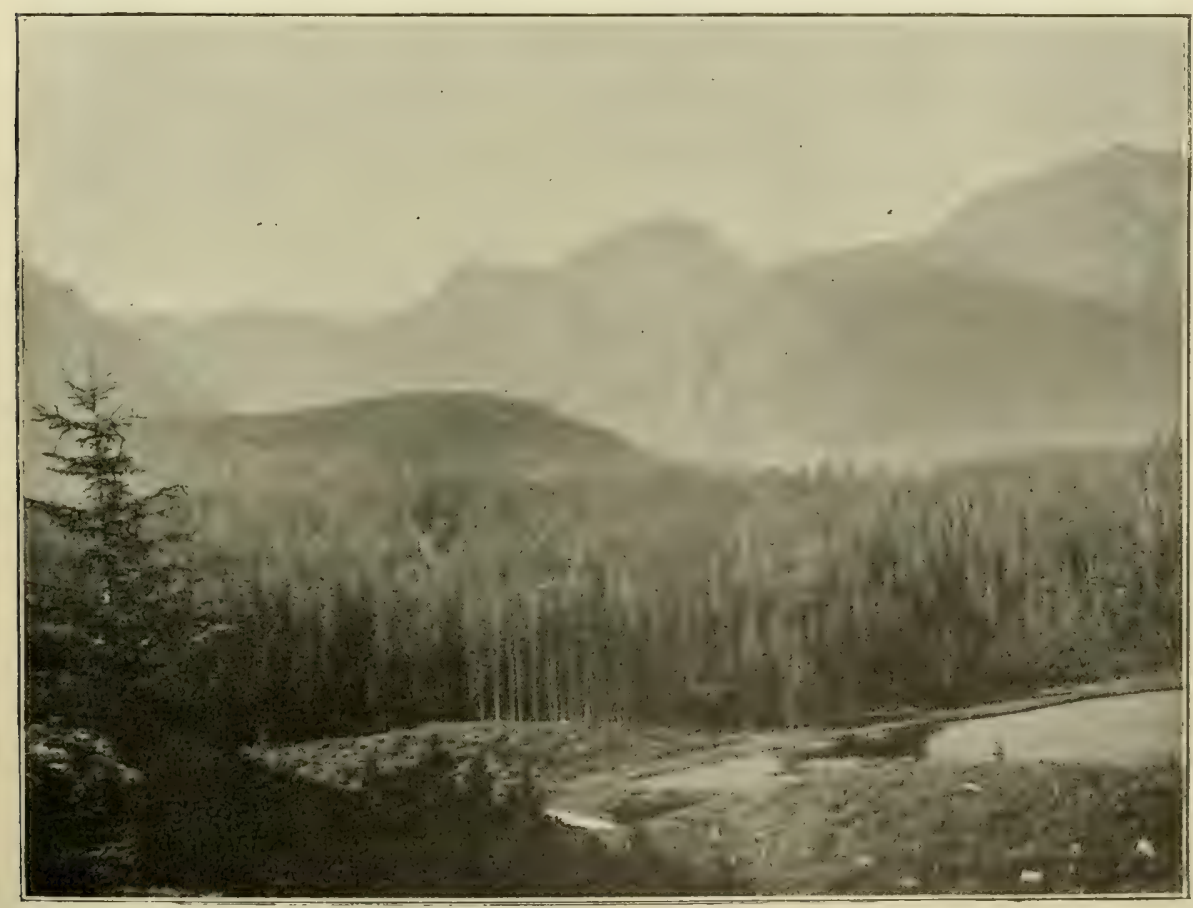

Abb. 217. Fichtenbestände am Csorbaer See an der Südseite der Hohen Tatra.

(Nach einer Aufnahme von Prof. J. Nevole, Knittelfeld.)

(Aus der Bildersammlung des botanischen Institutus der Wiener Universität.) 
sonders gegen Neuwalddorf zu, wo auch Carex pauciflora, C. dioica, $C$. polygama, G. limosa, Schenchzeria palustris, Viola palustris, Polentilla palustris, Drosera rolundifolia, Pedicularis silvatica und Menyanthes auftreten. Relativ tief, schon bei 1400-1500 m, finden die Wälder, in denen in dieser Höhe allenthalben Pinus Cembra eingesprengt vorkommt, in der T'atra ihre obere Grenze und werden durch dichte Bestände von Pinus Mughus, denen oft Juniperus nana, Belula pubescens *carpatica, Salix silesiaca und besonders Sorbus Aucuparia *glabrala

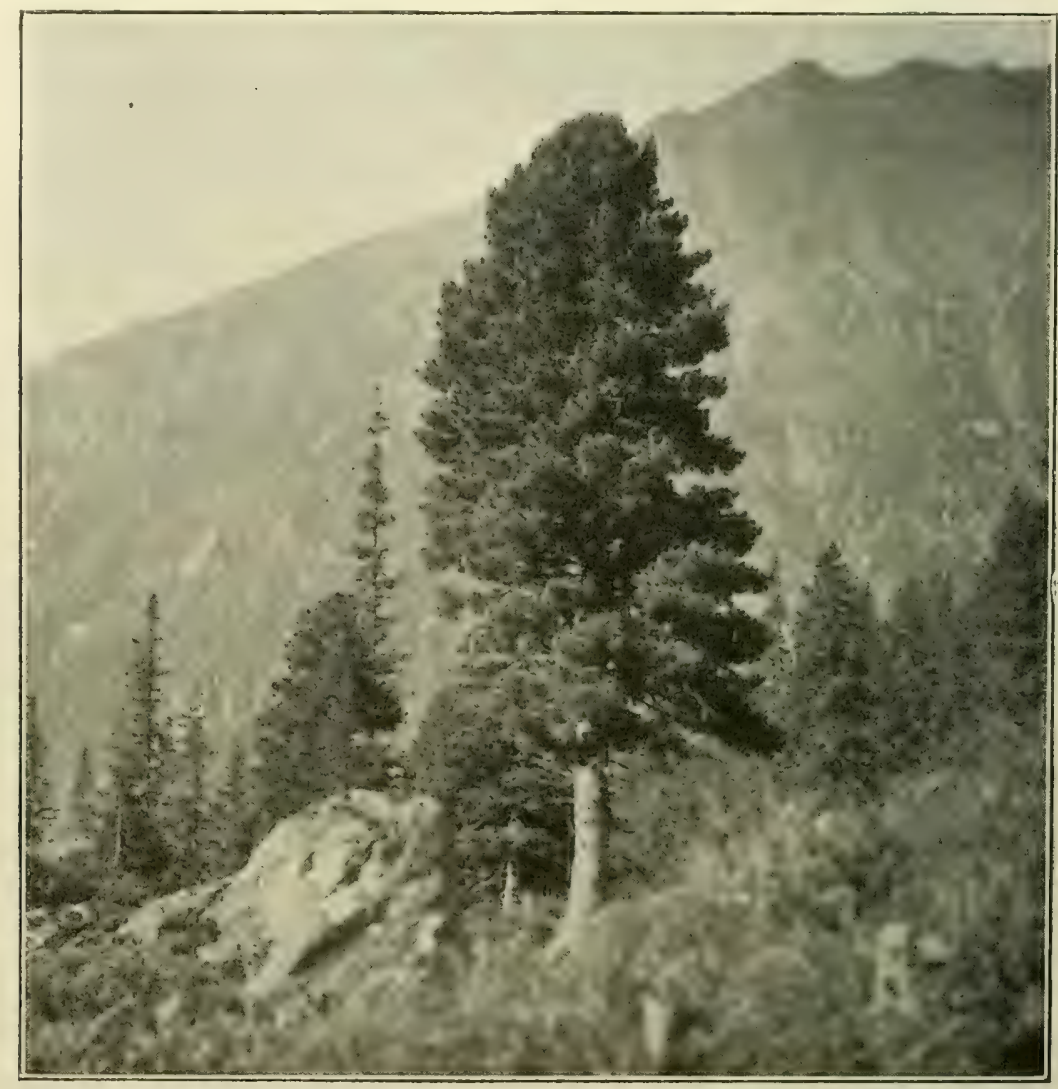

Abb. 218. Pinus Cembra im Kohlbachtale.

(Nach einer Aufnahme von Prof. J. Nevole, Knittelfeld.)

(Aus der Bildersammlung des botanischen Institutes der Wiener Universität.)

beigemischt ist, abgelöst und zugleich mit dem Krummholze treten auch andere alpine Arten auf.

Gasieniczowe stawy. Großer
Fischsee.

Schon um die Gasieniczowe stawy findet man Sesleria disticha, Avena versicolar, Juncus lrifidus, Carex Lachenalii, Oxyria digyna, Ranunculus glacialis, Arabis neglecla, Geum replans, Saxifraga hieracifolia, S. perdurans, S.-carpatica, Gentiana frigida; Soldanella carpatica, Campanula alpina usw. und um dic polnischen Fünf Seen Papaver Burseri, Viola alpina, Saxifraga cernua u. a. Alpenplanzen. Auch am Großen Fischsee (Morskie oko), in nur $1384 \mathrm{~m}$ 


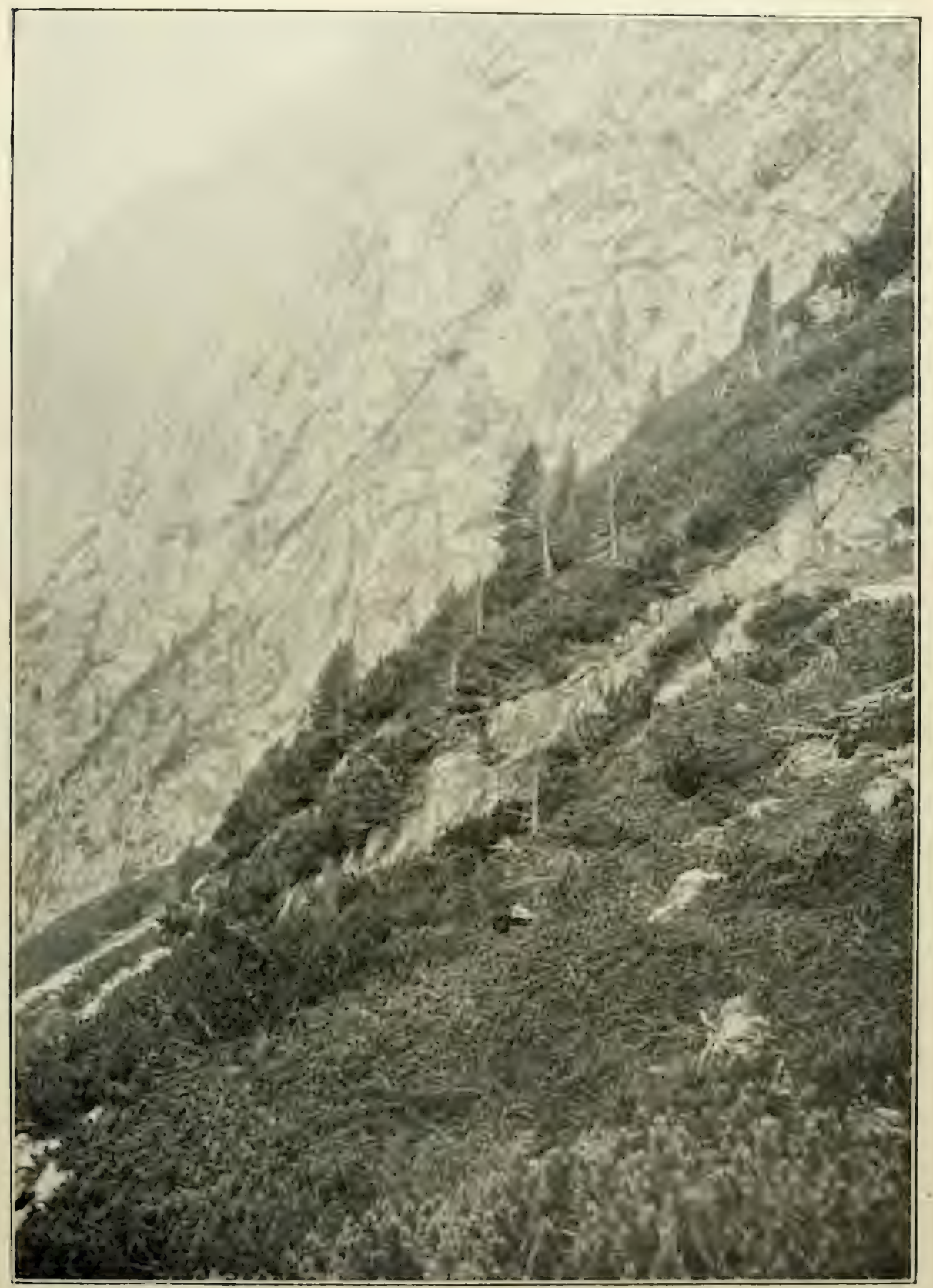

Abb. 219. Vereinzelte Exemplare von Pinus Cembra (,,Windzirben“) im Krummholz im Kleinen Kohlbachtal der Hohen Tatra.

(Nach einer Aufnahme von Prof. J. Nevole, Inittelfeld.)

(Aus der Bildersammlung des botanischen Institutes der Wiener Universität.)

Verlag von Franz Deuticke in Leipzig und Ẉį̣en. 



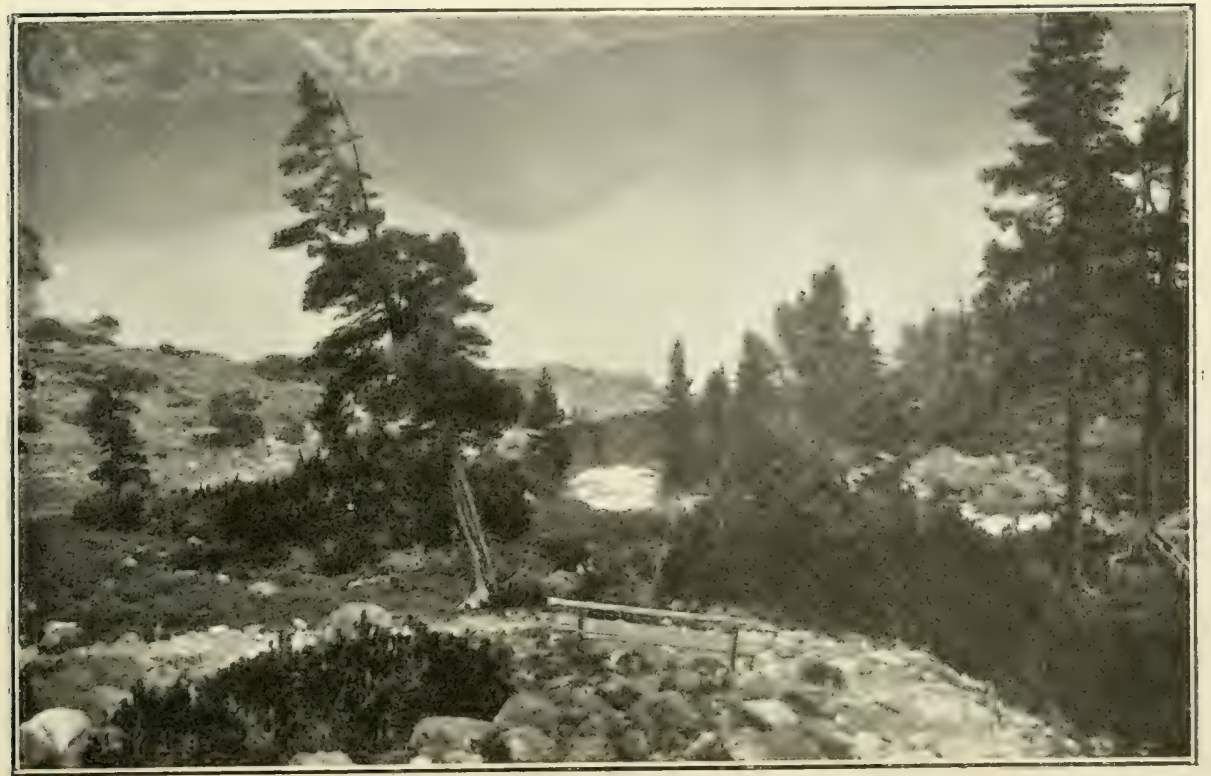

Abb. 220. Pinus Cembra und P. Mughus oberhalb des Großen Fischsees in der Hohen Tatra.

(Nach einer Aufnahme von A. v. Hayek.)

Meereshöhe, erreicht der geschlossene Wald schon seine obere Grenze und nur dichte Bestände von Pinus Mughus und lockere Bestände von Pinus Cembra umgeben seine Ufer, an denen auch schon Sedum alpeslre, S. roseum, Soldanella carpatica, Gentiana punclata, Veronica alpina, Doronicum Clusii, Taraxacum nigricans usw. zu finden sind, und an dem darüber gelegenen II eerauge (Czarny yeerauqe. staw) findet man auch bei kaum $1600 \mathrm{~m}$ Neereshöhe Sesleria disticha, Carex fuliginosa, C. Lachenalii, Cobresia bipartila, Cochlearia excelsa, Geum montanum und Leontodon clavalus. Auch beim Javorinaer Schwarzen See (Fekete Schorinaer tó) trifft man neben Pinus Cembra schon zahlreiche Alpenpflanzen, wie Poa cenisia, Salix reticulala, Ranunculus glacialis, Arabis neglecla, Cochlearia excelsa, Saxifraga hieracifolia, S. carpalica, Liguslicum Mulellina, L. simplex, Campanula alpina und Doronicum Clusii an. Geschlossene Alpenwiesen sind im Gebiete der Tatra, besonders an der Nordseite, kaum irgendwo anzutreffen; als charakteristische und verbreitete Arten der zerstückelten Rasen aus Fesluca supina, Poa alpina, Sesleria dislicha, Avena versicolor, Agrostis rupestris, Carex atrala, C. sempervirens, Luzula spadicea usw. in und über der Krummholzregion sind Lloydia serolina, Oxyria digyna, Anemone alba, A. narcissiflora, Ranunculus glacialis, Callianlhemum coriandrifolium, Arabis neglecta, Cochlearia excelsa, Saxifraga hieracifolia, S. moschata, S. carpalica, Geum montanum, Ligusticum Mulellina, Primula minima, Soldanella carpatica, Gentiana punctata, Veronica alpina, Pedicularis Oederi, Campanula alpina, Antennaria carpalica, Chrysanthemum alpinum, Doronicum Clusii, Leontodon clavatus und Hieracium alpinum zu nennen. Derart ist auch die Flora am Polnischen Ka m m zusammengesetzl, Polnischer $\begin{gathered}\text { Kamm. } \\ \text {. }\end{gathered}$ 


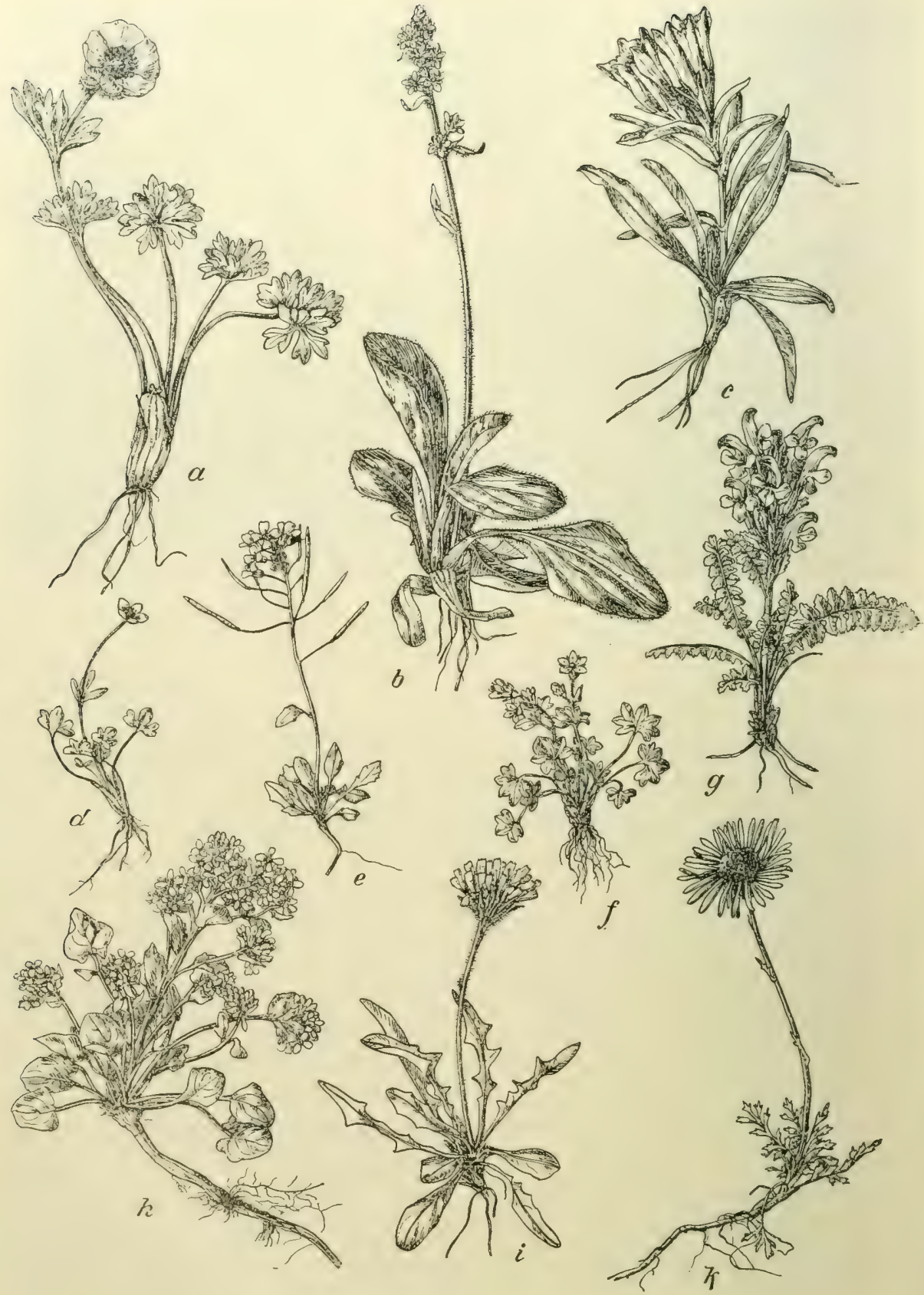

Abb. 221. Aus der Hochgebirgsflora der Hohen Tatra.

$a$ Ranunculus glacialis. $b$ Saxifraga hieracifolia. $c$ Gentiana frigida. $d$ Ranunculus pygmaeus. e Arabis neglecta. $f$ Saxifraga carpatica. $g$ Pedicularis Oederi. $h$ Cochlearia excelsa. $i$ Leontodon clavatus. $k$ Senecio carpaticus.

(Zirka $1 / 2$ nat. Gr.) 


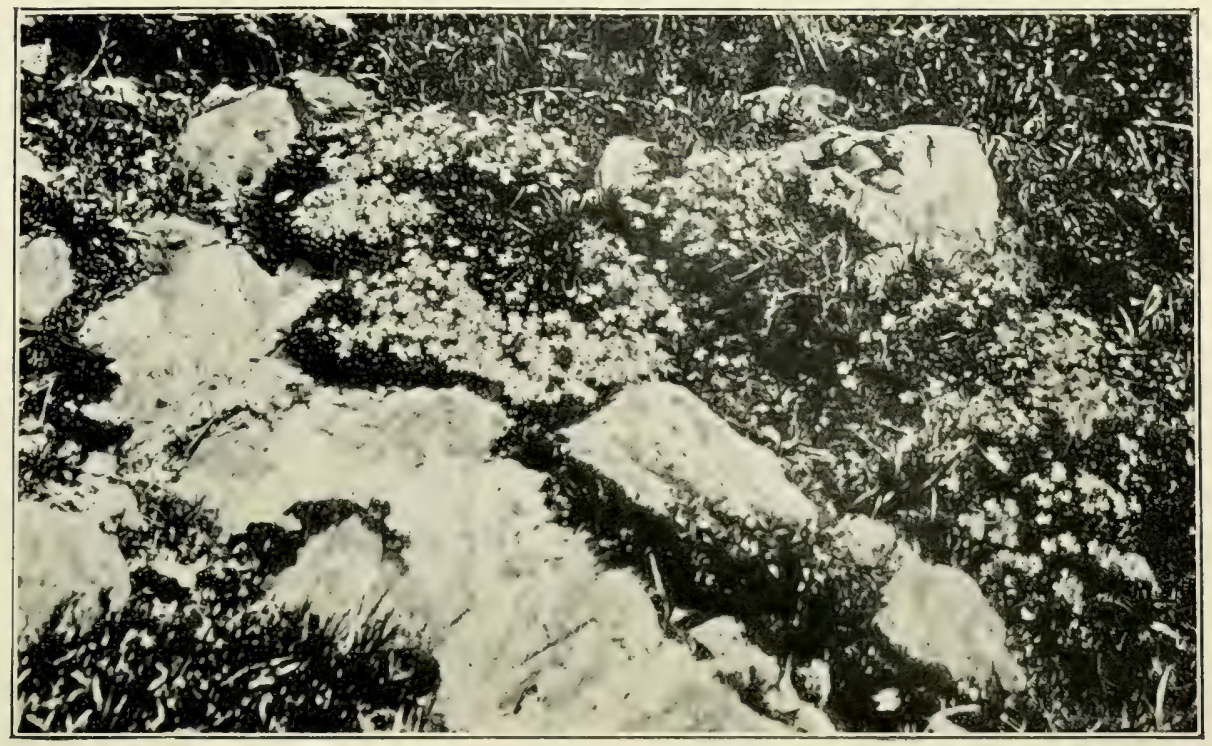

Abb. 222. Silene acaulis in Gesteinfluren auf dem Törichten Gern in den Belaer Kalkalpen.

(Nach einer Aufnahme von G. Nyarádyi, Maros-Vasarhely.)

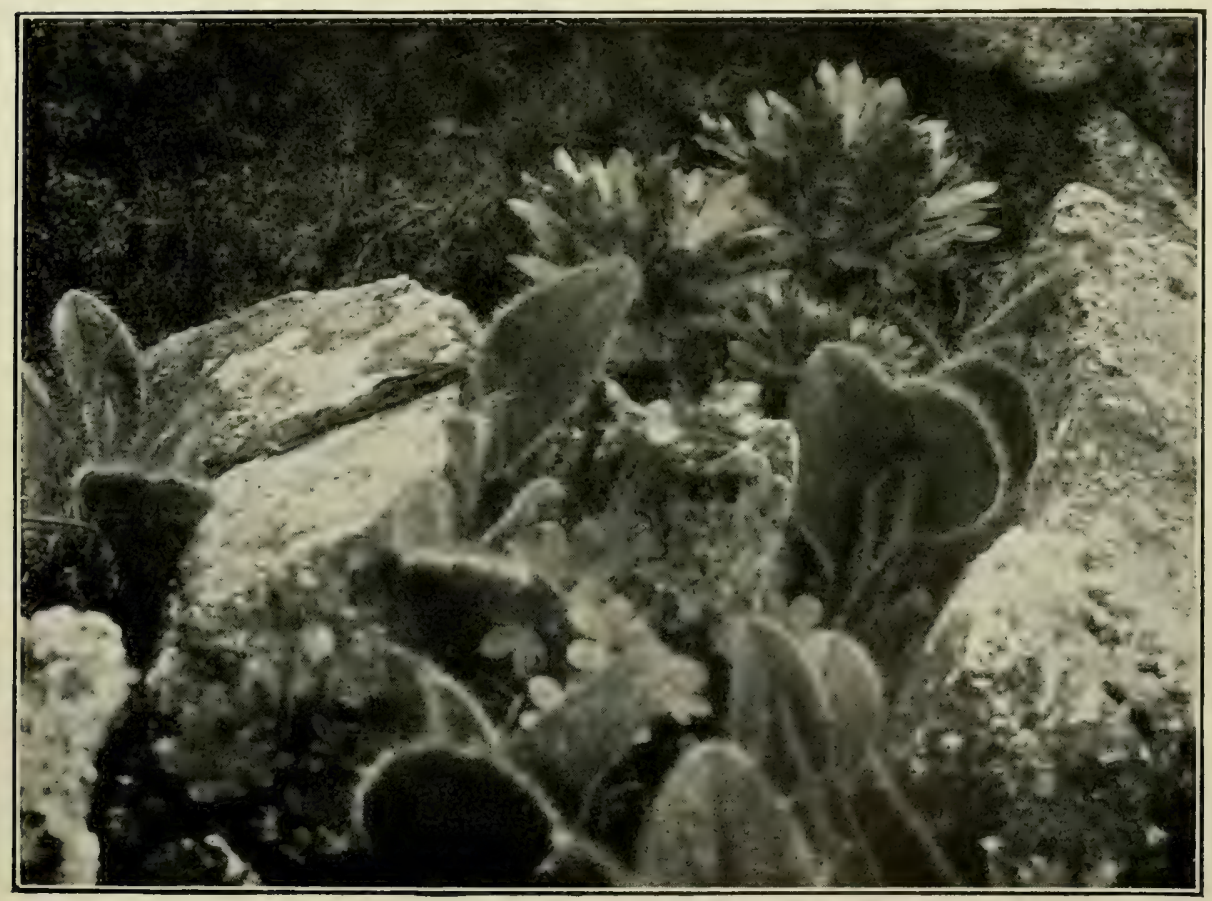

Abb. 223. Saxifraga carpatica mit Ranunculus glacialis und Doronicum Clusii in Gesteinsfluren auf der Höhe des polnischen Kammes in der Hohen Tatra. (Nach einer Aufnahme von A. v. Hayek.) 

wo übrigens auch schon die seltene Saxifraga Wulfeniana in Gesellschaft von S. oppositifolia sowie Genliana frigida auftreten. Über der Krummbolzregion erheben sich durchwegs jäh und steil die mächtigen, stark zerklüfteten Gipfel, so daß auch hier von einer zusammenhängenden Rasendecke nicht die Rede sein kann und nur Gesteinfluren und Felsenformationen setzen die interessante Flora der Hochgipfel zusammen, als deren bezeichnendste Arten Agrostis rupestris, Avena versicolor, Poa laxa, Sesleria disticha, Festuca varia, Carex Lachenalii, Luzula spadicea, L. spicala, Oxyria digyna, Cerastium villosum, Ranunculus glacialis, Arabis neglecta, Saxifraga opposilifolia, S. Wulfeniana, S. bryoides, S. carpatica, Primula minima, Gentiana frigida, Myosotis alpestris, Antennaria carpatica, Senecio carniolicus, S, carpalicus zu nennen sind. Der westlichste dieser Hochgipfel, der $2500 \mathrm{~m}$ hohe Krivan, ist in botanischer Be- Krivan ziehung ziemlich gut erforscht und weist neben den genannten Arten auch Dianthus glacialis, Geum reptans, Ligusticum simplex, Androsace oblusifolia, Gentiana tenella, Campanula Scheuchzeri, Hieracium alpicola *rhodopaeum und H. calenduliflorum auf; unter dem Lorenzjoch gegen das Mlinicatal kommt der seltene Ranunculus pygmaeus vor. Nördlich von der Krivangruppe liegt der Tychapa B, der bisher einzige Standort des Hieracium silesiacum in der Tatra. An der Meeraugenspitze wurde kürzlich Heliosperma alpestre entdeckt. Die MeeraugenGerlsdorfer Spitze $(2663 \mathrm{~m})$ und die Schlagendorfer Spitze $(2478 \mathrm{~m})$ Gerlsdorfer weisen außer den oben genannten Arten der Gipfelflora keine Besonderheiten auf; hingegen kommen auf der Eisthaler Spitze $(2628 \mathrm{~m})$ auch Minuarlia sedoides, Geum reptans, Senecio capilalus, Saussurea alpina, S. pygmaea, auf der Lomnitzer Spitze $(2635 \mathrm{~m})$ Gnaphalium supinum, Saussurea pygmaea und Hieracium alpicola *rhodopaeum vor; auf dem Mittelgratturm ( $2440 \mathrm{~m})$ Mittelgratfinden sich Ranunculus pygmaeus, Alchimilla glaberrima und Saxifraga perdurans, auf der Rotseespitze $(2402 \mathrm{~m})$ Geum replans, auf der Weißseespitzc (2236 m) Saussurea pygmaea. Eine etwas abweichende Flora weist die aus Kalk aufgebaute Javoriner Siroka auf, auf der auch Hutchinsia alpina, Dianthus glacialis, Arenaria ciliala, Saxifraga perdurans, Androsace Chamaejasme, Linum extraaxillare und am Stillen See auch Gentiana frigida und Corlusa Mallhioli, zwischen Grünem und Schwarzem See Pedicularis summana zu finden sind.

Reicher noch als an der Nordseite ist die Flora in den südseitigen, stei] einschneidenden Tälern und Schluchten entwickelt. So findet man im Fur-Furkotatal. kotatale Sempervivum carpalicum, Cirsium helerophyllum, Crepis conyzifolia, Hieracium alpicola *rhodopaeum, H. Fritzei, H. stygium, H. nigrescens, im Mlinicatale Woodsia ilvensis, Sesleria varia, Gymnadenia odoratissima, Salix Lapponum, Arabis neglecla, Saxifraga hieracifolia, S. carpalica, Angelica Archangelica, Gentiana frigida, Campanula Scheuchzeri, Chrysanlhemum rolundifolium, Hieracium alpicola *rhodopaenm. Im Felkertale kommt an den westlichen Felshängen Artemisia pelrosa, Carex rupestris und Saussurea alpina, am Felkersee Felkertal. Papaver Burseri vor; die obere Talstufe ober der Krummholzregion aber, den „Blumengarten“, bedecken üppige Alpenwiesen, die im Frühsommer von Tausenden von Blütensternen von Anemone alba und A. narcissiflora geschmückt 
sind. Die reichste Flora aber weisen wohl die beiden Kohlbachtäler ober Tátra-Füred (Schmecks) auf; schon am Kämmchen findet man Calamagrostis varia, Ranunculus plalanifolius, Melandryum silvestre, Sempervivum carpalicum, Lonicera nigra, Pelasites albus usw. und am Eingange in die Täler bildet Pinus Mughus, überragt von Picea excelsa und Pinus Cembra, ausgedehnte Kohlbach- Bestände, von alpinen Arten jedoch kommen im Großen Kohlbachtale
täler. u. a. Athyrum alpestre, Triselum fuscum, Trichophorum alpinum, Streptopus amplexifolius, Salix Lapponum, S. Arbuscula, S. nigricans, Anemone alba, A. narcissiflora, Callianthemum coriandrifolium, Ranunculus glacialis, Arabis neglecla, Cochlearia excelsa, Geum reptans, Epilobium alsinefolium, E. anagallidifolium, Crepis conyzaefolia, Hieracium alpinum, H. Fritzei, im Kleinen Kohlbachtale und besonders an den. Fünf Seen neben zahlreichen weit verbreiteten Tatrapflanzen Sesleria varia, Carex fuliginosa, C. Lachenalii, Luzula spicala, Allium sibiricum, Salix herbacea, Ranunculus alpestris, Delphinium elatum, Dianthus glacialis, Drosera rolundifolia, Senecio carpalicus, Hieracium alpicola *hodopacum und $H$. slygium vor. Am Ste in bachsee am Fuße der Lomnitzer Spitze wurde vor kurzem die in der Tatra sonst fehlende Loiseleuria procumbens entdeckt; im Tale

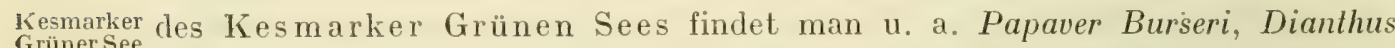
Grüner See. glacialis, Cerastium cerastioides, Astragalus alpinus, Hedysarum obscurum und

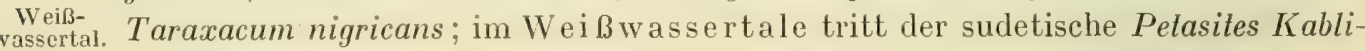
kianus auf.

Die beiden Kupferschächtentäler und der Kopapaß trennen die Tatra von dem von Nordwesten nach Südosten sich hinziehenden kurzen Zug der Belaer Kalkalpen, die trotz ihrer geringen Meereshöhe (Havran $2151 \mathrm{~m}$, Greiner 2158 m, Fleischbank. 2019 m, Stirnberg $1947 \mathrm{~m}$ ) eine seit langer Zeit bekannte, ungemein reiche Flora aufweisen, die hauptsächlich durch das kalkreiche Substrat bedingt wird. Der Wald ist auch hier ausschließlich Fichtenwald, in dessen Niederwuchs Athyrium Filix femina, Dryopteris dilalala, Poa Chaixii, Lilium Marlagon, Listera cordala, Coralliorhiza lrifida, Asarum europaeum, Thalictrum aquilegifolium, Ranunculus plalanifolius, Clemalis alpina, Astrantia maior, Pleurospermum austriacum, Homogyne alpina, Chrysanthemum rolundifolium, Cirsium Erisithales, Prenanthes purpurea, Corlusa Mallhioli die bezeichnendsten Arten sind; in den nach Norden sich öffnenden Tälern ist in höheren Lagen an Felsen Pinus Cembra nicht selten, an der Nordseite der Kičora kommt auch Taxus baccala vor.

Kupferschächten tâler.

Schon in den. Kupferschächtentälern treten an Felsen Trisetum fuscum, Carex capillaris, C. alrala, Arabis arenosa, Linum extraaxillare, Oxytropis carpalica, Bupleurum longifolium, Valeriana lripleris, Aster Bellidiaslrum, Carduus glaucus, Hieracium bupleuroides *scabriceps, H. villosum, an Bachufern ThalicIrum aquilegifolium, Anemone narcissiflora, Delphinium elalum, Cardamine Opizii, Geranium phaeum, Geum rivale, Astrantia maior, Anthriscus nitidus, Adenostyles Alliariae, Doronicum auslriacum, Carduus personalus, auf höher gelegenen Bergwiesen Avena versicolor, Phleum alpinum, P. Michelii, Orchis globosa, Polygonum Bistorta, P. viviparum, Anemone alba, Ranunculus Thora, Trollius europaeus, 

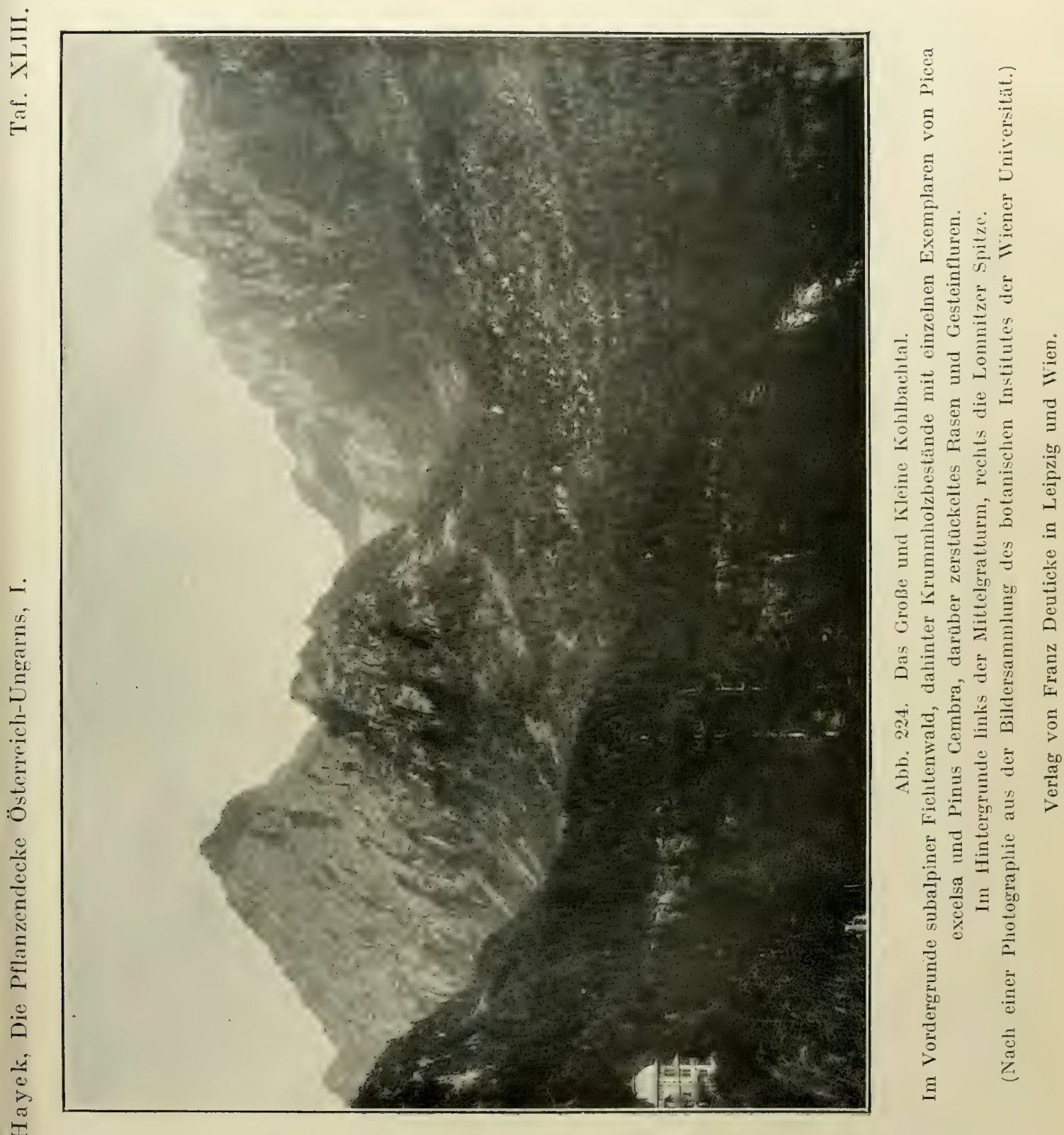



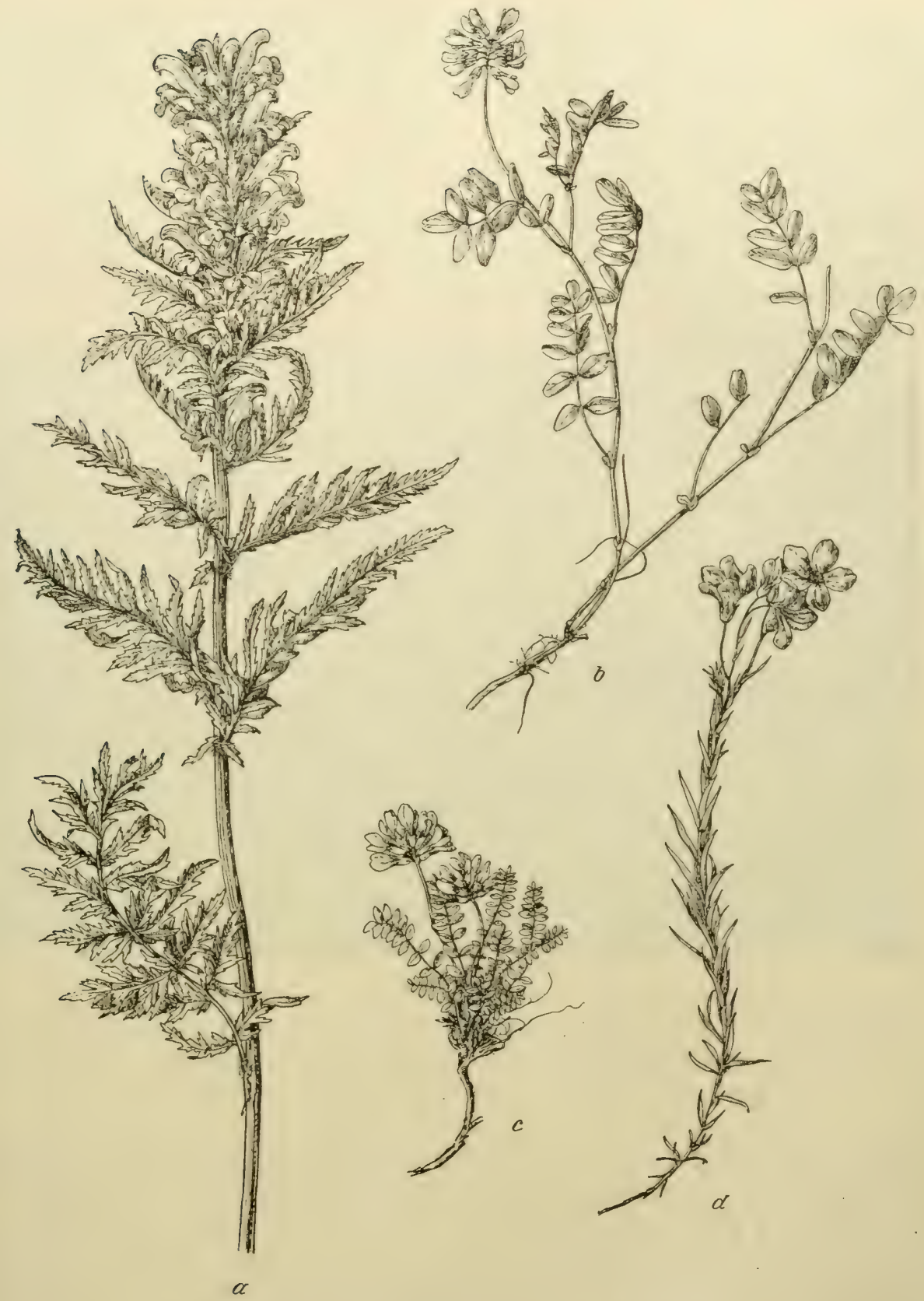

Abb: 225. Aus der-Flora der-Belaer Kalkalpen.

$a$ Pedicularis summana, $b$ Astragalus oroboides, $c$ Oxystropis carpatica. d Linum extraaxillare.

Arabis Halleri, Viola sudetica, Dianthus glacialis, Geranium silvalicum, Aslragalus alpinus. A. australis, Liguslicum Mulellina, Chrysanthemum alpinum, Centaurea austriaca, C. mollis, Hypochoeris uniflora, Hieracium aurantiacum, H. pratense, 
H. alpinum, H. nigrilum, H. Wimmeri auf, zu denen sich auf der Höhe des Kopapaß. Kopapasses noch Bisculella laevigata, Silene acaulis, Cerastium ceraslioides, C. villosum, Astragalus oroboides, Saxifraga hieracifolia, S. androsacea, S. moschata, Primula minima, Androsace Chamaejasme, Soldanella carpatica und Gentiana nivalis gesellen.

Reicher noch ist die Flora in höheren Lagen, wie in den Gebirgskesseln Novy, zwischen Novy und Havran, wo u. a. Cyslopteris regia, Poa cenisia, Juncus
ILavrai. Iriglumis, Allium sibiricum, Chamaeochis alpina, Gymnadenia odoratissima, Callianthemum coriandrifolium, Arabis Jacyuinii, Oxylropis Halleri, O. carpalica,

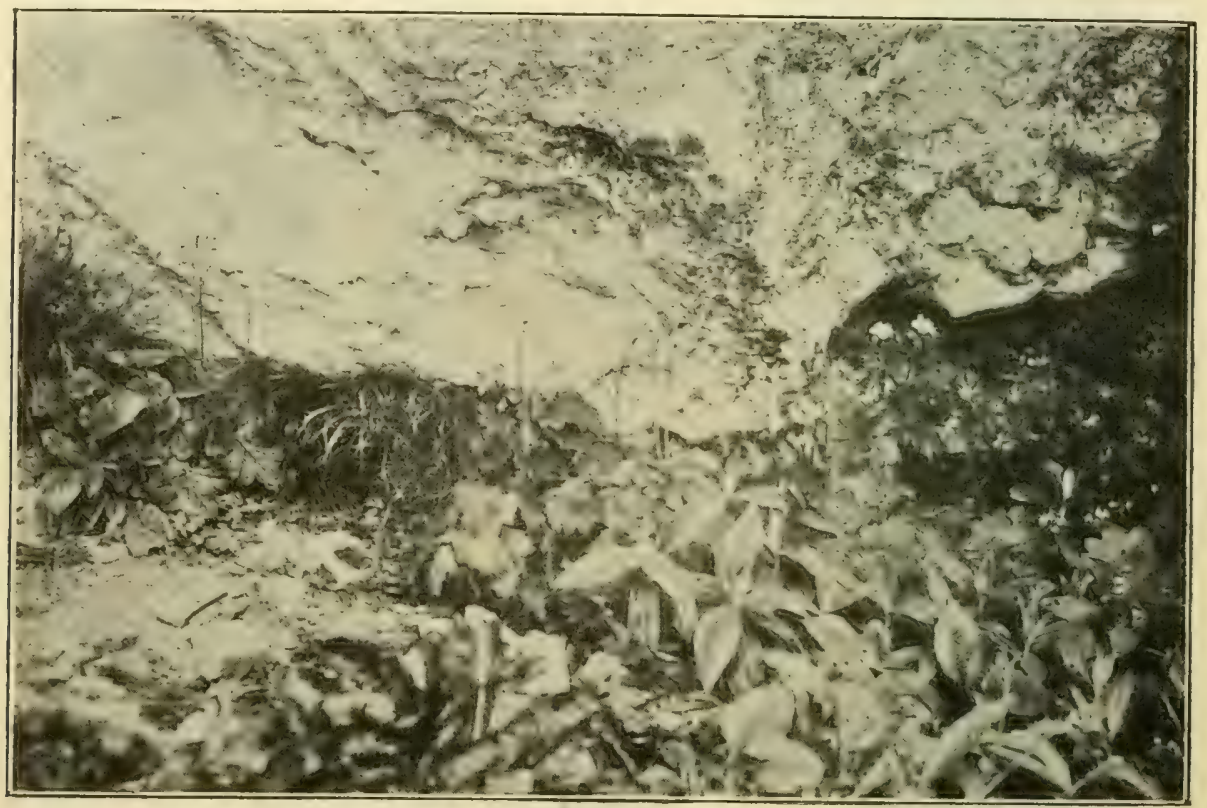

Abb. 226. Alpine Felsenpflanzen auf dem Greiner.

Unter dem Felsen Festuca varia, Cortusa Matthioli und (rechts) Geranium silvaticum. Im Vordergrunde Centaurea mollis und Primula carpatica.

(Nach einer Aufnahme von G. Nyarádyi, Maros-Vasarhely.)

Astragalus oroboides, Hedysarum obscurum, Polenlilla Granlzii, Bupleurum ranunculoides, Corlusa Malthioli, Primula carpalica, Senecio capilalus, Saussurea alpina, S. macrophylla vorkommen, und auf dem Gipfel des Havran selbst wachsen Carex firma, C. capillaris, Draba tomentosa, Saxifraga caesia und S. oppositifolia. Greiner. Auch der benachbarte, $2158 \mathrm{~m}$ hohe Gipfel des Greiner, der fast einzige Standort von Elyna Bellardii im Tatragebiete, weist eine ähnliche Flora, u. a. auch Delphinium oxysepalum, Ranunculus Hornschuchii, Astragalus frigidus und Artemisia petrosa auf. Die reichste Flora aber findet man im Südosten des Stinberg. Gebietes auf dem Stirnberg und im Hochtale Drechslerhäuschen. Hier Drechsler-
häuschen. kommen außer den genannten Arten (mit Ausnahme von Elyna) auch Gystopteris sudelica, Phyllites Scolopendrium, Festuca Tatrae, F. picta, Trisetum fuscum, 
Carex fuliginosa, G. Lachenalii, Gagea minima, Chamaeorchis alpina, Salix hastala, S. Jacquini, Ranunculus glacialis, Aconitum moldavicum, Actaea Cimicifugia, Arabis neglecla, Erysimum Wahlenbergii, Pelrocallis pyrenaica, Draba lomenlosa, Helianthemum alpestre, Dianthus hungaricus, Minuarlia Gerardi, Linum extraaxillare, Astragalus frigidus, Oxylropis campeslris, O. carpalica, Polenlilla Cranlzii, Saxifraga hieracifolia, S. rolundifolia, Conioselinum lalaricum, Pleurospermum austriacum, Primula Auricula, P. minima, P. longiflora, Cerinthe glabra, Gentiana tenella, Pedicularis summana, P. Oederi, Artemisia petrosa, Leontopodium alpinum, Senecio carpaticus, Saussurea alpina, S. discolor, Cenlaurea alpestris, C. mollis, Crepis Jacquini, C. mollis, H. stygium, H. prenanthoides vor, so daß diese Stelle gewiß eine der pflanzenreichsten im ganzen Gebiete der Zentralkarpathen darstellt. Auch der Törichte Gern und die Fleischbänke, wo kürzlich ein zweiter Standort von Elyna Bellardii entdeckt wurde, weisen eine Törichter Gern. reiche Hochgebirgsflora auf, wenn auch nicht alle Seltenheiten so auf einem Punkte vereint vorkommen. An der Nordostseite des Gebirges ist die Lange Wand bei Javorina wegen des Vorkommens von Erysimum Wahlenbergii und der im Gebiete der Zentralkarpathen sonst fehlenden Berberis vulgaris bemerkenswert.

Die nordöstlich von den Belaer Kalkalpen sich erhebende Zipser Magura trägt Fichtenwald und an der Südseite auch ausgerlehnte Bergwiesen mit Cirsium heterophyllum, C. rivulare, Hypochoeris uniflora, Crepis conyzifolia, Hieracium aurantiacum, H. prenanthoides usw.

Auch am Ostfuße des Gebirges reichen die subalpinen Nadelwälder meist bis ins Tal herab; in tieferen Lagen, wie im Großen Walde bei Rox, einige interessantere Arten, wie Bolrychium ramosum, B. Malricariae, Adenophora liliifolia und Knaulia carpalica aufweisend. Bei Rox treten überdies auch Hochmoore mit Dryopteris Thelypleris, Carex polygama, C. diandra, Salix myrtilloides, Viola palustris, Drosera rotundifolia, Trienlalis europaea und Pedicularis Sceplrum Carolinum sowie Erlenbrüche aus Alnus glulinosa mit zahlreicher Scorzonera humilis auf. Weiter abwärts im Popradtale, in der Umgebung von Kesmark, Kesmark. besonders auf dem Galgen-, Dürren- und Schloßberge, begegnet man schon einer reichen Triftflora mit Brachypodium pinnalum, Anemone silvestris, Linum flavum, Lavatera thuringiaca, Cylisus ratisbonensis, Trifolium rubens, Aslragalus danicus, Lathyrus silvester, L. megalanthus, Polentilla canescens, Seseli annuum, Stachys recta, St.germanica, Verbascum Lychnites, Veronica orchidea, Campanula bononiensis, Aster Amellus, Inula hirla, Arlemisia scoparia, Cenlaurea variegala, C. Scabiosa, Anthemis tincloria usw. Weiter flußabwärts aber treten wieder Nadelwälder auf, in denen zwischen Bela und Bauschendorf die ostwärts immer häufiger werdende Telekia speciosa vorkommt.

\section{e) Das Göllnitzer und Eperieser Gebirge.}

Der durch das Popradtal von den Zentralkarpathen geschiedene Bran is zk o- Braniszlsostock ist von Buchen-, in höheren Lagen auch von Fichtenwäldern bedeckt 


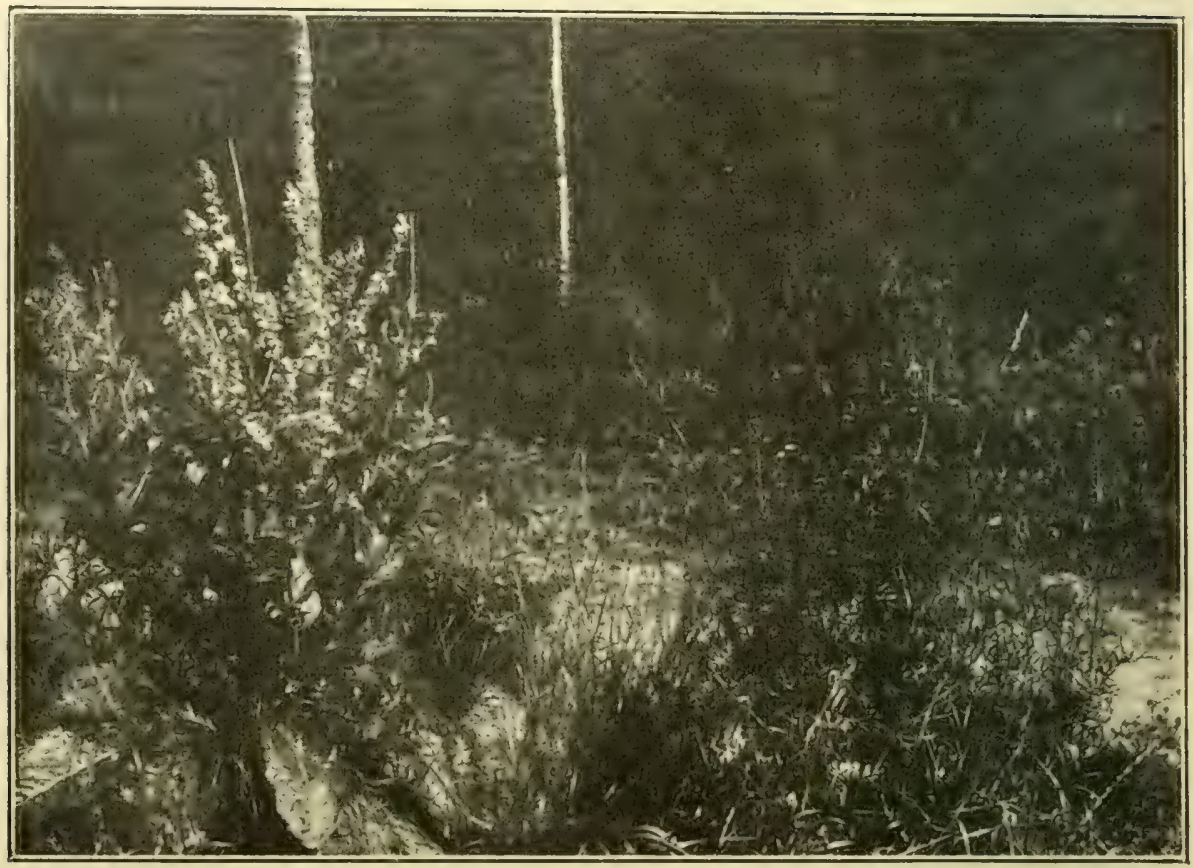

Abb. 227. Triftormation mit Verbascum Lychnites und Centaurea Scabiosa bei Kesmark.

(Nach einer Aufnahme von G. Nyarádyi, Maros-Vasarhely.)

und besitzt auch einige Hochmoore, in denen das in den Karpathen sonst fehlende Trichophorum austriacum vorkommt. Schon in relativ geringer Höhe, G.ehol. wie auf dem $1060 \mathrm{~m}$ hohen Gehol, treten zahlreiche subalpine Typen auf, wie Crocus Heuffelianus, Gymnadenia albida, Anemone narcissiflora, Potenlilla aurea, Primula longiflora, Valeriana lripteris, Mulgedium alpinum, und Hypochoeris uniflora; auf dem Holykámen bei Igló kommt sogar Leonlopodium alpinum váraly : vor. An der Südseite des Gebirges aber, wie auf dem Drevenyik bei Szepesváralya, treten Triftformationen mit Carex humilis, C. Michelii, Sesleria varia, Stipa pennala, Dianthus Carthusianorum, Anemone silvestris, A. slavica, Alyssum Arduini, A. montanum, Polentilla arenaria, Cylisus ratisbonensis, Astragalus danicus, Hippocrepis comosa, Polygala maior, Lavatera thuringiaca, Euphorbia polychroma, Helianthemum rupifragum, Nonnea pulla, Dracocephalum auslriacum, Veronica dentala, Cynanchum Vinceloxicum, Asperula glauca, Inula hirla, Senecio auranliacus, Scorzonera purpurea und der hier ihren einzigen ungarischen Standort aufweisenden Carex pediformis auf; dazwischen findet sich Buschwerk aus Juniperus communis, Evonymus verrucosus, Prunus Mahaleb, Spiraea media, Slaphylea pennala usw.

Auch die Höhen des: Göllnitzgebirges bei Göllnitzbanya und Dobschau bedecken größtenteils Wälder aus Fagus silvalica mit eingesprengter Picea excelsa und Abies alba, mit Maianthemum bifolium, Dianthus deltoides, Genista lincloria, Hypericum maculalum, Daphne Mezereum, Phyléuma spica- 


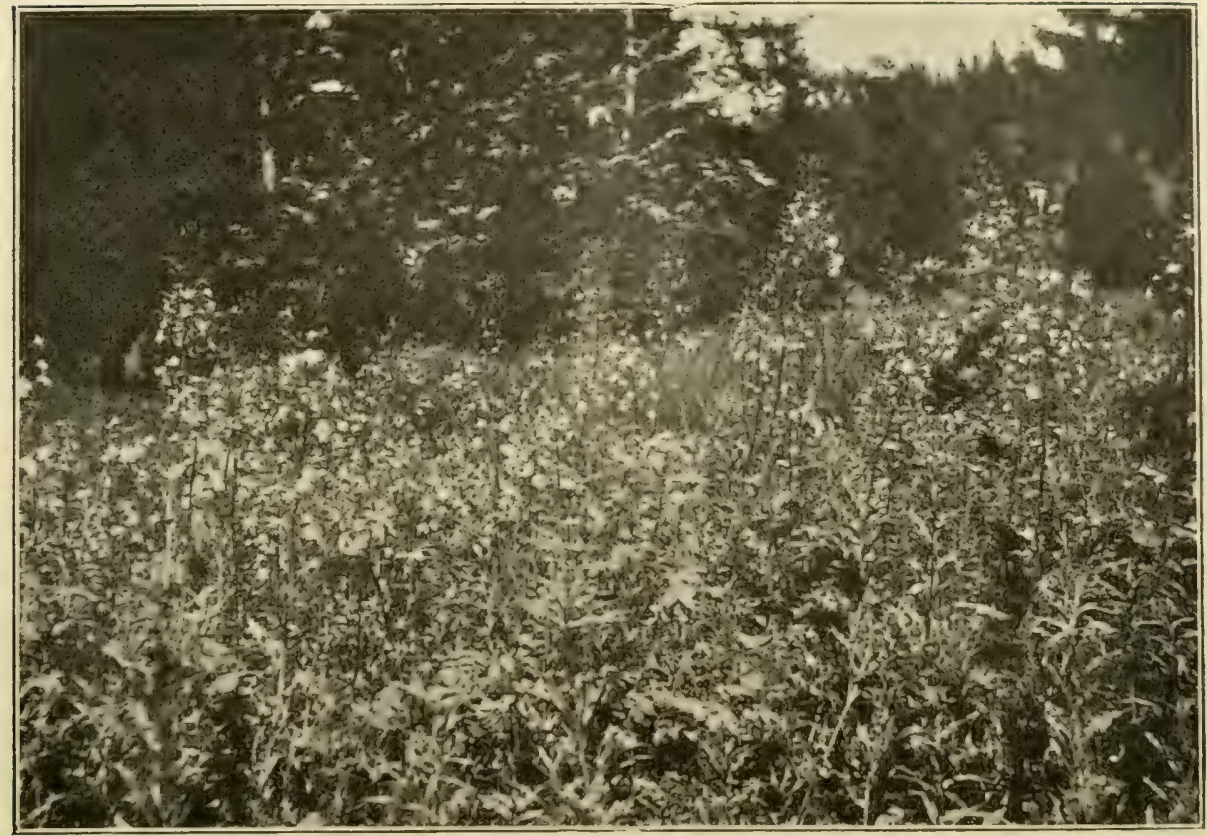

Abb. 228. Mulgedium alpinum in einer subalpinen Hochstaudenflur im Braniszkogebirge.

(Nach einer Aufnahme von G. Nyarádyi, Maros-Vasarhely.)

lum usw. An den Felsen bei der Burg von Murany aber treten zahlreiche Vor- Murany.gebirgsarten, vermischt mit einigen Formen der Triftformation, auf, wie Minuarlia laricifolia, Aconilum Anlhora, Saxifraga Aizoon, Sisymbrium slrictissimum, Hippocrepis comosa, Corlusa Matthioli, Primula veris, Digitalis ambigua, Teucrium monlanum, Siler Lrilobum, Asler Bellidiastrum, Cirsium Erisilhales, Lacluca perennis und in dieser Gesellschaft wächst hier der interessanteste Endemismus der Westkarpathen, die mit Daphne Cineorum zunächst verwandte Daphne Arbuscula. An den Südosthängen des Göllnitzgebirges sind zumeist Laubmischwälder aus Eichen, Linden, Hainbuchen, Ahornen usw. entwickelt; auch Bergtriften mit Anthericum ramosum, A. Liliago, Allium fallax, Orchis mililaris, O. globosa, Dianlhus collinus, Anemone grandis, Erysimum pannonicum, Linum austriacum, L. flavum, L. tenuifolium, Dorycnium herbaceum, Gentiana ciliala, Teucrium montanum, Linaria genistifolia, Campanula sibirica, Jurinea mollis, Hypochoeris maculala, Scorzonera purpurea, Crepis praemorsa fehlen nicht. Anderseits steigen in den kühlen Bergschluchten, wie in den Tälern von Szadellö und dem Agertale bei Torna Gebirgsplanzen, wie Asplenium viride; Phyllites Scolopendrium, Clemalis alpina, Arabis alpina, Kernera saxalilis, Corydalis capnoides, Saxifraga Aizoon, Geranium silvalicum, Astrantia maior, Primula Auricula, Valeriana monlana, V.tripleris, Campanula carpatica bis fast zu einer Meereshöhe von $200 \mathrm{~m}$ herab. An den. Felsen des Schloßberges von Torna Torna: wächst das hier endemische Onosma tornense. 


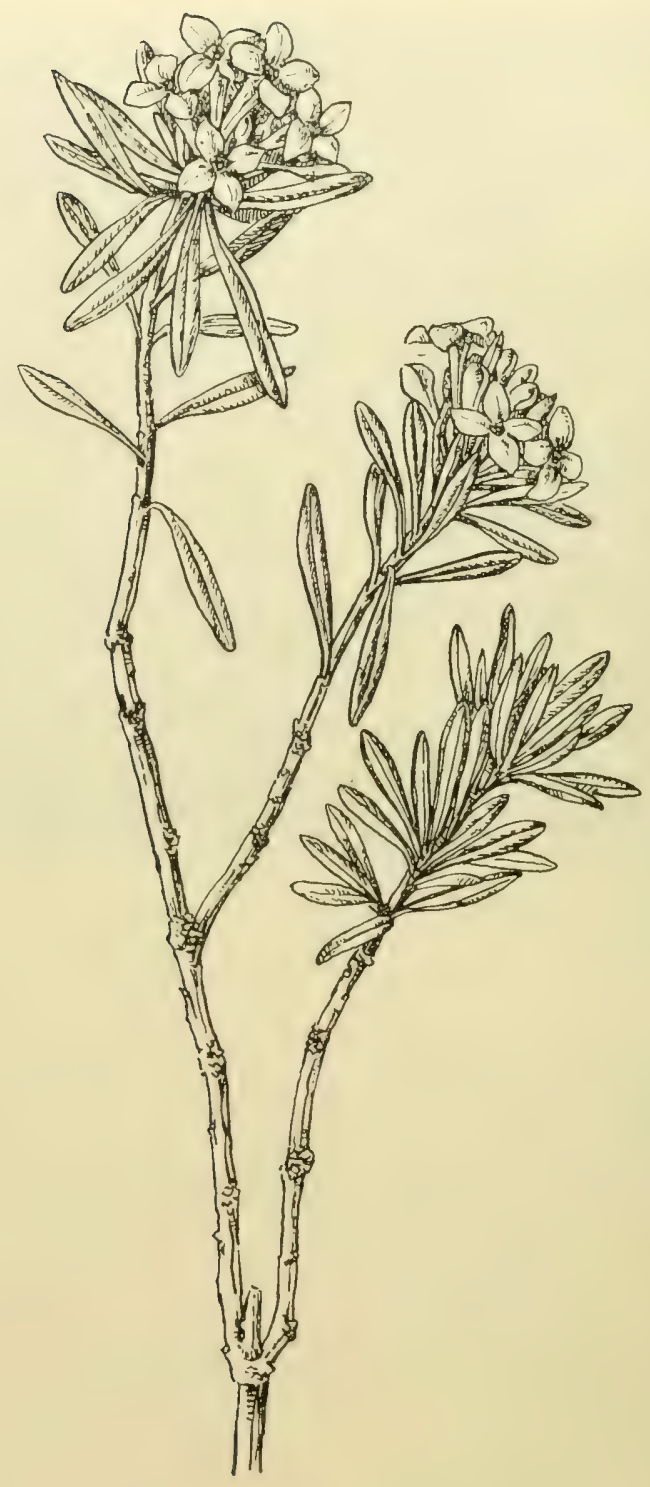

Abb. 229. Daphne Arbuscula.

Hernadtal. An den Hängen des Hernadtales von Eperies bis Kaschau und noch weiter südlich sind meist Laubwälder aus Quercus Robur und sessiliflora, Tilia cordala, Carpinus Betulus, Ulmus scabra und U. laevis, mit reichem Unterholze aus Juniperus communis, Corylus, Crataegus, Sorbus torminalis, Evonymus vulgaris und verrucosus, Slaphylea pinnala, Acer campestre, Lonicera Tylosteum usw. vorherrschend; dazwischen finden sich blumenreiche Bergtriften mit Anthericum ramosum, A. Liliago, Allium montanum, Orchis maculata, Dianthus collinus, Anemone slavica, Geranium sanguineum, Linum flavum, Linaria genisti- 
folia, Campanula sibirica, Centaurea variegala, Jurinea mollis usw. Im Tale selbst treten stellenweise feuchte Wiesen mit Iris sibirica, Orchis ustulata, Geum rivale, Alectorolophus maior, Campanula palula, Cirsium Erisithales usw. auf. In der Umgebung von Kaschau ist das Vorkommen von Eryngium planum und Kaschau. Trifolium szarosiense bemerkenswert.

Im Eperies-Tokajer Trachytzug sind im Norden bei Eperies noch Eperies. reiche Wälder aus Quercus Robur und Qu. sessiliflora mit eingemischten Hainbuchen, Birken und Kirschen vorhanden und in höheren Lagen, wie auf der Siroka $(1092 \mathrm{~m})$, treten dann Buchenwälder mit Dryopleris Filix mas, Euphorbia amygdaloides, Astrantia maior, Selinum Carvifolia, Salvia glutinosa, Campanula persicifolia, Prenanthes purpurea und besonders häufig Genliana asclepiadea auf. Weiter im Süden ist der Wald durch zahlreiche Weingärten stark eingeschränkt und am Fuße des Gebirges treten auch Triften auf, auf denen bei Satoralya - ujhely Anthericum Liliago, Allium montanum, A. flavum, Dianthus collinus, Cylisus austriacus, C. nigricans, Trifolium ochroleucum, Lalhyrus niger,

L. versicolor, Lavatera thuringiaca, Phlomis luberosa, Lactuca perennis usw. wachsen, während im Gerölle der Weingärten Asplenium seplentrionale, Aristolochia Clemalitis, Anthemis linctoria, Artemisia Absynthium, A. pontica und A. scoparia häufig sind und am Rande der Weingärten Prunus nana, Acer lalaricum und Staphylea pinnala im Vereine mit anderen Laubhölzern Gebüsche bilden. Den sürllichisten Teil dieses Gebirgszuges bildet das berühmte Weingebiet des Hegyalya, deren reiche Weinkulturen allerdings durch die Reblaus Hegyalya. fast zerstört sind. Zwischen den Maisfeldern und Weingärten ist auch hier an sonnigen, buschigen Stellen manche interessante pontische Art zu finden, wie Melica allissima, Minuartia frutescens, Linum flavum, Althaea pallida, Bupleurum affine, B. Gerardi, Onosma arenarium, Digilalis lanala, Cephalaria transsilvanica, Asyneuma canescens, Senecio erucifolius, Arlemisia pontica, A. Lobelii, Carduus candicans, Aster punctatus u. a. m. Am Fuße der Hegyalya bei Talcsva treten Talcsva. auch Edelkastanien auf und im äußersten Süden, bei Tokaj, kommen auch Adonis vernalis, Rapistrum perenne, Vinca herbacea, Cephalaria transsilvanica, Verbascum phoeniceum und Crepis pannonica in den Triften vor.

\section{f) Die südlichen Vorlagen der Westkarpathen.}

Die südwestliche Fortsetzung des Eperieser Trachytzuges bildet der isolierte, teils aus Andesit, teils aus Kalk aufgebaute, im Balyany bis $957 m$ Höhe crreichende Gebirgsstock des Bükkgebirges. Die Wälder dieses Bergstockes sind gemischte Laubwälder aus Quercus Robur, Qu. sessiliflora, Qu. Cerris, Ulmus glabra, Sorbus Aucuparia, S. torminalis und Fraxinus excelsior; daneben kommen auch buschige Stellen mit Prunus Mahaleb, Colinus Coggygria und Spiraea media vor. An Kalk- und Diabasfelsen findet man Allium flavum, Dianthus Ponlederae, Arabis arenosa *petrogena, Sempervivum soboliferum, Waldsteinia geoides, Linum flavum, Peucedanum Oreoselinum und Arlemisia pontica; 
auf Kalk überdies noch Ceterach officinarum, Iris pumila, I. variegata, Adonis vernalis, Aconitum Anlhora, Erysimum Willmanni, Hesperis Vrabelyana, Bu pleurum falcalum, B. longifolium, Scorzonera hispanica usw., während Alsine frutescens, Medicago prostrala und Saxifraga Aizoon auf Diabas beschränkt sind Auf Wiesen treten u. a. Adonis vernalis, Ranunculus pedatus, Silene Olites, Dianthus deltoides, Salvia pralensis, S. austriaca, Aleclorolophus glandulosus, in höheren Lagen auch Aiuga pyramidalis auf. Eine der interessantesten Punkte Belköhegy. ¿lcs Bükkgebirges ist der Belköhegy bei Beleap átfalva, an dessen sonnigen Hängen u. a. auch Diplachne serotina, Thalictrum foelidum, Gylisus Kilaibelii, Phlomis tuberosa, Onosma Visianii, Sculellaria altissima, Asyneuma canescens, angeblich auch Campanula divergens und Hieracium bupleuroides *Tatrae sowie die nur von wenigen Standorten bekannte Umbellifere Ferula Sadleriana wachsen.

Die doppelte 'Talfurche der Eger und Tarna trennt vom Bükkgebirge Matra. die östlich von demselben sich erhebende Matra, einen aus Trachyt aufgebauten, im K ékes 1009 m, im Nagy-Gallya $963 m$. Höhe erreichender Gebirgsstock. Den Fuß des Gebirges bedecken teils Weingärten, teils Buschbeständo aus Quercus Cerris und Qu. pubescens mit Populus tremula, Sorbus Aucuparia, Spiraea media, Acer talaricum, A. campestre, Fraxinus excelsior, F. Ornus, Prunus spinosa, P. frulicosa, Cornus sanguinea, Viburnum Lantana, sowie Triften mit Andropogon Gryllus, Aegylops cylindrica, Danlhonia calycina, Arenaria graminifolia, Dianthus collinus, Ranunculus polyphyllus, Adonis vernalis, Hesperis trislis, Cyllisus leucanlhus, Trifolium pannonicum, Silaus Rochelii, Scutellaria allissima, Veronica spuria, Asyneuma canescens, Galium pedemontanum, Inula cordala, Carduus collinus, Xeranthemum cylindraceum, Crupina vulgaris, Hypochoeris maculala und der seltenen Ferula Sadleriana neben' anderen weiter verbreiteten Formen; bei Gyöngryes treten auch Vinca herbacea, Iris spuria und Eryngium planum auf; ja, selbst einige typische Steppenpflanzen, wie Astragalus virgalus, Crambe talarica und Asler acris dringen bis ins Gebiet der Matra vor und an Felsen findet sich neben Allium montanum, Iris pumila, Sedum glaucum und Aconilum Anlhora auch der südliche Farn Ceterach officinarum. Die Kuppen des Gebirges aber bedecken Laubwälder, und zwar erst Eichenbestände mit eingemischten Exemplaren von Carpinus Betulus, Betula pendula usw., aus deren Niederwuchs Melandryum silvestre, Polygonalum verlicillalım, Lunaria rediviva und das ostkarpathische Symphylum cordatum hervorzuheben sind, in höheren Lagen Wälder aus Fagus silvatica, in deren Unterholz Rosa pendulina vorkommt und in deren Niederwuchs nicht nur Silene viridiflora, Helleborus purpurascens, Waldsleinia gloides, sondern bei Par ád auch Pirola minor, P. secunda, Monotropa glabra und auf Bergwiesen Thlaspi Jankae und Parnassia palustris gedeihen, während die noch im Bükkgebirge auftretende Astrantia maior hier fehlt.

Die letzten, gegen die Donau vorgeschobenen Ausläufer der Matra, die Magusta- Magusta- und Cserhatgruppe, mit dem 939 m hohen Csoványos, tragen und gruppe. auf ihren Iíppen ebenfalls gemischte Laubwälder aus Buchen, Hainbuchen 


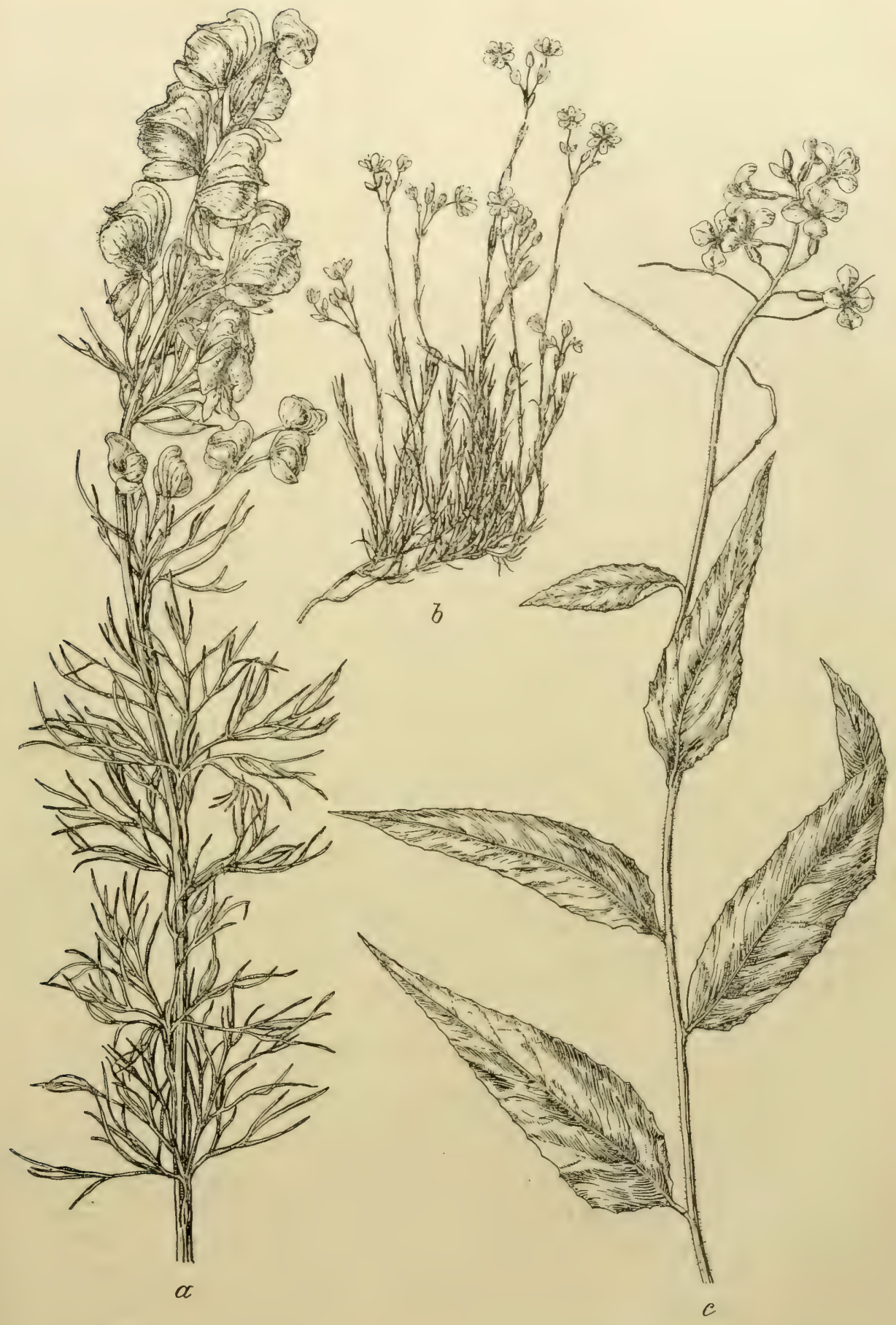

Abb. 230. Aus der-Flora der Matra-und des Bükkgebirges.

$a$ Aconitum Anthora. $b$ Minuartia frutescens, $c$ Hesperis Vrabelyana. 
und Eichen, mit massenhaftem Helleborus purpurascens, mit Waldsleinia geoides, Scrophularia vernalis, Digitalis ambigua usw., während an ihrem Fuße bei NagyNagy- Maros Ciastanea saliva cinen größeren Bestand bildet. Die Abhänge des Gebirges gegen die Donau sind teils von Weingärten, teils von Buschbeständen aus Quercus pubescens, Qu. Cerris, Acer talaricum, Staphylea pinnata, Cornus Mas, C. sanguinea, Spiraea media, Prunus Mahaleb, P. nana, Colulea arborescens, Fraxinus Ornus usw. bedeckt, auch Triftformationen sind reichlich anzutreffen, besonders auf dem Spitzberge ober Nagy - Maros, wo u. a. Dianthus Armeria, Adonis vernalis, Ranunculus illyricus, Erysimum erysimoides, Arabis auriculata, Linum hirsutum, Geranium sanguineum, Dictamnus albus, Trifolium rubens, Lathyrus ochroleucus, Bupleurum junceum, Sideritis montana, Verbascum austriacum, Artemisia Absynthium, Aster Linosyris, Chrysanthemum corymbosum wachsen. Am Ufer der Donau bei Vácz (Waizen) findet man an schotterigen Stellen Pencedanum arenarium, Achillea pectinala, Echium allissimum, Lactuca Scariola, Reseda inodora (bei Nagy-Maros), im Röhricht Asler Tripolium und Senecio paludosus. Eine besonders reiche Flora zeichnet den südwestlichsten Nagy-Szál. Ausläufer des Gebirges, den Nagy-Szál ober Vácz aus. Buschwerk aus Carpinus Betulus, Corylus Avellana, Fraxinus Ornus, Prunus Mahaleb, Acer Lalaricum und Triften mit Alyssum montanum, Potentilla arenaria, Vinca herbacea, Adonis vernalis, Lathyrus pannonicus, Seseli leucospermum, Salvia austriaca, Scorzonera purpurea, Orchis pallens, Carex humilis bedecken seine Hänge in den unteren Partien, darüber aber findet sich überall dichter Laubwald aus Quercus Cerris, Qu. pubescens und Qu. Robur, zu denen sich in der Gipfelregion auch Fagus silvatica und Acer platanoides gesellen, in dessen Niederwuchs Dryopteris Filix mas, Astragalus glycyphyllos, Waldsteinia geoides, Digitalis ambigua, Lalhyrus niger, Myosotis silvatica, Ranunculus auricomus, Helleborus purpurascens, Lamium vulgare, Pulmonaria angustifolia, Melica uniflora, Polygonalum officinale und Convallaria maialis usw. gedeihen. An den steilen, gegen die Donau gerichteten Südwänden aber treten Felsenpflanzen, wie Iris pumila, Anemone grandis, Minuartia selacea, Draba lasiocarpa, Erysimum crepidifolium, Globularia Willkommii, Seseli leucospermum, Paronychia Kapela auf.

\section{Die Ostkarpathen.}

\section{a) Die Waldkarpathen.}

Im Osten der als geographische Scheidelinie zwischen Ost- und West-

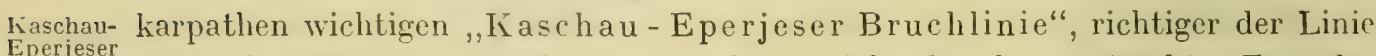
Eperjeser
Bruchlinie. Oslawica-Lupkov-Laborcza, erhebt sich der langgestreckte Zug der großenteils aus Sandstein aufgebauten Waldkarpathen, welche schon ein ganz anderes floristisches Bild bieten als die Westkarpathen, da die genannte Kaschau-Eperjeser-Bruchlinie auch in pflanzengeographischer Beziehung die Scheidelinie zwischen West- und Ostkarpathen bildet. Eine große Zahl von in Westen verbreiteten und oft häufigen Arten erreicht hier ihre Ostgrenze, jenseits welcher sie entweder ganz fehlen oder nur mehr an vereinzelten Standorten 
auftreten. Die wichtigsten dieser Arten sind Carex firma ${ }^{1}$, Dianthus hungaricus Gypsophila repens, Arabis Jacquinii, Sedum album, Saxifraga caesia, Viola sudetica, Hacquetia Epipaclis, Bupleurum ranunculoides, Primula Auricula (erst wieder im Banat), Salureia alpina, Aster Bellidiaastrum, Crepis succisifolia, Hieracium florenlinum und $H$. bupleuroides. Anderseits aber treten östlich der in Rede stehenden Linie oder wenig weiter östlich eine große Zahl von sehr in die Augen fallenden und für die Flora sehr bezeichnenden Arten auf, wie Dianthus compactus, Helleborus purpurascens (auch in der Matra), Viola declinala, Pulmonaria rubra, Campanula abietina, Scorzonera rosea, Aposeris foetida, das westwärts bis Hommona an der Laborcz reichende Hieracium transsilvanicum und endlich die die genannte Westgrenze an ein orler zwei Stellen überschreitende Telekia speciosa, auch Symphylum cordalum und Scopola carniolica sind westlich der Kaschau-Eperieser Bruchlinie nur vereinzelt in den Pieninen (und ersteres auch in der Matra) zu finden.

Besonders hervorgehoben muß aber werden, daß die Fichte (Picea excelsa), die in den Westkarpathen in den gleichen Formen wie in den Alpen und dem übrigen Mitteleuropa auftritt, in den Ostkarpathen in höheren Lagen, vielleicht sogar durchwegs durch eine abweichende Iiasse (Picea montana Schur, P. excelsa var. acuminala Beck) vertreten wird, welche sich vor allem durch die lang zugespitzten Zapfenschuppen unterscheidet.

Die eigentlichen Waldkarpathen bedecken ausgedehnte prächtige WaldBuchenbestände, oft noch fast reine Urwälder. Das Unterholz fehlt ganz oder ist nur an Waldrändern und an Lichtungen vorhanden und besteht aus Salix silesiaca, Spiraea media, Daphne Mezereum, Lonicera nigra usw. Sehr charakteristisch aber ist der Niederwuchs, der vornehmlich aus Luzula nemorosa, L. silvatica, Paris quadrifolia, Helleborus purpurascens, Aconitum moldavicum. Cardamine glandulosa, C. bulbifera, Aruncus silvesler, Gentiana asclepiadea, Symphytum cordalum, S. tuberosum, Pulmonaria rubra, Scopola carniolica, Galium rotundifolium und Aposeris foelida besteht. Auf der Nordseite des Gebirges aber herrscht die Fichte vor. Nach oben zu geht der Wald in Krüppelbuchenbestände über und schon von 1200-1300 m Neereshöhe breiten sich ausgedehnte Borstengrasmatten aus, als deren Charakterpflanzen Nardus slricla, Deschampsia caespilosa, Carex monlana, C. pallescens, Dianthus compaclus, Polenlilla lernata Hypericum alpigenum, Viola declinata, Ligusticum Mutellina, Laserpitium alpinum, Vaccinium Myrtillus, V.Vitis Idaea, Melampyrum silvaticum, Euphrasia stricta Phyleuma Vagneri, Homogyne alpina, Arnica monlana, Hypochoeris uniflora und Scorzonera rosea zu bezeichnen sind.

An feuchten, felsigen Stellen aber bildet hier vom Quellengebiete der Ung ostwärts zum ersten Male im Zuge der Karpathen die Grünerle (Alnus viridis)

1) Nach Angabe aller Autoren (auch $\mathrm{Pax}$ ) soll ferner Carex sempervirens in den Ostkarpathen fehlen und daselbst durch $C$. tristis vertreten sein. Nach Kükenthal (in Englers Pflanzenreich) ist aber C. tristis auf den Kaukasus beschränkt und die bisher dafür gehaltene Pflanze der Ostkarpathen von $G$. sempervirens nicht verschieden, welcher Ansicht ich auf Grund eigener Untersuchungen beistimmen muß. 
Buschbestände und an Bergbächen tritt neben Doronicum austriacum auch Telekia speciosa und besonders im Osten das dunkelrote Cirsium pauciflorum Pikuj. auf. Von den höheren Gipfeln ist besonders der Pikuj (1403 m) durch eine reichere Flora ausgezeichnet. An felsigen Stellen gedeihen hier Allium imontanum Sedum carpalicum, Pleurospermum auslriacum, Scabiosa lucida, Valeriana tripleris, Cirsium Erisithales, den Gipfel aber umgürten Krüppelfichten und über und zwischen denselben findet man Juniperus nana, Thesium alpinum, Sedum roseum, Saxifraga Aizoon, Alectorolophus alpinus, Solidago alpestris, Hieracium villosiceps, $H$. alpinum, $H$. glandulosodentalum usw. Der südöstlich vom Pikuj Stoj. sich erhebende Stoj $(1679 \mathrm{~m})$ trägt Buschbestände aus Alnus viridis und Pinus Mughus und an steinigen Stellen trifft man Lycopodium alpinum, Scleranthus uncinatus, Veronica Baumgarlenii, Gentiana Vagneri und Hieracium Auricula.

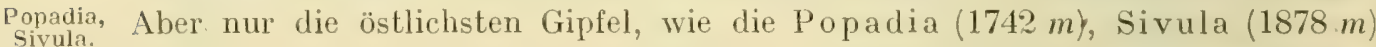
und Gsorna Cleva $(1723 \mathrm{~m})$ weisen ein wirklich alpines Gepräge auf. Hier treten schon Alpenrosen (Rhododendron myrlifolium) in kleinen Beständen neben Juniperus nana, Pinus Mughus und Alnus viridis auf, hie und da trifft man an der oberen Waldgrenze Pinus Cembra und auf den Gipfeln wachsen Selaginella selaginoides, Poa alpina, Carex alrata, C. sempervirens, Polygonum viviparum, Arabis alpina, Geum monlanum, Heracleum carpalicum, Genliana Kochiana, Pedicularis verlicillata, Phyleuma telramerum und Leontodon pyrenaicus, an quelligen Stellen Juncus castaneus, Cardamine rivularis, Stveerlia perennis, während in den Buschbeständen Knaulia silvalica. *pocutica, Carduus Kerneri und Hieracium poculicum vorkommen.

Nördlich ist den. Waldkarpathen ein waldreiches Hügelland vorgelagert, Przemysl. das sich über Sanok und Turka bis Przemysl, Drohobycz und Stryi
Drohobycz. erstreckt. Größtenteils sind es Buchen, untermischt mit Hainbuchen, Eichen, Linden und ZitterpappeIn, die diese Wälder zusammensetzen, in denen neben Deschampsia caespilosa, Calamagroslis silvalica, Melica nulans, Carex brizoides, C. silvatica, C. digitala, $C$. pallescens, $C$. leporina, Ranunculus auricomus, $R$. cassubicus, Polentilla alba, Lathyrus vernus, L. niger, L. laevigatus, Aclaea spicata, Digitalis ambigua, Mercurialis perennis, Trienlalis europaea, Aposeris foelida auch eine Reihe von Voralpenpflanzen, wie Lilium Marlagon, Thalictrum aquilegifolium, Cardamine bulbifera, Pleurospermum austriacum vorkommen, doch auch 'I'annen- und Fichtenwälder, in denen noch Polygonatum verticillatum, Poa Chaixii, Aclaea Cimicifugia, Aconilum gracile, Gircaea alpina auftreten, reichen in der Gegend von Przemysl bis $650 \mathrm{~m}$, Tannen sogar bis $450 \mathrm{~m}$ tief herab und auf Wiesen um Przemysl und Drohobyc z sind Gladiolus imbricatus, Arabis Halleri. und Primula carpatica noch verbreitete Erscheinungen.

Im Süden ist den Waldkarpathen eine aus jungvulkanischen Gesteinen Gebirge aufgebaute, vom Vihorlat bis zum Guttin reichende Kette vorgelagert, die von Ung gegen die Ebene steil abfällt. Am Fuße derselben trifft man Bestände aus
und Bereg. gegen Quercus Robur und Carpinus Belulus, hie und da auch kleine Birkenbestände, die allmählich in die Wälder der Nyirszeg übergehen, und dazwischen Buschwerk aus Quercus pubescens, Salix Caprea, Corylus Avellana, Acer campestre, 


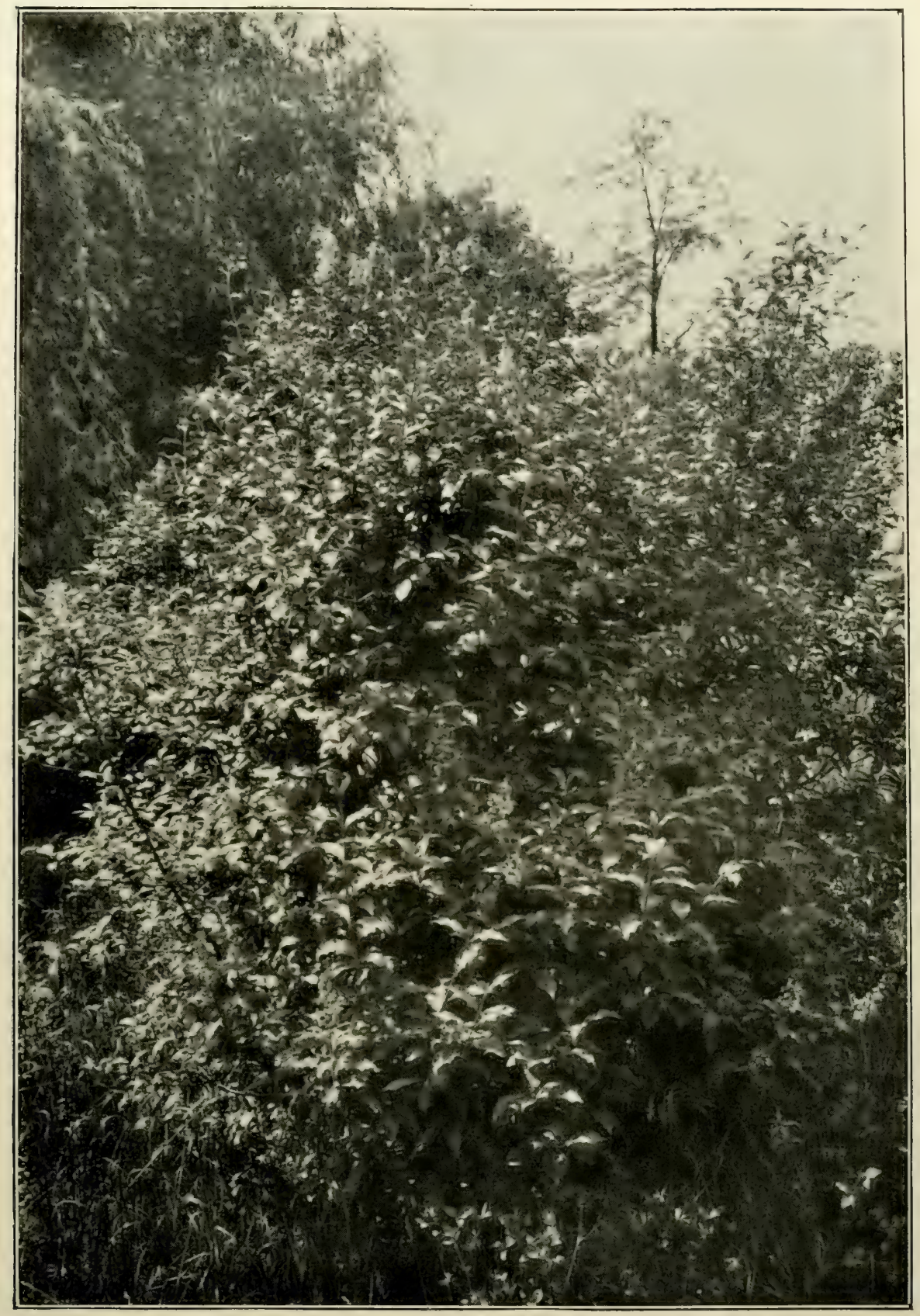

Abb. 231. Blühender Strauch von Syringa Josikaea im botanischen Garten zu Kolozsvár.

(Nach einer Aufnahme von Prof. A. Richter, Kolozsvár.) 

Rhamnus Frangula usw. und hie und da auch Triftformationen, die durch das Vorkommen von Koeleria pyramidala, Molinia coerulea, Melica uniflora, Allium vineale, Cytisus albus, Medicago prostrala, Linum flavum, L. hirsulum, Peucedanum Cervaria, Cynanchum Vinceloxicum, Slachys recla, Origanum vulgare *barcense, Odontiles lutea, Achillea Neilreichii, Arlemisia ponlica sowie der südlichen, bei Vinna, Homonna und Ungvár beobachteten Coronilla elegans und des in Ungrár. der Umgebung von Munkács endemischen Cytisus serolinus ausgezeichnet sind. Munkács. In höheren Lagen aber bildet Faqus silvatica Waldbestände, in denen Scilla bifolia, Helleborus purpurascens, Isopyrum thalictroides, Anemone nemorosa, Cardamine bulbifera, Lunaria rediviva, Daphne Mezerelim, Geranium phaeum, auf dem 1074 m hohen Vihorlat auch Luzula nemorosa, Lilium Marlagon, Polygonalum mulliflorum, Mercurialis perennis, Alropa Belladonna, Scopola carniolica, Phyleuma spicalum und Cenlaurea mollis gedeihen, während daselbst an Felsen Asplenium viride, Woodsia ilvensis, Spiraea media, Clematis alpina, Lonicera alpigena, auf Wiesen Gymnadenia conopea, Orchis globosa und Gentiana carpalica wachsen. Am, ,Kleinen Meerauge" findet man nur Juncus effusus, $J$. arliculatus, Galium palustre, Gnaphalium uliginosum und Bidens tripartita; auf dem Gipfel des Vihorlat kommen Aconilum gracile, Scrophularia Scopolii, Campanula lalifolia, Cirsium Erisithales und Cenlaurea austriaca vor. Im südöstlichen 'Teile des Gebirgsstockes aber ist im Latovca- und Stenyovatale sowie am Viesa- Latovcabache die prächtige Syringa Josikaea eine Zierde der das Bachufer umsäumenden stenyovaGebüsche.

\section{b) Die Rodnaer und Bistritzer Alpen.}

An dem die Waldkarpathen von den Rodnaer Alpen scheidenden Jablo- Jablonicanicapa $\beta$ erreicht ein für die Úfer der Flüsse und Bäche der W'est- und Waldkarpathen höchst charakteristischer Strauch, Salix incana, seine Ostgrenze, um nur ganz vereinzelt im Gebiete des Bucsecs wieder aufzutreten; auch Hieracium flágellare und $H$. floribundum kommen weiter ostwärts nicht mehr vor:

Die Rodnaer Alpen selbst stellen eines der in pflanzengeographischer Beziehung interessantesten Gebiete der Karpathen dar. Nur im Tale der Thei B und des Viszo und der Szamos dringen Elemente des Hügellandes bis gegen das Gebirge vor. So findet man noch bei Marmaros - Szigeth Eichenwälder, Marmarosin denen auch Quercus Cerris und Qu. pubescens nicht fehlen, bei Huszt treten an der Theiß, auf deren Sandbänken Myricaria germanica nicht selten ist, noch Sumpfwiesen mit Carex elala, Galega officinalis usw. auf und im Tale der Szamos findet man bis Ohla-Szt.-Györgey Triftformationen mit Ranunculus Steveni, Roripa pyrenaica, Bunias orientalis, Linum flavum, Polygala maior, Ferula silvalica, Nonnea pulla, Slachys germanica und Nepela pannonica. Die Halophytenflora bei Ronaszek ist arm und bietet nur Atriplex rosea, Spergularia salina, Bupleurum tenuissimum und Centaurium pulchellum. Aber bis tief ins Tal herab reichen die dichten Buchenbestände mit einem Niederwuchse aus Euphorbia carniolica, Cardamine glandulosa, Helleborus purpurascens, Telekia 'speciosa, Aposeris foelida und Hieracium lranssilvanicum, die bei 
etwa $1350 m$ von Fichtenwäldern, in denen auch Ranunculus carpaticus, Melampyrum saxosum, Campanula abietina, Phyleuma telramerum und Doronicum hungaricum auftreten, abgelöst werden; in Bergschluchten und an Waldbächen sind Aconilum paniculatum und Cirsium pauciflorum und besonders Delphinium elatum nicht selten.

Am Nordostabhange der Rodnaer Alpen, im Quellgebiete des Pruth, ist ähnlich wie in den Waldkarpathen noch die Buche der herrschende Waldbaum, Kniazdvor in deren Beständen auch Taxus baccala nicht selten ist. Bei Kniazdvor, unweit

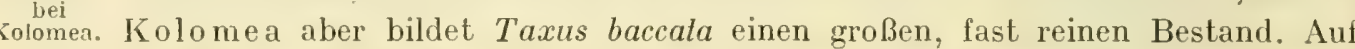

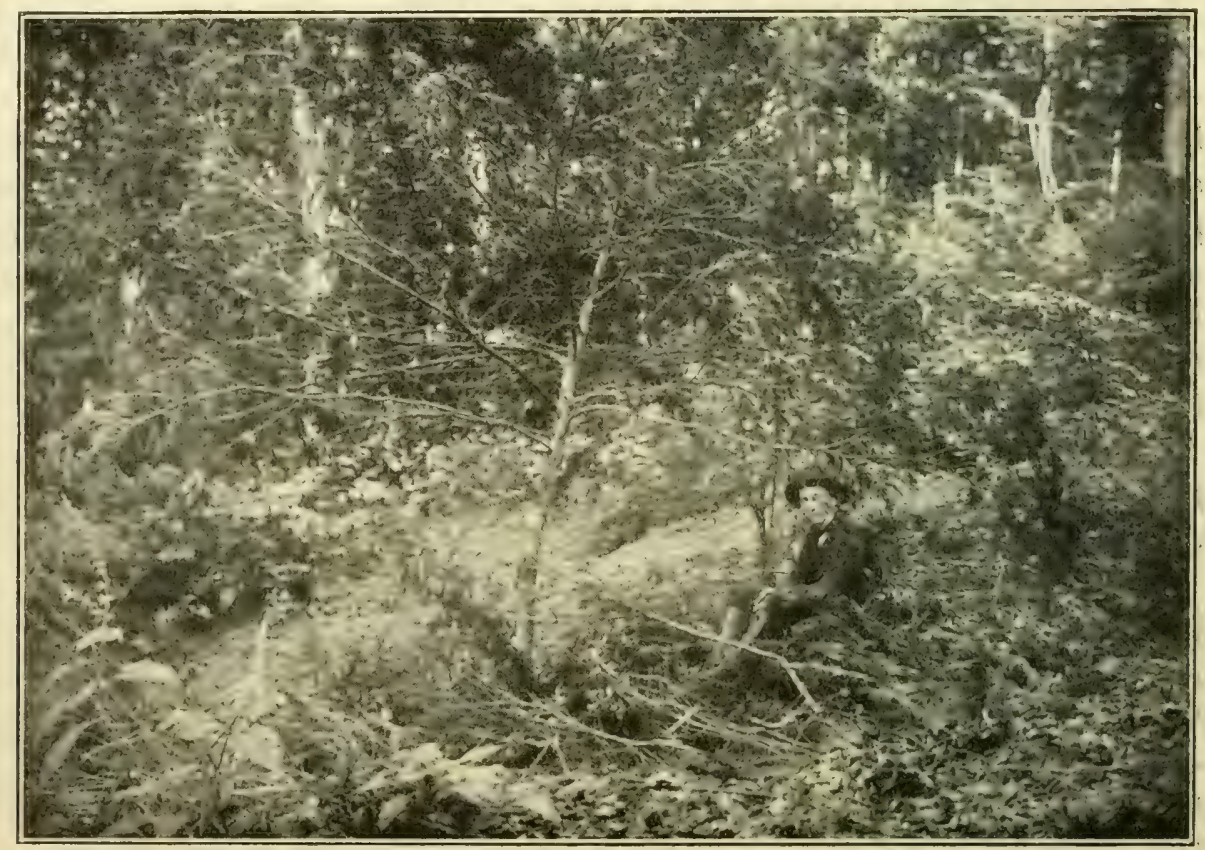

Abb. 232. Aus dem Eibenwald bei Kniazdvor nächst Kolomea.

(Nach einer Aufnahme von Dr. W. Szafer, Lemberg.)

einer Bodenfläche von 30 ha stehen hier 20.000-30.000 Eibenstämme, gewiß: der größte Eibenbestand Europas. Im Niederwuchse dieser Wälder findet man Alhyrium Filix femina, Dryopteris Filix mas, Carex pilosa, C. digitala, Leucoium vernum, Crocus banaticus, Anemone Hepatica, Cardamine bulbifera, Lalhyrus vernus, Sanicula enropaea, Pulmonaria officinalis, Galium Schultesii, Genliana asclepiadea, Senecio umbrosus, ferner Juncus Rochelianus und vor allem Sisyrhinchium angustifolium, welche sonst nordamerikanische und in Europa nur: vielfach eingeschleppt vorkommende Pflanze an den wildesten Stellen im ganzen Zuge von Kolomea bis auf die Hänge des Hoverla oft massenhaft auftritt und anscheinend eine hier ursprüngliche Pflanze darstellt.

Weiter gegen Südosten zu bedecken dann den Nordostabhang der Rodnaer Alpen ausgedehnte Fichtenwälder mit dem typischen Niederwuchs der Ostkar- 
pathen, mit zahlreichen Vaccinien, mit Cardamine glandulosa, Campanula abietina, Aposeris foetida usw. Auf der Pojana stampa wächst hier in einem von Pinus silvestris und Belula pendula bestandenen Moor in Gesellschaft von Eriophorum vaginalum, Oxycoccos quadripelala und Andromeda polifolia die nordische, angeblich auch auf der Pietrosa vorkommende Carex loliacea. In tieferen Lagen nimmt

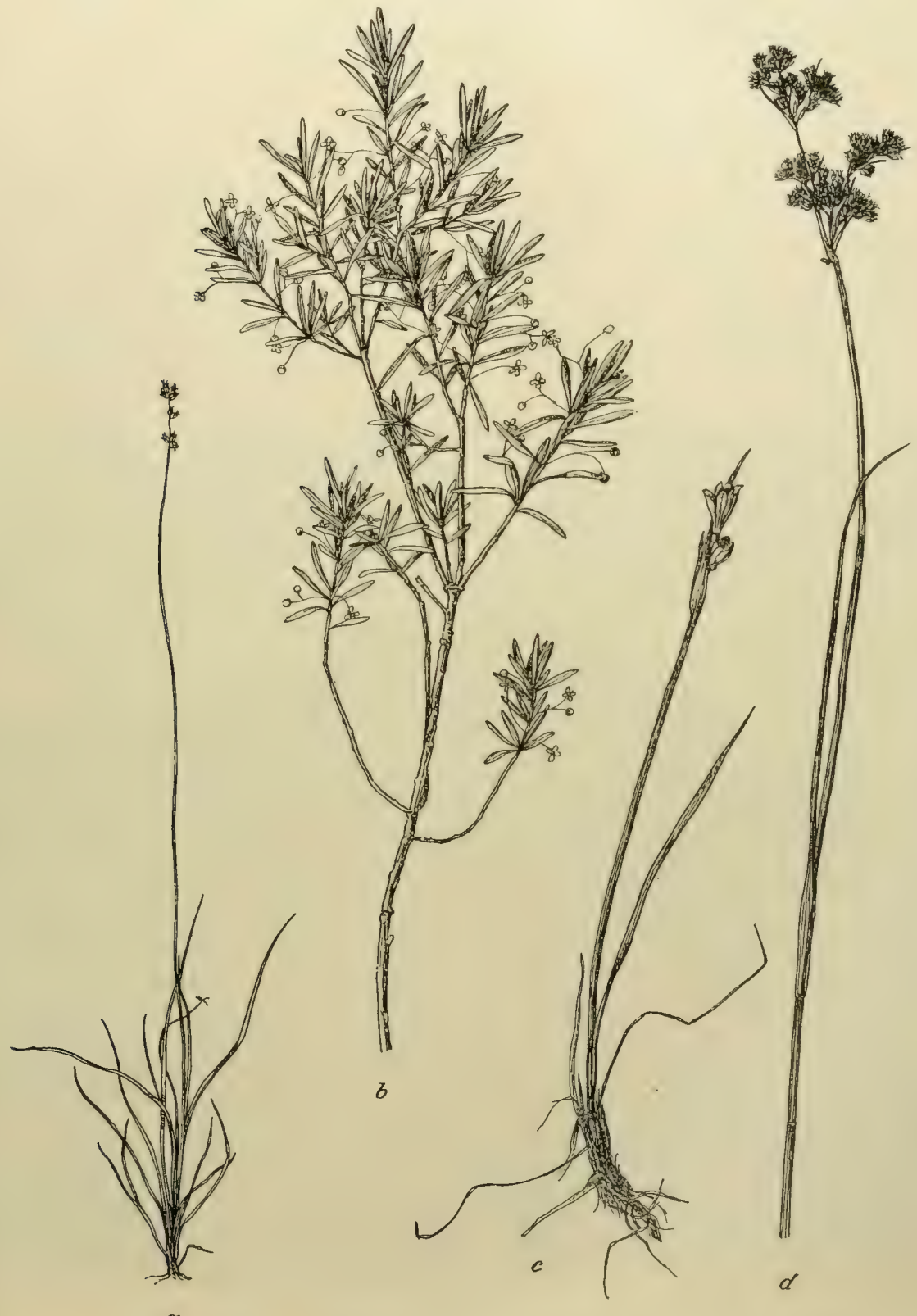

$\alpha$

Abb. 233. Einige bemerkenswerte Arten der Flora der Waldregion der Rodnaer Alpen. $a$ Carex loliacea, $b$ Evonymus nanus, $c$ Sisyrhinchium angustifolium, $d$ Juncus Rochelianus. 
in diesen Wäldern die Tanne (Abies alba) immer mehr überhand und Mischwälder aus Tannen und Buchen, in denen zwar Vaccinien und Calluna zumeist schon fehlen, in denen aber Lycopodium annotinum und Pirola-Arten noch häufig sind, erstrecken sich weit ins Hügelland hinaus bis fast in die Gegend von Czernowitz; wo zwei sehr interessante Vorkommnisse zu erwähnen sind, nämlich das Auftreten von Primula vulgaris bei Moldauisch-Banilla und das vereinzelte Vorkommen der nordasiatischen Larix sibirica an den kahlen Hängen des Runc bei Krasna-Ilska; weiter im Süden reichen diese Mischwälder bis Hliboka, zum Zusammenflusse des Großen und Kleinen Sereth, Fradautz und über Gurahomera bis Illischtie und an die Landesgrenze an der Moldava. Gerade hier, am Ostfuße des Gebirges, aber treten an einigen wenigen Stellen Steppenpflanzen tief im Gebirge auf, so vor allem im Moldavatale ober Campolung bis Briaza, besonders auf dem Muncel, Adam und Eva, wo außer dem Serpentinfarn Asplenium cuneifolium auch Alyssum orienlale, Polentilla recla, P. canescens, Cylisus hirsulus, Viola Joói, Thymus dacicus, Asperula cynanchica, Galium lucidum und einige südliche Waldpflanzen, wie

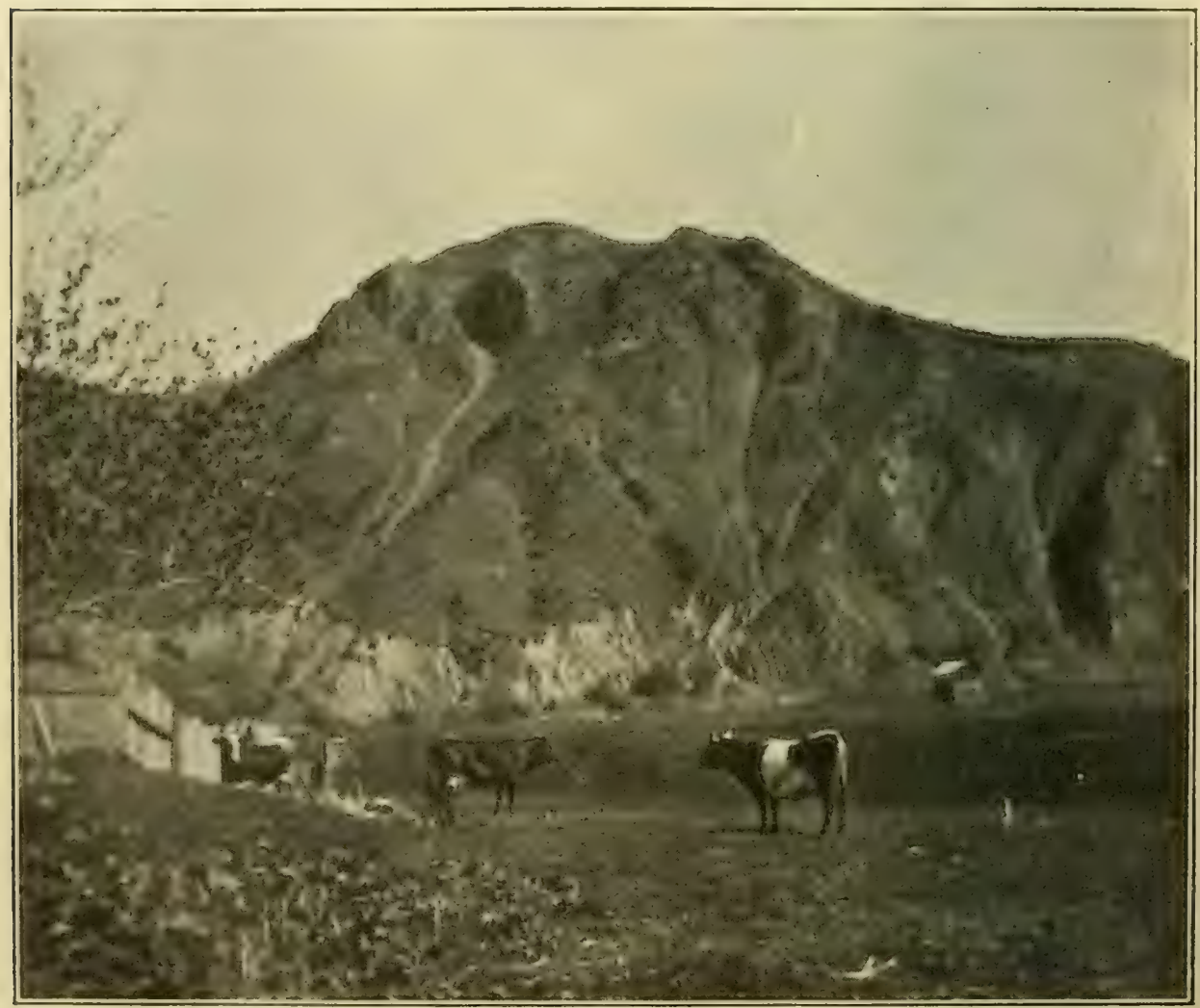

Abb. 234. Der Südabhang des Muncel bei Pojorita nächst Campolung. Die Hänge sind yon Natur aus waldlos und mit Steppenvegetation bedeckt. (Nach einer Aufnahme von C. Frh. v: Hormuzaki, Czernowitz.) 
Coronilla elegans, und vor allem am rechten Moldavaufer bei Briaza sowie im Tale Deia der erst kürzlich im angrenzenden Rumänien entdeckte und dann erst wieder im Kaukasus auftretende Evonymus nanus vorkommen.

Sonst wäre noch das stellenweise Auftreten von Hochmooren in den höher gelegenen Tälern zu erwähnen, so im obersten Dornatale, wo westlich von Dorna - Watra die Kosnasümpfe liegen, auf denen Pinus uliginosa Bestände bildet und wo u. a. Carex dioica, Scheuchzeria palustris, Calla palustris, Drosera rolundifolia, Oxycoccos quadripelala, Andromeda polifolia und Ligularia sibirica gedeihen. Bei Gurahumora ist das Vorkommen von Bolrychium Matricariae, Polystichum Braunii und Carex strigosa in den Wäldern hervorzuheben.

Die Voralpenwiesen der Rodnaer Alpen zieren Dianthus compactus, Anemone narcissiflora, Thlaspi Kovacsii, Potentilla lernala, Viola declinala, Laserpitium alpinum, Knaulia longifolia, Scorzonera rosea, Hypochoeris helvelica und Hieracium auranliacum; an Felsen gedeihen auch noch in tieferen Lagen Dianthus spiculifolius, Sempervivum assimile, Campanula carpatica und die schwarzrote Centaurea atropurpurea, die in höheren Lagen von der ähnlichen Centaurea Kotschyana abgelöst wird; an Kalkfelsen des Vrf Vaca bei Rodnaborberek tritt auch schon das weiter südlich häufigere Melandryum Zawadzliii auf. Ober der bei 1500-1600 m gelegenen Baumgrenze dehnt sich ein breiter Strauchgürtel aus Pinus Mughus, Juniperts nana, Alnus viridis und Rhododendron myrlifolium aus und darüber hinaus bedecken die Kuppen ausgedehnte, vom Vieh meist stark abgeweidete Alpenmatten. Bezeichnende Arten derselben sind insbesondere Phleum alpinum, Ph. Michelii, Deschampsia caespitosa, Avena versicolor, Sesleria disticha, Luzula sudelica, Gymnadenia albida, Crocus banalicus, Cierastium macrocarpuum, Thesium alpinum, Anemone alba, Ranunculus monlanus, Geum montanum, Saxifraga hieracifolia, Trifolium badium, Hypericum alpigenum, Ligusticum Mulellina, Vaccinium uliginosum, Soldanella hungarica, Gentiana punclata, Veronica alpina, V. bellidioides, Campanula alpina, Phyleuma Vagneri, Homogyne alpina, Anlhemis carpalica, Senecio carniolicus, Leonlodon pyrenaicus, Hieracium alpinum, Lycopodium alpinum und L. Selago.

Besonders reich aber ist die Hochalpenflora der Rodnaer Alpen. So wachsen schon auf dem Pop Ivan $(1940 \mathrm{~m})$ Agrostis rupestris, Carex curvula, Juncus Pop Ivan. Irifidus, Luzula spadicea, L. sudetica, Minuartia Gerardi, Heliosperma quadrifidum, Sempervivum monlanum, Saxifraga slellaris, Chrysosplenium alpinum, Ligusticum Mutellina, Heracleum carpalicum, Gentiana Kochiana, G. pyrenaica, G. lutea, Pedicularis sumana, Veronica Baumgartenii, Campanula alpina, C. Scheuchzeri, Phyteuma Vagneri, Gnaphalium supinum, Carduus Kerneri, Leontodon pyrenaicus, Hieracium alpinum. Reicher noch ist die Flora auf dem Hoverla $(2056 \mathrm{~m})$, dem höchsten. Gipfel der Cizarna hora, wo neben der Hoverla. Mehrzahl der genannten Arten auch Cyslopteris sudetica, Poa cenisia, Festuca Porcii, Triselum fuscum, Carex Lachenalii, C. dacica, Juncus castaneus, Allium Victoriale, Salix bicolor, Doronicum carpaticum und Senecio kukulensis vorkommen, und die Torojaga $(1939 \mathrm{~m})$ ist nicht nur durch den Besitze von Nigri- Torojaga. lella rubra, Senecio kukulensis und Hieracium macranthum ausgezeichnet, sondern 


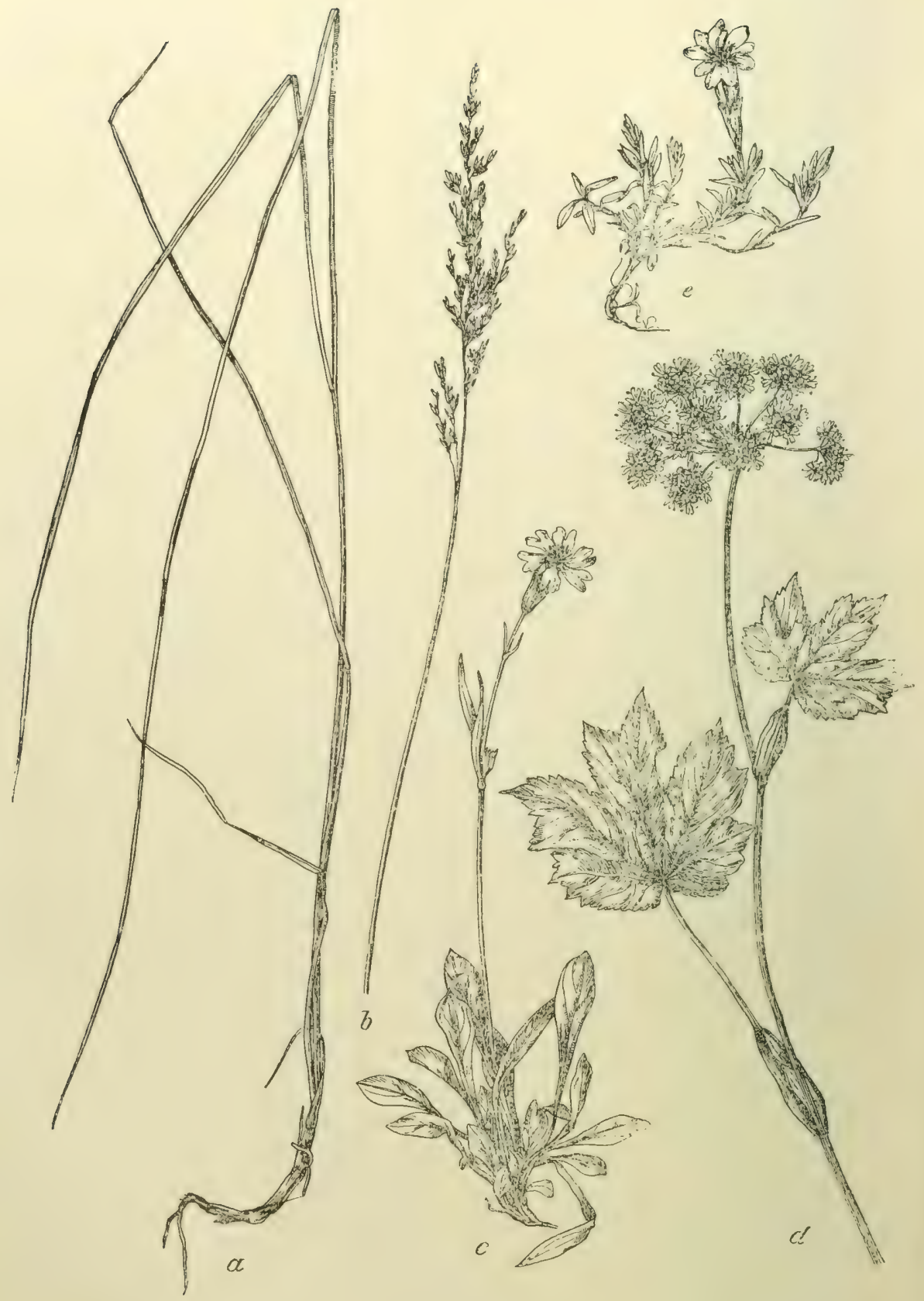

Abb. 235, Einige Charakterpflanzen der Marmaroser und Rodnaer Karpathen.

$a, b$ Festuca Porcii. $c$ Silene nivalis. $l$ Heracleum carpaticum. e Gentiana pyrenaica.

ist auch der einzige Standort von Silene rupeslris in den Karpathen überhaupt, die hier an Felsen ober Borsobánya bis zu einer Meereshöhe von $1500 \mathrm{~m}$ vorkommt. Aber erst auf den südlicheren Hochgipfeln kommt die reiche Flor: 
der Rodnaer Alpen recht zur Geltung. Auf dem höchsten Gipfel der Gruppe, dem südlich des Pop Ivan gelegenen, wild zerrissenen Vrf Pietrosu treten an Alpenbächen Veratrum album, Aconitum tauricum, Cardamine Opizii, Anthriscus nilidus, Angelica Archangelica, Heracleum palmalum, Gentiana lutea, Knautia lancifolia, Cirsium pauciflorum auf, auf Alpenwiesen findet man neben den verbreiteten Arten Crocus banaticus, Dianthus compactus, Ranunculus carpaticus, Potentilla ternala, Viola declinata, Scorzonera rosea und Hypochoeris uniflora auch Anemone narcissiflora, Herarleum carpalicum, Cimpanula pseudolanceolata, Hieracium aurantiacum, $H$. cruentum und $H$. Knulhianum und in der Gipfel-

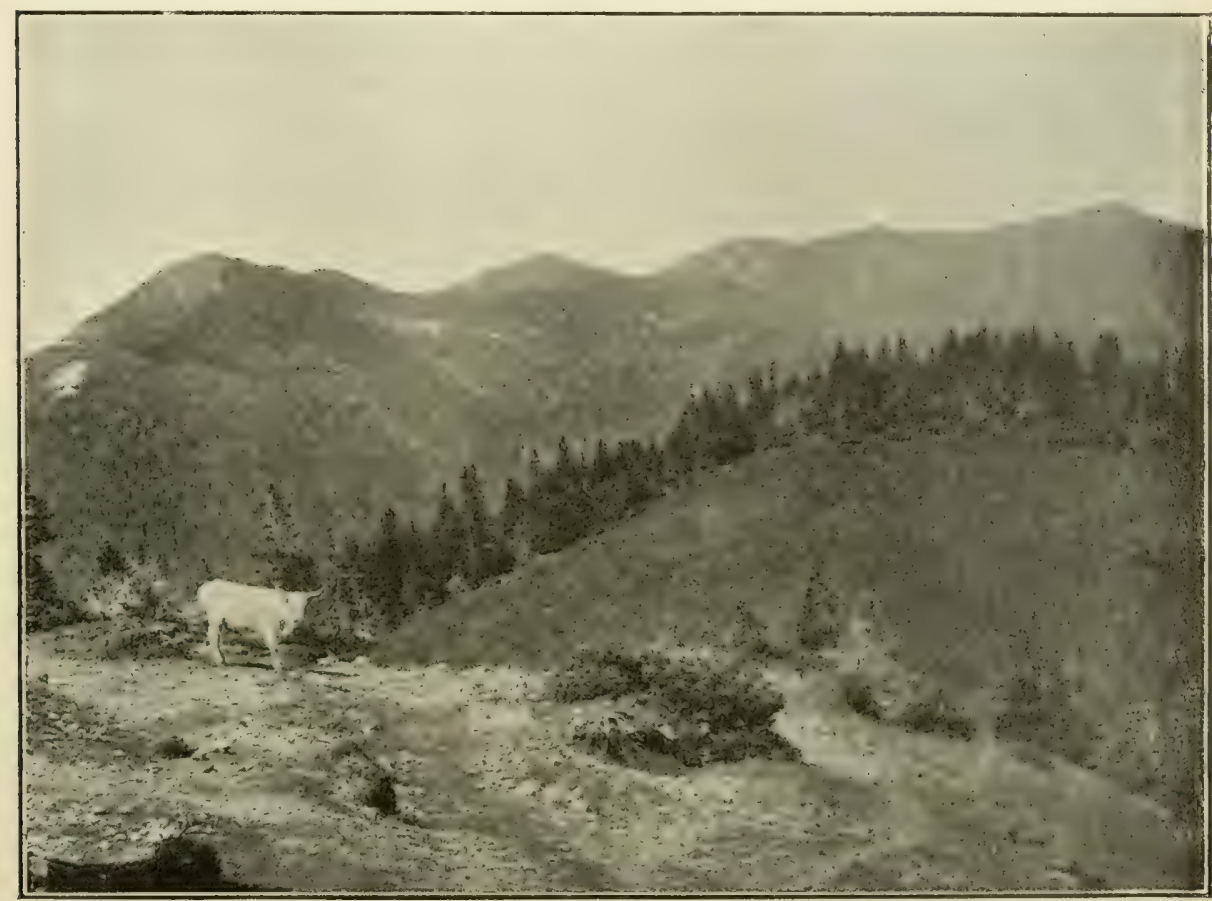

Abb. 236. Der Coringis und der Ineu bei Rodna.

Im Vordergrund die durch Ausschlagen des Waldes künstlich herabgedrängte Waldgrenzc. (Nach einer Aufnahme von Prof. G. Poschner, Bistritz.

region auch Scleranthus uncinatus, Silene nivalis, Arabis neglecta, Saxifraga cymosa, S. bryoides, Sempervivum montanum, Veronica Baumgartenii, Primula minima, Campanula alpina, Doronicum Clusii, Senecio carpalicus, S. glaberrimus, an Kalkfelsen im Nordabhange auch Sedum carpaticum, Conioselinum talaricum, Euphrasia salisburgensis und Achillea Schurii. Noch reicher und interessanter ist die Flora des nur $1994 \mathrm{~m}$ hohen, aus Kalk aufgebauten Vrfu Coron- Vrf Corongisului bei Rodna. Auf Bergwiesen treten hier auch Ranunculus platanifolius, Achillea lingulala, Scilla bifolia *praecox und Crocus veluchensis auf und auf steinigen Matten und an Felsen der Gipfelregion gedeihen Fesluca Porcii, F. carpatica, Dianthus gelidus, D. speciosus, Callianthemum coriandri- 
folium, Ranunculus Thora, Draba carinthiaca, Saxifraga luteoviridis, Linum extraaxillare, Bupleurum diversifolium, Leontopodium alpinum, Primula carpatica, P. longifolia, Centaurea pinnatifida sowie die hier endemische Saussurea Porcii, an quelligen Stellen Juncus castaneus und Allium sibiricum, an grasigen locker von Fichten bestandenen Hängen, zwischen 1550 und $1700 \mathrm{~m}$ wächst die bisher ebenfalls nur von hier bekannte Senecillis glauca *carpatica. Eine ähnliche Flora beherbergen auch die übrigen Hochgipfel des vom Vrf Pretrosu Gergaleu. zum Ineu ziehenden Kammes; so ist der Gergaleu durch den Besitz von Juncus Mihaiassa. castaneus und Alyssum repens, die Mihaiassa durch Festuca carpatica, MelanCraciunel. dryum Zawadzkii, Alyssum repens und Eritrichium nanum, der Graciunel durch Draba carinthiaca und das in der Teufelsschlucht wachsende Conioselinum lalaricum ausgezeichnet. Den Ostgipfel dieses gewaltigen Bergzuges bildet der

Ineu. $2280 \mathrm{~m}$ hohe Ineu (Kuhhorn, Unökö) ober Rodna. Buchenwälder mit Aruncus silvester, Melandryum silvestre, Salvia glulinosa, Telekia speciosa, Cirsium Erisithales bekleiden seinen Fuß, darüber treten Fichtenwälder mit Pulmonaria rubra, Campanula abielina usw. auf und an der Waldgrenze ist auch Pinus Cembra nicht selten. Die Höhen bedecken Alpenwiesen mit Dianlhus compaclus, Viola declinata, Slachys alpina, Arnica montana, Scorzonera rosea usw. und Bestände von Pinus Mughus, Alnus viridis und Rhododendron myrtifolium. In der Gipfelregion aber findet man auf den ausgedehnten Alpenmatten Avena versicolor, Sesleria disticha, Carex curvula, Polygonum viviparum, Polenlilla ternala, $\mathrm{Hy-}$ pericum alpigenum, Pedicularis verticillala, Phyleuma Vágneri, Campanula alpina, Leontodon pyrenaicus, Hypochoeris uniflora und Hieracium alpinum und an Felsen und im Felsschutte Papaver aurantiacum, Silene acaulis, Silene nivalis, Dianthus gelidus, Ranunculus crenalıs, Saxifraga cymosa, hieracifolia und moschala, Sedum roseum, Primula minima, Senecio carpaticus, Sesleria coerulans und stellenweise in Menge Scleranthus uncinalus. An Kalkfelsen im Tale der goldenen

Kirlibaba. Bistritz ober Kirlibaba, am Fuße des Ineu, gedeihen eine Reihe subalpiner Kalkpflanzen, wie Phegopleris Robertiana, Silene dubia, Aclaea Cimicifugia, Sempervivum assimile, Aconilum Anthora, Corydalis capnoides, Erysimum Wiltmanni, Sedum glaucum, Salureia alpina, Campanula carpalica und Carduus glaucus.

Von den in der Bukowina gelegenen Gipfeln weist die Tatarka Phyleuma Vágneri, die Flutorita bei Kirlibaba Aconitum moldavicum auf; auch die östGiumalau. licheren Gipfel, der Giumalau $(1857 \mathrm{~m})$, Petrile Doamnei $(1647 \mathrm{~m})$ und Rareu $(1653 \mathrm{~m})$ überschreiten nur wenig die Waldgrenze; und es kommen auf dem Giumalau von Gebirgspflanzen tatsïchlich nur Empelnum nigrum, Hypericum alpigenum und Vaccinium uliginosum vor. Hingegen bietet speziell der zerrissene Rareu. Kalkstock des Rareu noch manches Bemerkenswerte. In der Waldregion sind Cystopteris montana, C. sudetica, Aclaea Cimicifugia und Cirsium eriophorum häufig, über der Waldgrenze $(1600 \mathrm{~m})$ bilden Legföhren und Juniperus nana, seltener auch Alnus viridis den Zwergstrauchgürtel; hingegen fehlen hier Pinus Cembra und Rhododendron myrlifolium. Hart außerhalb der Reichsgrenze, beim Kloster Rareu, wurde auch Paenonia peregrina beobachtet. In der Flora der Gipfelregion sind bemerkenswert Fesluca apennina, Triselum 


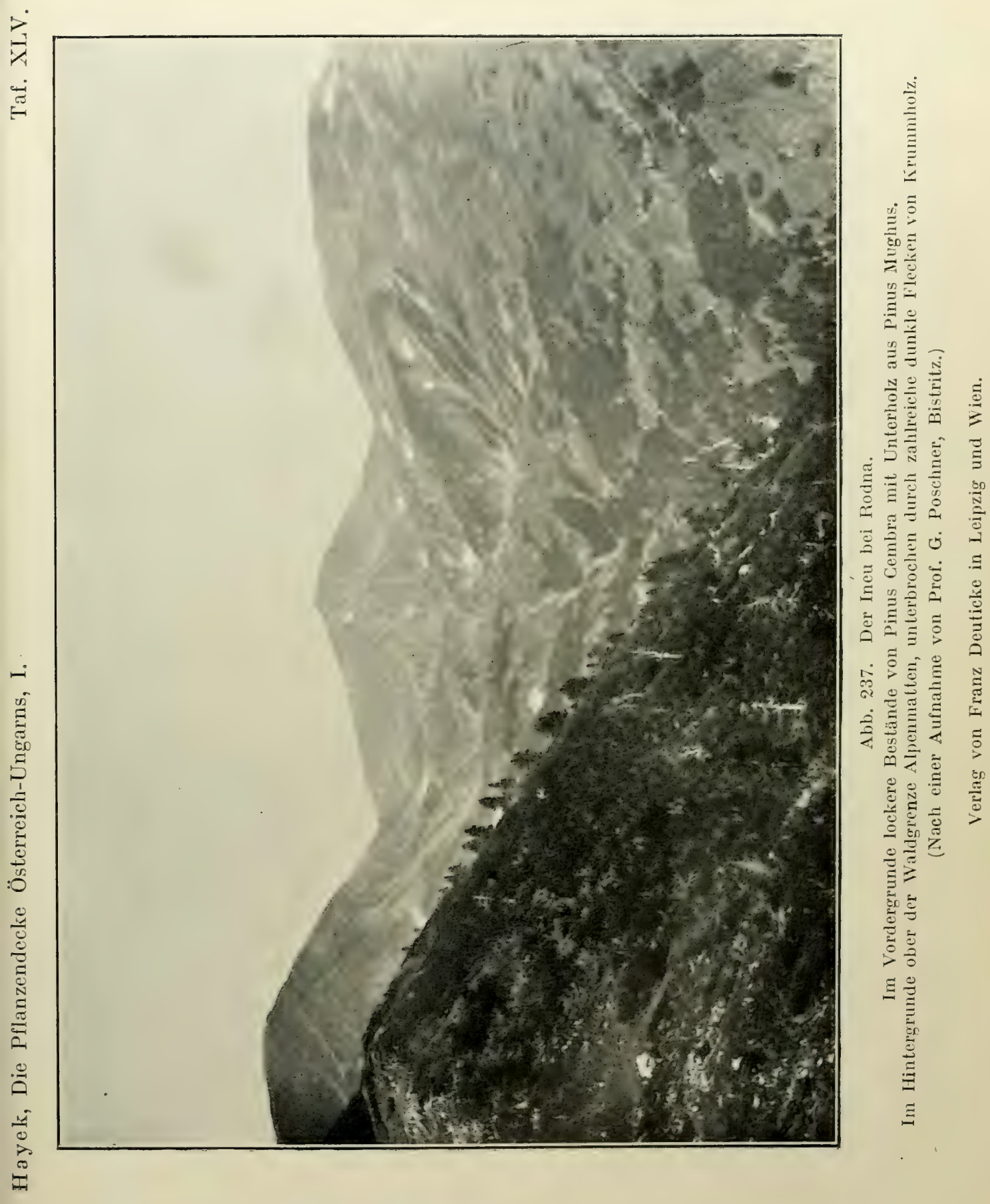





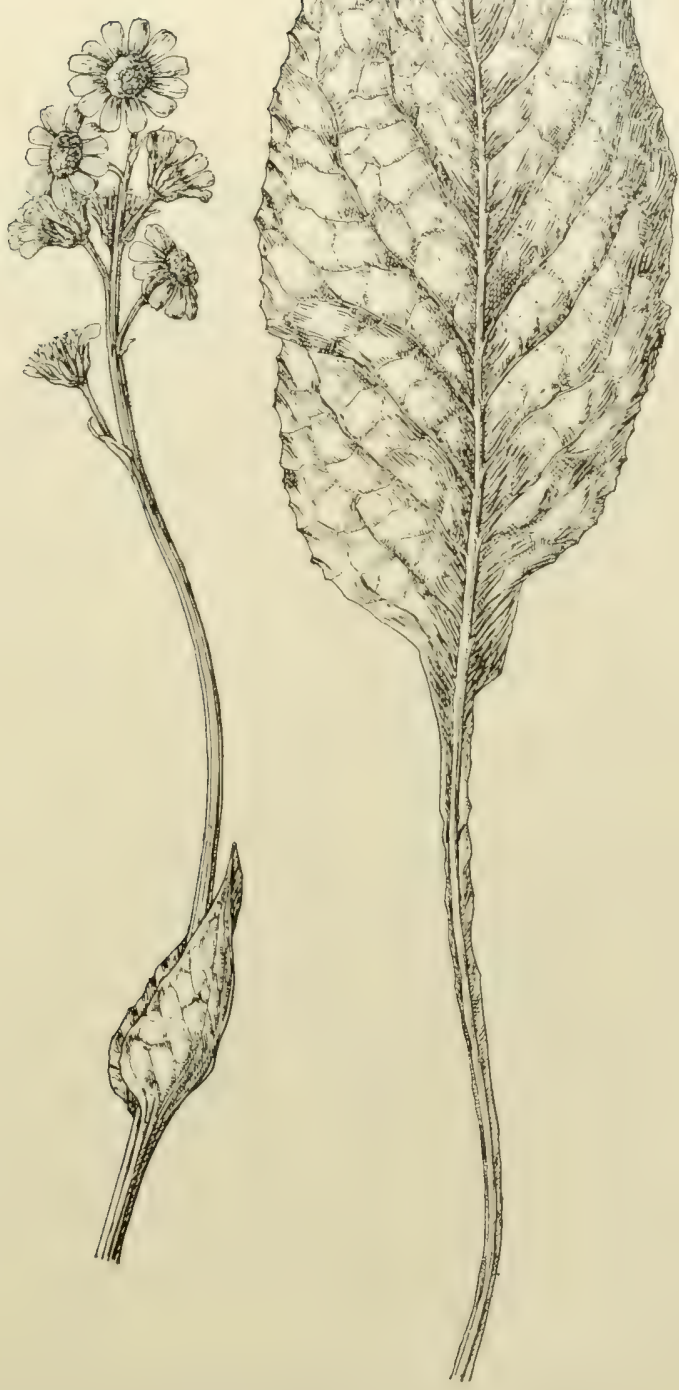

Abb. 238. Senecillis glauca Subsp. carpatica.

macrotrichum, Allium victoriale, Melandryum Zawadzkii, Dianthus spiculifolius, Arabis Jacquinii, Sempervivum Simonkaianum, Saxifraga Aizoon, S. luteo- 
viridis, Primula leucophylla, Cenlaurea pinnalifida und Achillea Schurii neben anderen weiter verbreiteten Arten, wie Lloydia serotina, Polygonum viviparum, Anemone narcissiflora, Dryas octopetala, Viola biflora, Cortusa pubens, Pedicularis summana, Knaulia longifolia, Leontopodium alpinum, Senecio capilatus, Crepis Jacquinii, Hypochoeris uniflora, Hieracium villosum usw. Auch die $1476 \mathrm{~m}$ 3arnita. hohe Tarniţa und der nur $1376 \mathrm{~m}$ hohe Cliffi tragen 'noch Bestände von Juniperus nana und zahlreiche Hochgebirgspflanzen, wie Melandryum Zawadzlii, Anemone narcissiflora, Dryas oclopelala, Sempervivum Simonkaianum, Saxifraga luteoviridis, Frimula leucophylla, Sweerlia punctala, Eritrichium terglouense und

Piatra Domnile. Kalkpflanzen, so Cystopteris montana, Minuarlia Gerardi, Arabis Jacquinii, Saxifraga Aizoon, Helianthemum rupifragum, Androsace lactea, Achillea Schurii und Adenoslyles Kerneri.

Südlich der Bistritz und des Borgopasses bis zum Tölgyespasse liegen die Bistritzer Alpen, deren Hauptzug, der Kelemen, größtenteils Borgo- aus Trachyt aufgebaut ist. Nur im Bistritztale bis Borgo-Prund treten
prund. noch Formationen des Hügellandes, spezicll Triften von gleicher Zusammensetzung wie im oberen Szamostale auf, und bei Bistritz ist auf Wiesen Leucoium vernum eine häufige Erscheinung. Die Wälder des Gebirges aber sind Nadelwälder, doch ist an der Südseite auch die Buche keineswegs selten und tritt besonders an den Hängen gegen das Marostal auch bestandbildend auf. An Bergbächen sind Delphinium elalum und Cirsium helerophyllum häufig. Die

Jelemen. höheren Kuppen des Kelemenstockes, die Bistricioara (1980) m, den Petrosul (2102 m), Kelemen-Izvoru (2033 m) und Kelemen-Cserbükk (2015 m), umgürtet Pinus Mughus mit Juniperus nana in dichten Beständen und auch Alnus viridis und Rhododendron myrtifolium treten oft gesellig auf. Prächtig sind die Bergwiesen des Gebietes, auf denen Phleum alpinum, Fesluca Porcii, Carex alrata, Juncus Thomasii, Veralrum album, Cerastium macrocarpum, Dianthus speciosus, Anemone alba, Arabis Halleri, Potentilla ternata, Viola declinata, Ligusticum Mutellina, Laserpitium alpinum, Soldanella hungarica, Melampyrum saxosum, Pedicularis summana, Arnica montana, Scorzonera rosea, Hypochoeris uniflora, Hieracium alpinum und $H$. umbellatum wachsen, doch sind sie infolge der ausgedehnten Weidewirtschaft nur dort, wo sie der Heunutzung unterliegen, schön erhalten und auf den Alpenmatten machen sich oft Ruderalpflanzen breit. An felsigen Stellen der Hochgipfel findet man nur Juncus lrifidus, Luzula spadicea, Carex fuliginosa, Minuarlia Gerardi, Scleranthus uncinatus, Chrysosplenium alpinum, Veronica frulicans, Euphrasia minima, Campanula alpina und Gnaphalium supinum, also eine relativ arme Flora; auf dem Pietro$s u l$ und der Lucsina ist das Vorkommen von Pedicularis exallata bemerkenswert.

An der Grenze der Bistritzer Alpen, bei Gyergy ó-Borszek, wird die Flora interessanter. Hier treten Iochmoore auf, auf denen neben Drosera rolundifolia, Oxycoccos quadripelala und Ligularia sibirica auch Cladium Mariscus, Belula humilis, Sweertia perennis und Pedicularis Sceplrum Carolinum, eine in Sieben- 


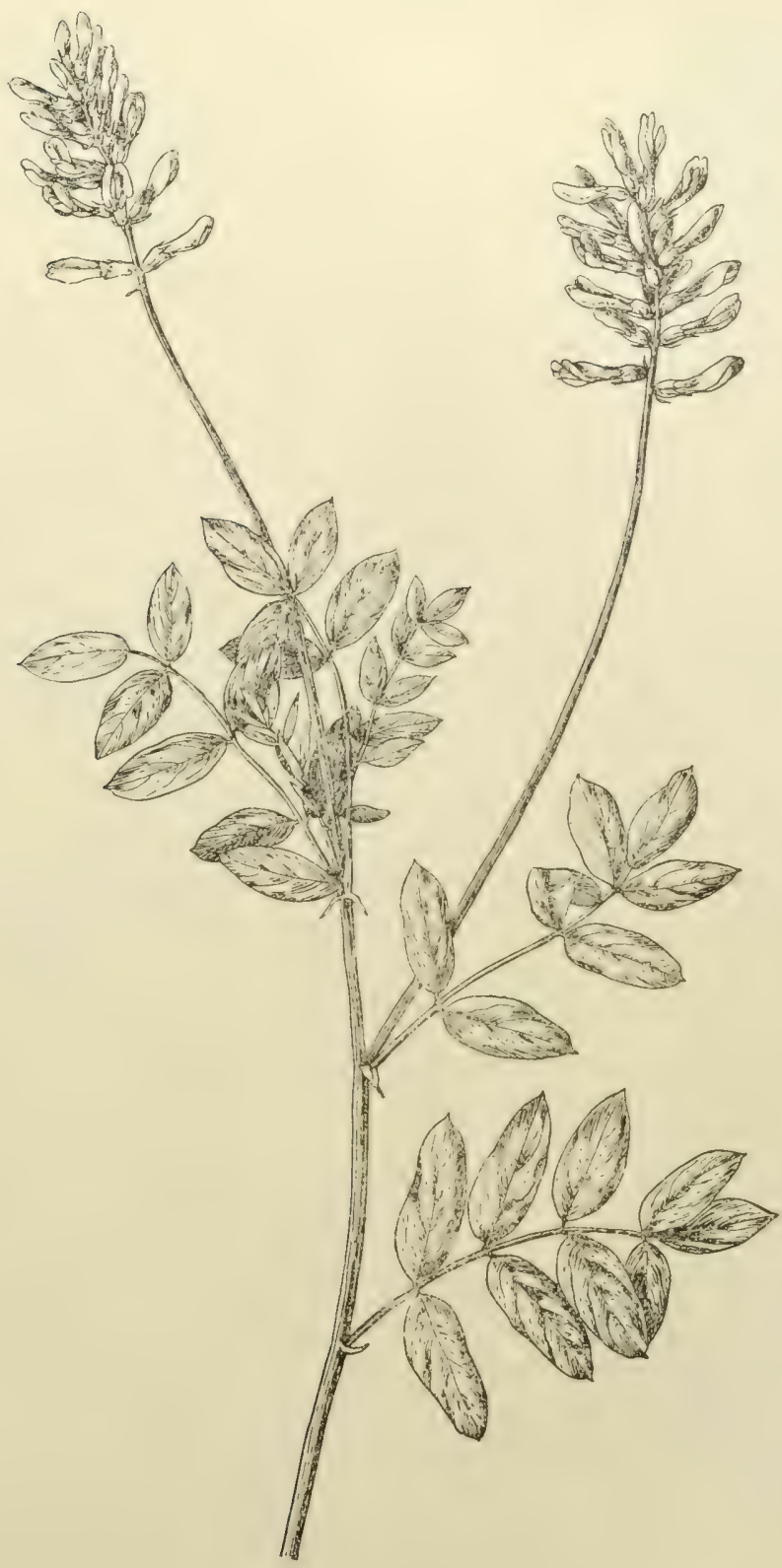

Abb. 239. Astragalus Roemeri.

bürgen keineswegs häufige Pflanze, vorkommen; und an Waldrändern an der Straße zum Tölgyespasse findet man Waldsleinia lrifolia, Anemone transsilvanica, Sedum glaucum und Viola Jóoi. Eine der interessantesten Pflanzen dieses Gebietes aber ist der hier endemische Astragalus Roemeri, der an den Abhängen des Vereckö, oberhalb Gyergyó-Tölgyes, in Gesellschaft von Thalictrum foe- Gyergyólidum gedeiht. 


\section{c) Die östlichen Randgebirge Siebenbürgens.}

Vom Tölgyespasse nach Süden erstreckt sich der langgestreckte, wenig

Csikgebirge.

\section{Gyimes.}

gegliederte Zug des aus Sandstein aufgebauten Csikge birges, cines ausgedelinten Waldgebirges, das keinen die Waldgrenze [überragenden Gipfel aufzuweisen kat. Im nördlichen Teile, wie in der Umgebung von Gyimes treten in tieferen Lagen Buchenwälder auf, in deren Nienlerwuchs Silene viridiflora, Chaerophyllum aromaticum, C. Cicularia, Daphne Mezereum, Galium Schullesii, Chrysanthemum corymbosum, Hieracium transsilvanicum gedeihen, von $1000 \mathrm{~m}$ Meereshöhe an aber herrscht als Waldbaum die Fichte, begleitet von Campanula abietina, Mulgedium alpinum und Telekia speciosa, vor. Die Bergwiesen beherbergen Agroslis vulgaris, Anlhoxanlhum odoralum, Triselum flavescens und andere Gräser. ferner Gladiolus imbricatus, Orchis globosa, Ranunculus Steveni, Viola banalica, Trifolium pannonicum, Alectorolophus montanus, Campanula pseudolanceolata, Scabiosa lucida, Genliana asclepiadea, Chrysanlhemum Leucanlhemum, Cenlaurea austriaca, Hypochoeris maculala usw., auf Viehweiden ist Cirsium decussatum häufig, während an Felsen Polentilla lernala, Moehringia muscosa, Scleranthus verticillalus, Scorzonera rosea usw. gedeihen.

Gyergyo. wohl kultiviert und von Getreide-, Mais- und Kartoffeläckern eingenommen, doch findet man stellenweise auch noch sumpfige Wiesen und an den Diluvialhügeln an der Maros auch Triften mit Dianthus saxigenus, Actaea Cimicifugia, Linum flavum, L. tenuifolium, Cytisus leucanthus, Bupleurum falcatum, Althaea pallida, Arlemisia pontica, A. campestris usw. Die von der Alt durchflossene Gsiker Hochebene hingegen ist, soweit sie nicht entwässert und von Kulturen bedeckt ist, vielfach sumpfig und von feuchten Wiesen und Beständen von Juncus Leersii bedeckt. Östlich von der Csik erhebt sich das in zerrissenen Steil-

Nagy- wänden abfallende Kalkplateau des $1793 m$ hohen Nagy-Hagymas mit dem Hagymas. isolierten Kalkfels des Egyes-Kö und dem $1803 \mathrm{~m}$ hohen Öesem Teteje. Schon die Wiesen um das am Fuße dieser Berge gelegene Gisik-Balanbanya schmückien Melandryum silvestre, Alectorolophus rumelicus, Campanula Cervicaria, Phyleuma lelramerum und Cenlaurea austriaca, den aus Schiefern gebildeten Fuß der Berge aber umgürten bis ins Tal reichenrle Fichtenwälder mit Cardamine glandulosa, Symphylum cordatum, Campanula abielina, Chrysanthemum rolundifolium und Hieracium lranssilvanicum und in höheren Lagen auch Ranunculus carpalicus. Die Kuppe des Nagy-llagymas bedecken teils verlirüppelte Fichten mit Juniperus nana, teils Alpenwiesen, auf denen Festuca picta, Anthoxanthum odoralum, Veralrum album, Bisculella laevigata, P'otentilla aurea, Linum extraaxillare, Viola declinata, Myosolis silvatica, Pedicularis verticillata sowie der seltenen Cytisus alpestris und die in den Karpathen fast nur hier vorkommende Nigritella rubra die häufigsten Arten sind; sowohl auf Alpenwiesen als unter Juniperusgebüsch und im Fichtenwalde aber ist die für die Kalliberge vom Rareu bis zum Öescem-teteje ungemein charakteristische Primula leucophylla anzutreffen. An den steilen Felsabstürzen aber gedeihen 


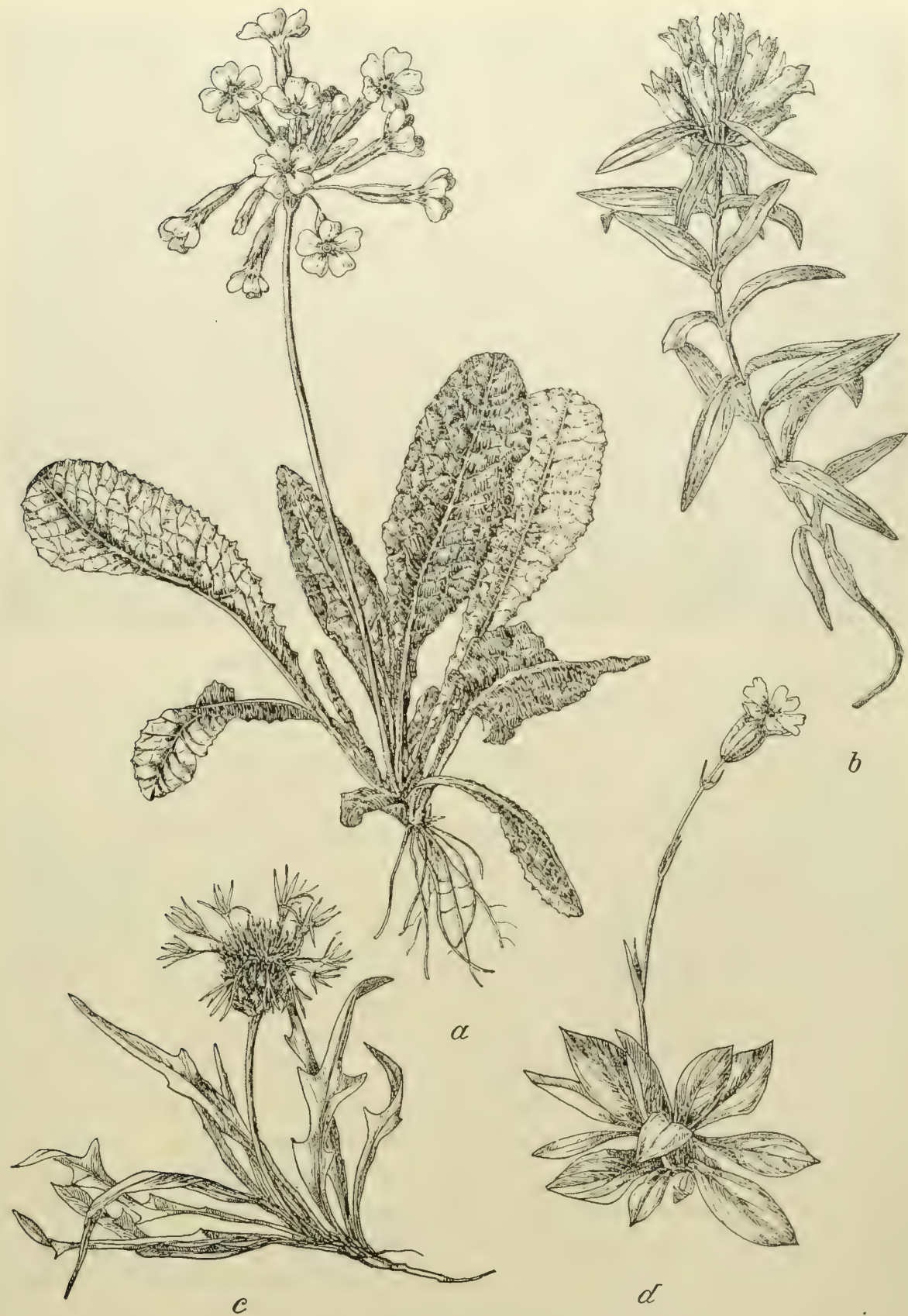

Abb. 240. Vier Charakterarten der Csiker Alpen.

$a$ Primula leucophylla, $b$ Gentiana phlogifolia. $c$ Centaurea pinnatifida. d Melandryum Zawadzkii.

Triselum alpestre, Melandryum Zawadzkii, Cerastium villosum, G. Lerchenfeldianum, Gypsophila pelraea, Kernera saxalilis, Erysimum Villmanni, Sempervivum Simonkaianum, Saxifraga luteoviridis, S. Aizoon, Helianthemum alpestre, Andro- 


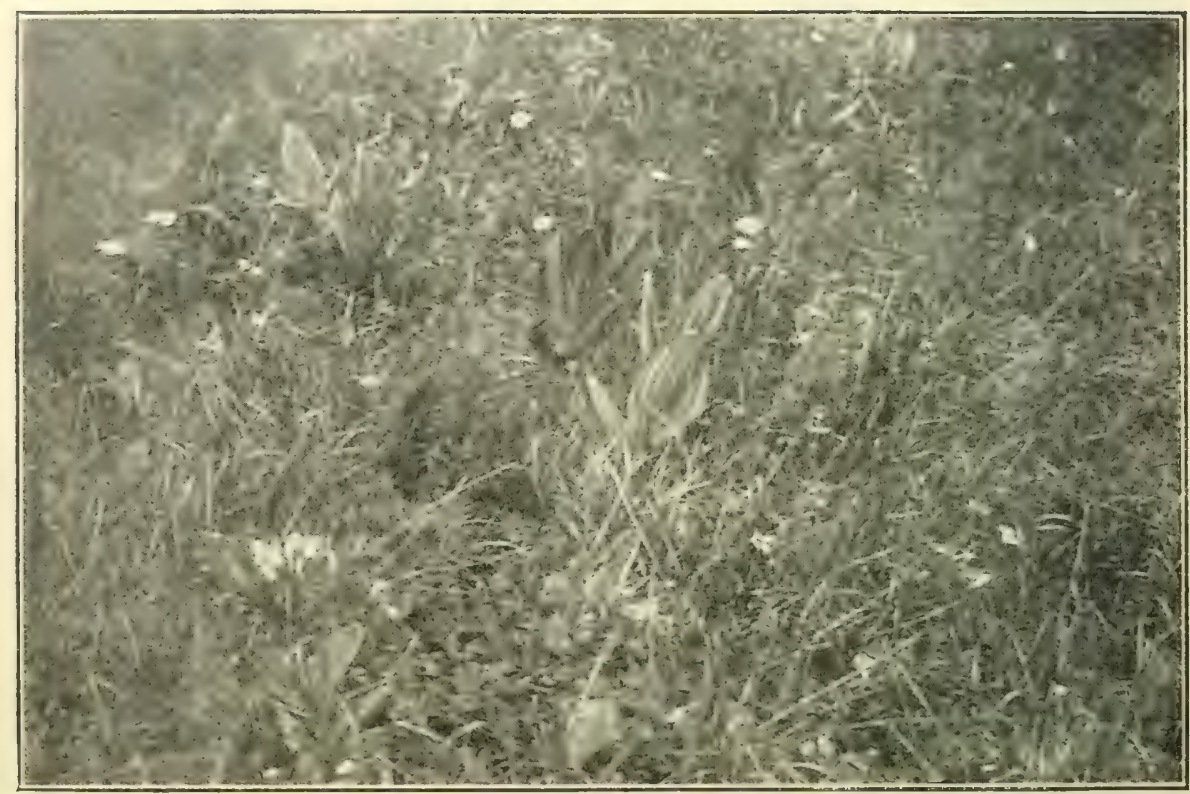

Abb. 241. Alpenwiese auf dem Nagy-Hagymas.

Viola declinata, Linum extraaxillare, Veratrum album, im Vordergrunde Blätter von Primula leucophylla.

(Nach einer Aufnahme von A. v. Hayek.)

öcsemteteje.

\section{Büđös.} gemischte Laubwälder aus Fagus silvatica, Quercus Robur, Qu. sessiliflora, Carvulgaris, E. verrucosus, Acer campestre, Viburnum Lantana, V. Opulus usw. zusammensetzen und deren Niederwuchs Dianthus superbus, Silene dubia, Anemone transsilvanica (die hier ihre Nordgrenze erreicht), Laserpitium pruthenicum und Campanula Cervicaria auszeichnen; an sumpfigen Stellen ist Ligularia sibirica zu finden. Erst in höheren Lagen wird die Buche vorherrschend und tritt dann die Fichte hinzu, die allerdings, mit Belula pendula vermischt, bei Bad Tusn ad St. Annen- bis ins Tal steigt und auch um dem St. Annensee, einem kleinen Kratersee,
see. barten Öcsem-teteje auf. In den Schluchten treten hier Delphinium elalum, Aclaea Cimicifugia und Cirsium Erisithales auf und im Felsschutte gedeihen Isalis praecox, Gentiana phlogifolia, Galium lucidum, Campanula carpatica, Senecio glaberrimus und Carduus glaucus, während an den Felsen in der Gipfelregion fast alle auf dem Nagy-Hagymas vorkommenden Arten (mit Ausnahmen der hier fehlenden Nigrilella rubra) gedeihen. Eine ähnliche Flora weist auch der nordöstlich schon ganz auf rumünischem Boden gelegene, $1907 \mathrm{~m}$ hohe Gsea hlau auf.

Einen ganz andern Charakter zeigt die Flora in dem weiter südwärts gelegenen Trachytstock des Büdös. Hier herrschen in den unteren Zonen

sace arachnoidea, Leontopodium alpinum, Centaurea pinnalifida und in der Gipfelregion auch Eritrichium lerglouense *Jankae, während auf dem Egyes-Kö Viola alpina häufig ist. Eine noch reichere Flora weisen die Kalkfelsen des benach- 
an dessen Ufer Lysimachia thyrsiflora wächst, tonangebend wird und in deren Beständen dann Telekia speciosa natürlich nicht fehlt. Auf der Höhe des Büdös aber liegt ein großes Hochmoor mit interessanter Flora. Pinus silveslris (wenn nicht P. uliginosa?) bildet hier Bestände und zwischen den Sphagnum-Polstern findet man Lycopodium inundalum, Salix aurita, S. repens, Carex lasiocarpa, C. rostrala, Eriophorum vaginalum, E. gracile, Malaxis paludosa, Achroanthes monophyllos, Potentilla palustris, Drosera rolundifolia, Empetrum nigrum, Peucedanum paluslre, Andromeda polifolia, Vaccinium uliginosum, Oxycoccos quadripelala, Pedicularis silvalica und angeblich auch Pseudorchis Loesetii und Belula

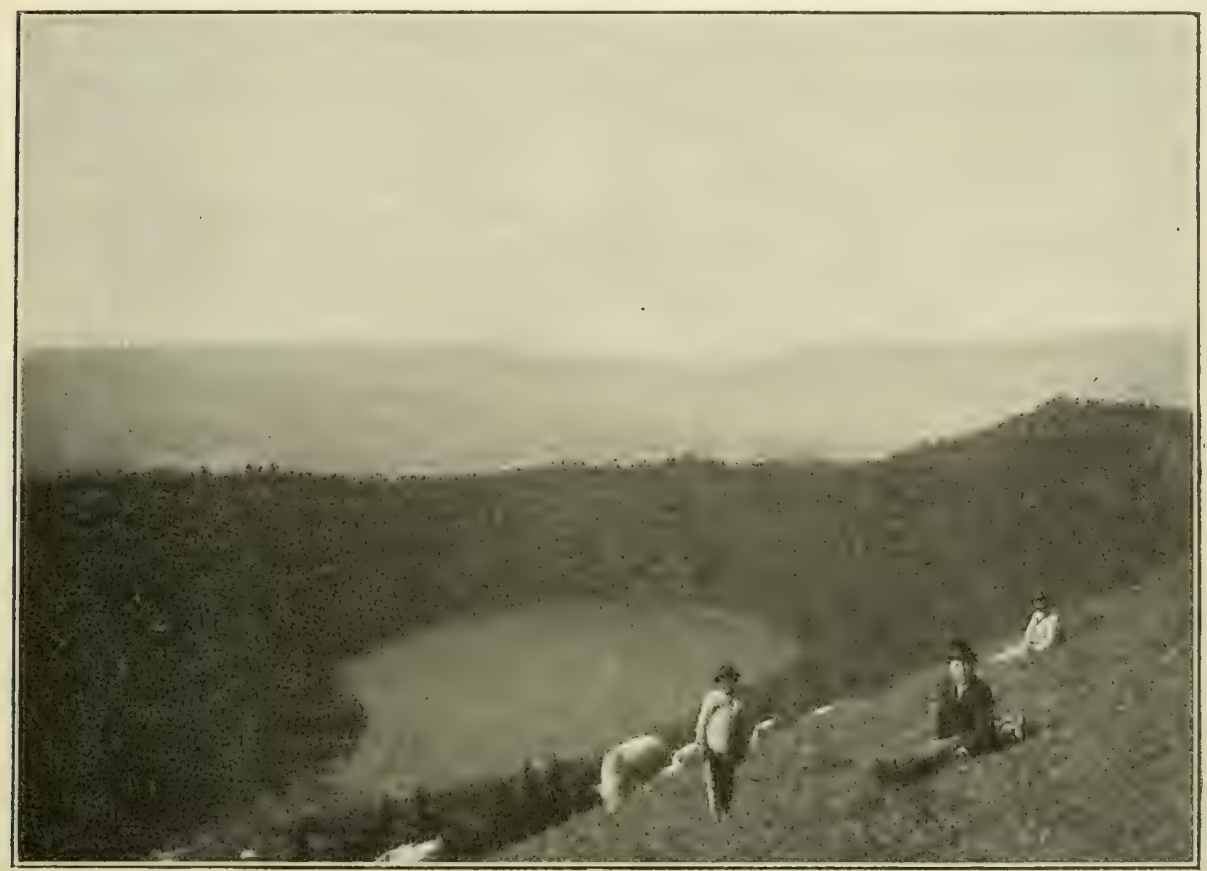

Abb. 242. Der St. Annensee auf dem Budös, von dichten Fichtenwäldern umgeben.

(Nach einer Aufnahme aus der Bildersammlung des geographischen Institutes der Wiener Universität.)

humilis. Drosera rolundifolia gedeiht sogar noch in den von den Schwefeltherinen des Bades Tusnad durchfeuchteten Mooren an der Nordseite des Gebirges.

Der weitere Zug dieses aus Sandstein aufgebauten Haromszeker Gebirges ist von Eichen- und Buchen-, in höheren Lagen auch von Nadelwäldern Tusnad. HaromGebirge. bedeckt, in Niederwuchs derselben sind Anemone transsilvanica und Waldsleinia trifolia bemerkenswert; die Flora der über die Waldgrenze reichenden Gipfel Lakócsa $(1777 \mathrm{~m})$, Gó r $(1785 \mathrm{~m})$ und Momyicska $(1677 \mathrm{~m})$ ist zurzeit noch fast unerforscht.

Das Haromszeker Talbecken stellt eine heute wohlliultivierte, stellenweise aber versumpfte Ebene dar. Hier liegt nordöstlich von Tartlau (Prazsmar) das etwa $5 \mathrm{~km}^{2}$ große Gebiet des Retyi-Nyir, aus Sandhügeln Retyi-Nyir. 
bestehend, die durch zahlreiche, im Sommer oft austrocknende Teiche und Wasseradern getrennt sind. Diese Sandhügel sind teils mit Birken, teils mit Nardus stricta, Cerastium glutinosum und semidecandrum, Linaria dalmatica, Myosotis micranlha, Alyssum alyssoides, Silene Armeria, Thymus collinus, Filago arvensis und Hieracium Pilosella bewachsen, während an den Ufern der Teiche Alnus rotundifolia Auen bildet und die Flora der Teiche einige seltenere Arten, wie Sparganium minimum, Caldesia parnassifolia (der einzige Standort dieser Pflanze in Ungarn), Elatine ambigua, Hollonia palustris, Lysimachia thyrsiflora und Aldrovandia vesiculosa aufweist.

\section{d) Das Burzenland.}

Die Burzenländer Ebene trennt die Hargita von den südlichen Randgebirgen. Heute ist selbe wohl kultiviert und von Äckern und Kulturwiesen bedeckt, die die ursprüngliche Vegetation derselben vollständig verdrängt haben, Tartlau. nur im Nordosten, bei T'artlau (Praszmár) sind noch ausgedehnte Sumpfwiesen und Röhrichte vorhanden, für deren Flora Typha angustifolia, T. lalifolia, Isolepis selacea, Scirpus radicans, Rumex Hydrolapathum, Filipendula Ulmaria, Gentiana Pneumonanthe, Pedicularis palustris, Asperula Aparine und Senecio palustris bezeichnend sind und die den einzigen Standort von Armeria barcensis Honigberg. bilden. Auch die Sumpfwiesen bei Honigberg (Szász-Hermany) weisen eine interessante Flora, wie Dianthus superbus, Menyanthes trifoliala, Pedicularis palustris, P. Sceplrum Carolinum, Ligularia sibirica und zahlreich die in Siebenbürgen mit Sicherheit nur hier vorkommende Primula farinosa auf.

Die südlichen Randgebirge sind überall bis fast an den Fuß herab mit Wäldern bedeckt. In der unteren Region sind es mit Eichen durchsetzte Buchen-

Zaizon. bestände, in denen beim Badeort Zaizon Actaea spicala, Anemone transsilvanica, Thalictrum aquilegifolium, Ranunculus cassubicus, Cylisus pallidus, Genliana asclepiadea, Campanula lalifolia, Telekia speciosa, Cenlaurea auslriaca den Niederwuchs bilden. An buschigen Stellen treten auch noch Elemente des Hügellandes, wie Iris caespilosa, Dianthus Armeria, Clemalis Vitalba, Cylisus pallidus, Dorycnium germanicum, Veronica orchidea, Galium rubioides, Echinops commulalus, Inula cordala, Cenlaurea orientalis und $C$. Reichenbachioides, auf; an sumpfigen Stellen im oberen Zaizontale findet man Ligularia sibirica und bei der Sachsenschänke Waldsteinia lernata. Auf Wiesen ist Narcissus poëticus *seriorflorens allenthalben zahlreich anzutreffen und steigt bis $1850 \mathrm{~m}$ an, in ihrer Gesellschaft treten auch Orchis globosa und Iris sibirica auf.

Csukas. Die Hänge des Cisukas aber bedecken dichte Buchenwälder mit Anemone transsilvanica, Helleborus purpurascens, Euphorbia amygdaloides, Asperula odorala, Lacluca muralis, Hieracium praecurrens, H. lranssilvanicum usw., die bis $1450 \mathrm{~m}$ reichen, und darüber Fichtenbestände. Die Höhen des $1958 m$ hohen Gipfels umgürten Bestände aus Pinus Mughus und Juniperus nana, auf Bergwiesen gedeihen Anemone alba, Thlaspi Kovacsii, Bisculella laevigala, Viola declinala, V. alpina, Potentilla ternala, Linum extraaxillare, Gentiana punclala, Achillea 


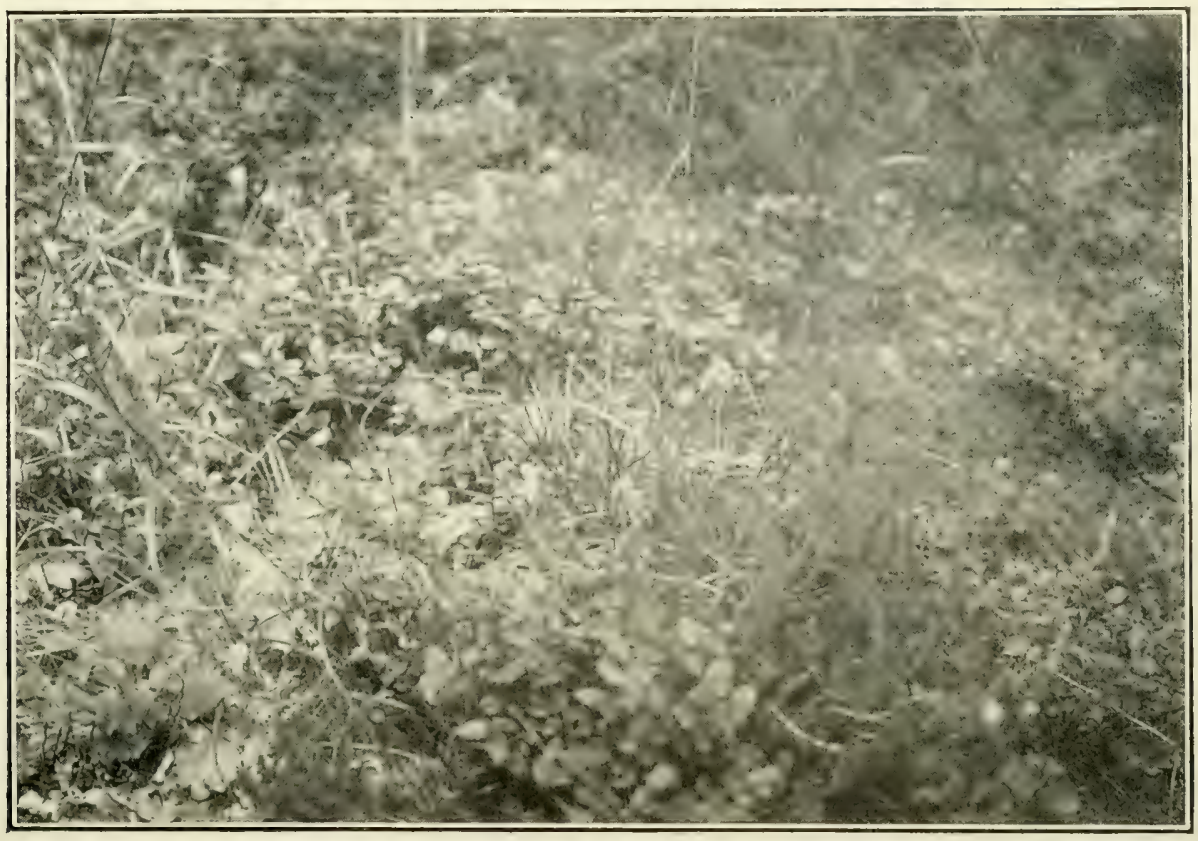

Abb. 243. Bruckenthalia spiculifolia und Vaccinium Myrtillus im Eichenwalde auf dem Kleinen Hangestein bei Kronstadt.

(Nach einer Aufnahme von A. v. Hayek.)

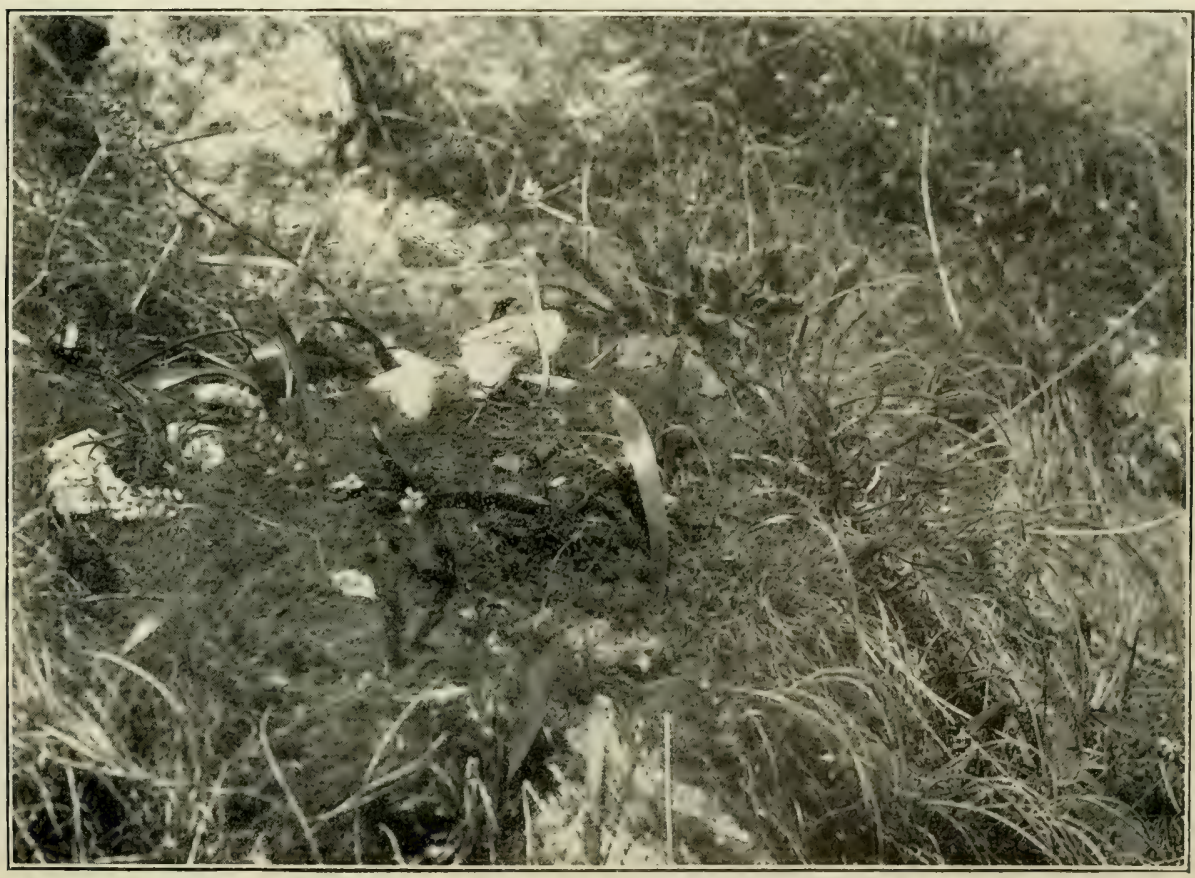

Abb. 244. Hyacinthella leucophaea an den steilen Hängen der Zinne bei Kronstadt. (Nach einer Aufnahme von H. Lehmann.)

(Aus der Bildersammlung des botanischen Institutes der Wiener Universität.) 

ligulata, Cenlaurea nervosa, Scorzonera rosea, Crepis viscidula usw.; besonders reich aber ist die Flora der Kalkfelsen, an denen Gypsophila petraea, Dianthus lenuifolius, Sempervivum Heuffelii, Saxifraga demissa, S. luteoviridis, S. aizoon, S. oppositifolia, Bupleurum longifolium, Campanula carpatica, Rhododendron myrlifolium, Aster alpinus und Centaurea Kolschyana zu finden sind, während an den jähen Felsen der Tuzla auch Androsace lactea, Gentiana lutea, G. tenella, Cerinthe glabra und Veronica Baumgarlenii vorkommen.

Eine ähnliche Flora wie der Csukas weist auch der ihm westlich benachbarte Hohenstein (Piatra mare) $(\mathbf{1 8 1 4} \mathbf{m}$ ) auf; derselbe ist ferner dadurch aus- Hohenstein gezeichnet, daß fauf ihm die weiter ostwärts durch fast die ganzen Transmare.) sylvanischen Alpen verbreitete zierliche Erikazee Bruckenlhalia spiculifolia ihre ersten Standorte hat und daß im Krummholze die seltene Daphne Blagayana zu finden ist. Aus der Felsenflora in der Gipfelregion des Hohensteins sind Ranunculus Thora, Scrophularia lasiocaulis, Draba Haynaldi und D. compacta, aus der der Bergwiesen Nigritella nigra mit der var, rosea besonders hervorzuheben.

Eine reiche Voralpenflora aber ist am Ostfuße der Piatra mare an den Hängen des Tömes-Passes entwickelt. An den kahlen Abhängen findet man hier Erysimum erysimoides, Alyssum transsilvanicum, Helianthemum canum, Dianthus spiculifolius, Dianthus lenuifolius, Silene dubia, Heliosperma quadrifidum, Cnidium apioides, Scrophularia Scopolii, Euphrasia salisburgensis, Scabiosa lucida, Anthemis tincloria, Senecio rupestris, während am Bache Telekia speciosa, Carduus Personala, Cirsium Erisithales, Senecio sarracenius üppig wuchern.

Um Kronstadt (Brásso) sind auf den niedrigen Hügeln um die Stadt, Kronstadt. besonders auf dem Kleinen Hangestein (Kis Függölö) Eichenwälder entwickelt, in deren Niederwuchs Poa nemoralis, Luzula nemorosa, Iris caespitosa, Silene dubia, Helleborus purpurascens, Trifolium medium, Cylisus nigricans, C. leucotrichus, Bupleurum falcatum, Melampyrum bihariense, Galium Schullesii und Hieracium transsilvanicum die auffallendsten Erscheinungen sind; doch wächst auf dem Kleinen Hangestein auch die sonst erst in höheren Lagen auftretende Bruckenthalia spiculifolia im Eichenwalde. Dort, wo der Wald zurücktritt, findet man üppige Triftformationen, wo neben Andropogon Ischaemum, Carex verna, Silene Otites, Dianthus Carthusianorum, Echium vulgare, Anchusa Barellierii, Salvia verticillata, Centaurea variegala usw. auch Dracocephalum austriacum und der um Kronstadt endemische Bromus barcensis wachsen. Noch üppiger sind diese Triften an der Nordseite der Zinne (Kapellenberg, Zenk) entwickelt, wo neben den meisten der genannten Arten und dem auch hier vorkommenden Bromus barcensis noch Phleum phleoides, Carex humilis, Hyacinthella leucophaea, Delphinium fissum, Silaus Rochelii, Origanum vulgare *barcense, Verbascum Lychnites und Pedicularis coronensis vorkommen, während an Felsen, besonders an der ,IKleinen Zinne“, Paronychia cephaloles, Dianthus spiculifolius, Sempervivum blandum, Teucrium Chamaedrys, Linaria dalmatica, Campanula carpalica gedeihen, von denen manche noch an Felsen unmittelbar über der Stadt zu finden sind; im Buschwerke aber treten auf der Zinne neben Quercus-, Cornus- und Cralaegus-Arten auch Fraxinus Ornus und Spiraea crenifolia auf. 


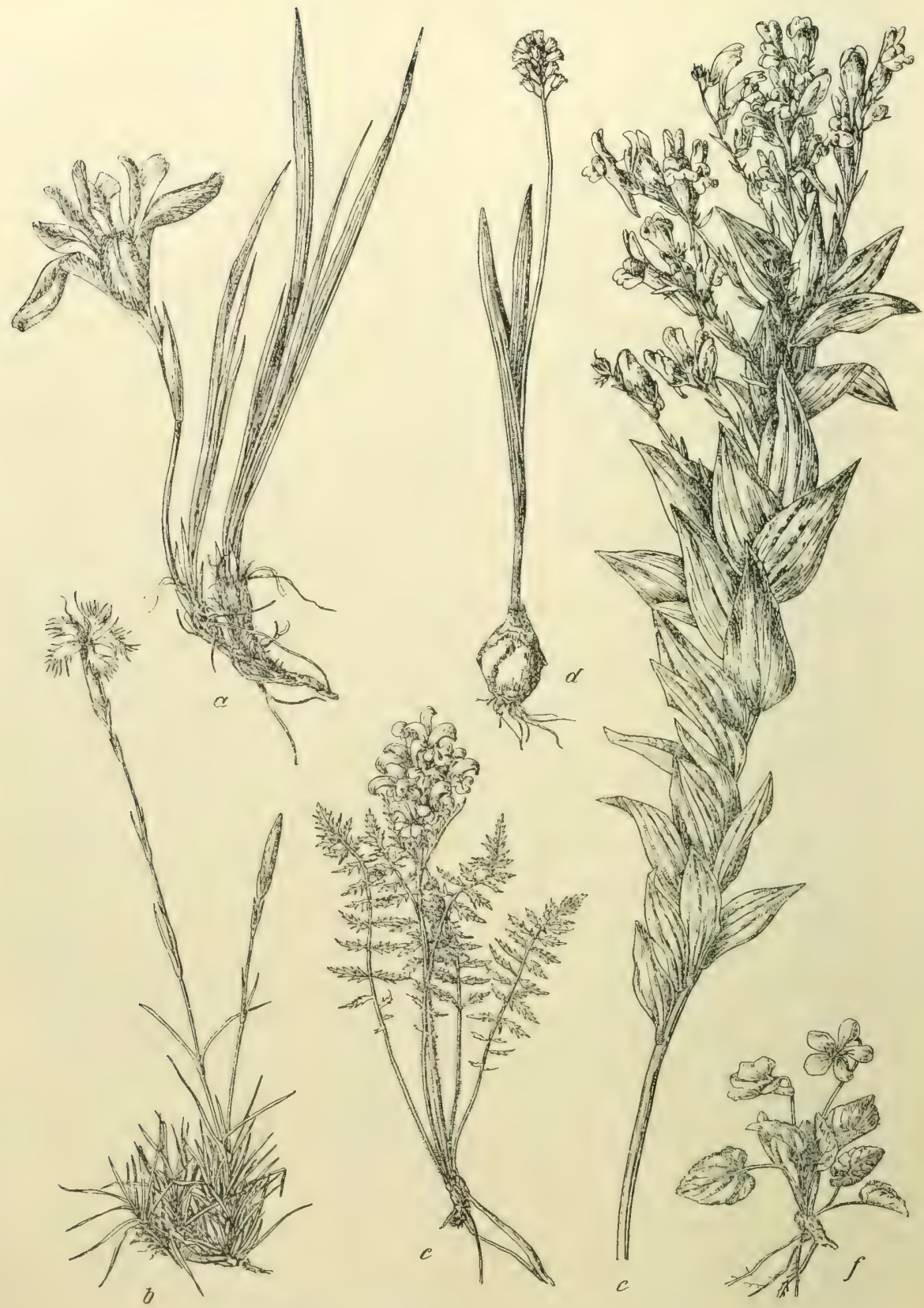

Abb. 245. Aus der Flora von Kronstadt.

$a$ Iris caespitosa. $b$ Dianthus spiculifolius. $c$ Pedicularis coronensis. $d$ Hyacinthella leucophaca. $e$ Linaria dalmatica. $f$ Viola Jooi.

Jedoch auch die subalpinen Buchenwälder reichen um Kronstadt fast bis ins 'Tal, so am Nordwestabhange der Zinne, wo in den Beständen aus Fagus silvalica schon Hepalica transsilvanica auftritt, während am Waldrande Campanulc latifolia auffallend häufig ist. 
An die Zinne schließt sich das südlich von Kronstadt sich erhebende Kalkmassiv des $1804 m$ hohen Schuler an. Bis $1450 m$ Höhe bedecken reiche Buchenbestände seine Hänge, denen sich schon von $1000 \mathrm{~m}$ an die Fichte beigesellt und in deren Niederwuchs Galanthus nivalis, Erylhronium Dens canis, Crocus Heuffelianus, Carex digilala, Anemone lranssilvanica, Hieracium transsilvanicum usw. häufig sind. Auf den höher gelegenen Bergwiesen, wie in der Schulerau blühen meist in Menge Polygonum Bislorla, Thlaspi Kovacsii, Phyteuma tetramerum, P. Vagneri, Campanula Cervicaria, C. persicifolia, Hypochoeris maculata, Scorzonera rosea, Tragopogon orientalis, Hieracium aurantiacum und auffallenderweise auch die eigentlich dem Alpengebiet cigentümliche Centaurea Pseudophrygia. Ober der bei $1450 \mathrm{~m}$ gelegenen Buchengrenze ist die Fichte der allein herrschende Waldbaum, in dessen Beständen besonders an Waldrändern Rumex arifolius, Ranunculus carpaticus, Aconilum lasianlhum, Cardamine glandulosa, Pulmonaria rubra, Symphytum cordalum, Primula carpalica, Soldanella maior, Campanula abielina, Telekia speciosa, Prenanthes purpurea, Chrysanthemum rolundifolium und Hieracium Iranssilvanicum den oft reichen Niederwuchs bilden und auch Bruckenthalia spiculifolia nicht selten ist. An Kalkfelsen findet sich schon in tieferen Lagen Dianthus spiculifolius, Saxifraga cuneifolia und Cenlaurea Kolschyana, in der alpinen legion Gypsophila pelraed, Alyssum repens, stavifraga luteoviridis und Eritrichium lerglouense sowie die höchst seltene, mit der südalpinen Primula Wulfeniana zunächst verwandte Primula Baumgarlenii; aus der reichen Gipfelflora sind insbesondere Saxifraga carpatica, Loiseleuria procumbens, Gentiana nivalis, G. frigida, Phododendron myrtifolium, Anthemis carpatica und die in den Ostkarpathen nur auf den Burzenländer Bergen vorkommende Armeria alpina hervorzuheben.

Auch westlich von Kronstadt, an den Hängen gegen das Weidenbachtal, herrschen Hainbuchen und Buchen in den Waldbeständen vor und an den Felsen les Schloßberges von Rosenau perleihen Dianthus spiculifolius, Paronychia Rosenau. cephalotes, Linaria dalmalica usw. Weiter aufwärts umsåumt den Großen Weidenbach Buschwerk aus. Myricaria germanica und verschiedenen Salixarten, darunter auch der sonst in den Ostkarpathen fehlenden Salix incana und zwischen dem Buschwerk gedeihen Thalictrum aquilegifolium, Aconitum lasianthum, A. loxicum und Telekia speciosa. Bei Törzburg aber hat im Bachgerölle Pelasites niveus seinen einzigen Standort im Karpathengebiete.

Einer der in botanischer Beziehung interessantesten Berge der Ostkarpathen ist der südlich von Kronstadt an der rumänischen Grenze sich erbehende, aus Kalkkonglomerat aufgebaute, im O mu $2507 \mathrm{~m}$ erreichende Bussecs. Buchenwälder mit Anemone transsilvanica, Cardamine glandulosa, C. bulbifera, Prenanthes purpurea, Hieracium transsilvanicum umgürten den Fuß des Gebirges und werden bald von Tannen und Fichten abgelöst, in deren Beständen an der oberen Waldgrenze auch die Lärche auftritt, während Pinus Cembra nur an der Südseite des Gebirges auf rumänischem Boden vorknmmt. An schattigen, feuchten Stellen trifft man' ab und zu Geranium macrorrhizum, Asperula laurina und Agropyrum biflorum, in Bachschluchten Aconitum lasianlhum, Delphinium 


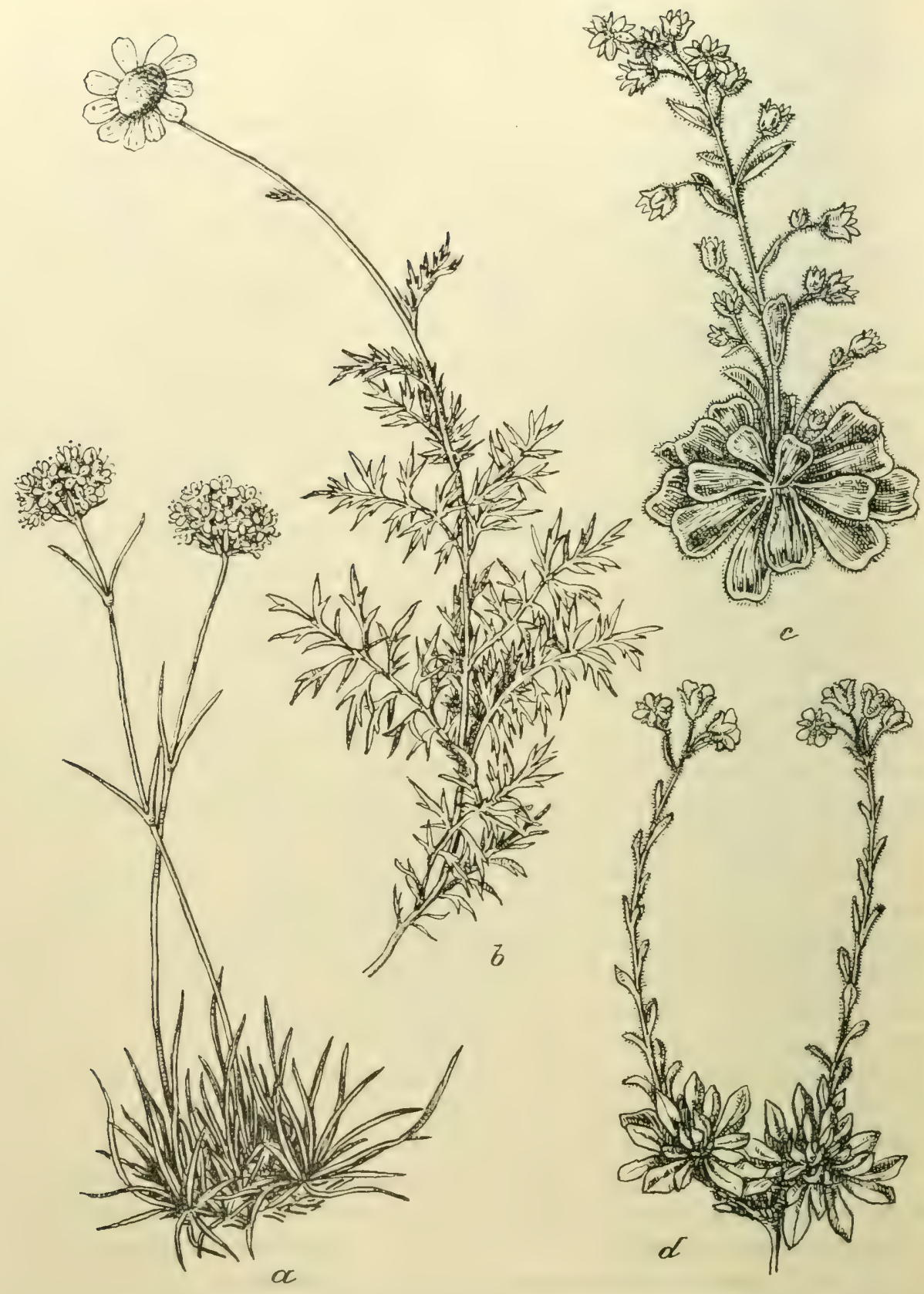

Abb. 246. Aus der Flora der Burzenländer Hochgebirge:

$a$ Gypsophila petraea. $b$ Achillea Schurii. $c$ Saxifraga demissa. ' $d$ Saxifraga luteoviridis.

elalum, Heracleum palmalum, Doronicum auslriacum und Cirsium Erisithales. An feuchten Felsen ist schon in der Waldregion das seltene Lebermoos Bucegia romanica sowie Saxifraga cuneifolia häufig. Ober der Waldgrenze findet man 


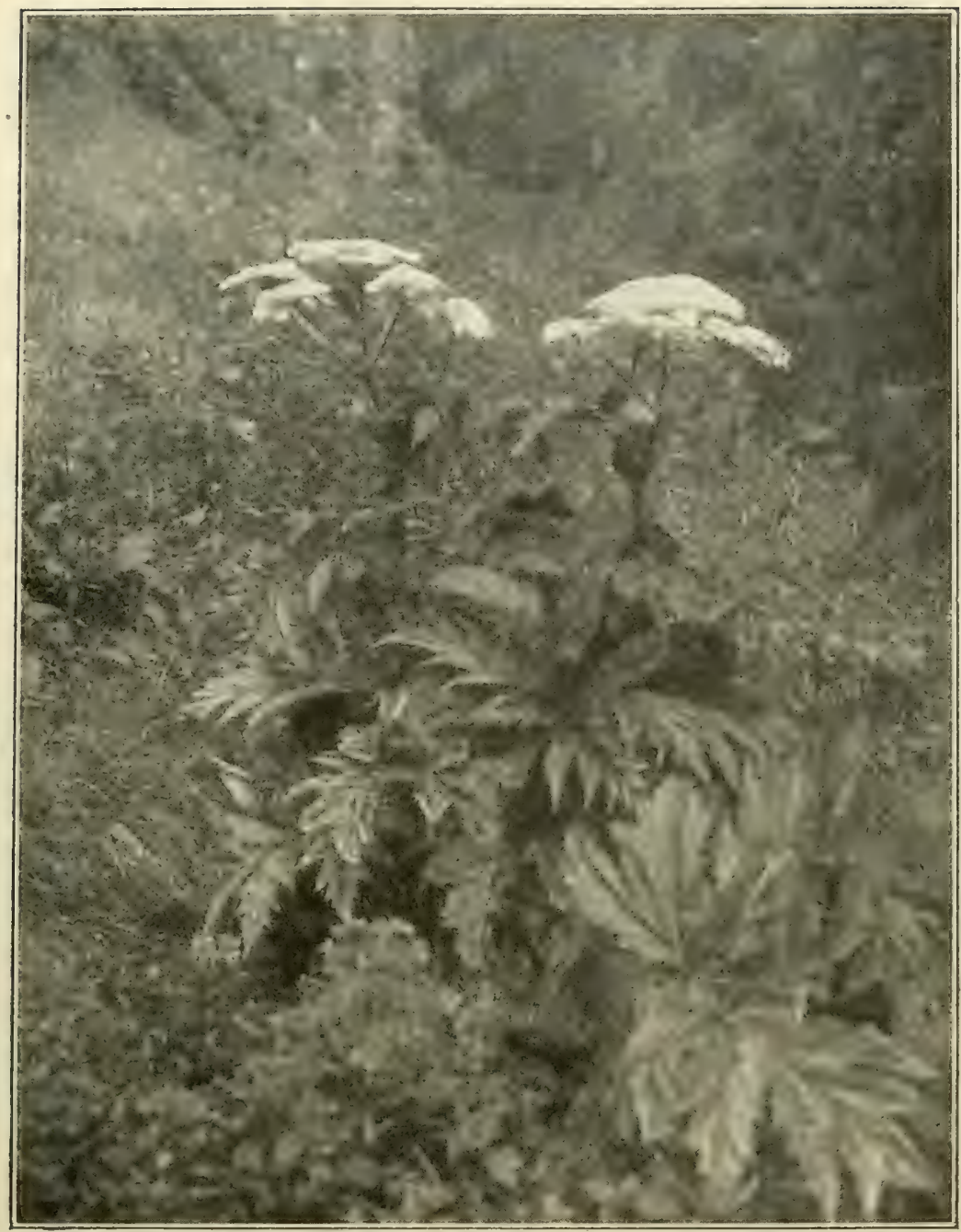

Abb. 247. Heracleum palmatum beim Malajesta-Schutzhause unter dem Bucsecs.

(Nach einer Aufnahme von A. v. Hayek.)

reiche Buschbestände von Pinus Mughus und Alnus viridis, hic und da begleitet von Salix silesiaca und Sorbus Aucuparia und auf dem Malajeschter Grat auch von Daphne Blagayana. An Felsen, nahe der Baumgrenze, treten Cerastium acutifolium, Heliosperma quadrifidum, Delphinium fissum, Alyssum transsilvanicum, Cortusa Mallhioli, Androsace laclea, Scrophularia lasiocaulis, Veronica aphylla, Valeriana tripteris, V. montana, Erigeron Atlicus und besonders häufig Achillea Schurii, auf dern Bukschoi auch Gypsophila petraea und Centaurea Kolschyana auf; im alpinen Felsschutt fallen neben Cerastium Lerchenfeldianum, Heliosperma quadrifidum, Alyssum repens, Satureia Baumgartenii, Anthemis carpatica und der durch Schafe oft hoch hinauf verschleppten Euphorbia

H a yek, Die Pflanzendecke Österreich-Ungarns, I. 


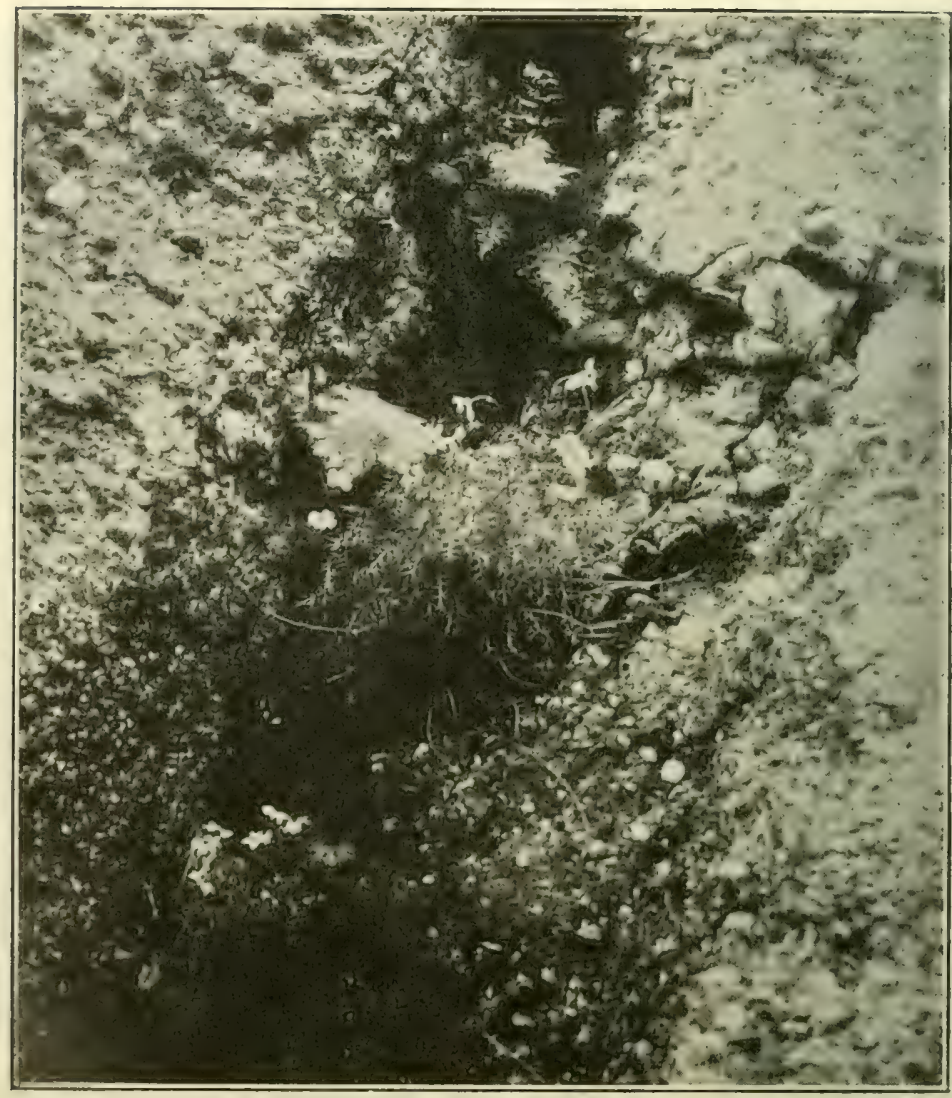

Abb. 248. Felsenflora bei der Malajestahütte unter dem Buesecs. Cystopteris fragilis, Cortusa Matthioli, Achillea Schurii.

(Nach einer Aufnahme von A, v. Hayek.)

Cyparissias die leuchtend gelben Blüten des Papaver aurantiacum in die Augen. Die oberen Talstufen und den Rücken des Bucsecs bedecken ausgedehnte Alpenmatten mit einer sehr reichen Flora. Carex sempervirens, C. curvula, Sesleria coerulans, S. disticha, Avena versicolor setzen den Rasen zusammen, in welchem Dianthus gelidus, Silene acaulis, Minuarlia sedoides, M. Gerardi, Anemone alba, A. narcissiflora, Polentilla ternata, P. Crantzii, Geum montanum; Onobrychis monlana, Helianthemum tomentosum, H. alpestre, Viola alpina, Ligusticum Mulellina, L. simplex, Soldanella hungarica, Armeria alpina, Gentiana orbicularis, G. nivalis, Pedicularis verticillala, P. Oederi, Hieracium alpinum häufig sind, während an felsigen Stellen besonders Lloydia serotina, Draba compacla, D. Slurii, Saxifraga Aizoon, S. luteoviridis, S. demissa, S. carpalica, Erilrichinm lerglouense, Campanula alpina, Artemisia eriantha, Senecio carpalicus gedeihen und am schmelzenden Schnee Oxyria digyna, Primula minima, Soldanella pusilla, Arenaria biflora, Saxifraga androsacea, Veronica alpina und besonders der in den Ostkarpathen wenig verbreitete Ranunculus alpeslris nicht selten auftreten. Von 
weniger häufigen Arten des Bucsecs seien Elyna Bellardi, Juncus monankros, Ranunculus Thora, Astragalus frigidus, Oxylropis carpatica, O. sericea, Primula intricala, Genliana frigida, G. phlogifolia, Achillea ligulala, Senecio carpalicus, die nur auf der Strunga vorkommende Campanula lranssilvanica sowie das auf dem Bucsecs und Königstein endemische Thesium Kernerianum genannt.

Der Törzburger $\mathrm{Pa} B$ trennt vom Bucsecs den mauerartig sich erhebenden, aus Kalk aufgebauten Felskamm des Königstein (Piatra Krajului, Kyralikö), Königstein. der in seiner Flora eine große Übereinstimmung mit dem Buesecs aufweist. Eine besonders reiche Flora weist hier die wilde Felsschlucht der Grepatura auf, in der insbesondere Geranium macrorrhizum, Isalis transsilvanica, Aconilum

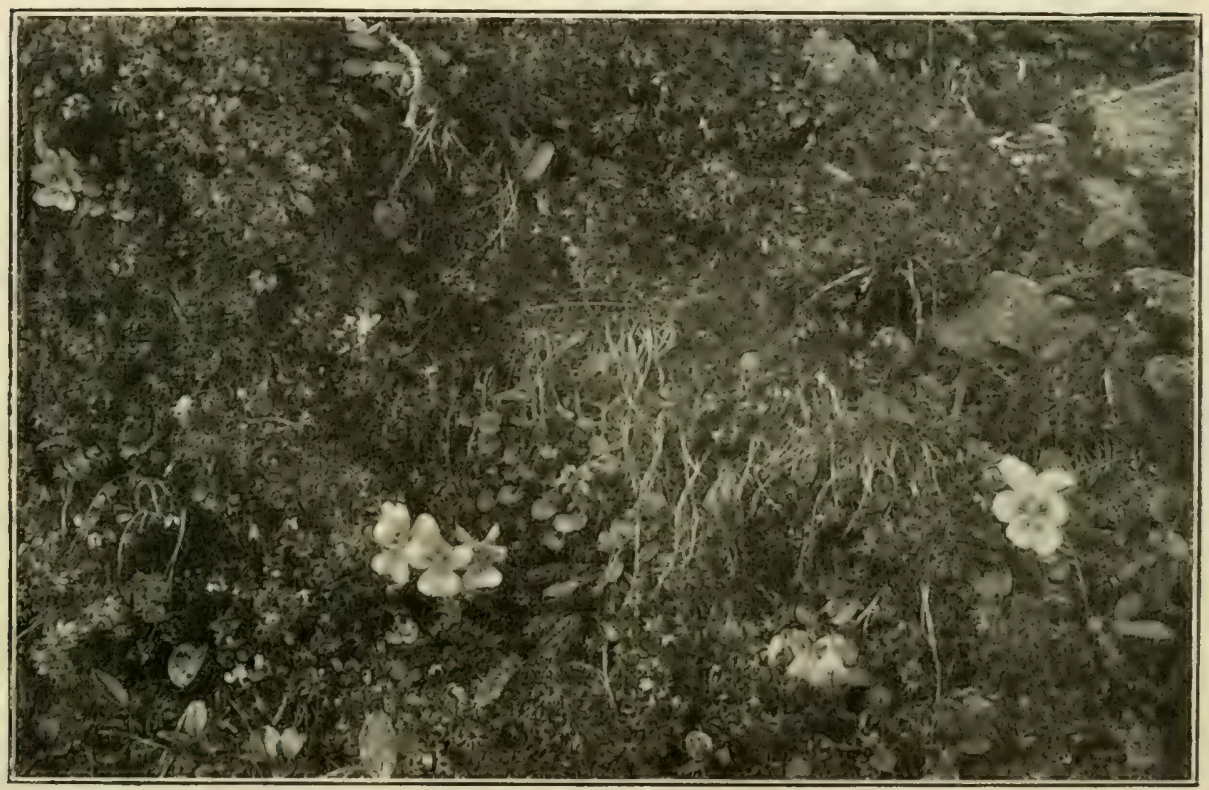

Abb. 249. Viola alpina auf Alpenmatten des Bucsecs.

(Nach einer Aufnahme von A. v. Hayek.)

Anthora, A. paniculalum, A. lasianthum, A. lauricum, Delphinium elalum, Mulgedium alpinum zwischen den moosigen Gesteinstrümmern Hochstaudenfluren bilden, während an den Felsen Arabis alpina und Sedum carpalicum gedeihen. In und über der Krummholzregion aber findet man häufig Gypsophila pelraea und den prächtigen, auf dem Königstein endemischen Dianlhus callizonus, ferner Linum exlraaxillare, Dianlhus tenuifolius, Campanula cochleariaefolia, Saxifraga luteoviridis usw. und in der Hochalpenregion sind insbesondere Anemone narcissiflora, Draba compacta, D. Haynaldi, D. Kotschyi, Sedum roseum, Primula longiflora, Androsace arachnoidea, Viola alpina, Erilrichium terglouense, Pinguicula alpina, Saxifraga heucherifolia hervorzuheben. Neben Dianthus callizonus heherbergt der Königstein noch eine zweite interessante Art, das nur noch auf der rumänischen Seite des Bucsecs vorkommende Geranium coerulalum. Hingegen 


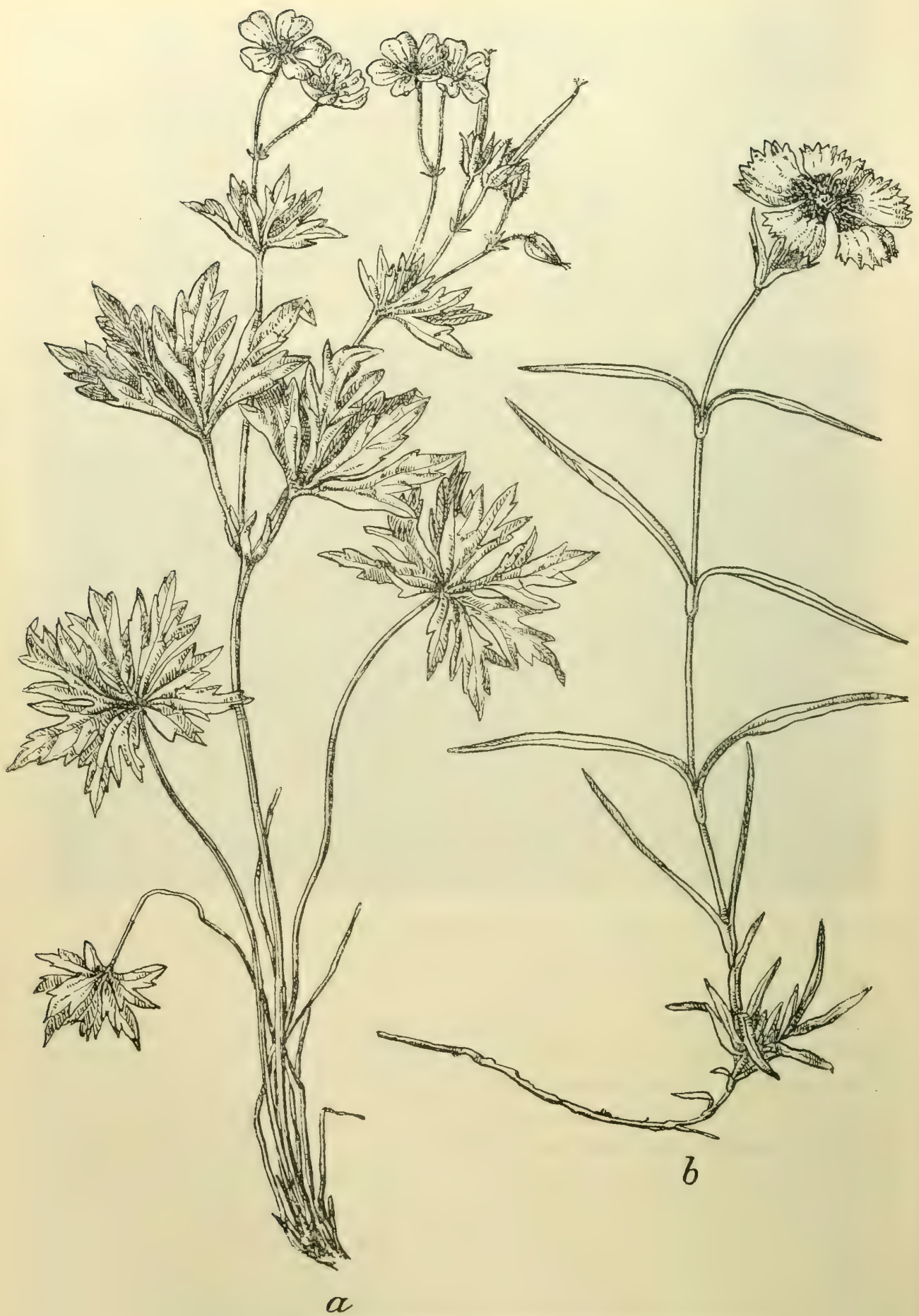

Abb, 250 Zwei interessante Arten aus der Flora des Königstein.

$a$ Geranium coerulatum. $b$ Dianthus callizonus. 
haben auf dem Königstein zwei für die subalpinen Kalkfelsen fast der ganzen Karpathen sehr bezeichnenden Arten, Campanula carpalica und Crepis Jacquinii, ihre letzten Standorte und kommen weiter im Südwesten nicht mehr vor.

Nördlich verbindet den Königstein mit der Hargita der Gebirgsstock des $1294 \mathrm{~m}$ hohen Zeidener Berges, eines mit Buchen und Fichten bestandenen Waldgebirges, in dessen Wäldern Phylliles Scolopendrium, Bromus lranssilvanicus, Hordeum europaeum, Anemone transsilvanica, Hypericum hirsulum, Geranium lucidum, Campanula latifolia und in höheren Lagen auch Bruckenthalia spiculifolia gedeihen.

\section{e) Die südlichen Randgebirge Siebenbürgens.}

Westlich vom Königstein ändert sich die geologische Natur des Gebirges vollständig. An Stelle der Kalke und Sandsteine treten kristallinische Schiefer, Transsilvanische Alpen. nur hie und da von Kalkadern durchzogen, und vulkanische Gesteine fehlen ganz. Und dieser Wechsel im Gestein zeigt sich natürlich auch in der Flora. Schon in den Fogarascher Alpen ist das Fehlen der sonst in den Karpathen so verbreiteten Campanula carpalica auffallend und ebenso vermißt man die in den Burzenländer Bergen verbreiteten Arten Dianthus spiculifolius und Gypsophila petraea. Bis ins Tal herab bedecken dichte Buchenwälder die Hänge des Gebirges, bis gegen $700 \mathrm{~m}$ von Ouercus sessiliflora begleitet; auch Pinus silvestris, Carpinus Betulus, Corylus Avellana, Alnus incana und Acer campestre sind nicht selten. Auf Viehweiden ist Pleridium aquilinum oft in großen Beständen vorhanden und an feuchten Waldrändern stehen häufig die hohen Stauden von Sambucus Ebulus und Telekia speciosa. Bei etwa $1000 \mathrm{~m}$ Meereshöhe tritt auch die Tanne im Buchenwalde eingesprengt auf, bei 120c--1300 $\mathrm{m}$ tritt die Fichte hinzu und bei etwa $1450 \mathrm{~m}$ erreicht die Buche ihre obere Grenze und dichte Nadelwälder bedecken die oberen Hänge bis zu einer Höhe von $1700-1800 \mathrm{~m}$. Der Niederwuchs dieser Wälder ist der für die ganzen Ostkarpathen charakteristische; Phyllites Scolopendrium, Lycopodium annotinum, Anemone transsilvanica, Gentiana asclepiadea, Pulmonaria rubra, Campanula abietina, und Hieracium transsilvanicum sind besonilers häufig; an Bergbächen und in Schluchten treten Onoclea Strulhiopleris, Aconilum paniculatum, Angelica Archangelica und Heracleum palmatum nicht selten auf. Über der Waldgrenze ist Alnus viridis allenthalben gemein, seltener ist Pinus. Mughus; Rhododendron myrlifolium bildet stellenweise ausgedehnte Zwergstrauchbestände und auch Bruckenlhalia spiculifolia ist nicht selten. In der Hochgebirgsregion herrscht die kalkfeindliche Krummseggenmatte mit Sesleria disticha, Avena versicolor, Carex curvula, Salix Jacquini, Polygonum viviparum, Anemone alba, A. narcissiflora, Liguslicum Mutellina, Gentiana Kochiana, Campanula alpina, Phyleuma confusum und Hieracium alpinum, an felsigen Stellen sind Poa laxa, Juncus trifidus, Oxyria digyna, Sempervivum monlanum, Loiseleuria procumbens, Veronica Baumgartenii, Doronicum Clusii, Artemisia eriantha, am schmelzenden Schnee Lloydia serolina, Polygonum viviparum, Arenaria biflora, Cerastium cerastioides, Soldanella pusilla, 
Primula minima verbreitet, und an feuchten Stellen, so am Lacul Doamnéi, wächst die seltene Carex pyrenaica. Die östlichen Hochgipfel der Fogarascher Alpen, der Berivoescul mare $(2290 \mathrm{~m})$, Vrf Ludisorului $(2300 \mathrm{~m})$, Vrf Urlei $(2474 \mathrm{~m})$ und Goltiu Vistea $(2529 \mathrm{~m})$ sind noch wenig erforscht, dürften aber von den westlicheren in floristischer Beziehung kaum abweichen; und die Angabe über das Vorkommen von Silene Lerchenfeldiana auf der Vistea mare und der Musterresidenz ist wohl auf eine Verwechslung mit $S$. dinarica zurückzuführen.

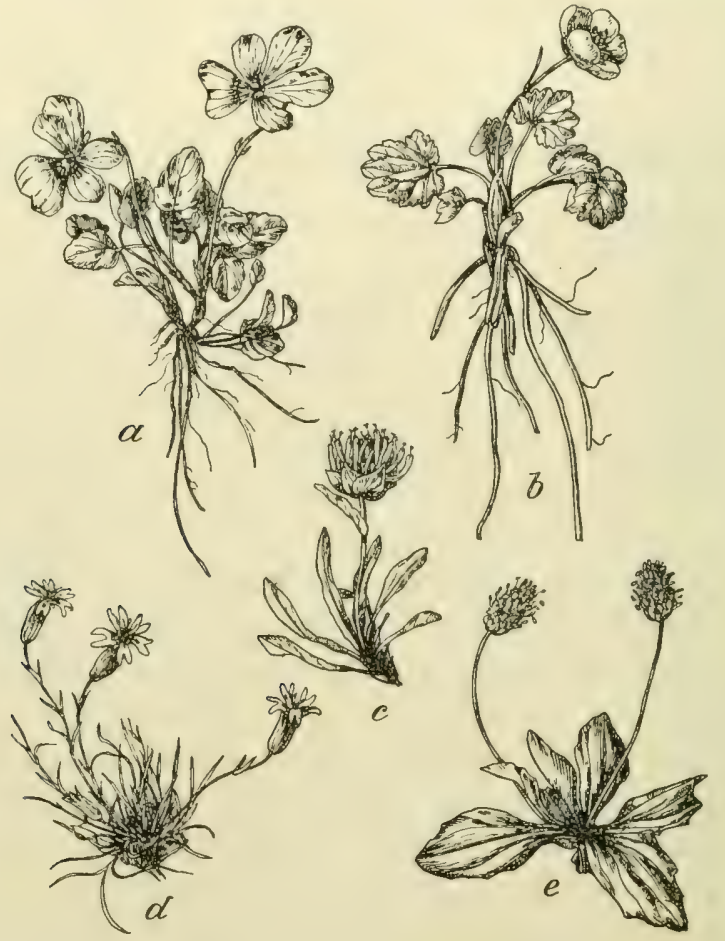

Abb. 251. Aus der Hochgebirgsflora der Fogarascher Alpen.

$a$ Viola alpina. $b$ Ranunculus crenatus. $c$ Phyteuma confusum. $d$ Silene dinarica. e Plantago gentianoides. ( $1 / 2$ nat. Gr.)

Buleatal.

Im Buleatale, gegenüber Kerz, findet man am Taleingange Gebüsch aus Weiden und Grauerlen und in demselben zahlreich Sambucus Ebulus und Telekia speciosa. Im dichten Buchenwalde gedeihen Cardamine glandulosa, Galium Schultesii und die seltene Orchidce Epipogium Gmelini, schon in geringer Höhe mischen sich Tannen unter die Buchen und bei etwa $1300 \mathrm{~m}$ beginnt die Fichte vorzuherrschen. An sonnigen Waldrändern gedeihen Festuca silvatica, Rubus Idaeus, Sambucus Ebulus und Cirsium Erisithales, an Felsen Symphyandra Wanneri und in höheren Lagen findet man in den Bachschluchten üppige Hochstaudenfluren mit Lamium cupreum, Doronicum austriacum, Senecio nemorensis, Mulgedium alpinum und dem prächtigen Cirsium pauciflorum; im Fichtenwalde ist neben Luzula nemorosa, Campanula abielina, Hieracium lranssilvanicum, Dryopleris Oreopteris und Polystichum lobalum auch Bruckenthalia nicht selten. 


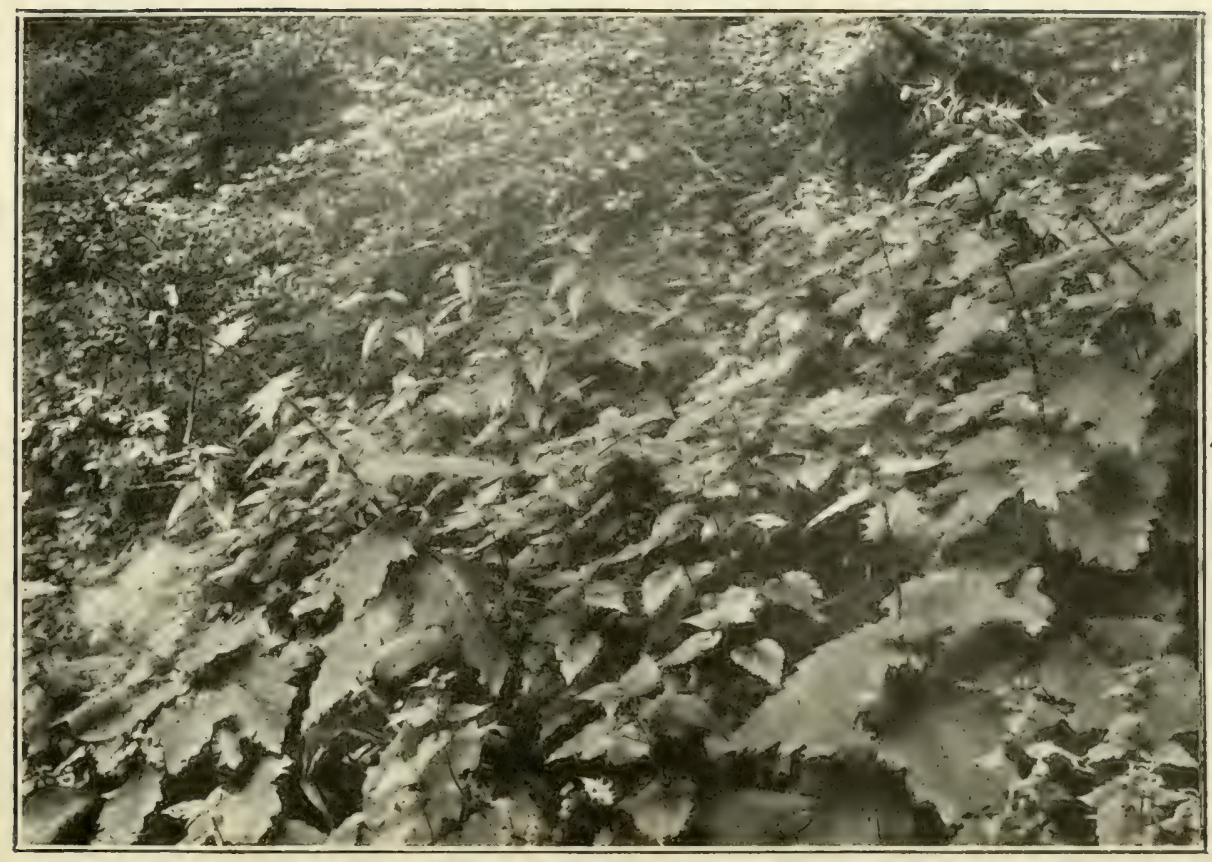

Abb. 252. Cirsium pauciflorum und Lamium cupreum in einer Bachschlucht des Buleatales in den Fogarascher Alpen.

(Nach einer Aufnahme von A. v. Hayek.)

Bei etwa $1800 m$ erreicht an den Hängen, etwa 200-300 $m$ tiefer im Tale, der Wald seine obere Grenze und darüber bilden Pinus Mughus und Alnus viridis, begleitet von Sorbus Aucuparia, Spiraea chamaedrytolia und Salix silesiaca reiche Buschbestände. Über diesen breiten sich eintönige, vom Weidevieh stark hergenommene kurzgrasige Aipenmatten mit Potenlilla ternala, Geum monLanum, Campanula alpina usw. aus. Um so reicher ist die Flora in höheren Lagen (über $2100 \mathrm{~m}$ ), bis auf den Gipfel der $2508 \mathrm{~m}$ hohen Věnatorea ${ }^{1}$ ), wo an den věnatorea. grasigen Schrofen Alopecurus laguriformis, Carex pyrenaica, Luzula spadicea, Cerastium alpinum, Silene dinarica, Dianlhus gelidus, Arabis neglecla, A. ovirensis, Cardamine gelida, Sedum alpestre, Saxifraga androsacea, S. heucherifolia, S. hieracifolia, S. carpatica, S. bryoides, Viola alpina, Gentiana frigida, Rhododendron myrtifolium, Phyteuma confusum, Doronicum carpalicum, Anthemis carpatica häufig sind und an Felsen Saxifraga luleoviridis, S. cymosa, S. opposilifolia, Achillea Schurii und Erigeron uniflorus gedeihen, während am schmelzenden Schnee zahlreich Ranunculus crenalus, Saxifraga androsacea, Chrysosplenium alpinum und Soldanella pusilla blühen und an vom Schmelzwasser durchfeuchteten Stellen Plantago gentianoides fast jede andere Vegetation erstickt. Auf dem der Věnatora nördlich vorgelagerten Albota wächst auch die seltene Campanula transsilvanica.

1) Das Gebiet des Buleatales, die Věnatorea und der Negoi sind hauptsächlich das Gebiet, das von den älteren Autoren (Baumgarten, Schur u. a.) als Arpascher oder Kerzesorer (Certisorer) Alpen bezeichnet wurde. 


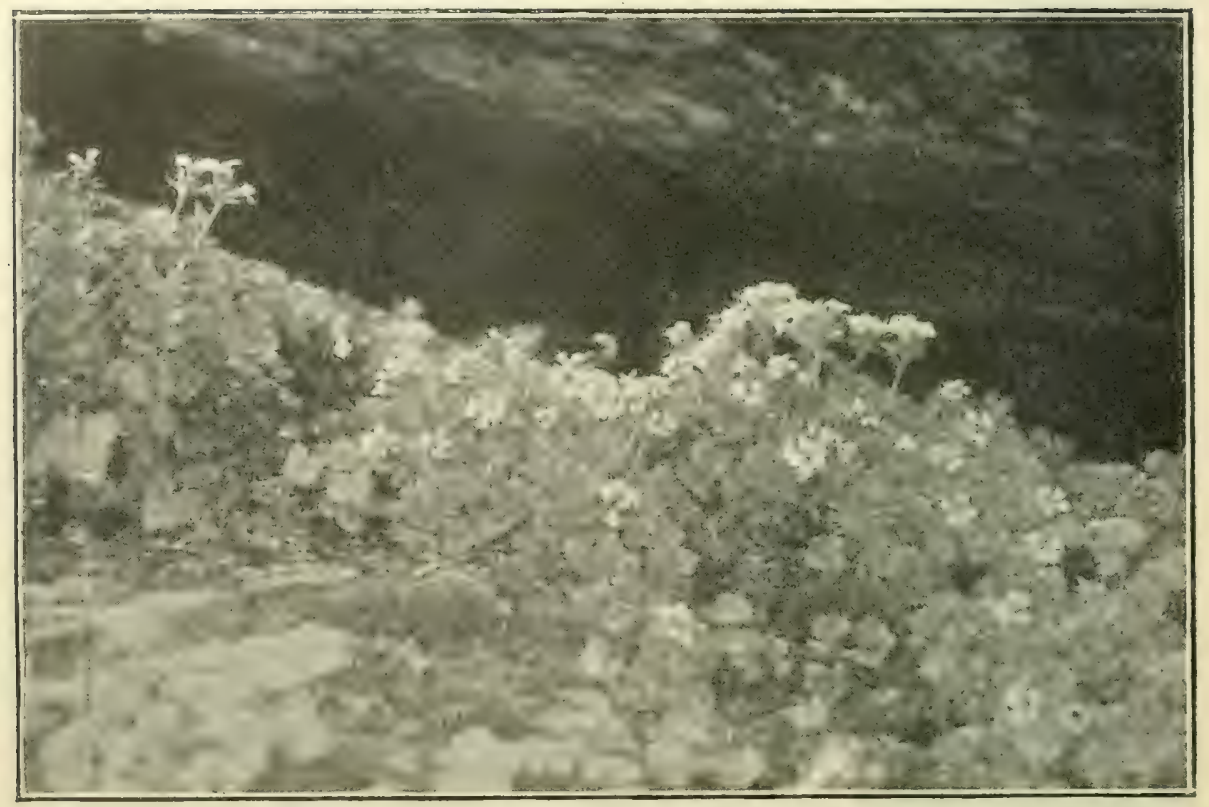

Abb. 253. Saxifraga cymosa in Felsspalten oberhalb des Buleasees, zirka $2300 \mathrm{~m}$. (Nach einer Aufnahme von A. v. Hayek.)

Negoi.

Eine ganz ähnliche Flora weist auch der Negoi $(2536 \mathrm{~m})$, der höchste Gipfel Siebenbürgens, auf.

An Felsen kommen hier Scrophularia lasiocaulis, Corlusa Matlhioli, Cenlaurea Kolschyana und Leonlopodium alpinum vor, auf steinigen Alpenmatten sind Alopecurus laguriformis, Ranunculus crenalus, Silene dinarica, Cardamine gelida, Hulchinsia brevicanlis, Saxifraga cymosa, Genliana punclala, G. Kochiana, Primula carpatica, Onobrychis monlana, Planlago gentianoides verbreitet. Auch auf dem Vrf Csortea findet man in der Voralpenregion an Felsen Saxifraga cuneifolia, in Bachschluchten Blechnum Spicant, Heracleum palmatum und im Walde Ranunculus plalanifolius, Aconilum Hosleanum, Spiraea ulmifolia, Bruckenlhalia spiculifolia, auf Wiesen Orchis cordigera, Knautia longifolia, Scorzonera rosea, Dianthus compactus, während in der Hochalpenregion Sesleria rigida, S. disticha, Alopecurus laguriformis, Cardamine rivularis, G. gelida, Saxifraga cymosa. S. heucherifolia, S. luleoviridis, Viola alpina, Dianthus gelidus, Anemone alba, Aquilegia transsilvanica, Gentiana Kochiana, G. nivalis, Arlemisia eriantha, Senecio carpalicus, S. carniolicus die bezeichnendsten Arten sind. Und die gleiche Szuru. Flora trägt auch der $2288 \mathrm{~m}$ hohe Szuru, von dem aus sich die Bergkette rasch gegen den Rotenturmpaß senkt. Schon an einem Zuflusse des Freckbaches tritt hier Bruckenthalia auf und über den dichten Buchen- und Fichtenwäldern bekleiden dichte Bestände von Alnus viridis die steinigen Halden und darüber überzieht Rhododendron myrtifolium weite Strecken. In der Gipfelregion aber sind Aquilegia transsilvanica, Saxifraga heucherifolia, S. stellaris, S. cymosa, Myosolis alpestris, Viola biflora, Veronica Baumgartenii, Phytenma confusum 


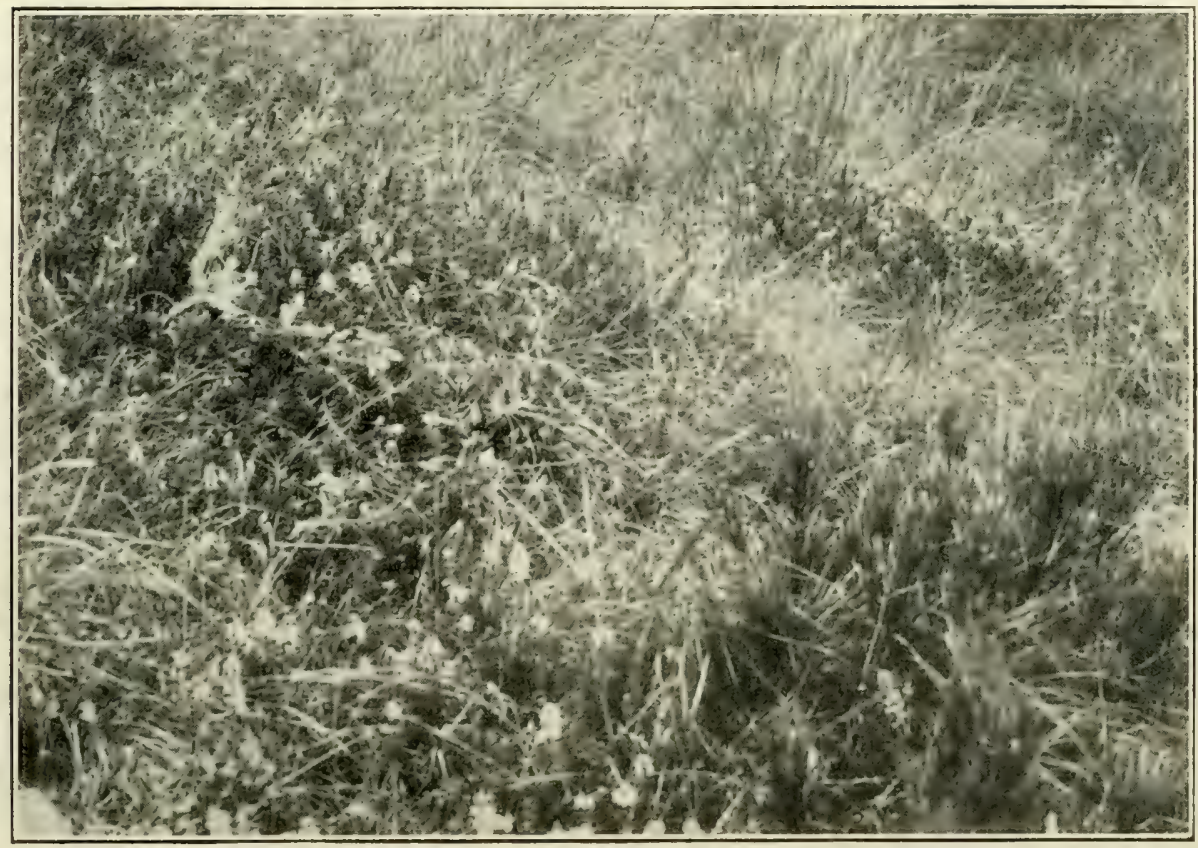

Abb. 254. Bruckenthalia spiculifolia und Pinus Mughus ober der Waldgrenze im Buleatale der logarascher Alpen.

(Nach einer Aufnahme von A. v. Hayek.)

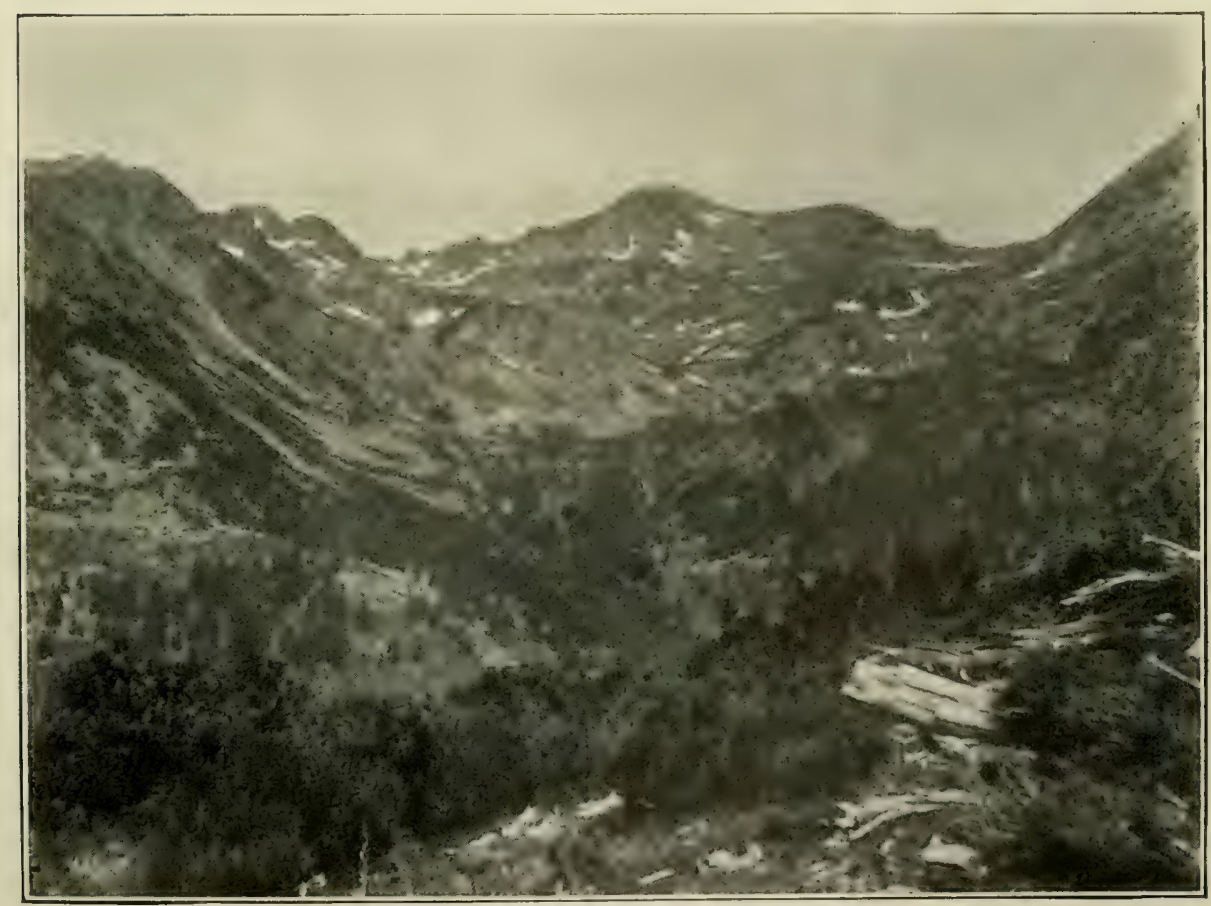

Abb. 255. Bestände von Pinus Mughus und Pinus Cembra im Bucuratale des Retyezat. (Nach einer Aufnahme von Dr. Z. v. Szabó, Budapest.)

Verlag von Franz Deuticke in Leipzig und IVien. 

und Doronicum carpaticum die häufigsten Arten; am Abhange gegen Felsö Sebes aber kommen an Kalkfelsen Salix reliculata, Kernera saxalilis, Saxifraga luleoviridis, Achillea Schurii und Leontopodium alpinum vor.

Im Rotenturmpa 13 treten an Felsen und Waldrändern neben Selaginella helvetica, Dianlhus lrifasciculalus, Arabis procurrens, Veronica Bachofenii und anderen subalpinen Arten auch Berleroa incana, Nepela pannonica, Centaurea micrantha, Arlemisia Absynthium usw, auf. Eine Reihe von Gebirgspflanzen findet hier die Westgrenze ihrer Verbreitung in den Karpathen, so Salix Jacquini, S. relusa, S. reliculata, Draba Kotschyi, Onobrychis monlana.

Die den Fogarascher Alpen vorgelagerte Fogarascher Hochebene ist Fogacrößtenteils von Ickern mit Getreirle, Mais, Lartoffeh, IIanf und hie und da Ifochebene auch Hopfen bedeckt; an den Ufern der Bäche trifft man Erlenamen, in denen Rudbeckia laciniala zahlreich verwildert ist, und oft auch kleinere Sümpfe mit Typha latifolia, Glyceria aqualica, Juncus Leersii, J. compressus, Alisma Plantago aquatica, Lylhrum Salicaria, Oenanthe aquatica usw. Gegen das Gebirge zu aber sind ausgedehnte Viehweiden und Wiesen entwickelt, als deren bezeichnendste Arten Holcus lanalus, Rumex Acelosa, Dianthus Armeriastrum, D. Carthusianorum, Ranunculus acer, Ononis hircina, Trifolium campestre, Genista lincloria, Filipendula hexapetala, Stachys officinalis, Galium verum, Campanula palula, C. Cervicaria, Alectorolophus rumelicus und Chrysanthemum Leucanlhemum zu nennen sind, während an sumpfigen Wegrändern Gypsophila muralis ungemein häufig ist.

Der Rotenturmpaß scheidet von den Fogarascher Alpen das Mühlbachoder Gibingebirge, das durch die tief eingeschnitenen Täler des Riu Sebes, Gibin und Zood reich gegliedert ist, dessen die Höhe von $2000 \mathrm{~m}$ nur selten überschreitenden Gipfel im Gegensatze zu den wildzerrissenen Felskämmen der Fogarascher Alpen sanft gerundete Kuppen zeigen. Infolge seiner sanft abgedachten, bei Talınasch mit dem zentralsiebenbürgischen Hügelland in direkter Verbindung stehenden Hänge bietet es Formationen der tieferen Höhenstufe ı ungleich mehr Raum zur Entfaltung als die jähen Nordhänge der Fogarascher Alpen gegen das Alt-Tal. Hier in der Umgebung von Talmasch Talmasch. findet man teils Laubmischwälder aus Fagus silvalica, Quercus sessiliflora, Carpinus Betulus, Acer campestre, A. platanoides, A. Pseudoplalanus und auch schon vereinzelter Tilia argentea mit einem Niederwuchse aus Luzula nemorosa, Dianlhus Armeriaslrum, Silene dubia, Genisla sagillalis, Geranium Roberlianum, G. phaeum, Sanicula europaea, Gentiana asclepiadea, Digilalis ambigua, Aiuga genevensis, Galium capillipes, Campanula persicifolia, Phyleuma telramerum, Chrysanthemum corymbosum usw., während im Unterholze Evonymus verrucosus nicht selten ist, teils Triftformationen mit Allium flavum, Clemalis Vilalba, Linum flavum, L. austriacum, Geranium sanguineum, Filipendula hexapelala, Cytisus leucanthus, Coronilla varia, Polygala maior, Slachys recla, Onosma viride, Echium vulgare, Linaria genistifolia, Chrysanthemum corymbosum usw. und an Felsen des Zoodtales und einiger benachbarter Täler wachsen der zierliche Zoodtal. Dianthus Henteri, Symphyandra Wanneri und das charakteristische Hieracium 
Pavichii. Höher oben dann bildet die Buche reine Bestände, die bei etwa $1400 \mathrm{~m}$ von Fichten und Tannen mit eingesprengten Lärchen abgelöst werden. Über der vielfach durch Ausrodung künstlich herabgedrückten Waldgrenze bilden Alnus viridis und Juniperus nana einen Strauchgürtel und am Gibinjeser, unter dem Gindrel $(2245 \mathrm{~m})$, ist auch noch ein ein schöner Bestand der ehedem gewiß weiter verbreiteten Pinus Cembra erhalten. Die Kuppen des Gebirges aber bedecken ausgedehnte eintönige Alpenweiden und die Hochgebirgsflora ist durch die starke Weidewirtschaft stark dezimiert, erinnert aber dennoch in ihrer Zusammensetzung stark an die Fogarascher Alpen. So wachsen z. B. an

Cindrel. den Abhängen des Cindrel beim Cibinjeser Carex pyrenaica, Dianthus gelidus, Anemone alba, Saxifraga stellaris, Ligusticum Mulellina, Heracleum palmatum, Tozzia alpina, Sweerlia punclala, Planlago gentianoides und Senecio carpalhicus; die auffallendste Erscheinung jedoch sind die gelblichweißen Blütenrispen des Polygonum alpinum; auch Draba carinthiaca und Arenaria biflora sollen hier wachsen; in der Gipfelregion des Cindrel (Fromoasa) findet man auch Saxifraga cymosa und Centaurea nervosa.

Noch reicher als um Talmasch sind die Formationen des Hügellandes an den westlichen Ausläufern des Gebirges entwickelt. So findet man bei

Broos. Piski nächst Broos auf der Magura Buschwerk aus Fraxinus Ornus und Triften mit Diplachne serolina, Allium flavum, Dianlhus giganleus, Sisymbrium Loeselii. Syrenia cuspidata, Cytisus leianthus, Orlaya grandiflora, Verbascum speciosum, Doronicum hungaricum, Carduus candicans, Cenlaurea atropurpurea, Galium flavescens und $G$. pedemontanum, also in einer Zusammensetzung, die schon sehr an die Bergtriften des Banates erinnert. Weit ins Hatszeger Tal ziehen sich

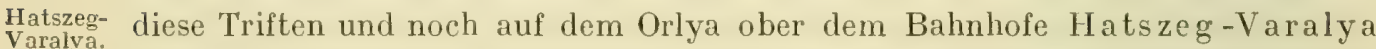
gedeihen Andropogon Ischaemum, Slipa capillala, Melica ciliala, Diplachne serotina, Allium flavum, Silene Armeria, Tunica prolifera, Dianthus giganteus, Minuartia frulescens, Alyssum murale, Genista sagittalis, Onobrychis arenaria, Astragalus linearifolius, Seseli Beckii, Verbascum nigrum, Veronica Jacquinii, Asperula tincloria, Cephalaria laevigala, Aster tinctorius, Chondrilla juncea, Crepis setosa, Hieracium echioides und in den Laubmischwäldern treten nicht nur Quercus Cerris und Qu. pubescens, sondern selbst schon Qu. conferta auf; auf feuchten Wiesen wachsen Thaliclrum lucidum, Oenanthe slenoloba und Peucedanum Rochelianum. Manche dieser Arten lassen sich im Tale des Schyl Petroszény. bis Petroszény verfolgen, wo an den Kalkfelsen der Piatra Rosie wieder cine üppige Flora anzutreffen ist. Zum ersten Male für den von Osten Kommenden bildet hier der Flieder (Syringa vulgaris) prächtig blühende Gebüsche. vergesellschaft mit Fraxinus Ornus und Evonymus latifolius und an die Kalkfelsen schmiegt sich Juniperus Sabina an; auch Asplenium viride, Dryopteris Robertiana, Dianthus integripelalus, Lychnis Coronaria, Minuartia frutescens, Sedum glaucum, Bupleurum falcatum, Thalictrum foelidum, Salureia Pulegium, Euphrasia salisburgensis, Scrophularia lasiocaulis und Valeriana tripteris gedeihen an den Kalkfelsen, und im Buchenwalde wachsen Phylliles Scolopendrium, Polygonalum latifolium, Clemalis alpina, Saxifraga rolundifolia, Hypericum umbellatum, 
Melitlis Melissophyllum, Verbascum glabralum und Hieracium Iranssilvanicum, Auf dem Pareng aber gedeihen an subalpinen Felsen neben Allium ochroleucum, Pareng. Bupleurum diversifolium und Symphyandra Wanneri die seltene Silene Lerchenfeldiana, oft dicht die Felsen überziehend, sowie die hier endemische Potentilla Haynaldiana. Ober dem an Bruckenthalia spiculifolia, Campanula abielina unr

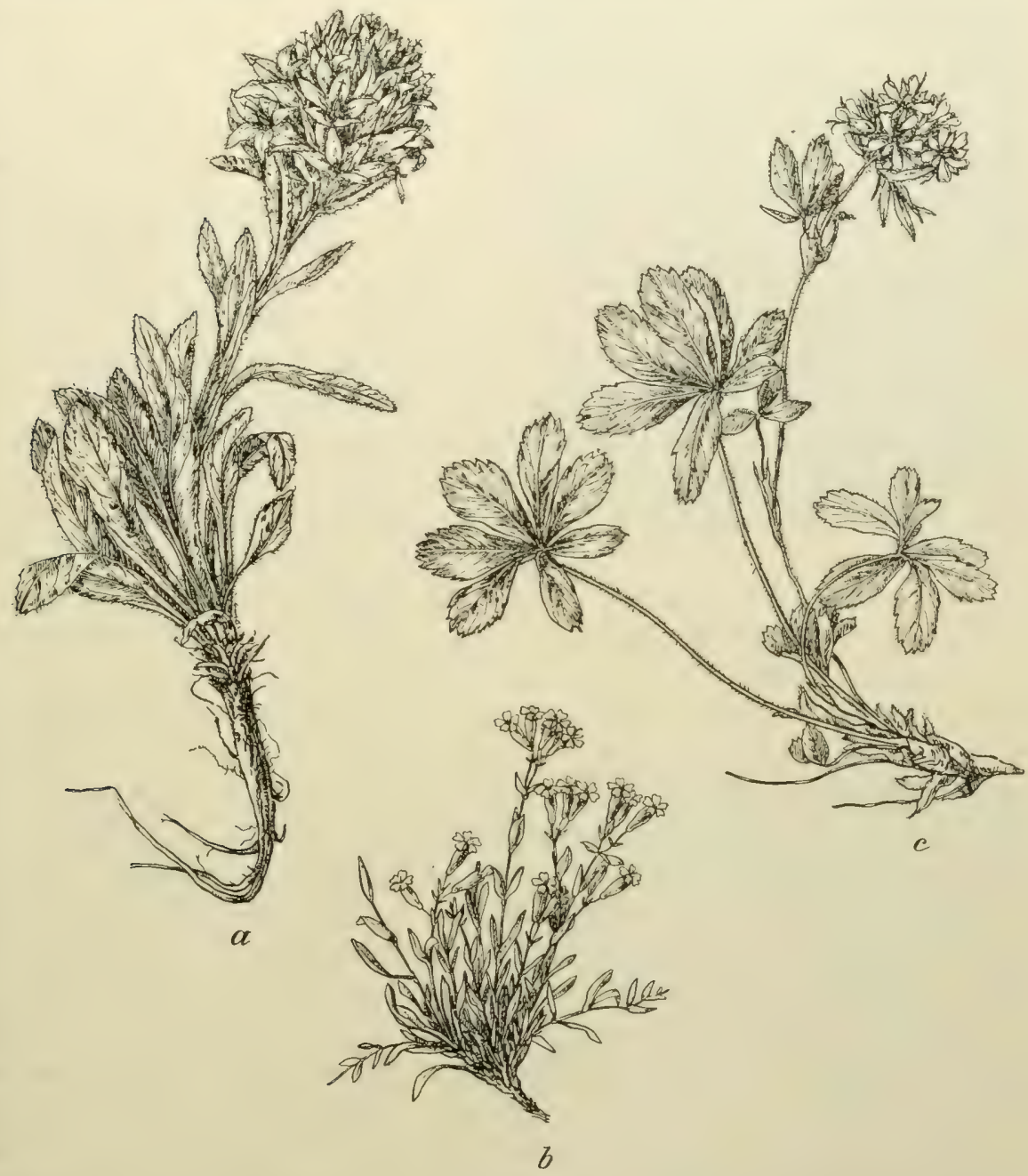

Abb. 256. Drei seltene Arten aus der Flora der westlichen transsilvanischen Alpen. $a$ Campanula transsilvanica. $b$ Silene Lerchenfeldiana. $c$ Potentilla Haynaldiana. (Zirka $3 / 5$ nat. Gr.)

Aposeris foetida reichen Walde breiten sich reiche Alpenmatten mit Ceraslium macrocarpum, Anemone alba, Aquilegia transsilvanica, Arabis ovirensis, Thlaspi dacicum, Myosolis alpestris, Polentilla lernala, Planlago gentianoides, Phyleuma Vagneri, Ph. confusum, Achillea Schurii, Centaurea nervosa und Crepis viscidula aus und an den Felsen der Gipfelregion gedeiht üppig Arlemisia eriantha. 
Szurdukpaß cebïsche auf und außerdem findet man hier in Geranium macrorhizum, Salureia inlermedia, Veronica Bachofenii und Campanula Grosseckii.

Retiezatgruppe. gruppe, deren Hänge ebenfalls von Buchen- und Fichtenwäldern bedeckt sind, an deren oberer Grenze auch Pinus Cembra vorkommt und über denen Alnus viridis und Rhododendron myrtifolium einen Strauchgürtel bilden, während Pinus Mughus mehr zurücktritt. An voralpinen Kalkfelsen der Paltina findet man Biscutella laevigata, Alyssum repens, Helianthemum alpeslre, Androsace lactea, Scrophularia lasiocaulis, Euphrasia salisburgensis, Knautia silvalica *lancifolia, Hieracium villosum sowie drei Arten, die in der übrigen Kette der Transsylvanischen Alpen fehlen, aber westwärts sich bis in das Banater Bergland erstrecken, nämlich Saxifraga Rocheliana, Alhamanla hungarica und Edraianthus graminifolius. In Bergschluchten der Retiezatgruppe wachsen Aconilum moldavicum *auslrale, Delphinium elalum, Angelica Archangelica, Laserpitium Archangelica und Doronicum auslriacum, an Schieferfelsen Symphyandra Wanneri und Saxifraga cuneifolia und auf den durch das Weidevieh stark hergenommenen Alpenmatten Nigrilella rubra, Viola declinala, $V$. alpina Polentilla lernala, Anemone alba, Sempervivum montanum, Phyteuma Vágneri. Campanula alpina, C. Iranssilvanica, Senecio glaberrimus, Cenlaurea nervosa, Crepis viscidula, Hieracium reliezalense, H. pseudocaesium, $H$. Kotschyanum und $H$. dacicum und auf dem Kalke der Paltina auch Leontopodium alpinum. Die höheren Kuppen bedecken vielfach Rasen au. Vardus stricla, Sesleria dislicha, Carex curvula und Loiseleuria procumbens, doch treten ab und zu auch seltenere Arten auf, wie Elyna Bellardi, Saxifraga cymosa, Androsace arachnoidea, Senecio carniolicus, ferner auf der Valeriasca (nordwestlich vom Retiezatgipfel) die endemische Iraba Dorneri, auf der Peleaga Gymnadenia Richleri, auf dem Dragean Pedicularis Baumgartenii und auf der Skorota Nigrilella nigra. Am schmelzenden Schnee wachsen in der Retiezatgruppe, wie überall in den Transsilvanischen Alpen, Polygonum viviparum, Tianunculus crenalus, Saxifraga androsacca, S. carpalhica, Primula minima, Soldanella pusilla und Plantago gentianoides. Eine ähnliche Flora weist auch der westlichste Hochgipfel der Szarko. Gruppe, der $2190 \mathrm{~m}$ hohe Szarko, auf. Hier befindet sich (ob jetzt noch?) ein kleiner Bestand von Pinus Cembra unter der Alpe Baiku. Den Gipfel aber umgürten Buschbestände von Juniperus nana, Alnus viridis und Rhododendron myrlifolium, auf den Alpenmatten wachsen Carex pyrenaica, C. sempervirens, C. fuliginosa, Lloydia serotina, Oxyria digyna, Dianlhus compaclus, Anemone alba, Cardamine gelida, Saxifraga cymosa, S. moschata, S. bryoides, Viola declinata, Y. biflora, Laserpitium alpinum, Loiseleuria procumbens, Primula longiflora, P. minima, Soldanella pusilla, Veronica Baumgarlenii, $V$. bellidioides, Planlago monlana, P. gentianoides, Phyteuma confusum, Arlemisia eriantha, Cientaurea Kolschyana, Saussurea discolor, Crepis viscidula, Hieracium: alpinum usw. 


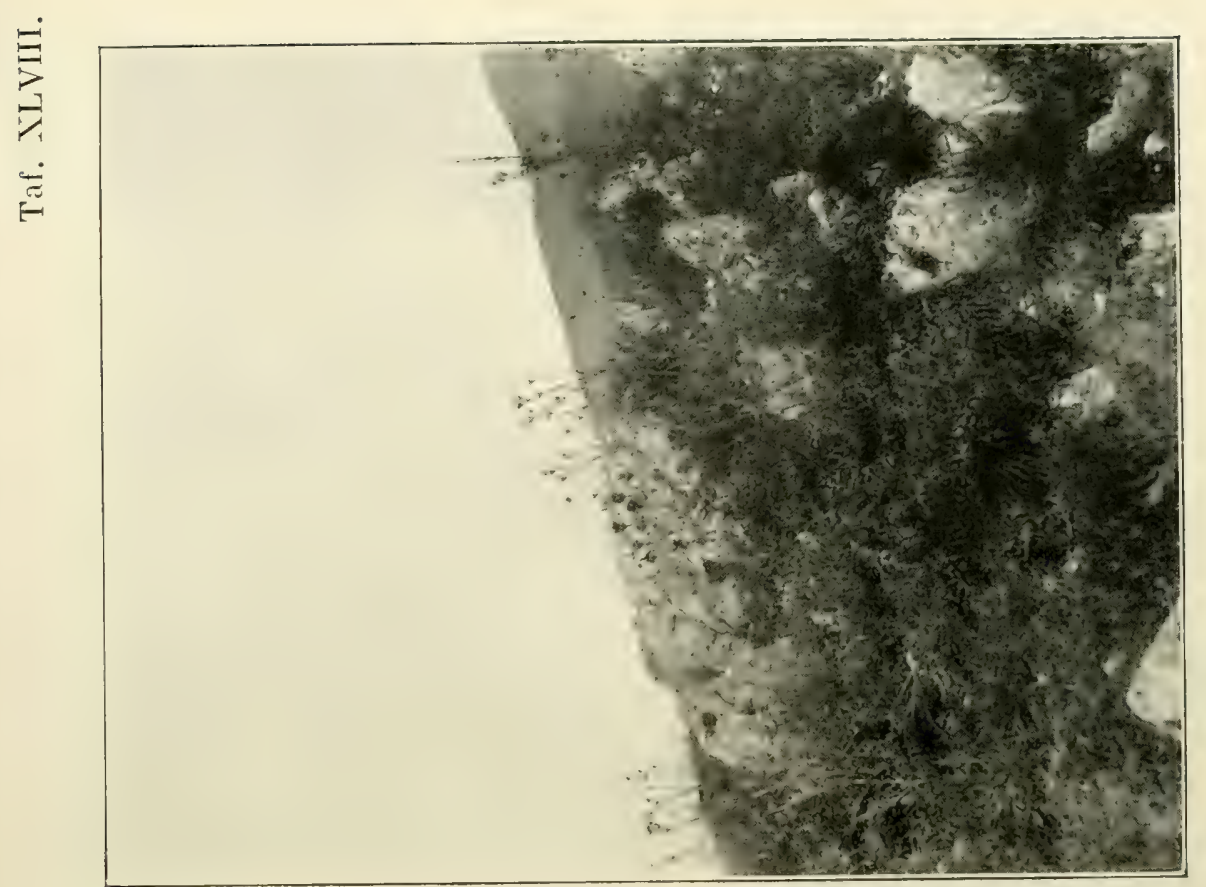

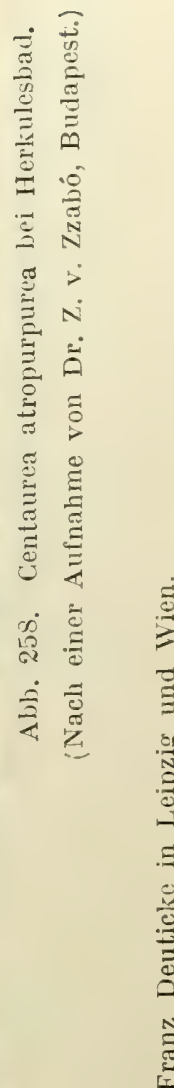

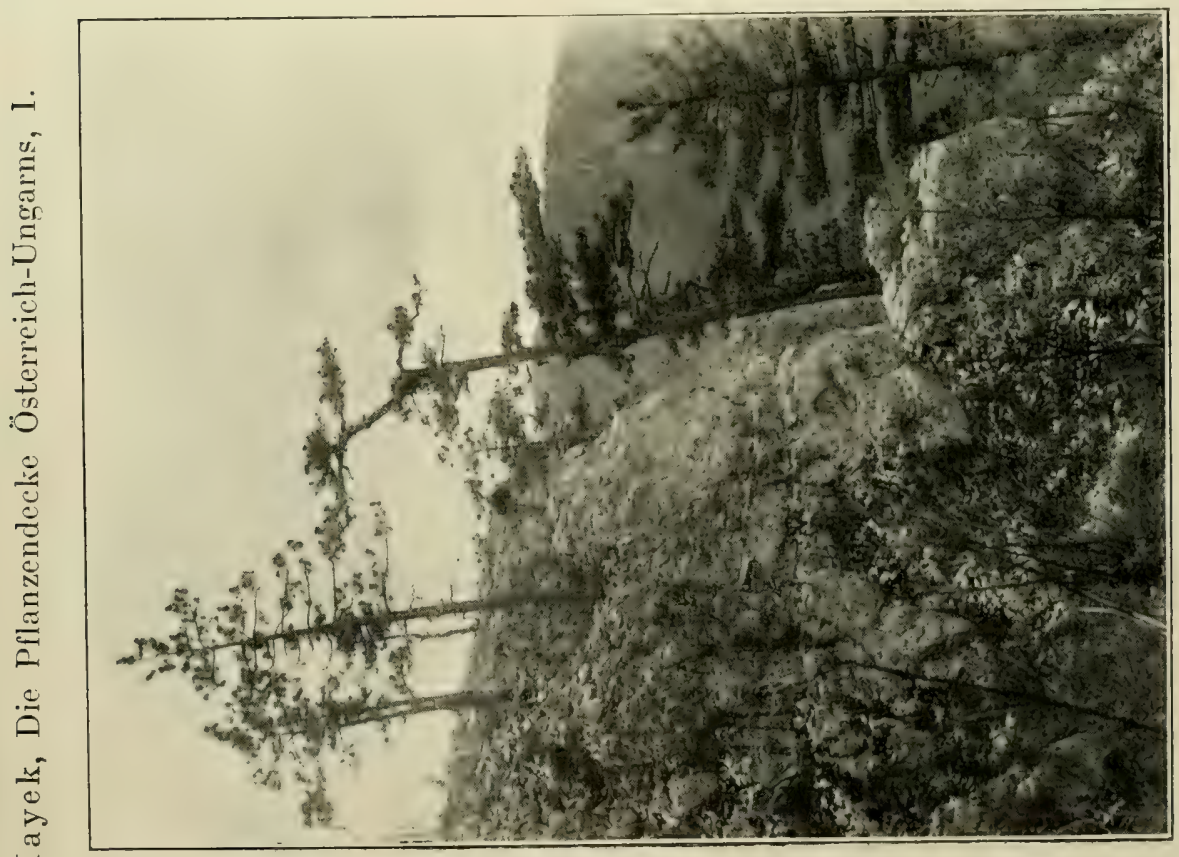

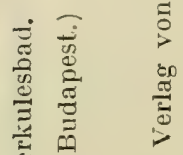





\section{f) Das Banater Bergland.}

Im äußersten Südwesten der Karpathen, wie im Czernatale bei Me had ia und Herkulesbad, berlecken prächtige uralte Buchenwädler, untermischt mit Irrouleseinzelnen Exemplaren von Tilia argentea, die Hänge und Schluchten der Berge, in denen Carex brevicollis, Saxifraga rotundifolia *Heuffelii, Geranium macrorhizum, Physocaulus nodosus, Lamium vulgare, Campanula Grosseckii, Galium capillipes, Doronicum cordalum, Hieracium pseudofastigialum und $H$. Iranssilvanicum häufig sind und stellenweise auch Ruscus aculealus auftritt. An Felsen finden sich Moehringia pendula, Silene petraea, Arabis procurrens, Kernera saxalilis, Draba lasiocarpa, Hypericum Rochelii, Athamanta hungarica, Salureia Pulegium, Campanula divergens, Edraianlhus graminifolius, Cenlaurea alropurpurea sowie der hier den Dianthus spiculifolius vertretende Dianlhus Kilaibelii, vermischt mit zahlreichen pannonischen Elementen, so Linum tauricum, Alyssum microcarpum, Jurinea macrocalathia und verschiedenen Umbelliferen, wie Seseli rigidum, S.gracile, Libanolis leiocarpa, Ferula Heuffelii, Ferulago silvalica; an subalpinen Kalkfelsen kommen ferner Saxifraga Rochelii und Primula Auricula *serralifolia vor. Im Unterholze des Waldes aber tritt an vielen Stellen duftender Flieder (Syringa vulgaris) auf, ferner Fraxinus Ornus, Cralaegus melanocarpa und Colinus Coggygria, im SuhaPadina-Tale und bei Herkulesbad selbst schon Carpinus orientalis und im Cizernatale gehört Vitis silvestris zu den häufigsten Lianen, während am Waldrande Telekia speciosa und Chrysanthemum macrophyllum wachsen. In höheren Lagen aber bildet Genisla radiala streckenweise kleine Buschbestände, Pinus nigra tritt in kleinen Wäldchen auf und auf den Höhen des nur $1100 \mathrm{~m}$ hohen Domugled bildet Juniperus Sabina und Junipera nana nierlriges Buschwerk Domugled. und daneben sind Phleum montanum, Saxifraga Aizoon, Polenlilla Tommasiniana, Geranium bohemicum, Seseli gracile, Asperula capilata und Hieracium villosum $\mathrm{zu}$ finden; der benachbarte, wenig höhere Vrfu Suskului bietet überdies Slipa pulcherrima, Iris variegata, Viola Jooi, Astragalus depressus, Campanula Welandi, Mulgedium sonchifolium und Hieracium Herculis. Auch die Prolazschlucht bei Herkulesbad ist wegen ihrer reichen Flora (u. a. Silene Cserei, Delphinium fissum, Geranium Iucidum, Crucianella oxyloba, Hieracium Herculis) berühmt.

Noch weiter südwärts, gegen die Donau zu, wird, wie bei Orsova, der Charakter der Flora ein immer mehr ausgesprochen südlicher. Die Buchen treten immer mehr zurück und Eichen, darunter auch Quercus conferla, gewinnen die Oberhand. Tilia tomentosa, Carpinus orientalis und Colinus Coggygria werden immer häufiger, Acer tataricum, Corylus Colurna uud selbst Juglans regia treten als Bestandteil des Laubmischwaldes auf und neben Clemalis Vilalba und Vitis silvestris ist Tamus communis eine häufige Liane. An lichten Waldstellen und an buschigen Hängen aber findet sich manche südliche Art, so Orchis papilionacea, Trifolium pannonicum, T. Molinerii, Torilis microcarpa, Stachys nitens, Crucianella oxyloba, Digitalis lanala, Acanthus hungaricus und Achillea compacta, an Felsen und Mauern ist Ceterach officinarum nicht selten. Bei Orsova kommt 


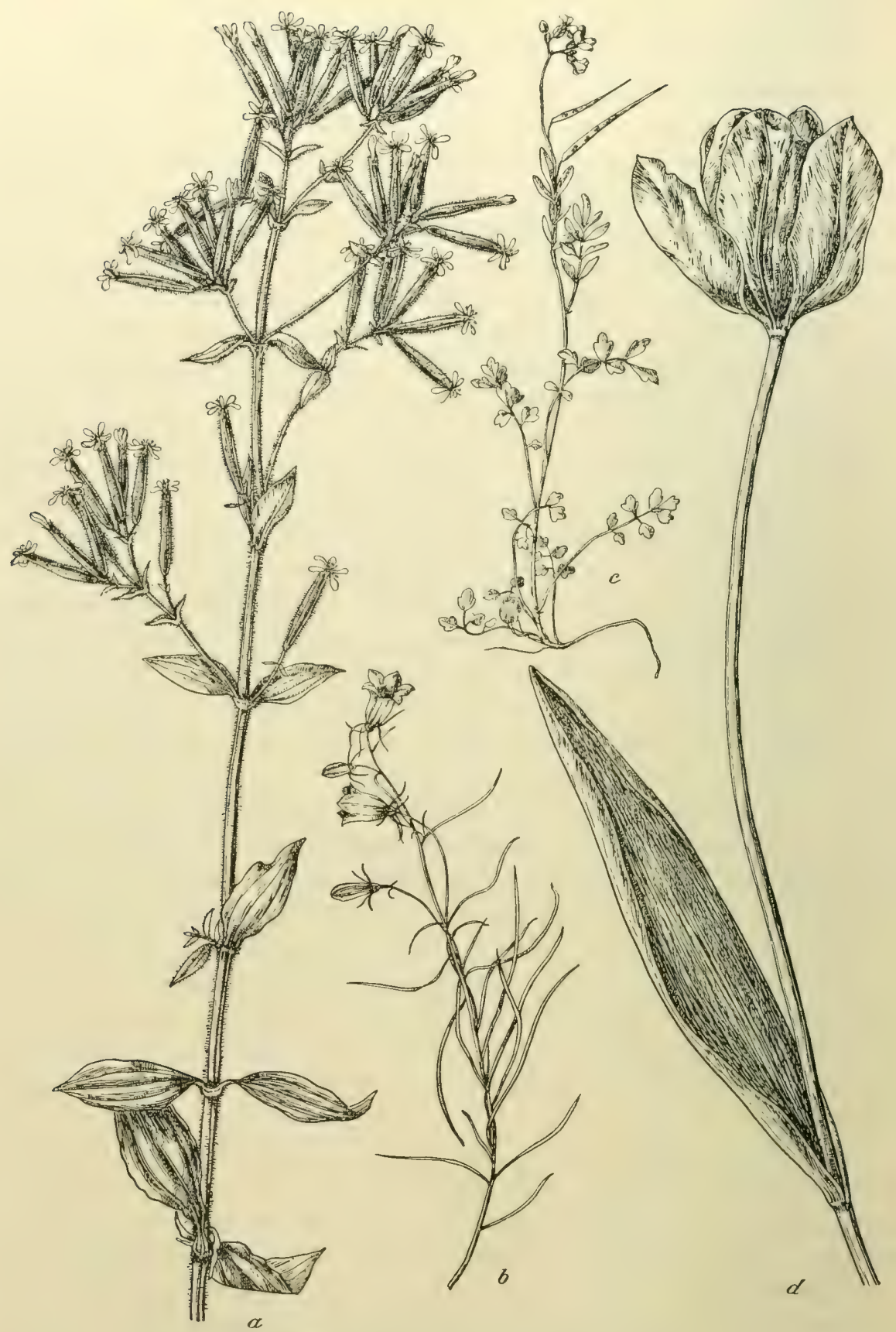

Abb. 259. Aus der Flora des Kazanpasses.

$a$ Saponaria glutinosa. $b$ Campanula crassipes. $c$ Cardamine graeca. $d$ Tulipa hungarica.

auch die eigenartige Umbellifere Prangos carinata vor und an der Donau bildet Glycyrrhiza echinala, vergesellschaftet mit Centaurea iberica Bestände, während auf feuchten Wiesen bei Jeselnica und Ogradina Galium constrictum wächst. 
Iöchst mannigfach ist auch die Flora der den Ka zan pa $\beta$ einschließenden Kazanpaß. Felswände. Buchenwälder, in denen bei Karlsdorf das seltene Bolrychium Karlsdorf. virginianum vorkommt, treten fast bis an die Donau heran und werden von einem Buschwerke aus Carpinus Betulus, C. orientalis, Corylus Avellana, C. tubulosa, Quercus pubescens, Acer campestre, Colinus Coggygria, Fraxinus Ornus, Slaphylea pinnala, Evonymus verrucosus, Colulea arborescens, Coronilla Emerus usw. eingefaßt. An den Felsen aber wachsen Alyssum microcarpum, Draba lasiocarpa, Syrenia cuspidata, Silene Armeria, Cerastium banalicum, Ferulago silvatica, Ferula Heuffelii, Campanula lingulala, C. macrorhiza, Centaurea atro-

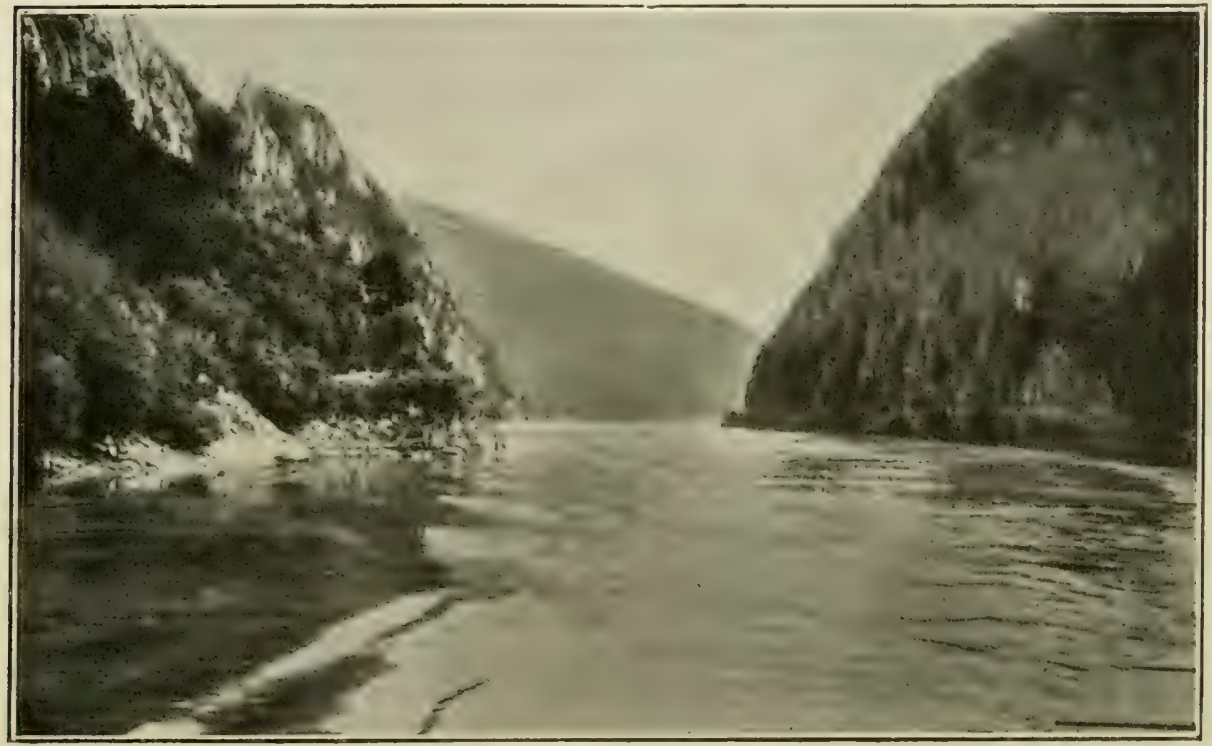

Abb. 260. Der Donaudurchbruch durch den Kazanpaß.

An den felsigen Hängen Buschwerk aus Quercus pubescens, Carpinus Betulus, C. orientalis, Acer tataricum, Cotinus Coggygria, Evonymus verrucosus, Coronilla Emerus usw. und reiche Felsenflora.

(Nach einem Diapositiv aus der Sammlung des geographischen Institutes an der Wiener Universität.)

purpurea und zwischen Plavisievitza und Dubova die prächtige gelbe PlavisieTulipa hungarica; bei Svinitza trifft man Polygala supina und Convolvulus tenuissimus, bei Bersatzka Cardamine graeca und die mediterrane Euphorbia Bersatzka. Myrsiniles, am Eingange in die Golubatzer Höhle bei Goronini das seltene Coronini. Asplenium lepidum. Auch der 'Treskovatz bei Svinitza beherbergt einige Svinitza. interessante Arten, wie Jasione Jankae und Hieracium Jankae; im Valle Jucz bei Tissovitza sind Symphytum ollomanum und Saponaria glutinosa zu finden. Tissovitza.

Die äußersten Ausläufer der Transsilvanischen Alpen bei Bazias sind mit Bazias. Eichenwäldern aus Quercus Cerris, Qu. sessiliflora, Qu. pubescens und Qu. conferla, von Buschgehölzen und Bergtriften bedeckt, in die sich schon manche 
Arten der Steppenregion mengen, wie Paeonia banalica, P. lenuifolia, Echinops banalicus und E. rulhenicus; an buschigen, felsigen Stellen sind Lychnis Coronaria, Silene Armeria, Syrenia cuspidata, Alyssum microcarpum, Vicia truncalula, Onosma viride, Anchusa Barellierii. häufige Erscheinungen. Auch das ober

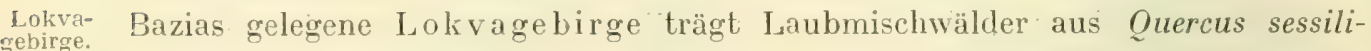
flora, Qu. Cerris, Fagus silvalica, Carpinus Belulus, Tilia argentea und T. cordala sowie an den gegen die Eberie gerichteten Abhängen Triftformationen, in denen stellenweise Cephalaria radiala in tonangebender Menge aufftritt. Ähnlich-liegen Versetz. auch die Verhältnisse bei Versetz. Carpinus Belulus, Acer lalaricum, Tilia

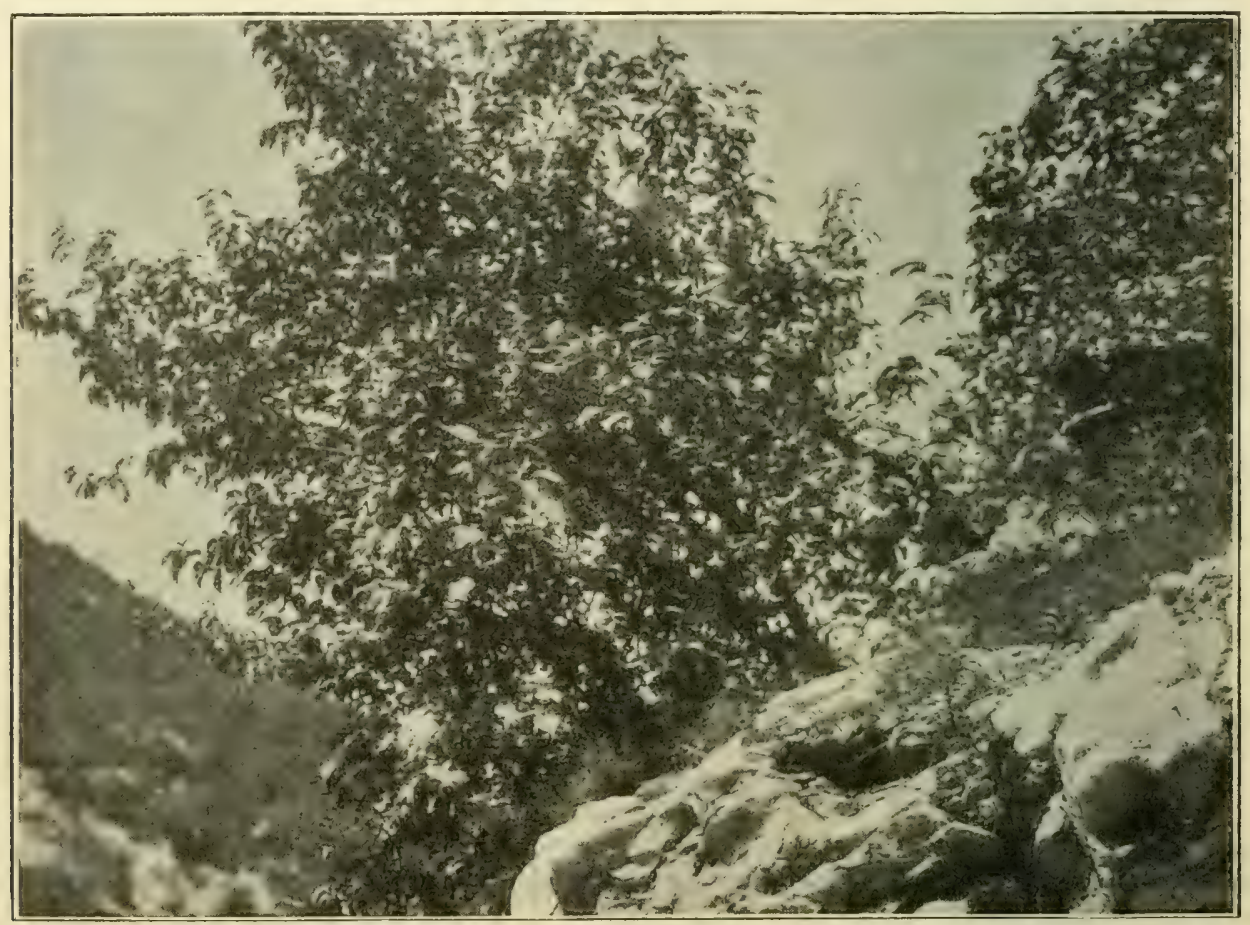

Abb.:261. Syringa vulgaris (links) und Prunus Mahaleb (rechts) bei Csiklova nächst Orawicza.

(Nach einer Aufnahme von Dr. J. v. Bernátsky, Budapest.)

argentea, Staphylea pinnata, Fraxinus Ornus sind an Waldrändern und buschigen Hängen verbreitet, auf dem Schloßberge ist Smyrnium perfolialum häufig, Ruscus Hypoglossum ist hie und da in Wäldern und unter dem Buschwerke anzutreffen, und wo nicht. Weingärten und Äcker die Abhänge bedecken, sind reiche Triften mit Avena compressa, Iris variegata, Silene nemoralis, Euphorbia salicifolia, Geranium phaeum, Cynoglossum officinale, Genisla ovala, Achillea crithmifolia, Centaurea slenolepis, Tragopogon dubius usw. entwickelt. Diesen

Lugos. Vegetationscharakter behält der Rand des Gebirges bis gegen Lugos bei, im Innern des Gebirges aber treten bald montane Buchenwälder auf, für deren Oravitza. Flora in der Umgebung von Oravitza Galanthus nivalis, Scilla bifolia, Er!y- 


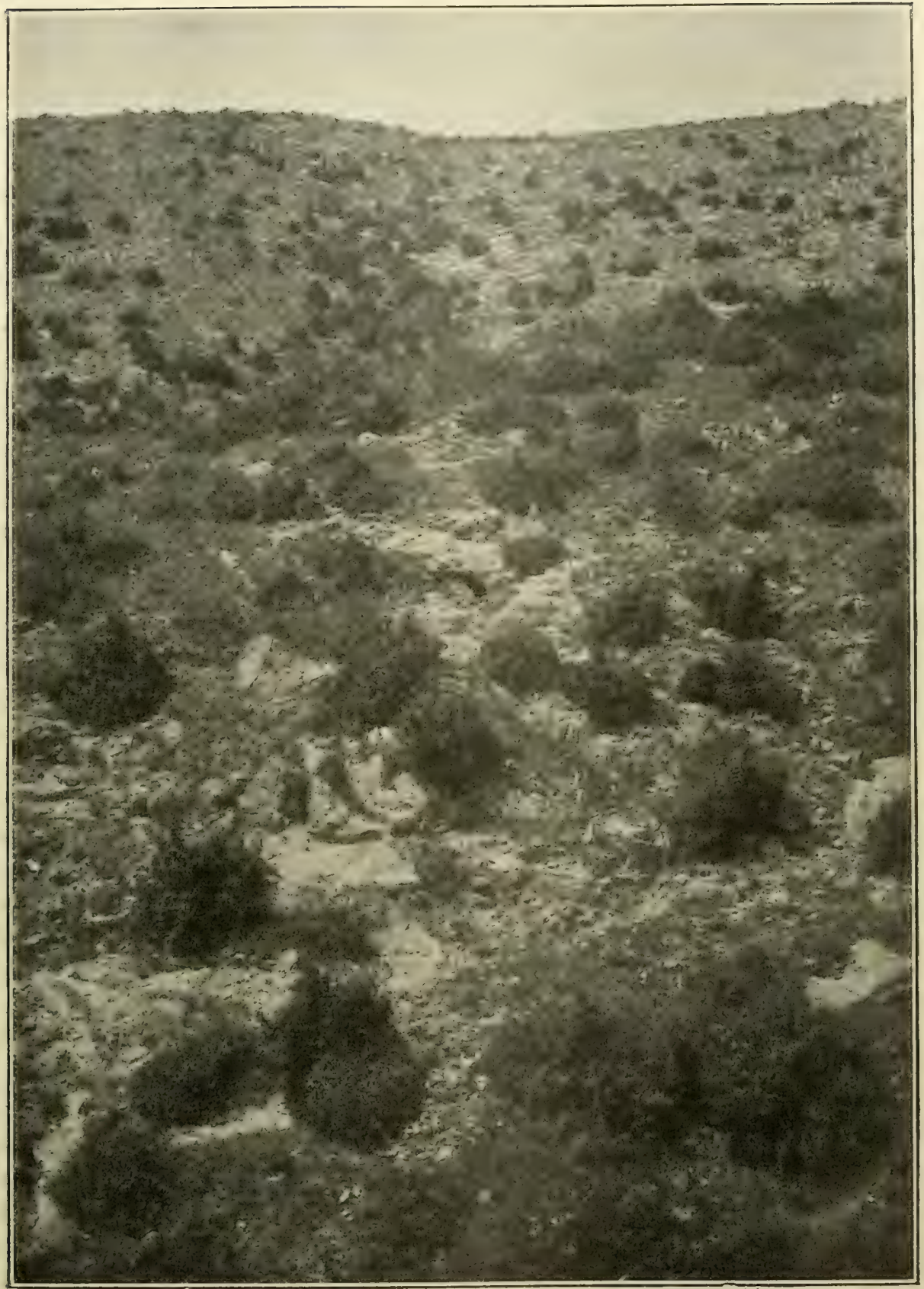

Abb. 262. Buschweide mit Carpinus Betulus und C. duinensis bei Csiklova.

(Nach Bernátsky, A magyar Alföld pusztás és erdei növenyzeteröl.) 
thronium Dens canis, Anemone Hepalica, Ranunculus auricomus, Helleborus odorus, Corydalis intermedia, Cardamine glandulosa, Aremonia agrimonioides, Primula vulgaris, Syringa vulgaris, Scopola carniolica, Daphne Mezereum, Asperula laurina und Pelasiles albus besonders bezeichnend sind, und bei Steyerdorf findet man auch Carex pilosa, Laserpitium Archangelica, Pleurospermum austriacum, Cirsium Erisithales, Doronicum Malthioli und Chrysanthemum macrophyllum.

szemenik. Auch der $1447 \mathrm{~m}$ hohe Szemenik trägt Buchenwälder mit Pleridium aquilinum, Slachys alpina, Cylisus Heuffelii und Telekia speciosa, auf Voralpenwiesen konmen hier Carex alrala, Cenlaurea austriaca und Hieracium aurantiacum vor, an nassen Stellen Oenanthe banatica und Crepis paludosa. Den Gipfel aber bedecken trockene Matten mit Nardus slricla, Luzula silvatica, Veralrum album, Hypericum maculalum, Gnaphalium silvalicum, Centaurea nervosa und Mulgedium alpinum.

\section{g) Die westlichen Randgebirge Siebenbürgens.}

Pojana Ruszka.

Déva.

Ruszka.

$$
\text { rigid }
$$

Das Tal der Temes trennt die Banater Berge von dem nördlich davon sich erhebenden IIöhenzug der Pojana Ruszka. Die Ausläufer dieses Gebirges tragen ebenfalls ganz den Charakter des Hügellandes; wo nicht Kulturen die Hänge bedecken, findet man Eichenwälder, Buschwerk aus mannigfachen Laubhölzern, wie Quercus pubescens, Qu. conferta, Carpinus Betulus, Acer tataricum, Viburnum Lantana oder Triftformationen. Auch an den Hängen gegen die Maros sind vielfach Triftformationen entwickelt, die besonders bei D é v a eine ungemein reiche, vielfach schon an die Steppenwiesen der Mezöség erinnernde Flora besitzen. Hier wachsen, besonders auf dem Sarhégy und einigen benachbarten Hügeln, zum Teil aber selbst schon auf dem Schloßberge Poa pannonica, Allium flavescens, Anemone nigricans, Minuartia frulescens, Dianthus giganteus, Alyssum murale, Syrenia cuspidala, Cylisus albus, C. leiocarpus, Althaea pallida, Acer lalaricum, Aiuga Laxmanni, Vinca herbacea, Asyneuma canescens, Campanula Grosseckii, Galium flavescens, Verbascum speciosum, Cephalaria laevigata, Crepis rigida, Leontodon asper usw. An den Abhängen der $1359 \mathrm{~m}$ hohen Ruszka bildet Fagus silvalica W'aldbestände, in denen Abies alba eingestreut vorkommt und deren Niederwuchs aus Arum maculalum, Melandryum nemorale, Euphorbia amygdaloides, Hypericum hirsulum, Epilobium monlanum, Chaerophyllum aromaticum, Gentiana asclepiadea, Asperula odorata, Stachys silvatica, Galium Schultesii, Prenanthes purpurea, Hieracium transsilvanicum usw. besteht; an Bachufern treten Salvia glutinosa, Telekia speciosa und Pelasites albus auf, auf welch letzterem Orobanche flava häufig schmarotzt; an Felsen gedeihen Moehringia muscosa, Sedum glaucum, Saxifraga rolundifolia und Veronica urticifolia. Auf Bergwiesen sind Veratrum album, Genista sagittalis, Galium vernum und Hieracium aurantiacum die bezeichnendsten Arten und den Gipfel selbst bedeckt Gestrüpp aus Vaccinium Myrlillus und V. Vitis Idaea. Am Ostrande

Vajada- des Gebirges aber, bei Vajda-Hunyad, wo auf felsigen Triften neben Alyssum
Hunyad. murale, Trifolium pannonicum, Trinia Kilnibelii, Silaus Rochelii, Jurinea trans- 
silvanica auch die zierliche Hyacinthella leucophaea auftritt, bildet besonders in den Tälern von Limpert und Gowasdia bis gegen Runc hin Syringa vulgaris prächtig blühende ausgedehnte Buschbestände.

Das weite Tal der Maros ist teils von Äckern, teils von feuchten Wiesen Marostal. und Weidengebüschen eingenommen, an den dasselbe im Nordwesten begrenzenden Hängen aber sind bis Gyula-Fehérvár (Karlsburg), ja, bis NagyEnyed Buschbestände und Triftformationen entwickelt, die denen von Déva in der Zusammensetzung ähnlich, nur artenärmer sind; hier gedeihen noch an mehreren Standorten Linum flavum, Cylisus albus, Acer lataricum, Astragalus linearifolius, A.dasyanthus, Anemone nigricans, Seseli gracile, Verbascum thapsiforme, Campanula Grosseckii und auf dem Mammuthegy bei Gyula-Fehérvár sogar Galium purpureum.

Nordwestlich von der Maros erhebt sich das niedrige Sandsteinmassiv des siebenbürgischen Erzgebirges. Dichre Buchenväller mit reichlichem Unterholz aus Spiraea chanaedryfolia, Ribes alpinum, Sorbus auslriaca usw. Erzgebirge. und einem Niederwuchs aus Helleborus purpurascens, Aconilum moldavicum, IIypericum hirsulum, H. umbellalum, Pulmonaria rubra, Salvia glulinosa, Genliana asclepiadea und Hieracium lranssilvanicum bedecken seine nordwestlichen llänge ; auf Waldwiesen gedeihen Pimpinella maior, Aslranlia maior, Trifolium ochroleucum, Cenlaurium umbellalum, Gentiana carpatica, Cirsium Erisilhales, Cenlaurea austriaca, Hypochoeris maculata usw; auf den Kuppen auch Lathyrus niger, Ferulago silvatica, Melampyrum bihariense und selten auch Lilium Jankae. An Felsen wachsen Dryopteris Robertiana, Melica ciliata, Moehringia muscosa, Sedum glaucum, Saxifraga _tizoon, Laserpilium latifolium, Euphrasia salisburgensis, Thymus comosus, Scabiosa lucida.

Die höchsten Erhebungen des Gebirges sind die Petrile alba (1299 m) und der Vulkan $(1266 \mathrm{~m})$ bei A brudhanya. Auch hier sind die Wälder, soweit sie noch erhalten sind, gemischte Laubwälder aus Carpinus Betulus, Fagus silvatica, Acer Pseudoplatanus usw., in denen Prunus spinosa, Crataegus Oxyacantha, Ligustrum vulgare usw. das Unterholz bilden. In diesen Wäldern wachsen auf dem Vulkan Helleborus purpurascens, Gulium purpureum, Clemalis alpina und Doronicum cordalum, während an felsigen Hängen Sesleria rigida, Dianthus spiculifolius, Sempervivum blandum, Saxifraga Aizoon, Isatis praecox, Aconitum Anthora, Campanula Kladniana, auf den waldfreien, meist von Calluna dicht bewachsenen Kuppen Lilium Jankae, Lathyrus niger, Ferulago silvalica und Melampyrum bihariense. An den Kalkfelsen des Luprapiétra poienile bei Vidra wächst in nur $1100 \mathrm{~m}$ Leontopodium alpinum, das auf den höheren Kuppen des Gebirges fehlt. Auf dem Somoskö gedeihen an buschigen Hängen Somoskö. Aristolochia pallida, Dianthus marisensis, Sedum carpalicum, an den Basaltfelsen der Detunata wächst Woodsia ilvensis. Das interessanteste Vorkommnis Detunata. im Bereiche des Siebenbürgischen Erzgebirges ist jedoch das Auftreten der südlichen Saponaria bellidifolia an den Kalkfelsen der Scarisora bei Pocsága, Scarisora. die hier ihren einzigen ungarischen Standort besitzt. Reicher ist die Flora im östlichen, im Vrfu Läcustii 1286 m Höhe erreichenden Kalkzuge. So wachsen 


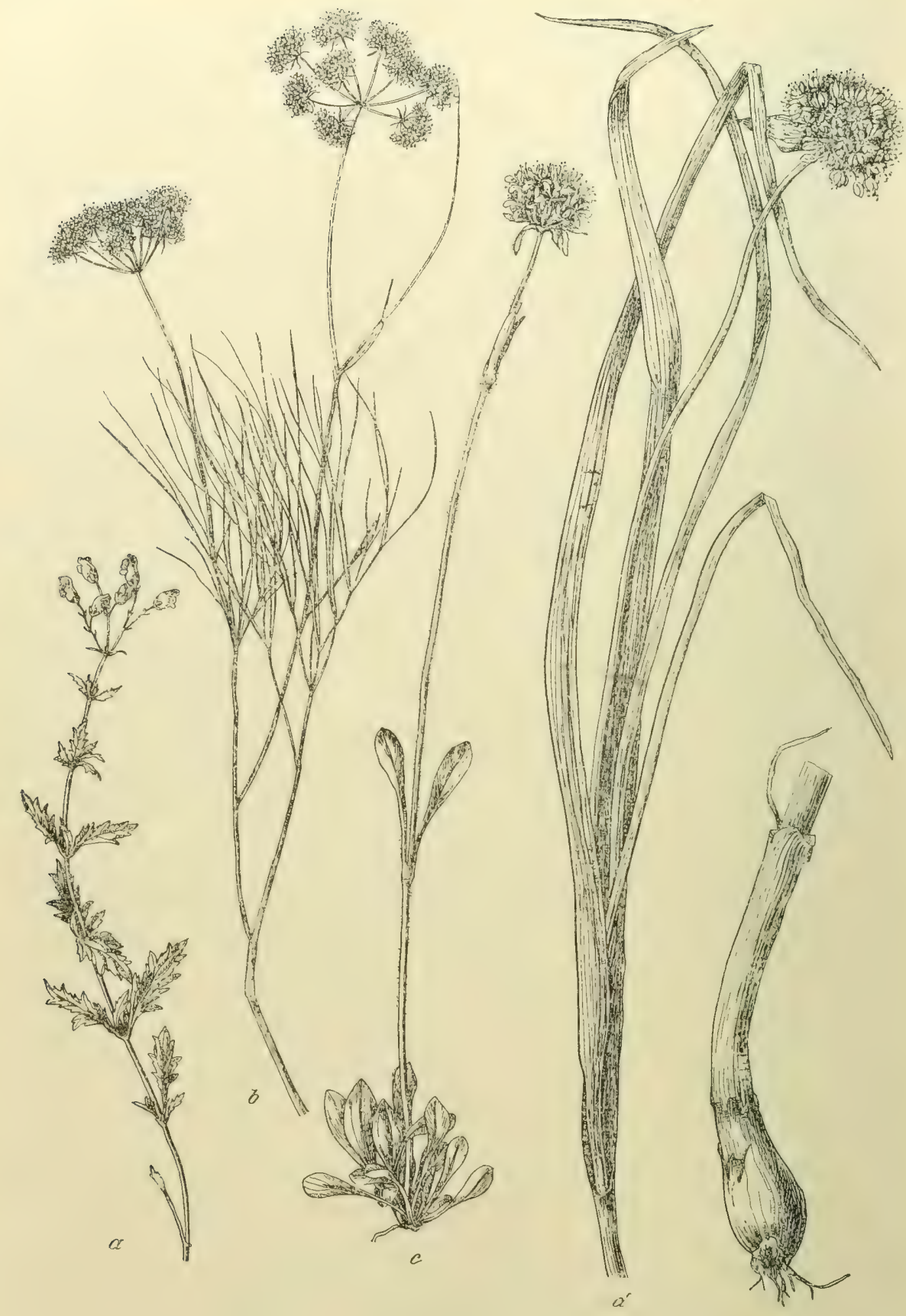

Abb. 263. Aus der Flora des Siebenbürgischen Erzgebirges.

$a$ Scrophularia lasiocaulis, $b$ Seseli gracile. $c$ Saponaria bellidifolia. $d$ Allium obliquum.

Piatra auf der Piatra Csaki (Csáklyakö) ober Tovis in der Gipfelregion auf Wiesen Csaki. Iris spuria, Lilium bulbiferum, Narcissus poëticus *seriorflorens, Orchis globosa, Crocus Heuffelianus, C. banalicus, an felsigen Hängen Lathyrus Hallersteinii, 
Silene dubia, Aclaea Cimicifugia, Aconilum moldavicum, Saxifraga luleoviridis, Centaurea variegala, Aleclorolophus alpinus, an der Tejte mare auch Dianlhus spiculifolius, Delphinium elalum, Sempervivum blandum, Sedum glaucum, Saxifraga Aizoon, S. adscendens, Veronica urticaefolia, Centaurea atropurpurea und Hieracium villosum, während in der Waldregion Hypericum monlanum, Slachys alpina, Clemalis alpina, am FuBe des Berges bei Felsö-Gald selbst Melira altissima, Aconitum Anthora, Echinops commutalus und Viola Jooi gedeihen. Fast die gleiche Flora beherhergt auch der $1920 \mathrm{~m}$ hohe Kecskekö bei Kiraly- Kecskekö

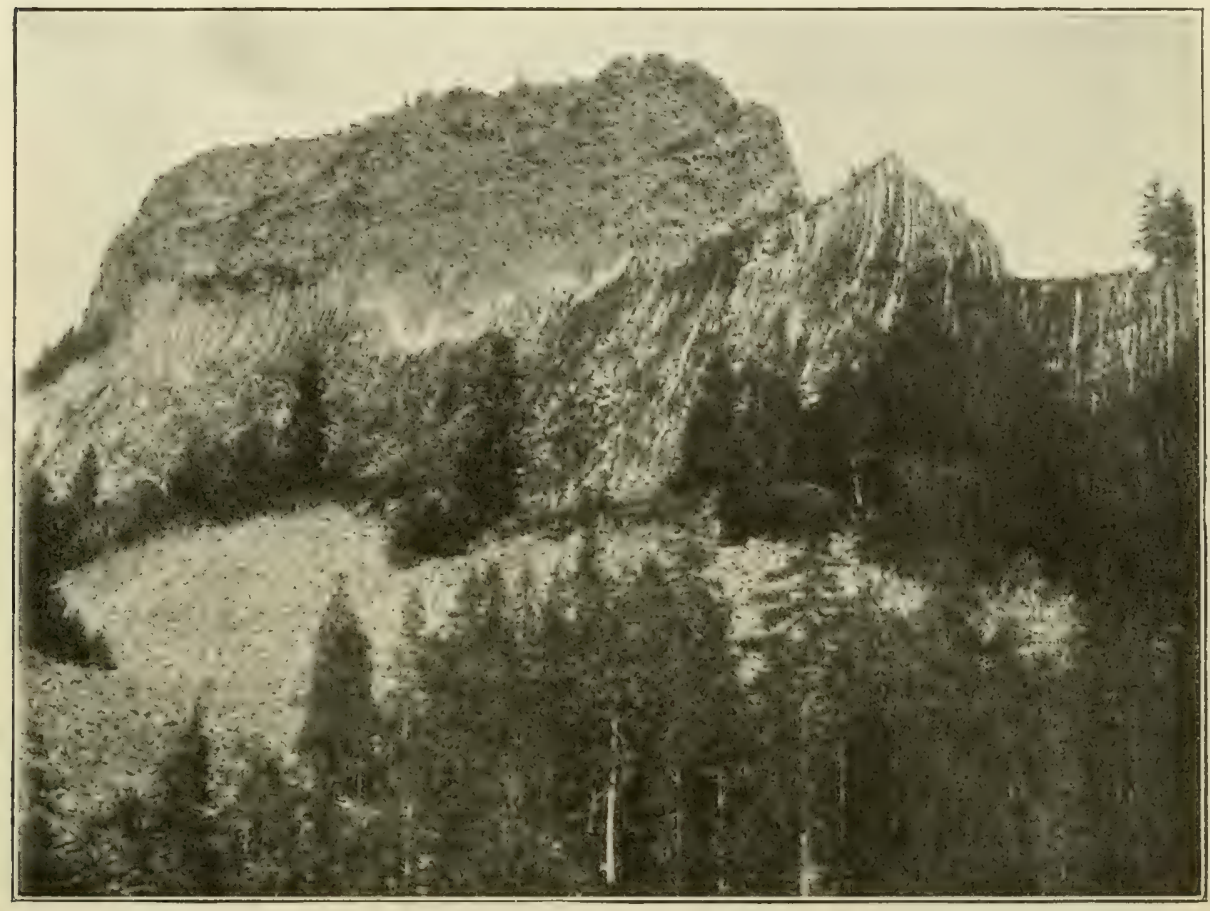

Abb. 264. Der Gipfel der Detunata.)

Fichtenwald, in den Basaltfelsen Woodsia ilvensis.

(Nach eines Aufnahme von Prof. Dr. L. v. Lóczy, Budapest.

(Aus der Bildersammlung des geographischen Institutes der Wiener Universität.)

patak, wo u. a. an den Kalkfelsen Aconitum Anthora, Alyssum murale, Silene nemoralis, Saxifraga adscendens, S. Aizoon, Sempervivum blandum, Cnidium apioides, Seseli gracile und Phyllites Scolopendrium vorkommen, während seine Hänge gemischte Eichenwälder und Buschwerk aus Corylıs, Cornus Mas, Sambucus racemosa, Sorbus Aria usw. bekleiden.

Reicher noch ist die Flora auf den Kalkbergen der nordöstlichen Ausläufer des Erzgebirges. So findet man in der Enyeder Schlucht Dryopleris Robertiana, Enveder Iris hungarica, Thaliclrum foetidum, Isatis praecox, Sempervivum blandum, Sorbus austriaca, Cnidium apioides und Onosma viride. Der Székelykö bei Székelyliö. Toroczko $(1130 \mathrm{~m})$ trägt gemischte Laubwälder aus Fagus silvalica, Carpinus 
Belulus, Tilia platyphyllos, T. cordala, Acer campestre, A. plalanoides, an seinen felsigen Westabstürzen aber gedeihen Moehringia muscosa, Silene nemoralis, Aconitum Anthora, Saxifraga Aizoon, S. adscendens, Sempervivum blandum, Sedum glaucum, Seseli gracile, Cnidium apioides, Aiuga Laxmanni, Salureia Baumgarlenii, Pedicularis campestris, Scrophularia lasiocaulis nebst Buschwerk aus Cornus sanguinea, Viburnum Lantana, Coloneasler integerrima usw. Fast die gleiche Flora findet man selbst noch an Kalkfelsen an den äußersten, schon fast ans Steppengebiet der Mezöség angrenzenden Ausläufern des Erzgebirges. Dort liegt, zwischen kaum über $700 \mathrm{~m}$ hohen, an ihrer Westseite baumlosen und von Viehweiden bedeckten Bergen eingeschlossen, die seit langer Zeit wegen Tordaer
Schlucht. ihrer ungemein reichen Flora bekannte Tordaer Schlucht (Tordai hászadek) $8 \mathrm{~km}$ westlich von Torda. Am Wege von Torda zur Schlucht findet man reichliches Buschwerk aus Cornus Mas, Acer Talaricum, Sorbus Aria, Corylus Avellana usw. mit Aclaea Cimicifugia, in der Schlucht selbst aber wachsen an den felsigen Hängen Avena decora, Melica altissima, Poa nemoralis, Carex brevicollis, Frilillaria lenella, Melandryum nemorale, Dianlhus spiculifolius, Paronychia cephaloles, Aconilum Anthora, Thaliclrum foelidum, Alysum murale, Isalis praecox, Bisculella levigata, Viola Jooi, Sempervivum blandum, Saxifraga Aizoon, Seseli gracile, S. Beckii, Silaus Rochelii, Cnidium apioides (sehr zahlreich), Ferulago silvalica, Scrophularia lasiocaulis, Linaria italica, Phyteuma orbiculare, Aster alpinus, A. linctorius, Cenlaurea alropurpurea, C. Reichenbachioides, Leonlodon asper usw, an den höchsten Felsen an der linken Talseite ferner das sibirische Allium obliquum, das hier seinen einzigen europäischen Standort besitzt, mit Ephedra dislachya und Taxus baccala, während an den gegenüberliegenden Hängen Dracocephalum austriacum und Ferula Sadleriana als Seltenheiten auftreten. Eine ähnliche, wenn auch weniger artenreiche Flora weist die benachbarte

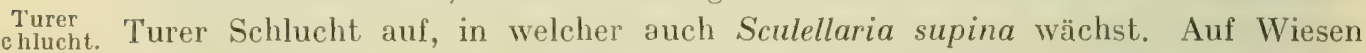
an der Westseite des die Schluchten begrenzenden Hügels sind Cirsium furiens und Ferula silvatica nicht selten.

Nordöstlich vom Erzgebirge erhebt sich das im Bihar und der Vlegyassa

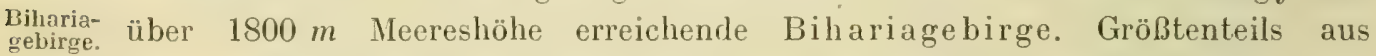
Schiefern und Porphyren aufgebaut, weist es selbst in der Hochregion eine ziemlich eintönige Flora auf. Dort aber, wo Kalk zutage tritt, also am Süd- und Südostrande des Gebirges, an den Steilhängen der Piatra Batrina, Piatra galbina und Piatra IJ ncelu, erinnert die Vegetation stark an die des Siebenbürgischen Erzgebirges. Auf Bergwiesen blühen hier Carex montana, Erylhronium Dens canis, Lilium Jankae, Gladiolus imbricalus, Grocus banaticus, Dianthus Carthusianorum, Trollius europaeus, Aquilegia Iranssilvanica, Trifolium pannonicum, Pedicularis campestris, Arnica montana usw. und an den felsigen Steilabstürzen findet man Avena decora, Sesleria rigida, Trisetum alpestre, Iris hungarica, Moehringia muscosa, Dianlhus spiculifolius, Sedum glaucum, Saxifraga cuneifolia, S. Aizoon, Amelanchier ovalis, Coloneaster tomentosa, Sorbus Aria, Cylisus leiocarpus, Peucedanum inlermedium, Libanolis leiocarpa, Hypericum umbellalum, Helianthemum rupifragum, Teucrium monlanum, Gen- 


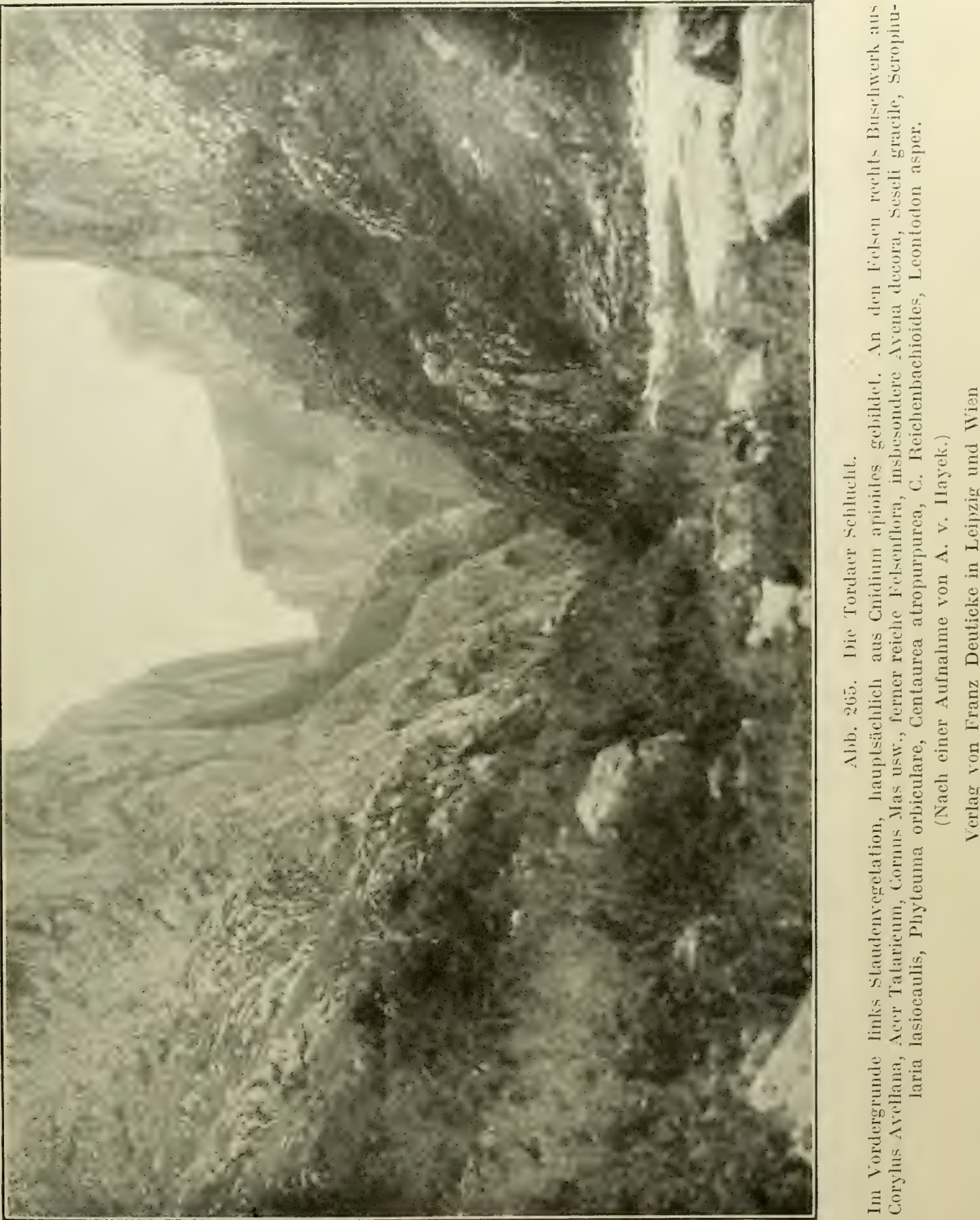





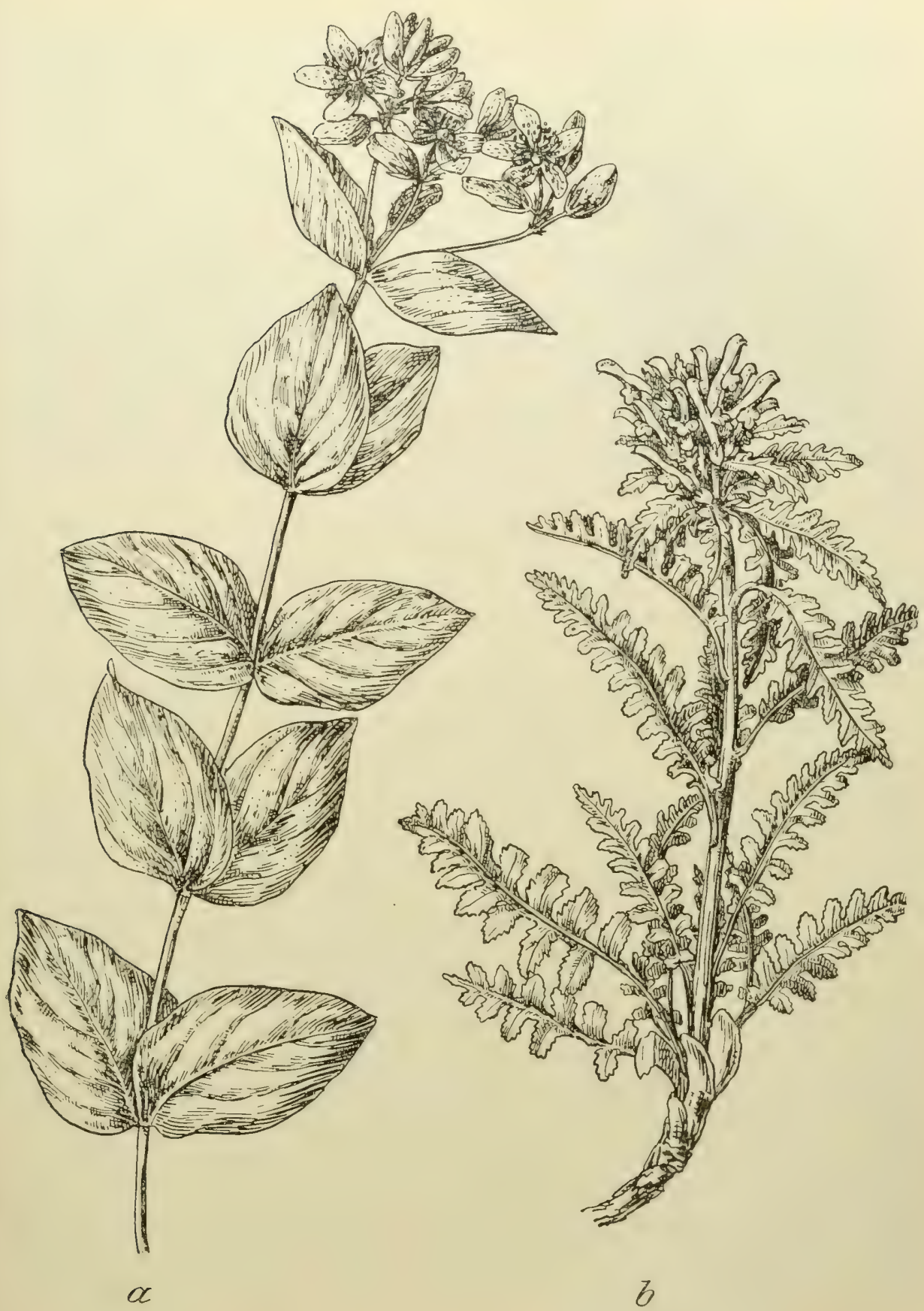

Abb. 266. Zwei seltene Arten des Bihariagebirges.

a Hypericum umbellatum, $b$ Pedicularis limnogena.

tiana Clusii, Galium lucidum, Asperula capitata und Edraianthus graminifolius. Die höheren Kuppen des ganzen Bihariagebirges bedecken Buchen- 
wälder, die bei etwa $800 \mathrm{~m}$ ihre untere Grenze finden und bei etwa $1100 \mathrm{~m}$ von Fichtenwäldern abgelöst werden. Der Niederwuchs dieser Buchenwälder ist derselbe wie allenthalben in den Ostkarpathen und besteht hauptsächlich aus Cardamine glandulosa, Helleborus purpurascens, Melandryum nemorale, Symphylum cordalum, Doronicum hungaricum und im Tale des Aranyos auch aus der in den Ostkarpathen sonst fehlenden Cardamine trifolia. Bei $1100 \mathrm{~m}$ beginnt der stark deziminierte Fichtenwald, die bei $1500 \mathrm{~m}$ am West-, bei $1800 \mathrm{~m}$ am Ostabhange seine obere Grenze findet. Darüber findet man Buschbestände aus Pinus Mughus, Alnus viridis, Juniperus intermedia (aber keine Alpenrosen) sowie ausgedehnte Alpenweiden und Borstengrasmatten, die auch schon in tieferen Lagen alle Kämme und Kuppen bedecken und neben Nardus slricla und Deschampsia flexuosa insbesondere noch Crocus Heuffelianus, Anemone alba, Polentilla lernala, Viola declinala, Laserpilum alpinum, Ligusticum Mulellina, Campanula abielina, Homogyne alpina, Scorzonera rosea, Hieracium alpinum und $H$. aurantiacum aufweisen. An quelligen Stellen findet man Carex magellanica, Saxifraga slellaris, S. heucheraefolia (=S. fonticola Kern.), Sweertia punclata und auf der Muntele mare und im Lagropetale die hier endemische Pedicularis limnogena. Der Gipfel des $1847 m$ hohen Vlegyassa bietet außer den oben genannten Arten noch Calamagroslis silvatica, Aconilum cernuum, A. Vulparia und Gnaphalium norvegicum.

In den Tälern des zentralen Teiles des Bihariagebirges sind die ehemaligen Eichenbestände größtenteils geschwunden, hingegen ist hier besonders im Aranyos- Aranyostale bei Felsö-Skerisora und Felsö-Girda das Auftreten der tal. prächtigen Syringa Josikaea bemerkenswert, die auch im nordöstlichen Teile des Gebirges bei Meleg-Szamos vorkommt und sich von hier bis in die Marmaros erstreckt. Auf den westlichen Ausläufern des Gebirges aber sind heute noch vielfach Eichenwälder erhalten, die größtenteils von Quercus Cerris, seltener von Qu. sessiliflora gebildet werden, in denen im Oberholze Juglans regia, Quercus pubescens, Carpinus Belulus, Tilia cordala, T. tomentosa eingesprengt vorkommen, während im Unterholze Acer talaricum, Cralaegus Oxyacantha und Fraxinus Ornus nicht selten sind. Daneben treten auch Triften mit Linum flavum, L. hirsulum, Geranium sanguineum, Diclamnus albus, Echium rubrum, Asyneuma canescens, Anlhemis macrantha, Doronicum hungaricum, Lacluca viminea, Hieracium umbellatum usw. auf und in der Schlucht der Weißen Körös bei Gurahoncz. Gurahoncz kommt die südrussische Centaurea trichocephala in der wenig abweichenden Form Simonkaiana vor. Am Fuße des Gebirges trifft man auf den tertiären Schottern und den Flußalluvionen auch Waldbestände von Quercus Robur und oft ausgedehnte, mit Buschwerk aus Juniperus und Cralaegus bewachsene Viehweiden.

Riszgebirge. Meszesgebirge.

Dées.
Das niedrige Bergland nördlich der Kiörös, das Részgebirge und Meszesgebirge, trägt Wälder aus Eichen, Hainbuchen und Buchen sowie Triften vom Gharakter derer des zentralsiebenbürgischen Hochlandes und nur weiter im Osten bei Dées und $\mathrm{G}$ a $\mathrm{n} \mathrm{cz}$ kommen auch einzelne Gebirgspflanzen, wie Orchis sambucina, Cypripedium Calceolus, Aconilum moldavicum, Cardamine 


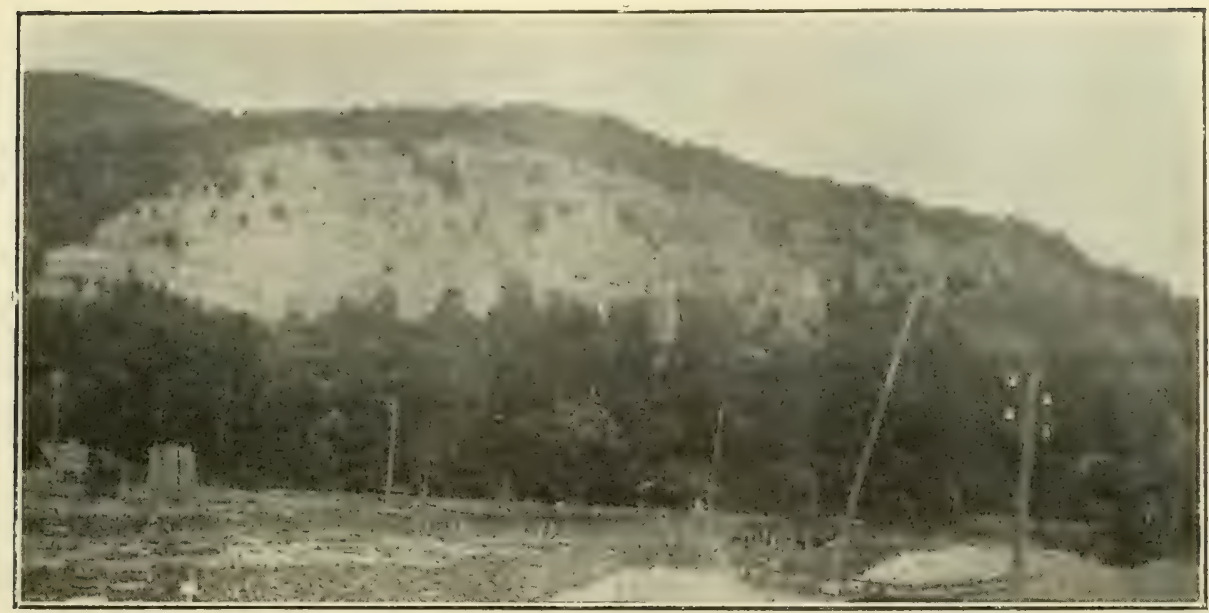

Abb. 267. Die Schlucht der Weißen Körös bei Gurahoncz, der einzige ungarische Standort Centaurea trichocephala.

(Nach einer Aufnahme von Direktor J. Wagner, Budapest.)

glandulosa, Scopola carniolica, Telekia speciosa, Doronicum auslriacum, Aposeris foetida usw. vor. Am Durchbruche der Schnellen Kiörös bei Zichybarlang aber reichen subalpine Buchenwälder bis ins T'al und an Kalkfelsen wächst hier neben Sedum glaucum, Verbascum phlomoides und Valeriana officinalis auch der südliche Farn Celerach officinarum.

Nördlich vom Lapos und der Theiß erhebt sich der Vulkanstock des Guttin, der in seiner Vegetation bereits große Ähnlichkeit mit der der Waldkarpathen zeigt. Vor allem ist hier aber das zahlreiche Auftreten von Castanea saliva in den Wäldern bei Nagybanya und Felsöbanya hervorzuheben, die sich in einzelnen Exemplaren bis ins Avasgebirge hinzicht. Über diesen Laubmischwäldern mit Edelkastanien reichen Buchenwälder mit Spiraea chamaedryfolia im Unterholze, Cardamine silvalica, Symplyylum cordalum, Campanula abietina, Veronica urticifolia, Doronicum austriacum im Niederwuchs bis zirka $1400 \mathrm{~m}$, dann folgt Buschwerk aus Alnus viridis und Juniperus nana und Alpenwiesen mit Arabis Halleri, Viola declinala, Laserpitium alpinum, Vaccinium Myrtillus, V. Vilis Idaea, V. uliginosum, Gnaphalium norvegicum und Achillea lingulala und selbst an den letzten Ausläufern gegen die Ebene bei Felsöfalu wächst noch Phyleuma lelramerum, und auf dem $1842 m$ hohen Gibles findet man neben den eben genannten Arten auch noch Juncus trifidus, Dianthus compactus, Hypericum alpigenum, Pedicularis summana, Campanula alpina, Phyteuma Vagneri, Carduus Kerneri und Scorzonera rosea.

\section{h) Das zentrale Hügelland von Siebenbürgen.}

Das zentrale Hügelland Siebenbürgens, jetzt größtenteils gut Zentrales kultiviert und von Weizen- und Maisfeldern eingenommen, war ehedem $\begin{gathered}\text { Sieben- } \\ \text { bürgens. }\end{gathered}$ größtenteils von Eichenwäldern bedeckt, deren Reste noch jetzt vielfach auf 
den Kuppen der Hügel vorhanden sind. Quercus sesseliflora, Qu. pubescens, Qu. Cerris, Carpinus Belulus, Fagus silvatica, Sorbus torminalis bilden das Oberholz dieser Wälder, im Unterholze ist Acer lalaricum häufig. Den bunten Niederwuchs bilden u. a. Erylhronium Dens Canis, Scilla bifolia, Galanthus nivalis, Silene nemoralis, Cerastium silvaticum, Anemone Hepalica, Ranunculus flabellifolius, Actaea Cimicifugia, Cardamine glandulosa, Potentilla chrysantha, Viola Riviniana, Astranlia maior, Peucedanum Rochelianum, Laserpilium pruthenicum, Vinca minor, Pulmonaria mollissima, Salureia intermedia, Lamium valgare, Melampyrum bihariense, Doronicum hungaricum, Telekia speciosa, Lactuca sagitlala, Hieracium boreale usw. Häufig sind auch Buschbestände aus Ulmus glabra, Prunus frulicosa, P. nana, Cylisus hirsulus, Acer campeslre, A. lalaricum, Cornus Mas, Viburnum Lantana sowie reichblumige Triften. In den breiteren Flußtälern finden sich ausgedehnte Talwiesen mit zahlreichen Orchideen, mit Gladiolus imbricalus, Ranunculus Steveni, Lathyrus Hallersteinii, Galega officinalis, Peucedanum Carvifolia, Galium boreale, Cirsium pannonicum, Tragopogon orientale usw., an den Flußufern treten Weidengebüsche mit Geranium palustre, Lythrum Salicaria, Calyslegia sepium, Senecio fluvialilis auf.

Im Süden und Südwesten bilden die breiten Flußtäler des Zibin und Alt eine scharfe Grenze zwischen den Randgebirgen und dem zentralsiebenbürgischen

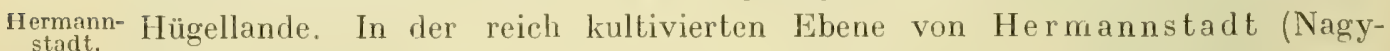
Szeben) sind nur wenige Reste von den ursprünglichen Eichenwäldern erhalten, so der ,junge Wald", aus Quercus Robur gebildet, mit reichem Unterholze aus Carpinus Belulus, Cralaegus monogyna, Prunus spinosa, P. avium, Evonymus vulgaris, Liguslrum vulgare usw., während den oft wiesenartigen Niederwuchs Dactylis glomerala, Fesluca gigantea, Galanthus nivalis, Scilla bifolia, Erylhronium Dens Canis, Ranunculus auricomus, Cylisus nigricans, Torilis Anlhriscus, Anthriscus leiocarpus, Slachys officinalis, Galium Schullesii, Campanula Cervicaria usw. bilden. Auf Wiesen tritt um Hermannstadt Narcissus poëlicus *seriorflorens, oft von Frilillaria Meleagris und Iris sibirica begleitet, zu Tausenden auf. Reiche Triften sind besonders auf den Hügeln nördlich von Hermannstadt, Hammers-
dorf. graminifolia, Crambe lalarica, Linum flavum, L. hirsutum, Astragalus monspessulanus (praecox), Gylisus leucanthus, Ferulago silvalica, Polygala maior, Verbascum phoeniceum, V. auslriacum, V.phlomoides, Campanula sibirica, Scorzonera purpurea, doch fehlt auch das eigentlich dem höheren Gebirge angehörige

Vizakna. Phyleuma letramerum hier nicht. Nördlich von Hermannstadt, bei Vizakna (Salzburg) ist der Boden weithin mit Kochsalz inkrustiert und hier findet man allenthalben auf Weiden, an Wegrändern usw. Salztriften mit Lepidium ruderale, Spergularia media, Planlago marilima, Pl. Schwarzenbergiana, Alriplex microsperma, Matricaria Chamomilla und an den mit gesättigter Sole erfüllten Teichen, soweit sie nicht in Badeanstalten umgewandelt sind, dichte Bestände von Salicornia herbacea mit Atropis salinaria, Suaeda maritima, Spergularia media, Bupleurum lenuissimum, Slatice Gmelini, Asler Tripolium, Artemisia Santonicum und Gypsophila muralis. An sonnigen Abhängen der Hügel aber sind Triften 


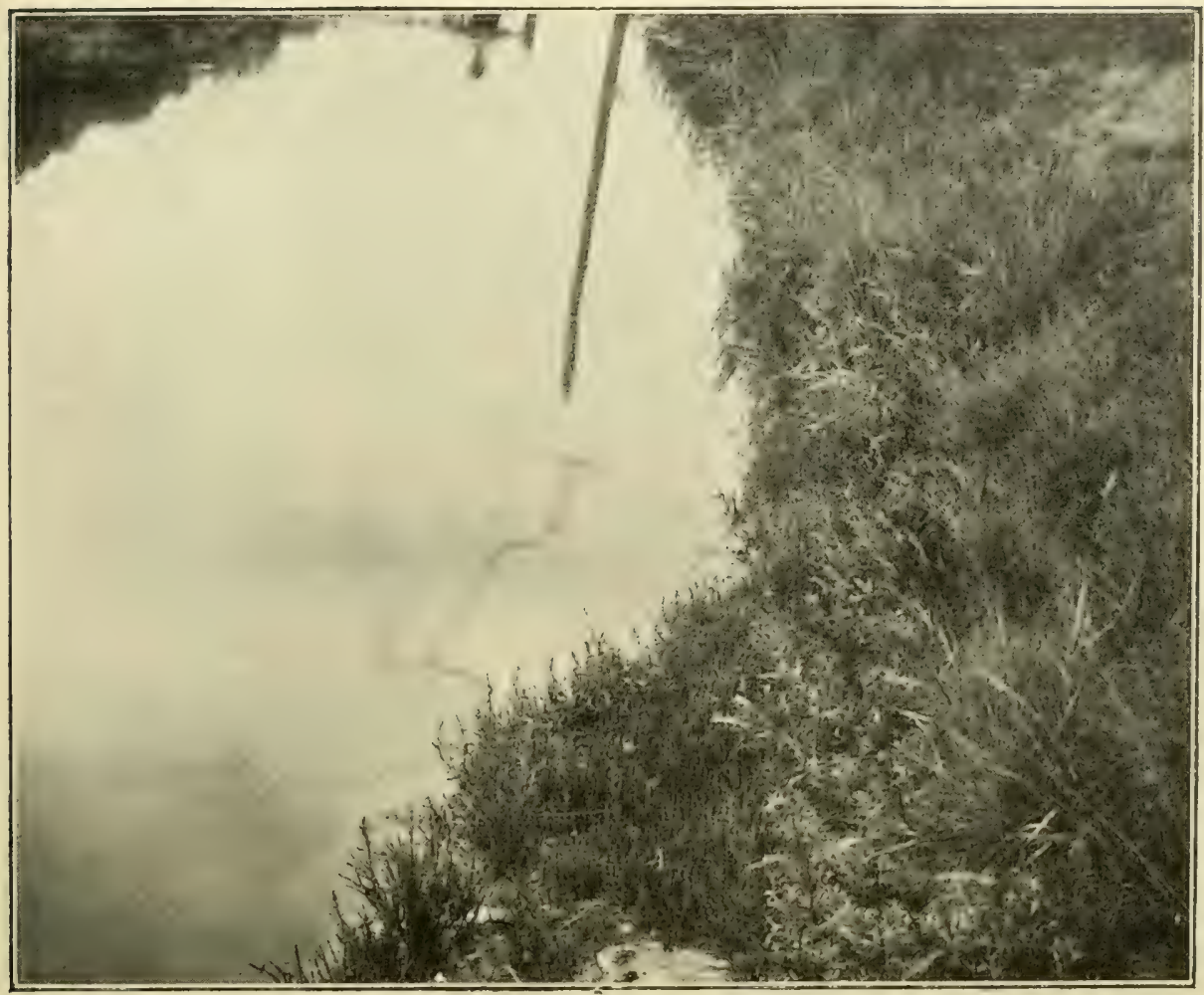

Abb. 268. Bestand von Salicornia herbacea mit Atropis salinaria und Gypsophila muralis am Ufer eines Salztümpels bei Vizakna.

(Nach einer Aufnahme von A. v. Hayek.)

mit Arenaria graminifolia, Ranunculus pedalus, Roripa pyrenaica, Rapistrum perenne, Genista sagillalis, Cylisus nigricans, Trinia Kilaibelii, Salvia nulans, S. belonicifolia, Echium rubrum, Veronica spicala, Centaurea slenolepis, Hypochoeris maculala usw. entwickelt. Bei Großpold, nordöstlich von Hermannstadt, wächst bereits das im Marostale verbreitete Verbascum speciosum mit Silene Armeria, Dianthus giganleus, Cylisus Rochelii, Althaea pallida usw. und zwischen ReuBmarkt und Mühlbach treten wieder Halophyten, wie Althaea officinalis, Trigonella procumbens, Stalice Gmelini auf.

Ähnliche Triften, wie bei Hammersdorf und Vizakna, sind am Rande des Hochlandes gegen das Gebirge zu überall anzutreffen. So findet man auf dem ,,Roten Rech“ bei Mühlbach, einem Lößhügel, Allium flavescens, Dianthus Mühbach. serotinus, Erysimum canescens, Cylisus polytrichus, Althaea hirsuta, Onosma viride, Aiuga Laxmanni, Salvia lranssilvanica, S. auslriaca, Verbascum speciosum, V. Lychniles, Echinops rulhenicus, Carthamus lanalus. Serralula radiala usw. und auf dem nahe gelegenen Billak Iris spuria, Delphinium fissum, Rapistrum perenne, Linum nervosum, L. flavum, L. tenuifolium, Phlomis tuberosa, Veronica spicala, Inula germanica, I. ensifolia, Jurinea transsilvanica, Cirsium pannonicum, Centaurea variegala. 
Im Kokeltale, zwischen Mediasch und Blasendorf, treten stellenweise Sümpfe mit Typha lalifolia, Leersia oryzoides, Glyceria aqualica, Schoenoplectus Iriqueler, Bulomus umbellalus, Alisma Planlago, Orchis elegans u. dgl. auf; die Ufer des Kokel umsäumt Buschwerk aus Salix alba, S. triandra, S. purpurea, S. viminalis und Myricaria germanica. Die Wälder des Gebietes sind durchwegs gemischte Laubholzbestände aus Fagus silvalica, Quercus sessiliflora und Carpinus Belulus, in deren Niederwuchs Erylhronium Dens Canis, Scilla bifolia, Galanthus nivalis, Polygonalum latifolium, Anemone Hepatica, Cardamine glandulosa, Vicia pisiformis, Genista sagittalis, Cylisus nigricans, C. leucanthus, Astrantia maior, hie und da, wie auf dem Hehves bei Klein-Probstelorf, auch Telelia speciosa die bezeichnendsten Arten sind. Vicl wichtiger als die vielfach abgeholzten Wälder aber sind für den landschaftlichen Charakter die Buschgehölze mit der rosenrot blühenden Zwergmandel (Prunus nana) sowie die hier besonders artenreichen und oft Steppencharakter annehmenedn Trift-

Mediasch. formationen. Die bezeichnendsten Arten dieser Triften sind bei Mediasch (Mergyes) Slipa pennala. Melica lranssiluanica, Carex Michelii, Fritillaria lenella, Iris caespilosa, Anacamptis pyramidalis, Adonis vernalis, Silene chlorantha, Gylisus leucanthus, Genisla sagillalis, Astragalus dasyanlhus, A. monspessulanus, Lalhyrus laevigalus, Polygala maior, Peucedanum Oreoselinum, Salvia nulans. Verbascum phoeniceum, Linaria genistifolia, Inula hirla, Echinops commulalus, Serralula radiala, Jurinea transsilvanica, Cenlaurea variegala und Hypochoeris Langental. maculala, bei Langental findet man überdies noch Andropogon Gryllus, Allium flavescens, Crambe talarica und Astragalus albidus. Dieselben Arten und überdies scholten. Hesperis runcinata kommen auch bei Scholten (Szasz Csanad) vor, wo auf dem Hohen Berge die asiatische Polygala sibirica ihren einzigen europäischen Standort besitzt. Hie und da treten im Kokeltale auch Halophytenformationen Tür. auf, wie bei Alsdorf und besonders bei Tür, wo sich u. a. Bupleurum tenuissimum, Slatice Gmelini und Aiuga Laxmanni finden.

Talaufwärts nehmen die Hügelpflanzen an Artenzahl rasch ab. Um Schäßburg. Schäßburg (Segesvar) nehmen die Wälder noch einen beträchtlichen Teil der Bodenfläche ein. Es sind, wie überall im Innern Siebenbürgens, gemischte Laubwälder aus Fagus, Carpinus Betulus, Quercus Robur, Qu. pedunculata, Sorbus torminalis, Tilia cordala, Acer plalanoides usw., denen॰jegliches Nadelholz, auch Föhren und Wacholder, fehlt. Das Unterholz bilden Corylus, Cornus Mas, C. sanguinea, Evonymus vulgaris, E. verrucosus, Cralaegus Oxyacantha, C. monogyna, Lonicera Xylosleum usw., der Niederwuchs ist derselbe wie überall im Innern Siebenbürgens und Erythronium Dens canis, Galanthus nivalis und Anemone Hepalica sind im Frühling ein herricher Schmuck des Waldes. Auch Wiesen sind um Schäßburg in großer Ausdehnung anzutreffen und sind durch das häufige Vorkommen von Dianthus Carlhusianorum, Trifolium pratense, T. repens, Geranium pratense, Alectorolophus rumelicus, Chrysanthemum Leucanthemum und Cichorium Intybus ausgezeichnet. Hie und da trifft man auch kleine Wiesenmoore mit Potentilla palustris, Menyanthes trifoliata usw., selten sind kleine Hochmoore mit Drosera rolundifolia. In Gebüschen gedeihen Prunus 
Padus und auch Acer lataricum; Triftormationen aber sind auf wenige Lokalitäten, wie Siechenberg, Wieteberg, Schustergraben usw. beschränkt und weisen von bezeichnenden Arten insbesondere Anthericum ramosum, Iris hungarica, I. caespitosa, Fritillaria tenella, Diclamnus albus, Astragalus monspessulanus, A. austriacus, Vinca herbacea, Verbascum phoeniceum, Linosyris vulgaris, Artemisia Absynthium auf, während im Frühling Prunus nana seine leuchtend rosenroten Blüten entfaltet. In höheren Lagen gegen die Hargita zu, wie bei Atelsloch, treten auch schon einige Gebirgsarten, wie Orchis globosa, Atelsloch. Cardamine glandulosa, Astrantia maior, Crepis pannonica und vereinzelt auch Picea excelsa, auf. In der Nähe des Barleortes Baassen (Bázna) kommen auch Baassen. wieder Halophyten, so Spergularia media, Salicornia herbacea, Alriplex microsperma, Lotus tenuis, Asler Tripolium und Scorzonera parviflora vor, an stehenden Wässern ist hier Schoenopleclus triqueler nicht selten und auf sonnigen Hügeln trifft man Buschwerk aus Cornus mas, Cylisus nigricans usw., begleitet von Adonis vernalis, Dorycnium herbaceum, Hibiscus lernatus, Allhaea officinalis u. a.

Den östlichen Abschluß des zentralsiebenbürgischen Berglandes bildet der mächtige, von Norden nach Süden sich erstreckende Trachytzug der H a rgita, der durch die Täler der Gyergyo und Gsik von den östlichen Randgebirgen getrennt wird. An der Ostseite dieses Gebirges reichen reichlich mit Juniperus communis und Pleridium aquilinum bewachsene Viehweiden bis $\mathrm{zu}$ einer Höhe von etwa $1400 \mathrm{~m}$, darüber aber bedecken Fichtenvälder mit eingestreuten Tannen die Hänge, in denen Vaccinium Myrlillus und V.Vitis Idaea, in höheren Lagen auch Vaccinium uliginosum und Juniperus nana den Boden bedecken und nur hie und da bringen Polygonalum verlicillalum, Helleborus purpurascens oder Pulmonaria rubra Abwechslung in den eintönigen Niederwuchs. Reicher ist die Flora auf den die höheren Kuppen bedeckenden Bergiviesen, auf denen in dem hauptsächlich aus Deschampsia flexuosa, D. caespitosa und Luzula sudetica grebilileten Rasen Crocus Henffelianus, Rumex arifolius, Melandryum silvestre, Dianthus speciosus, Trollius europaeus, Ranunculus carpaticus, Potentilla ternala, Hypericum maculatum, Solidago alpestris, Hypochoeris maculala und Hieracium aurantiacum gedeihen. Das niedrige Buschwerk besteht aber nur aus Juniperus nana und Vaccinien, und Krummholz fehlt hier ebenso wie Grünerlen und Alpenrosen. Auf dem von Felsblöcken bedeckten, $1801 \mathrm{~m}$ hohen Gipfel findet man überdies noch Carex curvula, Gymnadenia albida, Scleranthus uncinatus, Laserpitium alpinum, Soldanella hungarica, Campanula Scheuchzeri, Phyleuma Vágneri, Valeriana tripteris und Lycopodium Selago. Reicher ist die Flora an der Westseite des Gebirges. Hier stehen unter der Fichtenzone ausgedehnte Buchenwälder mit Hordeum europaeum, Poa Chaixii, Herminium Monorchis, Ceraslium silvalicum, Silene viridiflora, Cardamine glandulosa, Helleborus purpurascens, Ranunculus carpalicus, Mercurialis perennis, Hypericum transsilvanicum, Sanicula europaea, Symphytum cordalum, S. luberosum, Digitalis ambigua, Asperula odorata und von Homorodfürdö an südwärts sind auch Anemone transsilvanica und Waldsteinia trifolia nicht selten. An Bergbächen und feuchten Waldstellen findet man Aconilum moldavicum, A. gracile, Angelica Archangelica, Pleuro- 
spermum austriacum und Doronicum auslriacum, auf Wiesen Tausende von weißen Narzissen (Narcissus poëticus *seriorflorens) sowie Orchis globosa, Thesium ramosum, Adenophora liliifolia, Phyteuma letramerum und Scorzonera humilis. Auch Moore sind besonders zwischen Ohlafalva und Lövete anzutreffen, auf denen neben Juncus Rochelianus, Oenanlhe banalica, Oxycoccos quadripelala, Andromeda polifolia uud Senecio paludosus die in Siebenbürgen sehr seltene Ohlafalva. Pedicularis Sceptrum Carolinum wächst, bei Ohlafalva kommen auf feuchten Wiesen auch Cenlunculus minimus, Gratiola officinalis, Peplis Portula, Cicuta virosa, Cnidium venosum und Cirsium palustre vor. Am Fuße des Gebirges bis IIomorod-
fürdö. wie Potentilla canescens, Agrimonia pilosa, Linum flavum, Ferulago silvatica, Lacluca saligna und $L$. perennis auf und unter den Ackerunkräutern findet man schon Conringia orienlalis, Nigella arvensis und Lalhyrus Aphaca.

Auch die südlichsten Ausläufer dieses Bergzuges, der Talinenberg, Honigberg. Leimpeschberg und Breite Berg bei Honigberg (Szász-Hermany) beherbergen eine interessante Flora. Die Kuppen dieser Berge bedecken Eichenwälder, aus deren Niederwuchs Anemone lranssilvanica, Helleborus purpurascens und Melampyrum bihariense besonders hervorzuheben sind, an den Abhängen aber sind teils Buschbestände aus Prunus spinosa, P. fruticosa, P. nana, Coloneasler integerrima, Spiraea crenifolia, Rosa spinosissima, Cralaegus monogyna usw., teils steppenartige Triften mit sehr reicher Flora, wie Hyacinthella lencophaea, Ornilhogalum tenuifolium, Iris hungarica, Allium flavescens, Arenaria graminifolia, Dianthus saxigenus, Anemone nigricans, Ranunculus nemorosus, Adonis vernalis, Draba verna, D. nemorosa, Agrimonia glandulosa, Cytisus albus, C. pallidus, Onobrychis arenaria, Linum flavum, L. perenne, Helianthemum canum, Lavalera thuringiaca, Seseli annuum, Silaus Rochelii, Dictamnus albus *gymnostylis, Echium rubrum, Salvia nulans, Veronica orchidea, Linaria dalmatica, Scorzonera austriaca, Centaurea micranthos, Leontodon asper usw. entwickelt, so daß sie in ihrer Zusammensetzung schon lebhaft an die Steppenwiesen der Itezöseg erinnern. Auf lem Talinenberge liegt auch der einzige siebenbürgische Standort von Peucedanum arenarium.

Nördlich schließt sich an die Hargita der bedeutend niedrigere Sandsteinzug Görgenyer des Görgenyer Gebirges an. Am Westfuße desselben sind hie und da Halo-
Gebirqe. phyten anzutreffen, so im Görgenyer Tale und insbesondere bei Parajd, wo u. a. Atropis salinaria, Salicornia herbacea, Alriplex microsperma, Spergularia marginata und Aster Tripolium wachsen. Die Hänge des Gebirges jedoch bedecken genischte Laubwälder aus Carpinus Betulus, Quercus Robur, Qu. sessiliflora, Tilia cordala, Acer plalanoides usw. mit reichlichem Unterholze aus Spiraea chamaedryfolia, Rhamnus Frangula, Cornus sanguinea, Evonymus vulgaris, E. verrucosus usw., während die höheren Kuppen schöne Buchenbestände, die öfter durch Abies alba unterbrochen sind, überziehen, und in Bachschluchten hochwüchsige Stauden, wie Rumex arifolius, Melandryum silvestre, Geum rivale, Angelica silvestris, Polemonium coeruleum, Senecio nemorensis und Mulgedium alpinum üppig wuchern. 


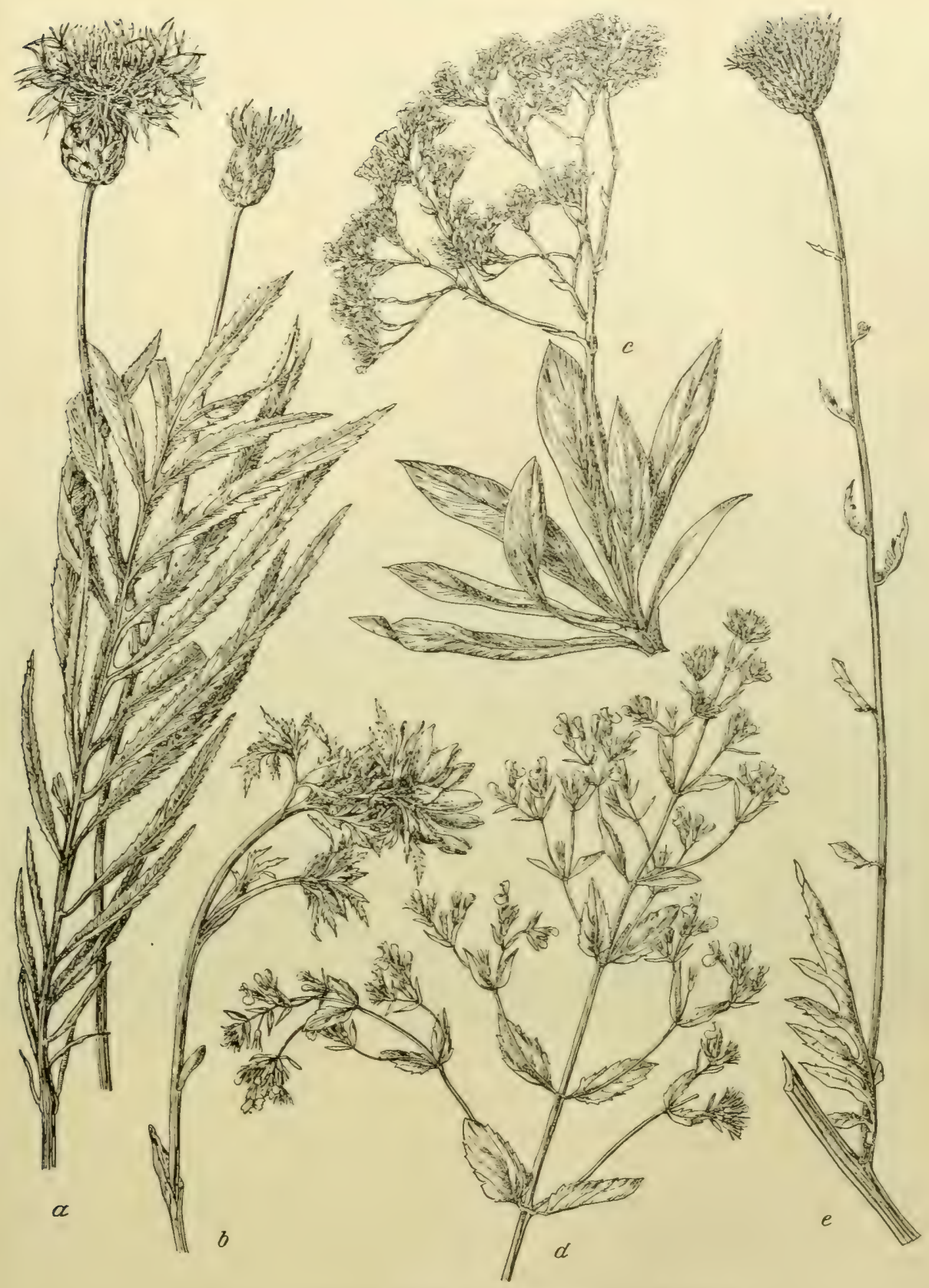

Abb. 269. Seltene Arten aus der Flora der Mezöség.

$a$ Centaurea ruthenica. $b$ Adonis wolgensis, $c$ Goniolimon tataricum. $d$ Nepeta ucranica. e Serratula Wolffii.

Den ganzen nordwestlichen Teil des zentralsiebenbürgischen Hügellandes vom Marostal nordwärts, nach Westen bis Kolozsvár und Torda, nach Osten bis Maros-Ujvár und Sächsisch-Regen, nach Norden bis Betlen 
und D é v a sich erstreckend, nimmt das über 5000 Quadratkilometer große Mezöség. Steppengebiet der Mezöség ein. Die Mezöség ist ein welliges Hügelland, dessen höchste Erhebungen die Höhe von $700 \mathrm{~m}$ kaum überschreiten und das des Baumwuchses ganz entbehrt und mit üppigen Wiesen und Triften bedeckt war. Am Rande ist der Boden der Mezöség allenthalben salzhaltig und an den in den Vertiefungen und Tälern zutage tretenden Quellen sind vielfach Halophyten anzutreffen, im Zentrum fehlt ein salzdurchdrängter Boden. Heute ist das Gebiet der Mesöség gut kultiviert und weithin von Mais- und Weizenäckern bedeckt, doch sind auch größere Wiesen- und Stepppenkomplexe

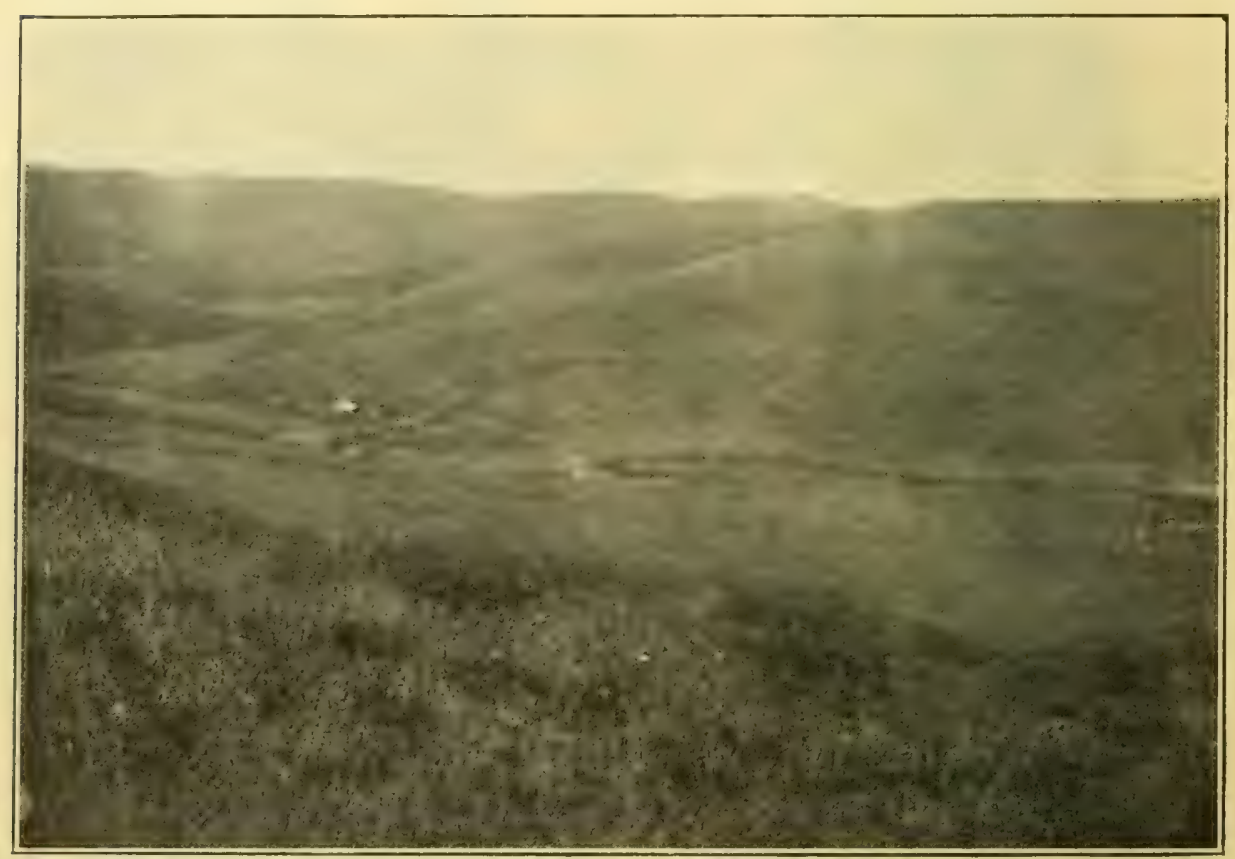

Abb. 270. Die Heuwiesen bei Kolozsvár, ein typisches Landschaftsbild aus der Mezöség.

(Nach einer Aufnahme von A. v. Hayek.)

noch jetzt erhalten. Im Norden und Osten der Mezöség scheinen Triftformationen über die eigentlichen Steppen wie auch sonst im Gebiete weitaus zu überwiegen ; Sächsisch- so werden für die Flora der Umgebung von Sächsisch-Regen (Szász-Regen)
Reren. Erysimum canescens, Allhaea hirsula, Aiuga Laxmanni, Salvia Lranssilvanica, Echium rubrum, Verbascum nigrum, V. Lychniles, Scabiosa ochroleuca und Serralula radiala als die bezeichnendsten Arten angeführt; doch ist die Flora des nördlichen Anteiles der Mezöség noch recht unvollkommen bekannt. Für die Wiesen und 'Triften der ganzen Mezöség sind Fesluca elalior, Allium flavescens, Dianthus Carthusianorum, Arenaria graminifolia, Adonis vernalis, Anemone montana, Filipendula hexapelala, Astragalus monspessulanus, Dorycnium herbaceum, Linum nervosum, Althaea pallida, Silaus Rochelii, Anchusa Barellieri, 


\section{Verlag von Franz Deuticke in Leipzig und Wien.}

Die europäischen Gattungen der Farn- und Blütenpflanzen nach dem Wettsteinschen System geordnet

ron

Erwin Janchen.

Zweite, verbesserte Autlage.

Preis M. $2 \cdot-=\mathrm{K} 240$.

\section{Waldwegebaukunde. \\ Von}

dipl. For. Julius Marchet,

o. . Professor an der $\mathbf{k}$. $\mathbf{k}$. Hochschule für Bodenkultur in Wien,

Fachberichterstatter des k. k. Ackerbamministeriums.

I. Band: Das Trassieren und die Projektverfassung.

Mit 15 lithographischen Tafeln und 29 Abbildungen im Text.

Preis M. $7 \cdot 50=\mathrm{K} 8 \cdot 40$.

\section{Der Holzhandel Norddeutschlands.}

\section{Von}

dipl. For. Julius Marchet,

o. ö. Professor an der k. k. Hochschule für Bodenkultur in Wien, Fachherichierstatter des $k$. $k$. Ackerbauministeriums.

Mit 16 Abbildungen, 1 Situationsplane und 1 Karte.

Preis M. $7 \cdot-=\mathrm{K} 8 \cdot 40$.

\section{Die Grundlagen der Bodenkunde.$$
\text { Von }
$$

Dr. L. Milch,

Privatdozent für Mineralogie und Geologie an der Universität Breslau.

Prois M. $4^{\circ}-=\mathrm{K} 4: 80$.

Flora des österreichischen Küstenlandes.

Von

Eduard Pospichal.

Nit 25 Tabellen und einer Kiarte des österreichischen Kiistenlandes.

Zwei Bïnde in drei Teilen.

Preis eines jeden Teiles geh. M. $8 \cdot-=\mathrm{K} 9 \cdot 60$, geb. M. $10^{\circ}-=\mathrm{K} 12 \cdot$.

Einleitung in die experimentelle Morphologie der Tiere.

\section{Von}

Dr. phil. Hans Przibram,

Privatdozenten an der Wiener Universitht.

Preis M. $4 \cdot-=\mathrm{K} 4 \cdot 80$.

\section{Experimental-Zoologie.}

\section{Von}

Dr. phil. Hans Przibram,

\section{Privatdozenten an der Wiener Universitat.}

I. Teil. Embryogenese. II. Teil. Regeneration. IlI. T'eil. Phylogenesc.

Nit 16 lithorraph. Tafeln. Nit 16 lithograph. Tafeln. Mit 24 lithograph. Tuf ln.

Prois M. 7. $=\mathrm{K} 8.40 . \quad$ Prois Mr. $14^{\circ}-=\mathrm{K} 16^{\circ} 80 . \quad$ Preis M. $18 \cdot-\mathrm{K} 21 \cdot 60$.

\section{Teil. Vitalitåt.}

Mit 10 lithographischen Tafeln.

Preis N. $10^{\circ}-=\mathrm{K} 12 \cdot-$.

\section{Teil: Funktion inkl. Sexualität.}

Nit 12 lithographischen 'l'afeln.

Preis Mr. $12^{\circ}-=\mathrm{K} 14 \cdot 40$. 


\section{Verlag von Franz Deuticke in Leipzig und Wien.}

\section{Lehrbuch der Pflanzenkunde}

fur die unteren Klassen der Mittelschulen

von

Dr. Rudolf Scharfetter,

k. k. Professor an der II. Staatsrealschule in Graz.

Mit 201 Abbildungen im Text und 28 farbigen Tafeln.

Preis geb. M. $3 \cdot 60=\mathrm{K} 4 \cdot$ -

\section{Vitalismus.}

\section{Elementare Lebensfunktionen.}

Von

Dr. Karl Camillo Schneider,

Privatdozent an der Universität Wien.

Preis geh. M. $11-=\mathrm{K} 13 \cdot 20$, geb. M. $12-=\mathrm{K} 14 \cdot 40$.

\section{Handbuch der systematischen Botanik.}

Von

Dr. Richard R. v. Wettstein, Professor an der Universität in Wien.

Zweite, umgearbeitete Auflage.

Mit 3692 Figuren in 600 Abbildungen und mit einer farbigen Tafel:

Preis geh. M. $20^{\circ}-=$ K $24^{\circ}-$, geb. M. $26 \cdot 60=$ K $32^{\circ}-$.

\section{Vegetationsbilder aus Südbrasilien.}

Von

Dr. Richard R. v. Wéttstein,

Professor an der Unirersitat in Wien.

Nit 58 Tafeln in Lichtdruck, 4 farbigen Tafeln und 6 Textbildern.

Preis M. $24 \cdot-=\mathrm{K} 2 \mathrm{k} \cdot 80$.

\section{Die Samenpflanzen.}

\section{(Blutenpflanzen, Phanerogamen.)}

Systematische Übersicht ihrer Familien und wichtigeren Gattungen und Arten mit besonderer Beriicksichtigung der fiir Land- und Forstwirtschaft, Technik und Arzneikunde in

Betracht kommenden Gewächse

von

Dr. Karl Wilhelm,

o. ö. Professor der Botanik an der k. k. Hochschule für Bodenkultur in Wien.

Mit einem Anhange, enthaltend eine Übersicht der wichtigsten kryptogamen Nutzpflanzen.

Preis geh. M. $5 \cdot-=\mathrm{K} 6 \cdot-$, geb. M. $6 \cdot 20=\mathrm{K} 7 \cdot 40$.

\section{Grundriß der Waldwegebaulehre}

nebst einer Aufgabensammlung

und neuen Hilfstafeln zur Erdmassen-Berechnung

von

Dr. Karl Wimmenauer,

o. Professor der Forstwissenschaft an der Unirersität Gießen.

Mit einer Waldkarto und 4 Figurentafeln.

Preis M. $4 \cdot-=\mathrm{K} 4 \cdot 80$.

\section{Grundriß der Waldwertrechnung und forstilichen Statik} nebst einer Aufgabensammlung

bearbeitet von

Dr. Karl Wimmenauer,

o. Professor der. Forstwissenschaft an der Universität Gießen.

Mit 1 Kurventafel.

Preis M. $3 \cdot-=\mathrm{K} 3 \cdot 60$. 


\section{DIE PFLANZENDECKE ÖSTERREICH-UNGARNS}

AUF GRUND FREMDER UND EIGENER FORSCHUNGEN GESCHILDER'T VON

Dr. AUGUST EDLER VON HAYEK, PRIVATDOZENT FÜR STSTEMATISCHE BOTANIK AN DER UNIVERSITÄT WIEN.

HERAUSGEGEBEN MIT EINEN DRUCKKOSTENBEITRAG DER KAISERLICHEN AKADEMIE DER WISSENSCHAFTEN IN WIEN.

VOLLSTÄNDIG IN ZWEI BÄNDEN VON ETWA JE 5 LIEFERUNGEN. MIT ZAHLREICHEN ABBILDUNGEN UND TAFELN. PREIS JEDER LIEFERUNG $6 K=5 \mathrm{Mk}$.

\section{BAND.}

5. LIEFERUNG.

LEIPZIG UND WIEN.

FRANZ DEUTICKE. 1916. 


\section{Verlag von Franz Deuticke in Leipzig und Wien.}

\section{Die Erscheinung der Anisophyllie.}

Eine morphologisch-physiologische Studie

von

Dr. Wilhelm Figdor,

Privatdozent für Anatomie und l'h

Mit 23 Abbildungen im Text und 7 T'afeln in Lichtdruck.

Preis M. $7 \cdot-=1 \mathrm{~K} 8 \cdot 40$.

Landwirtschaftliche Pflanzenzüchtung

und ihre Stätten in Österreich.

Dargestellt von

Prof. C. Fruhwirth,

diplomierter Landwirt, Dozent an der $k$. $k$. Hoclsschule für Bodenkultur.

Preis M. $1 \cdot 80=$ K 2.

Führer zu den wissenschaftlichen Exkursionen

des II. internationalen Kongresses Wien Igo5.

Herausgegeben vom

Organisationskomitee des II. intornationalen botanischen Kongresses unter Mitwirkung von

A. Cieslar, A. Ginzberger, I. Freih. v. Handel-Mazzetti, A. v. Hayek, M. Maly, V. Schiffner, F. Vierhapper und E. Zederbauer.

Mit 52 Lichturucktafeln, 1 Titelbild und 12 Textabbildungen.

Preis in Mappe M. $20^{\circ}-=\mathrm{K} 20^{\circ}$ - .

\section{Einführung in die Biochemie}

für Naturhistoriker und Mediziner.

Von

Dr. Viktor Grafe,

Privatdozent an der W.ener Universität.

Mit 41 Abildungen im Text.

Preis MI. $13 \cdot-=\mathrm{K} 15^{\circ} 60$.

Die Forstbetriebseinrichtung:

Fiir Studierende und ausibende Fachuäuner

dargestellt von

Dr. Adolf Ritter v. Guttenberg,

k. k. Hufrat und o. ö. P'rofessor an der k. k. Hochschule für Bodenkultur in Wien.

Zweite Auflage. Mit 3 Tafeln in Farbendruck und 41 Figuren in 'I'ext.

Preis geh. NI. $10 \cdot-=\mathrm{K} 12$. geb. M. $11 \cdot 20=\mathrm{K} 13 \cdot 40$.
Wachstum und Ertrag der Fichte im Hochgebirge.

\section{Von}

Dr. phil. Adolf Ritter v. Guttenberg,

Ehrendoktor der Bodenkultur, k. k. Hofrat und Professor i. $\mathbf{R}$.

Mit 3 Abbildungen im I'ext und 21. Tafeln.

Preis kart. M. $10^{\circ}-=\mathrm{K} 12$.

\section{Monographie der Gattung Taraxacum.}

\section{Von}

Dr. Heinrich Freiherr v. Handel-Miazzetti,

Assistent am botanischen Institut der $\mathrm{k}$, $\mathrm{k}$. Universität in Wien.

Mit 2 Tafeln in Lichtiruck, 3 lithographischen T'afcln und 2 Kitrten.

Preis M. 15 - $=$ K 18.

Flora von Brixen a. E.

Ein mit Standorts- und Höhenangaben verschenes Verzeichnis der im weiteren Gebiete von Irixen a. E. (Siidtirol) biobachteten wilıwachsenden höheren Sioren- und Samenptlanzen, der Nutzgemächse und Zicrgehölze.

Verfaßt von

Dr. Anton Heimerl.

Mit einer aus dem Legate Scholz gewiihrten Unterstïtzung der kaiserl. Akademie der IVissenschafton in Wien.

Preis M. $8 \cdot-=$ K $9 \cdot 60$. 
Echium rubrum, Nepela pannonica, Salvia nulans. Phlımis luberosa, Alectorolophus rumelicus, Scabiosa ochroleuca, Jurinea transsilvanica, Carduus candicans, Cenlaurea spinulosa, $C$. indurata die bezeichnendsten und häufigsten Arten. Bei Katona und Kisczeg treten auch Stipasteppen mit Stipa Lessingiana, Iris humilis, Astragalus transsilvanicus und Centaurea trinervia auf, und bei Zah wächst auch die prächtige, im Banat wiederkehrende Paeonia tenuifolia, Adonis wolgensis und Goniolimon lalaricum. Am reinsten ist der Steppencharakter dieser

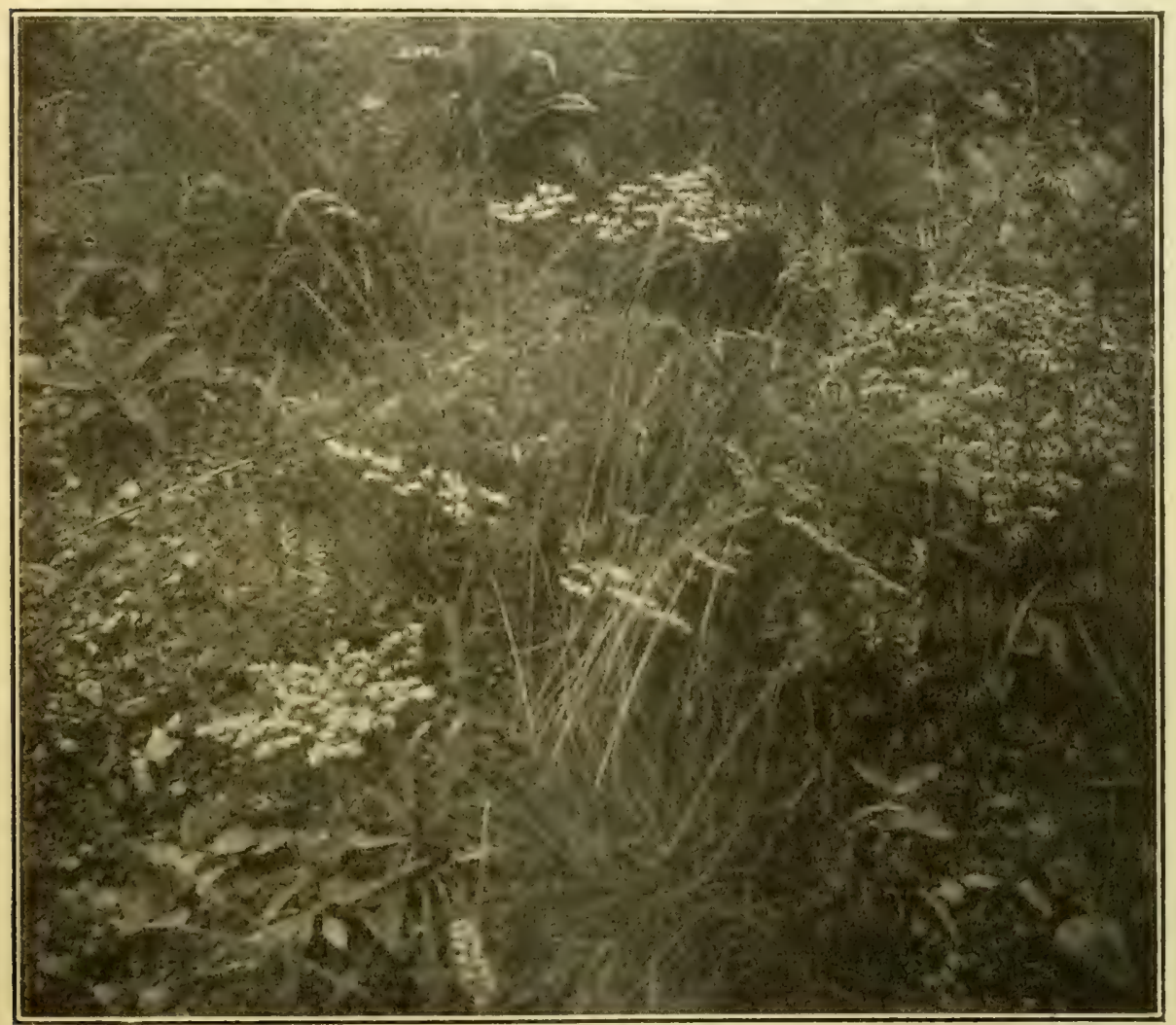

Abb. 271. Goniolimon tataricum bei Klausenburg.

(Nach einer Aufnahme von A. v. IIayek.)

Wiesen und Triften zwischen Kolos, Korpad und Apahida ausgeprägt,' wo auf Sandboden Stipa Tirsa, Sl. capillala, Fesluca vaginala, Koeleria glauca, Kolos. Polygonum palulum, Crambe aspera, Aslragalus monspessulanus, Oxytropis pilosa, Diclamnus albus, Androsace elongala, Phlomis luberosa, Campanula sibirica, Serralula radiata, S. nitida und $S$. Wolffii anzutreffen sind; die interessanteste Steppenpflanze dieses Gebietes jedoch, die südrussische Centaurea ruthenica, konnte in den letzten Jahren nicht mehr aufgefunden werden. Bei Kolos sind in den Niederungen übrigens auch schon Halophyten, wie Hordeum Gussoneanum, Atropis salinaria, Calabrosa aquatica, Pelrosimonia Volvox, Trifolium angulatum, 
Malricaria Chamomilla, Aster Tripolium, Scorzonera Jaquiniana zu finden. Eine ähnliche Flora wie um

Szt. Gott- Kolos ist auch bei Szt. Gotthard zu Hause, wo
hard. übrigens auch Astragalus dasyanlhus und Gonio-

Egerbcgy. limon talaricum wachsen, und bei Egerbegy gedeihen wieder zahlreiche Steppenpflanzen, wie Slipa Lessingiana, Astragalus transsilvanicus, A. asper, A. auslriacus und Cenlaurea trinervia. Den größten zusammenhängenden Wiesenkomplex im Gebiete Heuwiesen. der Mezöség aber stellen die Heuwiesen (Szenafü) nordöstlich von Klausenburg dar. Úppige Wiesen bedecken hier ganze Hügelketten, auf denen neben den oben genannten Arten auch Agrostis vulgaris, Poa trivialis, Phleum phleoides, Arrhenatherum elalius, Hierochloe odorala, Veralrum nigrum, Iris pumila, Silene chlorantha, S. longiflora, Anemone palens, Thaliclrum lucidum, Geranium sanguineum, Linum lenuifolium, L. flavum, Trifolium rubens, Ononis hircina, Lalhyrus Hallersleinii, Cylisus leucanthus, Salvia nemorosa, Aiuga Laxmanni, Cephalaria radiata, Serralula radiala, S. nilida, Hypochoeris maculata, Chrysanthemum corymbosum allgemein verbreitet sind, während Asparagus officinalis, Bulbocodium vernum *ruthenicum, Adonis wolgensis, Crambe aspera, Lalhyrus pallescens, Astragalus asper, A. albidus, A. austriacus, Nepela ucranica, Cenlaurea trinervia und Stipa Tirsa weniger häufig oder auf einzelne Standorte beschränkt sind. In den Tälern zwischen den Hügeln aber findet man allenthalben Sumpistellen mit reicher Halophytenflora aus Atropis salinaria, Scirpus maritimus, Schoenoplectus Tabernaemontani, Triglochin maritimum, Salicornia herbacea, Pelrosimonia Volvox, Spergularia media, Lolus tenuis, Melilotus dentalus *perfrondosus, Slatice Gmelini, Peucedanum latifolium, Plantago Cornuti,

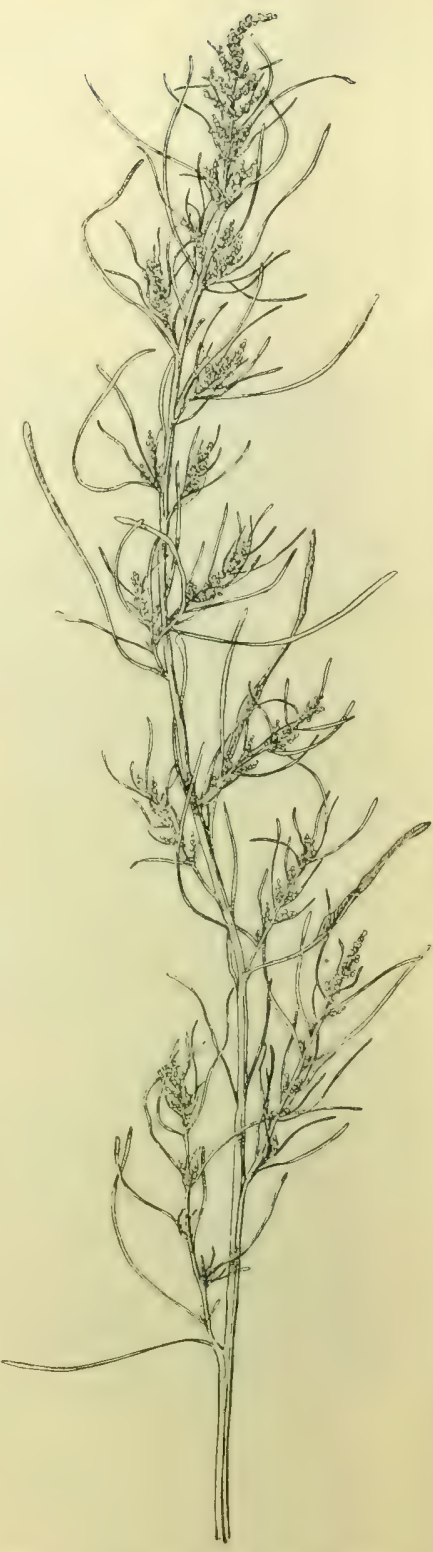

Abb. 272. Chenopodium Wolffii. P. marilima, Aster punclalus und Senecio Biebersteinii, während Goniolimon talaricum an trockenen, etwas salzigen Stellen wächst. Von Sträuchern ist besonders Prunus nana auf den Heuwiesen zu finden. Die Südabhänge der Heuwiesen gegen die Stadt zu sind größtenteils von Weinund Obstgärten bedeckt, auch die Ruderalflora ist hier sehr reich und stellenweise tritt Artemisia Absinthium in ganzen Beständen auf.

Die Hügel östlich und südlich von Kolozsvár weisen zwar stellenweise noch Triften von ähnlichem Gepräge wie auf den Heuwiesen auf, doch findet 


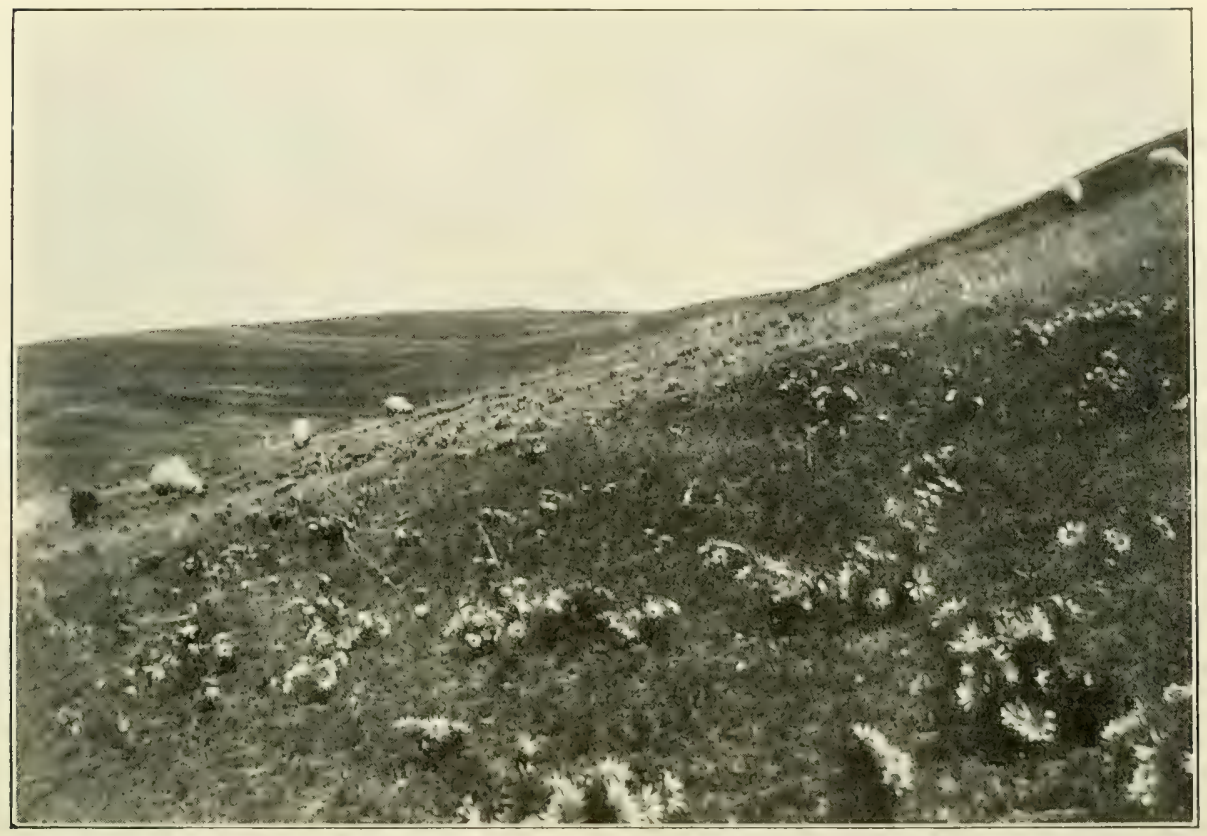

Abb. 273. Adonis vernalis auf den Heuwiesen bei Kiolozsvár.

(Nach einer Aufnahme von G. Nyarády, Maros-Vasarhély.)

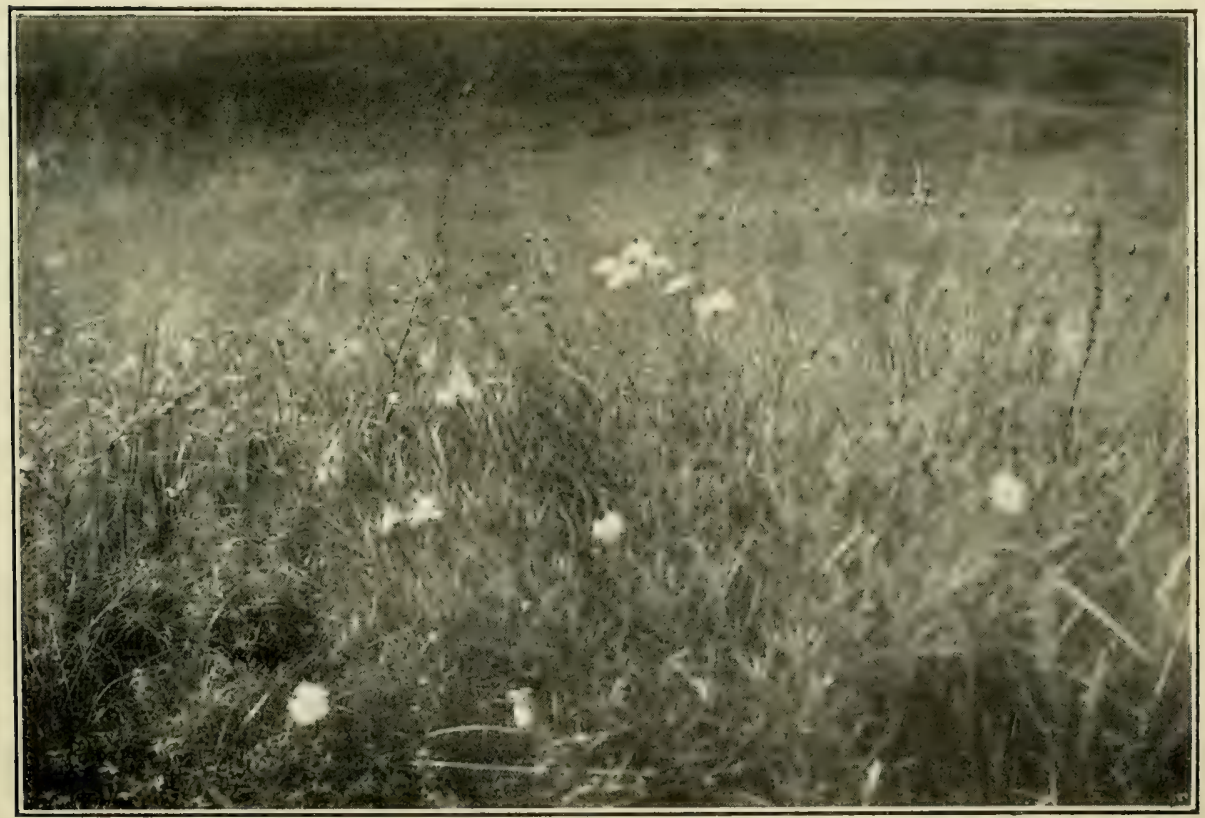

Abb. 274. Centaurea trinervia auf den Heuwiesen bei Kolozsvár. (Nach einer Aufnahme von A. v. Hayek.) 

man hier nicht nur Euschgehölze, sondern auch schon gemischte Laubwälder und auf den Anhöhen bei Felek treten in nur $900 \mathrm{~m}$. Meereshöhe schon subalpine Typen, wie Thesium alpinum, Anemone narcissiflora und Sweertia pe-

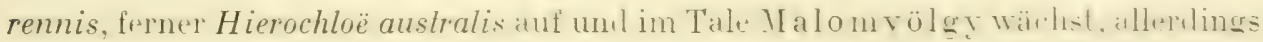
unter Verhältnissen, die die Spontaneität der Pflanze nicht ganz außer Zweifel setzen, die sibirische Achillea Impatiens. Wähend an den dusläufern drer Biharia im Gzuczaer Tale schon Syringa Josikaea anzutreffen ist.

Am Südostrande der Mezöség liegt bei Torda eines der reichsten HaloTorda. phytengebiete Siebenbürgens. Hier wachsen Atropis salinaria, Juncus Gerardi, Triglochin marilimum, Salicornia herbacea. Suaeda salsa. Melilotus macrorhizus, Lotus tenuis, Linum perenne. Statice Gmelini. Goniolimon tataricum. Planlago Cornuli. Pl. Schwarzenbergiana. Arlemisia monogyna. Asler Tripolium und Scorzonera partiflora und auf salzigen Schuttplätzen das hier endenische Chenopodium Wolffii. Auf feuchten Wiesen findet man Iris spuria und Senecio Biebersteinii, während auf den umgebenrien Hügeln Thalirlrum fle.ruosum. Hllhaea pallida. Lavatera thuringiaca, Seseli varium, Selinum Carvifolia, Crepis selosa usw. anzutreffen sind.

Wenn auch die Flora der Mezöség in mancher Beziehung an die der großen ungarischen Ebene erinnert, besitzt sie doch eine Anzahl von Arten, die im ganzen ungarischen Tieflande fehlen, hingegen in Südrußland, manche selhst schon in Ostgalizien vorkommen. Zu diesen Arten gehören Slipa Lessingiana. Arlonis wolgensis, Anemone palens, Crambe aspera, Astragalus transsilvanicus, Serratula Wolffii, S. nilida, Cenlaurea ruthenica und $C$. Irinervia. Auch von den siebenbürqischen Salzpflanzen fehlen Chenopodium Wolffii. Petrosimonia Volvox, Peucedanum latifolium, Goniolimon talaricum und Planlago Cornuti der ungrarischen Tiefebene. Anderseits fehlen in Siebenbürgen wieler zahlreiche ungarische Sandpflanzen, wie z. B. Corlmephorus canescens. Iris arenaria (nur in ter Tordaer Schlucht), Polygonum arenarium, alle Corispermum-Arten, Astragalus varius, A. exscapus, Rindera umbellala, Alkanna tincloria u. а. 


\section{Verzeichnis der benutzten Literatur.}

\section{a) Arbeiten iber das ganze Gebiet oder einen gröberen Teil derselben.}

Baumgarter, Enumeratio stirpium Magno Transsilvaniae principatui indigenarurı. Vindobonae, $1816-1846$.

Fritze R. und Ilse H., Karpathenreise. (Verh. zool. bot. Ges., WVien, XX [1870], S. 467.)

Fronius F., Zur Charakteristik der siebenbürgischen Karpathenflora. (Jahrb. d. siebenb. Karp.-Ver., I [1881], S. 124.)

Gáyer G., Magyarország és Also-Ausztria flórájának Lycoctonumféle sisalivirágai. Aconita Lycoctonoidea Regni Hungariae additis Lycoctonoideis Austriae inferioris. (Magyar bot. Lapok, VII [1908], S. 286.)

- Vorarbeiten zu einer Monographie der europäischen Aconitum-Arten. (Magy. bot. Lapok, VIII [1909], S. 114.)

Haszlinsky F., Beitrag zur Kenntnis der Flora der Karpathen. (Verh. zool. bot. Ver. (Ges.) Wien, I-XXVI [1853-1876].)

Herbich F., Planzengeographische Bemerkungen über die Wälder Galiziens. (Verh. d. zool. bot. Ges. Wien, X $[1860]$, S. 359.)

Pax F., Neue Planzenarten aus den Karpathen. (Österr. bot. Zeitschr, XLV [1895], S. 26.)

- Über die Gliederung der Karpathenflora. (Jahresber. d. schles. Ges. f. vaterl. Kultur, 1896.)

- Grundzüge der Planzenverbreitung in den Karpathen. (Engler und Drude, Die Vegetation der Erde. II [1898] und X [1908].)

Schur F., Enumeratio plantarum Transsilvaniae. Vindobonae, 1866.

Simonkai L., Erdely Edényes Flórájának helyeshittet foglalata. (Enumeratio florae Transsilvaniae.) Budapest, 1886.

Woloszczak E., Z granicy flory zachodnio i wschodnio-karpackiej. (Spraw. lom. fizyogr. Ak. umiętn. Krakow. XXXI (1896) p. 119.)

- Wo liegt die Kaschau-Eperieser Bruchlinie? (Magy. bot. Lapok, VII [1908] S. 110.)

\section{b) Kleine Karpathen.}

Bolla J., Beiträge zur Flora Preßburgs. (Verh. d. Ver. f. Natur- und Heilk. Preßburg I $[1856]$, S. 6.)

Brancsik, Ein Ausflug auf den Thetener Kobel. (Österr. bot. Zeitschr., XII [1862], S. 148.)

Dietl F., Ein $\Lambda$ usflug auf den Thebener Kobel bei Preßburg. (Österr. bot. Wochenbl., III [1853], S. 410.)

Endlicher St., Flora Posoniensis. Posonii 1830.

Holuby J., Zur Flora Preßburgs. (Österr. bot. Zeitschr., XX [1870], S. 168.)

- Beiträge zur Preßburger Flora. (Verh. d. Ver. f. Natur- und Heilk. Preßburg I [1856], S. 15.)

Knapp J. A., Zur Flora des Preßburger Komitates. (Österr. bot. Zeitschr., XIV [1864], S. 304.)

İ̌żisch J. F., Der Wetterlin in den Kleinen Karpathen. (Verh. d. Ver. f. Natır- und Heilk. Preßburg, I [1856], S. 51.)

- Eine botanische Exkursion auf die Vysoka. (Preßburger Zeitung v. 14. Juli 1857.)

Sabransky H., Beiträge zur Preßbuirger Flora. (Österr. bot. Zeitschr., XXXII [1882], S. 360.)

- Floristisches aus Preßburg. (Österr. bot. Zeitschr, XXXIV [1884], S. 131.) 


\section{c) Beskiden und Pieninen.}

Baier A., Zur Flora der Umgebung von Bielitz und Biala. (Österr. bot. Zcitschr., XXXVII [1887], S. 88.)

Brancsik K., Zoologisch-botanische Wanderungen. VIII. An Löwenstein. (Jahrb. d. nat. Ver. Trencsin [1886], S. 87.)

Bubela J., Verzeichnis der um Bisenz in Mähren wildwachsenden Planzen. (Verh. zool. bot. Ges. Wien, XXXI [1881], S. 775, XXXII [1882], S. 42.)

Chyzer K., Adatok északi Magyarország, különösen Zemplénmegye és Bártfa város Flórá jához. (Magy. bot. Lapok, IV [1905], S. 109.)

Coka F., Př́spěvky ku květenè moravské. (Věstnik klubu př́rod. Proßßnitz, 1905, 1906, 1908, 1910.)

- Pedicularis exaltata Besser in Mähren. (Nagy. bot. Lapok, V [1906], S. 373.)

Engler A., Über die Flora der Umgebung von Teschen und des mährischen Gesenkes. (Jahrb. schles. Ges. vaterl, Kultur [1868], S. 109.)

Fiek E., Flora von Schlesien. Breslau, 1881.

Filarszky F., Das Pieningebirge und seine Flora. (Jahrb. d. ung. Karpathenver., XXV [1898], S. 30.)

Form ánek E., Beitrag zur Flora der Beskiden und des Iochgesenkes. (Österr. bot. Zeitschr., XXXIV [1884], S. 157.)

- Beitrag zur Flora der Karpathen und des Hochgesenkes. (Österr. bot. Zeitschr., XXXVI [1886], S. 180.)

Giogela F., Z kvèteny Radhoštè. (Sborníl mus. spol. Val.-Meziřičského, IV [1900].)

- Flora von Rajnochowitz. (Verh. nat. Ver. Brünn, XXXIX [1901], S. 65.)

- Planzen aus den mährischen Karpathen. (Verh. nat. Ver., Brünn, XL [1902], S. 37.)

- Z květeny pahorkatiny podkarpatské na Moravě východní. (Věstník klubu přirod. Proßnitz, 1902.)

- O rozšiření některých druhủ rostlinných na severovýchodní Moravě. (Věstnik klubu př́rod. Proßnitz 1913.)

- Z květeny Smrku a Lisé hory. (Sbornik mus. spol. Val. Meziř́č. II [1904], S. 13.)

- Květana Beskyd moravských. (Časopis vlast. mus. spol. Olmütz, 1903, S. 109.)

- Z květeny Javorníka u Rajnochovic. (Věstnik klubu přirod. Proßnitz, X [1907].)

- Květena na dolním toku Rusavy v okoli Střebětic. (Věstník klubu přirod. Proßnitz, XI [1908].)

- Květena na dolním toku Rusavy. (Věstník klubu přirod. Proßnitz, XII (1909].)

Herbich F., Botanischer Ausflug in die galizischen Karpathen des Sandezer Kreises. Flora [1834], 561.)

Holuby J., Aus dem Trencsiner Komitate. (Österr. bot. Zeitschr., XV [1865], S. 8.)

- Das Ivonoczer Gebirge im südwestlichen Teile des Trenesiner Komitates. (Österr. bot. Zeitschr., XV [1865], S. 257.)

- Aus dem Ober-Neutraer Komitate. (Österr. bot. Zeitschr., XV [1865], S. 352.)

- Bemerkungen zur Flora des Neutraer Komitates. (Österr. bot. Zeitschr., XVI [1866], S. 372.)

- Zweimal auf der Javorina. (Österr. bot. Zeitschr., XXI [1871], S. 261.)

- Von Puchov bis Löwenstein. (Österr. bot. Zeitschr., XXI [1871], S. 347.)

- Beitrag zur Flora des Neutraer Komitates. (Österr. bot. Zeitschr., XXVII [1877], S. 170.)

- Einiges über meine botanischen Streifzüge durch das Trencsiner Komitat. (Jahrb, nat. Ver. Trencsiner Komitat. 1892-1893, S. 11.)

Knapp J. A., Zwei Tage im Trencsiner Komitat. (Österr. bot. Zeitschr., XIV [1864], S. 341.) Kolbenheyer K., Vorarbeiten zu einer Flora von Teschen und Bielitz. (Verh. zool. bot. Ges., Wien, XII [1862], S. 1185.)

Makowsky A., Eine Exkursion in die mährisch-ungarischen Karpathen. (Verh. nat. Ver. Brünn, XV [1876], S. 34.)

Oborny A., Flora von Mähren und Österr.-Schlesien. Brünn, 1883-1887. 
Peter A., Fin Ausflug auf die Babia Gora. (Österr, bot. Zeitschr., XXIX [1879], S. 23.)

Sapetza J., Beitrag zur Flora von Mähren und Schlesien. (Verh. zool. bot. Ver., Wien, VI [1856], S. 471.)

Schlögl J., Die Flora von Ungarisch-Hradisch.(Progr. Oberrealschule Ung,-Hradisch, 18751876.)

Wołośzczak E., O roślinności karpackíej między Dunajcem i granicą ślązką. (Sprawozd. kom. fiz. akad. Krakow, XXXII [1896], S. 1.)

- O roślinności Karpat między górnym biegiem Sanu i Osława. (Spraw. kom. fizyogr. Akad. Krakow XXIX [1894], S. 39.)

Zubrzycki J., Flora Pienin. (Spraw. kom. fizyogr. Akad. Krakow XXIX, [1894] S. 70.)

\section{d) Die Westkarpathen südöstlich der Waag.}

Barłal Ii., Adatok a Baba-hegycsoport és körnenyéke növenyzetének izmeretéhez. (Növ. Köz., II [1903], S. 97.)

Branczik K., Der Roszudec in Ungarn. (Österr. bot. Zeitschr., XII, S. 322.)

- Zoologisch-botanische Wanderungen. (Jahrb. d. nat. Ver. Trencsiner Komitat. 1880 - 1885.)

- Ein Ausflug auf den Mincsov. (Jahrb. d. nat. Ver. Trencsiner Kom., 1879, S. 25.)

Freyn J., Beiträge zur Flora Ober-Ungarns. (Verh. zool, bot. Ges. Wien, XXII [1872], S. 341.)

Ha ussknecht C., Mitteilungen über die Flora der Zentralkarpathen. (Österr. bot. Zeitschr., XIV [1864], S. 205.)

I oluby J., Aus dem Neutraer Komitate. (Österr. bot. Zeitschr., XVII [1867], S. 277.)

- Zur Flora von Sulov in Ungarn. (Österr. bot. Zeitschr., XXII [1872], S. 196.)

- Die Bečkover Hügel. (Österr. bot. Zeitschr., XXVIII [1878], S. 159.)

- Exkursion in das Kalnicaer Gebirge im Süden des Trencsiner Konitates. (Österr. bot. Zeitschr., XXXIII [1883], S. 182.)

- Flüchtige floristische Beobachtungen auf einem Streifzuge durch den südlichen Teil des Arvaer Komitates. (Deutsche bot. Monatsschr, [1892], S. 57.)

- Reise von Nemes-Podhragy zum Kl. Krivan. (Trenesénmegye term. tars. évk., XXVXXVI $[1907]$, S. 29.)

Hutten M. O., Beiträge zur Flora des oberen Neutratales. (Österr. bot. Zeitschr., XXIX [1879], S. 20.)

Ii eller E., Beiträge zur Flora des Neutraer Komitates. (Österr. bot. Zeitschr., XIV [1864], S. $283, \mathrm{XV}[1865]$, S. 48.)

Knapp J. A., Ausflug ins Bars-Honter Komitat. (Österr. bot. Zeitschr., XIV [1864], S. 104.)

- Zur Flora von Ober-Ungarn. (Österr, bot. Zeitschr., XIV [1864], S. 241.)

- Prodromus Comitatus Nitriensis. (Verh. zool, bot. Ges., Wien, XV [1865], S. 68.)

Margittai A., Adatok Turócz vármegye florájáhóz. (Magy. bot. Lapok, XII [1913], S. 236.)

Markus A., Beiträge zur Kenntnis der Flora von Neusohl. (Österr. bot. Zeitschr., XV [1865], S. 183.)

- Eine Exkursion auf den Ostri vrh bei Neusohl. (Österr. bot. Zeitschr., XVII [1867], S. 9.) Moesz G., Adatok Bars vármegye florájához. (Bot. Közlem. X [1911], S. 171.)

Sagorski E. und Schneider G., Flora der Zentralkarpathen. Leipzig, 1891.

Scherfel A., Kleine Beiträge zur Kenntnis der subalpinen und alpinen Flora der Zipser Tatra. (Jahrb. d. ung. Karp.-Ver. [1880], S. 335.)

Schiller S., Die planzengeographischen Verhältnisse der Stadt Neutra. (Verh. d. Ver. f. Naturund Heilk. Preßburg, IX [1866], S. 32.)

- Das Ufer der Neutra. (Österr. bot. Zeitschr., XIII [1863], S. 401, XIV [1864], S. 51.)

- Fragmente einer Flora des Warmbades Teplicz in Ober-Ungarn. (Österr. bot. Zeitschr., XVII [1867], S. 37.)

Stur D., Der Roszudec. (Österr. bot. Zeitschr., IX [1859], S. 16.)

Szontagh N. v., Enumeratio plantarum phanerog. et crypt. vasc. Com. Arvensis. (Verh. d. zool. bot. Ges., XIII [1863], S. 1045.) 
Szontagh N. v., Botanische Reise durch das Waagtal (Österr. bot. Zeitschr., XIV [1864], S. 269.)

- Beiträge zur Flora des Gömörer Komitates. (Österr. bot. Zeitschr., XVI [1866], S. 145.) Wagner J., Die Gefäßplanzen des Turoczer Komitates. (Jahrb, ung. Karp.-Ver., XVIII [1901], S. 1.)

Wetschky M., Botanischer Ausflug ins obere Waaggebiet. (Österr. bot. Zeitschr., XXII [1872], S. 321.)

- Zur Flora des nördlichen Ungarn. (Österr. bot. Zeitschr., XXVIII [1878], S. 224.)

\section{e) Die Zentralkarpathen nördlich der IVaag.}

Ascherson P. und Engler A., Beiträge zur Flora Galiziens und der Zentralkarpathen. (Österr. bot. Zeitschr., XV [1865], S. 276.)

Ascherson, Engler, IKuhn und Feimann., Eine Karpathenreise. (Verh. bot. Ver. Prov. Brandenburg. [1865], S. 276.)

Berdau F., Geographisch-botanische Skizze des Tatragebirges. (Österr. bot. Wochenbl., $\mathrm{V}[1855]$, S. 297.)

Borb ás V. v., Abies s. Picea ellipsoconis. (Magy. bot. Lapok, I [1902], S. 26.)

Cisakó K., Die Sommerflora des Unterschmeckser Moorbodens. (Jahrb. ung. Karp.-Ver., 1888, S. 194.)

Degen A. V., Heliosperma alpestre in der Hohen Tatra. (Magy. bot. Lapok, IV [1905], S. 90.)

- Entdeckung von Elyna Bellardi in der Hohen Tatra. (Magy. bot. Lapok, V [1906], S. 109.) Drude O., Bericht über die Isisfahrt nach den Zentralkarpathen im Juli und August 1893. (Isis, Dresden, 1893.)

- Die Vegetationsregionen der nördlichen Zentralkarpathen. (Petermanns geogr. Mitt. [1894], S. 175.)

Filarszy F., Von den Torflagern am Fuße der Hohen Tatra. (Jahrb. d. ung. Karp.-Ver., [1893], S. 22.)

Gregorzek A., Ausflug ins Tatragebirge. (Österr. bot. Wochenbl., V [1853], S. 84.)

Györffy J., Scolopendrium vulgare in der Hohen Tatra. (Magy. bot. Lapok, X [1911], S. 345.)

- Über die Verbreitung der Zirbelkiefer und der Eibe in den Javorinaer und Belaer Kalkalpen. (Magy. bot. Lapok, XI [1912], S. 40.)

- A Magas-Tátra növényvilága. (Turistaság és Alpinizmus, 1914, IV. Nr. 10-11.)

Ha ussknecht C., Mitteilungen über die FIora der Zentralkarpathen. (Österr. bot. Zeitschr., XIV [1864], S. 208.)

Herbich F., Botanischer Ausflug in die zalizischen Karpathen des Sandezer Kreises. (Flora, [1864], S. 561.)

Hoborski, Wanderungen im Tatragebirge. (Österr. bot. Wochenbl., III [1853], S. 9.)

Huljak J. A., Trifolium Lupinaster L. felfedezése Magyarországon. Über die Entdeckung von Trifolium Lupinaster L. in Ungarn. (Magy. bot. Lapok, VIII [1909], S. 33.)

Kolbenheyer K., Zusammenstellung der gemessenen Knieholzgrenzen. (Jahrb. d. ung. Karp.Ver., [1874], S. 97.)

Iiržisch J. F., Notizen über eine Lxkursion in die Tatra, die Zentralkarpathen, das Liptauund das Tátra-Gebirge. (Österr. bot. Zeitschr., X [1860], S. 143.)

Kuhn M., Rhododendron in der Tatra. (Österr. bot. Zeitschr., XIV [1864], S. 301.)

Nyarády E. G., Ujj növények a Magas-Tátra és közvetlen környékẻnek flỏrájában s adatok, ezek részletesebb ismeretéhez. Neue Pflanzen aus dem Florengebiete der Hohen Tatra und ihrer nächsten Umgebung sowie Beiträge zur ausführlichen Kenntnis ihrer Planzenwelt. (Magy. bot. Lapok, VIII [1909], S. 68.)

- Carex chorủorhiza Ehrh. felfedezése Magyarországon Késmárk környékén, a Magas-Tatra alatt. Die Entdeckung der Carex chordorhiza in Ungarn unter der Hohen Tátra in der Umgebung von Kesmark. (Magy, bot. Lapok, X [1911], S. 73.)

-. Néhány ritko Cyperaccáról Szepesvúrmegyében. (Magy. bot. Lapok, XI [1912], S. 42.) 
Nyárady, Az Allium strictum Schrad. hazánk llorájál)an. (Magy. bot. Lapok, XI [1912], S. 67.)

- Beiträge zur Kenntnis der Szepes-Belaer Kalkalpen. (Magy. bot Lapok, XII [1913], S. 117.) Pax F., Floristische Notizen. (Österr. Zeitschr., XXXIII [1883], S. 112.)

Richter L., Zwei Exkursionen in die Tatra. (Österr. bot. Zeitschr., XXV [1875], S. 203.)

Sagorski E. und Schneider K., Flora der Zentralkarpathen. Leipzig, 1891.

Scherfel A., Kleine Beiträge zur Kenntnis der subalpinen und alpinen Flora der Zipser Tatra.

(Jahrb. d. ung. Karp.-Ver., [1879], S. 265, [1886], S. 335.)

Seidel G. F., Botanische Anmerkungen über die Gegend von Zakopane. (Isis, Dresden, [1868], S. 65.)

Szontágh N. v., Fine Exkursion auf den Rohács. (Österr. bot. Zeitschr., XII [1862], S. 287.)

- Botanische Reise durchs Waagtal. (Österr. bot. Zeitschr., XIV [1864], S. 269.)

Uechtritz R.v., Botanische Exkursion in die Zentralharpathen. (Österr. bot. Zeitschr., VII [1857], S. 342.)

Wahlenberg, Flora Carpatorum principalium. Göttingae, 1814.

Wetschky M., Botanischer Ausflug ins obere Waaggebiet. (Österr. bot. Zeitschr., XXII [1872], S. $3 ? 1$.)

\section{i) Gölnitzer und Eperieser Gebirge.}

Borb ás V.V., Abau-Torna várnegye flórája. (Magyország Vármegye és Varosen [1896], S. 439.) Čelakovsky L., Über eine mitteleuropäische Daphne. (Sitz.-Ber. d. böhm. Ges. d. Wissensclı., Prag, [1890], S. 215.)

Chyzer K., Adatok északi Mlagyarorszag különösen Zemplénmegye és Bárlfaváros flórájảhoz. (Magy. bot. Lapok, IV [1905], S. 109.)

Fekete L., Zemplén vármegye eídötenyésztési viszonyairol. (Érd. Lap., XXXX [1890], S. 281.)

Lengyel G., Abau-Torna vármegye flórójúbol. (Magy: bot. Lap., VI [1907], S. 170.)

Pawlowski, Beitrüge zur Flora Ober-Ungarns. (Verh. d. Ver. 〔. Natur- und Heilk., Preßburg, I [1856], S. 25, II [1857], S.-B. 17.)

Richter A., Botanische Notizen zur Flora des Gömörer Knmitates. (Österr. bot. Zeitschr., XXXVIII [1888], S. 199.)

- Adatok a Veporhegység és a Fabova hegycsoport flórájának ismeretéhez. (Magy. növ. Lapok, XII [1888], S. 113.)

Szontagh N. v., Beiträge zur Flora des Gömörer Komitates. (Österr. bot. Zeitschr., XVI [1866], S. 145.)

\section{g) Südliche Vorlagen der IVestkarpathen.}

Budai A., A Béleapátfalva Belköhegy florája. (Magy. bot. Lapok, XI [1912], S. 68.)

Kerner A., Der Nagy-Szal. (Österr. bot. Wochenbl., VII [1857], S. 390:)

- Die Vegetationsverhältnisse des mittleren und östlichen Ungarns und angrenzenden Siebenbürgen. (Österr. bot. Zeitschr. XVII-XXIX, 1867-1879.)

Janka V. v., Neue Standorte ungarischer Planzen. (Österr. bot. Zeitschr., XVI [1866], S. 168, XVII [1867], S. 64.)

Prodan G., Adatok a Bükk-es elöhegyeinek florájához. (Bot. Közlem., VIII [1909] S. 103.)

Vrabelyi M., A Mátra növényföldrajzi ismertetése. (A Cisterce Rend Egri Kodh. fögyme. Ertesítöje [1890-1891], S. 65.)

\section{h) IValdkarpathen.}

Behrendsen O., Beiträge zur Flora des nordöstlichen Zempliner Komitates. (Bot. Zeitung, [1876], S. 657.)

B łocki B., Ein Beitrag zur Flora von Galizien und der Bukowina. (Deutsche bot. Monatsschr., [1895], S. 67.)

Dietz A., Ein botanischer Ausflug auf den Vihorlát. (Jahrb. d. ung. Karp.-Ver. [1882], S. 161.) 
Fekete L., Bereg vármegye erdötenyésztése viszonyairól. (Erdesz. Lap., XXIX [1890], S. 94.)

- Ung vármegye erdötenyéstése viszonyairól. (Erd. Lapok, XXIX [1890], S. 159.)

- Zemplén vármegye erdötenyéstése viszonyairól. (Erd. Lapok, XXIX [1890], S. 281.)

H ückel E., Botanische Ausflüge in die Karpathen des Stryer und Samborer Kreises in Galizien.

(Verh. zool. bot. Ges. Wien, XV [1865], S. 49.)

- Flora der Umgebung von Drohobycz. (Verh. zool. bot. Ges., Wien, XVI [1866], S. 237.)

Jachno J., Wykaz roślin z okolicy Stanislawowa. (Sprawozd, kom. fiz, Krakow, VI [1872], S. S.)

- Dalszy ciąg roślin zebranych w okolicy miasta Stanislawowa. (Sprawozd. kon. fiz. Krakow, VII, [1873] S. 52.)

Janka V. v., Syringa Josikaea und anderes Neue aus der Marmaros. (Österr. bot. Zeitschr., XXXV [1885], S. 313.)

Kotula B., Spis roślin naczyniowych z okolic górnego Strwiąza í Sanu, z uwgledniẹniem pionowego zasiągu gatunków. (Spraw. kom. fiz. Krakow, XVII [1883], S. 105.)

M üller, Verzeichnis der in der Marmaros gesammelten Planzen. (Verh. zool. bot. Ges., Wien, XIII [1865], S. 55.)

Simonkai L., Nehány észrevétel Vinna és Homonna vidékének flórájára. (Magy. bot. Lapok, VI [1907], S. 229.)

Śleńdziński, Przyczynek do flory obwodu Kołomyjskiego. (Spraw. hom. fiz. Krakow, IX [1875], S. 49.)

Thaisz L., A Syringa Josikaea Jacq. fil. mint növenygeografiai utmutáto. Syringa Josikaea als pflanzengeographische Leitpflanze. (Magy. bot. Lapok, VIII [1909], S. 217.)

- Adatok Berégvármegy flórájához. (Magy. bot. Lapok, X [1911], S. 38.)

Wo loszczak E., Przyezynek do flory Pokucia. (Spraw. kom. fiz. Krakow, [1887-1890].)

\section{i) Rodnaer und Bistritzer Alpen.}

Bauer K., Beitrag zur Phanerogamenflora der Bukowina und des angrenzenden Teiles ron Siebenbürgen. (Österr. bot. Zeitschr., XLVI [1896], S. 218.)

Degen A. v., Carex rupestris. (Magy. bot. Lapok, I [1902], S. 90.)

- Bemerkungen über orientalische Pflanzenarten. Saussurea Porcii. (Magy. bot. Lapok, III [1904], S. 311.)

Dörfler J., Beiträge und Berichtigungen zur Gefäßkryptogamenflora der Bukowina. (Verh. zool. bot. Ges., Wien, XL [1890], S. 43.)

Fuss M., Bericht über eine Reise in die nordöstlichen Karpathen Siebenbürgens. (Verh. u. Mitt. d. Siebenb. Ver. f. Nat., V [1854], S. 93.)

Haszlinszky F., Die alpine Flora der Alpe Pietrosz bei Borsa. (Bot. Zeitung [1868], S. 53.)

Herbich F., Flora der Bukowina. Leipzig, 1895.

- Botanischer Ausflug in einen Teil der Hochgebirge der Bukowina. (Flora, XIX. 2, [1836], S. 625.)

Hormuzaki K., Frh. v., Die Schmetterlinge der Bukowina. (Verh. zool. bot. Ges., Wien, XLVII [1897], S. 70, XLIX [1899], S. 32.)

- Aus dem Gebirge der Bukowina. (Globus, LXXIV [1898], S. 381.)

- Nachtrag zur Flora der Bukowina. (Österr. bot. Zeitschr., LXI [1911], S. 59.)

Porcius F., Die Umgebung von Alt-Rodna mit besonderer Rücksicht auf ihre botanischen Verhältnisse. (Jahrb. d. Siebenb. Karpath.-Ver., III [1883], S. 57.)

- Enumeratio plantarum phanerogamicarum Districtus quondam Naszodiensis. Claudiopoli, 1878.

Procopianu-Procopovici A., Eine botanische Exkursion von Rum. St. Georg bis Nedec. (Österr. bot. Zeitschr., XXXVII [1887], S. 430.)

- Floristisches aus den Gebirgen der Bukowina. (Verh. zool. bot. Ges., Wien, XL [1890], S. 85.)

Raciborski M., Pośliny polskie. (Plantae polonicae.) Kosmos, XXXV [1911], S. 995. 
Reckert D., Ausflug auf das Gebirge Kioron bei Jiodna. (Verh. u. Mitt. d. Siebenb. Ver. f. Nat., VI [1855], S. 17.)

Rudolph K., Vegetationsskizze der Umgebung von Czernowitz. (Verh. d. zool. bot. Ges., Wien, LXI [1911], S. 64.)

Schube Th., Botanische Ergebnisse einer Reise in Siebenbürgen. (Jahresber. d. schles. Ges. f. vaterl. Kultur, [1894], S. 64.)

Schur F., Bericht über eine botanische Rundreise durch Siebenbürgen, VI. Rodna, seine Gebirge und Umgegend. (Verh. u. Mitt. d. Siebenb. Ver. f. Naturw., X [1859], S. 119.)

- - VIII. Borszék. (Verh. u. Mitt. d. Siebenb. Ver. f. Naturw., X [1859], S. 151.)

Szafer W., Cisy w Kniaźdworze pod Kolomyją jako ochrony godny zabytek przyrody leśnej.

(Sylwan, 1913.)

\section{k) Das östliche Randgebirge Siebenbürgens.}

Degen A. v., Bemerkungen über einige orientalische Pflanzenarten. XLI. Sempervivum Simonkaianum n. sp. (Magy. bot. Lapok, I [1902], S. 134.)

Fronius F., Zwei Tage auf dem Szurul und sechs Tage im Széklerland. (Arch. d. Ver. f. siebenb. Landesk., N. F., III [1858], S. 141.)

- Ein Ausflug auf die Hargita am 1. Juni 1857. (Verh. u. Mitt. d. siebenb. Ver. f. Nat., VIII [1857], S. 102.)

- Eine naturhistorische Exkursion ins Széklerland im August 1857 ausgeführt. (Verh. u. Mitt.

d. siebenb. Ver. 1. Nat., IX [1858], S. 71.)

II oesz G., A Rétyi Nyír növényzete. Die Vegetation der Rétyi Nyir. (Magy. bot. Lapok, IX [1910], S. 333.)

Schur F., Oecsem Teteje. (Österr. bot. Zeitschr., VIII [1858], S. 18.)

- Bericht über eine botanische Rundreise durch Siebenbürgen. Der Ecsem Teteje bei Balanbanya. (Verh. u. Mitt. d. siebenb. Ver. f. Nat., X [1859], S. 160.)

- - XI. Bad Czik-Tusnad. (Verh. u. Mitt. d. siebenb. Ver. f. Nat., X [1859], S. 178.)

_ - XII. Der Büdös. (Verh. u. Mitt. d. siebenb. Ver. f. Nat., X [1859], S. 184.)

W'agner J., Eine Exkursion in der Umgebung von Gyímes. (Allg. bot. Zeitschr., V [1899], S. 41.)

\section{1) Die Burzenländer Berge und die südlichen Randgebirge Siebenbuirgens.}

Barth J., Eine botanische Exkursion ins Hatszégertal, dann in die beiden Schieltäler und auf das Páreng- oder Paringulgebirge vom 11. bis 26. Auzust 1881. (Verh. u. Mitt. d. siebenb. Ver. f. Nat., XXXIII [1882], S. 1.)

Blattny P., A veröfenyó östermöhelyei a Szébeni lıavasokban. Über einige ursprüngliche Standorte der Lärche in den Zibiner Alpen. (Magy. bot. Lapok, XI [1912], S. 305.)

Bornmüller J., Notizen aus der Flora der südlichen Karpathen. (Mitt. d. Thür. bot. Ver. N. F., XXX $[1913]$, S. 49.)

Degen A. v., Primula Baumgarteniana. (Magy. bot. Lapok, VII [1908], S. 92.)

Fronius F., Zwei Tage auf dem Szurul und sechs Tage im Széklerland. (Arch. d. Ver. f. siebenb. Landesk., N. F., III [1858], S. 41.)

- Zwei botanische Exkursionen. II. Von Kronstadt auf den Butschetsch. (Verh. u. Mitt. d. siebenb. Ver. f. Nat., V [1854], S. 196.)

- Eine naturhistorische Exkurison auf den Negoi. (Verh. u. Mitt. d. siebenb. Ver. f. Nat., VII [1856], S. 119.)

- Reise auf den Szurul. (Verh. u. Mitt. d. siebenb. Ver. f. Nat., IX [1858], S. 17.)

Fyörffy J., Neue Fundorte einiger Pflanzen in Siebenbürgen. (Magy. bot. Lapok, II [1903] S. 211.)

- Kileinere Beitrügre zur Flora von Siebenbürgen. (Magy. bot. Lapok, IV [1905], S. 33.)

Ienrich C., Durchforschung des Zibinsgebirges bei Talmatsch. (Verh. u. Mitt. d. siebenb. Ver. f. Nat., XLVIII [1899], S. 86.) 
Heuffel J., Enumeratio plantarum in Banatu Temesiensi sponte crescentium et frequentius cultarum. (Verh. zool bot Ges., Wien, VIII [1858], S. 39.)

Kotschy Th., Beiträge zur Kenntnis des Alpenlandes in Siebenbürgen. (Verh. zool. bot. Ges., Wien, III [1853], S. 57.)

Laus H., Botanische Streifzüge in Siebenbürgen. (II. Ber. d. nat. Sekt. d. Ver. ,Botanischer Garten" in Olmütz [1913], S. 125.)

Föm er J., Beiträge zur Flora von Zaizon. (Verh. u. Mitt. d. siebenb. Ver. f. Nat., XXXIV [1883], S, 143.)

- Die Malajeschter Schlucht und der Felsengrat Mălăjesci am Bucsecs. (Jahrb. d. siebenb. Karp-Ver., III [1883], S. 140.)

- Der Csukás. (Jahrb. d. siebenb. Karp.-Ver., VIII [1888], S. 1.)

- Aus den Burzenlander Bergen. (Jahrb. d. siebenb. Karp.-Ver., IX [1889], S. 87.)

- Die Frühlingsflora von Kronstadt in Siebenbürgen. (Deutsche bot. Monatsschr. [1895], S. 97.)

- Die Pflanzenwelt der Zinne und des Kleinen Hangestein. (Festschr. zur Wandervers. d ung. Ärzte u. Naturforscher, Kronstadt, 1892.)

- Aus der Pflanzenwelt der Burzenländer Berge in Siebenbürgen. Wien, 1898.

- Die Flora des Schulers. (Jahrb. d. siebenb. Karp.-Ver., XXV [1905], S. 145.)

Schube Th., Botanische Ergebnisse einer Reise in Siebenbürgen. (Jahresber. d. schles. Ges. f. vaterl. Kultur, [1894], S.64.)

Schur F., Zur Flora Siebenbürgens. (Österr. bot. Wochenbl., VI [1856], S. 225.)

- Die südlichen Hochgebirge Siebenbürgens. (Österr. bot. Zeitschr., VIII [1858], S. 393.)

- Bericht über eine botanische Fiundreise durch Siebenbürgen. XIII. Der Kapellenberg bei Kronstadt. (Verh. u. Mitt. d. siebenb. Ver. f. Nat., X [1859], S. 203.)

- - XIV. Ober-Tömösch und der Predjal. (Verh. u. Mitt. d. siebenb. Ver. f. Nat, X [1859], S. 206.)

\section{m) Das Banater Bergland.}

Bernatsky J., A lokvai hegység növenyformácziói Báziás es Fehértemplon vidékén. (Növen. Közl., I [1902], S. 29.)

Degen A. v., Korrespondenz. (Österr. bot. Zeitschr., XXXVII [1887], S. 287.)

- Die Flora von Herkulesbad. (Pártos, Herkulesbad (Herculesfürdö) und seine Thermen. Budapest, 1901.)

Fiel. E., Eine botanische Fahrt ins Banat. (Allg. bot. Zeitschr., I [1895], S. 64.)

Heuffel J., Enumeratio plantarum in Banatu Temesiensi sponte erescentium et frequentius cultarum. (Verh. d. zool. bot. Ges., Wien, VIII [1858], S. 39.)

Pan či ć, Zur Flora des Banates. (Österr. bot. Zeitschr., XVIII [1868], S. 78.)

Simkovics L., Bánsági s Hunyadmegyei utazásom 1874 ben. (Math. es term. közlem, XV [1878], S. 479.)

Wierzbicki P., Reisebericht. (Flora, XXIII [1840], S. 363.)

- Bericht über botanische Exkursionen im Banat. (Flora XXV [1842], S. 257.)

\section{n) Westliche Randgebirge Siebenbuirgens.}

Banyai J., Adatok Abrudbánya környékének flórájához. (Bot. Közl., XI [1912], S. 116.) Barth J., Eine botanische Exkursion auf das Vorgebirge Piatra Csáki bei Felsö Gald. (Verh. u. Mitt. d. siebenb. Ver, f. Nat., XIX [1868], S. 139.)

- Eine botanische Exkursion auf die Vlegyassa. (Verh. u. Mitt. d. siebenb. Ver. f. Nat., XLIII [1894], S. 30.)

Bielz E. A., Naturhistorische Reiseskizzen. (Verh. u. Mitt. d. siebenb. Ver. f. Nat., III [1852], S. 171.)

Flatt K., Syringa Josikaea Biharban. (Erdész. Lap., XXV [1886], S. 41.)

Kerner A, Das Pflanzenleben der Donauländer. (Innsbruck, 1863.)

-. Die Vegetationsverhältnisse des mittleren und östlichen Ungarn und angrenzenden Siehenbürgen. (Österr. bot. Zeitschr., XVII-XXIX [1867-1879].) 
Schur F., Bericht über eine botanische Rundreise durch Siebenbürgen. I. Von Hermannstadt nach Karlsburg. (Verh. u. Mitt. d. siebenb. Ver. f. Nat., X [1859], S. 59.)

- - II. Auf den Berg Keeskekö bei Krakkó. (Verh. u. Mitt. d. siebenb. Ver. f. Nat., X [1859], S. 65.)

- - III. Über N. Enyed, M. Ujvar, Torockó in die Thordaer Schlucht. (Verh. u. Mitt. d. siebenb. Ver, f. Nat., X [1859], S. 77.)

Sinıonkai I.., Nagy-Vảrad és a Sebes-Körösfelsöbb vidéke. (Math. es term. Közlem., XVI S. 71.)

Wolff G., Botanische Rückerinnerungen. (Verh. u. Mitt. d. siebenb. Ver. f. Nat., XVI [1865], S. 35.)

\section{o) Das zentralsiebenbürgisehe Hügelland.}

Barth J., Systematische Aufzählung der im großen Kokeltale zwischen Mediasch und Blasendorf wild wachsenden Pflanzen. (Verh. u. Mitt. d. siebenb. Ver. f. Nat., XVII [1866], ง. 43, XVIII $[1 \times 67], \rightarrow: \because 1$.

- A Hargita-hegység s szomszédságának Flórájá. Die Flora des Hargita-Gebirges und seiner nächsten Umgebung. (Magy. bot. Lapok, II [1903], S. 318.)

- Polygala sibirica, eine für Siebenbürgen neue Pflanze. (Verh. u. Mitt. d. siebenb. Ver. f. Nat., XXI [1870], S. 44.)

Fronius F., Ein Ausflug auf die Hargita am 1. Juni 1857. (Verh. u. Mitt. d. siebenb. Ver. f. Nat., VIII [1857], S. 10:.)

- Flora von Schäßburg. (Progr. d. evang. Gymn., Schäßburg, 1857-1858.)

Herzog M., Über die Phanerogamenflora von Bistritz. (Progr. d. evang. Gymn. Bistritz, 1859.)

Janka V. v., Korrespondenz. (Österr. bot. Wochenbl., V [1855], S. 229, VI [1856], 362.)

Römer J., Beiträge zur Flora von Salzburg (Vizakna) bei Hermannstadt. (Verh. u. Mitt. d. siebenb. Ver. f. Nat., XXXV [1884], S. 38.)

- Ein beachtenswertes pflanzengeographisches Gebiet des Burzenlandes. (Flora von Honigberg.) (Verh. u. Mitt. d. siebenb. Ver. f. Nat., LXII [1911], S. 1.)

- Beiträge zur Flora des Bades Bázna (Baassen). (Magy. bot. Lapok, XII [1913], S. 250.)

Schube Th., Botanische Ergebnisse einer Reise in Siebenbürgen. (Jahresber. d. schles. Ges. f. vaterl. Kultur, 1894, S. 64.)

Schur F., Verzeichnis der am 19. November 1851 teils in der Umgebung von Hermannstadt, teils am Scholtener Berge in Blüte beobachteten Pflanzen. (Verh. u. Mitt. d. siebenb. Ver. f. Nat., III [1852], S. 32.)

- Bericht über eine botanische Rundreise durch Siebenbürgen. I: Von Hermannstadt nach Karlsburg. (Verh. u. Mitt. d. siebenb. Ver. f. Nat., X [1859], S. 59.)

- - IV: Exkursion nach Thorda. (Verh. u. Mitt. d. siebenb. Ver. f. Nat., X, S. 77.)

- - V: Klausenburg, vorzüglich die Heuwiese. (Verh. u. Mitt. d. siebenb. Ver. f. Nat., X [1859], S. 81.)

- - VI: Die Mezöség. (Verh. u. Mitt. d. siebenb. Ver. f. Nat., X [1859], S. 110.)

- - IX: Der Kereszthegy bei Görgény. (Verh. u. Mitt. d. siebenb. Ver. f. Nat., X [1859], S. 156.) 


\section{Das ungarische Tiefland.}

\section{A. Die klimatischen und Bodenverhältnisse des ungarischen Tieflandes in ihren Bezie- hungen zur Vegetation.}

Der große Gebirgsbogen der Karpathen umschließt an seiner Innenseite ein weites Tiefland, das, im IVesten bis an das westungarische Bergland, im Süden bis an die illyrisch-serbischen Berge reichend, ehedem, bevor es größtenteils in Ackerland umgewandelt war, wenigstens in seinen zentralen Teilen ein waldloses Steppen- und Sumpfland dargestellt hat.

Die Ausläufer der Karpathen, besonders das Neograder Gebirge, sowie das Pilis-Vertes-Gebirge, teilen dieses Tiefland in zwei ungleiche Hälften, die Große und die Kleine ungarische Tiefebene.

Die ,Kleine ungarische Tiefebene" stellt ein von den Ausläufern des böhmisch-mährischen Plateaus, der Alpen, Karpathen und des Pilis-VertesGebirges umgebenes, durchschnittlich 125 m hohes Becken rar, das einen Flächenraum von etwa $16.650 \mathrm{~km}^{2}$ umfaßt. Die Ebene selbst besteht aus Alluvialboden, die westlichen Rändler aus Diluvial- und Belvedereschotter, die üłrigen aus Löß. Die Ebene wird von der zahlreiche Inseln, darunter die kleine und große Schüttinsel, bildenden Donau, der March und Paab durchströmt, in ihrer südlichen Hälfte liegt der Neusiedler See.

Die „Große ungarische Tiefebene" oder das „Alföld" wird von den Karpathen, dem westungarischen, kroatischen und serbischen Berglande begrenzt und umfaßt einen Flächenraum von fast $100.000 \mathrm{~km}^{2}$. Von der Donau und Theiß und dem Unterlauf der Drau, Save, Maros, Körös und Temes durchflossen, stellt sie eine bis $250 \mathrm{~km}$ breite und über $500 \mathrm{~km}$ lange, nur von Flugsandhügeln und niedrigen Landrücken unterbrochene Tiefebene dar, die aus Sand, Löß und an den Rändern auch aus Schotter besteht, welche in einer Mächtigkeit von 150 bis $200 m$ über den Neogenschichten gelagert sind.

Im Tertiär war das ganze ungarische Tiefland vom Meere bedeckt, das seit dem Pliozän sich langsam zurückzog und noch im Pleistozän, ja, selbst heute eigentlich noch nicht ganz geschwunden ist. Denn besonders zwischen Theiß 
und Donau findet man auch heute noch zahlreiche salzige Teiche und Tümpel und salzauswitternde Stellen und auf weite Strecken hin ist der Boden salzhaltig. Hauptsächlich handelt es sich um kohlensaure Salze (Soda), ferner um Chlornatrium (Kochsalz), doch treten manchenorts auch schwefelsaure Salze (Alaun, Bittersalz) und salpetersaure Salze auf. Dieser Salzgehalt des Bodens ist von großem Einfluß auf die Vegetation, da überall dort, wo der Salzgehalt des Bodens nur einigermaßen beträchtlich ist, sich eine åußerst charakteristische Halophytenflora einstellt, außerdem aber, da die Flora Mitteleuropas keine ausgesprochen salzliebenden Holzgewächse besitzt, auch ein Baum- und Strauchwuchs dadurch unmöglich gemacht wird.

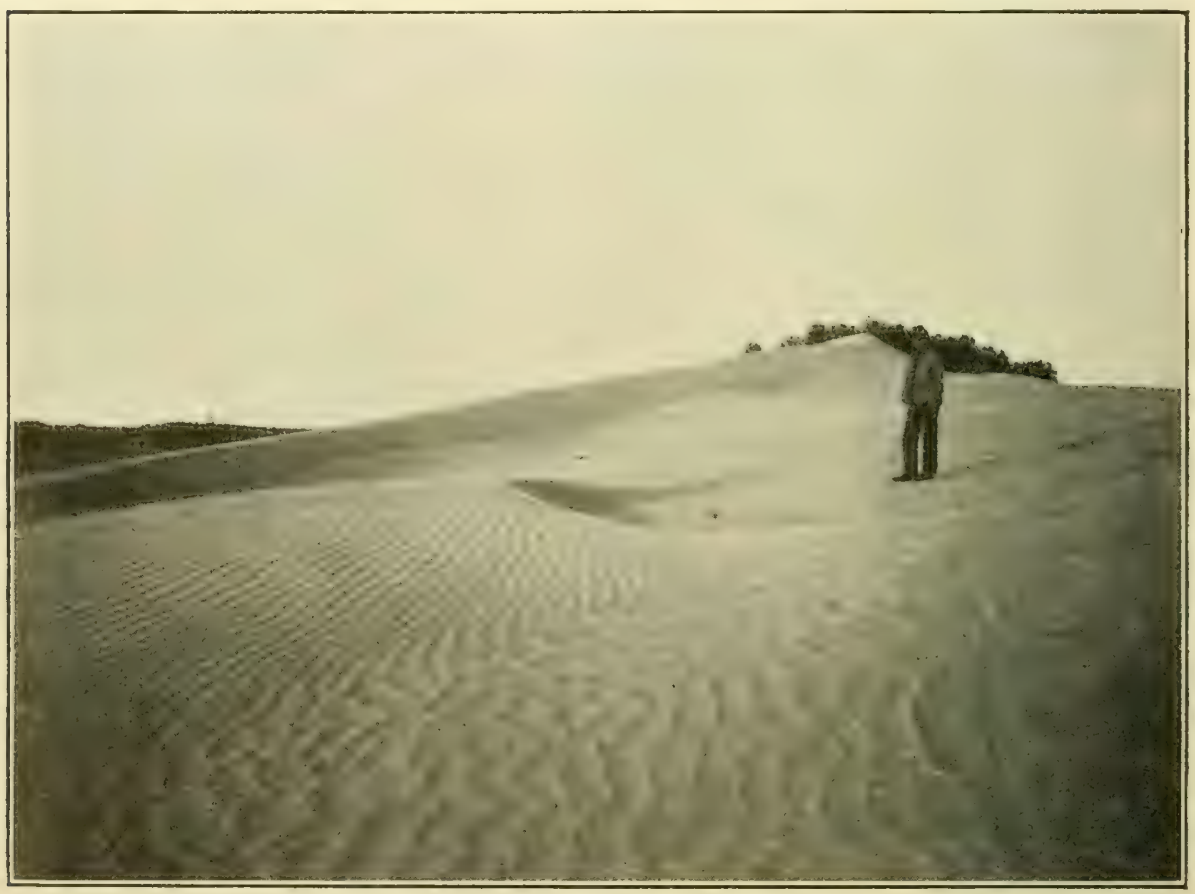

Abb. 275. Flugsanddüne (,Barchan $\left.{ }^{6}\right)$ in der Puszta Deliblat in Südostungarn.

(Nach einer Aufnahme von Prof. J. V. Cholnoky, Kolozsvár.)

(Aus der Bildersammlung des geographischen Institutes der Wiener Universität.)

Von ebenso großer Bedeutung für die Vegetation ist ferner der Flugsand, ein feinkörniger gelber lockerer Sand, der vom Winde umhergetrieben und oft zu mächtigen Dünen und Hügeln aufgetürmt wird, welcher in einer oft bis zu $70 \mathrm{~m}$ mächtigen Schicht auf weite Strecken hin den Boden bedeckt. Auch dieser feine sand ist vermöge seiner großen Wasserdurchlässigkeit einem Baumwuchs nicht günstig und würde, wenn im Lande nicht auch während der Sommerzeit ab und zu Regen fiele, der wenigstens die oberflächlichen Schichten des Sandes wierlor durchfeuchtet, zur Wüstenbildung führen. In der Tiefe aber kann sich das Grundwasser erst an der unteren Grenze des Sandes über einer wasserundurch- 
lässigen Schicht ansammeln unr ist daher, falls die Sandschicht sehr tief, für die Wurzeln von Bäumen nicht erreichbar. Freilich ist die Wasserkapazität des feinen Sandes nicht so gering wie die von grobem Schotter und in der Tiefe wird stets eine gewisse Feuchtigkeitsmenge zurückgehalten.

Die geringe Neigung des Terrains bringt es endlich mit sich, daß im Tieflande die Flüsse ein nur sehr geringes Grfällr habrn, welches infolge des schlängeligen Laufes derselben oft noch verringert wird. Dieser Umstand sowie die dort, wo mächtige Flugsandschichten fehlen, oft sehr geringe Tiefe des Grundwasserspiegels hat zur Versumpfung ausgedehnter Landstrecken geführt, die allerdings in den letzten Jahrzehnten durch ausgedehnte Entwässerungsarbeiten vielfach wieder trockengelegt worden sind.

Während an den Rändern der ungarischen Tiefebene sich noch überall die im folgenden Kapitel besprochenen Eichenwälder finden, ist das Zentrum, der großen und ein Teil der kleinen ungarischen Tiefebene waldlose Steppe, in der nur entlang der Flüsse Bäume (Pappeln und Weiden) gedeihen. Ob diese Baumlosigkeit in dem dort herrschenden Klima ihre Ursache hat oder bloß auf edaphische Verhältnisse (Trockenheit des Bodens, Salzgehalt desselben) zurückzuführen sei, ist eine noch nicht endgültig entschiedene Frage, und während A. Kerner und Schimper die ungarische Steppe als klimatische Formation auffassen, sind Grisebach, Drude und in neuerer Zeit auch Bernátsky der Meinung, daß das Klima der ungarischen Tiefebene nicht als ausgesprochen baumfeindlich angesehen werden könne, weil kultivierte Bäume, auch ganz sich selbst überlassen ohne künstliche Bewässerung, gut fortkommen. Es darf jedoch nicht außer acht gelassen werden, daß Aufforstungsversuche im Zentrum des Steppengebietes bisher immer fehlgeschlagen haben und nur die einzige Akazie (Robinia Pseudacacia) sich als dem Steppenklima anpassungsfähig erwiesen hat, während selbst Föhren an manchen Orten nicht fortkommen; und daß anderseits kultivierte Bäume meist in der Nähe menschlicher Wohnstätten sich befinden, wo doch andere Verhältnisse, speziell bezüglich der Bodenfeuchtigkeit, herrschen. Von edaphischen dem Baumwuchs schädlichen Einflüssen wäre jedenfalls in erster Linie der Salzgehalt des Bodens in Betracht zu ziehen, weniger die Trockenheit desselben, da vielerorts das Grundwasser sehr hoch steht und selbst in Gruben zutage tritt; an anderen Orten freilich, wie bei Debreczen, wurde selbst in großer Tiefe kein Wasser gefunden.

Was das Klima betrifft, so ist weniger die geringe Niederschlagsmenge als die lange sommerliche Dürre als baumfeindlich anzusehen. Die geringe Niederschlagsmenge des Winters steigt im Frühling und Frühsommer rasch an, im Spätsommer und Herbst herrscht aber große Trockenheit, es kommt vor, daß wochenlang kein Tropfen Piegen fällt und der Boden bei einer Temperatur von 28 bis $37^{\circ}$ bis auf $67^{\circ} \mathrm{C}$ erwärmt wird. Wenn aber in der Sommerzeit Regen fallen, sind es nur kurzdauernde Regengüsse, die zwar zu einer Befeuchtung der oberflächlichen Bodenschichten genügen, aber nicht zur Ergänzung des Wasservorrates in der Tiefe des Bodens. Auch die jährliche Regenmenge erreicht selten mehr als $60 \mathrm{~cm}$. Ein genaueres Bild des Klimas geben folgende Tabellen: 
a) Mittelwerte der Niederschläge in Millimetern.

\begin{tabular}{|c|c|c|c|c|c|c|c|c|c|c|c|c|c|c|c|c|}
\hline & & & & Jahr & 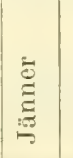 & 苛 & 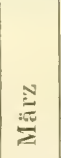 & $\bar{\Xi}$ & 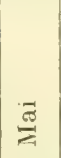 & $\stackrel{\Xi}{\Xi}$ & 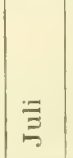 & $\sum_{\bar{y}}^{\vec{w}}$ & 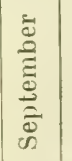 & $\frac{\ddot{d}}{0}$ & $\mid \begin{array}{l}0 \\
0 \\
\tilde{E} \\
\tilde{E} \\
\partial \\
0 \\
z\end{array}$ & 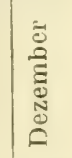 \\
\hline eßburg (Pozsony) & & & & 699 & 43 & 37 & 54 & 62 & 74 & 71 & 69 & 63 & 52 & 65 & 37 & \\
\hline & & & & 572 & 34 & 30 & 36 & 46 & 57 & 70 & 51 & 47 & 52 & 53 & 52 & \\
\hline alla . & & & & 598 & 33 & 30 & 40 & 55 & 70 & 63 & 54 & 51 & 48 & 61 & 46 & \\
\hline Kaposvái . . & & . & & 34 & 31 & 26 & 45 & 62 & 66 & 84 & 78 & 59 & 53 & 59 & 38 & \\
\hline Sudapest . & & 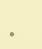 & & 640 & 37 & 31 & 45 & 58 & 74 & 74 & 53 & 50 & 51 & 66 & 53 & \\
\hline ász-Berényi . . . & & & & 605 & 31 & 27 & 38 & 53 & 68 & 81 & 57 & 48 & 49 & 66 & 44 & \\
\hline cskemet . . & & & & 577 & 29 & 24 & 37 & 55 & 72 & 71 & 52 & 48 & 54 & 56 & 40 & \\
\hline a ..... & & & & 636 & 34 & 24 & 38 & 48 & 72 & 89 & 65 & 59 & 46 & 69 & 47 & \\
\hline satz (Ujvidek) & & & & 663 & 38 & 34 & 44 & 61 & 79 & 80 & 60 & 52 & 59 & 70 & 47 & \\
\hline zolnok .... . & & & & 604 & 35 & 25 & 45 & 57 & 66 & 72 & 58 & 45 & 49 & 60 & 45 & \\
\hline es. . & & & & 545 & 34 & 28 & 36 & 51 & 56 & 70 & 52 & 47 & 39 & 62 & 34 & \\
\hline ezö-Vásárhely & & & & & & 16 & 35 & 56 & 65 & 64 & 60 & 44 & 53 & 55 & 34 & \\
\hline & & & & 593 & 31 & 27 & 35 & 53 & 68 & 76 & 61 & 47 & 65 & 61 & 44 & \\
\hline ladány & & & & 576 & 31 & 21 & 34 & 60 & 69 & 69 & 95 & 50 & 38 & 68 & 37 & \\
\hline Nyiregyháza . . & & & & 624 & 30 & 27 & 38 & 50 & 60 & 84 & 78 & 56 & 48 & 64 & 47 & \\
\hline Ujfaly & & & & 552 & 39 & 24 & 31 & 49 & 66 & 82 & 48 & 46 & 34 & 56 & 31 & \\
\hline Némety & & & & 718 & 43 & 39 & 46 & 55 & 72 & 90 & 74 & 62 & 51 & 73 & 54 & \\
\hline & & & & 565 & 26 & 17 & 34 & 50 & 61 & 87 & 64 & 56 & 33 & 60 & 39 & \\
\hline ardein (Nagy) & & & & 667 & 36 & 29 & 48 & 54 & 71 & 92 & 64 & 49 & 49 & 70 & 53 & \\
\hline & & & & 638 & 37 & $|32|$ & 40 & 52 & 76 & 93 & 61 & 44 & 51 & 63 & 46 & \\
\hline Pancsova & & & & 661 & $\mid 36$ & $\mid 35$ & 49 & 55 & 81 & 78 & 59 & 47 & 54 & 71 & 48 & \\
\hline nesvár & & & & 616 & $|35|$ & 30 & 39 & 58 & 73 & 85 & 56 & 49 & 47 & 57 & 44 & \\
\hline Deliblat . . . . & & & & 663 & $\mid 34$ & 34 & 49 & 62 & 80 & 85 & 63 & 50 & 48 & 69 & 44 & \\
\hline
\end{tabular}

Vor allem zeigt sich, daß die zentralen Teile des Tieflandes die regenärmsten sind (vgl. Leva, Kecskemet, Hód-Mezö-Vásárhely, Szeged, Puspökladány usw.), deren jährliche Regenmenge gegen die der Randgebiete um rund 50 bis $120 \mathrm{~mm}$ zurückbleibt. Aber auch diese Gebiete, deren ursprüngliche Waldlosigkeit wohl kaum von jemandem bezweifelt wird, weisen Mittelwerte auf, die nicht unter $545 \mathrm{~mm}$ im Jahre herabsinken, also höher liegen als in manchen bewaldeten Grgenden Zentralböhmens. Anders allerdigs steht es mit der Verteilung der Niederschläge. Besonders im zentralen Gebiete ist ihre Verteilung eine ziemlich gleichmäßige, so daß in keinem Monate die Regenmenge viel über $70 \mathrm{~mm}$ beträgt, und von einer gründlichen Wasserversorgung der tieferen Borenschichten nicht die Rede sein könnte. Hingegen fällt das Maximum der Niederschläge in den Monaten Mai und Juni, der Hauptvegetationszeit der Gräser, während im Hochsommer die Regenmenge gering ist. Da dabei, wie nachfolgende Tabelle zeigt, 
die Temperaturen sehr hoch sind und konstante wenn auch nur schwache Vinde wehen, ist die Transpiration der Pflanzen eine sehr starke und oft genug kann man beobachten, daß im Sommer die Blätter der Bäume und Sträucher welken, wie auch die Grasnarbe der Steppen frühzeitig vergilbt und vertrocknet.

b) Mittelwerte der Temperatur

\begin{tabular}{|c|c|c|c|c|c|c|c|c|c|c|c|c|}
\hline Jahr & 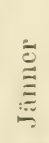 & 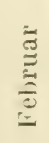 & $\stackrel{N}{=}$ & $\bar{z}$ & $\bar{\Xi}$ & $\Xi$ & $\equiv$ & $\stackrel{\vec{w}}{\stackrel{\vec{w}}{\underline{\underline{z}}}}$ & 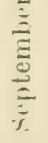 & $\frac{\frac{5}{0}}{\frac{0}{0}}$ & 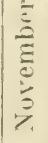 & \\
\hline
\end{tabular}

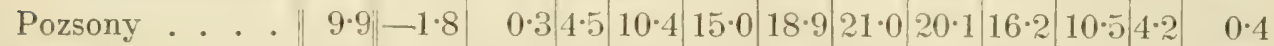

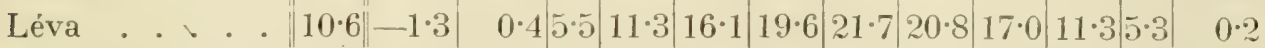

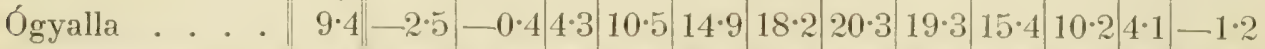

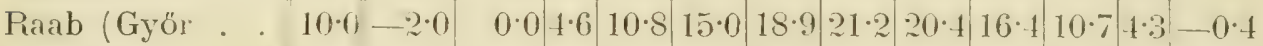

Budapest . . . | $9 \cdot 9-2 \cdot 1-0 \cdot 24 \cdot 6 \quad 10 \cdot 8|15 \cdot 4| 19 \cdot 1 \quad 21 \cdot 320 \cdot 1 \mid 16 \cdot 2 \quad 10 \cdot 54 \cdot 2-0 \cdot 8$

Jász-Berény . . || $10 \cdot 1 \|-3 \cdot 0-0.94 \cdot 8|11 \cdot 4| 16 \cdot 2|19 \cdot 7| 21 \cdot 0|21 \cdot 0| 16 \cdot 7|10 \cdot 94 \cdot 2|-1.5$

Kecskemét . . $10 \cdot 8|-2 \cdot 3-0.15 \cdot 3| 11 \cdot 8|16 \cdot 5| 20 \cdot 4|22 \cdot 7| 21 \cdot 8|17 \cdot 5| 11 \cdot 7 \mid 4 \cdot 7-0.4$

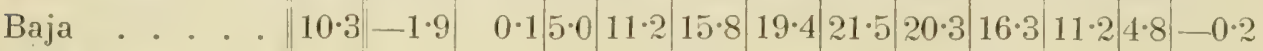

Hód-Mezö-

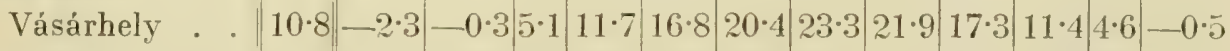

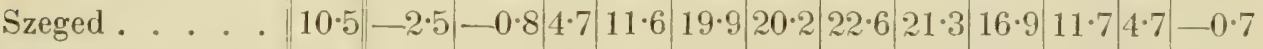

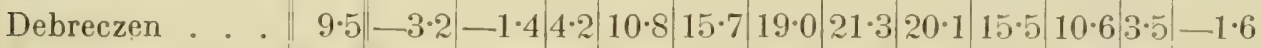

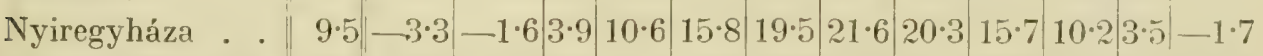

Szatmár-Némety $\quad 10 \cdot 2-2 \cdot 6-0 \cdot 84 \cdot 6 \quad 11 \cdot 316 \cdot 3 \quad 19 \cdot 6 \quad 21 \cdot 7 \quad 20 \cdot 8 \quad 16 \cdot 211 \cdot 24 \%, 0.8$

Großwardein

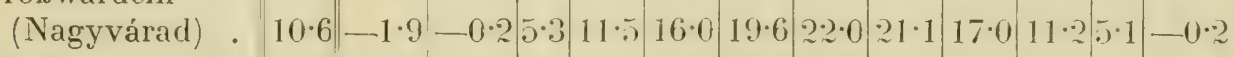

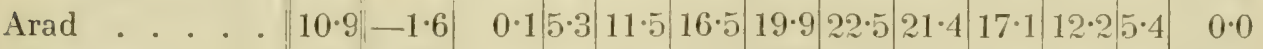

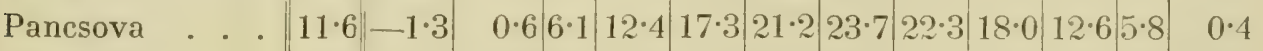

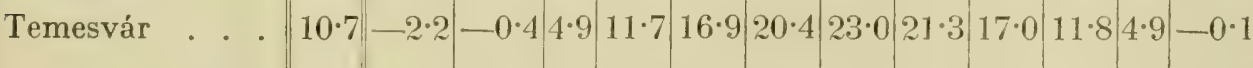

Besonders aber ist es die große Lufttrockenheit, die im Tieflande herrscht, die die starke Transpiration der Pflanzen fördert und demnach einem Baumwuchs entgegenwirkt. Die Luftfeuchtigkeit beträgt im

\begin{tabular}{ll|l|l|l|l|l|l}
\hline \hline & Jahr & Frühling & Sommer & Herbst & Winter \\
\hline \hline Steppengebiet . . . . . . . . . . & $71 \cdot 5$ & $67 \cdot 7$ & $63 \cdot 1$ & $72 \cdot 1$ & $82 \cdot 8$ \\
Randgebiet . . . . . . . . . . . & $76 \cdot 8$ & $71 \cdot 2$ & $69 \cdot 2$ & $81 \cdot 0$ & $84 \cdot 1$ \\
Gebirge . . . . . . . . . & $81 \cdot 3$ & $74 \cdot 5$ & $75 \cdot 2$ & $83 \cdot 2$ & $86 \cdot 7$
\end{tabular}

Besonders aber sind im Tieflande die monatlichen Minima sehr gering, wie folgende Übersicht zeigt:

Hayek, Die Pflanzendecke Österreich-Ungarns. I. 


\begin{tabular}{|c|c|c|c|c|c|c|c|c|c|c|c|c|}
\hline & 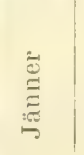 & & 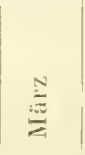 & $\stackrel{\overrightarrow{3}}{4}$ & $\ddot{\Xi}$ & $\stackrel{\Xi}{\Xi}$ & $\Xi$ & 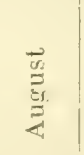 & 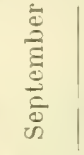 & $\frac{\frac{d}{0}}{\frac{\partial}{0}}$ & 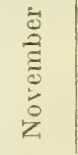 & 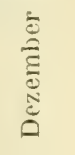 \\
\hline Preßburg . . & $54 \cdot 8$ & $53 \cdot 0$ & $37 \cdot 8$ & $22 \cdot 2$ & $27 \cdot 2$ & $29 \cdot 8$ & $30 \cdot 2$ & $24 \cdot 8$ & $32 \cdot 5$ & $39 \cdot 7$ & $53 \cdot 4$ & $56 \cdot 9$ \\
\hline Budapest . . & $59 \cdot 3$ & $55 \cdot 1$ & $41 \cdot 8$ & $33 \cdot 0$ & $32 \cdot 8$ & $35 \cdot 1$ & $35 \cdot 1$ & $32 \cdot 5$ & $37 \cdot 6$ & $41 \cdot 2$ & $51 \cdot 0$ & $58 \cdot 8$ \\
\hline Szeged . . . & $66 \cdot 0$ & $35 \cdot 0$ & $46 \cdot 0$ & $30 \cdot 0$ & $34 \cdot 0$ & $37 \cdot 0$ & $34 \cdot 0$ & $36 \cdot 0$ & $33 \cdot 0$ & $50 \cdot 0$ & $64 \cdot 0$ & $75 \cdot 0$ \\
\hline Pancsova.. & $54 \cdot 0$ & $42 \cdot 0$ & $20 \cdot 0$ & $28 \cdot 0$ & $20 \cdot 0$ & $26 \cdot 0$ & $21 \cdot 0$ & $22 \cdot 0$ & $23 \cdot 0$ & $32 \cdot 0$ & $40 \cdot 0$ & $46 \cdot 0$ \\
\hline
\end{tabular}

Besonders in den Sommermonaten von Mai bis September sind die Zahlen auffallend niedrig.

Aus dieser Darstellung ergibt sich, daß das Klima der ungarischen Tiefebene weit eher als ein Grasflurklima als ein Gehölzklima bezeichnet werden muß. Freilich ist es nicht so extrem gehölzfeindlich, daß ein Baumwuchs unmöglich wäre, aber natürlich treten in jedem Gebiete jene Formationen in den Vordergrund und gewinnen mit der Zeit die Oberhand, für welche die klimatischen Verhältnisse günstiger sind. Da aber in der Tiefebene noch dazu die Bodenverhältnisss (tief Flugsandschichten, Salzboden) einem Baumwuchs nicht günstig sind, ist es natürlich; daß die Grasflur hier die Oberhand gewonnen hat.

Daß die Grasflur in der ungarischen Ebene fast durchwegs als Steppe und nicht als Wiese ausgebildet ist, ist ganz zwangslos auf die sommerliche Trockenheitsperiorle zurückzuführen, die der mesophilen Wiese verlerblich wird, während die Steppenpflanzen entweder xerophil gebaut sind oder aber einjährige Arten darstellen, die zu Beginn der sommerlichen Trockenheit ihre ganze Entwicklung bis zur Samenreife bereits abgeschlossen haben.

Die ausdauernden Gräser der Sand- und Grassteppe besitzen größtenteils Blätter, die nach dem Typus des Falzblattes gebaut sind (vgl. S. 32), so die Stipa-Arten und Fesluca vaginala; bei den Andropogon-Arten rollen sich die bei feuchter Witterung flachen Blätter nach oben zu ein. Die jungen Blattsprosse aber sind durch die aus den Resten der alten Blattscheiden gebildete Tunika cingehüllt, die zumeist als Strohtunika ausggebildet ist (vgl. S. 32). Aber auch einjährige Gräser sind besonders in der Sandsteppe zahlreich vertreten, so z. B. Bromus tectorum und Secale silvestre, die schon im Juni ihre Früchte reifen. Unter den übrigen monokotylen Steppengewächsen sind vornehmlich Zwiebelgewächse vertreten, die entweder zeitlich im Frühjahr blühen und den trockenen Sommer nur mit der unterirdischen Zwiebel überdauern, wie z. B. Gagea pusilla, oder Herbstblütler, wie Colchicum arenarium; nur die Allium-Arten blühen während der Trockenzeit, doch haben auch diese dann die transpirierenden Blätter schon abgeworfen und begnügen sich mit den in der Zwiebel aufgespeicherten Wasservorräten. Ähnlich wie die Zwiebelgewächse verhalten sich unter den Dikotylen manche Ranunkulazeen, so Adonis vernalis, Anemone grandis, A. nigricans, Paconia tenuifolia, die ebenfalls im Frühling blühen und im trockenen Sommer 


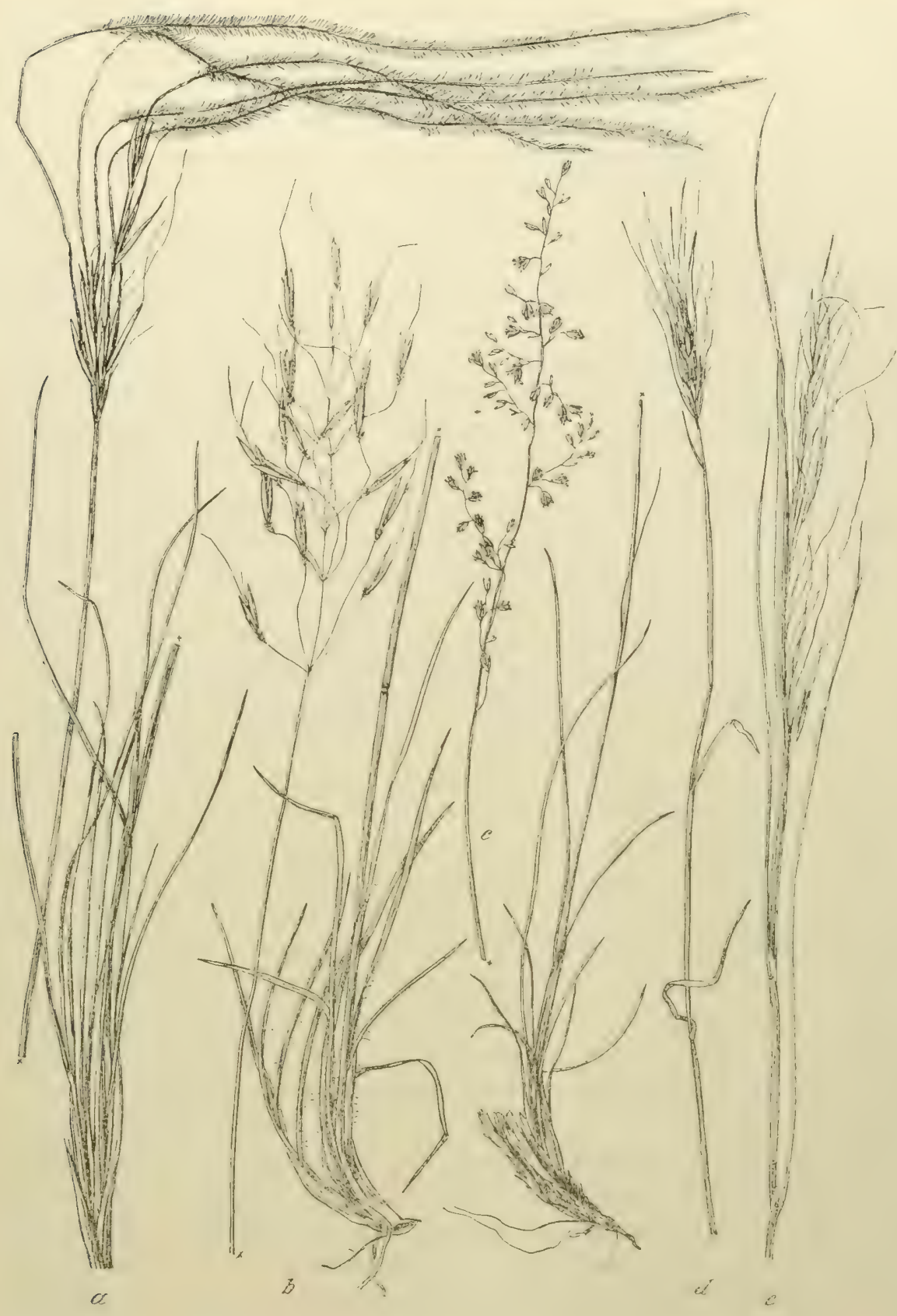

Abb. 276. Die wichtigsten Steppengräser Ungarns,

a Stipa pennata. $b$ Andropogon Gryllus. $c$ Festuca vaginata. $d$ Secale silvestre. $e$ Stipa capillata.

entweder schon ganz cingezogen haben oder ihn nur mit xerophil gebauten Blättern überdauern. Nicht unbeträchtlich ist auch die Zahl der annuellen Steppenbewohner, es sei hier nur auf Cerastium viscosum, Silene conica, Ranunculus 
lesticulalus, Draba verna, Tribulus orienlalis, Trigonella monspeliaca, Medicago minima, Myosolis micrantha, Veronica praecox hingewiesen, die im Frühling blühen und im Sommer bereits in Frucht stehen, und die einjährigen Arten, die während der heißen und trockenen Jahreszeit blühen, wie die Filago-Arten und Xeranthemum annuum, weisen eine dichte Behaarung als Transpirationsschutz auf. Die zwei- und mehrjährigen Arten aber, die während des Sommers blühen, sind alle mehr oder minder xerophil gebaut: Dichte Behaarung weisen die Verbascum-Arten und verschiedene Labiaten und Kompositen auf, die Um. belliferen wie Peucedanum arenarium und die Seseli-Arten haben in feine lineale Zipfel zerspaltene Blätter, die Dianthus-Arten und Tragopogon floccosus schmal jineale Blattspreiten. Dorngewächse findet man unter den Umbelliferen (Eryngium) und Kompositen (Carduus. Onopordon, Cenlauren solstitialisi. Relativ selten sind in der Sandsteppe typische Rutensträucher, wie Ephedra distachya, und Sukkulenten, wie z. B. Sedum Hillebrandtii. Zahlreiche Sandbewohner sind durch eine ungemein kräftige und lange, bis in feuchtere Bodenschichten vordringende Pfahlwurzel ausgezeichnet (Astragalus exscapus, Onosma, Alkanna, Verbascum, Cichorium). Auch am Boden hingestreckte Kräuter sind nicht selten (Polygonum arenarium, Herniaria, Tribulus).

Aber auch die Halophyten zeigen fast durchwegs xerophile Anpassungserscheinungen, obwohl ihre Standorte keineswegs so trocken scheinen. Auf der Salzsteppe ist zum mindesten im Frühling der salzhaltige Lehmboden bis in den Juni hinein feucht und im Frühling oft lang dirckt vom Wasser bedeckt; freilich im Sommer trocknet er gewöhnlich so vollständig aus, daß er Risse und Sprünge bekommt. Und die Pflanzen, die am Rande von Salztümpeln und Salzseen wachsen, haben ja während des ganzen Jahres Wasser zur Verfügung. Aber der große Salzgehalt eben ist es, der die Wasseraufnahme aus dem Boden außerordentlich erschwert (vgl. S. 20), und überdies macht die sommerliche Trockenheit einen Transpirationsschutz nötig. Merkwürdigerweise sind aber auf Salzboden Pflanzen mit dichter Behaarung relativ selten, als Beispiel sei -1rlemisia monogyna angeführt. Hingegen sind Sukkulenten auf Salzboden sehr häufig, und wenn auch nicht alle Arten so typische Fettpllanzen sind, wie Salicornia herbacea, so weisen doch die meisten Arten sehr saftreiche, leicht sukkulente Blätter auf, wie z. B. die Chenopodien, Lepidium crassifolium, L. latifolium, Statice Gmelini und Planlago Schuarzenbergiana; ausgeprägtere Fettpflanzen sind Camphorosma ovala, Suaeda maritima, Spergularia media und Sp. marina. Die Gräser der Salzstep pe sind sehr oft annuell, wie Hordeum Gussoneanum, Lepiurus pannonicus und (li überdies hochgradig xerophil gebaute Crypsis aculeala. Auch sonst sind annuelle Arten in der Salzsteppe nicht selten, wie Cerastium anomalum, Lepidium perfoliatum, Trifolium parviflorum, T. slriclum, Matricaria Chamomilla und die etwas : 11 kikulente Blätter aufweisende Plantago tenuiflora. Ja, die ansgesprochensten Ilalorhyten, wie Salicornia herbacea, sind ebenfalls einjährig, hingegen sind domige? Crewärhse auf Salzboden selten (z. B. Crypsis aculeala) und Rutensträucher fehien ganz, wie überhaupt salzliebende Holzgewächse, wie etwa Tamarix-Arten und holzige Chenopodiazeen im Ungarischen Tieflande nicht vorkommen. 


\section{B. Die Pflanzengenossenschaften des Gebietes.}

\section{Baum- und Strauchformationen.}

Eichenwälder. Während das Zentrum des ungarischen Tieflandes, besonders entlang der Theiß, waldlose Steppe darstellt, finden sich am Rande derselben stellenweise noch ziemlich ausgedehnte Wälder. Ein solches waldreiches Gebiet zieht sich streifenförmig zwischen Donau und Theiß über Gödöllö, Monor, Kecskemét bis fast gegen Szabadka (Maria-Theresiopel) herab; ein zweites bildet die Ebene an der oberen Theiß, der Nyirség; ferner finden sich überall Wälder am Rande der Ebene und auch entlang der aus den öst. lichen Gebirgen kommenden Flüsse, besonders der Maros.

Fast durchwegs sind es Eichenwälder, die daselbst auftreten und in ihrer Zusammensetzung besonder's auf feuchterem Untergrunde schon den slawonischen Eichenwäldern ähneln, während die Wälder auf reinem Sandboden eine etwas abweichende Physiognomie zeigen.

Die Hauptmasse des Oberholzes bildet überall Quercus Robur, der sich mitunter auch Q. Cerris und Q. pubescens beigesellen. Nicht selten sind auch Carpinus Betulus, Ulmus glabra, Populus alba und nigra, Acer campestre, Pirus Piraster, Sorbus torminalis, Prunus avium sowie Tilia cordata und im Südosten auch Tilia tomentosa zu finden. An Flußufern sind ferner fast stets auch $\mathrm{Fra}$ xinus excelsior und Alnus glutinosa und incana anzutreffen. Nadelhölzer fehlen natürlich vollkommen. Das meist reiche Unterholz bilden Corylus Avellana, Salix caprea, Acer lataricum, A. campestre, Evonymus verrucosus, Rhamnus cathartica und R. Frangula, Cornus sanguinea, Prunus spinosa, P. Mahaleb und P. Padus, Cralaegus monogyna, Ligustrum vulgare, Viburnum Opulus und V.Lantana, Lonicera Xylosteum, Sambucus nigra; im Banat auch Colinus Coggygria var. arenaria. Der Niederwuchs ist sehr mannigfach und je nach der Bodenunterlage wechselnd. An trockenen Stellen machen sich vor allem Agropyrum caninum, Brachypodium silvaticum, Melica allissima, Bromus erectus, Dactylis glomerala, Poa trivialis, Polygonalum multiflorum und P. latifolium, Cephalanthera rubra, Lychnis Coronaria, Dianthus Armeria, Ranunculus auricomus, Thalictrum aquilegifolium, Alliaria officinalis, Saxifraga bulbifera, Geum urbanum, Fragaria viridis, Vicia Cracca und V.pisiformis, Lathyrus vernus, L. niger und L. pannonicus, Astragalus glycyphyllos, Trifolium alpestre und T. montanum, Gytisus supinus, Euphorbia polychroma und E. amygdaloides, Hypericum hirsutum, Chaerophyllum temulum und C. bulbosum, Aiuga genevensis, Origanum vulgare, Satureia vulgaris, Echium rubrum, Symphytum tuberosum, Valeriana officinalis, Campanula trachelium, C. bononiensis und C. persicifolia, Doronicum hungaricum, Centaurea stenolepis, Hieracium Pilosella und $H$. murorum bemerkbar.

Auf den Alluvionen der Flüsse aber, auf feuchterem Boden, zeigt der Niederwuchs eine größere Ähnlichkeit mit dem der slawonischen Eichenwälder. 
Hier finden sich Agropyrum caninum, Brachypodium silvalicum, Daclylis glomerata, Melica altissima, Festuca gigantea, Carex muricala, Veralrum album, Leucoium aestivum, Orchis ustulata, O. palustris und O. incarnala, Urtica dioeca. Parielaria officinalis, Dianthus superbus, Ranunculus Lingua, Aegopodium Podagraria, Chaerophyllum temulum, Lythrum Salicaria, Lycopus europaeus, Leonurus Marrubiastrum, Stachys palustris, Salureia vulgaris, Brunella vulgaris, Glechoma hederacea, Scrophularia nodosa, Physalis Alkekengi, Valeriana officinalis, Adenophora liliifolia, Inula Helenium, Serralula linctoria, Crepis biennis usw.

Nirgends aber fehlen in diesen Wäldern reichliche Schlinggewächse, vor allem Clematis Vitalba und Vitis silvestris und auf den Flußalluvionen auch Humulus Lupulus.

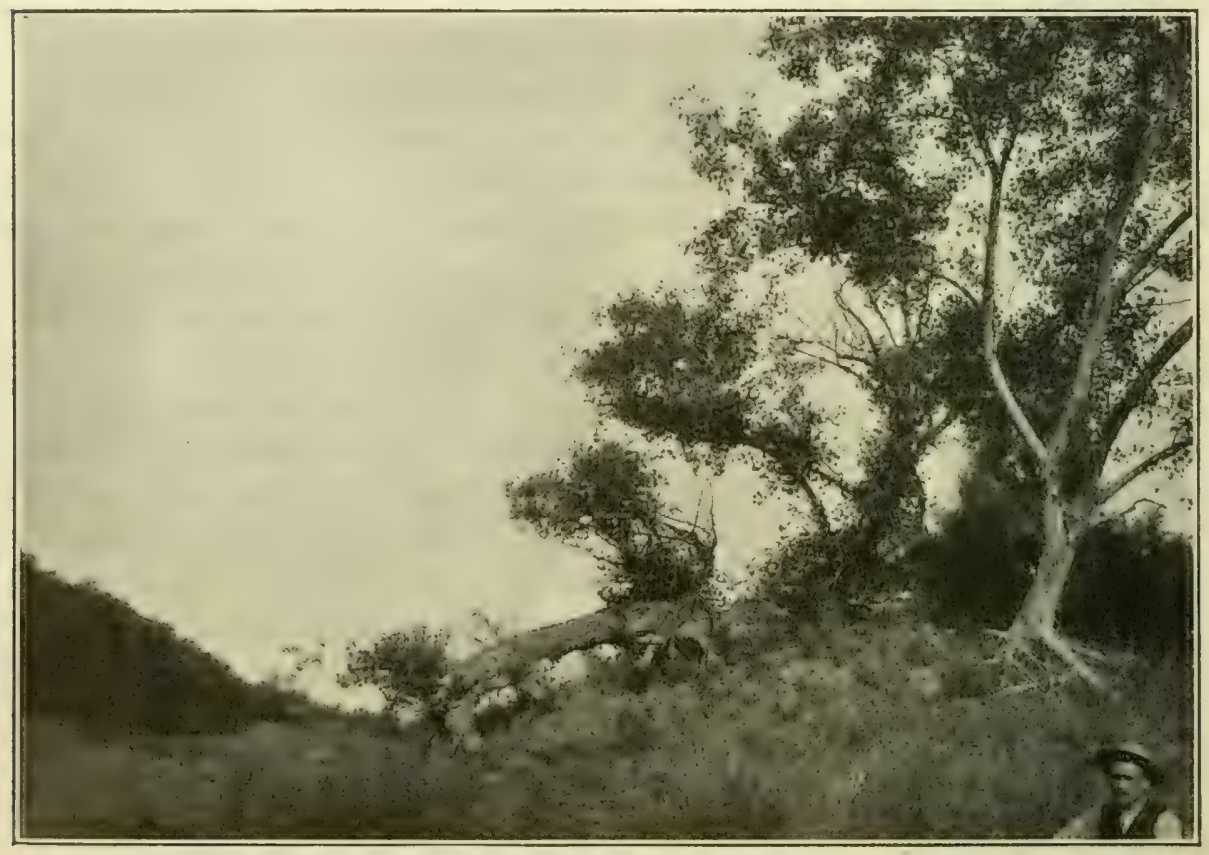

Abb. 278. Populus nigra im Flugsandgebiet bei Deliblat in Südostungarn.

(Nach einer Aufnahme von Dr. J. v. Bernátsky, Budapest.)

Pappelwälder. Ist im ungarischen Tiefland im Randgebiete auf humösem Boden die Eiche der herrschende Waldbaum, so ist auf den Flugsandflächen der Kecskemeter Landhöhe die Pappel das wichtigste Holzgewächs. Die mit einem langen Haarschopf versehenen Samen der Pappeln werden vom Winde weit umhergetragen und die Pappel, die zahlreiche Ausläufer treibt, trägt sehr zur Bindung des Flugsandes bei, so daß es ihr leicht fällt, auch in lockeren Sandboden Fuß zu fassen.

Vornehmlich Populus nigra, seltener $P$. lremula und $P$. alba sind es, die. dir... Wähler hilrlen, die allerdings im eigentlichen Steppengebiete gewöhnlich nur als Buschwälder ausgebildet sind, aber besonders im nördlichen Teile der 


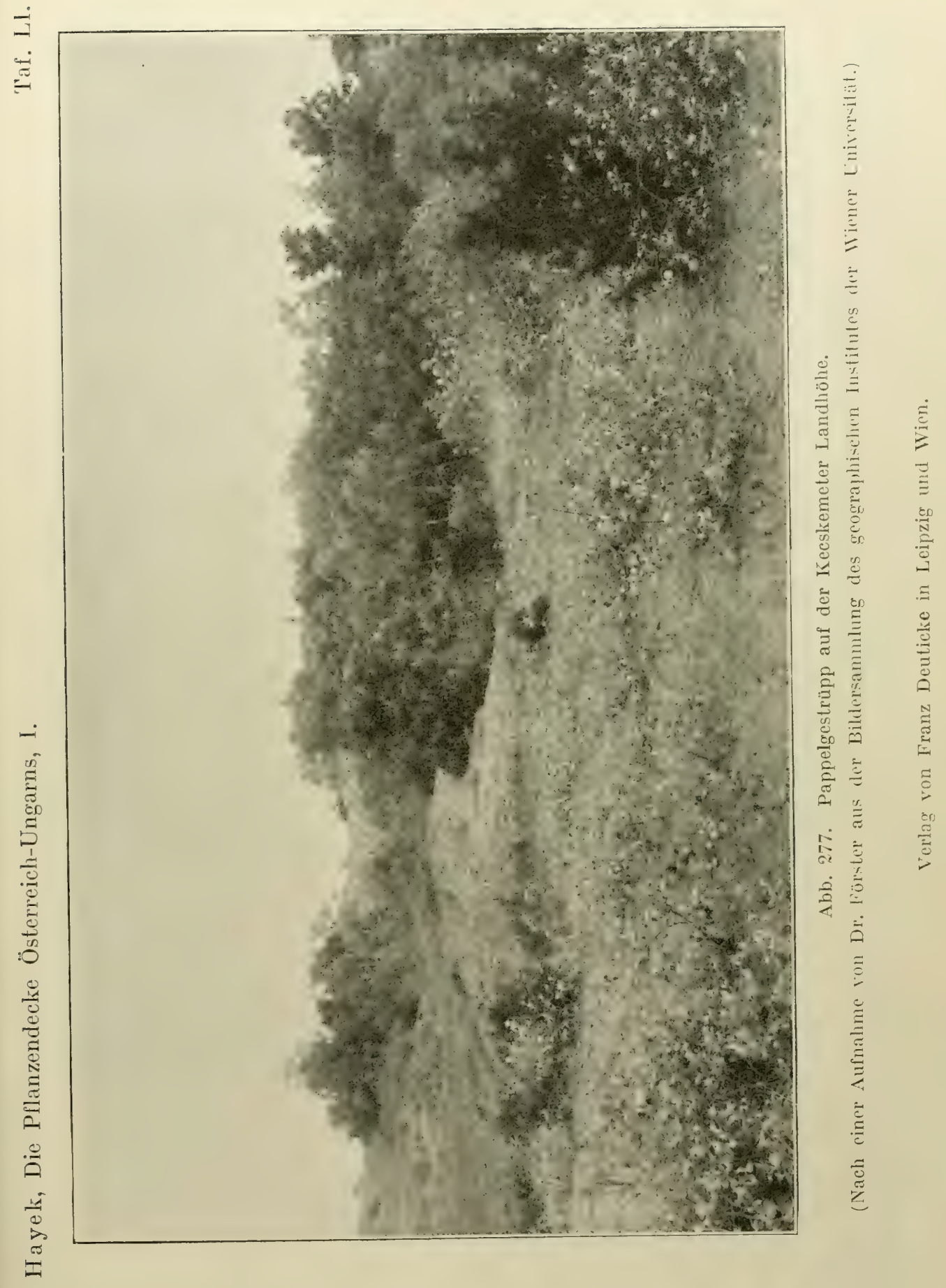



Kecskemeter Landhöhe auch manchmal zu Hochwäldern heranwachsen. Begleitpflanzen der Pappeln sind meist nur einzelne Weidenarten, wie Salix alba, $S$. fragilis und $S$. purpurea, die auch das spärliche Unterholz bilden. Der Niederwuchs ist gleichfalls sehr dürftig und besteht aus einigen Gräsern, wie Calamagrostis Epigeios, Festuca vaginala, Carex hirla, besonders aber Secale silveslre und vereinzelten Arten der Sandsteppe, wie Gypsophila paniculata, Syrenia anguslifolia, Erysimum canescens, Polentilla canescens, Astragalus varius, Onosma arenarium usw.

Ein ähnliches armseliges Bild, wie diese Pappelwälder, gewähren auch die zahlreichen in den letzten Jahrzehnten aufgeforsteten Wälder aus Pobinia Pseud-

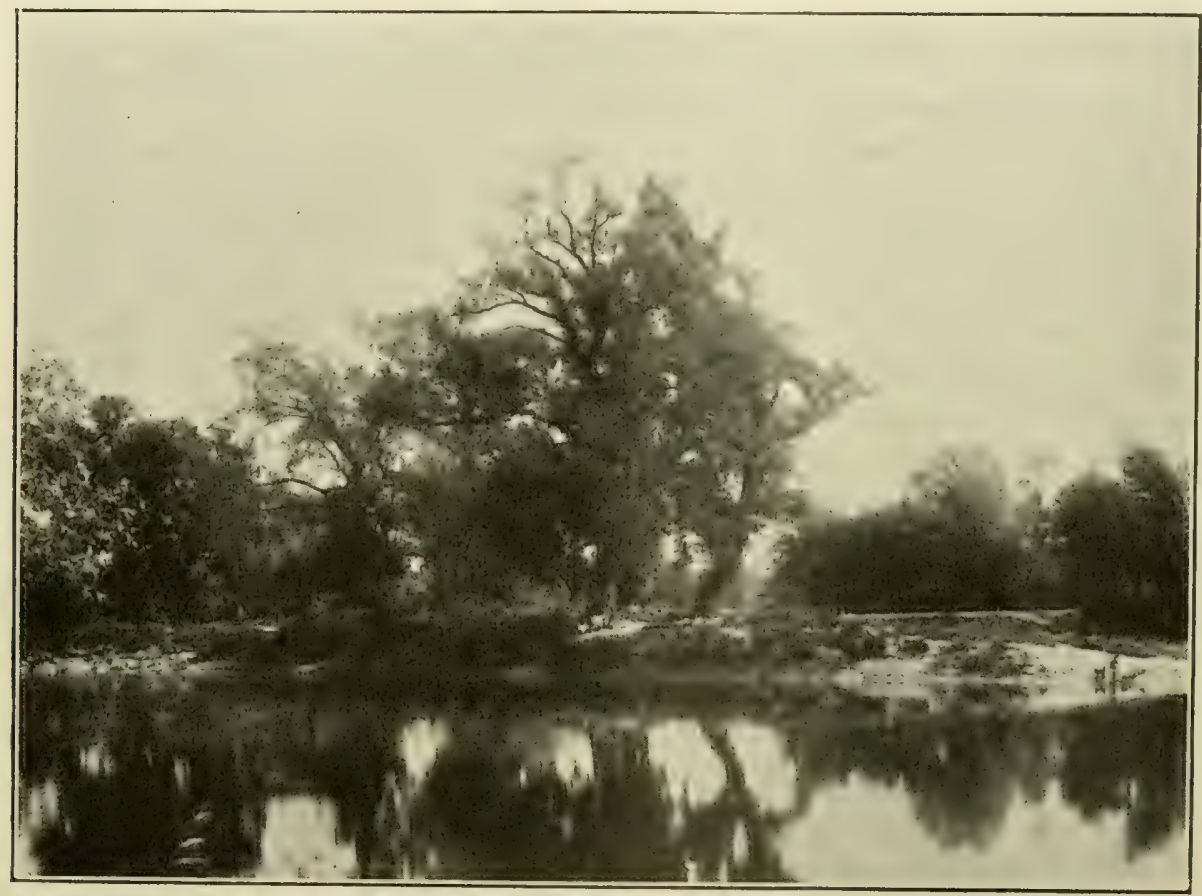

Abb. 279. Donau-Au bei Dömsöd im Komitate Pest.

(Nach einer Aufnahme von 'Prof. Dr. L. v. Lócsy, Budapest.)

(Aus der Bildersammlung des geographischen Institutes der Wiener Universität.)

acacia, die des Unterholzes gewöhnlich ganz entbehren und auch keinen oder nur aus vereinzelten Sandpflanzen bestehenden Niederwuchs besitzen.

Auenwälder. Mit Ausnahme des zentralsten Teiles des Steppengebietes sind an den Ufern der größeren Flüsse, soweit der Boden genügend durchfeuchtet ist, kleinere Auen ausgebildet. Vorwiegend sind es Weidenarten (Salix fragilis, alba, triandra, viminalis, daphnoides, purpurea), die in Strauch- oder Baumform an den Flußufern oft ziemlich ausgedehnte Bestände bilden; ihnen gesellt sich gern die Traubenkirsche (Prunus Padus) und Erlen (Alnus glutinosa und incana) sowie die Kratzbeere (Rubus caesius) zu. Doch auch Pappeln 
(Populus nigra, alba und lremula) treten nicht selten als Sträucher bestandbildend auf dem mit Humus vermengten Schotter auf, selten aber werden sie baumförmigl und dann gesellen sich ihnen auch Eschen (Fraxinus excelsior) und Ulmen (Ulmus glabra und laevis) bei. Eine unzertrennliche Begleitpflanze dieser Ufergehölze ist der Hopfen (Humulus Lupulus), der in Form dichter Laubdächer sich über das Gesträuch hinspinnt, oft vergesellschaftet mit der we i ßen II a l d re be (Clematis Vitalba). Mächtige Rohrgräser (Phragmites communis, Calamagrostis Pseudophragmiles und C. Epigeios) bilden oft ein undurchdringliches Dickicht, doch auch andere hochwüchsige Stauden wachsen gern in den Auen und Ufergebüschen, so Urtica dioeca, Clematis integrifolia, Symphylum officinale, Lysimachia vulgaris, Stenactis annua, Lalhyrus paluster, Aster salignus, Chrysanthemum uliginosum, Filipendula Ulmaria, Solanum Dulcamara usw.

Wacholdergestripp. Der IVacholder (Juniperus communis), das einzige in Lngarischen Tiefland sich findende Nadelholz, tritt stellenweise, besonders auf dem Landrücken zwischen der Donau und der unteren Theiß, im Verein mit anderen niederen Sträuchern formationsbildend auf. Unter dem stets vorherrschenden Gestrüpp jvon Juniperus communis finden sich da Berberis vulgaris, Prunus fruticosa und $P$. nana, verschiedenen Rosen, Crataegus Oxyacantha, Cylisus auslriacus und C.ralisbonensis, Rhamnus calhartica und Ligustrum vulgare und dazwischen einzelne Gräser und hochwüchsige Stauden der Steppe, wie Stipa capillata, Gypsophila paniculala, Astragalus varius und A. Onobrychis, Linum hirsutum, Peucedanum arenariun, Verbascum austriacum, Arlemisia campestris, Tragopogon floccosus und im Schatten des Buschwerkes gedeihen selbst Maiglöckchen (Convallaria maialis, Polygonatum lalifolium und multiflorum); ja, am Grunde breitet sich sogar ein Moosteppich (aus Thuidium abielinum, Hypnum cupressiforme, Camptothecium lutescens, Brachythecium salebrosum, Barbula ruralis, Pylaisia polyantha), in dem einige Strauchflechten, wie Cladonia furcala, gedeihen, aus, eine sonst im Steppengebiete nicht wiederkehrende Erscheinung.

\section{Formationen des Sand- und humösen Bodens.}

Die Trespensteppe. Die ersten Vorposten, die von den frisch aufgehäuften Flugsandhügeln Besitz ergreifen, sind einjährige Gräser und Kräuter, unter denen die Trespen (Bromus) die Hauptrolle spielen. Insbesondere sind es Bromus hordaceus, B. arvensis und B. lectorum, seltener B. squarrosus und B. commulalus, die in zahlloser Menge dem nackten Sandboden entsprießen. In ihrer Gesellschaft finden sich gern andere einjährige Gräser, wie Secale silvestre, Hordeum crinitum, Triticum villosum, Digitaria ciliaris, Tragus racemosus. |Häufig treten ferner Cynodon DacIylon, Polygonum arenarium und Tribulus orientalis auf, die durch ihre weit ausgebreiteten Stengel zur Festigung des Flugsandes beitragen, sowie Corispermum canescens und C.nitidum, Kochia arenaria und Salsola Kali. Auch Silene conica, Tunica prolifer a, Alyssum lorluosum treten gelegentlich in frischem Flugsande auf und auch einige mehrjährige Arten, wie Gypsophila paniculata, Dianthus serotinus, Euphorbia Gerardiana, Erysimum canescens, versuchen daselbst mitunter Fuß zu fassen. 


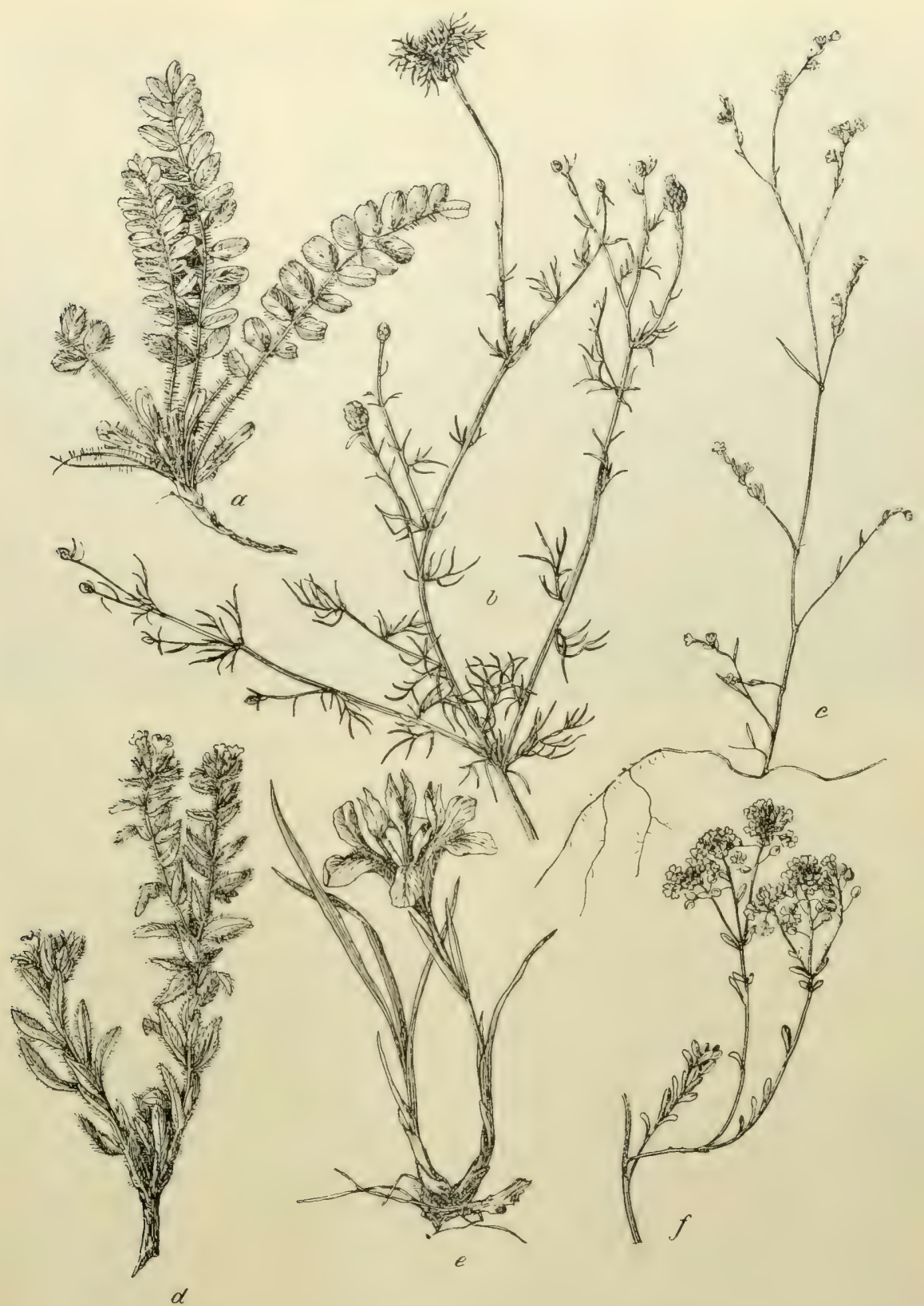

Abb. 280. Aus der Flora der ungarischen Sandsteppen.

$a$ Astragalus exscapus, $b$ Centaurea arenaria. $c$ Polygonum arenarium. $d$ Alkanna tinctoria. $e$ Iris arenaria. $f$ Alyssum tortuosum.

Die Federgrassteppe. Dort, wo die genannten einjährigen Arten den lockeren Flugsand einigermaßen gefestigt haben, breitet sich bald die typische Flora der Sandsteppen aus, welche insbesondere durch zwei Grastypen charakterisiert ist, den Pußtenschwingel und die Federgräser. 


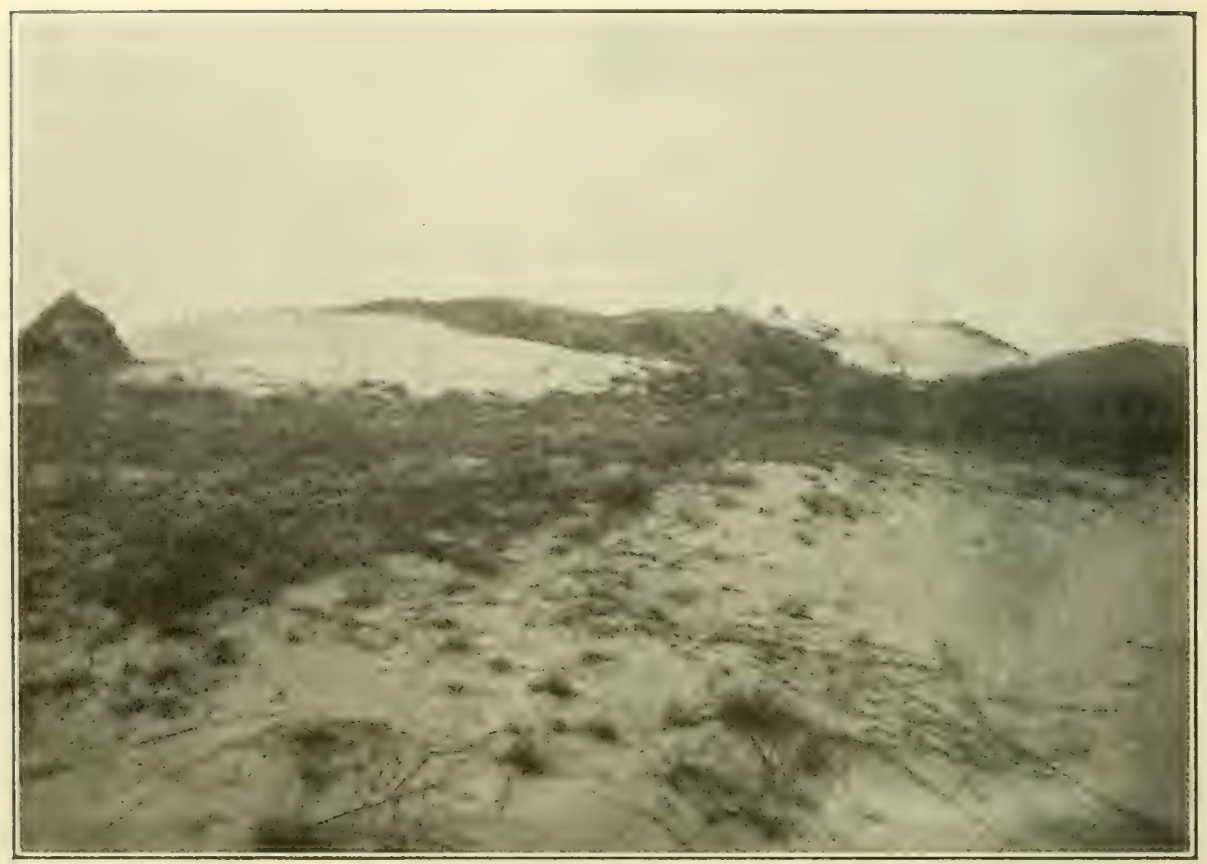

Abb. 281. Cynodon Dactylon auf Flugsand bei Vadkert im Pester Komitat.

(Nach einer Aufnahme von Prof. Dr. L. v. Lóczy, Budapest.)

(Aus der Bildersammlung des geographischen Institutes der Wiener Universität.)

Der PuBtenschwingel (Fesluca vaginata) bildet dicht geschlossene Rasen von derb borstigen, am Grunde von einer Strohtunika umgebenen Blättern, aus denen die etwa $30 \mathrm{~cm}$ hohen, oft violett überlaufenen blühenden Halme hervorragen. Einen ähnlichen Wuchs, aber derbere, fast binsenförmige Blätter zeigt das in verschiedenen Rassen zerfallende echte Federgras (Stipa pennata), dessen lange federartige Grannen von weitem einem silberigen wogenden über die Steppe hinziehenden Nebel gleichen und als "Waisenmädchenhaar" (Arva léanyhai) einen beliebten Hutschmuck bilden und auch sonst unter dem Namen Mariengras oder Frauenhaar als beliebter Zimmerschmuck zu MakartBuketten dienen. Später als Stipa pennala entfaltet Stipa capillala ihre Rispen mit nicht gefiederten, haarförmigen, verschiedenartig hin- und hergedrehten Grannen. Gern gesellt sich zu den Federgräsern auch das Bartgras (Andropogon Ischaemum) und das knollige Rispengras (Poa bulbosa), ferner einige CarexArten, wie Carex supina, $C$. stenophylla und $C$. obaesa. Auch die oben erwähnten einjährigen Grasarten fehlen selten; besonders Bromus hordaceus, tectorum und arvensis, denen sich gern $B$. inermis zugesellt, sind häufig vertreten. Von sonstigen Gräsern dieser Formation wären noch Cynodon Dactylon, Agropyrum cristalum, Koeleria glauca, Calamagrostis epigeios zu nennen. Groß ist die Zahl der auf der Steppe vorkommenden Kräuter und Stauden. Im ersten Frühling blühen Gagea pusilla, Cerastium semidecandrum, Holosteum umbellatum, Ane- 


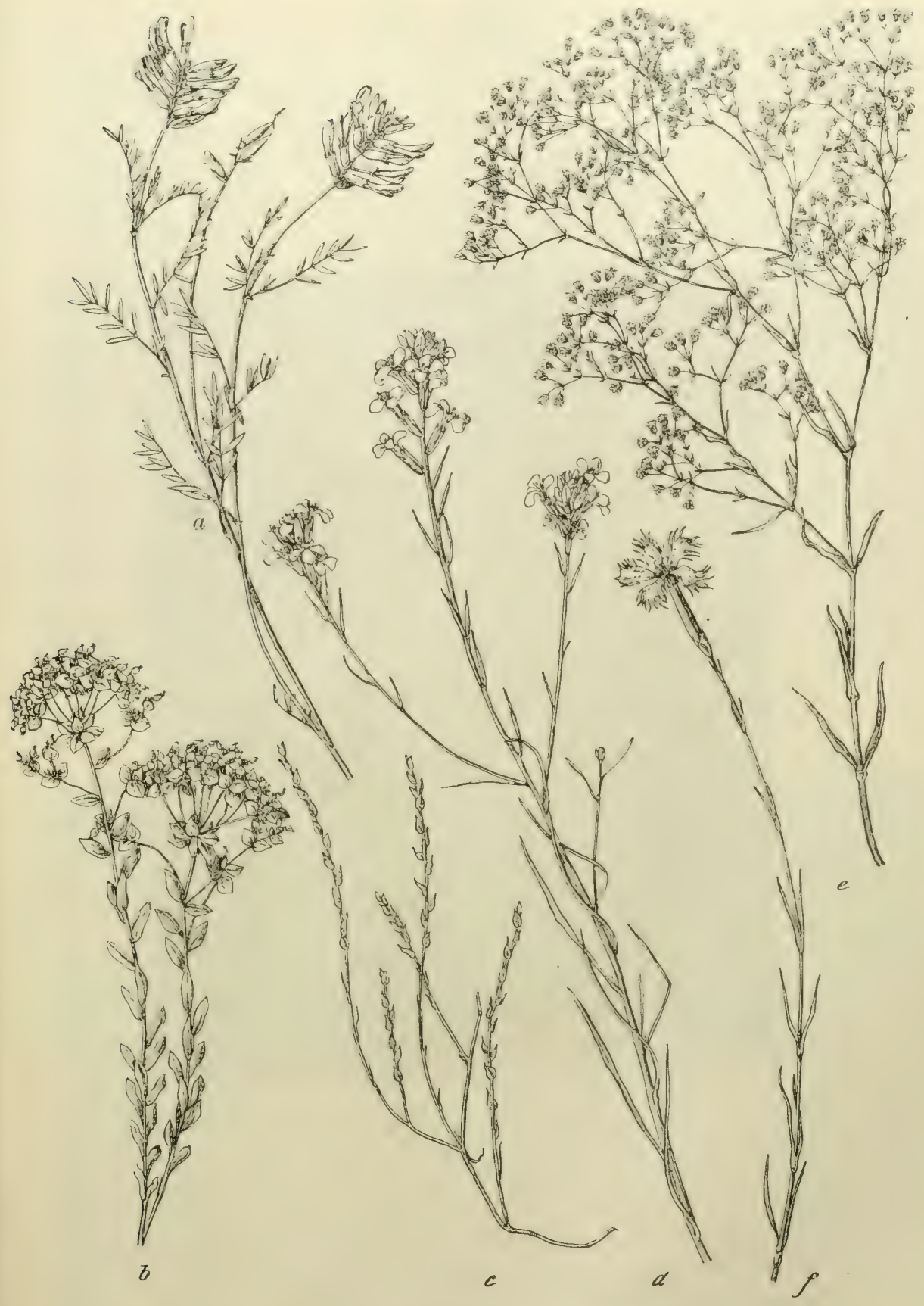

Abb. 282. Pflanzen der Sandsteppe.

$a$ Astragalus varius. $b$ Euphorbia Gerardiana. $c$ Corispermum nitidum. $d$ Syrenia angustifolia. e Gypsophila paniculata. $f$ Dianthus serotinus.

mone grandis, Alyssum desertorum, Veronica verna und $V$. praecox; ihnen folgen Luzula campestris, Iris arenaria und 1 . pumila, Orchis Morio, Minuartia verna. 
M. selacea und M. glomerata, Anemone nigricans, Polentilla arenaria, Cytisus ratisbonensis und C. austriacus, Medicago elongala, Fumana procumbens, Vinca herbacea. Im Mai und Juni hat die Pußta dann ihre höchste Blütenpracht erreicht, wenn Paeonia lenuifolia, Alyssum arenarium und lorluosum, Erysimum canescens, Syrenia angustifolia, Astragalus Onobrychis, A. varius, A. exscapus, Gypsophila paniculala und fastigiala, Dianthus serolinus und diutinus, Silene conica und Otiles, Melandryum viscosum, Polentilla argentea und canescens, Onobrychis arenaria,

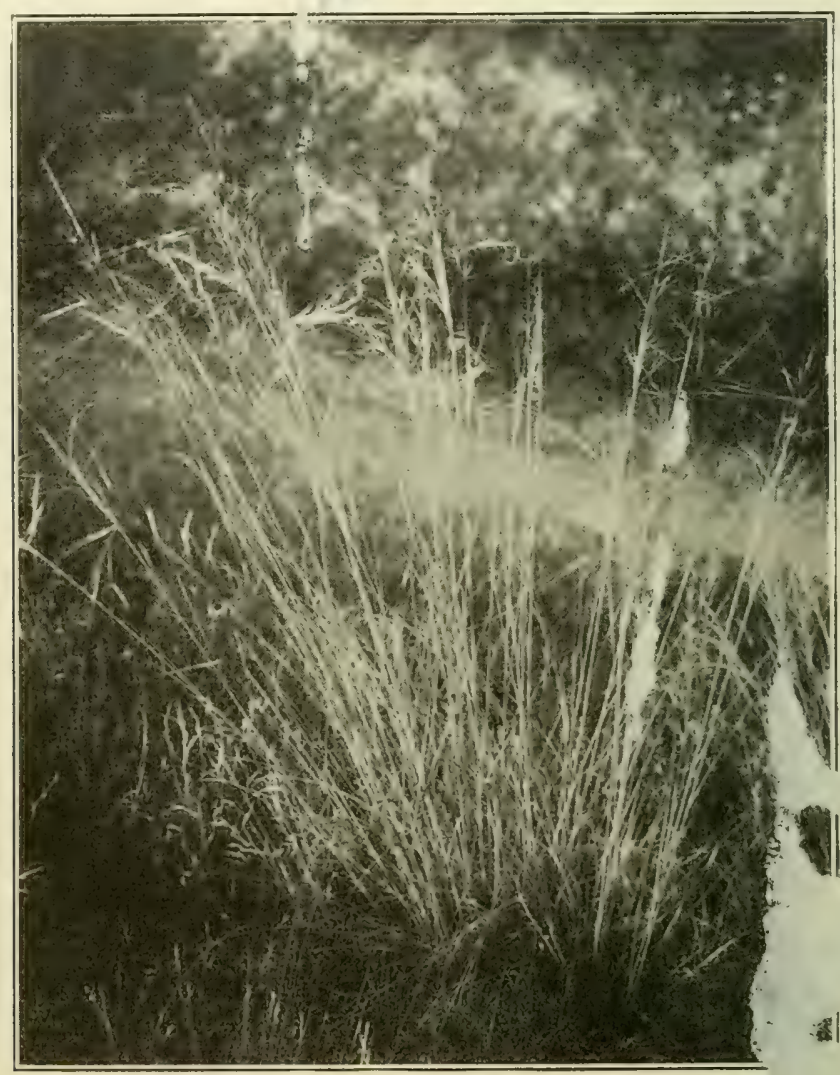

Abb. 283. Stipa capillata bei Deliblat in Südostungr? (Nach einer Aufnahme von Dr. J. v. Bernátsky, Buda

Eupharbia pannonica und E. Gerardiana, Seseli varium, Cynoglosum hungaricum, Alkanna tincloria, Achillea ochi floccosus in Blüten stehen. Im Hochsommer aber, wenn d Steppe bereits verschwunden, das Gras verdorrt ist, blüheituch einige hochwüchsige Stauden, wie Allium sphaerocephalum, Peucedanun trenarium, Artemisia campestris, Linosyris vulgaris, Centaurea arenaria, G. micrantha und i. Sadleriana, Helichrysum arenarium, - Veranlhemum annuum, Hieracium echioides, jurner die besonders in ter Nähe der Ortschaften selten fehlenden Spitzkletten ('irnthium strumarium und spinosum) und Disteln (insbesondere Carduus nutans 


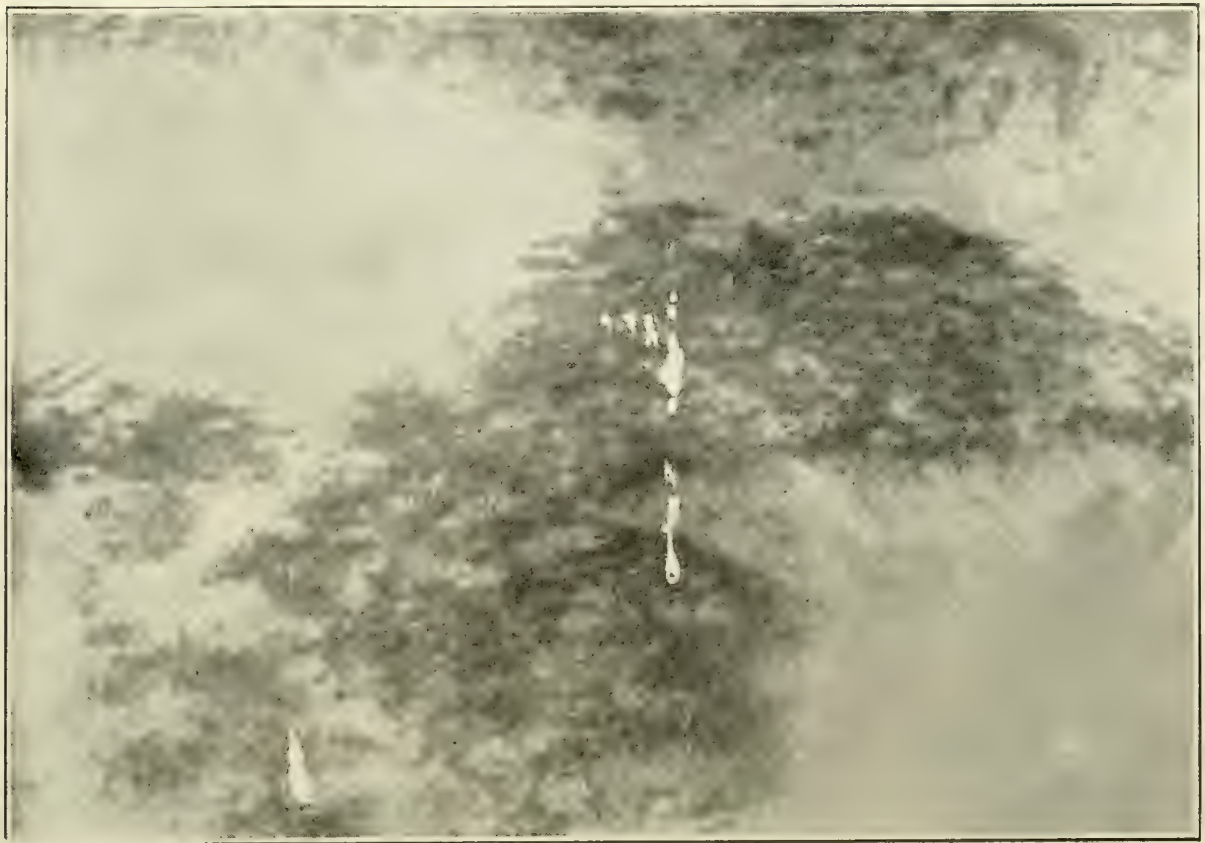

Abb, 284. Camphorosn i ovata als: erster Ansiedler auf ,Szikboden" bei Kun-Szent-Miklos. (Nach einer Aufnahme von A. v. Hayek.)

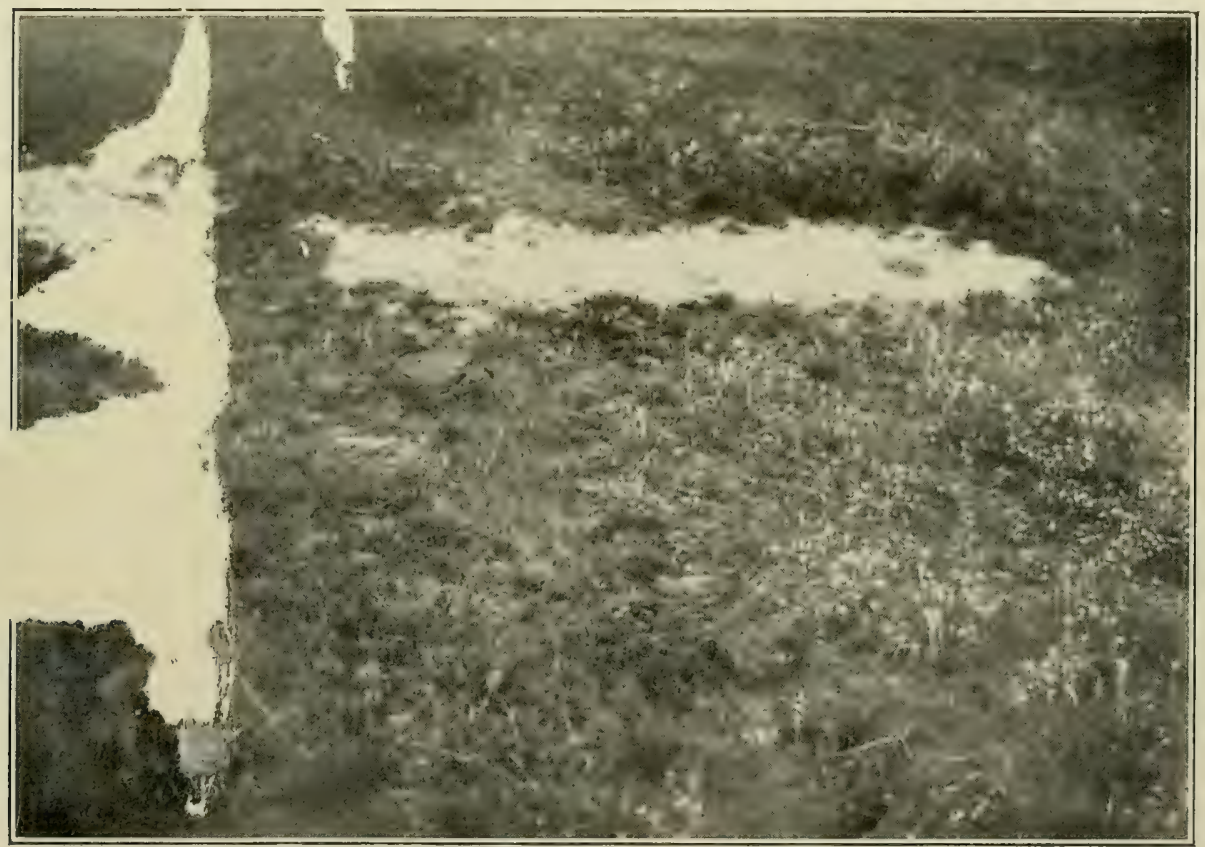

Abb. 285. Salzsteppe auf der Puszta Hortobagy bei Debreczen.

Hordeum Gussoneanum, Atropis limosa, Camphorosma ovata, Gypsophila muralis, Artemisia monogyna.

(Nach einer Aufnahme von D. H. Freiherr v. Handel-Mazzetti, Wien.)

Verlag von Franz Deuticke in Leipzig und Wien. 

und $C$. acanthoides, Cirsium eriophorum, lanceolatum und arvense, Onopordon Acanthium, Echinops ruthenicus); zuletzt erscheint dann die Sand-Zeitlose (Colchicum arenarium). Selten vermißt man in der Nähe von Budapest in der Sandpußta auch die schachtelhalmähnlichen Büsche von Ephedra distachya. Vollständig fehlen aber die auf den Sandheiden Norddeutschlands so charakteristischen Ericazeen; überhaupt sind Holzgewächse in der Sandpußta selten; außer den schon erwähnten Cytisus-Arten und Fumana procumbens treten nur ab und zu Sträucher auf, wie Juniperus communis, Prunus nana und spinosa, Cralaegus oxyacantha und C. nigra, Hyppophaëe rhamnoides und mancherorts in Menge das ursprünglich zur Festigung des Flugsandes kultivierte, aber so leicht verwildernde Lycium halimifolium. Hingegen sind einige Pilze für die Sandsteppen sehr bezeichnend, so insbesondere Peziza arenosa, P. ammophila, P. funerata, Helvella albipes, Tylostoma granulosum, T. valvulalum, Baltarea phalloides, Disciseda debreczeniensis, Geasler quadrifidus, G. Drummondii, G. hungaricus.

Die Goldbartilur. Dort, wo der Sandboden reichlicher mit Humus untermischt ist, nimmt die Steppe einen mehr wiesenartigen Charakter an und dichtrasige Gräser mit flachen Blättern, vor allem Andropogon Gryllus und A. Ischaemum, werden tonangebend. Fehlen auch die Stipa-Arten, Fesluca vaginala und die annuellen Bromus-Arten nicht immer vollständig, treten sie doch gegen die benachbarten Bartgräser stark zurück, hingegen kommen andere Gramineen, typische Wiesengräser hinzu, wie Phleum phleoides, Heleochloa explicala, Poa angustifolia, Koeleria gracilis, Daclylis glomerata, Avena subdecurrens, Festuca sulcala und elatior. Von Cyperazeen sind Carex slenophylla, supina, divisa und hirta nicht selten. Reich ist die Goldbartflur an Zwiebelund Knollengewächsen aus der Familie der Liliazeen, Iridazeen und Orchidazeen; es finden sich da u. a. Gagea pusilla, Ornithogalum comosum, O. refractum und 0 . narbonense, Sternbergia colchiciflora, Ciolchicum arenarium und C. autumnale, Iris variegata, Gladiolus paluster, Orchis Morio, O. coriophora, O. ustulata, O. tridentala, O. militaris, Anacamplis pyramidalis, Gymnadenia conopea, Spiranthes spiralis. In Menge blühen ferner im Frühling Adonis vernalis, Hesperis tristis, Potentilla arenaria und P. rubens, Fragaria collina, Herniaria incana, Saxifraga bulbifera, Ranunculus illyricus, Galium pedemontanum, Senecio campester, Scorzonera purpurea und S. hispanica, später Astragalus austriacus, A. Cicer, A. Onobrychis und A. asper, Trifolium alpestre und T. arvense, Coronilla varia, Filipendula hexapetala, Ranunculus pedalus, Silene longiflora und S. multiflora, Stachys officinalis, Thymus lanuginosus, Inula Oculus Christi, Verbascum phoeniceum und V. Blallaria, Campanula bononiensis, zuletzt dann Achillea selacea, Chrysanthemum Leucanthemum, Serratula linctoria, Cirsium eriophorum, Scabiosa ochroleuca, Verbascum Lychniles und V. phlomoides, Cenlaurea Sadleriana, Hieracium umbellalum usw., doch fehlen natürlich auch die Elemente der Federgrassteppe nicht, obwohl anderseits die Goldbartflur auch von der pannonischen Bergtrift nicht scharf geschieden ist. 


\section{Formationen des Salzbodens.}

Salzwiesen. Auf mäßig feuchtem, humösem, aber doch an kohlen-oder schwefelsauren Salzen reichem Boden tritt meist eine charakteristische Wiesenformation auf. Als besonders bezeichnend für diese Wiesen muß ein Gras von fremdartigem Habitus bezeichnet werden, die Beckmannia eruciformis. In ihrer Gesellschaft finden sich an Gräsern und Seggen Heleochloa explicala, Alopeculus aequalis, Phleum pralense, Atropis distans, A. festucaeformis und A. pannonica, Carex divisa und $C$. disticha, ferner Juncus compressus und an dikotylen Pflanzen besonders häufig die tiefpfirsichblütenrote Achillea crustata, mit ihr auch A. collina, ferner Lolus anguslifolius, Tetragonolobus siliquosus, Linum perenne, Samolus Valerandi, Aster Tripolium und Scorzonera parviflora.

Die Salzsteppen. Weite Strecken der groben ungarischen Tiefebene, besonders zwischen der Donau und dem Kecskemeter Landrücken und dann im Nordosten im Haiduckengebiete sind von einem eigenartigen salzhaltigen Lehm bedeckt, der im Frühling zur Regenzeit grau, weich und schmierig, oft sogar als wenig wasserdurchlï-igr Boden von einer Schicht Regenwasser bedeckt, im Hochsommer zu einer wriben, harten, trockenen, oft von Rirsen und Sprüngen durchzogenen Schicht erstarrt, der ,,Szik "-Boden der Ungarn. Weithin bedeckt diesen Boden eine eigenartige niedrige Grasflur, aus großenteils einjährigen Gewächsen bestehend, die relativ spät sich entwickeln und blühen und bis in den Spätsommer hinein den Boden mit einer vielfach durch vegetationslose, weiße Stellen unterbrochenen braungrünen Pflanzendecke überziehen. Der wichtigste Pionier auf diesem Szikboden ist Camphorosma ovala, die ihre kriechenden Rasen gegen den vegetationslosen Boden vorschiebend nach und nach von demselben Besitz ergreift. Von Gräsern sind es insbesondere Lepturus panonnicus und Hordeum Gussoneanum, die in meist tonangebender Menge vorhanden sind; ihnen gesellen sich bei Festuca pseudovina, Hordeum murinum, Cyperus pannonicus und Juncus compressus. Selten vermißt man auch die Blattrosetten von Stalice Gmelini, die im Hochsommer ihre sparrig verästelten violetten Blütenstände treibt, die grauen Blattbüschel von Lepidium crassifolium und die unscheinbare, zwischen den Grashalmen verborgene Plantago tenuiflora. Auch Plantago maritima und im Osten Plantago Schwarzenbergiana treten oft' fast bestandbildend auf und ebenso sind Suaeda salinaria, Spergularia marina, Gypsophila muralis, Lepidium Draba, L. perfoliatum, Ceraslium anomalum, Malva neglecla, Trifolium angulatum, T. slriclum, T. parviflorum, T. fragiferum, T. palens, Lolus tenuis, L. anguslissimus, Euphorbia Gerardiana, Bupleurum tenuissimum, Scorzonera Jacquiniana und S. parviflora nirgends selten. Ein weißer Champignon, Psalliota campestris, bildet stellenweise in der Salzsteppe große Hexenringe und im Spätherbste bedecken den Boden die dürren Rispen von Artemisia monogna.

Die Formation der Salzmelden. Am Rande salziger Seen und Lachen bildet sich eine sehr charaliteristische Vegetation aus. Der innerste Rand dieser Wasserbecken, von einer dichten Schicht der weißen Soda bedeckt, ist vegetationslos. Dann aber folgt ein dichter Ring aus Salicornia herbacea, Salsola 


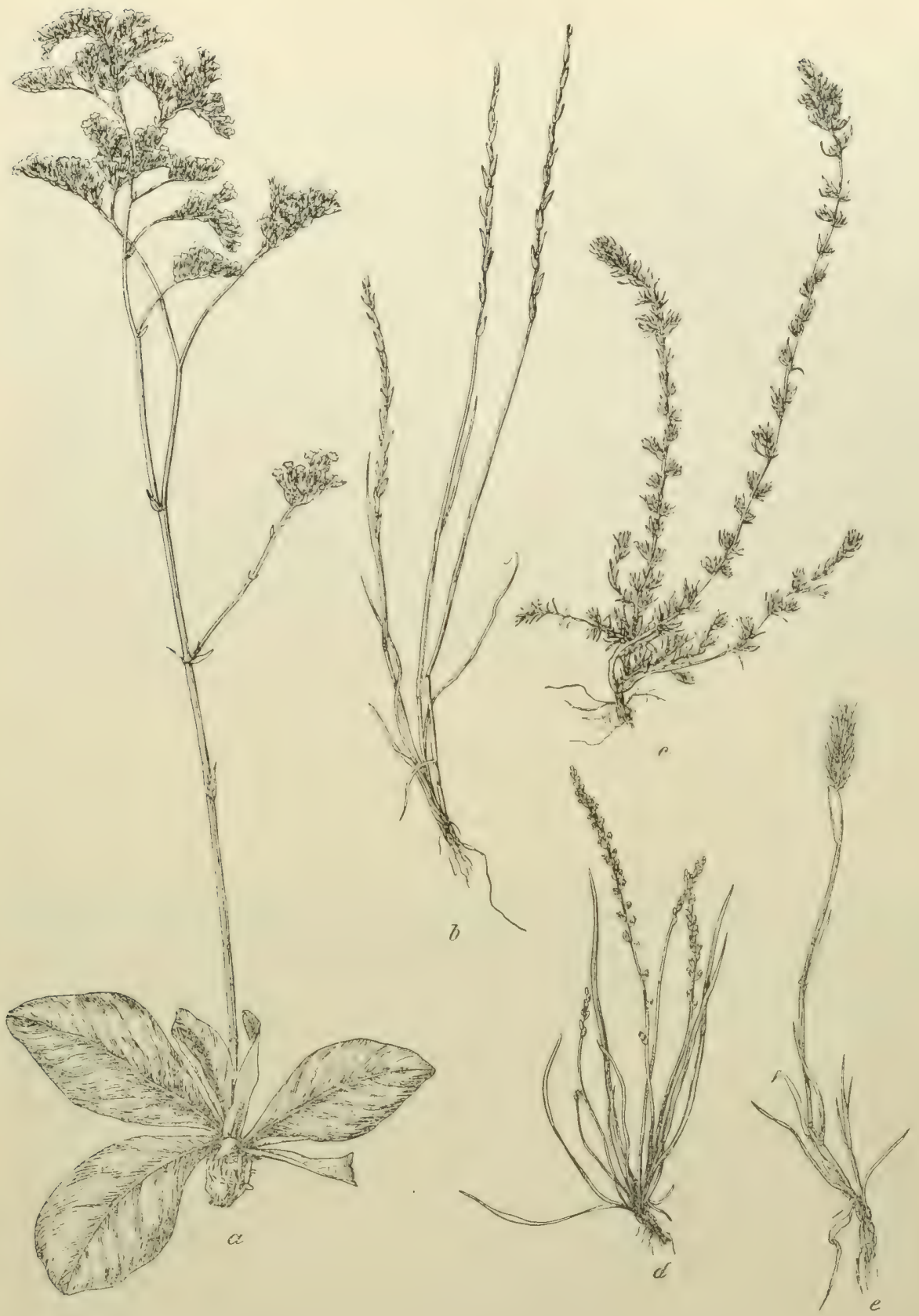

Abb. 286. Aus der Flora der ungarischen Salzsteppen.

a Statice Gmelini. $b$ Lepturus pannonicus. $c$ Camphorosma ovata: $d$ Plantago tenuiflora. e Hordeum Gussoneanum.

Kali und S. Soda, Kochia prostrala, Gyperus pannonicus, Grypsis aculeala, Spergularia media und marina, Lepidium crassifolium, an die sich dann ein äußerer Ring aus verschiedenen Ghenopodiazeen, wie Chenopodium opulifolium, 
C. rubrum, Suaeda maritima, Alriplex lalarica, A. haslala, A.liloralis und A. palula, Kochia scoparia sowie Artemisia monogyna, Planlago lenuiflora und P. marilima, Sedum acre, Hordeum Gussoneanum, Lepidium ruderale und L. perfolialum anschließt.

Salzsïmpie. Größere Lachen und Salzseen mit sumpfigem Ufer sind meist von einem dichten Kranz von Binsen umgeben. Besonders Scirpus marilimus und Schoenopleclus Tabernaemontani treten an solchen Stellen oft in Masse auf; in ihrer Gesellschaft Heleochloa explicala und $H$. schoenoides, Atropis festucaeformis und A. pannonica, Alisma ranunculoides, Aster Tripolium; seltener auch Rohrkolben (Typha latifolia und angustifolia) und selbst Schilfrohr (Phragmiles communis).

\section{Sumpf- und Wasserformationen.}

Röhricht. Wenn auch Bestände aus Schilfrohr an allen stehenden und fließenden Gewässern in ganz Mitteleuropa überall verbreitet sind, so erreichen sie doch selten eine so ungeheure Ausdehnung, wie es in Lngarischen Tieflande, besonders an den Sümpfen der Theiß und deren Nebenflüssen der Fall ist. Wenn auch seit den Zeiten, wo $\mathrm{A}$. Kerner seine glänzenden Schilderungen der ungarischen Rohrwildnisse schrieb, weite Strecken entsumpft und der Kultur zugeführt worden sind, gibt es doch auch heute noch Gebiete, wo man stundenlang durch die ungeheuren Rohrbestände wandern kann, die, bald geschlossen, bald durch engere oder breitere Kanäle zerschnitten, die Ufer der träge dahinströmenden Flüsse bedecken und den Aufenthaltsort des in großen Mengen sind findenden Wassergeflügels bilden. Das Schilfrohr ist in diesen Gegenden, wo weit und breit kein Holz zu finden ist, eine sehr wertvolle Nutzpflanze; es dient nicht nur zu Flechtwerk und Matten, sondern auch als Baumaterial zur Festigung der Lehmwände, zum Decken der Dächer und zur Bekleidung der Wände, als Brennmaterial, als Streu usw. und wird in großen Mengen geerntet; die stehen bleibenden dürren Halme werden im Herbste gewöhnlich niedergebrannt, um den frischen Halmen des nächsten Jahres Platz zu machen, wobei eine hellrötliche, zicgelmehlähnliche Asche zurückbleibt.

Bei der ungeheuren Menge des bestandbildenden bis über $4 \mathrm{~m}$ hohen Schilfrohres (Phragmites communis) treten die zahlreichen Begleitpflanzen natürlich in den Hintergrund. Vergesellschaftet mit ihm finden sich vor allem Typha angustifolia und T. latifolia, Calamagrostis lanceolala und C. Pseudophragmites, Typhoides arundinacea, Schoenoplectus lacustris, Iris Pseudacorus und I. spuria, Acorus Calamus; ferner an Stellen, wo die Schilfhalme lockerer stehen, Glyceria aquatica, G. fluilans und G. plicata, Calabrosa aqualica, Poa palustris, Carex disticha, C. vulpina, C. gracilis, C. elata, C. vesicaria, C. flava, Schoenus nigricans, Cladium Mariscus, Holoschoenus australis, Alisma Plantago unnalica, Sagitlaria sagitlacfolia, Dryopteris Thelypleris, Thalictrum flavum und T. Incidum, Ranunculus. Lingua, Lythrum Salicaria, Sium Latifolium. Peucedanum 


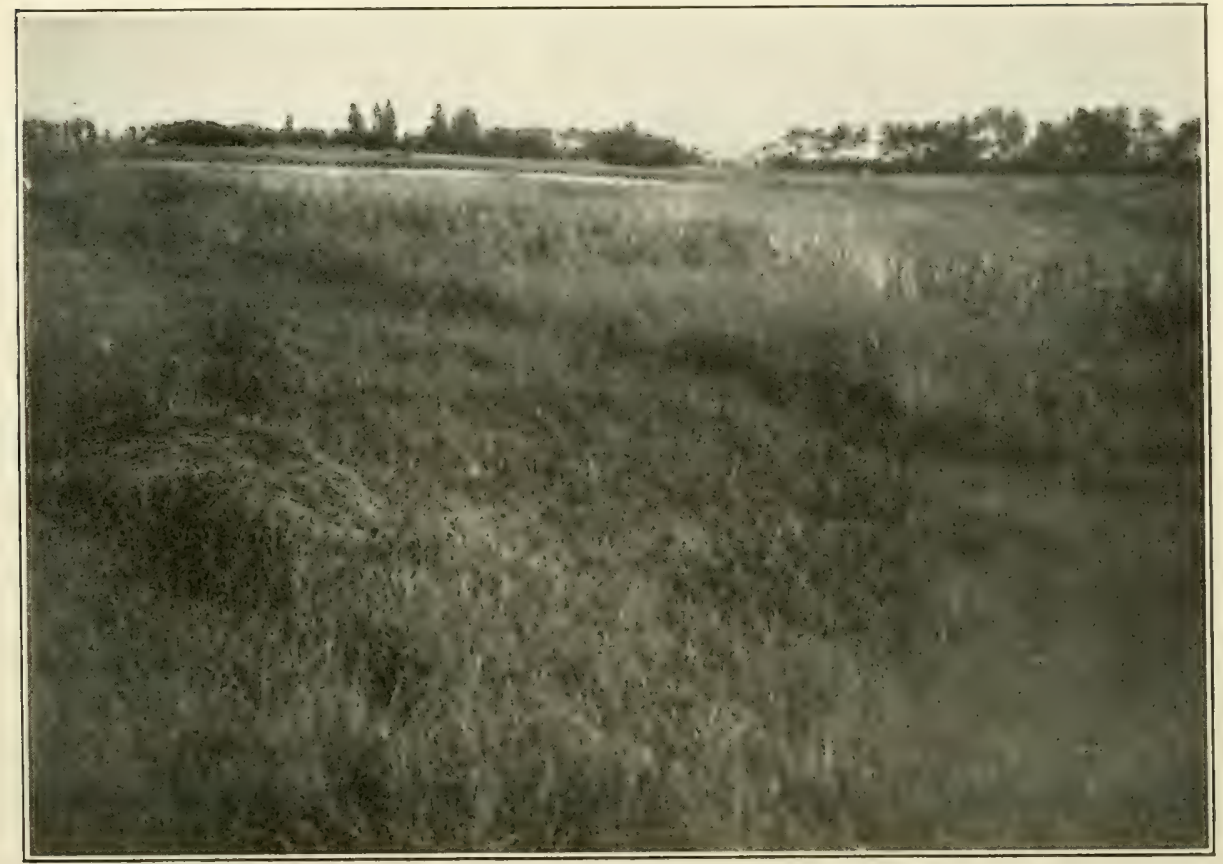

Abb. 287. Salzlache bei Soroksár nächst Budapest.

Innen ein Gürtel von Phragmites communis, dann Schoenoplectus Tabernaemontani und IFeleocharis palustris, außen Salzwiese mit Agrostis alba und Triglochin maritimum.

(Nach einer Aufnahme von Dr. II. Frh. V. Handel-Alazzetli.)

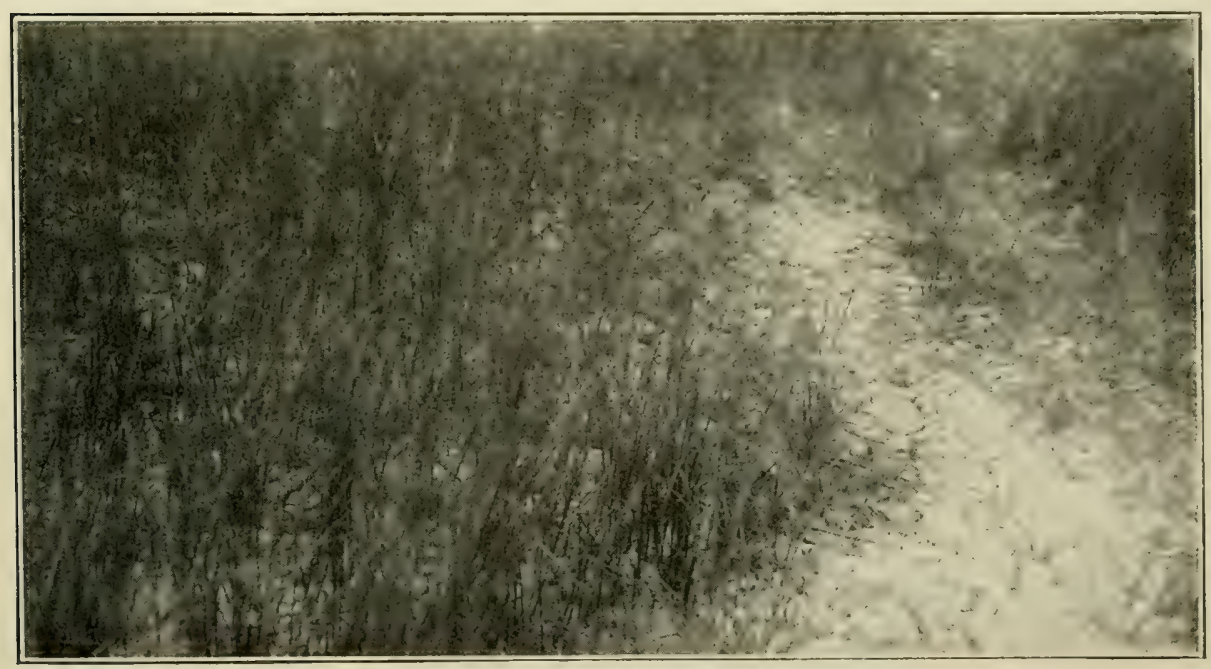

Abb. 288. Bestand von Scirpus maritimus auf, ,Sziliboden ${ }^{6}$ bei Kun-Szent-Miklos. Der ausgetrocknete Boden zeigt zahlreiche Risse und Sprünge.

(Nach einer Aufnahme von A. V. Hayek.) 

palustre, Cicula virosa, Graliola officinalis usw. In den zwischen den Schilfbeständen sich findenden freien Wassertümpeln und Kanälen wachsen alle möglichen Wasserpflanzen, doch sind insbesondere See- und Teichrosen (Castalia alba, Nuphar luleum), Tausendblatt (Myriophyllum spicalum und M. verticillalum), Seekannen (Nymphoides pellata) und Wasserscheeren (Straliotes aloides) häufig.

Nicht ohne Interesse ist das Auftreten von schwimmenden Inseln in diesen Röhrichten. Auf losgetrenntem Wurzelgeflecht von Schilf und Carex-Arten und zusammengeschwemmten Wasserpflanzen siedeln sich wieder Carices und $\mathrm{Schilfrohr}$ an, in deren bildendes Wurzelgeflecht natürlich sich wieder Wasserpflanzen und deren Reste verflechten, so daß bald ein fester Boden entsteht, der imstande ist, auch einen oder mehrere Menschen zu tragen, aber mit dem festen Untergrund in keiner Verbindung steht, so daß diese Schilfinseln vom Winde bald dahin, bald dorthin getrieben werden.

Binsenbestände. Am inneren Rande der Schilfbestände tritt oft Schoenopleclus lacustris in großen Mengen bestandbildend auf. In seiner Gesellschaft finden sich gelegentlich alle Bewohner des Röhrichts.

Schachtelhalmbestände. Stellenweise am rinde stehender seichter Gewässer bildet auch Equisclum limosum Bestände. In seiner Gesellschaft finden sich ab und zu auch andere Sumpfpflanzen, wie Myosolis scorpioides, Alopecurus geniculalus, Carex vesicaria usw.

Das Zsombékmoor. Eine eigentümliche, besonders im Ungarischen Tieflande verbreitete und für dasselbe charakteristische Formation stellen die vorwiegend aus Carex elala (,stricla") gebildeten, von den Magyaren als „Zsombekos rét" bezeichneten Moore dar. Carex elala pflanzt sich auf vegetativem Wege nur durch intravaginale Sprosse, ohne jede Ausläuferbildung, fort; während der obere Teil der Pflanzen alljährlich abstirbt, bleibt der untere Teil derselben, besonders die Blattscheiden erhalten und werden durch die ein festes Fasernetz bildenden äußeren Scheiden zusammengehalten, so daß bald mächtige säulenförmige Stämme entstehen. Diese $1 / 2$ bis gegen $1 m$ hohen festen, oben von einem mächtigen Blätterschopf gekrönten Rasen bleiben meist isoliert und sind durch gewöhnlich enge, von den Blättern überdeckte Wasserkanäle getrennt, so daß das Moor im Sommer einer Wiese gleicht, auf der man sich aber nur von einem Carexpolster auf den andern schreitend oder springend vorwärtsbewegen kann. Die Strünke in der Tiefe des Wassers aber verwesen allmählich und bilden einen festen Torf.

Die Zsombékmoore beherbergen meist eine reiche Tegetation. Ganz abgesehen von den in den die Carexpolster trennenden Kanälen sich findenden Wasserpflanzen treten in Gesellschaft von Carex elala zahlreiche andere Cyperazeen auf, wie Schoenus nigricans, Scirpus maritimus, Carex Davalliana, C. disticha, C. elongala, C. vulpina, C. vesicaria, C. panicea usw., Juncus articulatus, J.effusus u. a. Juncus-Arten. Ferner gedeihen daselbst Orchis palustris, O. incarnata und O. Latifolia, Allium angulosum, Ranunculus acer und R. Lingua, 
Lychnis Flos cuculi, Lylhrum Salicaria und L. virgalum, Lycopus europaeus und L. exallatus, zahlreiche Mentha-Formen aus den Gruppen der M. austriaca, M. arvensis, M. verticillata und $M$. aquatica, Teucrium Scordium, Pedicularis palustris, Gratiola officinalis, Galium palustre, Myosolis scorpioides, Cirsium palustre, Taraxacum paludosum u. a., hingegen fehlen die typischen Gewächse der Hochmoore, wie Drosera-Arten, Andromeda polifolia, Eriophorum vaginatum usw. vollständig.

Wiesenmoore. Dort, wo neben Carex elata auch andere Gyperazeen in größerer Menge auftreten, so daß eine ununterbrochene zusammenhängende Rasendecke entsteht, bilden sich Wiesenmoore von oft beträchtlicher Ausdehnung. Die Zusammensetzung dieser Wiesenmoore ist folgende: Glyceria aquatica, Carex Davalliana, C. disticha, C. elongala, C. elala, C. riparia, C. gracilis, C. flava, C. glauca, C. panicea, C. lasiocarpa, C. paradoxa, C. paniculala, C. vulpina, Schoenus nigricans, S. ferrugineus, Eriophorum angustifolium, Scirpus marilimus, Heleocharis palustris, Cladium Mariscus, Juncus arliculatus, ferner Dryopteris Thelypleris, Orchis incarnala, O. latifolia und O. palustris, Iris sibirica und I. spuria, Lychnis Flos cuculi, Ranunculus Lingua und R. acer, Caltha palustris, Roripa austriaca, Filipendula Ulmaria, Lythrum Salicaria, Oenanthe fistulosa, Blackstonia serolina, Menyanthes trifoliala, Symphylum officinale, Myosotis scorpioides, Pedicularis palustris, Gratiola officinalis, Teucrium Scordium, Galium palustre, G. uliginosum, Cirsium canum, G. palustre und C. brachycephalum.

Sumpiwiesen. Sumpfwiesen sind von den Wiesenmooren natürlich nicht scharf getrennt und mit denselben durch mancherlei Übergänge verbunden. Der Unterschied zwischen beiden liegt in dem häufigeren Auftreten der Gräser und dem Zurücktreten der rasenbildenden Gyperazeen in den Sumpfwiesen. Neben den in den Wiesenmooren sich findenden Arten sind auf Sumpfwiesen noch vertreten Panicum Crus galli, Holcus lanatus, Leersia oryzoides, Alopecurus pratensis und A. geniculatus, Heleochloa alopecuroides, ferner Triglochin palustre, Leucoium aestivum, Stellaria palustris, Clematis integrifolia, Cardamine pratensis, Potentilla anserina, Trifolium hybridum, T. angulalum und T. minus, Telragonolobus siliquosus, Lylhrum virgalum, Oenanthe media, Pencedanum palustre, Heracleum Spondylium, Pastinaca saliva, Euphorbia pilosa und E. palustris, Inula salicina, Achillea crustata usw.

Süßholzbestände. An den schlammigen im Frühjahre oft überschwemmten Ufern der größeren Flüsse, besonders der Theiß, bildet ähnlich wie an der unteren Drau und Save das stachlige Sü B holz (Glycyrrhica echinala) oft dichte Buschbestände. Stellenweise tritt in seiner Gsellschaft auch Glycyrrhiza glandulifera auf; häufig ist Althaea officinalis in diesen Beständen anzutreffen. Ferner gedeihen an solchen Stellen Thesium ebraclealum, Gypsophila muralis, Ranunculus lateriflorus, Trifolium fragiferum, Astragalus contorluplicalus, Melilotus dentalus, Abulilon Avicennae, Lythrum Hypsopifolia, Cenlaurium uliginosum, Mentha Pulegium, Leonurus Marrubiastrum, Verbena supina, Dipsacus 


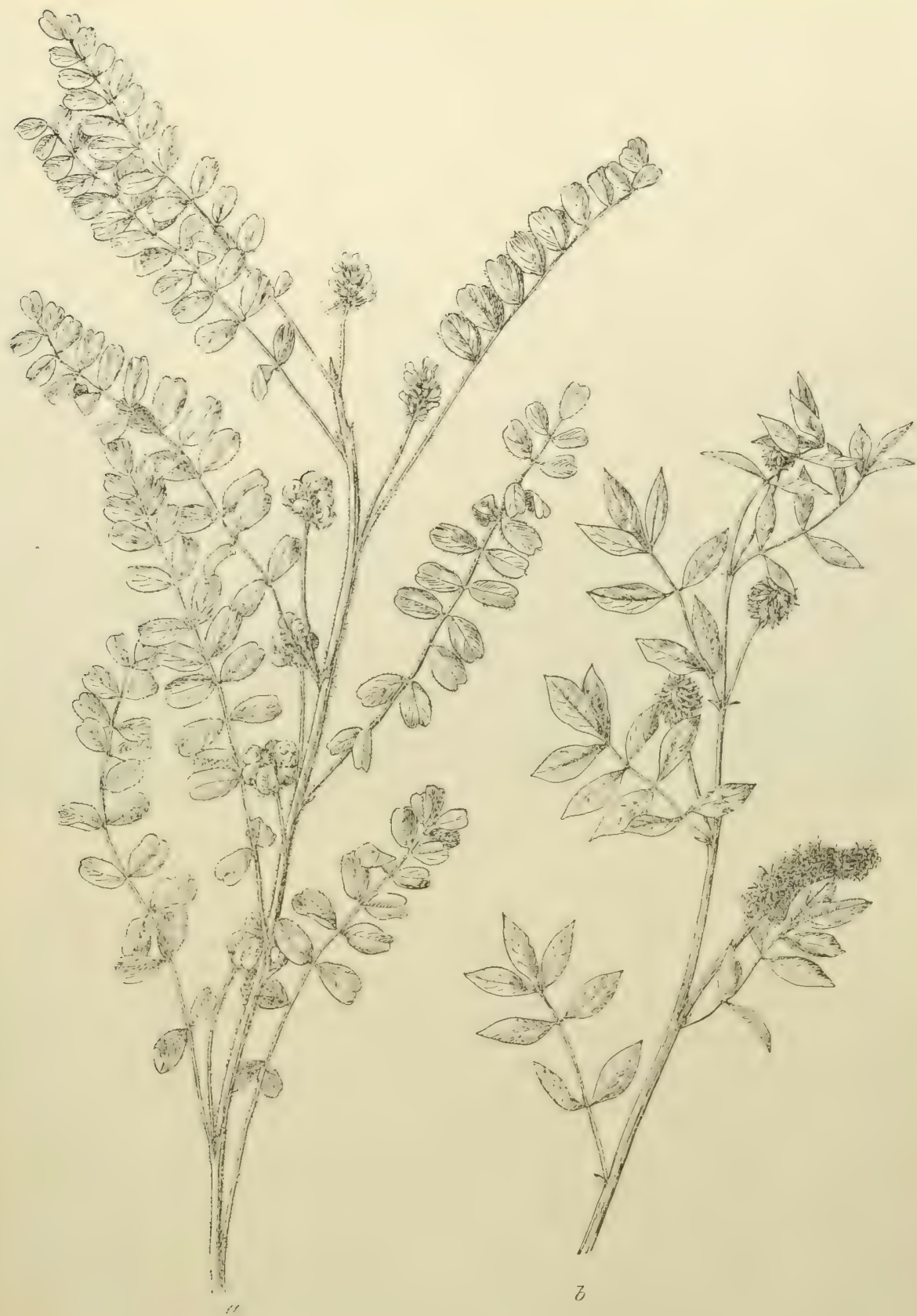

Abb. 289. a Astragalus contortuplicatus. $b$ Glycyrrhiza echinata.

fullonum, Asler pinrlalus und A. canus, Pulicaria vulgaris, Malricaria Chamomilla, Centaurea Calcitrapa; auch eine Reihe von Ruderalpflanzen mischt sich gern in die Süßholzbestände, wie z. B. Panicum Crus galli, Selaria glauca, Digitaria sanguinalis und D. riliaris, Ghenopodium glaucum, C. album und C. urbicum, Polygonum lapalhifolium, Xanthium strumarium und $X$. spinosum. 
Wasserpflanzen. Bei der mächtigen Ausdehnung von Sumpfgebieten, der großen Zahl stehenden und äußerst langsam fließender Gewässer (die Flüsse haben oft ein Gefälle von kaum $1: 20.000$ ) ist es begreiflich, daß in der ungarischen Tiefebene eine sehr reiche Wasserpflanzenflora sich entwickeln konnte. Zu Tausenden bedeckt oft die weiße Seerose (Caslalia alba) mit ihren großen Blättern und schneeweißen Blüten die Oberfläche der Tümpel und toten Flußarme, etwas seltener ist Nuphar luteum. Auch Froschbiß (Hydrocharis Morus ranae), Wasserscheeren (Stratiotes aloides) und Wasserranunkeln (Ranunculus aquatilis, $R$. paucistamineus und $R$. circinnalus) erheben oft in Menge ihre weißen Blüten über den Wasserspiegel und auch die einer Teichrose im kleinen ähnliche Nymphoides pellala ist keineswegs selten. Auch Hollonia palustris mit seinen reichen weißen Blütentrauben ist stellenweise in Menge anzutreffen, und in kleineren Tümpeln ist der Wasserspiegel von den massenhaften Blättern von Polamogeton natans oder Polygonum amphibium oft ganz bedeckt; auch alle Arten von Wasserlinsen (Lemna minor, L. gibba, L. Lrisulca, Spirodela polyrrhiza) sind fast überall anzutreffen, während Salvinia natans nicht überall, aber an ihren Standorten gewöhnlich in Menge vorkommt. Von sonstigen Wasserpflanzen sind vor allem Myriophyllum spicatum und $M$. verlicillatum, Ceralophyllum demersum und Hippuris vulgaris durch ihre Häufigkeit hervorzuheben; auch Potamogeton-Arten ( $P$. coloralus, $P$. gramineus, $P$. lucens, $P$. crispus, $P$. pusillus, $P$. pectinatus) sind nicht selten. Ferner finden sich ab und $\mathrm{zu}$ Naias marina und N. minor, Zannichelia palustris, Polamogelon compressus, Utricularia vulgaris sowie oft in großer Menge verschiedene Chara-Arten, wie $C$. foetida, und mancherorts die seltene Aldrovandia vesiculosa.

\section{Kulturgewächse.}

Die vorstehend geschilderten Sumpf- und Steppenformationen, die ehedem das ganze Ungarische Tiefland besetzt hielten, sind heutzutage schon sehr eingeschränkt. Durch Entwässerung der Sümpfe und Bindung des Flugsandes sind weite Strecken der Kultur zugänglich gemacht worden und an vielen Stellen, wie vor allem in der Gegend zwischen Donau und Theiß, der Kornkammer der Monarchie, reiht sich Acker an Acker und die Landschaft gewährt ein ähnliches Bild wie die durch ihre Fruchtbarkeit berühmte lombardische Tiefebene. In anderen Gegenden freilich sind noch ausgedehnte Steppengebiete vorhanden, wie im Sandgebiet des Banates bei Grebenac und Deliblat und vor allem in der großen Puszta Hortobágy bei Debreczen, die wenigstens teilweise, als eine Art Nationalpark, in ihrem Urzustand erhalten bleiben sollte.

Die ursprüngliche Beschäftigung der Magyaren ist die Viehzucht. Pferde, Rinder, Schafe und Schweine werden in großer Menge gezüchtet, da die natürlirhmn Terhältuisse des Landes diesem Erwerbszweig besonders günstig sind und die ausgedehnten Grasflächen dem Vieh genügend Nahrung bieten. Das Vieh bleibt fast das ganze Jahr (von April bis Oktober) auf der Puszta, wo es in großen 
Herden $^{1}$ ) von eigenen Hirten gehütet wird. Das Vieh bleibt Tag und Nacht auf der Weide und sucht höchstens hinter eigens hierzu erbauten Hürden Zuflucht gegen die Witterung. Von Pferden wird eine kleine schnellfüßige Rasse mit Vorliebe gehalten, doch bestehen auch eigene Gestüte, wo edlere Voll- und Halbblutpferde gezüchtet werden; von Rindern ist fast ausschließlich das langhörnige Steppenrind zu finden, von Schafen besonders das durch seine geraden, langen, schraubig gedrehten Hörner ausgezeichnete Zackelschaf.

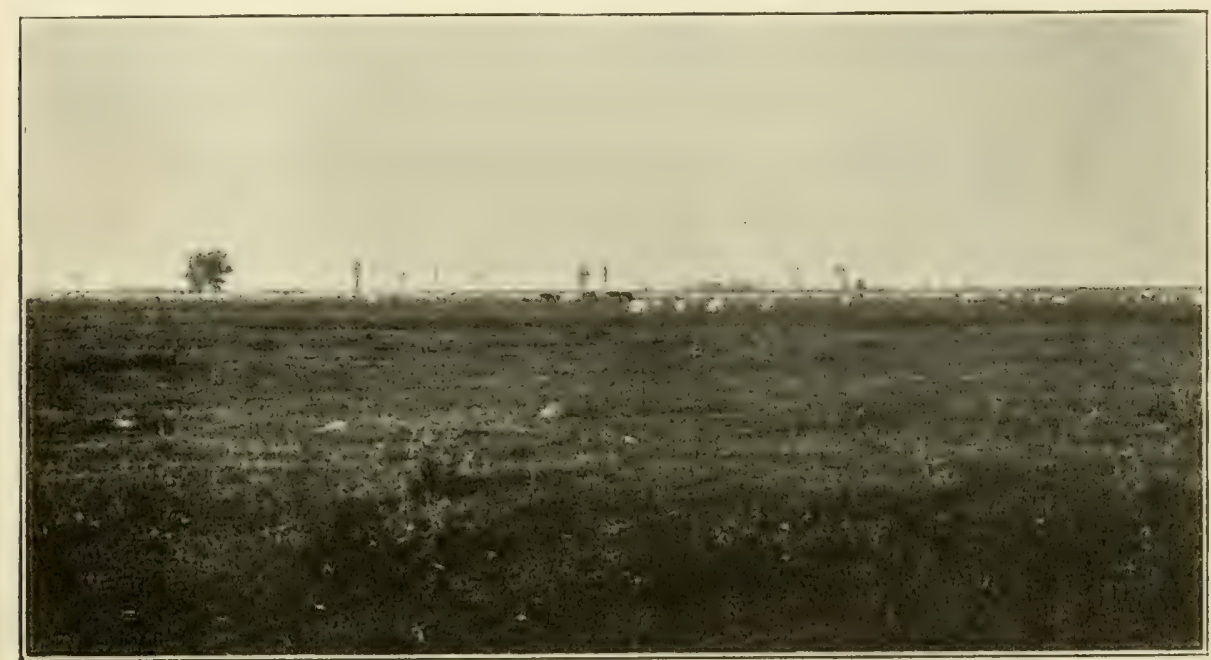

Abb. 290. Viehweide auf der Puszta Bugacs bei Lipoczi.

Ein charakteristisches Landschaftsbild aus der Großen ungarischen Tiefebene.

(Nach einer Aufnahme von Dr. Förster, Wien.)

(Aus der Bildersammlung des Geographischen Institutes der Wiener Universität.)

Ackerbau. Wie schon erwähnt, hat der schon früher in großem Maße betriebene Ackerbau in den letzten. Jahrzehnten einen riesigen Aufschwung genommen und steht jetzt auf sehr hoher Stufe. Wo das Klima demselben günstig ist, wie bei Kecskemét und Maria-Theresiopel, wird auch reicher Obstbau betrieben. Ein großer Teil des Landes ist in den Händen des Großgrundbesitzes, was, welche Nachteile es in volkswirtschaftlicher Beziehung auch haben mag, für die rationelle Bewirtschaftung der Äcker jedenfalls nur von Vorteil ist; doch existieren auch bäuerliche Besitztümer von beträchtlicher Ausdehnung. Die räumliche Ausdehnung des einzelnen Grundbesitzes²) und die weite Entfernung desselben von den geschlossenen Ortschaften machen eine Bewirtschaftung von diesen aus unmöglich, so daß die Bevölkerung genötigt ist, im Sommer eigene Wirtschaftsgehöfte (Tanyas) inmitten ihrer Äcker zu beziehen.

1) Auf der Puszta Hortobagy bei Debreczen, die ein Gebiet von $863 \mathrm{~km}^{2}$ umfaßt, weideten im Jahre 18905000 Pferde, 20.000 Rinder, 30.000 Schafe, 10.000 Schweine, 110 Büffel und 120 Esel.

2) Einzelne Äcker von 20-100 ha Größe, die von keinem einzigen Rain oder Feldweg durchschnitten werden, sind keine Seltenheit. 
Von Getreidesorten spielen in der Ungarischen Tiefebene Weizen und M a is die Hauptrolle, daneben wird aber auch Roggen, Hafer und Hirse gebaut, manehenorts, besonders in der Kleinen ungarischen Tiefebene und im Marchfeld, auch Buchweizen (Fagopyrum esculentum). In jenen Gegenden, wo die oben erwähnte Tanyen-Wirtschaft nicht im Gebrauche ist, wird oft noch die Dreifelderwirtschaft (Weizen als Winter-, Mais als Sommerfrucht, das dritte Feld Brache) geübt; an vielen Orten ist auch noch die reine Brache gebräuchlich. Oft nimmt auch der Mais die Brache in Beschlag und der Weizen wird mitunter ohne gehörige Bearbeitung in das Maisstoppelfeld gesät. Gedüngt wird in solchen Gegenden oft nur der an das Dorf anstoßende Teil der Felder. Besser liegen die

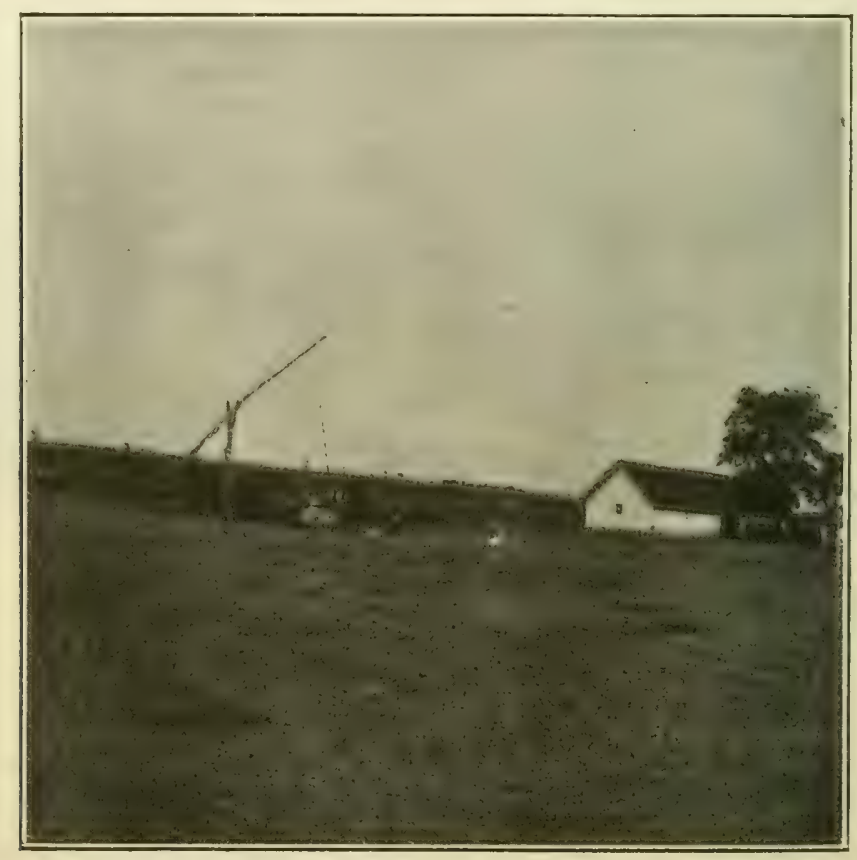

Abb. 291. Tanya auf der Puszta Bugacs bei Lipoczi. (Nach einer Aufnahme von Prof. Dr. N. Krebs, Wien.)

Verhältnisse, wo die mitten in den Feldern liegenden, nur im Sommer bewohnten Tanyen gebräuchlich sind. Hier wird regelmäßig gedüngt, sei es mit Stall-, sei es mit Kunstdünger; Mais und Weizen werden in der Regel in Wechselwirtshaft gebaut ${ }^{1}$ ). Bei kleineren Besitzern wird das Getreide meist nicht gedroschen, sondern von den Pferden ausgetreten, doch kommen landwirtschaftliche $\mathrm{Ma}-$ schinen immer mehr in Gebrauch.

Weinbau. Die Rolle, die der Weinbau im Tieflande spielt, ist gegenüber dem Berglande eine geringe, doch wird sogenannter „S andwein" auch im Tieflande gebaut; besonders geschieht dies im Gebiete der ,Szikra“ bei Kecskemét mit Erfolg, wo die Weingärten auf reinem Flugsandboden angelegt sind.

1) Lupinen gedeihen in der Ungarischen Tiefebene nicht. 
Obstbau. Während im zentralen und östlichen Teile des Ungarischen Tieflandes wegen der Ungunst des Klimas von einem auch nur halbwegs nennenswerten Obstbau kaum die Rede sein kann, wird derselbe im Waldgebiete, besonders auf der Kecskeméter Landhöhe eifrig gepflegt. Besonders sind es Aprikosen, die dort, wie bei Kecskemét und Nagy-Körös, in so großer Menge in den Weingärten kultiviert werden, daß die Gegend weithin einem üppigen Obstgarten gleicht und ein reicher Export dieser Früchte von Kecskemét aus nach fast ganz Europa stattfindet. Auch die Kultur von Weichseln und Weichselkirschen (Prunus Cerasus und Caproniana) ist dort eine sehr ausgedehnte. Im eigentlichen Steppengebiete ist hingegen die Kultur von Zucker-und WVassermelonen (Cucumis Melo und Cilrullus vulgaris) von großer Bedeutung.

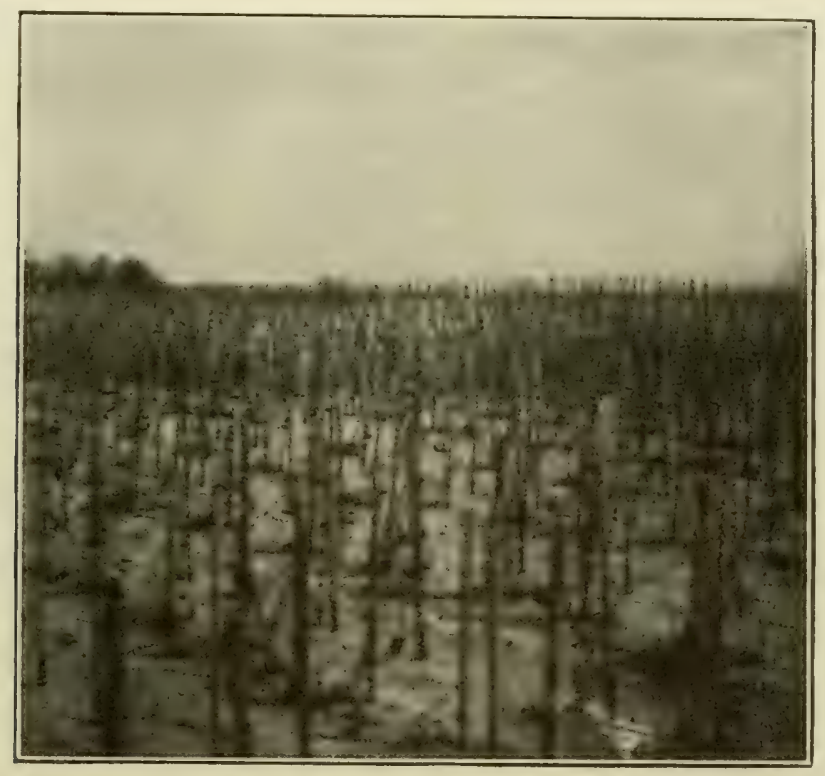

Abb. 292. Weingarten auf Flugsand bei Izság,

(Nach einer Aufnahme von A. v. Hayek.)

Gemüsebau. Von Gemüsesorten werden die in Mitteleuropa üblichen Arten allgemein teils auf freiem Felde, teils in Gärten gezogen, wie insbesondere Bohnen (Phaseolus communis), Saubohnen (Vicia Faba), alle Sorten von Kohl, Kraut, Blumenkohl, die verschiedensten Küchengewürze und natürlich auch Kartoffeln. In großer Menge werden fernerhin manchenorts wie bei Debreczen Meerrettig (Armoracia rusticana), Paprika (Capsicum annuum) (bei Szeged) und Gurken (Cucumis sativus) (bei Kecskemét und Nagy-Körös) gebaut; auch die Zucht von Spargel und von Champignons wird betrieben.

Sonstige Nutzpflanzen. Bei der hauptsächlich auf der Pusztenwirtschaft basierenden Viehzucht in Ungarn spielt der Bau von Futterpflanzen in Ungarn eine nur untergeordnete Rolle und ist erst in neuester Zeit im Auf- 
schwung begriffen. Hingegen ist die Kultur zweier anderer Nutzpflanzen, des Hanfes und des Tabaks, von ziemlicher Bedeutung. Hanf wird für den eigenen Bedarf in beschränktem Maße wohl überall gebaut; in größerem Maßstabe aber findet man die Hanfkultur in den Komitaten Bács-Bodrog und Torontál. Der Tabakbau ist weit ausgedehnter (in ganz Ungarn sind zirka $50.000 \mathrm{ha}$ mit Tabak bepflanzt) und könnte noch extensiver betrieben werden, wenn ihm das Staatsmonopol nicht gewisse Beschränkungen auferlegen würde. Die größeren Grundbesitzer lassen den Tabak meist durch sogenannte Gärtner kultivieren, der Kleinbesitzer baut auf kleinem Flächenraum selbst, die Ernte wird vom Ärar eingelöst.

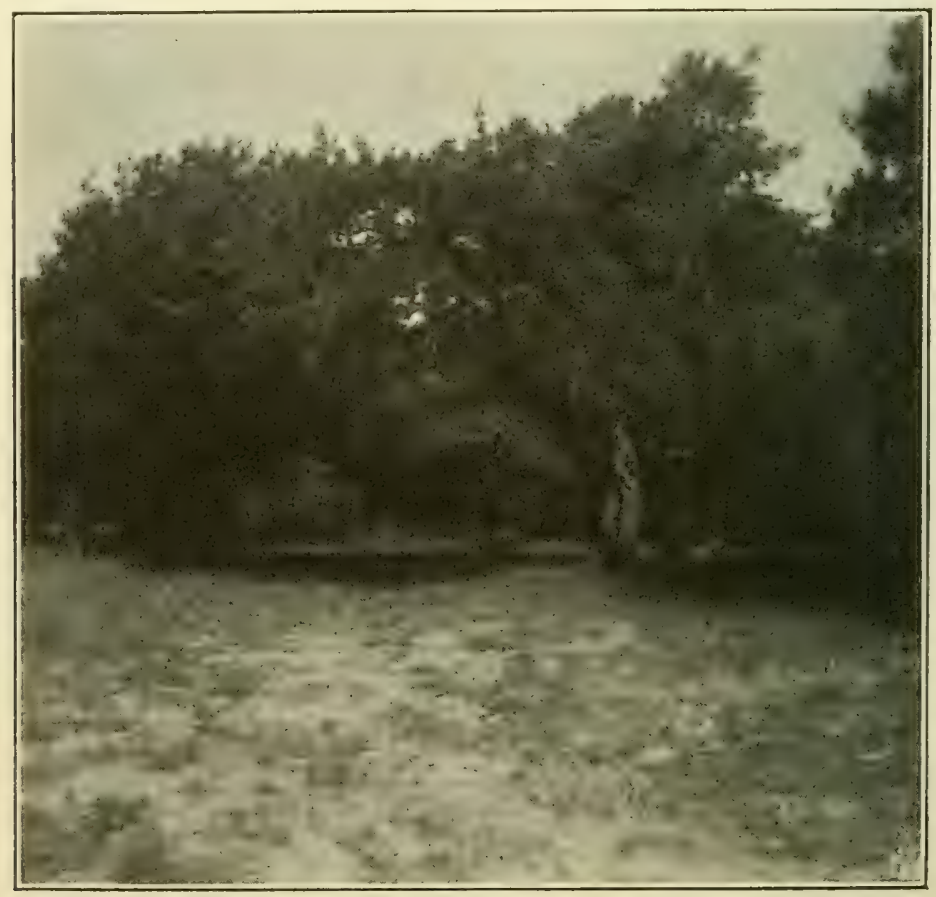

Abb. 293. Aufforstung von Pinus nigra auf Flugsand bei Fülöpszallas.

(Nach einer Aufnahme von Prof. Dr. N. Krebs, Wien.)

Forstkultur und Bindung des Flugsandes. Die Erhaltung der Wälder des Tieflandes, die in ihrer Ausdehnung durch die Tätigkeit des Menschen und den vordringenden Flugsand im Laufe der Zeiten eine beträchtliche Einschränkung erfahren haben, wird jetzt nicht nur mit allen Mitteln angestrebt, sondern man versucht auch, und zwar vielfach mit Erfolg, die wüsten Flugsandgebiete aufzuforsten. Im ursprünglich waldlosen Tieflande hat aber nur ein cinziger Baum sich in dieser Hinsicht bewährt, und das ist die aus Nordamerika stammende Akazie (Robinia Pseudacacia). Dieselbe hat sich aber so allgemein eingebürgert, daß sie jetzt zu einem wahren Charakterbaum des Tieflandes geworden ist. Nicht nur als Alleebaum und in der Nähe der Dörfer trifft 
man diesen Baum überall an, sondern man hat ganze IVälder desselben angelegt und selbst mitten im örlestenstepengebiete trifft man ganz allgemein größre oder kileinere Akazienwäldchen an. Im Banat wird auch die kanadische Pappel (Populus: canadensis), daselbst und auf der Kecskeméter Landhöhe vielfach auch die Schwarzföhre (Pinus nigra) zur Aufforstung des Flugsandes benutzt; während die Rotföhre nur in der kleinen Ungarischen Tiefebene und namentlich im Marchfelde günstige Resultate ergab. Als ein sehr wertvolles Mittel zur Bindung des Flugsandes hat sich auch die Anpflanzung von Bocksdorn (Lycium halimifolium) erwiesen, welcher Strauch sich jetzt im Tieflande überall eingebürgert hat und häufig verwildert vorkommt.

\section{Die Adventivflora.}

Ruderalflora. Wie fast überall im Tieflande, ist auch in den Ebenen Ungarns die Ruderalflora sehr artenreich. In den breiten Straßen der Dörfer, an den Ziehbrunnen vor denselben, auf Weideplätzen und an Wegen, überall breiten sich Unkräuter in großer Zahl aus. Besonders häufig sind in Ungarn die beiden Arten von Spitzklette, Xanthium strumarium und $X$. spinosum, die mittels ihrer mit widerhakigen Stacheln besetzten Früchte besonders durch das Vieh überall hin verschleppt werden. In ihrer Gesellschaft finden sich ferner echte Kletten (Arclium Lappa, A. minus und A. tomentosum) und allerlei Disteln (Onopordon Acanthium, Carduus nutans, G. hamulosus, Cirsium lanceolatum, Cnicus benediclus, Echinops sphaerocephalus). Gesellig treten auch die Melden und die Gänsefußarten (Alriplex palulum, A. lalaricum, Chenopodium glaucum, C. album, C. hybridum, C. Bolrys, C. murale) auf, mit ihnen Malva silvestris und M. neglecla, Marrubium vulgare, $M$. peregrinum und Leonurus Cardiaca. Nirgends fehlen ferner Urtica dioica, U. urens, Polygonum aviculare und auf Sandboden auch das ähnliche, aber am Boden hingestreckte Polygonum arenarium. Häufige Ruderalpflanzen sind ferner Panicum Crus galli, Hordeum murinum, Cynodon Dactylon, Euphorbia helioscopia, E. Gerardiana, E. pannonica, Sisymbrium orientale, S. Loeselii, Descurainia Sophia, Euclidium syriacum, Capsella Bursa pastoris, Lepidium ruderale, L. perfolialum, L. Draba, Erysimum repandum, Tribulus orientalis, Anchusa officinalis, Hyosciamus niger, Datura Stramonium, Ballota nigra, Lamium maculalum, Dipsacus Fullonum, D. laciniatus, Planlago maior, Anthemis Colula, Matricaria inodora, Arlemisia vulgaris, Centaurea solstilialis, Cichorium Intybus.

Ackerunkräuter. Unter den Ackerunkräutern sind fast alle in Mitteleuropa verbreiteten Arten häufig, so insbesondere Agropyrum repens, Bromus secalinus, B. arvensis, Apera Spica venti, Agrostema Githago, Ranunculus arvensis, Delphinium Consolida, Sinapis alba, S. arvensis, Brassica nigra, Raphanus Raphanistrum, Thlaspi arvense, Viola arvensis, Papaver Rhoeas, Bupleurum rolundifolium, Lycopsis arvensis, Lithospermum arvense, Vicia segelalis, V. Cracca, V. glabrescens, Lathyrus tuberosus, Kickxia Elatine, K. spuria, Aleclorolophus hir- 
sulus, Melampyrum arvense, Convolvulus arvensis, Cirsium arvense usw. Dazu gesellt sich manchenorts nicht sel' ${ }^{\prime}$ en das tief violette Delphinium peregrinum, ferner Moenchia mantica, Nigella ai jensis u. a.

\section{Spezielle pflanzengeographische Schilderung des Gebietes.}

\section{A. Die Kleine ungarische Tiefebene.}

Die Kleine ungarische Tiefebene, vom Wiener Becken durch das Leithagebirge, die Hainburger Berge und die Kleinen Karpathen, von der Großen ungarischen Tiefebene durch das Pilis-Vértes-Gebirge und die Ausläufer der Karpathen im Honter und Nograder Komitate getrennt, stellt ein von der Donau und ihren Armen und der Raab bewässertes, zum großen Teile versumpftes, jetzt allerdings vielfach entwässertes Tiefland dar.

Ratzers- Schon im nordwestlichen Teile des Gebietes treten bei Ratzersdorf Wiesendorf.

St. moore mit Schoenus nigricans, Holoschoenus vulgaris, Orchis palustris, Euphorbia villosa usw. auf; von größerer Ausdehnung sind dieselben bei St. Georgen, wo auf denselben Schoenus nigricans, Leucoium aeslivum, Orchis palustris, O. Latifolia, Thalictrum galioides, Caltha palustris, Cardamine Matlhioli, Lathyrus palusler, Oenanthe fistulosa und Cirsium brachycephalum die bemerkenswertesten

Schur. Arten sind. Südlich von St. Georgen erstı eckt sich auch der $4 \mathrm{~km}$ lange „Schur“, (1) eigenartiger Sumpfwald aus Alnus glutinosa und Quercus Robur mit Unterholz aus Salix cinera und Rhamnus Frangula. Vom Winter bis in den Hochsommer hinein unter Wasser gesetzt und nur im Spätsommer und Herbst zugänglich, ist der Wald von zahlreichen Gräben durchgeschnitten, zwischen denen die Bäume gruppenweise auf hohen Stelzwurzeln stehen, in deren Geflecht sich ler reichliche Niederwuchs, hauptsächlich aus Dryopteris spinulosa und D. Thelypteris sowie aus massenhafter Urtica kioviensis, ferner aus Carex elala, Sium latifolium und Sonchus uliginosus gebildet, angesiedelt hat, während in den Gräben Hottonia palustris in einer eigentümlichen Landform (var. diminula) auftritt und an trockeneren Stellen Chrysanlhemum uliginosum gesellig wächst.

Preßburg. An der Donau bei PreBburg sind ausgedehnte Auenwälder entwickelt, die hauptsächlich aus Populus alba, P. nigra, Salix alba, S. fragilis, Ulmus glabra und $U$. laevis zusammengesetzt sind, in denen neben Humulus Lupulus auch Tilis silveslris mit oft armdicken Stämmen nicht selten als Liane auftritt, während im Niederwuchs neben Galanthus nivalis, Parielaria officinalis und Senecio Doria lie von Jahr zu Jahr an Häufigkeit zunehmenden amerikanischen Kompositen Solidago serolina, Stenactis annua und Rudbeckia laciniata bemerkenswert sind. In Schilfrohr- und Carex-Beständen treten hie und da, wie in der ,Alten $\mathrm{Au}^{6 \prime}$, Leucoium aestivum, Senecio paludosus und Cicuta virosa auf, auf schotterigen Stellen ist Andropogon Ischaemum häufig, während Myricaria germanica nur auf lW Pötscheninsel vorkommt und Hippophaë rhamnoides anscheinend ganz fehlt. 


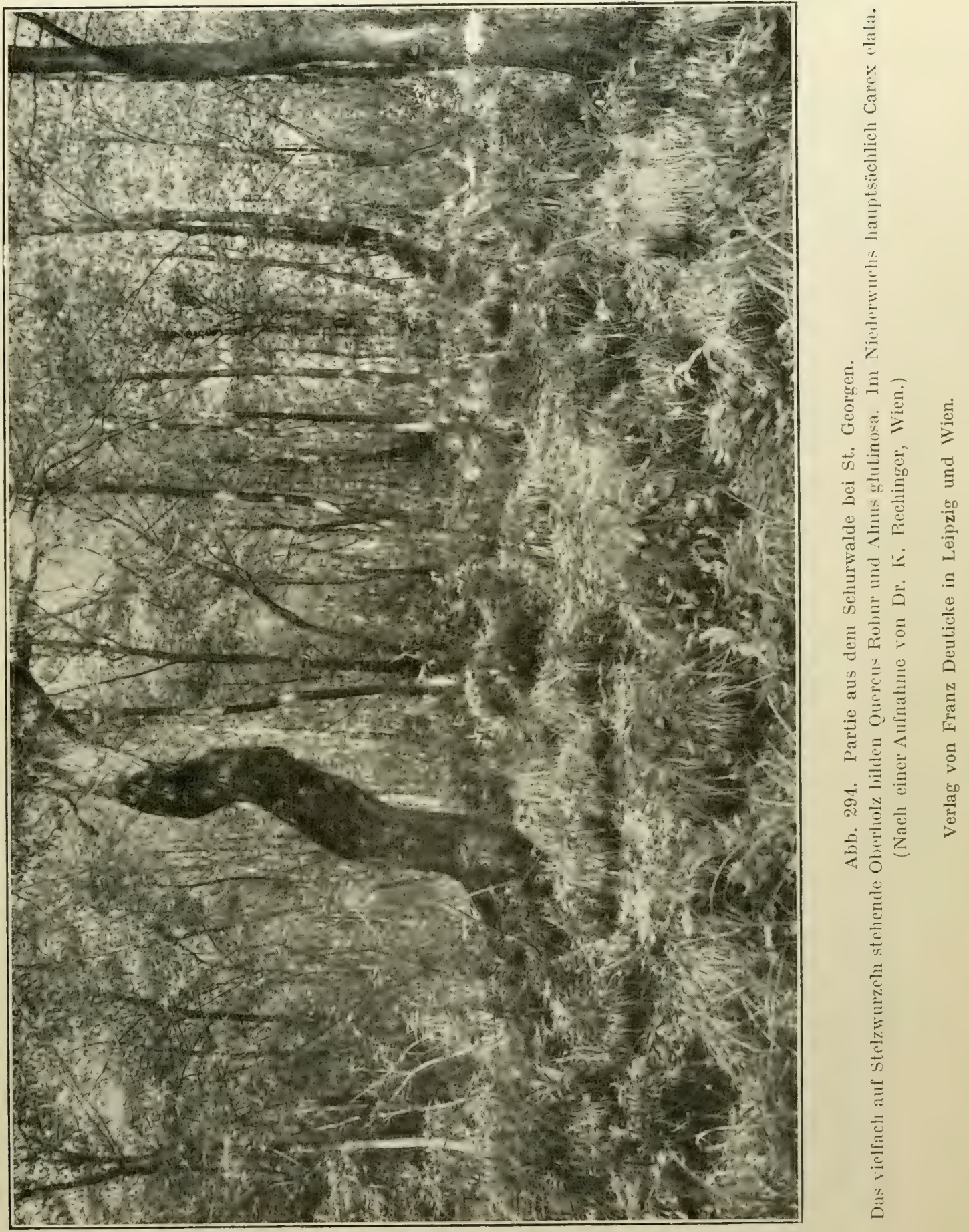





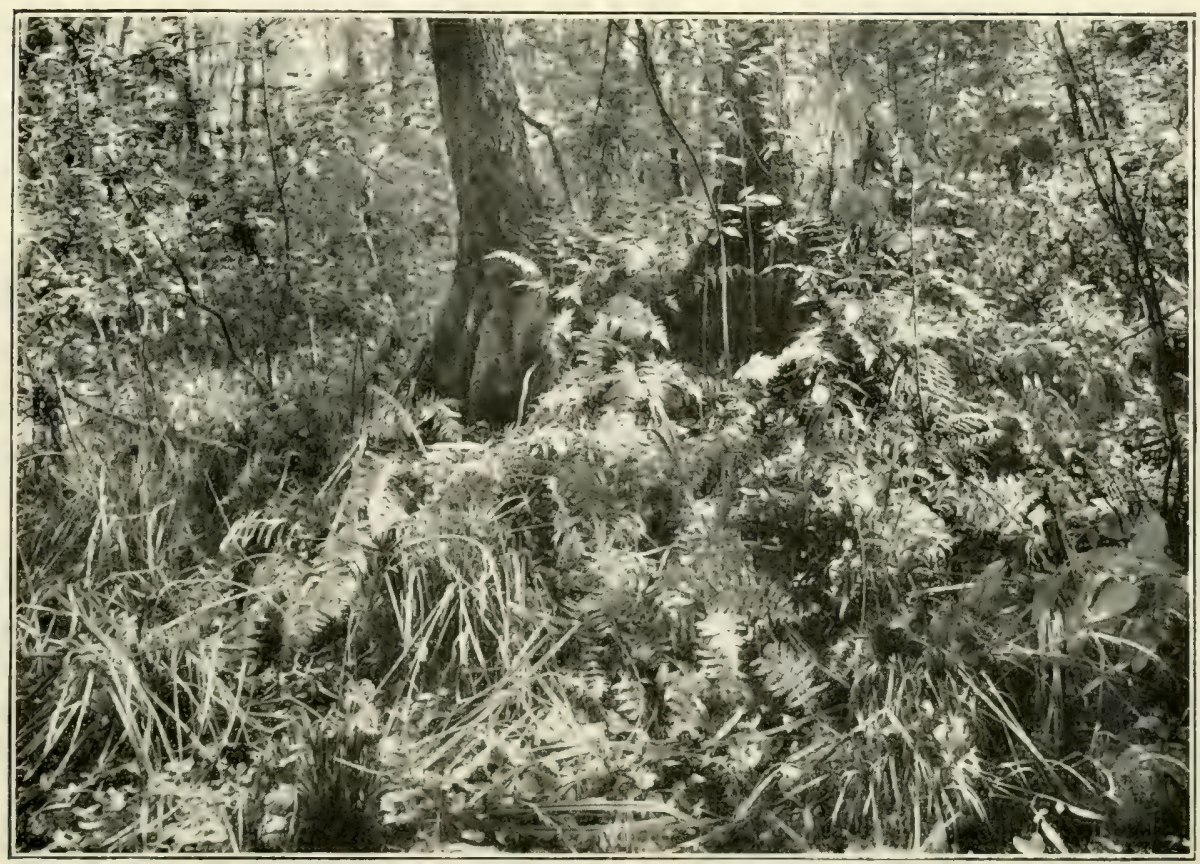

Abb. 295. Partie aus dem Schurwalde bei St. Georgen. Im Geflecht der Stelzwurzeln des Oberholzes üppige Vegetation aus Dryopteris Thelypteris und D. spinulosa. (Nach einer Aufnahme von Dr. K. Rechinger, Wien.)

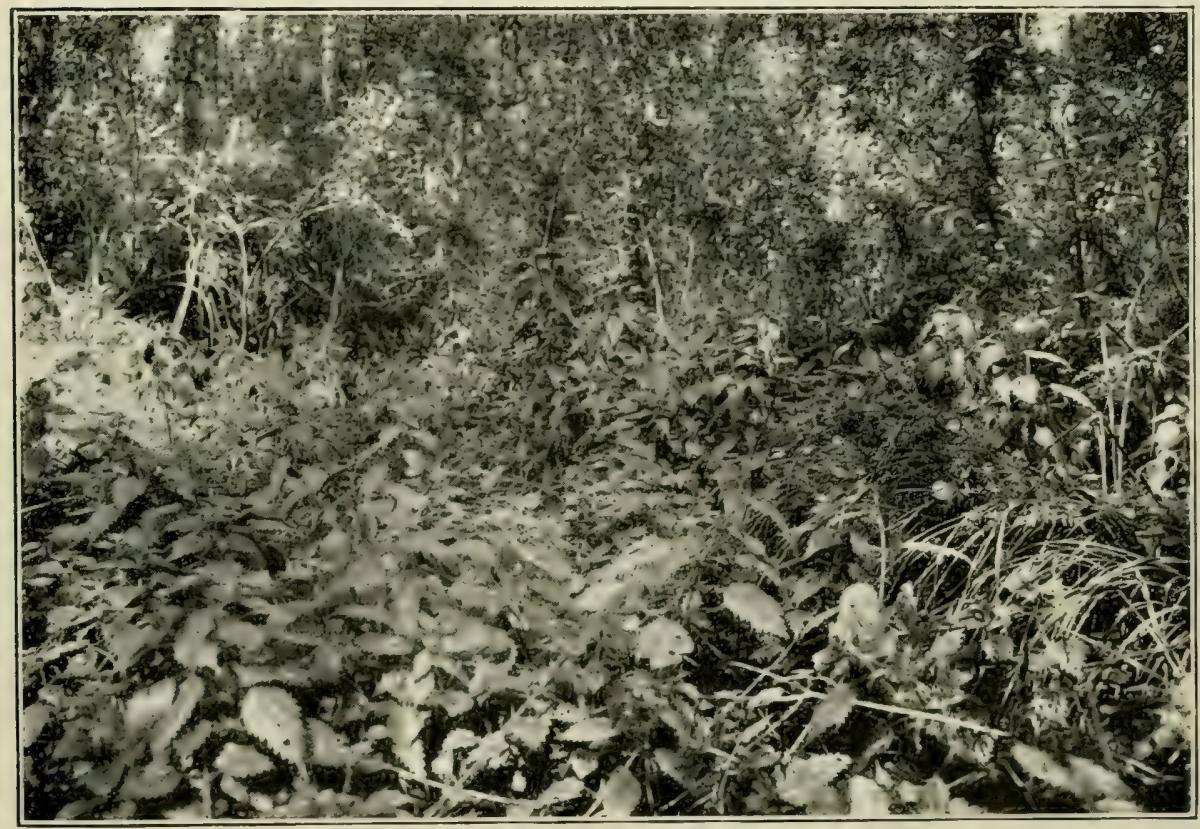

Abb. 296. Urtica Kioviensis im Schurwalde bei St. Gcorgen.

(Nach einer Aufnahme von Dr. K. Rechinger, Wien.) 

Den größeren Teil des nördlich der Donau gelegenen Anteils der Kleinen ungarischen Tiefebene nimmt die Große Schüttinsel (Csallokïz) ein, die ehedem von Auenwäldern bedeckt war und einen größtenteils sumpfigen Boden aufwies; doch ist heute der größte Teil derselben bereits von Ackern bedeckt, und nur mehr an wenigen Stellen trifft man die ursprünghichen Auenwälder, in denen sich die amerikanische Solidago serotina immer mehr ausbreitet, und Sumpfwiesen, auf denen Lychnis Flos Cuculi, Ranunculus Lingua, Thalictrum flavum, Lathyrus paluster, Euphorbia lucida, Peucedanum palustre, Succisa pratensis, Genliana Pneumonanthe und Cirsium canum häufige Erscheinungen sind; in den toten Donauarmen treten Hydrocharis Morsus ranae, Stratioles aloides und Hottonia palustris häufig auf.

Nördlich von der Schüttinsel aber macht sich bald der Steppencharaliter bemerkbar. Auf Weiden zwischen Szered und Groß-Mácséd treten Poa bulbosa, Carex stenophylla, Alyssum tortuosum, Lepidium perfolialum, Androsace maxima, Helichrysum arenarium und Arlemisia campestris auf und bei Ürmény Ürmény. im südlichen Neutraer Komitate trifft man schon Pusztaweiden mit Andropogon Ischaemum, Salsola Kali, Berleroa incana, Erysimum canescens, Marrubium peregrinum, Stachys germanica, Trifolium fragiferum, Ononis spinosa, Althaea pallida, Asperula cynanchica, Cirsium pannonicum, Lactuca saligna, Taraxacum serolinum usw.

Auch in der Umgebung von Neuhäusel (Érsekujvár) finden sich Vieh- Neuhäusel. weiden und Grassteppen mit Tragus racemosus, Cynodon Daclylon, Gypsophila paniculata, Glaucium corniculalum, Lavatera thuringiaca, Cephalaria transsilvanica, Xeranthemum annuum und massenhafter Salvia Aelhiopis; die Csendes- LapásPuszta bei Lapás-Gyarmath beherbergt u. a. Andropogon Ischaemum, Polentilla argentea, Echium vulgare, Melampyrum barbalum, Asperula cynanchica, Scabiosa ochroleuca, Cirsium eriophorum.

Südlich von Neuhäusel liegt bei Ó.-Gyalla ein reiches Tabakbaugebiet; ó.-Gyalla. außer Tabakfeldern trifft man hier teils Steppen mit Andropogon Ischaemum, Salsola Kali, Polycnemum arvense, Ononis spinosa usw, teils ausgedehnte feuchte etwas salzige Wiesen mit Ranunculus acer, $R$. sceleratus, Potentilla anserina, Lolus siliquosus, Trifolium fragiferum, Cenlaurium pulchellum, Aster Tripolium usw. Im Tale der Gran greift die Steppenflora zungenförmíg weit ins Hügelland ein und geht allmählich in die Triftformationen der Weinberghügel über. So findet man auf dem Örhegy bei Léva Medicago minima, Asperula glauca, Léva. Centunculus minimus, Achillea Neilreichii, Anthemis linctoria, Carthamus lanatus, auf dem Siklos auch noch Hesperis tristis, Adonis vernalis, Linum hirsulum, Polygala maior und Androsace maxima.

Bei Komorn (Kómarom) treten schon typische Flugsandsteppen auf. Komorn. Hier wachsen Tragus racemosus, Holoschoenus vulgaris, Iris arenaria, Kochia arenaria, Minuarlia verna, Dianthus serolinus, Gypsophila fastigiata, Adonis vernalis, Alyssum tortuosum, Syrenia cana, Euphorbia Gerardiana, Peucedanum arenarium, Seseli annuum, Eryngium planum, Onosma arenarium, Plantago ramosa, Arlemisia campestris, A. scoparia und in sandigen Wäldern auch Gypso- 
phila paniculala, Astragalus exscapus, A. asper, Jurinea mollis, während auf Sumpfwiesen Linum perenne, Senecio Doria und Aster Tripolium gedeihen.

Gran. Weiter donauabwärts, an der Mündung der Gran bei Beny, trifft man teils salzige Wiesen, teils typische Halophytenfluren mit Camphorosma ovala, Bupleurum lenuissimum, Glaux maritima, Statice Gmelini, Blackstonia serotina, Cenlaurium linearifolium, Plantago tenuiflora, Aster Tripolium, Arlemisia monogyna, Senecio paludosus, Scorzonera humilis usw.

En@erau bei

Preßburg.

Südlich der Donau gegenüber Preßburg bildet bei Engerau auf Weiden Euphorbia Gerardiana Massenvegetation, begleitet von Gypsophila paniculala und Plantago maritima. Weiter nach Süden zu aber ist die Ebene trefflich kultiviert und von ausgedehnten Äckern bedeckt, die nur selten, wie zwischen Gattendorf und Jahrndorf, von feuchten Wiesen unterbrochen sind.

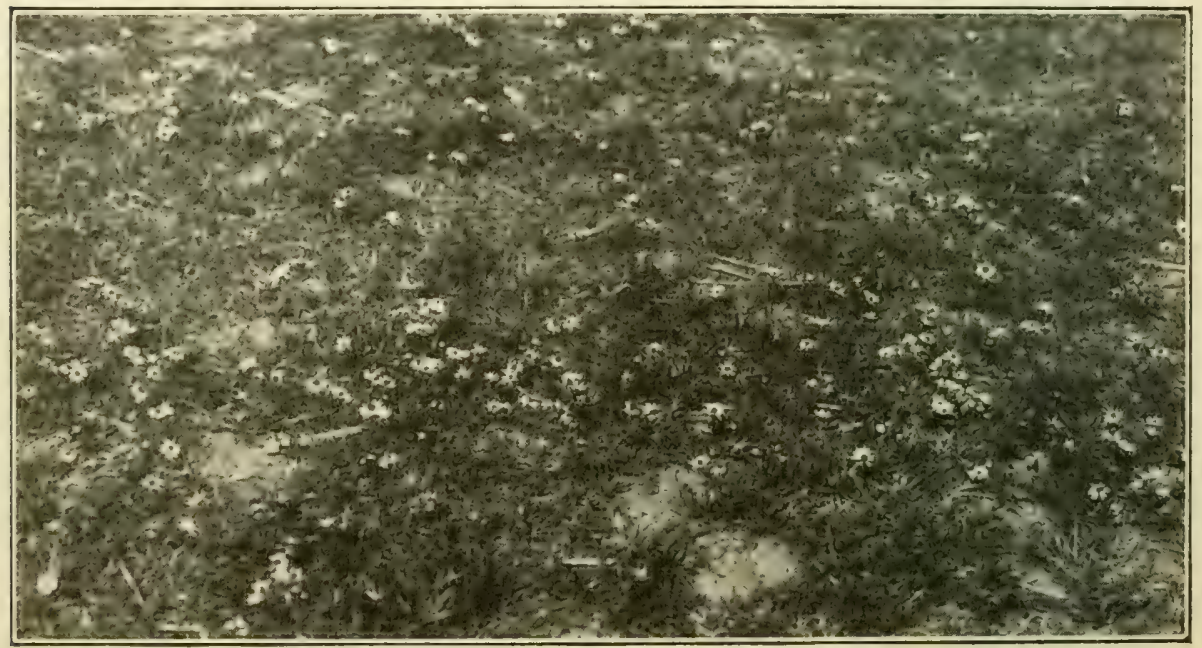

Abb. 297. Halophytentrift mit Aster Tripolium am Ufer des Neusiedlersees bei Goysz.

(Nach einer Aufnahme von Dr. E. Zederbauer, Wien.)

(Aus der Bildersammlung des botanischen Institutes der Wiener Universität.)

Neusiedler -

Im südwestlichsten Teile der Ebene liegt der ausgedehnte Neusiedlersee, dessen Wasserspiegel großen periodischen Schwankungen unterworfen ist und der infolge des Mangels eines regelmäßigen Abflusses salziges Wasser hat. Rings um den See finden sich, einen je nach dem Wasserstande wenige Meter bis zu 3-4 km breiten Gürtel einnehmend, Salztriften, auf denen Salicornia herbacea, Spergularia marginala, Crypsis aculeala und Cyperus pannonicus in tonangehender Irenge auftreten, begleitet von Heleochloa explicala, H. schoenoides, Alropis Peisonis, Cyperus fuscus, Carex secalina, Camphorosma ovala, Lepidium crassifolium, L. lalifolium, Centaurium pulchellum, Planlago maritima, Aster Tirinolium und Cirsium brachycephalum. Am See selbst bilden Phragmiles communis, Schoenoplectus triqueler, S. lacustris und S. Tabernaemontani stellenweise Bestände, eine eigentliche Wasserflora aber fehlt den salzigen Fluten. 
Das Gebiet östlich vom Neusiedlersee, ehedem jedenfalls auch größtenteils versumpft, ist heute von ausgedehnten Getreidefeldern bedeckt, die nur hie und da durch kleine Wäldchen oder die ursprüngliche Steppenvegetation, in der bei Parn- Parndorf. dorf Ranunculus laleriflorus seinen westlichsten Standort hat, unterbrochen sind. Im Südosten des Neusiedlersees aber breitet sich ein ausgedehntes Sumpfgebiet aus, der ,Hanság". Den größten Teil dieses Gebietes nehmen Moorwiesen ein, auf denen Glyceria aquatica meist in tonangebender Menge auftritt und mit Carex acutiformis, C. Pseudocyperus, C. paradoxa zsombékartige Bestände bildet, in denen Dryopleris Thelypteris, Poa palustris, P. trivialis, Carex nulans, Caltha palustris, Thalictrum galioides, Roripa amphibia, Myosolis scorpioides, Veronica scutellata und Cirsium palustre besonders häufig sind. Nordwestlich von Ki a puvár aber breitet sich zu beiden Seiten der Rabnitz und kleinen Raab der ,Große Erlenwald" (Nagy éger erdö) aus, der in seinem Aufbau sehr an den oben geschilderten Schurwald erinnert. Auch hier bildet Alnus glulinosa und Quercus Robur, hie und da von Alnus incana begleitet, das Oberholz, während das Unterholz dicht belaubte Büsche von Salix cinerea und S. alba zusammensetzen. Den Niederwuchs bilden auch hier Dryopleris Thelypleris und Urlica kioviensis, ferner Sium lalifolium, Rumex Hydrolapalhum, Sonchus uliginosus, Slachys palustris usw., während an offenen Stellen Glyceria aqualica Massenvegetation bildet.

Auch weiter östlich im Flußgebiete der Raab treten noch zahlreich feuchte Wiesen mit Leucoium aeslivum, Allium angulosum, Colchicum autumnale, Clematis inlegrifolia, Thaliclrum lucidum, Cardamine pralensis, Silene mulliflora, Lathyrus paluster, Angelica silvestris, Selinum Carvifolia, Cirsium canum usw. auf; aber auch Salzwiesen mit Atropis limosa, Agrostis alba, Juncus Gerardi, Orchis palustris, Girsium brachycephalum, Scorzonera parviflora sind nicht selten und an trockeneren Stellen findet man auch Crypsis aculeala, Spergularia marina, Camphorosma ovala, Plantago maritima, Artemisia monogyna und Aster Tripolium.

Im westlichen Teile des Raaber Komitates jedoch tritt wieder ein größeres Sandgebiet auf. Im südlichen Teile desselben, in Sokoróalja, sind hier auffallenderweise Sandheiden von ganz mitteleuropäischem Charakter entwickelt, auf denen Corynephorus canescens, Agrostis canina, Vulpia Myurus, Carex supina, Minuartia viscosa, Jasione montana, Filago montana, Hypochoeris maculala die bezeichnendsten Arten sind. Im übrigen Teile des Gebietes herrscht die Grassteppe, die allerdings mehr an die Steppen des niederösterreichischen Marchfeldes als an die der Großen ungarischen Tiefebene erinnert und durch das Eindringen zahlreicher Arten des Hügellandes ausgezeichnet ist. Als die wichtigsten Arten derselben seien Andropogon Ischaemum, Tragus racemosus, Stipa capillata, Salsola Kali, Kochia arenaria, Corispermum nilidum, Gypsophila fastigiala, Dianthus serolinus, Kohlrauschia prolifera, Silene Oliles, Anemone nigricans, Tribulus orientalis, Peucedanum arenarium, Onobrychis arenaria, Plantago ramosa, Helichrysum arenarium, Xanthium strumarium, X. spinosum und Chondrilla juncea genannt. Diese Sandsteppen dringen durch das Raabtal und 
auf der Kemenesalja stellenweise bis ins Günser Bergland und in den Bakonywald cin. In der Umgebung von Raab (Györ) wurden vielfach mit Erfolg Aufforstungen mit Populus alba, P. nigra, P. tremula, Robinia Pseudacacia und selbst mit Pinus silveslris durchgeführt.

An den Ufern der Donau sind auch hier schöne Auenwälder aus Salix fragilis, S. alba, Populus alba, P. nigra oder aus Alnus incana entwickelt. Das Unterholz dieser Auen besteht aus Prunus Padus, Evonymus vulgaris, Cornus sanguinea, Rhamnus Frangula, R. cathartica, Ligustrum vulgare usw.; sehr zahlreich sind Schlinggewächse in denselben vertreten, so Humulus Lupulus, Clemalis Vitalba und Vitis silvestris. Im Niederwuchs machen sich aber eingewanderte Arten stark bemerkbar, vor allem die überall häufige Solidago serolina und hie und da auch Althaea armeniaca. Auf den Schotterbänken der Donau sind Myricaria germanica und Chamaenerion palustre häufig.

Die Sandsteppen des Raaber Komitates setzen sich nach Osten im weiten Komárom. Donautale bis in die Gegend von Komorn (Komárom) fort. So finden sich schon bei Alt- und Neu-Szöny gegenüber von Komorn Andropogon Gryllus, Iris arenaria, Corispermum canescens, Polygonum arenarium, Peucedanum arenarium usw., während auf Sumpfwiesen in dieser Gegend Leucoium aestivum, Galium rubioides, Aster Tripolium auftreten und an den Donaufern bei Komorn Iris germanica häufig verwildert vorkommt.

\section{B. Die Große ungarische Tiefebene.}

Die Große ungarische Tiefebene zerfällt in einen zentralen, östlich und westlich der Theiß und an der unteren Donau sich hinziehenden waldlosen Teil und ein waldiges Randgebiet. Dieses Randgebiet ist vielerorts, besonders am Nord- und Ostrande der Steppe, auf einen schmalen Streifen reduziert, der unmittelbar in das Waldgebiet der anschließenden Vorberge der Karpathen übergeht; an anderen Stellen aber nehmen die wenigstens ehemals mit Wald bedeckten Partien des Tieflandes größere Flächen ein, so vor allem im nordöstlichen Winkel der Großen Tiefebene nördlich und östlich von Debreczen im Gebiete des „Nyirség", ferner im Tieflande an der unteren Donau und endlich im Nordwesten auf dem niedrigen Rücken der Kecskeméter Landhöhe.

Von den Ausläufern des Nagy-szál und der Matra zieht da ein breites, von ausgedehnten Kulturen und vielfach auch von Sand- und Salzsteppen unter-

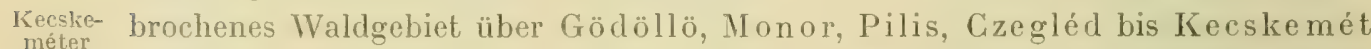
Landhöhe. und Szabadka (Maria-Theresiopel). Die einstigen IVälder dieses Gebietes sind Monor. bei Monor und Pilis noch in ziemlicher Ausdehnung erhalten und bestehen hier fast durchwegs aus Quercus Robur, der vereinzelt Quercus Cerris, Populus alba und $P$. nigra, Garpinus Belulus und (selten) Belula pendula beigemischt sind, hingegen wurde von Linden nur Tilia cordala und auch diese nur selten beobachtet. Im Unterholz gedeihen vornehmlich Berberis vulgaris, Acer campestre und A. Lalaricum, Cornus sanguinea, Corylus Avellana, Prunus spinosa, zahlreiche Cylisus- und Rosa-Arten; der Niederwuchs dieser Wälder erinnert 
an den der Wälder des Berglandes, da der Untergrund nicht sumpfig ist, sondern aus Flugsand besteht. So gedeihen bei Monor und Pilis in den Wäldern Clemalis recla, C. Vilalba, Ranunculus illyricus, Thalictrum aquilegifolium, Trifolium rubens, Phlomis tuberosa, Campanula bononiensis, Chrysanthemum corymbosum, Lacluca quercina und als Liane tritt selbst Vitis silvestris auf. Zwischen den einzelnen Waldparzellen aber dehnen sich teils Acker, teils Sandsteppen aus. für deren Flora Alyssum deserlorum, A. arenarium, Rapistrum perenne, Fumana procumbens, Tunica prolifera, Dianthus diutinus, Silene conica, S. mulliflora, Tribulus orientalis, Erodium Neilreichii, Astragalus varius, Pencedanum arenarium, Asperula glauca, Alkanna tinctoria, Artemisia pontica, Girsium spathulalum, Polygonum arenarium und Corispermum nitidum charakteristisch sind.

Diese Sandpuszten erstrecken sich bis in die Gegend von Budapest. Budapest. Besonders um Rákos-Palota und Káposztasmegyer gibt es auch heute Rákos. noch weite von Flugsand bedeckte Strecken, die mit typischer Steppenvegetation bedeckt sind. Während in unmittelbarer Nähe der Hauptstadt meist Bromus hordaceus, B. lectorum und B. sterilis in Gesellschaft von Hordeum murinum in übersehbarer Nenge den Boden bedecken, ist anderwärts zumeist die typische Federgrassteppe entwickelt. Neben Stipa capillala und $S$. pennala sind hier Fesluca vaginala und $F$. sulcala die vorherrschenden Gräser; von den übrigen Arten sind Gagea pusilla, Muscari racemosum, Iris arenaria, Gypsophila paniculala, Dianthus serotinus, Minuartia verna, M. selacea, M. glomerala, Cerastium semidecandrum, Erysimum canescens, Syrenia anguslifolia, Alyssum arenarium, Euphorbia Gerardiana, Sedum Hillebrandlii, Astragalus: varius, A. exscapus, Alkanna tincloria, Onosma arenarium, Cynoglossum hungaricum, Anchusa angustifolia, Achillea pectinala, Helichrysum arenarium, Crepis rhoeadifolia die augenfälliğsten; bezeichnend für die Burlaprster Sandflächen sind frrmer dir schachtelhalmähnlichen Büsche von Epherlra distachya, die hier von den benachbarten Dolomitbergen auf die sandige Ebene herabsteigt, sowie das ab und zu auftretende Gestrüpp von Hippophaë rhamnoides. Auch Reste der früher viel ausgedehnteren Sumpfwiesen sind entlang des Rákosbaches noch zu finden, für welche Juncus alpinus *fuscoaler, Schoenus nigricans, Molinia coerulea, Gymnadenia conopea, Silene multiflora, Euphorbia paluslris, Girsium brachycephalum, Scorzonera humilis und S. parviflora die bezeichnendsten Arten sind.

An der Donau sind bei Budapest schöne Auenwälder entwickelt, die heutè freilich nur mehr teilweise vorhanden oder wie auf der M argare teninsel in Parkanlagen umgewandelt sind, doch fallen auch hier noch die prächtigen uralten Stämme von Vilis silvestris, die hoch in die alten Eichen reichen, auf. An den toten Armen der Donau, südlich von Budapest ist eine reiche Sumpf- und Wasserflora entwickelt. Phragmiles communis bildet, oft von Typha lalifolia, Bulomus umbellalus u. a. begleitet, ausgedehnte Bestände, an Gräben findet man hie und da, wie auf dem Molnársziget bis Soroksár, Scirpus radicans und in den stehenden Wässern sind vor allem Spirodela polyrrhiza, Polamogeton nalans, P. perfoliatus, Hydrocharis Morsus ranae, Straliotes aloides, Elodea canadensis 
und Hollonia palustris häufig, während bei Erzsébetfalva auch Trapa nalans Csepel. auftritt. Die südlich von Budapest liegende Gsepelinsel ist vielfach von Kulturland bedeckt und von den ehemaligen Auenwäldern, in denen auch Ouercus Robur nicht selten ist, sind nur mehr einzelne Reste erhalten. Im nördlichen Teile der Insel jedoch liegt ein größeres Flugsandgebiet, das allerdings jetzt mit Robinia Pseudacacia aufgeforstet wird, doch sind trotzdem noch die Pflanzen der Sandsteppe in großer Zahl anzutreffen, vor allem das massenhaft auftretende Secale silveslre, ferner Stipa pennala *Joannis, Polygonum arenarium, Gypsophila paniculala, G. hungarica, Silene conica, Erysimum canescens, Syrenia

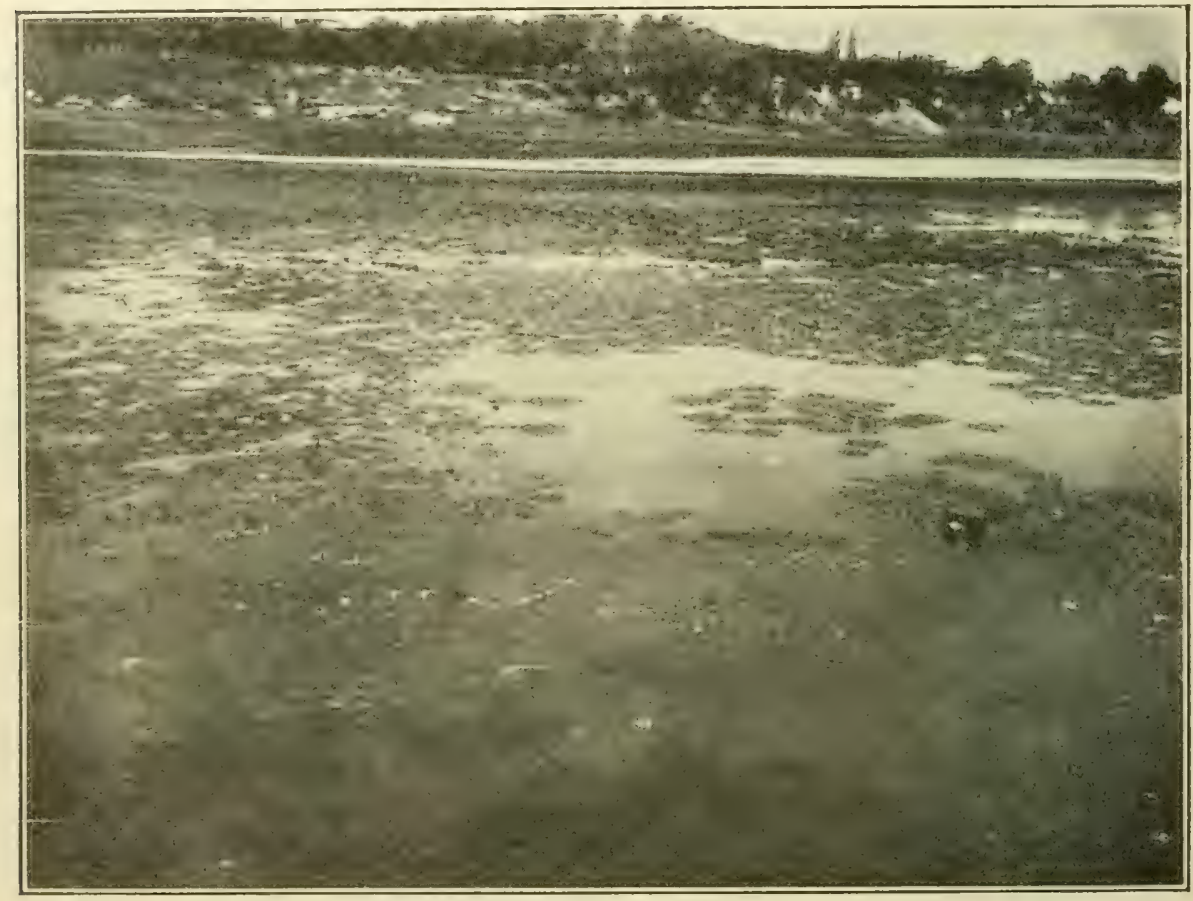

Abb. 298. Trapa natans in einem Donausumpf bei Erzsébetfalva.

(Nach einer Aufnahme von Dr. H. Frh. v. Handel-Mazetti, Wien.)

anguslifolia, Linum pannonicum, Euphorbia Gerardiana, Aslragalus varius, Onobrychis arenaria, Peucedanum arenarium, zu denen sich einige hier aus dem benarhlarten IIügellande bis in die Sandsteppe herabsteigende Arten gresellen, wie Melica transsilvanica, Carex obaesa, Sisymbrium pannonicum, Scabiosa ochroleuca und Linaria genislifolia; streckenweise tritt auch Oenolhera biennis in Beständen auf. Stellenweise trifft man entlang der Donau und auf ihren Inseln auch Sumpfiviesen, für die Agrostis alba, Rumex odontocarpus, Galium rubioides, Senecio Doria und Cirsium brachycephalum die bezeichnendsten Arten sind.

Unmittelbar im Süden von Budapest bei Soroksár beginnt ein Gebiet, das ungemein reich an Salztümpeln und Soda auswitternden Stellen ist und eine reiche Halophytenflora aufweist. Schon um Soroksár wachsen auf salzigen 


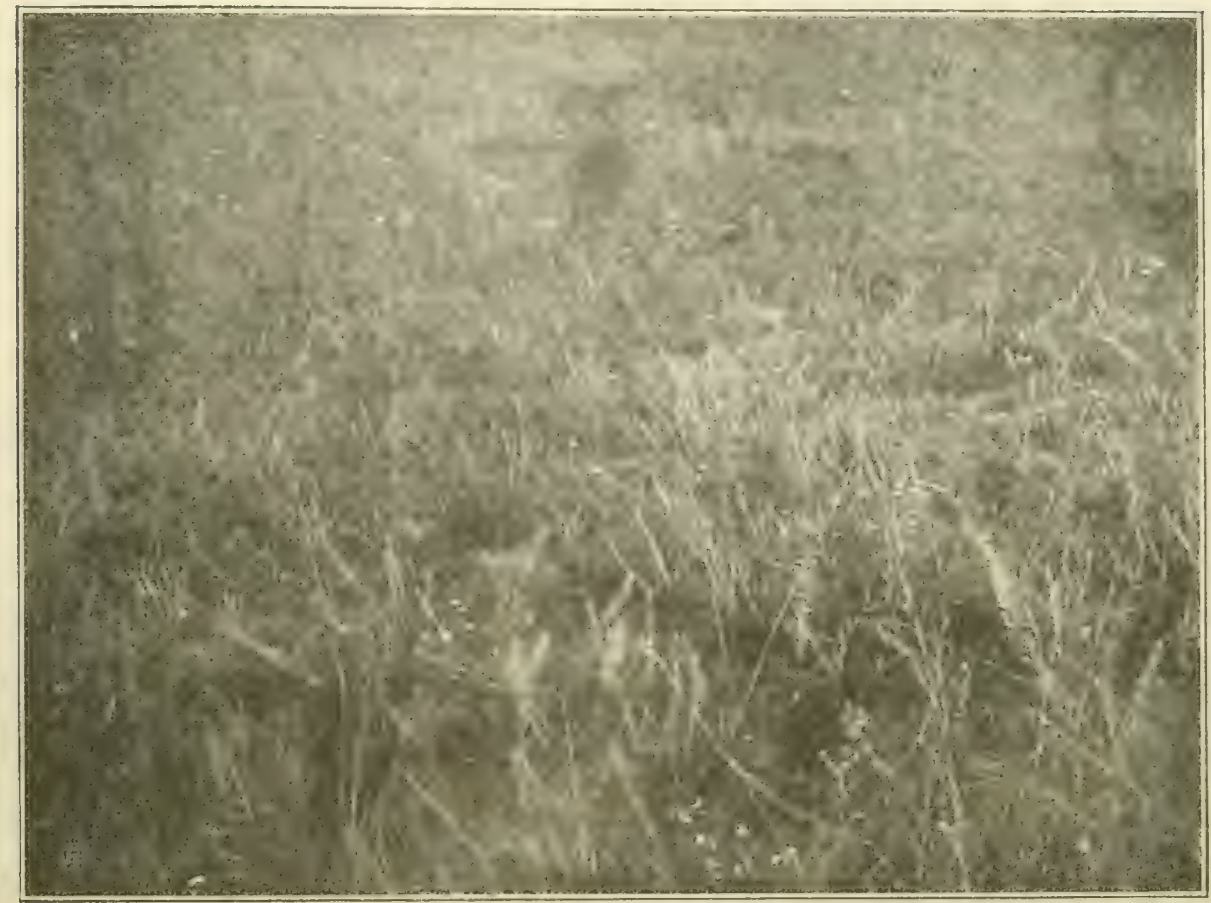

Abb. 299. Sandsteppe bei Szigetszentmiklos auf der Csepelinsel.

Festuca vaginata, Gypsophila hungarica, Euphorbia Gerardiana, Onosma arenarium, Scabiosa ochrolenca.

(Nach einer Aufnahme von Dr. H. Frh. v. Handel-1azzetti, Wien.)

Wiesen Cerastium anomalum, Linum perenne, Lolus siliquosus und Asler Tripolium, für die Salzsteppen sind besonders Polygonum Kilaibelianum, Camphorosma ovala, Salicornia herbacea, Slatice Gmelini, Glaux marilima, Bupleurum lenuissimum und Matricaria Chamomilla bezcichnend und die Salztümpel umsäumen neben Crypsis aculeala, Salicornia herbacea, Salsola IKali und Camphorosma ovala auch Chenopodium rubrum, C. glaucum, Alriplex lalarica, Lepidium crassifolium, Lolus lenuis und Abutilon Avicennae. Auch bei Kun-Szent- Kun-SzentMiklos trifft man ausgedehnte als Viehweide benutzte Salzsteppen mit Fesluca pseudovina, Leplurus pannonicus, Hordeum Gussoneanum, Salsola Tragus, Camphorosma ovala, Planlago marilima, P. tenuiflora und Arlemisia monogyna sowie größere Salztümpel, an deren Rändern Scirpus marilimus in großen Beständen auftritt.

Von Kun-Szent-Miklos zieht sich dieses Sodagebiet parallel der Donau und von derselben $10-20 \mathrm{~km}$ entfernt nach Süden fort. Hunderte von kleineren oder größeren Tümpeln und Seen mit salz- und sodahaltigem Wasser (,feher tó") liegen auf der Strecke zwischen Budapest und Szabadka, die größten derselben sind: der Sári-viz bei Laczháza, der Lapos-rét nördlich von Szabadszállás und der Zabszék und Kelemenszék bei Fullöpszállás. Das Wasser dieser Seen enthält oft über $3 \%$ kohlensaures Natron und 1 -2\% Chlor- 
natrium und im Hochsommer, wenn der nie ganz verdunstete Wasserspiegel stark eingeschränkt ist, bedeckt die auskristallisicrte Soda in weißer Schicht den Boden und um dieselbe siedeln sich dann Salicornia herbacea und Crypsis aculeala an und außen umgibt diese Trift ein Ring aus diversen Chenopodiazeen, Slalice Gmelini, Abulilon Avicennae, Allhaea officinalis usw. Die größeren WasserNádas rét. tümpel des Gebietes, wie der Nádas rét bei Szabadszállás und der Kolom tó bei Fullöpszállás, weisen einen geringeren Salzgehalt auf und sind mit bei ihrer geringen Tiefe fast in ihre Mitte reichenden ausgedehnten Schilf-

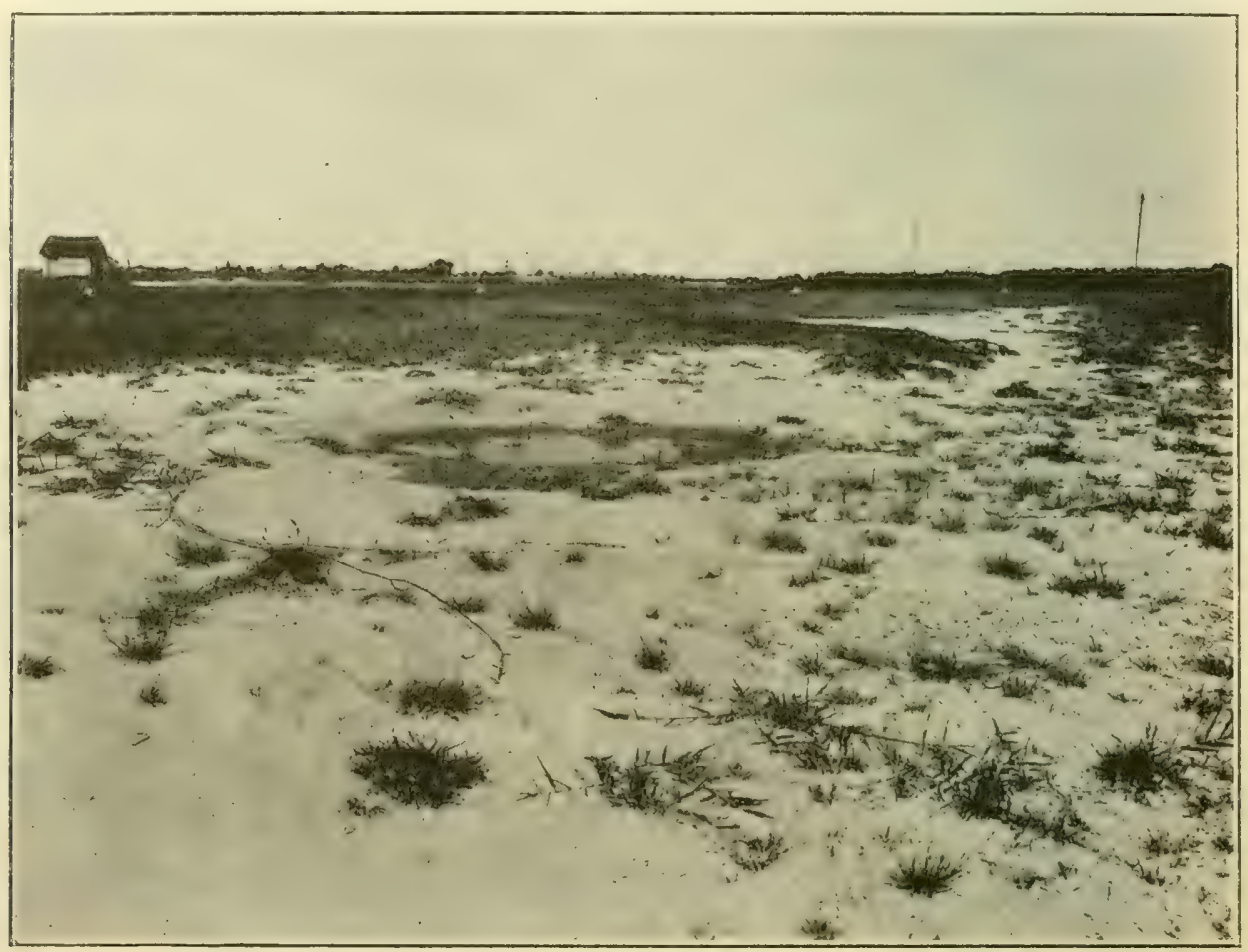

Abb. 300. Schwach besiedelter Szikboden bei Kun-Szent-Miklos.

Festuca vaginata, Atropis salinaria, Lepidium crassifolium, dazwischen die langen Ausläufer von Phragmites communis.

(Nach Bernátsky, A szikes talajok növényzete.)

beständen bedeckt. Der Boden zwischen diesen Seen und Tümpeln ist teils sandig, größtenteils aber lehmig und allenthalben salz- und sodahaltig; im Frühling oft weithin versumpft, wird er im Hochsommer oft so trocken, daß ur mit zahlreichen Sprüngen durchzogen ist. Nur eine spärliche Vegetation bedeckt diese als Weideflächen genutzten Gebiete. Atropis dislans, Fesluca pseudovina, Heleochloa explicata, Bromus lectorum, Hordeum maritimum, II. Gussoneanum, Carex stenophylla, C. divisa, Juncus Gerardi bilden die dürftige, im Sommer meist ganz verdorrte Grasnarbe und dazwischen gedeihen Spergularia marina, Cerastium anomalum, Trifolium fragiferum, T. angulalum, 


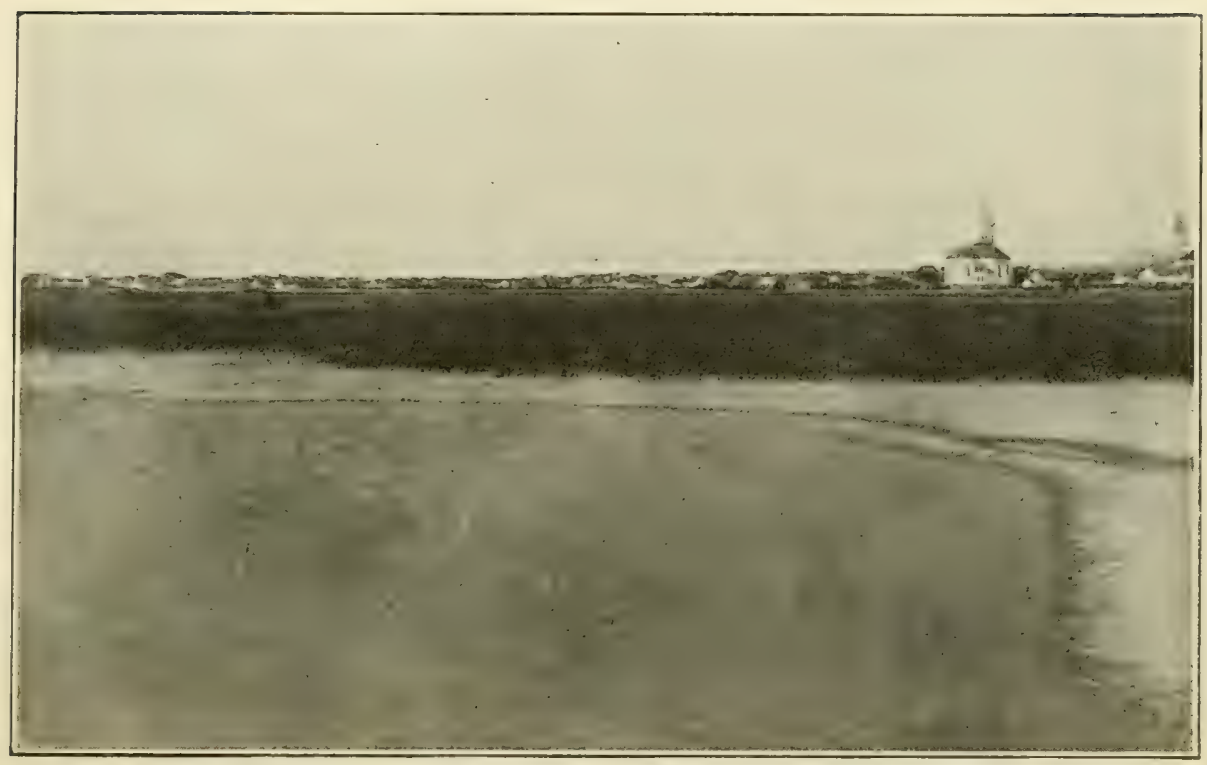

Abb. 301. Salztümpel bei Kun-Szent-Miklos.

Am Ufer cin vegetationsloser Streifen von salzinkrustiertem weißem Lehm, dann eir dichter Bestand von Scirpus maritimus.

(Nach ciner Aufnahme von A. v. Haycli.)

Medicago minima, Lolus siliquosus, Lolus tenuis, Bupleurum falcalum, B. tenuissimum, Stalice Gmelini, Sedum Hillebrandlii, S. rubens, Scorzonera Jacquiniana, S. parviflora und stellenweise, wie bei Szobosló und Halas, in großer Menge Szobosló. Triglochin marilimum.

In nächster Nähe dieser Strecken salzigen Bodens aber findet man auf der Kecskeméter Landhöhe auch Stellen, die von mächtigen Flugsandschichten bedeckt sind. Noch bei Nagy-Körös trifft man hier auf sandigem Boden natürliche Wälder aus Quercus sessiflora und Q. Cerris mit Acer talaricum im Unterholz und Clemalis integrifolia und Sculellaria altissima im Niederwuchs, daneben aber Sandsteppen mit Iris pumila, Polygonum arenarium, Kochia arenaria, Corispermum nitidum, C. canescens, Alyssum tortuosum, Kohlrauschia prolifera, Astragalus varius, Onobrychis arenaria, Vinca herbacea, Echium allissimum, E. rubrum usw. Von Nagy-Körös weiter südwärts bis gegen Kecskemét hin begegnet man allenthalb glücklichen Aufforstungsversuchen von Pinus nigra und Robinia Pseudacacia, in denen Juniperus communis das Unterholz bildet. Die mächtigste Entwicklung zeigt der Flugsand aber in: der Umgebung von Füllöpszállás und Izsag, wo weite Strecken von fast vegetationslosem lockerem Sande bedeckt sind und der Wind mächtige Flugsandhügel von 20 und mehr Metern Höhe aufgetürmt hat. Auch lockeres niederes Gestrüpp aus Populus nigra bedeckt stellenweise den sandigen Boden und neben Bromus-Arten sind Cerastium semidecandrum, Alyssum lortuosum, Euphorbia Cyparissias und E. Gerardiana die 
häufigsten Ansiedler auf dem losen Untergrunde. Nit großem Erfolge wurden lier in den letzten Jahren auf dem Flugsande Weinkulturen angelegt.

Kecskemét. Auch in der Umgebung von Kecskemét selbst wechseln salziger Boden und Flugsandgebiete miteinander ab und Sandsteppen, auf denen hier Salvia nulans auftritt, sind noch heute in großer Ausdehnung vorhanden, besonders in der Umgebung von Kis-Kun-Félegyháza, wo auch Crocus reticulatus wächst. Doch ist das ganze Gebiet der Kecskeméter Heide schon vielfach gut kultiviert und ist neben dem Getreidebau besonders die reiche Obstkultur Kis-Körös. und der Tabakbau hervorzuheben. Auch weiter im Süden, über Kis-Körös

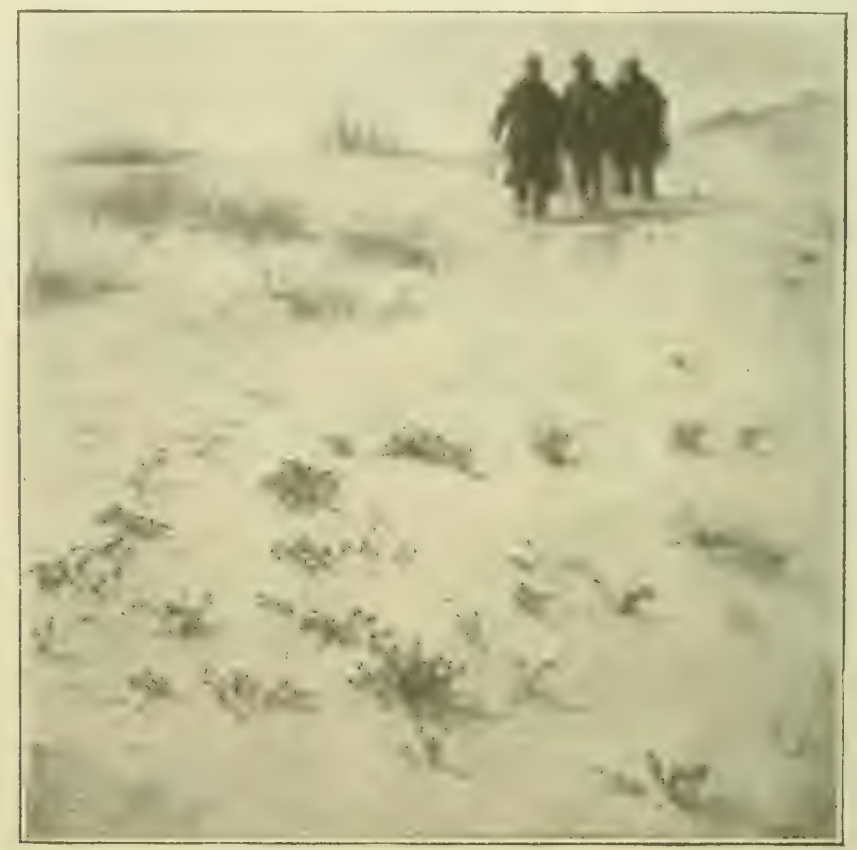

Abb. 302. Euphorbia Gerardiana im Flugsand bei Fülöpszállás: (Nach einer Aufnahme von A. v. Hayek.)

Szahadka. bis gegen Maria-Theresiopel (Szabadka), wurde das ehemalige ausgedehnte Flugsandgebiet durch Anpflanzungen von Lycium halimifolium, Robinia Pseudacacia, Populus nigra usw. der Kultur zugänglich gemacht und heute ist das ganze Gebiet von ausgुedehnten Weizen-, Mais- und Rübenäckern, Tabakfeldern und Obstgärten bedeckt. Bei Kis-Kun-Halas sind auch noch Reste der ursprünglichen Eichenwälder mit Liguslrum vulgare, Iris variegala, Valeriana officinalis usw. erhalten, die allerdings durch reichliche Anpflanzung von Cellis australis viel von ihrem ursprünglichen Charakter eingebüßt haben.

Entlang der Donau selbst sind hauptsächlich Auenwälder aus Populus alba, P. nigra, Ulmus glabra, Alnus incana usw. mit Cralaegus nigra, C. Oxyacantha, C. monogyna und Viburnum Opulus im Unterholz entwickelt, in denen die wilde Rebe (Vilis silveslris) allenthalben häufig ist und in deren Niederwuchs 


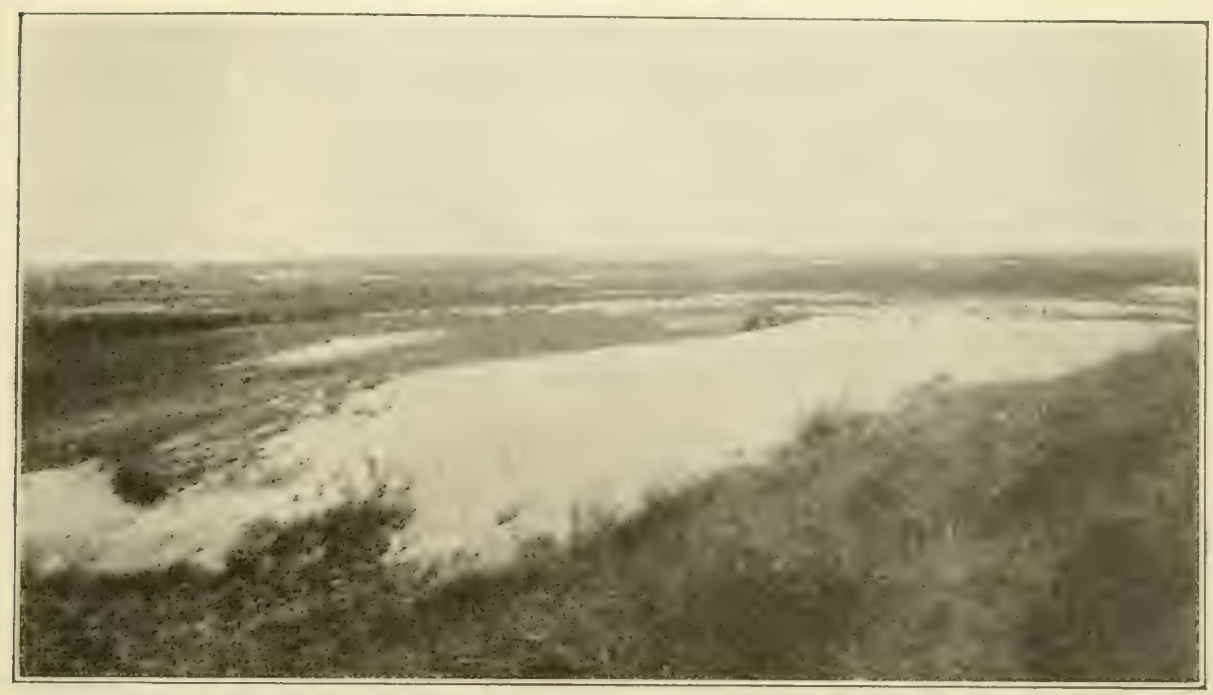

Abb. 303. Landschaftsuild aus dem Flugsandgebict auf der liecskeméter Landhöhe bei Vadkert.

(Nach einer Aufnahme von Prof. Dr. L. v. Lóczy, Budapest.)

(Aus der Bildersammlung des Botanischen Institutes der Wiener Universităt.)

Scilla bifolia, Leucoium vernum, Paris quadrifolia, Ornithogalum nulans und Bouchéanum, Festuca giganlea, Viola elalior, Cucubalus baccifer usw. auftreten. Eichen (Quercus Robur) sind seltener anzutreffen, wie z. B. auf der Csepelinsel und bei Kaloesa, werden aber nach Süden zu immer hänfiger und beginnen etwa von Mohács an in den Auenwäldern zu dominieren. Um Kalocsa ist übrigens neben den auch hier vorhandenen Sandsteppen die reiche Halopliytenflora mit Crypsis aculeala, Ranunculus pedalus, Lepidium rrassifolium, Lylhrum bibraclealum, Bupleurum tenuissimum, Stalice Gmelini, Plantago maritima, Scorzonera parviflora, Taraxarum bessarabicum usw. besonders hervorzuheben. Auch Moorwiesen mit Carex elala, C. riparia, C. acutiformis, Triglochin palustre, Dianthus superbus, Ranunculus Lingua, Peucedanum palustre, P. Ciervaria, Succisa pralensis usw. sind um Kalocsa reichlich entwickelt und in den toten Armen der Donau und sonstigen stehenrten Gewässern ist eine reiche Wasserflora aus Naias minor, Polamogelon nalans, P. lucens, P. crispus, P. acutifolius, P. marinus, Stratiotes aloides, Castalia alba, Nuphar lulenm, Ceralophyllum demersum, C. pentacanthum, Nymphoides pellala u. a. zu finden.

Zwischen Budapest und Kalocsa greift die Tiefebene auch auf das rechte Donaufer über urrt reicht hier bis ans Ostufer des Plattensees. Heute ist dieser Teil der Ebene grut kultiviert, ehedem war er wohl größtenteils bewaldet. wie die Waldreste bei Vajta und Kéer, Eichenbestände, in denen auch schon Tilia argentea auftritt, bezeugen, doch trifft man daneben auch noch Sandsteppen mit Minuarlia glomerata, Silene conica, Alyssum tortuosum, Syrenia angustifolia, Euphorbia Gerardiana, Alkanna tinctoria, Jurinea mollis, Helichrysum arenarium usw. Doch treten stellenweise, wie am dicht von Phragmiles communis be- 
Velenczer- wachsenen Velenczersee bei Pakozd, am Sós-tó bei Szt. Ivány und bei Sár-Keresztur auch Halophytenfluren auf, hauptsächlich Salzwiesen mit Spergularia media, S. marina, Lolus siliquosus, Trifolium fragiferum, Lythrum Hyssopifolia, Aster Tripolium, Scorzonera parviflora, seltener, wie am Velenczersee auch Salzsteppen mit Suaeda salina, S. marilima, Salicornia herbacea, Kochia prostrata, Lepidium perfolialum, Bupleurum lenuissimum, Aster Tripolium und Artemisia monogyna. Der sumpfige, dicht mit Schilf umwachsene Velenczersee selbst beherbergt eine reiche Sumpf- und Wasserflora, u. a. Hydrocharis Morsus ranae, Stratiotes a!oides und Rumex Hydrolapalhum; auf Sumpfwiesen sind in dieser Gegend Orchis palustris, Galega officinalis, Pastinaca saliva, Scutellaria hastifolia, Senecio Doria, Cirsium canum und Scorzonera humilis häufig. Auch bei Stuhlweißenburg (Székes-féhervár) sind im Rét Szilas noch Salzsteppen mit Ranunculus laleriflorus, Lepidium crassifolium, L. perfolialum, Statice Gmelini, Plantago lenuiflora und Malricara Chamomilla anzutreffen. Doch auch hier sind Sandsteppen oder wenigstens sandige Viehweiden stellenweise noch erhalten und beherbergen u. a. Gypsophila paniculata, Silene Otites, S. conica, Anemone nigricans, Ranunculus illyricus, Erysimum canescens, Astragalus Onobrychis, Euphorbia Gerardiana, Eryngium campeslre, Achillea pectinala Siofok. und Artemisia campestris, und noch am Ostende des Plattensees bei Siofok wachsen Secale silvestre, Andropogon Gryllus, Vulpia Myurus, Tunica prolifera, Silene conica, Alyssum deserlorum, Erysimum canescens, Trigonella monspeliaca, Nonnea pulla, Plantago ramosa, Anthemis ruthenica und Crepis selosa.

Im äußersten Süden des zwischen Donau und Theiß gelegenen Teiles der Bács- Großen ungarischen Tiefebene, also im Komitate Bács-Bodrog, ist besonders Bodrog. im nördlichen Teile noch reichlich Wacholdergestrüpp entwickelt und Sandsteppen wechseln mit Salzsteppen, auf denen insbesondere Cerastium anomalum, Coronopus didymus und Trifolium laevigalum häufige Erscheinungen sind, miteinander ab. Auch hier ist aber entlang der Donau noch 'ein reiches Halophytengebiet vorhanden, das sich von Bezdan über Monosterszeg, Apatin, Dernye bis Ó-Futak erstreckt. Teils sind es Salztriften mit Festuca pseudovina, Leplurus pannonicus, Sclerochloa dura, Ornilhogalum Kochii, Scilla aulumnalis, Cerastium semidecandrum, Ranunculus pedalus, Trifolium minus, T. striatum, T. parviflorum, Peucedanum officinale, Statice Gmelini, Aster Tripolium, die man hier antrifft, teils Salzwiesen mit Alopecurus pralensis, Ranunculus laleriflorus, Roripa Kerneri, Trifolium ornithopodioides, Planlago lenuiflora und Asler canus, welch letzerer besonders um Bakokyertes und Bezdan von charakteristischer Häufigkeit ist und daselbst auch an trockenen Auenrändern auftritt. Ủberhaupt Bezdan. ist die Flora von Bezdan reich an interessanteren Arten, z. B. Ranunculus ophioglossifolius, R. polyphyllus, R. laleriflorus, Myosurus minimus, Cardamine ranzens- parviflora, die hicr an Gräben vorkommen. Auch entlang des Franzenskanals findet man neben Schilf- und Binsenbeständen Salztriften mit Crypsis aculeala Lepidium crassifolium, Aster Tripolium usw. und selbst im Lößgebiet bei Örszállás, Cservenka und Tamás sind Atropis distans, Spergularia media, Trifolium fragiferum, Achillea asplenifolia und Scorzonera cana nicht selten. Sogar 
im Flugsandgebiete bilden um die kleinen Salzseen, wie um den Ludas-tó und Sós-tó Suaeda maritima, Cyperus pannonicus, Crypsis aculeala, Aster Tripolium, Taraxacum bessarabicum u. a. dichte Bestände.

Der südliche Teil des Komitates Bacs-Bodrog aber ist reich an Wiesenmooren, in denen Oenanthe media allgemein verbreitet ist, bei $\mathrm{Zombor}$ tritt auch Schoenus ferrugineus bestandbildend auf und auf der Ludzaspuszta wächst Hierochloe odorata. Auch Elaline Alsinastrum ist an stehenden Gewässern nicht selten und bei Dernye und Gombos findet man die seltene Marsilia quadrifolia. Entlang des Unterlaufes der Donau von Mohács abwärts bis gegen Bazias aber sind überall die auch in Slawonien verbreiteten Eichenniederungswälder reichlich entwickelt, die z. B. in der Umgebung von Peterwardein (Pétervárad) hauptsächlich aus Quercus Robur und Q. sessiliflora, Ulmus glabra, Carpinus Belulus, Fraxinus excelsior, Populus alba und nigra, seltener auch aus Q. Cerris gebildet sind und deren Unterholz vornehmlich aus Corylus Avellana, Evonymus vulgaris, Cornus Mas, C. sanguinea, Cralaegus Oxyacanlha, C. monogyna, C. nigra, Rhamnus Frangula, R. calharlica, Viburnum Lantana und V. Opulus besteht, während Hedera Helix, Clemalis Vilalba, Vilis silves!ris und Humulus Lupulus hoch ins Geäst hinaufklettern und oft undurchdıingliche Dickichte bilden und im Niederwuchs Melica transsilvanica und bei Futak Centrosis aborliva die bemerkenswertesten Arten sind.

Zwischen der Mátra, der Theiß und der Tarna liegt das Gebiet des ehemaligen Jazygien, ein Gebiet, das, soweit es nicht kultiviert ist, Sand- Jazygien. steppen mit Agropyrum cristalum, Polygonum arenarium, Corispermum nilidum, G. hyssopifolium, Silene mulliflora, Astragalus varius, Erodium Neilreichii, Tragopogon floccosus, Cirsium spalhulalum usw. trägt; im Süden des Gebietes aber sind ausgedehnte Sumpfwiesen vorhanden, auf denen Carex nulans, Iris spuria und Clematis integrifolia nicht gerade selten sind.

Die träge in zahlreichen Windungen dahinfließende Thei $\beta$, vordem wegen Theiß. ihrer verheerenden Überschwemmungen, die durch großartige Regulierungsarbeiten jetzt sehr vermindert sind, gefürchtet, ist entlang ihres ganzen Unterlaufes von Szolnok bis zu ihrer Mündung durch das reichliche Auftreten von Glycyrrhiza echinala an ihren im Frühjahre stets überfluteten Ufern ausgezeichnet. In Gesellschaft dieser SüBholzart sind meist auch Euphorbin lucida, Astragalus contortuplicalus, Abutilon Avicennae und Verbena supina zu finden. Hingegen treten die Auenwälder an der Theiß im Vergleiche zu den ausgedehnten Uferwaldungen der Donau stark zurück.

Die Gegend zwischen Szolnok und Csegled einerseits, Kis-Ujszállás und Debreczen anderseits stellt ein Gebiet dar, wo der Boden überall einen größeren oder geringeren Salzgehalt aufweist, so daß selbst an wüsten Stellen inmitten der Dörfer Halophyten gedeihen, wie Leplurus pannonicus, Hordeum Gussoneanum und Camphorosma ovata, bei Szolnok auch Calepina myagroides. In der von ausgedehnten Getreidefeldern, in denen Allium alropurpureum und das häufigere Delphinium orientale als Ackerunkräuter auftreten, bedeckten Umgebung von Szolnok sind auch noch beträchtliche Flächen Szolnck. 


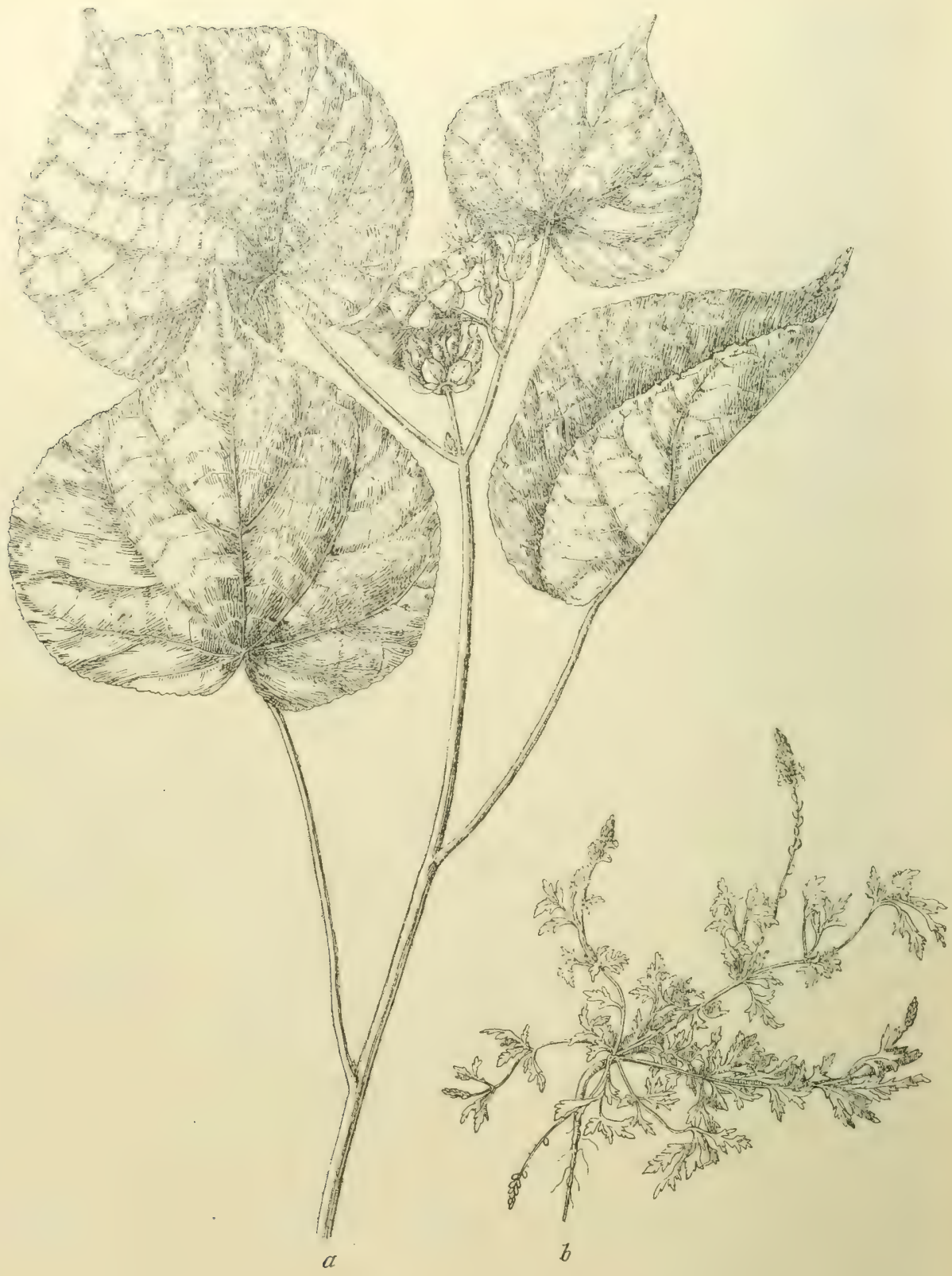

Abb. 304.

$a$ Abutilon Avicennae. $b$ Verbena supina.

von Sand- und Salzsteppen bedeckt, auf denen Fesluca vaginala, Carex stenopluylla, Polygunum arenarium, Centaurea Tauscheri bez. Heleochloa explicala, Beckmannia eruciformis, Cyperus pannonicus die bemerkenswertesten Erscheinungen sind, während in stehenden Gewässern Salvinia nalans und an der Theiß Csegléd. Senecio paludosus *Sadleri wachsen. Auch um Czegléd und nördlich davon 


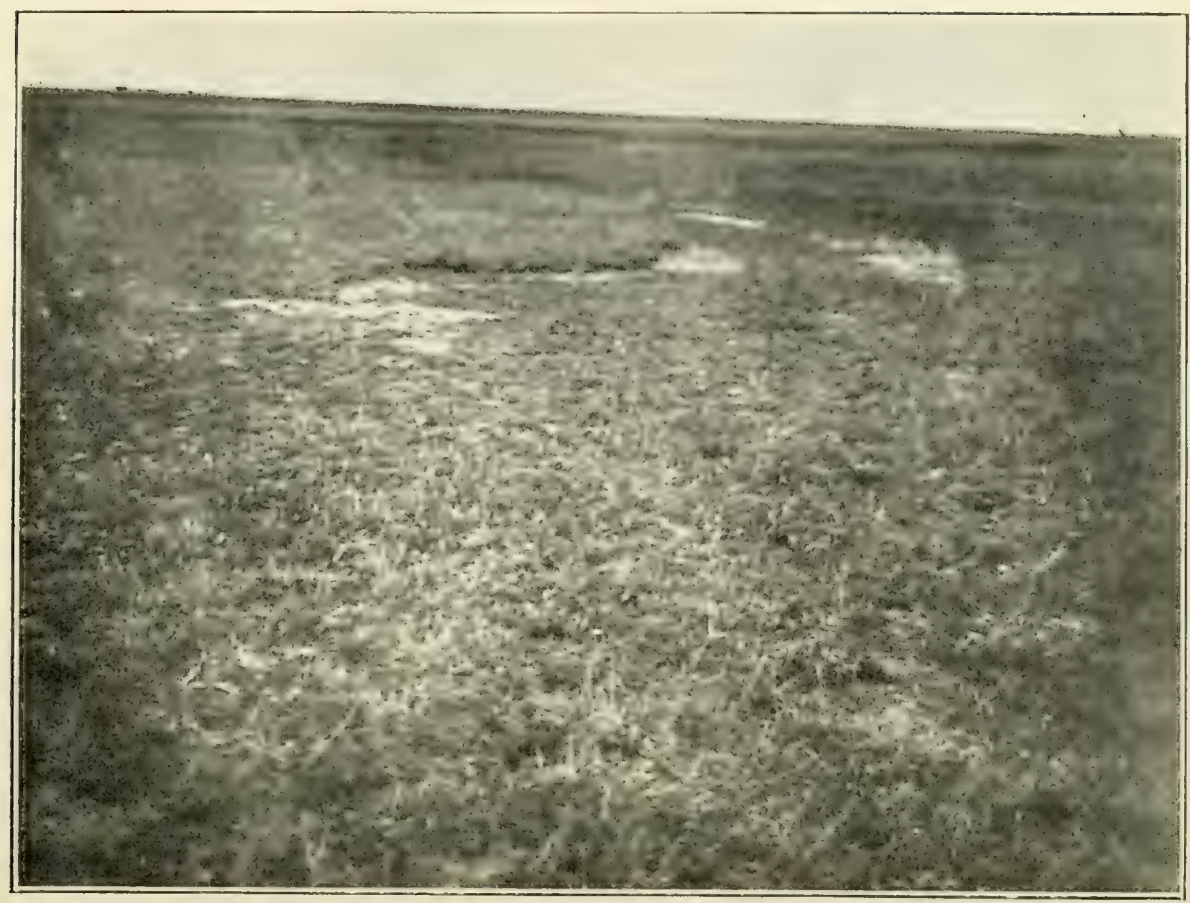

Abb. 305. Salzsteppe auf der Puszla Hortobágy bei Debreczen. Lepturus pannonicus, Lepidium crassifolium, Statice Gmelini, Matricaria Chamomilla.

(Nach einer Aufnahme von Dr. II. Frh. v. Handel-Mazetti, Wien.)

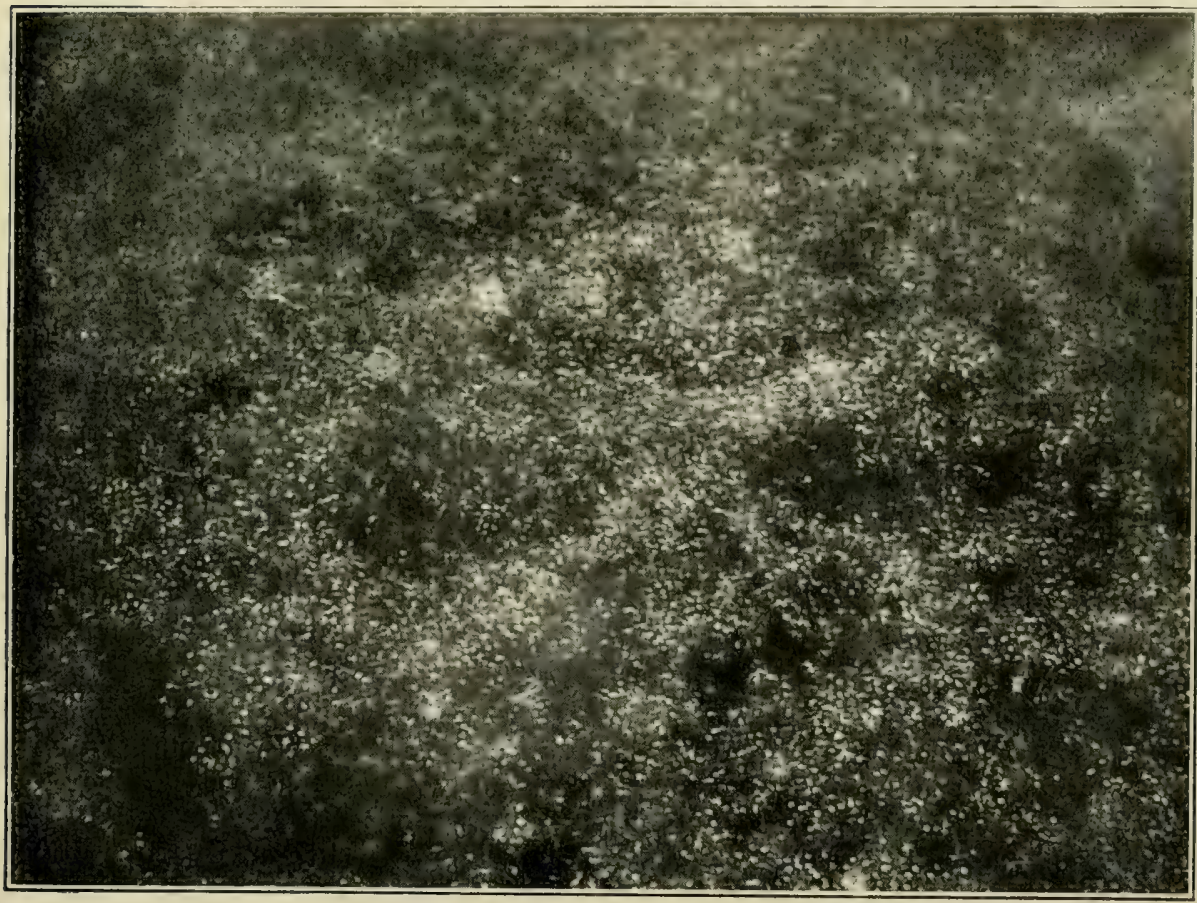

Abb. 306. Gypsophila muralis mit Hordeum Gussoneanum auf Salzsteppen der Puszta Hortobágy bei Debreczen.

(Nach einer Aufnahme von Dr. H. Frh. v. Handel-Mazetti, Wien.) 

bei Tápio-Szelle usw. trifft man teils Salzsteppen mit Kochia proslrala, Ranunculus pedatus, Gypsophila muralis, Taraxacum bessarabicum, Scorzonera Jacquiniana, teils besonders gegen die Kecskeméter Landhöhe hin Sandsteppen mit Polygonum arenarium, Corispermum nitidum, C. canescens (bei Szecsö), Euphorbia Gerardiana, Dianthus polymorphus, Silene parviflora, Allianna lincloria und Buschwerk aus Berleris vulgaris und Prunus nana. Ebenso findet man um Szentes und Csongrád Salzsteppen mit Bechmannia eruciformis, Alropis Csongrád. dislans, Leplurus pannonicus, Hordeum Gussoneanum, Camphorosma ovala, Lepidium ruderale, L. perfoliatum, Althaea officinalis, Scorzonera Jacquiniana und am Ufer der Theiß wachsen neben Glycyrrhiza echinala auch Euphorbia lucida, E. virgala, Lycopus exallalus und an trockenen Stellen Echium allissimum.

Die Umgebung der großen Städte Hódmezö-vásárhely und Szeged ist heute gut kultiviert und bietet nur wenige Reste der ursprünglichen Vegevásárhely. tation. Auf den Sandsteppen sind Andropogon Ischaemum, Cynodon Daclyjon, Kochia scoparia, Euphorbia Cyparissias, E. Gerardiana, Reseda lulea, Eryngium campestre, Echium vulgare, Lactuca Serriola häufig; an den Ufern der Theiß finden sich Heleochloa explicala, Dichostylis Micheliana, Glycyrrhiza echinala, Menlha Pulegium, Gnaphalium uliginosum, Pulicaria dysenterica neben spärlichem Weidengebüsch aus Salix alba und $S$. amygdalina. Bei Horgos treten aber auch Salzsteppen mit Fesluca pseudovina, Camphorosma ovala, Plantago marilima und Scorzonera Jacquiniana auf und an den Ufern der zahlreichen Salztümpel wachsen Alropis limosa, Carex dislans, Lotus lenuis, Aster Tripolum usw. Auch weiter südlich bei Zenta, Péterréve und Bács-földvár sind zwischen der Theiß und dem Kecskeméter Landrücken noch ausgedehnte Salzsteppen mit Cynodon Dactylon, Atropis limosa, Hordeum Gussoneanum, Camphorosma ovala, Atriplex lalarica, Gypsophila muralis, Trifolium parviflorum, T. ornithopodioides, Roripa Kerneri, Lepidium ruderale, Planlago lenuiflora und Malricaria Chamomilla erhalten.

Am Unterlaufe der Theiß nahe ihrer Mündung sind bei Titel wieder SandTitel. steppen in schöner Entwicklung anzutreffen. Die wichtigsten daselbst auftretenden Arten sind Andropogon Ischaemum, Tragus racemosus, Carex praecox, Allium flavum, A. sphaerocephalum, Gagea pusilla, Kochia prostrala, Silene Otites, Ranunculus orthoceras, Erysimum canescens, Alyssum desertorum, Astragalus austriacus, Androsace maxima, Allanna tinctoria, Siderilis montana, Campanula sibirica, Inula Oculus Christi, Cenlaurea arenaria und Tragopogon floccosus, sowie das kürzlich hier als neu für die ungarische Flora entdeckte Alyssum linifolium; bei Jánoshalma kommen überdies noch Adonis vernalis und Iris arenaria vor. Südlich von Titel sind an der Donau auch schon die oben erwähnten Eichenwälder entwickelt und auch Cotinus Coggygria tritt hier bereits auf.

Während in dem westlich von der Theiß gelegenen Teile der Großen ungarischen Tiefebene im Norden Flugsandgebiete überwiegen und der Süden größtenteils sumpfig ist, liegen im östlichen Teile derselben die Verhältnisse umgeliehrt. Freilich haben die großartigen Entwässerungsanlagen der letzten Jahrzehnte schon viele Gebiete trockengelegt. Ein glänzendes Beispiel für die 
großen Erfolge dieser Entsumpfung bietet z. B. die Umgebung von Debreczen, die, vordem ein ausgedehntes Sumpfgebiet, heute weithin kultiviert ist. Nur die

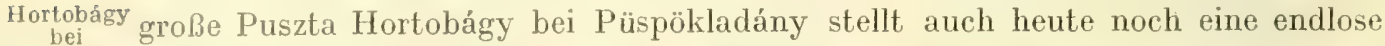
Deb eczen. trockene Salzsteppe dar, deren Hauptvegetation aus Leplurus pannonicus, Hordeum Gussoneanum, Camphorosma ovala, Lepidium crassifolium, L. perfolialum, Trifolium laevigatum, T. parviflorum, Slatice Gmelini, Plantago tenuiflora, P. Schwarzenbergiana und Malricaria Chamomilla besteht. Nur gegen den Hortobagyfluß zu sind Salzwiesen mit Beckmannia cruciformis, Alopecurus pralensis, Lythrum virgatum usw. anzutreffen. Die Hortobágy ist Eigentum der

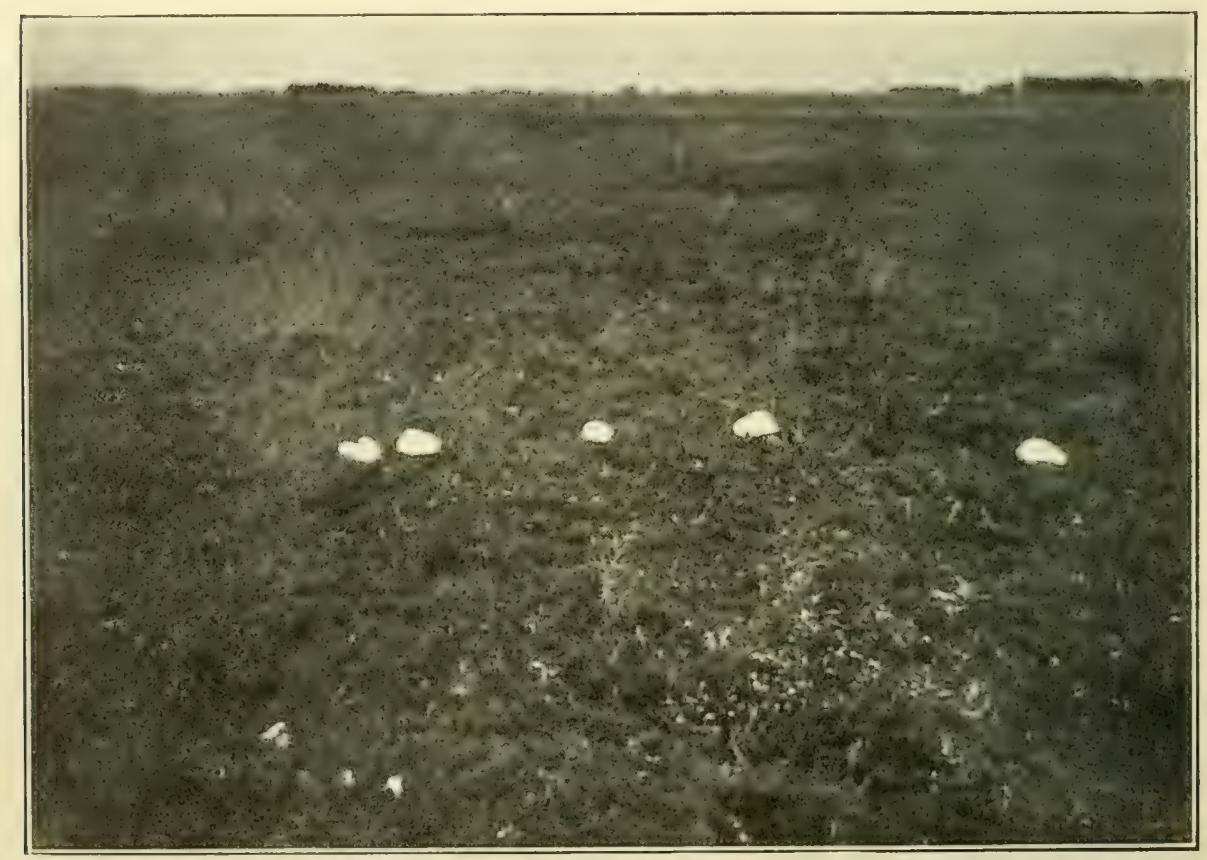

Abb. 307. Salzsteppe in der Puszta Hortobágy bei Debreczen.

lestuca pseudovina, Gypsophila muralis, Artemisia monogyna, in der Mitte Psalliota campestris.

(Nach einer Aufnahme yon Dr. H. Frh.v. Handel-Mazzetti, Wien.)

Stadt Debreczen und soll, wenigstens teilweise, in ihrer ursprünglichen Form als Puszta für ewige Zeiten erhalten bleiben, wenn auch Jahr für Jahı größere Strecken derselben dem Pfluge zum Opfer fallen.

Nördlich und östlich an die baumlose Hortobágy schließt sich in den KoniNyirség. Laten Szabolcs und Szathmár das große Waldgebiet Nyirség an. Die Birken $\left(\right.$, Nyir $\left.^{6}\right)$, die chemals diesem Gebiete den Namen gegeben haben, sind heute Preilich schon recht selten geworden, doch sind noch ausgedehnte schöne Eichenwilder vorhanden, aus Quercus Robur zusammengesetzt, in deren Gesellschaft Carpinus Belulus, Ulmus glabra, Populus alba, P. nigra, Acer campestre, A. lalaricum, Pirus Piraster, Sorbus lorminalis usw. auftreten, während Tilia cordala 
hier selten ist. Stellenweise kommen auch noch kleine Gruppen von Belula pendula und Populus lremula vor, auf stark durchnäBtem Boden auch Alnus glulinosa. Vilis 'silvestris ist allenthalben häufig, aus dem Niederwuchs dieser Wälder sind Pleridium aquilinum, Thalictrum aquilegifolium, Salvia glutinosa, Pulmonaria mollissima und das Lebermoos Madotheca plalyphylla bemerkenswert.

Neben Wäldern finden sich in diesem Gebiete auch heute noch ausgedehnte Sümpfe mit Zsombékmooren, weiten Schilfrohrbeständen usw. So liegt zwischen Theiß und Bodrog unweit von Sátoralya Ujhely der Hosszurétsumpf, in welchem Carex Buelii häufig auftritt und wo an schlammigen stellen an der Theiß Heleocharis acicularis und Abutilon Avicennae nicht selten sind; bei II un kács Munkács. liegt der Szernye-Sumpf, hauptsächlich von Phragmiles communis bewachsen, das hier von Typha angustifolia, T. latifolia, Alopecurus geniculalus, Glyceria aquatica, Heleocharis palustris und Sagillaria sagitlacfolia begleitet wird, während im Wasser selbst Salvinia natans und Hydrocharis Morsus ranae nicht selten sind und in Sumpfwäldern Urlica kioviensis und Cicuta virosa vorkommen. Auch im Ecseder Sumpf wurde letztere Art sowie Peucedanum paluslre beobachtet. Westlich vom Ecseder Sumpfe gegen Bátorliget zu findet man ebenfalls Zsombékmoore mit Carex lasiocarpa, Calamagrostis neglecla, Dryopleris Thelypteris, Potentilla palustris, Menyanthes trifoliala, Pedicularis paluslris u. a.; bei Nyirbátor selbst hingegen sind Sandsteppen mit Equiselum ramosissimum, Andropogon Gryllus, Bromus squarrosus, Rumex Acelosella, Silene conica, S. Otites, Onosma arenarium, Jasione monlana und Helichrysum arenarium entwickelt. Ein großes Sumpfgebiet endlich liegt zu beiden Seiten des Berettyo im nordwestlichen Teile des Biharer Komitates. Weite Strecken sind hier auch heute noch von Beständen von Phragmiles communis bedeckt, das von Glyceria aquatica, Schoenopleclus lacustris, Typha-Arten, Bulomus umbellalus, Sagillaria sagitlaefolia, Cicula virosa, Sium lalifolium, Lylhrum Salicaria usw. begleitet wird, während in den stehenden Gewässern eine reiche Flora aus Hydrocharis Morsus ranae, Stratiotes aloides, Polamogelon nalans, Naias minor, Ranunculus paucistamineus, Nuphar luteum, Castalia alba usw. gedeiht.

Diese Sümpfe setzen sich bis in den westlichen Teil des Békéser Komitates fort, wo sie allerdings durch die Entwässerungsarbeiten der letzten Jahrzehnte stark eingeschränkt wurden, wo aber zwei interessante Wasserfarne vorkicmmen, Salvia natans und die leider wahrscheinlich schon verschwundene Marsilia quadrifolia.

Bei Großwardein (Nagyvárad), das durch seine heißen Quellen, in denen Castalia Lolus vorkommt, bekannt ist, sind an der schnellen Körös schöne Auenwälder entwickelt, in denen u. a. Ranunculus Steveni wächst und die flußabwärts bis in die Gegend von Vesztö reichen, wo in diesen Wäldern Cenlaurea nigrescens, Epilobum Lamyi, bei Dobož Leucoium aestivum wachsen. Sandsteppen fehlen um Großwardein, hingegen sind hie und da kleine Salztriften mit Heleochloa explicata, Juncus Gerardi, Atriplex talarica, Ranunculus lateriflorus und Bupleurum tenuissimum anzutreffen; reicher ist die Sumpfflora der Um- 
gebung, die n. a. Carex nutans, C. Buekii, Leersia oryzoides, Slralioles aloides, Hydrocharis Morsus ranae, Naias minor, Rumex slenophyllus, Elatine lriandra, E. Hydropiper, Lindernia pyxidaria, Limosella aqualica, Hollonia palustris aufweist. Weiter westlich bei Kis-Ujszállás findet man wieder Sandsteppen mit Andropogon Ischaemum, Cynodon Dactylon, Koeleria gracilis, Bromus hordaceus, B. leclorum, Carex praecox, Euphorbia Gerardiana, Erysimum canescens, Melandryum viscosum, Alyssum alyssoides, A. desertorum, Medicago minima, Crepis

Szarvas. rhoeadifolia, Thymus Marschallianus usw. Auch um Szarvas und Orosháza sind solche Sandsteppen mit Aegilops cylindrica, Allium alropurpureum, Erysimum canescens, Linum austriacum, Anchusa ilalica, Ceratocephalus orlhoceras, Scorzonera laciniala entwickelt.

Die Umgebung von Békés-Gsaba war ehedem versumpft, ist aber durch Itiking

die Entwässerungsarbeiten der letzten Jahrzehnte trockengelegt und weithin mit Äckern bedeckt. Hingegen ist im Südwesten davon im Cs an ader Komitate auch heute noch ein ausgedehntes Sumpfgebiet vorhanden. Bei Földeák wachsen hier auf feuchten Wiesen Galega officinalis, Euphorbia lucida, Abutilon Avicennae, Teucrium Scordium, Lycopus exallalus und in stehenden Gewässern ist Salvinia nalans verbreitet; auch um Battonya sind ähnliche Sumpfwiesen anzutreffen.

Auch die Maros begleiten Wälder aus Quercus Robur und Q. Cerris, Ulmus glabra, U. laevis, mit Vilis silvestris, Viburnum Opulus, Cornus Mas, Corylus Arad. Avellana, Fesluca giganlea usw. bis über Arad. In den toten Armen der Maros ist das massenhafte Auftreten von Castalia alba und Trapa nalans bemerkenswert. Salzige Triften sind in der Umgebung von Arad bereits selten, finden sich aber doch noch z. B. im Gsalawalde. Selbst Sandsteppen mit Adropogon'Gryllus, A. Ischaemum, Kohlrauschia prolifera, Dianthus diutinus, Onobrychis arenaria sind in der gut kultivierten Umgebung der Stadt nur mehr in spärlichen Resten zu finden.

Temesvár. Auch die Umgebung von Temesvár ist heute in so ausgedehntem Maße von Kulturen bedeckt, daß nur hie und da an Feldrainen, auf Viehweiden usw. neben allgemein verbreiteten Ruderalpflanzen einzelne Reste der ursprünglichen Vegetation anzutreffen sind, wie Gypsophila muralis, Eryngium planum, Nepela pannonica, Xeranthemum cylindraceum, $X$. annuum, Verbascum austriacum, $V$. phoeniceum usw. und nur an den Ufern der Temes und an Gräben ist noch eine Sumpfflora mit Glyceria aquatica, Carex vulpina, Butomus umbelLatus, Lythrum virgalum, Leonurus Marrubiastrum, Inula salicina usw. erhalten. Artenreicher ist diese Sumpfflora bei Mihala, wo auch Marsilia quadrifolia, Naias minor und Rumex maritimus auftreten.

Im südlichen Teile des Temeser Komitates aber sind wieder weit ausgedehnte Flächen mit mächtigen Schichten Flugsandes bedeckt. Hier liegen Grebenac. die seit langem wegen ihrer reichen Flora bekannten Sandpuszten von Greben ac, Karlsdorf. Sus ara, Karlsdorf, Fontin a fetje und Dubovac. Stipa pennata, S. capillata, Andropogon Ischaemum, A. Gryllus, Fesluca vaginala, Agropyrum intermedium, Elymus arenarius sowie Bromus hordaceus, B. arvensis, B. squarrosus, B. tectorum 


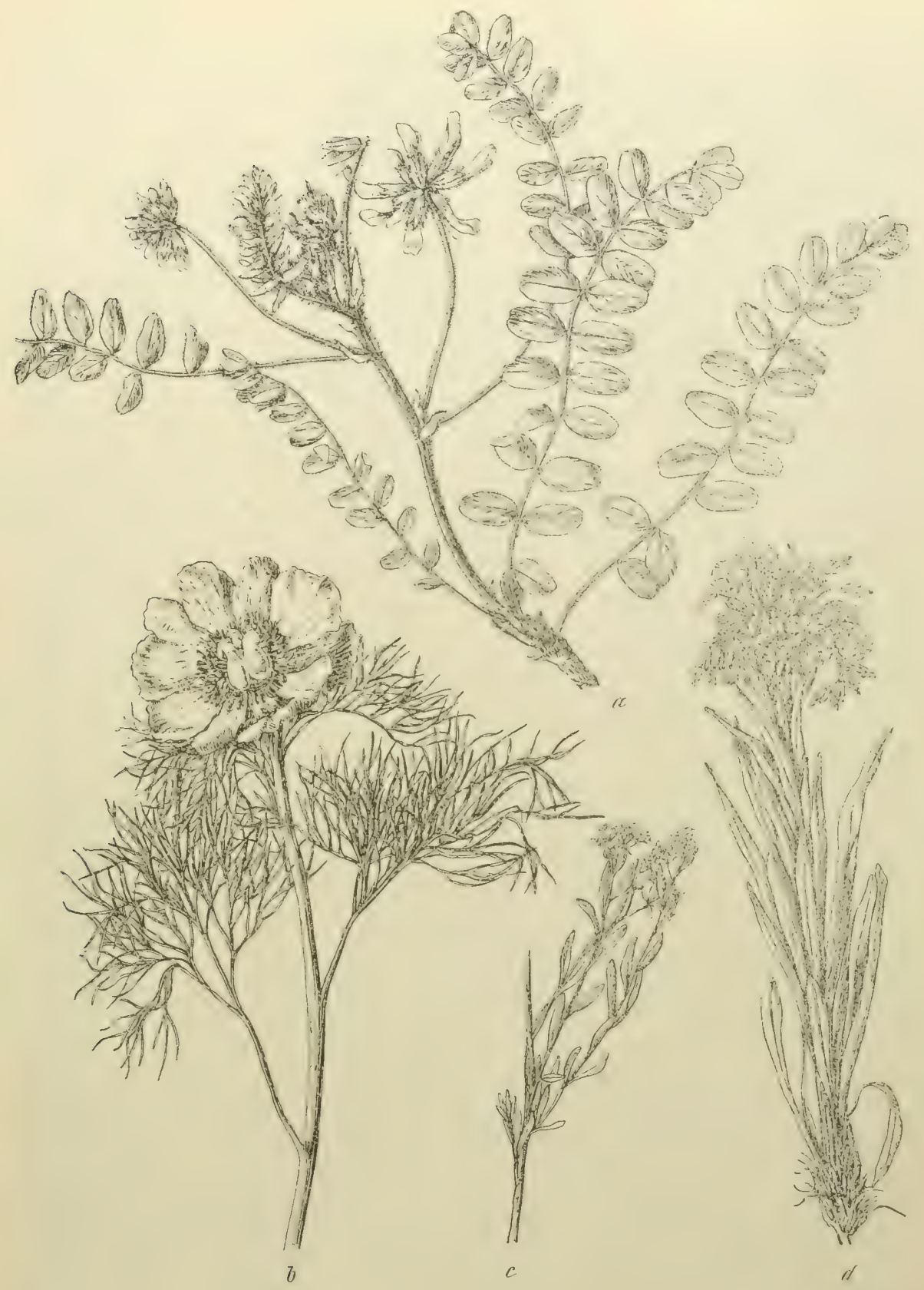

Abb. 308. Aus der Flora der Banater Sandsteppen.

$a$ Astragalus dasyanthus. $b$ Paeonia tenuifolia. $c$ Comandra elegans, $d$ Pindera umbellata.

sind hier die herrschenden Gräser; ferner sind verbreitet Colchicum arenarium, Gypsophila fasligiala, Crambe latarica, Erysimum canescens, Syrenia angustifolia, Alyssum arenarium, A. torluosum, Astragalus Onobrychis, Jurinea mollis, Trago- 


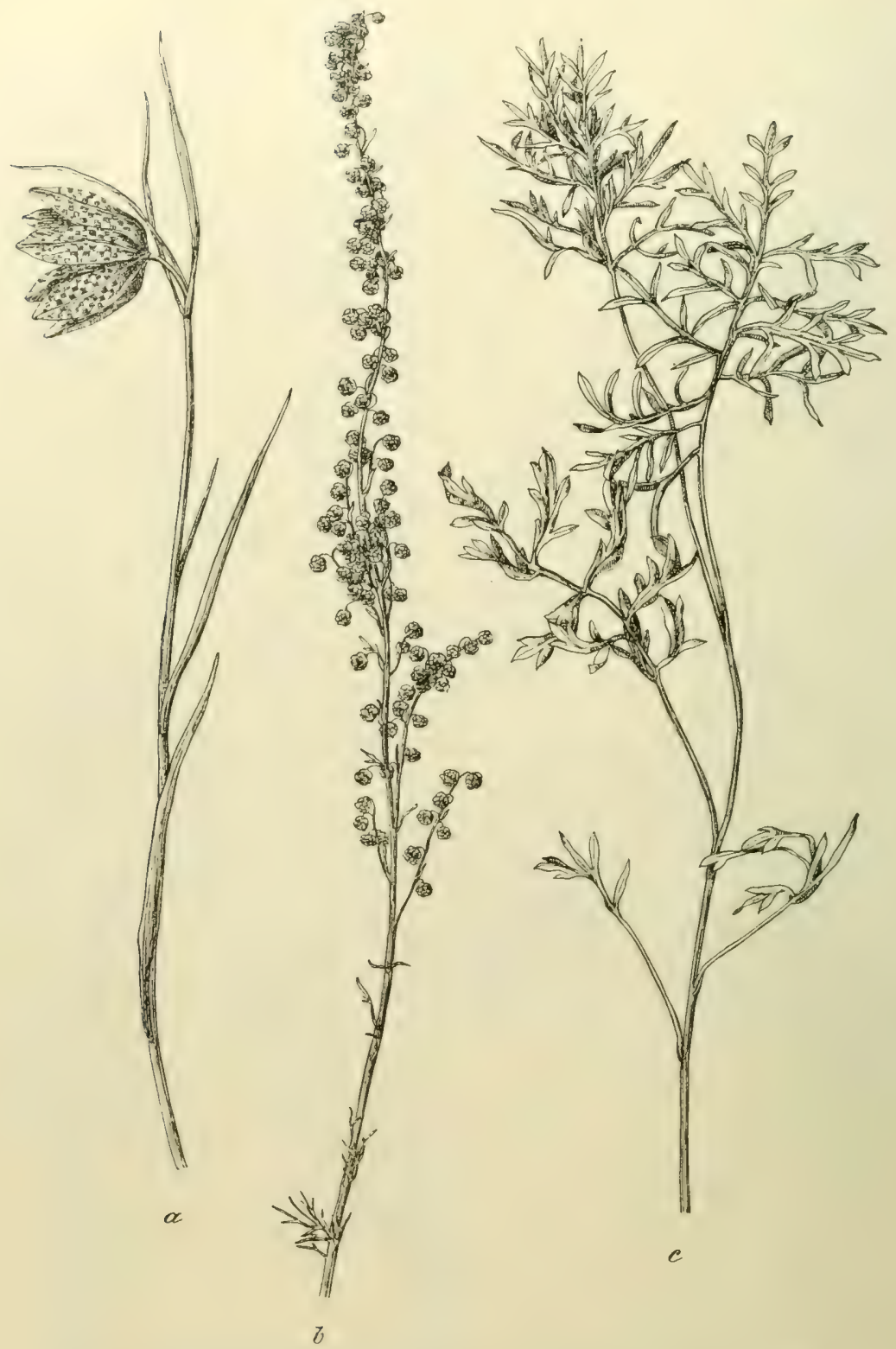

Abb. 309. Zwei bemerkenswerte Arten aus der Puszta Deliblat.

$a$ Fritillaria Degeniana. $b, c$ Artemisia latifolia.

pogon floccosus, Peucedanum arenarium u. a. verbreitete Arten der Sandsteppe, dazu gecellen sich aber mehrere Arten, die im übrigen Teile der Ungarischen Tirfebens fehlen und nur hier im südlichen Banate vorkommen, vor allem die hir. sicht seltene prächtige Paeonia lenuifolia, ferner Allium flavescens, Paeonia bannlica, Aslragalus dasyanthus, Anchusa ochroleuca, Rindera umbellala und Echinops banalicus sowie der eigenartige parasitische Strauch Comandra elegans. 


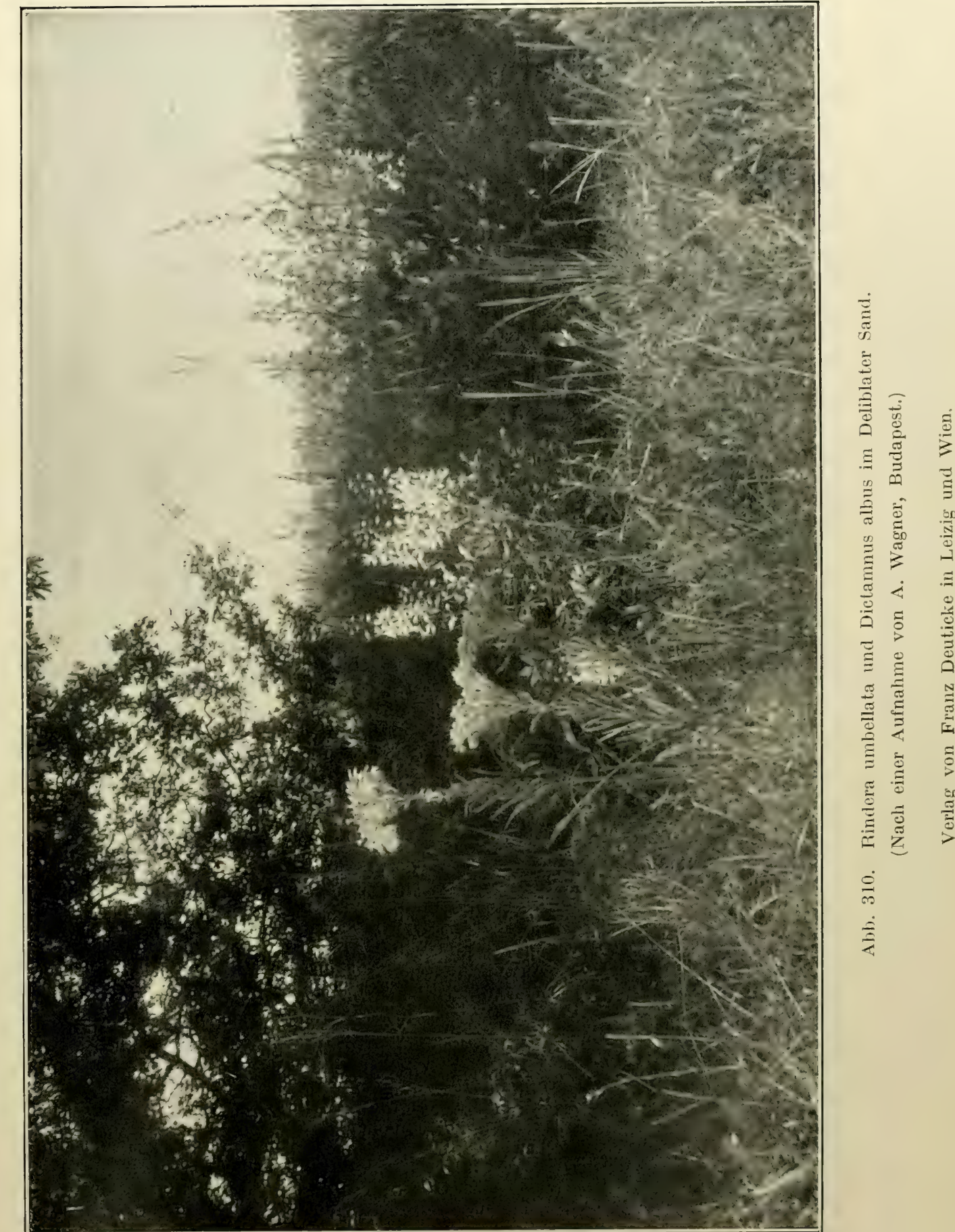



Auch Strauchwuchs findet sich hie und da, und zwar neben Juniperus communis auch Prunus nana und Cotinus Coggygria 'var. arenaria. Zur Bindung des Flugsandes werden Aufforstungsversuche mit Populus canadensis und Pinus nigra unternommen; in solchen Föhrenwäldern sind bei Grebenac u. a. Silaus virescens, Thalictrum aquilegifolium und T. galioides sowie Comandra elegans zu finden.

Im äußersten Süden des Banates, bei Deliblat, wo der Flugsand in tiefer Deliblat. Schichte den Boden bedeckt und typische Sandsteppen in der eben geschiderten

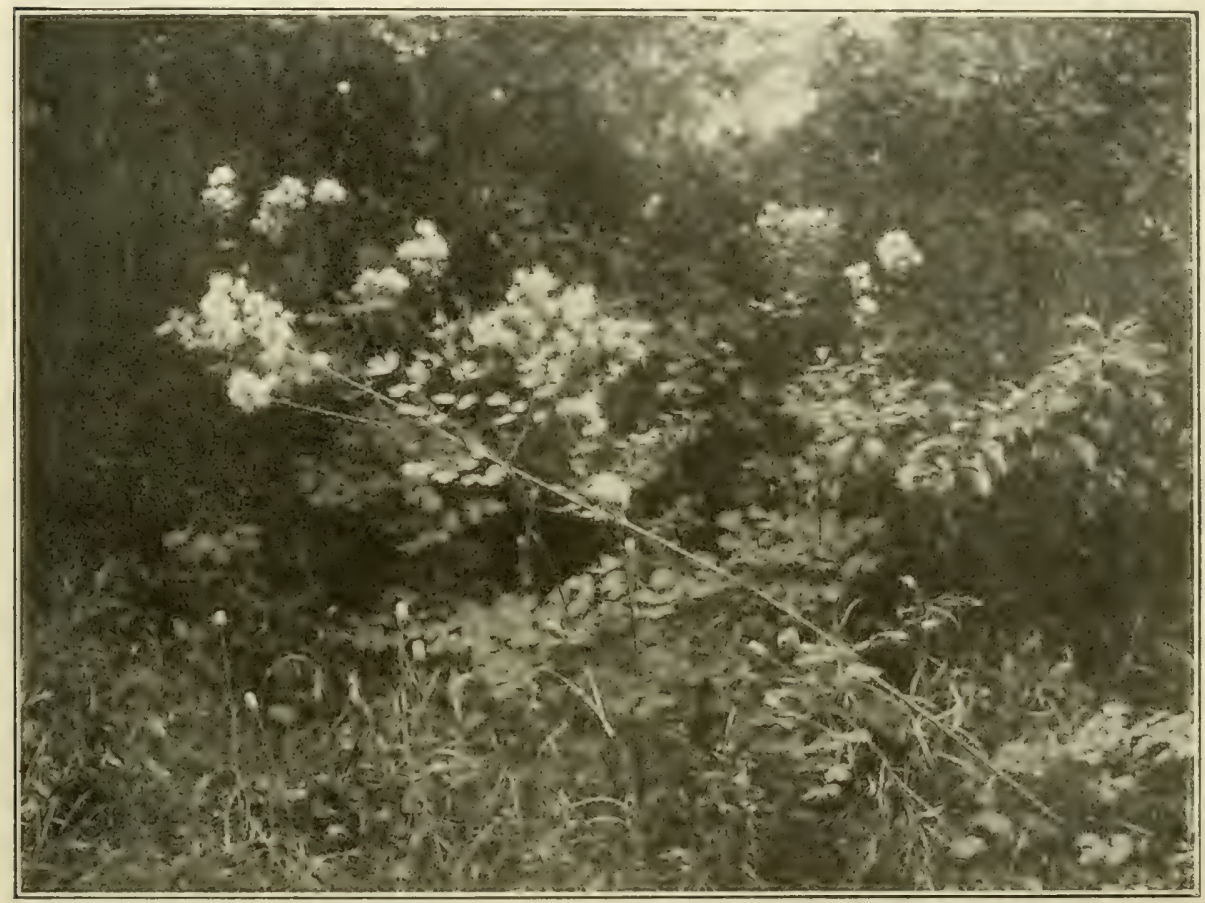

Abb. 311. Thalictrum aquilegifolium und Fritillaria Degeniana im Niederwuchs cines Eichengebüsches im Deliblater Sandgebiet.

(Nach einer Aufnahme von Dr. J.v. Bernátsky, Budapest.)

Zusammensetzung entwickelt sind, auf denen kürzlich die neue Frilillaria Degeniana und die asiatische Artemisia latifolia entdeckt wurden, beginnen wieder Eichenwälder ihre Herrschaft. Diese Wälder bestehen aus Quercus Robur und Tilia argenlea, denen sich Populus nigra und P. tremula beigesellen; das Unterholz derselben ist aus Evonymus vulgaris, Ligustrum vulgare, Rhamnus Frangula, Juniperus communis, Crataegus monogyna, Prunus Mahaleb, Cotinus Coggygria usw. zusammengesetzt; von Lianen sind Clematis Vitalba und Vitis silvestris häufig; im Niederwuchs ist das Vorkommen von Bolrychium Lunaria und Thalictrum aquilegifolium sowie das stellenweise massenhafte Auftreten von Pleridium aquilinum var. lanuginosum bemerkenswert; doch wurden auch ver- 


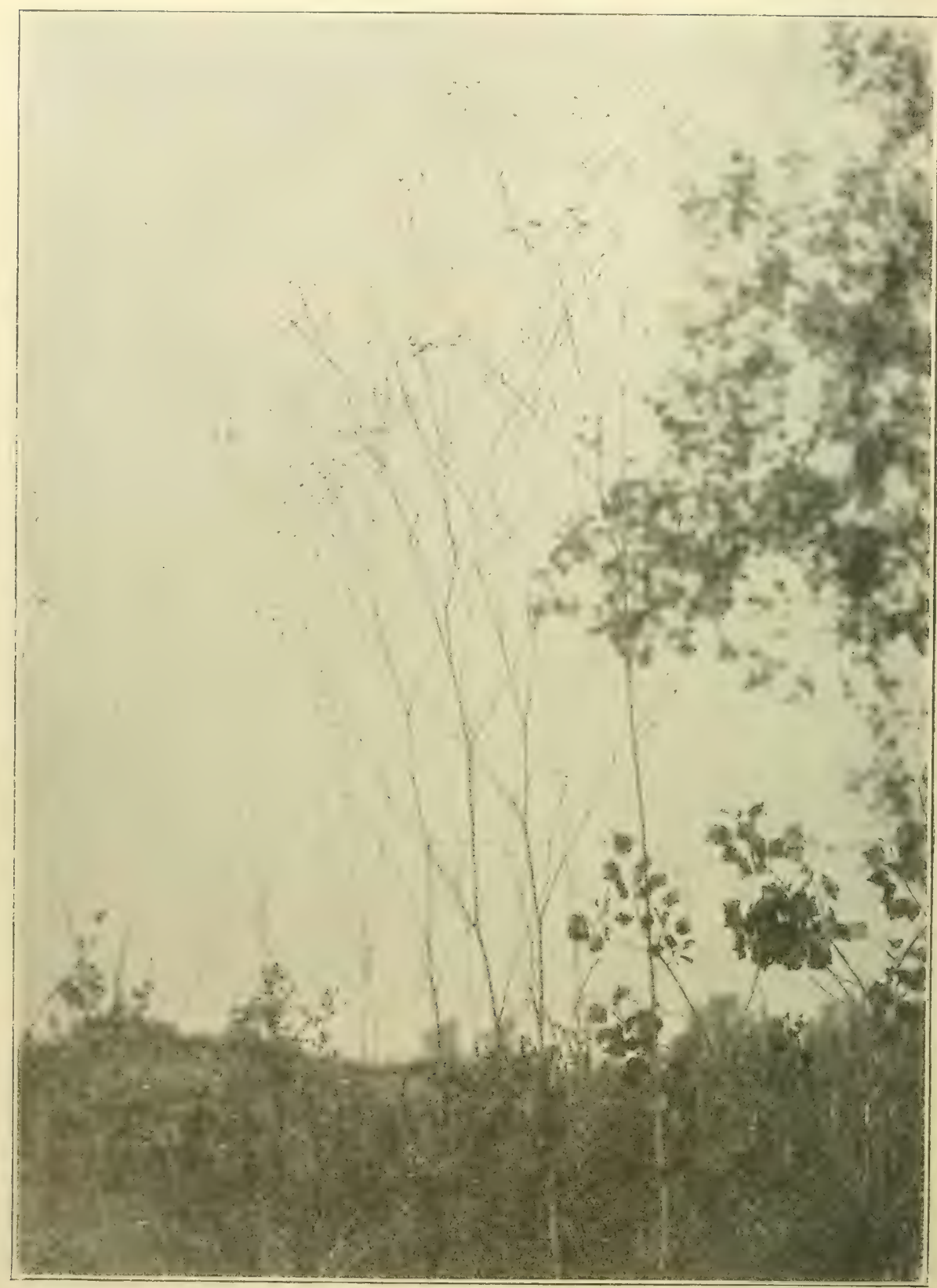

Abb. 312. Peucedanum arenarium im Deliblater Sandgebiet. Rechts Populus nigra. (Nach einer Aufnahme von Dr. J.v. Bernátsky, Budapest.)

schiedene andere Farne und selbst Celerach officinarum unter Buschwerk im Deliblater Sande beobachtet. Übrigens spricht manches dafür, daß diese Wälder früher ein größeres Areale eingenommen haben, aber durch den Flugsand und die menschliche Iultur immer mehr zurückgedrängt wurden. 


\section{Verzeichnis der benutzten Literatur.}

\section{a) Kleine ungarische Tiefebene.}

Ebenhöh F., Die plianerogamen Pflanzen von Koronczo und dessen Umgebung. Verh. d.

Ver. f. Natur- und Heilk. Preßburg, V [1860-1861], S. 40.)

Endlicher S., Flora Posoniensis. (Posonii, 1830.)

Hillebrand, Beitrag zur Flora von Ungarn. (Österr. bot. Wochenbl., VIII [1858], S. 297.)

Hitschmann H. H., Eine Exkursion um den Neusiedlersee. (Österr. bot. Wochenbl., VIII [1858], S. 221.)

Kornhuber A., Das Moor ,Schur" bei St. Georgen. (Verh. d. Ver. f. Natur- u. Heilk. Preßburg, III [1858], S. 29.)

- Botanischer Ausflug in die Sumpfniederung des ,Wasen" (magyarisch ,Hanság"') (Verh. d. zool.-bot. Ges. Wien, XXXV [1885], S. 619.)

Kerner A., Die Vegetationsverhältnisse des mittleren und östlichen Ungarns und angrenzenden Siebenbürgens. (Österr. bot. Zeitschr., XVII-XXIX [1867-1879].)

Iñap J. A., Beitrag zur Flora des Preßburger Comitates. (Österr. bot. Zeitschr., XIV [1864], S. 304.)

Neilreich A., Nachträge zur Flora von Wien. (Wien, 1851.)

- Flora von Niederösterreich. (Wien, 1859.)

- Aufzählung der in Ungarn und Slawonien bisher beobachteten Gefäßpflanzen. (Wien, 1866.) Niessl G. v., Ein Ausflug in die Gegend des Neusiedlersees. (Österr. bot. Wochenbl., VI, S. 377.)

Polgár S., Győrmegye növényföldrajza. (Geographia plantarum Comitatus Jaurinensis.) (Magy. bot. Lapok XI [1912] S. 308.)

Rechinger K., Botanische Beobachtungen im, Schur" bei St. Georgen. (Verh, d. Ver. 1. Natur- und Heilk, Preßburg [1901], S. 30.]

Resely M., Zur Flora der Insel Schütt in Ungarn. (Österr. bot. Zeitschr., XVII [1867], S 52.)

Sehiller S., Aus Ober-Ungarn. (Österr, bot. Zeitschr., XV [1875], S. 378.)

\section{b) Große ungarische Tiefebene.}

Bernátsky J., Von den Pflanzen der Nyirség. (Math. és term. Közlem., XIX [1901], S. 365.)

- Ceterach officinarum a Deliblati homokon. (Magy. botan. Lapok. I [1902], S. 357.)

- A Deliblati homok harasztjai és elöfordulásuk magyarázata. Die Farne des Deliblater Sandes und ihre pflanzengeographische Erklärung. (Annales Musei Hungarici, II [1904], S. 304.)

- Über die Baumvegetation des Ungarischen Tieflandes. (Festschrift zu Prof. Aschersons 70. Geburtstag [1904], S. 74.

- A Deliblati homok fás növényzete. Erdész.' Kisérletek [1910], XII., H. 3 und 4.)

- A magyar Alföld pusztái és erdei növényzetéről (Földr. Közl. XXXIX [1911], H. 6).

- A szikes talajok növényzete, különös tekintettel a befásitás kérdésére. (Erdész. IKisérletek [1913], XV, H. 3 und 4.)

Hayek, Die Pflanzendecke Österreich-Ungarns, I. 
Borbás V. V., Budapestnek és környékének növényzete. (Magyar orvosok és természet vizsg. 1879, etc. monografiából, 1879.)

— Béhésvármegye Flórája. (Értekez. a term. Köréb. XI. [1881].)

A magyar homokpuszták növényzete vonatkozással a homokliötésre. (Term. Közlem. [1884], S. 45.)

- Iráz puszta növényzete. (Magyar orvosok és termeszetv. munk. XX, Budapest.)

- Temesmegye vegetatiója. (Helyrajzi Emlékmü magy. orvos. és term. visgálók BaziásTemesvár, 1886.)

- Az alföldi zsombék. (Term. Közlem., XVII, S. 273.)

Chyzer K., Adatok északi Magyarország, különősen Zemplénmegye ès Bảrtfa város flórájához. (Magy. bot. Lapok, IV [1905], S. 304.)

Fanta A., Adatok Székesfehérvár növényzeti viszonyaihoz (Növ. Közlem., II [1903], S. 170.) Növ. Közl, 1902.

Fiek, Eine botanische Fahrt im Banat. (Allg. bot. Zeitschr., I [1895], S. 64.)

Fodor F., Adatok Szatmár-vármegye flórájához. (Egyet. termész. Szövetség 1908/09 évköny. Budapest, 1909.)

Hayek A. v., Uber die Vegetationsverhältnisse der ungarischen Tiefebene. (Verh. d, zool.bot. Ges. Wien, LVI [1906], S. 364.)

Hollós L., ,Keeskemét multja és jelene ${ }^{66}$. (Keeskemét, 1896.)

- Homokpusztáink jellemzö gombáiról. (Növényt. Közlem. II [1903], S. 107.)

- Adatok Kecskemét vidékének flórájához. (Magy. bot. Lapok, VIII [1909], S. 215.)

Janka V. v., Neue Standorte ungarischer Pflanzen. (Österr. bot. Zeitschr., XVI [1S66], S. 168 , XVII [1867], S. 64.)

Kanitz A., Sertum florae territorii Nagy-Körösensis. (Verh. d.k.k. zool.-bot. Ges. Wien, XII [1862], S. 201.)

- Reliquiae Kitaibelianae. (Verh. d. zool. bot. Ges. Wien, XII [1862], Abh. S. 589, XIII [1863] Abh. S. 57, 505.)

Kerner A., Uber die Zsombékmoore Ungarns. (Verh, d. zool.-bot. Ver. Wien, VIII [1858], S. 325.)

- Das Pflanzenleben der Donauländer. (Innsbruck, 1863.)

- Die Vegetationsverhältnisse des mittleren und östlichen Ungarns und angrenzenden Siebenbürgens, (Österr. bot. Zeitschr, XXVII-XXIX [1876-1879]).

- Die Flora der ungarischen Sandheiden. Eine pflanzengeographische Skizze. (Flora 1857.)

- Die Aufforstung des Flugsandes im Ungarischen Tieflande. (Österr. Monatsschr. f. Forstwesen 1865.)

Margittai A., Adatok Beregvảrmegye flórájához. (Magy. bot. Lapok, X [1911], S. 388.)

Mayr G., Ausflug nach szegedin im Herbst des Jahres 1855. (Verh. d. zool.-bot. Ver. Wien, VI [1856], S. 275.)

Menyhárt L., Kalocsa vidékének növénytenyészete. (Budapest, 1871.)

Neilreich A., Aufzählung der in Ungarn und Slawonien bisher beobachteten Gefäßpflanzen. (Wien, 1866.)

P a nčić H., Zur Flora des Banates. (Österr. bot. Zeitschr., XVIII [1878], S. 78.)

Prodan G., Alyssum linifolium Steph. Magyarországon és néhány adat Bácska flórájához. (Magy. bot, Lapok, X [1911], S. 325.)

- A Bácskai homokos és löszterületek egynéhány növénye. Über einige Pflanzen des Sandund Lößgebietes des Bács-Bodroger Komitates. (Magy. bot. Lapok, X [1911], S. 382.)

- Nehány adat Bácska flórájához. (Magy. bot. Lapok, IX [1910], S. 375.)

- A Ranunculus ophioglossifolius Magyarországon. (Magyar bot. Lapok, XI [1910], S. 60.

- Bick-Bodrog vármegye sziki nüvényej. - Die Halophytenflora des Iiomitates Bács-Bodrog. (Magyar bot. Lapok, XIII [1914], S. 96).

Rapaics R. V., Adatok Szolnok és vidéke florájához. (Magyar bot. Lapok, V [1906], S. 222.) Rochel, Botanische Reise in das Banat. (Pesth, 1838.)

Simkovics L., Arad város és megyéje flórajának főbb vonásai. (Term. füzetek, IX, 1, 1885.) 
Simkovies L., (Simonkai), Nagyvárad és vidékének növenyvilảga. (Nagyvảrad természetr. 1890.)

- Arad vármegye és Arad városa növényvilága. (Arad vármegye Arad, szab. kir. város monogr. Arad. 1893.)

Thaisz L., Floristikai adatok Csanád vármegyéből. (Növény. közlem. I [1902], S. 61.)

- Adatok Csongrád vármegye növényzétenek ismeretéhez. (Növen. közlem. II [1903], S. 89.)

- Adatok Bereg vármegye florájához. (Magyar bot. Lapok, X [1911], S. 38.

Tormay B., Landwirtschaft und Viehzucht. (Die österr.-ungar. Monarchie in Wort u. Bild. Ungarn, Bd. I [1888], S. 413.)

Tuzson J., A Magyar Alföld növényformációi. (Bot. Közlem. XIII [1914], S. 51.)

Wagner J., Az Artemisia latifolia Led. Délmagyarországon. Artemisia latifolia Led. in Südungarn, (Magyar bot. Lapok, X [1911], S. 2.)

Wierzbicki P., Reisebericht. (Flora, XVIII. [1846], S. 363.)

- Bericht über botanische Exkursionen im Banat. (Flora, XXV. [1842], S. 257.)

Woenig F., Die Pusztenflora der Großen ungarischen Tiefebene. (Leipzig, 1899.) 


\section{Sachregister.}

A.

Ackerbau in Ungarn 501.

Ackerunkräuter in Galizien 292.

- im herzynischen Bergland 103.

- in den Karpathen 374.

— in Mähren 161.

- in den Sudeten 119.

- im Ungarischen Tiefland 505.

- in Zentralböhmen 142.

Adventivflora 68.

- in Galizien 292.

- im herzynischen Bergland 103.

- in den Karpathen 373.

- in Mähren 161.

- in den Sudeten 119.

- im Ungarischen Tiefland 505.

- in Zentralböhmen 142.

Akazienwälder im Ungarischen Tiefland 487.

Alaun im Ungarischen Tiefland 478.

Algen auf Felsen 65.

Alpenrosenbestände in den Ostkarpathen 366.

Alpenwiesen der Ostkarpathen 367.

- hochhalmige, der Westkarpathen 344.

Alpine Felsenflora der Sudeten 117.

_ _ der Westkarpathen 347.

- - der Ostkarpathen 370.

Aluminium 17.

Änderungen des Klimas 39 .

Anthokyan 6.

Anthropochoren 68.

Apophyten 68 .

- in den Sudeten 120.

Aquilonare Relikte 41.

Assimilieren der Pflanze 7, 17.

Auenwälder im herzynischen Bergland 91.

- in Mähren 146.

- in den Sudeten 107.

- in den Ostkarpathen 351.
Auenwälder in Westgalizien 272.

- in den Ostkarpathen 351.

- im Ungarischen Tiefland 487.

- in Zentralböhmen 124.

B.

Barchan 478

Bartgrasflur in Zentralböhmen 133.

Basaltfelsen 22.

Bauden 119.

Baumgrenze im Gebirge 28.

Baumlosigkeit des Ungarischen Tieflandes 479.

Baumwuchs, Grenze desselben 25.

Befruchtung durch Tiere 23.

Beifußtrift in Mähren 156.

Benthos 60.

Bergmischwald, herzynischer 91.

Bergtrift, dazische 353.

- pannonische 331 .

Bergwiesen in Mähren 153.

- in den Sudeten 111.

-- in den Ostkarpathen 354.

- in den Westkarpathen 333.

- in Zentralböhmen 131.

Berg- und Voralpenwiesen im herzynischen Bergland 98.

Besamungsschläge 47 .

Binsenbestände 497.

Birkenbestände im herzynischen Bergland 90.

- in den Ostkarpathen 350.

- in Mähren 144.

- in Westgalizien 272.

- in den Westkarpathen 329.

- in Zentralböhmen 350.

Bittersalz im Ungarischen Tiefland 478.

Blattmosaik 9.

Blattstellung im Licht 9.

Bodenwärme 22. 
Bodenwärme im Hochgebirge 35.

Borstengrasmatte im herzynischen Bergland 100.

- in den Ostkarpathen 368.

- in den Sudeten 114.

Brennhaare 23.

Buchenhochwald der Ostkarpathen 356.

- der Westkarpathen 335.

Buchenwald in der Hügelregion der Westkarpathen 329.

- in der Hügelregion der Ostkarpathen 350.

- in Mähren 144.

- in Zentralböhmen 122.

herzynischer 91 .

- podolischer 282.

- sudetischer 105.

Bulten 59.

Burstwiese in Zentralböhmen 131.

Buschgehölze, sommergrüne, in Mähren 148.

- - in Zentralböhmen 126.

Buschwald, subalpiner, in den Ostkarpathen 361.

- - in den Westkarpathen 357.

\section{C.}

Chasmophyten 66 .

Chemische Zusammensetzung des Bodens 17. Chlornatrium im Ungarischen Tiefland 478.

\section{D.}

Donauauen in Niederösterreich 147.

- in Ungarn 487, $506 \mathrm{f}, 511 \mathrm{ff}$.

Dornen 15, 23.

Dreifelderwirtschaft in den Karpathen 372.

- im Ungarischen Tiefland 502.

Düngung 20,52 .

\section{E.}

Edaphische Faktoren 20.

Egartenwirtschaft in den Karpathen 372.

Eichenmischwald der Westkarpathen 328.

Eichenniederwald in Zentralböhmen 124.

Eichenwald in den Ostkarpathen 349.

- im Ungarischen Tiefland 485.

- dazischer 349.

- ostböhmischer 104.

- podolischer 280.

- süddeutscher 104.

Einjährige Gewächse 30 .

Eisen 17.

Eiszeit 40.
Ephemerophylen 69.

Epiphyten 43.

Erfrieren der Pflanzen 5.

Ergasiophyten 69.

Erlenbrüche in Zentralböhmen 126.

\section{F.}

Falzblätter 32,482 .

Fazies 44.

Federgrassteppe im herzynischen Bergland 100.

- in Zentralböhmen 135.

- im Ungarischen Tiefland 489.

Felsenflora 65.

Felsenflora, alpine, im herzynischen Bergland 101 .

- - in den Ostkarpathen 370.

- - in den Sudeten 117.

- - in den Westliarpatien 347.

- im herzynischen Bergland 101.

- in der Hügelregion der Ostkarpathen 353.

- in der Hügelregion der Westkarpathen 332.

- in Mähren 157.

- podolische 284 .

- subalpine, der Westkarpathen 342.

- - der Ostkarpathen 364.

- in Zentralbōhmen 136.

Felsschutt 60 .

Felsschuttflora der Westkarpathen 346.

- der Ostkarpathen 371.

Felsschuttfluren 60 .

Fettpflanzen 15.

Fettwiesen 15.

Fichtenwald in Mähren 144.

- in der Hügelregion der Westkarpathen 330.

- subalpine, der Westliarpathen 336.

- in Zentralböhmen 120.

- dazischer 358.

- herzynischer 91.

- sudetischer 105.

Filzige Behaarung im Hochgebirge 38.

Fingergrasfluren in Mähren 151.

Flachmoor 54 .

Flugsand in Galizien 269, $294 \mathrm{ff}$.

- im Ungarischen Tiefland 478.

Flugsandbindung im Ungarischen Tiefland 504.

Föhrenwälder im herzynischen Bergland 94.

- in Mähren 144.

- in den Ostkarpathen 351.

- in Westgalizien 270.

- in den Westkarpathen 330.

- in Zentralböhmen 120.

Formation 44. 
Forstbetriel) $47,48$.

Forste 47.

Forstwirtschaft in Galizien 291.

- im herzynischen Bergland 103.

- in Mähren 161.

- in den Sudeten 119.

- im Ungarischen Tiefland 504.

- in Zentralböhmen 142.

Futterpflanzenbau in Zentralböhmen 141.

\section{G.}

Galeriewälder 27.

Galmei 24.

Gemüsebau in Galizien 291.

- im herzynischen Bergland 102.

- in den Karpathen 373.

- in Mähren 160.

- in den Sudeten 119.

- im Ungarischen Tiefland 503.

- in Zentralböhmen 141.

Gerölle 66.

Geschiebe 66.

Geschlossene Formationen 45.

Gesteinfluren in den Sudeten 117.

- in den Westkarpathen 348.

- in den Ostkarpathen 371.

Getreidebau in Galizien 290.

- im herzynischen Bergland 102.

- in den Karpathen 372.

- in Mähren 160.

- in den Sudeten 119.

- im Ungarischen Tiefland 503.

- in Zentralböhmen 141.

Glazialrelikte 41 .

Goldbartflur im Ungarischen Tiefland 492.

Grasfluren 49.

Grasflurklima 34,

Grassteppe, siebenbürgische 356 .

Grünerlengebüsche der Ostkarpathen 365.

\section{H.}

Hainbuchenwald in Ostgalizien 282.

Haine in Zentralböhmen 126.

Halbschmarotzer 42.

Halophyten 20 .

- in Galizien 298.

- in Mähren 148.

- in Siebenbürgen 354, 355.

- im Ungarischen Tiefland 484.

- fakultative 20 .

- obligate 20.

IIanfbau im Ungarischen Tiefland 504.
Häufige Arten 45.

Heide 52.

- im herzynischen Bergland 97.

- in Mähren 150.

- in Westgalizien 276.

- in Zentralböhmen 129.

Heidepflanzen 53.

Heidetümpel 59.

Heliotropismus 7.

Herzynischer Bergmischwald 91.

Herzynischer Fichtenwald 91.

Hochgebirge, klimatische Verhältnisse 25.

Hochgebirgsklima 34.

Hochmoor 56.

Hochmoore im herzynischen Bergland 97.

- in den Sudeten 114.

- in den Ostkarpathen 363.

- in den Westkarpathen 340.

- in Zentralböhmen 130.

- in Westgalizien 273.

Hochstand der Wiesen 50.

Hochstaudenfluren, subalpine, der Sudeten 116.

- - der Ostkarpathen 363.

- - der Westkarpathen 341.

Holzschläge 48.

Holzschlagflora der Karpathen 342.

Hopfenbau in Galizien 291.

- in Zentralbölımen 142.

Humus 22.

Humussäuren 11, 22.

Hydrochariten 60, 61 .

Hygrophile Holzgewächse 16.

Hygrophyten 15.

\section{I.}

Interzellularräume 12.

Kahlschlag 47.

K.

Kalium 17.

Kalkfeindliche Pflanzen der Karpathen 327.

Kalkpflanzen der Karpathen 327.

Kalkstete Pflanzen 17.

Kälteschutz 29.

Kältetod der Pflanzen 6.

Kalte Zone 24.

Kalttemperierte Zone 24 .

Kalzium 17.

Kieselerde 17.

Kieselholde Pflanzen 17.

Kletterpflanzen 43.

Klettrrüchte 23. 
Klima, Änderung desselben 39.

- von Galizien 267.

- der Karpathen $319 \mathrm{ff}$.

- der Sudetenländer 81.

- des Ungarischen Tieflandes $479 \mathrm{ff}$.

Knäueltrift im herzynischen Bergland 98.

- in Zentralböhmen 129.

Kinollengewächse 16 .

Kinospen 16.

Kochsalz 20.

- im Ungarischen Tiefland 478, 513.

Kohlensäure 17.

Kohlensaures Natron 20.

- - im Ungarischen Tiefland 478, 513.

Iiolke 59.

Krummholzbestände in den Sudeten 107.

- in den Ostkarpathen 364.

- in den Westkarpathen 344.

Krummsegge, Formation der, in den Ostkarpathen 368 .

Krüppelfichten in den Sudeten 108.

Kulturgewächse in Galizien 29.

- im herzynischen Bergland 102.

- in den Karpathen 372.

- in Mähren 160.

- in den Sudeten 108.

- in Zentralböhmen 141.

Íutikula 15.

\section{L.}

Lëgerflora in den IVestkarpathen 344.

Laubmischwälder in Galizien 269.

- in Mähren 143.

Laubwälder im herzynischen Bergland 89.

Leguminosen 20 .

Lentizellen 16.

Licht 5.

Lichtgenu 39.

Lichtmangel 9.

Limnäen 63, 64.

Lithophyten 65.

Lohe 173.

Luft 16.

- bewegte 17.

Luftiruck 16.

\section{II.}

Mächtigkeit des Bodens 22 .

Magere Böden 20 .

Magerwiesen 52.

Magnesium 17.

Mahd 50.

Mediterranes Kilima 29.
Meeresstrand 20

Melonenkultur 503.

Mesophil 16.

Mineralquellen 20 .

Mitteleuropäisches Klima 29

Iloore 54.

- in den Sudeten 114.

Moorheide 60 .

- in Westgalizien 275.

- in Zentralböhmen 129.

Moorwälder im herzynischen Bergland 95.

- in Westgalizien 272.

- in Zentralböhmen 130.

Morïnen 67.

Iycorhiza 42.

\section{N.}

Nackter Teichboden, Formation des 139.

Nadelwälder, gemischte, in den Sudeten 104.

Natürliche Wiesen 49.

Nekton 60.

Neophyten 68.

Nereïden 63.

Niedere Temperaturen 11.

Niederschläge 26.

Niederschlagsverhältnisse in den böhmischen Randgebirgen 84.

- im Donautal bei Krems 89.

- in Galizien 268.

- in den Karpathen 319.

- in Mähren 88.

- im Ungarischen Tiefland 479.

- in Zentralböhmen 87.

Niederwuchs 46 .

Nomenklatur der Formationen $\mathbf{4 5 .}$

Nutzpflanzen, 'diverse, im herzynischen Bergland 102 .

- - in den Karpathen 373.

- - im Ungarischen Tiefland 503.

- - in Zentralböhmen 142.

0.

Oberholz 46.

Obstbau in Galizien 291.

- im herzynischen Bergland 102.

- in den Karpathen 373.

- in Mähren 160.

- in den Sudeten 119.

- im Ungarischen Tiefland 503.

- in Zentralböhmen 141.

Offene Formationen 45.

Ononis spinosa, Formation der, in Zentralböhmen 138. 
Orchideenwiese, zentralböhmische 133.

Organische Nährstoffe 17.

Ostkarpathenflora 323.

Ortstein 52.

\section{P.}

Pappelwälder im Ungarischen Tiefland 486.

Parasiten 41 .

Perückenstrauchiformation 352.

Pflanzenformation $43,44$.

Pflanzengenossenschaften 41 .

Phosphorsäure 17.

Phyllokladien 15.

Plankton 60,62 .

Plänterbetrieb 47.

Polsterpflanzen 36 .

Polsterseggenformation der Westkarpathen 344.

Pußta 500.

Pußtaweide in den Westkarpathen 333.

\section{Q.}

Quellfluren in den Sudeten 116.

- alpine, in den Westkarpathen 343.

- - in den Ostkarpathen 369.

\section{R.}

Randgebirge, böhmische 83.

Rauhreif im böhmischen Randgebirge 85 .

Relikte 41.

Röhricht in Zentralböhmen 138.

- im Ungarischen Tiefland 496.

Rosettenstauden 38.

Ruderalflora in Galizien 292.

- im herzynischen Bergland 103.

- in den Karpathen 373.

- in Mähren 161.

- in den Sudeten 119.

- im Ungarischen Tiefland 505.

Rutensträucher 12.

\section{S.}

Saisondimorphismus 51 .

Saisondiphylismus 51 .

Salpeter 478.

Salpetersaures Natron 20.

Salzboden in Mähren 157.

- im Ungarischen Tiefland 494.

Salze, gelöste, Wirkung 11 .

- lösliche, im Boden 20.

Salzmelden, Formation der 494.

SaIzpllanzen 20.
Salzpflanzen in Böhmen $192 \mathrm{ff}$.

- in Siebenbürgen 354.

- im Ungarischen Tiefland 494.

Salzsteppe im Ungarischen Tiefland 494.

Salzsümpfe in Mähren 152.

- im Ungarischen Tiefland 496.

Salzwiesen in Mähren 157.

- im Ungarischen Tiefland 494.

Salztrift in Mähren 159.

Samen, Verbreitung 23.

Sandboden 22.

- im Ungarischen Tiefland 487.

Sandfluren in Zentralböhmen 128.

Sandgrasfluren im herzynischen Bergland 93.

- in Mähren 151.

- in Westgalizien 276.

Sandheide in Zentralböhmen 129.

Sandsteppe in Mähren 153.

- im Ungarischen Tiefland 488.

Sandwein 502.

Saprophyten 42.

Sauere Böden 22.

Schachtelhalmbestände im Ungarischen Tiefland 497

Schilfrohr, Verwendung in Ungarn 496.

Schlesische Weide, Formation der, in den Sudeten 169.

Schließzellen 10.

Schlingplanzen 43 .

Schmarotzerpflanzen 41 .

Schneedecke 25.

Schneetälchenflora der Ostkarpathen 370.

- der Westkarpathen 346.

Schotter 22.

Schuttdecker 67.

Schuttstauer 67.

Schuttstrecker 67.

Schuttüberkriecher 67.

Schuttwanderer 67.

Schutzeinrichtungen gegen Kälte 6.

- gegen Trockenheit $11 \mathrm{ff}$.

Schwefelsäure 17

Schwefelsaures Natron 20.

- - im Ungarischen Tiefland 478.

Sclıwimmblätter 63 .

Schwingelsteppe in Zentralböhmen 134.

Serpentin 20 .

- in Nordmähren 226.

Silbergrasflur in Mähren 151.

Silizium 17.

Sociales (species) 45.

Soda im Ungarischen Tiefland 478 .

S:lilariae (species) 45. 
Spaliersträucher 34, 36 .

Spaltöffnungen 10 .

Sparsae (species) 45.

Spätfröste 6 .

Spiraea salicifolia, Formation, in Zentralböhmen 107.

Subalpine Hochstaudenfluren in den Ostkarpathen 363.

- - in den Sudeten 116.

- - in den Westkarpathen 341.

Sudetenhierazien 113

Sudetischer Buchenwald 105.

- Fichtenwald 105

Sukkulenten 15.

Sumpfflora in Mähren 159.

- in Ostgalizien 289.

- in Westgalizen 279.

- im Ungarischen Tiefland 496.

Sumpfwiesen im herzynischen Bergland 100.

- in Mähren 152.

- in Ostgalizien 289.

- in Westgalizien 279.

- im Ungarischen Tiefland 498.

Süßholzbestände in Ungarn 498.

Stärke, Umwandlung in Zucker 7.

Steppe in Ungarn 482.

- podolische 284.

Steppengebiet in Ostgalizien 303.

- in Ungarn 479, 510.

Șteppengräser des Ungarischen Tieflandes 482.

Steppenhafer, Formation des, in Mähren 154.

Steppenklima 33.

- in Galizien 269, 303.

- in Ungarn 482

Steppenpflanzen in Ungarn 482.

Steppenwiesen in Mähren 153.

Stickstoffreiche Nährstoffe 20.

Strahlenginstergebüsch in den Ostkarpathen 361.

Strauchformationen 46 .

Strauchgürtel der Hochgebirge 35.

Strohtunica $32,482$.

\section{T.}

Tabakbau in Galizien 291.

- in Ungarn 504.

Tag und Nacht, Wechsel von 10 .

Talwiesen im herzynischen Bergland 98.

- in Mähren 152.

- in den Ostkarpathen 356.

- in Ostgalizien 289.

- in den Sudeten 111.
Talwiesen im Ungarischen Tiefland 480.

- in den Westkarpathen 334.

- in Westgalizien 278.

- in Zentralböhmen 131.

Tanyas 501 .

Teichböden, Flora, der nackten 129.

Temperaturabnahme nach oben in den Böhmischen Randgebirgen 86.

- nach oben in den Karpathen $319 \mathrm{f}$.

Temperaturgrenzen 5, 6 .

Temperaturverhältnisse in den Böhmischen Randgebirgen 83.

- in Galizien 268.

- in den Karpathen 319.

- in Mähren 88.

- im Ungarischen Tiefland 481.

- in Zentralböhmen 87.

Teppichsträucher 36 .

Tiefstand der Wiesen 50 .

Tiere, Einwirkung auf die Vegetation 23.

Tierfraß 23.

Tonangebende Arten 45.

Tonerde 17.

Torfmoose 56.

Transpiration 10 .

- kutikuläre 10 .

- stomatäre 10.

Transpirationsschutz 12.

- im Hochgebirge 35.

Transpirieren 10.

Trespensteppe im Ungarischen Tiefland 488.

Triftformation, pannonische, in Mähren 154.

- - in den Karpathen 331.

- podolische 286.

- in Zentralböhmen 135.

Trockenheit des Standortes 10.

Tropische Zone 24.

Tropophil 16.

Tunica 482.

Uferflora 60.

U.

Uferformationen in Mähren 159.

- in den Ostkarpathen 356.

- in den Westkarpathen 334.

Ufergebüsche in Mähren 148.

- in den Ostkarpathen 351.

- in Ostgalizien 284.

- in den Westkarpathen 331.

- in Zentralböhmen 127.

- subalpine, in den Ostkarpathen 361.

- - in den Westkarpathen 338.

Umbelliferentrift in Mähren 155. 
Umtriebszeiten 47.

Unterholz 46.

Urwald auf dem Kubany 177.

\section{V.}

Vegelationsruhe 25 .

Vereinzelte Arten 45.

Verlandung stehender Gewässer 63, 65.

Vertrocknen der Pflanzen 10.

Viehzucht in den Sudeten 119.

- im Ungarischen Tiefland 500.

Viviparie 7.

Voralpenwiesen im herzynischen Bergland 99.

- in den Ostliarpathen 361.

- in den Sudeten 112.

- in den Westkarpathen 338.

- gedüngte, in den Sudeten 114.

Vorsteppe, podolische 288.

\section{IV.}

Wacholdergebüsche in den Ostkarpathen 352.

- in den Westkarpathen 331.

- im Ungarischen Tiefland 488.

Vachstum der Pflanzen 6.

Wachstumshemmende Wirkung des Lichtes 7. Wälder 46.

Waldgrenze im Hochgebirge 35.

- im Böhmerwald 174.

- in den Karpathen 321.

- in den Sudeten 106.

Wärme 46.

Wärmekapazität des Bodens 22.

Wärmezonen 24.

Warmtemperierte Zone 24.

Wasser 10.

Wasseraufnahme durch oberirdische Organe 11. Wasserdurchlässigkeit des Bodens 22.

Wasserflora 60.

Wasserpflanzen 62.

- in Mähren 159.

- in Ostgalizien 290.

- in den Ostkarpathen 356.

- im Ungarischen Tiefland 500.

- in Westgalizien 280.

- in den Westkarpathen 333.

— in Zentralböhmen 139.
Weidenröschen, Formation des rosmarinblätterigen 156 .

Weinbau in Bölumen 141.

- in der Bukowina 290.

- in Galizien 290.

- in den Karpathen 373.

- in Südmähren 160 .

- im Ungarischen Tiefland 502.

- in Zentralböhmen 141.

Wiesen 49.

Wiesenhafer, Formation des, in Zentralböhmen 132.

Wiesenmoore 54.

- im herzynischen Bergland 97.

- in Mähren 152.

- in den Ostkarpathen 356.

- im Ungarischen Tiefland 498.

- in Westgalizien 275.

- in den Westkarpathen 334, 340.

- in Zentralböhmen 130.

Wind 27.

- Einfluß auf den Baumwuchs 27.

Wirtspflanze 41.

Wurzelbakterien 43.

Wurzelknöllchen 21.

Wüste 26.

Wüstensteppc 49 .

\section{X.}

Xerophiler Bau 12.

Xerophyten 12.

Xerotherme Relikte 41.

\section{$\mathbf{Z}$.}

Zinkhaltiger Boden 20.

Zsombékmoore 497.

Zuckerrübenbau in Galizien 291.

- in Mähren und Niederösterreich 161.

- in Zentralböhmen 142.

Zusammenleben der Pflanzen 41.

Zweizeiliges Kammgras, Formation des 344.

Zwergwacholdergebüsch in den Ostkarpathen 366.

- in den Sudeten 109.

Zwergweichselgebüsch in Ostgalizien 282.

Zwiebel- und Knollengewächse 16. 


\section{Register der Pflanzennamen.}

Ein * vor der Seitenzalıl bedeutet eine auf die Pflanze bezügliche Abbildung.

A.

Abies alba Mill. (Tanne) 91, 93,94, 104, 106, $120,122,144,163,167,170,171,173,175$, $177,178,211,226,230,231,234,236$, $239,249,270,271,294,312,330,336,377$, $379,388,392,394,395,404,412,416$, $437,438,442,450,461,462$, " T. IX.

Abutilon Avicennae L. 498, 513, 514, 519, * $520,523,524$.

Acanthus hungaricus Simk. 350, 445.

Acer (Ahorn) 35, 191, 240, 242, 405.

- campestre L. $89,91,123,124,126,143$, $146,147,148, * 188,200,203,238,250$, $270,280,282,311,313,406,408,412,426$, $437,441,447,454,458,485,510,522$.

- platanoides L. 89, 104, 108, 126, 143, 178, * 199, 210, 220, 236, 269, 280, 282, 294, $311,329,377,410,426,441,454,460,462$.

- Pseudoplatanus L. (Bergahorn) 89, 92, 104, $105,106,108,120,122,123,126,166,168$, $175,178, * 195,206,210,220,221,230$, $239,294,311,319,329,336,338,377$, $441,451$.

- tataricum L. 280, 282, 284, 329, 350, 352, $386,407,408,410,445,448,450,451$, $454,456,458,461,485,510,515,522$, *T. XLIX.

Achillea asplenifolia Vent. 157, 498, 518.

- atrata L. 18, * 19.

- collina Becker. 129, 133, 136, 151, 156, 240, 241, 332, 494, * T. XXIV.

- compacta Willd. 353, 445.

- crithmifolia W. K. $353,448$.

- crustata Host. 494.

- distans W. K. 196, 344, 368.

- Impatiens L. 467.
Achillea lingulata W. IK. * $367,370,419$, $428,435,457$.

- Millefolium L. 103, 120, 131, 278, 333. - moschata Wulf. 18, * 19.

- Neilreichii Kern. 157, 245, 247, 332, 413, 507.

- nobilis L. 117.

- ochroleuca Ehrh. = pectinata Willd.

- pannonica Scheele. 153, 156, 353.

- pectinata Willd. (ochroleuca) 410, 492, 511 , 518.

- Ptarmica L. 177, 187, 207, 279, 288, 31:.

- salicifolia Bess. 301.

- Schurii Heimerl. 323, 328, 370, 371, 419 , $422, * 432, * 434,439,441,443$.

- setacea W. K. 136, 154, 193, 289.

- sericea Janka = compacta Willd.

- sudetica Op. 114, 164, 168, 225.

Achroanthes monophyllos (L.) Greenc. 378, $379,427$.

Aconitum 23, 365.

- Anthora L. 245, 248, 332, 361, 405, 408, * 409, 420,435, 451, 453, 454.

- - var. coeruleum Hölzl. 306.

- - var. Jacquini (Rchb.) Gay. 284, 303.

- Baumgartenii Schur. 361.

- cernuum Wulf. 456.

- eulophium Rchb. 284, 303.

- firmum Rchb. = A. Napellus Subsp. firinuin.

- gracile Rchb. $=$ A. variegatum Subsp. gracile.

- Hosteanum Schur. 94.

- Janoviense Blocki 300.

- lasianthum Rehb. 312, 361, 431, 435.

- Lycoctonum aut. = Vulparia. 
Aconitum moldavicum IIacqu. 338, 343, 361, $463,389,403,411,420,451,453,456,461$.

- - var. australe (Rehb.) Gay. 444.

Tapellus L. Subsp. firmum (Rehb.) Gay. $109,117,180,212, * 214,215,219,223$, $225,228,339,342,343,346,377,379,392$.

- Subsp. hians (Rehb.) Gay. 168.

- paniculatum Lam. 303, 361, 414, 435, 437.

- tauricum Wulf. 419, 435.

- toxicum Rehb. $361,431$.

- variegatum L. 176, 199, 245.

- - Subsp. gracile (Rchb.) Gay. 90, 107, $117,212,215,218,219,225,412,413,461$.

- Vulparia Richb. 107, 111, 187, 189, 225, $226,229,230,237,245,249,253,330,376$, $384,456$.

Acorus Calamus L. 296, 297, 496.

Actaea Cimicifugia L. 144, 229, 242, 245, 282, $298,303,305,323,338,389,395,403,412$, $420,424,426,453,454,458$.

- nigra (L.) Fritsch $=$ A. spicata.

- spicata L. $92,93,105,120,122,143,144$, $170,171,176,177,186,196,200,206,211$, $226,230,236,338,376,382,384,386,390$, $395,412,426,428$.

Adenophora liliifolia (L.) Bess. 133, 189, 192, $199,204,282,284,303,306,312,338,403$, $462,486$.

- suaveolens Mey. = liliifolia.

Adenostyles albifrons Rehb. $=$ Alliariae.

- Alliariae (Gou.) Kern. 107, 109, 111, 117, $180,207,211,212, * 214,215,218,219$, $221,224,225,338,342,343,365,379,388$, 392,400 , T. IV.

- Kerneri Simk. 422.

- orientalis Boiss. 359, 364.

Adlerfarn = Pteridium aquilinum.

Adonis aestivalis L. 143.

- vernalis L. $135,138,155,189,190,191$, 193 , * $194,196,197,198,240,242,244$, $249,250,251,253,287,289,298,303,304$, $306,353,356,376,384,407,408,410,460$, $461,462,464,482,493,507,521$, * T. L.

- wolgensis Stev. 356, "463, 465, 466, 467.

Adoxa moschatellina L. 91, 148, 211, 272.

Aegopodium Podagraria L. 90, 147, 148, 241, $272,331,334,407,486$.

Aegylops cylindrica Host. 408, 524.

Agrimonia Eupatoria L. 133, 153.

- glandulosa Simk.=A. odorata v. glandulosa 462 .

- odorata Mill. 292, 303, 305.

- - var. glandulosa Simk. 462.
Agrimonia pilosa Led. 162, 282, 284, 303.

Agropyrum biflorum (Brign.) R. S. 431.

- caninum (L.) R. S. $143,147,148,150,329$, $485,486$.

- cristatum Bess. 491, 519.

- glaucum (Desf.) R. S. 125, 126, 127, 132, 136, 288, 524 .

- intermedium Host. = glaucum.

- repens (L.) R. S. 119, 156, 157, 505.

Agrostemma Githago L. 68, 103, 142, 161, 505.

Agrostis alba L. 124, 131, 146, 152, 157, 272, $279,344,509,512$.

- canina L. 100, 237, 270, 276, 334, 509.

- rupestris All. 101, 173, 179, 214, 217, 219, $344,347,348,368,370,371,397,399,417$.

- scabra Willd. 232.

- vulgaris With. 90, 98, 99, 131, 145, 152, $206,209,230,238,276,278,279,331,339$, $342,386,424,466$.

Ahorn $=$ Acer.

Aira caespistosa L.= Deschampsia caespitosa.

- caryophyllea L. 98, 128, 171, 201, 204, 206, $\because 70,276, * 277,292,374$.

- flexuosa L. = Deschampsia flexuosa.

- praecox L. 98, 128, 200, 206.

Aiuga Chamaepitys (L.) Schreb. 374.

- genevensis L. 151, 278, 289, 441, 485.

- Laxmanni L. 253, 284, 288, 306, 313, 450, $454,459,460,464,466$.

- pyramidalis L. 94, 168, 207, 221, 408.

- reptans L. 104, 111, 147, 272, 278, 289.

Alchimilla 346 .

- arvensis L. 103, 142, 161.

- fissa Günth. et Schumm. = glaberrima.

- glaberrima Schm. 116, 207, 212, 214, 220, $348,399$.

- silvestris Schm. 278.

Aldrovandia 60 .

- vesiculosa L. 293, 428, 500.

Alectoria nigrescens Körb. 117.

- ochroleuca Nyl. 344.

Alectorolophus 43, 51 .

- alpinus Baumg. 368, 412, 453.

- glandulosus (Simk.) Stem. = A. rumelicus.

-- hirsutus All. 278, 279, 333, 505.

- maior (Ehrh.) Rehb. 142, 152, 153, 278, 279, 289, 290, 333, 334, 339, 394, 407.

- - Subsp. maior (Ehrh.) Wettst. * 51.

- - Subsp. montanus (Saut.) Wettst. " 51.

- minor (Ehrh.) Wimm. u. Grab. 100, 131, 133, 153, 278, 333, 334, 394,

- montanus (Saut.) Fritsch. 133, 202, 376, 424. 
Alectorolophus pulcher (Schumm.) WVimm. $113,344,380$.

- rumelicus VeI. 424, 441, 460, 465.

Alisma Plantago aquatica L. 138, 232, 279, $334,441,460,496$.

Alkanna tinctoria (L.) Tsch. 467, 484, * 489, $492,511,517,521$.

Alliaria officinalis Andrz. 91, 147, 241, 250, $272,485$.

Allium 482.

- angulosum L. 152, 203, 204, 241, 251, 252, $297,497,509$.

- atropurpureum W. K. 291, 519.

- fallax R. S. = montanum.

- flavescens Bess. 235, 356, 450, 459, 460, $462,464,526$.

- flavum L. 101, 102, 156, 157, 245, 248, 253, $332,333,356,374,377,384,407,441,442$, 521.

- montanum Schm. (= fallax R.S.) 101, $136,138,157,177,189,191,192,197,238$, $239,242,245,253,285,307,333,342,381$, $386,405,406,407,408,412$.

.- obliquum L. 364, , 452, 454 .

- ochroleucum W. K. 443.

- paniculatum Bot. mag. 289.

- podolicum Btocki 305, 306.

- rotundum L. 143, 189, 192.

- sativum L. 291.

- Schoenoprasum L. 198, 205.

- Scorodoprasum L. 203.

- sibiricum L. 116, 206, 224, 380, 400, 402, 420.

- sphaerocephalum L. 126, 246, 492, 521.

- strictum Schrad. 200.

- ursinum L. 91, 93, 105, 147, 148, 186, 200, $211,229,238,240,249,250,282,305,336$, $336,358,376,378$.

- Victorialis L. 214, 217, 343, 388, 390, 417, 421.

- vineale L. 162, 193, 196, 413 .

Allosorus crispus (L.) Bernh. 117, 173, 207, $212,217,219,347$.

Alnus (Erle) 300, 388, 441.

- glutinosa (L.) Gaertn. (= rotundifolia) 91, $107,125,126,127,130,146,148,181,193$, $232,238,239,240,269,272,284,292,294$, $295,330,377,381,403,428,487,506,509$, 523.

- incana (L.) Mch. 127, 147, 150, 257, * 258, $272,330,338,377,381,437,487,510,516$.

- rotundifolia Mill. = glutinosa.

- viridis (Chaix) DC. $35, * 36,110,126,172$,
$177,179,180,184,207,234,343,361,356$,

$380,411,412,417,420,421,433,437,439$,

$440,442,444,456,457,461$, * T. XXXVII.

Alepocurus 54.

- aequalis Sobol. 131, 152, 231, 275, 279, $289,334,494$.

- brachystachys M. B. = Iaguriformis.

- fulvus $\mathrm{Sm} .=$ aequalis.

- geniculatus L. 298, 334, 497, 498, 523.

- laguriformis Schur. 323, 368, 419, 439, 440.

- nigricans Horn. 306, 309.

- pratensis L. $98,99,111,112,114,152,239$, $251,278,279,234,498,518,522$.

Alpendost $=$ Adenostyles.

Alpenglöckchen $=$ Soldanella.

Alpenheckenkirsche $=$ Lonicera alpigena.

Alpenjohannisbeere $=$ Ribes alpinum.

Alpenrebe $=$ Clematis alpina.

Alpenrose $=$ Rhododendron.

Alsine = Minuartia.

Althaea armeniacz Ten. 510 .

- hirsuta L. 459, 464.

- officinalis L. $159,195,248,254,459,461$, $498,514,521$.

- pallida W. K. $356,407,424,450,459,467$, 507.

Alyssum alyssoides L. 151, 292, 428, 524.

- arenarium Gmel. 492, 511, 525.

- Arduini Fritsch. 101, 102, 136, 138, 155, $157,177,178,184,187, * 188,189,199$, $242,245,246,253,285,305,333,374,375$, $377,384,386,404$, * T. XI, * XXVII.

- argenteum aut. = murale.

- calycinum $\mathrm{L}_{\text {. }}=$ alyssoides

- desertorum Stapf. 491, 511, 518, 521, 524.

- linifolium Steph. 521.

- microcarpum Vis. 354, 445, 447, 448.

- montanum L. 102, 155, 157, 202, 245, 253, $294,332,384,404,410$.

- murale W. K. 353, 364, 442, 450, 453, 454.

- orientale Ard. 235, 416.

- repens Baumg. 323, 367, 371, 420, 431, $433,444$.

- saxatile Aut. = Arduini.

- tortuosum W. K. $488,{ }^{*} 489,492,507,515$, 517,525 .

- transsilvanicum Schur. 429, 433.

Amaranthus retroflexus L. 292.

- viridis L. 292.

Amblystegium 60 .

- subtile (Hedw.) Br. Sch. G. 91.

Amelanchier ovalis Med. 32, 342, 388, 454.

Ammophilia arenaria Lk. 294. 
Anacamptis pyramidalis Rich. 99, 189, 298, $377,379,460,493$.

Anagallis arvensis L. $68,120,142,161,374$ Anchusa angustifolia L. 511 .

Barellieri All. 284, 285, 289, 303, 306, * 311 $312,352,353,356,429,448,464$.

italica Petz. 524.

ochroleuca M. B. 526 .

officinalis L. 153, 154, 156, 157.

procera M. B. 284, 288, 289.

Andraea 117.

- petrophila Ehrh. 101, 119, 348. rupestris Heint. 119, 348.

Andromeda polifolia L. 54, * $58,96,97,116$, $130,168,170,176,178,181,200,209,213$, $221,231,234,272, * 274,275,294,295$, $341,378,415,417,427,462,498$.

\section{Andropogon 482.}

Gryllus L. 353, 356, 374, 408, 460, * 483, $493,510,51 \wedge, 5: 3,5: 4$.

Ischaemum L. 133, * 134, 153, 154, 155,

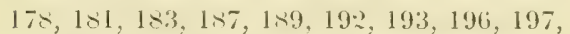
$202,204,231,238,239, * 240,242,243$, $244,245,250,287,288,306,307,331,333$, $353,356,376,429,442,490,493,506,507$, $509,521,524$.

Androsace arachnoidea Schott. $371,426,435$, 444.

- Chamaejasme Host. 345, 394, 399, 402.

- elongata L. 143, 190, 197, 247, 465.

- lactea L. 381, 390, 392, 393, 421, 429, 433, 444.

- maxima L. 384, 507, 521.

- obtusifolia All. 117, *118, 214, 220, 371, 399.

- septentrionalis L. 128, 198, 276, 285.

Anemone 38.

- alba (Richb.) Kiern. 18, 114, 207, 211, *213, $214, * 216,217,220,344,348,366,380$, $392,397,399,400,417,422,428,434,437$, $440,442,443,444,456$.

- Burseriana (Rehb.) Kern. 18.

grandis (Wender.) Kern. 153, 155, 229, $239,240,242,244,245,246,247,251,253$, $332,354,374,376,405,410,482,491$.

Hepatica L.91, 105, 127, 143, 145, 163, $177,186,192,230,236,238,242,249,270$, $282,293,300,308,312,329,331,336, \mathbf{3 4 9}$, $377,414,450,458,460$.

- montana Hoppe 354, 356, 464.

narcissiflora L. * 112, 113, 207, 217, 287, $303,344,348,380,388,390,392,397,399$, $400,404,417,419,422,434,435,437,467$, * T. XL.
Anemone nemorosa L. 93, 94, 105, 122, 124, $143,185,205,242,270,311,329,336$, 413 .

- nigricans (Störck) Beck. 121, 127, 128, 129, $133,135,138,151,155,184,189,198,202$, $243,245,313,374,450,451,462,482,492$, 509,518 .

- patens L. 133, 135, 167, 179, 186, 189, 196, $197,198,262,285,287,289,294, * 299$, $30,303,306,311,312,354,466,467$.

- polonica Błocki 287, 298, * 299, 312.

- Pulsatilla L. 312 .

- ranunculoides L. 124, 143, 148, 250, 270, $311,329$.

- silvestris L. 124, 136, 155, 178, 203, 246, $248,255,287,289,297,301,304,311,312$, $313,403,404$.

- slavica Reuss. 332, 342, " 385, 386, 387, $389,404,406$.

- transsilvanica (Fuß3) Ieuff. 323, 351, *358, * $359,423,426,427,428,430,431,437$, 461,462 .

- vernalis L. 186, 215, * $216,217,226,231$, 232, 242, 293.

Angelica Archangelica L. 111, 207, 213, 222, $339,343,399,419,437,444,461$.

- silvestris L. $100,111,126,127,147,334$, 462, 509.

Anoectangium compactum Schwägr. 119.

Antennaria carpatica (Wahlog.) R. Br. 344, $345,348,392,397,399$

- dioica (L.) Gärtn. 52, 53, 90, 94, 98, 100, $104,114,121,122,124,130,145,150,211$, $239,276$.

Anthemis alpina auct. Transs. = Achillea Schurii.

- arvensis L. 120, 374.

- austriaca Jacq. 128.

- carpatica IV. K. 323, 345, *367, 369, $370,417,431,433,439$.

- Cotula L. 162, 292, 505.

- macrantha Heuff. 456.

- montana L. 191, * 194, " T. X.

- ruthenica 11. B. 128, 143, 151, 252, 356, 518.

- tinctoria L. 92, 136, 151, 169, 202, 229, $231,301,312,313,353,379,403,407,429$, 507, " T. XXIV.

Anthericum Liliago L. 101, 127, 136, 156, 178, $186,187,189,190,192,202,405,406,407$.

- ramosum L. 101, 127, 136, 186, 187, 190, $191,192,197,238,240,242,250,287,289$, $312,313,342,376,386,405,406,461$. 
Anthirrhinum Orontium L. 68.

Anthoxanthum odoratum L. 99, 100, 111, 131 $133,150,152,187,199,206,225,238,252$ $278,289,333,339,386,424$.

Anthriscus leiocarpus Simk. 158.

- nitidus (Wahlbg.) Garcke 107, 111, 117 $207,210,211,212,218,219,225,337,338$, $342,343,378,400,419$.

- silvestris (L.) Hoffm. 90, 98, 107, 152, 278, $333,334$.

\section{Anthyllis 52.}

- polyphylla Kit. $153,155$.

- vulgaris (Koch) Kern. 332, 333.

- Vulneraria L. 127, 132, 133, 136, 153, 169, $199,202,217,278,312$.

Apera interrupta (L.) Beauv. 146, 252, 256. - Spica venti (L.) Beauv. 103, 119, 142, 505. Apfelbaum $=$ Pirus Malus.

Aposeris foetida (L.) Cass. 297, 298, 300, 305, $311,350,411,412,413,415,457$.

Aprikose $=$ Prunus Armeniaca.

Aquilegia transsilvanica Schur. 440, 443, 454.

- Ullepitschii Pax. 382, * 383.

- vulgaris L. 99, 338.

- - var. longisepala Zimm. 388.

Arabis alpina L. 117, 214, 220, 333, 339, 343, $348,371,405,412,435$.

- arenosa Scop. 157, 238, 285, 333, 342, 400.

- - Subsp. petrogena (Kern.) 332, 407.

- auriculata Lam. 189, 190, 198, 410.

- bellidiflora Jacq. = Jacquinii Beck.

- brassicaeformis IVallr. 186.

- Halleri L. 99, 111, 113, 166, 186, 205, 211, $219,224,230,298,401,412,422,457$.

- hirsuta Scop. 127, 136, 153, 155, 246, 278, $289,354,378$.

- Jacquinii Beck 402, 411, 421.

- neglecta Schult. 322. 343, 346, 348, 380 , 396,397 , *398, 399, 400, 403, 419, 439.

— ovirensis Wulf. $363,369,436,443$.

- petrogena Kern. = arenosa Subsp. petrogena.

- sudetica Tausch. 114, 225, 344, 348.

- Turrita L. 184, 284, 285, 342, 377.

Arbutus Unedo L. 25.

Arctium minus (Hill) Bernh. 292, 505.

- Lappa L. 292, 505.

- nemorosum Lej. 309.

- tomentosum Mill. 292, 505.

Arctostaphylos Uva ursi (L.) Spr. "295.

Aremonia agrimonioides (L.) Neck. 388, 390, 450.

Arenaria 38.
Arenaria biflora L. $346,369,431,437,442$

- ciliata L. 347, 394, 399.

- graminifolia Schrad. 159, 287, 289, 304, $\left.332,356,408,458^{1}\right) 462,464$

- grandiflora L. 157, 253.

- serpyllifolia L. 151, 292.

Aristolochia Clematitis L. 148, 189, 197, 202 , $284,407$.

- pallida IV. K. 451 .

Armeria alpina (Hoppe) Willd. 368, 431, 434.

- barcensis Simk. 428.

- elongata (Hoffm.) Koch. 20, 128, 151, 153, $154,200,240,247,255,276,292,293,330$.

Armoracia rusticana (Lam.) G. M. Sch. 160, 503.

Arnica montana L. 90, 99, 112, 130, 164, 166, $168,169,170,174,176,177,178,179,182$, $183,186,199,200,204,206,210,211,217$, - 218, 230, 231, 234, 340, 378, 411, 420, $422,454$.

Arnoseris minima (L.) Schw. Ki. 128, 171, 196, 204, 220, 236 .

- pusilla Gärtn. = minima.

Arrhenatherum elatius (L.) M. K. 51, 52, 98, $131,152,153,278,287,289,333,334,339$, 354,466 .

Artemisia 38, 252.

- Absynthium L. 156, 190, 192, 202, 204, $231,239,242,244,246,284,285,307,332$, $386,389,407,410,441,461,466$.

- - Subsp. calcigena Rehm. 381.

- austriaca Jacq. 156, 235, 249, 301, 305, 306.

- Baumgartenii Bess. = petrosa.

- campestris L. $138,156,289,306,332,356$, $424,488,492,507,518$, * T. XXIV.

- camphorata Vill. = Lobelii All.

- eriantha Ten. = petrosa

- Iatifolia M. B. * 526, 527.

- Lobelii All. 407.

- monogyna W. K. 467, 484, 494, 496, 508, $509,513,518,{ }^{*} 522$.

- petrosa (Baumg.) Fritsch.(eriantha) 399, $402,403,434,437,440,443,444$, " $\mathrm{T}$. XXXVIII.

- pontica L. 135, 156, 191, 193, 197, 202, $289,356,407,413,424,511$.

- procera Willd. 306 .

- Santonicum L. 458.

- scoparia W. K. 154, 156, 183, 187, 202, 226, $238,289,403,407,507$.

- vulgaris L. 505.

1) Vgl. Corrigenda. 
Arum macuiatum L. 144, 238, 330, 378, 386, 450.

_- var. immaculatum (Schott.) 148, 336. Aruncus silvester Kost. 94, 105, 106, 163, 171, $173,178,180,186,189,196,205,218,221$, $222,225,226,305,311,312,377,379,380$, $386,390,392,395,411,420$.

Asarum europaeum L. 91, 122, 124, 144, 200, $303,336,386,400$.

Asparagus officinalis L. 127, 130, 156, 160, $308,466$.

- tenuifolius Lam. 284, 306.

Asperugo procumbens L. 192.

Asperula Aparine M. B. 428.

- capitata Kit. $370,445,455$.

- cynanchica L. 101, 133, 135, 136, 138, 153, $184,220,228,229, \cdots 240,242,289,298$, $312,332,342,356,376,386,416,507$.

- galioides M. B. = glauca.

- glauca L. 101, 124, 127, 153, 156, 178, 189, $190,191,197,201,240,245,254,282,305$, $376,404,507,511$.

- odorata L. $91,93,105,143,144,163,189$ $200,230,236,242,249,270,303,311,336$, $377,379,380,428,450,461$.

- rivalis Sibth. 148, 242 .

- taurina L. 353, 431, 450.

- tinctoria L. 106, 133, 136, 190, 282, 442.

- thyraica Blocki 284, 285.

Aspicilia alpina (Smrft.) Syd. 117.

Aspidium vide Dryopteris $u$. Polystichum.

Asplenium Adiantum nigrum L. 101.

- adulterinum Milde 20, *21, 101, 171, 226 .

- cuneifolium Viv. 20, *21, 101, 171, 226, $235,245,416$.

- germanicum Weiss. 199.

- lepidum Presl. 354, 447.

- Ruta muraria L. 101, 136, 305, 332, 342.

- septentrionale L. 101, 136, 138, 332, 342, $374,384,407$.

- Serpentini Tausch $=$ cuneifolium.

- trichomanes L. 66, 101, 136, 138, 199, 305, $332,342, *$ T. XXVII.

- viride Hud. 66, 118, 212, 215, 242, 342, $377,378,381,390,405,413,442$.

Aster acris Schur = punctatus.

- alpinus L. 118, 226, 342, 348, 381, 386, 390 , $394,429,454$.

- - Subsp. hirsutus (Host.) 101, 106, "137, 138, " 197, 200, 206.

- Amellus L. 135, 156, 202, 235, 239, 240, $242,248,284,285,297,298,306,307,309$, $332,345,379,384,403$.
Aster Bellidiastrum (L.) Cass. 342, 348, 380 , $381,386,390,392,394,400,405,411$.

- canus W. K. " $256,499,518$.

- dracunculoides Bess. 354.

- Linosyris (L.) Bernh. (Linosyris vulgaris) $136,187,189,193,196,202,242,245,248$, $297,306,307,375,384,410,461,492$.

- Novi Belgii L. 68.

- punctatus W. K. 407, 408, 466, 499.

— salignus Willd. 488.

- tinctorius Wallr. 442, 454.

- Tripolium L. 21, 157, " 158, 159, 248, 256, $458,461,462,466,467,494,496,507,508$, $509,511,513,518,519$.

Asterella fragrans (Nees) Beauv. 236.

Asterionella formosa Hass. 62.

Astragalus 39.

- albidus W. K. 460, 466.

- alpinus L. 345, 348, 400, 401.

- arenarius L. 179, 204.

- asper Wulf. 249, 466, 493, 508.

- australis L. $327,345,{ }^{\star} 347,348,381,401$, 466.

- austriacus Jacq. 135, 193, * 194, 196, 197, $198,249,253,307,308,461,466,493,521$.

- Cicer L. 138, 203, 287, 289, 332, 493.

- contortuplicatus W. K. 498, * 499, 510.

-- danicus Retz. 124, 132, * 194, 249, 376, $389,403,404$.

- dasyanthus Pall. 356, 451, 460, 466, "525, 526.

- depressus L. 445.

- exscapus L. 135, 138, 193, 247, 249, 255, $467,484, " 489,492,508,511$.

- frigidus (L.) DC. 348, 402, 403, 435.

- glycyphyllus L. 90, 138, 282, 332, 410, 485.

- linearifolius Pers. 442, 451.

- monspessulanus L. 353, 458, 460, 461, 464, 465.

- Onobrychis L. 155, 202, 248, 249, 253, 255, $287,289,307,308,313,345,458,488,492$, $493,518,525$.

- oroboides Hornem. 327, * 401, 402,

- praecox Baumg. $=$ monspessulanus.

- Rochelianus Heuff. 353.

- Roemeri Simk. * 423.

- transsilvanicus Barth. 356, 465, 466, 467.

- varius Gmel. 467, 487, 488, *491, 492, $511,512,515,519$.

- vesicarius L. 233, 356.

- virgatus Pall. 408.

Astrantia maior L. 93, 133, 173, 189, 192, 203, $211,220,228,229,238,245,249,303,311$, 
$338,376,377,379,384,386,400,405,407$, $408,451,458,460,461$.

Asyneuma canescens Gris. 284, 285, 305, 306, $309,353,356,407,408,450,456$.

Athamanta hungarica Borb. 364, 445, 446.

Athyrium alpestre (Hoppe) Ryl. 93, 100, $105,107,163,174,215,219,221,343$, 400.

- Filix femina (L.) Roth. 91, 93, 100, 105, 106, $117,120,126,144,147,174,176,186,209$, $221,224,230,231,270,282,330,377,381$, $400,414$.

Atriplex hastata L. 157, 159, 248, 298, 496.

- latifolia Koch = hastata.

- litoralis L. 496.

- microsperma W. K. 354, 458, 461, 462.

- nitens Schk. 289, 292.

- patula L. 120, 292, 496, 505 .

- rosea L. 292, 374, 413.

- tatarica L. 157, 162, 292, 496, 505, 513, $521,523$.

Atropa Belladonna L. 93, 105, 211, 342, 376, $379,386,413$.

Atropis distans (L.) Gris, 157, 159, 170, 494, $514,518$.

- festucaeformis (Host.) Boiss. 494, 496.

- limosa Schur. 354, " 355, 509, 521.

- pannonica Hack. 494, 496, 508.

- Peisonis Beck. 508.

- salinaria (Schur.) Deg. 458, *459, 462, 465, 466,467, * 514 .

- transsilvanica (Schur.) Deg. 354.

Aulacomnium palustre (L.) Schwägr. 95, 97, $274,295$.

Avena argentea Willd, 66.

- Besseri Janka = decora.

- compressa Heuff. 306.

- decora Janka 306, 353, 454, * T. XLIX.

- desertorum Less. " 134, 135, 179, 193, *253,254, 285, 306.

- flavescens L. = Trisetum flavescens.

- planiculmis Schrad. 112, 114, 197, 219.

- pratensis L. 99, 132, 133, 135, 152, 153, - $155,189,193,278,333$.

- - var. stepposa Podp. 306.

- pubescens L. 99, 111, 132, 153, 199, 239, $278,287,304,333$.

- sativa L. $69,102,103,119,141,160,290$, 372,502 .

- subdecurrens Borb. 493.

- versicolor Vill. 344, 368, 389, 396, 397, $399,400,417,420,434,437$.

Azalea pontica $\mathrm{L}_{\text {. }}=$ Rhododendron flavum.
B.

Baeomyces roseus Pers. 114.

Bakterien 60.

Ballota nigra L. 292, 505.

Banffya petraea Baumg. = Gypsophila petraea.

Barbaraea stricta Andrz. 127.

- vulgaris R. Br. 127, 152, 289, 290.

Barbula muralis L. $101,138$.

- ruralis (L.) Hedw. 488.

- squarrosa Brid. 102.

Bartgras = Andropogon.

Bartramia ithyphylla (Hall.) Br. 101, 136.

- Oederi Gunn. 119.

Bartschia alpina L. 116, 215, 224, 344, 346, $348,370,380$.

Battarea phalloides (Dicks) Pers, 493.

Beckmannia eruciformis Host. 494, 520, 521, 522.

Bellis perennis L. 120, 278 .

Berberis vulgaris L. 120, 144, 145, 177, 280, $328,330,331,403,510,521$.

Bergahorn = Acer Pseudoplatanus.

Berula angustifolia (L.) Koch. 279, 290.

Berteroa incana (L.) DC. 127, 153, 156, 162, $356,441,507$.

Besenginster $=$ Sarothamnus scoparius.

Betonica $=$ Stachys.

Beta vulgaris L. 142, 516.

- - var. saccharifera Alef. (Zuckerrübe) 161, $291,292$.

Betula 249, 350, 428, 522 .

- carpatica W.K. = pubescens var. carpatica.

- humilis Schrk. 59, 272, *273, 275, 294, $363,427$.

- nana L. 56, 59, 97, 116, 166, 168, 176, 209.

- pendula Roth. 89, 90, 91, 93, 104, 106, $121, * 123,125,144, * 145,146,147,163$, $171,173,177,185,204,206,220,230,236$, $238,271,272,277,297,311,328,329,330$, $408,415,426,510,523$.

- - var. obscura (Kotula) Koehne. 271.

- pubescens Ehrh. 59, 97, 98, 107, 108, 116, $126,130,144,170,221,231,232,272,275$, 329.

- - var. carpatica (W. K.) Koch. 108, 176, 222, 223, 225, 338, 396.

- verrucosa Ehrh. = pendula.

Biatora aenea (Duf.) Arn. 117.

- Iygaea (Ach.) Syd. 117.

Bidens cernuus L. 200.

- radiatus Thuill. 139, 181, 183, 187, 200.

Hayek, Die Pflanzendecke Österreich-Ungarns, I. 
Bidens tripartitus L, 127, 200, 413.

Bimbaum $=$ Pirus communis.

Birke = Betula

Biscutella laevigata L. 136, 138, 189, 191, 202, $238,242,245,342,345,347,364,371,384$, $386,388,394,402,424,428,444,454$.

Blackstonia serotina (Koch.) Beck, 498, 508.

Blechnum Spicant (L.) Roth. 93, 105, 106, $168,191,205,206,221,228,375,440$.

Blysmus compressus (L.) Panz. 275, 276.

Bocksdorn = Lycium.

Bohne = Phaseolus.

Borstengras $=$ Nardus stricta.

Botrychium Lunaria (L.) Sw. 206, 212, 344, 381 .

- Matricariae (Schrk.) Spr. 205, 299, 378, $403,417$.

- ramosum (Roth.) Aschers. 166, 168, 169, 229,403 .

- rataefolium A. Br. = ramosum.

— virginianum (L.) Sw. 358, 447.

Brachypodium pinnatum (L.) Beauv. 104, 132, $136,138,177, * 240,241,270,280,282$, 403.

- silvaticum (Huds.) R. S. 90, 122, 124, 147, $200,282,392,485,486$.

Brachythecium 330.

- plicatum Br. Sch. G. 119.

- salebrosum (Hoffm.) Br. Sch. G. 488.

- Starkei (Brid.) Br. Sch. G. 93.

Brassica Napus L. 291.

- nigra (L.) (Senf) Koch. 292, 505.

- oleracea L. (Kohl) 141, 160, 291, 503.

Briza media L. 98, 131, 132, 138, 151, 153, 180 , $289,333$.

Brombeere $=$ Rubus.

Bromus arvensis L. 142, 333, 488, 490, 505, 524.

- asper Murr. 93, 94, 105, 120, 125, 147, 195 , $196,210,250,270,378$.

- barcensis Simk. 353, 429.

-. commutatus Schrad. 488.

- erectus Huds. 20, 52, 132, 136, 153, 155, $185,193, * 240,241,304,331,333,485$

- fibrosus Hack. 353.

- Inrdaceus L. 5:, 98, 151, 190, 331, 333, $488,490,511,524$.

- inermis L. $132,190$.

- mollis L. = hordaceus.

- secalinus L. 103, 120, 142, 374, 505 .

- serotinus Benek. 104, 105.

- squarrosus L. 488, 523, 524.

- sterilis L. $136,148,150,156,511$.
Bromus tectorum L. 151, 156, 276, 300, 333, $482,488,490,494,511,514,524$.

- transsilvanicus Steud. 437.

Bruckenthalia spiculifolia Salisb. 358, * 359 , $365,366,368,429,431,437,438,443$, * T. XLVI, " T. NLVII.

Brunella $=$ Prunella.

Bryum alpinum Huds. 189.

- argenteum L. 242.

- bimum Schreb. 274.

- elegans Nees. 119, 348.

- murale Wils. 238.

- pendulum (Hornsch.) Schimp. 119, 274.

- pseudotriquetrum (Hedw.) Schwägr. 130.

- Schleicheri Schwägr. 116.

Bryonia alba L. 147.

Bucegia romanica Radian 432.

Buche = Fagus silvalica.

Bulbocodium vernum L. var. ruthenicum (Bunge) 354, 466.

Bunias orientalis L. 254, 306, 413.

Buphthalmum salicifolum L. 153, 156, 179, $245,255,336,358,390$.

- speciosum = Telekia speciosa.

Bupleurum affine Sadl. 407.

- diversifolium Roch. 323, 370, 420, 443.

- falcatum L. 101, 124, 127, 133, 135, 136, $156,157,177,192,245,248,251,285,305$, $306,332,333,342,376,381,384,389,408$, $424,429,442,487,515$.

- Gerardi Jacq. 407.

- junceum L. 190,410 .

- longifolium L. 111, 124, 189, 190, 192, 196, 203, 212, 217, 225, 389, 400, 408, 429.

- ranunculoides L. 327, 345, 370, 394, 402, 411.

- rotundifolium L. 162, 374, 505.

- tenuissimum L. 159, 192, 195, 248, 249, $256,354,413,460,494,508,513,515,517$, $518,523$.

Butomus umbellatus L. 138, 160, 181, 259, $279,290,294,460,511,523,524$.

\section{C.}

Calamagrostis arundinacea (L.) Roth. 92, 126, $129,200,308,412,456$.

- Epigeios (L.) Roth. 129, 146, * 149, 157, $159,249,270,272,284,331,487,488,491$.

- Halleriana Gaud. = villosa

- lanceolata Roth. 107, 126, 127, 130, 270, 272, 279, 292, 496.

- litorea DC. = Pseudophragmites. 
Calamagrostis neglecta (Ehrh.) G. MI. Sch. 270, $294,523$.

- Pseudophragmites (Hall.) Baumg. 159, 203, $331,334,488,496$.

- silvatica DC. = arundinacea.

- varia (Schrad.) Baumg. 93, 94, 100, 163, $165,172,207,337,400$.

- villosa (Chaix) Mut. 94, 103, 106, 111, 112, $117,166,167,169,170,173,186,199,205$, $206,219,221,336,337,342,343,365$.

Caldesia parnassifolia Parl. 428.

Calendula officinalis L. 69.

Calepina cochlearioides (Murr.) Dum. 519.

Calla palustris L. $96,97,126,130,173,178$, $184, * 182,193,200,204,228,229,231$, $233,274,294,295,297,298,380,417$.

Callianthemum coriandrifolium Rehb. 346, 389, $397,400,402,419$.

- rutaefolium C. A. Mey. = coriandrifolium.

Callitriche hamulata Kütz. 141, 280.

- stagnalis Scop. 141.

- verna L. 141, 280, 290, 335.

- verna L. var. caepistosa C. F. Schultz 139. Calluna 20.

- vulgaris (L.) Salisb. 32, 52, *53, 54, 90, $94, * 95,96,97,100,104,109,114,116$, $120,124,129,130,136,144, * 145,150$, $154,169, * 175,176,177,181,182,185$, $186,187,191,192,202,204,205,206$, $207,208,211,214,225,230,234,237,238$, $247,252,270,271,272,274,275,276,292$, $295,329,336,341,380,384,416,451$, * T. XVIII.

Caltha cornuta Sch. N. K. 339.

- laeta Sch. N. K. 338, 340, 341.

- procumbens Huth. 126, 230.

- palustris L. 126, 127, 131, 147, 148, 181, 232, 279, 290, 334, 498, 506, 509.

Calystegia sepium (L.) R. Br. 107, 147, 148, $284,331,351,458$.

- silvatica (IV. K.) R. Br. 350, 351, 352.

\section{Campanula 51.}

- abietina Gris. $358,361,411,414,415,420$, $424,431,437,438,443,456,457$.

- alpina Jacq. 344, 369, 370, 371, 392, 396 , $397,417,419,420,422,434,437,439,444$, 457.

- barbata L. 108, 114, 207, 220, 225.

- bononiensis L. 136, 192, 282, 284, 297, 305, $307,403,485,493,511$.

- carpatica Jacq. 323, 333, 342, 348, * 365 , $405,417,420,426,429,437,504$.
Campanuia Cervicaria L. 124, 203, 220, 229, $240,288,424,426,431,441,458 ; * \mathrm{~T}$. XXxill.

- cochleariaefolia Lam. 342, 348, 364, 386, 435.

- crassipes Heuff. 354, * $446,447$.

- divergens W. K. 364, 408, 445.

- glomerata L. 124, 153, " 155, 242, 289. - - var. elliptica (Kit.) Hay. 344.

- Grosseckii Heuff. 358, 444, 445, 450, 451.

- Kladniana Schur. 451.

- latifolia L. 105, 109, 197, 204, 228, 236, $338,377,413,428,430,437$.

- lingulata W. K. $353,447$.

- macrorhiza aut. hung. = crassipes 447.

- patula L. 131, 152, 277, 278, 288, 289, 298, $312,334,340,356,394,407,441$.

- persicifolia L. 143, 203, 240, 242, 311, 330, $338,407,431,441,485$

- pseudolanceolata Pant. 330, 344, 386, 390, 419,424

- rapunculoides L. 120, 374, 394.

- Rapunculus L. 237.

- rotundifolia L. 100, 132, 230, 278, 332, 333, 356.

- - Subsp. solstitialis (Kern.) Wit. 234.

- Scheuchzeri Vill. 118, 217, 344, 399, 417, 461.

- sibirica L. 101, 156, 179, 242, 285, 288, $289,298,300,305,306,332,384,405,407$, $458,465,521$.

- Trachelium L. 133, 303, 485.

- transsilvanica Schur. 368, 369, 435, 439, * 443, 444.

- Welandi Heuff, 354, 445.

Camphorosma ovata IV. K. 354, 484, 494, * $495,508,509,513,519,521,522$; * T. LII.

Camptothecium lutescens (Huds.) Br. Sch. G. 488.

- nitens (Schreb.) Schimp. 275.

Campylopus turfaceus Br. Sch. G. 274.

Cannabis sativa L. 291, 373, 441, 504.

Capsella Bursa pastoris (L.) IVigg. 120, 292, $345,373,505$.

Cardamine bulbifera (L.) Cr. 91, 92, 93, 105, $122,144,163,189,200,205,210,211,218$, $221,230,233,234,236,242,245,249,282$, $303,311,351,358,374,379,386,388,389$, $395,411,412,413,414,431$.

- enneaphyllos (L.) Cr. 91, 105, 106, 123, 128, $144,163,170,205,210,211,218,221,230$, $234,236,242,253,323,336,351,378,379$, $386,388,389,390$. 
Cardamine flexuosa With. 91, 105, 457.

gelicla Schott. 439, 440, 444.

glandulosa (W. K.) Schmalh. 297, 298, 300,

$303,308,312,323,335,336,351,358,359$,

$378,379,382,389,395,411,413,415,424$,

$431,438,450,456,458,460,461$.

- Eracea L. 354 , * 446, 447.

- Lirsuta L. 93, 163.

impatiens L. 91, 105, 126, 148, 189, 195, $238,282,330,336$.

- Mathioli Mor. 506.

- Opizii Presl. 116, 219, 341, 343, 392, 339, $400,419$.

- palustris Peterm. 131.

- parviflora Lam. 518.

- pratensis L. $111,114,131,152,237,238$, $241,251,279,334,377,385,498,509$.

-resedifolia L. 117, 179, 207, 217, 226, 348, 440.

- rivularis Schur 370, 412.

silvatica $\mathrm{Lk}$, = flexuosa.

trifolia L. 94, " $172,178,207,230,233$ $234,293,358,390,456$.

Cardaria Draba (L.) Desv. 120, 162.

\section{Carduus 484.}

- acanthoides L. 103, 373, 493. candicans W. K. 353, 356, 407, 442, 465.

- collinus W. K. 332, 408.

- crispus L. $147,148,272,331$.

- glaucus Baumg. 342, 347, 400, 420, 426.

- hamulosus Ehrh. 289, 356, 505.

- Kerneri Simk. 366, 412, 417, 457.

- nutans L. 133, 135, 162, 331, 492, 505.

- personatus Jacq. 117, 211, 222, 225, 234, $339,342,343,400,429$.

Carex 20, 54.

-- acuta Aut. = gracilis.

- acutiformis Ehrh. 63, 130, 131, 152, 160 , $275,279,289,290,334,509,517$.

- alba Scop. 388, 390.

- arenaria L. 54.

- aristata R. Br. 298.

- atrata L. 112, 216, 226, 327, 344, 345, 347, $348,380,392,397,400,412,422,450$.

- bicolor All. 371.

- brevicollis DC. 204, 454.

- brizoides L. $125,126,185,270,298,377$, 412.

- brunnescens Poir. 368.

- Buekii Wimm. 183, 204, 300, 523, 524.

- Buxbaumi $=$ polygama

- caespitosa L. 152, 238, 239, 275, 279, 292.

- canescens L. 56, 57, 95, 97, 100, 116, 130 ,
$153,170,192,200,209,224,231,237,272$ $274,275,341,378$.

Carex capillaris L. $117,207,212,217,226,327$, $345,347,400,402$.

- caryophyllea Lat. = verna.

- chordorrhiza Ehrh. 56, 59, 116, 184.

- curvula All. 18, 328, 344, 368, " 369, 371 $417,420,434,437,444,461$.

- cyperoides L. 139, * 140, 183, 200, 229 , $\because 31,237,251$.

- dacica Heuff. 363, 417.

Davalliana Sm. 111, 152, 181, 192, 198, $200,229,239,274,275,279,334,384,497$. diandra Schk. 130, 170, 182, 183, 200, 229, 239, 252, 274, 275, 298, 300, 403.

- digitata L. 105, 143, 144, 185, 186, 206 $230,236,240,245,270,282,298,300,303$, $342,382,412,414,431$.

- dioica L. $95,97,178,179,182,192,229$, $233,234,274,293,295,380,396,417$.

- distans L. 131, 157, 202, 279.

- disticha Huds. 152, 159, 169, 195, 229, 254, $289,334,494,496,497,498$.

- divulsa Lam. 124, 143, 493, 494, 514.

- echinata Murr. = stellulata.

_- elata All. * $55,63,130,152,170,182,183$, $229,275,334,389,413,496,497,498,506$, 517.

- elongata L. 56, 126, 152, 275, 279, 497, 498.

- ericetorum Poll. 129, 145, 146, 202, 252.

- filiformis aut. = lasiocarpa.

- flacca Schreb. = glauca.

- flava L. 116, 152, 170, 206, 224, 229, 238, $274,275,279,334,340,496,498$.

- firma Host. 66, 323, 327, 345, 347, 368, $380,390,394,402,411$.

- fuliginosa Sclik. 327, 344, 348, 392, 394 , $397,400,403,444$.

- glauca Murr. 111, 132, 138, 152, 279, 498.

- Goodenoughii Gay. 56, 97, 100, 111, 130, $152,167,209,275,279,334,340,346,389$.

- gracilis Curt. 130, 138, 152, 183, 206, 279, $298,334,496,498$.

- hirta L. 98, 100, 152, 156, 239, 275, 276, $279,487,493$.

- hordeistichos Vill. 20, 159, 248.

- Hudsonii Benn. = elata.

- humilis Leyss. 101, 124, 133, 136, 138, 155, $184,192,193,202,235,239,244,245,249$, $285,287,312,333,356,404,410,429$.

- irrigua $\mathrm{Sm}$. = magellanica.

- Lachenalii Schk. 396, 397, 399, 400, 403, 417. 
Carex lagopina = Lachenalii.

lasiocarpa Ehrh. 59, 108, 116, 130, 131, $152,181,1 \div 7,: 2111,2116,213,221,271,275$, $298,427,498,523$.

- lepidocarpa Tsch. 202.

- leporina L. 52, *53, 90, 97, 98, 100, 114, $129,130,145,180,184,239,270,275,276$, $342,368,392,412$.

- limosa Schk. 56, 57, 59, 116, 168, 170, 176 , $179,183,209,221,234,252,275,295,298$, $300,341,396$.

loliacea L. * 415 .

magellanica Lam. 116, 173, 176, 207, 213, $219,370,456$.

- Michelii Host. 124, 155, 189, 240, 244, 250, $289,297,306,311,384,404,460$.

montana L. 52, 108, 124, 132, 153, 203, 282, $300,306,311,333,354,411,454$.

muricata L. 104, 249, 270, 282, 486.

- nemorosa Willd. 91, 195, 509, 519, 524

- obaesa All. 512.

- Oederi Retz. 275, 346,490, 512.

-. Pairaei F. Schultz 191.

- pallescens L. 99, 100, 104, 144, 217, 276, 411,412 .

- paludosa Good. = acutiformis.

- panicea L. 100, 111, 131, 152, 181, 200, 239, $275,279,298,334,340,497,498$.

- paniculata L. 152, 202, 229, 239, 279, 498.

- paradoxa Willd. 100, 152, 182, 192, 252, $279,300,389,498,509$

- pauciflora Lightf. 56, 57, " 58, 95, 97, 99, $116,176,178,179,181,209,213,2: 1,: 233$, $341,380,396$.

- pediformis C. May 187, 193, 404.

- pendula Huds. 105, 122, 200, 206, 229.

- pilosa Scop. 124, 143, 144, 228, 240, 249, $297,375,376,382,414,450$.

- pilulifera L. 98, 100, 111, 120, 124, 276.

- polygama Schk. 111, 183, 192, 396, 403.

- praecox Jacq. = verna

- praecox Schreb. 124, 126, 127, 134, 136, $138,250,289,521,524$.

- Pseudocyperus L. 138, 160, 181, 183, 193, 229, 452, 509.

- pulicaris L. 116, 170, 181, 274, 371, 438, 442, 444.

- pyrenaica Wahlenb. 371, 438, 442, 444.

- remota L. 91, 120, 122, 125, 270.

- riparia Curt. 159, 183, 195, 279, 289, 290, $298,309,498,517$.

- rigida Good. 114, 116, 213, 214, 216, 219, 225,389 .
Carex rostrata Willı, 63. 97, 131, 138, 152, $160,181,206,213,275,289,290,298$, $334,427$.

_- rupestris All. 117, 225, 399.

secalina Wahlbg. 159, 195, 202, 508

- sempervirens Vill. 18, 328, 344, 345, 347 , $348,368,389,394,397,411,412,434,444$. silvatica L. 90, 91, 94, 122, 125, 200, 206, $226,230,237,249,270,282,298,303,336$, 442.

- stellulata Good. 57, " $58,95,97,167,192$, $204,206,209,210,213,224,229,231,237$, $239,274,275,341$.

stenophylla Wahlenb. 197, 490, 493, 507, 514. 520.

- stricta = elata.

- strigosa Huds, 417.

- supina Wahlbg. 138, 156, 247, 253, 490, 493, 509 .

- tomentosa L. 204, 289, 334, 350.

- tristis M. B. 411.

- turfosa Fr. 183.

- umbrosa Host. 270 .

- vaginata Tausch. 116, 212, *216, 217, :25.

- verna Vill. 9S, 111, 153, 155, 429.

- vesicaria L. 63, 130, 131, 138, 152, 159, 181, $239,274,275,279,289,290,298,334,496$, 497.

- vulpina L. 152, 195, 239, 279, 309, 334, 389, 496, 497, 498, 524 .

Carlina acaulis L. 153, 230.

- longifolia Rchb. 118, 226.

- simplex W. K. 284.

- vulgaris L. 133, 150, 151, 169, 570.

Carpinus Betulus L. $89,91,92,104,123,124$, $126,138,143,144,146,147,169,184,187$, * $188,189,192,193,204,231,236,240,242$, $246,248,249,250,269,280,282,294,298$, $303,311,312,313,328,329,335,377,378$, $384,386,405,406,408,410,412,426,437$, $441, * 447,448,{ }^{*} 449,450,451,453,456$, $458,460,462,485,510,519,522$.

- duinensis Scop. = orientalis.

- orientalis Mill. $350,352,445, * 447$, * 449.

Carum Carvi L. 98, 111, 131, 133, 152, 153, $251,278,288,298,333,356,377,394$.

Carthamus lanatus L. 459, 507, 556 .

Castalia 63.

- alba (L.) Woodw. et Wood. 141, 160, 181, $183, * 232,335,497,500,517,523,524$; *'T. XIII.

- candida (Presl) Schinz et Thell. 141, 169, $170,181,280,290,296,298$. 
Castalia Lotus (L.) Tratt. 523.

Castanea sativa Mill. 141, 375, 410, 547.

Catabrosa aquatica (L.) Beauv. 465, 496.

Catharinea undulata (L.) Web. et Mohr. 329.

Caucalis daucoides L. 186.

Celtis australis L. 516 .

Centaurea alpestris Heg. 403.

- arenaria M. B. * 489, 492, 521.

- atropurpurea W. K. $364,417,442,445$, $417,453,454$; * T. XLVIII, * T. XLIX.

- austriaca Willd. 270, 300, 305, 340, 384, 401, 413, 424, 428, 450, 451.

- Calcitrapa L. 69, 499.

- Cyanus L. 68, 103, 142, 374.

- Jacea L. 98, 112, 131, 152, 153, 202, 238, $251,278,288,332,334$.

- - Subsp. banatica (Roch.) 355.

- iberica Trev. 446.

- indurata Janka 465.

- Kotschyana Heuff. 361, 364, 366, 417, 429, $431,440,444$.

- Marschalliana Spreng. 284, 285, *304, 306, 313.

- micrantha Gmel. 353, 356, 441, 462, 492.

- mollis W. K. 342, 379, 389, 401, 402, 403, 413.

- montana L. 196.

- - Subsp. mollis (W. K.) = mollis.

- nervosa Willd. $368,429,442,443,444,450$.

- nigrescens Willd. 523.

- orientalis L. 284, 306, 428.

- oxylepis (W. Gr.) Hay. 112, 205, 220.

- pannonica (Heuff.) Hay. 132.

- phrygia L.p.p. = austriaca.

- pinnatifida Schur. 420, 422, * 425, 426.

- pseudophrygia C. A. Mey. 99, 112, 133, 164, $166,168,186,192,199,211,220,234,379$, 431 .

- reichenbachioides Schur. 428, 454; * T. XLIX.

- rhenana Bor. 12, 101, 102, 127, 133, 135, $136,138,153,156,157,183,187,192,193$, $202,239,245,246,305,332,334$.

- ruthenica Lam. 356, * 463, 465, 467.

- Sadleriana Janka 492, 493.

- Scabiosa L. 21, 120, 132, 133, 138, 153, * 155, 156, 278, 289, 332, 333, 403, * 404.

- - Subsp. spinulosa (Roch.) = spinulosa.

- solstitialis L. 312, 484, 505.

- spinulosa Roch. 353, 356, 465.

- stenolepis Kern. 252, 282, 303, 308, 375, $448,459,485$.

- subjacea (Beck) Hay. 239.
Centaurea Tauscheri Kern. 520 .

- trichocephala M. B. f. Simonkaiana Hay. 456 , * 457.

- trinervia Stev. 465, 466, 556; * T. L.

- variegata Lam.184, 191, 192, 245, 306, $368,388,403,407,429,453,459,460$.

Centaurium linearifolium (M. K.) = uliginosum.

- pulchellum (Sw.) Druce. 152, 157, 181, 203, $220,237,354,413,498,507,508$.

- uliginosum (W. K.) Beck 203, 276, 508.

- umbellatum Gilib. 276, 451.

Centrosis abortiva Sw. 519 .

Centunculus minimus L. 187, 220, 276, 462, 507.

Cephalanthera alba (Cr.) Simk. 105, 106, 143, $187,189,192,204,236,242,249,294,312$, $388,379$.

- ensifolia Rich = longifolia.

- longifolia (L.) Fritsch 91, 105, 106, 144, $191,200,218,228,230,233,236,242,249$, $297,379,382$.

- pallens Rich. = alba.

- rubra (L.) Rich. 91, 124, 189, 192, 200, 242, $338,388,389,485$.

Cephalaria laevigata (W. K. = uralensis Murr). $285,356,442,450$.

- radiata Gris. $353,356,448,466$.

- transsilvanica (L.) Schrad. 329, 331, 356, $384,407,507$.

- uralensis Murr. = laevigata W. K.

Cephalozia sp. 130.

- fluitans (Nees) Spruce 209.

Cerastium acutifolium Schur. 433.

- alpinum L. 380, 439.

- anomalum W. K. 484, 494, 513, 514, 518.

- arvense L. 135.

- banaticum (Roch.) Heuff. 447.

- cerastioides (L.) Britton. 346, 400, 402, 437.

- glutinosum Fr. 136, 151, 384, 428.

- latifolium L. 394.

- Lerchenfeldianum Schur. 361, 368, 371, $425,433$.

- macrocarpum Schur. 112, 207, 220, 344, $417,422,443$.

- nemorale Uechtr. 219.

- pumilum Curt. 98.

- semidecandrum L. 136, 151, 154, 276, 428, $491,511,518$.

- silvaticum W. K. 282, 308, 458, 461.

- villosum Baumg. 347, 349, 371, 393, 394, $399,402,425$.

- viscosum L. 483. 
Cerastium vulgatum L. 100, 151 .

Ceratium tripos Schrk. *62.

Ceratocephalus orthoceras DC. = testiculatus.

- testiculatus (Cr.) Kern. 289, 524.

Ceratodon purpureus (L.) Brid. 157.

Ceratophyllum $60,63$.

- demersum L. 141, 160, 259, 290, 380, 500, 517.

- pentacanthum IIayn. 517.

- submersum L. 280.

Cerinthe glabra Mill. 403, 429.

- minor L. 143, 162.

Ceterach officinarum Willd. 179, 196, 197, 354, $408,457,528$.

Cetraria 308, 348 .

- cucullata (L.) Bell. 225, 344.

- islandica (L.) Ach. 100, 114, 225, 343, 344.

- nivalis (L.) Ach. 225.

Chaenorrhinum minus (L.) Lge. 374.

Chaerophyllum aromaticum L. 112, 206, 303, $333,337,424,450$.

- aureum L. 133, 164, 183, 186, 196.

- bulbosum L. 124, 329, 485.

- Cicutaria Vill. 107, 117, 126, 163, 186, 195, $196,224,226,337, * 338,343,364,424$.

- temulum L. 272, 485, 486.

Chamaenerion angustifolium (L.) Scop. 111, 342.

- palustre Scop. 156, 232, 259, 331, 377, 379, $381,510$.

Chamaeorchis alpina ((L.) Rich. 402, 403. Champignon 503.

Chara coronata L. 141 .

- foetida L. 500 .

Chelidonium maius L. 373.

Chenopodium 484.

- album L. 68, 103, 120, 292, 373, 499, 505.

- ambrosioides L. 373 .

- Bonus Henricus L. 103, 120, 292, 373.

- Botrys L. 151, 379, 505.

- capitatum (L.) Asch. 373.

- glaucum L. 159, 292, 354, 499, 505, 513.

- hybridum L. 505.

- murale L. 505.

- opulifolium Schrad. 495.

- polyspermum L. 292, 373.

- rubrum L. 103, 159, 354, 496, 513.

- urbicum L. 16:, 199, 292.

- Vulvaria L. 162.

- Wolffii Simk. 354, *466, 467.

Chimaphila umbellata (L.) Nutt. 94, 145, 186 , $200,203,206,220,230,231,270,295,384$.

Chondrilla juncea L. 101, 136, 154, 156, 276, $442,509$.
Chroolepus iolithus (L.) Ag. 339.

Chrysanthemum alpinum L. 347, 389, 397 , 401.

- corymbosum L. 121, 127, 156, 167, 186 , $187,195,196,201,204,270,284,303,305$, $312,319,329,338,340,342,344,361,368$, $379,410,424,441,466,511$.

- Leucanthemum L. 98, 152, 168, 180, 202, 238, 278, 289, 298, 312, 334, 339, * 340 , $377,424,441,460,493$.

- macrophyllum W. K. 445, 450.

- rotundifolium W. K. 337, 392, 395, 399, $400,424,431$.

- segetum L. 69.

- uliginosum W. K. 488, 506.

- vulgare (L.) Bernh. 148.

- Zawadzkii Herbich. 343, 382, * 383, 384.

Chrysosplenium alpinum Schur. 370, 392, $417,422,439$.

- alternifolium L. 111, 116, 126, 200, 215, 230.

- oppositifolium L. $170,186$.

Cichorium Intybus L. 142, 292, 332, 334, 460. 484, 505.

Cicuta virosa L. $97,127,131,160,170,174$, $181,183,193,231,232,279,290,297,308$, $380,462,497,506,523$.

Circaea alpina L. 105, 106, 126, 163, 173, $180,181,205,206,210,211,219,221$, $299,336,380,381,395,412$.

- intermedia Ehrh. 105, 106, 226, 337.

- lutetiana L. 91, 126, 143, 238, 336, 380, 384.

Cirsium 54.

- acaule (L.) Web. 124, 132, 135, 138, 166 , $169,170,192,201,202,206,377$.

- arvense (L.) Scop. 103, 124, 142, 147, 150, 161, 259, 331, 342, 374, 493, 506.

- Boujarti Pill. et Mitterb. 289.

- brachycephalum Jur. 498, 506, 508, 509, 511,512 .

- bulbosum (Lam.) DC. 202.

- canum (L.) M. B. 98, 100, 111, 131, 152, $157,180,193,204,237,238,239,242,251$, $279,288,334,384,498,507,509,518$.

- decussatum Janka 424.

- criophorum (L.) Scop. 124, 138, 342, 376, $381,384,420,493,507$.

- Erisithales (L.) Scop. 235, 282, 328, 340, $342,343,364,380,386,390,392,400$, $405,407,412,413,420,426,429,438$, 450,451 .

- furiens Gris. 350, 454. 
Cirsium heterophyllum (L.) Hill. 99, 103, 106 , 1169, 1]1, [164, 166, 16is, 169, 171, 1ะ1

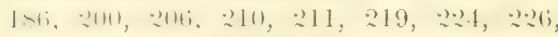
225, 234, 236, 339, 361, 392, 399, 422.

- Ianceolatum (L.) Scop. 103, 289, 292, 331, 334, 342, 372, 493, 505.

- oleraceum (L.) Scop. 98, 100, 111, 131, 148, $152,230,238,239,251,278,279,290,334$, $361,384$.

- palustre (L.) Scop. 100, 107, 131, 152, 180 , $193,202,290,331,334,340,377,462,498$, 509.

- pannonicum (L.f.) Gaud. 127, 136, 190 , $192,196,238,249,251,287,289,3111,31:$ $333,376,384,458,459,498,507$.

- pauciflorum (W. K.) Spr. 323, 361, 364, $412,414,419,438, * 439$.

- rivulare (Jacq.) All. 112, 152, 204, 205, 226, $231,237,239,242,278,279,292,294,334$, $340,380,384,390,394,403$.

- spathulatum Mor. 305, 511, 519.

Cistus 11.

Citrullus vulgaris Schrad. (Wassermelone) 503.

Cladium Mariscus (L.) R. Br. 202, 203, 334, $392,427,496,498$.

Cladonia $129,186$.

- furcata (Huds.) Fr. 94, 488.

- gracilis (L.) Coem. 102.

- pyxidata (L.) Fr. 114.

- rangiferina (L.) Hoffm. 94, 100, 114, 121, 128, 225, 368.

- silvatica (L.) Hoffm. 225.

- squamosa Hoffm. 94.

\section{Cladophora 60 .}

Clematis alpina (L.) Mill. 381, 389, 394, 395, $400,405,413,442,451,453$.

- integrifolia L. 147, 255, 287, 288, 304, 306, $331,385,488,498,509,515,519$.

- recta L. 124, 127, 167, 190, 192, 202, 245, $250,251,284, * 287,294,301,303,305$, $307,312,376,511$.

- Vitalba L. 143, 1.17, 148, 150, 243, 284, $329,350,352,379,428,441,445,486,488$, $510,511,519,527$.

Clinopodium vulgare L. = Satureia vulgaris

Cnicus Benedictus L. 505.

Cnidium apioides Spr. 364, 429, 453, 454; * T. NLIX.

- venosum (Hoffm.) Koch. 203, 252, 272, 297,462 .

Cobresia bipartita (Bell.) D. T. 397.

Cochlearia cxcelsa Zahlbr. 348, 392, 397, * 398 , 100; * T. XXXII.
Coeloglossum viride (L.) Hartm. 99, 111, 133, $186,344,388$.

Colchicum arenarium IV. K. 482, 493, 525.

- autumnale L. 98, 111, 131, 168, 230, 236, 238, 241, 251, 278, 293, 334, 493, 509.

Coleanthus subtilis Seidl. 139, 181, 183, 187, 232, 233, 245.

Collema cheileum Ach. 137.

— multifidum (Scop.) Körb. 137.

- plicatile Ach. 137.

Colutea arborescens L. 235, 240, 410, 447.

Comandra elegans Rehb. *525, 526, 527.

Comarum palustre $\mathrm{L}=$ Potentilla palustris.

Conioselinum tataricum Fisch. 109, 111, 117, $220,223,226, * 227,293,361,364,403$, 419,420 .

Conium maculatum L. 120.

Conringia orientalis (L.) Rehb. 462.

Convallaria maialis L. $90,104,121,147,166$, $240,376,410,488$.

Convolvulus arvensis L. 120, 333, 506.

- tenuissimus Sibth. Sm. 447.

Coralliorhiza innata $\mathrm{R} . \mathrm{Br} .=$ trifida.

- trifida Châtelain 91, 98, 105, 173, 221, 230, $336,400$.

\section{Corispermum 467.}

- canescens Kit. 488, 510, 515, 521.

- hyssopifolium L. 519.

- nitidum Kit. 488, * 491, 509, 511, 515, 519,521 .

Cornicularia aculeata Schreb. 128, 348.

- tristis (Web.) Ach. 70, 117, 370.

Cornus * 188, 193, 249, 429.

- Mas L. $126,143,147,148,189,197,280$, $284,311,328,331,410,453,454,458,460$, $461,519,524$; * T. XLIX.

- sanguinea L. $90,104,124,125,126,138$, $143,147,148,189,203,239,240,280,311$, $331,408,410,454,460,462,485,510,519$.

Coronilla Emerus L. 148, 353, * 447.

- elegans Panč. 413, 417.

- montana L. 156.

- vaginalis L. 198.

- varia L. $124,153,154,156,177,191,289$, $308,329,331,332,353,441,493$.

Coronopus didymus (L.) Sm. 518.

- procumbens Gilib. 192.

Corrigiola litoralis L. 198.

Cortusa Mathioli L. $348,392,399,400$, * 402 , $405,433, * 434,440$.

- pubens Sch. N. K. 422.

Corydalis capnoides Wbg. 333, 405, 420.

- cava (L.) Schw. et K. 90, 124, 143, 201, 
203, 204, 226, 230, 238, 249, 297, 308, 311, $329,336,376,379,382$.

Corydalis intermedia (L.) P. M. E. 211, 238, 450 - solida (L.) Sw. 124, 143, 147, 220, 228, $233,250,297,308,311,375,378,379,384$, 388.

Corylus Avellana L. 90, 92, 123, 126, 144, $147,148,166,177,187, * 188,191,193$, $203,204,234,240,270,280,311,330,331$, $337,386,406,410,412,437,447,453,454$, $460,485,510,519,521$; * T. XLIX.

- Colurna L. 350, 445.

- Lubulosa Willd. 447.

Corynephorus canescens (L.) Beauv. 20, 98, $128,146,151,154,196,200,202,204,246$, $252,254,255,270,276, * 277, * 278,292$. $293,294,296,297,300,330,467,509$.

Cosmarium Botrytis (Bory) Menegh. * 62 .

Cotinus Coggygria Scop. 185, 255, 329, 350 , $352,384,407,445,{ }^{*} 447,521,527$.

Cotoneaster integerrima Med. 117, 136, 138, $178, * 197,199,238,244,245,342,387$, 454,462 ; * T. VI.

- nigra Ehrh. 284, 285, 300, * 304, 306.

- tomentosa Ldl. 342, 454.

Crambe aspera M. B. 356, 465, 466, 467.

- tatarica Sebeök. 249, *254, 408, 458, $460,525$.

Crassula aquatica (L.) Schönl. 139, 180, 187, 232.

- Magnolii DC. 354.

Crataegus 303, 352, 406, 429, 456.

- melanocarpa M. B. 445.

- monogyna Jacq. 143, 147, 197, 270, 271, $280,281,330,458,460,462,485,516,519$, $5: 7$.

- nigra W. K. 493, 516, 519.

- Oxyacantha L. 123, 129, 143, 145, 185, 189 , $193,197,203,240,249,330,386,451,456$, $460,488,493,516,519$.

Crepis alpestris (Jacq.) Tausch. 389.

- aurea (L.) Cass. 18.

- biennis L. 98, 131, 152, 251, 279, 289, 334, 486.

- blattarioides (L.) Vill. 215.

- chondrilloides Jacq. 12.

- conyzaefolia (Gou.) D. T. 114, 215, 219, $225,344,388,399,400,403$.

- foetida L. 276, 284.

- grandiflora All. = conyzaefolia.

- Jacquinii Tausch. 343, 347, 394, 403, 422 , 437.

- mollis (Jacq.) Asch. 114, 212, 225, 403.
Crepis paludosa (L.) Mnch. 126, 163, 178, 230, $231,251,252,279,290,339,340,379,450$.

- pannonica (Jacף.) Koch. (= rigida W. K.) 249, 306, 407, 450, 461.

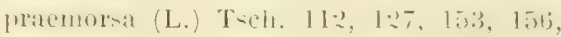
$171,189,193,203,239,240,252,300,356$, $376,379,405$.

- rhoeadifolia M. B. $133,135,156,186,193$, il1, 5:24.

- rigida $\mathbf{W} . \mathbf{K} .=$ pannonica.

- setosa Hall. f. 442, 467, 518.

- sibirica L. 109, 117, 207, 226, * 227, 25:?, $284,305,323,386$.

- succisaefolia Tsch.99, 112, 166, 170, 174, $180,183,201,217,231,233,234,210,34 \%$, 411.

- tectorum 1. 131, 151, 156, 15\%, 29:.

- visciclula Tsch. 368, 429, 443, 444.

Crocus banaticus Gay. 287, 361, 419, 452, 454.

- banaticus Heuff. $=$ Heuffelianus.

- iridiflorus Heuff. = banaticus Gay.

- Heuffelianus Herb. 111, 228, 300, 309, 311,334 , *339, 361, 368, 404, 417, 431, $452,456,461$.

- reticulatus $\mathrm{M}$. B. 516 .

- veluchensis Herb. 419.

Crypsis aculeata L. * 158, 159, 248, 253, 408, $445,484,495,508,509,513,514,517,519$.

Cucubalus baccifer L $102,125,150,282,292$, $378,517$.

Cucumis Melo L (Melone) 291, 273, 503.

- sativus L. 373 .

Cucurbita Pepo L. 291, 373.

Cuscuta Epilinum Whe. 120.

- Epithymum (L.) Murr. 156.

- europaea L. (Gurke) 331.

Cyanophyceen 60.

Cyclamen europaeum L. 145, 177, 213, 245, $248,323,336,358,388$.

Cyclotella comta Kütz. "62.

Cynanchum Vincetoxicum L. 127, 136, 157, $190,203,206,238,245,253,332,376,384$, $404,413$.

Cynodon Dactylon L. 156, 159, 333, 356, 384, $488, * 490,505,507,521,524$.

Cynodontium virens Schimp. 189.

Cynoglossum germanicum Jacq. = montanum L.

- hungaricum Simk. 492, 511.

- montanum L. 242, 303, 375, 384.

- officinale L. 151, 292, 448.

Cynosurus cristatus L. 98, 131, 163, 251, 287. 289, 334. 
Cyperus flarescens L. 139, 160, 184, 187. fuscus L. 139, 160, 181, 203, 251, 252, 279, 508

pannonicus Jacg. 494, 495, 508, 519, 520.

Cypripedium Calceolus L. 189, 192, 255, 294, $303,312,338,375,379,388,389,456$.

Cystopteris fragilis (L.) Bernh. 101, 136, 206, $342,343,417, * 434$.

- montana (Lam.) Bernh. 420, 421.

- regia Presl. 402.

- sudetica A. Br.et Hilde $207,222,225$, * 227, 229, 337, 381, 394, 402, 420.

\section{Cytisus 510 .}

- albus Hacq. 155, 287, 312, 352, 353, 413, $450,451,462$.

- alpestris Schur. 4:24.

- austriacus L. $202,203,240,407,488,492$.

- banaticus Roch. 352, 353.

- elongatus W. K. 353.

- Heuffelii Wierzb. 312, 450.

- hirsutus L. 124, 270, 312, 416, 458.

- Kitaibelii Vis. 148, 155, 179, 236, 255, 332, 408.

- leiocarpus Kiern. 450, 451.

- leucanthus W. K. 284, 303, 305, 308, 312, $408,424,441,442,458,460,466$.

- leucotrichus Schur. 312, 429.

- nigricans L. 90, 101, 124, 135, 145, 148, 153, $155,168,169,170,177,179,182,185,191$, 193, 201, 202, 203, 220, 235, 236, 244, 249, $250,252,255,281,257,295,296,298,303$, $307,312,329,330,331,332,352,353,386$, $407,429,458,459,460,461$.

- pallidus Schrad. 332, 352, 353, 428, 462.

- polytrichus M. B. 459.

- procumbens (IV. Ki.) Spr. 244.

-. ratisbonensis Schäff. 182, 228, 235, 239, 242, 244, 252, 403, 404, 488, 492.

- Rochelii Wierzb. 312, 459.

- ruthenicus Fisch. 270, 284, *286, 299, 303, 305,307 ,

- serotinus Kit. 413 .

- supinus L. 143, 145, 148, 155, 191, 226, $228,238,239,296,329,330,376,378,485$.

\section{D.}

Dactylis Aschersoniana Gräbn. 104.

- glomerata L. 91, 98, 107, 111, 131, 132, 136, $143,152,153,270,271,280,331,333,394$, $458,485,486,493$.

Danthonia calycina (Vill.) Rehb, 353, 354, 408. Daphne Arbuscula Čcl. 404, * 406.
Daphne Blagayana Frey, 429, 433.

- Cneorum L. 189, 249, 270, 300, 388, 389.

- Mezereum L. 91, 93, 120, 122, 163, 178 , $186,230,282,336,404,411,413,424,450$.

Datura Stramonium L. 505.

Daucus Carota L. 131, 132, 138, 153, 278, $334,356$.

Delphinium Consolida L. 68, 103, 161, 505. - clatum L. 109, 111, 117, 180, 207, 212, 213, $214,218,219,222,223,225,338,339,342$, $343,364,376,390,400,414,422,426,431$, $435,444,453$.

- fissum W. K. 429, 433, 445, 459.

- oxysepalum Borb. et Pax. 322, 338, 339, $343,390, * 391,402$.

- orientale Gay. 519.

- peregrinum L. 506.

Dentaria $=$ Cardamine

Dermatocarpon Michelii Th. Fr. 102, 236.

\section{Deschampsia 231 .}

- caespitosa (L.) Beauv. 54, 90, 99, 100, 111 , $112,125,126,127,130,131,138,147,152$, $181,207,216,225,238,239,250,270,272$, $276,279,287,330,334,336,339,340,342$, $343,344,386,411,412,417,461$.

- flexuosa (L.) Trin. 52, * 53, 90, 98, 99, $100,106,109,114,120,124,128,130,143$, $144,163, * 167,171,173,177,185,186$, $195,200,202,207,211,225,252,270,271$, $276,330,336,342,368,377,386,456,461$.

Desmatodon latifolius (Hedw.) Br. Sch. G, 225. Desmidiaceen 60.

Descureinia Sophia (L.) Webb. 148, 373, 505. Dianthus alpinus L. 18, " 19.

- Armeria L. 111, 124, 128, 192, 270,410, 485.

- Armeriastrum Wolfn. 441.

- Balbisii Ser. 354.

- banaticus (Heuff.) Borb. 353, 354.

- borussicus Vierh. 276, 294, 300.

- caesius $\mathrm{Sm} .=$ gratianopolitanus.

- callizonus Schott. 370,435 , * 436 .

- capitatus DC. 285, * 304, 306, 308, 312.

- Carthusianorum L. 121, 128, * 132, 133, $134,135,138,151,153,155,156,187,193$, $196,202,220,225,226,238,240,242,245$, $247,248,250,278,285,305,308,332,342$, $356,379,404,429,454,460,464$.

- - var, hannensis Podp. 239.

- collinus W. K. 287, 332, 405, 406, 407, 408.

- compactus Kit. * $360,361,411,417,419$, $420,440,444,457$.

- deltoides L.94, 100, 103, 128, 131, 173, 
$177,180,183,187,192,201,207,225,226$, $228,230,276,278,289,292,308,377,404$, 408.

Dianthus diutinus W. K. (= polymorphus aut.) $511,5: 1,5: 4$

- gelidus Schott. 309, 323, 328, 367, 419, $420,434,439,440,442$.

- giganteus Urv. 353, 442, 450, 459.

- glacialis L. 18, * 19, 327, 344, 348, 392, $399,400,401$.

- gratianopolitanus Vill. (= caesius Sm.) $136,138,187$, * 188,193, " $194,{ }^{*} 197,200$

- Henteri Heuff. 441 .

- hungaricus Pers. 327, 342, * 385, 389, 390, 393, 403, 411.

- integripetalus Schur. 442.

- Kitaibelii Janka 445.

- Lumnitzeri Wiesb. "375, 376.

- marisensis Simk. 451.

- nitidus IV. K. 386,390 , " 391 .

- petraeus W. K. 354, 364, 390.

- plumarius L. 253.

- polymorphus aut. = diutinus.

- Pontederae Kern. 153, 251, 376, 407.

- pseudoserotinus Blocki 289, 294, 306, 312.

- saxigenus Schur. 424, 462.

- serotinus W. K. 154, 179, 256, 289, 459, $489, * 491,507,509,511$.

- silvaticus Hoppe $90,100,164, * 165,166$, $169,170,180,186,200,205,207$.

- speciosus Rchb. 113, 212, 217, 219, 419, 422,461 .

- spiculifolius Schur. 328, 353, 364, 417, 421, $429, \quad 430,431,437,445,451,453,454$.

- superbus L. 104, 133, 152, 196, 202, 239, $275,279,294,297,426,428,486,517$.

- tenuifolius Schur.429, 435.

- trifasciculatus Kit. 353, 441.

Diatomaceen 60.

Dichostylis Micheliana (L.) Nees. 251, 521.

Dicranella cerviculata (Hedw.) Schimp. 115, 274.

- squarrosa (Starke) Schimp. 102, 196.

- subulata (Hedw.) Schimp. 102, 196.

Dicranodontium longirostre (Starke) Schimp. $101,120$.

Dicranoweisia Bruntoni Schimp. 101.

Dicranum albicans Br. Sch. G. 344.

- palustre Br. Sch. G 95, 130, 274.

- Schraderi Web. et Mohr. 116.

- scoparíum (L.) Hedw. 94, 144, 208, 225.

- Starkei Web. et M. 119.

- undulatum Ehrh. 225, 274.
Dictamnus albus L. 127, 155, 184, 190, 193 $198,240,244,248,253,287,306,312,332$ $356,376,379,410,456,461$.

- - var. gymnostylis Borb.462.

Digitalis ambigua Murr. 105, 106, 117, 127 $177,189,193,200,206,211,: 219,236,249$ $255,270,282,294,303,307,330,332,336$ $338,358,364,374,375,376,386,389,392$ $405,410,412,441,461$.

- ferruginea W. K. 356.

- lanata W. K. 350, 356, 407, 445.

- purpurea L. 165, 172, 205, 207, 232, 293, 379; T. SIV.

Digitaria ciliaris Pers. 151, 154, 252, 488, 499.

- filiformis Koel. 276, 292, 294.

- linearis Krock. $=$ filiformis

- sanguinalis (L.) Scop. 499.

Dinobryon divergens Imliof. "62.

Diplachne serotina (L.) Lk. 235, 408, 442.

Diplotaxis 120.

- muralis (L.) DC. 162.

- tenuifolia (L.) DC. 155, 162.

Dipsacus fullonum L. (= silvester Huds.) 285, $292,498,505$.

- laciniatus L. 196, 505.

- pilosus L. 148, 239, 272, 329.

Disciseda debrecinensis Holl. 493.

Dissodon Froelichianus (Hedw.) Greve et Arn. 343.

Ditrichum homomallum (Hedw.) Hampe 196.

Doronicum austriacum Jacq. 94, 109, 111, 117, $172,175,176,178,180,183,219,221,224$, $225,226,233,308,338,342,343,361$, * $363,364,379,388,392,400,412,414$, 432, 438, 444, 457, 462 .

- carpaticum(Griseb.) 323, 370, $417,439,441$.

- caucasicum M. B. 180.

- Clusii (All.) Tsch. 348, 389, 392, 397, 419, 437; " T. XLII.

- cordatum WVulf. 358, 445, 451.

- hungaricum Rchb. 442, 456, 458, 485.

- Matthioli Tsch. 183, 450.

Doryenium herbaceum Vill. 352, 353, 356, 405, $461,464$.

- germanicum (Gremli) Rouy.428.

- suffruticosum aut. = germanicum.

Draba aizoides L. $342,370,380,390$.

- carinthiaea Hoppe 371, 419, 420, 442.

- compacta Schott. 328, 370, 371, 429, 434, 435.

- Dorneri Heuff. 444.

- Haynaldi Stur. 370, 371, 429, 435.

- Kotschyi Stur. 371, 4341), 435, 441.

1) Conf. Corrigenda. 
Draba lasiocarpa Roch. 332, 364, 377, 384, * $385,386,410,445,447$.

- muralis L. 187.

- nemorosa L. 276, 285, 287, 462

- tomentosa Wahlenb. 402, 403.

- verna L. 151, 154, 157, 331, 462, 484.

Dracocephalum austriacum L. $136,189,190$, $284,285,303,404,429,454$.

- Ruyschiana L. * 286, 287, 300, 301.

Drosera 120, 234, 275, 498.

- anglica Huds. 57, 59, 97, 116, 130, 229, 231, 274, 295, 300 .

— intermedia Hayne * 58, 59, 116, 295.

- rotundifolia L. 57, *58, 59, 94, 97, 116 , $130,166,178,200,206,219,229,230,231$, $232,233,274,295,300,341,378,380,396$, $400,403,417,422,427,460$.

Dryas octopetala L. $38,345,347,371,380$, $390,394,421$.

Dryopteris cristata (L.) A. Gray. 126, 181, 204, $272,274,294,295$.

- dilatata (Hoffm.) A. Gray 105, 221, 400.

- Filix mas (L.) Schott. 93, 100, 105, 106, $120,144,163,186, * 195,206,209,221$, $230,270,282,330,337,342, \quad$ * 363,377 , $381,407,414$.

- Linnaeana Christens. * 92, 105.

- montana (Vogl.) O. Ktze. = Oreopteris.

- Oreopteris (Ehrh.) Max. * 92, 93, 105, 106 , $147,206,217,330,337,438$.

- Phegopteris (L.) Christ. (= polypodioides err. cal.) 105, 144.

_ rigida (Hoffm.) Underw. 66.

- Robertiana (Hoffm.) Christens. 342, 420, $442,451,452$.

- spinulosa (Müll.) O. Ktze. 93, 105, 106, 118 , $126,147,163,181,186,226,230,231,282$, $337,343,377,506$.

- Thelypteris (L.) A. Gray. 95, 181, 182, 239, $\because 72,295,298,413,496,494,506,509$ $5: 3$.

\section{E.}

Eberesche $=$ Sorbus

Echinops banaticus Roch. 352, 353, 448, 526.

- commutatus Jur. 285, 289, 305, 306, 428 , $453,460$.

- Ritro aut. = ruthenicus.

- rulhenicus M. B. 248, 255, 285, 353, 448, $459,493$.

- sphaerocephalus L. 246, 284, 285, 306, 505.

Echium altissimum Jacq. 410, $515,521$.
Echium rubrum Jacq. 153, * 244, 247, 249, $255,287,289,305,306,312,332,356,459$, $462,464,465,485,515$.

- vulgare L. 133, 150, 156, 157, 332, 429, $441,507,521$.

Edelwei $=$ Leontopodium alpinum.

Edraianthus graminifolius (L.) DC. 364, 445, 447,455 .

Efeu = Hedera Helix

Elatine Alsinastrum L. 160, 193, 195, 204, 280, 519.

- ambigua Moesz. 428.

- hexandra DC. 139, 187, 193, 200, 233, 280.

- Hydropiper L. 139, 140, 187, 193, 200, 297, $300,524$.

- triandra Schk. 139, 193, 231, 233, 293, 524.

Elodea canadensis Rich. 68, 141, 511.

Elymus arenarius L. 276, 291, 297, 524.

- europaeus L. = Hordeum europaeum.

Elyna Bellardii (All.) Sink. 402, 403, 435, 444,

Empetrum nigrum L. * 14, 57, 97, 116, 130, $170,176,181,209,213,217,272,341,346$, $369,379,388,420,427$.

Encalypta contorta (Wulf.) Lindb. 189.

- rhabdocarpa Schwägr. 119, 225.

Endopyrenium rufescens (Ach.) Körb. 137.

Ephedra 12, *13.

- distachya L. 306, 454, 484, 493, 511.

Epilobium 38.

- adnatum firis, 275.

- alpestre Jacq. 111, 117, 166, 218, 219, 224, $343,376,380$

- alsinefolium Vill, 116, 218, 219, 339, 346, $369,380,400$.

- anagallidifolium Lam. 116, 224, 343, 346, 400.

- angustifolium $\mathrm{L}_{\text {. }}=$ Chamaenerion angustifolium.

- Dodonaei Vill. = Chamacnerion palustre.

- hirsutum L. 138, 279.

- Lamyi F. Schultz. 523.

- montanum L. 94, 270, 342, 450.

- nutans Tausch. 116, 219, 224, 234, 369.

- palustre L. 95, 231, 275, 334, 340.

- parviflorum Schreb. 126, 280.

- trigonum Schrk. = alpestre.

Epipactis atropurpurea Raf. 105, 200, 203.

- latifolia (L.) All. 105, 120, 189.

- palustris (L.) Cr. 100, 152, 239, 279, 290.

Epipogon aphyllus (Schw.) Sw. 105, 229, * 250, $390,438$.

\section{Equisetum 12.}

- arvense L. 120 . 
Equisetum limosum L. 43, 45, 63, 138, 181 , 193, 279, 334, 497.

- maximum Lam. 380.

- palustre L. * 13, 131, 152, 279, 334.

- pratense Ehrh. 211, 279, 293.

- ramosissimum Desf. 523.

- silvaticum L. 105, 196, 270.

Eragrostis minor Host 151.

- pilosa (L.) Beauv. 151.

Erechtites hieracifolius Raf. 68, 69.

Ericaceen 282, 493.

Erica carnea L. " $14,166,169,170,178,186$, 235.

Erigeron acer L. 342.

- atticus Vill. 348, 433.

- canadensis L. $68,128,151,156,252,276$, 284, 292, 333, 373.

- hungaricus (Vierh.) 348.

- racemosus Baumg. 364.

- uniflorus L. 328, 369, 370, 439.

\section{Eriophorum 63.}

- alpinum L. = Trichophorum alpinum.

- angustifolium Roth. 100, 130, 131, 152, $237,275,279,334,340,389,498$.

- gracile Koch. 116, 207, 298, 380, 427.

- latifolium Hoppe 100, 111, 130, 131, 275, $279,334,340,389$.

- Scheuchzeri Vill. $341,346$.

- vaginatum L. 54, 57, *58,95,97, 116 , $130,131,166,168,170,176,181,187,200$, $206,209,210,213,221,233,234,272,274$, $275,341,379,380,415,427,498$; “ T. III, * T. VIII.

Eritrichium nanum Schrad, = terglouense.

- terglouense (Hacq.) Kern. 371, 420, 422, $431,434,435$.

- - Subsp. Jankae (Simk.) 426.

Erodium cicutarium (L.) L'Her. 333.

- Neilreichii Janka 511, 519.

Erucastrum elongatum Rchb. 189.

\section{Eryngium 484.}

- campestre L. 133, 135, 156, 204, 289, 306, $331,518,521$.

- planum L. 252, 256, 288, 289, 294, 298, 306, $307,308,407,408,507,524$.

Erysimum canescens Roth. 101, 154, 155, 156 , $157,179,235,252,353,459,464,487,489$, $492,507,511,512,518,521,524,525$.

- crepidifolium Rehb. 119, 138, 186, 193, * $194,197,410$.

- durum Presl. 166, 192, 196, 197, 254.

- erysimoides (L.) Fritsch 127, 135, 189, 192, $285,298,304,306,405,410,429$.
Erysimum exaltatum Andrz. 308

- pallescens IIerbich 285 .

- pannonicum $\mathrm{Cr} .=$ erysimoides.

- repandum L. 192, 505.

- Wahlenbergii (Asch. et Engl.) Simk. 403.

- Wittmanni Zaw. 343, 382, " 383, 389, 408, 420,425

Erythronium Dens canis L. 171, 179, 187, 431, $450,454,458,460$.

Esche $=$ Fraxinus excelsior.

Euclidium syriacum R. Br. 289, 505.

Eupatorium cannabinum L. 147, 148, 150, 198, $239,329,331,335$.

Euphorbia acuminata Lam. 162.

- amygdaloides L. 105, 106, 144, 204, 210, $220,221,236,249,255,311,329,376,377$, $378,389,407,428,450,485$.

- angulata Jacq. 187, 236, 244.

- Cyparissias L. 133, 146, 151, 155, 252, 373, $413,433,515,521$.

- dulcis L. 105, 120, 122, 190, 200, 209, 226, 236,377 .

- falcata L. 162, 143.

- exigua L. 374.

- Gerardiana Jacq. 154, 196, 245, 249, 289, $305,356,489, * 491,492,494,505,507$, $508,511,512, * 513,515$, * $516,517,518$, $521,524$.

- glareosa M. B. 289.

- gracilis Bess. 306

- helioscopia L. 373, 374, 505.

- lucida WV. K. 160, 252, 289, 294, 297, 301, $312,507,519,521,524$.

- Myrsinites L. 447.

- palustris L. 152, 241, 252, 279, 294, 297, $498,511$.

- pannonica Host. 492, 505 .

- pilosa = villosa.

- polychroma Kern. 338, 375, 388, 404, 485.

- salicifolia Host. 448.

- stricta L. 331, 342, 378, 379, 381 .

- villosa W. K. 152, 239, 289, 294, 297, 309 , $312,498,506$.

- virgata W. K. 160, 284, 521.

- tristis Bess. 289, 305, 308.

Euphrasia 26, 43, 51.

- coerulea Tausch. 112, 113.

- curta Fr. 207, 211.

- gracilis Fr. 98.

- minima Jacq. 220, 422.

- picta Wimm. 113, 207, 218.

- Rostkoviana Hayne 52, 111, 202, 276, 278, 279,334 . 
Euphrasia salisburgensis Funck. 342, 344, 345, $347,381,386,389,390,419,429,442,444$, 451 .

- stricta Host. 150, 153, 278, 411.

Eurotia ceratoides (L.) C. A. Mey. " 247.

Evonymus 249, 330.

- latifolius (L.) Scop. 282, 442.

- nanus M. B. 303, * 415, 417.

- verrucosus Scop. 143, 145, 148, 270, 280, $282,284,311,328,330,336,352,384,386$, $406,426,441, * 447,460,462,485$.

- vulgaris (L.) Scop. 90, 123, 127, 143, 145, $147,148,203,270,280,284,309,311,313$, $328,330,352,386,404,406,426,458,460$,

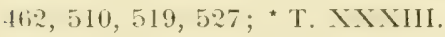

\section{F.}

Fagopyrum esculentum Gilib. (Buchweizen) $160,290,502$.

Fagus silvatica L. (Buche) 35, 89, 90, 91, 94, $104,105,108,120,122,123,143,144,163$, $166,167,170,171,173,175,177,178,185$, $186, * 195,204,206,210,211,218,221$, $223,225,233,234,236,240,245,248,249$, $269,280,282, * 283,294,297,298,300$, *302, 308, 309, *310,311, 312, 321, 329, $335,336,350,356,374,375,376,377,378$, $379,381,382,384,386,387,388,389,390$, $395,403,404,407,408,410,411,412,413$, $420,422,424,426,427,428,430,431,437$, $441,444,445,447,448,450,451,453,454$, $456,457,458,461,462$; * T. IX.

Falcaria vulgaris Bernh. 133, 143, 187, 239, 292.

Ferula Heuffelii Griseb. 364, 445, 447.

- Sadleriana Led. 408, 454.

Ferulaga silvatica (Bess.) Rchb. 282, * 287, $303,305,306,350,413,445,447,451,454$, $458,462$.

Festuca alpina Sut. 344.

- apennina Dnt. 420.

- arundinacea Schreb. 127, 148, 272, 331, 334.

- capillata Lam. G. E. Sur. 182.

- carpatica Dietr. 419, 420.

- Iuriuscula L. 111, 114, 132, 134, 136.

- elatior L. $98,111,131,152,153,251,278$, $289,304,333,334,354,356,464$.

- flavescens Host, = xanthina.

- rigantea L. 91, 107, 120, 125, 143, 147 , $185,195,196,204,249,250,272,280,303$, $331,336,458,486,517,524$; “T. XXXIII.

- glauca Lam.134, 136, 151, 155, 177, 184, - $188,189,190, * 197,246,253,332,342$.
Festuca glauca var. psammophila Hack. 128.

- heterophylla Lam. 104, 106, 120, 191, 255, 280, 292, 303.

- ovina L. $52,98,104,114,128,136,150$, $182,184,206,230,252,300,333$.

- picta Kit. 327, 348, 402, 424.

- Porcii Hack. 368, 417, " 418, 419, 422.

- pseudovina Hack. 304, 306, 494, 513, 514, $518,521,{ }^{*} 522$.

- pumila Vill. 394.

- rubra L. 99, 100, 111, 153, 180, 278, 339.

- silvatica Vill. 91, 93, 105, 107, 108, 163, $171,183,186,205,206,217,218,221,226$, $237,260, * 305,377,437,438,442,460$.

- sulcata (Hack.) Richt. ' 33, 133, 134, 135, $136,146,151,153,155,202,247,331,333$, 493, 511 .

- supina Schur. 114, 225, 344, 368, 397.

- Tatrae (Csakó) Deg. 344, 402.

- vaginata W. K. $151,154,179,252,256$, $294,333,465,482,{ }^{*} 483,487,490,493$, $511, * 513, * 514,520,524$.

- vallesiaca Sch1. 253, 285, 353.

- varia Haenke 117, 212, 214, 215, 217, 219, $344,348,380,399$, * 402 .

- xanthina R. S. (flavescens Host.) 354, 364. Fichte $=$ Picea excelsa.

\section{Filago 484.}

- apiculata G. E. Sm, 333.

- arvensis L. 169, 333, 428.

- germanica L. 333.

- montana L. 128, 146, 156, 276, 300, 333, 509.

Filipendula hexapetala Gilib. 21, 133, 135, 202, $278,289,307,332,356,441,464$.

- Ulmaria (L.) Max. 107, 126, 127, 128, 138, $147,148,160,163,181,239,279,284,334$, $428,488,498$.

Flachs $=$ Linum usitatissimum.

Föhre $=$ Pinus silvestris.

Fragaria collina Ehrh. = viridis.

- vesca L. $300,342$.

- viridis Duch. 127, 301, 485, 493,

Fragilaria virescens Ralfs. * 63 .

Fraxinus excelsior L. (Esche) 89, 91, 146, 166, $195,238,239,240,250,272,330,407,408$, 488, 519.

- Ornus L. (Mannaesche) 18, 350, 352, 408, $410,429,442,445,447,448,456$.

- oxycarpa Willd, 280, 282, 308.

Fritillaria Degeniana J. Wagn. * 526, *527.

- Meleagris L. 158, 289, 297, 298, 303, 308, 309. 
Fritillaria tenella M. B. 454, 460, 461.

Fumana procumbens (Dun.) Gr. G. 492, 493, 511.

Fumaria Reuteri Boiss, 354.

- Vaillantii Lois 156.

\section{G.}

Gagea bohemica (Zauschn.) R. et S. 244, 247. $248,374$.

- lutea (L.) Ker. 90, 91, 143, 147, 148, 207, $239,250,272,311,330,355$

- minima (L.) Ker. 124, 297, 388, 403.

- pusilla (Schm.) R. S. 151, 154, 179, 482, 493, 511,521 .

Galanthus nivalis L. 125, 144, 195, 220, 228, $238,240,259,270,282,293,298,303,308$, $330,334,358,379,388,431,448,458,460$, 506 ; * T. XXII.

Galega officinalis L. 152, 203, 252, 254, 413, 458, 518, 524 .

Galeobdolon luteum = Lamium luteum und vuIgare.

Galeopsis angustifolia Ehrh. 276, 277.

-- Ladanum L. 151.

- speciosa Mill. 90, 91, 238.

- versicolor Curt, = speciosa.

- Tetrahit L. 374.

Galium 51, 66.

- anisophyllum Vill, 212, 215, 380.

- - var. sudeticum (Tausch.) 117.

- Aparine L. 147, 331.

- boreale L. 111, 133, 152, 231, 278, 458.

- capillipes Rchb. 441, 445.

- constrictum Chaub. 446.

- Cruciata L. 278, 378, 379.

- erectum Huds. 332, 353, 356.

- flavescens Borb. 353, 442, 450.

- hercynicum Weig. 100, 104, 163, 166.

- lucidum All. 416, 426, 455.

- Mollugo L. 127, 131, 152, 153, 278, 332, 377.

- palustre L. 126, 152, 182, 279, 280, 413, 498.

- pedemontanum All. 384, 408, 442, 493.

- purpureum L. 451.

- rotundifolium L. 104, 106, 230, 270.

- rubioides L. 428, 510, 512.

- Schultesii Vest. 270, 303, 308, 336, 414, 424, $429,438,450$; * T. XXXIII.

- silvaticum L. 105, 124, 163, 201, 210, 226, $230,236$.

- uliginosum L. 120, 275, 279, 294, 498.

- vernum Scop. 124, 190, 228, 332, 342, 379, 395,450 .
Galium verum L. 111, 127, 131, 132, 135, 152, $153,155,270,289,294,356,441$.

Geaster Drummondii Berk. 493.

- hungaricus Holl. 493.

- quadrifidus Holl. 493.

Genista germanica L. * $53,94,98,124,135$, $143,145,150,163,177,187,196,200,226$, $239,242,270$.

- lasiocarpa Spach. 353.

- Mayeri Janka 352.

- ovata Kit. 312. 448 .

- pilosa L. 52, 133, 145, 1N1).:71, 276, 39:, $353,375,384,389$.

- pubescens Láng 353.

- radiata (L.) Scop. 361, 445.

- sagittalis L. 441, 450, 459, 460.

- tinctoria L. 52, * 53, 94, 120, 143, 145, 150, $177,187,196,200,230,238,242,270,276$, $329,331,332,390,404,441$.

- virgata Kit. 353.

Gentiana 26, 38, 51 .

- asclepiadea $\mathrm{I} .111,209,219,270,294,312$, $330,336,338,342,344,364,377,378,379$, $388,389,390,407,411,414,424,428,437$, $441,450,451$.

- aspera Kern. Subsp. norica (Kern.) Wettst. $* 51$.

- - Subsp. Sturmiana (Kern.) Wettst. "51.

- axillaris Willd. 279 .

- campestris L. 112, 299.

- - Subsp. baltica Nurb. 211.

- carpatica Wettst. 230, 339, 344, 356, 381, $384,413,451$.

- ciliata L. 190, 217, 236, 284, 303, 379, 405.

- Clusii l'err. Song. 18, * 19, 327, 342, 344, $345,380,390,393,394,455$.

- - var. Rochelii (Kern.) * 385.

- cruciata L. 333, 342, 379, 392.

- frigida Haenke 322, 327, 348, 369, 392, 396, * $398,399,431,435,439$.

- Kochiana Perr. Song. 18, * 19, 369, 412, $417,437,440$.

- lutea L. $365,368,417,419,429$.

- nivalis L. 402, 431, 434, 440 .

- orbicularis Schur. 369, 434.

- pannonica Scop. 145, 173, 174, 176, 179, 207.

- phlogifolia Schott. 328, *425, 426, 435.

- Preumonanthe L. 133, 152, 186, 187, 202, 203, 239, 242, 253, 276, 278, 279, 297, 312, $334,428,507$.

- punctata L. 113, 225, 344, 380, 388, 392, $397,417,428,440$. 
Gentiana wrenaica L. (Vágneri) 368, 412 , $417, . * 418$.

Sturmiana Kern, 100, 230. tenella Wulf. 399, 403, 439.

- Vágneri $=$ pyrenaica.

- verna L. 116, 186, 225, 369, 380.

- Wettsteinii Murb. 100, 112, 186.

Geranium bohemicum L. 389, 445.

- coerulatum Schur. $368,435,{ }^{*} 436$.

- divaricatum Ehrh. 166.

- Iucidum L. 238, 364, *375, 376, 437, 445.

- macrorrhizum L. 358, 431, 435, 444, 445.

- palustre L. 107, 152, 160, 238, 458.

- phaeum L. 229, 293, 336, 378, 379, 400, $413,441,448$.

- pratense L. $98,131,152,153,217,220,230$, $293,307,308,334,460$.

- Robertianum L. 144, 329, 336, * 338, 441.

- sanguineum L. 127, 133, 148, 155, 192, 193, 199, 202, 203, 244, 248, 255, 288, 297, 300, $3016,307,313,331,33:, 353,376,405,406$, $410,441,456,466$.

- silvaticum L. $99,100,109,117,164,166$, $170,176,189,210,224,225,339,343,344$, $379,386,392,401, * 402$.

Gerste $=$ Hordeum.

Geum aleppicum Jacq. (strictum Ait.) * 281, 282, 300, 303, 338, 388.

- montanum L. 113, 114, 216, 217, 218, 344, * $345,366,368,372,380,397,412,417$,

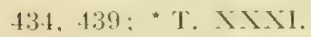

- reptans L. $117,327,348,396,399,400$.

- rivale L. 152, $163,166,224,239,334,340$, $392,400,407,462$.

- strictum Ait. = aleppicum.

- urbanum L. 90, 91, 107, 148, 272, 303, $329,345,485$.

Gladiolus illyricus Koch, 252.

- imbricatus L. 111, 203, 211, 228, 229, 236, $242,292,298,300,308,339, * 340,377$, $378,379,394,412,424,454,458$.

- palustris Gaud. 279, 493.

Glaucium corniculatum (L.) Curt. 192, 373, 507.

Glaux maritima L. $100, * 158,159,170,192$, 193, 202, 249, 253, 254, 351, 508, 513.

Glechoma hederacea L. 111, 147, 329, 486.

- hirsuta W. K. 253.

Globularia cordifolia L. 32 , " 38 .

- Willkommii Nym. 32, 155, 200, 249, 250, $254,333,343,384,386,410$.

Glyceria aquatica (L.) Wahlbg. 107, 138, " 146, $159,181,237,296,441,460,496,498,509$, 523,524 .
Glyceria fluitans L. 126, 138, 153, 181, 309, $334,496$.

- plicata Fr. 131, 152, 496.

Glyeyrrhiza echinata L. 446, 498, * 499.519, $5: 1$.

- glandulifera WV. K. 498.

Gnaphalium luteoalbum L. 139, 146, 187, 204, $270,276$.

- norvegicum Gunn. 100, 107, 114, 163, 209, $219,344,388,456,457$.

- silvaticum L. 100, 237, 270, 276, 342, 450.

- supinum L. $111,117,220,348,371,399$, $417,422$.

- uliginosum L. 120, 139, 198, 413, 521.

Goniolimon tataricum (L.) Boiss. * 463, * 465 , $466,467$.

Goodiera repens (L.) R. Br. 181, 186, 297, 336, 392.

Gratiola officinalis L. 116, 148, 160, 239, 275, $279,462,497,498$.

Grimaldia fragrans Corda 196, 236.

\section{Grimmia 117.}

- alpestris Schl. 119.

- apocarpa Hedw. (Schistidium apocarpum Br. Sch. G.) 101.

- elatior Bruch. 142.

- Mühlenbeckii Schimp. 141.

- pulvinata (L.) Sm. 101.

- spiralis Saut. 119.

- sulcata Hook. et Tayl. 119.

Gurke = Cucumis sativus.

Gymnadenia albida (L.) Rich. 99, 100, 113, $164,166,219,344,345,378,379,404,417$, 461.

- conopea (L.) R. Br. 99, 111, 113, 131, 153, $156,167,196,199,200,202,211,225,230$, $237,278,282,339,354,377,381,384,388$, $394,413,493,511$.

- cucullata (L.) Rich. 271, 301.

- odoratissima (L.) Rich. 202, 344, 345, 388, $399,402$.

- Richteri Györffy. 444.

Gymnostomum calcareum Br. Sch. G. 137.

- curvirostre Hedw. 189.

- rupestre Schl. 119, 137, 189.

Gypsophila altissima L. 285, 289, 306.

- fastigiata L. 252, 276, 289, 292, 294, 356, $507,509,525$.

- hungarica Borb. 512, * 513.

- muralis L. 120, 139, 312, 354, 441, 458, $459,494,498,521$, * 522, 524; * T. LII.

- paniculata L. $154,252,256,487,488,489$, $491,507,508,511,512,518$. 
Gypsophilia petraea (Baumg.) Rchb. 327, 370 , $371,425,429,431$, " $432,435,437$.

- repens L. $327,345,346,348,370,390,393$, 411.

- transsilvanica Spr. = petraea.

Gyrophora 136.

- cylindrica (L.) Ach. 102, 117, 348.

- deusta (L.) Fw. 101, 117.

- hirsuta (Ach.) Fr. 101.

- polyphylla (L.) Fw. 101.

- proboscidea (L.) Ach. 117.

- tornata 348.

\section{H.}

Hacquetia Epipactis (L.) DC. 249, 323, 330, * $335,336,349,376,377,379,384,390$, 411.

Haematomma coccineum (Dicks.) Kbr. 101.

- ventosum (L.) Mass, 117.

Hafer = Avena sativa.

Hainbuche $=$ Carpinus Betulus.

Hanf $=$ Cannabis sativa.

Haselnu $B=$ Corylus Avellana.

Hedera Helix L. 91, 93, 143, 269, 282, 336, 519.

Hedraeanthus $=$ Edraianthus.

Hedwigia ciliata Ehrh. 101.

Hedysarum obscurum L. 117, 207, 217, 226, $345,347,348,394,400,402$.

Heidekraut $=$ Calluna vulgaris.

Heidelbeere $=$ Vaccinum Myrtillus.

\section{Heleocharis 54 .}

-- acicularis (L.) R. Br. 160, 181, 183, 198, 523.

- ovata (Roth) R. Br. 139, 140, 181, 183, 279, 280.

- palustris (L.) R. Br. 111, 131, 275, 279, 289, $334,340,498,523$.

- pauciflora (Lightf.) Lk. 274.

- uniglumis (Lk.) Schult. 195.

Heleochloa alopecuroides Host $=$ explicata.

- explicata (Lk.) Hack. (H. alopecuroides) $160,493,494,496,498,508,514,520,521$, 523.

- schoenoides (L.) Host. 157, 159, 248, 253, $496,508$.

Helianthemum alpestre (Jacq.) DC. 345, 403, $425,434,444$.

- canum (L.) Baumg. 155, 189, * 190, 332, $333,429,462$.

- nummularium (L.) Dun. 132, 133, 135, 163, 173.

- obscurum Pers.= ovatum.

Hayek, Die Pflanzendecke Österreich-Ungarns, I.
Helianthemum ovatum (Viv.) Dun. 146, 151, 153, 187, 199, 250, 252, 287, 332, 333.

- rupifragum Kern. 404, 422, 454.

- tomentosum (Scop.) Spr. 434.

- vulgare Gärtn. = nummularium.

Helianthus annuus L. 373.

Helichrysum arenarium (L.) DC. 98, 128, 151, $154,156,202,247,256,276,289,297,306$, 492, 507, 509, 511, 517, 523.

Heliosperma alpestre (Jacq.) Rchb. 399.

- quadrifidum (L.) Rchb. 339, 343, 346, 348 , $369,417,429,433$.

Helleborus odorus W. K. 450.

- purpurascens W. K. 282, 284, 305, 306, $323,350,353,356$, *359, 408, 410, 411, 413, 428, 429, 451, 456, 461, 462.

- - var. Baumgartenii Kov. 350.

Helvella albipes Fuck. 493.

Hepatica = Anemone.

Heracleum carpaticum Porc. 412, 417, 418 , 419.

- flavescens Borb. 338, 339, 343.

- palmatum Baumg. 361, 368, 419, 432, "433, $437,440,442$.

- sibiricum L. 117, 270, 287, 306.

- Spondylium L. 67, 98, $111,127,131,15 \%$, $206,230,237,238,239,251,279,334,361$, 498.

Herminium Monorchis (L.) R. Br. 166, 461.

Herniaria 296, 484.

- glabra L. 128, 151, 198, 276, 297, 331, 381.

- hirsuta L. 128, 276, *277, 297.

- incana Lam. 493.

Hesperis inodora L. 338.

- nivea Baumg. $361,376$.

- runcinata W. K. 203.

- tristis L. 253, 408, 493, 507.

- Vrabélyana Kern. 408, *408.

Heterocladium dimorphum Br, Sch. G. 93.

Hibiscus ternatus L. 292, 461.

Hieracium albinum Fr. 212, 217.

- alpicola Schl. Subsp. rhodopaeum (Gris.) N. P. 399,400 .

- alpinum L. 114, 211, 212, 214, 216, 219, $225,337,344,348,368,380,388,390,392$, $394,397,400,402,412,417,420,422,434$, $444,456$.

- asperulum Freyn 114.

- atratum Wimm. 114, 212, 217, 219.

- aurantiacum L. 114, 173, 209, 217, 340, 344, $363,368,370,380,386,401,403,417,419$, $431,450,456,461$. 
Hieracium Auricula Lam. et DC. 100, 153 $276,279,333,344,412$.

- auriculoides Láng (pannonicum N. P.) 332.

- barbatum Tsch. 166.

- Bauhini Bess. 153, 156, 333, 356.

- hohemicum Fr. 218.

- boreale Fr. 135, 329, 458.

- bupleuroides Gmel. 327, 342, 347, 353, 411.

- - Subsp. scabriceps N. P. 400.

- - Subsp. Tatrae (Gris.) N. P. 381, 394.

- calenduliflorum Backh. 399.

- candicans Tsch. 187.

- carpaticum Gris. 344.

- chartaceum Čel. 138.

- chlorocephalum Wimm. 114, 118, 138, 212, $\because 17$.

- corconticum Kinaf. 212.

- crocatum Fr. 209.

- cruentum Naeg. 419.

- cymosum L. 133, 136, 246, 247.

- dacicum Heuff. 444.

- decipiens Tausch. 217, 218, 219.

- dentatum Hoppe 347, 348.

- echioides Lumn. 128, 136, 154, 189, 198, $245,246,247,256,287,297,300,312,332$, $356,442,492$.

- Engleri Uechtr. 114, 118, 226.

- Fatrae Pax 388.

- flagellare Willd. 112, 114, 124, 211, 228, $231,333,413$.

- florentinum All. 136, 153, 157, 411.

- floribundum Wimm. Grab. 100, 112, 114, $164,388,413$.

- Fritzei F. Schultz * 113, 114, 214, 218 , $399,400$.

- Fussianum (Schur) N. P. = Pavichii.

- glandulosodentatum Liechtr. 114, 412.

- glaucum All. 347.

- glomeratum Fr. 112.

- gothicum Fr. 176.

- Herculis Borb. 364, 445.

- Jankae Uechtr. 447.

- inuloides Tausch. 212, 218, 219, 388.

- iseranum Uechtr. 114.

- Knuthianum Pax. 419.

- Kotschyanum Heuff. 444.

- macranthum Ten. 417.

- murorum L. (silvaticum [L.] Beck) 93, 100 , 163, 240, 330, 377, 395, 485.

- nigrescens Willd. 114, 212, 218, 219, 399.

- nigritum Uechtr. " $113,114,217,344,402$.

- pannonicum N. P. = auriculoides.

- Pavichii Heuff. 351, 441.
Hieracium pedunculare Tausch. 114, 212, 213.

- Pilosella L. 52, 98, 100, 114, 122, 124, 127, $128,129,130, * 132,133,146,150,151$, $154,156,157,185,230,276,279,330,332$, $333,346,356,374,428,485$.

- plumbeum Fr. ${ }^{*} 118$.

- pocuticum Wot. 412.

- praccurrens Vuk. 428.

- pratense Tausch. 112, 136, 153, 251, 333, 401.

- prenanthoides Vill. * 113, 114, 218, 219, 225, 344, 394, 403.

- pseudocaesium Deg, et Zahn. 444.

- pseudofastigiatum Deg. et Z. 358, 445.

- psendopersonatum G. Schneid. 114.

- racemosum W. K. 94, 143, 196.

- ramosum W. K. 333.

- retiezatense Deg. et $Z .444$.

- riphaeum Uechtr. " $113,114,217$.

- rupicolum Fr. 114, 212.

- Schmidtii Tausch. 101, 118, 127, 138, 187, * 188, 197, 213.

- setigerum Tausch. 127, 135, 151, 156, 189, 191, $217,25: 2$.

- silesiacum Krause 225, 399.

- silvaticum (L.) Beck = murorum.

- stygium Uechtr. 114, 220, 225, 344, 388, $399,400,403$.

- sudeticum Fr. 114, 212, 213.

- suecicum Fr. 112.

- tatrense (N. P.) 344, 361 .

- transsilvanicum Heuff. 218, 323, 349, 350, $356,{ }^{*} 357,359,411,413,421,428,429$, $431,437,438,443,445,450,451$.

- umbellatum L. 143, 284, 340, 422, 456, 493.

- villosiceps N. P. 412.

- villosum L. 118, 226, 347, 348, 388, 394, 400, 422, 441, 445, 453.

— virosum Pall. 305, 306, 309.

- vulgatum Fr. 100, 146, 330.

- Wimmeri Jechtr. 212, 344, 388, 402.

- Winkleri Čel. 158.

Hierochloë australis (Schrad.) R. S. 124, 126, $183,186,187,193,202,203,244,467$.

- borealis R. S. = odorata.

- odorata (L.) Wahlbg. (H. borealis) 198, 204, 284, 285, 301, 306, 466, 519.

Himantoglossum hircinum (L.) Spr. 156, 244, $255,376$.

Himbeere $=$ Rubus Idaeus.

Hippocrepis comosa L. 204, 327, 332, 333, 342, $348,384,386,388,404,405$. 
Hippophaë rhamnoides L. 147, 149, * 150, 156 $259,493,506,511$.

Hippuris vulgaris L. 203, 237, 280, 293, 298 500.

Hirschholler $=$ Sambucus racemosa.

Holcus lanatus L. $52,100,131,152,153,180$, $238,239,251,278,441,498$.

- mollis L. 111 .

Holosteum umbellatum L. 151, 154, 491.

Holoschoenus australis Richb. 496.

- vulgaris Lk. 506, 507.

Homalothecium Philippeanum (Spr.) Br. Sch. G. 348 .

Homogyne alpina (L.) Cass. 94, 100, 105, 106 , $163,167,169,174,176,177,17 \pi, 1 \times 6$, $206,207,209,210,211,213,216,218$, $234,336,344,368,379,381,395,400$, $411,417,456$.

Hopfen = Humulus Lupulus.

Hordeum (Gerste) 160, 290, 502.

- crinitum Desf. 488.

- distichum L. 102, 141.

- europaeum (L.) All. (Elymus europaeus L.) $91,93,105,163,186,205,206,210,211$, $230,249,297,371,437,461$.

- Gussoneanum Parl. 465, 484, 494, * 495, 496, 513, 514, 521, 522; * T. LII.

- murinum L. 120, 290, 494, 505, 511, 514.

- vulgare L. 69, 372.

\section{Hottonia 60.}

- palustris L. 159, 160,211, 220,237, 259, $280,290,297,335,428,500,507,512$, $5: 24$.

- - var. diminuta Simk. 506.

Humulus Lupulus L. (Hopfen) 107, 142, 147, $148,150,239,259,284,291,329,331,441$, $486,488,506,510,519$.

Hutchinsia alpina (L.) R. Br. 348, 394, 399.

- brevicaulis Hoppe 440.

Hyacinthella leucophaea (Stev.) Schur. 285, $289,306,330,429,{ }^{*} 430,451,462 ;{ }^{*} \mathrm{~T}$. XLVI.

Hydrocharis Morsus ranae L. 60, 160, 259, $280,290,335,500,507,511,518,523,524$; * T. XIII.

Hydrocotyle vulgare L. 130, 181, 182, 200, 204, 274, 293, 295.

Hylocomium 330 .

- loreum (Dill.) Br. Sch. G. 93.

- splendens (Dill.) Br. Sch. G. 93, 94, 144, 208.

- triquetrum (L.) Br. Sch. G. 93, 208.
Hymenostomum tortile (Schwägr.) Br. Sch. G. $1112,137,231 ;$.

Hyosciamus niger L. 505 .

Hypericum acutum Mnch. 127.

- alpigenum Kit. $363,364,366,368,411,417$, $420,457$.

- elegans Steph. 136, 196, 236, 281, 306, 307, $333,354$.

- Elodes L. 179.

- hirsutum L. 90, 124, 228, 33ঙ, 377, 378, $437,450,451,485$.

- humifusum L. 183, 229, 231, 245, 276.

- maculatum Cr. 99, 116, 225, 238, 339, 354, $377,404,450,461$.

- montanum L. 133, 164, 220, 228, 238, 270, $338,453$.

- perforatum L. 124, 151, 281, 285, 289, 331, 332, 333. 342, 354 .

- quadrangulum aut. = maculatum.

- Rochelii Gris. 445.

- transsilvanicum Čel. 461.

- umbellatum Kern. 442, 451, 454, " 455.

- veronense Schrk. 156.

Hypnum 54, 130, 274, 330.

- aduncum Hedw. 274, 275.

- cordifolium Hedw. 275.

- Crista castrensis L. 94.

- cupressiforme L. 93, 94, 488.

- cuspidatum L. 97, 275.

- exannulatum (Gümb.) Br. Sch. G. 116, 274.

- fertile Sendtn. 93.

- fluitans L. 93.

- Heufleri 119.

- molluscum Hedw. 119.

- nitens Schreb. 275.

- purum L. 144, 274.

- reptile Rech. 93.

- sarmentosum Wahlenbg. 116.

- Schreberi Willd. 94, 144.

- scorpioides L. 274.

- Sendtneri Schimp. 274.

- stellatum Schreb. 274.

- stramineum Dicks 97.

- uncinatum Hedw. 97.

Hypochoeris carpatica Pax 388.

- glabra L. 128, 220, 374.

- maculata L. 100, 133, 156, 166, 196, 199, $207,236,237,242,288,298,312,333,356$, $390,405,408,424,431,451,459,460,461$, 466, 509.

- radicata L. 128, * $177,288$.

- uniflora Vill. 213, 219, 344, 380, 386, 392, $401,403,404,417,419,420,422$. 


\section{J.}

Jasione montana L. 94, 98, 128, 146, 150, 151, $169,173,177,183,185,204,207,220,228$, $230,231,236,247,248,252,270,276$, * 277, 296, 297, 300, 330, 384, 509, 523.

- Jankae Neilr. 447.

Illecebrum verticillatum L. 139, * 140, 220, 276.

Impatiens Noli tangere L. 91, 107, 122 .

- parviflora DC. 292, 374.

Imperatoria Ostruthium L. = Peucedanum Ostruthium.

Inula bifrons DC. 353.

- britannica L. 150, 278, 279, 284.

- Conyza DC. = squarrosa.

- cordata Boiss. 332, 353, 408, 428.

- ensifolia L. 156, 235, 300, 306, 308, 332 $343,376,381,386,459$.

- germanica L. 156, 190, 192, 193, 306, 309, 459.

- Helenium L. 284, 306, 308, 312, 351, 486.

- hirta L. 127, 135, 153, 156, 190, 196, 201, $235,245,300,332,356,376,403,404,460$.

- Oculus Christi L. 156, 245, 246, 374, 384, 493,521 .

- salicina L. 124, 127, 133, 135, 189, 203, 240, $249,253,279,284,308,313,498,524$.

- squarrosa (L.) All, 229, 238, 384.

Iris arenaria W. K. $179,247,467,{ }^{*} 489,491$, $507,510,511,521$.

- bohemica Schm. 138, 189, 190, 202, 253.

- caespitosa Pall. (ruthenica) 287, 313, 428, $429, * 430,460,461$.

- germanica L. 236, 510 .

- graminea L. 306, 379.

- lnungarica W. K. = nudicaulis.

- humilis M. B. 465.

- nudicaulis Lam. (hungarica WV. K.) 284, $285,287,289,300,312,313,354,453,454$, 461, 462.

- Pseudacorus L. 63, 126, 138, 181, * 182, $279,290,294,298,309,312,334,380,496$.

- pumila L. $101,102,156,157,179,247,248$, $249,253,255,307,374,408,410,466,494$, 515.

- ruthenica Dryand = caespitosa.

- sambucina L. 203.

- sibirica L. 131, 152, 181, 200, 226, 229, 231, $252,275,279,294,297,334,407,428,458$, 498.

- spuria L. 353, 354, 408, 452, 459, 467, 496, 498,519
Iris variegata L. $101,156,157,242,244,245$, $249,251,255,353,376,408,445,448,493$, 516 .

Isatis praecox Kit. $353,426,451,453,454$.

- tinctoria L. 101, 128, 198, 235, 285. transsilvanica Simk. 101.

Isoëtes echinospora Dur. * 176.

- lacustris L. $175,{ }^{*} 176$.

Isolepis setacea (L.) R. Br. 139, 181, 198, 428. - var. fluitans 141 .

Isopyrum thalictroides L. $124,147,220,228$, $238,245,249,300,376,377,378,384,388$, 413.

Juglans regia L. (Walnuß) 350, 445, 456.

Juncus alpinus Vill. 97, 131, 228, 231.

- - var. fuscoater (Schreb.) Rchb. 183, 511.

- articulatus L. 100, 279, 413, 497, 498.

- atratus Krock. 152, 252, 279, 287.

- bufonius L. 139, 160.

- bulbosus L. p. p. = supinus.

- capitatus Weig. 139, 295.

- castaneus Sm. 412, 417, 420.

- compressus Jacq. 279, 420, 441, 494.

- conglomeratus L. p. p. = Leersii.'

- effusus L. 98, 100, 127, 131, 272, 276, 279, $334,413,497$.

- filiformis L. 95, 97, 100, 130, 131, 167, 178, 206, 219, 231, 233, 295, 334, 379.

- Gerardi Lois. 157, 159, 195, 354, 467, 509, $514,523$.

- glaucus Ehrh. 97, 127, 279.

- Leersii Marss. (conglomeratus L. p. p.) 98, $279,334,424,441$.

- Rochelianus Schult. = Thomasii.

- silvaticus Reich. 192.

- squarrosus L. $57,95,97,100,167,170,178$, $180,205,206,209,228,272, * 273,276$, 294,380 .

- supinus L. (capitatus Weig.) 139, 168, 229, $276,294$.

- Tenageia Ehrh. 139, 180, 181, 232, 233.

- Thomasii Ten. (Rochelianus Schult.) 414, * $415,422,462$.

- trifidus L. 101, 114, 173, 174, * 175, 225, $348,389,396,417,422,435,437,457$.

- triglumis L. 402.

Jungermannia curvifolia Dicks. 93.

- inflata Huds. 116.

- Taylori Hook. 95, 116, 130.

- Wenzelii Nees 116.

Juniperus communis L. 94, 98, 104, 106, 141, $145,148,173,185,197,270,272,282,330$, 
331 ＊352, 404, 406,456,460,461, 488, $493,515,518,527$.

Juniperus intermedia Schur。 456.

- nana Willd. 35, *36, 108, 109, 209, 213, $219,223,343,366,392,396,412,417,422$, $424,428,441,442,445,457$.

- Sabina L. 12, * 13, 343, 382, 442, 445.

Jurinea arachnoidea Bunge 284, 285, 288, 289, $303,305,306,313$.

- cyanoides (L.) Rehb. 128, 179, 186.

- macrocalathia Borb. 445.

- mollis (L.) Rehb. 248, 249, 254, 405, 407, $508,517,525$.

- transsilvanica Spr. 356, 450, 459, 460, 485.

\section{K.}

Kartoffel = Solanum tuberosum.

Kernera saxatilis (L.) Rchb. 327, 342, 364, 386, $390,405,425,441,445$.

Kickxia Elatine (L.) Dum. 161, 374, 505.

- spuria (L.) Dum. 143, 161, 505.

Kirsche $=$ Prunus avium.

Kautia arvensis (L.) Coult. 131, 153, 278.

- carpatica (Fisch.) Heuff. 237, 333, 374, 381, $390,403$.

- lancifolia = silvatica Subsp. lancifolia.

- longifolia (W. K.) Koch. 422, 440.

- silvatica Duby 173, 176, 338.

- - var. lancifolia (Heuff.) Simk. 419, 444.

- - var. pocutica Szabó 412.

- turocensis Borb. 388.

Kobresia $=$ Cobresia.

Kochia arenaria (G. M. Sch.) Roth 156, 179, $252,295,488,507,509,515$.

- prostrata (L.) Schrad. 255, 495, 518, 521.

- scoparia (L.) Schrad. 157, 289, 312, 496, 521.

Koeleria glauca (Schk.) DC. 128, 151, 154, 240, $252,253,256,270,276, * 277,293,294$, $299,300,465,491$.

- gracilis Pers. 101, 121, 134, 135, 136, $146,153,154,155,156,187,189,192$, $193,197,202,239,247,250,255,376$, 493,524

- nitidula Vel. 135, 179, 198.

- polonica Domin. 287, 288, 304.

- pyramidata (Lam.) Dom. 121, 126, 132, $311,413$.

Kohlrauschia prolifera (L.) Kth. 353, 375, $514,524$.

Kren = Armoracia rusticana.

Kürbis = Cucurbita.

\section{L.}

Lactura muralis (L.) Fres. 93, 104, 105, 106, $120,171,211,230,236,237,336,342,428$.

- perennis L. $136,189,192,332,376,405$, $407,462$.

- quercina L. 511.

- sagittata IV. K. 458.

- saligna L. 159, 193, 306, 374, 462, 507.

- sativa L. (Salat) 160.

- Scariola L. 148, 156, 410, 521 .

- viminea (L.) Presl. 135, 136, 148, 187. 189, 456.

Lamium album L. 120, 292, 373.

- amplexicaule L. 292.

- cupreum Schott. 336, 358, 361, 438, * 439.

- luteum (Huds.) Krock. 91, 105, 106, 107, $120,122,143,147,163,177,196,200,230$, 249.

- maculatum L. $90,107,147,200,292,373$, 505.

- purpureum L. 292, 373.

- vulgare (Pers.) Fritsch 209, 221, 270, 303, $311,336,358,377,386,410,445,458$.

Lappa $=$ Arctium.

Lappula echinata Gilib. 151, 192.

Larix decidua Mill. (Lärche) 98, 106, 166, 220, $226,228,230,231,236,238,240,245,249$, $293,336,343,377,395,431,442$.

- sibirica Led. 416.

Laserpitium alpinum IV. K. 323 , * 360,368 , $411,417,422,444,456,457,461$.

- Archangelica Wulf. 109, 117, 180, 223, 225, *226, 388, 444, 450 .

- latifolium L. 144, 146, 196, 199, 282, 303, $306,307,332,337,376,451$.

- podolicum Rehm. 284.

- pruthenicum L. 90, 132, 133, 152, 186, 187, $203,211,239,275,279,298,305,309,426$, 458.

Lathraea Squamaria L. 41, * 42, 147, 148, 282. Lathyrus Aphaca L. 462.

- Hallersteinii Baumg. 353, 453, 458, 466.

- heterophyllus L. 198.

- laevigatus (IV. K.) Fritsch 282, 298, 303, $412,460$.

- megalanthus Steud. 312, 319, 376, 386, 403.

- montanus Bernh. 90, 99, 133, 166, 170, $186,192,193,196,199$.

- ochroleucus (W. K.) Beck, 410.

- niger (L.) Bernh. 90, 104, 187, 201, 240, $282,298,311,329,407,410,412,451,485$.

- pallescens (M. B.) K. Koch. 466. 
Lathyrus paluster L. 152, 202, 239, 275, 297, 298, 300, 488, 506, 507, 509.

- pannonicus (JacI.) Garcke 251, 287, 376, $410,485$.

- pisiformis L. $179,306$.

- pratensis L. 133. 152, 199, 238, 278, 289, $334,353,354$.

silvestris L. $153,156,353,386,403$.

tuberosus L, 143, 162, 374, 505 .

venetus (Mill.) Wohlf. 329.

- vernus (L.) Bernh. 90, 103, 104, 124, 143, 185, 191, 203, 204, 206, 240, 249, 270, 25:, $298,412,414,485$.

- versicolor (Gmel.) Beck. 106, 127, 189, 190, 193, 203, 306, 407 .

Lavatera thuringiaca L. 148, 193, 198, 240 , $244,255,307,332,403,404,407,462,467$, 507.

Lecanora atra (Huds.) Ach. 117.

- badia (Pers.) Ach. 101.

- frustulosa (Dicks.) Kbr. 117.

- nigrescens (Th, Fi.) Slein. 117.

- petrophila Th. Fr, I0l.

- polytropha (Ehrh.) Th. Fr. 101.

- sulfurea (Hoffm.) Ach, 101.

Lecidea cinereoatra Ach. 117.

- confluens $\mathrm{Fr}^{2} .117,370$.

- crustulata (Ach.) Kbr. 101.

- lurida Ach. 102, 236.

- superba Kibr. 117.

Lecidella alboflava Kbr. 117.

- bullata Kbr. 117.

- lapicida líbr. 117.

- marginata (Schaer.) Kibr. 117.

- nodulosa Kbr. 117.

- plana Lahm. 117.

- sudetica (Kbr.) Stein. 117.

Ledum palustre L. * $58,96,97,116,130,170$, $176,180,200,205,221,224,228,231,232$, $272,275,293,295,308,341,363,380$, *3-1. * T. IIII, * T. X1, *T. NVIII, * T. XXV.

Leersia oryzoides (L.) Sw. 279, 292, 297, 460, $498,524$.

Legousia Speculum Veneris (L.) Fisch. 103, 162.

Lemna gibba L. 160, 280, 290, 500.

- minor L. $60,{ }^{*} 61,141,160,280,290,335$.

- trisulca L. 60, 160, 259, 280, 290.

Leontodon asper (W. K.) Rehb. 354, 356, 450, 154, 462, * T. XLIX.

- autumnalis L. $98,100,111,225,278,333$, $334,346,356,374$.
Leontodon clavatus Sag. Schn. (tatricus) 322 , $347,380,389,392,397$, * 398 .

- danubialis Jacq. 346, 356.

- Iispidus L. 98, 107, 153, 278, 289, 356, 374.

- incanus (L.) Sehrk. 327, 342, 380, 386, 388.

- opimus (Koch) 114.

- pyrenaicus Gou. 368, 412, 417, 420.

- tatricus (Berd.) = clavatus.

Leontopodium alpinum Cass. (Edelweiß) 38, $345,348,364,388,389,392,394,403,404$, $420,422,426,440,441,444,451$.

Leonurus Cardiaca L. 292, 373, 505.

- Marrubiastrum L. 147, 162, 241, 255, 284, $486,498,524$.

Lepidium campestre (L.) R. Br. 151.

- crassifolium W. K. 484, 495, 508, 513, ${ }^{\star} 514$, $517,518,522$.

- Draba L. 133, 285, 289, 494, 505.

- latifolium L. 249, 254, 484, 494, 508.

- perfoliatum L. 289, 484, 494, 496, 506, 507, 518, 521, 522.

- ruderale L. 458, 496, 505, 521 .

Leptotrichum flexicaule Hampe 348.

Lepturus pannonicus (Host.) Kunth. 484, 494, $513,51 \varsigma, 519,5: 21,522$.

Leskea nervosa (Schwägr.) Myrin. 93.

Leucobryum glaucum (L.) Schimp. 100, 208, $274,336$.

Leucodon sciuroides (L.) Schwägr. 119.

Leucoium aestivum L. 486, 498, 506, 509, 510, 523.

- vernum L. 91, 111, *125, 163, 196, 207, $211,217,228,229,231,238,240,308,339$, $385,414,422,517$.

Libanotis leiocarpa Heuff. 445, 454.

- montana Cr. 101, 127, 156, 178, 199, 238, 245, 285, 298, 332, * T. XXVII.

Ligularia sibirica Cass. 200, *201, 288, 389, $417,426,427,428$.

Ligusticum Mutellina (L.) Cr. 113, 173, 174, $176,219,225,344,369,380,386,388,390$, $392,397,401,411,417,432,434,437,442$, 456 .

- simplex (L.) All. 344, 369, 392, 397, 399, 434.

Ligustrum vulgare L. 104, 143, 147, 184, 189 , $191,193,203,240,331,352,451,458,485$, $488,510,516,527$, * T. XXXIII.

Lilium bulbiferum L. 99, 103, 165, 172, 180, 452.

- Jankae Kern. 451, 454.

- Martagon L. 93, 105, 111, 117, 124, 144, $170,178,186,187,191,192,196,201,204$, 
$205,206,209,218,228,229,236,237,245$, $282,298,303,308,338,364,374,376,382$, $384,386,400,412,413$.

Limodorum abortivum (L.) Sw. 374.

Limosella aquatica L. $139,181, * 183,1 \leqslant 7$, 198, 203, 251, 280, 524.

Linaria alpina (L.) Mill. 66.

- arvensis (L.) Desf. 103, 142, 161, 276.

- dalmatica Mill. 353, 428, 429, * 430, 431, 462.

- genistifolia (L.) Mill. 101, 151, 156, 157, $235,245,252,259,305,332,374,375,405$, $406,441,460,512$.

- italica Trev. 454.

- vulgaris Mill. 161, 292, 332.

Linde $=$ Tilia.

Lindernia pyxidaria L. 139, 181, 204, 251, 280, 293, 524.

Linnaea borealis L. $111,336,395$.

Linosyris vulgaris Cass. = Aster Linosyris.

Linum austriacum Jacq. 153, 193, 249, 250, $303,312,313,405,441,524$.

- catharticum L. 99, 150, 153, 202, 239, 332, $333,334,354$.

- extraaxillare Kit. 327, 344, 347, 388, 389, $392,394,399,400, * 401,403,419,424$, $426,428,435$.

- flavum L. 155, 189, 198, 203, 235, *240, $242,287,289,297,300,301,303,305,306$, $307,312,313,332,353,354,356,376,389$, $403,405,406,407,413,424,441,451,456$, $458,459,462$.

- hirsutum L. 179, 332, 356, 410, 413, 456, $458,488,507$.

- nervosum Kit. 353, 354, 356, 459, 464.

- perenne L. 309, 462, 467, 494, 508, 513.

- tauricum Willd. 304, 445.

- tenuifolium L. 101, 153, 155, 196, 244, $353,354,356,374,376,405,424,459$, 466.

- usitatissimum L. (Flachs) 102, 119, 142, $291,373$.

Listera cordata (L.) R. Br. 170, 173, 206, 400.

- ovata (L.) R. Br. * 99, 125, 147, 238, 270, $278,336$.

Lithospermum arvense L. 138, 505.

- officinale L. 127, 156, 284.

- petraeum A. DC. 354.

- purpureocoeruleum L. 124, 144, 148, 156, $244,284,313,376,384$.

Litorella lacustris L. 141.

Lloydia serotina (L.) Salisb. 328, 346, 370, 392 , $394,397,422,434,437,444,{ }^{*} \mathrm{~T}$. XXXII.
Loiseleuria procumbens (L.) Desv. $11,315$. $368,400,431,437,444$.

Lolium perenne L. 133, 278, 292.

- remotum Schrk. 142, 374.

Lonicera alpigena L. 413.

- Caprifolium L. 148, 374.

- nigra L. 91, 94, 105, 106, 107, 110, 163, 170 , $173,177,17 x, 204,219,225,229,230,293$, $336,338,377,386,388,400,411$.

- Xylosteum L. 90, 104, 105, 106, 126, 143, $147,148,184,230,303,330,336,378,386$, $406,460,485$.

Lophozia Floerkei (Web. et Mohr.) St. 210. - inflata (Huds.) Howe 209, 210.

Loranthus europaeus L. 124, 177, 196.

Lotus 52 .

- angustissimus L. 159, 494.

- corniculatus L. 112, 127, 131, 135, 153, 157 , $278,289,332,333,342,353,354$.

- siliquosus L. 133, 159, 195, 254, 354, 494, $498,507,513,515,518$.

- tenuis litit. 20, 152, 157, 159, 461, 466, 494, $513,515$.

- uliginosus Schk. 157, I83, 186, 193, 334.

Lunaria rediviva L. $93,105,163,178,183$, $200,206,210,218,219,225,226,233,253$, $293,305,338,375,376,377,378,381,408$, 113.

\section{Lupinus 22.}

- albus L. 142.

- angustifolius L. 142 .

- luteus L. 142.

Luzerne = Medicago sativa.

Luzula angustifolia Garke = nemorosa.

- campestris (L.) DC. 146, 151, 153, 196, 249, $333,342,491$.

- flavescens Gaud. 336.

- maxima DC. = silvatica.

- multiflora (Ehrh.) Lej. 99, 100, 112, 114, 206.

- nemorosa (Poll.) E. Mey. 90, 93, 94, 100, $104,105,106,108,120,163,166,177,180$, $185,186,191,199,204,206,208,210,211$, $221,226,230,249,282,330,336,342,365$, $377,411,413,429,438,441$.

- var. rubella Garecke 94.

- pallescens Bess. 192, 203.

- pilosa (L.) WVilld. (vernalis) 143, 146.

- silvatica (Huds.) Gaud. (maxima) 93, 100, $107,111,116,163,167,176,180,206,219$, $336,337,368,388,411,450$.

- spadicea (All.) Lam. et DC. 344, 348, 368, $380,397,399,417,422,439$. 
Luzula spicata (L.) DC. 117, 214, 220, 344, $348,368,392,399,400$.

- sudetica Mey. 114, 164, 219, 344, 388, 417 , 461 .

- vernalis (L.) DC. = pilosa.

Lychnis Coronaria (L.) Desr. 332, 442, 448, 485.

- Flos cuculi L. 98, 100, 111, 131, 168, 180 , 181, 238, 241, 251, 279, 289, 290, 334, 498, 5117.

Lycium halimifolium Mill. 148, 493, 505, 516 .

Lycopodium alpinum L. 100, 119, 366, 380, $390,412,417$.

- annotinum L. 591), 94, 226, 228, 229, 230, $\left.294^{\mathbb{1}}\right), 378,416,437,531$.

- clavatum L. 191, 295, 380.

- complanatem L. 94, 120, 167, 191, 309.

- inundatum L. 130, 187, 274, 2941), 427.

- Selago L. 94, 101, 107, 138, 168, 174, 196, $207,309,348,366,387,390,417,461$.

Lycopsis arvensis L. 151, 505.

Lycopus europaeus L. 126, 147, 148, 159, 181, $198,250,272,335,486,498$.

- exaltatus L. f. 147, 255, 308, 498, 521, 524.

Lysimachia nemorum L. $93,126,148,230$, $290,336$.

- nummilaria L. 147, 278.

- punctata L. 282.

- thyrsiflora L. 116, 126, 130, 138, 152, 169, $170,181,182,183,193,200,231,239,274$, $380,428$.

- vulgaris L. 126, 127, 138, 181, 276, 298, 488.

Lythrum bibracteatum Salzm. 517.

- IIyssopifolia L. 186, 203, 251, 498, 518.

- Salicaria L. 127, 138, 147, 152, 160, 181, $239,279,284,290,334,335,441,486,496$, $498,523$.

- virgatum L. 147, 255, 498, 522, 524.

\section{II.}

Madotheca platyphylla (L.) Dum. 523.

Maianthemum bifolium (L.) Schm. 93, 94, $104,106,108,124,180,203,221,230,233$, $236,238,249,270,294,303,404$.

Malaxis paludosa (L.) Sw. 179, 274, 295, 427. Malva Alcea L. 124, 307.

- neglecta Wallr. 292, 494, 505.

- silvestris L. 292, 505.

Marrubium peregrinum L. 162, 505, 507.

1) Conf. Corrigenda.
Marrubium peregrinum $\times$ vulgare 162.

- vulgare L. 162, 292, 505.

Marsilea quadrifolia L. $160,306,519,523,524$.

Matricaria Chamomilla L. 20, 158, 162, 466, $484,499,513,518,521$.

- discoidea DC. 68, 103, * 162.

- inodora L. 505.

- tenuifolia (Kit.) 355.

Mattia umbellata Schult. = Rindera umbellata.

Medicago elongata Roch. 492.

- falcata L. 132, 133, 135, 138, 156, 27R, $333,353,354$.

- lupulina L. 153, 278, 333, 354.

- minima (L.) Bartal. 133, 135, 186, 187, $197,253,276,484,507,515,524$.

- prostata Jacq. 179, 408, 413.

- sativa L. (Luzerne) 102, 141, 273.

Meerrettig $=$ Armoracia rusticana.

Meesea longiseta Hedw. 232, 274.

- triquetra (L.) Angstr. 341.

- tristicha Br. Sch. G. 274.

- uliginosa Hedw. 274.

Melampyrum 43, 51 .

- arvense L. 135, 374, 506.

- barbatum W. K. 353, 374, 507.

- bihariense Kern. 258, 350, * 357, 429, 451, 458,462 .

- bohemicum Čel. 204, 229.

- cristatum L. 124, 127, 156, 204, 245, 25\%, $306,307$.

- nemorosum L. $90,104,120,124,133,143$, $146,166,177,201,204,230,240,242,249$, $312,329,350$.

- - Subsp. moravicum (H. Br.) Ronn. 377.

- pratense L. Subsp. alpestre (Brügg.) Ronn. $100,114$.

- - Subsp. paludosum(Gaud.) Ronn.97,272.

- - Subsp. vulgatum (Pers.) Ronn. = vulgatum.

- saxosum Baumg. 395, 414, 422.

- silvaticum L. 93, 99, 100, 104, 144, 163, 204, 225, 226, 237, 330, 395, 411.

- vulgatum Pers. 93, 94, 106, 120, 145, 163, $177,185,201,203,204,242,336$.

Melandryum album (Mill.) Garcke 120.

- nemorale (Heuff.) A. Br. 349, 350, 450, $454,456$.

- silvestre (Schk.) Rehb. 67, 109, 113, 114, $167,169,171,183,217,219,236,341,395$, $400,408,420,424,461,462$.

- viscosum (L.) Čel. 154, 249, 252, 256, 284, 492,524 . 
Melandryum Zawadzkii (Herb.) A. Br. 37I, $417,420,421,422, * 425$.

Melica altissima L. 280, 284, 306, 329, 407, $453,454,485,486$.

- ciliata L. 101, 102, 136, 138, 148, 187, 190, $191,197,226,229,238,242,245,254,285$, $331,332,342,375,442,451$.

- nutans L. 104, 105, 124, 143, 144, 187, * 195, 236, 245, 249, 280, 298, 329, 385, 412.

- picta G. Kočh 104, 124, 143, 186, 187, 189, $190,245$.

- transsilvanica Schur. 136, 198, 239, 254, $282, * 318,413,460,512,519$.

- uniflora Retz. 236, 249, 371, 410.

Melilotus albus Desr. 333.

- altissimus Thull. 378.

- dentatus (W. K.) Pers. 20, 157, 159, 192, 195, 202, 253, 498.

- - var. perfrondosus Borb. 354, 466.

- macrorrhizus Pers. 200, 467.

- officinalis (L.) Lam. 333.

Melittis Melissophyllum L. 143, 186, 187, 199, $201,203,220,228,242,311,338,378$.

\section{Mentha 284.}

- aquatica L. 138, 148, 272, 335, 498.

- arvensis L. 120, 272, 498.

- austriaca Jacq. 335, 498.

- longifolia (L.) Huds. 138, 148, 272, 335, $338,498$.

- Pulegium L. 162, 198, 255, 498, 521.

- verticillata L. 148, 152, 335, 498.

Menyanthes trifoliata L. 56, 130, 139, 177, $181,183,193,200,203,204,219,220,229$, $231,232,290,298,379,389,396,460,498$, 523.

Mercurialis perennis L. 93, 120, 127, 163, 185, $195,205,207,238,282,330,336,376,384$, $412,413,461$.

- ovata Sternb. et Hoppe 144, 282, 285, 306, 354.

Meum athamanticum Jacq. 99, 164, "165, $166,167,169,172,174,180,205,206$, * T. VII.

- Mutellina Gaertn. = Ligusticum Mutellina.

Milium effusum L. 91, 93, 122, 124, 125, $143,147,186,200,206,207,250,255,270$, $280,303,336$.

Mimulus guttatus DC. 192, 205, 293, 373, 377.

- luteus = guttatus.

Minuartia banatica (Heuff.) 354 .

- frutescens (Kit.) 387, 407, 408, " 409, 442, 450 .
Minuartia Gerardi (Willd.) Hay. 117, 217, 345, 347, 394, 403, 417, 422, 434.

- glomerata (II. B.) 492, 511, 517.

- Jacquini (Koch) 253, 255.

- laricifolia (L.) Schinz et Thell. 18, 327, 342, $353,381,385,390,393,394,405$.

- sedoides (L.) Hiern. 37, 348, 369, 399, 434.

- setacea (Thuill.) Hay. 189, 246, 253, 255, 285, 306, 381, 410, 492, 511 .

- verna (L.) Hiern. 101, 154, 342, 491, 507, 511 .

- viscosa (Schreb.) Schinz et Thell. 509.

Mnium 330.

- palustre L. 275.

- punctatum (L.) Hedw. 116.

- spinosum (Voit) Sehw. 93.

- spinulosum Br. Sch. G. 93.

- stellatum L. 531.

Moehringia muscosa L. 187, 342, 386, 390, $424,450,451,454$.

- pendula (W. K.) Fenzl 354, 445.

- trinervia L. 91 .

Moenchia mantica (L.) Bartl. 506.

Moln = Papaver somniferum.

Molinia altissima Lk. 90, 138.

- arundinacea Schrk.= altissima.

- coerulea (L.) Mch. 54, 97, 98, 100, 130, 152, $200,202,239,252,272,274,279,289,295$, $334,340,413,511$.

\section{Monotropa 43.}

- Hypopitys L. 106, 206.

- glabra (Roth) 408.

Montia rivularis Gmel. 141.

Mulgedium alpinum (L.) Less. 94, 109, 114, $117,163,166,167,168,173,177,206,210$, $211,219,224,229,343, * 363,364,376$, $388,390,392,404, * 405,424,435,438$, $450,462, *$ 'T. IV.

- sonchifolium Vis, et Panč. 445.

Muscari botryoides (L.) Lam. et DC. 197.

- comosum (L.) Mill. 301, 306, 376, 379.

- racemosum (L.) Lam. et DC. 511.

- tenuiflorum Tausch. 127, 287, 289, 308, 313.

Myosotis alpestris Schm. 118, 348, 349, 369, $394,399,440,443$.

- arenaria Schrad. (= micrantha) 292.

- arvensis (L.) Hill, 374.

- caespitosa Schultz 130, 139.

- micrantha Pall. 428.

- palustris (L.) Roth = scorpioides

- scorpioides (L.) Hill 100, 127, 139, 275. $279,280,284,334,497,498,509$.

- silvatica Hoffm. 94, 401, 424. 
Myosotis sparsiflora Mik. 124, 186, 190, 284, 311.

suaveolens W. K. 102, 235

Myricaria Germanica (L.) Desv. 147, * 149, $150,259,281, * 285,331,377,379,381$, $413,431,460,506,510$.

Myriophyllum 63

spicatum L. $160,280,290,497,500$.

- verticillatum L. * $64,141,181,259,280$, $298,33 \overline{5}, 49 \overline{7}, 500$.

Myosurus minimus L. 518.

Myrrhis odorata (L.) Scop. 112, 211, 217.

Myurella julacea (Vill.) Br. Sch. G. 225.

\section{N.}

\section{Naias 63}

- maior All. = marina.

- marina L. (naior) 160, 259, 280, 297, 300, $500,517$.

- minor All. 280, 297, 300, 500, 517, 523, 524.

Narcissus poëticus L. var. seriorflorens (Schur.) $428,452,458,462$.

Nardus stricta L. 52, 90, 98, 99, 100, 104, $109,114,120,124,129,130,131,170,182$, $184,186,187,202,206,209, * 213,214$, $217,230,231,234,236,237,270,271,272$, $276,296,342,344,368,390,411,428,441$, $450,456$.

Neckera pennata (L.) Hedw. 91.

Neottia Nidus avis (L.) Rich. 43, 93, 124, 144, 189, 200, 236, 249, 270, 303, 311, 329, 336, 384.

Nepeta Cataria L. 292.

- nuda L. 249, 306, 307.

- pannonica Jacq. 284, 303, 312, 356, 413, $441,465,524$.

- ucranica L. * 463, 466.

Nephrodium = Dryopteris.

Nerium Oleander L. 12, * 14.

Neslia paniculata (L.) Desv. 374.

Nicotiana Tabacum L. (Tabak) 291, 373, 504, 516.

Nigella arvensis L. 143, 162, 462, 506.

Nigritella nigra (L.) Pcìh. 429, 444.

- - var. rosea Wettst. 429.

- rubra (Wettst) Richt. 369, 417, 426, 444, Nitella trichoides 141 .

Nonnea pulla (L.) DC. 133, 156, 246, 247, 288, $289,313,356,404,413,518$.

Notholaena Marantae (L.) R. Br. 20, 102, 235, 215 .

\section{Nuphar 63.}

- luteum (L.) Sm. * 139, 141, * 258, 280, $290,298,335,497,500,517,523,{ }^{*}$ T. XIII.

- pumilum (Timm.) DG. 231.

Nymphaea $=$ Castalia.

Nymphoides peltata (Gmel.) Ktze, 160, 183, $255,280,497,500,517, *$ T. XX.

\section{0.}

Odontites lutea (L.) Rehb. 156, 202, 246, 332, $353,374,413$.

- rubra Gilib. 120.

Oedogonium 60.

Oenanthe aquatica (L.) Lam. 138, 160, 193, $237,294,334,441$.

- banatica Heuff. 450, 462.

- fistulosa L. 279, 294, 498, 506.

- media Gris. 498, 519.

- Phellandrium Lam. = aquatica.

- silaifolia M. B. 255.

- stenoloba Schur. 442.

Oenothera biennis L. 68, 150, 151, 156, 198, $259,372,379,51:$.

- muricata L. 156, 198, 259.

Oligotrichum hercynicum (Ehrh.) Lam, et DC. $93,116,343,348$.

Omphalaria pulvinata (Schaer.) Nyl. 137.

Omphalodes scorpioides (L.) Haenke 124, 190, 197, 202, 242, 311.

Onobrychis 52.

- alba (IV. K.) Devs. 353.

- arenaria Kit. 191, 356, 442, 462, 492, 509, $512,515,524$.

- montana DC. 434, 440, 441.

- transsilvanica Simk. $=$ montana.

- viciaefolia Scop. 103, 132, 141, 161, 289, $312,332$.

Onoclea Struthiopteris IV. 205, 300, 331, 339, $377,437$.

Ononis hircina Jacq. 279, 287, 293, 306, 307, $354,379,441,466$.

- spinosa L. $133,138,157,332,333,507$.

Onopordon 484.

- Acanthium L. 120, 292, 493, 505.

Onosma 484 .

- arenarium W. K. 252, 356, 407, 492, 507, $511, * 513,523$.

- austriacum Beck 101, 235.

- tornense Jáv. 405.

- viride (Borb.) Jáv. 353, 356, 441, 448, 453, 459.

- Visianii Clem. 156, 252, 408. 
Ophioglossum vulgatum L. 206, 381.

Ophrys apifera Huds. 156, 255.

- aranifera Huds. 156, 255.

- fuciflora (Cr.) Rehb. 156, 255, 384.

- muscifera Huds. 200, 255, 381.

Orchis angustifolia Rehb. 181.

- cordigera Fr. 440.

- coriophora L. 202, 203, 279, 493.

- elegans Ieuff. 460.

- fusca Jacq. (purpurea) 124, 189, 190, 236, 255,311 .

- globosa L. 99, 100, 111, 113, 164, 166, 172, $196,199,205,206,234,339,344,377,379$, $400,405,413,424,428,452,461,462$.

- incarnata L. 54, 100, 152, 202, 239, 486, 497, 498.

- latifolia L. 111, 116, 131, 180, 181, 183, $202,204,206,237,278,279,298,334,377$, $496,497$.

- maculata L. 94, 99, 100, 108, 133, 196, 199, * 218, 226, 278, 334, 339, 340, 379, 406.

- mascula L. 99, 111, 113, 133, 166, 196, 199, 228, 237, 379.

- - Subsp. signifera Vest. 284, 339.

- militaris L. 153, 156, 202, 240, 255, 354, $377,405,493$.

- Morio L. 237, 278, 354, 377, 491, 493.

- pallens L. 124, 376, 379, 410.

- palustris Jacqu. 54, 195, 202, 203, 486, $497,498,506,509,518$.

- papilionacea L. 445.

- purpurea Huds. = fusca.

- saccilera Brogn. 359.

- sambucina L. 99, 111, 127, 133, 196, 199 , $228,230,237,339,374,376,377,379,384$, 456.

- tridentata Scop. 354, 379, 493.

- ustulata L. $111,183,197,200,202,228$, 239, 278, 312, 333, 354, 381, 407, 486, 493.

Orchideen 21.

Oreochloa disticha (Hoffm.) Lk. (= Sesleria disticha) $344,345,347,348,368,370,371$.

Oreoweisia Bruntoni (Sm.) Milde 196.

Origanum vulgare L. 138, 270, 329, 485.

- - var. barcense (Simk.) 413, 429.

Orlaya grandiflora (L.) Hoffm. 101, 235, 352, $353,442$.

Ornithogalum Bouchéanum (Kunth) Asch. 151, 517.

- comosum L. 493.

- Kochii Parl. 518.

- narbonense L. (pyramidalc) 374, 493.

- nutans L. 517.
Ornithogalum pyramidale $\mathrm{Vis},=$ narbonense.

- refractum Kit. 493.

- tenuifolium Guss. 125, 462.

Orobanche $\mathbf{4 1 .}$

- alba Stepl. 136, 151, 156, 332.

- alsatica Kirschl. 196.

- coerulescens Steph. 198.

- caryophyllacea Sm. 278, 332.

- flava Mart. 450.

- gracilis Sm. 153.

- lutea Baumg. "42, 153, 278.

- Picridis Schultz 198.

Orobus = Lathyrus.

- tuberosus L. = Lathyrus montanus.

Orthotrichum rupestre Schl. 101.

- stramineum Hornsch, 91.

Oryzopsis virescens (Trin.) Beck 350, 375.

Osmunda regalis L. 274, 294, 295, " 297.

Ostericum palustre Bess, 152, 202, 239, 279, 298.

Oxalis Acetosella L. $91,104,105,111,122$, $126,144,200,204,205,206,270,303,305$. $309,311,336$.

Oxyeoccos 54 .

- microcarpa (Hook.) 106, $116,168,221$.

- palustris P'ers. = quadripetala.

- quadripetala Gilib. ${ }^{*} \mathbf{5 7}, 58,94,96,97,116$, $120,130,166,170,178,181,187,200,213$, $229,231,233,234,272$, * 274, 275, 294, $304,341,378,395,415,417,421,427,462$.

Oxyria digyna (L.) Hill 346, 370, 380, 392, $397,399,434,437$.

Oxytropis campestris (L.) DC. 348, 403.

- carpatica Uechtr. 345, 347, 348, 371, 394, $400,{ }^{*} 401,402,403,435$.

- Halleri Bunge (sericea) 345, 348, 402, 435.

- pilosa (L.) DC. 135, 189, 190, * 194, 242, $248,249,254,284,289,306,356,465$.

\section{P.}

Paeonia peregrina Mill. 193, 420.

- banatica Roch. 353, 448, 526.

- tenuifolia L. 448, 465, 482, 492, ${ }^{\star} 525,526$.

Pandorina morum (Müll.) Bory * 62 .

Panicum capillare L. 232.

- Crus Galli L. 292, 498, 499, 505.

Pannaria lepidota (Smrft.) Anzi 117.

Papaver Argemone L. 156.

- aurantiacum Lois. 371, 420, 434.

- Burseri Cr. 346, 394, 396, 400.

- Rhoeas L. 68, 103, 142, 161, 374, 505.

- somniferum L. 372 . 
Parietaria erecta M. K. = officinalis.

- officinalis L. 148, 255, 259, 272, 331, 376, $486,506, *$ T. V.

Paris quadrifolia L. 104, 125, 144, 147, 186 , $195,228,238,241,272,300,303,336,358$, 411,517 .

Parmelia encausta (Smrft.) Nyl. 117.

- diffusa (Web.) Th. Fr. 102.

- perlata (L.) Ach. 117.

- sasatilis (L.) Fr. 101, 117.

Parnassia palustris L. 100, 111, 131, 181, 202, $333,343,408$.

Paronychia cephalotes (M. B.) Bess. 429, 431, 451.

- Kapela (Hacq.) Kern. 410 1 ).

Pastinaca opaca Bernh. 169, 180. sativa L. $98,131,153,230,237,239,251$, $278,279,498,518$.

\section{Pedicularis $38,43$.}

- Baumgartenii Simk. 444.

- campestris Gris. 287, 303, 305, 454.

- coronensis Schur. 429, * 430.

- exaltata Bess. 376, 422.

- limnogena Kern. * 455, 456.

- Oederi Vahl. 20, 328, 344, 345, 346, 368, * 369, 392, 394, 397, * 398, 403, 434.

- palustris L. * $55,56,100,131,177,192$, $204,206,220,231,239,274,275,279,290$, $298,334,340,389,395,428,498,523$.

- Sceptrum Carolinum L. 272, * 273, 274, $275,298,300,301,341,395,403,422$, $428,462$.

- silvatica L. $97,100,112,173,177,178$, 204, 206, 220, 226, 231, 237, 272, 334, 396, 427.

- sudetica Willd. * 115, 116, 207, 213, 220.

- summana Poll. 343, 380, 394, 399, *401, $403,417,422,457$.

- verticillata L. $328,344,345,346,348,369$, $370,390,392,393,394,412,420,424,434$.

Peplis Portula L. 139, 183, 198, 251, 462.

Periclineen 60.

Pertusaria corallina (L.) Körb. 117.

Petasites albus (L.) Gärtn. * 92, 93, 94, 117 . $163,171,173,177,178,186,200,217,218$, $226,228,236, * 237,248,293,338,361$, $377,379,395,400,450,{ }^{*}$ T. IX.

- hybridus (L.) G. M. Sch. 361.

- Kiablikianus Tausch 207, 211, 220, 400.

- niveus (Vill.) Baumg. 431.

Petrocallis 37.

1) Vigl. Corrigenda.
Petrocallis pyrenaica (L.) R. Br. 403.

Petrosimonia Volvox (Pall.) Bunge 345, * 355 , $465,466,467$.

Peucedanum alsaticum L. * 155, 156, 240, 284, 285, 332 .

- arenarium W. K. 374, 410, 462, 484, 488, $492,507,509,510,511,512,526$, * 528.

- Carvifolia Vill. 301, 458.

- Cervaria (L.) Cuss. 124, 127, 133, 144. * $155,156,196,204,238,242,251,287$. $298,332,376,413,517$.

- intermedium Schur 454.

- latifolium M. B. 354, 466, 467.

- longifolium W: K. 353, 354 .

- officinale L. $255,256,518$, * T. XXI.

- Oreoselinum (L.) Mch. 127, 153, 187, 201, $287,407,460$.

- Ostruthium (L.) Koch 113, 114, 174.

- palustre (L.) Mch. 126, 127, 131, 138, 170, $1 \times 1, \cdot 1 \times 2,183,187,202,239,275,279$, $296,427,496,498,507,517,523$.

- Rochelianum Heuff. 442, 458. Schottii Bess. 332 .

Peziza ammophila Holl. 493.

- arenosa Holl. 493.

- funerata Cke. 493.

Pfaffenkäppchen $=$ Evonymus.

Pfirsich $=$ Prunus Persica.

Pflaume $=$ Prunus.

Phacelia tanacetifolia Benth. 142.

Phalaris canariensis L. 69.

Phaseolus communis L. (Bohne) 373, 503.

Phegopteris $=$ Dryopteris.

- Dryopteris A. Br. = DryopterisLinnaeana.

Philonotis caespitosa Wils, 274.

- fontana (L.) Brid. 95, 97, 130.

- marchica (Willd.) Brid, 274.

Phleum alpinum L. 100, 112, 114, 217, 219, $225,344,345,378,380,386,400,417,422$.

- commutatum Gaud. 399.

- Michelii All. 344, 400, 417.

- montanum C. Koch 445.

- phalaroides $\mathrm{Koel}$ = phleoides.

- phleoides (L.) Simk. 132, 133, 135, 153, $155,156,187,192,193,204,239,240,242$, * 244, 252, 253, 287, 308, 311, 354, 375, 429, 466, 493.

- pratense L. 98, 131, 152, 153, 239, 251, 278, 334, 394, 494.

- - var. nodosum L. 276.

Phlomis tuberosa L. 242, 248, 249, 253, 254, $284,288,303,306,312,356,407,408,459$, 465,511 . 
Phragmites communis (L.) Trin. (Schilfrohr $127,138, * 139,159,181,198,210,248$, $259,279,284,290,298,300,309,334$, $488,496,506,508,511, * 514,517,523$, * T. XIII.

Phyllites Scolopendrium (L.) Newm. 336, 343, $375,381,402,405,437,442,453$.

Physalis Alkekengi L. 143, 272, 329.

Physocaulis nodosus (L.) Tsch. 361, 445.

Phyteuma confusum Kern. 323, 328, 369, 437, * 438, 439, 440,443, 444.

- nigrum Schm. 99, 164, *165, 169, 170, $174,177,178,180,183,205,233,234$.

- orbiculare L. 100, 112, 153, 156, 186, 201, $237,242,255,344,392,454$, * T. XLIX.

- spicatum L. 94, 168, 189, 192, 203, 204, 237, 270, 361, 404, 413.

- tetramerum Schur. * $362,363,412,414$, $424,431,441,457,458,462$.

- Vágneri Kern. 356, * 360, 363, 411, 417, $420,431,443,444,457,461$.

Picea excelsa (Lam.) Lk. (Fichte) 28, 35, 48, $59,90,91,93,95,104,105,107,{ }^{*} \mathbf{1 0 8}$, $120,122,124,144,163,166, * 167,168$, $169,170,171,173, * 174, * 175,177,178$, $180,183, * 185,186,191,196,198,204$, $205,206, * 208, * 210,211,219,220,221$, $223,224,225,226,228,229,230,231$, 232 , “ $233,234,239,245,248,270,292,293$, $294,308,321,330,336$, * $337,343,358$, 376,377 , * $378,381,382,386,388,392$, $414,293,394, * 395,400,403,404,411$, $412,420,424,426,{ }^{*} 427,428,431,437$, $438,441,444, * 453,456,461, *$ T. III, "T. XXIX, " T. XXXV, * T. XLIII.

- - var. acuminata Beck. 411.

- var ellipsoconis Borb. 386.

- montana Schur. 411.

Picris hieracioides L. 136, 153, 329, 332, 353. Pilularia globulifera L. 205.

Pimpinella alpina Host. 117, 214.

- magna L.= maior.

- maior Huds. 98, 112, 113, 126, 147, 152, $278,339,451$.

- Saxifraga 1. 136, 153, 163, 278, 332.

Pinguicula alpina L. $346,370,435$.

- vulgaris L. 56, 116, 170, 176, 202, 274, $298,301,333,341,343,395$.

Pinus 29, 32 .

- Cembra L. (Zirbelkiefer) 336, 343, *396, *397, 400, 412, 420,431, 442, 444, *T .XLI, * T. XLHH, * T. XLV, "T. XLVII.

- montana Mill. = Mughus.
Pinus Mughus Scop. (Kirummholzkiefer) 35 ${ }^{*} 36,48,57,106,107,108,116,130,{ }^{*} 168$, * $174,209, * 210, * 215,217,218,219$, $223,338,{ }^{*} 341,343,364,366,{ }^{*} 371,381$, $388,389,392,396, * 397, * 400,412,417$, $420,422,428,433,437,439,444,456,461$, * T. II, " T. III, " T. XXX, " T. XXXVII, *T. XLI, *T. XLIV, *T. XLV, *T. XLVII.

- nigra Arn. 48, 145, 252, 256, 364, *504, 505, 515, 527, " T. XLVIII.

- Pseudopumilio (Willk.) Beck. 300, 380.

- Pumilio Hänke = Mughus

- silvestris L. (Föhre, Rotföhre) 43, 59, 90 , 93, 94, * 95, * $96,104,106,120, * 121$, * $122,126,130,143,144,145,163,169$, $170,171,173,177,180,182,184,185,196$, $200,201,202,203,204,205,226,228,230$, $231,233,234,236,238,239,242,245,247$, $248,249,252,270, * 271,272,275,277$, $292,293,294,295,296,297,301,330,335$, $351,374,378,386,415,427,437,460,505$, $510, *$ T. XII, * T. XXIII.

- Strobus L. 47, 119.

- uliginosa Neum. * 59, 95, * 96, 97, 116, $121,166,170,176,180,181,184, * 221$, $231,232,234,380,417,427$, * T. VII, T. XVIII.

Pirola 202, 228, 230, 245, 416.

- chlorantha Sw. 94, 104, 106, 186, 200, 206, 221, 230, 231, 236, 237, 270, 389 .

- media Sw. 106, 236, 238.

- minor L. 94, 104, 106, 145, 163, 180, 186 , $189,200,220,226,230,236,238,250,270$, 282, 309, 336, 376, 384, 408.

- rotundifolia L. 94, 104, 106, 120, 144, 145, $180,185,191,196,200,206,230,236,270$, $305,309,311,336$.

- secunda L. 94, 104, 106, 120, 144, 186, $189,206,226,231,237,270,295,296,305$, $311,336,395,408$.

- umbellata L. = Chimaphila umbellata.

- uniflora L. 94, 106, 144, 163, 173, 185, 196, 221, 226, 230, 231, 237, 238, 390, 392, 395.

Pirolaceen 282.

Pirus acerba DG. 126, 143, 386.

- communis L. (Birnbaum) 119, 141, 160, 291.

- Malus L. (Apfelbaum) 119, 141, 291.

- Piraster (L.) Borckh. 126, 138, 147, 193, $328,330,485,522$.

- silvestris (L.) S. F. Grey 328. 
Placodium albescens (Hoffm.) Mass. 101.

- saxicolum (Poll.) Kbr. 101.

Plagiothecium undulatum (L.) Br. Sch. G. 93.

Plantago arenaria $\mathbf{W} . \mathbf{I}$. = ramosa.

Cornuti Gou. 354, * 355, 466, 467.

- gentianoides Sm. 323, 328, 369, * 438, 439. 440, 442, 443, 444 .

- lanceolata L. 153, 278, 289.

- maior L. 103, 120, 133, 139, 346, 373, 505 .

- maritima L. $157,159,193,248,249,254$. $256,354,458,466,494,496,508,509,513$, $517,5 \% 1$, " T. ХХल11

- media L. 111, 131, 153, 27^,249, 346, 374.

- montana Lam. 118, 226, 444.

- ramosa (Gilib.) Asch. (arenaria) 128, 151. 154, 206, 25:2, 276, *277, 297, 300, 507, $509,518$.

- Schwarzenbergiana Schur. 354, * 355, 458, $467,484,494,495,522$.

- tenuiflora W. K. 484, 494, 496, 508, 513, $518,521,522$

Platanthera bifolia (L.) Rich. 113, 120, 124, $127,143,144,201,203,255,303,339,388$.

- montana Schm. 124, 186, 379.

Pleurospermum austriacum (L.) Hoffm. 109, $111,133,180,199,207,223,225,242$, $298,309,388,400,403,412,450,462$.

Poa alpina L. 7, 18, 101, 173, 179, 2.25, 328. $344,345,347,348,368,392,394,397,412$.

- angustifolia L. 111, 153, 331, 354, 493.

- annua L. 114.

- badensis Haenke 101, 102, 253, 384.

- bulbosa L. 138. 240, 246, 249, 331, 490, 507.

- caesia Sm. 117, 225.

- cenisia All. 346, 397, 402, 417.

- Chaixii Vill. (sudetica) 94, 105, 107, 108, $117,180,186,210,218,219,337,343,365$, $379,400,412,461$.

- compressa L. 151, 154, 156.

- laxa Haenke 18, 117, 214, 216, 219, 327, $348,349,370,371,380,392,399,437$.

- minor L. 18.

- nemoralis L. $91,117,122,144,147,200$, $236,280,454$.

- palustris L. 107, 131, 138, 152, 279, 496, 509.

- pannonica Kern. 450.

- polonica Blocki 289, 304.

- pratensis L. $111,112,114,131,238,278$, 306 , * $308,334,354$.

- sterilis M. B. 287, 289, 303, 304.

- supina Schrad. 114.
Poa trivialis L. 52, 100, 107, 111, 131, 152, 153, $238,272,275,278,279,289,334,466,485$, 509.

Podanthum = Asyneuma.

Podospermum = Scorzonera.

Pogonatum alpinum (L.) $100,343,344,348$.

Pohlia polymorpha H. et H. 225.

Polemonium coeruleum L. 272, 391, 462.

Polyenemum arvense L. 151, 507.

Polygala alpestris Rehb. 348 .

- amara L. 333, 388.

- amarella Cr. 182, 202.

- Chamaebuxus L. 163, 166, 169, 173, 183, $185,186,192,207,236$.

- comosa Schk. 356.

- maior Jacq. 153, 155, 179, 240, 242, 248, $255,287,332,333,374,404,413,441,458$, $460,507$.

- sibirica L. 460.

- supina L. 447.

- vulgaris L. 131, 132, 153, 289.

Polygonatum latifolium (Jacq.) Desf. 195, 282, 294, 329, 442, 460, 485, 488, 499.

- multiflorum (L.) All. 91, 147, 200, 203, 207, $236,249,255,298,312,413,485,488$.

- officinale All. 107, 136, 250, 282, 410.

- verticillatum (L.) All. 91, 93, 94, 104, 111, $127,163,166,170,173,177,178,186,218$, $221,225,226,228,229,230,236,242,269$, $305,336,377,379,408,412,461$.

Polygonum alpinum All. 328, 442.

- amphibium L. 62, 141, 160, 181, 280, 500.

- arenarium W. K. 467, 481, 488, * 489, 505, $510,511,512,515,519,520,521$.

- aviculare L. 103, 120, 151, 154, 292, 333, $373,505$.

- Bistorta L. 7, 99, 100, 109, 111, 114, 117, $133,152,164,{ }^{*} 165,168,169,170,192$, $199,211,217,225,226,236,239,290,339$, $344,379,386,394,400,431$, * T. IV.

- Convolvulus L. 103, 120.

- dumetorum L. 147, 148.

- Hydropiper L. 279.

- Iritaibelianum Sadl. 513.

- lapathifolium L. 127.

- mite Schrk. 126, 127, 279.

- patulum M. B. 465.

- Persicaria L. 103, 230.

- viviparum L. $7,{ }^{*} 8,344,346,370,380$, $400,412,420,437,444$.

Polypodium Dryopteris L.= Dryopteris Linnaeana.

Polystichum aculeatum (L.) PresI 336, 376. 
Polystichum Braunii (Spenn.) Fée 105, 106, $207,211,221,417$.

- Filix mas (L.) Roth = Dryopteris Filix mas.

- lobatum (Huds.) Presl 105, 106, 205, 206, 209, 217, 228, 238, 336, 438.

- Lonchitis (L.) Roth 118, 166, 212, 217, 226, $336,375,399$.

- montanum Roth $=$ Dryopteris Oreopteris

- spinulosum Lam. et DC. = Dryopteris spinulosa.

Polytrichum 94, 104, 120, 129, 130, 329, 334 .

- alpinum L. 225.

- commune L. 52, 95, 97, 100, 115, 126, 167. $232,274,275,276$.

- formosum Hedw. 100.

- gracile Dicks 97, 232, 274.

- juniperinum Willd. 100, 116, 225, 232.

- piliferum Schreb. 100, 132.

- sexangulare Floerke 116, 346.

- strictum Bancks. 97, 225.

Populus alba L. 127, 146, 147, 148, 239, 257. $272,309,485,486,500,506,510,519,5: 2$.

- canadensis L. 505, 527.

- nigra L. 125, *146,147, 150, 156, 239. $257,272,328,330,485$, * 486, 488, 506 . $510,515,516,519,522,527, *$ T. LJ.

- tremula L. 89, 91, 93, 104, 106, 121, 125. $126,127,144,146,166,193,195,203,221$. $230,250,269,271,311,328,330,408,41:$. $486,488,510,523,527$.

Portulaca oleracea L. 151.

Potamogeton 63, 300.

- acutifolius Lk. 100, 160, 204, 237, 298, 517.

- alpinus Balb. 141, 204, 280.

- coloratus Horn. 500.

- compressus L. 500.

- crispus L. 141, 160, 181, 280, 290, 500, 517.

- gramineus L. 169, 204, 500.

- lucens L. 141, 160, 169, 181, 237, 289, 500. 517.

- marinus L. 517.

- natans L. ${ }^{*} 64,141,160,169,181,237$, $280,290,335,500,511,517,523$.

- obtusifolius M. K. 141.

- pectinatus L. $280,500$.

- perfoliatus L. * $64,335,511$.

- plantagineus Ducr. 160.

- polygonifolius Pourr. 255.

- praelongus Wulf. 255, 280.

- pusillus L. * $64,141,160,280,290,500$.

- trichoides Cham. 141.

Prangos carinata Gris. 446.
Preiselbeere $=$ Vaccinium Vitis Idaea .

Prenanthes purpurea L. 92, 93, 94, 104, 105. $106,120,144,159,163,169,171,173,177$. $178,180,182,186,191,192,196,207,215$, $218,219,226,230,236,237,336,375,376$, $377,400,407,431,450$.

\section{Primula 38 .}

- Baumgartenii Deg. 431.

- acaulis Jacq. = vulgaris.

- Auricula L. 342,345 , * $347,348,370,380$, $386,393,403,405,411$.

- - var. serratifolia Roch. 445.

- carpatica Gris. 358, 361, 368, * 402, 412 , $420,431,440$.

- Clusiana Tausch * 37 .

- elatior (L.) $104,111,169,177,183,186$, $206,211,234,238,308,333,344,356,379$.

- farinosa L. 229, 389, 428.

- intricata Gren. 435.

- leucophylla Pax 422, 424, * 425, * 426.

- longiflora All. 403, 404, 420, 435, 444.

- minima L. 117, *118, 207, 214, 216,220, $346,348,349,371,389,392,397,399,402$, $403,419,420,434,438,444$, " T. III.

- officinalis (L.) Jace. = veris.

$-\operatorname{veris}\left(\mathbf{I}_{.}\right) 104,111,133,153,17,193,: 2177$, $211,278,289,306,312,377,405,450$.

- - var. canescens (Op.) 127, 284, 333.

- - var. hardeggensis (Beck) 245.

- vulgaris Huds. 143, 323, 329, 331, 346, 349, 386, 416.

- Wulfeniana Schott 431.

Prunella alba L. 124.

- grandiflora Jacq. 121, 124, 132, 17ホ, 1ヘ7, 225, 242.

- vulgaris L. $111,132,153,278,334,374$, 486.

Prunus Armeniaca L. (Aprikose) 291, 503.

- avium L. (Kirsche) 90, 104, 119, 138, 143, 203, 286, 282, 303, 311, 328, 458, 485, * T. XXXill.

- Caproniana Rchb. 503.

- Cerasus L. (Weichsel) 503.

- Chamaecerasus Jacq. = fruticosa.

- dasyphylla Borkh. 352.

- domestica L. (Zwetschke) 119, 141, 160, 291 .

- fruticosa Pall. 126, 127, 148, 190, 193, 197, * 199, * 235, 239, * 241, 242, 283, 284, * $286,288,303,306,311,313,328,330,331$, 408, 458, 462, 488 .

- Mahaleb L. 148, 245, 328, 386, 404, 407, $410,{ }^{*} 448,485,527$. 
Prunus nana (L.) Stokes $179,255,306,328,407$, $410,458,460,461,462,466,488,521,527$.

- Padus L. 91, 107, 120, 123, 125, 126, 147, $181,195,203,238,239,272,311,331,460$, $485,487,510$.

- Persica L. (Pfirsich) 373.

- petraea Tsch. 107, " 110, 212, 390.

- spinosa L. 104, 105, 123, 126, 138, 144, $145,163,184,185,193,197,241,249,270$, $271,284,288,311,312,331,328,386,408$, $451,462,485,493,510$.

Psalliota campestris (L.) 503

Psamma arenaria (L.) Schult. 276.

Pseudoleskea catenulata Br. Sch. G. 119.

Pseudorchis Loeselii (L.) Gray 300, 427.

Psora lurida (Ach.) Kbr. 137.

- testacea Hoffm. 137.

Pteridium aquilinum (L.) IKth. 68, 90, 94, 105, $121,122,144,145,173,175,184,187,270$, $272,295,329,342,350,437,450,461,523$.

— - var. lanuginosum (L.) Gray 527.

Pulicaria dysenterica (L.) Gärtn 521.

- vulgaris (L.) Gärtn. 162, 220, 255, 280, $298,499$.

Pulmonaria angustifclia L. 124, 196, 199, 204, $220,228,255,410$.

- molissima Kern. 189, 244, 248, 282, 303, $305,311,390,458,523$.

- obscura Dum. 124, 147, 220, 236, 249.

- officinalis L. $90,105,143,207,303,311$, $329,331,414$.

- rubra Schott 323, 350, 358, * 359, 411, $420,431,437,451,461$.

Pylaisia polyantha (Schreb.) Br. Sch. G. 488.

\section{Q.}

Quercus (Eiche) 48, 104, 120, 166, 169, 170, $171,181,187,191,196,{ }^{*} 199,202,204$, $210,220,228,240,242,249,252,292$, $294,297,298,300,303,335,374,375$, $378,405,412,427,429,516,521,527$, * T. XXXIII.

- Cerris L. 235, 244, 328, 329, 350, 384, 386, $407,408,410,412,442,447,448,456,458$, $485,510,515,519,524$.

- conferta Kit. $350,442,445,447,450$.

- pubescens Willd. 124, 126, 144, 148, 189, $193,197,235,244,328,350,352,384,386$, $408,410,412,413,442, * 447,450,456$, 458,485 , " T. VI.

- Robur L. 89, 91, 92, 107, 123, 124, 125, $126,143,163,177,189,200,203,204,236$,
$238,239,240,246,248,255,259,269,280$, $282,294,297,303,311,328,330,350,377$. $386,406,407,410,428,456,458,460,462$, $485,506,509,510,512,517,519,522,524$, 527.

- rubra L. 103.

- sessiliflora Salisb. 89, 104, 123, 124, 126, $143,144,146,147,177,185,192,193,200$, $203,204,220,236,246,250,255,280,311$, $328,329,350,384,386,406,407,426,437$, $441,447,448,456,458,460,462,515,519$

R.

Racomitrium 130, 136.

- aciculare (L.) Brid. 101.

- canescens (WeiB) Brid. 128.

- fasciculare (Schrad.) Brid. 101, 119.

- heterostichum (Hedw.) Brid. 101.

- lanuginosum (Ehrh.) Brid. 101.

- patens Hüben. 119.

- sudeticum (Funck) Br. Sch. G. 119, 225.

Radiola linoides Roth. 139, * 140, 153, 181, $187,276$.

Ranunculus 54.

- acer L. 98, 100, $111,113,114,117,131$, $147,152,153,237,241,251,278,279,289$, $334,345,354,373,394,441,497,498,507$.

- alpestris L. * $37,328,344,346,370,389$, $390,394,400,434$.

- aquatilis L. 63, 100, 141, * 159, 280, 290, 335,500 .

- arvensis L. 103, 162, 505.

- auricomus L. 111, 126, 143, 195, 238, 239, $270,278,282,298,334,354,410,412,450$, 458,485 .

- bulbosus L. 133, 278.

- carpaticus Herb 323, 358, 361, 414, 419, $424,431,461$.

- cassubicus L. 144, 204, 252, 270, * 281, $282,298,308,312,336,412,428$.

- circinnatus Sibth. 280, 500 .

- crenatus W. K. $323,328,370,420$, * 438 , $439,440,444$, * T. XXXVIII.

- Ficaria L. 147, 250, 272.

- flabellifolius Heuff. 458.

- Flammula L. 126, 181, 275, 279, 295, 334, 384.

- glacialis L. $327,346,348,349,380,392$, 396,397 , * $398,399,400,403$, * T. XLII.

- Hornschuchii Hoppe 402.

- illyricus L. 240, 245, 246, 247, 252, 256, $332,356,410,493,511,518$. 
Ranunculus lanuginosus L. 105, 124, 126, 147, $185,201,230,282,303,308$.

- lateriflorus DC. 498, 509, 518, 523.

- Lingua L. 138, 193, 279, 334, 486, 496 , $497,498,507,517$.

- montanus Willd. 18, 344, 348, 368, 380, 417.

- nemorosus DC. 90, 93, 94, 111, 167, 196, $217,298,366,462$.

- ophioglossifolius Vill. 518.

- orthoceras $=$ testiculatus.

- paucistamineus Tsch. 63, 335, 500, 523.

- pedatus W. IK. 408, 459, 493, 517, 518, 521 .

- platanifolius L. 78, 93, 100, 107, 109, 111, $117,163, * 164,166,167,169,170,173$, $175,177,: 206,209,: 211,212,215,219,223$, $225,233,293,339,341,343,361,364,377$, $378,379,392,395,400,419,440$.

- polyanthemus L. 112, 127, 201, 289.

- polyphyllus W. IK. 303, 408, 518.

- pygmaeus Wahlenb. 322, 327, 346, 392, * $398,399$.

- repens L. $111,131,148,152,279$.

- sardous Cr. 292.

- scleratus L. 229, 507.

- Steveni Andrz. 282, 305, 354, 358, 413, $424,458,523$.

- testiculatus Cr. (orthoceras) 483, 521.

- Thora L. 327, 345, 346, 371, *391, 394, $400,419,429,435$.

Raphanus Raphanistrum L. 103, 142, 161, 374, 505.

Rapistrum perenne (L.) Bergeret. 135, 154, 157, 196, 256, 259, 407, 459, 511.

Raps $=$ Brassica Napus.

Reseda inodora L. 410 .

- lutea L. 132, 333, 521.

- luteola L. 192.

- Phyteuma L. 236, 247, 255.

Rhamnus cathartica L. 90, 104, 124, 125, 127, $147,280,311,328,485,488,510,519$, * T. XXVII.

- Frangula L. 91, 96, 104, 107, 108, 120, $124,125,126,127,147,148,181,195,238$, $239,272,280,311,331,413,462,485,506$, $510,519,527$.

- saxatilis L. 384 .

Rhizocarpon geographicum (L.) DC. 101, 117, $136,348,370$.

- postumum (Nyl.) Th. Fr. 117.

Rhododendron flavum G. Don. 295, *296, * T. XXVI.

- hirsutum L. var. glabratum Kotula 395.
Rhododendron myrtifolium Schott. 323, 343, 365 , "366, 412, 417, 420,422, 429, 431, $437,439,440,444,461$.

Rhynchospora alba (L.) Vahl, 95, 97, 116, 130 , $170,181,187,274,275,380$.

- fusca (L.) R. S. 59, 200.

Ribes alpinum L. 91, 105, 163, 191, 200, 205, $206,219,242,243,336,378,388,451$.

- Grossularia L. 105, 284, 336.

- nigrum L. 147, 272, 284.

- petraeum Wulf. 108, 110, 213, 223; 336, $343,378,388$.

Rindera umbellata (W. K.) Gürke 467, *525, 526. T. LVII.

Rinodina Biatorina Kbr. 117.

Robinia Pseudacacia L. 47, 479, 487, 504, 512 , 515,516 .

Rochelia stellulata Rchb. 392.

Roggen = Secale cereale.

Roripa amphibia (L.) Bess. 279, 509.

- austriaca (Cr.) Bess. 498.

- islandica (Oed.) Schinz und Thell. 127, 279.

- Kerneri Menyh. et Borb. 518, 521 .

- palustris (Leyss.) Bess. = islandica.

- pyrenaica (L.) 413, 459.

- silvestris (L.) Bess. 127, 334.

Rosa 103, 280, 328, 488.

- agrestis Savi 148.

- alpina $L_{\text {. }}=$ pendulina.

- Blockiana H. Br. 284.

- canina L. 104, 120, 123, 124, 126, 331.

- collina Jacq. 104.

- coriffolia Fr. 120, 123, 126, 148, 331.

- dumetorum Thuill. 123, 124, 126, 148, 331.

- gallica L. 124, 126, 127, 155, 189, 193, 238, $240,245,303$.

- glauca Vill. 104, 241.

- - Subsp. Ilseana (Crép.) * 387.

- 'gypsicola Blockii 284.

- Jundzilli Bess. 126, 184, 236, 284.

- Kluckii Bess. 284.

- Kremsensis J. Kern. 236.

- pendulina L. (alpina) 107, 108, 110, 173, $178,219,222,223,225,226,230,234,237$, $336,337,343,378,386,388,408$.

- rubiginosa L. 123, 126, 148, 189, 331.

- rubrifolia Vill. Subsp. Ilseana (Crép.) 602.

- sepium Thuill. 126, 331.

- spinosissima L. 155, 301, 303, 462.

- thyraica Blocki 284.

- tomentella Lem. 126. 
Rosa tomentosa Sm. 126, 184, 386.

trachyphylla Rau 126, 184, 193.

- umbelliflora Swartz 104.

vestita God. 126.

Rotföhre $=$ Pinus silvestris.

Rubus (Brombeere) 230, 280, 328, 510.

- apricus Wh. 104.

- Bayeri Focke 342.

- Bellardii W. N. 90, 92, 04, 104, 175.

- caesius L. 120, 156, 284, 331, 487.

- Chamaemorus L. * 115, 116, 207, 209, 213, 220.

- dumetorum W. N. 123.

- Gremlii Focke 94.

- Guentheri W. N. 342.

- hirtus W. K. 93, 104, 105.

- Idaeus L. (Himbeere) 90, 91, 94, 105, 107, $108,110,120,123,126,163,170, * 171$, $173,177,187,223,284,305,329,330,336$, 337,342 .

- Koehleri W. N. 104.

- nessensis W. Hall 90, 94.

- plicatus W. N. 90, 94, 104.

- saxatilis L. 94, 183, 186, 189, 211, 229, $230,234,338,343,390$.

- suberectus Anderss. = nosisensis.

- szepusiensis Borb. 342.

- tomentosus Borkh. 126.

Rudbeckia laciniata L. 68, 373, 441, 506.

Rumex Acetosa L. 114, 153, 238, 289, 312 , 441.

- Acetosella L. 98, 150, 151, 185, 523.

- alpinus L. 114, 220, 346, 379.

- aquaticus L. 107, 193, 272, 279.

- arifolius L. 108, 117, 166, 167, 215, 219, $223,225,431,461,462$.

- confertus Willd. 303, 305.

- conglomeratus Murr. 120, 279, 292, 373.

- crispus L. 103, 120, 292, 373.

- Hydrolapathum 107, 193, 271, 279, 428, 509, 518.

- limosus Thuill. 127.

- maritimus L. 127, 229, 232, 249, 279, 524

- obtusifolius L. 292.

- odontocarpus Sándor (stenophyllus) 159, 248, 512,524 .

- sanguineus L. 148 .

- scutatus L. $343,346$.

- silvester Wallr. 68.

- stenophyllus aut. $=$ odontocarpus.

Ruscus aculeatus L. 350, 358, 445.

- Hypoglossum L. 350, 375, 448.

Ruta patavina L. 354

\section{S.}

Sagedia chlorotica Ach. 117.

Sagina Linnaei Presl $=$ saginoides .

- procumbens L. $111,331,381$.

- saginoides (L.) D. T. (saxatilis) 100, 111 , $117,215,217$.

- saxatilis Wimm, = saginoides.

Sagittaria sagittifolia L. 138, 160, 259, 279, $290,496,523$.

Salicornia herbacea L. 15, * 158, 248, :253, $298,354,458, * 459,461,462,466,4177$, $484,494,508,513,514,518$.

Salix (Weide) 239, * $310,377,388$.

- alba L. $91,107,124,125,127, * 146,147$, $148,198,257,272,284,330,379,460,4 \times 7$, $506,509,510,521$.

- amygdalina $\mathrm{L}_{\text {. }}=$ triandra.

- arbuscula L. $346,400$.

- aurita L. 96, 97, 98, 108, 126, 127, 270, $275,328,341,427$.

- bicolor Ehrh. 127, 207, 217, 220, 343, 417.

- caprea L. 90, 92, 104, 105, 108, 1:3, $125,126,143,148,238,270,328,336$, $412,485$.

- cinerea L. 59, 91, 126, 127, 130, 181, 195, $272,275,301,506,509$.

- daphnoides Vill. 107, 148, 330, 379, 4N7.

- fragilis L. $107,109,125,127,147,14$, $198,211,238,257,272,284,303,330,487$, 506,510 .

- glauca L. 343.

- grandifolia Sér. 172, 207, 235, 343.

- hastata L. 110, 116, 117, 207, 224, 22.25, $346,403$.

- herbacea L. $38,117, * 118,207,212,217$, * $223,225,344,346,348,370,389,392$, 460 .

- Jacquini Willd. 345, 346, 369, 380, 403, 437, 441.

- incana Schrk. 147. 149, 207, 259, 331, 338, 351, 381, 413, 431.

- Lapponum L. 109, *110, 116, 117, 213, $220,225,301,322,346,369,399,400$.

- livida Wahlenb. * 273, 275, 297, 298.

- myrtilloides L. $97,{ }^{*} 115,116,173,176$, 181, 209, 219,275, 300,301, 403.

- nigricans Sm. 301, 343, 400.

- pentandra L. $107,125,126,127,148,170$, $181,272,330,392$.

- purpurea L. 91, 107, 109, 125, 126, 127, $147,148,193,211,238,259,272,301,331$, $338,381,460,487$. 
Salix repens L. 219, 272, 275, 276, 298, 301, $341,427$.

- reticulata L. $345,{ }^{*} 369394,441$.

- retusa L. * $38,66,344,345,346,348,389$, $392,394,441$

- silesiaca Willd. 105, 106, 107, 108, 109, * $110,117,180,205,207,211,219,224$, $225,300,323,330,336,338,343,361,378$, $379,388,392,396,411,433,439$.

- triandra L. (amygdalina) 107, 125, 127, $147,148,331,460,487,521$.

- viminalis L. 107, 127, 147, 148, 198, 272, $460,487$.

Salsola Kali L. 151, 156, 296, 488, 494, 507, $509,513$.

- Soda L. 495.

- Tragus L. 513.

Salvia Aethiopis L. 179, 507.

- austriaca Jacq. 179, 189, 235, 408, 410, 459.

- betonicifolia Etl. 459.

- dumetorum Andrz. 284, 288, 306.

- glutinosa L. 105, 106, 147, 183, 237, 245, $250,282,293,294,296,303,311,329,338$, $374,375,376,377,380,392,407,420,450$, 451,523 .

- nemorosa L. 135, 156, 184, 191, 197, 204, $289,306,307,356,466$.

- nutans L. 287, *288, 289, 292, 303, 305, 306, 333, 353, 356, 459, 460, 462, 465, 516.

- pendula Vahl 303.

- pratensis L. 98, 132, 135, 136, 138, 153, $156,177,193,202,204,239,251,278,289$, $306,312,356,408$.

- tránssilvanica Schur. 353, 459, 464.

- verticillata L. 135, 138, 153, 177, 186, 193, $204,226,289,292,379,429$.

Salvinia natans L. 237, 293, 294, 298, 500, $520,523,524$.

Salweide $=$ Salix caprea.

Sambucus Ebulus L. 148, 437, 438.

- nigra L. $90,91,126,147,148,178,238$, $239,272,284,311,328,337,485$.

- racemosa L. 90, 91, 92, 94, 104, 105, 106, $167,110,153,170, * 171,177,200,204$, $229230,237,293,311,329,331,336,337$, 342 343, 384 .

Samolys Valerandi L. 248, 249, 494.

Sanzuisorba minor Scop. 133, 134, 135, 153, 379.

- officinalis L. 98, 111 153, 192, 206, 207, 230, 238, 239, 251, 284334 .

- polygama W. K. 332 .
Sanicula europaea I. 91, 93, 104, 106, 120, $144,185,186,189,192,200,204,211$, $243,270,282,303,311,336,386,414$, $441,461$.

Saponaria bellidifolia Sm. 451, * 452.

- glutinosa M. B. " 446, 447.

- officinalis L. 150, 284, " 285, 331, 379.

- pumila (St. Lag.) Janch. 37, 67.

Sarcoseyphus adustus Limpr. 119.

- sphacelatus Nees. 116.

Sarothamnus scoparius (L.) WVimm. 12, 32, $52,{ }^{*} 53,90,97,98,124,129,145,169$, $184,185,200,201,203,207,226,228,230$, $234,236,237,245,249,252,256,270,271$, $276,292, * 293$.

Satureia Acinos (L.) Scheele 135, 138, 156, 332.

- alpina (L.) Scheele 323, 370, 411, 420.

- Baumgartenii (Simk.) 323, 328, 361, * 367, $370,433,454$.

- Calamintha (L.) Scheele 353.

- hungarica (Simk.) Hay. 353.

- intermedia Baumg. 329, 444, 458.

- Pulegium (L.) Briqu. 354, 442, 445.

- vulgaris (L.) Fritsch 107, 147, 329, 331, $332,485,486$.

Sauerklee $=$ Oxalis

Saussurea alpina (L.) DC. 348, 399, 402, 403.

- discolor (Willd.) DC. 403, 444.

- macrophylla Saut. 402.

- Porcii Deg. 420.

- pygmaea (Jacq.) Spr. 348, 399.

Saxifraga 15, 38 .

- adscendens L. 342, 380, 388, 453, 454.

- aizoides L. 339, 343, 347, 390, 393.

- Aizoon Jacq. 117, 157, 189, 225, 226, 238, $242,243,245,253,342,345,347,348,364$, $377,380,381,384,386,387,390,394,405$, $408,412,421,422,429,434,445,451,453$, 454.

- - var. robusta (Sch. N. K.) Engl. 342.

- androsacea L. 346, 370, 389, 391, 392, 394, 402, 434, 439, 444.

- bryoides L. 117, * 118, 207, 214, 220, 327, $349,369,370,371,392,399,419,439,444$.

- bulbifera L. 179, 252, 384, 485, 493.

- caesia L. $323,327,345,347,370,380,390$, 391, 393, 394, 402, 411.

- carpatica Rchb. 322, 346, 349, 370, 389, $394,396,397$, ' $398,399,431,434,439$, 444, T. XLII.

- cernua L. 394, 396.

- cuneifolia L. 18, 385, 364, 431, 440, 444, 454. 
Saxifraga cymosa W. K. * $367,370,419,420$, $439, " 440,442,444$.

- decipiens Ehrh. 138, 184, 196, * 197, 199, 245.

- demissa Schott 328, 370, 429, * 432, 434.

- fonticola Kern. = heucherifolia.

- granulata L. 98, 151, 169, 186, 204, 206, $217,220,230,237,238,242,278,384$.

- heucherifolia Gris. 358, 366, *367, 370, $435,439,440,456$.

- hieracifolia W. K. 327, 344, 348, 389, 392, $394,396,397, * 398,402,403,417,420$, 439.

- Hirculus L. 228, * 273, 274, 294, 300.

- luteoviridis Schott. 323, 328, 370, 371, 419, $421,422,425,429,431, * 432,434,435$, $439,440,441,453$.

- moschata Wulf. 117, 207, 214, 220, 328, $348,349,369,370,371,380,391,392,393$, $394,397,402,420,444$.

- nivalis L. 39, 117, *118, 207, 214, 220, 323.

- oppositifolia L. 66,117 , * 118, 207, 212, $214,217,220,349,371,392,394,399,402$, $429,439$.

- perdurans W. K. $322,347,348,380$, * 391 , 392, 394, 396, 399.

- retusa aut, = Wulfeniana.

- Rocheliana Sternb. 364, 444, 445.

- rotundifolia L. 339, 390, 403, 442, 450.

- - var. Heuffelii (Schott) 358, 445.

- stellaris L. 7, * 8, 370, 417, 440, 442, 456.

- tridactylites L. 189.

- Wulfeniana Schott. 322, * 349, 371, 392, 399.

Scabiosa canescens W. K. 129, 156, 242.

- lucida Vill. 217, 238, 340, 342, 346, 381, $412,424,429,451$.

- ochroleuca L. 128, 129, 132, 133, 134, 136 , $153,156,184,187,245,278,284,307,308$, $313,332,356,376,464,465,493,507,512$, * 513.

Scandix Pecten Veneris L. 143.

Scapania albicans (L.) 225.

- undulata (L.) Dum, 116.

Scheuchzeria palustris L. 57, 59, 97, 116,209 , $221,295,380,396,417$.

Sehievereckia podolica (Bess.) Andrz. et Bess. 285, * 304, " T. XXVII.

Schistidium apocarpum (L.) Br. Sch, G. 136. Schistostega osmundacea (D.) Mohr 9.

Schlehe $=$ Prunus spinosa.

Schoenus 54.
Schoenus ferrugineus L. * 55, 202, 203, 275, $300,301,340,389,498,519$.

- nigricans L. 202, 203, 275, 300, 496, 497, 498, 506, 511 .

Schoenoplectus carinatus (Sm.) Palla 259.

- lacustris (L.) Palla 63, 138, 159, 181, 259, 279, 290, 298, 334, 496, 508, 523, “T. XIII.

- supinus (L.) Palla 280.

- Tabernaemontani (Gmel.) Palla 20, 157, $159,170,195,203,248,279,354,466,496$, 508.

- triqueter (L.) Palla 259, 460, 461, 508.

Schwarzföhre $=$ Pinus nigra.

Scilla bifolia L. 125, 144, 148, 195, 282, 297, $303,308,336,358,513,448,458,460,517$, 518.

- - var. praecox (Willd.) Richt. 419.

Scirpus caespitosus $\mathrm{L}_{0}=$ Trichophorum caespitosum.

- lacustris L. = Schoenoplectus lacustris.

- maritimus L. 20, 138, 159, 181, 195, 248, $254,279,354,384,466,496,497,498,513$, * 515 .

- palustris $\mathbf{L} .=$ Heleocharis palustris.

- radicans L. 138, 181, 292, 428, 511.

- silvaticus L. 100, 138, 152, 181, 279, 289.

- supinus L. $=$ Schoenoplectus supinus.

- Tabernaemontani Gmel. = Schoenoplectus Tabernaemontani.

- triqueter L. = Schoenoplectus triqueter. Scleranthus 296.

- annuus L. 98, 103, 120, 142, 151, 161, 198.

- intermedius Kitt. 151.

- perennis L. 98, 103, 128, * 129, 150, 151 , $154,169,174,184,187,200,201,220,235$, $247,248,252,276,292,297,300$.

- uncinatus Schur 364, 370, 412, 419, 420, 422,461 .

- verticillatus Tsch: 424.

Sclerochloa dura (L.) Beauv. 518.

Scopola carniolica Jacq. 323, 381, 411, 413, $450,457$.

Scorzonera austriaca Willd. 156, 179, 249, 253, 462.

- cana (DC.) 518.

- hispanica L. 131, 133, 156, 203, 255, 332, $353,408,462,493$.

- humilis L. 99, 133, 152, 157, 166, 170, 177, $180,183,186,189,196,197,199,202,203$, $225,234,237,278,279,295,403,508,511$, 518.

- Jacquiniana.(Koch) Čelak. 159, 466, 494, 515,521 . 
Scorzonera laciniata L. 289,524 .

- parviflora Jacq. 159, 170, 195, 203, 248, $249,253,254,256,461,467,494,509,511$, $515,517,518$.

- purpurea L. 156, 193, 244, 252, 287, 289, $297,313,332,353,363,404,405,410,458$, 493.

- rosea W. K. 323,361, * $362,411,417,419$, $420,422,424,429,431,440,456,457$.

Scrophularia alata Gilib. 148, 290.

- Iasiocaulis Schur 353, 429, 433, 440, 442, 444 , * 452, 454, * T. XXXIV, *T. XLIX.

- nodosa L. 107, 127, 147, 270, 272, 486.

- Scopolii Hoppe 109, 220, 222, 224, 226, * 227, 236, 292, 300, 338, 377, 413, 429.

- vernalis L. $375,376,384,410$.

Scutellaria altissima L. 284, 329, 353, 408, 515.

- Columnae Ten. 353.

- galericulata L. 139, 148, 152, 279, 290.

- hastifolia L. 293, 369, 518

- Iupulina aut. = supina.

- supina L. (lupulina) 284, 454.

Secale cereale L. (Roggen) 102, 119, 141, 160, $163,290,372,502$.

- silvestre Host. 482, " 483, 487, 488, 518.

\section{Sedum 25.}

- acre L. 129, 135, 138, 151, 332, 496.

- album L. 101, 136, 191, 238, 242, 332, 333, $353,384,411$.

- alpestre Vill. (repens) 117, 207, 211, 369, $371,397,439$.

- atratum L. 345, 348, 371, 393, 394.

- boloniense Lois. 151, 332 .

- carpaticum Reuss. 342, 412, 419, 435, 451.

- glaucum W. K. 354, 408, 420, 423, 442, $450,451,453,454,457$.

- Hillebrandtii Fzl. 484, 511, 515.

- maximum L. 206.

- micranthum Bast. 102, 235.

- polonicum Blocki 285.

- purpureum (L.) Schult. 200.

- repens Schl. $=$ alpestre.

- roseun (L.) Scop. 66, 117, 207, 214, * $216,348,380,390,397,412,420,435$, * T. XL.

- rubens (L.) 515.

- rupestre L. 197, 202.

- villosum L. 97, 186, 229, 230, 231, 232, 234.

Seidelbast $=$ Daphne Mezereum.

Selaginella helvetica (L.) Lk. 157, 441.

- selaginoides (L.) Lk, 217, 348, 380, 412.

- spinulosa A. Br. 412 .
Selinum Carvifolia L.90, 126, 144, 166, 236, $239,279,407,467,509$.

Sempervivum 15, 38 .

- assimile Schott. 353, 364, 417, 420.

- blandum Schott. 364, 370, 429, 451, 453, 454.

- carpaticum Wettst. 348, 380, 389, 399, 400.

- globiferum L. 305, 307, * T. XXVII.

- Heuffelii Schott. 370, 429.

- hirtum L. 332, 353, 377, 381, 386, 387, 390.

- montanum L. 328, 370, 417, 419, 437, 444.

- Pittonii Schott. 20.

- Simonkaianum Deg. 421, 422, 425.

- soboliferum Sims. 157, 170, 189, 190, 240, $245,253,332,348,407$.

Senecillis glauca (L.) Gärtn. Subsp. carpatica (Sehott.) $420, * 421$.

Senecio aquaticus Huds. 100, 151, 181, 293.

- aurantiacus (Hoppe) DC. 231, 389, 404.

- Biebersteinii Lindem. (macrophyllus) 288, $313,466,467$.

- campestris (L.) DC. 127, 156, 249, 287, $312,493$.

- capitatus (Hoppe) DC. 344, 348, 399, 402, 422.

- carniolicus Willd. $344,348,349,399,417$, $440,444$.

- carpaticus Herbich 348, 366, 368, 370, 389 , 392 , * $398,399,400,403,419,420,434$, $435,440,442$.

- Doria L. 249, 257, 303, 506, 508, 512, 518.

- erucifolius L. 245, 306, 407.

- fluviatilis Wallr. 160, 252, 259, 284, 308, 458.

- glaberrimus Roch. 370, 419, 426, 444.

- Jacobaea L. 278.

- kukulensis Wol. 417.

- macrophyllus aut. $=$ Biebersteinii.

- nemorensis L. 105, 106, 107, 111, 173, 177, $187,204,206,209,211,219,230,233,236$, $245,255,282,338,342,361$, * 363,364 , $365,392,438,462$.

- paludosus L. $160,280,293,297,298,392$, $462,506,508$.

- - var. Sadleri (Láng) 520.

- palustris (L.) DG. 165, 170, 207, 279, 280, 428 .

- rivularis (W. K.) DC. 111, 126, 163, 170, $180,206,211,215,217,226,229,231,234$, $282,340,346,379$.

- rupestris W. K. 429.

- sarracenius L. 92, 93, 106, * 195, 196, 224, $225,226,230,231,377,388,429$. 
Senecio silvaticus L. 342.

- subalpinus Koch 100, 172, 339, 343, 346, 380,392 .

- umbrosus W. K. 282, 336, 388, 390, 392, 414.

- vernalis W. K. 69, 276, 292.

- viscosus L. 128, 342 .

vulgaris L. 103, 120, 373.

Serratula lycopifolia (Vill.) Kern. 284, 304. nitida W. K. $353,356,465,466,467$. radiata W. IK. $353,356,459,460,464,465$, 466.

tinctoria L. 124, 127, 230, 270, 284, 303, $307,312,486,493$.

-- Wolffii Andrae 376, * 463, 465, 467.

Seseli 484.

annuum L. 153, 156, 197, 202, 284, 313, 403, 462, 507.

- Beckii Seefr. 101, 102, 136, 138, 156, 157, $187, * 188,191,235,253,333,374,377$, $442,454$.

- austriacum (Beck) Wohlf. 242, 245.

- gracile W.-K. 445, 451, * 452, 453, 454, * T. NLIX.

- Hippomarathrum L. 136, 138, 154, 245, $254,255,332,374$

- leucospermum W. K. 410.

- rigidum W, K. 445.

- varium Trev. 235, 249, 467, 492.

Sesleria coerulans Friv. 323, 420, 434.

- coerulea aut. = varia.

- disticha IVulf, 18, 328, 344, 345, 347, 348, $368,370,371,380,389,392,394,396,397$, $399,417,420,434,437,440,444$.

- Heufleriana Schur. 285, 286, 306, 353, 364.

- ovata (Hoppe) Kern. 242.

- rigida Heuff. 364, 440, 451, 454.

- uliginosa Op. 202.

- varia (Jacq.) Wettst. 52, 132, 138, 155, $157,190,193,198,204,244,253,332$, $342,345,347,353,364,384,394,399$, $400,404$.

Setaria glauca (L.) R. S. 162, 292, 333, 499. - viridis (L.) R. S. 292, 333.

- verticillata (L.) R. S. 276.

Sherardia arvensis L. 120, 161.

Sicyos angulatus L. 292.

Sideritis montana L. $156,244,356,384,410$, 521.

Sieglingia decumbens (L.) Lk. 90, 94, 98, 104, $120,121,124,163,185,249,270,271,276$.

Silaus pratensis Bess. 98, 131, 152, 169, 192, $197,252,278$.
Silaus Rochelii Heuff. (virescens) 408, 429 , $450,454,462,464,527$.

- virescens Gris $=$ Rochelii.

Silene acaulis L. $37,328,344,348,369,389$, $390,393,394,402,420,434, *$ T. XLII.

- alpina (Lam.) Thom. 346.

- Armeria L. 20, 353, 428, 442, 447, 448, 459

- chloranthą Ehrh. 276, 282, 284, 285, 287. $306,354,356,460,466$.

- conica L. 151, 254, 256, 483, 488, 492, 511, $512,517,518,523$.

- Cserei Baumg. 361, 445.

- dichotoma Ehrh. 287, 289.

- dinarica Spr. 328, 369, * 438, 439, 440.

- dubia Herbich 313, 361, 364, 420, 426, $429,441,453$.

- flavescens W. K. 364.

- gallica L. 120, 276, 374.

- inflata $\mathrm{Sm}$. = vulgaris.

- Lerchenfeldiana Baumg. 438, * 443.

- longiflora Ehrh. 179, 198, 466, 493.

- multiflora Ehrh. 179, 256, 493, 509, 511, 519.

- nemoralis W. K. 189, 342, 448, 453, 454, 458 .

- nivalis Rohrb. 369, * 418, 419, 420.

- nutans L. 121, 127, 129, 146, 153, 187, 189 , $196,201,252,270,338,388$.

- Otites L. 101, 129, 133, 151, 156, 157, 190, $196,235,239,245,247,250,253,276,297$, $306,332,354,356,408,429,492,509,518$, $521,523$.

- parviflora Ehri. 521.

- petraea IV. K. 354, 364, 445.

- pseudotites Schur. 285, 289, 304.

- rupestris L. 39, 364, 418.

- venosa (Gilib.) Asch. = vulgaris.

- viridiflora L. 358, 408, 424, 461.

- vulgaris (Mnch.) Garcke 114, 136, 153, 235, $276,287,297,339$.

Siler trilobum (L.) Cr. 376, 405.

Sinapis alba L. 505.

- arvensis L. 142, 161, 374, 505 .

\section{Sisymbrium 120 .}

- Irio L. 285.

- junceum W. K. 306.

- Loeselii L. 148, 442, 505.

- pannonicum Jacq. = orientale.

- officinale L. 373.

- orientale L. (pannonicum) 157, 284, 285, $505,512$.

- Sinapistrum Cr. 151, 157, 259.

- strictissimum L. 306, 313, 376, 405. 
Sisyrrhinchium angustifolium Mill. 414, * 415 Sium erectum Huds. 309.

- Iatifolium L. 279, 290, 496, 506, 509, 523.

Smyrnium perfoliatum L. 374 .

Solanum Dulcamara L. 126, 127, 139, 141, 150, $272,488$.

- Melongena L. 291.

- nigrum L. 292, 373.

- tuberosum L. (Kartoffel) 102, 119, 160 , 163, 290, 291, 373, 424, 441, 503.

Soldanella carpatica Vierh. 336, 346, 380, 390 . 396,397, * T. NXXI.

- Lungarica Simk. *369, 417, 422, 434, 461.

- maior (Neilr.) Vierh. 386, 389, 390, 431.

- montana Willd. 94, * 172, 173, 176, 177, $178,180,183,186,207,230,233, * 234$.

- pusilla Baumg. 323, 370, 434, 437, 439, 444, * T. XXYIIII.

Solidago alpestris WV. K, 100, 114, 207, 211 , $219,344,386,388,412,461$.

- serotina Ait. 68, 506, 507, 510.

- Virga aurea L. 90, 94, 111, 143, 145, 151, $186,252,270,282,342$.

Solorina crocea (L.) Ach, 114.

Sonchus arvensis L. 161, 374.

- oleraceus (L.) Hill 292, 373.

- palustris L. 280.

- uliginosus M. B. 506, 509.

Sorbus Aria (L.) Cr. 126, 127, 136, 184, 189 , $245,253,330,336,337,342,386,389,453$, 454 .

- Aucuparia L. 28, 89, 94, 104, 163, 168, $221,234,336,337,338,343,407,408,433$, 439.

- - Subsp. glabrata (W. Gr.) Hedl. 106, $107,108,110,117,211,219,223,392,396$.

- austriaca (Beck) Hedl, 451, 453.

- Chamaemespilus (L.) Cr. 343389.

- sudetica (Tsch.) Nym. 107, *110, 207, 213, $217,220$.

- torminalis L. $90,104,123, .125,143,189$, $203,242,280,330,386,406,407,460,485$, 522.

Sparganium *232.

- affine Schnitzl. 175.

- minimum Fr. 141, 169, 182, 183, 200, 231 $252,275,428$.

- ramosum L. 138, 181, 279, 309.

- simplex L. * 159, 279, 334.

Spartium junceum L. 12, * 13.

Spergula arvensis L. 103, 120, 142, 161.

- Morisonii Bor. 98, 202.

- pentandra L. 128, 129, 276.
Spergularia campestris Asch.= rubra

- echinosperma Čel. 139, 181

- marginata (DC.) Kitt. = media.

- marina (L.) Gris. = salina.

- media (L.) Presl (marginata) 157, * 15 i $159,195,248,249,253,354,458,461,462$. $466,484,494,495,508,518$.

- rubra (L.) Presl (campestris) 139, 198, 276 .

salina Presl (marina) 159, 192, 195, 24غ, 249, 254, 298, 354, 413, 484, 495, 509, 514, 518.

Sphagnum 54, 56, 94, 95, 120, 209, 427.

- acutifolium Ehrh. 95, 97, 115, 116, 130, 232,341 .

- compactum Brid. 130, 343.

- cuspidatum Ehrh. 97, 115, 116, 126, 130, 273.

- cymbifolium Ehrh. * 57, 97, 116, 126, 130, 232.

- Dusenii Russ et Warnst. 115, 209.

- fimbriatum WVils. 130.

- fuscum (Schimp.) Klingg. 115, 341.

- Girgensohnii Russ. 341.

- Lindebergii Schimp. 115, 116.

- medium Limpr. 95, 96, 126, 130.

- molluscum Bruch. 115, 341.

- papillosum Lindb. 209.

- recurvum Pal. 97.

- quinquefarium Warnst. 126, 130.

- spectabile Schimp. 116.

- squarrosum Pers. 95, 116, 232.

- subsecundum Nees.97, 126, 130, 232, 273.

- teres (Schimp.) Angstr. 95, 116, 130, 341.

Spiraea chamaedryfolia L. $330,336,361$, * 387 , $389,439,451,457,462$.

- crenifolia C. A. Mey. 361, 429, 462.

- media Schmidt 303, 404, 407, 408, 410, $411,413$.

- salicifolia L. 127, * 128, 180, 183, 312.

- ulmifolia Scop. 358, 440.

Spiranthes spiralis (L.) C. Koch 493.

Spirodela polyrrhiza (L.) Schleid. 60, 141, 280, $290,500,511$.

Splachnum ampullaceum L. 232, 274.

Stachys alpina L. 107, 111, 163, 337, 338, 342, $378,379,420,450,453$.

- annua L. 143, 162.

- arvensis L. 284.

- germanica L. 124, 132, 187, 189, 238, 245, $288,300,301,305,306,331,332,333,353$, $403,413,507$.

- nitens Janka 445 . 
Stachys officinalis (L.) Trev. 99, 131, 132, 153, 240, 278, 307, 441, 458, 493.

- palustris L. 126, 152, 202, 272, 280, 486, 509.

- recta L. 101, 148, 156, 157, 178, 238, 241, $245,246,287,288,297,307,331,332,403$, $413,441$.

- silvatica L. 107, 126, 147, 148, 211, 250, $272,284,337,335,450,495$.

Staphylea pinnata I. 143, 148, 191, 245, 249, $280, * 311,313,323,352,404,406,407$, $408,410, * 447,448$.

Statice 20.

-. Gmelini Willd. 354, 458, 459, 460, 466, 467, $484,494, * 495,508,513,514,515,517$, $518,522$.

Stellaria aquatica (L.) Scop. 107, 279.

- glauca With. = palustris.

- graminea L. 276, 289, 345, 373, 377.

- Holostea L. 91, 143, 147, 270, 298, 311.

- longifolia Mühlenb. 126.

- media (L.) Vill. 107, 373.

- nemorum L. 91, 126, 163, 195, 239, 339, 358 .

- palustris Retz. (glauca) 152, 181, 192, 193, $231,239,252,275,279,498$.

- uliginosa Murr, 116, 231, 275, 384.

Stenactis annua (L.) Nees 68, 272, 284, 488, 506.

Stenophragma Thalianum Čel. 374.

Sternbergia colchiciflora WV. K. 493.

Stereocaulon alpinum Laur. 225.

- coralloides Fr. 117.

Stipa 197, 482.

- capillata L. 101, 133, 136, 154, 184, 190, $192,193,196,198,202,235,239,242,245$, $\because 47,252,255,256,285,287,288,306$, *308, 442, 445, * 483, 488, 490, * 492, $509,511,524$.

- Joannis Cel. = pennata Subsp. Joannis.

- Lessingiana Trin. et Rupr. 356, 465, 466, 467.

- pennata L. 18, 32, 33, 133, 136, 138, 154, $155,157,184,189,190,192,193,198,202$, $203,235,244,246,248,249,252,253$, $255,285,288,306,307$, * 308, 311, 331, $333,342,374,386,404,460, * 483,490$, $511,524$.

- - Subsp. Grafiana (Stev.) = pulcherrima.

- _ Subsp. Joannis Čel. 101, 127, 135, 512, 524.

- pulcherrima C. Koch (Grafiana) 135, 356, 445.
Stipa Tirsa Stev. * 134, 135, 136, 189, 193, $356,465,466$.

Stratiotes aloides L. 60, 160, 255, 259, 2811, $298,497,500,507,511,517,518,523$, 524.

Streptopus amplexifolius L. 100, 107, 111, 175, $176,205,206,217,219,225,229,379,392$, 400 .

Suaeda maritima (L.) Dum. 159, 248, 249, 458, $496,518,519$.

- salinaria Schur. 354, 494.

- salsa (L.) Pall. 354, 467, 518.

Succisa inflexa (Jundz.) Kluk 279, 296.

- pratensis Mnch. * 55, 100, 111, 152, 278, $279,334,507,517$.

Sweertia perennis L. 116, 168, 215, 272, 274, $275,346,370,380,389,412,422,467$.

- punctata Baumg. 422, 442, 456.

Symphyandra Wanneri (Roch.) DC. 328, 364, 438, 443, 444.

Symphytum cordatum W. K. 293, 305, 323, $336, * 357,381,408,411,424,431,456$, 457,461 .

- officinale L. $127,239,278,279,289,488$, 498.

- ottomanum Friv. 447.

- tuberosum L. 220, 230, 378, 411, 461, 485.

Syntrichia intermedia Brid. 102, 236.

Syrenia angustifolia (cana) 487, * 491, 492, $507,512,517,525$.

- cana Pill. = angustifolia.

- cuspidata Rehb. 353, 442, 447, 448, 450.

Syringa Josikaea Jacq. 350, 413, 456, 467, * T. XLIV.

- vulgaris L. $350,442,444,445, * 448$, 451 .

\section{T.}

Tabak $=$ Nicotiana Tabacum

Tamarix 484.

Tamus communis L. 350, 445 .

Taraxacum alpinum (Hoppe) Heg. et Heer 368 .

- bessarabicum (Hornem.) Hand. Mazz. 157, $159,195,248,249,517,519,521$.

- laevigatum (Willd.) DG. 151.

- nigricans (Kit.) Rchb. 114, 397, 400.

- paludosum (Scop.) Schlechter. 152, 239, 498.

- serotinum (W. K.) Poir. 151, 179, 255, 507.

- vulgare (Lam.) Schrk. 114, 279, 289, 334 
Taxus baccata L. 9, 229, 245, 400, * 414, 454.

Teesdalea nudicaulis (L.) R. Br. 98, 128, 185 , $196,220,276,300$.

Telekia speciosa Baumg. 312, 323, * 351, 358, * $361,364,407,411,412,413,420,424$, $427,428,429,431,437,438,445,450,457$. $458,460, * \mathrm{~T} . \mathrm{XXXVI}$.

Tetragonolobus siliquosus (L.) Schrk. (Lotus siliquosus) $133,159,195,254,354,494$, $498,507,513,515,518$.

Teucrium Botrys L. 189, 253, 276.

- Chamaedrys L. 132, 138, 156, 189, 301 , $356,384,429$.

- montanum L. 156, 157, 333, 381, 384, 405, 454.

- Scordium L. 152, 204, 242, 279, 297, 498, 524.

- Scorodonia L. 165, 166, 197, 207, 239.

Thalictrum aquilegifolium L. 93, 105, 107, 111 , $117,156,163,176,177,178,186,204,206$, $210,211,218,220,221,222,226,230,233$, $236,242,248,294,296,338,361,378,379$, $381,388,395,400,412,428,431,485,511$, $5: 23, * 5: 7$.

- flavum L. 203, 496, 507.

- flexuosum Bernh. 289, 297, 467.

- foetidum L. $136,384,408,413,442,453$, 454, 490.

- galioides Nestl. 252, 506, 509, 527.

- lucidum L. 54, 133, 152, 193, 195, 239, $279,280,292,385,442,466,496,509$.

- minus L. 124, 127, 189, 332, 342.

- simplex L. 297.

- uncinatum Rehm. 306.

Thamniola vermicularis (Sw.) Syd. 344, 348 . Thesium 41.

- alpinum L. 219, 225, 344, 412, 417, 467.

- Dollineri Murb. 244, 249.

- ebracteatum Hayne 202, 498.

- Kernerianum Simk. 435.

- Linophyllum L. 136, 196, 201, 289, 312.

- montanum Ehrh. 199.

- pratense Ehrh. 99, 111, 166, 170, 234.

- ramosum Hayne 462.

- rostratum M. K. 187.

Thlaspi alpestre L. 20, 99, 163, 164, 168, 169, $172,174,180,183,186,187,191,199,205$, 207.

- arvense L. 374, 505.

- cepaeaefolium (Wulf.) Koch 20.

- dacicum Heuff. 361, 368, 443.

- Goesingense Hal. 20.
Thlaspi Jankae Kern. 408.

- Kovácsii Heuff. 361, *362, 368, 417, 4:8, 431 .

- rotundifolium (L.) Gaud, 66.

Thuidium abietinum (Dill.) Br. Sch. G. 488.

- tamariscinum (Hedw.) Br. Sch. G. 341.

Thymelaea Passerina L. 156, 384.

Thymus alpestris Tseh. 114.

- angustifolius Pers. 128, 151, 156, 202, 252, 255,300

- collinus M. B. 135, 428.

- comosus Heuff. 353, 451.

- dacicus Borb. 416.

- Ianuginosus Mill. 101, 135, 197, 289, 308, 493.

- Lövyanus Op. 193, 197, 202.

- Marschallianus Willd. 136, 138, 146, 156. $252,289,305,524$.

- montanus W. K. $332,384$.

- nummularius M. B. 117, 371 .

- ovatus Mill. 131, 150.

- praecox Op. 132, 135, 136, 138, 193.

- pulcherrimus Schur. 344, 371.

- stenophyllus Op. 135.

- transsilvanicus Schur. 356

Tilia (Linde) 240, 242, 249, 255, 405, 412.

- argentea Desf. = tomentosa.

- cordata Mill. (ulmifolia) 89, 104, 105, 124, $143,148,177, * 199,220,269,280,294$, $311,313,328,329,330,386,406,448,454$, $456,460,462,485,510,522$, * T. VI.

- grandifolia Ehrh. = platyphyllos.

- parvifolia Ehrh. = cordata.

- platyphyllos Scop. 89, 104, 105, 143, * 199, $269,280,311,329,454$.

- tomentosa Mch. (argentea) 350, 358, 441, $445,448,456,485,517,527$.

- ulmifolia scop. = cordata.

Tofieldia calyculata (L.) Wahlbg. 279, 343, $345,347,392$.

Tolypellopsis stelligera (Bauer) Migula 300 .

Torilis Anthriscus (L.) Gmel. 90, 143, 338, 458, * T. XXXIII.

- helvetica Gmel. 384.

- microcarpa Bess. 445.

Tordylium maximum L. 353.

Tortula ruralis (L.) Ehrh. 101, 136.

Tozzia alpina L. 442.

- carpatica Wol. 379.

Tragopogon dubius Scop. 135, 156, 231, 306, $332,448$.

- floccosus W. K. 484, 488, 492, 519, 521, 526. 
Tragopogon pratensis L. 197, 238 .

- orientalis L. 156, 278, 334, 356, 431, 458.

Tragus racemosus L. 154, 179, 488, 507, 509, 521.

Trapa natans L. 160, 182, 183, 255, 280, 296, $298,512,524$.

Tribulus orientalis L. 484, 488, 509, 511.

Trichophorum 54.

- alpinum (L.) Pers. 57, " 58, 95, 97, 170, $173,175,176,178,181,207,213,217,219$, $234,274,341,400$.

- austriacum Palla 97, 116, 209, 210, 211, 215, 219, 233, 274, 404.

- oliganthum (C. A. Mey.) Fritseh 388.

Trichostomum crispulum Bruch 137.

- pallidisetum H. Müll. 137.

Trientalis europaea L. 57, 94, 96, 100, 116 , $163,167,177,186,187,200,206,209,211$, $213,219,226,234,272,274,300,368,341$, $380,395,403,412$.

\section{Trifolium 161.}

- alpestre L. $90,94,121,124,127,129,135$, $153,155,189,239,240,250,270,312,332$, $333,353,485,493$.

- angulatum W. I. 465, 494, 498, 514.

- arvense L. 98, 151, 493.

- badium Schreb. 333, 344, 417.

- campestre Schreb. 161, 441.

- expansum W. K. 350.

- fragiferum L. 20, 152, 159, 193, 195, 242, 249, 354, 494, 498, 507, 514, 518.

- liybridum L. 131, 141, 152, 278, 334, 498.

- laevigatum Poir. 518, 522.

- Lupinaster L. 392, * 393.

- medium L. 132, 143, 270, 322, 353, 429.

- minus Belh. 498, 518.

- Molinerii Ball. 350, 353, 445.

- montanum L. 99, 112, 121, 129, 138, 152, $153,155,201,202,237,278,289,339,353$, $354,390,485$.

- ochroleucum L. 112, 124, 127, 132, 138, $143,155,186,192,203,204,236,250,287$, $332,353,354,407,451$.

- ornithopodiodes Sm. 518, 521.

- pannonicum Jacq. * 237, 353, 408, 424, 445.

- parviflorum Ehrh. 136, 484, 494, 518, 521, 522.

- pritense L. 10:, $11 \%, 114,131,141,15 \%$, $236,278,287,289,312,333,334,345,353$, $354,373,460$.

- procumbens L. 103.
Trifolium repens L. 114, 131, 152, 141, 225, 278, 289, 334, 345, 373, 460.

- rubens L. 124, 127, 135, 153, 155, 189, 202, $203,220,228,245,255,287,332,353,379$, $403,410,466,511$

- spadiceum L. 97, 99, 100, 112, 133, 173, $183,186,228,229,231,232,237,379$.

- striatum L. 183, 187, 193, 197, 202, 354, 518.

- strictum L. 353, 484, 494.

- szarosiense Hazsl. 353, 407.

Triglochin maritimum L. 157, 354, 466, 467 . 515.

- palustre L. 100, 152, 200, 202, 239, 249, $275,290,334,498,517$.

Trigonella monspeliaca L. 198, 384, 484, 518. - procumbens (W. K.) 459.

Trinia Henningii Hoffm. 285, 289.

- Kitaibelii M. B. 450, 459.

- vulgaris DC. 249.

Trisetum alpestre (L.) Beauv. 454.

- flavescens (L.) Beauv. 98, 111, 131, 152, 153, 238, 239, 311, 333, 339, 354, 424.

- fuscum (Schult.) R. S. 344, 394, 400, 402, 417.

- macrotrichum Hack. 344, 420.

Triticum sativum Lam. (Weizen) 141, 160 . $290,372,502,516$.

- villosum (L.) Pers. 488.

- vulgare Vill. = sativum.

Trollius europaeus L. 99, 111, 131, 133, 152, $166,169,183,186,189,196,199,201,217$, $220,224,228,229,239,279,282,303,339$, $343,379,390,400,454,461$.

Tulipa hungarica Borb. * $446,447$.

Tunica prolifera (L.) Scop. 151, 193, 276, 332, $442,488,511,518$.

- Saxifraga (L.) Scop. 248.

Turritis glabra L. 301.

Tylostoma granulosum Lev: 493.

- valvulatum Borsz. 493.

Typha 63, * T. XIII.

- angustifolia L. 138, 181, 279, 334, 428, 496, 523.

- latifolia L. 138, 159, 279, 290, 296, 334, 428, 441, 460, 496, 511, 523.

Typhoides arundinacea (L.) Mnch. 63, 127, 138, $181,279,334,496$.

\section{U.}

Ulmus (Ulme) 240, 249, 300.

- campestris L. p. p. = glabra. 
Ulmus glabra Mill. 91, 104, 107, 124, 125, 126 , $143,146,147,203,220,238,239,253,259$, $272,280,311,328,330,407,458,485,488$, $519,522,524$.

- - var. suberosa (Mch.) Gürke 148.

effusa Willd. = laevis.

- laevis Pall. 104, 107, 147, 195, 220, 259, $282,328,330,406,488,506,524,{ }^{*}$ T. V.

- montana With, = seabra.

- pedunculata Foug. = laevis.

- scabra Mill. 92, 104, 105, 122, * 195, 206, 272, 280, 336, 408, 506 .

\section{Umbilicaria 136 .}

- pustulata (L.) Hoffm. 101.

Urtica dioeca L. 68, 103, 107, 114, 241, 259, $272,292,307,331,346,373,486,488$, 505.

- kioviensis Rogov. 506, 509, 523, *'T. LIII.

- urens L. 103, 107, 114, 272, 292, 373, 505.

\section{Utricularia 60 .}

- intermedia Hayne 110, 130, 232.

- minor L. 130, 141, 181, 183, 232, 275.

- neglecta Lehm. 141.

- ochroleuca Hartm. 130, 141, 181.

- vulgaris L. $130,170,183,275,290,500$.

\section{V.}

Vaccinium $54,109,173$, * 175, 182, 184, 202, $205,230,245,365,415,416$.

- Myrtillus L. 52, 90, 93, 94, " 95, 97, I00, $104,106,107,108,114,120,121,122$, $1: 99,130,144,145,150,163,166,173$, $177,180,185,186,192,204,205,206$, $207,208,214,221,225,226,228,230$, $231,233,234,237,238,250,270,271$, $272,275,294,329,330,336,343,344$, $368,375,380,388,390,392,395,411$, $450,457,461$, * T. XLVI.

- uliginosum L. 57, * 58, 94, 96, 97, 116 , $120,130,176,177,178,181,187,209$, $213,221,272, * 274,275,294,295,341$, $346,368,417,420,427,457$, * T. VIII, * T. XVIII.

- Vitis Idaea L. 52, 90, 93, 94, 96, 97, 100, $104,106,107,114,120,121,129,130,145$, $163,177,180,181,192,204,206,207,214$, $221,225,226,228,230,233,234,250,270$, $272,295,336,343,344,366,368,380,392$, $395,411,450,457,461$.

Valeriana dioeca L. 100, 112, 279, 334.

- montana L. 388, 405, 433.
Valeriana officinalis L. $127,133,136,156,195$, $289,330,457,485,486,516$.

- polygama Bess. = simplicifolia

- sambucifolia Mik. 225, 338.

- simplicifolia Kabath (polygama) 294, 334, 380.

- tripteris L. 225, 226, 342, 343, 377, 378, $379,386,400,404,405,412,433,442$, 461.

Ventenata dubia (Leers) Schultz 239, 245, 247, 375.

Veratrum album L. $279,338,364,419,422$, $424, * 426,450,486$.

- - Subsp. Lobelianum (Bernh.) Richt. $107,108,111,117,210,212,215,217$, $219,226,228,237,378,381,384,392$, *T. IV.

- nigrum L. 287, *288, 303, 312, 349, 466, * T. $X$.

Verbascum 32, 484.

- austriacum Schott, 178, 250, *251, 332, $410,458,488,524$.

- banaticum Schrad. 352, 353.

- Blattaria L. 153, 278, 353, 493.

- glabratum Friv. 443.

- Lychnites L. 135, 184, 252, 353, 403, * 404, $429,459,464,493, *$ T. XXIV.

- nigrum L. 352, 442, 464.

- phlomoides L. 133, 156, 157, 184, 259, 312, $353,457,458,493$.

- phoeniceum L. 135, 136, 153, 196, 197, $198,202,236,239,245,249,252,287,305$, $306,332,352,353,407,458,460,461,493$, 524.

- speciosum Schrad. 245, 296, 353, 442, 450, 459.

- thapsiforme Schrad. 156, 252, 332, 451.

- Thapsus L. 133.

Verbena officinalis L. 292, 333, 373.

- supina L. 498, 519, " 520.

Veronica agrestis L. 68 .

- alpina L. $220,344,345,389,394,397,417$, 434.

- Anagallis L. 148, 280, 290.

- aphylla L. $327,341,345,380,389,390$, $393,394,433$.

- arvensis L. 151, 374.

- Bachofenii Heuff. 350, 441, 444.

- Baumgartenii R. S. 323, 369, 370, 371, 412, $417,419,429,437,440,444$.

- Beccabunga L. 280, 290.

- bellidioides L. 118, 207, 216, 226, 417, 444. 
Veronica Chamaedrys L. 90, 94, 100, 104, 107, $111,124,131,138,143,153,187,225,278$, $289,333,334,342,346,374$.

- crassifolia Wierzb. 353.

- dentata Schm. 136, 190, 353, 404.

- Dillenii Cr. 98, 128, 151, 187, 247.

- fruticans Jacq. 327, 345, 347, 348, 389, $393,422$.

- Jacquinii Baumg. 284, 285, 305, 306, 312, 442 .

- incana L. 284, 285, *286, 303, 306.

- longifolia L. (maritima) 152, 111, 202, 231, 279, 288, 293, 294, 297, 312.

- maritima $L .=$ longifolia.

- montana L. 93, 105, 186, 196, 209, 229, 336.

- officinalis L. $100,106,124,270,282,342$, 346,374 .

- orchidea Cr. 202, 353, 376, 403, 428, 462.

- praecox All. 162, 196, 484, 491.

- prostrata L. 121, 129, 136, 191, 201, 248. $289,306,307$.

- scutellata L. 139, 274, 275, 279, 509.

- serpyllifolia L. 100, 131, 346.

- spicata L. 121, 129, 133, 151, 156, 186, 187, $192,195,196,239,252,278,285,288,297$, $306,307,332,459$.

- spuria L. 90, 192, 288, 300, 306, 307, 309 , 408.

- Teucrium L. 127, 153, 156, 195, 282, 288.

- Tournefortii Gmel. 68, 374.

- urticifolia Jacq. 450, 453, 457.

- verna L. 252, 491.

Viburnum 163, 193. 249,

- Lantana L. 32, 126, 143, 145, 148, 189, 193 , $203,284,303,328,408,426,450,454,458$. 485,519 .

- Opulus L. 90, 125, 147, 148, 203, 230, 272. $311,331,426,485,516,519,524$.

Vicia casubica L. $124,186,201,202,270,332$. $358,374$.

- Cracca L. 131, 153, 278, 333, 353, 485, 505.

- dumetorum L. 106, 143, 191, 282, 329. 378.

- Faba L. 503.

- glabrescens (Koch) Heimerl 162, 505.

- hirsuta L. 120.

- lathyroides L. 130.

- pisiformis L. 90, 124, 143, 186, 189, 191 . $203,220,282,284,303,329,374,386,460$, 485 .

- sativa L. 374 .
Vicia segetalis L. 120, 161, 505.

- sepium L. 152, 332, 334.

- serratifolia Jacq. 353.

- silvatica L. 90, 105, 106, 124, 186, 189, 211, $228,243,282,303,386$.

- striata M. B. 254.

- truncatula Fisch, et Mey. 448.

- villosa Roth. 142, 161.

Vinca herbacea W. K. 255, 407, 408, 410, 450, $461,492,515$.

- minor L. 186, 297, 458.

Viola alpestris (DC.) Jord. 99, 333.

- alpina Jacq. 328, 369, 392, 394, 396, 426, $434, * 435, * 438,439,440,444$.

- ambigua W. K. 127, 193, 235.

- arenaria DC. 127, 128, 151, 276.

- arvensis Huds. 151, 374, 505.

- banatica Heuff. 424.

- biflora L. 111, 116, 205, 219, 224, 343, 379, $380,422,440,444$

- calcarata L. * 37.

- collina Bess. 127, 136, 332, 386.

- declinata W. K. " $360,361,368,369,411$, $417,419,420,422,424, * 426,428,444$, 456,457 .

- elatior Fr. 107, 152, 517.

- epipsila Led. 174, 295, 388.

- hirta L. 270, 332, 333.

- Joói Janka 353, 364, 416, 423, 430, 453, 454.

- mirabilis L. 124, 143, 167, 190, 201, 204, $270,282,311$.

- montana L. 127.

- odorata L. 239, 270, 272.

- palustris L. 57, 94, 97, 167, 213, 229, 231, $234,274,341,396,403$.

- pumila Chaix 289.

- Riviniana Rchb. 458.

- rupestris Schm. 146, 270, 289.

- silvestris Lam. 94, 120, 143, 145, 147, 270.

- sudetica Willd. 114, 207, * 216, 217, 219, $225,344,361,379,388,389,401,411$.

- stagnina Kit. 279.

- tricolor L. 103, 120.

Viscaria vulgaris Röhl. 127, 131, 150, 153, 180, $187,206,220,230,270,390$.

Viscum 41 .

Vitis silvestris L. $147,259,350,445,486$, $506,510,511,516,519,523,524,527$, * T. XXII.

- vinifera L. (Weinstock) 141, 161, 290, 372, - $503,516$.

Vuipia Myurus Gmel. 98, 509, 518. 
IV.

Waldmeister $=$ Asperula odorata.

Waldsteinia geoides Willd. * 281, 282, 281, $305,407,408,410$.

- ternata (Steph.) Fritsch (trifolia) 423, 427, 428,461 .

Webera Breidleri 116.

- elongata (Hedw.) Schw. 189.

- Ludwigii (Spreng.) Schimp. 116.

Weingärtneria $=$ Corynephorus.

Weinstock $=$ Vitis vinifera.

Willemetia stipitata (Jacq.) Cass. 173, 176, 178.

Wolffia arrhiza (L.) WVimm. 300.

Woodsia alpina (Bolt.) Gray. 118, 215, 226.

- ilvensis (L.) R. Br. 101, " 137, 138, 170, $196,199,200,206,332,387,399,413,451$, - 453.
X.

Xanthium italicum Moretti 198.

- spinosum L. 162, 292, 307, 334, 373, 492, 499, 505, 509 .

- strumarium L. 228, 292, 373, 492, 505, 509.

Xeranthemum annuum L. 190, 356, 484, 492, 507, 524.

- cylindraceum Sm. 356, 408, 524.

\section{Z.}

Zannichelia palustris L. 141, 181, 280, 500.

Zea Mays L. 290, 372, 424, 441, 502, 516.

Zitterpappel $=$ Populus tremula.

Zwetschke $=$ Prunus domestica. 


\section{Index der geographischen Namen.}

A.

Ahertham 168.

Abrudbanya 451.

Absdorf 257, 460.

Abtsdorf 229.

Adam 416.

Adamstal 242.

Adersbach 219

Adlergebirge 219.

Adlerkosteletz 209.

Agertal 405.

Aggsbach 102, 235

Akna-Sugatag 320.

Aleschtal 236.

Alföld 471.

Alpen 207.

Also-Tátrafüred 395 .

Alt 458 .

Althammer 378.

Alt-Melon 234.

Alt-Szöny 510.

Alt-Tal 441.

Altvater 225.

Angel 187.

Angern 256.

Annaberg 169.

Apahida 465.

Apatia 518.

Apsinecz 320.

Arad 480, 481, 524.

Aranyos 456 .

Aranyosmarót 384 .

Arber 125.

Arbersee 175.

Arpascher Alpen 439.

Arva 390.

Arvaváralya 326.
Asch 170.

Atelsloch 461 .

Auerschitz 248.

Auschau 200.

Auspitz 157, 248, 249.

Aussergefield 176 .

Aussig 197.

Autrozin 187.

B.

Baassen 461.

Baba 389.

Babiagora 317, 321, 380 .

Babina 199.

Bács-Bodrog 518.

Báes-földvár 521.

Baja 480, 48I.

Baiku 444.

Bakokyertes 518 .

Balyany 407.

Bản 384.

Banater Berge 327.

Banater Bergland 445 .

Banikov-Vrh 392.

Baranya 379.

Barbarateich hei Dux 193.

Bärenkamm 224.

Bärenlohe 173.

Bärenwald 219.

Bärn 226.

Bartfa 382.

Bartfeld 382.

Batzdorf 219.

Bastina 182.

Baudenberg 226.

Baumgarten 256.

Bauschendorf 403.
Bátorliget 523.

Batrina 454.

Battonya 524 .

Bazias 447, 519.

Bazna 461.

Becsko 384.

Bélís-Csaba 524.

Béla 403.

Belaer Kalkalpen 318, 400.

Belatal 395.

Beleapátfalva 408.

Belköhegy 408.

Belska 390.

Benisch 228.

Bény 508.

Beraun 187, 189.

Beréttyo 523.

Beréttyo-Uifalu 480, 481.

Berivoescul mare 438 .

Bersatzka 447.

Beskiden 317, 336, 376.

Besztercze 326.

Beszterczebánya 288, 324, 325.

Betlen 463.

Bezdán 518.

Biala 293, 379.

Biala Fl. 292, 379.

Bielitz 268, 293, 324, 325, 379.

Bielitzer Gebirge 379.

Bihar 454, 523.

Bihariagebirge $318,454$.

Bila skala bei Drysic 242.

Bilcze 306.

Bilin 196.

Billak 459 .

Bisamberg 255.

Bisenz 161, 250, 252.

Bistricioara 422 . 
Bistritz 326, 377, 422.

Bistritzer Alpen 422.

Bistritztal 422.

Blansker Wald 177.

Blansko 242.

Blatnitz, Groß- 376 .

Blatowiese 203.

Blasendorf 460 .

Blatna 183.

Blumengarten 399.

Bobróce Tral 392.

Bochnia 268.

Bodenbach 84 .

Bodrog 523.

Böhmerwald 89, 166, 170, 171 , 207.

Böhmischer Kamm 211.

Böhmisches Mittelgebirge 180, 193.

Böhmisch-Kamnitz 205.

Böhmisch-Leipa 87, 200, 206.

Böhmisch-mährisches Gebirge 228.

Böhmisch-mährischer Höhenzug $89,150$.

Bohnwiese 217.

Bolowetz 186.

Bor 180.

Bořen 196.

Borgopaß 422.

Borgoprund 422 .

Borschitz 376.

Borsobánya 418.

Borszezow 306.

Borysümpfe 341,380 .

Boschowitz 249.

Branizkostock 403.

Brassó 429 .

Bratonitz 183.

Braunsdorf 228.

Brdo 249.

Brdywald 89, 185.

Breitensee 256.

Breiter Berg 462.

Breiter Busch 166.

Breznobánya 388.

Briaza 416.

Brodek 308.

Brody 300, 301 .

Broos 442.

Brünn 88, 242, 244.

Brunnberg 217.

Brünnelheide 225.
Brüx 193, 195

Brzezany 301.

Buchberg 210.

Buchberg, Großer 206.

Buesecs 317,431 .

Buczacz 305.

Budapest 480, -181, 482, 511 .

Büdös 426 .

Budweis 87, 177, 180, 182.

Budweiser Becken 127, 182.

Bühl bei Plan 187.

Bükkgebirge 31s, 407.

Bukova hora 186.

Bukowina 267, 420.

Bukowina, nördliche 30 s.

Buleatal 438 .

Burberg 192.

Burwald 256.

Burzenland 428.

Burzenländer Berge 317.

Burzenländer Ebene 428 .

Bustyaháza 320 .

Bystra 392.

Bzinekwald 252.

\section{C.}

Caganowteich 252.

Campolung 416.

Capu Campului 309.

Časlau 87, 204.

Cecina 311 .

Čelakowitz T. XII.

Černahora 382.

Certisorer Alpen 439.

Chlumetz 180.

Choč $390,392$.

Chotucberg 203.

Chrostau 229.

Chrudim 204.

Chrzanow 293.

Cibin 441.

Cibingebirge 441 .

Cibinjezer 442.

Cindrel 442.

Cliffi 422

Corongis 419.

Coronini 447.

Coltin Vistea 438 .

Craciunel 420 .

Csaklyakő 452.

Czallaköz 507.

Csalawald 524.
Csanád 524.

Cseahlau 426 .

Csegled 510, 519, 520.

Csendes-Puszta 507.

Csepelinsel 512, 517.

Cserhat-Gruppe 408.

Csernikamen 388

Cservenka 518

Csik 461 .

Csiker Hochebene 424.

Csiligebirge 424.

Csik-Gyergyoer Alpen 317.

Csongrád 521.

Csorbaer See 395.

Csorna Cleva 412.

Csoványos 408 .

Csukas 428.

Cygan 306.

Czarna hora 322.

Czarny staw 397.

Czartory 379.

Czartowska skalka 300 .

Czeitsch 249 .

Czeitscher See 248.

Czerkow 173.

Cizerlany 300.

Czerna hora 317, 417.

Czernatal 445.

Czernanka 309.

Czernitzer Teich 182.

Czernowitz 268, 309 ff., 324, $325,416$.

Czerwony vrh 394.

Czibles 457.

Czortkow 306.

Czuczaer Tal 467.

\section{D.}

Dabrowicza 294.

Datschitz 83, 84, 231.

Daole 187.

Debreczen 519.

Dées 456.

Deia 416 .

Deliblát 527, 480, 481.

Dernye 518, 519 .

Detunata 451 .

Deutsch-Brod 229.

Déva $450,451,464$.

Devény 374.

Dittersbach 205 .

Dittersdorf 229. 
Djumbir 388, 389.

Dnjester 267, 298, 305.

Dnjesterdurchbruch bei Zalesczyki 306.

Dołož 523.

Dobriš 186.

Dobschau 404.

Dobsina 326.

Dolina $324,325$.

Dombó 320 .

Domugled 445.

Donau 102, 157, 477, 478, 510, 513,516 .

Donau, alte, bei Wien 259.

Dornatal 417.

Dorna Watra 417.

Doroszowe 308.

Dragean 444.

Drahan 242.

Drahaner Plateau 240.

Drasenhofen 254.

Dražovic 242.

Drechslerhäuschen 402.

Dreiberg 199.

Dreisesselberg 176.

Drevenyik 404.

Drohobyez 268, 298, 324, 325, 412.

Dubova 447.

Dubovac 524.

Dubrawawald 252.

Dunajec 381.

Dunajecdurchbruch 381.

Duppauer Gebirge 192.

Dürrenberg bei Kesmark 403.

Dušna 377.

Dux 193.

Dvorce 189.

Dymokury 191.

Dziekanowice 294.

\section{E.}

Ecseder Sumpf 523.

Eger (Böhmen) 83, 84, 169, 173.

Eger (Ungarn) 319, 324, 325.

Eger Fl. (Ungarn) 408.

Egerbegy 466.

Egerland 163.

Egertal 195.

Eggenburg 247.

Egyeskő 424, 426 .
Eibenschitz 160, 244.

Eichwald 166.

Eidlitzer Eichbusch 192.

Einsiedel 85, 171.

Eisenberg 226.

Eisenbrünnel 374.

Eisenstein 85, 175.

Elbe 205, 211.

Elbesandsteingebirge 89, 165, 205.

Elbetal 128, 195, 197.

Elbfall 213.

Elbgrund 212.

Elbwiese 213.

Ellnitzer Teiche 180.

Elstergebirge 89, 163, 169.

Engerau 508.

Enyeder Schlucht 453.

Enzersdorf, Lang- 000.

Enzersdorf, Groß- 256.

Eperies 324, 325, 406, 407.

Eperieser Gebirge 403.

Eperies-Tokayer Trachytzug 407.

Erdweis 232.

Erlau 319, 324, 325.

Ernstbrunnerwald 255.

Érsekujvár 507 .

Erszébethfalva 512.

Erzgebirge, Böhmisch-sächsisches $89,163,173,207$.

- Schemnitz-Kremnitzer 318, 386.

- Siebenbürgisches 318, 451.

- Ungarisches 318, 386.

Esseklee 246.

Eva 416.

\section{F.}

Fatra 318, 380, 388.

Fehér tó 513.

Fekete tó 397.

Felek 467.

Felkersee 399.

Felkertal 399.

Fellinger Teich 182.

Felsöbánya 457.

Felsöfalu 457.

Felsö Girda 456.

Felsö Sebes 441.

Felsö Skerisora 456.

Fenyöháza 388.
Fichtelberg 86, 163.

Fichtelgebirge 170.

Fichtling 224 .

Fischsee, Großer 396.

Fleischbank 400.

Fleischbänke 403.

Flutorita 420.

Fogarascher Alpen 318, 321, 437.

Fogarascher Hochebene 318, 441.

Földeák 524.

Fontina alba 300 .

Fontina fetje 524.

Fradautz 416.

Frain 157, 245.

Franzensbad 169.

Frauenberg 87, 183.

Freistadt 178, 379 .

Freiwaldau 220, 221.

Freudenthal 220, 228.

Friedeberg 220.

Friedek 378, 379.

Friedland 378.

Friedrichstal 85 .

Fröllersdorf 248.

Fromoasa 442.

Fuchsberg 217.

Függökő, kis 429.

Fülöpszállás 513, 515 .

Fulnek 226.

Fünf Seen 400.

Fünf Seen, polnische 396.

Furkotatal 399.

Fürstenhut 85, 176.

Furth 173.

Futak 519 .

\section{G.}

Gaidel 386.

Galgenberg bei Kesmark 403.

Galgenberg bei Nikolsburg 253.

Galizien 267.

Galizische Tatra 392.

Ganocs-Lucivnaer Höhenzug 389.

Galgoczgebirge 318,386 .

Gancz 456.

Gänserndorf 256.

Gasieniczowe stawy 396.

Gattendorf 508.

Gatterschlager Moor 231. 
Gaunersdorf 255 .

Gehol 404.

Geltsch 200.

Gemsenberg 374.

Georgental 180.

Georgenthal, St. 206.

Georgsberg 196.

Georgswalde 206.

Gergaleu 420.

Gerlsdorfer Spitze 318, 399

Gerolding 235 .

Gerungs, Groß- 234

Gesenke 220, 225.

Gesenke, Niederes 226 .

Gewitsch 229.

Gföhl 234.

Gföhler Wald 234.

Gicwont 394.

Gilgenberger Wald 231 .

Giumalau 420.

Glatzberg 170.

Glatzer Schneeberg 86, 218, $219,226$.

Gmünd 232 .

Göding 88, 161, 252,

Gödöllö 485, 510.

Goggendorf 247.

Goldberg 192.

Goldenkron 177.

Goldenstein 226.

Golica 381.

Göllnitzbánya 404.

Göllnitzer Gebirge 403, 404.

Goltsch-Jeniliau 204.

Golubatzer Höhle 447.

Gombos 519

Gór 427.

Görgenyer Gebirge 462.

Goswadia 451.

Göttersdorf 166.

Gottesgab 167, 168.

Goysz 508.

Gräfenberg 221.

Gran 507, 508.

Graslitzer Sattel 169.

Grätz, Schloß 228.

Gratzen 180.

Graupen 166.

Grebenac 257, 524.

Greifendorf 229.

Grein 179.

Greiner 400, 402.

Greiner Wald 179.
Grodek 297, 298.

Groß-Blatnitz 376.

Große Iserwiese 209.

Große Innieholzwiese 209.

Große Lohe 173.

Groß-Enzersdorf 256.

Großer Buchberg 206.

Großer Erlenwald 509.

Großer Fischsee 396.

Großer Kessel 225.

Großer Sereth 416.

Großer Winterberg 205.

Großes Kohlbachtal 400 .

Große Sturmhanbe 215.

Große ungarische Tiefebenc $477,510$.

Groß-Gerungs 234.

Groß-Herlitz 228.

Groß-Macséd 507.

Groß-Meseritsch 230 .

Grosspold 459.

Groß-Priesen 197.

Groß-Seelowitz 157, 248.

Großwardein 480, 481, 523.

Grugau 239.

Grumberg 226 .

Grumiř 249 .

Grün 170.

Grünbach 234 .

Grüner See 399.

Grüner See, Kesmarker 400.

Grünhart 171.

Grußbach 248.

Gurahoncz 456.

Gurahumora 416, 417.

Gurhofgraben 102, 235.

Gutenbrunn 234.

Guttin 318, 412, 457.

Gwozdiec 295.

Gyergyó 461 .

Gyergyó-Borszek 422.

Gyergyóer Hochebene 424.

Gyergyó-Tölgyes 423.

Gyimes 424.

Gyömber $38 s$.

Gyöngyes 408.

Győr 510.

Gyula-Fehérvár 451.

\section{H.}

Habrina 204.

Hadiberg 244.
Haj bei Bisenz 25?.

Haj hei Pilsen 186.

Hainhurger Berge 506.

Haislik 293, 379.

Halás 515 .

Hammersiorf 458.

Hangestein, Kleiner 429.

Hanichen 85 .

Hanna 238, 242.

Hanság 509.

Hardegg 245.

Hargita $318,461$.

Harmannschlag 233.

Haromszéker Gebirge 427.

Haromszéker Talbecken 427.

Harta 211.

Hatszeg-Varalya 442.

Haugsdorf 254.

Havran 400, 402.

Hegyalya 407.

Hehves 460 .

Heida 206.

Hellmonsödt 178.

Herkulesbad 445.

Herlitz 228 .

Hermannschlag 231.

Hermannstadt 458 .

Hermersdorf 229.

Hernadtal 406.

Herrenlohe 173.

Herrnskretschen 205.

Herzynisches Bergland 89.

Heuwiesen 1466.

Hiboka 416.

Hiesberg 235.

Hirschbergen 86.

Hirschberger Teiche 200.

Hirschwiesen 222.

Hochbeskiden 379.

Hochfichtel 174, 178.

Hochgesenke 220, 226.

Hochleiten 255.

Hoch-Lieben 202.

Hochschar 225, 232.

Hochwald 178.

Hódmezö-Vasárhely 480,481, 521.

Hofberg 168.

Höflitz 200.

Hohe Heide 225.

Hohe Lausche 206.

Hohe Mense 219.

Hoheneich 232. 
Hohenelbe 84, 211.

Hohenfurth 178.

Hohenleipa 205.

Hohenmauth 205.

Hohenruppersdorf 255.

Hohenstadt 228.

Hohenstein 429 .

Hohenstein bei Iglau 230 .

Hoher Schneeberg 205.

Hohes Rad 214.

Hohe Tatra 318, 380, 394.

Holleschau 377.

Holykámen 404.

Homale 190.

Hommona 411, 413.

Homorodfürdö 461 .

Honigberg 438, 462.

Horaberg 196.

Horaica 312

Horn 248

Hornberg 229.

Horodenka 306 .

Horowitz 186.

Hortobảgy 522.

Horzinabach 228.

Hosszuréssumpf 523 .

Hosteinerzug 377.

Hoverla 317,417 .

Hradek 392 .

Hradiskoberg 249.

Hustopetsch 237.

Huszt $320,413$.

\section{I.}

Igelbach 231.

Iglau 83, 84, 230.

Iglawa 248.

Iglawatal 231, 244.

Igló 404.

Illischtie 416 .

Ineu 420.

Ingrowitz 229 .

Inovecz 3784.

Inoveczgruppe 384.

Ipostie 312 .

Isergebirge 107, 207 .

Iserwiese, Große 209.

Iscrwiese, Kleine 209.

Izság 515.

\section{J.}

Jablonicapaß 413.

Jablunkagebirge 377 .

Jägerndorf 220.
Jahrndorf 508.
Janow 300.
Jánoshalma 521.
Jaromeř 204.
Jaroslau 268, 296.
Jász-Berényi 480, 481.
Jauerling 234.
Javorina (Beskiden) 376.
Javorina 403.
Javorina (Tatra) 395.
Javorinaer Schwarzer See 397.
Javorinaer Siroka 399.
Javornik 377.
Javornikgebirge 377.
Jaworow $297,298$.
Jazygien 519.
Jelenitz 202.
Jeschken $85,206$.
Jeselnica 446.
Jetzelsdorf 254.
Jeziorki 295.
Jičin $203,204,211$.
Josefsberg bei Biala $293,379$.
Jungbunzlau 201.

\section{K.}

Kaaden 192.

Kagran 256

Kaiserwald 170.

Kalinow 298.

Kaller Heide 254.

Kalocsa 517.

Kaltenberg 206.

Kamaik 183.

Kamenista 392.

Kamenitz 229.

Kamionka 300.

Kamitzer Platte $\mathbf{3} 79$.

Kämmchen 400 .

Kammerbühel 169 .

Kamp 102.

Kamptal 248 .

İapellenberg 429.

Kaplitz 178, 180.

Kaposvár 480, 481 .

Kaposztásmégyer 511 .

Kapuvár 509.

Karbitz 197

Karlsbad 169, 170, 192.

Karlsbrunn 222.

Karlsburg 451.
Karlsdorf 447

Karlstein 189, 190.

Karlstift 233 .

Karpathen 106, 207, 307, 308, $317,477$.

Karpathen, Kleine $318,374$.

Karpathen, Weiße $317,376$.

Kaschau 406.

Kaschau-Eperieser Bruchlinie 410.

Katharinenberger Moor 170 .

Katona 465.

Kazanpaß 447.

Kecilow 303.

Kecskekő 453.

Kiecskemét 480, 481, 485, 502, $503,510,515$.

Kecskeméter Heide 516.

Kecskeméter Landhöhe 486 .

Kéer 517.

Keilberg 163, 167, 168.

Kélies 408.

Kelemen 422.

Kelemen-Cserbükk 422.

Kelemen-Izvoru 422.

Kelemenszék 513.

Kemenesalja 510.

Kerzcisorer Alpen 439.

Késmark 326, 403.

KKésmarker Grüner See 400.

Kessel, Großer 225.

Kessel, Kleiner 226.

Kesselgrube 212.

Kesselkoppe 212.

Kesselwiese 225.

Kičora 400.

Kienberg 389.

Kiesberg 217.

Kimpolung 416.

Kiralykő 435.

Királypatak 453

Kirchschlag 178.

Kirlibaba 420.

Kisczég 465.

Kis Függöhő 429.

Kis Körös 516 .

Kis Kun Félegyháza 516.

Ǩis-Ujszállás 519, 524.

Klak 388.

Klattau 176.

IKlausenburg 326, 466.

Kleine Iserwiese $209,210$.

Kleine Karpathen 318, 374, 506. 
Kileine Knieholzwiese 209.

Kleiner Hangestein 429 .

Kleiner Kessel 226.

Kleiner Sereth 416.

Kleines Kohlbachtal 400 .

Kleines Meerauge 413.

Kleine Schneegrube 214.

Kleine Sturmhaube 215.

Iileine ungarische Tiefebene $477,506$.

Kilein-Krivan 318, 390 .

Flein-Probstdorf 460 .

Kleis 206.

Kilencě 196.

Iilimezok 379.

Ḱlingenberg 183.

Kilobouk 249 .

Kniazdvor 414.

Knieholzwiese, Große 209.

Knieholzwiese, IKleine 209.

Kobily 249 .

Kobyli-See 248 .

Kohlbachtäler 400.

Kohling 169, 170.

liojetitz 202.

Koheltal 460.

Kolben bei Auerschitz 248.

Kolbuszow 295.

Kiolom tó 514 .

Kolomea 268, 307, 234, 325, 414.

Kiolos 465.

Kolozsvár 326, 463, 466.

Kómarom 507, 510 .

Komorn 507, 510 .

Komotau 166, 192.

Königgrätz 204.

Königshütte 205.

Königstadl 204.

Königstein 318, 435.

Königswart 171.

Konopischt 187.

Konska 379.

Kopanina 190.

Kopapaß 400,402.

Köpernik 224 .

Kopytnoteich 301.

Kořenskyteich 183.

Kiörös, Schnelle 457, 523.

Körös, Weiße 457.

Körösmezó 320 .

Korpad 465.

Koscieliskotal 392.
Kostel 251.

Kostelec 187.

Kotarz 379.

Kotzendorf 248.

Krakau 268, 294

Kralova Hola 388, 389.

Krasna Ilska 416 .

Krechovee 298.

Krems 89, 235, 257.

Kremsier $240,242$.

Krinetz 203.

Krivan 399.

Kriwan, Klein- 318, 390.

Križna 388.

Krkonoseh 212.

Kronenberg 381.

Kronstadt 439.

Kroscienko 381.

Krumau 83, 84, 177, 178.

Krystynopol 300.

Krzesanica 394.

Krzywezycze 300.

Kubany 103, 177.

Kuchelbad 189.

Kuhberg bei Brünn 144 .

Kuhberg bei Znaim 246.

Kuhhorn 420.

Kulm 197.

Kiunstadt 229 .

Kun Szent Miklos 513.

Kupferschächtentäler 400 .

Kuschwarda 176.

Kvaczanpaß 392.

Květnitza 243 .

\section{L.}

Laa 254 .

Laborcza 410.

Laczháza 513.

Lagropetal 456.

Lakaberg 174, 175.

Lakasee 175.

Lakócsa 427.

Landskron 228, 293.

Langenbrucker Teich T. VIII.

Langenthal 460.

Lang-Enzersdorf 160.

Langer Berg 198.

Lange Wand 403.

Lapas-Gyarmak 507.

Lápos 457.

Lápos-rét 513.
Lassee 257.

Lateinerberg 244.

Latoveatal 413.

Laun 87, 193, 195.

Lausche, Hohe 206.

Lausitzer Gebirge 89, 165, 205.

Lautsch 239.

Lažan 183.

Leimpeschberg 462.

Leipnik 237.

Leißer Berge 255.

Leitersberg 221, 222.

Leithagebirge 506.

Leitmeritz 87, 198.

Leitomischl 205.

Lemberg 267, 268, 290, 300.

Lesienice 300.

Leskatal 246.

Leština 182.

Léva 480, 481, 507.

Lezaisk 296.

Lhota 211.

Lichten 228.

Lichtenstadt 169.

Lieblitz 203.

Lilijowepaß 392.

Limpert 451.

Lindewiese 222.

Linz 179.

Lipau 376.

Lippau 151.

Lippein 236.

Liptau 389.

Liptauer Alpen 392.

Liptó-Szent-Miklos 392.

Liptó-Ujvár 319.

Litschau 232.

Littau 238.

Lobau 259.

Lobkowitz 202.

Lobositz 87.

Loka 301.

Lokvagebirge 448.

Lomnitz 211, 242.

Lomnitzer Spitze 399.

Lorenzjoch 399.

Lotschnauer Moor 229.

Lövete 462.

Löwenstein 377.

Lubien maly 298.

Lubochnatal 388.

Lucha 376.

Lucsina 422 . 
Luesivna 389

Lucski 392.

Ludas tó 519.

Luggau 246.

Lugos 448.

Lundenburg 25:.

Lupkov 410.

Luprapiétra poienile 451.

Lusen 174, 176.

Lysa 202.

Lysahora 378.

\section{II.}

Mackow 183.

Mader 176.

Magura 379, 442.

Magura, Zipser 403.

Magustagruppe 408.

Magyarfálva 255.

Mähren 236.

Mährisch-Budwitz 245.

Mährisch-Kromau 245.

Mährisch-Schönberg 84, 226, 236.

Mährisch-Trübau 229 .

Mährisch-Weißkirchen 237.

Majdan 295.

Malacka 255.

Malajeschter Grat 433.

Malajeschter Hütte 433.

Malenicza 386.

Malesitz 186.

Malinow 379.

Malomvölgy 467.

Mammuthégy 451.

Maninschlucht 386 .

Mannhardsberg 150.

March 146, 152.

Marchegg 256.

Marchfeld 151, 157, 256.

Marchtal 250, 255.

Margareteninsel 511.

Mariakron 229.

Mariaschein 197.

Maria-Theresiopel 485, 516 .

Marienbad 170,171 .

Mármaros 456 .

Mármaros-Szigeth 413.

Maros 318, 485, 524.

Marostal 451, 463.

Maros-Ujvár 463.

Marosvásárhely 326. \begin{tabular}{|l} 
Marsgebirge 249. \\
Mátra $318,408,510,519$. \\
Mautern 235. \\
Mazocha 242. \\
Médgyes 460. \\
Mediasch 460. \\
Medzihole 390. \\
Meerauge 396. \\
Meerauge, Kleines 413.
\end{tabular}

Meeraugenspitze 399.

Mehádia 445.

Meleg Szamos 456.

Melk 235.

Melnik 203.

Melon, Alt- 234.

Mense, Hohe 219.

Meseritsch, Groß- 230.

Meszesgebirge 456.

Mezöség 349, 464.

Miava 256,317 .

Mies 187.

Mietec 295.

Mietusia 394.

Mihaiassa 420.

Mihala 524.

Milkow 238.

Milleschaver 196.

Miodobory 303.

Mistelbach 255.

Mitoka 312.

Mittagsberg 174.

Mittelgebirge 124, 135.

Mittelgratturm 399.

Mittelmähren 143.

Mlinicztal 399.

Mlynarz 395.

Modern 374, 375.

Modes 231.

Mödring 248.

Mohács 517, 519.

Mohelno 245.

Moldau 177, 183.

Moldau im Erzgebirge 166.

Moldauisch-Banilla 416 .

Moldava 416.

Molnársziget 511 .

Momyicska 427.

Mönchhof 379 .

Mönchsbusch 196.

Mönitz 248.

Monor 485, 510.

Monosterzyska 305.

Monosterszeg 518.

\author{
Moosebruch 221. \\ Morskie oko 396. \\ Müglitz 228 . \\ Mühlbachgebirge 441 . \\ Mühlbach 459. \\ Mühlfraun 246. \\ Mühlviertel 170, 178 . \\ Muncel 416. \\ Münchengrätz 200, 201. \\ Munkács 413. \\ Muntele mare 456. \\ Murány 405. \\ Musterresidenz 438.
}

\section{N.}

Nadas rét 514.

nade Mziky 377.

Nagybánya 324, 325, 457.

Nagy eger erdö 509.

Nagy-Enyed 451.

Nagy Gallya 408.

Nagy Hagymas 321, 424.

Nagykároly 480, 481.

Nagy Körös 502, 515.

Nagy Maros 410.

Nagy-Szál 410, 510.

Nagy-Szében 458.

Nagyvárad 480, 481, 523.

Namiest 244, 245.

Napajedl 250.

Nebotein 239.

Neisse 207, 208.

Negoi 318, 439, 440.

Nemčich 191.

Nemira 392.

Nemschen 198, 199.

Neograder Gebirge 318, 477.

Neratowitz 202.

Nesselsdorf 238.

Neu-Bydžow 204.

Neu-Bystritz 231.

Neudeck 169.

Neuer Teich 182.

Neuhaus 231.

Neuhaus a. d. Donau 178.

Neuhäusel 245, 507.

Neu-Lhota 376.

Neumark 174.

Neumarkt 341.

Neu-Prerau 248.

Neusatz 480, 481.

Neusiedlersee 508. 
Neusohl 324, 325, 388.

Neu-Szöny 510.

Neutitschein 238.

Neutra 324, 325, 385.

Neuwaldsdorf 396.

Niedere Tatra $380,388$.

Niederes Gesenke 226 .

Niedergrund 205.

Niedergrund bei Sternberg 236.

Niederschrems 232.

Niemes 200.

Niepolemice 294.

Niklasberg 166.

Nikler Moorwiesen 229.

Nikles 226.

Nikolčic 249.

Nikolsburg 88, 157, 248, 253, 254.

Nisko 295.

Nixdorf 206.

Nizniow 305.

Nollendorf 166.

Novy 402.

Novy Targ 380.

NußIau 248.

Nyirbátor 523 .

Nyiregyháza 480, 481.

Nyirgegend 350 .

Nyirség 412, 485, 522.

Nyitra 324, 325.

\section{0.}

Oberbergern 235.

Obergrund bei Sternberg 236.

Oberleutensdorf 83,84 .

Ober-Moldau 176.

Obertham 86.

Obertyn 307.

Ócsem teteje $317,424,426$.

Oderberg 292.

Odergebirge 236, 239.

Odertal 238.

Odrau 238.

Oels 229.

6 Futak 518.

Ogradina 446 .

Ó.-Gyalla 480, 481, 507.

Ohlafalva 462.

Ohla-Szt. György 413.

Okna 308.

Okrzesicne 307, 308.

Okruh 311.
Olbersdorf 228.

Olenyne boloto 306 .

Olmütz 239.

Olsa $378,379$.

Opoěno 204.

Oravitza 448.

Orhégy 507.

Orlisk 294.

Orlija 442.

Örszállás 518 .

Orosháza 524.

Orsova $327,445$.

Oslawan 244.

Oslawatal 244.

Oslawica 410.

Osseg 166.

Osser 174.

Ostapie 306.

Ostkarpathen $323,327,349$, 410.

Östliche Randgebirge, Siebenbürgen 424.

Ostritza 312.

Ostroug 234.

Ostrowce 306.

Ostsudeten 108, 150.

Oswieczym 293.

Ottenschlag 234.

Ottenteich 169.

Ottenthal 254.

Ottmarau 248.

Oužitz 202.

\section{P.}

Pakozd 518.

Palenica 380.

Paltina 444.

Pancsowa 480, 481, 482.

Pantalicha 303.

Pantschefall 213.

Pantschewiese 213.

Parád 408.

Parajd 462.

Pardubitz 204.

Pareng 443.

Parndorf 509.

Parschnitz 211.

Pasiku 382.

Pausram 157, 248.

Peilstein 234.

Peleaga 444.

Pellew 300.

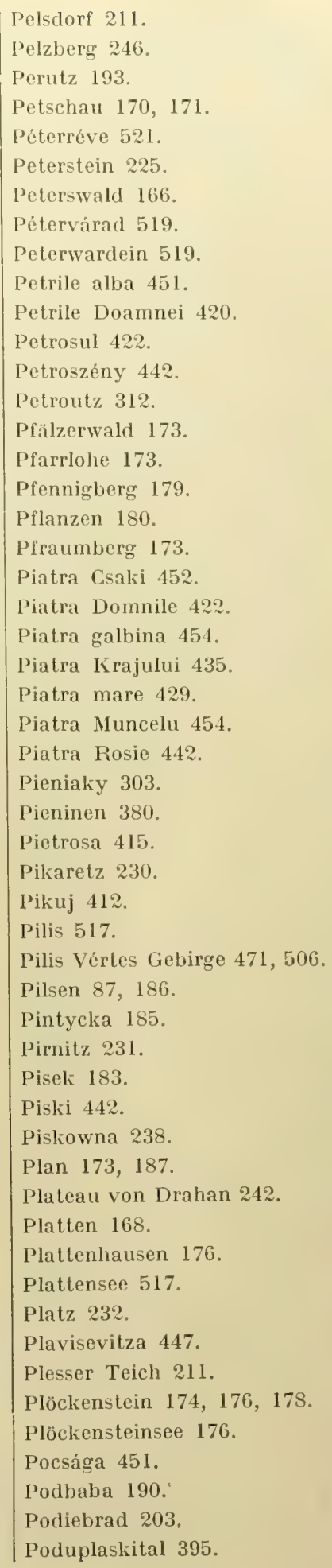


Pojana 312.

Pojana Ruszka 450.

Pojana stampa 415.

Poisdorf 255.

Polauer Berge 157, 253.

Polhora 380.

Poljana 387.

Polička 229.

Polnische Fünf Seen 396.

Polnischer Kamm 397.

Polnisch-Ostra 379.

Poludnica 389.

Popadia 412.

Pop Ivan 417.

Poppitz 230, 246.

Poprad 389.

Poreba 294.

Postelberg 193.

Pöstlingberg 179.

Petscherad 195.

Poturyeza 301.

Pozsony 324, 325, 480, 481, 506 .

Prag 87, 124, 126, 189.

Prater 259.

Prazsmár 427, 428.

Preßburg 324, 325, 374, 480, 481, 482, 506.

Preßnitz 167.

Přibram 183, 185.

Prisacareni 312.

Přivor 203.

Prolazschlucht 445.

Proßnitz 240 .

Protiwanow 242.

Prusie 290.

Prusinskaer Tal 386.

Pruth 308, 312.

Przemsza 293.

Przemysl 296, 297, 412.

Puchov 377.

Pulka 254.

Pulkatal 157.

Pulkau 247.

Püllna 192.

Püspökladány $480,481$.

Puszta Hortobágy 522.

Putim 183.

Pyrawarth 255.

\section{R.}

Raab 509, 510.

Raabs 233.
Raabtal 509.

Rachel 175.

Rachsturm 376.

Rad, Hohes 214.

Radbusa 187.

Radelstein 196.

Radeschin 230.

Radhost 377.

Radlow 294.

Radobyl 198.

Rajnochowitz 377.

Rakonitz 192.

Rákos Palota 511.

Rakwitz 253.

Ranna 193.

Ranzersteich 231.

Rareu 317, 420, 424.

Ratschitz 186.

Ratzersdorf 506.

Raudnitz 194.

Rauschenbacher Heide 171.

Rautenberg 226.

Rawa Ruska 298, 299, 300.

Reckenteich 231.

Rečko 200.

Rehhorn 217.

Rehsteiner Gebirge 220.

Peichenau a. d. Knežna 204.

Reichenbach 232.

Reichenberg 207, 208.

Reichensteiner Gebirge 220.

Reifträger 214.

Rejkovits 186.

Reiwiesen 221.

Részgebirge 456.

Retyezat 444 .

Retyezatgruppe 318.

Retyi-Nyir 427.

Rét-Szílas 518 .

Retz 247, 254.

Reußmarkt 459.

Revan 386.

Richterstein 199.

Rídka 186.

Riegersdorf 192.

Riesenburg 166.

Riesengebirge 107, 210, 219.

Riesengrund 217.

Řihateich 204.

Řip 196.

Riu Sebes 441.

Roblin 190.

Rodna 420.
Rodnaer Alpen 317, 321, 413.

Rodnaborberek 417.

Pohač 393.

Rohrbach 178 .

Rohrwald 255.

Rokytnitz 219.

Rollberg 200.

Ronaszek 413.

Ropitzer Teich 183.

Rosenau 231.

Rosenau bei Kronstadt 431 .

Rosenberg 205.

Rosenberger Teich 181.

Roszudec 390.

Rotenturmpaß 318, 441.

Roter Rech 459.

Rotes Moos 180.

Rotseespitze 399.

Rottalowitz 377.

Rownica 379.

Rox 403 .

Roždalowitz 203.

Rübezahl-Garten 217.

Rumburg 206.

Runc 416, 451.

Ruszka 450.

Rzesna ruska 300.

Rzeszow 268.

Rzycki 298.

Saar 229.

Saaz 193, 195.

Sachsenthal 232.

Sächsisch-Regen 463, 464.

Sadagora 309.

Saidschitz 192.

Saitz 248.

Salnau 176.

Salzberg bei Bielitz 293, 379.

Salzburg 458.

Sambor 298.

San 294.

Sandberg 199.

Sandomirer Urwald 294.

St. Annensee 426.

St. Georgen 374, 506.

St. Georgenthal 206.

St. Ivan 189.

St. Prokop 190.

St. Veith bei Wittingau 181 .

Sanok 412.

Sárhegy 450 . 
Sárkeresztur 518.

Saro-vicz 513.

Satorálja-ujhély 407, 523.

Sazawa 187.

Sazawatal 228.

Scarisora 451.

Scharkatal 191.

Schäßburg 326, 460.

Schatzberg 230 .

Schatzlar 217.

Schemnitz 319, 324, 325, 386.

Schemnitz-Iremnitzer Erzge-

birge 386

Schenkellohe 173.

Schlackenwerth 169.

Schlägel 178.

Schlagendorferspitze 399.

Schlan 191.

Schlapanitz 244.

Schlegelwasser 229.

Schleinbach 255.

Schlesien, östliches 267 .

Schloßberg bei Kesmark 403.

Schlößchen 389.

Schlössel 83, 84.

Schloßhof 256.

Schloßrevier bei Wittingau 180.

Schmecks 400 .

Schmiedeberg 167.

Schneeberg, Glatzer 219.

Schneeberg, Hoher 205.

Schneeberg, Spieglitzer 219.

Schneegrube, Kleine 214.

Schneekoppe 85, 86, 215.

Schnelle İörös 457.

Scholten 460.

Schönau 232.

Schöne Wiese 209.

Schönlinde 169.

Schreckenstein 197.

Schrems 233.

Schuler 431.

Schur 506.

Schustergraben 461.

Schüttenhofen 83, 84, 177.

Schüttinsel, Große 507.

Schwarzawa 146, 248.

Schwarzawatal 243.

Schwarzbach T. VIII.

Schwarzenbach 178.

Schwarzenberg 207, 209.

Schwarzenberg (Riesengebirge) 217.
|Schwarzer See (Böhmerwald) 175.

-, Javorinaer 397.

- (Tatra) 399.

Schwarze Teiche 209.

Schwarzlohe 173.

Schwarzwassertal 395.

Schweinitz 180.

Schyl 442 .

Sebastiansberg 167.

Sebinwald 195.

Seefelder 224 .

Seewand 174.

Segesvár 460, 326.

Selmeczbánya $319,386$.

Sennohrad 245.

Sereth 309, 312, 416.

Setz, 191 .

Siebenbrunn 256.

Siebenbürgen $317,327$.

Siebenbürgisches Erzgebirge $318,451$.

Sieben Gründe 215.

Siechenberg 461.

Siedlisko 299.

Sieghübel 207, 209.

Siegmundsherberg 348.

Silbersberg 233.

Silberwasser 229.

Siklos 507.

Siófok 518.

Siroka 407.

Siroka, Javorinaer 399.

Sivula 412.

Skalitz 198.

Sklener Teich 230.

Skleny 230.

Skomorochy 301.

Slobodzia 312.

Sloup 242.

Smečno 191.

Smolnik 389.

Smrk 378.

Sniatyn 308.

Sobotka 204.

Sokolniki 294.

Sokoró alja 509.

Somoskő 451.

Sonnenberg 167.

Soos 170 .

Sophienschloß 179.

Soroksár 511, 512.

Sós-tó 518.
Spieglitzer Schneeberg 219.

Spitzberg 163, 166, 167, 168, $169,199$.

- bei Iglau 230.

- bei Nagy Maros 410 .

Staatz 254, 255.

Stablowitz 228.

Stallecker Teich 231.

Stampfen 255, 256.

Stanislau 268, 298, 307.

Stebnik 298.

Stěchowitz 188.

Steinbachsee 400.

Steinitzer Wald 249.

Steinröhrenteich 181 .

Stenyovatal 413.

Stern 191.

Sternberg 191, 236.

Sternstein 178.

Steyerdorf 450.

Stiller see 399.

Stirnberg 400, 402.

Stitzendorf 247.

Stockerau 255.

Stolpichstraße 208.

Straczenatal 389.

Stradonitz 195.

Stradonitzer Tal 193.

Strakonitz 183.

Stramberg 238.

Strazyskatal 395.

Strilek 250.

Strobnitzberg 166.

Strunga 435.

Stryi 298, 412.

Strypa 303, 306.

Stuhlweißenburg 518.

Suczawa 312.

Sudeten 104, 207.

Südmähren 143, 236.

Sulov 386.

Susara 524.

Světteich 181.

Svinitza 447.

Swietla 211.

Sytna 387.

Szabadka 485.

Szabadszállás 513, 514 .

Szaboles 522.

Szadellö 405.

Szamos 413.

Szamostal, oberes 422 .

Szarko 444. 
Szarvas 524.

Szász Csanad 460

Szász-Hermany 428, 462.

Szász-Regen 464.

Szathmár 522.

Szatmár-Némety 480, 481.

Szczakowa 293.

Szczawnica 324, 325.

Szeged 480, 481, 482, 521 .

Székelykő 453.

Szemenik 450.

Szenafú 466.

Szentes 480, 481, 521.

Szt. Gotthard 466.

Szt. lvany 518.

Szepesvaralya 404.

Szernye-Sumpf 523.

Szikra 502.

Szoboslo 515.

Szolnok 480, 481, 519 .

Szomolany 375 .

Szoróta 444.

Szurdukpaß 444.

Szuru 321, 440.

Szydlowiec 295.

\section{T.}

Tabor $184,185$.

- bei Lomnitz 211.

Tachau 173

Tafelberg 178.

Tafelfichte 207, 209.

Talesva 407

Talinenberg 462

Talmasch 441.

Taniás 518.

Tápio-Szelle 521.

Tárna 408, 519.

Tarnita 422

Tarnopol 268, 303.

Tarnow 294

Tarnowitzer Platte 267.

Tartlau 427, 428.

Taßwitz 246.

Tatarka 420.

Tatra 336 .

- galizische, 392 .

-, Hohe 318, 321, 380, 394.

-, Niedere $318,380,388$

Tatrafüred $319,326,400$.

Taus 173.

Tavosch 199.
Tejte mare 453.

Tellnitz 157, 166, 248.

Teltsch 231.

Temesvár 480, 481, 524.

Temetveny 384 .

Teplic 389.

Teplitz 196

Teschen 378.

Teschener Kreis 292

Tetschen 205.

Teufelsfelsen 300 .

Teufelsgärtchen 217.

Teufelsmauer 178.

Teufeksee 175.

Thaya $146,152$.

Thayatal 157, 246.

Theben 374.

Thebener Kogel 374.

Theiß 413, 457, 477, 519, 523.

Theresiental 180 .

Thomasdorf 222.

Tiefenlohe 173 .

Tillenlohe 173.

Timoracz 384.

Tischnowitz 242, 243.

Tissovitza 447.

Titel 5:1.

Tokaj 407.

Tölgyespaß 422, 424.

Tollenstein 206 .

Tömöspaß 429.

Torda 454, 463, 467.

Tordaer Schlucht 454 .

Tordai hászadek 454

Törichter Gern 403.

Torna 405.

Toroczlio 453.

Torojaga 417.

Tovis 452 .

Transsilvanische Alpen 321, 437.

Trautenau 84, 211.

Trebichnia 384 .

Trebitsch 231

Trenesin 384.

Treskovatz 447.

Triebsch 199.

Troja 190.

Troppau 84, 228.

Trzebinja 293.

Tschihadlwiese 209.

Tür 460 .

Turbat 320 .
Turer Schlucht 454.

Turkowitz 178.

Turka 412

Turn 196.

Tusnad 426 .

Tussetberg 176.

Tuzla 429

Tychapaß 399.

\section{U.}

Uhorce 303

Ujvidek 480, 481.

Ung 411.

Ungarische Tiefebene, Große 477,510 .

- - Kleine 477, 506.

Ungarisches Tiefland 477.

Ungarisches Erzgebirge 318 , 386.

Ungarisch-Hradisch 251.

Ungarisch-Ostra 251, 376.

Ungvár 324, 325, 413.

Unhoscht 189.

Ünökő 420 .

Unter-Moldau 176.

Unter-IValdau 178

Urmény 507.

Uttigsdorf 229.

\section{V.}

Vácz 410.

Vág-Tepla 386.

Vág-Ujhely 376.

Vajda-Hunyad 450.

Vajta 517.

Valeriasca 444.

Valle Jucz 447.

Vavřinetz 203

Velenczer See 518

Velenka 202

Velichovky 204.

Velika hora 189.

Velka 376.

Velka Lukna 386.

Věnatorea 318, 439.

Vereckö 423.

Versetz 448.

Veseč 204.

Vesztő 523.

Veterna hola 386.

Vètrnik 242.

Vichodno 392. 
Viczabach 413.

Vidra 451.

Vihorlat $318,412,413$.

Vinek 196.

Vinna 413.

Visoka 376.

Vizakna 458.

Vjepor 387.

Vistea mare 438.

Viszó 413.

Vlegyassa 454, 456 .

Vlčak 250.

Volhynien 295.

Vollmail 174.

Volovec 392.

Volovlet 309.

Vratnatal 390.

Vraune 191.

Vrf Corongisului 419.

Vrf Csortea 440.

Vrf Lacustii 451.

Vrf Ludisorului 438.

Vrf Pietroszu 317, 419.

Vrf Suskului 445.

Vrf Urlei 318, 438.

Vrf Vaca 417.

Vrutitz 202

Všetat 202.

Vulkan 451

\section{W.}

Waag 384.

Waag-Neustadtl 376.

Waagtal, oberes 389 .

Wachau 235.

Wachholderberg 196.

Wadowice 268, 293, 324, 325.

Wagram 256.

Waidhofen a. d. Thaya 233.

Waizen 410 .

Waldenburg 222, 226.

Waldhausen 179 .

Waldkarpathen $317,323,410$, 411.

Walterschlag 231.

Waldviertel 102, 232.

Weckelsdorf 219.

Weichsel 292, 294, 379.

Weidenau 220.

\begin{tabular}{|c|c|}
\hline 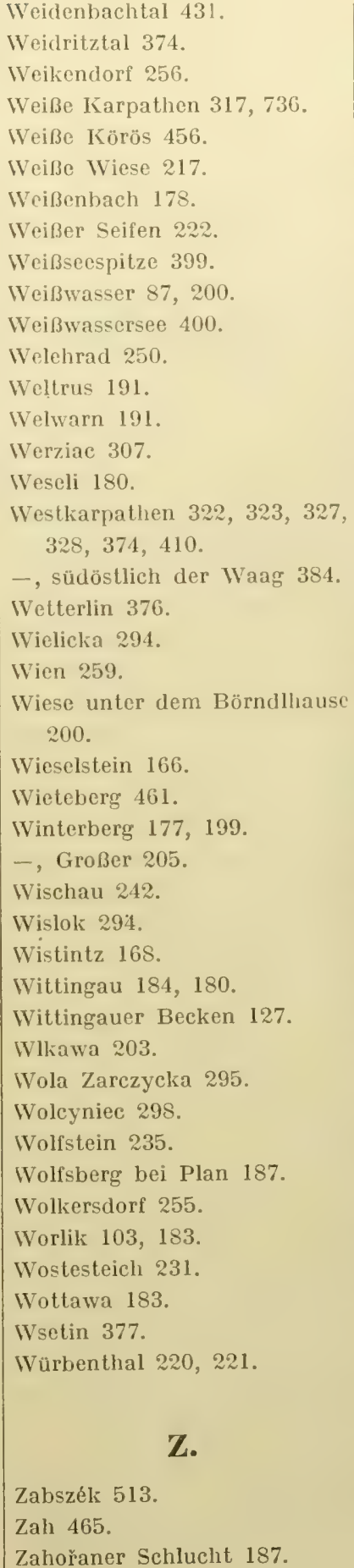 & 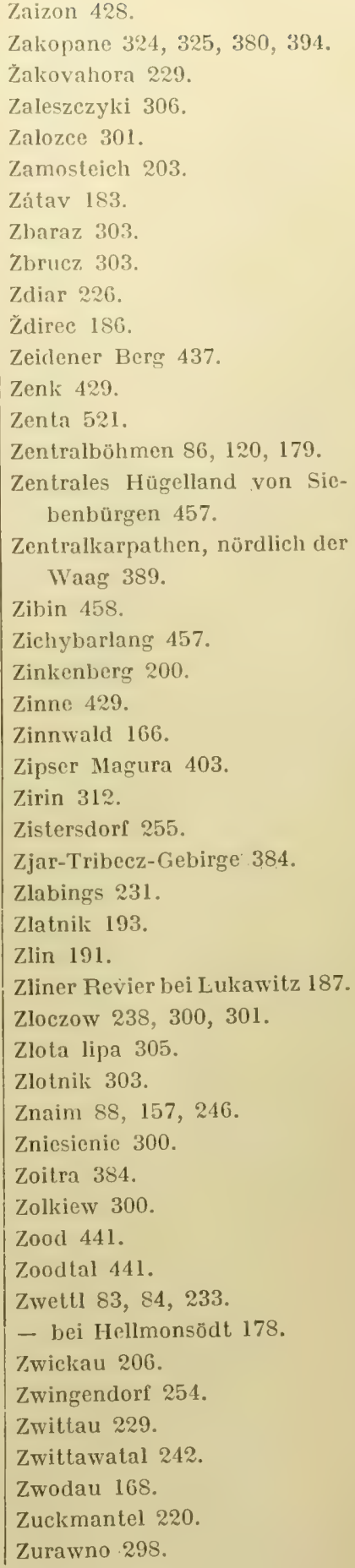 \\
\hline
\end{tabular}

Hayek. Die Pflanzendecke Ósterreich-Ungarns I. 


\section{Corrigenda.}

S. 59, Z. 14 v. o., statt Lycopodium annotinum setze L. inundatum.

S. 119, Z. 3 v. o., statt Grimmia alpina lies G. alpestris.

S. 275, Z. 14 v. u., statt IInium palustre setze Aulacomnium palustre.

S. 294, Z. 3 und 13 v. o., statt Lycopodium annotinum setze L. inundatum.

S. 353 , Z. 23 v. o., statt Onosma vireseens setze O. viride.

S. 354, statt Ruta patavina setze R. Biebersteinii.

S. 387 statt Rosa glauca *Ilseana setze R. rubrifolia * Ilscana.

S. 403, Z. 13 v. 0., statt Elyna Bellardi setze Cobresia bipartita.

S. 408, Aiuga pyramidalis ist zu streichen.

S. 410 , Z. 12 v. u., statt Paronychia Kapela setze P. cephalotes.

S. 411, Z. 2 v. 0., Arabis Jacquini ist zu streichen.

S. 418, Z. 8 v. o., statt Cephalaria radiata setze C. laevigata.

S. 424 statt Festuca picta setze F. amethystina.

S. 434 , Z. 6 v. U., statt Draba Sturii setze D. Kotschyi. 


\title{
Verlag von Franz Deuticke in Leipzig und Wien.
}

Die europäischen Gattungen der Farn- und Blütenpflanzen nach dem Wettsteinschen System geordnet

von

Erwin Janchen.

Zweite, verbesserte Auflage.

Preis M. $2-=$ K 2.40 .

\section{Waldwegebaukunde. \\ Von}

dipl. For. Julius Marchet,

o. ö. Professor an der k. k. Hochschule für Bodenkultur in Wien, Fichberichtersiatter des $k$. k. Ackerbauministeriums.

I. Band: Das Trassieren und die Projektverfassung.

Mit 15 lithographischen Tafeln und 29 Abbildungen im Text.

Preis NI. $7 \cdot 50=\mathrm{K} 8 \cdot 40$.

\section{Der Holzhandel Norddeutschlands.}

\author{
Von
}

dipl. For. Julius Narchet,

o. ö. Professor an der k. k. Hochschule für Bodenkultur in Wien Fachberichterstatter des k. k. Ackerbauministeriums.

Mit 16 Abbildungen, 1 Situationsplane und 1 Karte.

Preis M. $7 \cdot-=\mathrm{K} 8 \cdot 40$.

Die Grundlagen der Bodenkunde.

\author{
Von
}

Dr. I. Nilch,

Privatdozent für Mineralogie und Geologie an der Universitäl Breslau.

Preis M. $4 \cdot$ - $=$ K $4 \cdot 80$.

\section{Flora des österreichischen Küstenlandes.}

Von

\section{Eduard Pospichal.}

Mit 25 Tabellen und einer Karte des österreichischen Kiistenlandes.

Zrvei Bände in drei Teilen.

Preis eines jeden Teiles geh. M. $8^{\circ-}=\mathrm{K} 9 \cdot 60$, geb. M. $10 \cdot-=\mathrm{K} 12 \cdot$

Einleitung in die experimentelle Vorphologie der Tiere.

$$
\text { Von }
$$

Dr. phil. Hans Przibram,

Privatdozenten an der Wiener Universität.

Preis M. $4 .-=\mathrm{K} 4: 80$.

\section{Experimental-Zoologie.}

\section{Von}

Dr. phil. Hans Przibram, Privatdozenten an der Wiener Universität.

\section{Teil. Embryogenese.}

Nit 16 lithograph. Tafeln.

Preis M. $7 \cdot-=\mathrm{K} 8 \cdot 40$.
II. Teil. Regeneration.

Nit 16 lithograph. Tafeln.

Preis M. $14 .-$ K 16.80 .
III. 'I'eil. Phylogenese. Mit 24 lithograph. Tafeln. Preis M. $18 \cdot-=\mathrm{K} 21 \cdot 60$.
IV. Teil. Vitalität.

Mit 10 lithographischen Tafeln. Preis M. $10-=\mathrm{K} 12 \cdot$
V. Teil: Funktion inkl. Sexualität.

Mit 12 lithographischen 'Tafeln.

Preis M. $12-=\mathrm{K} 14 \cdot 40$ 


\section{Le'xrbuch der Pflanzenkunde}

fur die unteren Klassen der Mittelschulen

von

Dr. Rudolf Scharfetter,

k. k. Professor an der. II. Staatsrealsehule in Graz.

Mit 201 Ablvildungen im 'Text und 48 farbigen' Tafeln.

Preis geb. M. $3 \cdot 60=\mathrm{K} 4$ -

\section{Vitalismus.}

\section{Elementare Lebensfunktionen.}

Von

Dr. Karl Camillo Schneider,

Privatdozent an der Universität Wien.

Preis geh. M. 11 - = K 13.20, geb. M. $12-=\mathrm{K} 14 \cdot 40$.

\section{Handbuch der systematischen Botanik.}

Von

D.. Richard R. v. Wettstein,

Professor an der Universität in Wien.

Zweite, umgearbeitete Auflage.

Mit 3692 Figuren in 600 Abbildungen und mit einer farbigen Tafel.

Preis geh. M. $20^{\circ}-=\mathrm{K} 24^{\circ}$-, geb. MI. $26 \cdot 60=\mathrm{K} 32^{\circ}$ -

\section{Vegetationsbilder aus Südbrasilien. \\ Von}

Dr. Richard R. v. Wettstein,

Professor an der Universitat in Wien.

Mit 58 Tafeln in Lichtdruck, 4 farbigen Tafeln und 6 Textbildern.

Preis M. $24 \cdot-=\mathrm{K} 28 \cdot 80$.

\section{Die Samenpflanzen. \\ (Blutenpflanzen, Phanerogamen.)}

Systematische Übersicht iłrer Familien und wichtigeren Gattungen und Arten mit besonderer Berïcksichtigung der fiir Land- und Forstwirtschafr, Technik und Arzneikunde in

Betracht kommenden Gewächse

von

Dr. Karl Wilhelm,

o. ö. Professor der Botanik an der k. k. Hochschule für Bodenkultur in Wien.

Mit cinem Anlange, enthaltend eine Übersicht der wichtigsten kryptogamen Nutzpflanzen.

Preis geh. M. 5. - K $6 \cdot-$, geb. M. 6:20 = K 7·40.

\section{Grundriß der Waldwegebaulehre}

nebst einer Aufgabensammlung und neuen Hilfstafeln zur Erdmassen-Berechnung

von

Dr. Karl Wimmenauer,

o. Professor der Forstwissenschaft an der Universität Gießen.

Mit einer Waldkarte und 4 Figurentafeln.

Preis M. $4 \cdot-=\mathrm{K} 4 \cdot 80$.

Grundriß der Waldwertrechnung und forstlichen Statik nebst einer Aufgabensammlung

bearbeitet von

Dr. Karl Wimmenauer,

o. Professor der Forstwissenschaft an der Unirirsität GieBen.

Mit 1. Kurventafel.

Preis M. $3-=\mathrm{K} 3 \cdot 60$. 


QK 318. New York Botanical Garden Library

QK 318 . H36 c.2 v.1

ek, August/Die Pflanzendecke Osterrei

3 5185001087384 
